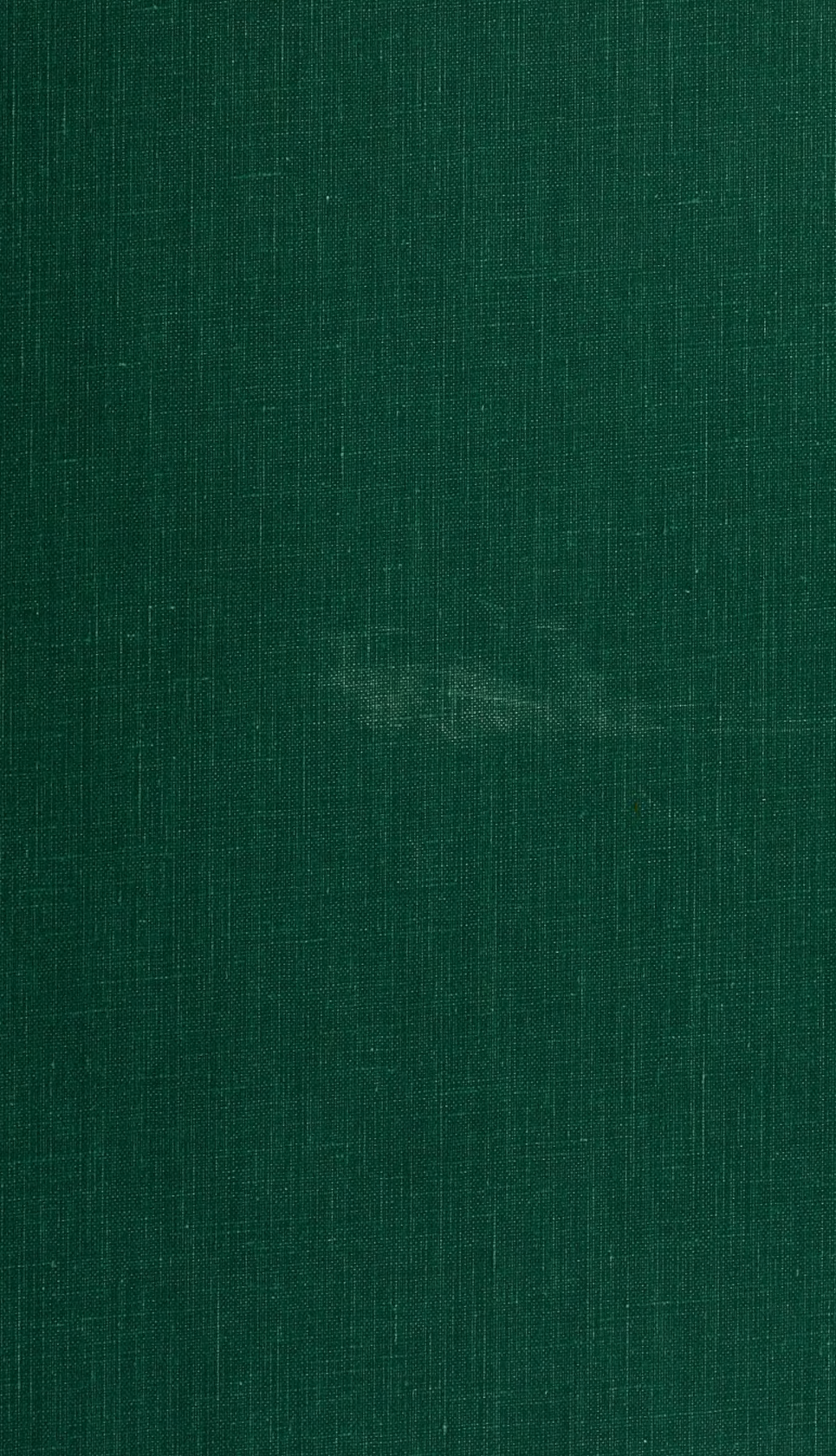




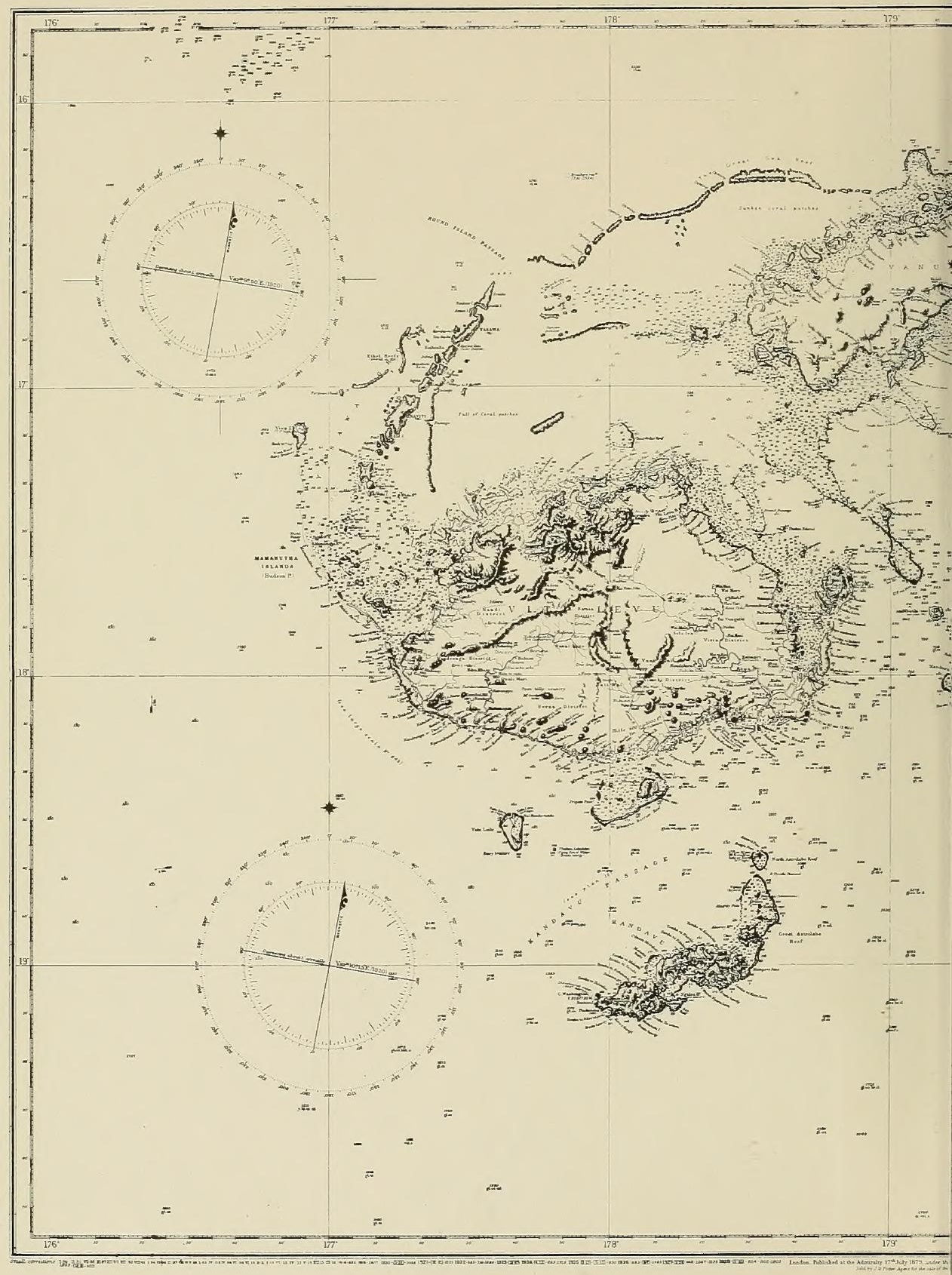




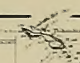



FLORA VITIENSIS NOVA

VOLUME 4 



\title{
FLORA VITIENSIS NOVA \\ A NEW FLORA OF FIJI \\ (SPERMATOPHYTES ONLY)
}

\section{ALBERT C. SMITH}

\author{
Volume 4
}

Angiospermae: Dicotyledones, Families 164-169

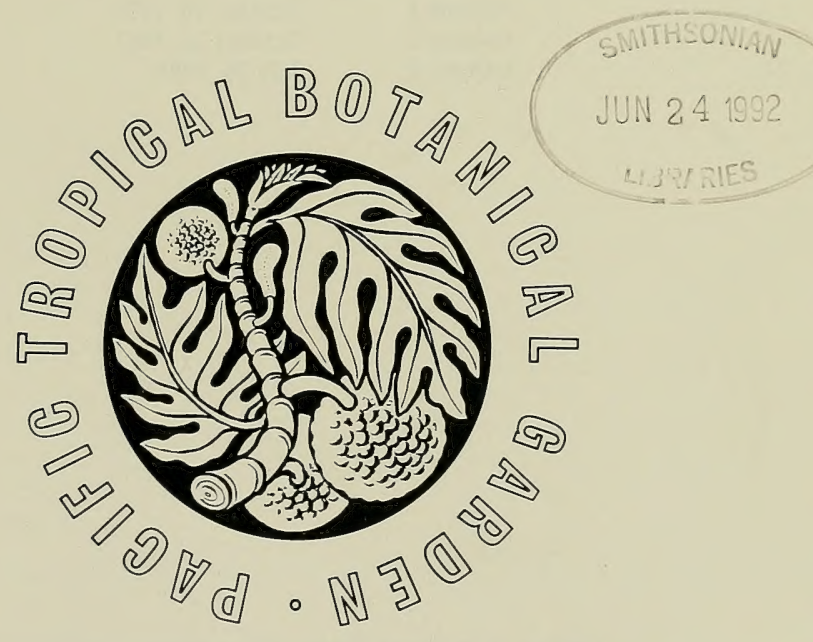

Lawai, Kauai, Hawaii 
(c) Pacific Tropical Botanical Garden 1988

Lawai, Kauai, Hawaii

All Rights Reserved

Dates of Issue

Volume $1 \quad$ January 10, 1979

Volume $2 \quad$ October 26, 1981

Volume 3 July 26, 1985

Library of Congress Catalog Card Number 78-61712 Printed for the Pacific Tropical Botanical Garden

by

SB Printers, Inc., Honolulu, Hawaii 
CONTENTS OF VOLUME 4

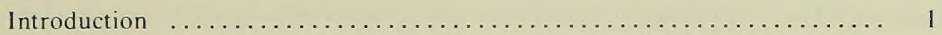

Supplementary References ......................... 3

Division Angiospermae (Magnoliophyta) (continued) $\ldots \ldots \ldots \ldots \ldots \ldots \ldots .4$

Class Dicotyledones (Magnoliatae) (continued) $\ldots \ldots \ldots \ldots \ldots \ldots \ldots \ldots . \ldots \ldots$

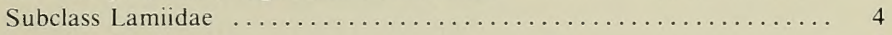

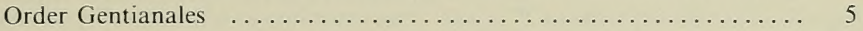

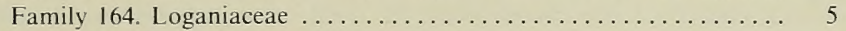

Family 165. Apocynaceae ....................... 43

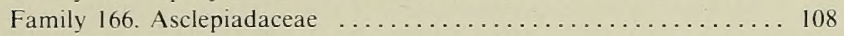

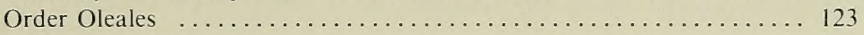

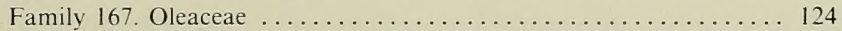

Order Rubiales ........................... 142

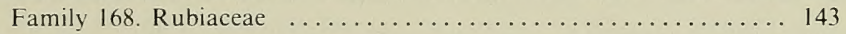

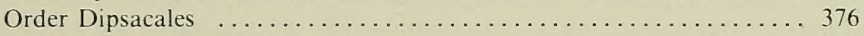

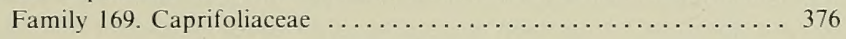





\section{INTRODUCTION}

As in earlier volumes of this Flora, it has been found necessary to propose a few new names, which are here listed for the convenience of compilers of indices of such names:

Apocynaceae: Alyxia ser. Bracteolosae (ser. nov.), A. stellata var. amoena (comb. et stat. nov.), A. samoensis (comb. et stat. nov., Samoa), Alstonia vitiensis f. glabra (f. nov.), Carruthersia macrantha (sp. nov.).

Oleaceae: Chionanthus vitiensis (comb. nov.).

Rubiaceae: Porterandia tenuiflora (comb. nov.), P. crosbyi (comb. nov., Tonga), Tarenna seemanniana (nom. nov.), T. joskei (comb. nov.), Psydrax odorata (comb. nov.), Cyclophyllum barbatum (comb. nov.), C. sessilifolium (comb. nov.), C. rectinervium (comb. nov.), Gynochtodes epiphytica (comb. nov.), Psychotria araiosantha (sp. nov.), $P$. unicarinata (comb. et stat. nov.), $P$. impercepta sp. nov.).

As in prior volumes, I am indebted to many professional colleagues for occasional advice on technical matters and nomenclature. In preparing the present volume, my especial thanks are due to Steven P. Darwin, Department of Biology, Tulane University, New Orleans, Louisiana, who has coauthored the included treatment of the family Rubiaceae. Dr. Darwin served as Visiting Research Associate of the Pacific Tropical Botanical Garden during the last six months of 1986, spending that period in Hawaii to facilitate our joint work on the family. For making his visit and his active collaboration possible, I here extend my thanks to the Trustees and the Director of the Garden, as well as to the University of Hawaii and the Bernice P. Bishop Museum for providing Dr. Darwin with honorary staff appointments and working facilities.

It has recently been proposed by Ehrendorfer (1983, pp. 879, 890)' to subdivide the subclass Asteridae into smaller subclasses, Lamiidae and Asteridae. This suggestion has been followed by Takhtajan (1986, pp. 305-356, 1987) in his most recent reconsiderations of the families of living vascular plants, and indeed it seems to offer a reasonable method of dividing the former Asteridae into two subclasses commensurate with the other six subclasses of dicotyledons formerly recognized (Takhtajan, 1980).

In Volume 2(1981, p. 5) of the present work I diffidently offered a key to the seven subclasses of dicotyledons then recognized by Takhtajan. While the unsatisfactory and even rash nature of such keys should again be emphasized, I herewith offer a supplementary division of the former Asteridae, which might be considered as an insert at the bottom of page 5, Volume 2 (1981):

${ }^{1}$ References indicated in this Flora by parenthetical dates, if not otherwise modified by an adjacent textual reference, are listed in Volume 1, pp. 84-88, in Volume 2, p. 3, in Volume 3, p. 2, and in the present volume, p. 3. 
Anthers free, not connivent or connate into a tube around style; pollen grains bi- or trinucleate when shed; ovaries superior to inferior; habit often woody (but also frequently herbaceous).

LAMIIDAE

Anthers connivent or connate into a tube around style; pollen grains trinucleate when shed; ovaries inferior; habit usually herbaceous (but also sometimes woody). ............ AsTERIDAE

The two subclasses seem logical on the basis of these characters. The Lamiidae have free anthers, bi- or trinucleate pollen, superior (but often also inferior) ovaries, a frequently woody habit, the presence of starch and iridoid compounds, and the lack of polyacetylenes. The Asteridae (sensu str.) in contrast tend to have the anthers connate, consistently trinucleate pollen grains, inferior ovaries, a usually herbaceous habit, and the presence of inulin (in place of starch) and polyacetylenes.

Of the subclasses of dicotyledons, the Lamiidae and Asteridae are considered to be the most recent, their ancestry probably being among the primitive Rosidae and perhaps dating from early in the Tertiary period. Phylogenists seem to have difficulties in grouping the families of these subclasses into logical orders and sometimes cannot agree on the delimitation and alliances of families. The comparative recency of the subclasses and the lack of time for effective extinction to create strong discontinuities may account for the difficulties encountered in constructing a classification scheme agreeable to all specialists. Chemical characteristics have often been utilized to group the component families into orders.

Although the groupings within the Lamiidae and Asteridae proposed by Ehrendorfer (1983) and Takhtajan (1986, 1987) (or within the Asteridae sensu lato proposed by Takhtajan (1980) and Cronquist (1981)) are not seriously discrepant, the sequence of Cronquist is now well known to English readers; his approximate sequence of families and orders is here utilized and his keys are here freely abstracted, although for purposes of a local flora the use of chemical characters is put aside as impracticable in general floristic study.

It had been anticipated that coverage of the dicotyledons for this Flora would be completed in the present volume, but as work on the families of Lamiidae progressed it was realized that the volume would then exceed in size the already unwieldy Volumes 2 and 3 . The Rubiaceae alone are found to include substantially more than $10 \%$ of all indigenous Fijian flowering plants. Consequently, only the first four orders of Lamiidae (as here construed) are included in this volume.

As an updating of my remarks on the founding of the Fiji Herbarium by B. E. V. Parham in 1933 and its subsequent growth (cf. this Flora, vol. 1, pp. 76, 78. 1979), the discussion by J. M. Miller (1987) will be of interest and value to students of southern Pacific plants. The Fiji Herbarium remained a part of the Ministry of Agriculture until 1982 , at which time, together with its housing steel cabinets and its small library, it was transferred to the Institute of Natural Resources of the University of the South Pacific. The collection, as the South Pacific Regional Herbarium, is now well housed in airconditioned and dehumidified quarters; it has grown to more than 45,000 specimens. It now provides an important museum resource to the governments and citizens of the eleven member countries of the University of the South Pacific: Cook Islands, Fiji, Kiribati, Nauru, Niue, Solomon Islands, Tokelau, Tonga, Tuvalu, Vanuatu, and Western Samoa. Other than its large holdings of Fijian plants, the South Pacific Regional Herbarium contains small but important collections from most of the areas mentioned above, as well as from New Caledonia, Norfolk Island, and parts of eastern Polynesia. Plans for the future include collecting and exchange programs to increase 
the Herbarium's holdings from all these areas as well as from New Guinea and Hawaii. It is perhaps needless to reiterate that the collections of the South Pacific Regional Herbarium provide one of the important bases for documentation incorporated in the present Flora. A consecutive field numbering system ( $D A$, originally implying Department of Agriculture) is being maintained for newly collected Fijian specimens, and the herbarium acronym SUVA will continue in use for the South Pacific Regional Herbarium. It is a pleasure to acknowledge the important services of Dr. Miller and his immediate predecessors at the University, D. Hassall and J. Ash, in organizing the collections into their new headquarters at the University of the South Pacific.

A recent publication that will prove useful to residents in Fiji and to students of cultivated plants is that of MacKee(1985), published as a supplement to the Flore de la Nouvelle-Calédonie et Dépendances; here are listed (in alphabetical sequence) the flowering plants introduced and cultivated in New Caledonia, many (or perhaps most) of which may also be anticipated to occur in Fijian gardens or as adventives.

Index Nominum Genericorum (1979; for comment cf. this Flora, vol. 2, p. 2) has proved invaluable to plant taxonomists, and a first Supplement (1986) adds to it value. As mentioned in the present Flora, the Index has been abbreviated as ING (1979). The Supplement will be abbreviated as ING Suppl. (1986).

It is a pleasure to note the continuation and acceleration of the second edition of Taxonomic Literature (Stafleu \& Cowan, 1985, 1986), covering authors whose family names begin with Sal-Ste (Vol. 5) and Sti-Vuy (Vol. 6). Completion of this superb work, of the greatest value to authors and users of Floras among all other botanists, may confidently be anticipated in the near future.

As was the case in Volume 3 of this Flora, William G. Ziarnik kindly offered the use of kodachrome photographs of Fijian plants, and two are here utilized.

\section{SUPPLEMENTARY REFERENCES}

Ehrendorfer, F. 1983. Übersicht des Pflanzenreiches: Spermatophyta, Samenpflanzen. In: Denffer, D. von, H. Ziegler, F. Ehrendorfer, \& A. Bresinsky. Lehrbuch der Botanik (begr. von E. Strasburger). Aufl. 32: 758-915. Gustav Fischer, Stuttgart.

FARR, E. R., J. A. Leussink, \& G. ZiJlstra. 1986. Index Nominum Genericorum Supplementum I. Regnum Veg. 113: I-XV, 1-126. Utrecht.

MacKeE, H. S. 1985. Les Plantes Introduites et Cultivées en Nouvelle-Calédonie. 160 pp. Flore de la Nouvelle-Calédonie et Dépendances (volume hors série). Paris.

Miller, J. M. 1987. The South Pacific Regional Herbarium. Taxon 36: 422-424.

Stafleu, F. A., \& R. S. Cowan. 1985. Taxonomic Literature. Ed. 2. Vol. 5: Sal-Ste. Regnum Veg. 112: 1-1066. Utrecht.

\& . 1986. Taxonomic Literature. Ed. 2. Vol. 6: Sti-Vuy. Regnum Veg. 115: 1-926. Utrecht.

TAKHTAJAn, A. 1986. Floristic Regions of the World. i-xxii, 1-522. University of California Press, Berkeley. 1987. Systema Magnoliophytorum. 439 pp. Leningrad. (In Russian.) 


\section{DIVISION ANGIOSPERMAE (MAGNOLIOPHYTA) (continued) Class DICOTYLEDONES (MAGNOLIATAE) (continued) SUBCLASS LAMHDAE}

KEY TO ORDERS OCCURRING IN FIJI

Plants nearly always with opposite or whorled leaves; flowers actinomorphic or nearly so (bilabiate in our representative of Dipsacales) and with as many stamens as corolla lobes (but usually fewer in Oleales).

Ovary superior or slightly sunken into receptacle (rarely semi-inferior but not in our taxa).

Corolla sympetalous, the lobes ( 4 or) 5 , convolute (less of ten imbricate or valvate), the stamens usually as many as and alternate with corolla lobes, attached to corolla tube; ovary ( 1 or $2(-8)$-carpellate, with united (or partly or completely separate) carpels, the ovules 1-many per locule or on each placenta; endosperm development nearly always nuclear; internal phloem nearly always present; leaves simple, usually entire; interpetiolar stipules usually lacking (but when present often with

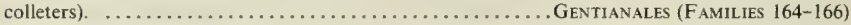

Corolla typically sympetalous and $4(-12)$-lobed, but sometimes the petals essentially distinct (or obsolete), the stamens commonly 2 (as in all our genera); ovary 2-carpellate, 2-locular, the ovules commonly 2 (1-4, rarely more) per locule; endosperm development cellular; internal phloem lacking; leaves simple to imparipinnately compound or 3- or 1-foliolate; stipules lacking.

OLEALES (FAMILY 167)

Ovary inferior (with few exceptions); internal phloem lacking.

Interpetiolar (sometimes intrapetiolar) stipules usually present and obvious, commonly with colleters on inner surface; leaves simple, usually entire; corolla actinomorphic and sympetalous (with few exceptions), the lobes various, often contorted, the stamens as many as and alternate with lobes; endosperm development nearly always nuclear. .............. Rubiales (FAmiLy 168)

Stipules typically lacking (as in our representative), when present not interpetiolar, without colleters; leaves simple or less often compound, often at least crenate to serrate (but simple and entire in our representative); corolla actinomorphic or (as in our representative) bilabiate, the lobes never contorted, the stamens as many as and alternate with lobes (as in our representative) or fewer, rarely twice as many; endosperm development cellular. .......... DiPSACALES (FAMILY 169)

Plants only rarely with both opposite (or whorled) leaves and internal phloem, and then with asymmetric flowers that have fewer stamens than corolla lobes; ovary superior (with few exceptions); endosperm development cellular (much less often nuclear); stipules lacking (with few exceptions).

Gynoecium composed of 2-4 (-8) carpels with (1 or) 2-many ovules each, but the carpels only rarely divided into uniovulate segments; fruit commonly capsular or baccate, only rarely composed of half-carpellary nutlets; internal phloem often present.

Corolla not scariose; flowers usually entomophilous or ornithophilous, 4- or 5-merous, the stamens isomerous or anisomerous; leaves very seldom basal, not phyllodial or parallel-veined.

Flowers mostly actinomorphic but sometimes irregular, typically 5-merous, the stamens usually as many as corolla lobes (but sometimes only 4 , and then the corolla irregular and 5-lobed); gynoecium mostly bicarpellate, the carpels (infrequently as many as 5) united in a compound ovary with axile, subbasal, or parietal placentation (seldom subdistinct and united by a gynobasic style), when 2 obliquely oriented to median plane of flower; ovules (1 or) 2-many per locule; fruit commonly a capsule or berry (seldom a drupe). . . SolAnALES (FAmilies 170-173)

Flowers mostly zygomorphic, commonly with an irregular, basically 5-merous, often bilabiate corolla and only 4 or 2 functional stamens (corolla infrequently 4 -merous and nearly actinomorphic, or 5-lobed and essentially regular, or reduced); gynoecium usually composed of 2 (rarely 3 or 4) carpels united in a compound ovary with axile, parietal, or free central placentation (one carpel seldom reduced or suppressed), the carpels when 2 median (not oblique); ovules ( 1 or) 2-many (mostly numerous) per functional locule; fruit usually a capsule, sometimes a drupe or

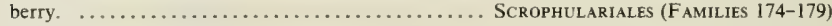

Corolla scariose, persistent, actinomorphic; flowers mostly anemophilous, 4-merous, mostly in pedunculate spikes or heads; leaves commonly in a radical rosette, phyllodial, essentially parallel-veined;

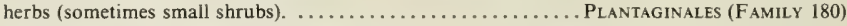

Gynoecium commonly composed of 2 (rarely as many as 14 ) carpels, these united by a gynobasic style (or sometimes more fully united into a compound ovary with a terminal style), each carpel usually biovulate and divided into 2 uniovulate segments; fruit most commonly composed of (1-) 4 halfcarpellary separating nutlets, sometimes drupaceous (with each seed with its own putamen or its own locule of a compound putamen); internal phloem only very rarely present; corolla actinomorphic or zygomorphic, the lobes mostly 5 , imbricate, convolute, or valvate; stamens 5 or 4 or 2 . 


\section{ORDER GENTIANALES}

Many phylogenists adopt a broad view of the Gentianales as an order, and sometimes included in it are the families Oleaceae, Rubiaceae, and Menyanthaceae, which in the present work are treated in different orders. Most concur in placing in the Gentianales the three families Loganiaceae, Apocynaceae, and Asclepiadaceae, which are represented in Fiji. The family Gentianaceae itself does not appear to be represented in Fiji, although Erythraea australis has been listed as occurring there. The correct name for that species is apparently Centaurium spicatum (L.) Fritsch. The presumably erroneous Fijian record is here clarified. ${ }^{1}$

KEY TO FAMILIES OCCURRING IN FIJI

Plants without a latex system; carpels fully united into a usually 2(-5)-locular ovary sometimes with distally imperfect partitions, the placentation axile (or infrequently parietal), the style with a capitate or lobed stigma, not especially thickened or modified or (in our taxa) deeply cleft; stipules interpetiolar or intrapetiolar or reduced to interpetiolar lines; leaves opposite (or verticillate); fruit a capsule, berry, or

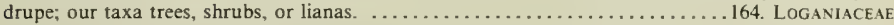

Plants with well-developed systems of laticifers (with rare exceptions); carpels often proximally distinct and united only distally (but sometimes united into a bilocular or unilocular ovary), the style usually thickened and modified at tip; stipules lacking or small; leaves opposite or verticillate, rarely alternate.

Flowers with androecia lacking translators, the pollen not forming pollinia, the anthers distinct or connivent around an often thickened and specialized style head or adherent to it by a retinaculum of viscid exudates; filaments lacking coronal appendages; fruit baccate, drupaceous, or follicular, apocarpous or syncarpous, the seeds comose or ecomose; trees, shrubs, lianas, or herbs.

165. APOCYNACEAE

Flowers specialized for mass-transfer of pollen by insects, the androecia provided with translators, the pollen (in our taxa) coherent into pollinia, the combined filaments, anthers, and style (in all our taxa) forming a central column (gynostegium); filaments often with appendages developed into a corona; fruit a follicetum, the seeds comose; perennial herbs or shrubs or herbaceous vines or lianas.

166. AsCLEPIADACEAE

\section{FAMILY 164. LOGANIACEAE}

Loganiaceae Mart. Nov. Gen. Sp. Pl. 2: 133, as Loganieae. 1827.

Trees, shrubs, or lianas, rarely herbs, usually stipulate (sometimes ochreate), the stipules often with colleters, interpetiolar or intrapetiolar or sometimes reduced to interpetiolar lines; leaves opposite, simple, the blades usually entire, pinnate-nerved or with prominent lower lateral nerves; inflorescences terminal or axillary, sometimes borne on branches, rarely on trunk, usually cymose, rarely 1-flowered, bracteate and bracteolate, the flowers $\varnothing$ or sometimes unisexual, actinomorphic (in all our taxa), usually 4- or 5-merous; calyx dentate to deeply cleft, the lobes imbricate or valvate; corolla sympetalous, the tube short to elongate, the lobes imbricate, contorted, or valvate; stamens as many as and alternate with corolla lobes (in all our taxa), borne on corolla tube or at its throat, the anthers 2-locular, dehiscing by longitudinal slits; disk

'Centaurium spicatum (L.) Fritsch in Mitt. Naturwiss. Vereins Univ. Wien, n. s. 5: 97. 1907; Druce in

Bot. Soc. Exch. Club Brit. Isles 1916: 614. 1917.

Gentiana spicata L. Sp. PI. 230. 1753.

Erythraea australis R. Br. Prodr. Fl. Nov. Holl. 451. 1810; Seem. in Bonplandia 10: 153. 1862, Viti, 439.

1862, Fl. Vit. 167. 1866; Drake, Ill. Fl. Ins. Mar. Pac. 239. 1892; J. W. Parham, Pl. Fiji Is1. 228. 1964, ed.

2. 318.1972

The putative record of this species in Fiji is based on a collection of Home (вм). originally noted as "New Caledonia or Fiji Isles-Sir E. Home (1844);" to the specimen someone (Seemann?) has added the notation: "Ervthraea australis R. Brown. Fiji?" Home's few Fijian collections seem to have been made in 1852 (cf. this Flora, vol. 1, p. 42), and it is probable that the specimen in question actually came from New Caledonia. As to the occurrence of the species in New Caledonia, MacKee (Pl. Intro. Cult. Nouv.-Caléd. 57. 1985) notes: "Pourrait être indigène, comme il en donne l'impression aujourd'hui, mais ne semble pas avoir èté récolté avant 1850." Van Balgooy's record (in Blumea Suppl. 6: 172. 1971) of Centaurium in Fiji was presumably taken from some of the references listed above. 
usually lacking, sometimes poorly developed; ovary superior (rarely semi-inferior but not in our taxa), (I or)2(-5)-locular, sometimes with distally imperfect partitions, the placentation axile (or infrequently parietal), the ovules numerous (rarely as few as 2 ) in each locule, anatropous to hemitropous, the style terminal, capitate or lobed; fruit a (usually septicidal) capsule or a berry, rarely a drupe, the seeds sometimes winged, the embryo straight, small, the endosperm fleshy to bony.

Distribution: Pantropical, extending into temperate areas, with about 20 genera and 500 species. Four genera have indigenous species in Fiji.

USeful treatments of family: Leenhouts, P. W. Loganiaceae. Fl. Males. 1. 6: 293-387. 1963. Leeuwenberg, A. J. M., et al. Loganiaceae, In: Engl. \& Prantl, Nat. Pflanzenfam. ed. 2. 28bl: 1-255. 1980.

The admirably complete review of the Loganiaceae by Leeuwenberg and seven coauthors (1980) recognizes 29 genera in ten tribes. Of these tribes, at least four are often removed from the family, some of them to other orders than the Gentianales, and at one time or another most of the remaining tribes have been considered distinct families (cf. Hutchinson, 1973). For present purposes four genera indigenous in Fiji may be assigned to three of the tribes and retained in the Loganiaceae. The genus Buddleja, represented in Fiji only by cultivated species, is here (following Takhtajan, 1980, Dahlgren, 1980, and Cronquist, 1981) taken to represent the family Buddlejaceae, order Scrophulariales.

KEY TO GENERA

Fruit a 2-valved septicidal (or septifragal) capsule, the seeds numerous, embedded in yellow to red pulp; corolla lobes imbricate or contorted in bud; flowers often slightly dimorphic (and plants sometimes at least incipiently gynodioecious); stipules intrapetiolar and forming a short sheath or interpetiolar and adnate to margins of petiole; trees or shrubs (Loganieae). . . . . . . . . . . . . . Geniostoma

Fruit a berry or drupe; flowers $\Varangle$

Corolla lobes valvate in bud (Strychneae)

Fruit a berry, the pericarp often becoming thick and hard, the seeds 1-many; stipules reduced to an interpetiolar ridge or essentially lacking; leaf blades with the proximal lateral nerves more prominent and more ascending than distal nerves; our species an often high-climbing liana.

2. Siruchnos

Fruit a drupe, the mesocarp dry, hard, fibrous, the seeds usually 1 per locule or 1 per fruit; stipules interpetiolar, adnate to petioles, often conspicuous, at length often split; leaf blades pinnate-

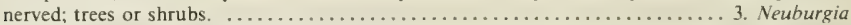

Corolla lobes dextrorsely contorted; fruit a berry, the seeds many, immersed in pulpy placentae; stipules interpetiolar, adnate to petioles, often conspicuous, usually splitting between petioles; leaf blades pinnate-nerved; our species trees or shrubs (Potalieae).

4. Fagraea

1. Geniostoma J. R. \& G. Forst. Char. Gen. Pl. 12. 1775, ed. 2. 23. 1776; Seem. Fl. Vit. 163. 1866; A. C. Sm. \& Stone in Contr. U.S. Nat. Herb. 37: 7. 1962; Leenh. in Fl. Males. 1. 6: 369. 1963, in Blumea Suppl. 5: 74. map 39. 1966; St. John in Naturaliste Canad. 98: 573. 1971; Leeuwenb. \& Leenh. in Engl. \& Prantl, Nat. Pflanzenfam. ed. 2. 28bI: 30. 1980; Conn in Blumea 26: 269, p. p. 1980.

Geniostoma subgen. Geniostoma; Conn in Blumea 26: 273. 1980.

Shrubs or trees, the branches terete to 4 -angled or -winged, the indument when present of simple or few-many-celled hairs, the stipules intrapetiolar and forming short sheaths or infrequently interpetiolar, then adnate to margins of petiole (sometimes to basal part of leaf blade) and forming soon disrupted foliaceous sheaths; leaves opposite, decussate, petiolate or sometimes essentially sessile, the blades membranaceous to coriaceous; inflorescences axillary or sometimes borne on branches or trunks, cymose, (1-)few-many-flowered, sometimes freely branching at or near base, bracteate and bracteolate, the flowers 5-merous (calyx rarely 4-lobed), often slightly dimorphic (in style length and anther development, the plants then at least incipiently gynodioecious); calyx cupuliform to rotate-campanulate, deeply divided, the tube short, the lobes ( 4 or) 5 , imbricate in bud, persistent; corolla campanulate to subrotate, 
within glabrous or (as in all our taxa) copiously pilose especially at throat with multicellular hairs up to $1 \mathrm{~mm}$. long, the tube cupuliform to campanulate, the lobes suborbicular, imbricate or contorted in bud, soon spreading; stamens inserted on corolla tube near throat, exserted, recurved after anthesis, the filaments ligulate, usually short, the anthers suborbicular to narrowly ovate, sometimes tufted-pilose at base; ovary 2-locular, often subglobose, the ovules numerous, the style long to short, included or exserted, the stigma globose to clavate or obovoid; fruit capsular, ellipsoid or subglobose to ovoid or obovoid, septicidally 2-valved or sometimes septifragal, the valves finally recurved, the placentae at length free and pulpy, the seeds numerous, ellipsoid to subglobose, embedded in pulp.

TYPE SPECIES: Geniostoma rupestre ("rupestris") J. R. \& G. Forst.

Distribution: Malesia to southern Japan and the Bonin Islands, and southward and eastward to Queensland, New Zealand, and Henderson Island in the Tuamotus; also in the Mascarenes. The number of species is variously indicated as between 20 and 100 or more.

Useful treatments of Genus: Smith, A. C., \& B, C. Stone. Studies of Pacific Island plants, XVII. The genus Geniostoma (Loganiaceae) in the New Hebrides, Fiji, Samoa, and Tonga. Contr. U. S. Nat. Herb. 37: 1-41. 1962. ConN, B. J. A taxonomic revision of Geniostoma subg. Geniostoma (Loganiaceae). Blumea 26: 245-364. 1980.

LOCAL NAMES AND USES: In Fiji most elements of Geniostoma are widely known as mboimboinda (and variants such as mbatimbati, mbatimbona, mbatimboni, mbatimara, mbitimbiti, and mbuimbuita), referring to the characteristic malodor of the plants. Sometimes the macerated bark is squeezed in water to provide a reputed cure for stomach ailments, constipation, "women's diseases," etc.

In our species of Geniostoma the calyx is green at anthesis and the corolla is white to greenish white, with copious white multicellular hairs within the tube and especially at its throat; the filaments are white to pale green, and the anthers white to pale yellow; the gynoecium (strictly glabrous in all our representatives except in G. macrophyllum) has a white or pale green style and a white to pale yellow stigma; the fruit is at first green, becoming black at maturity, the placental mass and seeds varying from red to orange or yellow. Several of our species are locally abundant and may be expected to bear flowers or fruits throughout the year.

Geniostoma is readily divisible into two groups, recognized as sections by Conn (1980), sect. Geniostoma (p. 278) for the bulk of the genus, with small, essentially intrapetiolar stipules (FIGURE 1B), and sect. Macrostipulare (p. 348) for the four species (Solomon Islands to Fiji) with large, interpetiolar stipules (FIGURE 1A).

Although more than 100 species of Geniostoma have been described, many of them appear to be reticulately interrelated, and as a result local populations have been treated at different nomenclatural levels. Both Leenhouts (1963, p. 371) and Conn (1980, recognizing 23 species) have utilized a vast coenospecies, $G$. rupestre, to accommodate the residual populations after the more obvious ones have been characterized. This viewpoint reflects the fact that in Malesia and the Pacific (excluding New Caledonia, where a greater degree of stability seems to have been reached) there are many local populations reticulately allied and sometimes connected by transitional forms (Leenhouts, 1963). But in Pacific areas from the New Hebrides eastward there appear to be several populations of Geniostoma that have become reasonably stabilized, even though their individual characteristics inevitably reflect their derivation from Malesian elements. One need not necessarily anticipate evolution (Conn, 1980, p. 269) to observe that most of these taxa differ to a degree from typical New Hebridean $G$. rupestre as well as from one another. 

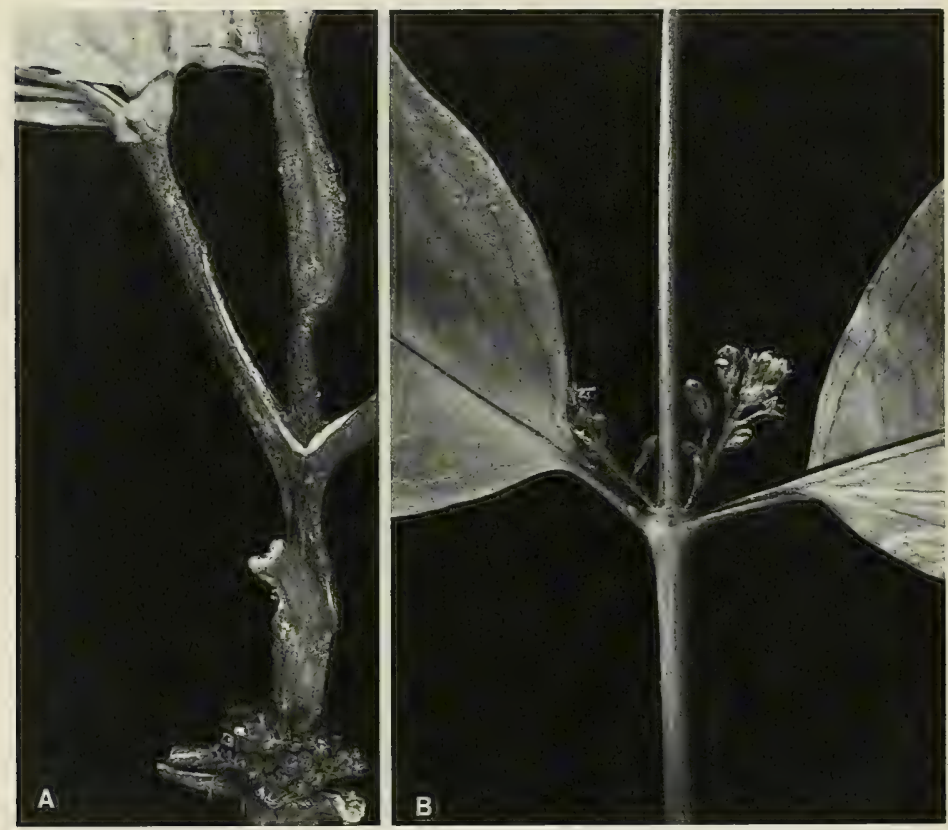

FIGURE 1. A, Geniostoma stipulare; interpetiolar stipules at ultimate node of branchlet, their scars on petioles at penultimate node, and a congested axillary inflorescence below, $\times 1$. B, Geniostoma rupestre; node, leaf bases, inflorescences, and intrapetiolar stipules, × 2. A from Smith 9148, B from Smith 132.

With Conn's (1980, p. 252) remarks as to corolla characters in mind, the representatives of the genus from the Fijian Region were reexamined, and it may indeed be acknowledged that the multicellular hairs within the corolla are too variable in length to provide a reliable means of separating taxa (cf. Figure 6). Hence, three species noted by Smith and Stone (1962, p. 9) as having "short trichomes" (0.1-0.4 mm. long) within the corolla are scarcely to be maintained on the basis of that sole character. However, Geniostoma vitiense is well separated from a reasonably inclusive concept of $G$. rupestre by its copious vegetative indument of several-many-celled trichomes (FIgURE 8A). The other Fijian taxon with "short" indument within the corolla, $G$. macgregorii, may on the basis of its other characters be incorporated in G. rupestre.

As to "simple" vs. "complex" corolla venation, I believe that the extremes within the very broad concept of Geniostoma rupestre adopted by Conn (1980, pp. 278-313) merit a degree of consideration (cf. Figures 4 and 5). Those taxa with comparatively "simple" corolla venation (i. e. with the five corolla traces unbranched in the tube and only sparingly branched in the throat and lobes) are readily distinguished from a reasonable concept of $G$. rupestre, in which the five corolla traces branch comparatively freely in the tube, sometimes from its base, and often copiously in the lobes. 
Supporting characters for recognition of three Fijian taxa with "simple" corolla venation (species numbered 3-5 in the present treatment) are also to be noted.

The present review of Geniostoma in Fiji is abstracted from Smith and Stone (1962), with modifications, for the convenience of those who prefer to utilize binomial nomenclature for taxa that seem to have resulted from the acquisition of isolating mechanisms by small founder populations of uncertain, but probably Tertiary, dates of arrival.

KEY TO SPECIES

Stipules interpetiolar, large, forming soon disrupted sheaths $1-3.5 \mathrm{~cm}$. long, adnate to margins of petioles (or bases of leaf blades) and caducous, leaving obvious linear scars; leaves large for the genus, the blades often exceeding $20 \times 15 \mathrm{~cm}$., ovate to obovate; inflorescences borne on trunks or defoliate branchlets (rarely axillary) (sect. Macrostipulare).

Ovary conspicuously hirtellous on distal surface; corolla $3-3.5 \mathrm{~mm}$. long, the tube $1.5-1.7 \mathrm{~mm}$. long; inflorescences cauline, glomerulate to elongate (to $25 \mathrm{~cm}$. long) and with as many as 200 or more flowers; leaves and other vegetative parts glabrous or essentially so; leaf blades essentially sessile, 20-55 × 9-25 cm., gradually decurrent proximally and not clearly distinguished from the broadly alate petioles, the secondary nerves $11-20$ per side. ............... . G. macrophyllum

Ovary glabrous; corolla 4-5.5 $\mathrm{mm}$. long, the tube $2.5-4 \mathrm{~mm}$. long; inflorescences ramuline (rarely axillary), 15-20-flowered; young parts, stipules, petioles, and leaf blades beneath at least on principal nerves pilose with 3(-5)-celled trichomes about $0.5 \mathrm{~mm}$. long; leaf blades $6.5-35 \times 3-18 \mathrm{~cm}$., cuneatedecurrent proximally but clearly distinguished from petioles (these $1-5 \mathrm{~cm}$. long), the secondary

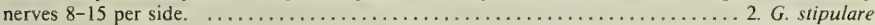

Stipules interpetiolar or essentially so, small, forming inconspicuous sheaths no more than $2 \mathrm{~mm}$. long (in our species), the petioles without obvious linear scars; leaves comparatively small, the blades not exceeding $24 \times 13 \mathrm{~cm}$. and usually much smaller; inflorescences axillary or borne on defoliate branchlets; gynoecium (in our taxa) strictly glabrous (sect. Geniostoma).

Corolla venation comparatively simple, each principal nerve unbranched in corolla tube and with inconspicuous, short, lateral nerves in each lobe, or each nerve with 2-4 lateral branches arising at level of corolla throat or in each lobe; inflorescences often ramuline as well as axillary; leaf blades elliptic to ovate, usually about twice (sometimes 3 times) as long as broad, acute to acuminate at apex; plants (except for indument within corolla) glabrous or with indument (if sparsely present on vegetative parts) of mostly unicellular hairs.

Stigma oblong-clavate to obovoid or ellipsoid, 1.5-2 times as long as broad; each corolla lobe supplied by a median nerve and 2-4 lateral nerves slightly less prominent and shorter than median nerve. Corolla 4-5.5 mm. long, the tube and lobes about equal in length, the lobes ovate, $2-2.5 \mathrm{~mm}$. long and broad; leaves comparatively large, the petioles (3-) 9-20 mm. long, the blades (7-) $10-24 \times(2.5-)$ 5-13 cm.; inflorescences 5-11-flowered. ....................... confertiflorum Corolla 4.5-6 mm. long, the tube longer than the lobes, these about $2 \times 1.5 \mathrm{~mm}$.; leaves smaller, the petioles 5-9 $(-15) \mathrm{mm}$. long, the blades 3-8 $\times 1-3.6 \mathrm{~cm}$; inflorescences 3-5(-9)-flowered.

4. G. clavigerum

Stigma subglobose; each corolla lobe supplied by a relatively conspicuous median nerve with brief and comparatively obscure lateral nerves; corolla $3.7-4 \mathrm{~mm}$. long, the tube slightly longer than the lobes, these about $1.5 \times 1.3 \mathrm{~mm}$.; leaves with petioles $5-20 \mathrm{~mm}$. long, the blades $10-15 \times 3-7 \mathrm{~cm}$; inflorescences 3-20-flowered.

5. G. uninervium

Corolla venation comparatively complex, each principal nerve branching in corolla tube or at its base and with 1 or more pairs of lateral nerves, these usually again branched within tube or within each lobe; corolla 2.5-4 mm. long; stigma subglobose, seldom ellipsoid but usually not much longer than broad, sometimes inconspicuously bilobed; inflorescences axillary, occasionally borne on branchlets below leaves.

Vegetative indument present (usualiy copious and congested) on young parts, young distal internodes, young petioles, and often on leaf blades (e. g. on ventral surface of young costa), the hairs severalmany-celled (although sometimes minute), 0.05-0.5 mm. long.

Indument of leaf blades limited to lower surface and sparse, sometimes obvious on costa, or lacking; petioles 3-10 mm. long; leaf blades ovate to lanceolate-ovate, $2.5-15 \times(0.7-) 1-6.5 \mathrm{~cm}$., rounded to acute at base, obtuse to acuminate at apex, the lateral nerves $5-12$ per side; corolla tube about

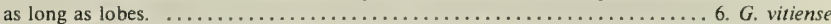

Indument of leaf blades copious on both surfaces; petioles $3-5 \mathrm{~mm}$. long; leaf blades elliptic to oblong-elliptic, 3-5 × 1.5-2.5 cm., obtuse at base, rounded to subemarginate at apex, the latera! nerves 4-6 per side; corolla tube about twice as long as lobes. ......... 7. G. calcicola 
Vegetative indument lacking, or if sparsely present composed of unicellular hairs (an occasional multicellular hair sometimes sporadically present), these never copious nor congested; corolla tube about as long as lobes.

Leaf blades lanceolate to elliptic- or oblong-ovate, $(1.5-)$ 3-14 (-16) $\times 1-4.5(-6) \mathrm{cm} .,(2.5-)$ 3-4 times longer than broad, attenuate or long-attenuate to a sharply acuminate or narrowly acute apex.

8. G. rupestre

Leaf blades ovate to elliptic or elliptic-obovate, (2-) 4-10 (-13) $\times(1-) 2.5-6(-7) \mathrm{cm} ., 2(-2.5)$ times longer than broad, rounded, obtuse, or slightly retuse at apex (infrequently broadly acute or

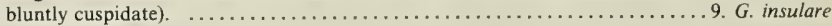

1. Geniostoma macrophyllum Gillespie in Bishop Mus. Bull. 91:25. fig. 28. 1932; A. C. Sm. \& Stone in Contr. U. S. Nat. Herb. 37: 10. pl. 1, fig. 1; pl. 2, fig. 1-3. 1962; J. W. Parham, Pl. Fiji Isl. 178. 1964, ed. 2. 253. 1972; Conn in Blumea 26: 349. fig. 27. 1980.

Figure 2.

A slender tree 3-10 m. high, with a trunk 4-10 (rarely to 25 ) $\mathrm{cm}$. in diameter and with large, complex inflorescences borne on the trunk often near the ground, found in dense, wet forest at elevations from near sea level to $850 \mathrm{~m}$. Flowers and fruits have been collected between May and December.

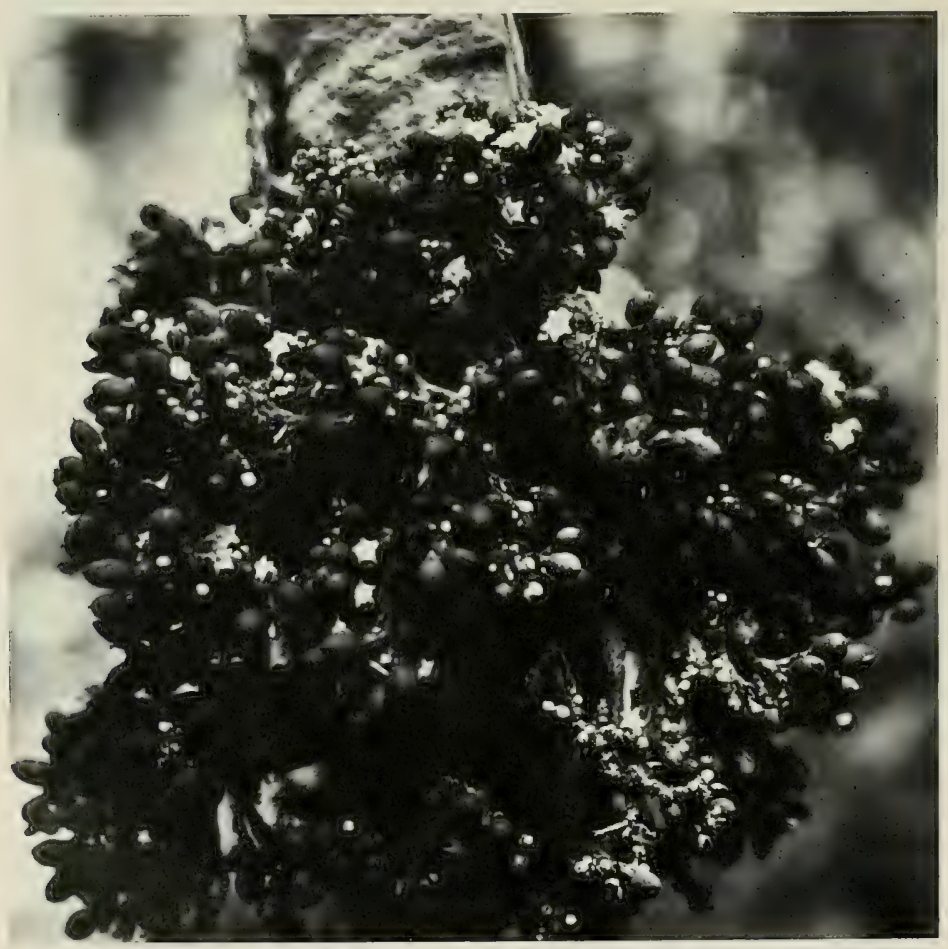

Figure 2. Geniostoma macrophyllum, from Namosi Province, Viti Levu (Smith 8899); infructescences, with some persisting flowers, aggregated on the trunk of a slender tree, approximately natural size. 
TYPIFICATION: This remarkably distinct species is based on Gillespie 3638 (BISH HOLOTYPE; ISOTYPES at GH, UC), collected Oct. 29, 1927, in the vicinity of Nasinu, Naitasiri Province, Viti Levu.

Distribution: Endemic to Fiji and known from Viti Levu, Ovalau, and Vanua Levu, but apparently frequent only in southeastern Viti Levu; 24 collections are now at hand.

RePRESENTATIVE COLleCtions: VITI LEVU: MBA: Hills between Nandala and Nukunuku Creeks, along trail from Nandarivatu toward Lewa, Smith 6168. SERUA: Hills along coastal road, Greenwood 976A. Namosi: Hills east of Wainikoroiluva River, near Namuamua, Smith 8899. NAITASIRI: Vicinity of Viria, Parks 2046I; Tamavua-Sawani road, Setchell \& Parks 15071; Savura Creek, DA 1255I. NAITASIRI-RewA boundary: Mt. Kombalevu, Parks 20317. RewA: Mt. Korombamba, Gillespie 2997. OVALAU: Mt. Tana Lailai, Graeffe, in 1864 (earliest known collection); summit of main range west of Levuka, Gillespie 4449. VANUA LEVU: Thakaundrove: Southern slope of Korotini Range, below Navitho Pass, Smith 573.

This species and the next seem not to be recognized as true members of the genus by Fijians, as the names firmly applied to Geniostoma in Fiji (mboimboinda and variants) are not utilized for them.

2. Geniostoma stipulare A. C. Sm. \& Stone in Contr. U. S. Nat. Herb. 37: 12. pl. 1, fig. 2; pl. 2, fig. 4-9. 1962; J. W. Parham, Pl. Fiji Isl. 178. 1964, ed. 2. 253. 1972; Conn in Blumea 26: 348. 1980.

Figure 1A.

A slender shrub or tree $1-5 \mathrm{~m}$. high, with usually ramuline inflorescences, infrequent in dense forest at elevations of $100-1,075 \mathrm{~m}$. Flowers have been noted only in November, fruits in June, September, and November.

Typification: The type is Smith 9148 (Us 2192146 \& 2336118 HolotyPE; many ISOTYPES), obtained Nov. 2, 1953, in hills east of Navua River, near Nukusere, Serua Province, Viti Levu.

Distribution: Endemic to Fiji and thus far known from only four collections from Viti Levu and Vanua Levu. From these same four collections, Conn (1980, p. 349) concluded: "often associated with disturbed areas, such as next to walking tracks. Altitude 100-500 m." Actually the known localities are in forest as undisturbed as can be found in Fiji.

Available Collections: VITI LEVU: Namosi: Mt. Naitarandamu, Gillespie 3364; track to Mt. Vakarongasiu, DA 16111. VANUA LEVU: ThaKaundrove: Mt. Ndikeva, eastern buttress, Smith 1860 .

3. Geniostoma confertiflorum A. C. Sm. \& Stone in Contr. U. S. Nat. Herb. 37: 14. pl. 1, fig. 3; pl. 2, fig. 15, 16. 1962; J. W. Parham, Pl. Fiji Isl. 178. 1964, ed. 2. 251. 1972.

Figures 3A, 4A, 6A, 7A.

Geniostoma rupestre var. rupestre group $A$ Conn in Blumea 26: 289, p. p. 1980.

Tree $2-10 \mathrm{~m}$. high, with a trunk up to $5 \mathrm{~cm}$. in diameter, occurring in open to dense forest, sometimes on ridges or in rocky areas, at elevations from near sea level to $626 \mathrm{~m}$. Flowers and fruits have been noted between May and September.

TYPIFICATION: The type is Smith 8488 (us 2191173 HOLOTYPE; many ISOTYPES), collected Sept. 14, 1953, in hills north of Wainavindrau Creek, between Korombasambasanga Range and Mt. Naitarandamu, Namosi Province, Viti Levu.

Distribution: Endemic to Fiji and known from four of the high islands.

AVAilable Collections: VITI LEVU: SeRuA: Inland from Namboutini, DA 13873 (DF 153, Bola 44); Mbuyombuyo, near Namboutini, Tabualewa 15593; hills west of Waivunu Creek, between Ngaloa and Korovou, Smith 9240. NaITASIRI: Tholo-i-suva, DF 441 (Bola 136); Central road, Tothill 611: vicinity of Tamavua, Gillespie 2059; vicinity of Nasinu, Gillespie 3637. RewA: Namboro, DA 5920; Veisari, DA 10994; vicinity of Lami, Gillespie 2317. OVALAU: Summit of Mt. Ndelaiovalau and adjacent ridge, Smith 7381 , 7621. NGAU: Slopes of Mt. Ndelaitho, on northern spur toward Navukailangi, Smith 7878; hills east of Herald Bay, inland from Sawaieke, Smith 7744. TAVEUNI: Wainisavu, Nggeleni, DA 14402. 
Of the three species (here numbered 3-5) excluded from Conn's catch-all Geniostoma rupestre var. rupestre group $A$ because of their comparatively simple corolla venation, $G$. confertiflorum and $G$. clavigerum are further characterized by their large corollas and elongate stigmas.

4. Geniostoma clavigerum A. C. Sm. \& Stone in Contr. U. S. Nat. Herb. 37: 16. pl. 1, fig. 4. 1962; J. W. Parham, Pl. Fiji Isl. 178. 1964, ed. 2. 251. 1972.

Figures 4B, 6B, 7B.

Geniostoma rupestre sensu Gibbs in J. Linn. Soc. Bot. 39: 157, p. p. 1909; non J. R. \& G. Forst.

Geniostoma rupestre var. rupestre group $A$ Conn in Blumea 26: 289, p. p. 1980.

Tree (2-) 4-10 m. high, found in dense, wet forest at elevations of $800-1,190 \mathrm{~m}$. Flowers and fruits have been observed between August and January.

TyPification: The type is Gillespie 3916 (BISH HOLOTYPE; ISOTYPES at K, UC), collected Nov. 21, 1927, on lower slopes of Mt. Nanggaranambuluta, east of Nandarivatu, Mba Province, Viti Levu.

Distribution: Endemic to Fiji and thus far known only from northwestern Viti Levu.

Available Collections: VITI LEVU: Mba: Mt. Koroyanitu, Mt. Evans Range, DA 14151; vicinity of Nandarivatu, Gibbs 724, DA 13012; Mt. Nanggaranambuluta, east of Nandarivatu, Gillespie 3782, 4334. DA 10404, 13549, 14455, 14671 .

5. Geniostoma uninervium A. C. Sm. \& Stone in Contr. U. S. Nat. Herb. 37: 17. pl. 1, fig. 5; pl. 2, fig. 10-14. 1962; J. W. Parham, Pl. Fiji Isl. 178. 1964, ed. 2. 253. 1972.

Figures 3B, 4C, 7C.

Geniostoma rupestre var. rupestre group A Conn in Blumea 26: 289, p. p. 1980.

An often slender tree (2-) 3-10 m. high, known from dense or secondary forest or from thickets at elevations of $100-1,240 \mathrm{~m}$. Flowers and fruits occur throughout the year.

TYPIFICATION: The species is based on Smith 8437 (US 2191135 HOLOTYPE; many ISOTYPES), obtained Sept. 11, 1953, in hills north of Wainavindrau Creek, between Korombasambasanga Range and Mt. Naitarandamu, Namosi Province, Viti Levu.

Distribution: Endemic to Fiji and now known from four of the high islands.

Available Collections: VITI LEVU: SeRuA: Upper Navua River, DA 14877, 14879, 15521. Namosi: Wainikoroiluva River, between Nanggarawai and Saliandrau, Gillespie 3217; Mt. Vakarongasiur, $D A$ 14599, 14705, 16136. NAITASIRI: Track to Mendrausuthu Range, DA 15023; Waimanu River, DA 15597. TaIlevu: Hills east of Wainimbuka River, vicinity of Ndakuivuna, Smith 7099. RewA: Mt. Korombamba, Gillespie 2295. OVALAU: Hills west of Lovoni Valley, on ridge south of Mt. Korolevu, Smith 7527. VANUA LEVU: Mbua: Track to Mt. Seatura, DA 17535. Thakaundrove: Mt. Mariko, Smith 461. TAVEUNI: Summit of Mt. Uluingalau, Smith 896.

6. Geniostoma vitiense Gilg \& Benedict in Bot. Jahrb. 56: 542. 1921; A. C. Sm. in Sargentia 1: 97. 1942; Yuncker in Bishop Mus. Bull. 220: 216. 1959; A. C. Sm. \& Stone in Contr. U. S. Nat. Herb. 37: 18. pl. 1, fig. 6; pl. 2, fig. 21-23; pl. 3, fig. 12-15. 1962; J. W. Parham, Pl. Fiji Isl. 179. 1964, ed. 2. 253. 1972; Sykes in New Zealand Dept. Sci. Indust. Res. Bull. 200: 109. 1970. Figures 5A, 6C, 8A.

Geniostoma crassifolium var. glaberrimum Benth. in J. Proc. Linn. Soc. Bot. 1: 97. 1856.

Geniostoma rupestre var. puberulum A. Gray in Proc. Amer. Acad. Arts 4: 321, nom. nud. 1859, in op. cit. 5: 320, nom. nud. 1862, in Bonplandia 10: 37, nom. nud. 1862; Seem. Viti, 439, nom. nud. 1862.

Figure 3. A, Geniostoma confertiflorum; branchlet showing inflorescences and leaf bases, $\times 1 . \mathrm{B}$, Geniostoma uninervium; branchlet showing foliage and inflorescences, $\times 1$. C \& D, Geniostoma calcicola; C, branchlet showing foliage and an inflorescence, $\times 1$; D, upper surface and margin of leaf blade, showing indument of many-celled hairs, $\times 30$. A from Smith 8488, B from Smith 46I, C \& D from Smith 1116 . 

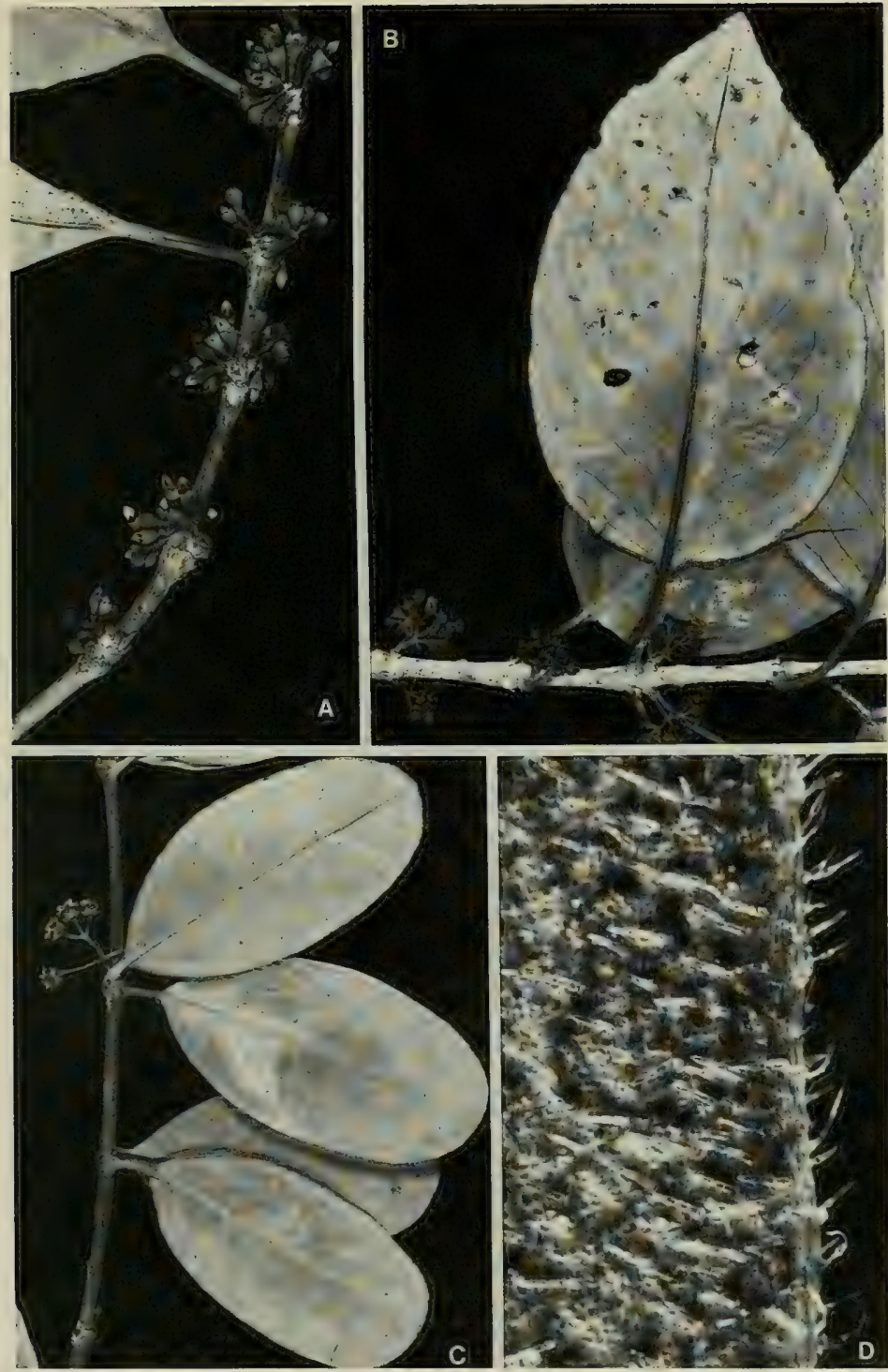

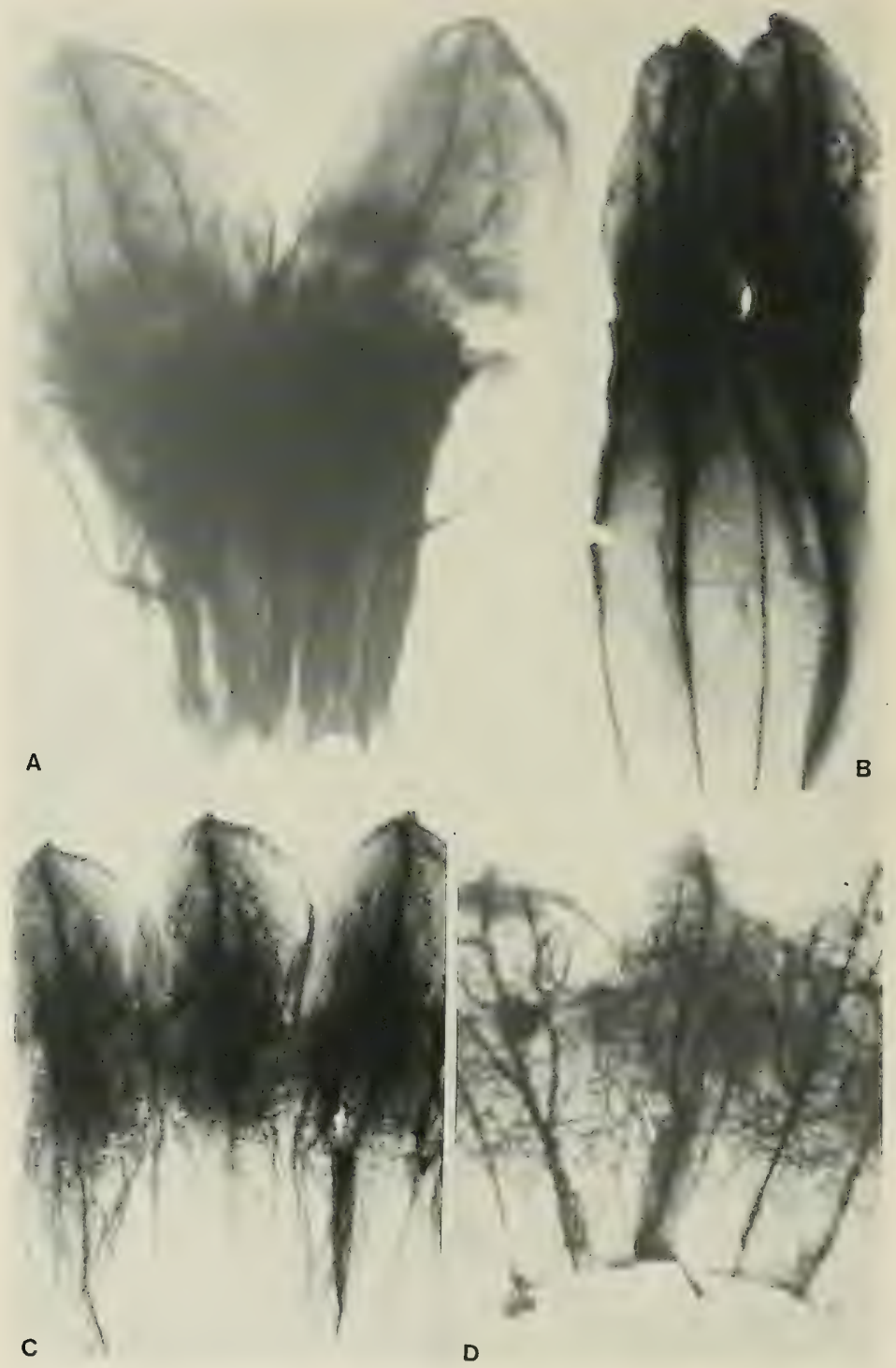
Geniostoma rupestre sensu Seem. in Bonplandia 9:257. 1861, Viti, 439. 1862, Fl. Vit. 164, 1866; Drake, Il]. Fl. Ins. Mar. Pac. 236, p. p. 1892; Gibbs in J. Linn. Soc. Bot. 39: 157, p. p. 1909; Yuncker in Bishop Mus. Bull. 178: 95. 1943; non J. R. \& G. Forst.

Geniostoma crassifolium sensu Seem. in Bonplandia 9:257. 1861; A. Gray in op. cit. 10:37. 1862, in Proc. Amer. Acad. Arts 5: 320. 1862; non Benth.

Geniostoma calcicola sensu Yuncker in Bishop Mus. Bull. 220: 215. 1959; non A. C. Sm.

Geniostoma insulare var. 1ongense A. C. Sm. \& Stone in Contr. U. S. Nat. Herb. 37: 39. 1962; Sykes in

New Zealand Dept. Sci. Indust. Res. Bull. 200: 109. 1970.

Geniostoma rupestre var. rupestre group E Conn in Blumea 26: 292. 1980.

Geniostoma rupestre var. glaberrimum Conn in Blumea 26: 302, quoad lectotypum. 1980.

Geniostoma rupestre var. tongense Conn in Blumea 26: 308, excl. G. calcicola et fig. 11, A-G. 1980.

Shrub or tree 2-12 m. high, often slender or freely branched and with branches often curved and pendent, with a trunk to $8 \mathrm{~cm}$. in diameter, sometimes frequent at elevations from near sea level to about $1,150 \mathrm{~m}$. in dry or secondary forest, in coastal thickets, and in open hilly areas. Inflorescences and fruits occur throughout the year.

TyPIFICATION: Geniostoma vitiense is typified by Seemann 301 ( B HOLOTYPE probably destroyed; K LECTOTYPE here designated; ISOTYPES at BM, GH), collected in 1860 in Fiji without specified locality.

In describing Geniostoma crassifolium var. glaberrimum, Bentham cited two Milne localities. One of these is represented by Milne 270 (K LECTOTYPE), from Ovalau. This collection had been indicated as the "type" by Smith and Stone (1962, p. 20), in spite of which Conn (1980, p. 279) designated as "lectotype" a third collection listed by Bentham (1856) as "et ins. Sandwich teste herb. Hooker, sed hic forte latet error quidam." Such designation of a specimen of questionable provenance seems unsuitable, especially as it sets aside an earlier suitable lectotypification. The other Milne collection mentioned by Bentham is Milne $163(\mathrm{~K})$, from Ngau, mounted on the same sheet as Milne 271. Geniostoma rupestre var. glaberrimum Conn is here placed in accord with the identity of the appropriate lectotype, although Conn's concept (exclusive of the Milne lectotype) seems to refer in part to $G$. insulare (as here construed).

The source of the name Geniostoma rupestre var. puberulum A. Gray, never formally described, is U.S. Expl. Exped. (GH, K, NY, US), from Vanua Levu without further locality.

Geniostoma insulare var. tongense is based on Parks 16261 (UC 297257 HOLOTYPE; ISOTYPES at BISH, GH, Us), collected on the plateau on 'Eua, Tonga, in June or July, 1926.

Distribution: Frequent in Fiji, Tonga, and on Niue; 65 Fijian collections from six islands may be here referred, but the species is to be anticipated on other islands.

RePRESENTATIVE COLLections: YASAWAS: WAYA: Olo Creek, north of Yalombi, St. John 18018. VITI LEVU: MBA: Mt. Koroyanitu, Mt. Evans Range, DA 14139; north of Lomolomo, Degener \& Ordonez 13650: Nandarivatu, Gibbs 555, p. p. Nandronga \& Navosa: Above Nathotholevu, H. B. R. Parham 246. Serua: Hills between Navua River and Wainiyavu Creek, near Namuamua. Smith 8986. Namosi: Valley of Wainambua Creek, south of Mt. Naitarandamu, Smith 8767. RA: Vicinity of Rewasa, near Vaileka, Degener 15461. NaITASıRI: Near Korosuli, Wainimala River, Horne 978; vicinity of Nasinu, Gillespie 3493. Rewa: Near Suva, Yeoward 100. OVALAU: Port Kinnaird, Seemann 300. NGAU: Shore of Herald Bay, vicinity of Sawaieke, Smith 8000 . VANUA LEVU: Mbua: Rukuruku Bay, H. B. R. Parham 5. Mathuata: Summit ridge of Mt. Numbuiloa, east of Lambasa, Smith 6507. THAKaUndrove: Eastern drainage of Yanawai River, Degener \& Ordonez 14104. TAVEUNI: Vicinity of Wairiki, Gillespie 4400.2.

FIgURE 4. Venation of corolla tube and lobes, all $\times 20$. A, Geniostoma confertiflorum, from Smith 8488. B, Geniostoma clavigerum, from DA 14455. C, Geniostoma uninervium, from Smith 7099. D, Geniostoma calcicola, from Smith 1116. 
Geniostoma vitiense differs sharply from a reasonable concept of $G$. rupestre in the invariable presence of congested, usually minute but several-many-celled hairs on young parts, distal internodes, young petioles, etc. The exclusion of Milne 270 (taken as a "syntype" of G. crassifolium var. glaberrimum by Conn, 1980, p. 292) from this concept seems unwarranted. Some of the Tongan representatives have a tendency toward less congested vegetative indument, the hairs being sometimes slightly longer than those of Fijian specimens, and the leaf blades being bluntly obtuse rather than typically acuminate. However, the prevalent Fijian form, with very congested, short indument and acuminate leaf blades, also frequently occurs in Tonga. Thus, $G$. insulare var. tongense ( $G$. rupestre var. tongense Conn) seems scarcely to be separable from $G$. vitiense.

7. Geniostoma calcicola A. C. Sm. in Sargentia 1: 99. 1942; A. C. Sm. \& Stone in Contr. U. S. Nat. Herb. 37: 26. pl. 1, fig. 9; pl. 2, fig. 24. 1962; J. W. Parham, Pl. Fiji Isl. 178. 1964, ed. 2. 251. 1972. Figures 3C \& D, 4D, 6D.

Geniostoma sp. A. C. Sm. in Bishop Mus. Bull. 141: 125. 1936.

Geniostoma rupestre var. tongense Conn in Blumea 26:308, p. p., quoad fig. 11, A-G. 1980.

An apparently rare scandent shrub about $50 \mathrm{~cm}$. high found on a cliff face in limestone formation near sea level. The only known collection was flowering in February.

TyPIFICATION: The type is Smith 1116 (GH HOLOTYPE; many ISOTYPES), collected Feb. 22, 1934, near Monothaki, Fulanga.

Distribution: Known only from the original collection.

Although it is distasteful to many botanists to acknowledge a species represented by a single collection, I find no reasonable way to incorporate Geniostoma calcicola into any other taxon. Its separation from the New Caledonian $G$. crassifolium Benth. was discussed by Smith and Stone (1962). It is also related in its indument to G. vitiense (including $G$. insulare var. tongense), differing in its rounded leaf blades being copiously pilose on both surfaces (FIGURE 3D). Conn (1980, p. 308) included G. calcicola (and illustrated it in his fig. $11, A-G$ ) in his varietal concept $G$. rupestre var. tongense. The latter is correctly to be excluded from $G$. insulare, the other elements of which were unaccountably placed by Conn in $G$. rupestre var. glaberrimum ( $=G$. vitiense in the present treatment). While $G$. insulare var. tongense seems well placed in a reasonab̆le concept of $G$. vitiense, the nomenclaturally typical element of $G$. insulare must be excluded from that.

8. Geniostoma rupestre J. R. \& G. Forst. Char. Gen. Pl. 12. t. 12, as G. rupestris. 1775, ed. 2. 24. t. 12, as G. rupestris. 1776; Gibbs in J. Linn. Soc. Bot. 39: 157, p. p. 1909; Gilg \& Benedict in Bot. Jahrb. 56: 542. 1921; Guillaumin in Bull. Soc. Bot. France 72: 701. 1927, in op. cit. 76: 299. 1929, in J. Arnold Arb. 13: 22. 1932, in J. Linn. Soc. Bot. 51: 557. 1938; A. C. Sm. \& Stone in Contr. U. S. Nat. Herb. 37: 34. pl. 1, fig. 14. 1962; Conn in Blumea 26: 278, p. p. 1980.

\section{Figures 1B, 5B \& C, 6E \& F, 7D, 8B-D.}

Plectronia mcgregori Horne, A Year in Fiji, 266, nom. nud. 1881.

Plectronia macgregori Horne ex Baker in J. Linn. Soc. Bot. 20: 363. 1883; Drake, 1ll. Fl. Ins. Mar. Pac. 194. 1890.

Geniostoma stenocarpum A. C. Sm. in Sargentia 1:98. 1942; A. C. Sm. \& Stone in Contr. U. S. Nat. Herb. 37: 29. pl. I, fig. 12; pl. 3, fig. 7, 8. 1962; J. W. Parham, Pl. Fiji Isl. 178. 1964, ed. 2. 253. 1972.

Geniostoma macgregorii A. C. Sm. \& Stone in Contr. U. S. Nat. Herb. 37:23. pl. 1, fig. 8; pl. 2, fig. 17-19. 1962; J. W. Parham, Pl. Fiji Isl. 178. 1964, ed. 2. 251. 1972. 

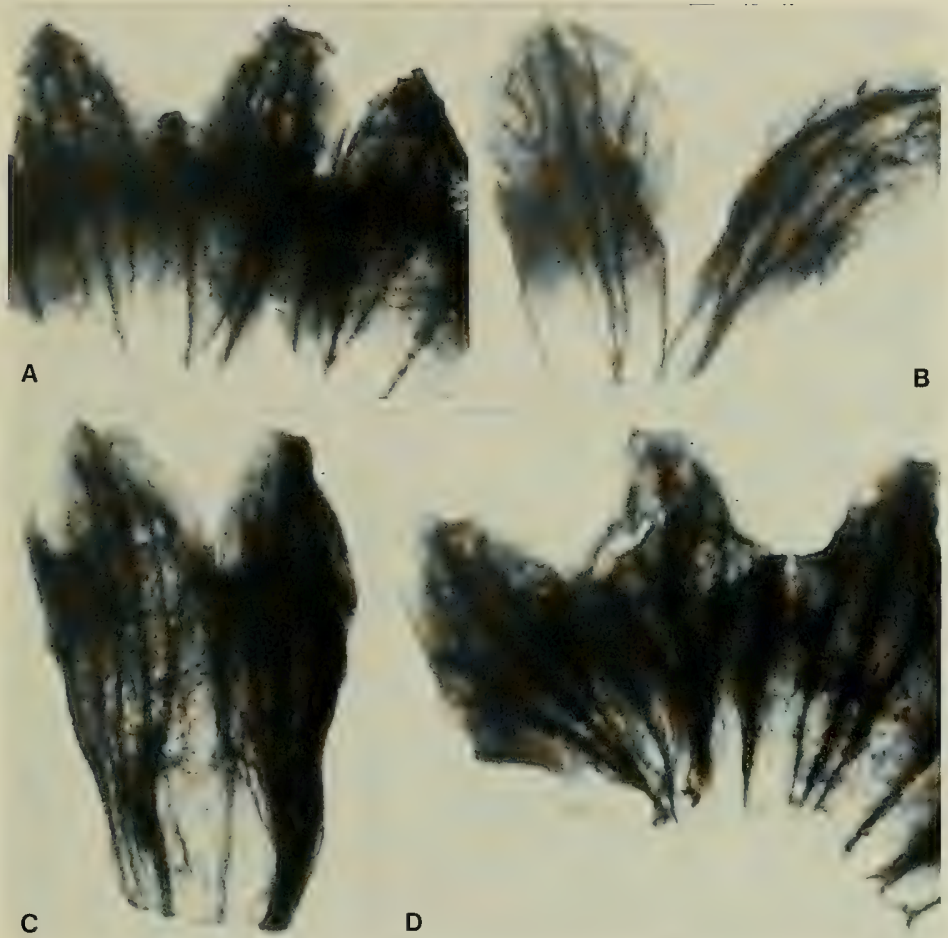

Figure 5. Venation of corolla tube and lobes, all $\times 20$. A, Geniostoma visiense, from Gillespie 3493. B \& C, Geniostoma rupestre, from Degener \& Ordonez 13591 and Smith 668. D, Geniostoma insulare, from Smith 7814.

Geniostoma insulare var, insulare f. cuspidatum A. C. Sm. \& Stone in Contr. U. S. Nat. Herb. 37: 39. 1962.

Geniostoma rupestre var. rupestre group $A$ Conn in Blumea 26: 289, p. p. et fig. 6. 1980.

Shrub or slender tree $2-10 \mathrm{~m}$. high, often abundant from near sea level to an elevation of $500(-1,190) \mathrm{m}$. in dense, open, or dry forest, often on ridges, in thickets on open slopes, and in the forest-grassland transition. Flowers and fruits do not appear seasonal.

TYPIFICATION: Geniostoma rupestre was based on J. R. \& G. Forster "103" (BM LECTOTYPE; ISOLECTOTYPE at K), collected during Cook's second voyage on Tanna, New Hebrides. The type of Plectronia macgregori (sic) is Horne 261 ( $\mathrm{K}$ HOLOTYPE; ISOTYPE at GH), collected in January, 1878, in the mountains of Ovalau (the number was erroneously cited as 227 by Baker in 1883). The type of $G$. stenocarpum is Degener \& Ordonez 13591 (A HOLOTYPE; many ISOTYPES), obtained Nov. 22, 1940, near Nandari- 

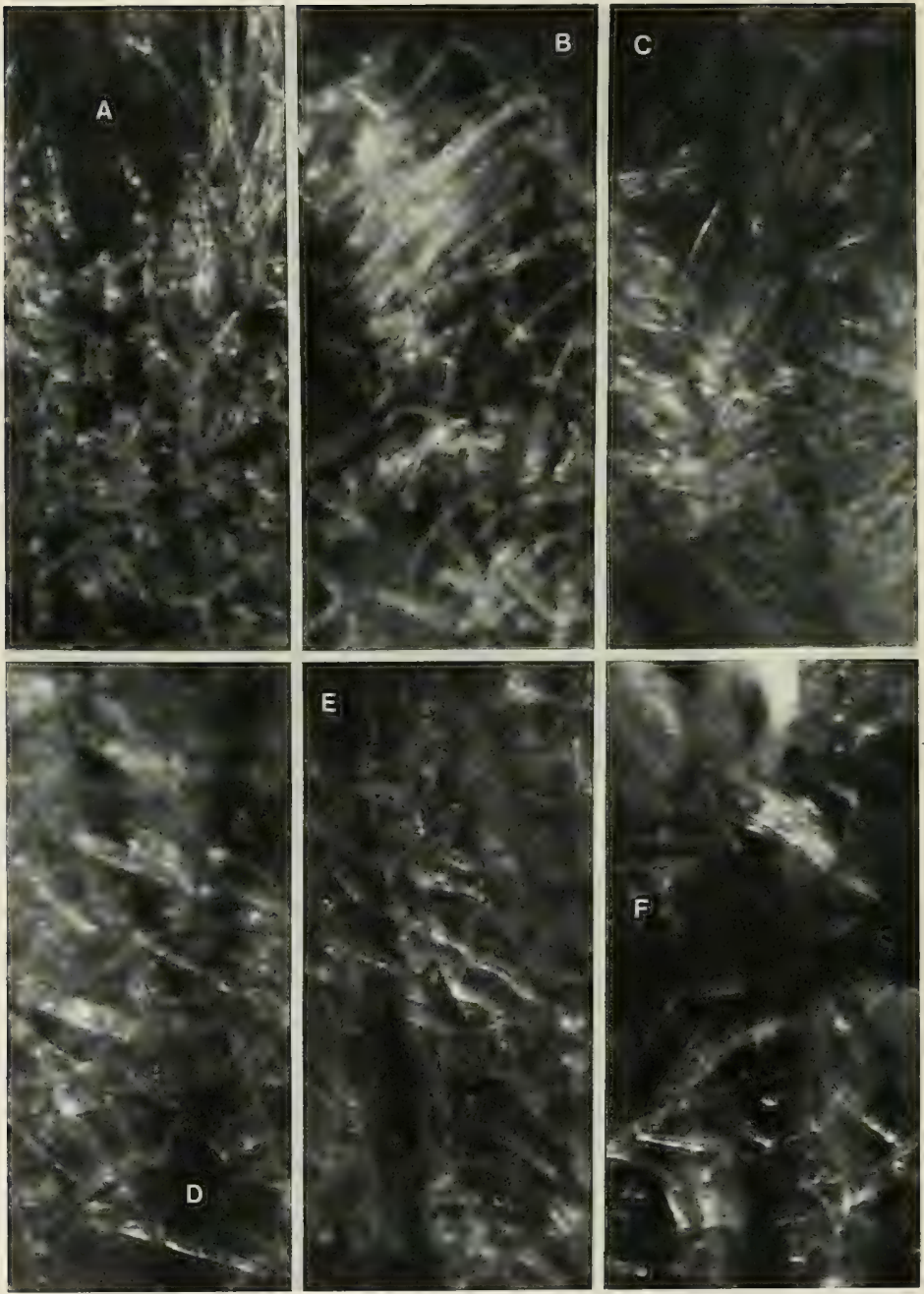

Figure 6. Indument within corolla tube and throat, all $\times 70$. A, Geniostoma confertiflorum, from Smith 8488. B, Geniostoma clavigerum, from DA 14455. C, Geniostoma vitiense, from Gillespie 3493. D, Geniostoma calcicola, from Smith 1116. E \& F, Geniostoma rupestre, from Smith 668 and Degener \& Ordonez 13591 , the latter showing the pilose base of an anther. 
vatu, Mba Province, Viti Levu. Geniostoma insulare var. insulare f. cuspidatum is based on Christophersen 569 (BISH HOLOTYPE; ISOTYPE at UC), collected Sept. 6, 1929 , on Mt. Fao, Upolu, Samoa.

DistribuTION: Opinions as to the geographic limits of Geniostoma rupestre have ranged from those of Gilg and Benedict (1921) and Smith and Stone (1962), who believed it limited to the New Hebrides, Santa Cruz Islands, and perhaps New Caledonia, to that of Conn (1980), who treats it as a very polymorphic species with a range approaching that of the genus and including perhaps more than half of the known collections of Geniostoma. Conn's treatment is persuasive and doubtless will be accepted by many floristic students, as local populations, distinct from one another in a few minor characters, are found to be nearly duplicated in other parts of the range of the genus. Within the Fijian Region several local populations of Geniostoma sect. Geniostoma appear to have substance, although more careful examination than that of Smith and Stone (1962) does indeed suggest modifications of that. Typical $G$. rupestre is here interpreted to extend at least from the New Hebrides and Santa Cruz Islands eastward to Samoa; its extension beyond this area is indeed probable, but one may hesitate to assign to it essentially the generic range. In Fiji it is represented by about 85 collections from seven islands, but no doubt it occurs on many other islands in the group.

REPRESENTATIVE COLLeCtions: VITI LEVU: MBA: Mt. Koroyanitu, DA 14140; northern slopes of Mt. Namendre, east of Mt. Koromba, Smith 4554; vicinity of Nandarivatu, Gibbs 555, p. p., Degener \& Ordonez 13592. NANDRONGA \& NavosA: Northern portion of Rairaimatuku Plateau, between Nandrau and Rewasau, Smith 5394; near Mbelo and Vatukarasa, Degener 15296. SERUA: Vatutavathe, vicinity of Ngaloa, Degener 15206. Namosi: Coastal hills, Greenwood 541A. NAITASIRI: Viria, Meebold 16507; vicinity of Tamavua, Gillespie 2170. TAllevu: Naingani Island, DA 3347; Uthunivanua, DA 9251 (McKee 2817). REWA: Mt. Korombamba, DA 16509. KANDAVU: Hills above Namalata and Ngaloa Bays, Smith 132. OVALAU: Northwest of Levuka, Gillespie 4566. KORO: Tothill 612, p. p. VANUA LEVU: MATHUATA: Southern slopes of Mt. Numbuiloa, east of Lambasa, Smith 6576. THAKAUndRove: Southwestern slope of Mt. Mbatini, Smith 668. Matuku: Milne 128. KAMBARA: Central wooded basin, Bryan 504.

Geniostoma rupestre is here interpreted as the taxon with the following characteristics: habit completely glabrous (except for indument within corolla, sometimes on bases of anthers, and occasionally on margins of calyx lobes); stipules intrapetiolar, forming a sheath not more than $2 \mathrm{~mm}$. long (FIGURE 1B); leaf blades lanceolate to narrowly ovate-elliptic, tapering to an acuminate apex (FIGURE 8C); inflorescences comparatively few-flowered and usually axillary, rarely ramuline, sometimes freely branching from base (FIGURES 1B, 8D); corolla 2.5-4 mm. long, copiously pilose with multicellular hairs within the tube and at throat, the lobes about as long as the tube, the principal nerves branching from base of tube or within it and freely branching in the lobes (FIgURES 5B \& C); gynoecium completely glabrous, the stigma subglobose to bilobed but scarcely longer than broad (FIgURES 7D, 8B); fruit variable in shape, usually ellipsoid and 2-3.5 times longer than broad (FIGURE 8D).

Adherence to this interpretation will exclude from Geniostoma rupestre many varieties and groups incorporated by Conn (1980, pp. 286-312), for instance those taxa with the gynoecium pilose, without corolla indument on the inner surface of the tube, or with several-many-celled hairs on vegetative parts. Interpretation of $G$. rupestre as here suggested will doubtless seem unacceptable to those who prefer to utilize polynomial nomenclatural terminology within vague coenospecies.

As length of the hairs composing the indument within the corolla seems of minor consequence (Conn, 1980, p. 252), Geniostoma macgregorii may be synonymized with $G$. rupestre; it agrees well with the typical phase of that species from the New Hebrides. 
Geniostoma stenocarpum, as noted by Conn (1980, p. 289), is to be distinguished from typical $G$. rupestre only by its smaller, narrower leaf blades, and it may be dismissed as a primarily montane form, abundant in the uplands of northern Viti Levu; the few pilose specimens noted by Smith and Stone (1962, p. 31) seem better referred to G. vitiense.

Probably Geniostoma insulare var. insulare f. cuspidatum, although not entirely typical, is referable to $G$. rupestre rather than to $G$. insulare. The latter is thus limited to Tonga and Fiji. Other Samoan collections referred by Smith and Stone (1962) to $G$. gracile Rechinger, $G$. fleischmannii Rechinger, $G$. samoense Reinecke, and $G$. biseriale Rechinger appear to me to have combinations of characters that exclude them from $G$. rupestre, although Conn (1980) has so placed all these Samoan taxa except the last, which he retains as a species.

9. Geniostoma insulare A. C. Sm. \& Stone in Contr. U. S. Nat. Herb. 37: 36. pl. 1, fig. 15. 1962.

Figures 5D, 8E.

Geniostoma rupestre var. ellipticum A. Gray in Proc. Amer. Acad. Arts 4: 321, nom. nud. 1859.

Geniostoma fleischmannii sensu Yuncker in Bishop Mus. Bull. 220: 216. 1959; non Rechinger.

Geniostoma rupestre sensu Yuncker in Bishop Mus. Bull. 220: 216. 1959; non J. R. \& G. Forst.

Geniostoma dictyoneurum A. C. Sm. \& Stone in Contr. U. S. Nat. Herb. 37: 27. pl. 1. fig. 10. 1962; J. W. Parham, Pl. Fiji Isl. 178. 1964, ed. 2. 251. 1972.

Geniostoma insulare var, insulare f. insulare; A. C. Sm. \& Stone in Contr. U. S. Nat. Herb. 37: 38, 1962; J. W. Parham, Pl. Fiji Isl. 178. 1964, ed. 2. 251. 1972.

Geniostoma insulare var. insulare f. sphaerococcum A. C. Sm. \& Stone in Contr. U. S. Nat. Herb. $37: 38$. pl. 2, fig. 20. 1962; J. W. Parham, Pl. Fiji Isl. 178. 1964, ed. 2. 251. 1972.

Geniostoma rupestre var. glaberrimum Conn in Blumea 26: 302, p. p. 1980.

Shrub or slender tree $(0.5-)$ 2- $15 \mathrm{~m}$. high, found from near sea level to $450 \mathrm{~m}$. in forest, thickets, patches of forest in open country, and often on rocky areas or sea cliffs on limestone. In Fiji flowers have been recorded only in February in June, fruits between October and February.

Typification: The type of Geniostoma insulare is Setchell \& Parks 15334 (UC 296979 HOLOTYPE; ISOTYPES at BISH, GH, K, US), collected between June and August, 1926, near Nukualofa, Tongatapu, Tonga. The undescribed G. rupestre var. ellipticum was based upon U.S. Expl. Exped. (GH, NY), collected in Tonga without precise locality. The type of $G$. dictyoneurum is Smith 7814 (US 2190641 HoLOTYPE; many ISOTYPES), obtained June 18, 1953, in hills east of Herald Bay, inland from Sawaieke, Ngau. Geniostoma insulare var. insulare f. sphaerococcum is based on Smith 112 (US 1674613 HOLOTYPE; many ISOTYPES), collected Oct. 14, 1933, in hills above Namalata and Ngaloa Bays, Kandavu.

Distribution: Fiji and Tonga; in Fiji it has been noted on six islands but is infrequent; in Tonga the species is probably more abundant.

Available Collections: KANDAVU: Tothill 614; hills above Namalata and Ngaloa Bays, Smith 71. KORO: Tothill 612, p. p. (BISH); east coast, Smith 1037. VANUA LEVU: MATHUATA: Natua and vicinity, Seanggangga area, DA 12856,13582 , p. p.; Nanggengge Valley, DA 10510. ThaKaUndrove: Maravu, near Salt Lake, Degener \& Ordonez 14170. VANUA MBALAVU: Nambavatu, northern limestone section, Tothill 615. FULANGA: On limestone, Smith 1142, 1203. Fij without further locality, U. S. Expl. Exped. (Us).

I am now inclined to agree with Conn (1980) that the distinctions between var. insulare formae insulare and sphaerococcum are not worth retaining at any level, but

Figure 7. Gynoecia, all $\times 25$. A, Geniostoma confertiflorum, from Smith 8488 . B, Geniostoma clavigerum, from DA 14455. C, Geniostoma uninervium, from Smith 8437. D, Geniostoma rupestre, with infrequent 4-lobed calyx, from Smith 668. 

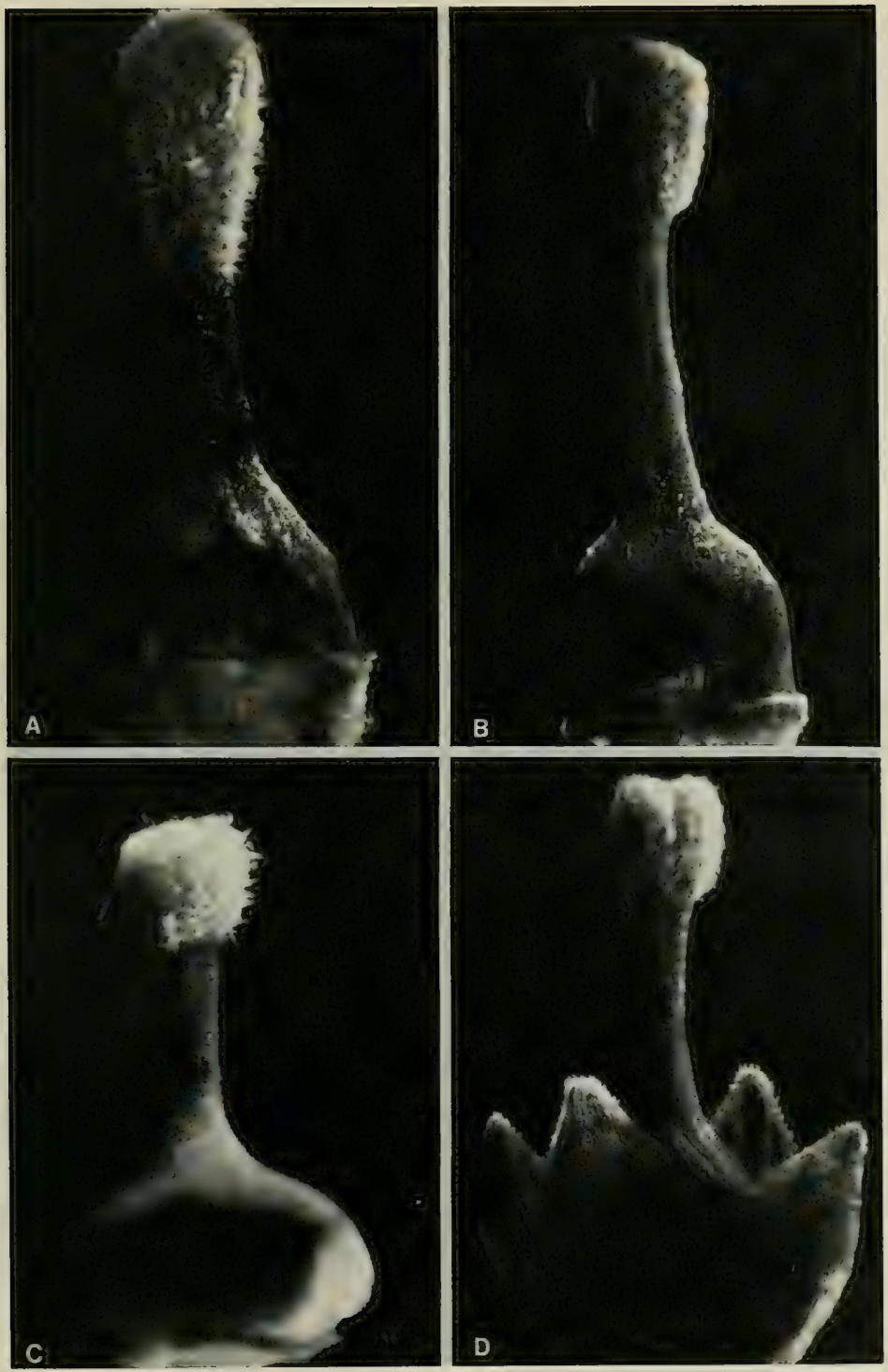
they are certainly not referable to Geniostoma rupestre var. glaberrimum $(=G$. vitiense in the sense of its lectotype). Reexamination of the corolla lobe venation of the type collection of $G$. dictyoneurum (FIGURE 5C) shows that the fine veins are free at their
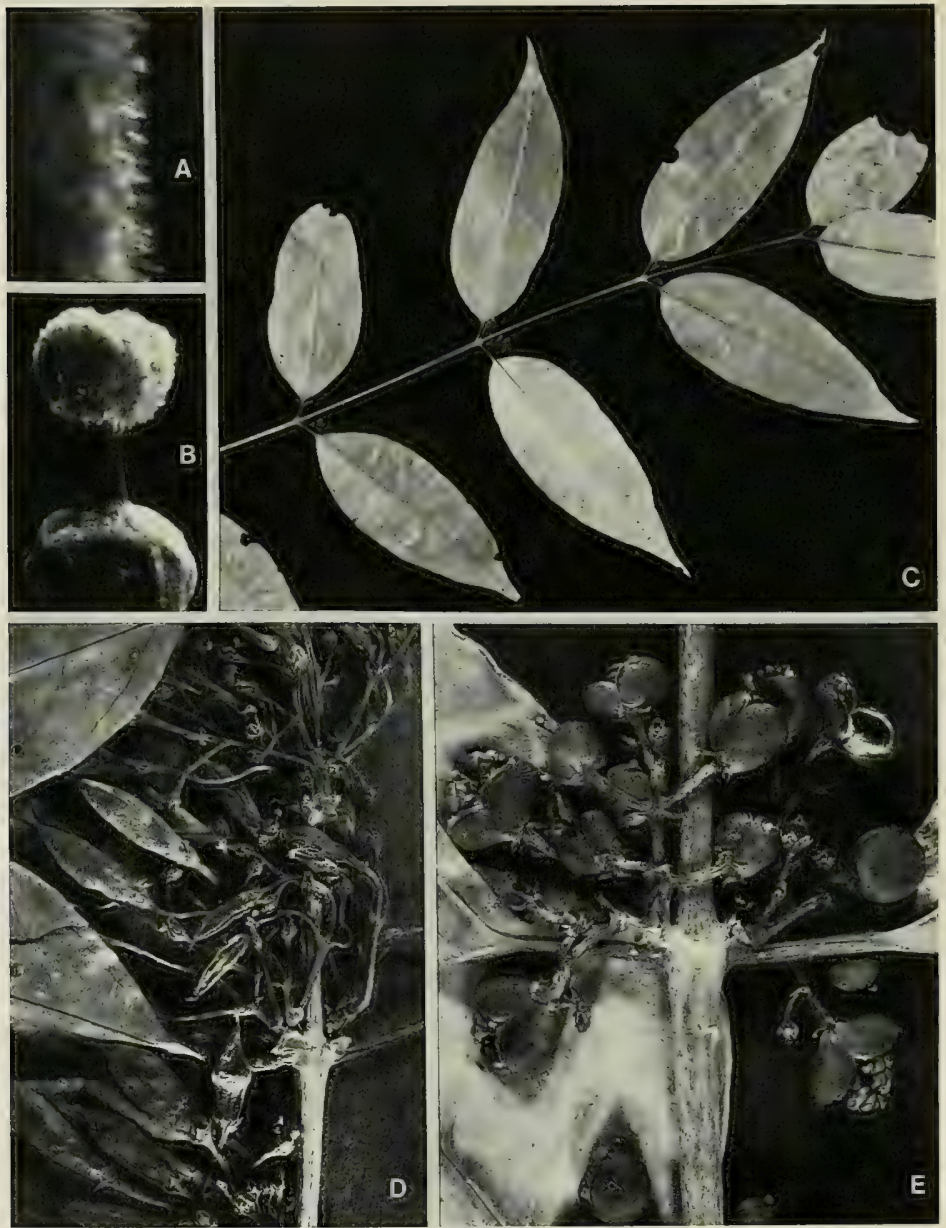

Figure 8. A, Geniostoma vitiense; indument of a distal internode, the hairs minute, congested, manycelled, $\times 70$. B-D, Geniostoma rupestre; B, gynoecium, $\times 25 ; \mathrm{C}$, distal portion of branchlet, with foliage and inflorescences, $\times 1 / 3 ; \mathrm{D}$, infructescences, $\times 2$. E, Geniostoma insulare; infructescences, $\times 2$. A from Smith 8767, B \& D from Degener \& Ordonez 13591, C from Smith 132, E from Smith 112. 
ultimate apices and do not form a real reticulum (as stated in the original description); no other characters indicate separation of $G$. dict $y$ oneurum from a reasonable concept of $G$. insulare.

\section{QUESTIONABLE TAXON}

Geniostoma microphyllum A. Gray in Bonplandia 10: 37, nom. nud., as G. microphylla. 1862; Seem. Viti, 439, nom. nud. 1862, Fl. Vit. 164. 1866; Drake, Ill. Fl. Ins. Mar. Pac. 237. 1892; A. C. Sm. \& Stone in Contr. U. S. Nat. Herb. 37: 41. 1962; Conn in Blumea 26: 356. 1980.

Gaertnera sp. Seem. in Bonplandia 9: 257. 1861.

Geniostoma A. Gray in Proc. Amer. Acad. Arts 5: 320. 1862.

A juvenile, glabrous plant, the thin stems appressed to tree trunks and with adventitious roots, the stipules forming an intrapetiolar sheath about $2 \mathrm{~mm}$. long, the petioles 1-2 mm. long, the leaf blades ovate-lanceolate, about $20 \times 6 \mathrm{~mm}$. and bluntly acuminate.

TyPification: The type is Seemann 304 (K HOLOTYPE; ISOTYPES at BM, GH), collected in 1860 along the Navua River, Serua Province, Viti Levu.

Available collection: VITI LEVU: Nattasiri: Central road, Tothill $61 /$ (K).

Since this juvenile form was actually described by Seemann in 1866, the name should be accounted for. Smith and Stone (1962) suggested that it might represent a juvenile form of a Psychotria, but actually the stipules are more suggestive of Geniostoma, although the sarmentose habit has not otherwise been observed in the Fijian Region. Possibly Gillespie's pencilled reference on the holotype to Geniostoma rupestre provides as good a guess as any.

2. Strychnos L. Sp. Pl. 189. 1753; Seem. Fl. Vit. 166. 1866; A. W. Hill in Kew Bull. 1911: 281. 1911, in op. cit. 1917: 121. 1917; A. C. Sm. in J. Arnold Arb. 36: 287. 1955; Leenh. in Fl. Males. I. 6: 343. 1963; Leeuwenb. \& Leenh. in Engl. \& Prantl, Nat. Pflanzenfam. ed. 2. 28bI: 35. 1980.

Shrubs, trees, or frequently lianas (often with curled or uncinate tendrils), armed or unarmed, glabrous or with indument of simple hairs, the stipules reduced to an interpetiolar ridge or essentially lacking; leaves opposite or ternate, petiolate to subsessile, the blades usually coriaceous, suborbicular to ovate, with 1-3 pairs of proximal secondary nerves curved from or near base and more obvious than the often obscure distal nerves; inflorescences terminal or axillary, thyrsoid, bracteate and bracteolate, the lower bracts sometimes leaflike, the flowers $\not, 1$-many, pedicellate or sessile, (4 or) 5-merous, actinomorphic (or calyx lobes unequal); calyx small, deeply divided, the lobes ovate or orbicular to linear; corolla rotate to hypocrateriform, somewhat thickened distally, sometimes with a corona at throat, the tube short or well developed, the lobes deltoid to oblong, valvate in bud, erect to recurved; stamens inserted on corolla tube, included or exserted, the filaments usually filiform, short to long, glabrous to pilose, the anthers orbicular to oblong or ovoid, introrse, cordate or sagittate at base, 2-locular; ovary 2-locular (sometimes incompletely so, or rarely 1-locular), the ovules few-many in each locule, the style cylindric to conical, included or exserted, persistent, the stigma usually capitate to inconspicuously 2-lobed; fruit a berry, subglobose to ellipsoid, the pericarp often becoming thick and hard, the pulp fleshy, the seeds I-many, large.

Lectoty Pe SPEcies: Strychnos nux-vomica (vide Hitchcock, Prop. Brit. Bot. 133. 1929). 
Distribution: Tropical and subtropical, with about 190 species (Leeuwenberg and Leenhouts, 1980); termination of the Pacific range of the genus with an endemic
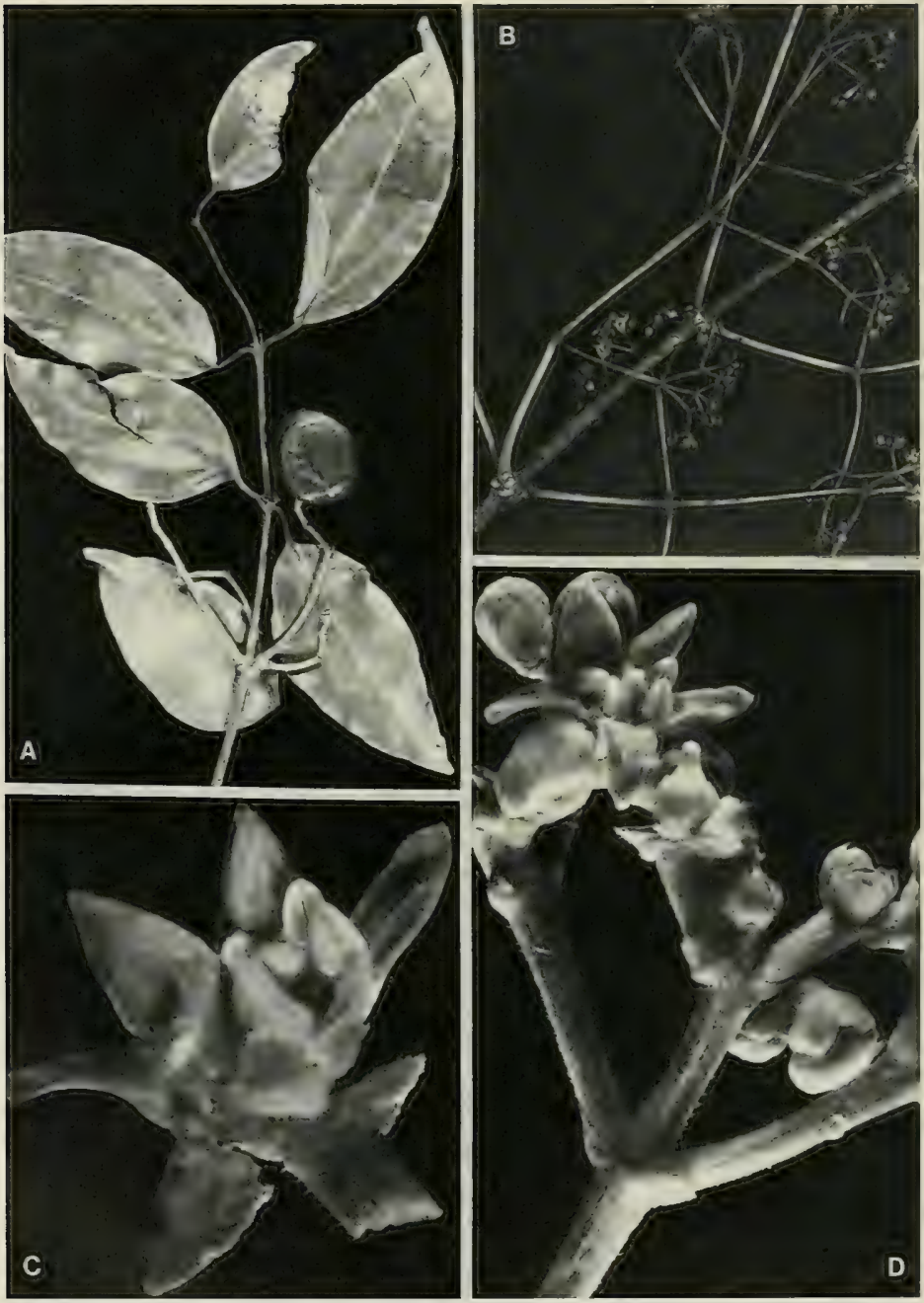

FIGURE 9. Strychnos vitiensis; A, distal portion of branchlet, with foliage and infructescences, $\times 1 / 2 ; \mathbf{B}$, inflorescences, $\times 1 ; \mathrm{C}$, flower with corolla spread open, one anther removed, $\times 14 ; \mathrm{D}$, cymules of inflorescence, with one flower at anthesis, $\times 8$. A from Smith 9468, B-D from Smith 6198. 

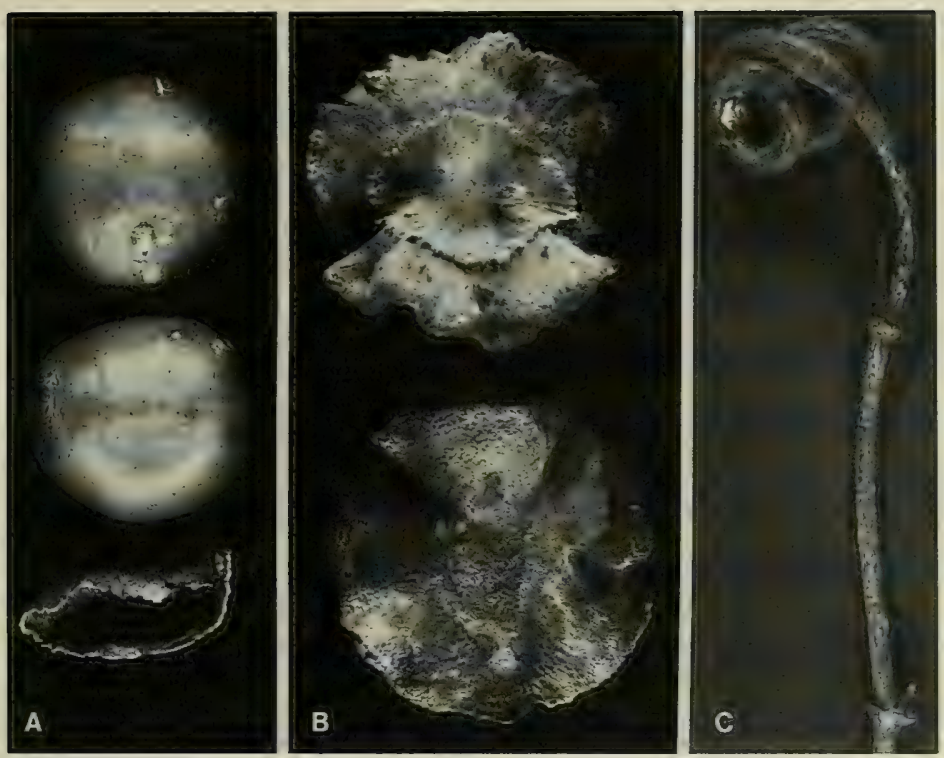

Figure 10. Strychnos vitiensis; A, proximal and distal surfaces of fruits, with broken pericarp to show thickness, $\times 1$; B, seeds, proximal surface showing attachment, with part of testa (remainder of testa sticking to pulp and not shown), and distal surface (without testa), $\times 2 ;$ C, paired tendrils, $\times 2$. A from $\operatorname{Smith} 1584$, B \& $C$ from $D A 15103$

species in Fiji (Smith, 1955; van Balgooy in Blumea Suppl. 6: 180. 1971) must now be amended, as a single sterile collection of the genus from Samoa extends the range into western Polynesia.

USEFul tREATMENTS OF GENUS: Hill, A. W. Strychnos ignatii and other East Indian and Philippine species of Strychnos. Kew Bull. 1911:281-302. 1911. HiLL, A. W. The genus Strychnos in India and the East. Kew Bull. 1917: 121-210. 1917.

1. Strychnos vitiensis A. W. Hill in Kew Bull. 1911: 295. 1911, in op. cit. 1917: 146. 1917; A. C. Sm. in J. Arnold Arb. 36: 287. 1955; J. W. Parham, Pl. Fiji Isl. 179. 1964, ed. 2. 254. 1972; Leeuwenb. \& Leenh. in Engl. \& Prantl, Nat. Pflanzenfam. ed. 2. $28 \mathrm{bI}: 42.1980$.

Figures $9 \& 10$.

Strychnos colubrina sensu Seem. in Bonplandia 9:257. 1861, Viti, 439. 1862, Fl. Vit. 166. 1866; Drake, III.

Fl. Ins. Mar. Pac. 238, 410. 1892; non L.

An often high-climbing liana, infrequent in dense or secondary forest at elevations of 50-850 m., the corolla pale yellow, the fruits yellowish green to dull brownish green. Flowers have been obtained only in August and September, fruits in November, December, and April to June. Since Hill's description was based on a single flowering specimen and a sterile one, a description based on presently available material is here added.

Liana, glabrous on vegetative parts, with paired tendrils, these (when coiled) 2-4 $\mathrm{cm}$. long and 3-4 mm. thick in distal, coiled portions; leaves with petioles 7-15 mm. long, 1-2 mm. in diameter, and shallowly canaliculate above, the blades coriaceous, 
ovate or elliptic, (6-) 7.5-12 × 3-6.5 cm., vernicose above, cuneate at base and short-decurrent on petiole, acute to obtusely cuspidate at apex, 5- or 7-nerved, the innermost secondaries concurrent with costa for 3-8 $(-15) \mathrm{mm}$., the outermost secondaries submarginal and often inconspicuous, the costa and principal nerves strongly elevated on both surfaces, the veinlets copiously reticulate and prominulous on both surfaces; inflorescences axillary, thyrsoid-paniculate, many-flowered, $5-9 \mathrm{~cm}$. long, 3-6 $\mathrm{cm}$. broad, the axes and pedicels puberulent with spreading or appressed hairs about $0.1 \mathrm{~mm}$. long, the peduncles $1.5-3 \mathrm{~cm}$. long, the principal bracts ovate-deltoid, 1-1.5 mm. long, the ultimate cymules composed of 3-7 congested flowers, these at anthesis subsessile or with inconspicuous pedicels to $1 \mathrm{~mm}$. long, the bracteoles $0.5-1$ $\mathrm{mm}$. long; calyx at anthesis subrotate, about $1 \mathrm{~mm}$. long and $1.5 \mathrm{~mm}$. in diameter, the lobes broadly ovate, subacute to broadly obtuse, minutely puberulent without and glabrate, ciliolate; corolla subrotate at anthesis and 3-5 mm. in diameter, 2-2.7 mm. long, glabrous without, weakly pilose on lobes within but without stiff hairs, the tube 0.5-1 mm. long, the lobes ovate, $1.5-1.8 \mathrm{~mm}$. long, acute to obtuse; anthers subsessile, attached to tube slightly below sinuses, ovoid, $0.6-0.8 \mathrm{~mm}$. long, at base weakly villose with hairs $0.2-0.3 \mathrm{~mm}$. long; gynoecium at anthesis $1-1.5 \mathrm{~mm}$. long, glabrous, the ovary ovoid, the style thick-conical and about as long as ovary, the stigma minutely capitate; fruits subglobose, $2.5-3.5 \mathrm{~cm}$. in diameter, the pericarp thin and brittle in drying, the seed solitary (as far as observed), embedded in pulp, irregularly planoconvex, 20-28 mm. broad, 5-7 $\mathrm{mm}$. thick, undulate-margined when dried, the testa thin, minutely velutinous but sticking to pulp when seed is washed.

TYPIFICATION: Of the two specimens originally cited by Hill, the better is: Seemann 302 ( $\mathrm{K}$ LECTOTYPE here designated; ISOLECTOTYPE at BM), collected in flower Aug. 22, 1860, between Namosi and Vuniwaivutuku (west of Namosi, toward Wainikoroiluva River), Namosi Province, Viti Levu. The cited paratype, a sterile specimen, is Milne 64 (K), from inland Viti Levu without further locality.

Distribution: Endemic to Fiji and now known sparingly from the two largest islands. It is conceivable that the Samoan specimen discussed below will also be referred to this species.

Local NAMES: Sauthimbuthimbu (Mba); wa masi (Mbua).

Avallable COLlections: VITI LEVU: MBa: Hills between Nandala and Nukunuku Creeks, along trail from Nandarivatu toward Lewa, Smith 6198. SERUA: Mbuyombuyo, near Namboutini, Tabualewa 15604; hills west of Waivunu Creek, between Ngaloa and Korovou, Smith 9468. TAILEvU: Hills east of Wainimbuka River, vicinity of Ndakuivuna, Smith 7151. VITI Levu without further locality, "in mountains," Milne 52.VANUA LEVU: Mbua: Upper Ndama River Valley, Smith 1584; Koromba Forest, DA・15103. Mathuata: Nasealevu, Sasa Tikina, DA 15247.

Among the Malesian species treated by Leenhouts (1963), Strychnos vitiensis seems most suggestive of $S$. maingayi C. B. Clarke and $S$. ovata A. W. Hill, neither of which is known east of the Philippines and Celebes, but our species differs from both in several obvious characters. In fact, although $S$. vitiensis is a member of sect. Brevitubae (Hill, 1917; Leeuwenberg and Leenhouts, 1980), the two Malesian species mentioned above are referable to sect. Lanigerae (Leeuwenberg and Leenhouts, 1980), although they had been placed in sect. Brevitubae by Hill (1917).

The genus is now represented in Samoa by Whistler 1775 (BISH), collected in 1974 in forest southwest of Aopo, Savai'i, at $300 \mathrm{~m}$. This sterile Samoan collection could indicate an extension of Strvchnos vitiensis, but more probably it represents a distinct taxon differing from $S$. vitiensis in having leaves with shorter petioles (3-4 $\mathrm{mm}$. long) and chartaceous to thin-coriaceous blades more obviously acuminate at apex (acumen to $1.5 \mathrm{~cm}$. long). 
3. Neuburgia Bl. Mus. Bot. Lugd.-Bat. 1: 156. 1850; Markgraf in Bot. Jahrb. 61: 222. 1927; Merr. \& Perry in J. Arnold Arb. 23:415. 1942; Leenh. in Fl. Males. I. 6: 363. 1963, in Blumea Suppl. 5: 72. map 38. 1966; A. C. Sm. in Pacific Sci. 23:387. 1969; Leeuwenb. \& Leenh. in Engl. \& Prantl, Nat. Pflanzenfam. ed. 2. 28bI: 48. 1980.

Couthovia A. Gray in Proc. Amer. Acad. Arts 4: 324. 1859, in op. cit. 5: 320. 1862; Seem. Fl. Vit. 165 1866; Gillespie in Bishop Mus. Bull. 83: 28. 1931; A. C. Sm. in Sargentia 1:99. 1942, in J. Arnold Arb. 36: 287. 1955.

Trees or shrubs, glabrous or with simple hairs, the lateral branchlets opposite and shortly coherent with a central branchlet, the stipules interpetiolar, adnate to petioles and forming an often split sheath; leaves opposite, petiolate to subsessile, the blades pinnate-nerved (our species with 5-11 secondary nerves per side); inflorescences terminal, thyrsoid, the bracts and bracteoles small, the flowers sessile or pedicellate, 5-merous; calyx deeply lobed, the lobes suborbicular; corolla rotate to hypocrateriform, glabrous (as in all our taxa) or sparsely pilose without, pilose within at throat and sometimes on tube, the lobes valvate, deltoid to ovate, thicker than tube; stamens inserted on distal part of corolla tube, included, the filaments ligulate, usually short, the anthers 2-locular, introrse, the locules divergent at base, the base and apex sometimes bearded (but in none of our taxa); ovary 2-locular, the placenta thickened, the ovules many, the style included or scarcely exserted, early deciduous, the stigma usually ellipsoid; fruit drupaceous, the mesocarp dry, hard and fibrous, the endocarp woody and not sharply distinct from mesocarp, the seed usually 1 per locule, sometimes only 1 per fruit (usually 2 in our taxa), fusiform.

TYPE SPECIES: The lectotype species of Neuburgia is $N$. tuberculata Bl., nom. illeg. (Cerbera musculiformis Lam., Neuburgia musculiformis Miq.) (vide Pfeiffer, Nomencl. Bot. 2: 437. 1874) = Neuburgia moluccana (Boerl.) Leenh. (1963, p. 367). The type species of Couthovia is C. corynocarpa A. Gray, validly published in 1859 as part of a descriptio generico-specifica.

Distribution: Eastern Malesia (Philippines and Celebes) eastward to the Caroline Islands, New Caledonia, New Hebrides, and Fiji, perhaps with 20 or more species (10-12 species, Leenhouts, 1963, 1966, Leeuwenberg and Leenhouts, 1980). Five species (at least four of them endemic) terminate the generic range in Fiji.

Useful treatment of Genus: Smith, A. C. Couthovia A. Gray. Sargentia 1: 99-107. 1942.

The Fijian taxa of Neuburgia are trees (rarely noted as shrubs) 2-30 m. high, the larger individuals having trunks to $40 \mathrm{~cm}$. (or more?) in diameter. The faintly fragrant flowers have greenish white to pale yellow corollas that become pure white at anthesis, with white throat-indument. The anthers and styles are pale yellow to white, and the young fruits are green, becoming white or dull cream-white at maturity.

KEY TO SPECIES

Branchlets subterete, sometimes drying irregularly striate or slightly flattened in distal internodes but not quadrangular; flowers sessile at anthesis; calyx lobes $0.7-2 \times 1.2-2.5 \mathrm{~mm}$; corolla 4-7 mm. long, barbate at throat but otherwise glabrous within, the tube $2-3.5 \mathrm{~mm}$, in diameter, the corolla limb smooth in bud; style $0.3-1.5 \mathrm{~mm}$. long; fruits at maturity obovoid to clavate, cylindric in cross section, not more than $20 \mathrm{~mm}$. in diameter.

Corolla 4-6 mm. long, the lobes 1.8-2.5 $\times 1.2-2 \mathrm{~mm}$, the tube 2-3 mm. in diameter, 1.5-2.5 times longer than lobes; anthers $1.3-1.7 \mathrm{~mm}$. long; mature fruits $13-35 \times 5-15 \mathrm{~mm}$.

Free petioles sometimes angled but scarcely winged, the stipular sheath smooth; mature fruits 13-35 $\times$ 5-13 mm., the woody endocarp about as thick as the fibrous mesocarp; leaf blades with secondary nerves spreading to erecto-patent, nearly straight to curved.

Stipular sheath 4-20 (-25) mm. long, on older branchlets often thick-coriaceous and subpersistent; free portions of petioles (2-) 4-10 (-30) mm. long, often stout; leaf blades broadly elliptic to obovate, (7-) $11-35(-40) \times(4-) 6-22(-30) \mathrm{cm}$, subattenuate to subrounded at base, obtuse at apex; inflorescences broadly spreading, the primary branchlets of cymes $6-30 \mathrm{~mm}$. long. 
Stipular sheath 2-5 mm. long, not exceeding this even on older branchlets and soon caducous; free portions of petioles 2-9 mm. long, slender; leaf blades obovate-oblong, (3-) 4-9 (-10) $\times(1-)$ $1.5-5 \mathrm{~cm}$., attenuate or rarely obtuse at base, rounded to broadly obtuse at apex; inflorescences more compact and slender, the primary branchlets of cymes $2-10 \mathrm{~mm}$. long. $\ldots 2$. N. collina Petioles essentially none, the leaves conspicuously winged to base, the wings $1-3 \mathrm{~mm}$. broad, confluent with those of opposite leaf and forming a transverse wing across petiolar sheath, this $5-15 \mathrm{~mm}$. long: mature fruits $15-25 \times 6-15 \mathrm{~mm}$., the woody endocarp about $1 / 3$ as thick as the fibrous mesocarp; leaf blades obovate-oblong, (11-) 14-24×(4-) 5-12(-16) cm., gradually narrowed to a subobtuse base, obtuse at apex, the secondary nerves ascending, slightly curved. .... 3. N. alata

Corolla 5-7 mm. long, the lobes 3-4 × 1.5-2 mm., the tube 3-3.5 mm. in diameter, about as long as lobes; anthers $1.8-2 \mathrm{~mm}$. long; mature fruits $30-45 \times 9-20 \mathrm{~mm}$., the woody endocarp at maturity about as thick as the fibrous mesocarp; stipular sheath $8-17 \mathrm{~mm}$. long, smooth; free portions of petioles 0 - 10 $\mathrm{mm}$. long, narrowly winged; leaf blades obovate-elliptic, 12-27 (-33) $\times(5-) 7-24 \mathrm{~cm}$., gradually narrowed at base, obtusely cuspidate to rounded at apex, the secondary nerves ascending to

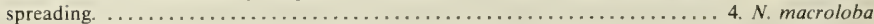

Branchlets quadrangular in distal internodes; flowers at anthesis with pedicels $0.5-3 \mathrm{~mm}$. long; calyx lobes $1.8-3 \times 1.8-4 \mathrm{~mm}$; corolla $6-8 \mathrm{~mm}$. long, tomentellous- to strigose-barbate at throat and also on tube within, the tube about as long as lobes, $2.5-5 \mathrm{~mm}$. in diameter, the lobes $3.7-4.5 \times 1.5-3 \mathrm{~mm}$., the corolla limb angled in bud; style $1.5-3 \mathrm{~mm}$. long; fruits at maturity ellipsoid-obovoid, usually notably flattened, $25-55 \times 18-35 \times 10-25 \mathrm{~mm}$., the woody endocarp at maturity $1 / 3-1 / 4$ as thick as the fibrous mesocarp (young fruits ellipsoid-clavate); stipular sheath 5-13 mm. long, smooth; free portions of petioles 5-20 ( -25$) \mathrm{mm}$. long; leaf blades broadly elliptic, (8-) 9-20 (4-) 5-20 cm., obtuse to subcordate at base, rounded to broadly obtuse at apex, the secondary nerves spreading. . . . . . . . N. macrocarpa

1. Neuburgia corynocarpa (A. Gray) Leenh. in Fl. Males. I. 6: 365, saltem quoad basionymum. 1963; A. C. Sm. in Pacific Sci. 23: 387. 1969; J. W. Parham, Pl. Fiji Isl. ed. 2. 254. fig. 75. 1972. Figures 11 A, 12A \& B, 14A, 15A \& B.

Couthovia corynocarpa A. Gray in Proc. Amer. Acad. Arts 4: 324. 1859; A. C. Sm. in Sargentia 1: 102. 1942; J. W. Parham, Pl. Fiji Isl. 179. 1964.

Gaerınera barbata Seem. in Bonplandia 9: 257, nom. nud. 1861; Seem. ex A. Gray in op. cit. 10:37, nom. nud. 1862.

Couthovia seemanni A. Gray in Proc. Amer. Acad. Arts 5:320. 1862, in Bonplandia 10: 37. 1862; Seem. in op. cit. 10: 296. 1862, Viti, 439. 1862, Fl. Vit. 166. 1866; Drake, Ill. Fl. Ins. Mar. Pac. 238. 1892; Gillespie in Bishop Mus. Bull. 83: 29, p. p., as C. seemannii. fig. 36. 1931.

Tree 3-30 m. high (rarely noted as a shrub), often frequent from near sea level to an elevation of $626 \mathrm{~m}$. (very rarely to $1,000 \mathrm{~m}$.) in dense or secondary forest or in patches of forest in open country. Flowering and fruiting specimens have been noted in every month.

TyPIFICATION: The type of Couthovia corynocarpa is U.S. Expl. Exped. (us 62109 HOLOTYPE; putative ISOTYPES at GH, K, NY), collected in 1840 from "Ovalau and Sandal-wood Bay [i. e. Mbua Bay, Mbua Province, Vanua Levu], Feejee Islands." Since two localities were noted by Gray, all the type material may not be from the same collection. The type of $C$. seemanni (and source of the name Gaertnera barbata) is Seemann 305 (GH HOLOTYPE; ISOTYPES at BM, K, P), obtained in 1860 at Port Kinnaird, Ovalau; the precise locality is noted only on the $\mathrm{K}$ sheet, but Gray based his name on a duplicate sent him by Seemann.

Distribution: Fiji, and probably in some archipelagoes to the west. From Fiji 92 collections have been examined, although these are from only five of the high islands.

LOCAL NAMES AND USE: Recorded local names from Viti Levu are $m b o, m b o l o a$, and langaleka, from Vanua Levu theketheke and mbulei; Parham $(1964,1972)$ also lists mbonokonoko and ola. The timber is said to provide a hard wood. The fruits are noted as attractive to pigeons, as those of other species of the genus; nevertheless Neuburgia, abundant in Fiji, has not by that means been transported to western Polynesian archipelagoes. 

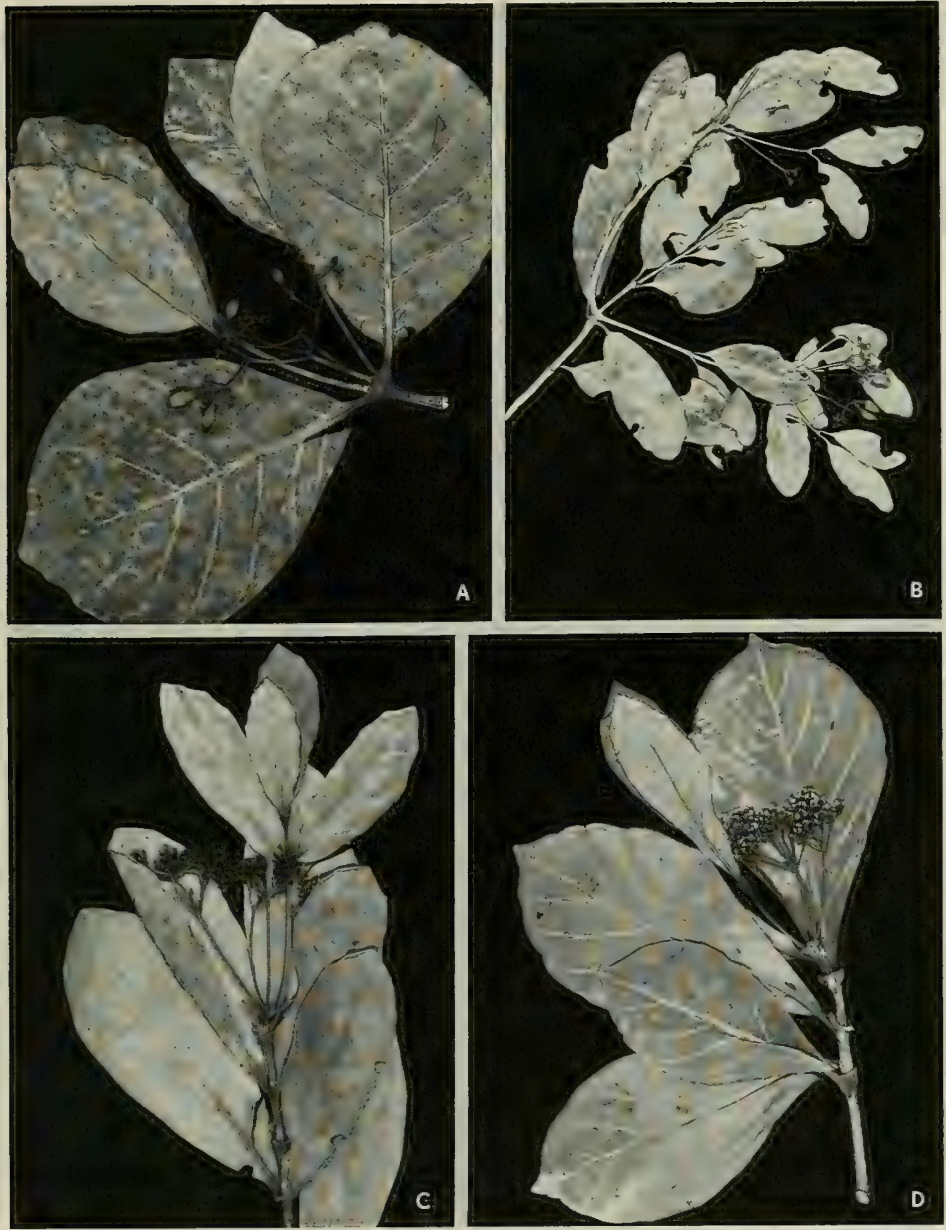

Figure 11. A, Neuburgia corynocarpa; distal portion of branchlet, with foliage and infructescence, $\times$ 1/4. B, Neuburgia collina; distal portion of branchlet, with foliage and infructescence, $\times 1 / 4$. C, Neuburgia alata; distal portion of branchlet, with foliage and inflorescence, $\times 1 / 4 . \mathrm{D}$, Neuburgia macroloba; distal portion of branchlet, with foliage and inflorescence, $\times 1 / 4$. A from Meebold 26520, B from Degener 14370, C from Parks 20869, D from Smith 917. 

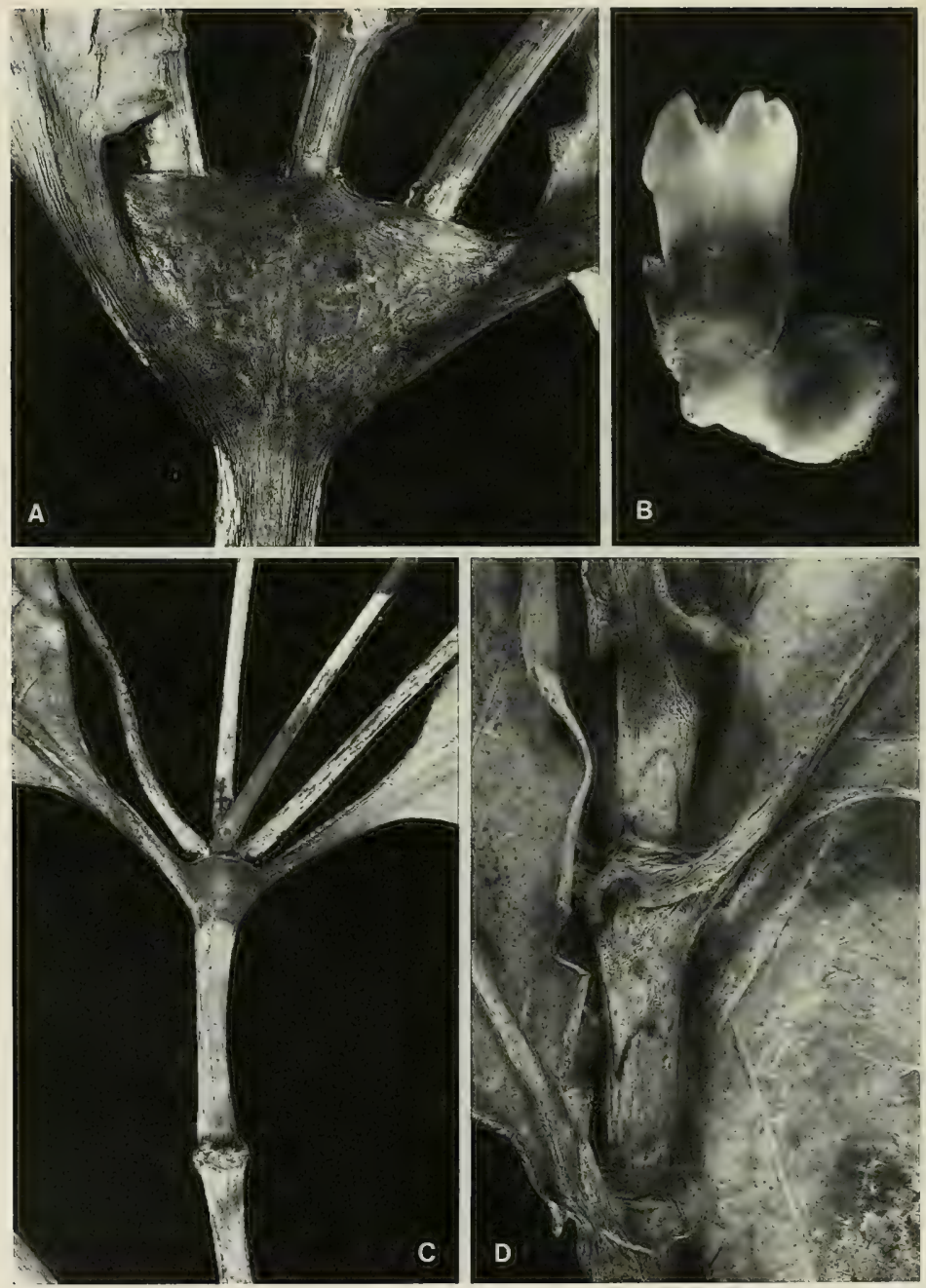

Figure 12. A \& B, Neuburgia corynocarpa; A, stipular sheath, $\times 2$; B, sessile flower, with subtending bracteoles, $\times 6$. C, Neuburgia collina; stipular sheath, $\times 2$. D, Neuburgia alata; stipular sheaths at three nodes, $\times$ 2. A \& B from Smith 8991, C from DA 14450, D from Meebold 17012, p. p. 

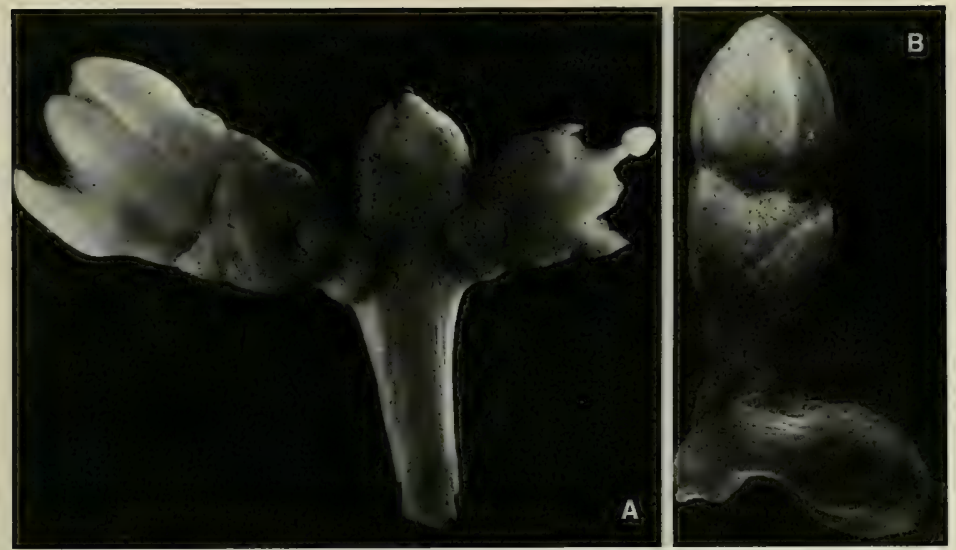

FIgURE 13. A, Neuburgia macroloba; cymule of inflorescence, one flower with a mature corolla, one showing upper part of gynoecium with short style, $\times 6 . \mathrm{B}$, Neuburgia macrocarpa; young flowers, showing pedicels, $\times 6$. A from Smith 917. B from Gillespie 2951.

Representative Collections: VITI LEVU: MBa: Mt. Evans Range, Greenwood 435; Naloto Range, DA 14770. SerUA: Hills between Navua River and Wainiyavu Creek, near Namuamua, Smith 8991 ; vicinity of Ngaloa, Degener 15118. NAmosi: Mt. Naitarandamu, Gillespie 3344; Wainandoi River, DA I2995. NAITASIRI: Waindina River basin, Mac Daniels 1037; vicinity of Tamavua, Gillespie 2195. TAILEVU: Hills east of Wainimbuka River, vicinity of Ndakuivuna, Smith 7133. REwA: Coastal road west of Suva, Meebold 26520. KANDAVU: Hills above Namalata and Ngaloa Bays, Smith 200. OVALAU: Summit of Mt. Ndelaiovalau and adjacent ridge, Smith 7385: Port Kinnaird, Storck 899. NGAU: Hills east of Herald Bay, inland from Sawaieke. Smith 7774. VANUA LEVU: MBUA: Mt. Seatura, DA 15180; lower Wainunu River Valley, Smith 1726. Mathuata: Vicinity of Lambasa, Greenwood 533. ThaKaundrove: Savusavu Bay region, Degener \& Ordonez 14024.

As interpreted by Leenhouts (1963), Neuburgia corynocarpa is "a widespread species and consists of a reticulate relationship of local races, both in New Guinea and in the Pacific." I believe that the complex merits more careful study and that variation in foliage, stipules, corollas, and fruits should be reexamined. Even whether the New Hebridean population should be placed within the circumscription of $N$. corynocarpa is not obvious, as the type material of Couthovia neo-ebudica Guillaumin (Kajewski 774) has fruits somewhat longer, proportionately more slender, and more attenuate distally than any fruits of $N$. corynocarpa observed in Fiji.

2. Neuburgia collina (A. C. Sm.) A. C. Sm. in Pacific Sci. 23: 387. 1969; J. W. Parham, Pl. Fiji Isl. ed. 2. 254. 1972.

Figures 11B, 12C, 14B, 15C \& D.

Couthovia seemannii sensu Gibbs in J. Linn. Soc. Bot. 39: 157. 1909; non A. Gray.

Couthovia corvnocarpa sensu Gillespie in Bishop Mus. Bull. 83: 28, quoad descriptionem. fig. 35.1931.

Couthovia collina A. C. Sm, in Sargentia 1: 101. 1942; J. W. Parham, Pl. Fiji Isl. 179. 1964.

An often slender or compact tree (rarely noted as a shrub) $2-12 \mathrm{~m}$. high, found in dense, dry, or secondary forest or on its edges at elevations of $500-1,195 \mathrm{~m}$. Flowers have been collected between June and January, fruits in months scattered throughout the year. 


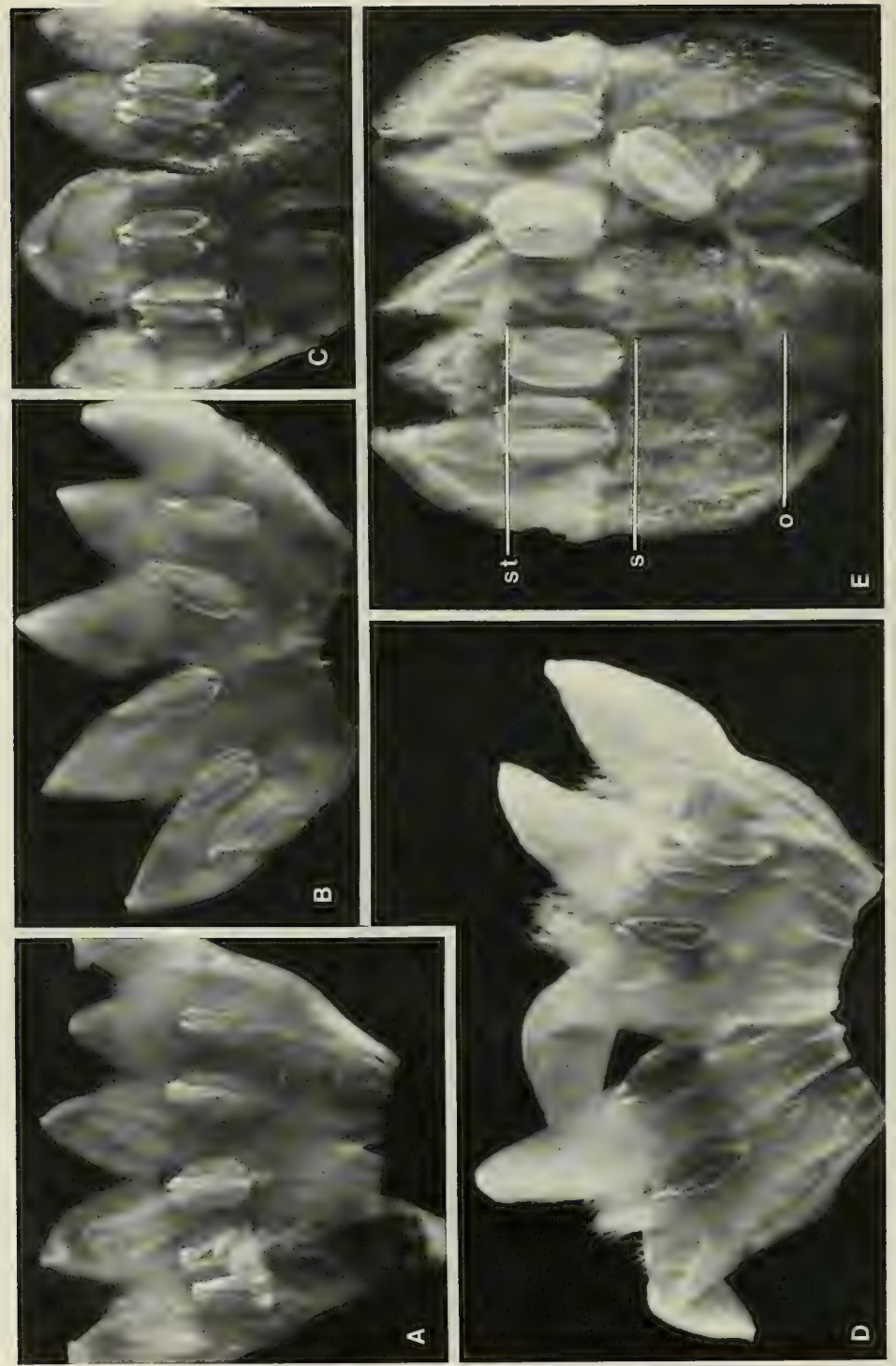


TYPIFICATION: The species is typified by Gillespie 3913 (BISH HOLOTYPE; ISOTYPES at BISH, K, NY, UC, US), collected in flower Nov. 21, 1927, on the slopes of Mt. Nanggaranambuluta, east of Nandarivatu, Mba Province, Viti Levu.

Distribution: Endemic to Fiji and thus far known only from Viti Levu, with a single collection from Vanua Levu. Twenty-eight collections have been examined.

LOCAL NAMES: Names recorded from Viti Levu are kau toi, mbonuwambu, and tava, from Vanua Levu theketheke.

RePresentative COlLections: VITI LEVU: MBa: Summit of Mt. Koroyanitu, high point of Mt. Evans Range, Smith 4183; slopes of Mt. Koromba, Horne 924 (Aug., 1878, earliest known collection); vicinity of Nandarivatu, Gillespie 3969. Degener 14370, DA 14450; ridge between Mt. Nanggaranambuluta and Mt. Namama, east of Nandarivatu, Smith 4989; between Navai and Mt. Tomanivi, DA 14968. NANDrongA \& Navosa: Nandrau Valley, Gibbs 745; Nausori Highlands, $O$. \& I. Degener 32179. Namosi: Mt. Naitarandamu, Gillespie 3100; slopes of Mt. Voma, Gillespie 2908. NAITASIRI: Northern portion of Rairaimatuku Plateau, between Mt. Tomanivi and Nasonggo, Smith 5750 . VANUA LEVU: MathUATA-ThaKaUndrove boundary: Crest of Korotini Range, between Navitho Pass and Mt. Ndelaikoro, Smith 552.

Leenhouts's reduction of Neuburgia collina to $N$. corynocarpa seems unwarranted, as is his remark: "The variation in Fiji is mainly altitudinal, 'Couthovia collina' being a small-leaved form of mainly higher altitudes, $N$. corynocarpa sensu stricto with larger leaves is mainly restricted to the lowlands; these two forms are grading." In fact, among the 120 collections of the two taxa that I have now examined, none has required more than a glance to place in accord with the very dependable foliage, stipule, and inflorescence characters utilized in my key.

3. Neuburgia alata (A. C. Sm.) A. C. Sm. in Pacific Sci. 23: 387. 1969; J. W. Parham, Pl. Fiji Isl. ed. 2. 253. 1972.

Figures 11C, 12D, 14C, 15E \& F.

Couthovia alata A. C. Sm. in Sargentia I: 104. 1942; J. W. Parham, Pl. Fiji Isl. 179. 1964.

Tree (infrequently noted as a shrub) 3-6 m. high, found in a limited area of dense or secondary forest from near sea level to an elevation of about $400 \mathrm{~m}$. Flowers have been noted between May and October, fruits between March and October.

TYPIFICATION: The type is Parks 20869 (BISH HOLOTYPE; ISOTYPES at SUVA, UC, Us), collected on Viti Levu (without further locality) between May and July, 1927.

Distribution: Endemic to Fiji and thus far known with certainty only from a restricted area in southeastern Viti Levu.

LoCAL NAME: $M$ Mbo.

Available Collections: VITI LEVU: Naitasiri: Tamavua-Sawani road, Setchell \& Parks 15086; Central road, Tothill 478; Tholo-i-suva and vicinity, DA 7580,10199, 11260, 11898, 14520; vicinity of Tamavua, Gillespie 2095, 2433; vicinity of Nasinu, $D A$ 7491, 7492. REwA: Ridge of Mt. Korombamba, $D A$ 1253, 1297; "Suva," Meebold 17012, p. p. (BISH).

The very distinct Neuburgia alata is related to $N$. corynocarpa, differing in its essentially sessile leaves with proximal wings that are confluent with those of the opposite leaf and which thus form transverse wings across the stipular sheaths (FIGURE 12D). The leaf blades are characteristically obovate-oblong, with curved, ascending secondaries. The species seems limited to a compact area in southeastern Viti Levu; although the type material is without detailed locality, many of Parks's collections were obtained in that area.

FiguRE 14. Opened corollas of Neuburgia, showing indument and stamens, all $\times 9 . \mathrm{A}, N$. corynocarpa, also showing gynoecium with short style. B, N. collina. C, N. alata. D, N. macroloba. E, N. macrocarpa, also showing gynoecium with elongate style (s), stigma (st), and ovary (o); one stamen out of position. A from Smith 8991, B from Smith 4989, C from Parks 20869, D from Smith 917, E from Gillespie 2951. 

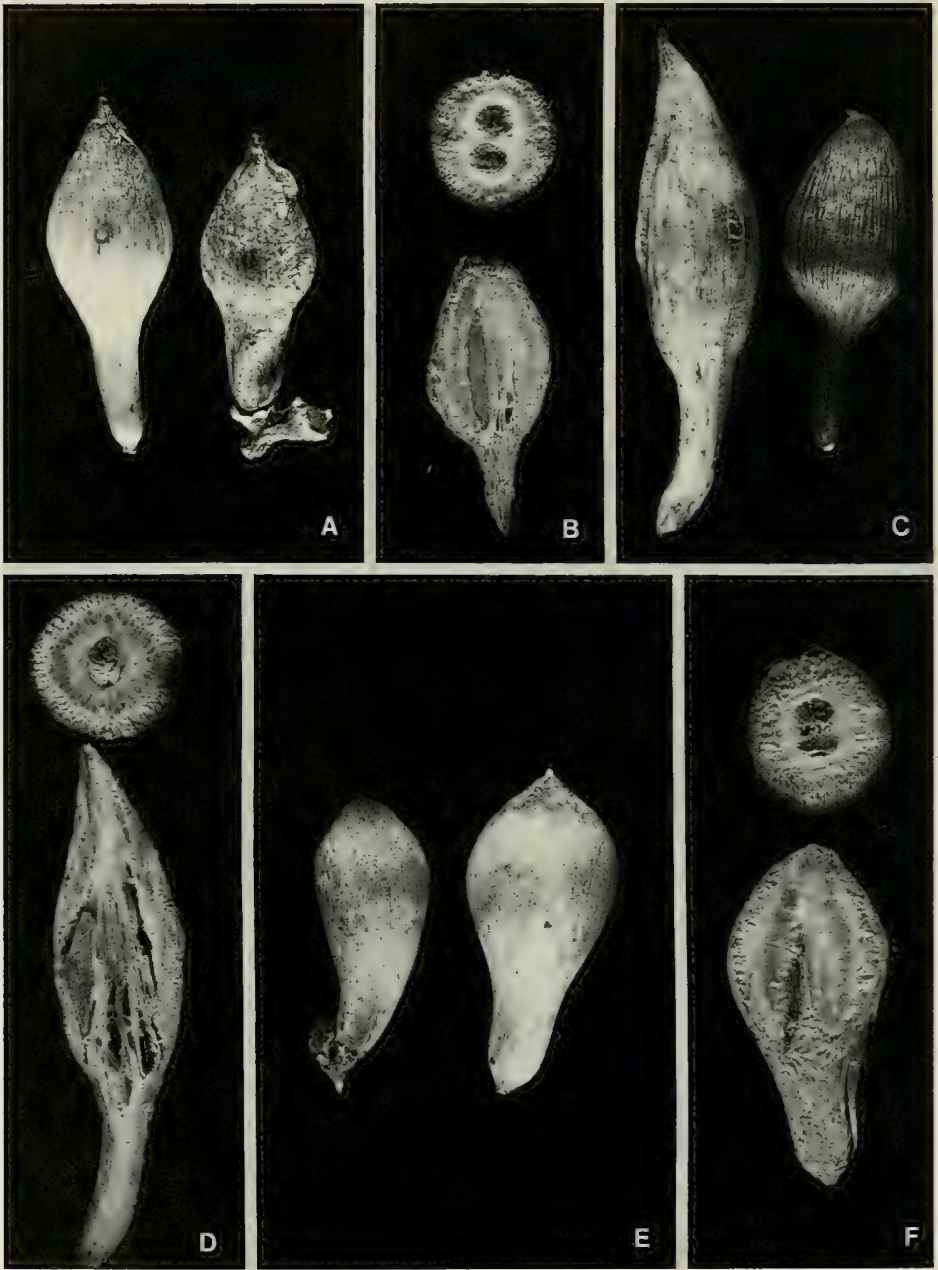

Figure 15. Neuburgia, mature fruits, all $\times 2$. A \& B, $N$. corynocarpa. C \& D, $N$. collina. E \& F, $N$. alata. A from Smith 7385 (left) and MacDaniels 1037 (right), B from Smith 7385 (cross section) and 1726 (longitudinal section), C from Smith 5750 (left) and 552 (right), D from Smith 552 (cross section) and 5750 (longitudinal section), E from Gillespie 2095 (left) and Meebold 17012, p. p. (right), F from Meebold 17012, p. p. 

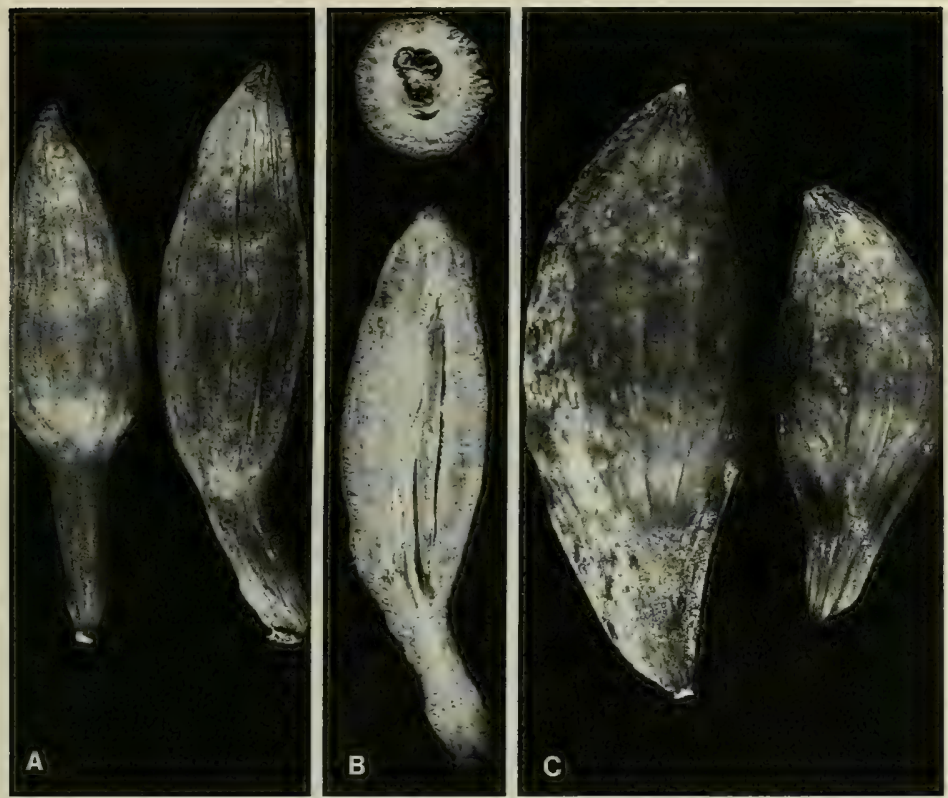

FIGURE 16. Neuburgia, fruits, all $\times 2$. A \& B, N. macroloba, mature fruits. C, $N$. macrocarpa, young fruits. A from Smith 8230 (left) and 917 (right), B from Smith 8230 (cross section) and 917 (longitudinal section), C from $D A 15043$.

4. Neuburgia macroloba (A. C. Sm.) A. C. Sm. in Pacific Sci. 23: 387. 1969; J. W. Parham, Pl. Fiji Isl. ed. 2. 254. 1972. Figures 11D, 13A, 14D, 16A \& B. Couthovia macroloba A. C. Sm. in Sargentia 1: 104, 1942; J. W. Parham, Pl. Fiji Isl. 179. 1964.

Tree (or shrub) 3-10 m. high, sometimes spreading, occurring in a limited area of sometimes dense forest at elevations of 200-900 m. Flowers and fruits have been collected in January, July, and August.

TYPIFICATION: The type (and the only collection previously cited) is Smith 917 (NY HOLOTYPE; many ISOTYPES), collected Jan. 8, 1934, on borders of the lake east of Somosomo, Taveuni.

Distribution: Endemic to Fiji and apparently to the island of Taveuni.

\section{LOCAL NAME: Vathea.}

AVAILABLE COLLECTIONS: TAVEUNI: Hills east of Somosomo, west of old crater occupied by small swamp and lake (type locality). Smith 8395, DA 14369: Wainisavu, Nggeleni, DA 14406: above coconut plantations, vicinity of Waiyevo, Gillespie 4734; summit and adjacent slopes of Mt. Manuka, east of Wairiki, Smith 8193. 8230.

This very distinct Neuburgia is the only species of the genus known from Taveuni, to which island it appears endemic. In foliage and stipular sheaths it is not unlike some individuals of $N$. corynocarpa, but its corolla (FIGURE 14D) has conspicuously larger 
lobes and consequently a proportionately shorter (although thicker) tube. Its mature fruits (FIGURE 16A \& B) are consistently larger than those of the first three species
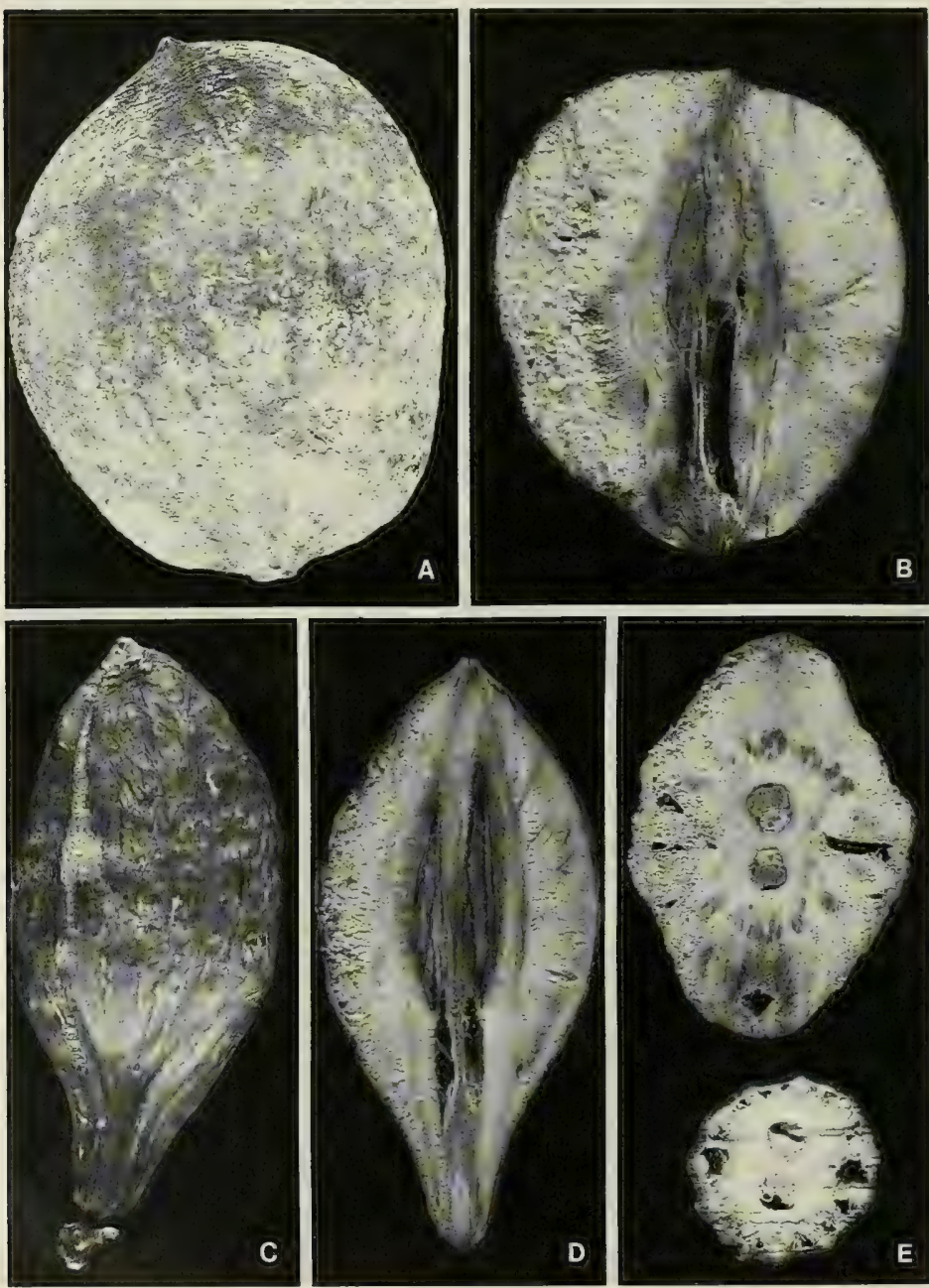

FIGURE 17. Neuburgia macrocarpa, fruits, all $\times 2$, all essentially mature except FiguRE E, lower, cross section of a young fruit. A from Degener \& Ordonez 14125. B from Mac Daniels 1038, C \& D (longitudinal section) from Smith 8990, E (cross sections) from MacDaniels 1038 (upper) and DA 15043 (lower). 
(FIGURE 15) in the present treatment, although not approaching in size those of the following species.

5. Neuburgia macrocarpa (A. C. Sm.) A. C. Sm. in Pacific Sci. 23: 387. 1969; J. W. Parham, Pl. Fiji Isl. ed. 2. 254. 1972.

Figures 13B, 14E, 16C, 17.

Gaertnera pyramidalis Seem. in Bonplandia 9: 257, nom. nud. 1861; Seem. ex A. Gray in op. cit. 10: 37 , nom. nud. 1862.

Couthovia corynocarpa sensu A. Gray in Proc. Amer. Acad. Arts 5: 320. 1862, in Bonplandia 10:37. 1862; Seem. Viti, 439. 1862, Fl. Vit. 165. 1. 32. 1866; Drake, Ill. Fl. Ins. Mar. Pac. 238. 1892; non A. Gray, 1859.

Couthovia macrocarpa A. C. Sm. in Sargentia 1: 105. 1942; J. W. Parham, Pl. Fiji Isl. 179. 1964.

Couthovia pachyantha A. C. Sm. in Sargentia 1: 106. 1942; J. W. Parham, Pl. Fiji Isl. 179. 1964.

Neuburgia pachyantha A. C. Sm. in Pacific Sci. 23: 387. 1969; J. W. Parham, PI. Fiji Isl. ed. 2. 254. 1972.

Tree 3-20 m. high, often with a compact crown and a straight, slender trunk to 40 $\mathrm{cm}$. in diameter, occurring in dense or open forest or on its edges at elevations from near sea level to about $400 \mathrm{~m}$. Flowers have been obtained in August to October and also in January, fruits in scattered months (January, March, May, September, October).

TYPIFICATION: Couthovia macrocarpa was based on Gillespie 2951 (BISH HOLOTYPE; ISOTYPE at UC), collected Sept. 22, 1927, in the vicinity of Namuamua, Namosi Province, Viti Levu. The type of Couthovia pachyantha is Degener \& Ordonez 14125 (A HOLOTYPE; ISOTYPES at BISH, K, US), obtained Jan. 10, 1941, between Mbalanga and Valethi, Savusavu Bay, Thakaundrove Province, Vanua Levu. The source of the name Gaertnera pyramidalis is Seemann 303 (BM, K), collected in 1860 in the "valley of Namosi" [Waindina River], Namosi Province, Viti Levu.

Distribution: Endemic to Fiji and thus far known only from the two largest islands (from Vanua Levu only from the type of Couthovia pachyantha).

Local names: Names recorded in Namosi and Serua Provinces are $m b o, m b o a$, mbola, mboloa, and mbulei.

AVAilable Collections: VITI LEVU: SeRUA: East of Nambukelevu, upper Navua River, Berry 89; hills between Navua River and Wainiyavu Creek, near Namuamua, Smith 8990. Namosi: Wayauyau Creek, tributary of Wainikoroiluva River, DA 14250: vicinity of Namosi, near the stream, Gillespie 2590; Namosi without further locality, DA 5895. NAmosi or NAITASIRI: Upper Waindina River, MacDaniels 1038. NAITASIRI: Sovi River (Waindina River tributary), DA 15043. VITI LEVU without further locality, Torhill 620. FIJI without further locality, Horne $589(\mathrm{GH})$.

This very distinct species differs from its congeners in Fiji in its distally quadrangular branchlets, in its broadly elliptic leaf blades being obtuse to subcordate at base and rounded to broadly obtuse at apex, with spreading secondary nerves, in its flowers being obviously pedicellate rather than sessile at anthesis (FIGURE 13B), and in other obvious floral and fruit characters. The large corolla (FIGURE 14E) is pilose on the tube within as well as at the throat, and the style is comparatively elongate. While the developing fruits (FIGURES 16C, 17E as to lower cross section) suggest those of Neuburgia macroloba, at maturity (FIGURE 17) they are strikingly larger and laterally somewhat flattened.

Reexamination of the type material of Couthovia macrocarpa and C.pachyantha, in conjunction with study of material made available since 1942, indicates that only one species of this relationship should be maintained. The sole difference between them appears to be in the indument of the corolla throat and within the tube, the Viti Levu specimens having this indument of curled, lax hairs, while the only known material from Vanua Levu has such hairs stiffer and slightly longer. The somewhat broader corollas of the Vanua Levu collection are probably not very significant, in view of the striking vegetative similarity. 
4. Fagraea Thunb. in Kongl. Vetensk. Acad. Nya Handl. 3: 132. 1782, Nova Gen. Pl. 34. 1782; A. Gray in Proc. Amer. Acad. Arts 4: 323. 1859; Seem. Fl. Vit. 164. 1866; Leenh, in Bull. Jard. Bot. Brux. 32: 418. 1962, in Fl. Males. I. 6: 299. 1963; van Balgooy \& Leenh. in Blumea Suppl. 5: 168. map 91. 1966; Leeuwenb. \& Leenh. in Engl. \& Prantl, Nat. Pflanzenfam. ed. 2. 28bI: 82. 1980.

Trees or shrubs, sometimes scrambling or climbing or epiphytic, usually unarmed and glabrous, the stipules interpetiolar, connate into an ocrea, this free or adnate to base of petiole, usually splitting between petioles; leaves petiolate or subsessile, the blades coriaceous or subcarnose, sometimes auriculate at base, pinnate-nerved, the secondary nerves often inconspicuous; inflorescences usually terminal with a pair of strong basal branches, cymose, (1-)3-many-flowered, the bracts scalelike, the bracteoles usually present, the flowers $\Varangle, 5$-merous, glabrous; calyx campanulate to tubular, carnose to coriaceous, usually persistent, the lobes imbricate, usually rounded; corolla often carnose, sometimes thick, the tube infundibuliform or only slightly broadened, thinner in texture toward base, the lobes dextrorsely contorted, shorter than tube, rounded; stamens inserted on corolla tube, included or exserted, the filaments ligulate or filiform, the anthers elliptic to ovate, cordate or sagittate at base; ovary ellipsoid, 2-locular with axile placentae or 1-locular with parietal placentae, the ovules many, the style filiform or cylindric, shortly or distinctly exserted, the stigma capitate to peltate or 2-lobed; fruit baccate (sometimes if large 4-valved), usually globose to ellipsoid, the style base persistent, the seeds many, irregularly angled, immersed in pulpy placentae.

TYPE SPECIES: Fagraea ceilanica Thunb.

Distribution: Ceylon, India, Hainan, and Formosa throughout Malesia to northern Australia and the Mariana Islands, and eastward in the Pacific to the Marquesas and Austral Islands, with 35-50 species. Two species are indigenous in Fiji.

Wide distributions are attributed to both species indigenous in Fiji by Leenhouts (1962, 1963) and van Balgooy and Leenhouts (1966), but probably both species (in the broad sense) require detailed reconsideration. Dimensions noted in the following key are applicable only to the Fijian populations. Leaf blade size, shape, and texture are very similar in both Fijian taxa. The petioles are $1.5-4 \mathrm{~cm}$. long, the blades elliptic to oblong-ovate, usually $9-20 \times 5-12 \mathrm{~cm}$., submembranaceous to subcoriaceous in drying, acute to attenuate at base, and rounded to acute at apex.

KEY TO SPECIES

Leaf blades with 6-10 pairs of primary secondary nerves (an intermediate pair between primary pairs nearly as conspicuous); calyx 12-15 mm. long; corolla tube subcylindric, $3-5 \mathrm{~cm}$. long, gradually broadened distally; stamens inserted on a thickened ring in corolla tube, the filaments $11-18 \mathrm{~mm}$. long, the anthers narrowly linear, 5-10 mm. long, inconspicuously bifid at base; stigma 2-lobed, the lobes 3-5 mm. in diameter; fruits $3-5 \times 2-4 \mathrm{~cm}$., obtuse to acute at apex, the seeds very numerous.

1. F. berteroana

Leaf blades with 5-9 pairs of secondary nerves (lacking intermediate pairs); calyx 5-7 mm. long; corolla tube hypocrateriform, $1.5-2.5 \mathrm{~cm}$. long, tubular and slender proximally, abruptly broadened distally; stamens not inserted on a thickened ring in corolla tube, the filaments $15-25 \mathrm{~mm}$. long, the anthers oblong to elliptic, 3-4 mm. long, deeply bifid at base; stigma small, subconical, essentially entire; fruits $1.5-2.3 \times 1-1.5 \mathrm{~cm}$., terminated by a conical beak, the seeds comparatively few. ....2. F. gracilipes

FIgURE 18. Fagraea berteroana; A, distal portion of branchlet, with foliage and infructescence, $\times 1 / 3 ; \mathrm{B}$, inflorescence, with a detached corolla, $\times 1 / 2 ; \mathrm{C}$, stamens, $\times 2 ; \mathrm{D}$, cross section of dried fruit, $\times 2$; E, longitudinal section of dried fruit and persistent calyx, $\times 2$. A from DA 14794, B \& C from Smith 9333, D from Bryan 346, E from Gillespie 2513. 

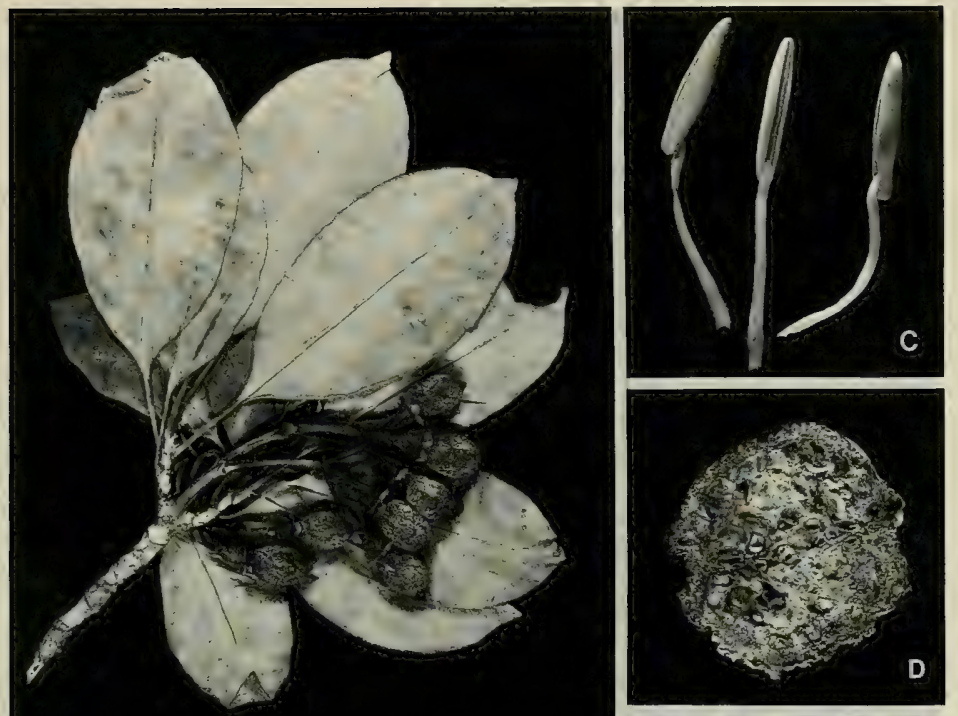

A
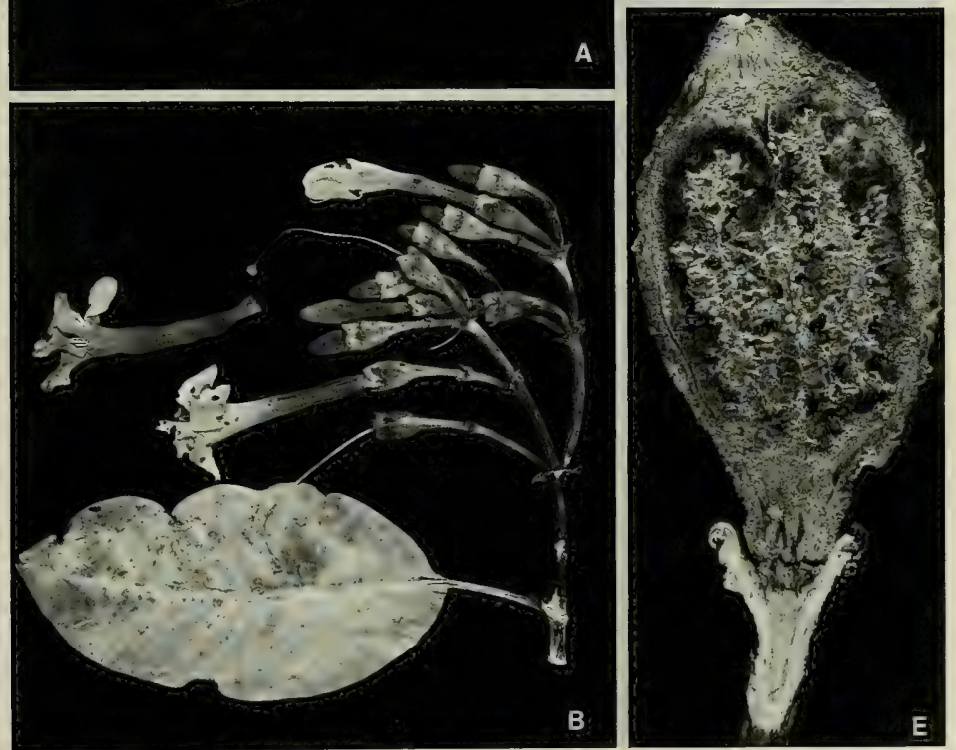
1. Fagraea berteroana A. Gray ex Benth. in J. Proc. Linn. Soc. Bot. 1: 98, as F. berteriana. 1856.

Figures 18, 126 (upper).

Carissa grandis Bertero ex Guillemin in Ann. Sci. Nat. Bot. II. 7: 248, nom. nud. 1837.

Fagraea berteriana Benth. ex Seem. in Bonplandia 9: 257. 1861, Viti, 439. 1862, Fl. Vit. 164. 1866; Drake, Ill. Fl. Ins. Mar. Pac. 238. 1892; Turrill in J. Linn. Soc. Bot. 43:34. 1915; Gilg \& Benedict in Bot. Jahrb. 56: 550. 1921; Christophersen in Bishop Mus. Bull. 128: 176. 1935; Yuncker in op. cit. 178: 96 . 1943, in op. cit. 184: 57. 1945, in op. cit. 220:217. 1959; Leenh, in Bull, Jard. Bot. Brux. 32:419, saltem p. p. 1962, in Fl. Males. 1. 6: 335, saltem p. p. 1963; J. W. Parham, Pl. Fiji Isl. 176. 1964, ed. 2. 251. 1972; van Balgooy \& Leenh. in Blumea Suppl. 5: 168. map 91, saltem p. p. 1966; Sykes in New Zealand Dept. Sci. Indust. Res. Bull. 200: 108. 1970; St. John \& A. C. Sm. in Pacific Sci. 25: 338. 1971; B. E. V. Parham in New Zealand Dept. Sci. Indust. Res. Inform. Ser. 85: 104, 105, 106. 1972; Fosberg \& Sachet in Phytologia 28: 470. 1974, in D. J. Carr, Sydney Parkinson, 98. pl. 90. 1983.

Fagraea grandis Pancher \& Sebert in Sebert, Not. Bois Nouv. Caléd. 184, nom. superfl. 1874.

Fagraea vitiensis Gilg \& Benedict in Bot. Jahrb. 56: 553. 1921; J. W. Parham, Pl. Fiji Isl. 176, 1964, ed. 2. 251. 1972; non Seem. (1861, nom. nud.).

An often branching tree or shrub 1.5-20 m. high, sometimes locally abundant, occurring from near sea level to about $900 \mathrm{~m}$. in dry, open, or dense forest and in forest patches in open country. Its fragrant flowers have cream-white corollas that fade to rich yellow and a greenish style; the fruit is yellow, becoming orange or red at maturity, with seeds embedded in orange pulp. Flowers are usually most abundant between October and March, but fruits are found throughout the year.

TYPIFICATION: In first describing this species and adopting a manuscript name of Gray, Bentham cited collections of Bertero, Bidwill, Hinds, and Barclay (Society Islands), Barclay (Marquesas), and MacGillivray (Louisiade Archipelago), also listing Carissa grandis Bertero (nom. nud.). Leenhouts (1962, p. 420) indicated the specimen upon which Bertero's name was based, collected by Bertero and Moerenhout in Tahiti, as the type. A proper citation is: Bertero \& Moerenhout (P LECTOTYPE), collected in Tahiti, Society Islands. That specimen (in the original mention by Guillemin) is said to lack flowers. Since the corolla and associated organs provide critical characters in Fagraea, it may prove desirable to supersede the lectotypification (ICBN, Art. 8.1); any of the flowering specimens originally cited by Bentham could be substituted.

Although the original spelling of the epithet was berteriana, and although that spelling seems to have been adopted by all subsequent students, it is here corrected to berteroana. Such a form seems required by ICBN, Art. 73.10, which mandates correction of orthographic errors mentioned in Rec. 73C.1, in which Recommendation (c) an adjectival epithet based on the name Bertero is given as an example.

The type of Fagraea vitiensis Gilg \& Benedict is Weber 105 (B HOLOTYPE, presumably destroyed), collected between 1881 and 1883 at Somosomo, Taveuni.

Distribution: New Guinea, the Caroline and Mariana Islands, and northeastern Queensland eastward in the Pacific to the Marquesas and Austral Islands (Leenhouts, 1962, 1963). In Fiji the species is known with certainty from only five islands, about 45 collections being at hand, but it is to be expected on all the high islands.

LOCAL NAMES AND USES: The usual names are mbua, mbuandina, mbuani Viti, and mbua ni veikau; the name kandisa was noted in Mba Province. The wood is considered useful for tools and building, and the timbers are often used for houseposts; the fragrant flowers are used in necklaces and also for scenting coconut oil; and in parts of Viti Levu the plant is reputed to have medicinal value, a concoction from the inner bark being used in treating asthma and diabetes.

RePResentative COllections: VITI LEVU: MBA: Mt. Evans Range, Greenwood 1282; Ndrasa Forest Reserve, DA 13771 (DF 468, Damanu 117); Vunanamo, DA 14794; vicinity of Nandarivatu, Degener 14381. Nandronga \& Navosa: Nausori Highlands, DF 144 (Johns 1). Serua: Flat coastal strip in vicinity of 
Ngaloa, Smith 9333. Namosi: Namosi Valley, Seemann 308; vicinity of Namosi, Gillespie 2513; between Namosi and Namuamua, Weiner 17. NaITASIRI: Wainamo Creek, near Matawailevu, Wainimala River, St. John 18194: Tamavua-Sawani road, Setchell \& Parks 15081. REwA: Queen's Road 20 miles west of Suva, Vaughan 3309; vicinity of Suva, im Thurn 16. OVALAU: Graeffe 1417; hills above Levuka, Gillespie 4466. VANUA LEVU: MBUA: Southern portion of Seatovo Range, Smith 1709; ridge west of Thongea, Wainunu River, DA 15777. Mathuata: Southern slopes of Mt. Numbuiloa, east of Lambasa, Smith 6406 . THAKAUNDRove: Southern slope of Mt. Mariko, Smith 407; Maravu, near Salt Lake, Degener \& Ordonez 14257. MOALA: Summit of ridge, Bryan 346.

Fagraea berteroana is here provisionally accepted in the comprehensive sense of Leenhouts (1962, 1963), who discussed its range of variability, as did Fosberg and Sachet (1974); the latter authors consider the species too broadly interpreted by Leenhouts and divisible at least into taxa of infraspecific rank. Pending a revision of the complex in Polynesia, it may be noted that in Fiji the corolla tube at full anthesis is 3-5 cm. long, the anthers and style being exserted. Many Polynesian specimens have the corolla tube about $8 \mathrm{~cm}$. long (e. g. those described as $F$. samoensis Gilg \& Benedict). In Fiji the taxon is reasonably uniform; if eventually typical $F$. berteroana is construed as having a corolla tube $6.5-8 \mathrm{~cm}$. long (Fosberg and Sachet, 1974) and Fijian material is excluded from it, the name $F$. vitiensis Gilg \& Benedict is available for that at some nomenclatural level.

2. Fagraea gracilipes A. Gray in Proc. Amer. Acad. Arts 4: 323. 1859, in op. cit. 5: 320. 1862, in Bonplandia 10: 37. 1862; Seem. Viti, 439. 1862, Fl. Vit. 165. 1866; Drake, Ill. Fl. Ins. Mar. Pac. 238. 1892; A. C. Sm. in J. Arnold Arb. 33: 113. 1952; Leenh. in Bull. Jard. Bot. Brux. 32: 426, saltem p. p. 1962, in Fl. Males. I. 6: 332, saltem p. p. 1963; J. W. Parham, Pl. Fiji Isl. 176. fig. 64. 1964, ed. 2. 251. fig. 74. 1972; van Balgooy \& Leenh. in Blumea Suppl. 5: 168. map 91, saltem p. p. 1966.

FIGURES 19, 125.

Fagraea viridiflora Seem. in Bonplandia 9: 257, nom. nud. 1861.

An often spreading tree 3-25 m. high, with a trunk up to $1 \mathrm{~m}$. or more in diameter, sometimes locally abundant, found from near sea level to about $500 \mathrm{~m}$. in dry or dense forest, in forest patches in grassland, and infrequently on the inner edges of mangrove swamps. The corollas and filaments are cream-white, soon fading to pale yellow or orange-yellow; the fruits at maturity are waxy-white to ivory-white or cream-colored. Flowers and fruits are found throughout the year.

TyPifiCATION: The type is U. S. Expl. Exped. (US 62265 HOLOTYPE; ISOTYPES at GH, K), collected in 1840 in Fiji without detailed locality. The source of the name $F$. viridiflora is Seemann 306 (BM, GH, K), obtained in July, 1860, at Port Kinnaird, Ovalau.

Distribution: In a broad sense (Leenhouts, 1962, 1963) Fagraea gracilipes extends from New Guinea and northeastern Queensland to the Solomon and Santa Cruz Islands and Fiji. Leenhouts (1962) points out that the species is composed of five geographically restricted races (for all of which specific epithets are available); the characters outlined by him (and readily observed in available material) suggest that nomenclatural recognition at some level may be desirable. In a narrow sense, therefore, $F$. gracilipes may be considered a Fijian endemic. In Fiji it is now known from four of the high islands, 47 collections having been examined by me. The taxon is obviously more abundant (at least near the south-central coast of Viti Levu and in northern Vanua Levu) than I previously (1952) indicated. It is represented by many recent collections because of its interest to foresters, its timber being valued as more durable than that of $F$. berteroana. 
LOCAL NAMES AND USES: Mbuambua is the name in general use; makamakandora has been noted in Serua Province. The timber has been used for houseposts and is in considerable demand for wharf piles, being very durable for underwater use, but it is now in short supply. In Mathuata and Mbua the cutting of trees with a girth of less
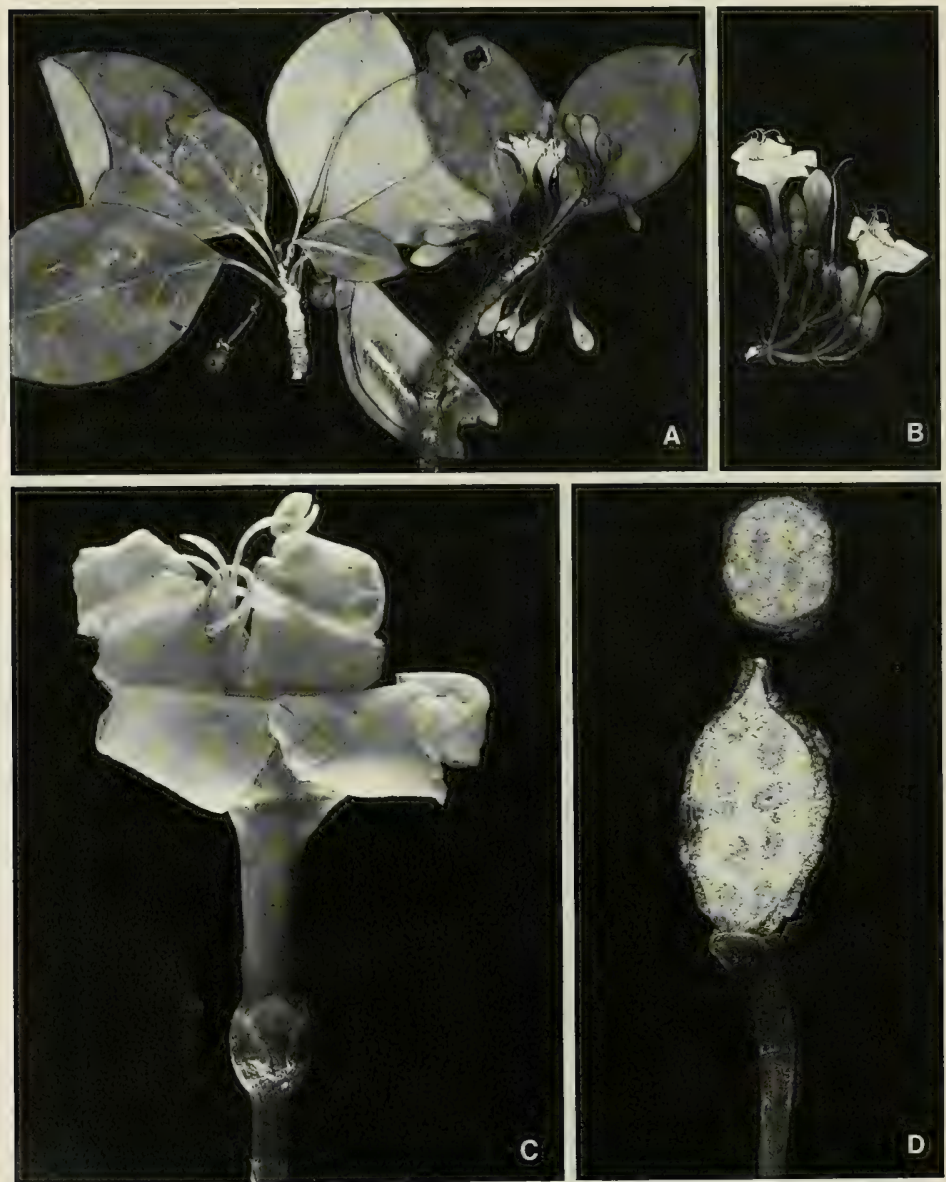

FIgURE 19. Fagraea gracilipes; A, distal portions of branchlets, with infructescence and influrescence, $\times$ $1 / 3$; B, portion of inflorescence, $\times 1 / 2$; C, expanded flower, one anther remaining, $\times 2$; , cross and longitudinal sections of dried fruits, $\times 2$. A from $D F 837$ (fruits) and $D A 15670$ (flowers), B-D from Smith 9574. 
than three feet has been prohibited (Parham, 1972). A tea made from the bark and leaves is said to be used medicinally in Serua.

RePresentative Collections: VITI LEVU: NandRonga \& Navosa: Nausori Highlands, DA 13503. SERUA: Vicinity of Ngaloa, DA 15670; coastal hills in vicinity of Taunovo River, east of Wainiyambia, Smith 9574: Nggaraninggio River, DA 3809; Ndeumba, DA 9219 (McKee 2783). NAmosi: Nambukavesi Creek, DF 760, Damanu NI-36. NAITASIRI: Tholo-i-suva, DA 13773 (DF 137). KANDAVU: DA 11955 (DF 35 , Watkins 704), DF 837 (S1422/2). VANUA LEVU: MBUA: "Mbua district," Horne 1124; Nasarowangga, DA 11839. Mathuata: Vicinity of Ndreketi (Bull's timber area), DF 861 (S/422/4); Naravuka, Ndreketi River, DF 999 (S1422/3); Natindoyanga Creek, Korovuli River headwaters, DA 12907; Seanggangga Plateau, in drainage of Korovuli River, vicinity of Natua, Smith 6665; vicinity of Lambasa, Greenwood 489. ThaKAUNDRove: Nambunambuna Creek area (Ndreketi River drainage), Berry 18.

\section{FAMILY 165. APOCYNACEAE}

Apocynaceae Juss. Gen. Pl. 143, as Apocineae. 1789.

Trees, shrubs, lianas, or herbs, with a well-developed system of laticifers (except in Nerium), with consistently present internal phloem, estipulate or stipules small and interpetiolar or intrapetiolar; leaves simple, opposite or whorled, rarely alternate, the blades entire, pinnate-nerved; inflorescences terminal, axillary, or lateral between 2 petioles, cymose or thyrsoid, sometimes paniculiform, sometimes 1-flowered, bracteate and bracteolate; flowers $\zeta$, actinomorphic (rarely weakly zygomorphic), often showy, (4 or)5-merous (except gynoecium); calyx with (usually quincuncially) imbricate lobes, sometimes bearing glands within; corolla sympetalous, often hypocrateriform or infundibuliform, regular or nearly so, the tube sometimes with appendages within, the lobes convolute, rarely imbricate or valvate; stamens borne on corolla tube, as many as and alternate with corolla lobes, the filaments without coronal appendages, the anthers distinct or connivent around style head, sometimes adherent to style head by a retinaculum of viscid exudates, 2-locular, dehiscing by longitudinal, introrse or sublateral slits, often sagittate or sagittate-tailed at base, the locules sometimes empty at base; nectary glands often present about base of ovary, alternating with stamens or sometimes confluent into an annular disk or fewer than stamens or lacking; gynoecium usually of 2 carpels, these variously connate, sometimes forming a superior, bilocular ovary with simple or apically cleft style, sometimes the ovary unilocular with intruded parietal placentae, sometimes the carpels partly or completely separate, the ovules 2-many in each ovary or locule or on each placenta, anatropous to amphitropous or hemitropous, usually pendulous, the styles united or sometimes distinct and united only at apex, the style head often thickened and specialized, the stigmas free or shortly united; fruits baccate, drupaceous, or follicular, sometimes apocarpous and then the mericarps opposed or parallel, sometimes syncarpous, the seeds usually flat, sometimes comose, the embryo large, straight, the endosperm oily, copious to scanty.

Distribution: Pantropical and subtropical, extending into temperate areas, with 200-220 genera and 2,000-2,300 species. The family includes well-known ornamentals, but many taxa have poisonous parts if ingested. Sixteen genera are recorded from Fiji, ten of them with indigenous species, the others known only from cultivated or naturalized taxa.

USEFul treatments of Family: BaCker, C. A., \& R. C. Bakhuizen VAn den Brink, JR. Apocynaceae. Fl. Java 2: 218-244. 1965. BoIteAu, P. (avec la collaboration de L. Allorge). Apocynacées. In: Aubréville, A., \& J.-F. Leroy (eds.). Fl. Nouv.-Caléd. et Dépend. 10: 1-302. 1981. Huber, H. Apocynaceae. In: Dassanayake, M. D., \& F. R. Fosberg (eds.). Rev. Handb. Fl. Ceylon 4: 25-72. 1983.

The great diversity of flowers and fruits of Apocynaceae has permitted the development of various systematic arrangements. That proposed by $\mathrm{M}$. Pichon is now widely adopted; as elaborated by him and several colleagues and as utilized by Boiteau (1981) it recognizes five subfamilies, all but one of which are represented in Fiji, as in New Caledonia. The subfamilial circumscriptions outlined in the following key are based only on genera that occur in Fiji. 
KEY TO GENERA

Anthers not adherent to style head by a retinaculum of viscid exudates.

Anthers fertile to base, the locules parallel, equal, ellipsoid; seeds without a fleshy arillode.

Corolla eventually sliding along style and leaving it exposed with style head visible at its apex; anthers with introrse dehiscence (subfam. Plumerioideae).

Fruit more or less fleshy, syncarpous and baccate or apocarpous and with drupaceous mericarps, the seeds ecomose; indigenous taxa.

Filaments short and broad; fruit syncarpous, baccate, large, subglobose, with fleshy pulp, the pericarp sclerose but without fibers, the seeds numerous, slightly compressed; disk lacking; corolla lobes sinistrorsely contorted in bud; corolla throat with suprastaminal, sometimes lobulate scales; lianas with opposite (or rarely ternate) leaves. ......... Melodinus

Filaments obvious, slender; mericarps of fruit simple or moniliform, drupaceous, the seeds 1-few; corolla throat without scales; trees, shrubs, or lianas, the leaves verticillate or opposite.

Corolla lobes dextrorsely contorted in bud; mesocarp thick, the endocarp fibrous; placental ridges paired in each carpel; seeds compressed, winged or margined; trees or shrubs.

Disk lacking, the carpels not immersed in tissue but glandular at base, long-attenuate into style, this progressively attenuate distally; endocarp of mature fruit fibrous but smoothsurfaced or cavernous, with 2 cavities distinct from seminiferous cavity, not muricate on surface nor with fibrous extensions into mesocarp. .............. Ochrosia

Disk often reduced to 2 scales alternate with carpels, these immersed in tissue at base or adnate to disk scales, abruptly truncate below style, this comparatively broad, consisting of 2 readily separable strands; endocarp of mature fruit fibrous, muricate, emitting into mesocarp hornlike and distally directed processes, without cavities other than seminifer-

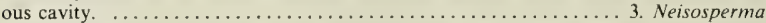

Corolla lobes sinistrorsely contorted in bud; mesocarp thin, fleshy, without fibers, the endocarp crustaceous, usually thin; mericarps not or indistinctly compressed, sometimes moniliform with superposed articles, each article 1-seeded; seeds not or indistinctly compressed, with a deep ventral groove; scandent shrubs or lianas; disk inconspicuous or none. . ...4. Alvxia

Fruit dry, a dehiscent double follicle; trees, shrubs, or suffrutescent plants, the leaves alternate or opposite or clustered at apices of thick branchlets.

Leaves opposite or verticillate, persistent; bracts persistent; ovary superior or partly inferior but not adherent to receptacle.

Trees, shrubs, or lianas with woody branches; indigenous taxa.

Trees or erect shrubs; inflorescences terminal; calyx lobes without glands; corolla tube staminiferous near middle or toward apex, the lobes sinistrorsely or dextrorsely (as in our taxa) contorted in bud; disk annular, often indistinct from ovary; carpels in flower obviously free or concrescent at base; style head densely velutinous at least at base, membranous-indusiate above, with a narrow, reflexed flange; mericarps very slender, often elongate, the seeds pilose on margins and sometimes on surfaces, comose at both

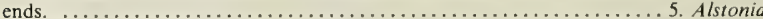

Lianas or scandent shrubs; inflorescences axillary; calyx lobes with a few small glands within at base; corolla tube staminiferous below middle, the lobes sinistrorsely contorted in bud; disk 2-lobed, subcarnose; carpels in flower appressed to one another; style head narrowly oblong-subconical or clavate, without a flange; mericarps gradually narrowed distally, the seeds with a distal coma of numerous hairs. .............6. Carruthersia Suffrutescent plants with herbaceous branches; seeds ellipsoid, black, shining, glabrous, not winged, with a ventral groove; our species cultivated and sometimes naturalized.

7. Calharanthus

Leaves irregularly clustered at apices of thick, fleshy branchlets; bracts caducous; ovary adherent to receptacle for most of its length, semi-inferior; seeds glabrous, flattened, basally winged, ecomose; corolla thickened, especially at base; our taxa cultivated and sometimes naturalized.

\section{Plumeria}

Corolla eventually becoming detached together with style and style head, these retained among the infra- and suprastaminal scales, the lobes sinistrorsely contorted in bud; anthers with lateral or sublateral dehiscence; seeds moderately compressed, not or narrowly winged, ecomose; trees or shrubs (subfam. Cerberoideae).

Calyx deeply lobed, each lobe with 7-12 glandular scales at base within; corolla tube narrow at base, campanulately broadened in lower quarter or fifth; stamens inserted at apex of narrow portion of corolla tube, the filaments broadened, lobulate, pilose, the anthers with a short-acuminate or subacute appendage; disk cupular or pulvinate; style head with isomorphic, spreading lobes; fruit with mericarps united into a laterally compressed, obdeltoid or pyriform drupe; our species cultivated and naturalized. 
Calyx divided essentially to base, the lobes without glands; corolla tube narrowly cylindric, inflated below the narrow throat; stamens inserted in swollen part of corolla tube, subsessile, the anthers with filiform apical appendages; disk lacking; style head with annular swellings, without lobes; fruit apocarpous, the mericarps drupaceous; indigenous. $\ldots \ldots \ldots \ldots \ldots \ldots 10$. Cerbera Anthers sagittate at base, the locules with short sterile prolongations; fruit apocarpous, the mericarps fleshy, without a differentiated woody layer, dehiscent at maturity, with ecomose seeds covered by a fleshy arillode; leaves opposite, often anisophyllous; style head round in cross section, without ribs or dilated parts, the stigmas subequalling it or exceeding it in height; corolla eventually sliding along style and leaving it exposed with style head visible at its apex, the lobes (in our taxa) sinistrorsely contorted; ovary apocarpous, the carpels concrescent only at base; indigenous or cultivated taxa (subfam. Tabernaemontanoideae).

Corolla subcoriaceous or thick-carnose, staminiferous below middle of tube, the lobes forming a subglobose, thick, coherent mass deeply inflexed in bud and penetrating into corolla throat; style

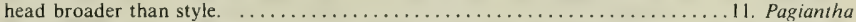

Corolla membranous or somewhat carnose, staminiferous near or above middle of tube or toward its apex, the inflexed portions of lobes in bud not penetrating into corolla throat; style head broader than style or sometimes nearly as slender. ........................ Ervatamia Anthers adherent to style head by a retinaculum of viscid exudates, the ensemble of corolla, stamens, style, and style head caducous soon after anthesis; fruit a bivalved capsule aculeate with long, soft spines and with compressed, ecomose seeds, or fruit with united mericarps that sometimes become separated and bear apically comose seeds (subfam. Echitoideae).

Fruit a septicidal capsule covered with spines, the seeds circumalate, ecomose; corolla campanulateinfundibuliform, broadened at throat, large (in our taxa at least $4 \mathrm{~cm}$. long and spreading to a limb at least $3.5 \mathrm{~cm}$. in diameter); shrubs, usually scandent, or lianas, the corolla yellow or purplish, with small, pilose scales above each stamen; anthers without an elongated connective, adherent to style head by a retinaculum of a few viscid filaments; ovary unilocular, with 2 parietal placentac; our taxa

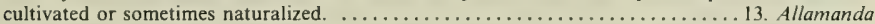

Fruit with united mericarps, these sometimes at length separating, the seeds unwinged, with an apical coma of fine hairs; anthers adherent to style head by a retinaculum of numerous exudates; ovary bilocular.

Anthers with apical appendages as long as or longer than locules; retinaculum forming a conspicuous brush; corolla lobes dextrorsely contorted in bud; carpels united to apex; calyx lobes with many glandular scales within; fruit syncarpous or sometimes with the mericarps at length separating; our taxa cultivated or infrequently naturalized.

Erect shrubs; leaves usually verticillate; corolla glabrous without, the tube villose within, with projecting staminal nerves, the corona composed of 5 epipetalous lobes; filaments short, the anthers with long, pilose, intertwisted apical appendages; disk lacking; style head with a basal flange. . . . . . . . . . . . . . . . . . . . . . . . . . . . . . . . . . . . . Lianas; leaves opposite; corolla at least partially pilose without, the tube glabrous within, without protruding staminal nerves, the corona indistinct, without free parts; filaments longer than anthers, the anther appendages not intertwisted; disk shallowly lobed; style head without a basal

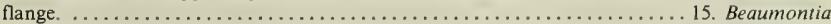

Anthers without apical appendages; retinaculum reduced to a row of hairs forming a covering; corolla without a corona or suprastaminal scales, the lobes valvate in bud; carpels essentially concrescent, the fissure between them sometimes scarcely apparent; filaments appressed to style, adherent to or intertwisted with it; disk 5-lobed, free from ovary; calyx lobes usually with few, inconspicuous glandular scales within; fruit syncarpous but the mericarps at length separating; lianas or scandent shrubs; indigenous. . . . . . . . . . . . . . . . . . . . . . . . . . . . . .

1. Melodinus J. R. \& G. Forst. Char. Gen. Pl. 19. 1775, ed. 2. 37. 1776; Seem. Fl. Vit. 155. 1866; Pichon in Mém. Mus. Nat. Hist. Nat. 24: 125. 1948; Backer \& Bakh. f. Fl. Java 2: 221. 1965; Boit. et al. in Adansonia II. 15: 397. 1976; Boit. in Fl. Nouv.-Caléd. et Dépend. 10: 16. 1981.

Lianas, the stipules reduced to interpetiolar lines; leaves opposite (rarely ternate), the blades pinnate-nerved; inflorescences axillary, cymose; calyx without basal glands within, the lobes longer than tube, broadly ovate, obtuse, ciliolate; corolla hypocrateriform, the tube subcylindric, often pilose within, widened at insertion of stamens, the throat with 5 or more erect scales, these sometimes fused into a many-lobulate corona (as in our species), the lobes sinistrorsely contorted in bud, at length spreading; 
stamens attached to corolla tube about at its middle, the filaments very short, the anthers ovate-lanceolate, glabrous, the locules introrsely dehiscent; disk lacking; ovary glabrous, 2-locular, the ovules numerous in each locule, the style short, glabrous, the style head cylindric or oblong-ovoid, glabrous, with a short, prostrate flange at base, the stigmas apiculate or subulate; fruit syncarpous, baccate, indehiscent, subglobose, with fleshy pulp, the pericarp sclerose but without fibers, the seeds numerous, slightly compressed, glabrous, the hilum punctiform.

TYPE SPECIES: Melodinus scandens J. R. \& G. Forst., the only original species.

Distribution: Southeastern Asia throughout Malesia to Australia and into the Pacific as far as Fiji and Tonga, with about 75 species. Two species are indigenous in Fiji.

Although the two Fijian species of Melodinus are partially sympatric (at least in Mba Province, Viti Levu), they are readily distinguished as noted in the following key. The inflorescence indument of $M$. vitiensis is at first obvious but is eventually lost; characters of leaf venation and fruit size seem dependable. It is interesting to note that $M$. vitiensis extends eastward to Tonga, while $M$. glaber extends westward to the New Hebrides. I consider the record of $M$. vitiensis in the Loyalty Islands (Boiteau, 1981, p. 47) to be doubtful; $M$. vitiensis has a somewhat longer corolla tube than that of Loyalty Island material, with a corona composed of fewer lobules, and its fruits are larger. The critical character of leaf blades with impressed nerves above is not mentioned by Boiteau, but I would suspect the Loyalty Island collections of this alliance to represent an undescribed species.

\section{KEY TO SPECIES}

Petioles (3-) 5-11 mm. long; leaf blades ovate to oblong- or lanceolate-ovate, (5-) 6-14.5 × (2-) $2.5-6 \mathrm{~cm}$., obtusely cuspidate at apex, the secondary and tertiary nerves sharply but narrowly impressed above; inflorescence branches, pedicels, calyx, and corolla tube without puberulent, tardily glabrate, the inflorescence comparatively congested, with pedicels $1-4 \mathrm{~mm}$. long; mature fruits (4-) $6-10 \mathrm{~cm}$. in

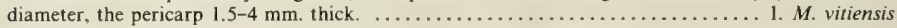

Petioles 3-7 mm. long; leaf blades lanceolate to oblong-or ovate-lanceolate, $4-9 \times(1.3-) 1.5-3.5(-4.5) \mathrm{cm}$., obtuse at apex, the secondary and tertiary nerves prominulous above; inflorescence branches, pedicels, calyx, and corolla tube without glabrous, the inflorescence comparatively lax, with pedicels 3-7 mm. long; mature fruits $2.5-4 \mathrm{~cm}$. in diameter, the pericarp $1-1.5 \mathrm{~mm}$. thick. ........ 2. M. glaber

1. Melodinus vitiensis Rolfe in J. Bot. 21:201. 1883; Yuncker in Bishop Mus. Bull. 220: 217. 1959; J. W. Parham, Pl. Fiji Isl. 185. 1964, ed. 2. 261. 1972.

Figures 20A \& B, 21, 22A.

Melodinus scandens sensu Seem. in Bonplandia 9:257. 1861, Viti, 439. 1862, Fl. Vit. 155. 1866; Drake, 111. FI. Ins. Mar. Pac. 231. 1892; non J. R. \& G. Forst.

An often high-climbing liana with milky latex, found from near sea level to about $1,000 \mathrm{~m}$. in dense, dry, or open forest or on its edges or in forest patches in open country. The corolla is yellowish to cream-colored or white, with the tube sometimes greenish or pink-tinged, and the large fruit is at first green, eventually turning brown. Flowers have been noted in most months, fruits between July and December.

TyPIFICATION: The type (apparently the earliest collection) is Seemann 311 (K HOLOTYPE; ISOTYPES at BM, P), collected in 1860 on Ovalau.

Distribution: Fiji and Tonga. All Fijian collections seen by me are here cited.

Available Collections: VITI LEVU: MBa: Slopes of Mt. Mangondro, Webster \& Hildreth 14287; hills between Nandala and Nukunuku Creeks, along trail from Nandarivatu toward Lewa, Smith 6153; Nandarivatu, Gillespie 3761; Mt. Nanggaranambuluta, Gillespie 3190. SERUA: Hills west of Waivunu Creek, between Ngaloa and Korovou, Smith 9254; vicinity of Ngaloa, Degener 15190, DA 14681; hills between Waininggere and Waisese Creeks, between Ngaloa and Wainiyambia, Smith 9543; hills east of Navua River, near Nukusere, Smith 9120. Namosi: Hills bordering Wainavindrau Creek, vicinity of Wainimakutu, Smith 

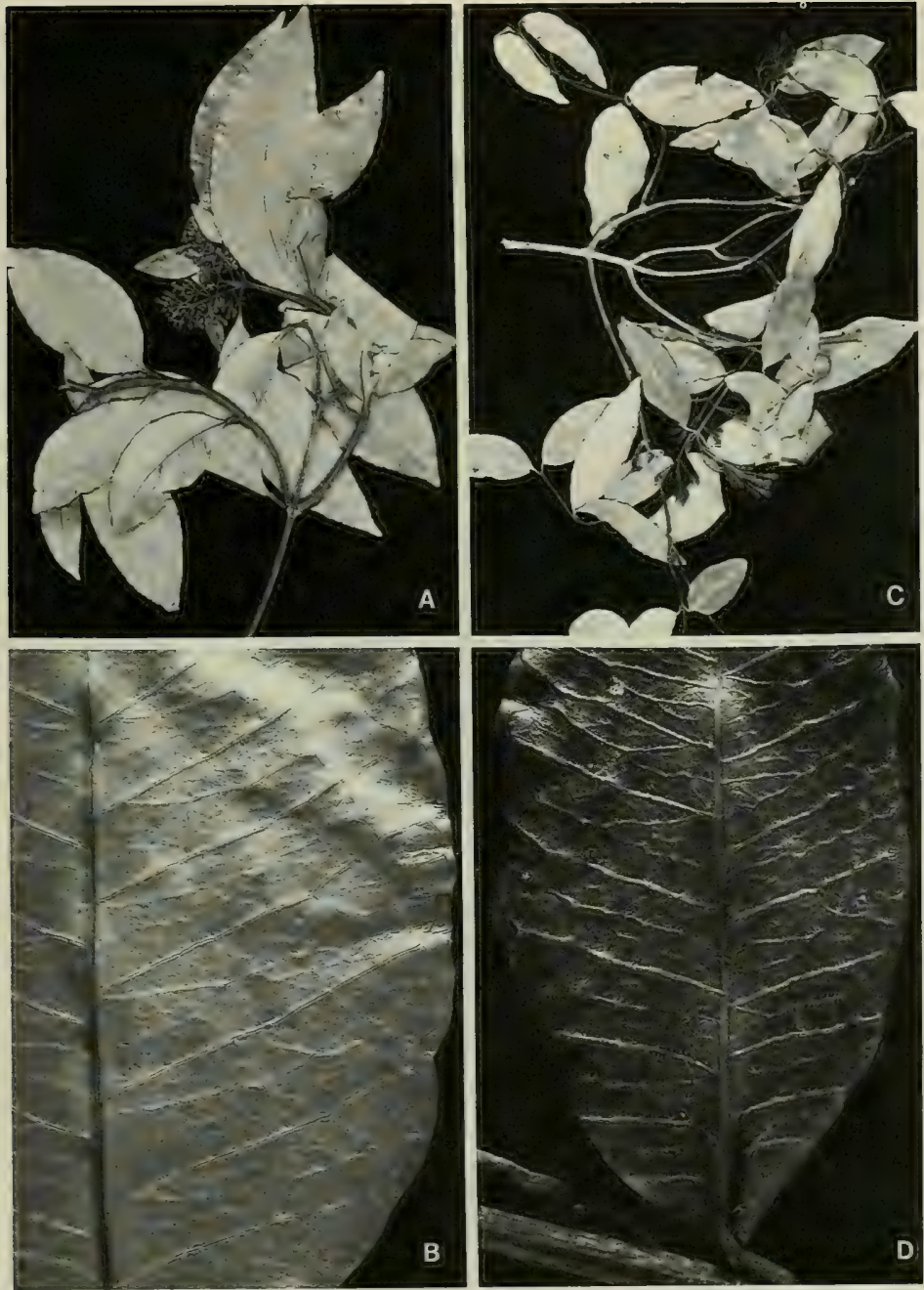

Figure 20. A \& B, Melodinus vitiensis; A, distal portion of branchlet, with foliage and inflorescences, $x$ 1/3; B, portion of upper surface of leaf blade, showing sharply impressed secondary and tertiary nerves, $\times 2$. C \& D, Melodinus glaber: C, distal portion of branchlet, with foliage and inflorescences, $\times 1 / 3 ; \mathrm{D}$, portion of upper surface of leaf blade, showing prominulous secondary and tertiary nerves, $\times 2$. A from DA //620, B from Smith 8562, C from Gillespie 3720, D from Gillespie 3830.2. 
8562; Mborotu, DA 11620. NAITASIRI: Matawailevu, Wainimala River, St. John I8299; vicinity of Nasinu, Gillespie 3562, 3581, DA 7353. TAIlevu: Track to Nandrano, DA 13611. OVALAU: Slopes of Mt. Korotolutolu, west of Thawathi, Smith 8016; Lovoni Valley, DA 17084 . VANUA LEVU: MathuATA: Sasa Tikina, Howard 193; Seanggangga Plateau, in drainage of Korovuli River, vicinity of Natua, Smith 6725 ; mountains near Lambasa, Greenwood 633. FiJi without further locality, Tothill 521.
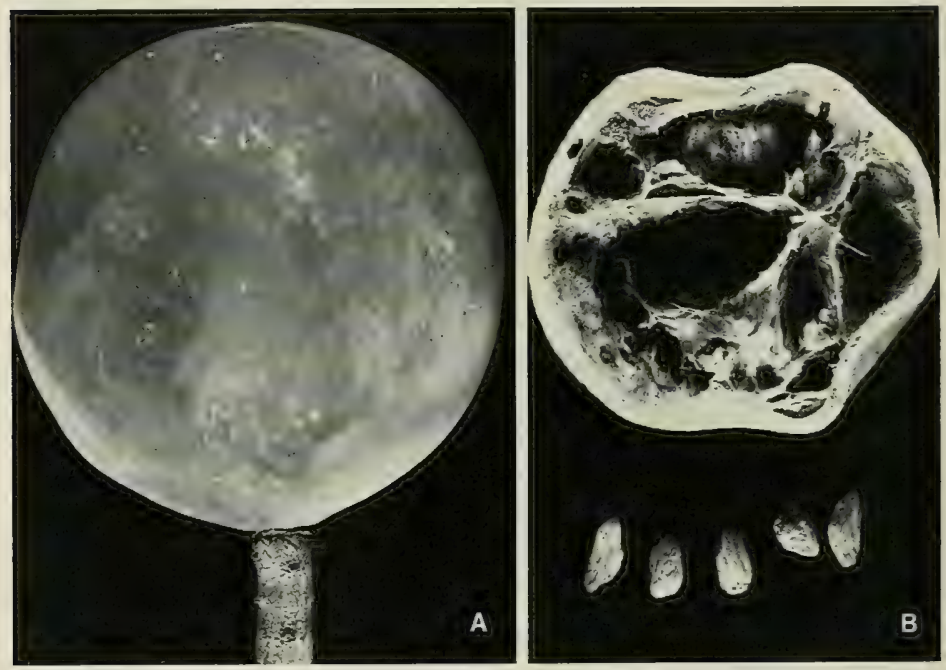

Figure 21. Melodinus vitiensis; A, mature fruit, $\times 1$; B, cross section of mature fruit and seeds, $\times 1$. A from Smith 9254, B from Smith 6153 (seeds from Gillespie 3562).

2. Melodinus glaber Turrill in J. Linn. Soc. Bot. 43:31. 1915; J. W. Parham, PI. Fiji Isl. 185. 1964, ed. 2. 261. 1972; P. S. Green in Bramwell, Plants and Islands, 45.1979.

Figures 20C \& D, 22B-E.

Melodinus neo-ebudicts Guillaumin in J. Arnold Arb. 13: 17. 1932.

An often high-climbing liana with milky latex, occurring in dense forest or on its edges at elevations from near sea level to $1,050 \mathrm{~m}$. (sometimes with mangroves, $\mathrm{cf}$. Parham 85, cited below). Corolla and fruit colors are as in $M$. vitiensis. Flowers have been obtained between November and January, fruits between June and November.

TYPIFICATION AND NOMENCLATURE: The type is im Thurn 60 (K HOLOTYPE; ISOTYPE at BM), collected Jan. 31, 1906, at Nandarivatu, Mba Province, Viti Levu. For Melodinus neo-ebudicus Guillaumin cited Kajewski 729 as "type of the flower" and Kajewski 392 as "type of the fruit." An appropriate citation is: Kajewski 729 (A LECTOTYPE here designated; ISOLECTOTYPES at BISH, P), obtained Feb. 11, 1929, at Anelgauhat Bay, Aneityum, New Hebrides. The paratype, Kajewski 392 (A, BISH, P), is from Dillon Bay, Eromanga. Green's (1979) reduction of the New Hebridean taxon to M. glaber is certainly correct.

Distribution: Fiji and the New Hebrides.

LOCAL NAMES: The names wa motu, wa masi, and vaka tasi have been noted from Mba, kau loa from Mbua. 
Available COLlections: YASAWAS: WaYA: Naruarua Gulch, near Mbatinaremba, St. John $18053 \mathrm{~A}$. VITI LEVU: MBA: Vicinity of Nandarivatu, Tothill 391, 392, Parks 20596, Gillespie 3720, 3830.2; western slope of Mt. Nanggaranambuluta, east of Nandarivatu, Gillespie 3684, Smith 4897. VANUA LEVU: MBUA: Liuka Creek, Rukuruku Bay, with mangroves, H. B. R. Parham 85 (k); Mbua without further locality, H. B. R. Parham s. n. (BM).
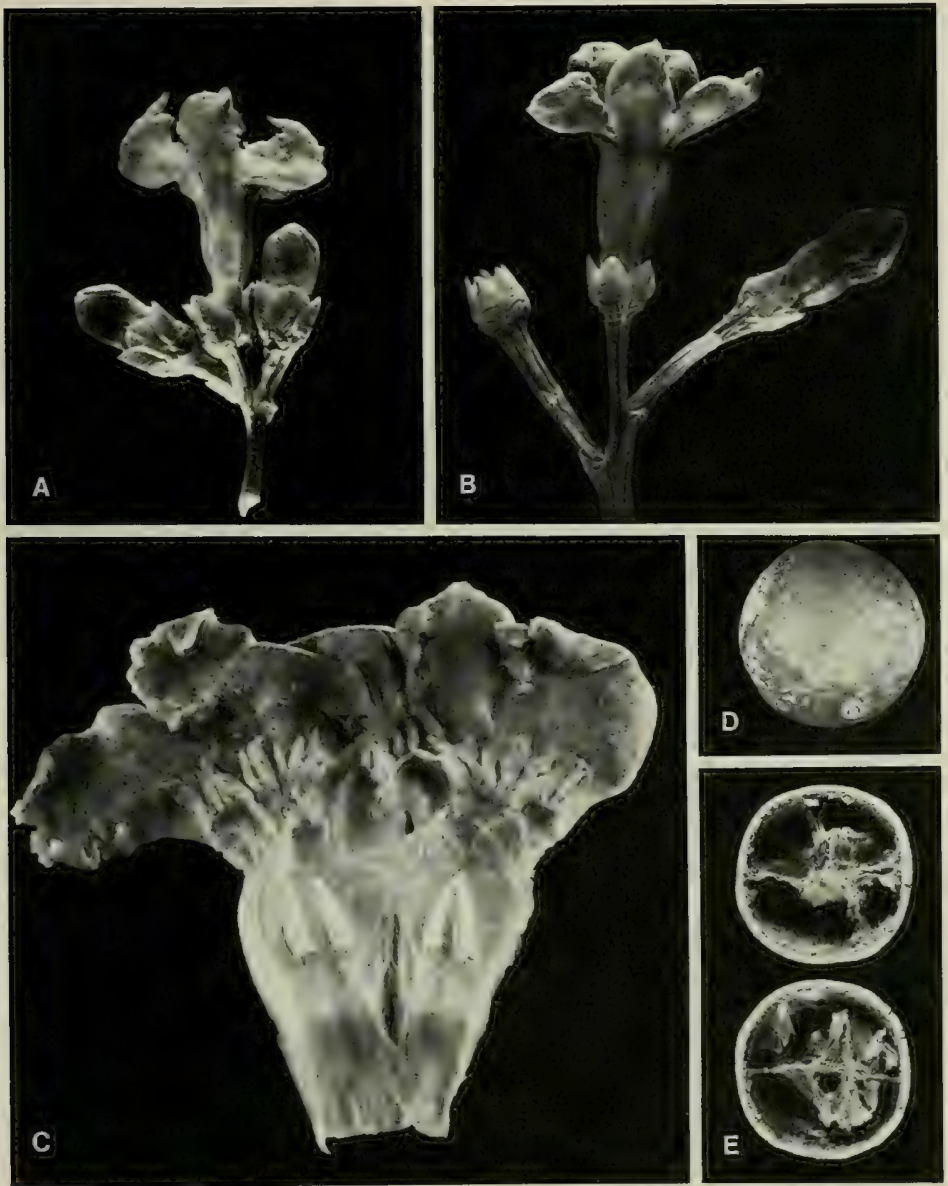

Figure 22. A, Melodinus vitiensis; ultimate cluster of flowers, $\times 4$. B-E, Melodinus glaber; B, ultimate cluster of flowers, $\times 4 ; \mathrm{C}$, opened corolla, showing stamens ( 1 fallen) and many-lobulate corona, $\times 8 ; \mathrm{D}$, mature fruit, $\times 1$; E, cross-sectioned mature fruit, $\times 1$. A from DA $11620, \mathrm{~B} \& \mathrm{C}$ from Gillespie $3720, \mathrm{D} \& \mathrm{E}$ from Gillespie 3684. 
2. Ochrosia Juss. Gen. Pl. 144. 1789; Seem. Fl. Vit. 158, p. p. 1866; Pichon in Bull. Mus. Hist. Nat. (Paris) II. 19: 205, p. p. 1947; Fosberg \& Sachet in Micronesica 10: 254. 1974; Boit. et al. in Adansonia II. 14: 485. 1974; Fosberg, Boit., \& Sachet in op. cit. 17: 23. 1977; Markgraf in Blumea 25: 233. 1979; Boit. in Fl. Nouv.-Caléd. et Dépend. 10: 47. 1981.

Bleekeria Hassk, Retzia 1: 38. 1855.

Excavatia Markgraf in Bot. Jahrb. 61: 194. 1927.

Trees or shrubs; leaves usually verticillate, sometimes opposite, the blades chartaceous to subcoriaceous, the secondary nerves straight, nearly horizontal; inflorescences axillary, cymose, dichotomously or trichotomously branched, with small bracts; calyx lobes broadly ovate, obtuse, without glands; corolla hypocrateriform, the tube cylindric, slightly broadened below the constricted throat, this without scales, the lobes dextrorsely contorted in bud; stamens with short filaments and oblong, acute anthers; disk lacking; ovary bicarpellate, glabrous, the carpels not immersed in tissue but glandular at base, with 2-6 2-seriate ovules, long-attenuate into style, this progressively attenuate distally, the style head short-cylindric, with a basal row of conglutinate hairs, 2-apiculate at apex; fruit usually apocarpous (as in our species), sometimes more or less syncarpous at least toward base, the mericarps drupaceous, somewhat dorsiventrally compressed, with or without a wing; exocarp and mesocarp more or less fleshy, the mesocarp without fibers; endocarp hard-fibrous but smooth-surfaced, with 2 somewhat extended cavities distinct from the laterally compressed seminiferous cavity and at first filled with milky parenchyma (usually empty at maturity), not muricate on surface nor with fibrous extensions, the seeds 2-6, compressed, narrowly winged, the hilum linear.

TYPE SPECIES: Ochrosia borbonica Gmelin; this typification is interestingly discussed by Markgraf (1979, p. 234). An earlier epithet in Ochrosia was $O$. maculata Jacq., the identity of which still seems questionable. Pichon (1947, p. 206), Fosberg and Sachet (1974, p. 255), and Markgraf (1979) seem to imply that O. maculata is conspecific with $O$. borbonica, but Fosberg, Boiteau, and Sachet (1977, p. 32, in index only) indicate that $O$. maculata is to be synonymized with Neisosperma oppositifolium.

Bleekeria is typified by B. kalocarpa Hassk. (= Ochrosia elliptica Labill., cf. Markgraf, 1979, p. 240, and Boiteau, 1981, p. 54).

For Excavatia Markgraf no type species was indicated by ING (1979); in describing the genus in 1927 Markgraf provided a key to three species, but only two were discussed, E. littoralis (Merr.) Markgraf and E. coccinea (Teijsm. \& Binnend.) Markgraf. The first of these (based on Ochrosia littoralis Merr.) has been referred to $O$. ackeringae (Teijsm. \& Binnend.) Miq. by Markgraf (1979, p. 238), the second (based on Lactaria coccinea Teijsm. \& Binnend.) to O. coccinea (Teijsm. \& Binnend.) Miq. by Markgraf (1979, p. 239). Since only the second of these now retains a specific epithet first utilized by Markgraf when he proposed Excavatia, and since it was illustrated by him in 1927, the lectotype species of Excavatia is probably best indicated as $E$. coccinea.

Distribution: Mascarene Islands to Malesia, the Bonin Islands, and Australia, and eastward in the Pacific to the Society and Marquesas Islands and Hawaii. Fosberg, Boiteau, and Sachet (1977) in their preliminary list include 21 species (also stated by Boiteau, 1981), only one of which is from Hawaii, but St. John (in Adansonia II. 18: 199-220. 1978) accounts for eleven species in Hawaii alone. Markgraf (1979) 
indicated the genus as including about 23 species. One species is indigenous in Fiji and Tonga.

Useful treatment of Genus: Markgraf, F. Florae Malesianae Praecursores LIX. Apocynaceae V. Ochrosia, Neisosperma. Blumea 25: 233-247. 1979.
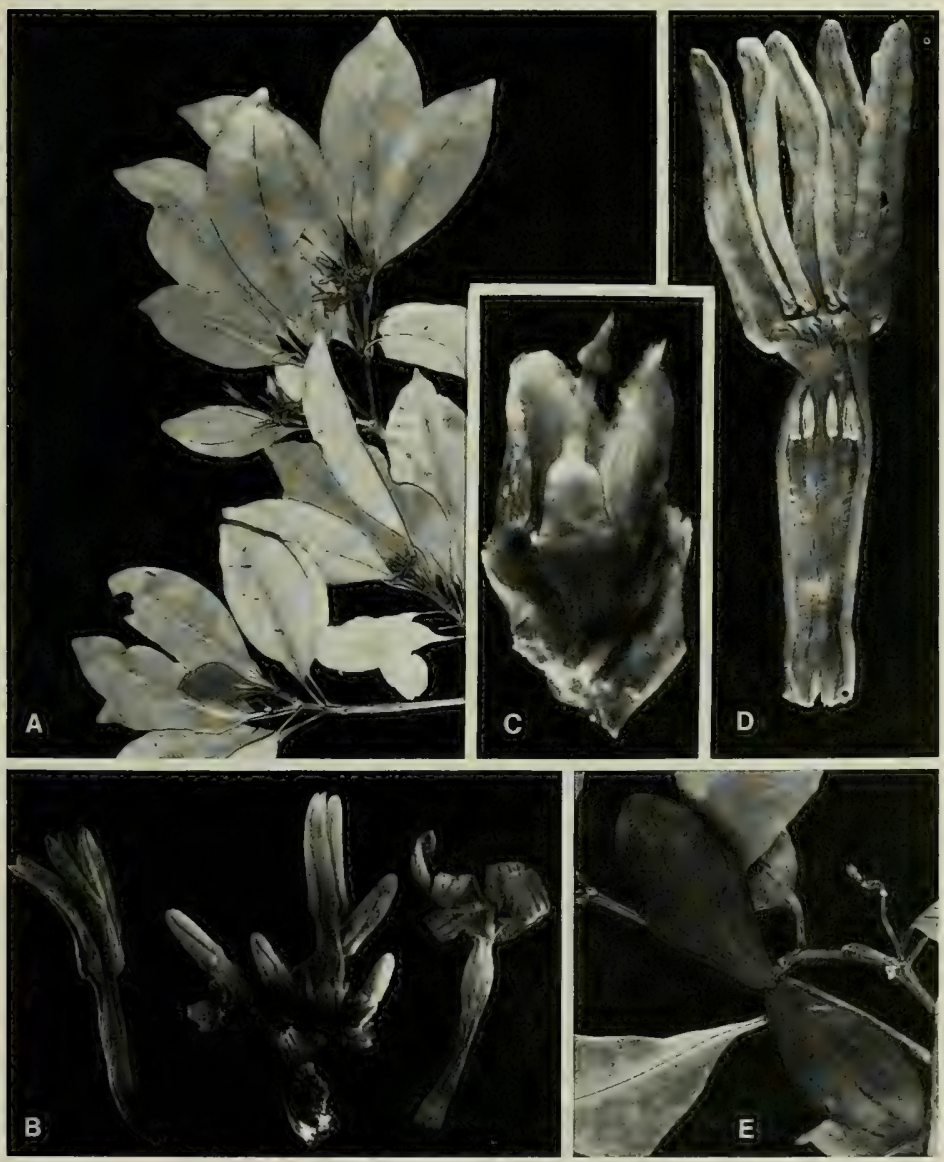

Figure 23. Ochrosia vitiensis; A, distal portion of branchlet, with foliage and inflorescences, $\times 1 / 3 ; \mathbf{B}$, inflorescence and detached corollas, $\times 2$; C, gynoecium of young flower, also showing 3 calyx lobes and a bracteole, $\times 12 ; \mathrm{D}$, opened corolla, showing stamens, $\times 4 ; \mathrm{E}$, spreading mericarps of developing fruit, $\times 1$. A-D from Smith 1224, E from Smith 1501 . 

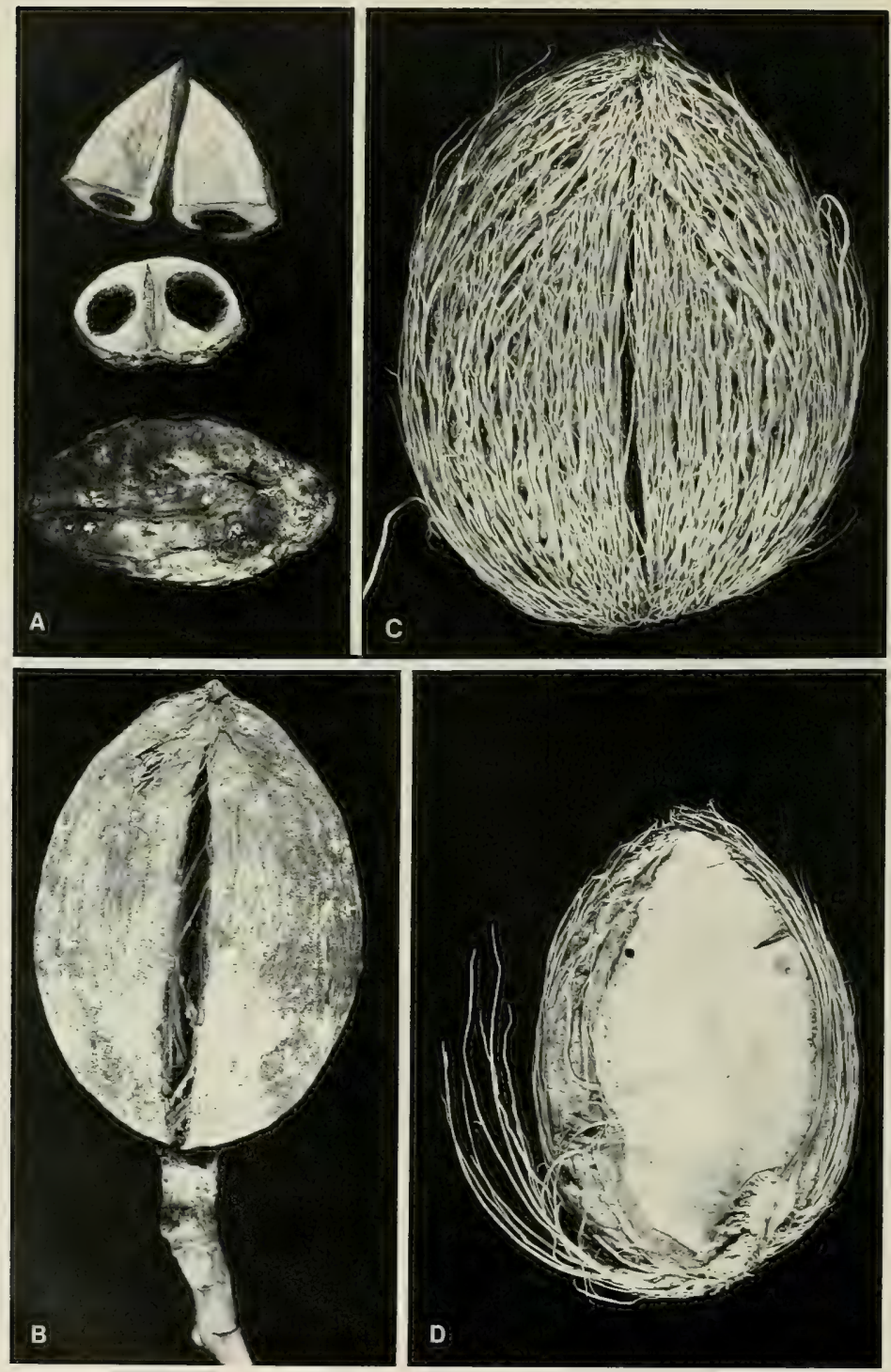
1. Ochrosia vitiensis (Markgraf) Pichon in Bull. Mus. Hist. Nat. (Paris) II. 19: 207.

1947; Fosberg, Boit., \& Sachet in Adansonia II. 17:28. 1977. Figures 23, 24A.

Excavatia vitiensis Markgraf in Bishop Mus. Bull. 141: 127. fig. 66, b, c. 1936.

Bleekeria vitiensis A. C. Sm. in Bull. Torrey Bot. Club 70: 549. 1943; Yuncker in Bishop Mus. Bull. 220: 221. 1959; J. W. Parham, PI. Fiji Isl. 183. 1964, ed. 2. 259. 1972.

Tree or shrub 2-12 m. high, with white latex, occurring from near sea level to about $500 \mathrm{~m}$. in dense, dry, or open forest or on its edges, in beach thickets, and on cliffs along beaches, often on limestone. The corolla is pale yellow and the fruit becomes red at maturity, or it is sometimes noted as brown with red pulp. Flowers have been obtained between November and May, fruits in most months.

TYPIFICATION: The type is Smith 1155 (BISH HOLOTYPE; many ISOTYPES), collected Feb. 23, 1934, on Fulanga.

Distribution: Fiji and Tonga. The species appears scattered and infrequent in Fiji, but probably it is more abundant in the Lau Group than suggested by the known collections.

LOCAL NAMES: In southern Lau the names ndongondongo and vaoko have been recorded, but both are questionable for this species.

Available collections: VITI LEVU: Serua: Hills west of Waivunu Creek, between Ngaloa and Korovou, Smith 9478: hills between Waininggere and Waisese Creeks, between Ngaloa and Wainiyambia, Smith 9659; Loloma Beach, DA 16644. KANDAVU: Ndravuwalu Village, Natheva Tikina, Berry 248. VANUA LEVU: MathUATA: Southern slopes of Mt. Numbuiloa, east of Lambasa, Smith 6581. VANUA MBALAVU: Northern limestone section, Smith 1501: Namalata islet, southern limestone section, Smith 1434. FULANGA: On limestone, Smith 1224. ONGEA LEVU: Bryan 428 (fruits only); on rocky beach cliff, Bryan 438.

3. Neisosperma Raf. Sylva Tellur. 162. 1838; Fosberg \& Sachet in Micronesica 8: 48, as Neiosperma. 1972, in op. cit. 10: 254, as Neiosperma. 1974, in Adansonia II. 17: 21. 1977; Fosberg, Boit., \& Sachet in op. cit. 17:28. 1977; Markgraf in Blumea 25: 241. 1979; Boit. in Fl. Nouv.-Caléd. et Dépend. 10: 64. 1981.

Ochrosia sensu Seem. Fl. Vit. 158, p. p. 1866; non Juss.

Trees, often with thick branchlets; leaves verticillate (3-6 at a node), rarely opposite, the blades usually subcoriaceous, with straight secondary nerves; inflorescences axillary, cymose, usually long-pedunculate, the peduncle producing an irregular whorl of branchlets, these branched again or not, the flowers spirally arranged and crowded, the pedicels short; calyx lobes ovate-orbicular, obtuse, without glands; corolla hypocrateriform, soon caducous, the tube comparatively short, cylindric, broadening toward middle, the throat contracted, glabrous, without scales, the lobes dextrorsely contorted in bud; stamens inserted near middle of corolla tube, the filaments short, the anthers erect, longer than filaments; disk often reduced to 2 scales alternate with carpels; ovary bicarpellate, the carpels immersed in tissue at base or adnate to disk scales, with 2-6 2-seriate ovules, abruptly truncate below style, this comparatively broad, consisting of 2 readily separable strands, the style head ellipsoid, short, with a basal ring of hairs and 2 apical appendages; fruit always apocarpous, fleshy, the mericarps not or rarely dorsiventrally compressed, drupaceous, the exocarp thin, the mesocarp usually more fleshy than that of Ochrosia, fragrant, often consumed by animals, the endocarp fibrous, muricate, emitting into mesocarp numerous, hornlike, distally directed processes, without cavities other than seminiferous cavity, this incom-

Figure 24. A, Ochrosia vitiensis; dorsal surface of mature mericarp (lower), cross section through mericarp (center) showing 2 cavities and central seminiferous cavity, and distal portions of mericarp (above) separated and disclosing distal portions of seeds, $\times$ I. B-D, Neisosperma oppositifolium: B, mericarp of fruit with exocarp still mostly intact, $\times 1$; , mericarp (exocarp and mesocarp decayed and absent) showing distally directed processes of endocarp, $\times 1 ; \mathrm{D}$, inner surface of longitudinally split mericarp (exocarp and mesocarp absent), showing flattened seed, $\times 1$. A from Bryan 428, B from Brian 336, C \& D from Bryan 444. 
pletely 2-locular, containing 1-4 seeds, these oblong, compressed, the hilum punctiform.

LECTOTYPE SPECIES: No type species was designated by ING (1979). In proposing Neisosperma, Rafinesque (1838) included two species in his concept, $N$. muricata, based on Cerbera platyspermos ("platisperma") Gaertn., and N. musculiformis, based on Cerbera musculiformis Lam. The second of Rafinesque's species has been referred to the loganiaceous Neuburgia musculiformis (Lam.) Miq. (cf. Merr. Interpret. Rumph. Herb. Amb. 425. 1917, Index Rafin. 194. 1949), which is probably referable to N. moluccana (Boerl.) Leenh. (cf. Leenh. in Fl. Males. I. 6: 367. 1963). Therefore, in accord wth ICBN (T.4(e)), the first of Rafinesque's species provides the appropriate lectotype species of Neisosperma: N. muricata Raf., nom. illeg. (Cerbera platyspermos Gaertn.) $=$ N. oppositifolium (Lam.) Fosberg \& Sachet (cf. Fosberg, Boit., \& Sachet in Adansonia 11. 17: 30. 1977; Markgraf in Blumea 25: 243. 1979).

Distribution: The Seychelles to Malesia and Australia, north to the Ryukyu and Bonin Islands, and east in the Pacific to the Marquesas Islands, with 18-20 species. One widespread species is indigenous in Fiji.

USEFUl TREATMENT OF GenUS: MARKGRAF, F. 1979, as listed under Ochrosia.

Neisosperma has been treated as feminine by Fosberg, Sachet, and Boiteau, following the first specific combination (Neisosperma muricata Raf.), in spite of ICBN, Rec. 75A.2(c), which states that all modern compounds ending in such neuter words as -sperma (not specifically mentioned in the Recommendation) should be treated as neuter. Boiteau (1981) states: "La première combinaison spécifique a été donnée au féminin; malgré son étymologie, le genre doit donc être considéré comme féminin." Markgraf (1979) used Neisosperma as neuter, in which I believe he should be followed.

1. Neisosperma oppositifolium (Lam.) Fosberg \& Sachet in Micronesica 8: 48, as Neiosperma oppositifolia. 1972, in op. cit. 10:255. 1974, in Adansonia II. 17: 21. 1977; Fosberg, Boit., \& Sachet in op. cit. 17: 30. 1977; Markgraf in Blumea 25: 243. 1979; Boit. in Fl. Nouv-Caléd. et Dépend. 10: 66. pl. 12. 1981.

Figure 24B-D.

Cerbera oppositifolia Lam. Encycl, Méth. Bot. 1: 62. 1783.

Cerbera parviflora Forst. f. Fl. Ins. Austr. Prodr. 19. 1786.

Neisosperma muricata Raf. Sylva Tellur. 162. 1838

Ochrosia parviflora Hensl. in Ann. Nat. Hist. 1: 345. 1838; A. Gray in Proc. Amer. Acad. Arts 5: 333. 1862, in Bonplandia 10:37. 1862; Seem. Viti, 439. 1862, Fl. Vit. 158. 1866; Drake, Ill. Fl. Ins. Mar. Pac. 233. 1892; Guillaumin in J. Arnold Arb. 13: 19. 1932; Christophersen in Bishop Mus. Bull, $128: 185$. 1935; Yuncker in op. cit. 178: 97.1943.

Ochrosia elliptica sensu Seem. in Bonplandia 9: 257. 1861; non Labill.

Ochrosia oppositifolia K. Schum. in Engl. \& Prantl, Nat. Pflanzenfam. IV. 2: 156. fig. 57, K-M. 1895; Merr. Interpret. Rumph. Herb. Amb. 431. 1917; Pichon in Bull. Mus. Hist. Nat. (Paris) II. 19: 211. 1947; Yuncker in Bishop Mus. Bull. 220: 220. 1959; Sykes in New Zealand Dept. Sci. Indust. Res. Bull. 200; 45. 1970; St. John \& A. C. Sm. in Pacific Sci. 25:338. 1971; J. W. Parham, Pl. Fiji Isl. ed. 2. 261. 1972; M. Grant, Fosberg, \& H. M. Sm. in Smithsonian Contr. Bot, 17: 51. 1974.

Bleekeria elliptica sensu A. C. Sm. in Bull. Torrey Bot. Club 70: 549. 1943; J. W. Parham, Pl. Fiji Is1. 183. 1964; non Koidz.

As seen in Fiji, Neisosperma oppositifolium is a tree $4-15 \mathrm{~m}$. high, with abundant white latex and with a trunk up to $15 \mathrm{~cm}$. or more in diameter, occurring near sea level in coastal forest, beach thickets, and clearings, sometimes on the inner edges of mangrove swamps, and often on limestone. The large leaves have petioles $3-6 \mathrm{~cm}$. long and elliptic-obovate blades $12-32 \times 6-15 \mathrm{~cm}$., with $16-25$ spreading lateral nerves 
interspersed with others nearly as prominent. The comparatively large, repeatedly dichasial inflorescence has a stout peduncle elongating to $5-8 \mathrm{~cm}$. and secondary branches of very variable length. The corollas are white to pale yellow, with a narrow tube 5-7 mm. long and slightly longer lobes. The fruit (FIGURE 24B-D) of the species is highly characteristic, with a buoyancy that permits its wide dispersal. The mericarps turn from green to brown, and the strikingly elongate processes of the endocarp are also pale brown. Flowers have been noted in Fiji between December and April, fruits between February and August.

TyPIFICATION: Cerbera oppositifolia is based on Lactaria salubris Rumph. Herb. Amb. 2: 255. t. 84. 1741. For Cerbera parviflora, G. Forster noted: "Insulae Amicorum et Savage island," but I have seen no Forster specimens indicated as from Tonga. An appropriate citation is: $J . R$. \& G. Forster (BM LECTOTYPE, 2 sheets; ISOLECTOTY PE at K), obtained during Cook's second voyage on Niue (Savage Island). Neisosperma muricata (nom. illeg.) is based on Cerbera platyspermos Gaertn. (1791).

Distribution: Seychelles to Ceylon and eastward to the Mariana Islands and Polynesia.

LOCAL NAMES: The species is well known locally as vaoko, vavaoa, vao, and vavakana; a name noted only on Vanua Mbalavu is papaio.

AVAIlABle COllections: VITI LEVU: NANDRONGa \& Navasa: Korotongo, O. \& I. Degener 32123. Serua: Vunindilo Beach, DA, May 8, 1951 (L.2424), 16575. RewA: Nukulau Island, Barclay. VANUA LEVU: ThaKaundrove: Along Hibiscus Highway leading from Savusavu, Bierhorst F162; Ndromoninuku, DA 16819; Mbutha Bay, DA 13417. VANUA LEvU without further locality, Seemann 316. MOALA: Bryan 336. VANUA MBALAVU: Southern limestone section, Smith 1430. FULANGA: Bryan 444. FIJI without further locality, Horne 504.

4. Alyxia Banks ex R. Br. Prodr. Fl. Nov. Holl. 469. 1810; Seem. Fl. Vit. 156. 1866; Pichon in Mém. Mus. Nat. Hist. Nat. 27: 164. 1948; Fosberg \& Sachet in Micronesica 10: 251. 1974; M. Grant, Fosberg, \& H. M. Sm. in Smithsonian Contr. Bot. 17: 46. 1974; Markgraf in Blumea 23: 377. 1977; Boit. in Fl. Nouv.-Caléd. et Dépend. 10: 96. 1981. Nom. cons.

Gynopogon J. R. \& G. Forst. Char. Gen. Pl. 18. 1775, ed. 2. 35. 1776; K. Schum. in Engl. \& Prantl, Nat. Pflanzenfam. IV. 2: 151. 1895. Nom. rejic.

Lianas or scandent shrubs, the branchlets often angular when young; leaves opposite or verticillate, the blades often coriaceous, entire, glabrous, nitid, the costa prominent, the secondary nerves inconspicuous; inflorescences axillary or pseudoterminal, thyrsoid, cymose, or paniculiform, few-many-flowered (rarely 1-flowered), the pedicels with small bracts at base and sometimes bracteolate distally, the flowers (4 or)5-merous; calyx deeply lobed, the lobes ovate to lanceolate, usually ciliolate, without glands; corolla hypocrateriform, the tube slightly expanded at insertion of stamens, constricted at throat and without scales, pilose distally within, the lobes sinistrorsely contorted in bud, often asymmetrical, rounded; stamens included in upper part of corolla tube, the filaments short, slender, the anthers lanceolate to ovate, obtuse; disk inconspicuous or none; ovary bicarpellate, the carpels free or shortly adherent at base, usually pilose near base, the ovules $2-6$, biseriate, the style single, glabrous, the style head subglobose to cylindric, usually glabrous, without a flange, the stigma with 2 short tips; fruit composed of paired, drupaceous mericarps, frequently only 1 maturing, the mericarps stipitate, ellipsoid, not or indistinctly compressed, short-beaked, composed of a single article or moniliform (in our taxa articles usually 1 , sometimes 2, rarely 3 ), each article with its own endocarp, 1-seeded, the pericarp thin, the mesocarp without fibers, thin, fleshy, the endocarp crustaceous to subligneous, usually thin, the seeds black to reddish, not or indistinctly compressed or angled, with a deep ventral groove, ecomose, the endosperm ruminate.

TYPE SPECIES: The conserved type species of Alyxia is $A$. spicata R. Br. The Forsters proposed two species of Gynopogon in 1775, G. stellatum (sic) and G. scandens; since 
the generic name is now rejected, lectotypification is unnecessary, but Grant, Fosberg, and Smith (1974) provide a justification for considering G. stellatum the lectotype species.

Distribution: Southeastern Asia throughout Malesia to Australia, and eastward to the Tuamotus (Henderson Island) and Hawaii, with 120-130 species. In Fiji five species are here considered, three of them endemic.

Useful treatment of genus: Markgraf, F. Florae Malesianae Praecursores LV. Apocynaceae IV. Alyxia. Blumea 23: 377-414. 1977.

LOCAL NAMES AND USES: Throughout Fiji all taxa of Alyxia are known as vono, sometimes as vono matailevu, vono yauyau, or vono niveikau. The stems and attached leaves are used for necklaces in dances and on other festive occasions for their attractive fragrance, as throughout the Pacific.

Markgraf (1977) has arranged the Malesian species in twelve series, and Boiteau (1981) the New Caledonian species in six series. The species of Alyxia in the Fijian Region clearly fall into two series, those species without pedicellary bracteoles under the calyx ( $A$. stellata and its allies, to be referred to ser. Reinwardtianae), and those species with pedicellary bracteoles subtending the calyx and suggestive of calyx lobes. The latter group, a cluster of species consisting of $A$. bracteolosa and its allies, is apparently not represented among the series discussed by Markgraf and Boiteau and is here taken to compose a new series Bracteolosael. Although Boiteau (1981, p. 98) has remarked that several Fijian species fall into ser. Globuliferae, neither his nor Markgraf's definition of that series permits the inclusion in it of Fijian species.

KEY TO SPECIES

Inflorescences 3-6-flowered and without secondary branchlets; pedicels 1-9 mm. long, without distal bracteoles; corolla tube $2-5 \mathrm{~mm}$. long; mericarps 1 or 2 per fruit, each with 1 or 2 (rarely 3 ) articles, these 7-17 $\times 6-11 \mathrm{~mm}$., smooth-surfaced but drying somewhat wrinkled and inconspicuously several-costate or shallowly grooved, the endocarp crustaceous, about $0.1 \mathrm{~mm}$. thick, adherent to the very thin mesocarp, the seed round in cross section (ser. Reinwardtianae).

Leaves usually ternate, infrequently opposite, the blades elliptic to elliptic- or oblong-lanceolate, (1.2-) 2-6 cm. long, (3-) 5-23 mm. broad, 2-6 times longer than broad, rounded or retuse at apex, the margins not parallel; peduncle $7-40 \mathrm{~mm}$. long; pedicels $1-9 \mathrm{~mm}$. long. ....... 1. A. stellata

Leaves usually quaternate or ternate, infrequently opposite, the petioles negligible or to $2 \mathrm{~mm}$. long, the blades oblong-linear, 2-6.5 cm. long, 1.2-5.5 (-7) mm. broad, (6-) 10-20 times longer than broad, obtuse at apex, the margins usually parallel; peduncle $3-10 \mathrm{~mm}$. long; pedicels $1-3.5 \mathrm{~mm}$. long; corolla tube $2-3.5 \mathrm{~mm}$. long; articles of mericarps $8-11 \times 6-8 \mathrm{~mm}$. ........ 2. A. linearifolia Inflorescences sometimes many-flowered and often with short secondary branchlets; pedicels negligible to 3 $\mathrm{mm}$. in length (sometimes appearing longer but then presumably solitary at apex of an ultimate inflorescence branchlet and not clearly differentiated from it), bearing 3-many bracteoles distally, these often congested and closely subtending calyx, simulating calyx lobes in shape and texture; corolla tube 3.5-12 mm. long; mericarps usually $\mathrm{I}$ (sometimes 2 ) per fruit, each with a single article, this $10-40 \times 7-25$ mm., smooth-surfaced but drying irregularly wrinkled or sharply angled, the endocarp crustaceous or subligneous, $0.1-1 \mathrm{~mm}$. thick, adherent or not to mesocarp, the seed round or angled in cross section (ser. Bracteolosae).

\footnotetext{
'Alyxia ser. Bracteolosae A. C. Sm., ser. nov.

Frutices scandentes, foliis pro genere saepe magnis; inflorescentia interdum multiflora et ramulosa, pedicellis brevibus et distaliter bracteolatis, bracteolis vulgo congestis et calycem arcte amplectentibus; corollae tubo $3.5-12 \mathrm{~mm}$. longo; fructuum mericarpiis plerumque 1 (interdum 2) et cum articulo unico, articulis saepe amplis (10-40 × 7-25 mm.) in sicco irregulariter rugosis vel angulatis, endocarpio crustaceo vel sublignoso, semine in sectione transversali rotundo vel angulato. SPECIES TYPICA: Alyxia bracteolosa A. Gray.
} 
Branchlets stout (4-6 mm. in diameter), sharply 4-angled and shallowly canaliculate in several ultimate internodes; leaves quaternate, sessile or subsessile (petioles if present less than $5 \mathrm{~mm}$. long, laterally sharply angled, broadened from base, 3-5 mm. thick); leaf blades coriaceous, elliptic to oblongobovate, obtusely cuspidate to emarginate at apex, 9-14 $\times 3-5.5 \mathrm{~cm}$.; infructescences compact, the mericarps 1 or 2 , ellipsoid, drying wrinkled but 5-angled $2.5-3.5 \times 1.5-1.8 \mathrm{~cm}$, the endocarp subligneous, $0.5-1 \mathrm{~mm}$. thick, the seed drying 5-angled. ............ A. erthrosperma

Branchlets comparatively slender (1-4 mm. in diameter), terete or 3-angled (the faces then essentially flat) in several ultimate internodes; leaves ternate (rarely quaternate in juvenile specimens), obviously petiolate, the petioles (2-) 7-20 mm. long, comparatively slender (if as short as 2-7 mm. then very slender and obviously distinct from leaf blade).

Inflorescences congested-capitate, each consisting of a stout (1.5-2 mm. in diameter) peduncle 3-4 mm. long and 10-15 flowers, the pedicels negligible (to $1 \mathrm{~mm}$. long and completely concealed by bracteoles at anthesis), the corolla tube $10-12 \mathrm{~mm}$. long at anthesis; mericarps at apparent maturity ellipsoid to obovoid, $15-20 \times 8-12 \mathrm{~mm}$., when dry irregularly wrinkled or longitudinally 5-7angled, the endocarp $0.2-0.5 \mathrm{~mm}$. thick, the seed irregularly angled in cross section; petioles stout, 9-13 mm. long; leaf blades coriaceous, prevailingly elliptic, $5-9 \times 2.5-5 \mathrm{~cm}$, rounded to obtusely

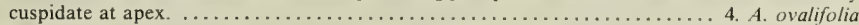

Inflorescences less congested, not capitate, the peduncles 2-30 mm. long, comparatively slender (0.5-1.5 mm. in diameter at anthesis), often shortly branching distally, each ultimate branchlet with 2-6 flowers, the pedicels negligible to $3 \mathrm{~mm}$. long (occasionally appearing longer but then presumably solitary at apex of an ultimate inflorescence branchlet and not clearly differentiated from it).

Mericarps at maturity subglobose to ellipsoid, irregularly wrinkled in drying but not regularly nor sharply angled, the endocarp crustaceous, $0.1-0.2 \mathrm{~mm}$. thick, frangible and readily separating from mesocarp, the seed drying terete in cross section or bluntly 5-7-angled; branchlets subterete or shallowly grooved to inconspicuously 3-angled in ultimate 3-5internodes; petioles 2-17 mm. long, narrowly winged in distal half or nearly to base; leaf blades chartaceous to subcoriaceous.

5. A. bracteolosa

Mericarps at maturity ellipsoid, sharply 5-angled in drying, (2-) 2.5-3.5 $\times(1.3-) 1.4-2 \mathrm{~cm}$., the endocarp subligneous, $0.3-0.5 \mathrm{~mm}$. thick, not frangible nor readily separating from mesocarp, the seed drying 5-angled; branchlets usually sharply 3-angled in ultimate 3-5 internodes; petioles 11-20 mm. long, narrowly winged nearly to base; leaf blades coriaceous, elliptic to oblong or obovate-oblong, (6-) 9-16.5 x (2-) 3-5 cm., short-acuminate or obtusely cuspidate at apex (acumen 4-10 mm. long); Samoa, at elevations of $600-1,600 \mathrm{~m} . . . . . . .$. . . samoensis

1. Alyxia stellata (J. R. \& G. Forst.) Roemer \& Schultes, Syst. Veg. 4: 439. 1819.

Ginopogon stellatum (sic) J. R. \& G. Forst. Char. Gen. Pl. 18. t. 18. 1775, ed. 2. 36. t. 18. 1776.

Interesting discussions of the perplexing Alyxia stellata in Polynesia, its variability, and its relationship to $A$. scandens (J. R. \& G. Forst.) Roemer \& Schultes have been provided by Fosberg (1968), Fosberg and Sachet (1974), and Grant, Fosberg, and Smith (1974). No satisfactory treatment of these species in their entirety has been offered, but it would seem probable that at least some of the proposed Polynesian varieties will be found to merit specific rank. Fairly typical material (i. e. in the sense of the original Forster collections) of $A$. stellata seems to occur from the Societies to Samoa (Christophersen, 1935) and New Caledonia (Boiteau, 1981). On mature consideration, I am now disposed to consider the taxon I described in 1952 as A. amoena to be of no more than varietal significance; $A$. linearifolia, however, appears to be such an extreme variant that it is here retained as a separate species.

\section{KEY TO VARIETIES}

Petioles 2-4 mm. long; leaf blades elliptic to elliptic-lanceolate, (2.5-) 3.5-6 cm. long, (6-) 10-23 mm. broad, 2-5 times longer than broad, rounded or retuse at apex; corolla tube $2.5-5 \mathrm{~mm}$.long; articles of

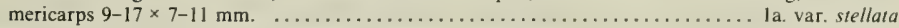

Petioles negligible or to $2 \mathrm{~mm}$. long; leaf blades narrowly oblong-elliptic, (1.2-) 2-5 cm. long, (3-) $5-12 \mathrm{~mm}$. broad, (2-) 4-6 times longer than broad, obtuse at apex; corolla tube 2-3.5 mm. long; articles of

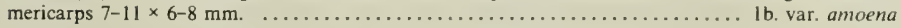


1a. Alyxia stellata var. stellata.

FigURE 25A \& B.

Gynopogon stellatum (sic) J. R. \& G. Forst. Char. Gen. Pl. 18. t. 18. 1775, ed. 2. 36. t. 18. 1776; Forst. f. Fl. Ins. Austr. Prodr. 19. 1786.

Alyxia stellata sensu Roemer \& Schultes, Syst. Veg. 4: 439. 1819; A. Gray in Proc. Amer. Acad. Arts 5: 333 , p. p. 1862; Seem. Viti, 439. 1862, Fl. Vit. 157, p. p. 1866; Drake, Ill. Fl. Ins. Mar. Pac. 233. 1892; Christophersen in Bishop Mus. Bull. 128: 184. 1935; Yuncker in op. cit. 178:97. 1943, in op. cit. 184:58. 1945, in op. cit. 220: 220. 1959; J. W. Parham, Pl. Fiji 1sl. 183. 1964, ed. 2. 259. 1972; Fosberg in Micronesica 4: 258. 1968; Sykes in New Zealand Dept. Sci. Indust. Res. Bull. 200: 44. 1970; St. John \& A. C. Sm. in Pacific Sci. 25: 338. 1971; B. E. V. Parham in New Zealand Dept. Sci. Indust. Res. Inform. Ser.85: 42, 59, 65, 88. 1972; Fosberg \& Sachet in Micronesica 10: 253. 1974; M. Grant, Fosberg, \& H. M. Sm. in Smithsonian Contr. Bot. 17:47. 1974; Boit. in Fl. Nouv.-Caléd. et Dépend. 10: 137. pl. 27 (1-7). 1981.

Gynopogon stellatus J. R. \& G. Forst. ex K. Schum. in Engl. \& Prantl, Nat. Pflanzenfam. IV. 2: 151. 1895; Rechinger in Denkschr. Akad. Wiss. Wien 85: 331. 1910.

As seen in Fiji, the typical variety of Alyxia stellata is usually a liana, sometimes a scandent shrub $0.5-2 \mathrm{~m}$. high, found from near sea level to about $350 \mathrm{~m}$. in dense or thin forest, in thickets on hillsides and ridges, in beach thickets, and on sea cliffs, often on limestone. The corolla is pale yellow, or the tube may vary to pale orange or pink-tinged and the limb to white. The fruits turn from green to black at maturity. Flowers and fruits have been obtained in months scattered throughout the year.

TyPIFICATION: Specimens collected by J. R. \& G. Forster during Cook's second voyage, presumably from the Society Islands, are to be found at BM, $\mathrm{K}$, and P. The BM sheet is indicated as from the Pallas Herbarium, but it was doubtless available to the Forsters in 1775 and may be taken as the LECTOTYPE. Boiteau (1981) considered "Forster 54" (P) as the holotype.

Distribution: Widely distributed in the southern Pacific, at least between the Society Islands and New Caledonia, and perhaps farther to both east and west.

AVAILABLE COLlECTIONS: YASAWAS: WaYA: Naruarua Gulch, west of Mbatinaremba, St. John 18052. MAMANUTHAS: NGgaLito Island, Malolo Group, $O . \&$ \%. Degener 32234. OVALAU: Hills southeast of valley of Mbureta River, Smith 7437; slopes of Mt. Koronimoko, vicinity of Thawathi, Smith 8074; vicinity of Levuka, Gillespie 4570. MAKONDRONGA: Degener \& Ordonez 13799. NAIRAI: Milne 178. TOTOYA: Milne 84, Tothill 602. THIKOMBIA: Tothill 398. VANUA MBALAVU: Namalata Islet, southern limestone section, Smith 1455. FULANGA: On limestone formation, Smith 1196. FijI without further locality, U. S. Expl. Exped. (GH, p. p.).

1b. Alyxia stellata var. amoena (A. C. Sm.) A. C. Sm., comb. et stat. nov.

Figures 25C \& D, 26A, \& B.

Alyxia stellata sensu A. Gray in Proc. Amer. Acad. Arts 5:333, p. p. 1862; Seem. Fl. Vit. 157, p. p. 1866; non sensu str.

Alyxia amoena A. C. Sm. in J. Arnold Arb. 33: 115. 1952; J. W. Parham, Pl. Fiji Isl. 181. 1964, ed. 2. 257. 1972.

A liana or sometimes a scandent shrub 1-2 m. high, occurring at elevations of 100-900 m. in dense or open forest usually on crests and ridges. Flowers and fruits, in color similar to those of the typical variety, have been obtained in scattered months.

TYPIFICATION: The type is Smith 6375 (A HOLOTYPE; many ISOTYPES), collected in flower and fruit Oct. 27, 1947, on the southern slopes of Mt. Numbuiloa, east of Lambasa, Mathuata Province, Vanua Levu.

Distribution: Endemic to Fiji.

Available Collections: YASAWAS: Waya: Nangua, St. John 18161. ViTI LEVU: Mba: Northern slopes of Mt. Namendre, east of Mt. Koromba, Smith 4513. Nandronga \& Navosa: Southern slopes of Nausori Highlands, above Tumbenasolo, Greenwood 1065 A. OVALAU: Vicinity of Levuka, Gillespie 4568.

Figure 25. A \& B, Alyxia stellata var. stellata; A, foliage and inflorescences, $\times 2$; , foliage and infructescences, showing a mericarp with 3 articles, $\times 2$. C \& D, Alyxia stellata var. amoena; , inflorescence, $\times 8$; D, opened corolla (1 stamen fallen), $\times 20$. A from Smith 1455, B from St. John 18052, C \& D from DA 14631 . 

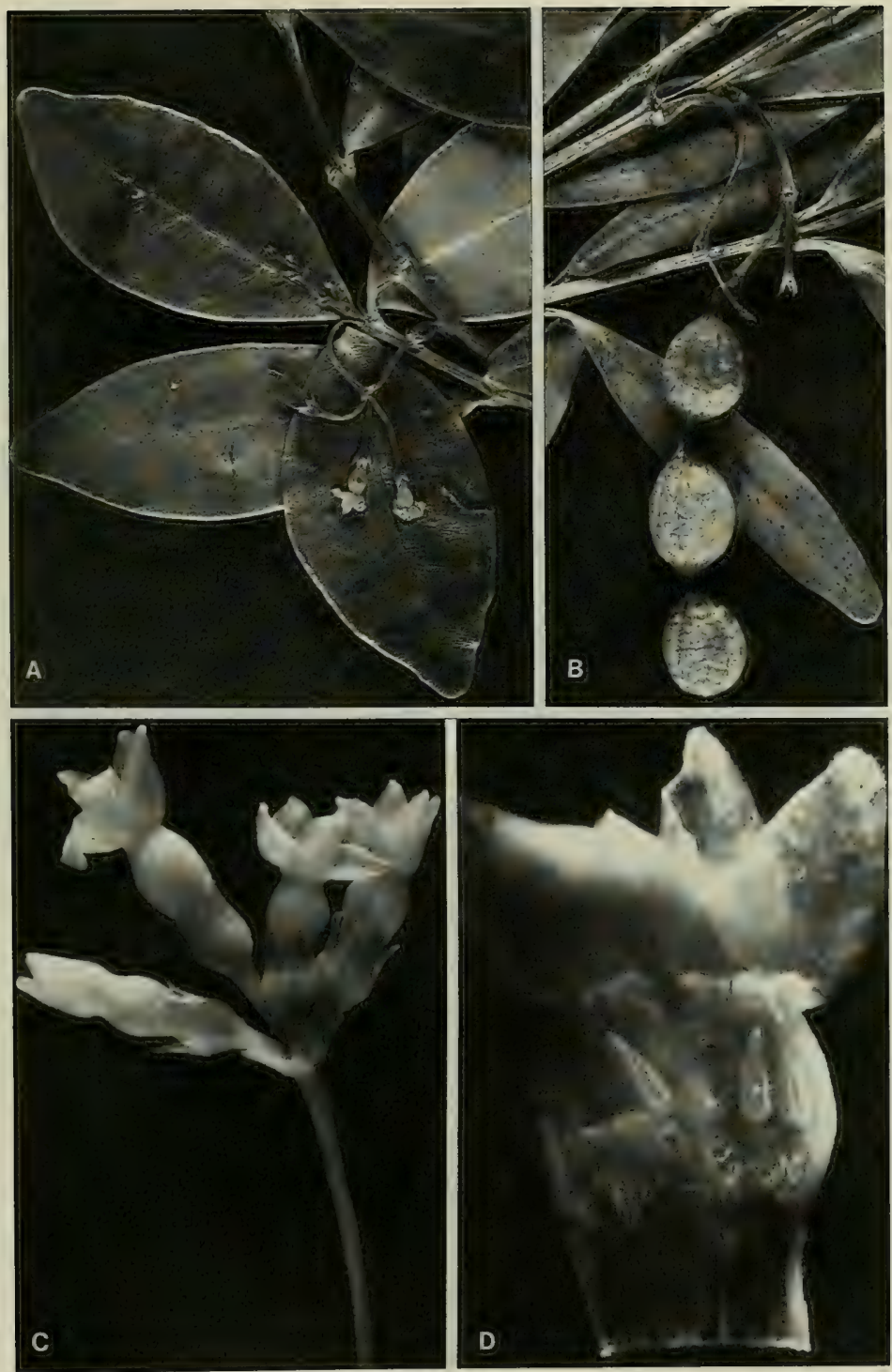

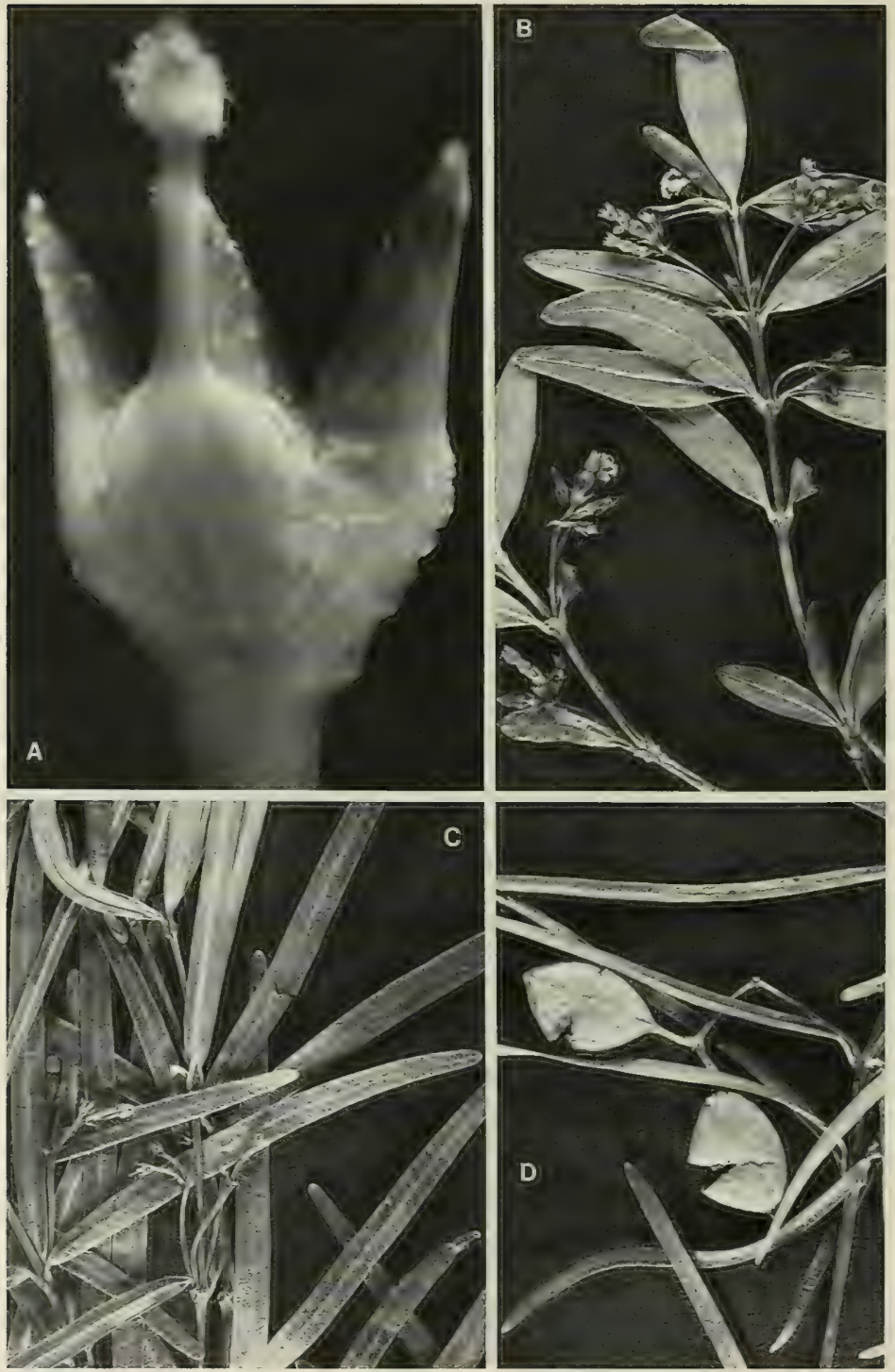
p. p. VANUA LeVU: Mbua: Ramasa Hill, H. B. R. Parham VIII; vicinity of Nasarowangga, DA 1100. Mathuata: Summit ridge of Mt. Numbuiloa, east of Lambasa, Smith 6498, DA 14631. Fist without further locality, U. S. Expl. Exped. (GH, p. p., us 65908), Horne 671.

2. Alyxia linearifolia A. C. Sm. in Sargentia 1: 107. fig. 5. 1942, in J. Arnold Arb. 27: 321. 1946, in op. cit. 33: 114. 1952; J. W. Parham, Pl. Fiji Isl. 182. 1964, ed. 2. 259. 1972.

FIGURE 26C \& D.

A liana or subscandent shrub 1-3 m. high, found between 50 and $950 \mathrm{~m}$. in forest along streams, dry forest, or dense crest forest. Flower and fruit colors are as in the preceding species. Flowers have been observed between February and June, fruits throughout much of the year.

TYPIFICATION: The species is based on Degener 15396 (A HOLOTYPE; ISOTYPES at BISH, K, US), collected June 2, 1941, in flower and fruit, at Vatundamu, vicinity of Rewasa, near Vaileka, Ra Province, Viti Levu.

Distribution: Endemic to Fiji.

AVAilable Collections: YASAWAS: WaYA: Nangua, St. John 18113. VITI LEVU: Mba: Mt. Evans Range, Greenwood 1065: vicinity of Nalotawa, eastern base of Mt. Evans Range, Smith 4471. REwA: Mt. Korombamba, Gillespie 2356, DA 1163. OVALAU: Vicinity of Levuka, Gillespie 4568, p. p. VANUA LEVU: Mbua: Vicinity of Nasau, Rukuruku Bay, H. B. R. Parham II. Mathuata: Southern slopes of Mt. Numbuiloa, east of Lambasa, Smith 6563. Vanua Levu without further locality, H. B. R. Parham $340,358$. FIII without further locality, Tothill 437.

3. Alyxia erythrosperma Gillespie in Bishop Mus. Bull. 74: 17. fig. 20. 1930; J. W. Parham, Pl. Fiji Isl. 181. 1964, ed. 2. 259. 1972. FIGURE 27A.

A scandent shrub characterized by stout, sharply 4-angled, grooved branchlets, essentially sessile, quaternate, coriaceous leaves, and large mericarps with a subligneous, 5-angled endocarp. Flowers are not yet known.

TYPIFICATION: The type is Gillespie 3219 (BISH HOLOTYPE and ISOTYPE), collected Oct. 1, 1927, between Nanggarawai and Saliandrau, Wainikoroiluva River, Namosi Province, Viti Levu, elevation 150-200 m.

Distribution: Endemic to Fiji and known only from the type collection.

It is curious that this sharply demarcated taxon, which would readily be recognized even if sterile, has not been obtained by other collectors, since the type locality has been traversed by other botanists, including the present writer. Gillespie perceptively recognized the distinct nature of this species and the following, although he saw only a single fruiting collection of each of them. The Samoan collections that Christophersen in 1935 described as a variety of Alyxia erythrosperma, with which they share a type of fruit very distinct within ser. Bracteolosae, are believed to be specifically distinct, as noted below.

4. Alyxia ovalifolia Gillespie in Bishop Mus. Bull. 74: 17. fig. 21. 1930; J. W. Parham, Pl. Fiji Isl. 183. fig. 65, B. 1964, ed. 2. 259. fig. 76, B. 1972. Figure 27B-D. Alyxia stellata sensu Gibbs in J. Linn. Soc. Bot. 39: 156. 1909; non Roemer \& Schultes.

An infrequent liana, recorded from forest, sometimes on ridges, at elevations between 150 and $1,127 \mathrm{~m}$. The highly distinctive congested-capitate inflorescences bear flowers with white corollas, but the fruits are not obviously to be distinguished from those of Alyxia bracteolosa. Flowers have been collected in May, fruits in April and December.

Figure 26. A \& B, Alyxia stellata var. amoena; A, gynoecium and calyx with 2 lobes removed, $\times 40$; B, distal portion of branchlet, with foliage and inflorescences, $\times 2 . \mathrm{C} \& \mathrm{D}$, Alyxia linearifolia; C, foliage and inflorescences, $\times 2 ; \mathrm{D}$, foliage and fruit with 2 mericarps, $\times 2$. A \& B from DA 14631 , C from Greenwood 1065, D from Smith 6563. 

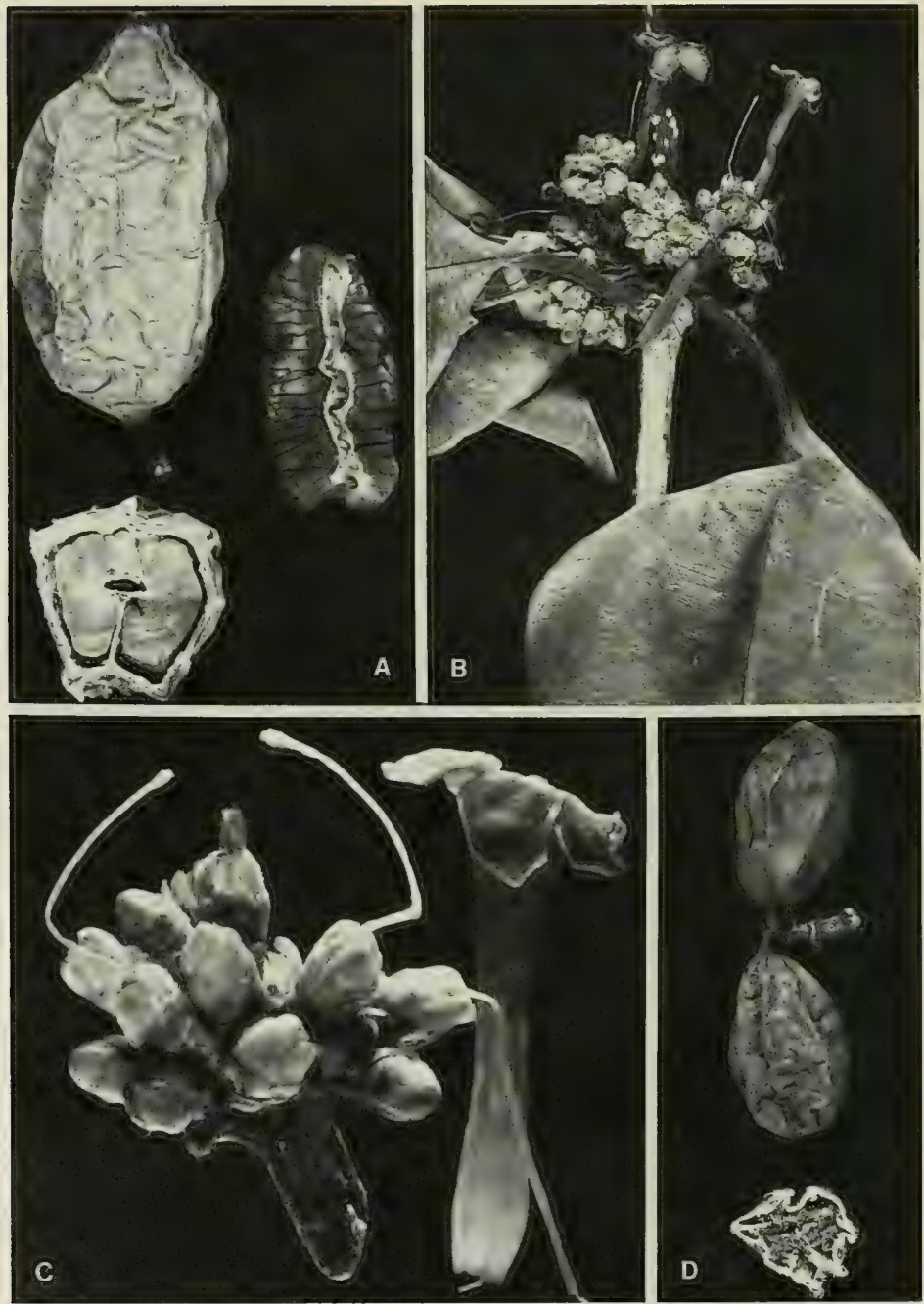

Figure 27. A, Alyxia erythrosperma; mericarp and cross section, with ventral surface of seed, $\times 2$. B-D, Alyxia ovalifolia; $\mathrm{B}$, inflorescences at a node and proximal portions of leaves, $\times 2$; $\mathrm{C}$, inflorescence, with some styles remaining, and a detached corolla, $\times 6 ; \mathrm{D}$, fruit with 2 mericarps and cross section of a mericarp, $\times$ 2. A from Gillespie 3219 , B \& C from DA 15176, D from Gillespie 4340 . 
Typification: The species was based on Gillespie 4340 (BISH holotype and ISOTYPE), collected Dec. 19, 1927, on the summit of Mt. Nanggaranambuluta, east of Nandarivatu, Mba Province, Viti Levu.

Distribution: Endemic to Fiji and known only from the two largest islands.

AVAILABle Collections: VITI LEVU: MBa: Vicinity of Nandarivatu, Gibbs 669. NaITASIRI: Naitauvoli, Waingga Creek, Wanimala River tributary, $D A$ 7025. VANUA LEVU: MBUA: Mt. Uluimbau, DA 15176.

Possibly the Milne specimen (K) from Ovalau cited by Seemann (Fl. Vit. 157. 1866) as Alyxia scandens (cf. also J. W. Parham's $(1964,1972)$ references to A. scandens) belongs here, together with Horne $343(\mathrm{~K})$ and 444 (к) without further data.

5. Alyxia bracteolosa A. Gray in Proc. Amer. Acad. Arts 5: 332. 1862; Seem. Fl. Vit. 156. 1866; Gillespie in Bishop Mus. Bull. 91: 26. 1932.

Gynopogon bracteolosus Rich ex K. Schum. in Engl. \& Prantl, Nat. Pflanzenfam. IV. 2: 151. 1895.

Alyxia bracteolosa (sensu lat.) is a liana with copious white latex, occurring with some frequency at elevations between sea level and $1,050 \mathrm{~m}$. (up to 1,500 m. in Samoa) in dense, dry, or crest forest, in hillside thickets, and in patches of forest in open country. The corolla is white or cream-white to pale yellow, the tube sometimes orange-tinged; the mericarps at maturity are deep blue to black. Flowers are most frequently obtained between October and June, but fruits persist throughout most of the year.

In describing Alyxia bracteolosa, Gray included three varieties (vars. macrocarpa, angustifolia, and parvifolia), but it would seem that he intended to append these to his concept of the species as additional entities (as customary in taxonomic work of that period) rather than to interpret them as comprising his entire concept of the species. As lectotypes of the species itself (i. e. var. bracteolosa) and the three appended varieties I have accepted the specimens at Us so annotated in Gray's hand; U. S. Exploring Expedition specimens at other herbaria are not necessarily strict isolectotypes of any of the components. Gillespie's suggestion (1932) that Samoa is properly considered the type locality of the species is therefore not accepted; in fact all the us lectotypes of the four original components of the species are from either Fiji or Tonga.

The additional taxa of Alyxia described from Samoa by Christophersen in 1935 must be taken into consideration in discussing $A$. bracteolosa and its immediate relatives in the Fijian Region. But still a satisfactory solution is elusive. I here retain four populations of $A$. bracteolosa as varieties. Variety angustifolia is perhaps the most realistic of them, characterized by consistently short-petiolate leaves with narrow blades rounded at apex, a compact inflorescence, and short corollas. Variety retusa, although known only from the type collection, also seems reasonably distinct by virtue of its rounded to retuse leaf blades and short corollas. Variety macrocarpa seems scarcely separable from the typical variety in foliage or inflorescence, but its comparatively large mericarps (FIGURE 30D) suggest that varietal recognition is reasonable. Of var. bracteolosa itself Gray's var. parvifolia seems only a variant with slightly smaller than usual leaves, without recognizable differences in either inflorescences or fruits. In describing the Samoan A. septangularis, Christophersen emphasized only its 7angular seeds (FIGURE 30B). In my opinion no differences of foliage or inflorescence separate this Samoan population from A. bracteolosa var. bracteolosa, in which may be found 5-7-angled seeds (FIGURE 30A), seeds round in cross section (FIGURE $30 \mathrm{C}$ ), and all intermediates. Also, some of the specimens referred by Christophersen to his $A$. erythrosperma var. samoensis seem better placed in $A$. bracteolosa var. bracteolosa. 
SYNOPSIS OF VARIETIES

Petioles 6-17 mm. long; leaf blades narrowly elliptic or lanceolate to elliptic-oblong, (5-) 6-13 $\times(1.2-) 2-4.5$ $\mathrm{cm}$., cuspidate or short-acuminate at apex (acumen 3-10 mm. long, obtuse); peduncle (2-) 4-27 mm. long; corolla tube (4-) 5-12 mm. long; mericarps subglobose to ellipsoid, 12-22 × 9-16 mm.

5a. var. bracteolosa

Petioles 5-17 mm. long; leaf blades elliptic-oblong to elliptic-lanceolate, 5-12 $\times 1.8-4.5 \mathrm{~cm}$, cuspidate or short-acuminate at apex (acumen 2-10 mm. long, obtuse); peduncle 5-30 mm. long; mericarps subglobose to ellipsoid, $20-40 \times 18-25 \mathrm{~mm} . \quad \ldots \ldots \ldots \ldots \ldots \ldots \ldots \ldots \ldots \ldots \ldots . . \ldots \ldots$ b. var. macrocarpa

Petioles slender, 2-8 mm. long; leaf blades oblong- or elliptic-lanceolate, (2-) 3-9 $\times(0.5-) 1-2.5 \mathrm{~cm}$., obtuse or rounded or faintly retuse at apex; peduncle $2-6 \mathrm{~mm}$. long; corolla tube 5-8 mm. long; mericarps

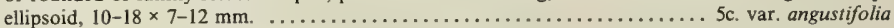

Petioles 7-13 mm. long; leaf blades elliptic-obovate, 4-7.5 $\times 2-3.7 \mathrm{~cm}$., rounded to shallowly retuse at apex; peduncle $10-15 \mathrm{~mm}$. long; corolla tube $3.5-4 \mathrm{~mm}$. long. .................. $5 \mathrm{~d}$. var. retusa

5a. Alyxia bracteolosa A. Gray var. bracteolosa; J. W. Parham, Pl. Fiji Isl, 181, 1964, ed. 2. 257. 1972; St. John \& A. C. Sm. in Pacific Sci. 25: 338. 1971.

Figures 28, 29C, 30A-C.

Alyxia bracteolosa sensu A. Gray in Proc. Amer. Acad. Arts. 5: 332. 1862; Reinecke in Bot. Jahrb. $25: 668$. 1898; Rechinger in Denkschr. Akad. Wiss. Wien 85: 331. 1910; Gillespie in Bishop Mus. Bull. 91: 26, p. p. fig. 29 (a-e). 1932; Christophersen in op. cit. 128: 180. 1935; Yuncker in op. cit. 184: 58. 1945, in op. cit. 220: 219 . 1959; B. E. V. Parham in New Zealand Dept. Sci. Indust. Res. Inform. Ser. 85: 59. 1972; St. John in Phytologia 36: 373. 1977.

Alyxia bracteolosa var. parvifolia A. Gray in Proc. Amer. Acad. Arts 5: 333. 1862; Seem. Fl. Vit. 157. [866; J. W. Parham, Pl. Fiji Isl. 181. 1964, ed. 2. 259. 1972.

Alyxia septangularis Christophersen in Bishop Mus. Bull. 128: 182. fig. 29. 1935; B. E. V. Parham in New Zealand Dept. Sci. Indust. Res. Inform. Ser. 85: 59. 1972.

TYPIFICATION: For the species as a whole Gray noted: "Navigators', Tonga, and Feejee Islands"; the only sheet at us unequivocally identified by Gray as Alyxia bracteolosa (without modification) is U.S. Expl. Exped. (US 78371 LECTOTYPE here designated), obtained on Tongatapu, Tonga. The type of $A$. bracteolosa var. parvifolia may be taken as the only sheet at us so annotated by Gray: $U$. S. Expl. Exped. (US 78368 LECTOTYPE here designated), collected in Mathuata Province, Vanua Levu, Fiji. The type of A. septangularis is Christophersen 3297 (BISH HOLOTYPE and ISOTYPE), collected in fruit Nov. 19, 1931, between Siuvao and Auala, Savai'i, Samoa.

Distribution: Fiji, Tonga, Samoa, and Horne and Wallis Islands. In Samoa it is seen for the most part at elevations up to about $800 \mathrm{~m}$. but occasionally up to $1,500 \mathrm{~m}$. From Fiji about 30 collections from six of the high islands are at hand.

REPRESENTATIVE COLLECTIONS: VITI LEVU: MBA: Savundamatau Creek, west of Nandarivatu, Webster \& Hildreth 14242; Nandala, south of Nandarivatu, Degener 14850. NANDRONGA \& NAvosA: Southern slopes of Nausori Highlands, in drainage of Namosi Creek above Tumbenasolo, Smith 4569; vicinity of Mbelo, near Vatukarasa, Degener 15305. Serua: Ngaloa Nature Reserve, DA 16589. Namosi: Hills bordering Wainavindrau Creek, vicinity of Wainimakutu, Smith 858I. NAITASIRI: Plant Introduction and Quarantine Station, Nanduruloulou, DA 8393. REwA: Vicinity of Lami, Gillespie 4591, p. p. KANDAVU: Summit of Mt. M buke Levu, Smith 281. NGAU: Hills east of Herald Bay, inland from Sawaieke, Smith 7858. VANUA LEVU: Mbua: Track to Volili, DA 17537. Mathuata: Vicinity of Lambasa, Greenwood 514. ThaKaUNDROve: Hills west of Mbutha Bay, Natewa Peninsula, Smith 819. TAVEUNI: Track to lake above Somosomo, DA 1407I. MOALA: Forest above Maloku, Smith 1352.

FIGURE 28. Alyxia bracteolosa var. bracteolosa; A, inflorescences and proximal portion of a leaf, $\times 2 ; \mathrm{B}$, ultimate cluster of flowers, $\times 6$; C, inflorescences, $\times 2 ; \mathrm{D}$, ultimate cluster of flowers, $\times 6$. A \& B from Degener 15305, C from DA 14071 , D from Smith 819. 

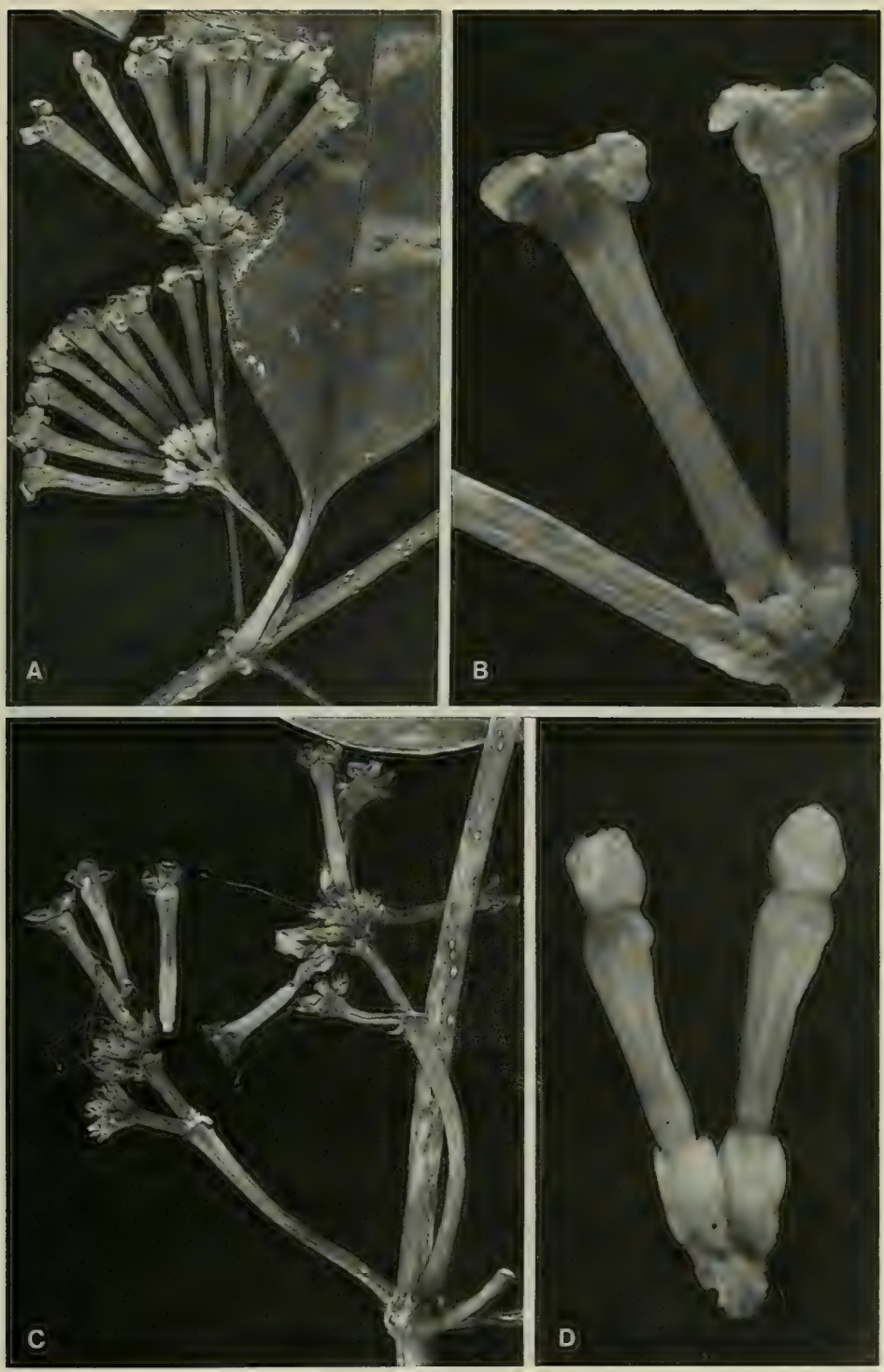
Vol. 4
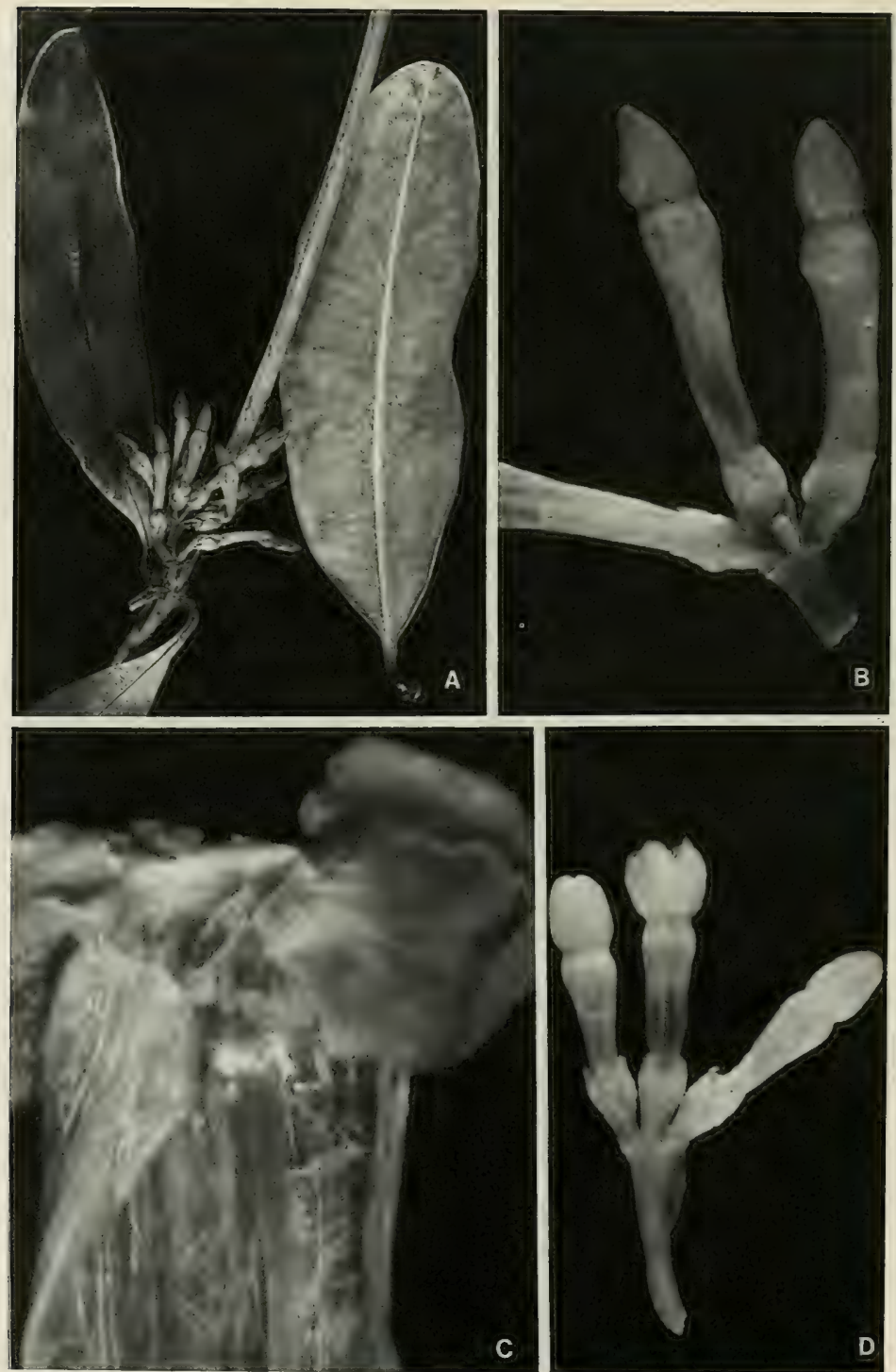
5b. Alyxia bracteolosa var. macrocarpa A. Gray in Proc. Amer. Acad. Arts 5: 332. 1862; Seem. Fl. Vit. 157. 1866; J. W. Parham, Pl. Fiji Isl. 181. 1964, ed. 2. 259. 1972.

FIGURE 30D.

Alyxia macrocarpa Rich ex A. Gray in Proc. Amer. Acad. Arts 5: 332, pro syn. 1862.

Alyxia bracteolosa sensu Gillespie in Bishop Mus. Bull. 91: 26, p. p. fig. 29 (habit). 1932.

TYPIFICATION: The only us sheet so annotated by Gray, from Fiji without further locality, is $U$. S. Expl. Exped. (US 78369 LECTOTYPE here designated).

Distribution: Endemic to Fiji and apparently less abundant than var. bracteolosa; its recognition as a separate variety is open to question.

Available Collections: VITI LEVU: Mba: Slopes of Mt. Nairosa, eastern flank of Mt. Evans Range, Smith 4055. KORO: Eastern slope of main range, Smith 951, 1000. NGAU: Slopes of Mt. Ndelaitho, on northern spur toward Navukailangi, Smith 7886; hills east of Herald Bay, inland from Sawaieke, Smith 7790. VANUA LEVU: MATHUATA: Seanggangga Plateau, in drainage of Korovuli River, vicinity of Natua, Smith 6743. TAVEUNI: Borders of lake east of Somosomo, Smith 932; vicinity of Wairiki, Gillespie 4752.

5c. Alyxia bracteolosa var. angustifolia A. Gray in Proc. Amer. Acad. Arts 5: 332. (Jan.) 1862, in Bonplandia 10: 37. (Feb.) 1862; Seem. in op. cit. 10: 296. 1862, Fl. Vit. 157. 1866; Drake, Ill. Fl. Ins. Mar. Pac. 232. 1892; J. W. Parham, Pl. Fiji Isl. 181. 1964, ed. 2. 257. 1972.

Figures 29A \& B, 30E.

Alyxia stellata sensu Seem. in Bonplandia 9: 257. 1861; non Roemer \& Schultes.

Alyxia bracteolosa sensu Seem. Viti, 439. 1862.

Alyxia scandens sensu Gibbs in J. Linn. Soc. Bot. 39: 156. 1909; non Roemer \& Schultes.

TyPIFICATION: The only us sheet so annotated by Gray is $U$. S. Expl. Exped. (us 78370 LECTOTYPE here designated), collected on Tongatapu, Tonga.

Distribution: Fiji and Tonga. In Fiji this comparatively distinctive variety is now known from about 40 collections but from only four islands.

REPRESENTATIVE COLLeCtIONS: YASAWAS: WaYA: Nangua, St. John 18117. VITI LEVU: MBa: Lomolomo Levu, Mt. Evans Range, DA 14040; northern slopes of Mt. Namendre, east of Mt. Koromba, Smith 4517; Naloto Range, DA 14765; vicinity of Nandarivatu, Gibbs 598. NANDronga \& NAvosa: Southern slopes of Nausori Highlands, in drainage of Namosi Creek above Tumbenasolo, Smith 4586. SERUA: Coastal hills in vicinity of Taunovo River, east of Wainiyambia, Smith 9572; Loloma Beach, DA 16640. NAmosi: Mountains near Namosi, Milne 63. RA: Vicinity of Rewasa, near Vaileka, Degener 15389. REWA: Vicinity of Lami, Gillespie 4591, p. p.; vicinity of Suva, MacDaniels 1079. VITI LEVU and OVALAU: Seemann 310. OVALAU: Slopes of Mt. Koronimoko, vicinity of Thawathi, Smith 8070; Korotumbuitho, Lovoni Valley, DA 13291. VANUA LEVU: Mathuata: Vicinity of Lambasa, Greenwood 564. ThaKaundrove: Mt. Uluinambathi, Savusavu Bay region, Degener \& Ordonez 13931. FuI without further locality, Storck 900.

5d. Alyxia bracteolosa var. retusa Markgraf in Bishop Mus. Bull. 141: 125. fig. 66, a. 1936; J. W. Parham, Pl. Fiji Isl. 181. 1964, ed. 2. 259. 1972. Figure 29D.

TYPIFICATION: The type is Smith 1775 (BISH HOLOTYPE; many ISOTYPES), collected May 10, 1934, in flower, in dense, low forest on Mt. Kasi, Yanawai River region, Thakaundrove Province, Vanua Levu, 300-430 m. alt.

Distribution: Endemic to Fiji and known only from the type collection.

LOCAL NAME: Vono mbuli.

Figure 29. A \& B, Alyxia bracteolosa var. angustifolia; A, foliage and inflorescences, $\times 2$; B, ultimate cluster of flowers, $\times 6 . \mathrm{C}$, Alyxia bracteolosa var. bracteolosa; opened distal portion of corolla, showing style head and partly concealed stamens, $* 20$. D, Alyxia bracteolosa var. retusa; ultimate cluster of flowers, $\times 6$. A from $D A 16640$, B from Degener \& Ordonez 13931, C from Degener 15305, D from Smith 1775. 
Alyxia samoensis (Christophersen) A. C. Sm., comb. et stat. nov. ${ }^{1}$ Figure 30F.

Christophersen correctly discerned the similarity of the mericarps of the fruits of his new variety samoensis to those of Alyxia erythrosperma, but his taxon sharply differs from the Fijian species in having its branchlets more slender, 3-angled rather than 4-angled in the ultimate internodes, and there with nearly flat rather than canaliculate faces, in its ternate rather than quaternate leaves that are obviously petiolate, and in its leaf blades being less coriaceous and more obviously cuspidate or acuminate at apex. In spite of the similarity of the fruits, I believe that these Samoan and Fijian taxa both merit specific status. No dependable characters of foliage or inflorescences separate $A$. samoensis from $A$. bracteolosa var. bracteolosa, which in Samoa usually (but not always) occurs at lower elevations; in general the latter taxon has the ultimate internodes of its branchlets less obviously angled than those of $\boldsymbol{A}$. samoensis.

5. Alstonia R. Br. Asclepiadeae, 64.1810 (preprint from Mem. Wern. Nat. Hist. Soc. 1: 75. 1811); Seem. Fl. Vit. 160. 1866; Pichon in Bull. Mus. Nat. Hist. (Paris) II. 19: 294. 1947; Monach. in Pacific Sci. 3: 137. 1949; Pichon in Mém. Mus. Nat. Hist. Nat. Ser. B, Bot. 1: 170. 1950; Markgraf in Blumea 22: 21. 1974; Boit. in Fl. Nouv.-Caléd. et Dépend. 10: 160. 1981; non Scop. (1777). Nom. cons.

Trees or erect shrubs, the stipules reduced to lines or sometimes intrapetiolar; leaves opposite or verticillate, the blades usually with obvious secondary nerves and inconspicuous veinlets; inflorescences terminal, cymose, with several often freely branched primary peduncles, the flowers 5-merous; calyx deeply or shallowly lobed, the lobes broad, ciliolate or not, without glands; corolla tube cylindric, usually staminiferous near middle or toward apex and there slightly inflated, often pilose within, the throat thickened or not, pilose or glabrous, the lobes sinistrorsely or dextrorsely (as in our species) contorted in bud, spreading at anthesis; stamens with short filaments, the anthers not exserted, without appendages; disk annular, free or adnate to and often indistinct from ovary; ovary apocarpous, superior or partly inferior, glabrous to densely pilose, the carpels free or shortly concrescent at base, the ovules numerous (18-110), 2-8-seriate, the style filiform to short, glabrous, the style head cylindric or truncate-conical, often densely velutinous at least at base, membranous-indusiate above, the stigma apiculate or short-conical; fruit a double follicle, the mericarps free or very shortly connate proximally, slender, not compressed, slightly striate, the placentae marginal, the seeds numerous, sessile, dorsiventrally flattened, not imbricate, marginally ciliate with simple, distinct hairs and often also pilose on surfaces, without wings or with a distal wing or with both distal and proximal wings, these sometimes variously bifid or bipartite or irregularly branched, the hilum punctiform near middle of one surface of seed body.

TYPE SPECIES: Alstonia scholaris (L.) R. Br. (Echites scholaris L.) (typ. cons.).

Distribution: Tropical Africa to tropical Asia, Malesia, and Australia, and eastward in the Pacific to the Society and Marquesas Islands, with 40-45 species.

'Alyxia samoensis (Christophersen) A. C. Sm., comb. et stat. nov.

Alyxia erythrosperma var. samoensis Christophersen in Bishop Mus. Bull. 128: 181. fig. 28.1935.

TYPIFICATION: The type is Christophersen \& Hume 2157 (BISH HOLOTYPE and ISOTYPE), collected in fruit July 24, 1931, in forest above Matavanu Crater, alt. 1,300 m., Savai'i, Samoa.

Distribution: Endemic to Samoa and now known from Savaiti and Upolu at elevations of $600-1,600 \mathrm{~m}$.

AdDitional SPECIMENS EXAMINED: SAMOA: SAVAI'I: Vaupel 606, Christophersen \& Hume 2563. Whistler 2563, 2636. UPOLU: Christophersen 388, 391, Whistler 699, 1155, 1910. 

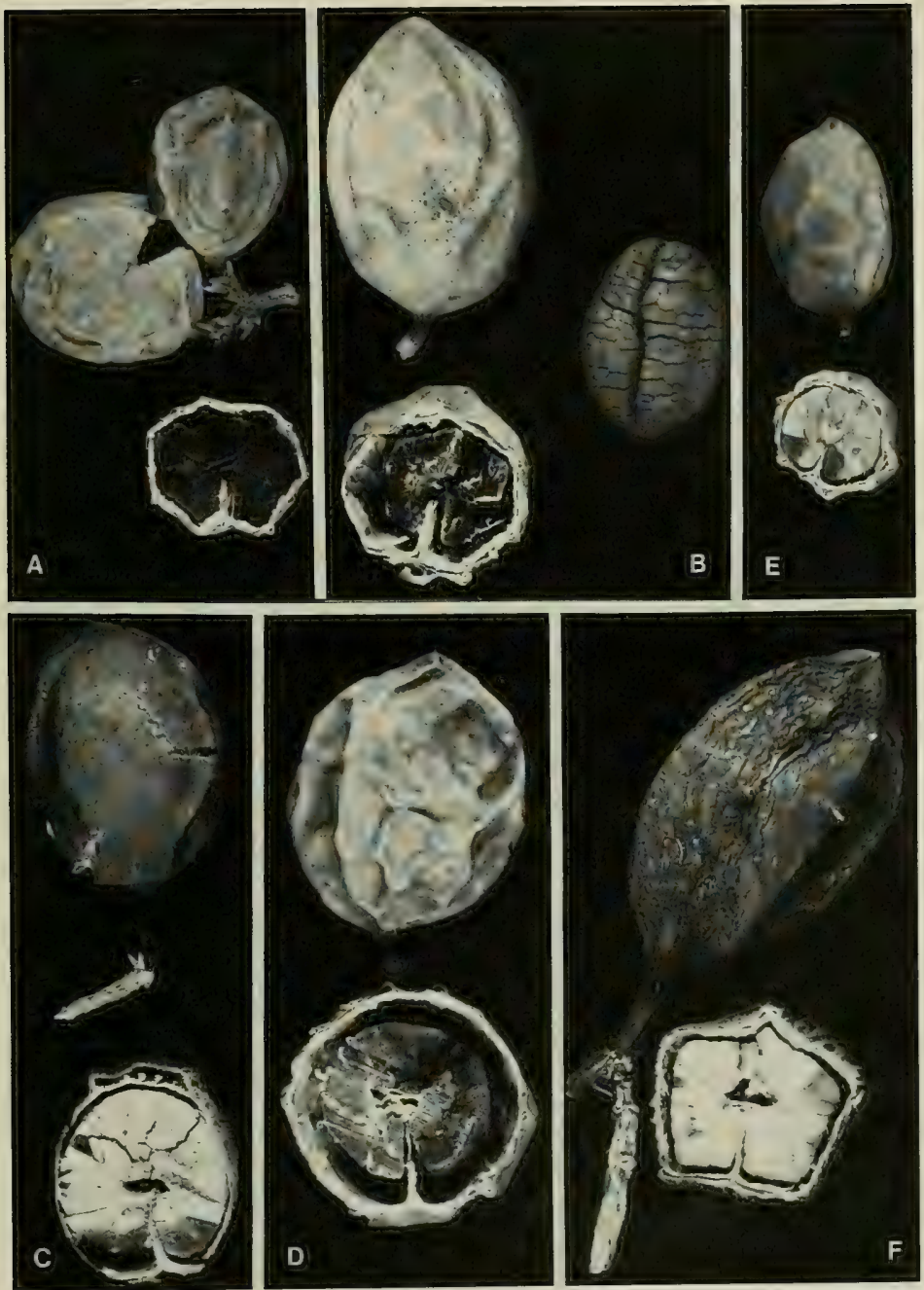

Figure 30. Alyxia, dried mericarps and cross sections, all $\times 2$. A-C, Alyxia bracteolosa var. bracteolosa (B also with ventral surface of seed). D, Alyxia bracteolosa var. macrocarpa. E, Alyxia bracteolosa var. angustifolia. F, Alyxia samoensis. A from Smith 8581, B from Christophersen 3297 (Savai'i, Samoa), C from Smith 1352, D from Smith 7790, E from DA 16640, F from Christophersen 388 (Upolu, Samoa). 
(However, Alstonia is presumably lacking from Tonga and Niue; Yuncker's (1959) record of the genus in Tonga is referable to Ervatamia obtusiuscula, q. v.) Three indigenous species, of which two are endemic, and one cultivated species are recorded from Fiji; all of these belong in sect. Dissuraspermum (A. Gray) Benth. as that is defined by Pichon $(1947,1950)$ to include sect. Monuraspermum Monach. (1949). Tonduzia Pittier, a small Central American genus, was treated as a section of Alstonia by Pichon (1947, p. 296), but this suggestion was refuted by Monachino (1949, pp. 179-180), who pointed to a substantial difference in seed morphology between the two genera. Monachino's observation was verified by Pichon $(1950$, p. 168) but did not cause him to modify his point of view, which is also adopted by Gentry (in Ann. Missouri Bot. Gard. 70: 206. 1983). The generic distribution stated by Markgraf (1974) indicates that he has not accepted the inclusion of Tonduzia in Alstonia.

Useful treatments of Genus: Pichon, M. Classification des Apocynacées: IV, gente "Alstonia" et genres voisins. Bull. Mus. Hist. Nat. (Paris) II. 19: 294-301. 1947. MonaCHINO, J. A revision of the genus Alstonia (Apocynaceae). Pacific Sci. 3: 133-182. 1949. MARK GRAF, F. Florae Malesianae Praecursores LIV. Apocynaceae III. Blumea 22: 20-29. 1974.

The taxa of Alstonia indigenous in the Fijian Region are difficult to analyze, as pointed out by Monachino (1949, pp. 167-168), but they seem amply distinct from the Polynesian $A$. costata (Forst. f.) R. Br. on the basis of leaf blade shape (blades of the latter being abruptly long-acuminate at apex) and seed proportions. The species of our area have coriaceous leaf blades of very diverse size, in shape varying from lanceolateelliptic to broadly oblong- or obovate-elliptic, rounded to obtuse to long-decurrent on petiole at base, rounded to obtuse to cuspidate or short-acuminate at apex (but then the acumen obtuse and not exceeding $1 \mathrm{~cm}$. in length), the costa and secondary nerves often sulcate above and prominent beneath, the secondary nerves spreading-arcuate and 9-22 per side. The petioles are slender to stout, shallowly canaliculate or deeply so at base and often expanded and clasping, sometimes with an obvious erect ligule, when fallen leaving conspicuous, pale, broad, obdeltoid or lunate scars. The inflorescences are often long-pedunculate, spreading, and freely branched; the calyces are 1-2 mm. long and not more than $2.5 \mathrm{~mm}$. in diameter, with rounded, eciliate lobes; the corolla tube is $2-6 \mathrm{~mm}$. long and the variable lobes are oblong- or linear-lanceolate, usually $5-10 \times 1.5-2 \mathrm{~mm}$. The mature fruits have sharply divergent mericarps that are very slender $(2.5-5 \mathrm{~mm}$. in diameter prior to dehiscence) and variable in length $(6-40 \mathrm{~cm}$. long); the seeds are caudate-winged at both ends, copiously short-ciliolate and often minutely pilose on the flattened surfaces; the seed wings are entire or bifid or sometimes irregularly forked. Dimensional characteristics as to branchlets, leaves, and inflorescences are useful in separating taxa but are certainly not sharply differentiating. Floral differences among the taxa seem inconsequential, but mericarp length and seed proportions are worthy of consideration.

LOCAL NAMES AND USES: Commonly used names for any indigenous species of Alstonia are mbulei, ndrenga, ndrengandrenga, ndrenga nggurungguru, and sorua; other recorded names are rerese and mbuleki; mbulei lailai usually refers to $A$. montana. The latex of all species is used as a chewing gum, and it has been noted as part of a preparation used to relieve eye troubles. The commercial potential of the Fijian caoutchouc was interestingly discussed by Horne (1881, pp. 195-202), but apparently his recommendations have been ignored. 
KEY TO SPECIES

Leaves opposite; calyx and corolla lobes eciliate; seeds caudate-winged at both ends; indigenous species. Seeds 5-10 mm. long, the body $2-4 \times 1.5-2 \mathrm{~mm}$. (about twice as long as broad), abruptly caudate-winged at both ends, the wings 1-4 mm. long; mericarps of mature fruits $6-20 \mathrm{~cm}$. long; inflorescences at full anthesis $4-11 \mathrm{~cm}$. long, 2-7 cm. broad, the peduncles (1-) 2-7 cm. long; petioles slender $(1-2 \mathrm{~mm}$. in diameter), 1-3 cm. long, slightly expanded at base but without a clasping ligule; leaf blades (3-) 5-15 $\times(1.5-)$ 2.5-5 (-6) cm., glabrous, the secondary nerves $2-10(-12) \mathrm{mm}$. apart; branchlets comparatively slender, $1.5-4(-5) \mathrm{mm}$. in diameter in ultimate $10-20 \mathrm{~cm}$, the leaf scars $2-5 \mathrm{~mm}$. broad and $1-2$

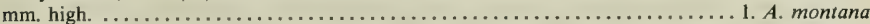

Seeds $12-19.5 \mathrm{~mm}$. long, the body $4-6 \times 1-2 \mathrm{~mm}$. ( 3 or 4 times as long as broad), gradually caudate-winged at both ends, the wings 4-8 $\mathrm{mm}$. long; mericarps of mature fruits (8-) $13-40 \mathrm{~cm}$. long; inflorescences at full anthesis often exceeding $15 \mathrm{~cm}$. long and broad, the peduncles usually $5 \mathrm{~cm}$. long or much longer; petioles comparatively stout, expanded to a broad base and often with a clasping ligule; leaf blades usually exceeding $15 \times 5 \mathrm{~cm}$., the secondary nerves (4-) 5-40 mm. apart; branchlets comparatively stout, $2.5-15 \mathrm{~mm}$. in diameter in ultimate $10-20 \mathrm{~cm}$, the leaf scars usually exceeding $5 \mathrm{~mm}$. in breadth and $2 \mathrm{~mm}$. in height.

Branchlets 2.5-5 (-8) $\mathrm{mm}$. in diameter, the leaf scars 3-8 $(-10) \mathrm{mm}$. broad and 1.5-4 (-6) $\mathrm{mm}$. high; petioles $1-5(-7) \mathrm{cm}$. long, $1-2.5 \mathrm{~mm}$. in diameter, often with a comparatively inconspicuous ligule to $1 \mathrm{~mm}$. high or this obscure or lacking; leaf blades $(5-) 7-22(-26) \times(2-) 3-11(-16) \mathrm{cm}$., glabrous, the secondary nerves (4-) 5-20 mm. apart; inflorescences 4-16 $(-22) \mathrm{cm}$. long and 4-13 cm. broad, the peduncles (1-) 4-10 (-12) cm. long; mericarps of mature fruits (8-) 13-38 cm. long.

2. A. pacifica

Branchlets (5-) 7-15 mm. in diameter, often obviously fistulose, the leaf scars $10-16 \mathrm{~mm}$. broad and 4-8 $\mathrm{mm}$. high; petioles (2-) 4-10 cm. long, (2-) 3-6 mm. in diameter, with a coriaceous clasping ligule 1-3 (-5) mm. high; leaf blades (13-) 20-60 × (6-) 12-30 cm., sometimes soft-villose beneath, the secondary nerves $10-40 \mathrm{~mm}$. apart; inflorescences $10-35 \mathrm{~cm}$. long and broad, the peduncles (1-) $5-20 \mathrm{~cm}$. long; mericarps of mature fruits $20-40 \mathrm{~cm}$. long. ................ vitiensis Leaves verticillate, usually 4 per node; calyx and corolla lobes ciliate; seeds caudate-winged at one end only;

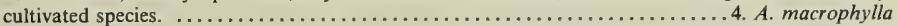

1. Alstonia montana Turrill in J. Linn. Soc. Bot. 43: 32. 1915; Monach. in Pacific Sci. 3: 173.1949.

Figures $31,32 \mathrm{~A} \& \mathrm{~B}, 33 \mathrm{~A}$.

Alstonia plumosa sensu Seem. Fl. Vit. 161. 1866; Drake, Ill. Fl. Ins. Mar. Pac. 234. 1892; Gibbs in J. Linn. Soc. Bot. 39: 157. 1909; non Labill.

Alstonia smithii Markgraf in Bishop Mus. Bull. 141: 125. fig. 65, a. 1936.

Alstonia moniana var. filiformis Monach. in Pacific Sci. 3: 173. 1949; J. W. Parham, Pl. Fiji Isl. 181. 1964, ed. 2. 257. 1972 .

Alstonia montana var. montana; J. W. Parham, Pl. Fiji Isl. 181. 1964, ed. 2. 257. 1972.

Shrub or tree (1-) 2-15 m. high, with white latex, often abundant from near sea level to $1,195 \mathrm{~m}$. (more common at higher elevations) in dense, dry, or open forest or in the thickets of crests and ridges. The corolla is white to pale yellow, but with the tube often greenish and the lobes often bright yellow to orange as well as white (such colors apparently lacking in the other indigenous species). Flowers and fruits have been obtained in all months.

TYPIFICATION AND NOMENCLATURE: Alstonia montana is based on im Thurn 58 (K HOLOTYPE; ISOTYPE at BM), collected Jan. 31, 1906, near Nandarivatu, Mba Province, Viti Levu. The type of $A$. smithii is Smith 697 (BISH HOLOTYPE; many ISOTYPES), obtained Nov. 29, 1933, on the summit of Mt. Mbatini, Thakaundrove Province, Vanua Levu. Markgraf did not compare his species with $A$. montana, but no differences are apparent. Alstonia montana var. filiformis is typified by Horne 1043 (K HоLоTYPE), collected in June, 1878, at Na Vasi ("Navesi"), Rewa Province, Viti Levu. Monachino distinguished the variety by its small flowers and slender inflorescence branches, characters now seen to be very variable.

Distribution: Endemic to Fiji but known from only three of the high islands, from which some 75 collections are now at hand. Monachino (1949) believed Alstonia montana to occur in Samoa on the sole basis of Christophersen 1061, a flowering 
specimen in my opinion indistinguishable from various others of Samoa accepted by Monachino as $A$. reineckeana (i. e. A pacifica).

RePresentative COLlections: VITI LEVU: MBA: Northern portion of Mt. Evans Range, between Mt. Vatuyanitu and Mt. Natondra, Smith 4386; Mt. Lomolomo Levu, DA 14045; upper slopes of Mt. Koromba, Smith 4638; vicinity of Nandarivatu, Gibbs 563, 605. Parks 20505; summit of Mt. Nanggaranambuluta, Gillespie 3801. NANDRONGA \& NAVOSA: Northern portion of Rairaimatuku Plateau, between Nandrau and Rewasau, Smith 5427. Serua or NAmosi: Mountains between Vienungga and Waionamoli Creeks, Horne 861. Namosi: Mt. Naitarandamu, Gillespie 3375; Mt. Voma, Gillespie 2912; Mt. Vakarongasiu, DA 14596. NAITASIRI: Northern portion of Rairaimatuku Plateau, between Mt. Tomanivi and Nasonggo, Smith 6091; Central road, Mac Daniels 1150. VITI LEVU without further locality, Milne 101. OVALAU: Hills west of Lovoni Valley, on ridge south of Mt. Korolevu, Smith 7541; mountains west of Levuka, Gillespie 4428. VANUA LEVU: MBUA: Mt. Seatura, DA 15170; woods above Nandi, Milne 213; lower Wainunu River Valley, Smith 1722. Mathuata; Mt. Ndelaikoro, DA 12621. Thakaundrove: Mt. Mbatini, Smith 711; Navonu Creek, Natewa Peninsula, DA 15081. VANUA Levu without further locality, Milne 261.

2. Alstonia pacifica (Seem.) A. C. Sm. in Brittonia 27: 151. 1975.

Figures 32C, 33B.

Tabernaemontana sp. Seem. in Bonplandia 9: 257. 1861.

Alstonia plumosa sensu A. Gray in Proc. Amer. Acad. Arts 5: 334. 1862; non Labill.

Tabernaemontana pacifica Seem. Fl. Vit. 160. 1866; Drake, Ill. Fl. Ins. Mar. Pac. 235. 1892; J. W. Parham, Pl. Fiji Isl. 185. 1964, ed. 2. 262. 1972.

Alstonia godeffroyi Reinecke in Bot. Jahrb. 25: 667. 1898.

Alstonia reineckeana Lauterb. in Bot. Jahrb. 41: 233. 1908; Christophersen in Bishop Mus. Bull. $128:$ I 77.

1935; Monach. in Pacific Sci. 3: 172. 1949; J. W. Parham, Pl. Fiji Isl. 181. 1964, ed. 2. 257. 1972; B. E. V.

Parham in New Zealand Dept. Sci. Indust. Res. Inform. Ser. 85: 52, 81. 1972.

Alstonia villosa f. calvescens sensu Guillaumin in J. Arnold Arb. 13: 19. 1932; non Markgraf.

Rejoua pacifica Markgraf in Notizbl. Bot. Gart. Berlin 12: 546. 1935.

Alstonia aff. plumosa Christophersen in Bishop Mus. Bull. 128: 177. 1935.

Alstonia setchelliana Christophersen in Bishop Mus. Bull. 128: 178. fig. 27. 1935.

Alstonia sp. Christophersen in Bishop Mus. Bull. 128: 180. 1935.

Alstonia vitiensis var. novo-ebudica Monach. in Pacific Sci. 3: 171. 1949.

Alstonia vitiensis var, whitmorei Markgraf in Gard. Bull. Singapore 22: 24. 1967.

Tree 2-20 m. high, often slender, with white latex, found in various types of forest and sometimes in coastal thickets, between sea level and about $1,000 \mathrm{~m}$. (but less frequently at the higher elevations than Alstonia montana). The corolla is white to pale yellow, often with the tube greenish. Flowers and fruits have been noted throughout the year.

TYPIFICATION AND NOMENCLATURE: Tabernaemontana pacifica is based solely on Seemann 314 (K HOLOTYPE), collected in May, 1860, in the vicinity of Somosomo, Taveuni. The specimen clearly represents the widespread "transitional species between A. vitiensis and A. montana" (Monachino, 1949). The type of Alstonia godeffroyi is Reinecke 483 (HOLOTYPE presumably at WRSL), obtained in April, 1895, at "LetogoSiuma-Kamm," Upolu, Samoa. I have seen no duplicates or photographs of this type, but nothing in the description indicates it to be different from the common Samoan species usually identified as $A$. reineckeana, typified by Vaupel 353 (ISOTYPES at BISH, K, US), collected July 19, 1906, at "Maugamu," Savai'i, Samoa. The type of $A$. setchelliana is Christophersen 1265 (BISH HOLOTYPE), collected Nov. 14, 1929, west of Pago Pago, Tutuila, Samoa. Alstonia vitiensis var. novo-ebudica is based on Kajewski 292 (NY hOLOTYPE), obtained May 23, 1928, at Dillon Bay, Eromanga, New Hebrides; A. vitiensis var. whitmorei on Whitmore BSIP 605 (depository not indicated), collected Oct. 13, 1962, at Gold Ridge, Guadalcanal, Solomon Islands. The occurrence of A. vitiensis in the New Hebrides and Solomon Islands, as suggested by the last two

Figure 31. Alstonia montana; A, portion of inflorescence, $\times 4$; B, corolla with 2 lobes removed, showing a stamen, $\times 12$; C, calyx with 2 lobes removed and gynoecium, $\times 24 ; \mathrm{D}$, seeds, $\times 4$. A-C from Smith 1722, D from Gillespie 4428 (left), DA 14045 (center), and Parks 20505 (right). 

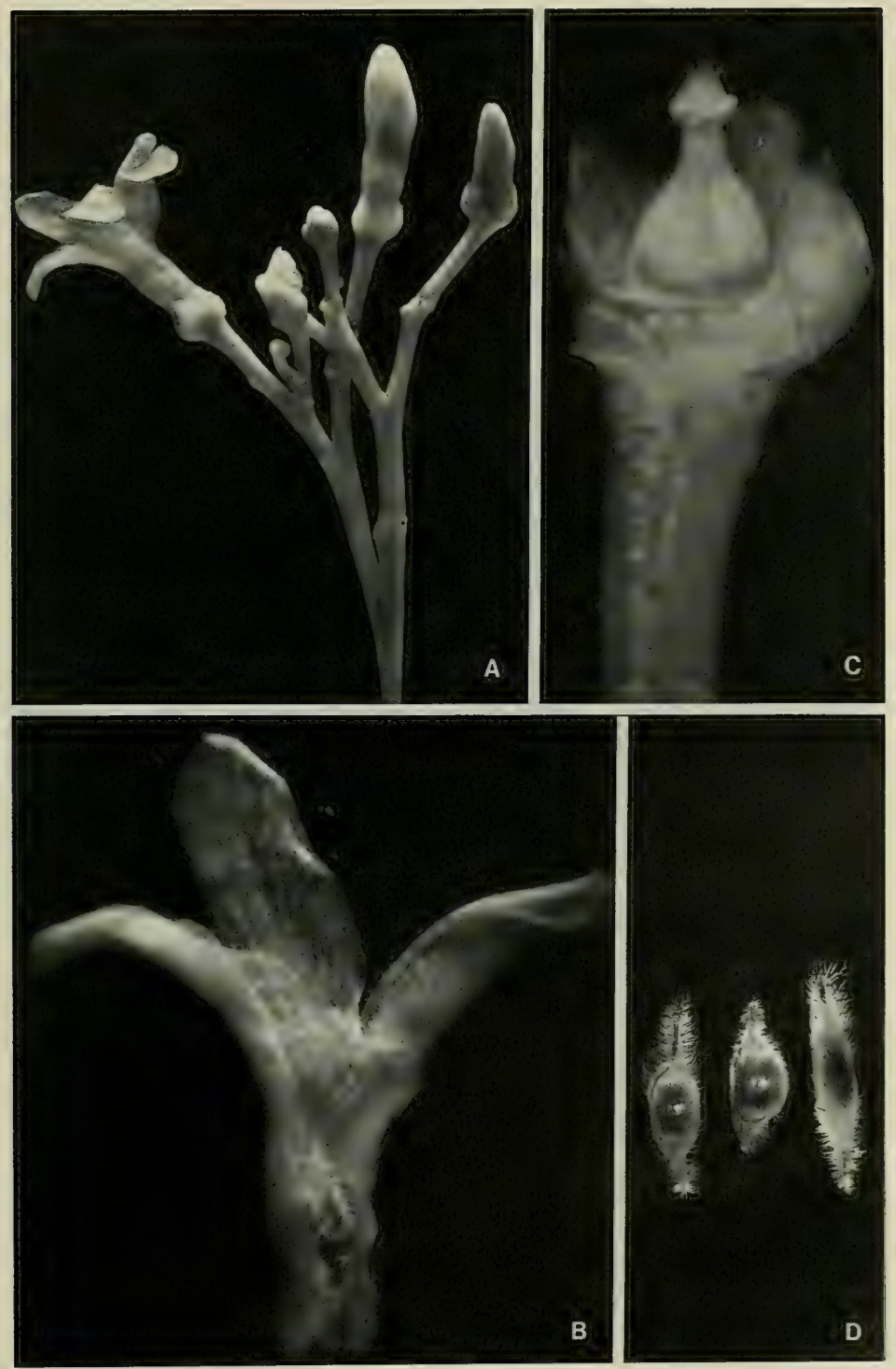
varietal taxa, cannot be supported. Specimens from those areas of this general relationship appear to me indistinguishable from a reasonable concept of $A$. pacifica.
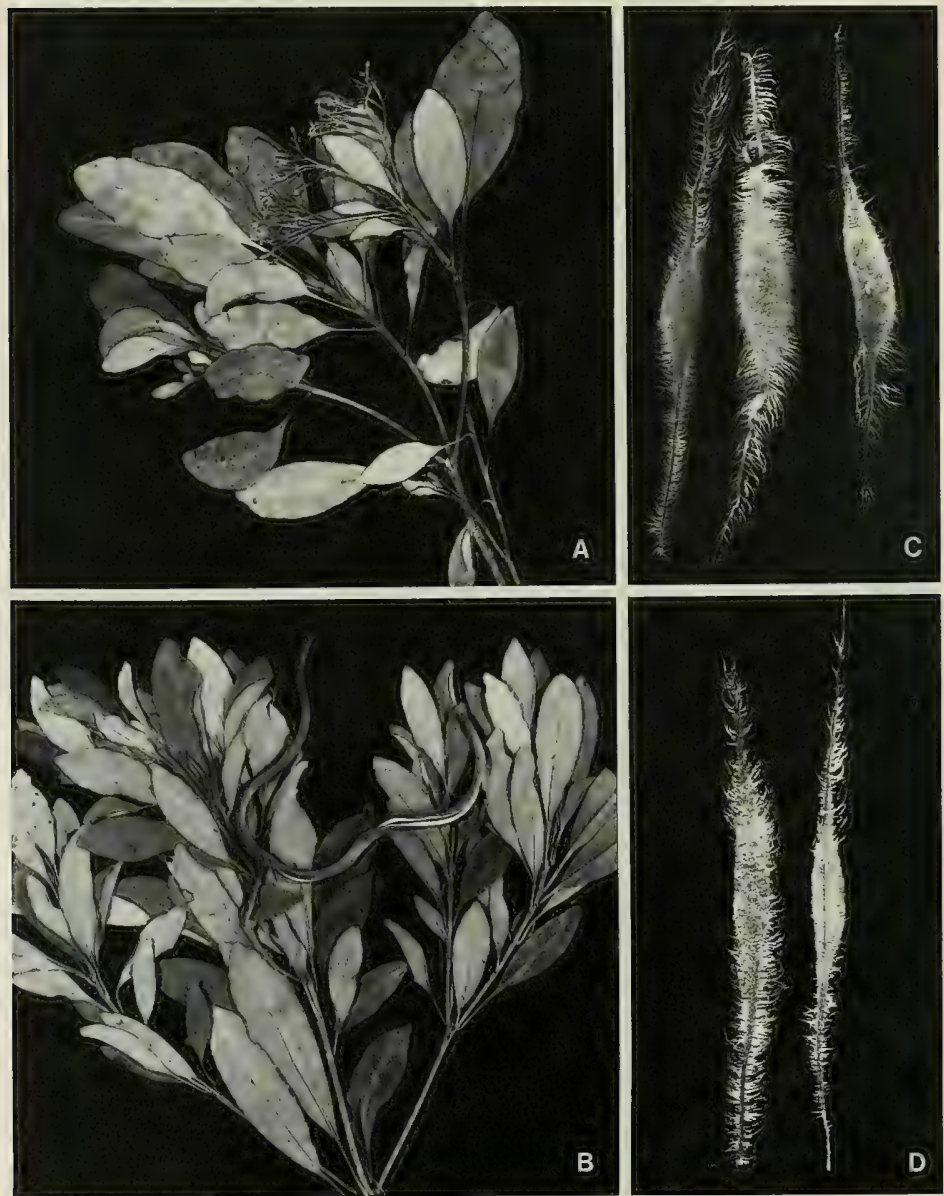

FIGURE 32. A \& B, Alstonia montana; A, distal portion of branchlet, with foliage and an inflorescence, $x$ 1/3; B, distal portion of branchlet, with foliage and a mature fruit, $\times 1 / 3 . \mathrm{C}$, Alstonia pacifica; seeds, $\times 4$. D, Alstonia vitiensis $\mathrm{f}$, vitiensis; seeds, $\times 4$. A from Smith 1722, B from DA 14045, C from Gillespie 4273 (left), Bryan 343 (center), and Smith 1701 (right), D from DA 9612 (left) and Gillespie 3623 (right). 
Distribution: Solomon Islands (Bougainville eastward) through the Santa Cruz Islands, New Hebrides, and Fiji to Samoa. In Fiji the species has been collected on eight of the high islands but doubtless occurs on others; 55 Fijian collections have been examined.

RePRESENTATIVE COLlections: VITI LEVU: MBA: Nandala Valley, vicinity of Nandarivatu, Gillespie 4273; western and southern slopes of Mt. Tomanivi, Smith 5286. NANDRonga \& Navosa: Nausori Highlands, DA 12657 (Melville et al. 7032). SERUA: Nathengathenga Creek, upper Navua River, DA 14273; hills between Waininggere and Waisese Creeks, between Ngaloa and Wainiyambia, Smith 9380. NAMOSI; Hills bordering Wainavindrau Creek, vicinity of Wainimakutu, Smith 8853; Mt. Voma, DA 11650. NAITASIRI: Lower Waimanu River, DA L.13301; Tholo-i-suva, DA 14515. TAILEvu: Track to Nandrano, DA 13609. REWA: Mt. Korombamba, DA 16527. KANDAVU: Western end of island, near Cape Washington, Smith 251; hills above Naikorokoro, DA 11698 (Krauss 401). OVALAU: Hills southeast of valley of Mbureta River, Smith 7444. KORO: Eastern slope of main ridge, Smith 1026. NGAU: Hills east of Herald Bay, inland from Sawaieke, Smith 7803. VANUA LEVU: MBUA: Southern portion of Seatovo Range, Smith 1701. Mathuata: Seanggangga Plateau, in drainage of Korovuli River, vicinity of Natua, Smith 6651; Mathuata coast, Greenwood 491A. ThaKAUndrove: Wailevu, DA 14283. TAVEUNI: Summit ridge above Somosomo, Gillespie 4836. MOALA: Summit ridge, Bryan 343. Fivi without further locality, U.S. Expl. Exped.

In my opinion Alstonia pacifica and $A$. vitiensis are well distinguished, but some previous workers have found difficulties in separating them, referring to the latter non-Fijian elements that seem better referred to the former. If the two taxa should be combined in the future, the older specific epithet is pacifica.

3. Alstonia vitiensis Seem. Fl. Vit. 430. 1873.

Tree 2-15 m. high, with copious white latex, occurring from sea level to about 1,100 $\mathrm{m}$. in dense or open forest, in hillside thickets, and in beach thickets. The corolla is white, rarely yellowish, frequently with the tube green-tinged. The mericarps of mature infructescences are sometimes aggregated in a mass as much as $1 \mathrm{~m}$. in diameter. Flowers and fruits do not appear seasonal.

Distribution: Endemic to Fiji, here construed to be composed of two elements that have been denoted (Monachino, 1949, p. 171) as a pubescent-leaved series and a glabrous-leaved series. While the latter has all the remarkable dimensional features of typical (pubescent-leaved) Alstonia vitiensis, its leaf blades are completely without indument, and intermediates have not been noted. The glabrous specimens of this complex, here designated as a form for convenience, could conceivably be considered better placed in $A$. pacifica, but they would expand dimensional characteristics of that species to an unwarranted degree.

KEY TO FORMS

Leaf blades copiously soft-villose beneath with pale hairs $0.3-0.7 \mathrm{~mm}$. long. ........3a. f. vitiensis Leaf blades glabrous beneath. ................................ glabra

3a. Alstonia vitiensis $\mathrm{f}$. vitiensis.

Figures 32D, 33C.

Alstonia plumosa sensu Seem. in Bonplandia 9: 257. 1861, Viti, 439. 1862; A. Gray in Bonplandia 10: 37. 1862; non Labill.

Alstonia villosa Seem. Fl. Vit. 161. 1866; Drake, Ill. Fl. Ins. Mar. Pac. 234. 1892; non Bl.

Alstonia vitiensis Seem. Fl. Vit. 430. 1873; Gillespie in Bishop Mus. Bull. 74: 18. fig. 23. 1930; Monach. in Pacific Sci. 3: 171, p. p. 1949.

Alstonia vitiensis var. vitiensis; J. W. Parham, Pl. Fiji 1sl. 181. fig. 65, A. 1964, ed. 2. 257. fig. 76, A. 1972.

The nomenclaturally typical form, occurring from sea level up to about $400 \mathrm{~m}$., with leaf blades copiously soft-villose beneath.

Typification: The type of Alstonia villosa Seem. (non B1.), for which $A$. vitiensis was a new name, is Seemann 318 (K HOLOTYPE; ISOTY PE at BM). Doubt must remain as 
to the type locality; although this was given as Viti Levu by Seemann in 1866, the holotype bears a label indicating "Port Kinnaird, July 1860." Seemann spent part of July at Port Kinnaird (Ovalau) and also visited parts of southeastern Viti Levu during that month.

Distribution: Viti Levu, Ovalau (?), and Vanua Levu, but frequent only in southeastern Viti Levu.

AVAilable collections: VITI LEVU: NANDRONGa \& NAVOSA: Vicinity of Mbelo, near Vatukarasa, Degener 15266. SERUA: East of Nambukelevu, upper Navua River, Berry 88; hills between Navua River and Wainiyavu Creek, near Namuamua, Smith 8979; hills west of Waivunu Creek, between Ngaloa and Korovou, Smith 9479; Ndeumba Beach, DA 11008, 11452. NaITASIRI: Waindina River, Tothill 385; Waimanu River, DA 15845; Tholo-i-suva, Parks 20900, DA 11253, 12211 (Watkins 729); 9 miles from Suva, Meebold 16787; Tamavua, Yeoward 77, Gillespie 2467: Nasinu, Gillespie 3623, 3653, DA 9587; Koronivia, DA 9612 . TAILEVU: Hills east of Wainimbuka River, vicinity of Ndakuivuna, Smith 7168. VANUA LEVU: ThaKaUndrove: Mt. Kasi, Yanawai River region, Smith 1795. Fivi without further locality, Storck XXI. Horne 514, DA 262, DF 155.

3b. Alstonia vitiensis $\mathrm{f}$. glabra A. C. Sm., f. nov. ${ }^{1}$ Figure 33D.

A form of Alstonia vitiensis differing from the typical form only in having its leaf blades completely glabrous; it is known from similar habitats but occasionally occurs at higher elevations (up to about $1,100 \mathrm{~m}$.) than the typical form of the species.

TYPIFICATION: As type I designate Smith 5474 (BISH HOLOTYPE, 2 sheets; many ISOTYPES), collected in flower Aug. 4, 1947, on the northern portion of the Rairaimatuku Plateau, between Nandrau and Nanga, Nandronga \& Navosa Province, Viti Levu.

Distribution: Known from several Fijian islands, more widely distributed than the typical form of the species.

Available Collections: VITI LEVU: MBa: Mountains near Lautoka, Greenwood 361 A; Mt. Evans Range between Vakambuli and Nalotawa, Greenwood 26; Vovono, DA 14718; Nandarivatu, DA 8533; Mt. Nanggaranambuluta, DA 10389; western and southern slopes of Mt. Tomanivi, Smith 5228. NANDRONGA \& NAvOSA: Southern slopes of Nausori Highlands, in drainage of Namosi Creek above Tumbenasolo, Smith 4560; Mbulu, near Sovi Bay, Degener 15040. Serua: Hills west of Waivunu Creek, between Ngaloa and Korovou, Smith 9214; Ngaloa, DF 935 (Kunawaqe 19); Ndeumba, DA 9212; Ndeumba Beach, DA 11455. Namosi: Vicinity of Namuamua, Gillespie 3040. NAItasıri: Matawailevu, Wainimala River, St. John l830l. OVALAU: Hills east of Lovoni Valley, Smith 7277. VANUA LEVU: MbUA: $R$. L. Holmes (к); Ndama road, DA 16694; Koromba Forest, DA 15157. Mathuata: South of Ndreketi, Mead 2006; vicinity of Lambasa, Greenwood 491; Nasautha, DA 13478. ThaKaundrove: Vatunivuamonde Mt., Savusavu Bay region, Degener \& Ordonez 14022; between Salt Lake and Natewa Bay, Bierhorst F194. TAVEUNI: Vicinity of Waiyevo, Gillespie 4790. VANUA MBALAVU: Nambavatu, northern limestone section, Tothill 399. FIJI without further locality, Sir Arthur Gordon (K), Horne 255, Joske.

Monachino (1949, p. 171) was aware that certain Fijian specimens could be distinguished from typical Alstonia vitiensis only by their glabrous leaves, but he did not apply a formal name to his "glabrous-leaved series," of which he remarked: "The leaves are frequently smaller and easily confused with those of $A$. reineckeana and $A$. montana." In fact, of the specimens cited by Monachino as representing his glabrousleaved series, only three can actually be referred to $A$. vitiensis. In my opinion he also there cited specimens of $A$. pacifica (Degener 15062, 15124, 15153, Meebold 16716, Smith 251, 1701) and A. montana (Gillespie 2912). Monachino's mixed impressions of the three indigenous Fijian taxa caused him to refer to $A$. vitiensis certain collections from the Solomons and New Hebrides that are surely better placed in A. pacifica.

'Alstonia vitiensis Seem. f. glabra A, C. Sm., f, nov.

Arbor grandifolia a forma typica foliorum laminis omnino glabris recedens. HoLOTYPE: FIJI: VITI LEVU: NANDRONGA \& NAVOSA: Smith 5474 (BISH). 
Although the glabrous form of $A$. vitiensis has all the dimensional characteristics of the typical form of that species, it may indeed be confused with $A$. pacifica if welldeveloped leaves and branchlets or mature inflorescences are not available.
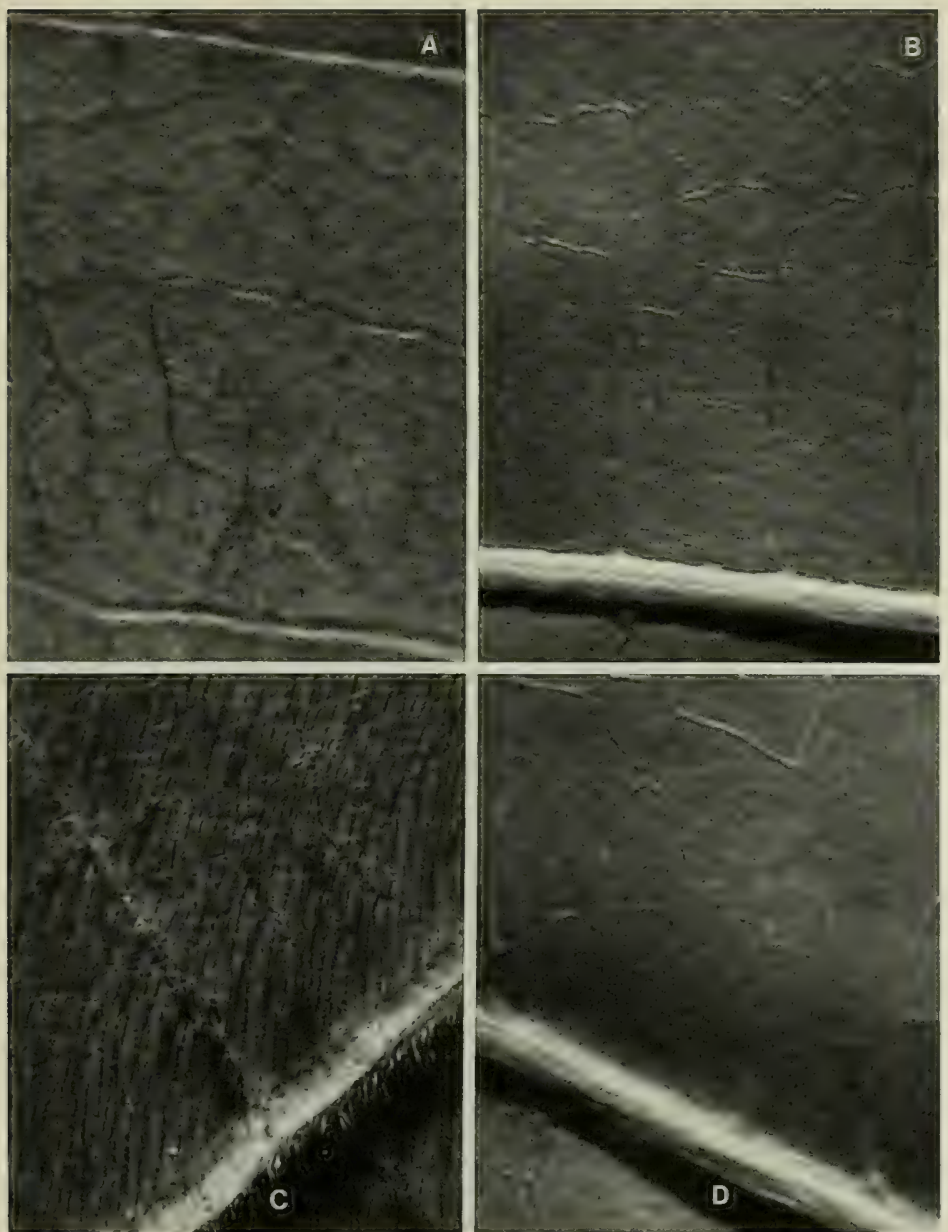

FIGURE 33. Lower surfaces of leaf blades of Alstonia, each photo showing one (or two) secondary nerves and veinlet reticulation, all $\times 10$. A, A. montana, from MacDaniels 1150. B, A. pacifica, from Smith 6651. C, A. vitiensis f. vitiensis, from Gillespie 2467. D, A. vitiensis f. glabra, from Smith 9214. 
4. Alstonia macrophylla Wall. ex G. Don, Gen. Hist. Dichlam. Pl. 4: 87. 1837; Monach. in Pacific Sci. 3: 164. 1949; J. W. Parham, Pl. Fiji Isl. ed. 2. 257. 1972; Markgraf in Blumea 22: 28. 1974.

Tree 3-4 m. high (as noted in Fiji, but where indigenous to $20 \mathrm{~m}$. high), cultivated near sea level, with white corollas.

TyPification: The type is Wallich 1648 (K HOLOTYPE), from Penang, Malaya.

Distribution: Southeastern Asia (from Thailand) into Malesia (to the Moluccas); cultivated elsewhere. It is said to have been recently introduced into Fiji by the Department of Forestry.

Available Collection: VITI LEVU: Rewa: Suva Botanical Gardens, DA 11569, in flower, January, 1959.

6. Carruthersia Seem. Fl. Vit. 155. 1866; Benth. in Benth. \& Hook. f. Gen. Pl. 2: 718. 1876; K. Schum. in Engl. \& Prantl, Nat. Pflanzenfam. IV. 2: 174. 1895; A. C. Sm. in J. Arnold Arb. 36: 287. 1955.

High-climbing lianas or scandent shrubs; leaves opposite, the blades with wellspaced secondary nerves; inflorescences axillary, pedunculate, cymose, laxly paniculiform, bracteate and bracteolate; calyx small, deeply lobed, the lobes ovate or deltoid, obtuse, ciliolate, with a few small glands within at base; corolla hypocrateriform, the tube cylindric, slender, slightly swollen proximally by stamens, pilose within, the throat pilose but without scales, the lobes asymmetrically obovate or obdeltoid, conspicuously nerved, sinistrorsely contorted in bud, spreading at anthesis; stamens attached toward base of corolla tube, the filaments short, pilose or essentially glabrous, the anthers oblong-linear or lanceolate, shortly mucronulate, loosely connivent by extruded pollen about style head but free from it, inconspicuously subcordatesagittate at base; disk 2-lobed, subcarnose, the lobes broad, alternating with carpels and about half their length; ovary bicarpellate, the carpels appressed to one another, the ovules numerous, the style filiform, the style head narrowly oblong-subconical or clavate, without a flange, the stigma with 2 acute lobes; fruit apocarpous, the mericarps follicular, strongly divaricate, terete, gradually narrowed distally, the seeds numerous, oblong-lanceolate, subcoriaceous, slightly thickened on one margin and narrowly winged on the other, with a conspicuous distal coma of numerous hairs longer than seed body.

TYPE SPECIES: Carruthersia scandens (Seem.) Seem. (Rejoua scandens Seem.), the only original species.

Distribution: Philippines to Solomon Islands, New Hebrides, and Fiji, with 10-12 species; three endemic species terminate the generic range in Fiji.

KEY TO SPECIES

Leaf blades elliptic-oblong or oblong-ovate, usually 8-16 × 3-7.5 cm., about 2.5-3 times longer than broad, narrowly subcordate to broadly obtuse at base, glabrous, the secondary nerves 6-11 pairs; petioles $1.3-2.5 \mathrm{~cm}$. long; vegetative parts glabrous; inflorescences comparatively narrow, $4.5-15 \times 3-9 \mathrm{~cm}$. (including flowers), with 3-15 flowers; pedicels variable in length, at anthesis $6-25(-30) \mathrm{mm}$. long; corolla tube 13-24 mm. long, glabrous without, the limb $15-28 \mathrm{~mm}$. in diameter at anthesis, the lobes

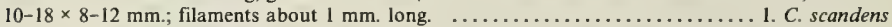
Leaf blades elliptic-ovate to suborbicular, usually $9-19 \times 6-14.5 \mathrm{~cm}, 1.1-1.7$ times longer than broad, openly cordate to broadly obtuse at base, the secondary nerves $5-9$ pairs; petioles $1.5-5 \mathrm{~cm}$. long; vegetative parts glabrous or with patches of evanescent indument on leaves or copiously pilose; inflorescences about as broad as long, up to $15 \times 13 \mathrm{~cm}$. (including flowers), with $10-30(-70)$ flowers; pedicels at anthesis 2.5-6 mm. long; corolla limb $20-37 \mathrm{~mm}$. in diameter at anthesis; filaments $1.5-2 \mathrm{~mm}$. long.

Young branchlets glabrous; petioles glabrous to spreading-pilose with pale hairs to $0.5 \mathrm{~mm}$. long when young especially distally, usually very soon glabrate; leaf blades glabrous but sometimes with a few evanescent or subpersistent hairs on proximal parts of costa and secondaries beneath; inflorescence peduncle, branches, and pedicels glabrous; corolla tube $10-27 \mathrm{~mm}$. long at anthesis, glabrous without (or with a few sporadic distal hairs), the limb 20-35 mm. in diameter at anthesis, the lobes $11-20 \times$

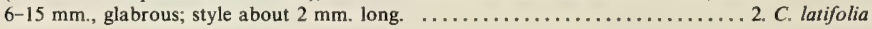


Young branchlets copiously spreading-pilose with pale hairs $0.3-0.7 \mathrm{~mm}$. long; petioles persistently pilose like branchlets; leaf blades copiously and persistently spreading-pilose beneath; inflorescence peduncle, branches, and pedicels copiously spreading-pilose with hairs $0.2-0.4 \mathrm{~mm}$. long; corolla tube 30-35 mm. long at anthesis, copiously pale-spreading-pilose with hairs $0.2-0.4 \mathrm{~mm}$. long, the limb 33-37 mm. in diameter at anthesis, the lobes $15-18 \times 13-22 \mathrm{~mm}$; style 2.5-3 mm. long.

3. C. macrantha

1. Carruthersia scandens (Seem.) Seem. Fl. Vit. 156.t. 30 (excl. figs. 6-10). 1866; Rolfe in J. Bot. 21: 201. 1883; Drake, Ill. Fl. Ins. Mar. Pac. 235. 1892; Turrill in J. Linn. Soc. Bot. 43: 33, p. p. 1915; A. C. Sm. in J. Arnold Arb. 36: 287. 1955; J. W. Parham, Pl. Fiji Isl. 183. fig. 66 (excl. 6-10). 1964, ed. 2. 260. fig. 77 (excl. 6-10). 1972.

FiguRES 34A-C, 35A.

Rejoua scandens Seem. in Bonplandia 10: 296. 1862, Viti, 439. 1862.

A liana with white latex (rarely indicated as a slender shrub to $1 \mathrm{~m}$. high in exposed situations), occurring in dense or secondary forest or in crest thickets at elevations between 100 and $1,000 \mathrm{~m}$. The corolla is white to yellowish, or more commonly the tube is pinkish or red toward base, tinged with these colors in throat, and the limb is white. Flowers have been obtained between October and April, but no fruiting collections have been noted.

TYPIFICATION: The species is based on Storck 901 (K HOLOTYPE; ISOTYPE at BM), collected in December, 1860, at Port Kinnaird, Ovalau. The fruit and seeds figured by Seemann (1866) belong to Melodinus vitiensis Rolfe; this mixture was noted by Rolfe (1883) when he described the Melodinus.

Distribution: Endemic to Fiji and thus far known from the two large islands and Ovalau; it has been most frequently obtained in southeastern Viti Levu.

LOCAL NAMES AND USE: The name wa rerenga was recorded by Storck, who noted that the leaves were used medicinally; the name vono was reported from Mathuata.

Available collections: VITI LEVU: MBA: Nandarivatu and vicinity, im Thurn 121, Tothill 393. SERUA: Hills between Waininggere and Waisese Creeks, between Ngaloa and Wainiyambia, Smith 9370 . 9530. NAITASIRI: Prince's Road (or Central road), DA 3805, Tothill 387, Mac Daniels 1155; Tholo-i-suva, DA $17,159,3287,3787,7578,9823,9855,11580,12065,12989$; Tamavua ridge, Vaughan 3167; vicinity of Nasinu, Greenwood 722C, DA 7336. OVALAU: Above Levuka reservoir, Gillespie 4523. VANUA LEVU: Mathuata: Summit ridge of Mt. Numbuiloa, east of Lambasa, Smith 6473. Thakaundrove: Mt. Mbatini, Smith 652, 661. Fiy without further locality, Horne, Joske.

2. Carruthersia latifolia Gillespie in Bishop Mus. Bull. 74: 18. fig. 22. 1930; A. C. Sm. in J. Arnold Arb. 36: 287. 1955; J. W. Parham, Pl. Fiji Isl. 183. 1964, ed. 2. 259. 1972.

Figures 34D, 35B-D, 37A \& B.

Echites scabra sensu Seem. in Bonplandia 9:257. 1861, Viti, 439. 1862; A. Gray in Proc. Amer. Acad. Arts 5: 333. 1862; non Labill.

Carruthersia scandens sensu Turrill in J. Linn. Soc. Bot. 43: 33, p. p. 1915; non Seem.

An often high-climbing liana with abundant white latex, occurring in dense or thin forest or on its edges from near sea level to about $900 \mathrm{~m}$. The flowers (noted by different collectors as fragrant or odorless) have white corollas, of which the tube is often pink-tinged proximally or yellowish. Flowers have been collected between October and April, fruits only in April and July. Of the three indigenous Fijian species of Carruthersia, only C. latifolia seems to have been collected in fruit (Smith 1522, Parks 20678). This highly distinctive fruit (FIGURE 35C \& D) is probably characteristic of the genus and has been seldom if ever described: Mature mericarps widely spreading and directly opposed, coriaceous, terete, gradually narrowed distally to a slender, blunt tip, $15-20 \mathrm{~cm}$. long, $7-11 \mathrm{~mm}$. broad proximally, at first soft-pilose with hairs $0.3-0.5 \mathrm{~mm}$. long, at length glabrate; seeds numerous, about $15 \mathrm{~mm}$. long and $2-3 \mathrm{~mm}$. broad, gradually narrowed to an obtuse base, distally narrowed and elongated into an abruptly flaring apex subtending the conspicuous coma, this composed of numerous silky hairs 25-30 mm. long. 
TyPIFICATION: The type is Gillespie 4656 (BISH HOLOTYPE; ISOTYPES at BISH (3), K, Us), collected Feb. 22, 1928, on edge of woods above coconut plantations east of Wairiki, Taveuni.

Distribution: Endemic to Fiji and now known from five of the high islands.

LOCAL NAME: Rumbarumba (recorded from Mbua).

AVailable collections: VITI LEVU: MBA: Vicinity of Nandarivatu, im Thurn 114, Parks 20678; Nandala, south of Nandarivatu, O. \& I. Degener 32021. NANDRONGA \& NAVOSA: Singatoka River, Greenwood 835. Serua: Hills between Navua River and Wainiyavu Creek, near Namuamua, Smith 8973. Namosi: Nakavika, DA 11626. NAITASIRI: Near Korosuli, Wainimala River, Horne 967. REWA: Near Wainisasa, Horne 89; vicinity of Suva, Yeoward 68. OVALAU: Graeffe 1587. VANUA LEVU: MBUA: Upper Ndama River Valley, Smith 1697; southern portion of Seatovo Range, Smith 1522; Mbua without further locality, $R$. L. Holmes (K). Mathuata: Southern base of Mathuata Range, north of Natua, Smith 6797; mountains along Mathuata coast, Greenwood 639. Thakaundrove: Nasuvasuva, hills south of Nakula Valley, Smith 356. RAMBI: Horne 460. TAVEUNI: Western slope between Somosomo and Wairiki, Smith 844 . FIJI without further locality, Seemann 315 , Joske.

Carruthersia latifolia is amply distinct from $C$. scandens in its more robust habit, leaf blade shape, and long petioles $(1.5-5 \mathrm{~cm}$. long); the sparse, sporadic vegetative indument (described by Gillespie) is suggestive of the uniform and persistent indument of the following species. Both $C$. latifolia and $C$. macrantha have a broad and many-flowered inflorescence in comparison with that of $C$. scandens.

3. Carruthersia macrantha A. C. Sm., sp. nov. ${ }^{1}$

Figures $36,37 \mathrm{C} \& \mathrm{D}$.

A robust liana with abundant, white, sticky latex, apparently rare in perhaps secondary forest at an elevation of about $200 \mathrm{~m}$. The flowers, collected in November, are said to be white and fragrant.

TyPIFICATION: The type is $D A 11029$ (BISH HOLOTYPE; ISOTYPES at MASS, SUVA), collected by $M . K$. Ledua on Nov. 13, 1957, in the vicinity of Ndakuivuna. east of Wainimbuka River, Ra Province, Viti Levu.

Distribution: Endemic to Fiji and thus far known only from the type collection.

Carruthersia macrantha A. C. Sm., sp. nov.

Frutex scandens latice albo copioso, ramulis junioribus teretibus in sicco subtiliter striatis $2.5-4 \mathrm{~mm}$. diametro copiose pilosis (pilis pallidis $0.3-0.7 \mathrm{~mm}$. longis); petiolis crassis (2-3 mm. diametro) $2.5-3 \mathrm{~cm}$. longis supra vadose canaliculatis ut ramulis pilosis; foliorum laminis coriaceis late elliptico-ovatis, 10-15 $\mathrm{cm}$. longis, $8.5-10 \mathrm{~cm}$. latis (1.2-1.5-plo longioribus quam latis), basi aperte et vadose cordatis, apice rotundatis vel abrupte et obtuse cuspidatis, margine integris in sicco anguste recurvato-undulatis, supra glabris, subtus pilis $0.5-0.8 \mathrm{~mm}$. longis copiose et persistenter indutis, nervis secundariis utrinsecus $6-8$ patentibus subcurvatis ut costa in sicco supra sulcatis subtus prominentibus, rete venularum copioso supra haud impresso subtus prominulo vel subplano; inflorescentia cymoso-paniculiformi pauciramosa ad $9 \mathrm{~cm}$. longa et lata 10-20-flora, pedunculo complanato crasso $(3-5 \mathrm{~mm}$. lato) sub anthesi $5-6.5 \mathrm{~cm}$. longo, ramulis (ut pedunculo pedicellisque) pilis $0.2-0.4 \mathrm{~mm}$. longis indutis; pedicellis crassis $2.5-6 \mathrm{~mm}$. longis, bracteolis 1 vel 2 deltoideis subacutis ciliolatis ad $1 \mathrm{~mm}$. longis latisque; calycis lobis deltoideis $1.5-2 \mathrm{~mm}$. longis latisque obtusis ciliolatis extus parce pilosis; corollae tubo gracili (1-1.8 mm. diametro supra stamina) sub anthesi 30-35 mm. longo utrinque pilis $0.2-0.4 \mathrm{~mm}$. longis pallidis piloso, limbo sub anthesi $33-37 \mathrm{~mm}$. diametro, lobis late et oblique obdeltoideis $15-18 \mathrm{~mm}$. longis et apice inaequilateraliter truncato $13-22 \mathrm{~mm}$. latis glabris vel basim versus utrinque parce pilosis; filamentis filiformi-ligulatis ad $1.5 \mathrm{~mm}$. longis subglabratis supra corollae tubi basim $3 \mathrm{~mm}$. insertis, antheris oblongo-lanceolatis $2-2.5 \mathrm{~mm}$. longis et $0.3-0.5 \mathrm{~mm}$. latis apice mucronulatis basi inconspicue sagittatis; carpellis parce pilosis, stylo gracili tereti $2.5-3 \mathrm{~mm}$. longo basi parce piloso, styli capitulo anguste clavato ad $2 \mathrm{~mm}$. longo et $0.5 \mathrm{~mm}$. diametro apice attenuato. HoLoTYPE: FIJI: VITI LEVU: RA: DA 11029 (BISH).

FigurE 34. A-C, Carruthersia scandens; A, distal portion of branchlet, with foliage and inflorescences, $\times$ $1 / 2$; B, flower bud near anthesis, $\times 2$; C, opened lower part of corolla tube showing gynoccium and 3 stamens, $\times 16 . \mathrm{D}$, Carruthersia latifolia; distal portion of branchlet, with foliage and inflorescences, $\times 1 / 2 . \mathrm{A}$ from DA 11580, B \& C from MacDaniels 1155, D from Smith 844. 

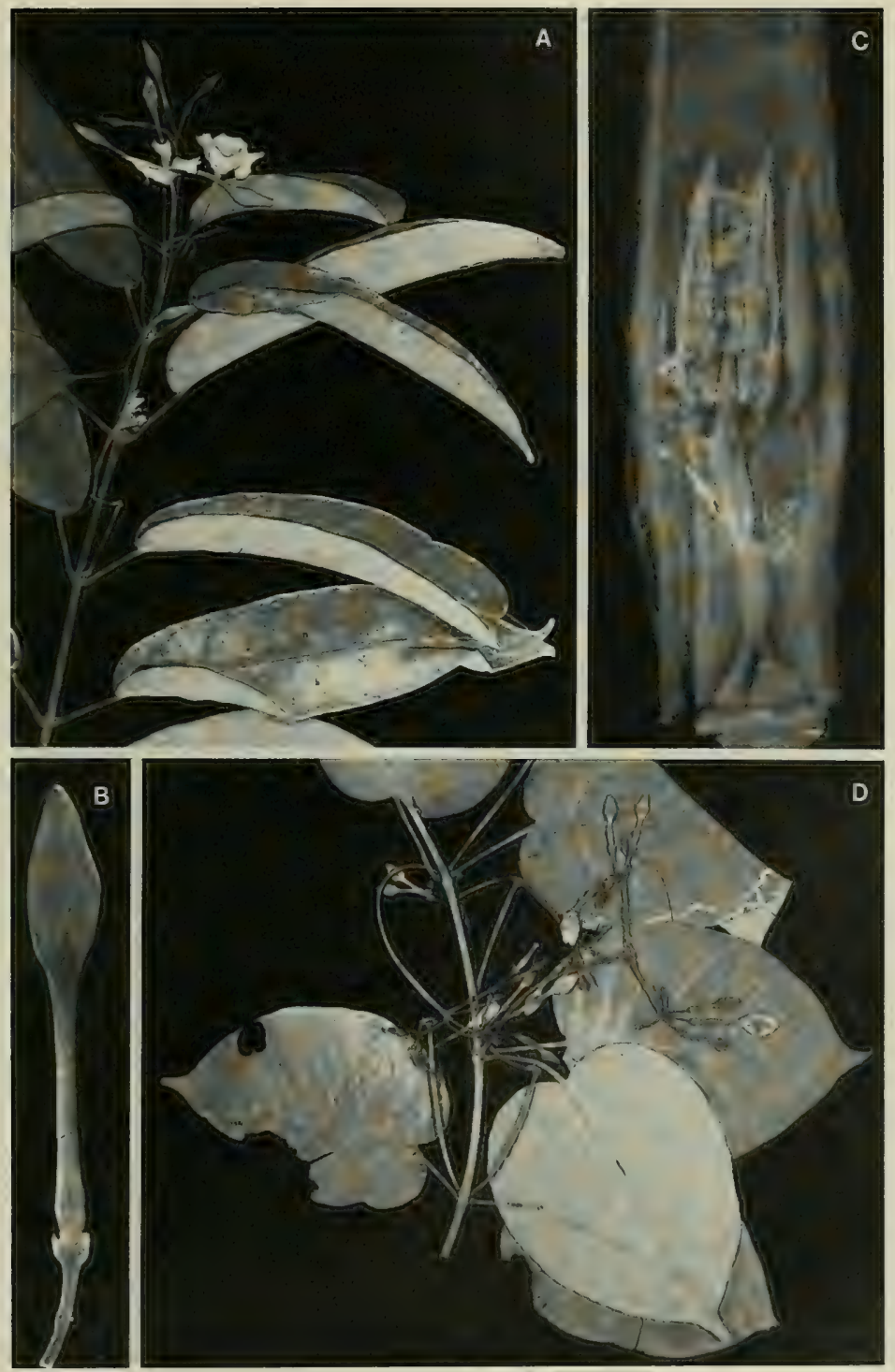


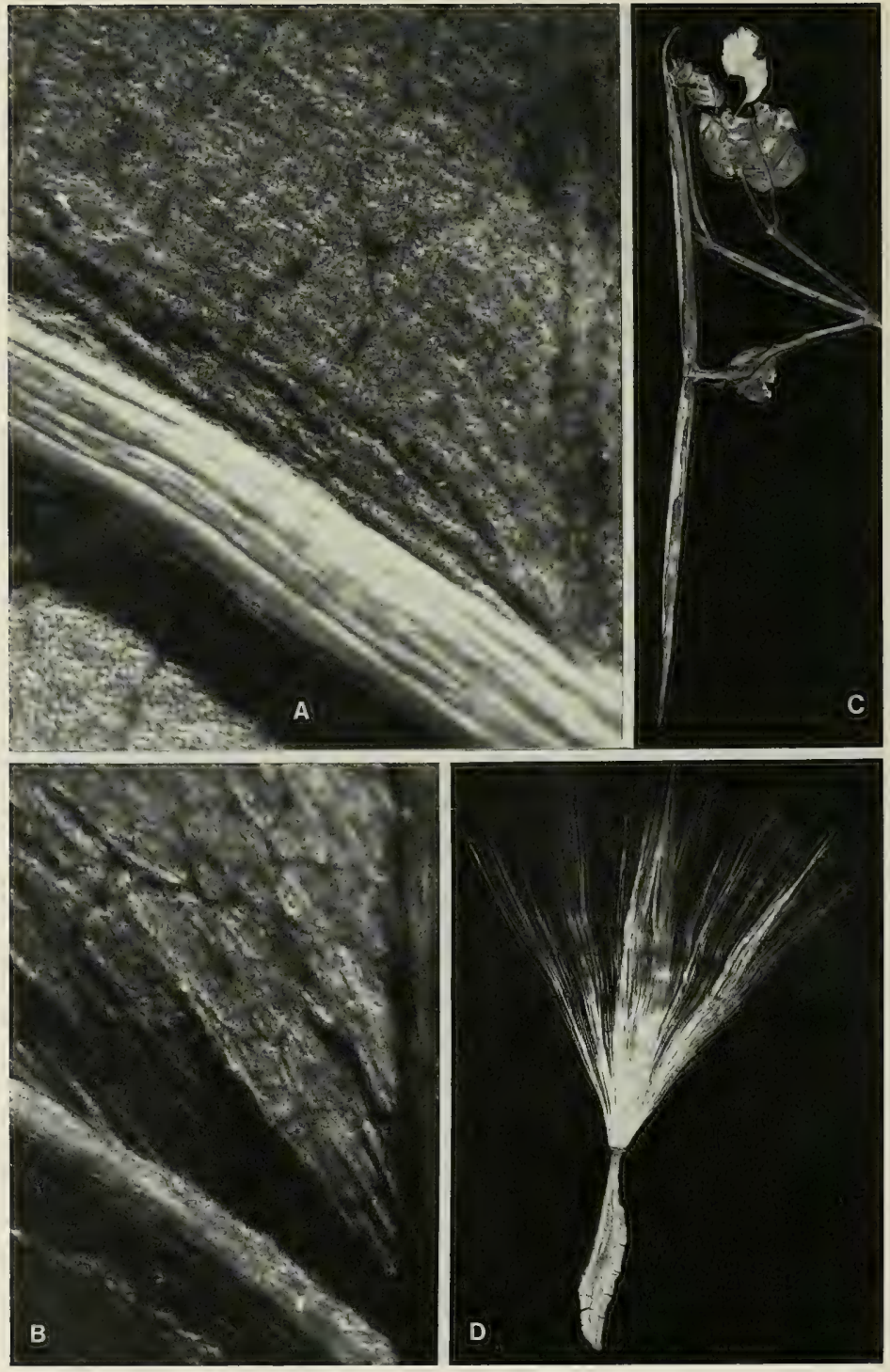



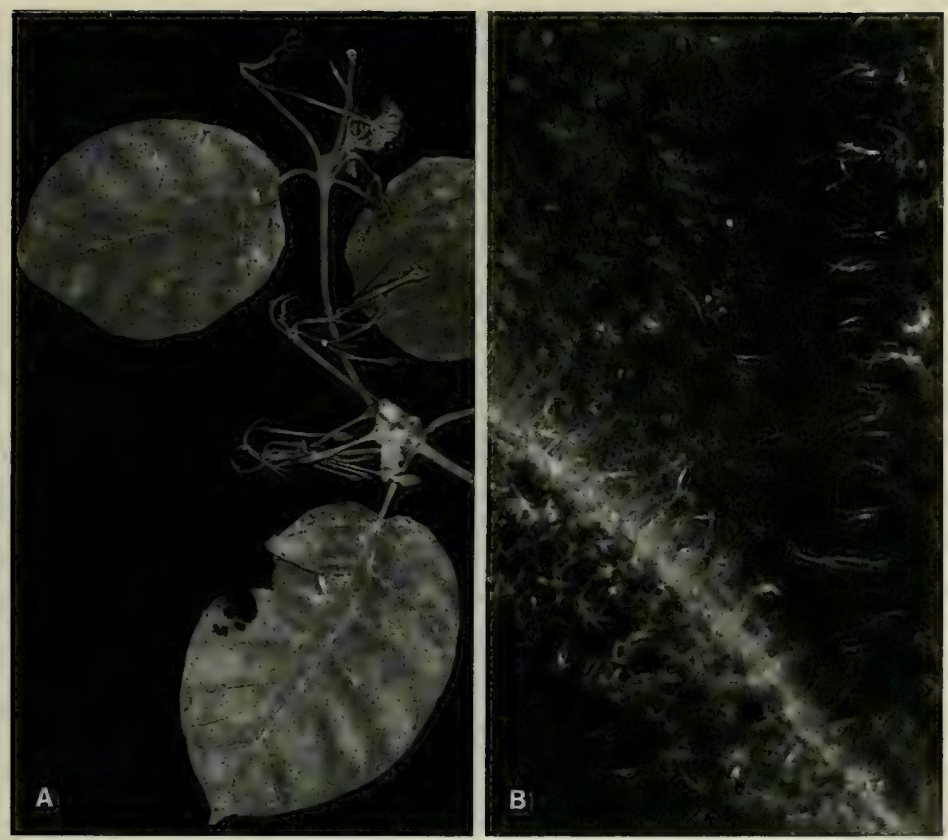

Figure 36. Carruthersia macrantha, from DA 11029; A, distal portion of branchlet, with foliage and inflorescences, $\times 1 / 3 ; \mathrm{B}$, indument of lower surface of leaf blade at junction of costa (diagonal in photo) and a secondary nerve, $\times 20$.

The new species is related to Carruthersia latifolia Gillespie, from which it is readily distinguished by the copious indument of its young branchlets, leaves, inflorescence branches, pedicels, and corolla tube. The indument occasionally noted on individuals of $C$. latifolia is of the same type but is sporadic in occurrence and very sparse, usually quite lacking. The corollas of $C$. macrantha are notably larger than those of $C$. latifolia, in which the corolla tube is $10-27 \mathrm{~mm}$. long, variable in different individuals but appreciably short in contrast to that of the new species $(30-35 \mathrm{~mm}$. long). In characters of indument $C$. macrantha suggests the Solomon Island $C$. mollis Markgraf (in Gard. Bull. Singapore 22: 25. 1967), but that species has substantially smaller and more conspicuously acuminate leaf blades with shorter petioles, longer pedicels, and much smaller corollas (the tube $8-9 \mathrm{~mm}$. long, the limb $10-15 \mathrm{~mm}$. in diameter).

FIGURE 35. A, Carruthersia scandens; lower surface of leaf blade at junction of costa (diagonal in photo) and a secondary nerve, $\times 20$. B-D, Carruthersia latifolia; B, lower surface of leaf blade at junction of costa (diagonal in photo) and a secondary nerve, $\times 20 ; \mathrm{C}$, mature fruit, $\times 1 / 4 ; \mathrm{D}$, seed, $\times 2$. A from $D A 11580, \mathrm{~B}$ from Gillespie 4656, C \& D from Parks 20678. 

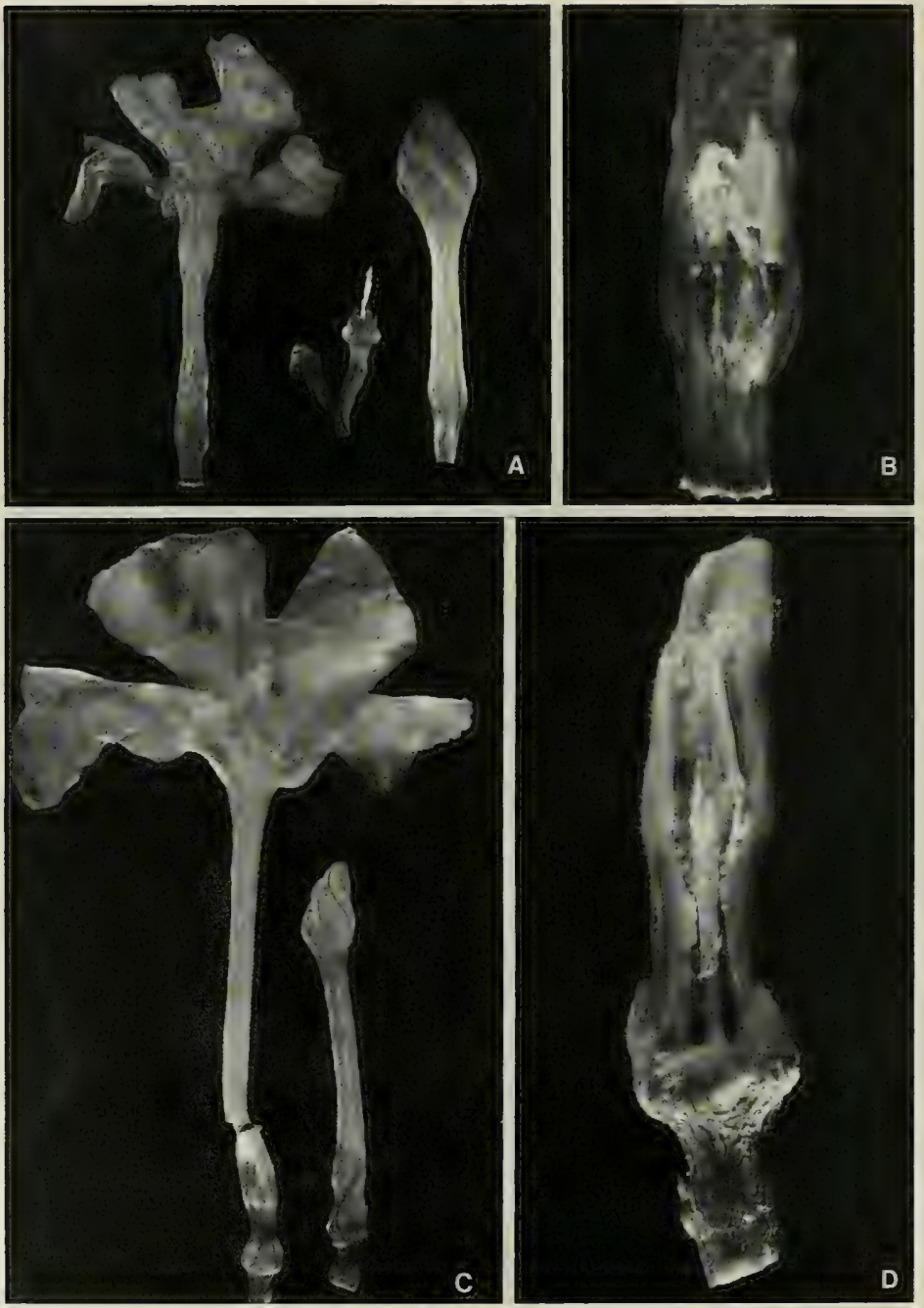

Figure 37. A \& B, Carruthersia latifolia, from Smith 356; A, mature corolla, flower bud, calyx from which corolla has fallen leaving style, and corolla in advanced bud, $\times 2$; B, opened lower part of corolla tube showing 4 stamens, $\times 8 . \mathrm{C} \& \mathrm{D}$, Carruthersia macrantha, from DA 11029; C, mature flower (corolla tube broken) and flower bud, $\times 2 ; \mathrm{D}$, pedicel and calyx ( 1 lobe removed) and opened lower part of corolla tube showing style, style head, and stamens, $\times 8$. 
7. Catharanthus G. Don, Gen. Hist. Dichlam. Pl. 4: 71, 95. 1837; Markgraf in Fl. Madagasc. Fam. 169. 139. 1976; Boit. in Fl. Nouv.-Caléd. et Dépend. 10: 207. 1981.

Lochnera Reichenb. Consp. Reg. Veg. 134, nom. nud. 1828; Reichenb. ex Endl. Gen. PI. 583. 1838.

Perennial herbs or subshrubs with herbaceous branches, with intra- and interpetiolar, stipiform, stipular glands; leaves opposite, the blades usually membranaceous; inflorescences pseudolateral, alternating left and right at adjacent nodes, usually 2-flowered; calyx deeply lobed, the lobes narrow, acute, without glands; corolla hypocrateriform, the tube long, pilose within, narrowed at throat, the lobes sinistrorsely contorted in bud, spreading at anthesis, obliquely ovate or obovate, shortacuminate; stamens inserted near corolla throat or slightly lower in tube swelling, the filaments short, the anthers free or connivent (but free from style head), oblong, shortly sagittate at base; disk composed of 2 linear-oblong scales alternate with carpels; ovary of 2 distinct carpels, these ovate-oblong, the ovules numerous, the style elongate, the style head short-cylindric, enlarged and pilose distally, with a reflexed flange of long hairs at base; fruit apocarpous, composed of 2 follicles, the mericarps cylindric, acuminate, finely furrowed, thin-walled, the seeds oblong to ellipsoid, truncate, black, with a ventral groove, ecomose.

TYPE SPECIES: The type species of Catharanthus is C. roseus (L.) G. Don (Vinca rosea L.) (Markgraf, 1976; Boiteau, 1981; not listed by ING, 1979). The same species is the type species of Lochnera, as L. rosea (L.) Reichenb. ex K. Schum.

Distribution: Paleotropical, mostly Madagascan, with eight species, one of which is widely cultivated and naturalized.

1. Catharanthus roseus (L.) G. Don, Gen. Hist. Dichlam. Pl. 4: 95. 1837; A. C. Sm. in Sargentia 1: 107. 1942; Yuncker in Bishop Mus. Bull. 220: 219. 1959; J. W. Parham in Dept. Agr. Fiji Bull. 35: 100. 1959, Pl. Fiji Isl. 183. 1964, ed. 2. 261. 1972; Sykes in New Zealand Dept. Sci. Indust. Res. Bull. 200: 44. 1970; Markgraf in Fl. Madagasc. Fam. 169. 152. 1976; Boit. in Fl. Nouv.-Caléd. et Dépend. 10: 208. 1981.

Vinca rosea L. Syst. Nat. ed. 10. 944. 1759.

Lochnera rosea Reichenb. ex K. Schum. in Engl. \& Prantl, Nat. Pflanzenfam. IV. 2: 145. fig. 57, A-D. 1895; Safford in Contr. U. S. Nat. Herb. 9: 310. 1905; Christophersen in Bishop Mus. Bull. $128: 180$. 1935; Yuncker in op. cit. 178: 97. 1943; Greenwood in Proc. Linn. Soc. 154: 100. 1943.

In Fiji Catharanthus roseus is commonly seen as a cultivated subligneous herb or low shrub to $1 \mathrm{~m}$. high, often found at low elevations escaped and naturalized in clearings, coconut plantations, and waste places, and along roadsides. The corolla varies from white to purple, commonly pink or rich pink, with a crimson throat. Flowers are most often noted between January and July.

TYPIFICATION: Linnaeus's citation was "Mill. fig. 186." Markgraf (1976) notes: Miller 1849 (вм LестотYPE); cf. Stearn in Taylor \& Farnsworth, The Catharanthus Alkaloids, 35. 1975.

Distribution: Endemic to Madagascar, but now cultivated and naturalized throughout the tropics. Thurston's Catalogue (1886) suggests that he may have made the introduction into Fiji.

LOCAL NAMES AND USE: Periwinkle, red periwinkle, or Madagascar periwinkle; an attractive garden plant. Markgraf (1976) notes two varieties in Madagascar, but only var. roseus seems to be in cultivation.

Available Collections: VITI LEVU: MBa: Lautoka, Greenwood 192; Ndreketi, Lautoka, DA 11397, 11398: Tumbenasolo, valley of Namosi Creek, Smith 4611. NANDronga \& Navosa: Thuvu, west of Singatoka, DA 11465. NAITASIRI: Plant Introduction and Quarantine Station, Nanduruloulou, DA 12155. MBENGGA: Rukua, DA 6073. KORO: Eastern slope of main ridge, Smith 1029. VANUA LEVU: ThakAundrove: Maravu, near Salt Lake, Degener \& Ordonez 14188. 
8. Plumeria L. Sp. Pl. 209. 1753; Woodson in Ann. Missouri Bot. Gard. 25: 202. 1938;

Pichon in Mém. Mus. Nat. Hist. Nat. 27: 207. 1948; Boit. in Fl. Nouv.-Caléd. et Dépend. 10: 209. 1981.

Erect trees, small or medium-sized, freely branching, the branches swollen and fistulose distally, with a spongy, suberized periderm marked by scars of fallen leaves, without stipules; leaves spiralled, clustered at ends of branches, persistent or caducous, the blades with well-spaced secondary nerves and often indistinct veinlets; inflorescences terminal or pseudolateral, pedunculate, broadly corymbose or fastigiatethyrsiform, the bracts small, scariose, caducous before anthesis; calyx deeply lobed, the lobes broad, glandular at tips, without glands at base within; corolla infundibular, the tube narrow, staminiferous near base, pilose within including throat, the throat not thickened, the lobes sinistrorsely contorted in bud, glabrous or pilose; stamens with minute filaments and slender anthers, the outer lobes of these exceeding inner lobes at base, the inner ones with a protuberance at base; disk lacking; ovary adherent to receptacle for most of its length, glabrous, the carpels free, with 40-506-seriate ovules, united by the short, fusiform style, the style head cylindric, without a flange, the stigmas conical or digitaliform; fruit apocarpous, follicular, the mericarps free, recurved, cylindric, acuminate, each with an accrescent, hardened placenta, the seeds numerous, glabrous, dorsiventrally flattened, imbricate, basally winged, ecomose, the hilum short-linear.

Lectoty Pe SPEcies: Plumeria rubra L. (vide Britton \& Wilson, Sci. Surv. Porto Rico 6: 87. 1925).

Distribution: Tropical America, especially in the West Indies, with seven or eight species. One variable species has been introduced into Fiji.

USEFUl TREATMENT OF GenUs: Woodson, R. E., JR. Studies in the Apocynaceae. VII. An evaluation of the genera Plumeria L. and Himatanthus Willd. Ann. Missouri Bot. Gard. 25: 189-224. 1938.

1. Plumeria rubra L. Sp. Pl. 209. 1753; Woodson in Ann. Missouri Bot. Gard. 25: 207. 1938; St. John \& A. C. Sm. in Pacific Sci. 25: 338. 1971; M. Grant, Fosberg, \& H. M. Sm. in Smithsonian Contr. Bot. 17: 40. 1974; Boit. in Fl. Nouv.-Caléd. et Dépend. 10: 210. 1981; MacKee, Pl. Intro. Cult. Nouv.-Caléd. 17. 1985.

As seen in Fiji, Plumeria rubra is extensively cultivated in towns and villages and is naturalized along nearby streams; it is a freely branched tree $5-8 \mathrm{~m}$. high, with abundant white latex and fragrant flowers which are seen throughout the year.

Distribution: Tropical America from Mexico to Panama (Woodson, 1938), but early cultivated and naturalized in the West Indies and northern South America, now extensively cultivated and frequently naturalized in most tropical and subtropical areas. The references listed above are to $P$. rubra in the broad sense, as taken by Woodson (1938) to include more than one of his forms.

LOCAL NAMES AND USES: Mbua ni vavalangi; frangipani; plumeria. A common garden ornamental with flowers that are used for adornment.

Because of the paucity of collections in herbaria, it is not feasible to document the cultivation in the Fijian Region of more than one variable species of Plumeria, which, following Grant, Fosberg, and Smith (1974) in Polynesia, may be assigned to P. rubra. Those authors indicate that $P$. alba L. has been frequently but erroneously reported from Polynesia. However, $P$. alba is said to be in cultivation in New Caledonia (Boiteau, 1981; MacKee, 1985), and a third species, $P$. obtusa L., is listed from Micronesia by Fosberg, Sachet, and R. Oliver (in Micronesica 15: 217. 1979). Either or both of the latter species may indeed occur in Fiji; Woodson's (1938) key and discussion should permit their recognition. Of the four color forms recognized by Woodson, at least the two following are commonly grown in Fiji. 
1a. Plumeria rubra L. f. rubra; Sykes in New Zealand Dept. Sci. Indust. Res. Bull. 200: 46. 1970.

Plumeria rubra f. typica Woodson in Ann. Missouri Bot. Gard. 25: 211, nom. inadmis. 1938.

Plumeria rubra sensu Yuncker in Bishop Mus. Bull. 178:96. 1943; J. W. Parham in Agr. J. Dept. Agr. Fiji

19: 96. 1948; Yuncker in Bishop Mus. Bull. 220:218. 1959; J. W. Parham, Pl. Fiji Isl. 185. 1964, ed. 2.

262. 1972.

The form with the corolla predominantly rose-colored of variable intensity, usually with a yellow center; commonly seen in Fiji but no herbarium specimens noted.

TyPIFICATION: Linnaeus gave several prior references and noted: "Habitat in Jamaica, Surinamo."

1b. Plumeria rubra f. acutifolia (Poir.) Woodson in Ann. Missouri Bot. Gard. 25:211.

1938; Sykes in New Zealand Dept. Sci. Indust. Res. Bull. 200: 46. 1970.

Plumeria acuminata Ait. Hort. Kew. 2: 70. 1789; Merr. in Trans. Amer. Philos. Soc. n. s. 24: 311. 1935; Christophersen in Bishop Mus. Bull. 128: 186. 1935; Yuncker in op. cit. 178: 96. 1943, in op. cit. 184:58. 1945, in op. cit. 220: 218. 1959; B. E. V. Parham in New Zealand Dept. Sci. Indust. Res. Inform. Ser. 85: 103. 1972.

Plumeria obtusa Lour. Fl. Cochinch. 117. 1790; non L. (1753).

Plumeria acutifolia Poir. in Lam. Encycl. Méth. Bot. Suppl. 2:667. 1812; J. W. Parham in Agr. J. Dept. Agr. Fiji 19: 96. 1948, in op. cit. 29: 33. 1959, Pl. Fiji Isl. 185. 1964, ed. 2. 262. 1972.

The form with the corolla white or occasionally flushed with rose without, usually with a yellow center; widely cultivated and sometimes naturalized in Fiji.

TyPification AND NOMENCLATURE: Plumeria acuminata was based on a cultivated plant introduced by Banks from the East Indies; $P$. obtusa Lour. (non L.) on material from Cochinchina and China; $P$. acutifolia was a new name to replace $P$. obtusa Lour. Woodson listed his new combination with the parenthetical author "Ait.", apparently intending to base it on P. acuminata Ait., but since he used the epithet acutifolia, presumably inadvertently, it would seem that Poiret's binomial of 1812 must be taken as the basionym of the form.

AVAILABLE COLleCtION: VITI LEVU: MBA: Vicinity of Tumbenasolo (naturalized near village), valley of Namosi Creek, Smirh 4612.

At least this form of Plumeria rubra may have been first introduced into Fiji in the 1880 's by J. B. Thurston, who listed it in his 1886 Catalogue as Plumeria acutifolia.

9. CasCabela Raf. Sylva Tellur. 162. 1838; Lippold in Repert. Sp. Nov. 91: 52. 1980.

Thevetia sensu Adanson, Fam. Pl. 2: 171. 1763; Pichon in Notul. Syst. (Paris) 13:226, p. p. 1948; et auct.; non L. (1758) sensu str.

Small trees or shrubs, freely branched; leaves spiralled, the blades linear, thincoriaceous, the secondary nerves inconspicuous; inflorescences terminal, cymose, the flowers showy; calyx deeply lobed, the lobes persistent, each with 7-12 glandular scales at base within; corolla infundibuliform, the tube narrow at base, campanulately broadened in the lower quarter or fifth, pilose within, with small, infrastaminal, pilose scales, the lobes sinistrorsely contorted in bud; stamens inserted at apex of narrow portion of corolla tube, the filaments very short, lobulate, stiff-pilose, the anthers concealed by corolla scales, not connivent, ovoid to ellipsoid, short-acuminate or subacute, appressed to stigma but free from it; disk cupular or pulvinate, entirely or partly adnate to ovary; ovary bicarpellate, the carpels concrescent proximally, glabrous, the ovules 2-6, biseriate, the placenta intruded, the style head obconical, with many isomorphic, spreading lobes, surmounted by 2 thick, apically separated stigmatic appendages; fruit with mericarps united into an obdeltoid or pyriform drupe, laterally compressed, with a perceptible median suture, not winged, the exocarp fleshy, the mesocarp stony, the endocarps free, thick, corky, the seeds slightly compressed, narrowly winged, ecomose, the hilum punctiform. 
Type SPECIES: Cascabela peruviana (Pers.) Raf., nom. illeg. (Cerbera peruviana Pers.) = Cascabela thevetia $($ L.) Lippold.

Distribution: Tropical America from Mexico and the West Indies to Paraguay, with seven or eight species, one of which is widely cultivated and naturalized throughout tropical and subtropical areas.

Useful treatment of Genus: Lippold, H. Die Gattungen Thevetia L. und Cascabela Rafin. (Apocynaceae). Repert. Sp. Nov. 91: 45-55. 1980.

It has long been recognized that Thevetia L. comprises two groups (e. g. by K. Schumann in Engl. \& Prantl, Nat. Pflanzenfam. IV. 2: 159. 1895, as sect. Ahouai and sect. Euthevetia). It seems reasonable to recognize these groups at the generic level as proposed by Rusby and Woodson (in Ann. Missouri Bot. Gard. 24: 11. 1937) and by Lippold (1980). Since Thevetia ahouai (L.) DC. is the conserved type species of Thevetia (ICBN), that genus (syn.: Plumeriopsis Rusby \& Woodson) if strictly limited is monotypic; for the remaining species the generic name Cascabela Raf. is available. Differences between Thevetia and Cascabela are well summarized and illustrated by Lippold (1980, pp. 49, 50) and may be thus expressed:

Corolla white, the tube inflated in the upper third or quarter; filaments glabrous, slender; anthers oblong, the locules curved and separated at base; disk small, many-lobed; style head with 10 irregular, pendent lobes, scarcely projecting distally into stigmatic lobes; fruits with mericarps united, berrylike, obversely pyriform, the exocarp and endocarp thin, the mesocarp fleshy. ............... Thevetia

Corolla yellow to red, the tube campanulately broadened in the lower quarter or fifth; filaments pilose, broadened, lobulate; anthers ovoid to ellipsoid; disk cupular or pulvinate; style head with isomorphic, spreading lobes, the stigmatic lobes appressed into a conical protuberance; fruits with mericarps united into an obdeltoid to pyriform drupe but with a perceptible median suture, the exocarp fleshy, the

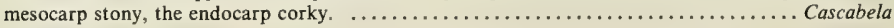

1. Cascabela thevetia (L.) Lippold in Repert. Sp. Nov. 91: 52. 1980.

Cerbera thevetia L. Sp. Pl. 209. 1753.

Cerbera peruviana Pers. Syn. Pl. 1: 267. 1805.

Cascabela peruviana Raf. Sylva Tellur. 162. 1838.

Thevetia nereifolia Juss. ex Steudel, Nomencl. Bot. ed. 2. 680. 1841; K. Schum. in Engl. \& Prantl, Nat. Pflanzenfam. IV. 2: 159. fig. 57, T-X. 1895.

Thevetia peruviana K. Schum. in Engl. \& Prantl, Nat. Pflanzenfam. IV. 2: 159. 1895; Merr. in Philipp. J. Sci. Bot. 9: 130. 1914; Christophersen in Bishop Mus. Bull. 128: 186. 1935; Yuncker in op. cit. $178: 97$. 1943, in op. cit. 220: 222. 1959; J. W. Parham in Agr. J. Dept. Agr. Fiji 29: 33. 1959, Pl. Fiji Isl. 185. 1964, ed. 2. 262. 1972; Sykes in New Zealand Dept. Sci. Indust. Res. Bull. 200: 46. 1970; M. Gtant, Fosberg, \& H. M. Sm. in Smithsonian Contr. Bot. 17: 52. 1974; Boit. in Fl. Nouv.-Caléd. et Dépend. 10: 211. 1981; MacKee, Pl. Intro. Cult. Nouv.-Caléd. 17. 1985.

As seen in Fiji, Cascabela thevetia is widely cultivated in villages and gardens near sea level, also being freely naturalized in pastures, under coconuts, etc., as a shrub or tree 2-4 m. high with copious white latex. The corolla is bright yellow, the tube being greenish proximally. It seems to flower most profusely between November and March.

TyPification: Linnaeus in 1753 gave references to works of Plumier and Plukenet, the former being considered to provide the better lectotype by Lippold (1980). The other synonyms listed above are essentially based on Linnaeus's concept.

Distribution: Tropical America including the West Indies, now widely cultivated and naturalized elsewhere.

LOCAL NAME AND USE: The yellow oleander is a frequent garden and street tree in Fiji; it was probably introduced by J. B. Thurston, being listed in his 1886 Catalogue.

Available collections: VITI LEVU: Nandronga \& Navosa: Tonuve, Ruwailevu Tikina, $H$. B. $R$. Parham 166. Serua: Ngaloa, Smith 9617. VANUA LEVU: Thakaundrove: Along Hibiscus Highway leading from Savusavu, Bierhorst F184. KAMBARA: Tokalau, on limestone, Smith 1303. 
10. Cerbera L. Sp. Pl. 208. 1753; Seem. Fl. Vit. 157. 1866; Pichon in Notul. Syst. (Paris) 13: 221. 1948; Markgraf in Fl. Madagasc. Fam. 169. 156. 1976; Lippold in Repert. Sp. Nov. 91: 51. 1980; Boit. in Fl. Nouv.-Caléd. et Dépend. 10: 212 . 1981.

Trees, often with rounded crowns; leaves spirally arranged, clustered at apices of branchlets, the petioles long, the blades coriaceous, glabrous, the secondary nerves spaced, widespread, connected by a marginal nerve, the veinlet reticulation usually obvious; inflorescences terminal, large, pedunculate, laxly cymose, glabrous, the peduncles and branchlets thick, the bracts large, caducous, the flowers large; calyx deeply divided, the lobes nearly free, large, attenuate or narrowed at base, without glands, caducous; corolla hypocrateriform, glabrous without, the tube narrowly cylindric, inflated below the narrow throat, distally infundibular or campanulate, with 5 suprastaminal scales projecting nearly to center of tube, the lobes sinistrorsely contorted in bud, spreading, obovate, obtuse or emarginate; stamens inserted in swollen part of tube, attached to 5 thickened projections in corolla tube, the filaments short, slender, glabrous, the anthers obliquely ascending, lanceolate, contiguous to style head by means of filiform apical appendages; disk lacking; ovary bicarpellate, each carpel usually with 4 biseriate ovules, the style long, the style head composed of 2 annular swellings, surmounted by 2 apical, conical, obtuse, thick, appressed stigmatic appendages, the ensemble of corolla, stamens, style, and style head caducous soon after anthesis; fruits apocarpous, the mericarps (often only 1 developing) large, drupaceous, the exocarp fleshy, the mesocarp reticulate-spongy, with numerous fibers, these independent of endocarp (contrary to those of Neisosperma), the endocarp lignified, smooth or rugose-striate without, with an apical wing, the seeds large, 1 per locule, moderately compressed, elliptic or oblong, not or narrowly winged, ecomose, the hilum large.

LECTOTYPE SPECIES: Although all three of the original species of Linnaeus have at one or another time been chosen as the lectotype species (ING, 1979), they are now taken to represent three different genera. Recent authors seem unanimously to have listed Cerbera manghas L. as the type (i. e. lectotype) species (cf. Pichon, Markgraf, Lippold, and Boiteau, as cited above).

Distribution: Madagascar, Indian Ocean islands, and eastern Asia throughout Malesia and into the Pacific to the Tuamotus (Pitcairn Island), with about eight species. In Fiji one widespread species is indigenous.

1. Cerbera manghas L. Sp. Pl. 208. 1753; Forst. f. Fl. Ins. Austr. Prodr. 19. 1786; Gaertn. Fruct. Sem. Pl. 2: 192. $t$. 123, 124, fig. $f$ - $h$. 1791; Merr. Interpret. Rumph. Herb. Amb. 432. 1917; Guillaumin in J. Arnold Arb. 13: 18. 1932; Christophersen in Bishop Mus. Bull. 128: 185. 1935, in op. cit. 154: 37. 1938; Yuncker in op. cit. 184: 58. 1945; J. W. Parham, Pl. Fiji Isl. ed. 2. 261. 1972; M. Grant, Fosberg, \& H. M. Sm. in Smithsonian Contr. Bot. 17: 51. 1974; Boit. in Fl. Nouv.-Caléd. et Dépend. 10: 214. 1981; Fosberg \& Sachet in D. J. Carr, Sydney Parkinson, 186. pl. 177.1983.

Figures 38, 39, 126 (lower).

Cerbera lactaria Buch.-Ham. in Trans. Linn. Soc. 13: 509. 1822, ex A. DC. in DC. Prodr. 8: 353. 1844; A. Gray in Proc. Amer. Acad. Arts 5: 333. 1862, in Bonplandia 10: 37. 1862; Seem. Viti, 439. 1862, Fl. Vit. 158. 1866; Drake, IIl. Fl. Ins. Mar. Pac. 233. 1892.

Cerbera odollam sensu Seem. in Bonplandia 9: 257, as C. odallam. 1861; Gibbs in J. Linn. Soc. Bot. 39: 157. 1909; J. W. Parham in Agr. J. Dept. Agr. Fiji 29: 32, as C. adollam. 1959, Pl. Fiji Isi. 183. $1964 ;$ B. E. V. Parham in New Zealand Dept. Sci. Indust. Res. Inform. Ser. 85: 65. 1972; non Gaertn.

As seen in Fiji, Cerbera manghas is a tree (or shrub) 1-20 m. high, with copious white latex, often locally abundant in beach thickets and inland in dense or open forest or among reeds in open country at elevations from near sea level to about $1,000 \mathrm{~m}$. The leaves have petioles $1-3.5(-5) \mathrm{cm}$. long and oblong- to obovate-lanceolate blades $8-23$ 

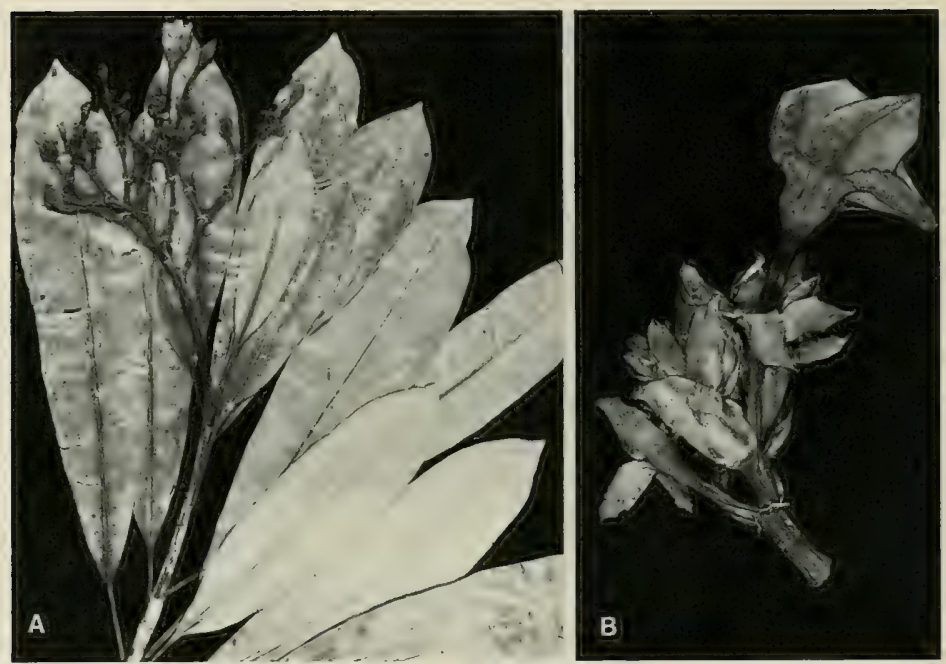

FIgURE 38. Cerbera manghas; A, distal portion of branchlet, with foliage and inflorescence, $\times 1 / 3 ; \mathbf{B}$, portion of inflorescence, showing bracts, calyx lobes, and a corolla, $\times 1$. A from $S$ mith 8897 , B from $S$ mith 68 .

$\times 2.5-7 \mathrm{~cm}$. that are obtuse to acute or short-acuminate at apex. The inflorescence (often to $15-20 \mathrm{~cm}$. long and broad) may have a stout peduncle to $10 \mathrm{~cm}$. long and conspicuous but soon caducous bracts. The fragrant flowers have the corollas white, more or less conspicuously pink to red at throat, and often with the limb deeply pink-tinged without. The corolla tube is (25-) $30-40 \mathrm{~mm}$. long, distally inflated to an infundibular portion sometimes to $10 \mathrm{~mm}$. long and $7 \mathrm{~mm}$. in diameter, the limb spreading to a breadth of $25-35 \mathrm{~mm}$. The ellipsoid fruit, at first green but becoming bright red at maturity, attains a size of about $9 \times 6 \times 5 \mathrm{~cm}$. Flowers and fruits occur throughout the year.

LECTOTYPIFICATION AND NOMENCLATURE: Merrill (1917) noted that Linneaus described Cerbera manghas from a Javan specimen of Osbeck. This opinion is seconded by Boiteau (1981), who cites the later description by Osbeck (Dagb. Ostind. Resa, 91. 1757); the actual lectotype may be taken as Linnaeus's description, as suggested by Fosberg (in Boiteau, 1981). Hamilton based C. lactaria on references to Gaertner (as cited above as $C$. manghas) and Rumphius; his name may be taken as a direct synonym.

Distribution: Malesia eastward to the Tuamotus as far as Pitcairn, widespread and often abundant, and also in the Seychelles and Comores Islands (Markgraf, 1976). About 60 Fijian collections from eight islands have been examined, but the species may be anticipated on most islands.

LOCAL NAMES AND USES: The usual names in Fiji are vasa and rewa, but also noted are vasavasa, vasa ni veikau, savisavirewa, and leva. The dried leaves are sometimes 

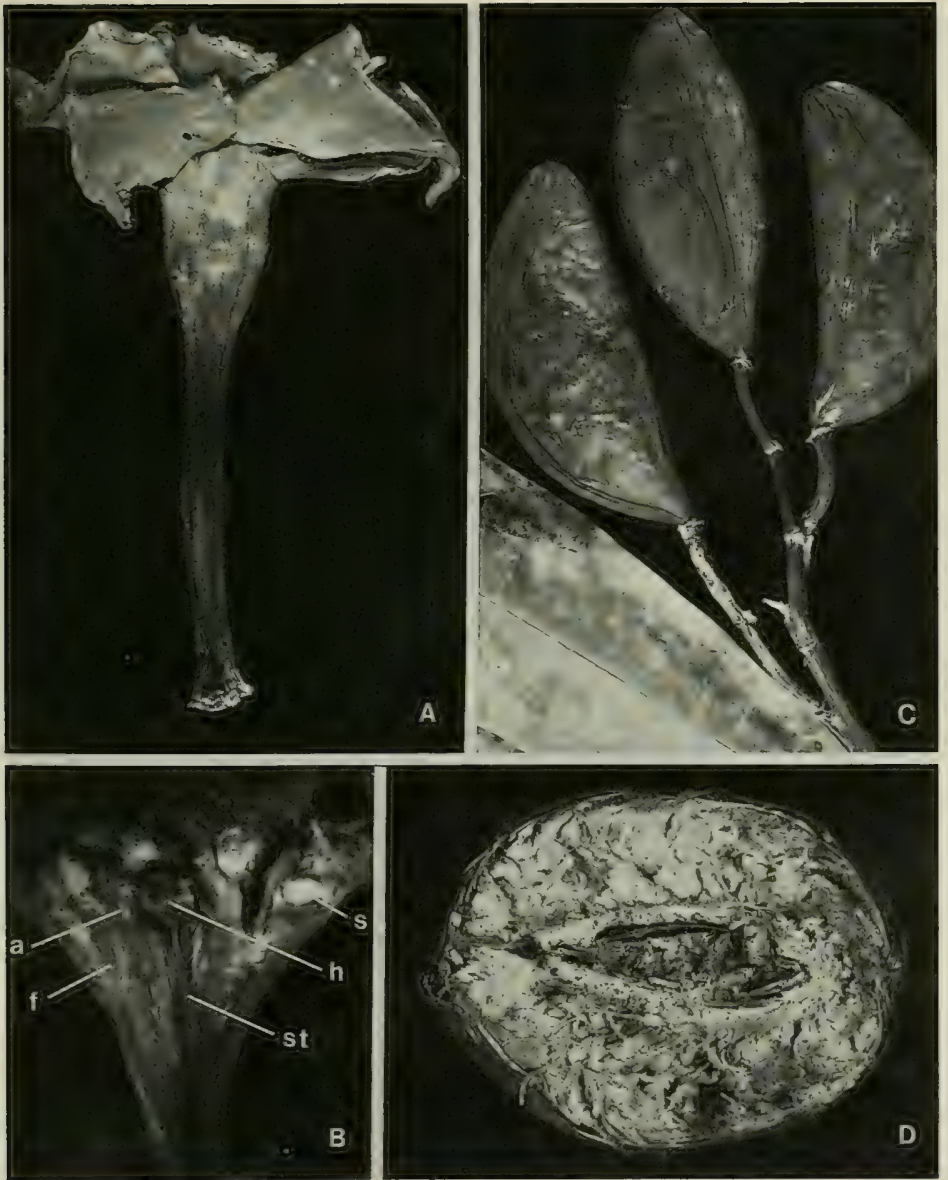

FIGURE 39. Cerbera manghas; $\mathrm{A}$, mature corolla, $\times 2$; $\mathrm{B}$, corolla throat spread open, showing style (st), style head (h), filaments (f), anthers (a), and suprastaminal scales (s), $\times 4$; C, young fruits, each with a single developing mericarp, × 1; D, longitudinal section of mature fruit, × 1. A from Smith 1581. B from Gillespie 2267. C from Smith 9201, D from Whistler 2835 (Tutuila, Samoa).

applied to skin irritations and are also used as part of an internal remedy for eye pains. The latex is said to be used in various medications, although it contains a violent poison and indeed can cause death. 
RePresentative Collections: VITI LEVU: MBa: North of Lomolomo, Degener \& Ordonez 13718; vicinity of Tumbenasolo, valley of Namosi Creek, Smith 4708; vicinity of Nandarivatu, Gillespie 3731; Mt. Tomanivi, O. \& I. Degener 32077. Serua: Korovisilou, DF 498 (Damanu 137); hills north of Ngaloa, in drainage of Waininggere Creek, Smith 9201 . NAmosı: Hills east of Wainikoroiluva River, near Namuamua, Smith 8897. RA: Rakiraki, DA 7928. NAITASIRI; Suva Pumping Station, Degener \& Ordonez 13768; vicinity of Nasinu, Gillespie 3429. TAILEvU: Hills east of Wainimbuka River, vicinity of Ndakuivuna, Smith 7170; Raralevu, Weiner 106. RewA: Mt. Rama (Joske's Thumb), Vaughan 3292; trail between Lami and Mt. Korombamba, Gillespie 2267; Nukulau Island, Barclay. KANDAVU: Hills above Namalata and Ngaloa Bays, Smith 68; Naikorokoro, DF 436 (Damanu 100). OVALAU: Port Kinnaird, Seemann 309. NGAU: Shore of Herald Bay, near Sawaieke, Smith 7913. VANUA LEVU: MBUA: Southern portion of Seatovo Range, Smith 1581. Mathuata: Natindoyanga Creek, Korovuli River headwaters, DA 12943. THAKAUNDROVE: Track from Valeni to Mathuata, DA 15718. TAVEUNI: Vicinity of Waiyevo, Gillespie 4686. VANUA MBALAVU: Near Lomaloma, Garnock-Jones 998. LAKEMBA: Ridge east of Tumbou Valley, Garnock-Jones 835. FiJi without further locality, U. S. Expl. Exped.

Uncertainty has often been associated with the distinctions between Cerbera manghas and C. odollam Gaertn. (Fruct. Sem. Pl. 2: 193. $t$. 124, fig. i-m. 1791, based on Rheede, Hort. Ind. Malabar. 1: 71. t. 39. 1678) and their geographic ranges. Fosberg and Sachet (1985) indicate that the two taxa are easily distinguished in a living state by flower color; $C$. manghas has a white corolla with a red eye around the mouth of the corolla tube, whereas the corolla of $C$. odollam has a yellow eye. They also imply that both species occur in Tahiti, and, indeed, Seemann (Fl. Vit. 157. 1866) had described the yellow-eyed taxon as $C$. forsteri Seem. (Wiles \& Smith (Bм ноlotyPE), from Tahiti). If corolla throat color is the essential character, $C$. forster $i$ would indeed be referable to $C$. odollam. Grant, Fosberg, and Smith (1974), however, had placed $C$. forsteri in the synonymy of $C$. manghas, which they considered the only Tahitian species of Cerbera, not mentioning the corolla color character.

Boiteau (1981) implies that Cerbera manghas may sometimes have a corolla with a yellow eye (C. manghas var. manghas f. luteola Boit., 1981, p. 219). Huber (in Rev. Handb. Fl. Ceylon 4:53. 1983) indicates that the only species of Cerbera in Ceylon is $C$. odollam Gaertn., with a yellow-throated corolla, indicating its eastern range as extending into Malesia. Both species are stated to occur in Java (Backer \& Bakh. f. Fl. Java 2: 233. 1965) and New Caledonia (Boiteau, 1981), other characters supplementing the red vs. yellow corolla eye. Earlier, Pichon (in Notul. Syst. (Paris) 13: 223. 1948) had based two sections of the genus (sect. Odollam, with six species, and sect. Manghas, with two species) on corolla shape differences.

Characters to separate Cerbera odollam from $C$. manghas have indeed seemed elusive, but if the color of the corolla throat is of primary importance it would seem that the former extends as far east as the Societies (Fosberg and Sachet, 1983), perhaps occurring westward in Tonga and Samoa as well as in New Caledonia. In Fiji, however, only C. manghas (sensu Boiteau, 1981, as C. manghas var. manghas $\mathrm{f}$. manghas) occurs, all the collections with color notes having the corolla pink to red in the throat, while the shape of the corolla tube agrees with that indicated by Pichon (1948).

11. Pagiantha Markgraf in Notizbl. Bot. Gart. Berlin 12:542, 546, 549. 1935; Pichon in Mém. Mus. Nat. Hist. Nat. 27: 217. 1948; A. C. Sm. in J. Arnold Arb. 36: 287. 1955; Boit. in Fl. Nouv.-Caléd. et Dépend. 10: 232. 1981.

Trees or shrubs, the stipules forming a short intrapetiolar sheath; leaves opposite, often anisophyllous, petiolate, the blades coriaceous or subcoriaceous, entire, the secondary nerves spreading; inflorescences terminal or pseudoaxillary, cymose, longpedunculate, the bracts small; calyx deeply lobed, the lobes broadly ovate, obtuse, 
ciliolate or not, with 6-15 glandular scales at base within; corolla subcoriaceous or thick-carnose, hypocrateriform, the tube glabrous within, the lobes forming a subglobose, thick, coherent mass deeply inflexed in aestivation and penetrating into corolla throat, sinistrorsely contorted, at length spreading, oblong or falciform; stamens inserted below middle of tube, with slender filaments, the anthers basifixed, not adnate, apically mucronulate, sagittate at base with short sterile prolongations; disk adnate and indistinct; ovary apocarpous, the carpels concrescent only at base, glabrous, gradually contracted into style, the ovules numerous (35-250), 6-16-seriate, the style head broader than style, obconical or ellipsoid-cylindric, without ribs or dilated parts, the stigmas slightly shorter or longer than style head; fruit apocarpous, the mericarps subglobose or obliquely ovoid or obovoid, dehiscent along ventral suture, the exocarp opaque, thick, verrucose at maturity, the mesocarp thin, the seeds numerous, oblong to obliquely pyramidal, not compressed, ecomose, completely covered by a fleshy arillode.

TYPE SPECIES: Pagiantha dichotoma (Roxb.) Markgraf (Tabernaemontana dichotoma Roxb.). In describing the genus Pagiantha, Markgraf assigned to it eleven species, clearly indicating $P$. dichotoma as the type species (although this was not listed by ING, 1979). Boiteau (1981) erroneously listed $P$. cerifera (Pancher \& Sébert) Markgraf as the type species.

Distribution: Southeastern Asia, Malesia, and eastward to Fiji, where a single apparently endemic species terminates the generic range. Pagiantha was retained by Pichon (1948) as distinct from Ervatamia, but only as including sect. Dichotomae Markgraf (i. e. sect. Pagiantha), with six species; Markgraf's sect. Corymbosae was transferred to Ervatamia by Pichon, who correctly listed the Fijian P. koroana in Pagiantha, although he referred Tabernaemontana thurstoni to Ervatamia, unaware of the conspecificity of these taxa.

According to the concepts of Pichon and Boiteau, the Fijian taxon is properly referred to Pagiantha, having the stamens slightly below the middle of the corolla tube and the thick corolla lobes inflexed into the throat in bud (FIGURE 40C). Pichon (1948) states that the style head of Pagiantha is always glabrous, whereas that of Ervatamia is usually pubescent-velvety; this character apparently is not reliable, since the style head of $P$. thurstonii is seen to be very minutely but copiously velutinous (FIGURE 40E).

In his introductory remarks on the genus Tabernaemontana L. in Africa, Leeuwenberg (in Adansonia II. 16: 383-392. 1976) interpreted that genus very broadly, to include not only Ervatamia and Pagiantha but also many other genera recognized by such recent specialists as Markgraf, Pichon, Boiteau, and their colleagues. Whether or not to interpret Tabernaemontana in such an extremely broad sense remains for future specialists to consider, when all species of this pantropical complex have been thoroughly studied.

1. Pagiantha thurstonii (Horne ex Baker) A. C. Sm. in J. Arnold Arb. 33: 114. 1952, in op. cit. 36: 287. 1955; J. W. Parham, Pl. Fiji Isl. 185. 1964, ed. 2. 262. 1972.

Figures 40, 41.

Tabernaemontana thurstoni Horne, A Year in Fiji, 268, nom. nud. 1881; Horne ex Baker in J. Linn. Soc. Bot. 20: 368. 1883; Anon. in Kew Bull. 1898: 164. 1898; Burkill in J. Linn. Soc. Bot. 35: 46. 1901; Gillespie in Bishop Mus. Bull. 74: 19. fig. 24. 1930.

Tabernaemontana pacifica sensu Horne, A Year in Fiji, 195, 268. 1881; non Seem.

Pagiantha koroana Markgraf in Notizbl. Bot. Gart. Berlin 12: 546, 549. 1935, in Bishop Mus. Bull. 141: 129. fig. 65, h-k. 1936; J. W. Parham, Pl. Fiji Isl. 185. 1964, ed. 2. 262. 1972.

Ervatamia thurstoni Pichon in Mém. Mus. Nat. Hist. Nat. 27: 220. 1948.

Tree 4-30 m. high, with abundant but thin white latex, occurring at elevations of $30-1,100 \mathrm{~m}$. in dense forest or on its edges. The leaves have stout petioles $4-15 \mathrm{~mm}$. 

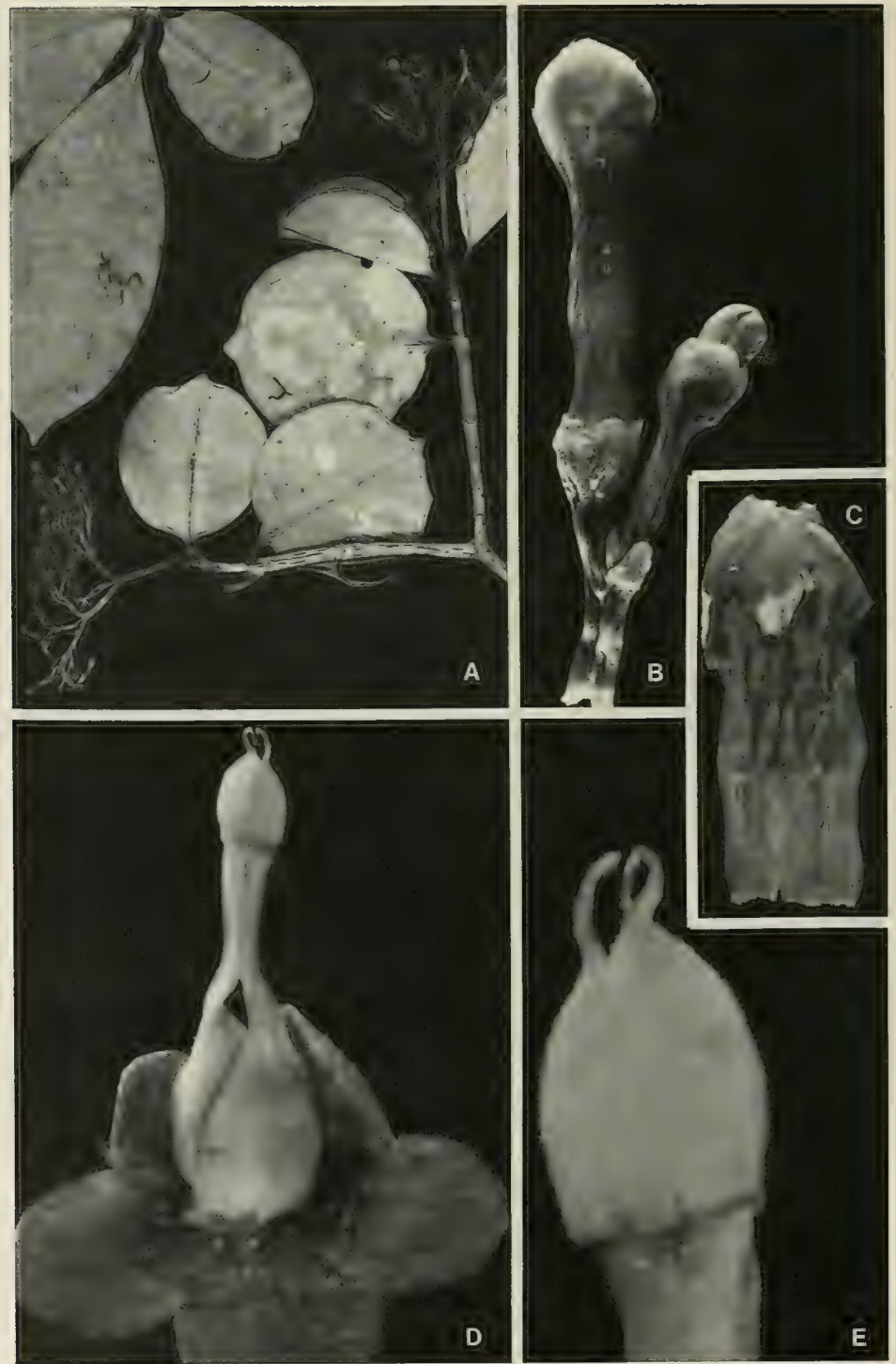

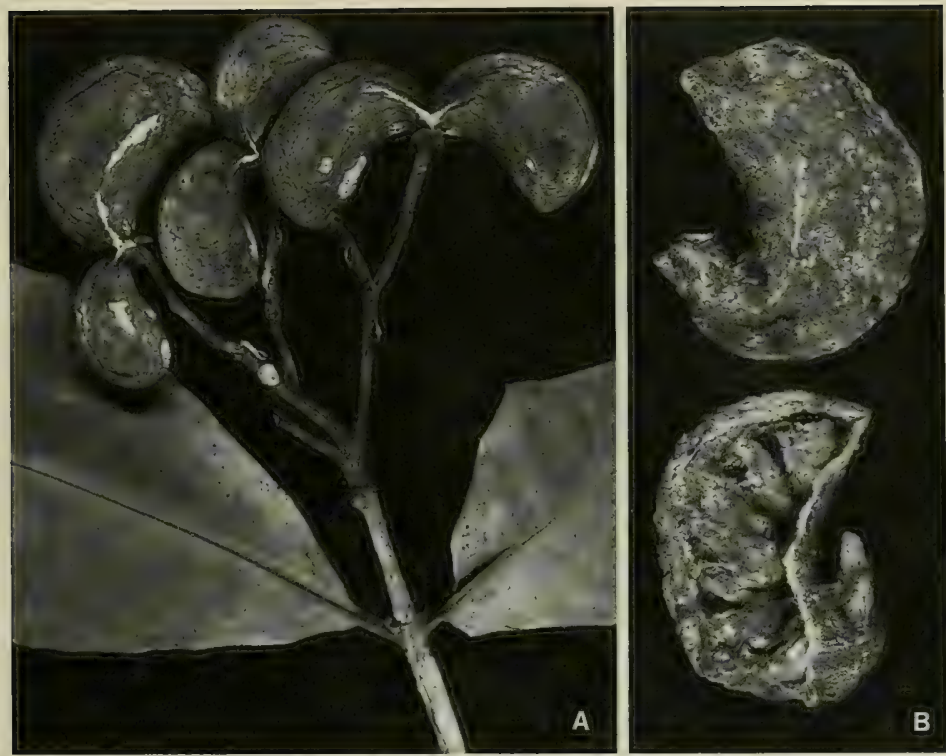

Figure 41. Pagiantha thurstonii; A, infructescence with developing fruits, $\times 1$; B, mature mericarps, one opened to show seeds, $\times 1$. A from $D A 14440$, B from Gillespie 4128 .

long and coriaceous or thick-chartaceous blades variable in shape and size, ovate or elliptic to obovate-elliptic, 7-22 × (3-) 4-12 cm., with 8-20 well-spaced secondaries prominent beneath. The inflorescence may be $5-12 \mathrm{~cm}$. long and broad, few-branched. The fragrant flowers have the corolla pure white or sometimes with the tube greenish, the tube at anthesis $15-20 \mathrm{~mm}$. long and 3-5 mm. in diameter, the swollen lobes forming a globose bud $7-8 \mathrm{~mm}$. in diameter, eventually becoming obliquely oblong and $20-25 \times$ about $8 \mathrm{~mm}$. The mericarps are at first green, eventually becoming brownish and coarsely verrucose, the endocarp yellowish within; the seeds are brownish but covered by red, fleshy arillodes. The largest mericarps seen, apparently mature, are about $5 \times 3 \mathrm{~cm}$., sharply recurved, with obovoid seeds up to $15 \times 8 \mathrm{~mm}$. Flowers and fruits have been obtained throughout the year.

TyPification and nOMENClature: The type is Horne s. $n$. (K HOLOTYPE), collected in August, 1878, in Fiji without further locality; Baker cited 268 as the number, but actually that was the page number of Horne's 1881 listing of the name. This taxon is doubtless the one that Horne referred to as Tabernaemontana pacifica (Alstonia pacifica in the present work) in his discussion of Fijian caoutchouc-yielding plants; the fact that the latex is thin and Horne's description of the fruit make it apparent that he

FIGURE 40. Pagiantha thurstonii; A, distal portion of branchlet, with foliage and inflorescences, $\times 1 / 3 ; \mathrm{B}$, maturing flower and bud, $\times 3 ; \mathrm{C}$, maturing corolla spread open, showing the coherent, inflexed lobes and the stamens (1 removed), $\times 3$; D, gynoecium and calyx, showing glands within calyx lobes, $\times 9 ; \mathrm{E}$, style head and stigmas, × 30. A from DA 16297 (separate foliage from Gillespie 3557), B-E from DA 16297. 
did not refer to a species of Alstonia. The type of Pagiantha koroana is Smith 1019 (BISH HOLOTYPE; many ISOTYPES), obtained Jan. 31, 1934, on the eastern slope of the main ridge of Koro. Markgraf was unaware of Baker's earlier name for the species.

Distribution: Endemic to Fiji and now known from four of the high islands; 38 collections have been studied.

LOCAL NAMES AND USES: The most often used names for this distinctive species are ndrenga, kau ndrenga, and tandalo, but also recorded are ndatalu, nda'alu, tambuasere, tambua rakolavu, and vueti naitasiri. The species is infrequently used for timber, and the latex, although thinner than that of Alstonia, is sometimes used as a chewing gum. An anonymous article on "Fiji India Rubber" (in Kew. Bull. 1898: 164-166. 1898) discusses Tabernaemontana thurstoni based on the collection of R. L. Holmes from Mbua, cited below.

RePRESENTATIVE COLlections; VITI LEVU: MBA; Navai, DA 14440; vicinity of Nambuyasa, Nggaliwana Creek, Gillespie 4128; western and southern slopes of Mt. Tomanivi, Smith 5089. NANDRoNGA \& Navosa: Nausori Highlands, DA 13323; northern portion of Rairaimatuku Plateau, between Nandrau and Rewasau, Smith 5638. SERUA: Namboutini, DA L.22289 (DF 83). NAmosr: Between Mburotu and Namuamua, $D A$ 11611. NAITASIRI: Vicinity of Nanduna, DA 1049; Toninaiwau, Tholo-i-suva, DA 16297; vicinity of Nasinu, Gillespie 3557. TAILEvu: Hills east of Wainimbuka River, vicinity of Ndakuivuna, Smith 7190 ; Namulomulo, DF 1072 (Damanu 186). VANUA LEVU: MBUA: Koromba Forest, DA 15126; Mbua without further locality, $R$. L. Holmes (K). TAVEUNI: Vicinity of Waiyevo, Gillespie 4788; Nggathavula, Valentine 36 (BISH).

From the description of Pagiantha koroana var. salomonensis Markgraf (in Gard. Bull. Singapore 22: 28. 1967), that taxon is questionably referable to $P$. thurstonii, than which it is said to have larger leaves, calyx lobes ( $6 \mathrm{~mm}$. long rather than $3-4 \mathrm{~mm}$.), and mature mericarps (up to $15 \mathrm{~cm}$. long) with more numerous seeds.

12. Ervatamia Stapf in This.-Dyer, Fl. Trop. Afr. 4 (1): 126. 1902; Markgraf in Notizbl. Bot. Gart. Berlin 12:544, 547. 1935; Pichon in Mém. Mus. Nat. Hist. Nat. 27: 218. 1948; Boit. in Fl. Nouv.-Caléd. et Dépend. 10: 238. 1981.

Tabernaemontana sensu Seem. Fl. Vit. I59, p. p. 1866.

Tabernaemontana sect. Ervatamia A. DC. in Prodr. 8: 373.1844.

Trees or erect shrubs, the stipules intrapetiolar; leaves opposite, often anisophyllous; inflorescences terminal or pseudoaxillary, pedunculate, cymose; calyx deeply lobed, the lobes ciliolate or not, with or without glandular scales within; corolla membranous or somewhat carnose, hypocrateriform, the tube staminiferous above middle or toward apex, without faucial scales, the lobes sinistrorsely (rarely dextrorsely) contorted, the inflexed portions in aestivation not penetrating into corolla throat; stamens with obvious or short filaments, the anthers basifixed, not adnate, mucronulate at apex or with a tuft of hairs, sagittate at base with short sterile prolongations; disk adnate and indistinct, rarely prominent; ovary apocarpous, the carpels concrescent only at base, smooth, the ovules usually numerous (2-100), 2-6-seriate, the style slender, the style head broader than style or sometimes nearly as slender, subglobose to conical or obovoid, usually glandular-pilose with hairs at least forming a flange at base, without ribs or dilated parts, the stigmas usually as long as or longer than style head; fruits apocarpous, the mericarps spreading, the seeds ecomose, with a fleshy arillode.

TYPE SPECIES: Ervatamia coronaria (Jacq.) Stapf (Nerium coronarium Jacq.).

DisRibution: Tropical eastern Asia throughout Malesia and eastward to the Tuamotus, with 90-95 species. One indigenous and one cultivated species are known to occur in Fiji. 
KEY TO SPECIES

Stamens borne near apex of corolla tube, essentially in corolla throat, the anthers about $2 \mathrm{~mm}$. long; corolla tube 7-17 mm. long, the lobes 7-15 mm. long and 3-7 mm. broad; leaf blades obtuse to obtusely acuminate and then with the apex (rarely to $20 \mathrm{~mm}$. long) broad and usually rounded; indigenous.

1. E. obtusiuscula

Stamens borne near middle of corolla tube, the anthers about $3 \mathrm{~mm}$. long; corolla tube $13-25 \mathrm{~mm}$. long, the lobes 20-35 mm. long and nearly as broad, often with crisped edges; leaf blades abruptly acuminate, the apex slender, $10-15 \mathrm{~mm}$. long; cultivated only. ............................ conaria

1. Ervatamia obtusiuscula Markgraf in Notizbl. Bot. Gart. Berlin 12:547, 551. 1935, in Bishop Mus. Bull. 141: 128. fig. 65, b-d. 1936; J. W. Parham, Pl. Fiji Isl. 184. 1964, ed. 2. 261. 1972.

Figure 42.

Tabernaemontana vitiensis Seem. in Bonplandia 9: 257, nom. nud. 1861, Viti, 439, nom. nud. 1862; A. Gray in Bonplandia 10: 37, nom. nud. 1862.

Tabernaemontana orientalis sensu Seem. Fl. Vit. 159. 1866, op. cit. 430. 1873; Drake, Ill. Fl. Ins. Mar. Pac. 235. I892; Reinecke in Bot. Jahrb. 25: 668. 1898; Christophersen in Bishop Mus. Bull. 128: 180. 1935; non R. Br. (1810).

Ervatamia orientalis sensu Turrill in J. Linn. Soc. Bot. 43: 32. 1915; Guillaumin in J. Arnold Arb. 13: 20. 1932; Yuncker in Bishop Mus. Bull. 220:219. 1959; J. W. Parham, PI. Fiji Isl. 185. 1964, ed. 2. 261. 1972; M. Grant, Fosberg, \& H. M. Sm. in Smithsonian Contr. Bot. 17: 46. 1974; non Domin (1913).

Alstonia reineckeana sensu Yuncker in Bishop Mus. Bull. 220: 218. 1959; non Lauterb.

As seen in Fiji, Ervatamia obtusiuscula is an often abundant shrub or tree 1-10 m. high, with white latex, occurring at elevations from near sea level to about 900 $\mathrm{m}$. in dense, dry, or secondary forest, in thickets and on open hillsides, and along coasts, often on limestone. Its variable leaves have slender petioles (4-) 7-17(-22) mm. long and chartaceous or submembranaceous blades, these elliptic or less frequently lanceolate, (4-) 7-20 $\times(1-)$ 2.5-8.5 cm., obtuse to obtusely acuminate at apex. The inflorescences vary from compact to $12 \mathrm{~cm}$. in length and breadth and are few-manyflowered, the pedicels (3-) 7-20 mm. long. The fragrant flowers have obtuse calyx lobes $1-1.5 \mathrm{~mm}$. long; corolla white, sometimes with the tube greenish and the lobes pale yellow, the tube $7-17 \mathrm{~mm}$. long and 1-2 mm. in diameter at anthesis, enlarged below throat, the lobes forming a globose-ovoid bud 5-6 $\mathrm{mm}$. in diameter, at anthesis spreading into a limb $10-28 \mathrm{~mm}$. broad, briefly ascending in basal portion and then curved and spreading, obliquely obovoid, 7-15 $\times 3-7 \mathrm{~mm}$; stamens borne in corolla throat, the filaments slender, about $1 \mathrm{~mm}$. long, the anthers about $2 \mathrm{~mm}$. long; style filiform, $9-12 \mathrm{~mm}$. long. The fruits at maturity are orange or yellow, with orange to red or purple pulp, the mericarps obliquely ovoid, at maturity $2-3 \times 0.8-1.5 \mathrm{~cm}$., with $8-12$ seeds about $7 \times 4 \mathrm{~mm}$. No flowering or fruiting season is apparent.

As here circumscribed, Ervatamia obtusiuscula is very variable (although well distinguished from $E$. orientalis by corolla characters). In Fiji, scattered collections have exceptionally narrow, lanceolate leaf blades, and a few others demonstrate a teratological variation sometimes or frequently showing phyllodic calyx lobes (cf. Markgraf, 1936).

TYPIFICATION AND NOMENCLATURE: Ervatamia obtusiuscula was typified by Vaupel 265 (B HOLOTYPE probably destroyed; K LECTOTYPE here designated; ISOTYPE at BISH), collected Jan. 30, 1906, near Safune, Savai'i, Samoa. The source of the name Tabernaemontana vitiensis is Seemann 312 (BM, K), obtained in July, 1860, at Port Kinnaird, Ovalau. In proposing E. orientalis as a new combination in 1915, Turrill understandably overlooked the same combination made by Domin (in Repert. Sp. Nov. 12: 97. 1913). In the sense of the present treatment, the only collection cited by Turrill, im Thurn 75, belongs in E. obtusiuscula. 
Distribution: New Hebrides, Fiji, Tonga, and Samoa, and very probably eastward to the Society and western Tuamotu Islands. It seems likely that only one indigenous species of Ervatamia occurs from the New Hebrides eastward. In describing E. obtusiuscula, Markgraf $(1935,1936)$ assigned it a range of Fiji, Samoa, and Tonga, pointing out its differences from $E$. orientalis, which, however, he believed to occur in Melanesia including Fiji as well as in Australia and Malesia. The fact that Loyalty Islands material of this alliance also differs from $E$. orientalis was indicated by Boiteau and Allorge (in Fl. Nouv.-Caléd. et Dépend. 10: 240.pl. 43. 1981) when they described $E$. lifuana, which seems to differ very little from the concept of E. obtusiuscula as here interpreted. From Fiji about 75 collections have been examined, these coming from 15 islands.

LOCAL NAMES AND USES: The many Fijian names, none very convincing, that have been recorded for this species are: kolovesi (Kandavu), langgainggai, mbelolanggai, meme, naselelevu, nasio, ndrenga kai lango (Mathuata), ndrenga talotalo, tambua ni kalavo (Lau), totoka (Yasawas), and tutunggainggai (Thakaundrove, Taveuni). Although the fruits are sometimes considered edible, the latex is said to cause skin irritation. Medicinally, a decoction is reportedly used to cause abortion, and the roots have been noted as part of a remedy to treat tuberculosis.

RePRESENTATIVE COLLections: VITI LEVU: MBA: Vicinity of Tavua, Degener 14938; Nandarivatu, im Thurn 75. NANDronga \& NavosA: Track north of Komave, St. John 18961. Serua: Hills west of Waivunu Creek, between Ngaloa and Korovou, Smith 9475. NaITAsiri: N. T. C. Farm, DA 9653. Rewa: Vicinity of Lami, Gillespie 4590. MBENGGA: Ndakuni, DA 2074. VATULELE: Nawai, DA 13802. KANDAVU: Namalata isthmus region, Smith 35. KORO: North coast, Smith 1043. VANUA LEVU: MBUA: Koromba Forest, DA 15131. Mathuata: Vicinity of Lambasa, Greenwood 570. ThaKaundrove: Hills south of Nakula Valley, Smith 324. TAVEUNI: Vicinity of Wairiki, Gillespie 4674. MUNIA: Lower slopes, Bryan 588. MANGO: Limestone ridge forest, Bryan 565. ONEATA: Graeffe 1381. FULANGA: On limestone formation, Smith 1197.

Narrow-leaved form: YASAWAS: YaSAWA: DA 13656. WAYA: St. John 18149. MAMANUTHAS: NgGalito: $O$. \& $I$. Degener 32239. VITI LEVU: MBa: Greenwood 260. VANUA LEVU: MBUA: $H . B . R$. Parham 456. Mathuata: Tothill 397, 601, 603, Smith 6543, 6602. ThaKaundrove: Horne 587a.

Form with phyllodic calyx lobes: VITI LEVU: SERUA: Smith 9643 . VANUA LEVU: ThAK AUNDROVE: Smith 811, DA 17104.

2. Ervatamia coronaria (Jacq.) Stapf in This.-Dyer, Fl. Trop. Afr. 4 (1): 127. 1902; Markgraf in Notizbl. Bot. Gart. Berlin 12: 547. fig. 7 (6). 1935; Boit. in Fl. Nouv.-Caléd. et Dépend. 10:241. 1981; MacKee, Pl. Intro. Cult. Nouv.-Caléd. 17. 1985.

Nerium coronarium Jacq. Icon. Pl. Rar. 1: t. 52. 1787, Collect. 1: 127. 1787.

Tabernaemontana coronaria Willd. Enum. Pl. Horti Berol. 275. 1809.

Ervatamia divaricata sensu Burkill in Rec. Bot. Surv. India 10: 320, typ. excl. 1925; Alston in Trimen, Handb. Fl. Ceylon 6: 191. 1931; Sykes in New Zealand Dept. Sci. Indust. Res. Bull. 200:45. 1970; J. W.

Parham, Pl. Fiji Isl. ed. 2. 261. 1972; M. Grant, Fosberg, \& H. M. Sm. in Smithsonian Contr. Bot. 17: 45. 1974; H. Huber in Rev. Handb. Fl. Ceylon 4: 27. 1983; non sensu Nerium divaricalum L.

As seen in Fiji, Ervatamia coronaria is a shrub $0.5-2 \mathrm{~m}$. high, with white latex, occasionally cultivated near sea level. The fragrant flowers have white corollas sometimes yellowish in throat and often double. Flowers have been collected in March and November.

TYPIFICATION AND NOMENCLATURE: Jacquin's plate of 1787 may be taken as the type. This cultivated species is often identified as Ervatamia divaricata(L.) Burkill, the

FIGURE 42. Ervatamia obtusiuscula; A, distal portion of branchlet, with foliage and inflorescences, $\times 1 / 3$; $B$, portion of inflorescence with a maturing corolla bud, a flower with corolla removed to show style, and a mature corolla, $\times 3$; C, maturing corolla spread open, showing stamens, $\times 3$; D, style head and stigmas, $\times 50$; E, mature mericarps, $\times 1$. A-D from Smith 324, E from St. John 18961. 

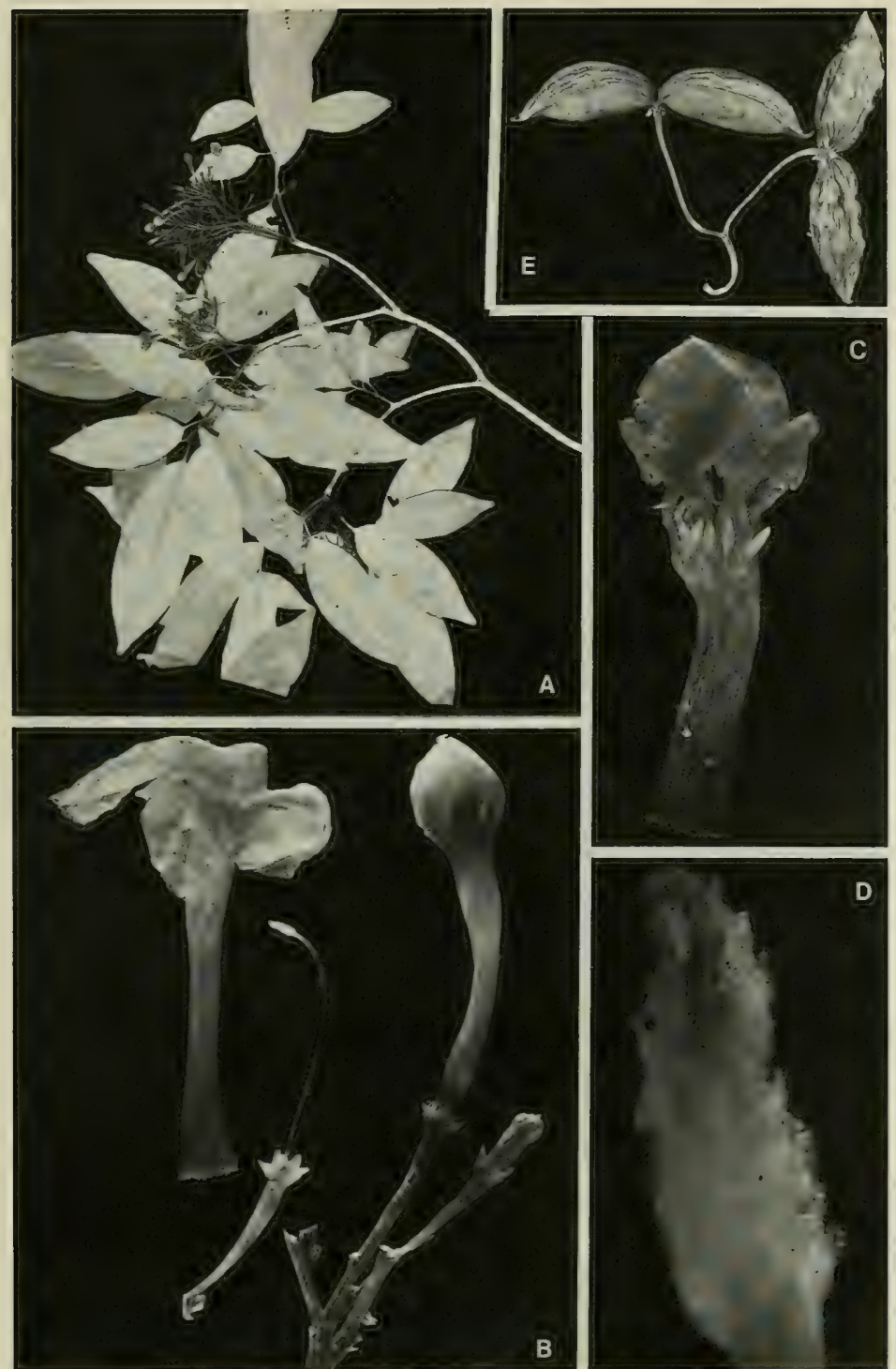
basionym of which is Nerium divaricatum L. (Sp. Pl. 209. 1753), typified by Hermann material from Ceylon. Stapf (1902) indicated that Linnaeus's species is to be placed in the genus Wrightia, a position also noted by Boiteau (1981). Burkill's combination must accompany the Linnaean binomial, regardless of his concept of the species.

Distribution: Perhaps of Himalayan or Himalayo-Burmese origin (Burkill, 1925) but now widely cultivated throughout tropical areas and with many cultivars.

LOCAL NAMES AND USE: Frequent names are rosebay and crape jasmine, although neither has been recorded as used in Fiji. An attractive ornamental with flowers that are particularly fragrant at night.

Available Collections: VITI LEVU: NaITASIRI: Cocoa Station, Nanduruloulou, DA 12250. VANUA LEVU: Mathuata: Ndreketi Plantations, DA 14303.

13. Allamanda L. Mant. Pl. Alt. 146, 214 (as Allemanda). 1771; K. Schum. in Engl. \& Prantl, Nat. Pflanzenfam. IV. 2: 127. 1897; M. Grant, Fosberg, \& H. M. Sm. in Smithsonian Contr. Bot. 17: 39. 1974; Markgraf in Fl. Madagasc. Fam. 169. 303. 1976; Boit. in Fl. Nouv.-Caléd. et Dépend. 10: 242. 1981.

Shrubs or small trees, scandent or semierect, the branchlets terete; leaves verticillate or opposite, with axillary glands, the blades with distant secondary nerves; inflorescences terminal or pseudoaxillary, corymbose-cymose, short-pedunculate, bracteolate, the flowers showy; calyx deeply lobed, the lobes large, ovate-oblong to lanceolate, often slightly unequal, acute, with or without glands within; corolla campanulate-infundibuliform, the tube proximally cylindric and slender, distally dilated, bearing suprastaminal scales surmounted by tufts of hairs, the lobes sinistrorsely contorted in bud, shorter than tube, spreading, ovate to orbicular or obovate, obtuse; stamens borne at base of upper part of corolla tube, concealed by faucial scales, the filaments short, the anthers subsessile, adherent to style head by a retinaculum of a few viscid filaments, oblong to lanceolate, inconspicuously sagittate at base, the connective acute at apex; disk cupuliform, 5-lobed or subentire; ovary unilocular, glabrous, with 2 parietal placentae, the ovules numerous, the style long, the style head cylindric, with a basal flange, the stigma bifid; fruit a unilocular, bivalved capsule, subglobose, aculeate with long, soft spines, the seeds numerous, imbricate, compressed, circumalate, not comose.

TYPE SPECIES: Allamanda cathartica L., the only original species. The genus was named after Frédéric Allamand; therefore Linnaeus's spelling on p. 146 was corréct.

DistribUtion: Tropical America, but now widely cultivated in tropical, subtropical, and some warm temperate areas, with 12-15 species. Three species are in cultivation in Fiji, two of them sometimes naturalized.

The three taxa cultivated in Fiji are not readily distinguished when lacking flowers, all having the leaves usually in fours (sometimes in threes or fives), the petioles short (2-7 mm. long), the leaf blades subcoriaceous and ovate-elliptic to obovate-lanceolate, $5-15 \times 2-4(-5) \mathrm{cm}$., and the fruits $2.5-5 \mathrm{~cm}$. in diameter, with coarse spines $10-15 \mathrm{~mm}$. long. However, there are readily discernible differences among them in corolla color and shape, and to a certain extent in habit and indument.

KEY TO SPECIES

Corolla yellow; calyx glabrous; young branchlets and leaf blades glabrous or sometimes with a faint, inconspicuous indument.

Calyx lobes $10-15 \times 3-6 \mathrm{~mm}$; corolla $8.5-13 \mathrm{~cm}$. long, the tube in lower portion $30-40 \mathrm{~mm}$. long and $2.5-5$ $\mathrm{mm}$. in diameter, not swollen at base, broadly expanded above and campanulate-infundibuliform, the upper portion $30-50 \mathrm{~mm}$. long and $30-40 \mathrm{~mm}$. in diameter at throat, the limb spreadinghorizontal, 6-13 cm. in diameter, the lobes 30-60 × 30-50 mm.; vigorous liana or climbing shrub. 
Calyx lobes 7-8 $\times 2-3 \mathrm{~mm}$; corolla 6-8 cm. long, the tube in lower portion $10-15 \mathrm{~mm}$. long and $2.5-5 \mathrm{~mm}$. in diameter, swollen to $5-7 \mathrm{~mm}$. in diameter at base, campanulate-cylindric above, the upper portion $30-40 \mathrm{~mm}$. long and $15-20 \mathrm{~mm}$. in diameter at throat, the limb spreading to $3.5-6 \mathrm{~cm}$. in diameter, the lobes ascending, $15-20 \times 10-20 \mathrm{~mm}$; shrub, only slightly scandent. . . . . . . . . A. schottii Corolla rose-pink to reddish purple, $6-9 \mathrm{~cm}$. long, the tube greenish yellow, in lower portion $15-20 \mathrm{~mm}$. long and 2.5-3 mm. in diameter, not appreciably swollen at base, the upper portion campanulate-cylindric, 25-30 mm. long and $20-25 \mathrm{~mm}$. in diameter at throat, the limb $5-6.5 \mathrm{~cm}$. in diameter at apex, the lobes rounded, 20-25 × 25-30 mm.; calyx pubescent, the lobes 15-18 $\times 5-9 \mathrm{~mm}$.; young branchlets and leaf

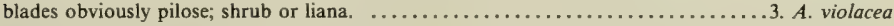

1. Allamanda cathartica L. Mant. Pl. Alt. 214, as Allemanda c. 1771; K. Schum. in Engl. \& Prantl, Nat. Pflanzenfam. IV. 2: 128. fig. 49, E-G. 1897.

TYPIFICATION: The only original reference was to "Barrer. aequin. 48. Habitat per totam Guianam."

Distribution: Tropical America, now widely cultivated. The large-flowered variant most frequently seen in cultivation in the Pacific is usually referred to var. hendersonii or var. grandiflora (although the latter, if based on Aublet's epithet, is illegitimate). This common large-flowered form is probably best considered a cultivar, as suggested in Hortus Third (1976).

\section{1a. Allamanda cathartica cv. 'Hendersonii.'}

Orelia grandiflora Aubl. Hist. Pl. Guiane Fr. 271, nom. illeg. $t$. 106. 1775

Allamanda hendersonii Bull ex Dombrain in Fl. Mag. (London) 5: $t$. 263. 1866.

Allamanda cathartica var. hendersonii Raffill ex Bailey, Stand. Cycl. Hort. 1: 247. 1914; Yuncker in Bishop Mus. Bull. 178: 96. 1943, in op. cit. 220:218. 1959; Sykes in New Zealand Dept. Sci. Indust, Res. Bull. 200: 44. 1970; B. E. V. Parham in New Zealand Dept. Sci. Indust. Res. Inform. Ser. 85: 105, 1972.

Allamanda cathartica var. grandiflora Raffill ex Bailey, Stand. Cycl. Hort. 1: 247, nom. illeg. 1914; Markgraf in Fl. Madagasc. Fam. 169. 303. 1976.

Allamanda cathartica (forsan pro parte maxima) sensu Christophersen in Bishop Mus. Bull. $128: 177$. 1935; Greenwood in J. Arnold Arb. 30: 78. 1949; J. W. Parham in Dept. Agr. Fiji Bull. 35; 101. 1959, Pl. Fiji Isl. 180. 1964, ed. 2. 256. 1972; M. Grant, Fosberg, \& H. M. Sm. in Smithsonian Contr. Bot. 17: 39. 1974; Boit. in Fl. Nouv.-Caléd. et Dépend. 10: 243. 1981; MacKee, Pl. Intro. Cult. Nouv.-Caléd. 17. 1985.

A vigorous scrambling vine or liana, abundantly cultivated near sea level and occasionally naturalized, with a large, long-tubed yellow corolla. Although flowers have been collected between March and November, they are probably to be seen throughout the year.

TyPIFICATION AND NOMENCLATURE: Allamanda hendersonii was introduced from Guiana by Henderson \& Co., of St. John's Wood, England. Aublet's material was also from Guiana, but he listed $A$. cathartica as a synonym. Cultivated in Fiji at least since the 1880's and listed (as $A$. hendersonil) in Thurston's 1886 Catalogue.

LOCAL NAMES AND USE: This striking and luxuriant ornamental is known in Fiji as allamanda, yellow allamanda, or golden allamanda.

Available Collections: VITI LEVU: NAitAsiri: Near Nasinu, Greenwood 1195. Rewa: Lami, in private garden, DA 16785; Department of Agriculture compound, Suva, DA 11553, 12082.

2. Allamanda schottii Pohl, Pl. Bras. Ic. Descr. 1: 73. t. 58. 1827; K. Schum. in Engl. \& Prantl, Nat. Pflanzenfam. IV. 2: 128. 1897; M. Grant, Fosberg, \& H. M. Sm. in Smithsonian Contr. Bot. 17: 39. 1974; Markgraf in Fl. Madagasc. Fam. 169. 304. 1976.

Allamanda neriifolia Hook, in Bot. Mag. 77: 1 . 4594. 1851; J. W. Parham, PI. Fiji Isl. 181. 1964, ed. 2. 257. 1972; MacKee, Pl. Intro. Cult. Nouv.-Caléd. 17. 1985.

A shrub 1-3 m. high, infrequently subscandent, cultivated near sea level and sometimes naturalized, with a comparatively short-tubed yellow corolla that is sometimes tinged proximally with purplish brown. Flowers have been noted between March and June and fruits slightly later. 
TyPIFICATION: Allamanda schottii was based on a Brazilian plant, $A$. neriifolia on a cultivated plant of unknown origin. Apparently Hooker misinterpreted Pohl's species as a form of $A$. cathartica and therefore redescribed this quite different taxon as $A$. neriifolia; some confusion still exists in the horticultural literature.

Distribution: South America, now widely cultivated. It may have been introduced into Fiji by Thurston, being listed (as Allamanda neriifolia) in his 1886 Catalogue.

LOCAL NAMES AND USE: Known as allamanda and locally (on Ovalau) as yere, this shrub is a pleasing garden ornamental.

AVAIl able COLlections: VITI LEVU: Rewa: Lami, in private garden, DA 16787; Suva Botanical Gardens, DA 12089. OVALAU: Valley of Mbureta and Lovoni Rivers, Smith 7483.

3. Allamanda violacea Gardner in Fielding \& Gardner, Sert. Pl. t. 41. (March) 1844; J.

W. Parham, Pl. Fiji Isl. ed. 2. 257. 1972.

Allamanda blanchetii A. DC. in DC. Prodr. 8: 319. (March) 1844.

A sometimes scandent shrub $1.5-3 \mathrm{~m}$. high, cultivated near sea level, the corolla purplish pink to mauve, with a yellowish or greenish yellow tube. Flowers have been observed between January and April.

TYPIFICATION AND NOMENCLATURE: Syntypes of Allamanda violacea are Gardner 1980 and 2230 (OXF), from Ceara, Brazil, near Villa do Crato and west of Terra de Araripe. The type of $A$. blanchetii is Blanchet 2695 (G-DC HOLOTYPE), from Bahia, Brazil, "in montibus Jacobinae." There is probably no way to decide as to the priority of either of the two nearly simultaneously published binomials; that of Fielding and Gardner seems to be more frequently used, perhaps because of their good description and illustration.

Distribution: South America, now often cultivated elsewhere. This species was also included in Thurston's 1886 Catalogue and may have been brought into Fiji by him.

LOCAL NAME AND USE: An attractive ornamental locally known as purple allamanda.

AVAILABle Collections: VITI LEVU: NAITASIRI: Koronivia nursery, DA 4012. Rewa: Lami, in private garden, DA 16796. VANUA LEVU: ThaKaUndrove: Namale, DA 16859.

14. Nerium L. Sp. Pl. 209. 1753; Pichon in Mém. Mus. Nat. Hist. Nat. Ser. B, Bot. 1:

58. 1950; Boit. in Fl. Nouv.-Caléd. et Dépend. 10: 243. 1981.

Erect shrubs, without stipules; leaves verticillate (or opposite or alternate), the petiole with storied glands in lower half, the blades with numerous, parallel secondary nerves; inflorescences terminal, corymbose; calyx deeply lobed, the lobes narrowly oblong, with many glandular scales at base within; corolla glabrous without, the tube proximally cylindric and slender, staminiferous near middle, distally infundibuliform, villose below and above stamens and in throat, with projecting staminal nerves, the lobes dextrorsely contorted in bud, weakly pilose within at base, glabrous above, recurved at margins, the corona distinct from lobes but adnate to them, composed of 5 epipetalous lobes; stamens with short, laxly pilose filaments, the anthers included, with long, pilose, intertwisted apical appendages, with basal appendages slightly shorter than fertile locules, adherent to style head by a retinaculum of numerous hairs; disk lacking; ovary pubescent distally, the carpels united to apex, the ovules numerous, 12-20-seriate, the style head subglobose, with a basal flange, the retinaculum brushy; fruit with united mericarps, the seeds densely short-pilose, with an apical coma.

Lectoty PE SPECIES: Nerium oleander L. (vide Steudel, Nomencl. Bot. 1: 553. 1821). 
Distribution: Mediterranean region eastward to Japan, with three species, one of which is cultivated and naturalized in Fiji.

1. Nerium oleander L. Sp. Pl. 209. 1753; Christophersen in Bishop Mus. Bull. 128: 186. 1935; Yuncker in op. cit. 178: 98. 1943, in op. cit. 220: 222. 1959; J. W. Parham, Pl. Fiji Isl. 185. 1964, ed. 2. 261. 1972; Sykes in New Zealand Dept. Sci. Indust. Res. Bull. 200: 45. 1970; B. E. V. Parham in New Zealand Dept. Sci. Indust. Res. Inform. Ser. 85: 94. 1972; M. Grant, Fosberg, \& H. M. Sm. in Smithsonian Contr. Bot. 17: 53. 1974; Boit. in Fl. Nouv.-Caléd. et Dépend. 10: 244. 1981; MacKee, Pl. Intro. Cult. Nouv.-Caléd. 17. 1985.

As seen in Fiji, Nerium oleander is a shrub to $5 \mathrm{~m}$. high, with pale latex, cultivated in towns and villages and sometimes naturalized in forest along creeks at elevations from near sea level to $600 \mathrm{~m}$. The attractive flowers have the calyx deep pink, the corolla bright pink or white and pinkish at base or purple and with a bright pink corona. Flowers seem most frequent between November and May.

Typification: Linnaeus gave several prior references. Miller (Gard. Dict. ed. 8. 1768) takes a Hort. Cliffort. specimen as the type and indicates Nerium oleander to be the Mediterranean species with linear, spear-shaped leaves in threes. Another species, $N$. indicum Mill., growing naturally in India but also elsewhere cultivated, has rigid, linear, much narrower leaves which are alternate, opposite, or sometimes in threes.

Distribution: Mediterranean area but now cultivated and often naturalized throughout the tropics and subtropics.

LOCAL NAMES AND USES: The oleander is often known in Fiji as vasa or rusi. It is a garden ornamental, first introduced about 1880 and listed in Thurston's 1886 Catalogue under other names. All parts of the plant are poisonous; ingestion of the leaves or flowers can be fatal.

AVAILABLE COLLECTIONS: VITI LEVU: MBA: Vicinity of Nalotawa (in forest along creek), eastern base of Mt. Evans Range, Smith 4431. Serua: Ngaloa, Smith 9618. Rewa: Suva, in private garden, DA 16232, 16233. KANDAVU: Namara, DA 13854 (Damanu 6).

15. Beaumontia Wall. Tent. Fl. Napal. Ill. 14. 1824; Benth. in Benth. \& Hook. f. Gen. Pl. 2: 721. 1876; K. Schum. in Engl. \& Prantl, Nat. Pflanzenfam. IV. 2: 177. 1895; Pichon in Mém. Mus. Nat. Hist. Nat. Ser. B, Bot. 1: 61. 1950.

Lianas, with stipular lines but lacking stipules; leaves opposite, the blades submembranaceous; inflorescences terminal, cymose, several-flowered, the flowers large; calyx deeply lobed, the lobes oblong, large, with uniformly distributed scales within; corolla pubescent without, at least partially, the tube short, staminiferous below or near middle, dilated and infundibular or campanulate above, glabrous within, the throat glabrous, without scales, the lobes dextrorsely contorted in bud, pubescent within, the staminal nerves not protruding, the corona indistinct, without free parts; stamens with glabrous filaments longer than anthers, the anthers included or exserted, dorsally glabrous, connivent about style head and adherent to it by a retinaculum, the basal projections about as long as locules, the connective ventrally thickened between locules and retinaculum; disk shallowly lobed, usually pilose; ovary pilose, the carpels united to apex, the ovules numerous, 22-28-seriate, the style filiform, glabrous or short-pilose, the style head with a brushy retinaculum, without a flange; fruit with united mericarps, these at length separating, the seeds compressed, ovate or oblong, distally attenuate, apically comose.

TYPE SPECIES: Beaumontia grandiflora Wall., the only original species.

Distribution: Tropical Asia into Malesia, with about ten species, some of which are elsewhere in cultivation. 
1. Beaumontia grandiflora Wall. Tent. Fl. Napal. Ill. 14. t. 7. 1824; K. Schum. in Engl. \& Prantl, Nat. Pflanzenfam. IV. 2: 177. fig. 59, E. 1895; J. W. Parham, Pl. Fiji Isl. ed. 2. 259. 1972.

Echites grandiflora Roxb. Hort. Beng. 20, nom. nud. 1814, Fl. Ind. ed. 2. 2: 14. 1832.

An ornamental climber, apparently infrequent in cultivation in Fiji near sea level, the large, fragrant flowers with a white corolla.

TYPIFICATION: Wallich presumably took his specific epithet from Roxburgh, whose material was from Chittagong and Sylhet (Bangladesh); however, Roxburgh's name had not been validly published in 1824 .

Distribution: Southeastern Asia, now elsewhere cultivated.

Available Collection: VITI LEVU: Rewa: Suva, DA L. 15802 (SUVA).

This garden ornamental has been recorded from Fiji only by Parham (1972) and is apparently a recent introduction. The specific identity should be checked against the related species Beaumontia multiflora Teijsm. \& Binnend. and $B$. jerdoniana Wight, known to be in cultivation in Malesian and other Pacific areas.

16. Parsonsia R. Br. Asclepiadeae, 53. 1810 (preprint from Mem. Wern. Nat. Hist. Soc. 1: 64. 1811); Pichon in Mém. Mus. Nat. Hist. Nat. Ser. B, Bot. 1:42. 1950; A. C. Sm. in J. Arnold Arb. 36: 287. 1955; Boit. in Fl. Nouv.-Caléd. et Dépend. 10: 245. 1981. Nom. cons.

Lyonsia R. Br. Asclepiadeae, 55. 1810 (preprint from Mem. Wern. Nat. Hist. Soc. 1: 66. 1811); Seem. Fl. Vit. 160.1866.

Lianas or scandent shrubs, the leaves opposite, the blades elliptic to ovatelanceolate, with few secondaries; inflorescences axillary or terminal, composed of simple or paniculiform cymes, the flowers often comparatively small; calyx deeply lobed, the lobes ovate to deltoid, rarely puberulent within, usually with 1-7 glandular scales within; corolla with a relatively broad tube staminiferous near base or toward middle, infundibular or subcampanulate distally, without a corona or suprastaminal scales, without infrastaminal indument except on alternipetalous staminal nerves, usually with suprastaminal indument, the throat rarely thickened, the lobes valvate in bud, subsymmetrical, not involute; stamens with long filaments appressed to style and closely adherent to or intertwisted with it, the anthers entirely or partially exserted, basifixed or subventrifixed, dorsally glabrous, with attenuate to lobed basal appendages, adherent to style head by a retinaculum, the connective glabrous below retinaculum; disk 5-lobed, short or about as high as ovary, free from ovary; ovary bicarpellary with carpels essentially concrescent, the fissure between them sometimes scarcely apparent, the ovules numerous, 4-20-seriate, the style sometimes long, glabrous, the style head with a basal flange or rim, the retinaculum reduced to a row of hairs, the ensemble of corolla, stamens, style, and style head caducous soon after anthesis; fruits with mericarps at first united into a capsule, cylindric or ovoid-apiculate, the mericarps separating but closely parallel at full maturity, the seeds compressed, 2-5-times longer than broad, with a coma of hairs 2-4 times longer than seed.

TYPE SPECIES: Parsonsia is typified by P. capsularis (Forst. f.) R. Br. ex Endl. (Periploca capsularis Forst. f.) (typ. cons.), Lyonsia by L. straminea $\mathbf{R}$. Br.

Distribution: Tropical Asia to Formosa, throughout Malesia to Australia and New Zealand, and eastward to Fiji, with about 80 species. Two species terminate the generic range in Fiji.

The species indigenous in Fiji have the leaves with obvious petioles and membranaceous to chartaceous blades, these ovate to ovate-lanceolate, shallowly cordate or rounded to broadly obtuse at base, obtuse (rarely slightly emarginate) to acuminate at apex; inflorescences axillary, 2-5-times branched, with peduncles (1.5-) 3-6 cm. 
long; calyx cupuliform to cyathiform, with deltoid, acute lobes; disk lobes obvious, elliptic, approaching the calyx lobes in size. The two species are readily distinguished by corolla characters, but the anthers and gynoecia are fairly similar. The fruits have mericarps that eventually separate but remain closely parallel; seed body obliquely oblong-ovoid, flattened, $8-11 \times 1.5-2 \mathrm{~mm}$., the hairs of the coma $30-40 \mathrm{~mm}$. long.
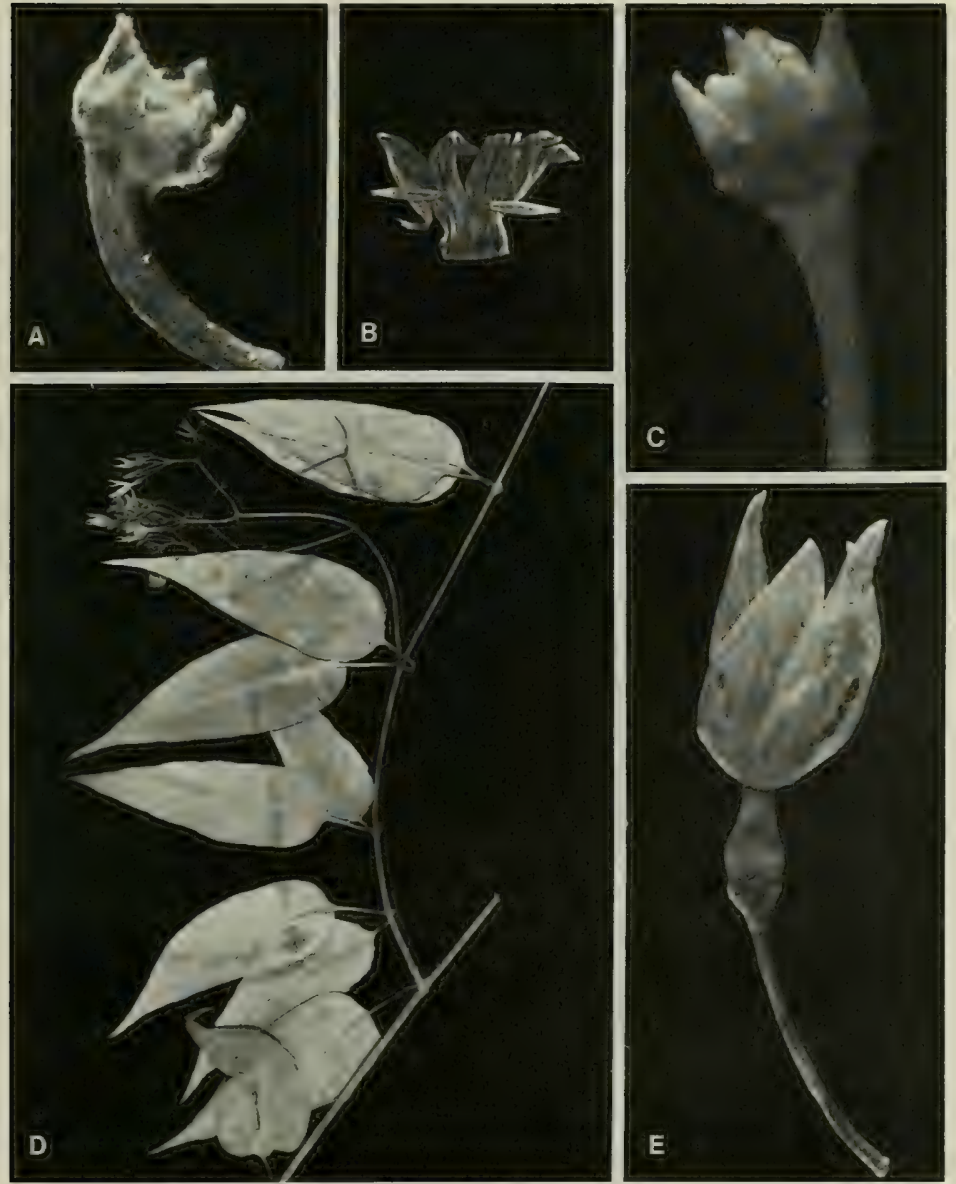

Figure 43. A \& B, Parsonsia laevis, from U. S. Expl. Exped. (GH ISOTYPE); A, pedicel and calyx, $\times 9$; B, mature corolla spread open, showing stamens (some fallen), × 3. C-E, Parsonsia smithii, from Smith 1664; $\mathrm{C}$, distal portion of pedicel and calyx, showing disk lobes and distal part of ovary, $\times 9 ; \mathrm{D}$, distal portion of branchlet, with foliage and an inflorescence, $\times 1 / 3 ; \mathrm{E}$, flower, $\times 3$. 
Vol. 4

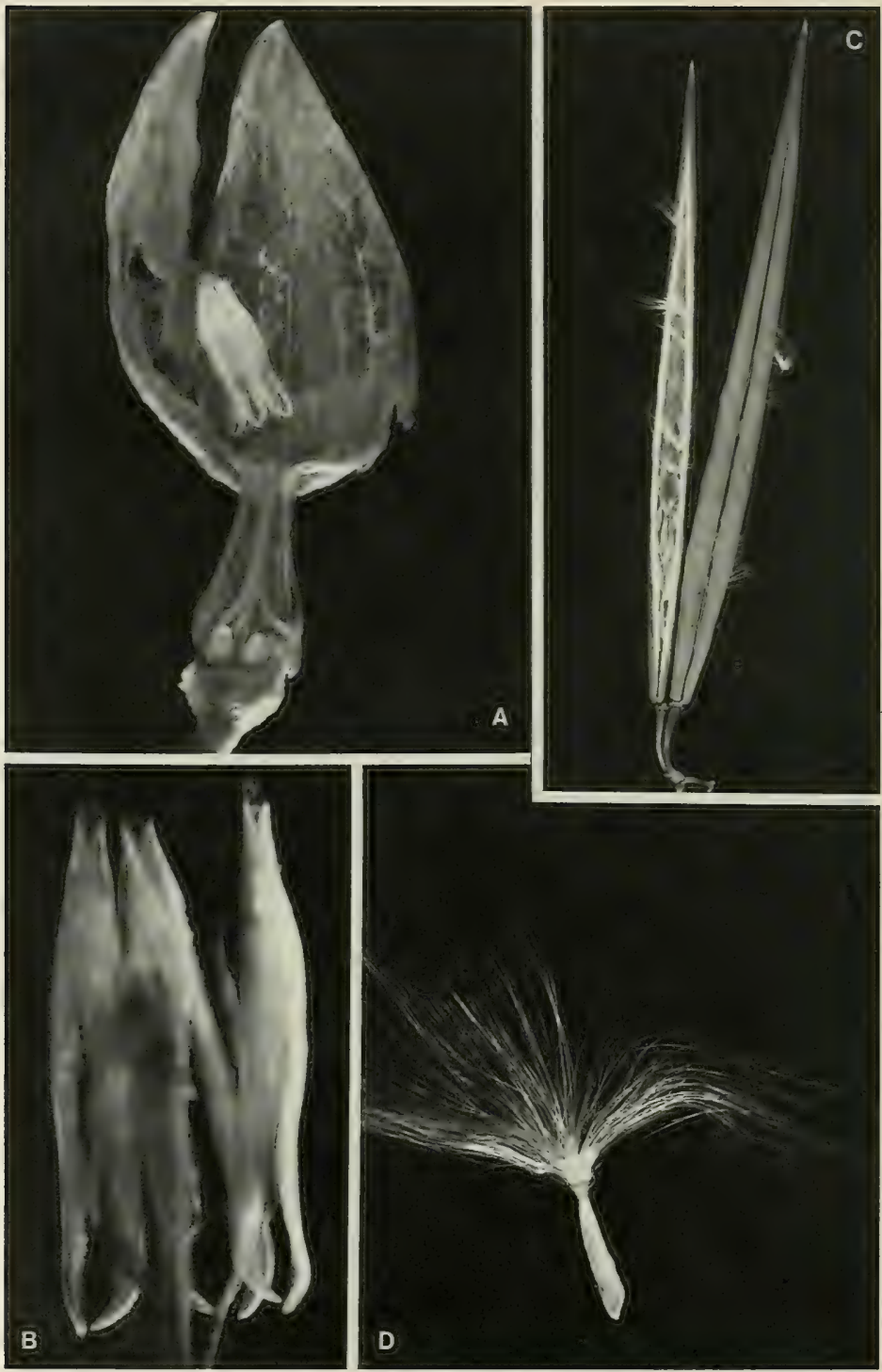


KEY TO SPECIES

Inflorescences (4-) 6-12 cm. long and broad, the pedicel at anthesis 3-7 mm. long; calyx 2-2.5 $\times 2-3 \mathrm{~mm}$., the lobes $1-1.5 \mathrm{~mm}$. long and broad; corolla comparatively small, (4-) 6-10 mm. long, the tube (1.5-) 2-3 $\mathrm{mm}$. long and about $3 \mathrm{~mm}$. in diameter, not contracted distally, the lobes oblong-lanceolate, (2.5-) 4-7 $\mathrm{mm}$. long and about $1.5 \mathrm{~mm}$. broad; filaments $1-2.5 \mathrm{~mm}$. long, the anthers $2-3 \mathrm{~mm}$. long; mature mericarps $14-14.5 \mathrm{~cm}$. long, 7-8 mm. in diameter; leaves with petioles $16-30 \mathrm{~mm}$. long and blades (6-)

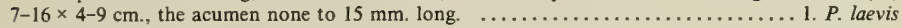

Inflorescences 10-20 cm. long and broad, the pedicel at anthesis $10-15 \mathrm{~mm}$. long (in fruit up to $20 \mathrm{~mm}$. long); calyx about $3 \times 3-4 \mathrm{~mm}$., the lobes $1.5-1.7 \mathrm{~mm}$. long and about $1 \mathrm{~mm}$. broad; corolla comparatively large, $16-18 \mathrm{~mm}$. long, the tube 4-6 mm. long, 2.5-3 mm. in diameter at base, contracted to $1-1.3 \mathrm{~mm}$. at throat, the lobes ovate-lanceolate, $11.5-12.5 \times 2.5-3 \mathrm{~mm}$; filaments 5-6 mm. long, the anthers 3-4 $\mathrm{mm}$. long; mature mericarps $18-20 \mathrm{~cm}$. long, about $10 \mathrm{~mm}$. in diameter; leaves with petioles $20-40 \mathrm{~mm}$. long and blades $8-14 \times 3-6 \mathrm{~cm}$, the acumen $5-20 \mathrm{~mm}$. long. . . . . . . . . . . . . . . 2. Pithi

1. Parsonsia laevis (A. Gray) Markgraf in Bishop Mus. Bull. 141: 130. 1936; A. C. Sm. in J. Arnold Arb. 36: 287. 1955; J. W. Parham, Pl. Fiji Isl. 185. 1964, ed. 2. 262. 1972.

Figure 43A \& B.

Lyonsia laevis A. Gray in Proc. Amer. Acad. Arts 5: 333. 1862; Seem. Viti, 439. 1862, Fl. Vit. 160. 1866; Drake, IIl. Fl. Ins. Mar. Pac. 235. 1892.

Parsonsia neo-ebudica Guillaumin in J. Arnold Arb. 13: 20. 1932.

An infrequent liana, with copious white latex, occurring at elevations of $50-520 \mathrm{~m}$. in dry forest. The corolla is pale green. Flowers have been obtained in August and December (and from the undated type collection, which also bears fruits).

TyPification AND NOMENClature: The type of Lyonsia laevis is $U$. S. Expl. Exped. (US 84627 HOLOTYPE; ISOTYPE at GH; fragmentary ISOTYPE at K), collected in 1840 in Fiji without definite locality. Parsonsia neo-ebudica is based on Kajewski 396 (A HOLOTYPE; ISOTYPES at BISH, P), collected June 8, 1928, at Dillon Bay, Eromanga, New Hebrides. In proposing this taxon Guillaumin did not compare it with Gray's species, with which it appears essentially identical. Another collection from Eromanga is Raynal RSNH 16232 (BISH, K, P).

Distribution: New Hebrides and Fiji, where it is definitely known only from Viti Levu.

LOCAL NAME AND USE: In Naitasiri the name wa sailele has been recorded, and there the latex is used as a chewing gum by children.

AVAilable COLLections: VITI LEVU: SeRuA: Hills between Waininggere and Waisese Creeks, between Ngaloa and Wainiyambia, Smith 9644. NAITASIRI: Wainamo Creek, near Matawailevu, Wainimala Valley, St. John 18247.

2. Parsonsia smithii Markgraf in Bishop Mus. Bull. 141: 130. fig. 66, d. 1936; A. C. Sm. in J. Arnold Arb. 36: 287. 1955; J. W. Parham, PI. Fiji Isl. 185. 1964, ed. 2. 262. 1972.

Figures $43 \mathrm{C}-\mathrm{E}, 44$.

An infrequent liana, with white latex, known from near sea level to $840 \mathrm{~m}$. in patches of forest in open country or in crest thickets. The corolla is white, with the tube greenish, but becomes brown in drying. Flowers have been collected in April and July, fruits in December.

TyPification: The type is Smith 1664 (BISH HOLOTYPE; ISOTYPES at K, NY, US), collected April 27, 1934, on the summit of Navotuvotu, Mt. Seatura, Mbua Province, Vanua Levu.

Figure 44. Parsonsia smithii; A, longitudinal section of mature flower with 2 calyx lobes and 2 corolla segments removed, showing disk lobes, filaments, and anthers, $\times 6 ; \mathrm{B}, 3$ anthers connivent around style head, $\times 20$; C, 2 fruits, each with 2 mericarps separating at maturity, $\times 1 / 2 ;$ D, seed, $\times 2$. A \& B from Smith 1664, C \& D from Smilh 6814 . 
Distribution: Endemic to Fiji and thus far known from only three collections from Vanua Levu.

Available collections: VANUA LEVU: Mathuata: Ndreketi River, DA 13454; Seanggangga Plateau, in drainage of Korovuli River, vicinity of Natua, Smith 6814.

\section{FAMILy 166. ASCLEPIADACEAE}

Asclepiadaceae R. Br. Asclepiadeae, 8, as Asclepiadeae. 1810 (preprint from Mem. Wern. Nat. Hist. Soc. 1: 19. 1811).

Perennial herbs or scrambling shrubs or herbaceous vines or lianas, seldom erect shrubs or trees, sometimes succulent, with a well-developed system of laticifers, estipulate or with vestigial stipules; leaves usually opposite, sometimes verticillate, rarely alternate, simple, the blades usually entire, rarely lobed or dentate, pinnatenerved; inflorescences cymose, often umbelliform, infrequently racemose or paniculiform, the flowers $\Varangle$, infrequently functionally unisexual, actinomorphic and usually 5 -merous (except for gynoecium), specialized for mass-transfer of pollen by insects; calyx deeply lobed, sometimes glandular at base within, the lobes imbricate or valvate, often reflexed; corolla sympetalous, rotate to campanulate or hypocrateriform, the tube short to elongate, the throat sometimes with an annulus of distinct or connate scales, the lobes convolute or imbricate or valvate, often spreading or reflexed; stamens borne on corolla tube usually toward base, the filaments connate or contiguous around style and adherent to it (in our genera) or distinct, the anthers coherent or connate, basifixed, introrse, dehiscing longitudinally or apically, adherent to thickened style head, the combined filaments, anthers, and style forming (in all our genera) a central column (gynostegium); corona often well developed, composed of appendages arising from filaments, an additional set of appendages sometimes arising from dorsal or apical parts of anthers; pollen grains (in subfam. Asclepiadoideae) coherent into pollinia (these 1 or rarely 2 in each anther theca), the pollinia attached to translators, these acellular structures consisting of arms (retinacula or caudicles) joined by a 2-parted "gland" (corpusculum), each arm of a translator attaching to pollinia of adjoining thecae of 2 anthers (in subfam. Periplocoideae the pollen tetrads loosely coherent and the translator arms concave); disk lacking; gynoecium bicarpellate, the ovaries separate, unilocular, superior or slightly sunken into receptacle, with distinct styles united by the common style head, the ovules 1-many on marginal placentae, anatropous, often pendulous, the style head thickened and with longitudinal stigmatic surfaces alternating with anthers; fruit a follicetum of 2 separate follicles (often only 1 developing), the seeds usually flattened and with a terminal coma of long hairs, the embryo straight, the endosperm scanty.

Distribution: Pantropical and subtropical, extending into temperate areas, with about 250 genera and 2,000 or more species. In Fiji three genera have indigenous species and three others are represented only by cultivated or naturalized species. All of our taxa fall into subfam. Asclepiadoideae, with a well-developed translator-pollinium mechanism and pollinia solitary in each anther theca.

USeful treatments of Family: BaCkeR, C. A., \& R. C. BaKhuizen VAn den Brink, JR. Asclepiadaceae. Fl. Java 2: 244-274. 1965. Huber, H. Asclepiadaceae. In: Dassanayake, M. D., \& F. R. Fosberg(eds.). Rev. Handb. Fl. Ceylon 4: 73-124. 1983.

KEY TO GENERA

Pollen in basal part of anthers, the pollinia suspended from translator arms; anther thecae dehiscing apically by pores or clefts; cultivated or naturalized taxa.

Perennial herbs; corona scales hood-shaped, each lacking a dorsal spur but with an incurved, hornlike appendage; corolla of our species red, $1-1.5 \mathrm{~cm}$. in diameter; leaf blades of our species oblonglanceolate, acute at base and apex, pilose only on nerves beneath, about 5-15 $\times 1-3 \mathrm{~cm}$. 
Erect shrubs; corona scales laterally compressed, each with a revolute, dorsal spur; corolla of our species white or pale lavender, $3-4.5 \mathrm{~cm}$. in diameter; leaf blades of our species oblong to oblong-obovate, cordate at base and obtuse at apex, white-pilose on both surfaces when young, often persistently tomentose beneath, usually $12-16 \times 6-10 \mathrm{~cm} . \ldots \ldots \ldots \ldots \ldots \ldots \ldots \ldots \ldots \ldots \ldots \ldots \ldots \ldots \ldots$ Calotropis

Pollen in apical part of anthers, the pollinia erect or suberect from translator arms; anthers with terminal appendages, dehiscing by longitudinal clefts.

Corolla infundibular, the tube inflated at base, the lobes shorter than tube, dextrorsely contorted in bud; follicles ellipsoid or ovoid, in our species at least half as broad as long, our species a cultivated

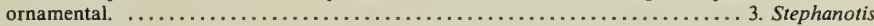

Corolla subrotate to campanulate-subrotate (or urceolate), the lobes (in our taxa) longer than tube, narrowly imbricate or valvate in bud; follicles ovoid to slenderly fusiform, much longer than broad.

Lobes of corolla narrowly dextrorsely imbricate in bud; anthers thickened or spurred dorsally, but without elongate, spreading appendages; indigenous taxa.

Leaf blades comparatively thin in texture, usually 1.5-3 times longer than broad; corolla glabrous; distal anther appendages not or sparsely glandular; follicles ovoid to fusiform, those of our species 5-18 mm. broad at maturity, the seeds comose with hairs 20-25 mm. long; perennial

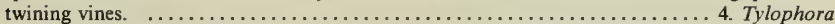

Leaf blades narrowly lanceolate, 15 or more times longer than broad, appearing linear because of strongly revolute margins; corolla lobes villose within; distal anther appendages copiously opaque-glandular; follicles narrowly fusiform, those of our species 3-4 mm. broad at maturity, the seeds comose with hairs 5-10 mm. long; our species a sclerophyllous shrub.

5. Leichardtia

Lobes of corolla valvate in bud; anthers with conspicuously spreading dorsal appendages (corona lobes); perennial twining vines or climbing shrubs, often with carnose (sometimes chartaceous or coriaceous) leaf blades; indigenous or cultivated or naturalized taxa. ........... 6. Hoya

\section{Asclepias L. Sp. Pl. 214. 1753.}

Perennial lactiferous herbs, sometimes woody at base; leaves with short petioles and herbaceous blades; inflorescences pedunculate, umbelliform cymes, borne between petioles of a pair of leaves; calyx deeply lobed, with 5-10 basal glands within, the lobes acute; corolla deeply lobed, the lobes valvate in bud, becoming spreading or reflexed; corona composed of 5 scales borne on staminal tube, each scale erect, hood-shaped, and with an incurved, hornlike appendage; filaments connate into a tube, the anthers each with an incurved, apical membrane, each theca with a pendulous, obovoid, compressed pollinium; ovaries with numerous ovules, the style head 5-angled; follicles of fruit slender, acuminate, the seeds flat, with long apical comas.

LeCtoTYPe SPECIES: Asclepias syriaca L. (vide Hitchcock, Prop. Brit. Bot. 136. 1929), one of the 18 species originally included by Linnaeus.

Distribution: America, with about 120 species, one of which, as in Fiji, has become an adventive throughout tropical and subtropical areas.

1. Asclepias curassavica L. Sp. Pl. 215. 1753; Seem. Fl. Vit. 161. 1866; Reinecke in Bot. Jahrb. 25: 668. 1898; Gibbs in J. Linn. Soc. Bot. 39: 157. 1909; Rechinger in Denkschr. Akad. Wiss. Wien 85: 159. 1910; Guillaumin in J. Arnold Arb. 13: 20. 1932; Christophersen in Bishop Mus. Bull. 128: 186. 1935; Greenwood in Proc. Linn. Soc. 154: 100. 1943; Yuncker in Bishop Mus. Bull. 220: 222. 1959; J. W. Parham in Dept. Agr. Fiji Bull. 35: 101. fig. 50. 1959, Pl. Fiji Isl. 186. 1964, ed. 2. 263. 1972; St. John \& A. C. Sm. in Pacific Sci. 25: 338. 1971; B. E. V. Parham in New Zealand Dept. Sci. Indust. Res. Inform. Ser. 85: 41, 100, 150. 1972; MacKee, Pl. Intro. Cult. Nouv.-Caléd. 20. 1985; Morat \& Veillon in Bull. Mus. Nat. Hist. Nat. (Paris) IV. 7, sect. B, Adansonia 3: 302. 1985.

In Fiji Asclepias curassavica is seen as a coarse herb to $1.5 \mathrm{~m}$. high from near sea level to about $900 \mathrm{~m}$., locally frequent along roadsides, in open fields, and in coconut plantations. Its flowers have red corollas and bright yellow or orange corona scales; the mature follicles are $5-10 \mathrm{~cm}$. long and $1-1.5 \mathrm{~cm}$. in diameter, and the seeds are $5-7 \mathrm{~mm}$. long, with coma hairs usually $2-2.7 \mathrm{~cm}$. long. Flowers and fruits occur throughout the year. 
TYPIFICATION: Linnaeus cited several prior references and indicated the habitat as Curacao.

Distribution: A native of tropical America, now a widespread weed. Seemann (1866) mentioned the species from the New Hebrides, Tonga, and the Societies, but not from Fiji; the earliest Fijian specimen I have noted is Gibbs 592, collected in 1907, but this now abundant weed was doubtless established in Fiji before that. It was listed in Thurston's (1886) Catalogue and may have been introduced as an ornamental by him. More than 30 specimens have been examined from five islands, but the species is to be seen on most inhabited islands.

LOCAL NAMES AND USES: The milkweed or butterfly weed is also locally known as false ipecacuanha, wathiwathi, vu ni lolia, and madhar (Hindi). Although presumably introduced as an ornamental, it is now considered a weed and is said to be poisonous to stock.

RePresentative Collections: VITI LEVU: MBA: Lautoka, Greenwood 198; Nalotawa, eastern base of Mt. Evans Range, Smith 4318; Nandarivatu, Gibbs 592. NandRonga \& NavosA: Nathotholevu, near Singatoka, H. B. R. Parham 110. TaIlevu: Waimaro River, DA 7698. RewA: Suva, Tothill 606. VANUA LEVU: ThaKaundrove: Namawa Estate, east of Savusavu, DA 88I7. TAVEUNI: Nggathavula Estate, DA 8882. TOTOYA: DA 13247. LAKEMBA: Near Tumbou, Garnock-Jones 891 .

2. Calotropis R. Br. Asclepiadeae, 28. 1810 (preprint from Mem. Wern. Nat. Hist. Soc. 1: 39. 1811).

Erect shrubs with milky latex; leaves short-petiolate; inflorescences cymose, many-flowered, pedunculate, borne between petioles of a pair of leaves; calyx deeply lobed, with many basal glands within; corolla campanulate-rotate, deeply lobed, the lobes slightly imbricate in bud; corona composed of 5 scales inserted on staminal tube, these carnose, laterally compressed, each with a revolute dorsal spur at base; stamens with connate filaments, the anther connectives with incurved apical membranes, the thecae each with a pendulous, obliquely obovoid-oblong pollinium; style head slightly convex; fruits with ovoid-oblong follicles, these oblique at base and acuminate, the seeds comose.

TYPE SPECIES: Calotropis procera (Ait.) Ait. f. (Asclepias procera Ait.).

Distribution: Tropical Asia and Africa, with six or fewer species, one. of which is sparingly cultivated and naturalized in Fiji.

1. Calotropis gigantea (L.) Ait. f. Hort. Kew. ed. 2. 2: 78. 1811; Merr. Interpret.

Rumph. Herb. Amb. 434. 1917; J. W. Parham, Pl. Fiji Isl. 186. 1964, ed. 2. 263.

1972; Sykes in New Zealand Dept. Sci. Indust. Res. Bull. 200: 48.1970.

Asclepias gigantea L. Sp. Pl. 214. 1753.

Shrub 1-5 m. high, cultivated or sparingly naturalized in open places near sea level. The fragrant flowers have the corolla white to pale lavender; the mature follicles are $7-10 \mathrm{~cm}$. long and $2.5-4 \mathrm{~cm}$. in diameter, and the seeds are $5-7 \mathrm{~mm}$. long, with coma hairs usually 3-6 cm. long. Flowers have been noted in Fiji in July and September.

TyPIFICATION: Several earlier references were listed by Linnaeus.

Distribution: Indigenous in India and southeastern Asia, now widely cultivated and often naturalized elsewhere.

LOCAL NAME AND USE: The crown flower is grown as an ornamental in Fiji, but elsewhere the bark provides a fiber and the seed comas a kapoklike floss.

Available Collections: VITI LEVU: MbA: Tavua, DA 5677. OVALAU: Levuka, DA 12172 (L.8255). 
3. Stephanotis Thou. Gen. Nova Madagasc. 11. 1806; Brongn. in Ann. Sci. Nat. Bot. II. $7: 30.1837$.

Glabrous twining shrubs, the leaves opposite; inflorescences pedunculate umbelliform cymes, borne between petioles of a pair of leaves; calyx deeply 5-lobed, lacking glands within, the lobes ovate; corolla infundibular, carnose, the tube elongate, inflated at base, slightly broadened at apex, the lobes (sometimes 6) shorter than tube, dextrorsely contorted; gynostegium short, borne in basal swelling of corolla tube; corona composed of scales borne on staminal tube near its base, these dorsally compressed, each with a free, deltoid, membranous, apical appendage appressed to anther; filaments connate, the connective with an erect, apical membrane, the pollinia erect, the caudicles short; style head conical, scarcely exceeding corona scales; follicles ellipsoid or ovoid, the seeds comose.

LECTOTYPE SPECIES: In reconsidering the genus in 1837 Brongniart described three species, two of them (Stephanotis thouarsii and S. acuminata) on the basis of material available to Du Petit-Thouars. Either of these could presumably serve as the lectotype, but ING (1979) lists $S$. acuminata Brongn. as the type species without providing a reference to the selection.

Distribution: Madagascar, with about five species, at least one of which is now widely cultivated in tropical and subtropical areas.

1. Stephanotis floribunda Brongn. in Ann. Sci. Nat. Bot. II. 7: 30. 1837; Yuncker in Bishop Mus. Bull. 178: 98. 1943; J. W. Parham, Pl. Fiji Isl. 186. 1964, ed. 2. 264. 1972; Sykes in New Zealand Dept. Sci. Indust. Res. Bull. 200: 48. 1970; MacKee, Pl. Intro. Cult. Nouv.-Caléd. 21. 1985.

A twining shrub, cultivated near sea level; leaf blades thick-carnose to subcoriaceous, oblong-elliptic, usually 5-10 $\times 4-6 \mathrm{~cm}$., obtuse at apex; flowers fragrant, especially at night, the corolla waxy-white, the tube $2.5-3 \mathrm{~cm}$. long, pink-tinged or basally greenish, the lobes ovate, spreading, usually 1.5-2 × 1.2-1.6 cm.; follicles ovoidellipsoid, $8-15 \times 5-10 \mathrm{~cm}$.

TYPIFICATION: Brongniart based his species on a plant cultivated in the Botanical Garden of Paris, said to have been sent from La Réunion under the unpublished name Asclepias odoratissima and to have come originally from Madagascar.

Distribution: Madagascar, but now widely cultivated. It was probably introduced into Fiji by J. B. Thurston, being listed in his 1886 Catalogue. Although no herbarium material from Fiji has been noted, the vine is commonly cultivated in Suva and doubtless elsewhere.

LOCAL NAME AND USE: An attractive ornamental known locally as stephanotis.

4. Tylophora R. Br. Asclepiadeae, 17. 1810 (preprint from Mem. Wern. Nat. Hist.

Soc. 1: 28. 1811); Seem. Fl. Vit. 161. 1866; A. C. Sm. in Brittonia 27: 154. 1975.

Gymnema sensu Seem. Fl. Vit. 162, p. p. 1866; A. C. Sm. in J. Arnold Arb. 36: 287, p. p. 1955; non R. Br.

Perennial twining vines; leaves opposite, with slender, canaliculate petioles, the blades usually papyraceous; inflorescences pedunculate, simply or compound umbelliform-cymose, borne between petioles of a pair of leaves; calyx campanulatesubrotate, membranaceous, deeply lobed, the sinuses between lobes (often obscurely) glandular within; corolla subrotate, glabrous, the tube short, the lobes narrowly dextrorsely imbricate in bud and eventually subvalvate; stamens with short, connate filaments, the anthers erect, often dorsally thickened proximally or antrorsely spurred, laterally free or connate, distally fused to style head and with membranaceous, imbricate, rounded, cucullate appendages, these proximally thickened within, the thickenings laterally concave and each sheltering a pollinium on each margin; translators with short, slender, curved caudicles, the pollinia erect, attached laterally or 
basally to caudicles; style head pentagonal, carnose, thickened in center, marginally membranaceous; follicles ovoid to slenderly fusiform, the seeds flattened, ovate, truncate at apex, copiously comose.

LECTOTYPE SPECIES: Tylophora flexuosa R. Br. (vide Bullock in Kew Bull. 1954: 580. 1955).

Distribution: Paleotropical, including southern Africa, and extending eastward in the Pacific to Tonga and Samoa, with about 50 species, four of which are indigenous in Fiji.

USEful treatment of Genus: Smith, A. C. Tylophora R. Br. Brittonia 27: 154-164. 1975.

KEY TO SPECIES

Leaf blades ovate to ovate-elliptic, less than twice as long as broad, usually $4-13 \times 2.5-8.5 \mathrm{~cm}$; inflorescences 2-9 cm. long at anthesis, consisting of ( 1 or) 2-4 racemiform umbels borne laterally on a fractiflex axis; pedicels often comparatively elongate, $4-23 \mathrm{~mm}$. long at anthesis; gynostegium oblong, not conspicuously narrowed at base of anthers; pollinia attached to caudicles laterally, sometimes near base.

Flowers comparatively large, the corolla $9-13 \mathrm{~mm}$. in diameter at anthesis, the lobes 5-6 $\times 3-3.5 \mathrm{~mm}$.; gynostegium with anthers dorsally swollen proximally and angled distally but not spurred; leaf blades ovate or ovate-elliptic, usually $4-9 \times 2.5-6 \mathrm{~cm}$., broadly obtuse to rounded or subcordate at base, mucronulate-acuminate (acumen 1-3 mm. long) to rounded or subretuse at apex, with none of the secondary nerves strictly basal; follicles $3-9.5 \mathrm{~cm}$. long, 5-12 mm. in diameter, the seeds 6-7 mm.

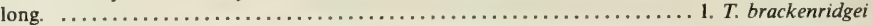

Flowers comparatively small, the corolla 4-10 mm. in diameter at anthesis, the lobes $2-3.5 \times 1.2-2.7 \mathrm{~mm}$; gynostegium with anthers dorsally spurred, the spurs conspicuously antrorse; leaf blades broadly ovate, usually $5.5-13 \times 3.5-8.5 \mathrm{~cm}$, conspicuously cordate to subcordate at base, caudate-acuminate at apex (acumen 10-15 $\mathrm{mm}$. long), with the 2 lower pairs of secondary nerves essentially basal; follicles to $25 \mathrm{~cm}$. long, 10-13 mm. in diameter, the seeds $11-14 \mathrm{~mm}$. long. . . 2. T. samoensis

Leaf blades oblong- to ovate-lanceolate, 2-3 times as long as broad, usually $5-8.5 \times 1.5-3.5 \mathrm{~cm}$; inflorescences 1-2 cm. long at anthesis, consisting of a simple congested-racemiform umbel or 2 or 3 such umbels borne together at apex of peduncle; pedicels comparatively short, 3-6 mm. long at anthesis; gynostegium narrowed at base of anthers; pollinia attached to caudicles basally.

Flowers comparatively small; calyx $2-2.5 \mathrm{~mm}$. in diameter at anthesis, the lobes ovate, $0.6-0.9 \mathrm{~mm}$. long and broad; corolla $4-4.5 \mathrm{~mm}$. in diameter at anthesis, the lobes oblong, $1.8-2.2 \times 1-1.5 \mathrm{~mm}$., inconspicuously nerved; umbels 1-3 at apex of peduncle, each with (8-) 25-30 flowers.

3. $T$. subnuda

Flowers comparatively large; calyx 4-6 mm. in diameter at anthesis, the lobes elliptic, $2.2-3 \times 1.5-2.3$ $\mathrm{mm}$.; corolla $10-13 \mathrm{~mm}$. in diameter at anthesis, the lobes elliptic, 5.5-6 $\times 3-3.5 \mathrm{~mm}$., with conspicuous venation; umbels simple, with $3-8$ flowers. $\ldots \ldots \ldots \ldots \ldots \ldots \ldots$..$\ldots \ldots$. venulosa

1. Tylophora brackenridgei A. Gray in Proc. Amer. Acad. Arts 5: 334.1862; Seem. Viti, 439. 1862, Fl. Vit. 162. 1866; Drake, Ill. Fl. Ins. Mar. Pac. 236. 1892; Greenwood in Proc. Linn. Soc. 154: 100. 1943; J. W. Parham, Pl. Fiji Isl. 186. 1964, ed. 2. 264. 1972; A. C. Sm. in Brittonia 27: 157. fig. 13-18. 1975.

Figure 45A.

A slender, climbing vine, sometimes copiously sprawling over other vegetation in beach thickets or dry or open forest from near sea level to about $200 \mathrm{~m}$. The corolla is yellow to greenish; the follicles, as far as noted, are green, with dark brown seeds comose with silvery hairs. Flowers have been noted between April and December, fruits in July and December.

TyPification: The type, $U$. S. Expl. Exped. (Us 62245 holotyPE; fragmentary ISOTYPE at GH), was obtained in 1840 on Ovalau.

Distribution: Endemic to Fiji and thus far known only from Viti Levu and Ovalau; from the latter island only the type has been recorded.

Available collections: VITI LEVU: MBA: Lautoka, Greenwood 722; north of Lomolomo, south of Lautoka, Degener \& Ordonez 13716; north of Natalau, south of Lautoka, Degener 15002; Vatia, west of Tavua, Degener 14972; Vatia Point, DA 13574. Nandronga \& Navosa: Thuvu, west of Singatoka, Greenwood 243, 722B; Vatukarasa, DA 9285 (McKee 2855). RA; Ellington, Greenwood 722A; Waindawa, vicinity of Rewasa, near Vaileka, Degener 15517. 

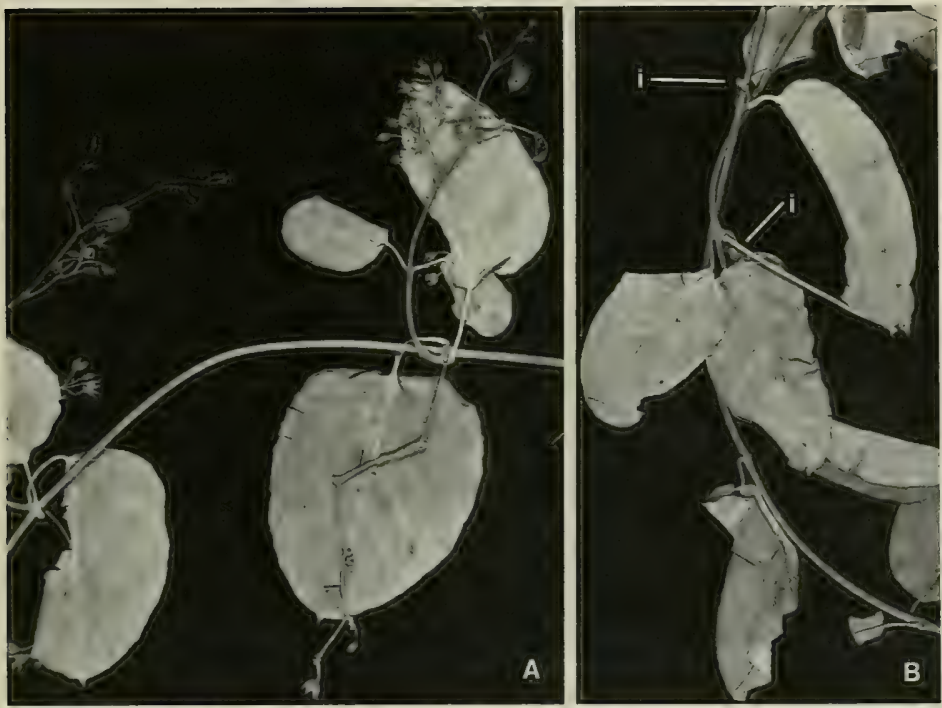

Figure 45. A, Tylophora brackenridgei; portion of stem with foliage and racemiform umbels borne on fractiflex axes, $\times 1 / 2$. B, Tylophora subnudum; portion of stem with foliage and simpler inflorescences (i), most flowers fallen, x 1/2. A from $D A$ 13574, B from Gillespie, Dec. 5, 1927.

2. Tylophora samoensis A. Gray in Proc. Amer. Acad. Arts 5: 334. 1862; Seem. Fl. Vit. 162. 1866; Drake, Ill. Fl. Ins. Mar. Pac. 236. 1892; Reinecke in Bot. Jahrb. 25: 668. 1898; Rechinger in Denkschr. Akad. Wiss. Wien 85: 332. 1910; Christophersen in Bishop Mus. Bull. 128: 186. 1935; A. C. Sm. in Brittonia 27: 159. fig. 19-24. 1975.

Tylophora samoensis Schlechter in Bot. Jahrb. 40: Beibl. 92: 4. 1908; non A. Gray.

Tylophora powellii Hochr. in Candollea 6: 476. 1936.

Tylophora brackenridgei sensu Yuncker in Bishop Mus. Bull. 220: 223. 1959; non A. Gray.

A climbing vine, infrequent in Fiji at elevations up to about $850 \mathrm{~m}$. (in Samoa known from thickets and open forest); the corolla lobes are yellowish. The only dated Fijian collection was flowering in December.

TyPifiCATION AND NOMENClatURE: The type of Gray's species is $U$. S. Expl. Exped. (US 62244 HOLOTYPE; ISOTYPE at NY), collected on Savai'i without further locality, Samoa. Tylophora samoensis Schlechter (a new species, Schlechter having overlooked the Gray binomial) was based on Betche 38 and Powell $33 g$, presumably deposited at B and now destroyed. I have not seen duplicates of those syntypes, but Schlechter's description fits Gray's species perfectly. Tylophora powellii was proposed as a new name to replace Schlechter's later homonym.

Distribution: Samoa (Savai'i and Upolu), Tonga ('Eua), and Fiji. The species is rare in Fiji, known from one montane collection and one without locality (but probably not coastal like the preceding species). Seemann mentioned the species only as a Samoan endemic.

AVAIlable collections: VITI LEVU: MBA: Vicinity of Nandarivatu, Gillespie 4172. FiJI without further locality, Storck $X I V$. 
3. Tylophora subnuda (A. Gray) A. C. Sm. in Brittonia 27: 160. fig. 25-30. 1975.

FIGURE 45B.

Gimnema subnudum A. Gray in Proc. Amer. Acad. Arts 5: 335, as G. subundum, sphalm. 1862; Seem. Viti, 439. 1862, Fl. Vit. 162. 1866; Drake, Ill. Fl. Ins. Mar. Pac. 236. 1892; A. C. Sm. in J. Arnold Arb. 36: 287. 1955; J. W. Parham, Pl. Fiji Isl. 186. 1964, ed. 2. 263. 1972; St. John \& A. C. Sm. in Pacific Sci. 25: 338. 1971; Morat \& Veillon in Bull. Mus. Nat. Hist. Nat. (Paris) IV. 7, sect. B, Adansonia 3: 302. 1985.

A climbing vine, infrequent at elevations from perhaps 600 to $1,050 \mathrm{~m}$. (but littoral in the Horne Islands), probably from upland thickets and ridges in Fiji. Flowering specimens are dated November, December, and February.

Typification: The type is $U$. S. Expl. Exped. (US 63574 holotype), collected in 1840 in mountains (probably Mathuata Range) of Mathuata Province, Vanua Levu.

Distribution: Fiji (known only from the type from Vanua Levu and from upland Viti Levu) and Futuna, Horne Islands (from near sea level).

AVAILABLE COLlections: VITI LEVU: MBA: Vicinity of Nandarivatu, Tothill 610; Mt. Nanggaranambuluta, east of Nandarivatu, Gillespie 4070, Nov. 28, 1927. Virr Levu without further locality, Gillespie, Dec. 5 , 1927 (probably from same plant as Gillespie 4070).

4. Tylophora venulosa A. C. Sm. in Brittonia 27: 163. fig. 31-36. 1975.

A sprawling or climbing vine, inadequately known from open forest at an elevation of $800 \mathrm{~m}$. and from a rocky coastal habitat, the ccrolla yellow or greenish. Flowers have been obtained in February and March.

TyPIFICATION: The type is Degener 14508 (A HOLOTYPE; ISOTYPES at BISH, K, NY, US), collected Feb. 18, 1941, on Mt. Matomba, near Nandala, south of Nandarivatu, Mba Province, Viti Levu.

Distribution: Endemic to Fiji and known only from the type and a second collection from the northern part of the Lau Group.

Available COLlection: YATHATA: On coastal rocks, DA 15551.

5. Leichardtia R. Br. in Sturt, Exped. Centr. Austral. Bot. App. 81. 1849; Bullock in Kew Bull. 11: 287. 1956; A. C. Sm. in Brittonia 27: 152. 1975.

Gymnema sensu Seem. Fl. Vit. 162, p. p. 1866; A. C. Sm. in J. Arnold Arb. 36: 287, p. p. 1956; non R. Br.

Shrubs or slender, twining plants; leaves opposite, with coriaceous, narrowly lanceolate or linear blades; inflorescences umbelliform or congested-racemiform, borne between petioles of a pair of leaves; flowers as in Tylophora but the corolla sometimes urceolate and with the tube as long as or longer than lobes (but in our species campanulate-subrotate and with the tube shorter than lobes); pollinia erect, attached basally to very slender caudicles; our species a sclerophyllous shrub with narrow, sometimes tightly revolute leaf blades, the corolla lobes villose within, the anther appendages copiously opaque-glandular, and the follicles narrowly fusiform, the seeds comose with comparatively short hairs $5-10 \mathrm{~mm}$. long.

TYPE SPECIES: Leichardtia australis $\mathrm{R}$. Br.

Distribution: Australia, New Caledonia, and with a disjunct Fijian endemic, with about six species.

Although Brown's genus was named for F. W. L. Leichhardt, Bullock (1956) considered the original spelling (with a single "h") deliberate, and that spelling is adopted by ING (1979). However, Brown proposed his only species as Leichhardtia australis (at least in the Ray Society Misc. Bot. Works of Robert Brown; I have not seen the original), which suggests that the first spelling may have been a typographic error; nevertheless, it is here maintained. 

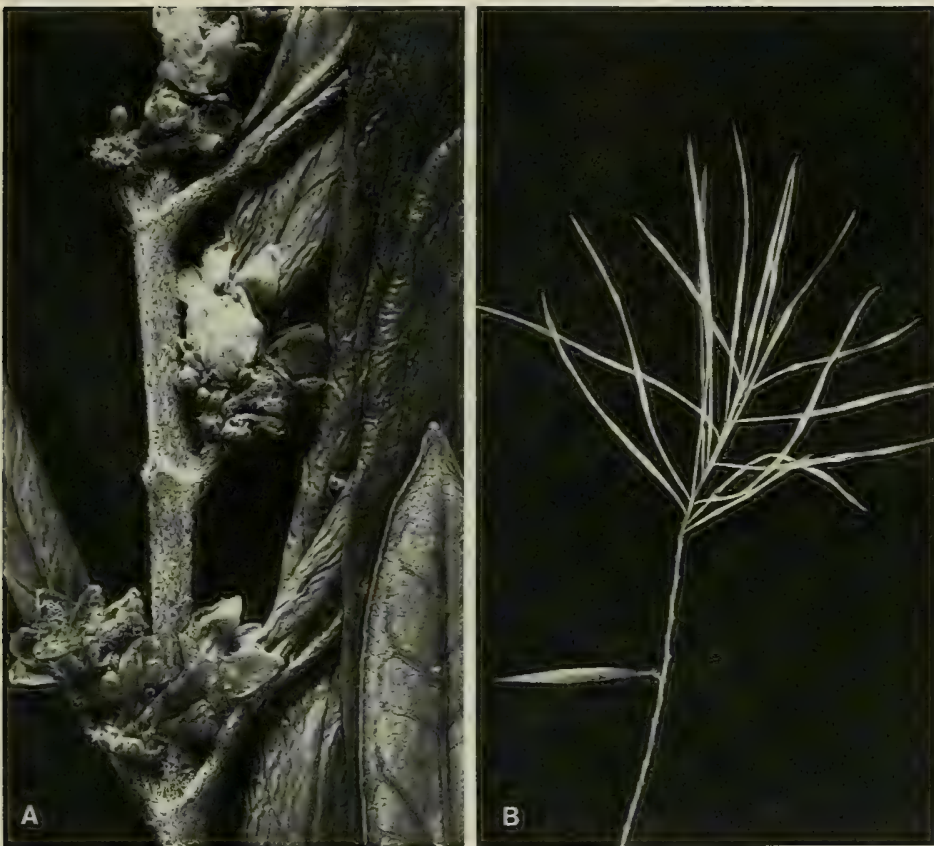

Figure 46. Leichardtia stenophylla; A, inflorescences and foliage, $\times 4$; B, distal portion of branchlet, with foliage and a fruit with a single follicle, $\times 1 / 2$. A from St. John 18032, B from Smith 6802.

1. Leichardtia stenophylla (A. Gray) A. C. Sm. in Brittonia 27: 152. fig. 1-6. 1975.

Figure 46.

Asclepiadearum (gen. nov.) Seem. in Bonplandia 9: 257. 1861.

Gymnema stenophyllum A. Gray in Proc. Amer. Acad. Arts 5: 335. (Jan.) 1862, in Bonplandia $10: 37$. (Feb.) 1862; Seem. Viti, 439. 1862, Fl, Vit. 162. t. 31. 1866; Drake, Ill. Fl. Ins. Mar. Pac. 236. 1892; K. Schum. in Engl. \& Prantl, Nat. Pflanzenfam. IV. 2: 284. fig. 85, D, E. 1895; A. C. Sm. in J. Arnold Arb. 36: 287. 1955; J. W. Parham, Pl. Fiji Isl. 186. 1964, ed. 2. 263. 1972.

Shrub 1-2 m. high, with white latex, occurring at elevations between about 60 and $250 \mathrm{~m}$. in dry thickets (talasinga), in thin forest on cliffs, and on sunny ledges. Dated collections have flowers borne in July and October, fruits in those months and also in December.

TyPIFICATION: The type is $U$. S. Expl. Exped. (us 63573 HOLOTYPE; ISOTYPES at GH, NY), collected in 1840 in Mathuata Province ("on barren upland"), Vanua Levu.

Distribution: Endemic to Fiji and known definitely only from northern Vanua Levu and one of the Yasawa Islands.

LOCAL NAMES: Yauyau (Vanua Levu), langaingai (Waya).

AVAilable Collections: YASAWAS: WAYA: Naruarua Gulch, west side of Mbatinaremba, St. John 18032. VANUA LEVU: MBUA or Mathuata: Between Nasarowangga and Ndreketi, DA 1089. MathuATA: Southern base of Mathuata Range, north of Natua, Smith 6802; dry hills of Mathuata coast, Greenwood 595. Mathuata without further locality, Seemann 322. Fiji without further locality, Horne 604, 669. 
6. Hoya R. Br. Asclepiadeae, 15. 1810 (preprint from Mem. Wern. Nat. Hist. Soc. 1: 26. 1811); Seem. Fl. Vit. 163. 1866; A. C. Sm. in Sargentia 1: 108. 1942.

Vines or shrubs, usually twining or climbing, sometimes epiphytic; leaves opposite, the blades chartaceous to carnose or coriaceous; inflorescences umbelliform to racemiform, borne between petioles of a pair of leaves; calyx deeply lobed, often with glands at base or at sinuses of lobes within; corolla often carnose, sometimes submembranaceous, subrotate or broadly cyathiform, the tube short, the lobes valvate in bud, becoming spreading, upwardly curved, or reflexed; corona lobes borne on staminal tube, carnose, often horizontally spreading, shallowly concave or flattened above, rounded or sulcate or bicarinate beneath; anthers with apical membranes, the pollinia erect, often unilaterally pellucid-margined; ovaries with short styles detached from style head soon after anthesis; follicles terete, the seeds comose.

TYPE SPECIES: Hoya carnosa (L. f.) R. Br. (Asclepias carnosa L. f.).

Distribution: Southern China, southern Japan, and southeastern Asia through Malesia to Australia, and eastward in the Pacific to Tonga and Samoa, with 100 or more species. Five species are recorded from Fiji, four of them indigenous.

Useful treatment of genus: Smith, A. C. Hoya R. Br. Sargentia 1: 108-113. 1942.

KEY TO SPECIES

Corolla 23-45 mm. in diameter, rich pink or purple, minutely and densely papillose-puberulent within, the lobes 7-13 $\times 10-14 \mathrm{~mm}$., the sinuses obtuse or flattened; lobes of corona 4-6 mm. long, shallowly concave above, rounded and deeply sulcate beneath; calyx lobes ovate-deltoid, 1.5-2.5 $\times 1.3-1.8 \mathrm{~mm}$., glabrous except at sometimes ciliolate margin; leaf blades subcoriaceous to papyraceous, elliptic-ovate, 4-10 $\times 1.8-4 \mathrm{~cm}$; occurring at elevations of $700-1,300 \mathrm{~m} . \ldots \ldots \ldots \ldots \ldots \ldots$. H. megalantha Corolla $11-20 \mathrm{~mm}$. in diameter, the lobes 4-8 mm. broad; lobes of corona $2-5 \mathrm{~mm}$. long.

Lobes of corona $2-3.5 \mathrm{~mm}$. long, concave above, inconspicuously bicarinate beneath; calyx lobes oblong-deltoid or lanceolate-oblong, longer than broad, $1.5-3 \mathrm{~mm}$. long, dorsally strigillose or conspicuously puberulent; corolla submembranaceous, white, purplish or reddish at base within, densely but minutely puberulent within, the lobes 6-7 $\times 4-5.5 \mathrm{~mm}$., the sinuses acute; leaf blades chartaceous or subcarnose, broadly elliptic or oblong or suborbicular, (3-) 5-13(-15) $\times 3-9 \mathrm{~cm}$., subcordate or rounded at base; indigenous, often in beach thickets or mangrove swamps but also in

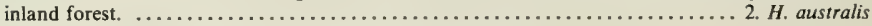

Lobes of corona 3-5 mm. long, flattened above, rounded and often deeply sulcate beneath; corolla copiously and conspicuously sericeous-puberulent within.

Calyx 5-7 mm. in diameter, conspicuously spreading-pilose without, the lobes deltoid to deltoidlanceolate, 2-3.5 $\times 1-2 \mathrm{~mm}$; corolla subcarnose, waxy-white, 12-17 mm. in diameter, the lobes broadly ovate, about $5 \mathrm{~mm}$. long, the sinuses acute; corona lobes pink-tinged or reddish; leaf blades thick-carnose, broadly or narrowly ovate to elliptic, $5-12 \times 2-5.5 \mathrm{~cm}$., rounded or shallowly cordate to obtuse at base; cultivated and sparingly naturalized near sea level. .... 3. H. carnosa

Calyx 3-4 mm. in diameter, glabrous except for ciliolate margins, the lobes deltoid or ovate-deltoid, inconspicuous, $0.7-1.7 \times 0.6-1.5 \mathrm{~mm}$; leaf blades carnose to chartaceous, elliptic to ovate- or oblong-elliptic, $3.5-11 \times(1.5-) 2-7 \mathrm{~cm}$.; indigenous species.

Corolla subcarnose, 16-20 mm. in diameter, purplish or reddish within, the lobes 5-7 $6-8 \mathrm{~mm}$., the sinuses obtuse; lobes of corona 4-5 mm. long; calyx lobes $1-1.7 \times 1.2-1.5 \mathrm{~mm}$; pedicels $22-40$ $\mathrm{mm}$. long; leaf blades (5-) 6-11 x (1.5-) 3-7 cm., with 4-7 spreading nerves per side.

4. H. vitiensis

Corolla submembranaceous, 11-16 mm. in diameter, yellow, the lobes 4-6 mm. long and broad, the sinuses acute; lobes of corona 3-4.2 mm. long; calyx lobes $0.7-1.5 \times 0.6-1 \mathrm{~mm}$; pedicels $8-20$ $\mathrm{mm}$. long; leaf blades $3.5-8 \times(1-) 2-3.2 \mathrm{~cm}$, with 3 or 4 secondary nerves per side, these ascending, oriented from costa toward base. ................... diptera

1. Hoya megalantha Turrill in J. Linn. Soc. Bot. 43: 33. 1915; A. C. Sm. in Sargentia 1: 109. 1942; J. W. Parham, PI. Fiji Isl. 186. 1964, ed. 2. 263. 1972. Figure 47.

Twining vine, climbing in dense forest or in crest thickets at elevations of about $700-1,300 \mathrm{~m}$. The large, cyathiform corolla is rich pink to deep purple, as are the calyx lobes. Flowers have been obtained in all months between December and June.

FIgURE 47. Hoya megalantha; A, portion of stem, with foliage and an inflorescence, $\times 1 / 2$; , calyx and ovaries, $\times 20$; C, proximal surface of corolla and calyx, $\times 4 ; \mathrm{D}$, distal surface of corolla and corona lobes, $\times 4$. A from Smith 863, B \& D from Gillespie 4815, C from Smith 1649. 

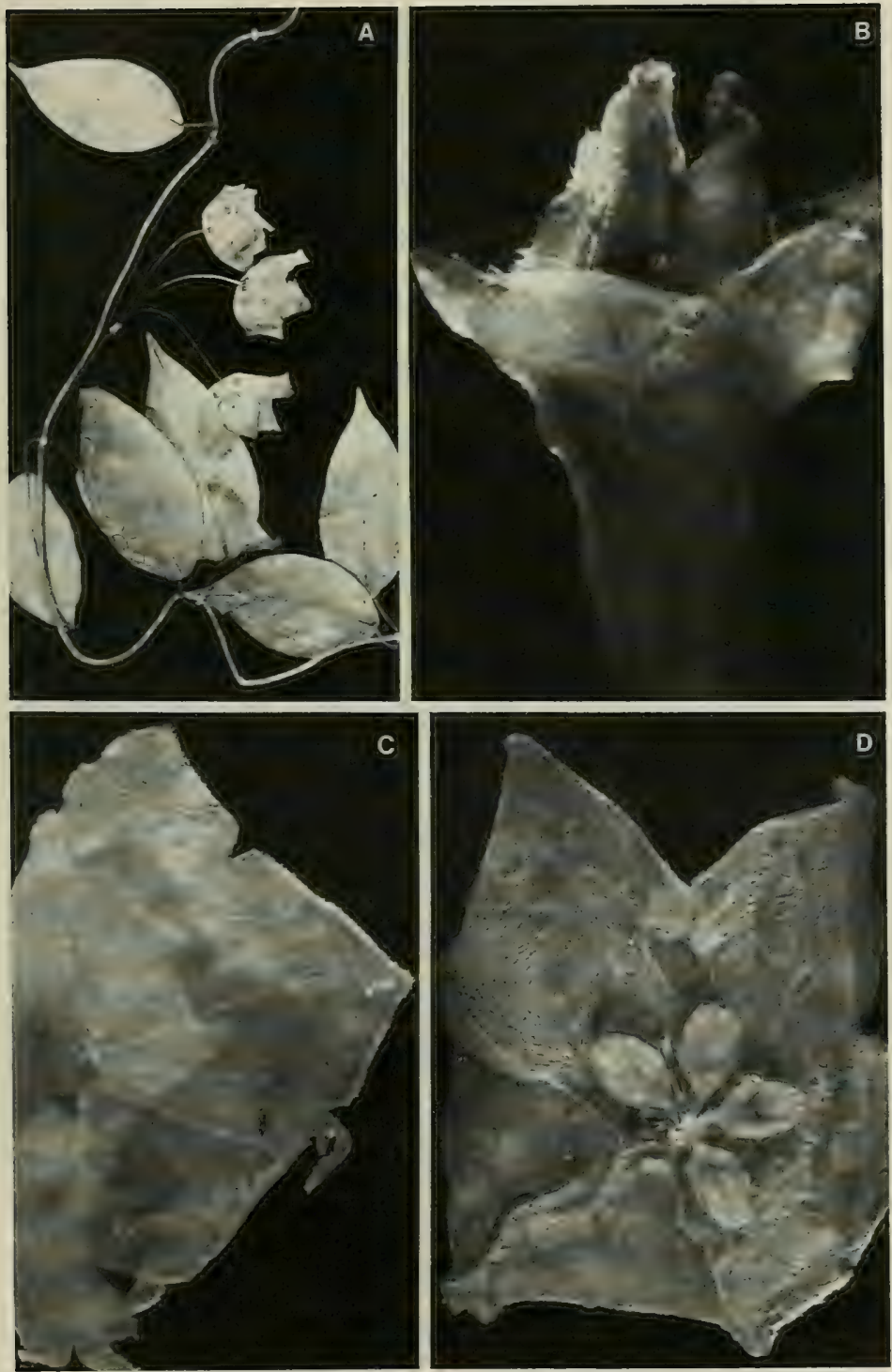
TYPIFICATION: The species is based on im Thurn F6 (K HOLOTYPE), composed of specimens from two localities: from Mt. Mbuke Levu, Kandavu, on April 4, 1905, and from Mt. Tomanivi, Mba Province, Viti Levu, on May 1, 1905. A note on the $\mathrm{K}$ sheet indicates that the two collections were carelessly mixed. Both parts bear flowers and it is not now possible to separate them; therefore the mixture must be taken as the holotype.

Distribution: Endemic to Fiji and known from four of the high islands.

LOCAL NAME: Ndraumbimbi (Taveuni).

Available Collections: VITI LEVU: Mba: Mt. Tomanivi, DA 7122, 12718 (Melville et al. 7107). Namosi: Track to Mt. Vakarongasiu, DA 17608. NaITASIRI: Between Navai and Nasonggo, DA 15302. VANUA LEVU: MrUa: Navotuvotu, summit of Mt. Seatura, Smith 1649. TAVEUNI: Mountain slopes east of Somosomo, Gillespie 4815, DA 17384; borders of lake east of Somosomo, Smith 863.

This upland endemic is the most striking and most distinct species of the genus in the Fijian Region; its large, richly colored flowers at once distinguish it.

2. Hoya australis R. Br. in Traill in Trans. Hort. Soc. London 7: 28. 1827; Gibbs in J. Linn. Soc. Bot. 39: 157. 1909; Turrill in op. cit. 43: 33. 1915; Setchell in Carnegie Inst. Wash. Publ. 341: 57. 1924; Guillaumin in J. Arnold Arb. 13: 21. 1932; A. C. Sm. in Sargentia 1: 110. 1942; Yuncker in Bishop Mus. Bull. 220: 223. 1959; J. W. Parham, Pl. Fiji Isl. 186. 1964, ed. 2. 263. 1972; St. John \& A. C. Sm. in Pacific Sci. 25: 338. 1971; B. E. V. Parham in New Zealand Dept. Sci. Indust. Res. Inform. Ser. 85: 40, 113. 1972; MacKee, Pl. Intro. Cult. Nouv.-Caléd. 21. 1985; Morat \& Veillon in Bull. Mus. Nat. Hist. Nat. (Paris) IV. 7, sect. B, Adansonia 3: 302. 1985.

Hoya billardieri sensu Seem. in Bonplandia 9: 257. 1861; non Dec.

Hoya bicarinata A. Gray in Proc. Amer. Acad. Arts 5: 335. (Jan.) 1862, in Bonplandia 10: 37. (Feb.) 1862; Seem. Viti, 439. 1862, Fl. Vit. 163, 1866; Drake, Ill. FI. Ins. Mar. Pac. 236. 1892; Reinecke in Bot. Jahrb. 25: 670. 1898; Christophersen in Bishop Mus. Bull. 128: 188. 1935; Yuncker in op. cit. 184: 58. 1945; B. E. V. Parham in New Zealand Dept. Sci. Indust. Res. Inform. Ser. 85: 96.1972.

Hoya pilosa Seem. in Bonplandia 9: 257, nom. nud. 1861; Seem, ex A. Gray in op. cit. 10: 37, nom. nud. 1862; Seem. Viti, 439, nom. nud. 1862, Fl. Vit. 163, nom. nud. 1866; Britten in J. Bot. 36: 417, 418, nom. nud. 1898

Hoya barracki Horne, A Year in Fiji, 263, nom. nud. 1881; Horne ex Baker in J. Linn. Soc. Bot. 20: 369, pro syn. 1883.

Hoya pubescens Reinecke in Bot. Jahrb. 25: 669. 1898.

A vine with copious white latex, found at elevations from near sea level (and there often locally frequent) to about $1,200 \mathrm{~m}$., occurring in beach thickets, on sea cliffs and rocky shores, on edges of mangrove swamps, and inland in open or dense forest. The fragrant flowers have the pedicels and calyx greenish white or pink-tinged, the corolla white with the center rich pink to red or purplish, and the corona lobes pure white. Flowers have been collected throughout the year, but the species appears to fruit most freely between October and December.

TYPIFICATION AND NOMENCLATURE: The type of Hoya australis (BM HOLOTYPE; photo at BISH) was collected by Banks and Solander in 1770, on Cook's first voyage, at Endeavour River (site of modern Cooktown), Queensland, Australia. For $\mathrm{H}$. bicarinata Gray listed "Samoan, Tonga, and Feejee Islands;" the only Exploring Expedition specimen at us unequivocally so identified in Gray's hand is $U$. S. Expl. Exped. (US 78372 LECTOTYPE here designated), collected in 1840 on Tongatapu, Tonga. The source of the nomen nudum $H$. pilosa is Seemann 321 (GH, K), obtained in Fiji without further locality in 1860. Hoya barracki, also undescribed, is based on Horne 1096 (K), collected 
in September, 1878, on Nawi Island (near Valethi), Savusavu Bay, Thakaundrove Province, Vanua Levu. The type of $H$. pubescens is Reinecke 220 (ISOTYPE at BISH), collected in January, 1894, above Apia, Upolu, Samoa. Many specimens of $H$. australis, perhaps those growing in the more exposed places, have a slight indument on stems and leaf blades; the type of $H$. pubescens and the voucher specimens for $H$. pilosa, among many others, demonstrate this character. Characters of the calyx (with elongate, pilose lobes), corolla, and corona appear quite uniform throughout the specific range.

Distribution: Northeastern Australia eastward to Tonga and Samoa, sometimes cultivated within this range as well as elsewhere. From Fiji I have examined 40 collections from ten islands, but the species no doubt occurs on many other islands.

LOCAL NAMES: Hoya australis in Fiji is most often noted as mbitimbiti, mbitambita, mbitumbitu, wa mbi, wa mbimbi, and ndraumbimbi; occasionally recorded names are nambetembete, nambetiambete, wa tambua, wa mbi levu, and mbulimbuli sewaro.

RePresentative Collections: YASAWAS: Waya: Nangua, St. John 18164. VITI LEVU: Mba: Mountains near Lautoka, Greenwood 81; Nandarivatu, im Thurn 296; slopes of Mt. Tomanivi, Gillespie 4096.1. SERUA: Hills between Navua River and Wainiyavu Creek, near Namuamua, Smith 8975; Ndeumba, $D A$ 8644. Namosi: Vicinity of Namosi, Gillespie 2523. NaITASIRI: Foot of Korolevu, north of Navuniyasi, Wainimala River, Gibbs 765. TAILEvU: Mburerua, Weiner 147; Namara, Seemann 319. ReWA: Queen's Road near Mile 7, Vaughan 3319. VITI LEVU and OVALAU: Seemann 319. KANDAVU: Namalata isthmus region, Smith 4. ONO (northeast of Kandavu): DA 14950. VANUA LEVU: MATHUATA: Nasolo, Ndreketi, DA 12955; southern base of Mathuata Range, north of Natua, Smith 6800. TAVEUNI: Vicinity of Waiyevo, Gillespie 4747; slopes of Mt. Manuka, east of Wairiki, Smith 8189. VANUA MBALAVU: Southern limestone section, Smith 1460. SOVU: Bryan 590. FULANGA: On limestone, Smith 1214. FiJI without further locality, U.S. Expl. Exped.

3. Hoya carnosa (L. f.) R. Br. Asclepiadeae, 16. 1810 (preprint from Mem. Wern. Nat. Hist. Soc. 1: 27. 1811); J. W. Parham, Pl. Fiji Isl. 186. 1964, ed. 2. 263. 1972.

FIGURE 48.

Asclepias carnosa L. f. Suppl. Pl. 170. 1782.

Hoy a intermedia A. C. Sm. in Sargentia 1: 111. 1942; J. W. Parham, Pl. Fiji Isl. 186. 1964, ed. 2. 263. 1972.

A climbing vine occasionally cultivated near sea level and infrequently becoming naturalized in lowland thickets. The flowers have the corolla waxy-white and the corona lobes pink-tinged or reddish. The only Fijian collection at hand was flowering in November.

TYPIFICATION AND NOMENCLATURE: No specimens were cited by Linnaeus, who indicated: "Habitat in China." Brown's (1810) citation was "In Asiae tropicae variis regionibus, etiam in Nova Hollandia (ubi et in hort. Angl. v. v.);" he also noted that "Hoya carnosa probably includes several species, which can only be determined from living specimens..." The type of $\boldsymbol{H}$. intermedia is Smith 399 (NY HOLOTYPE; many ISOTYPES), collected Nov. 12, 1933, near Valethi, Savusavu Bay, Thakaundrove Province, Vanua Levu.

DisTRIBUTION: Eastern Asia; now widely cultivated and sometimes naturalized elsewhere. It was presumably introduced into Fiji by J. B. Thurston, who listed it in his 1886 Catalogue. No Fijian specimens have been noted except the type cited above.

LOCAL NAME AND USE: Ndraumbimbi; ornamental.

Hoya intermedia was based on a single collection made in the vicinity of a settlement in which there exist a few European gardens; I did not adequately consider 

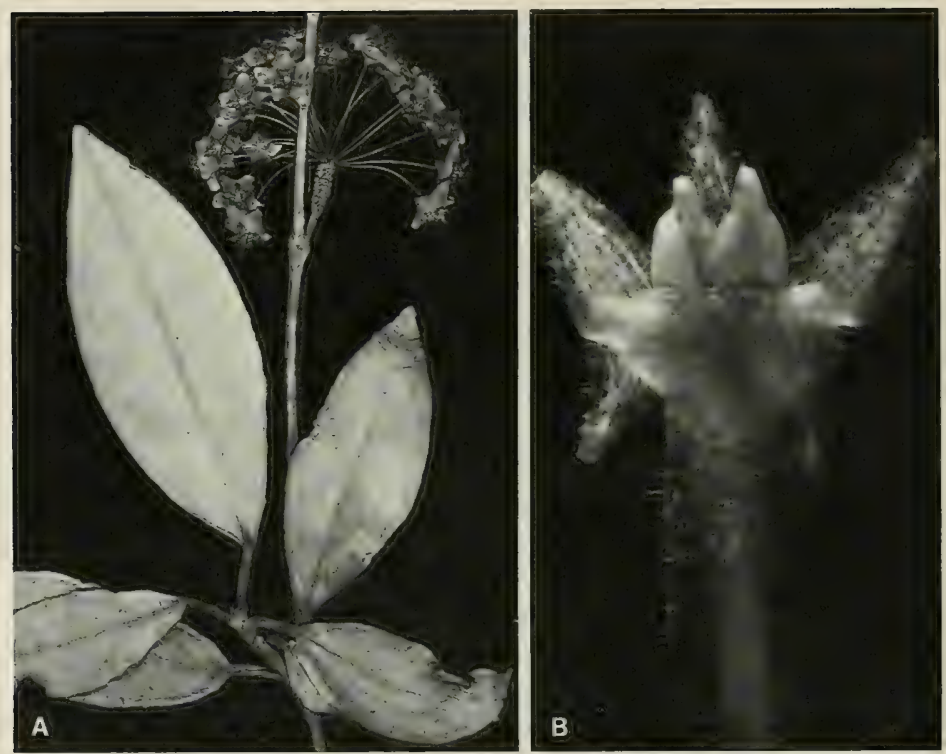

Flgure 48. Hoya carnosa, from Smith 399; A, portion of stem, with foliage and an inflorescence, $\times 1 / 2$; B, calyx and ovaries, $\times 10$.

the possibility that the collection may have represented a garden escape. Since no additional collections of "Hoya intermedia" in Fiji have since come to light, reconsideration suggests that the supposed Fijian endemic is merely one of the several variants (cultivars?) that are commonly grouped under the binomial $H$. carnosa. While the Fijian collection has leaf blades proportionately narrower than those of many cultivated specimens of $H$. carnosa, no inflorescence characters seem to differentiate it from that species in the sense of such standard Floras of Oriental areas as those of Ohwi (Fl. Japan, English ed. 751. 1965) and E. Walker (Fl. Okinawa \& S. Ryukyu Isl. 858. 1976).

4. Hoya vitiensis Turrill in J. Linn. Soc. Bot. 43: 34. 1915; A. C. Sm. in Sargentia 1: 112. 1942; J. W. Parham, Pl. Fiji Isl. 186. 1964, ed. 2. 263. 1972.

FIGURE 49.

A vine climbing on trees in dense or dry forest at elevations of $50-1,323 \mathrm{~m}$. This colorful species has the calyx lobes rich pink to purple, the corolla purple or pale purplish red or brownish, sometimes pale pink without and with the lobes yellowishmargined, and the corona lobes rich, deep purple and sometimes tipped with pale green. Flowers have been obtained in the months between July and March, fruits in February and March.

TYPIFICATION: The species is based on im Thurn 260 (K HOLOTYPE), collected Nov. 20, 1906, near Nandarivatu, Mba Province, Viti Levu. 

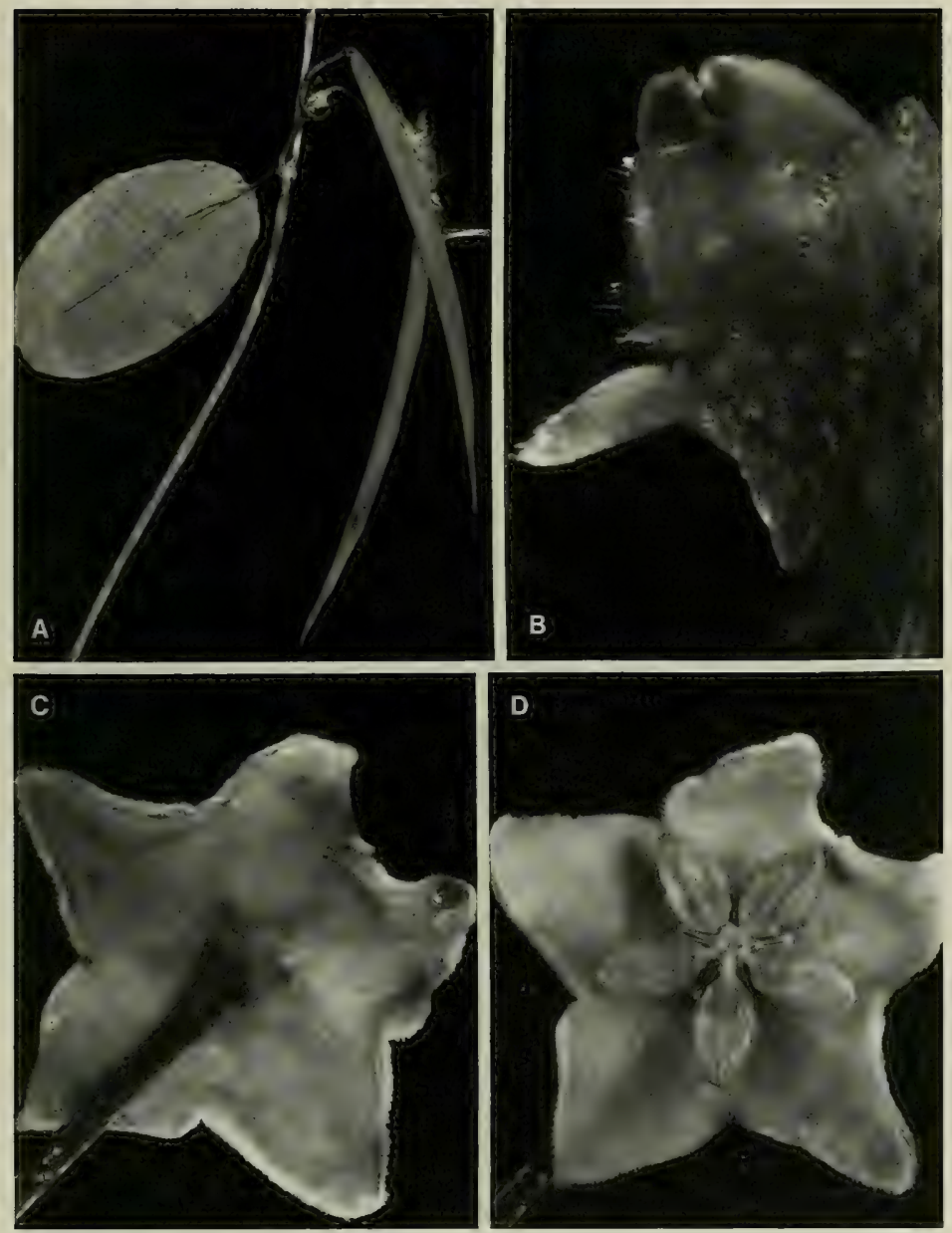

Figure 49. Hoya vitiensis; A, leaf and mature follicles, $\times 1 / 2$; B, calyx and ovaries, $\times 20$; C, proximal surface of corolla and calyx, $\times 4 ; \mathrm{D}$, distal surface of corolla and corona lobes, $\times 4$. A from Degener 14304 , B-D from Parks 20732.

Distribution: Endemic to Fiji and known from the two large islands, although all known specimens except one apparently come from Viti Levu.

LOCAL NAMES AND USE: Recorded names are wa ndra (Mba) and wa tambua ndamundamu (Namosi); the flowers are sometimes used in garlands. 
AVAilable collections: VITI LEVU: MBa: Slopes of Mt. Yöo, west of Nandarivatu, Webster \& Hildreth 14150; vicinity of Nandarivatu, Parks 20732, Degener 14304; Mt. Matomba, south of Nandarivatu, Degener 14627a; summit of Mt. Tomanivi, DA 7135. Serua: Tawavulu Creek, north of Ngaloa, Webster \& Hildreth 14347; hills between Waininggere and Waisese Creeks, between Ngaloa and Wainiyambia, Smith 9529. Namosi: Mt. Naitarandamu, Gillespie 3095; northern base of Korombasambasanga Range, in drainage of Wainavindrau Creek, Smith 8660; Korombasambasanga Range, DA 2163; vicinity of Namosi,
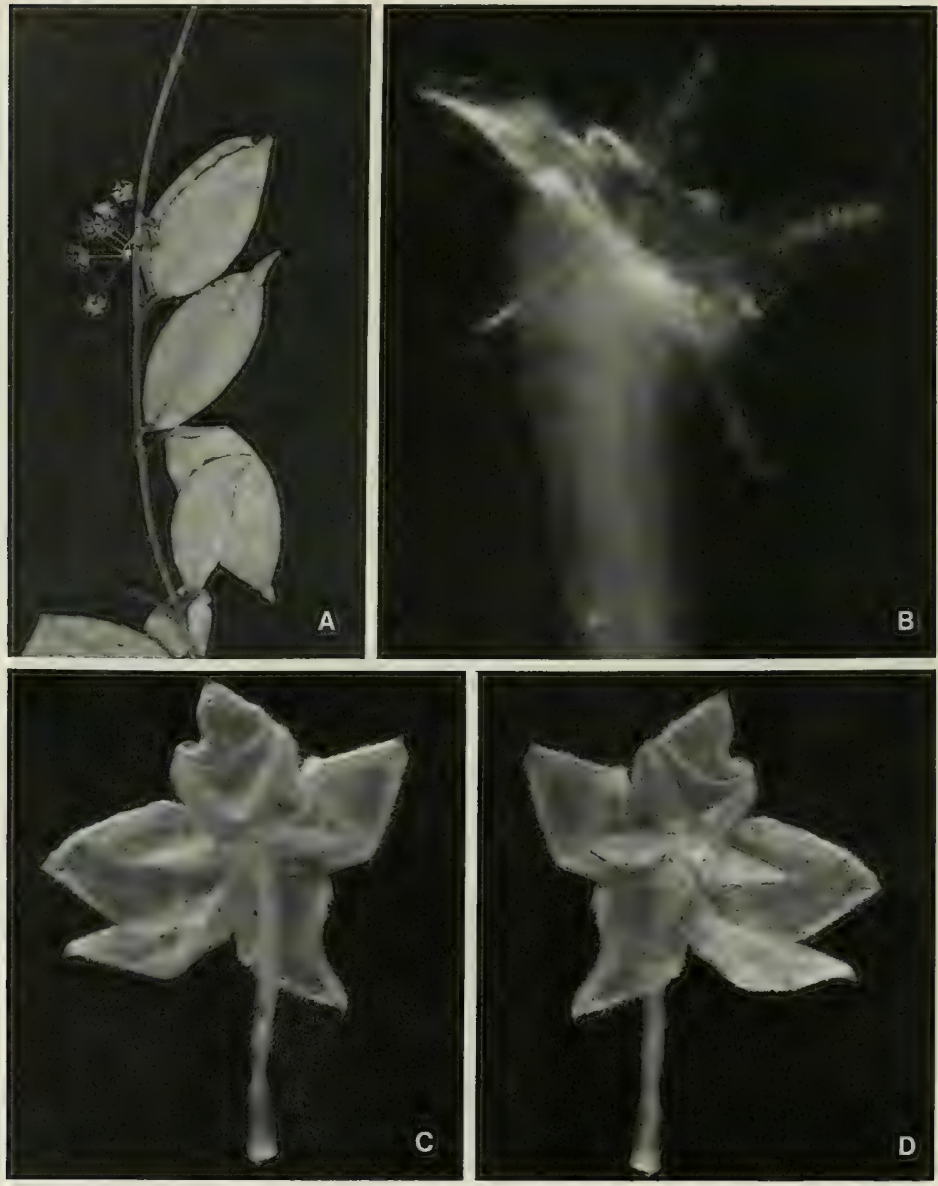

Figure 50. Hoya diptera; A, portion of stem, with foliage and an inflorescence, $\times 1 / 2$; B, calyx, showing glands within at sinuses, $\times 20 ; C$, proximal surface of corolla and calyx, $\times 4$; D, distal surface of corolla and corona lobes, $\times 4$. A from Smith 9680 , B-D from DA 11212. 
Gillespie 2599; Wainandoi River, DA 12509. NAITASIRI: Tholo-i-suva, DA 9822; Central road, Tothill 604, 609. Rewa: Mt. Korombamba, Gillespie 2305; vicinity of Suva, Gillespie 2180. VANUA LEVU: MaTHUATA: Mountains near Lambasa, Greenwood 632. FIJI without definite locality, Horne s. n. (GH, not a duplicate of Horne 1096 , i. e. not $H$. barracki, nom. nud.).

5. Hoya diptera Seem. in Bonplandia 9: 257, nom. nud. 1861; A. Gray in Proc. Amer. Acad. Arts 5: 336, nom. nud. 1862, in Bonplandia 10: 37, nom. nud. 1862; Seem. Viti, 439, nom. nud. 1862, Fl. Vit. 163. 1866; Drake, Ill. Fl. Ins. Mar. Pac. 236. 1892; Turrill in J. Linn. Soc. Bot. 43: 33. 1915; A. C. Sm. in Sargentia 1: 113. 1942; J. W. Parham, Pl. Fiji Isl. 186. 1964, ed. 2. 263. 1972.

FIGURE 50.

An often high-climbing vine with white latex, found at elevations from near sea level to about $900 \mathrm{~m}$. in dense, dry, or open forest. The corolla is yellow (infrequently noted as cream-colored), sometimes faintly reddish-tinged at base on both surfaces, and the corona lobes are pale yellow to white, often dull red or pink toward base. As far as collections are dated, flowers have been obtained between October and January and in June; no fruiting specimens have been noted.

TYPIFICATION: The type is Seemann 320 (K HOLOTYPE; ISOTYPES at BM, GH); the holotype bears two specimens mounted on one sheet, one noted as from Taveuni and dated June, 1860, and the other from Viti Levu. It is not now possible to separate these and to indicate one as the lectotype; they obviously represent the same species, and it seems best to treat them as jointly constituting the holotype. The binomial was mentioned several times before its description by Seemann in 1866.

Distribution: Presumably endemic to Fiji, thus far known from three of the high islands. However, the Samoan species should be critically examined in this connection; Hoya filiformis Rechinger (1908) and $H$. attenuata Christophersen (1935) appear scarcely separable from $H$. diptera, although both are recorded as having white corollas.

LOCAL NAMES: The recorded names are perhaps more strictly applicable to the better known Hoya australis; they are wa tambua, mbulimbuli sewaro, ndraumbimbi, and wa mbi.

AVAilable Collections: VITI LEVU: MBA: Vicinity of Nandarivatu, Gillespie 4009; Nauwangga, south of Nandarivatu, Degener 14333, 14755. Serua: Namboutini, H. B. R. Parham 497; flat coastal strip in vicinity of Ngaloa, Smith 9680 . Namosi: Nakavu, on Navua River, Horne (K); track to Mt. Vakarongasiu, DA 16141. NaITASIRI: Between Navai and Nasonggo, DA 15301; Waimbau, Sawani, DA 11212; Central road, Tothill 608; vicinity of Nasinu, Gillespie 3556. REwA: Government House paddock, im Thurn 7. VANUA LEVU: Mathuata: Southern base of Mathuata Range, north of Natua, Smith 6775; southern slopes of Mt. Numbuiloa, east of Lambasa, Smith 6586. ThaKaundrove: Savuthuru Mt., near Valethi, Degener \& Ordonez 13832; Vatunivuamonde Mt., Savusavu Bay region, Degener \& Ordonez 14014. FIJI without further locality, U. S. Expl. Exped., Horne 66.

\section{ORDER OLEALES}

The family Oleaceae has frequently been included in the order Gentianales (or Loganiales, cf. Hutchinson, 1973), sometimes in the Scrophulariales (Cronquist, 1981), and sometimes in a separate order Oleales (Melchior, 1964; Takhtajan, 1980, 1986; Dahlgren, 1980; Ehrendorfer, 1983), with or without one or two associated families. For present purposes the family is taken to represent its own order, probably most closely related to the Gentianales and somewhat less closely to the Scrophulariales. I am indebted to P. S. Green for helpful suggestions in reference to Fijian Oleaceae, but the conclusions herewith stated are the author's responsibility. 


\section{FAMILY 167. OLEACEAE}

Oleaceae Hoffmannsegg \& Link, Fl. Portug. 1: 385, as Oleinae. 1813-1820.

Trees, shrubs, or climbing plants, estipulate; leaves opposite or very rarely alternate, simple to imparipinnately compound, sometimes trifoliolate or unifoliolate; inflorescences axillary or terminal, basically cymose or thyrsoid, often racemiform or paniculiform, infrequently 1 -flowered, the flowers actinomorphic, $\zeta$ or rarely unisexual (plants then dioecious or polygamodioecious), usually small; calyx (rarely lacking) with $4(-15)$ lobes, the lobes valvate; corolla usually 4-lobed (sometimes up to 12lobed), rarely with separate petals (as in Chionanthus) or even obsolete, the lobes imbricate, induplicate-valvate, or contorted; stamens usually 2 (rarely 4 but not in our genera) and attached to corolla tube, usually alternipetalous and opposed, rarely hypogynous, the filaments short, the anthers 2-locular, dehiscing by longitudinal slits; disk sometimes present around base of ovary, usually lacking; ovary superior, bilocular, the placentation axile, the ovules usually 2 (1-4, rarely numerous) per locule, anatropous or amphitropous, the style simple, terminal (or lacking), the stigma 2-lobed or bifid; fruit a capsule (loculicidal or circumscissile), samara, berry, or drupe, often 1(-4)-seeded, the seeds with a straight embryo, the endosperm often oily, sometimes lacking.

Distribution: Temperate and pantropical, best developed in Asia and Malesia, with 27-30 genera and about 600 species. The family includes food and oil plants (Olea), timber plants (Fraxinus), and many ornamentals. Three genera are present in Fiji, two of them with indigenous species.

USEFul tReatments of Family: BaCker, C. A., \& R. C. Bakhuizen van den Brink, JR. Oleaceae. Fl. Java 2: 212-218. 1965. Scort, A. J. Oléacées. Fl. Masc. Fam. 119. 1-15. 1981.

\section{KEY TO GENERA}

Calyx lobes (4 or) 5-10; corolla with a comparatively long tube and with 4-11 lobes; fruit a bilobed berry; erect or climbing shrubs or lianas, the leaves simple (unifoliolate), trifoliolate, pinnatifid, or pinnate;

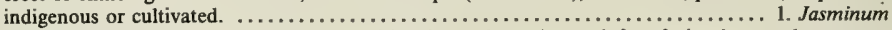

Calyx truncate or 4-dentate or -lobed; corolla with a short tube or the petals free; fruit a drupe or berry; trees or shrubs, the leaves simple.

Corolla tube obvious, nearly as long as or longer than lobes; stamens borne on corolla tube; style often filiform; fruit a carnose berry or somewhat drupaceous; our species cultivated only.

2. Ligustrum

Petals free or basally connate in pairs, usually obviously longer than broad; stamens hypogynous or with filaments scarcely adherent to petal bases; style usually short; fruit a drupe, the exocarp carnose, the endocarp bony or cartilaginous or subligneous; indigenous. . . . . . . . . . . . .

\section{Jasminum L. Sp. Pl. 7. 1753; Seem. Fl. Vit. 153. 1866; Backer \& Bakh. f. Fl. Java 2:} 216. 1965; M. Grant, Fosberg, \& H. M. Sm. in Smithsonian Contr. Bot. 17: 29. 1974; A. J. Scott in Fl. Masc. Fam. 119. 2. 1981.

Erect or climbing shrubs or lianas, the indument if present of simple hairs; leaves simple (unifoliolate, the petiole articulate), trifoliolate, pinnatifid, or pinnate; inflorescences few-many-flowered (or 1-flowered), bracteate and bracteolate, the flowers usually fragrant and heterostylous, sometimes unisexual; calyx tube campanulate or infundibular, the lobes ( 4 or) 5-10, sometimes unequal, short to long; corolla hypocrateriform, the tube slender, sometimes curved, the lobes 4-11, imbricate, spreading, sometimes in several series in cultivated taxa; stamens 2 , inserted on corolla tube, the filaments short, the anthers not or slightly exserted, the connective apiculate; ovary 2-locular, the ovules usually 2 per locule, the stigma oblong or subulate, 2-dentate or -cleft; fruit a berry, 2-lobed, 2-locular, and 2-seeded, sometimes entire and 1-seeded by abortion. 
LECTOTYPE SPECIES: Jasminum officinale L. (vide Britton, Fl. Bermuda, 287. 1918), one of the five original species.

Distribution: Paleotropical and subtropical, with more than 200 species. Several species are widely cultivated as ornamentals. Six species are here considered indigenous in Fiji and two are known to be in cultivation.

Useful treatments of Genus: Green, P. S. Studies in the genus Jasminum, II. The species from New Caledonia and the Loyalty Islands. J. Arnold Arb. 43: 109-131. 1962. GreEN, P. S. A revision of Jasminum in Australia. Allertonia 3: 403-438. 1984.

Leaves compound or deeply pinnatifid or pinnate.

Leaves 5-7-foliolate or deeply pinnatifid; calyx lobes subulate, 5-10 (-13) mm. long; corolla sometimes pink-tinged, often reddish in bud, the tube $20-30 \mathrm{~mm}$. long; cultivated only. ... $1 . J$. grandiflorum

Leaves trifoliolate; calyx lobes obscure, essentially none to $0.5 \mathrm{~mm}$. long; corolla white, the tube $6-10 \mathrm{~mm}$. long at anthesis; indigenous species.

Inflorescences $4-30 \mathrm{~cm}$. long, the branches glabrous or sometimes minutely and evanescently puberulent, the flowers usually 15-49, the pedicels at anthesis (0.5-) 1-3 mm. long, the calyx glabrous; corolla tube 6-10 mm. long at anthesis, the lobes (3-) 4-6 mm. long; anthers 3.5-4.5 mm. long, included, their apices not attaining apex of corolla tube; fruits at full maturity with each lobe ellipsoid or subglobose, to $23 \mathrm{~mm}$. in diameter, the seeds to $15 \mathrm{~mm}$. in diameter; scandent shrub or sometimes high-climbing liana, the young parts and leaves glabrous; petioles (7-) 15-25(-35) mm. long; petiolules of terminal leaflets (5-) 11-20 (-25) mm. long; leaflet blades lanceolate to ovate, (3-) 5-10 (-12) cm. long, (2-) 2.5-6.5 (-7.5) cm. broad, acute to gradually long-acuminate at apex (acumen to $2 \mathrm{~cm}$. long). .................................. didymum

Inflorescences $1-5 \mathrm{~cm}$. Iong, the branches copiously puberulent, the flowers $3-18$, the pedicels at anthesis not more than $1 \mathrm{~mm}$. long, the calyx densely puberulent but eventually essentially glabrate; corolla tube 5-9 mm. long at anthesis, the lobes 3-3.5 $\mathrm{mm}$. long; anthers 3-3.5 mm. long, included or exserted, their apices attaining or exceeding apex of corolla tube; fruits (inadequately known) apparently with each lobe not exceeding $10 \mathrm{~mm}$. in diameter; subscandent shrub or sprawling, scrambling liana, the young branchlets, petioles, and petiolules puberulent, sometimes copiously so; petioles 4-15 mm. long; petiolules of terminal leaflets 5-15 mm. long; leaflet blades ovate, 1-6 cm. long, $0.8-3.5(-4) \mathrm{cm}$. broad, acute to short-acuminate at apex, puberulent on costa at least when young and with subpersistent tufts of indument in axils of some secondary nerves beneath, occasionally with acrodomatia. $\ldots \ldots \ldots \ldots \ldots \ldots \ldots \ldots \ldots \ldots \ldots \ldots \ldots \ldots$. degeneri Leaves simple.

Calyx lobes comparatively short, to $2 \mathrm{~mm}$. long; indigenous species.

Leaves appearing subsessile, the petioles to $2 \mathrm{~mm}$. long, the blades ovate, $3-5 \times 2-3.5 \mathrm{~cm}$., truncate to subcordate or often subamplexicaul at base; inflorescences compact, often 3-flowered; pedicels 1-3 $\mathrm{mm}$. long; calyx lobes about $0.5 \mathrm{~mm}$. long; corolla tube $15-20 \mathrm{~mm}$. long, the lobes 4 or $5,7-10 \times 2-3$ $\mathrm{mm}$; anthers about $5 \mathrm{~mm}$. long; style $4-5 \mathrm{~mm}$. long. ................ sessile

Leaves obviously petiolate, the petioles $5-15 \mathrm{~mm}$. long, the blades ovate-elliptic to lanceolate, usually $4-14 \times 1.5-8 \mathrm{~cm}$., acute to truncate at base; inflorescences (including flowers or fruits) $3-11 \mathrm{~cm}$. long, the pedicels usually much longer than $3 \mathrm{~mm}$; calyx lobes $4-6,0.1-2 \mathrm{~mm}$. long; corolla lobes 6-10; anthers $3.5-7 \mathrm{~mm}$. long; style $10 \mathrm{~mm}$. long or more.

Inflorescences with 9-40 flowers, the pedicels $2-20 \mathrm{~mm}$. long; corolla tube $7-20 \mathrm{~mm}$. long, the lobes 6-15 mm. long; style $10-16 \mathrm{~mm}$. long; mature fruits with each lobe subglobose to slightly ellipsoid, $10-16 \mathrm{~mm}$. in diameter. ...................... J. simplicifolium

Inflorescences with 2-5 flowers, the pedicels $13-40 \mathrm{~mm}$. long; corolla tube (12-) 20-25 mm. long, the lobes $12-30 \mathrm{~mm}$. long; style 16-30 mm. long; mature fruits with each lobe ellipsoid, 13-22 ×8-14

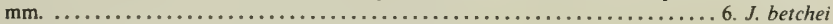

Calyx lobes subulate, as long as or longer than calyx tube.

Glabrous shrub, the leaf blades ovate, acute to obtuse at base; inflorescences few-flowered, shortpedunculate; fruiting calyx with the tube narrowly 4-winged or -angled, the wings decurrent on the long pedicel, the lobes 4 , subulate-lanceolate, 2-3-times longer than tube; indigenous.

7. J. tetraquetrum

Spreading shrub, sometimes climbing; branchlets and inflorescence axes copiously pilose; leaves short-petiolate, the blades ovate, usually (2-) 3-6 $\times(1.5-) 2-4 \mathrm{~cm}$., truncate or subcordate at base, obviously pubescent on both surfaces or sometimes glabrate above; flowers in short, compact clusters; calyx not winged or angled, the lobes filiform, 4-8, densely pubescent with spreading hairs, 8-18 mm. long; corolla tube 19-28 mm. long, the lobes 4-9, 12-20 mm. long; cultivated only. 
1. Jasminum grandiflorum L. Sp. Pl. ed. 2. 9. 1762; Yuncker in Bishop Mus. Bull. 178: 95. 1943; Sykes in New Zealand Dept. Sci. Indust. Res. Bull. 200: 141. 1970; P. S. Green in Kew Bull. 41: 414. 1986.

Jasminum officinale f. grandiflorum Kobuski in J. Arnold Arb. 13: 161. 1932; Backer \& Bakh. f. Fl. Java 2: 216 (as var.). 1965; M. Grant, Fosberg, \& H. M. Sm. in Smithsonian Contr. Bot. 17: 30. 1974. Jasminum officinale sensu J. W. Parham, Pl. Fiji Isl. ed. 2. 255. 1972; non L.

A slender liana, occasionally cultivated in Fiji near sea level. The corolla is white, with the tube and lobes pink-tinged. Flowers have been noted in January and March.

TYPIFICATION: Although Linnaeus gave several prior references, the appropriate type is Linn. Herb. 17.2 (LINN HOLOTYPE), the single specimen in the Linnaean Herbarium with the name in Linnaeus's hand (P. S. Green, in litt. and 1986).

Distribution: The taxon presumably originated in Arabia as a cultivated clone derived from the "wild type" of the species, Jasminum grandiflorum subsp. floribundum (R. Br. ex Fresen.) P. S. Green; cf. Green (1986, p. 414). Subspecies grandiflorum is known only as a cultivated plant, now widely grown in warm temperate and tropical regions throughout the world.

LOCAI. NAMES AND USE: Jasmine, Spanish jasmine, jessamine; an attractive ornamental, probably introduced into Fiji during the present century. It is often used in the perfume industry as the source of jasmine oil.

Available Collections: VITI LEVU: Rewa: Lami, in private garden, DA 16795; Suva, in private garden, $D A 16088$.

\section{Jasminum didymum Forst. f. Fl. Ins. Austr. Prodr. 3. 1786.}

For present purposes Jasminum didymum is interpreted only in the sense of its typical subspecies (Green, 1984, pp. 409-410. fig. 2, $A-C$ ); this subspecies, as it occurs between Fiji and the Societies, is usually essentially glabrous in vegetative and inflorescence parts, its leaflet blades as noted in Fiji are characteristically tapering into an often prolonged tip, and its fruits are often large. Westward of Fiji J. didymum is obviously much more complex, substantially more variable in foliage and indument, and perhaps usually with smaller fruits. In a comprehensive sense the species must be taken to include several or many taxa in addition to the typical one, but in Fiji it seems reasonably distinct from one other trifoliolate and indigenous taxon.

2a. Jasminum didymum subsp. didymum; P. S. Green in Allertonia 3: 409. fig. 2, $A-C$. 1984.

Jasminum didymum sensu Forst. f. Fl. Ins. Austr. Prodr. 3. 1786; Seem. in Bonplandia 9: 257. 1861, Viti, 439. 1862; A. Gray in Proc. Amer. Acad. Arts 5: 332. 1862; Seem. Fl. Vit. 154. 1866; Drake, Ill. Fl. Ins. Mar. Pac. 231. 1892; Guillaumin in J. Arnold Arb. 13: 17. 1932; Christophersen in Bishop Mus. Bull. 128: 174. 1935; Yuncker in op. cit. 178:95. 1943, in op. cit. 184:57. 1945, in op. cit. 220:214. 1959; P. S. Green in J. Arnold Arb. 43: 112. 1962; J. W. Parham, Pl. Fiji Isl. 180. 1964, ed. 2. 255. 1972; Sykes in New Zealand Dept. Sci. Indust. Res. Bull. 200: 140. 1970; B. E. V. Parham in New Zealand Dept. Sci. Indust. Res. Inform. Ser. 85: 38, 39. 1972; M. Grant, Fosberg, \& H. M. Sm. in Smithsonian Contr. Bot. 17: 31.1974.

A climbing woody vine or liana found in Fiji from near sea level to an elevation of $1,150 \mathrm{~m}$. in dense or open forest or on its edges, in the forest-grassland transition, in crest forest and on ridges, and sometimes in coconut plantations. The fragrant flowers have the corolla white and fading yellowish, and the fruits become purple-tinged or black at maturity. Flowers seem most profuse between December and May, and fruits persist throughout the year.

Typification: The type locality was cited by G. Forster as the Society Islands. Green (1984) indicated that type material is available at BM and $\mathrm{K}$, but the BM specimen 
is apparently noted as from New Caledonia (Seemann, 1866; Grant, Fosberg, and Smith, 1974). The $\mathrm{K}$ specimen is marked as from the Society Islands and is doubtless part of the original material. Perhaps a suitable citation is: J. R. \& G. Forster (K LECTOTYPE here designated), collected in the Society Islands during Cook's second voyage.

Distribution: The species in a broad sense extends from the Society Islands westward to northern Australia, New Guinea, and Timor (Green, 1984); subsp. didymum extends westward to the northern and eastern coasts of Australia (Green, 1984, fig. 4). Two other subspecies were recognized by Green from Australia, but his 1984 study did not extend beyond that area. More than 30 Fijian collections from nine islands have been examined, but the species doubtless occurs on many other islands.

LOCAL NAMES: Recorded names are wa vula, wa vere, and wa kai.

RePresentative COLLections: VITI LEVU: MBA: Mountains inland from Lautoka, Greenwood 426; Mt. Mbotilamu, Mt. Evans Range, DA 14816; northern slopes of Mt. Namendre, east of Mt. Koromba, Smith 4512; slopes of Mt. Mangondro, Webster \& Hildreth 14276; Nandarivatu, Tothill 382; slopes of Mt. Tomanivi, Smith 5220. NANDRONGA \& NAvOSA: Northern portion of Rairaimatuku Plateau, between Nandrau and Rewasau, Smith 5401. SerUa: Ngaloa, DA 14854. NAITASIRI: Vicinity of Tamavua, Gillespie 2147. ReWA: Mt. Korombamba, Meebold 16562. KANDAVU: Hills above Namalata and Ngaloa Bays, Smith 203. NGAU: Milne 221; slopes of Mt. Ndelaitho, on northern spur toward Navukailangi, Smith 7889. TOTOYA: Tothill 378. THIKOMBIA: Tothill 380. NAITAMBA: Tothill 383. YATHATA: DA 13940. ONGEA NDRIKI: Bryan 397. FIJI without further locality, Seemann 299.

3. Jasminum degeneri Kobuski in Sargentia 1: 97. 1942; J. W. Parham, Pl. Fiji Isl. 180. 1964, ed. 2. 254. 1972.

FIGURES 51, 52.

Jasminum smithianum Kobuski in Sargentia 1:96. 1942; J. W. Parham, Pl. Fiji Isl. 180. 1964, ed. 2. 256. 1972.

A subscandent shrub or vine scrambling over bushes in open places, among rocks along arid coast, or in dry, forested ravines near coast at elevations from near sea level to $370 \mathrm{~m}$. The corolla is noted as white and the fruit as black. Flowers have been obtained in April and May, fruits in July and September.

TYPIFICATION: Jasminum degeneri is based on Degener 14980 (A HOLOTYPE; ISOTYPES at BISH, K, Us), collected April 2, 1941, at Vatia, west of Tavua, Mba Province, Viti Levu; J. smithianum on Degener 15331 (err. cit. as 15321 by Kobuski) (A HOLOTYPE; ISOTYPES at BISH, K, Us), obtained May 27, 1941, near Korovou, near Nandi, Mba Province, Viti Levu.

Distribution: Endemic to Fiji and thus far known only from coastal northern Viti Levu and the Yasawas.

LOCAL NAMES AND USE: From the Yasawas St. John noted the local names rautolu and nunganunga, recording a medicinal use for stomachache or sore eyes.

AVAIl ABLE COLlections: YASAWAS: WAYA: Naruarua Gulch, west side of Mt. Mbatinaremba, St. John I8036; Nangua, St. John 18103. VITI LEVU: MBA: Vatia, near the jetty, DA 13568 (P. S. Green III7). RA: Near King's Road west of Penang, DA 7151.

Jasminum degeneri and J. smithianum, on the basis of the original collections, can be distinguished from one another as pointed out by Kobuski; the former (FIGURES $51 \mathrm{~A} \& \mathrm{~B}, 52 \mathrm{~A}$ ) has the more copious indument, larger leaflet blades and inflorescences, somewhat more abundant flowers, and a longer corolla tube (7-9 mm. long, with anthers reaching its apex); the corolla tube of $J$. smithianum (FIGURES $51 \mathrm{C} \& \mathrm{D}, 52 \mathrm{~B}$ ) is $5-5.5 \mathrm{~mm}$. long and its anthers are exserted. Nevertheless, if they are combined (and the distinctions are somewhat blurred by material other than the types) the resulting taxon is still morphologically cohesive and (on the basis of currently available collections) is limited to arid coastal situations in northern Viti Levu and the nearby 
Vol. 4
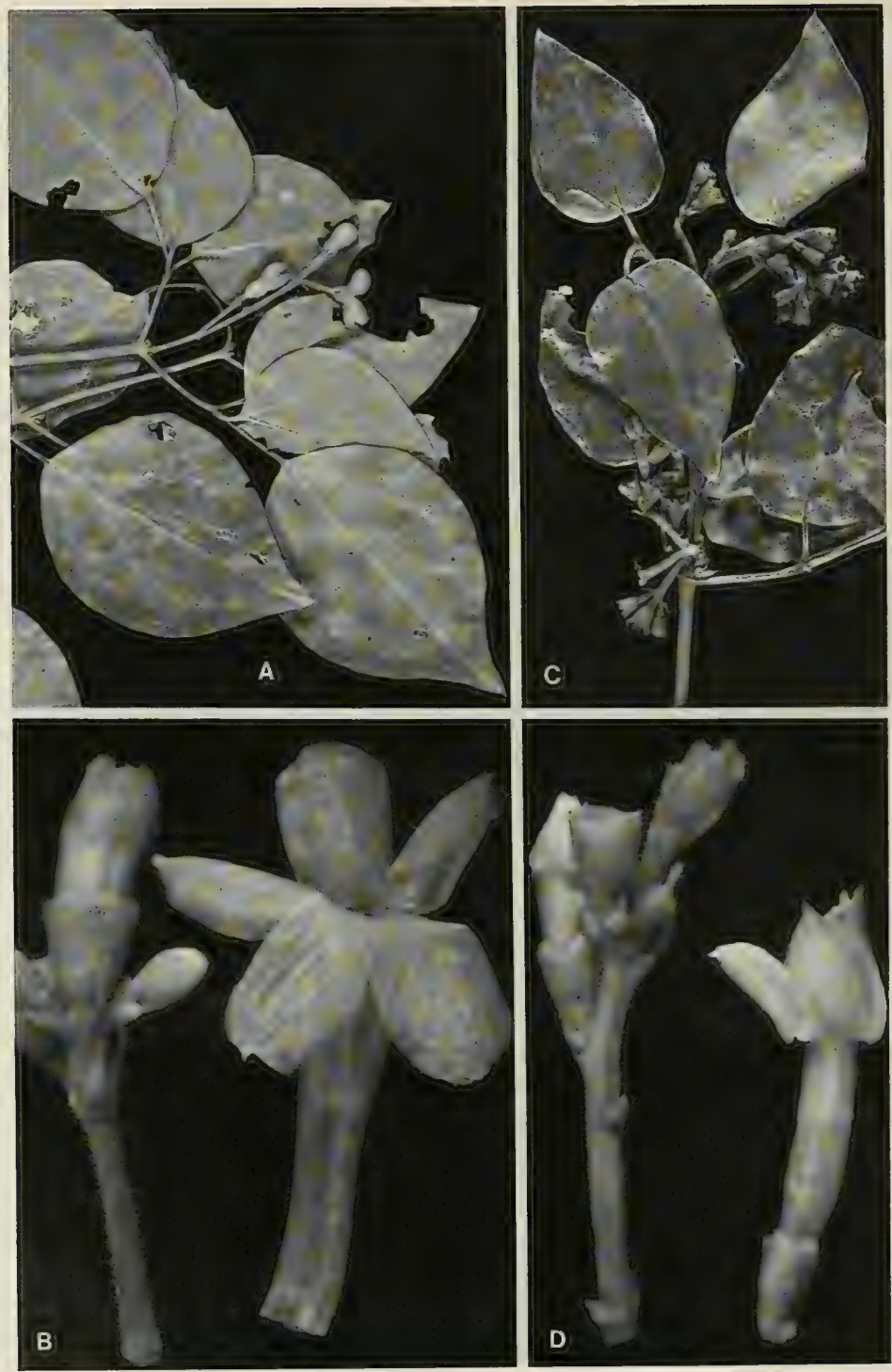

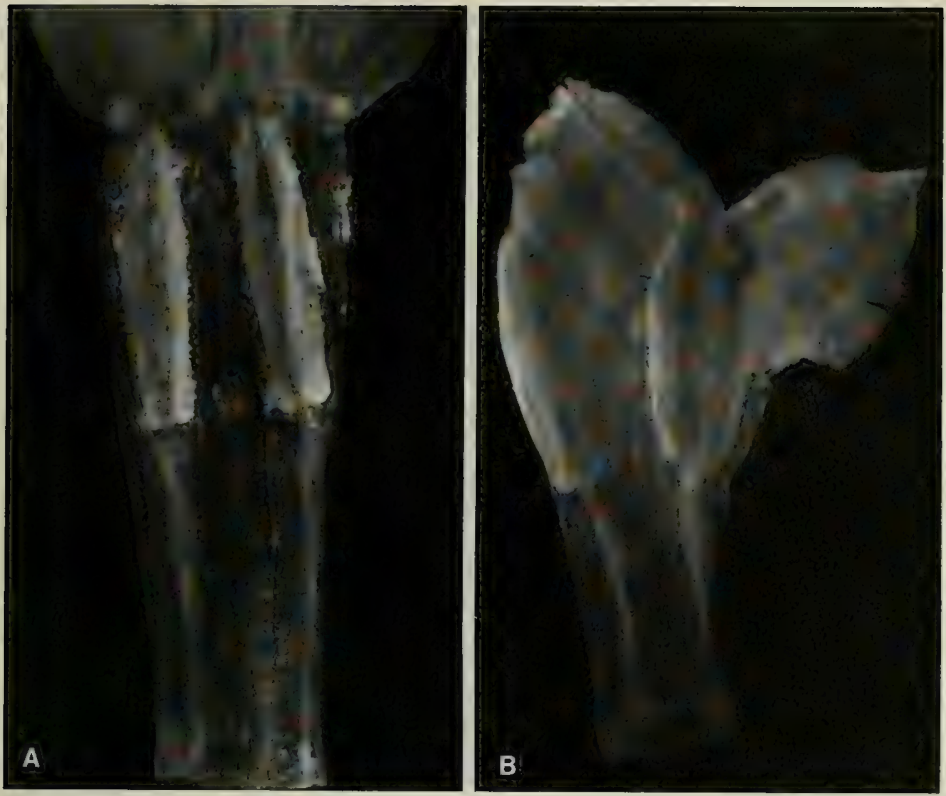

FIGURE 52. Jasminum degeneri; A, stamens in corolla tube (2 lobes and corresponding portion of tube removed), $\times 12$; B, stamens in corolla tube ( 1 lobe and corresponding portion of tube removed), $\times 12$. A from Degener 14980, B from Degener 15331.

Yasawas. In fact, if $J$. didymum is interpreted in a fairly inclusive sense (Green, 1962, pp. 112-115; 1984, pp. 405-417), both of Kobuski's taxa could perhaps be included within it; both are mentioned by Green (1962) as belonging to a complex of Australian -Malesian-Pacific taxa (including $J$. didymum, with the oldest epithet) that requires a careful review. For the time being, a single Fijian trifoliolate species (J. degeneri) is here retained as reasonably distinct from $J$. didymum, although certainly closely related to it. In Fiji the two resulting taxa have discrete habitats; although both may be coastal, $J$. degeneri seems strictly limited to very arid conditions, whereas $J$. didymum often occurs inland, in diversely forested areas, and upward to high crests and ridges.

4. Jasminum sessile A. C. Sm. in Bishop Mus. Bull. 141: 124. fig. 64, a, b. 1936; J. W. Parham, Pl. Fiji Isl. 180. 1964, ed. 2. 256. 1972.

A slender shrub 1-3 m. high, apparently rare on rocky slopes near the sea, with a white corolla and known to flower in January and May.

FIguRE 51. Jasminum degeneri; A, distal portions of branchlets, with foliage and an immature infructescence, $\times \mathrm{I} ; \mathrm{B}$, inflorescence and detached corolla, $\times 8 ; \mathrm{C}$, distal portion of branchlet, with foliage and inflorescences, $\times 2$; D, inflorescence and detached flower, $\times 8$. A from DA 13568, B from Degener $14980, \mathrm{C} \&$ D from Degener 15331 . 
TyPIFICATION: The type is Greenwood 656 (K HOLOTYPE), collected Jan. 10, 1924, on "dry rocky slopes of the seacoast," Mathuata Province, Vanua Levu.

Distribution: Endemic to Fiji and thus far known only from the Mathuata coast of Vanua Levu.

Available Collection: VANUA LEVU: Mathuata: Tutu Island (Mathuata coast at $179^{\circ} 35^{\prime}$ E.), Horne 672 (k), May, 1878.

Jasminum sessile, still known only from the two specimens that were cited in 1936 , appears to be a very distinct species of the general relationship of J. simplicifolium, from which it is at once distinguished by its small, subsessile leaves and its fewflowered, compact inflorescences, the corollas having only four or five lobes. It is thus far known only from dry, rocky, coastal slopes of Mathuata Province, and it does not seem closely allied to any of the New Caledonian species discussed by Green (1962).

5. Jasminum simplicifolium Forst. f. Fl. Ins. Austr. Prodr. 3. 1786.

Only the typical subspecies of Jasminum simplicifolium, from Fiji and Tonga, is here taken into consideration. The species as a whole (Green, 1984, pp. 419-427) includes elements extending westward to eastern Australia.

5a. Jasminum simplicifolium subsp. simplicifolium; P. S. Green in Allertonia 3: 423. 1984.

Figures 53A \& B, 54A.

Jasminum simplicifolium sensu Forst. f. Fl. Ins. Austr. Prodr. 3. 1786; A. Gray in Proc. Amer. Acad. Arts 5: 332. 1862, in Bonplandia 10: 37. 1862; Seem. Fl. Vit. 430. 1873; Gibbs in J. Linn. Soc. Bot. 39: I56. 1909; P. S. Green in J. Arnold Arb. 43: 119. 1962; J. W. Parham, Pl. Fiji Isl, 180. 1964, ed. 2. 256. 1972; Sykes in New Zealand Dept. Sci. Indust. Res, Bull. 200: 142. 1970.

Jasminum australe Pers. Syn. Pl. 1: 8, nom. illeg. 1805; Seem. Fl. Vit. 153. 1866; Drake, Ill. Fl. Ins. Mar. Pac. 231. 1892.

Jasminum gracile sensu Seem. in Bonplandia 9: 257. 1861, Viti, 439. 1862; non Andrews.

An often high-climbing liana found from near sea level to about $900 \mathrm{~m}$. in dense or open forest, thickets and patches of forest in open country, and on dry, exposed ridges. The fragrant flowers have the corolla white, the tube sometimes greenish or pink-or purple-tinged; the fruit becomes black at maturity. Flowers have been collected between May and December, fruits in months scattered throughout the year.

TyPification: The type is $J$. R. \& G. Forster (BM LeCtOTYPE here designated; ISOLECTOTYPE at $\mathrm{K}$ ), collected on Tongatapu, Tonga, during Cook's second voyage. The вM specimen is clearly marked "Tongatabu (Amsterdam Island)," whereas the $\mathrm{K}$ sheet (transferred from LIV) is indicated as "Habitat in America" (presumably a garbling of "Amicorum"). Jasminum australe is a direct renaming of J. simplicifolium, cited as a synonym.

Distribution: Although the species in a broad sense extends from Australia to Tonga, the typical subspecies is presumably limited to Fiji and Tonga. Some 55 Fijian collections from nine islands have been studied, suggesting that this is the most abundant Jasminum in Fiji.

LOCAL NAMES AND USE: Wa vatu (general); names mentioned infrequently by collectors have been mbene viriviri, wa ndakua (Mba), wa tirikalou (Nandronga \& Navosa), vono ni mbengga (Kandavu), nggilawa (Ovalau), mothe ni vai and ngilangila wawa (Thakaundrove), and wa ndundundawa (Lakemba). A concoction prepared from the leaves is said to be used for fevers and sore throat.

RePResentative Collections: VITI LEVU: MBA: Mountains near Lautoka, Greenwood 1076; Vatia, near the jetty, DA 13567 (coll. Green); Nandarivatu, Gibbs 657; Mt. Nanggaranambuluta, Gillespie 4291. NANDRONGA \& NAvOSA: Northern portion of Rairaimatuku Plateau, between Nandrau and Nanga, Smith 

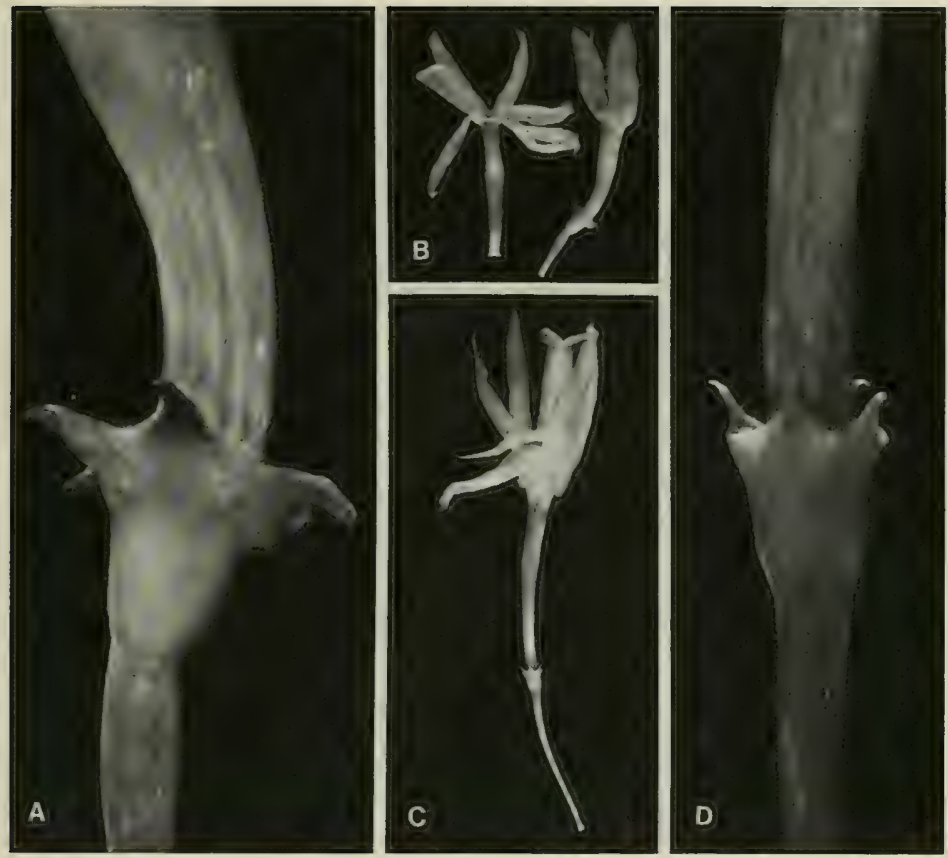

FIGURE 53. A \& B, Jasminum simplicifolium, from Smith 8907; A, calyx, with distal portion of pedicel and proximal portion of corolla, $\times 8$; B, flower and detached corolla, $\times 1$. C \& D, Jasminum betchei, from Gillespie 2160; C, flower, $\times 1$; D, calyx, with distal portion of pedicel and proximal portion of corolla, $\times 8$.

5566; vicinity of Mbelo, near Vatukarasa, Tabualewa 15635. Serua: Hills east of Navua River, near Nukusere, Smith 9109. NAmOSI: Hills east of Wainikoroiluva River, near Namuamua, Smith 8907; Wainandoi River, DA 11976. TaIlevu: King's Road, DA 856. NaITASIRI: Vicinity of Nasinu, Gillespie 3553. REWA: Wainisasa, Horne 98. KANDAVU: Hills above Namalata and Ngaloa Bays, Smith 105. OVALAU: Vicinity of Levuka, Gillespie 4485. VANUA LEVU: Seemann 298. MBUA: Koromba Forest, DA 15145. MathUATA: Wainunu-Ndreketi divide, Smith 1852; Lambasa, Greenwood 508. THAKAUnDRove: Hills west of Korotasere, Natewa Bay region, Smith 1922. TAVEUNI: Somosomo, DA 14371. MOALA: Milne 119. THIKOMBIA: Tothill 381. LAKEMBA: Between Yandrana and Vakano, Garnock-Jones 956. AIWA: Central wooded basin, Bryan 524. Fisı without further locality, U.S. Expl. Exped.

Green (1962, pp. 115-122) distinguished the New Caledonian Jasminum leratii Schlechter from J. simplicifolium, also suggesting (p. 121) that the simple-leaved Jasminum from the New Hebrides is referable to J. leratii. In the same treatment (p. 119 ) he maintained $J$. volubile Jacq. as a distinct species, but later (1984, p. 419) he referred that element to J. simplicifolium subsp. australiense P. S. Green. In view of that 1984 treatment, I doubt if $J$. leratii should be maintained at the species level. 

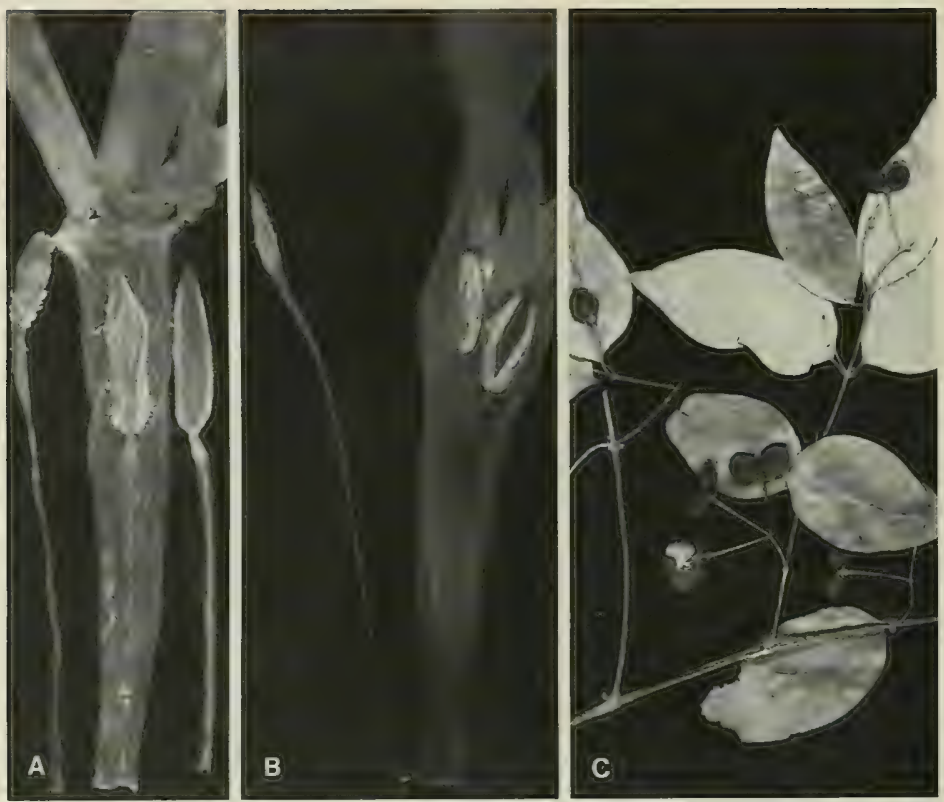

FigURE 54. A, Jasminum simplicifolium; half of corolla tube with attached stamen (introrse surface), with style and stigma (left) and stamen (extrorse surface) attached to a strip of corolla tube tissue (right), $\times 4$. B \& C, Jasminum betchei; B, opened corolla tube with attached stamens and detached style and stigma, $\times 4$; C. portion of branchlet, with foliage and infructescences, × 1/3. A from Smith 8907, B from Gillespie 2160, C from Smith 9470 .

6. Jasminum betchei F. v. Muell. in Vict. Chem. \& Druggist, Sept. 1881; P. S. Green in Kew Bull. 23: 343. 1969; Sykes in New Zealand Dept. Sci. Indust. Res. Bull. 200: 140. 1970; J. W. Parham, Pl. Fiji Isl. ed. 2. 254. 1972.

Figures 53C \& D, 54B \& C.

Jasminum unifoliolatum Gillespie in Bishop Mus. Bull. 74: 16. fig. 19. 1930; J. W. Parham, Pl. Fiji Isl. 180. 1964.

Jasminum simplicifolium sensu Christophersen in Bishop Mus. Bull. 128: 175. 1935; Yuncker in op. cit. 178: 95.1943 , in op. cit. 220: 215 . 1959; non Forst. f.

Jasminum pedicellatum A. C. Sm. in Bishop Mus. Bull. 141: 122. fig. 64. 1936; J. W. Parham, Pl. Fiji Isl. 180. 1964

An often high-climbing liana occurring in dense or dry forest, in thickets, and sometimes on the edges of forest along rocky coasts, at elevations from near sea level to $1,130 \mathrm{~m}$. The corolla is white and the mature fruits black. Flowers have been noted from August to November and in March, fruits between July and February.

TYPIFICATION AND NOMENCLATURE: Jasminum betchei is based on Betche s. $n$. (MEL HOLOTYPE), from "lower mountain-region of Apia," Upolu, Samoa. The type of $J$. 
unifoliolatum is Parks 20667 (BISH HOLOTYPE; ISOTYPE at US), collected in July, 1927, in fruit, near Nandarivatu, Mba Province, Viti Levu; and that of J. pedicellatum is Smith 1400 (BISH HOLOTYPE; many ISOTYPES), collected March 24, 1934, on the rocky shore of the north coast of Moala. Green's (1969) reduction of the two latter taxa to J. betchei seems justifiable.

Distribution: Fiji, Tonga, Niue, and Samoa. From Fiji I have examined 21 collections, all here cited, but these are all from Viti Levu except for the type of Jasminum pedicellatum, from Moala.

Local NAMES: Wa vatu (Viti Levu); vere (Moala).

AVAILABle Collections: VITI LEVU: MBa: Mountains near Lautoka, Greenwood 719; Savundamatau Creek, west of Nandarivatu, Webster \& Hildreth 14246; vicinity of Nandarivatu, Parks 20642; Mt. Nanggaranambuluta, Gillespie 3805, 4058, DA 13548, p. p. Serua: Hills west of Waivunu Creek, between Ngaloa and Korovou, Smith 9470; hills between Waininggere and Waisese Creeks, between Ngaloa and Wainiyambia, Smith 9359. Namosi: Valley of Wainambua Creek, south of Mt. Naitarandamu, Smith 8788 ; hills bordering Wainavindrau Creek, vicinity of Wainimakutu, Smith 8561; ridge southeast of Namosi, Gillespie 2850; vicinity of Namuamua, Gillespie 3001. RA: Mountains near Penang, Greenwood 508A. NAITASIRI: Central road, Tothill 390; Prince's Road, Nasinu River, Vaughan 3282; Tholo-i-suva, DA 10914; vicinity of Tamavua, Gillespie 2160; vicinity of Nasinu, Gillespie 3559. RewA: Mt. Korombamba, Gillespie 2231, 2351.

In foliage Jasminum betchei is difficult to distinguish from $J$. simplicifolium subsp. simplicifolium, but if mature inflorescences are available the key characters utilized above seem readily to differentiate the two taxa. The available fruits also suggest a difference, but this remains to be verified by field study.

7. Jasminum tetraquetrum A. Gray in Proc. Amer. Acad. Arts 5:332. 1862; Seem. Viti, 439. 1862, Fl. Vit. 153. 1866; Drake, Ill. Fl. Ins. Mar. Pac. 231. 1892; J. W.

Parham, Pl. Fiji Isl. 180. 1964, ed. 2. 256. 1972.

FiguRE 55.

Glabrous shrub, known only in fruit; petioles slender, $5-8 \mathrm{~mm}$. long, the leaf blades ovate, (3.5-) 4-6 × (1.3-) 2-3 cm., acute to obtuse at base, gradually narrowed to an acuminate apex, the venation inconspicuous; inflorescences apparently 3-7-flowered (flowers unknown), the peduncles less than $1 \mathrm{~cm}$. long, the bracteoles subulate, $1-1.5$ $\mathrm{mm}$. long; pedicels in fruit $18-20 \mathrm{~mm}$. long, slender, terete or 4-angled near base but conspicuously 4-angled or narrowly 4-winged distally; fruiting calyx 13-17 mm. long, the tube infundibular, about $5 \mathrm{~mm}$. long, narrowly but sharply 4-winged, the wings decurrent on pedicel, the sinuses rounded, the lobes 4 , erect, subulate-lanceolate, 8-12 $\mathrm{mm}$. long, $1-1.5 \mathrm{~mm}$. broad proximally, sharply carinate dorsally into a basally conspicuous wing; fruits 1-lobed (as far as noted), ellipsoid, 10-15 $\times 8-10 \mathrm{~mm}$. at apparent maturity.

TYPIFICATION: The type is U.S. Expl. Exped. (Us 62666 HOLOTYPE; fragmentary ISOTYPE at GH), collected in 1840 "on the mountain summit back of Muthuata" (Gray, 1862, but not indicated on specimen), Mathuata Province, Vanua Levu. It is probable that Gray's allusion was to Mathuata-i-wai Island and the Mathuata (Nawavi) Range (cf. this Flora, vol. 1, Figures 6, 12), doubtless visited by the U.S. Exploring Expedition in 1840 .

Distribution: Endemic to Fiji and known only from the type collection.

The relationship of this apparently very rare Fijian endemic is uncertain; among the New Caledonian species discussed by Green (1962) it is suggestive only of Jasminum noumeense Schlechter, from which it is readily distinguished by its longer, winged or angled pedicels, its winged calyx tube, and its longer calyx lobes. Jasminum tetraquetrum, like $J$. sessile, points to our very inadequate knowledge of the plants of the coastal areas of Mathuata Province. 

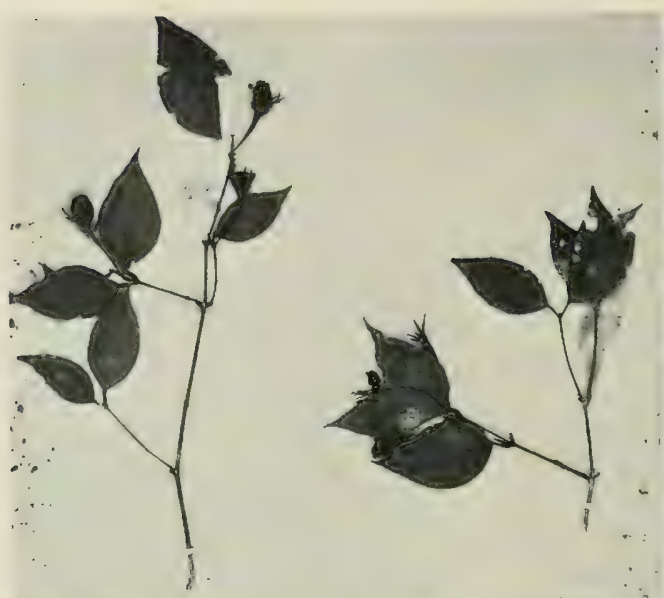

Co - 00 Q FISHER SCIENTIFIC
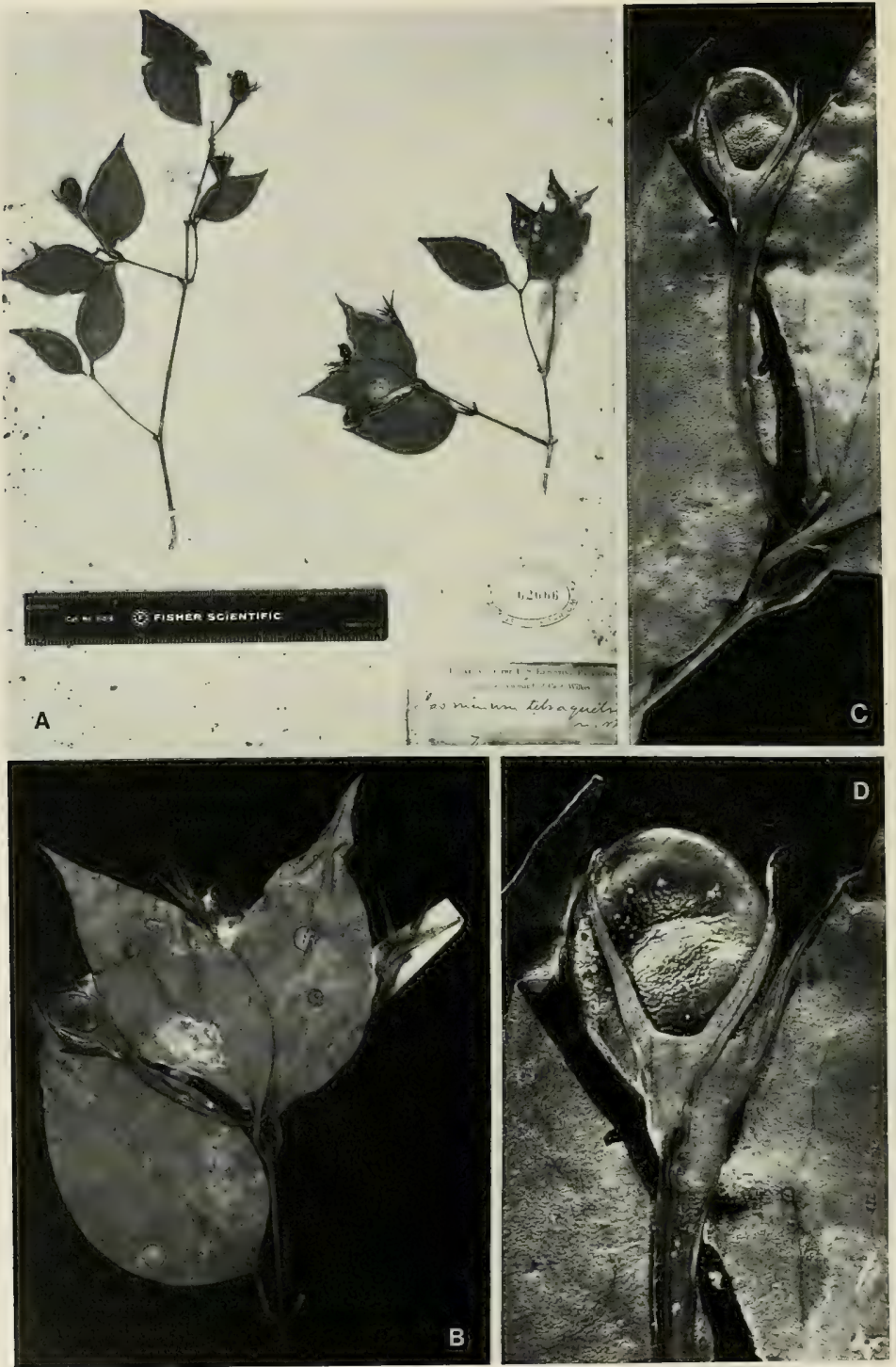
8. Jasminum multiflorum (Burm. f.) Andrews, Bot. Repos. 8: $t$. 496. 1807; Kobuski in J. Arnold Arb. 13: 172. 1932; Christophersen in Bishop Mus. Bull. 128: 175. 1935; Backer \& Bakh. f. Fl. Java 2: 218. 1965; Sykes in New Zealand Dept. Sci. Indust. Res. Bull. 200: 141. 1970; J. W. Parham, PI. Fiji Isl. ed. 2. 255. 1972; M. Grant, Fosberg, \& H. M. Sm. in Smithsonian Contr. Bot. 17: 30. 1974; MacKee, Pl. Intro. Cult. Nouv.-Caléd. 103. 1985.

Nyctanthes multiflora Burm. f. Fl. Ind. 5. t. 3, fig. l. 1768.

Nyctanthes pubescens Retz. Obs. Bot. 5: 9. 1789.

Jasminum pubescens Willd. Sp. Pl. 1: 37. 1797; Yuncker in Bishop Mus. Bull. 184: 57. 1945.

Shrub 1-2 m. high, sometimes with subscandent branches, cultivated in villages and European gardens from near sea level to about $800 \mathrm{~m}$. The flowers are fragrant, especially at night, with a greenish corolla tube and pure white corolla lobes. Flowers have been observed between May and July.

TYPIFICATION: Andrews's drawing was based on a cultivated plant introduced by Lady Hume from the East Indies, but the nomenclatural type was probably collected from cultivation (perhaps in Kleinhoff's garden in Java, cf. Fl. Males. I. 1: 284. 1950) and may be extant at G-DEL. Nyctanthes pubescens was based on a Koenig specimen from Calcutta, almost certainly from a cultivated plant. The species was often noted as Jasminum pubescens (Retz.) Willd. in pre-1920 literature (Kobuski, 1932).

DisTRIBUTION: Indigenous in India and probably an early introduction into China (P. S. Green, in litt.), where the flowers were dried and used to flavor tea. It is now widely cultivated in tropical and subtropical areas.

USE: An attractive ornamental.

AVAilable Collections: VITI LEVU: MBa: Nandarivatu, Smith 5026. Rewa: Botanical Gardens, Suva, DA 12105. OVALAU: Lovoni Village, Smith 7465.

Jasminum sambac (L.) Ait., noted in Thurston's 1886 Catalogue, has not since that time been recorded in Fijian cultivation, but it is to be anticipated in Fijian gardens, since it is cultivated in many Pacific archipelagoes. It is related to J. multiflorum but is readily distinguished by its essentially glabrous foliage (the leaf blades with axillary hair tufts beneath) and comparatively inconspicuous inflorescence indument, shorter calyx lobes (7-10 in number), and smaller corollas.

2. Ligustrum L. Sp. Pl. 7. 1753; Backer \& Bakh. f. Fl. Java 2: 215. 1965; Kiew in Blumea 24: 143. 1978; A. J. Scott in Fl. Masc. Fam. 119. 5. 1981.

Small trees or erect shrubs, sometimes deciduous; leaves simple, short-petiolate, the blades entire, often glandular beneath; inflorescences terminal, thyrsoid or paniculiform, bracteate, the flowers small, $\not, 4$-merous, subsessile or short-pedicellate; calyx campanulate, truncate or shortly 4-dentate; corolla infundibular or campanulate, the tube equal to or longer than calyx tube, the lobes induplicate-valvate in bud, becoming spreading, slightly shorter than or longer than corolla tube; stamens 2 , inserted on corolla tube, the filaments slender, short, the anthers basifixed, ellipsoid or oblong, usually exserted; ovary subglobose, the ovules 2 per locule, pendulous, the style often filiform, the stigma 2-lobed; fruit a carnose berry or somewhat drupaceous, the endocarp chartaceous or membranous, the seeds usually solitary, sometimes 2-4.

TYPE SPECIES: Ligustrum vulgare L., the only original species.

FiguRE 55. Jasminum tetraquetrum; A, HOLOTYPE, $\times 1 / 3 ; \mathrm{B}$, foliage and infructescence, $\times 1 ; \mathrm{C}$, infructescence, showing a single fruit, $\times 2 ; \mathrm{D}$, fruit, with calyx and upper part of pedicel, $\times 4$. All from $U . S$. Expl. Exped. 
Distribution: Eurasia to Malesia and tropical Australia, with about 40 species, some of which are widely cultivated and naturalized. One cultivated species occurs in Fiji.

Useful tREATMENT OF GENUS: KIEW, R. Florae Malesianae Praecursores LVII. The Oleaceae of Malesia. I. The genus Ligustrum. Blumea 24: 143-149. 1978.

1. Ligustrum sinense Lour. Fl. Cochinch. 19. 1790; Merr. in Trans. Amer. Philos. Soc. n. s. 24 (2): 307. 1935; J. W. Parham, Pl. Fiji Isl. ed. 2. 256. 1972; Kiew in Blumea 24: 149. 1978; A. J. Scott in Fl. Masc. Fam. 119. 6. 1981; MacKee, Pl. Intro. Cult. Nouv.-Caléd. 104. 1985.

As seen in Fiji, Ligustrum sinense is occasionally cultivated near sea level; it is a shrub or small tree $2-4 \mathrm{~m}$. high, with young parts and leaf blades usually pale-villose, the blades elliptic, $2-5 \times 1-2 \mathrm{~cm}$., the flowers fragrant, with white corollas about $3 \mathrm{~mm}$. long at anthesis. The noted collections were flowering and fruiting between October and December.

TYPIFICATION: The type is Loureiro (P HOLOTYPE, cf. Merrill, 1935; but not found by Scott, 1981), collected near Canton, China.

Distribution: Southern China, often cultivated elsewhere.

LOCAL NAME AND USE: The privet is a garden ornamental, often used in hedges.

Avallable collections: VITI LEVU: Naitasiri: Plant Introduction and Quarantine Station, Nanduruloulou, DA 9809. Rewa: Suva, near Government Pharmacy, DA 12240.

3. Chionanthus L. Sp. Pl. 8. 1753; Stearn in Ann. Missouri Bot. Gard. 63: 355. 1977; A. J. Scott in Fl. Masc. Fam. 119. 10. 1981.

Linociera Sw. ex Schreber, Gen. Pl. 2: 784. 1791; Backer \& Bakh. f. Fl. Java 2:213. 1965. Nom. cons. (sed non vs. Chionanthus).

Olea sensu Seem. Fl. Vit. 154. 1866; non L.

Trees or erect shrubs, the branchlets often lenticellate; leaves opposite (or essentially so), simple, the blades entire, usually coriaceous, often glandular-punctate, sometimes with domatia in axils of secondary nerves beneath; inflorescences axillary, cymose or laxly thyrsoid, racemiform or paniculiform, sometimes fasciculate, the flowers small, $\varnothing$; calyx 4-lobed or -dentate; corolla white to yellow or rose, composed of 4 free petals or these coherent in pairs at base, induplicate-valvate in bud, subcarnose, linear or oblong; stamens 2 , hypogynous or scarcely coherent to petal bases, the filaments short, the anthers exceeded by petals when these are fully developed; ovary 2-locular, the ovules 2 per locule, collateral, pendulous, the style short, the stigma entire to 2-lobed; fruit a drupe, the exocarp carnose, the endocarp bony or cartilaginous or subligneous, the seed usually solitary.

LECTOTYPE SPECIES AND NOMENCLATURE: The lectotype species of Chionanthus is $C$. virginica L. (vide Britton \& Brown, Ill. Fl. N. U. S. ed. 2. 2: 728. 1913), one of Linnaeus's two original species; the type species of Linociera is L. ligustrina (Sw.) Sw. (Thouinia ligustrina Sw.). Until recently the two generic names have been retained by most concerned taxonomists, who used Chionanthus for the few temperate species and Linociera for the many tropical ones. Although real distinctions between the genera had been questioned as long ago as 1860 , Stearn (1977) was the first recent student to unite them. The arguments in favor of this union are so convincing that there now seems complete unanimity among students of Oleaceae to relegate Linociera to synonymy.

Figure 56. Chionanthus vitiensis; $\mathrm{A}$, distal portion of branchlet, with foliage and inflorescences, $\times 1 / 3$; $B$, portions of inflorescence, the petals in early anthesis, about as large as anthers, $\times 4$; C, portion of inflorescence, the petals elongating, $\times 4 ; D$, portion of inflorescence, the petals fully elongated, $\times 4$. A \& D from $D A 15635$, B from $D F 1118, \mathrm{C}$ from $D A 13920$. 

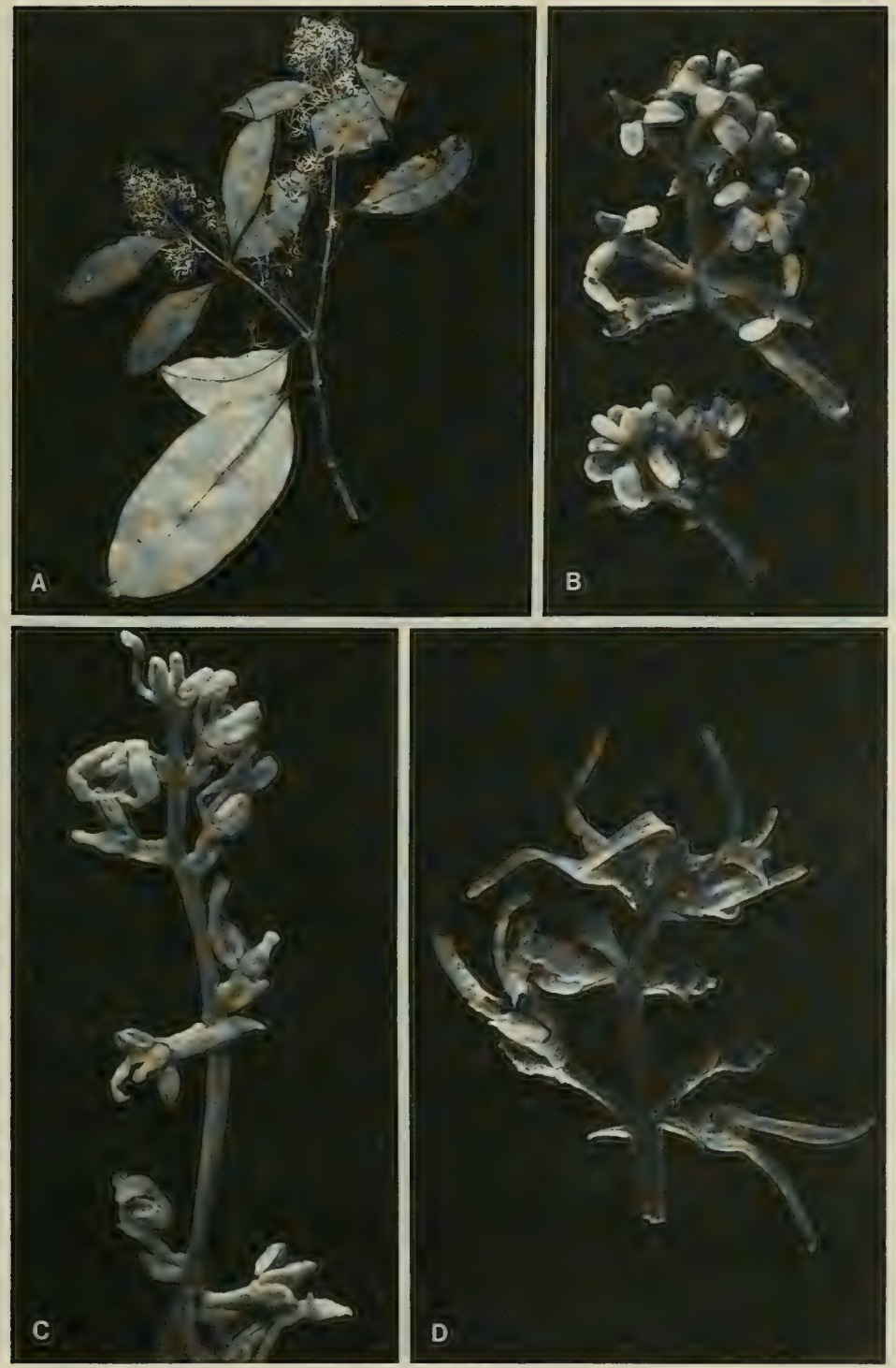

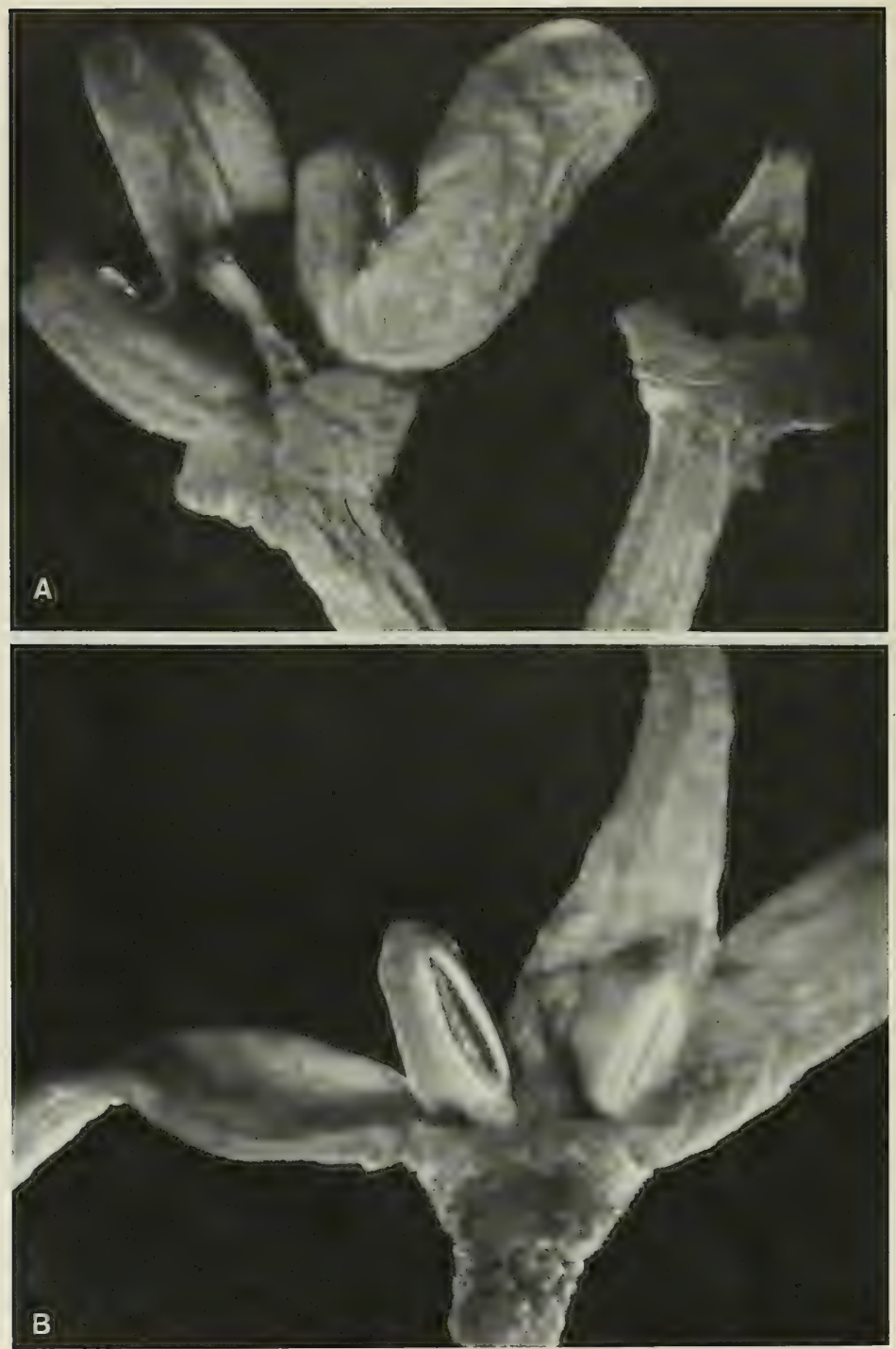
Linnaeus treated the generic name Chionanthus as feminine "because the plants were trees or large shrubs" (Stearn, 1977), but nevertheless Stearn treats Chionanthus as masculine, as do most subsequent students (Kiew in Malaysian Forester 42: 259-279. 1979, in op. cit. 43:362-392. 1980, in op. cit. 44: 143-162. 1981; Stearn in Bot. J. Linn. Soc. 80: 191-206. 1980; Harborne \& Green in op. cit. 81: 155-167. 1980; Kiew \& Ibrahim in op. cit. 84: 79-101. 1982). Scott (1981), however, continues use of Chionanthus as feminine.

DisTRIBUTION: Tropical, subtropical, and temperate regions of both hemispheres, with about 100 species. A single indigenous species represents the genus in Fiji and nearby Polynesian archipelagoes.

USeful TReatment of Genus: Stearn, W. T. Union of Chionanthus and Linociera (Oleaceae). Ann. Missouri Bot. Gard. 63: 355-357. 1977.

1. Chionanthus vitiensis (Seem.) A. C. Sm., comb. nov.

Figures 56-59.

Fagraea vitiensis Seem. in Bonplandia 9: 257, nom. nud. 1861; Seem. ex A. Gray in Proc. Amer. Acad. Arts 5: 320, nom. nud. 1862, in Bonplandia 10:37, nom. nud. 1862; Seem. Viti, 439, nom. nud. 1862; non Gilg \& Benedict (1921).

Olea vitiensis Seem. Fl. Vit. 155. 1866; Drake, Ill. Fl. Ins. Mar. Pac. 231. 1892.

Linociera pauciflora sensu Burkill in J. Linn. Soc. Bot. 35:45. 1901; Yuncker in Bishop Mus. Bull. $178: 94$. 1943; non C. B. Clarke.

Linociera gillespiei A. C. Sm. in Bull. Torrey Bot. Club 70:548. 1943, in J. Arnold Arb. 33: 113. 1952; J. W. Parham, Pl. Fiji Isl. 180. 1964, ed. 2. 256. 1972.

Linociera vitiensis A. C. Sm. in Bull. Torrey Bot. Club 70: 549. 1943, in J. Arnold Arb. 33: 112. 1952; J. W. Parham, Pl. Fiji Isl. 180. 1964, ed. 2. 256. 1972; Sykes in New Zealand Dept. Sci. Indust. Res. Bull. 200: 142. 1970.

Linociera sp. Yuncker in Bishop Mus. Bull. 220: 214. 1959.

Tree (2-) 10-20 m. high, often slender, occurring from near sea level to an elevation of about $1,130 \mathrm{~m}$. in dense or open forest or on forested ridges. The fragrant flowers have the petals and stamens white to cream-colored or yellowish and the ovary greenish; mature fruits are yellow to orange. Flowers have been collected between July and March, fruits between December and May. The species, previously described only from the three type collections (all in fruit), is here redescribed from the ample material now at hand.

Plant glabrous throughout or with inflorescence branches and calyx obscurely and evanescently puberulent, the branchlets cinereous to pale brown, subterete, sparsely to copiously lenticellate, slightly flattened and thickened at nodes; leaf pairs $0.5-3.5 \mathrm{~cm}$. apart, the petioles rugulose, shallowly canaliculate, $10-25 \mathrm{~mm}$. long, $1-3 \mathrm{~mm}$. in diameter, the blades coriaceous, drying olivaceous and often rugulose, without domatia, with immersed glands, lanceolate-elliptic to ovate-oblong or broadly elliptic, $6.5-22 \mathrm{~cm}$. long, $2.5-9 \mathrm{~cm}$. broad, acute to attenuate or obtuse at base and decurrent on petiole, obtusely cuspidate (rarely rounded) to acuminate at apex (acumen to $15 \mathrm{~mm}$. long), slightly recurved at margin, the costa stout, nearly plane or elevated above, prominent beneath, the secondary nerves 5-8 $(-10)$ per side, erecto-patent, slightly curved, inconspicuously anastomosing within margin, plane or raised or slightly impressed above, inconspicuously to strongly elevated beneath, the veinlet reticulation immersed or inconspicuously prominulous on both surfaces, usually obvious beneath; inflorescences axillary or borne on defoliate branchlets, racemiform-or paniculiformcymose (sometimes merely fasciculate on branchlets and 3- or 4-flowered), up to $6 \mathrm{~cm}$. long and broad, with or without a few or several lateral (or basal) branches decreasing in length distally (ultimate flowers solitary or 2-4-fasciculate), the bracts deltoid-

FIGURE 57. Chionanthus vitiensis; A, flowers, one with 2 developing petals removed, showing 2 petals, stamens, gynoecium, and calyx, the other with only calyx and gynoecium remaining, $\times 24 ; \mathrm{B}$, fully developed flower, with 1 petal removed, $\times 24$. A from Howard 302, B from DA 15635. 

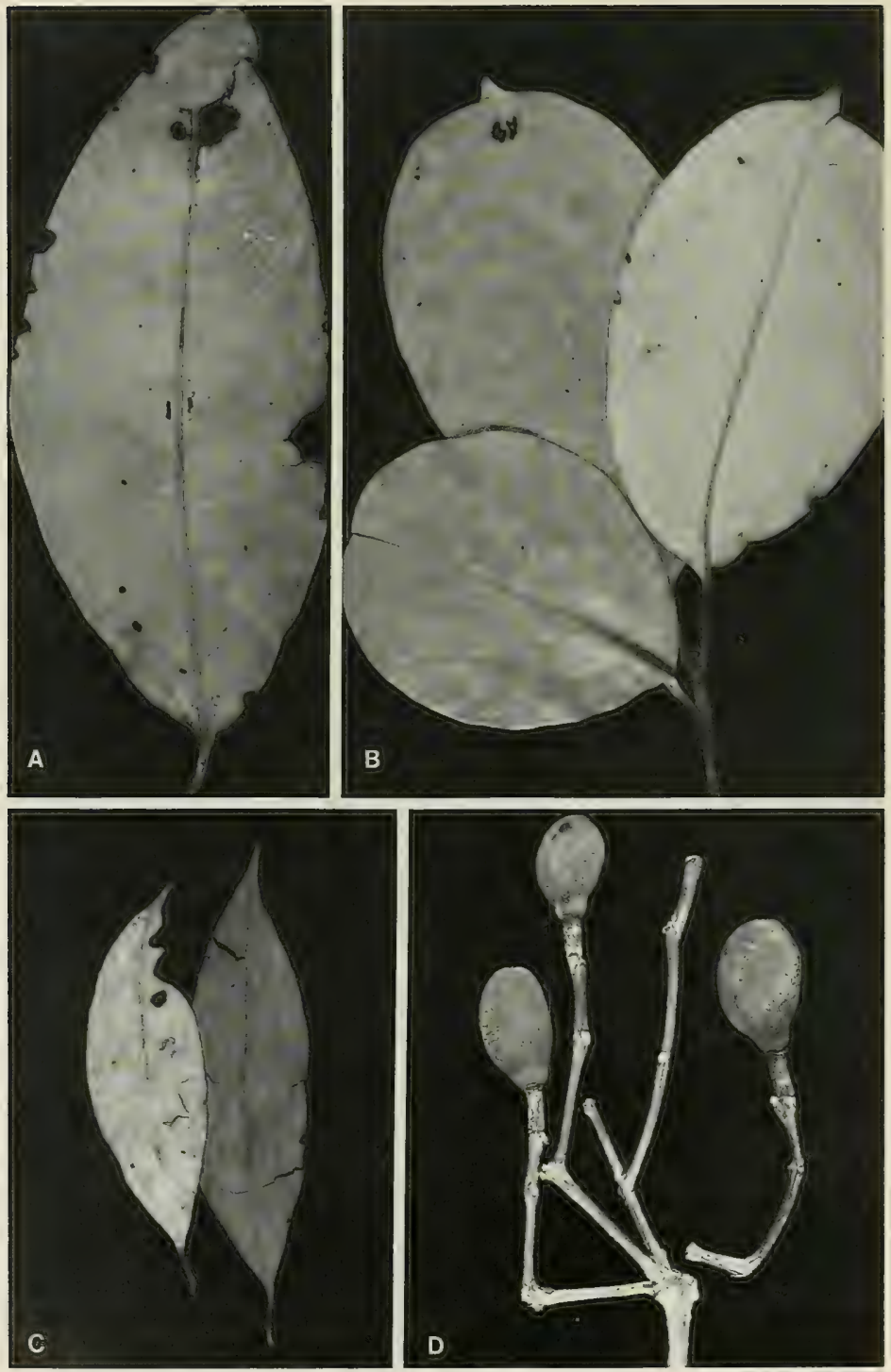

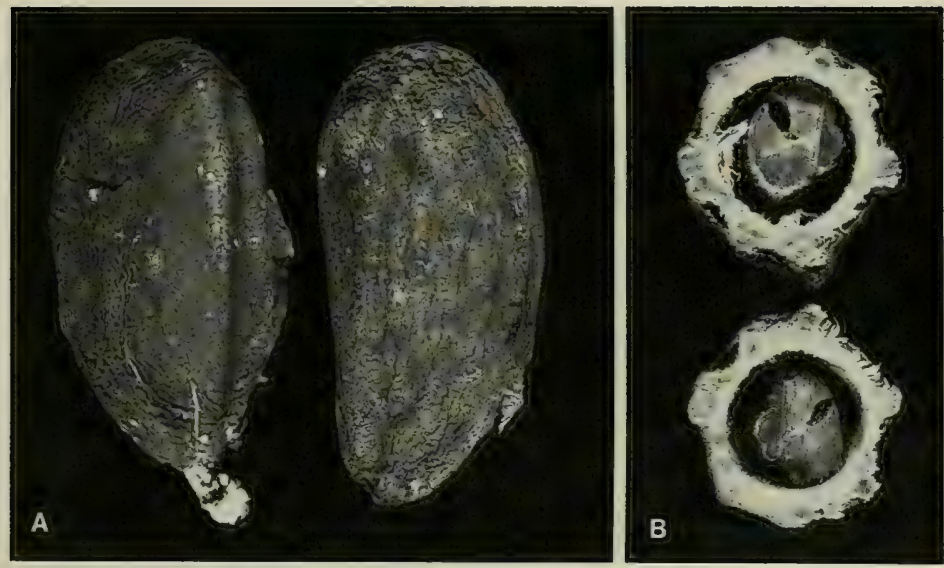

FIGURE 59. Chionanthus vitiensis, from Smith 864 ; A, mature fruits, $\times 2$; B, cross sections of mature dried fruit, $\times 2$

oblong, obtuse, 1.5-2 mm. long, the flowers subsessile or borne on pedicels to $4 \mathrm{~mm}$. long, these with 1 or 2 obscure bracteoles or ebracteolate; calyx cupuliform, at anthesis about $1 \mathrm{~mm}$. long and $1.5 \mathrm{~mm}$. in diameter, the lobes deltoid, subacute, $0.2-0.5 \mathrm{~mm}$. long, $0.5-1 \mathrm{~mm}$. broad, the sinuses rounded or obtuse; petals free or loosely adherent at base, thin-carnose, at first oblong and apically rounded $(1.5 \times 1 \mathrm{~mm}$. in early anthesis), rapidly elongating and ultimately lanceolate-ligulate, finally to $7 \mathrm{~mm}$. long and $1-1.3$ $\mathrm{mm}$. broad and subacute to obtuse at the cucullate apex; stamens subsessile, the filaments carnose, flattened, to $0.2 \mathrm{~mm}$. long, the anthers oblong-ellipsoid, 1.2-1.7 $\mathrm{mm}$. long, 0.6-0.7 mm. broad, truncate or obtuse at apex; ovary ellipsoid, abruptly or gradually narrowed into a conical or subterete style $0.2-0.8 \mathrm{~mm}$. long, the stigma obscurely or obviously lobed; infructescences to $14 \mathrm{~cm}$. long, usually with 1-4 fruits persisting to maturity, the rachis thickening to $2-3 \mathrm{~mm}$. in diameter, the pedicels becoming thick and rugose, $(0-) 1.5-7 \mathrm{~mm}$. long (above ultimate articulation); fruit carnose, becoming coriaceous in drying, ellipsoid or obovoid, slightly flattened, rounded at base and apex, at maturity $30-35 \mathrm{~mm}$. long, $17-20 \mathrm{~mm}$. broad, $14-16 \mathrm{~mm}$. thick, the exocarp strongly rugulose in drying, the endocarp subligneous, (1-) 2-3 mm. thick, drying longitudinally ridged.

TyPifiCATION AND NOMENCLATURE: Three Fijian types are involved in the synonymy. Olea vitiensis is based on Seemann 307 (K HOLOTYPE; ISOTYPE at GH), collected on Viti Levu without further locality in July, 1860. During that month Seemann visited several coastal areas of southeastern Viti Levu (cf. Viti, 82-119, 133-134. 1862). Between July 1 and 10 he called at Rewa village, Nanggara Island (coastal Namosi Province), and the Navua delta region and coastal Serua Province west of the delta. Toward the end of the month, while based at Mbau, he visited parts of the opposite Tailevu mainland. Therefore it is not possible to suggest a more detailed locality than coastal southeastern Viti Levu.

FIgURE 58. Chionanthus vitiensis; A-C, leaves, showing variability in size and shape, $\times 1 / 2 ; \mathrm{D}$, portion of infructescence with maturing fruits, $\times 1$. A from DF 1118. B from Smith 9242, C from Gillespie 4289, D from Smith 6135. 
Seemann's description of a species of Olea was completely overlooked by me in 1943, when I rashly described the only two Fijian collections of Linociera then known to me as two new species. Linociera gillespiei is typified by Gillespie 4289 (BISH HOLOTYPE; fragmentary ISOTYPE at A), collected Dec. 13, 1927, near the summit of Mt. Nanggaranambuluta, east of Nandarivatu, Mba Province, Viti Levu. The type of Linociera vitiensis is Smith 864 (GH HOLOTYPE; many ISOTYPES), obtained Dec. 29, 1933, from the borders of the montane lake east of Somosomo, Taveuni.

The three type collections are all in fruiting condition. Differences in foliage between the type material of Linociera gillespiei and $L$. vitiensis are apparent but, in light of the many collections of the genus now available from Fiji, it is obvious that such foliage differences are inconsequential. The foliage of Olea vitiensis is very similar to that of $L$. vitiensis. The use of Seemann's epithet in Linociera would create a later homonym, but in Chionanthus his epithet is available, and it is very suitable that the first known collection of this interesting species can now serve as its nomenclatural type.

Distribution: Fiji, Tonga, and Niue. Also, it is probable that a single sterile collection from Samoa (Whistler 4495, from the island of Nututele) represents this species, as well as providing a new easternmost record in the Pacific for the genus. In Fiji 19 collections are now at hand from four of the high islands.

Local NAMES: Teinivia and thaunilawa (inland Viti Levu); lolovatu (Taveuni).

Available collections: VITI LEVU: MBa: Nandarivatu, Tothill 384; Mt. Nanggaranambuluta, Stauffer \& Koroiveibau 5828. NANDRONGA \& NavosA: Nausori Highlands, DA 15635; northern portion of Rairaimatuku Plateau, between Nandrau and Rewasau, Smith 5632. SERUA: Nathengathenga Creek, Navua River tributary, DF 1118 (Damanu 216); hills west of Waivunu Creek, between Ngaloa and Korovou, Smith 9242. Namosi: Ridges above Wainikoroiluva River, $D A$ 2487. NAITASIRI: Northern portion of Rairaimatuku Plateau, between Mt. Tomanivi and Nasonggo, Smith 5794, 6135; Tholo-i-suva, DA 14530, Bola 134. OVALAU: Korotumbuitho, Lovoni Valley, DA 13290. VANUA LEVU: Mathuata: Serau, DA 13920; inland from Lambasa, Howard 302; southern slopes of Mt. Numbuiloa, east of Lambasa, Smith 6374, 6580.

Specimens from the New Hebrides cited by Guillaumin (in J. Arnold Arb. 14: 59. 1933) as Linociera ramiflora Wall. are suggestive of Chionanthus vitiensis, but I hesitate to refer them (and Green RSNH 1298, from Eromanga) to that species. Kajewski 765 , from Aneityum, has inflorescences at full anthesis with very slender branchlets and pedicels (these $6-8 \mathrm{~mm}$. long) and anthers about $2 \mathrm{~mm}$. long. The relationship of $C$. vitiensis to Malesian species is at present speculative, but at any rate it is unlikely that Seemann's 1866 epithet will be antedated by those of taxa from New Guinea or the Solomon Islands.

\section{ORDER RUBIALES}

The large family Rubiaceae is perhaps most often placed in the order Gentianales, e. g. by Melchior (1964), Thorne (1976), Dahlgren (1980), Takhtajan (1980, 1986), and Ehrendorfer (1983). An order Rubiales has been used in the classifications of Lawrence (1951), Hutchinson (1973), and Cronquist (1981), although with different included families in each case. Arguments for a separate order are well summarized by Cronquist (1981, pp. 998-1,000), who suggests that the Rubiaceae form a connecting link between the orders Gentianales and Dipsacales. 


\section{FAMILY 168. RUBIACEAE}

\section{By Albert C. Smith and Steven P. Darwin (Tulane University)}

Rubiaceae Juss. Gen. Pl. 196. 1789.

Trees, shrubs, vines, lianas, or herbs, sometimes myrmecophilous, sometimes spiny; stipules interpetiolar or intrapetiolar, often connate, highly variable, sometimes conspicuous, commonly with colleters on inner surface, rarely reduced to a mere interpetiolar line; leaves simple and usually with entire blades, mostly decussately opposite, sometimes verticillate, rarely alternate by suppression of one of a pair at each node, petiolate or less often sessile, sometimes containing small bacterial nodules; inflorescences basically cymose but diverse (flowers rarely solitary), terminal or axillary, sometimes with conspicuous bracts and bracteoles, the flowers $\Varangle$ or unisexual, actinomorphic (rarely somewhat irregular), often heterostylous, nearly always epigynous, basically 4- or 5-merous; calyx gamosepalous, mostly adnate to ovary and forming a hypanthium, the free portion (calyx limb) variable, minute to conspicuous (sometimes completely enclosing corolla in bud and then variously dehiscing), the lobes obsolete or small to obvious, one or more of them sometimes enlarged and highly colored; corolla sympetalous (very rarely with petals free to base, as in Mastixiodendron and Hedstromia), (3 or) 4 or $5(-11)$-lobed, the lobes valvate, convolute, or imbricate; stamens as many as and alternate with corolla lobes, attached within corolla tube or at its throat, sometimes at its base, the filaments short to elongate, the anthers 2-locular, basifixed or dorsifixed, dehiscing by introrse longitudinal slits; epigynous disk often obvious, frequently surrounding (rarely basally united with) style; ovary inferior (rarely semisuperior, as in Mastixiodendron, or essentially superior), the locules ( 1 or) 2 or often more numerous, the placentation axile (or essentially basal or essentially apical) or parietal (in a unilocular ovary as in Gardenia, etc.), the ovules 1-many per locule, anatropous to hemitropous, sometimes embedded in fleshy placentae, the style terminal, slender, or styles rarely distinct to base (as in Hedstromia and Coprosma), the stigma often capitate or lobed or otherwise modified; fruit a capsule, berry, or drupe, or dry and indehiscent, or schizocarpic, occasionally united into syncarps; seeds with well-developed endosperm (or this scanty or lacking), the embryo straight to curved.

Distribution: Pantropical and subtropical but also extensively extratropical, probably with about 500 genera and 6,500-7,000 species. In Fiji we here recognize the occurrence of 42 genera, 34 of which have indigenous species; 188 species are recorded as occurring in Fiji, 165 of them indigenous (and 138 of these endemic).

USEFUL TREATMENTS OF FAMILY: The literature on Rubiaceae is so vast that a listing of even the most essential discussions would be out of place in the present treatment. Only a few of those recent papers discussing currently utilitarian classification systems are here listed. Other references are noted under generic treatments. VERDCOURT, B. Remarks on the classification of the Rubiaceae. Bull. Jard. Bot. Brux. 28: 209-290. 1958. BREMEKAMP, C. E. B. Remarks on the position, the delimitation, and the subdivision of the Rubiaceae. Acta Bot. Neerl. 15: 1-33. 1966. HallÉ, N. Famille des Rubiacées. Fl. Gabon 12: 1-278. 1966; 17: 1-335. 1970. Verdcourt, B. Rubiaceae (Part 1). In: Polhill, R. M. (ed.). Fl. Trop. E. Afr. Rub. 1-414. 1976. DARWIN, S. P. The subfamilial, tribal and subtribal nomenclature of the Rubiaceae. Taxon 25: 595-610. 1976. Darwin, S. P. A synopsis of the indigenous genera of Pacific Rubiaceae. Allertonia 2: 1-44. 1979. Keddam-Malplanche,-M. Le pollen et les stomates des Gardéniées (Rubiacées) du Gabon: morphologie et tendances évolutives. Mém. Mus. Hist. Nat., Sér. B, Bot. 29: 1-109. 1985.

The Rubiaceae are one of the largest families of angiosperms (probably the fifth largest after Asteraceae, Orchidaceae, Fabaceae sensu lat., and Poaceae), and its members are frequent components of tropical vegetation worldwide. The family is well circumscribed; various segregate families (e. g., Naucleaceae Wernham) have not been generally accepted. The genera are fairly easily grouped into tribes, but the arrange- 
ment of tribes into subfamilies is far from settled. The traditional classifications of de Candolle (Prodr. 4: 341-622. 1830), J. D. Hooker (in Benth. \& Hook. f. Gen. Pl. 2: 7-151. 1873), and Schumann (in Engl. \& Prantl, Nat. Pflanzenfam. IV. 4: 1-156. 1891) divide the family into two groups, one having solitary ovules in each ovary locule, the other with two or more ovules per locule. Such a classification, while partially useful and maintained by some recent authors (e. g. Hallé, 1966, 1970), is manifestly artificial. A more natural classification, proposed by Verdcourt (1958) and modified by Bremekamp (1966), is primarily based on the presence or absence of raphid crystals, a distinction that is at least as readily determinable as ovule number. Additional features, among others, considered important in the delimitation of tribes are ovule number (within limits), number of ovary locules, aestivation of corolla lobes, fruit type, alate vs. nonalate seeds, presence or absence of endosperm, and pitting of seed testa cells. The Rubiaceae as a whole or selected tribes have been studied from the points of view of comparative palynology (summarized by Keddam-Malplanche, 1985), wood anatomy (e. g. Koek-Noorman in Acta Bot. Neerl. 18: 108-123, 337-395. 1969; 19: 154-164. 1970; 21: 301-320. 1972; Koek-Noorman and Hogeweg in op. cit. 23: 627-653. 1974; Koek-Noorman and Puff in Pl. Syst. Evol. 143: 17-45. 1983), and serology (Lee and Fairbrothers in Taxon 27: 159-185. 1978).

While some authors (e. g. Hallé, 1966, 1970; Keddam-Malplanche, 1985) suggest the tribe Gardenieae as containing the most primitive living Rubiaceae, there is no consensus as to infrafamilial phylogeny except that the herbaceous and largely temperate Rubieae are a highly modified and advanced group. While Bremekamp (1966) arranged the various tribes into eight subfamilies, the simpler classification employed by Verdcourt (1976) is at present the more adaptable and is the one used here. In the present treatment the sequence of tribes largely follows that of Verdcourt, with modification where suggested by more recent studies; the generic sequence is arbitrary, and the keys to tribes and genera are adapted from Darwin (1979).

The Rubiaceae are of some considerable biological interest for their variety of pollination mechanisms. While the majority of species have hermaphrodite, homostylous flowers, a high proportion (probably a majority) of all known instances of heterostyly occurs in the family. Heterostyly is especially common in certain tribes (e. g. Psychotrieae, Hedyotideae) but is often not constantly present even throughout a genus. Unisexual flowers (possibly derived from heterostylous flowers) and dioecism are not uncommon in Rubiaceae, especially among Guettardeae. A specialized type of floral system, the ixoroid pollination mechanism (here discussed under Ixora), characterizes a number of evidently related genera.

Other than Coffea, and to a lesser extent Cinchona, the Rubiaceae include no crop plants of great economic significance. However, a number of species are prominent tropical ornamentals, especially in the genera Gardenia, Ixora, and Pentas. A few other species (e. g. Morinda citrifolia) have some local uses.

KEY to tRIBES OCCURRING IN FiJi

Raphid crystals absent in all plant parts; corolla lobes valvate, imbricate, or contorted in bud.

Fruit drupaceous, containing several I-seeded pyrenes or a fused stone (putamen) with several locules; ovules solitary and pendulous in each ovary locule; endosperm absent; corolla lobes valvate or imbricate in bud (subfamily AnTIRHEOIDEAE); indigenous species. ......... 1. GUETTARDEAE

Fruit various but not as above; ovules 1-many in each ovary locule; endosperm usually present (subfamily Cinchonoldeae). 
Flowers arranged in dense, globose heads; ovules numerous in each ovary locule; corolla lobes imbricate or valvate in bud; indigenous or cultivated species. . . . . . . . . NAUCLEEAE

Flowers variously arranged but not in dense, globose heads.

Ovules 2-many in each ovary locule.

Fruit capsular, dehiscent.

Seeds alate (in our species with a long, narrow wing at each end); capsules (in our species) conspicuously elongate, more than 10 times as long as broad; corolla lobes contorted in

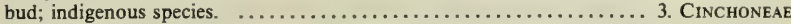

Seeds not alate, or inconspicuously winged; fruit not conspicuously elongate.

Stamens inserted in corolla throat; corolla lobes imbricate or contorted in bud; indigenous or

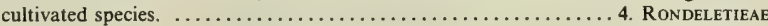

Stamens inserted at base of corolla; corolla lobes imbricate or valvate in bud; indigenous

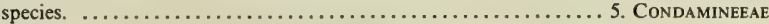

Fruit indehiscent.

Corolla lobes valvate in bud; calyx (in our species) with one lobe expanded and petaloid; indigenous or cultivated species. .......................... ISERTIEAE

Corolla lobes contorted in bud; calyx lobes never petaloid.

Seeds several in each ovary locule (or ovary unilocular and placentation parietal) and immersed in pulp; flowers or inflorescences often appearing lateral due to sympodial growth of branchlets; indigenous or cultivated species. .......... GARDENIEAE

Seeds 1-several in each ovary locule, not immersed in pulp; inflorescences terminal, the branchlets monopodial; indigenous or cultivated species. . ........ 8. PAVETTEAE

Ovules solitary in each ovary locule; fruit indehiscent.

Corolla lobes contorted in bud.

Fruit not conspicuously tapering toward apex or strongly compressed contrary to dissepiment; ovules basal or attached near middle of dissepiment.

Inflorescences terminal; indigenous or cultivated species. . . . . . . . . PAvetteAE

Inflorescences axillary at both sides of node; cultivated species. . . . . . . . 9. CoFFEEAE

Fruit (in our species) conspicuously tapering toward apex and strongly compressed contrary to dissepiment; ovules pendulous in each ovary locule; indigenous species.

10. Alberteae

Corolla lobes valvate in bud; ovules pendulous in each ovary locule.

Stamens inserted in throat of sympetalous corolla; terminal portion of style conspicuously swollen; indigenous species. $\ldots \ldots \ldots \ldots \ldots \ldots \ldots \ldots \ldots \ldots \ldots \ldots \ldots \ldots \ldots \ldots$. VANGUERIEAE

Stamens (in our species) inserted at base of polypetalous corolla; terminal portion of style not conspicuously swollen; indigenous species. . . . . . . HIOCOCCEAE

Raphid crystals present in leaves or other plant parts; corolla lobes valvate in bud (subfamily RUBIOIDEAE).

Ovules 2-many in each ovary locule, the placenta attached near base of dissepiment; fruit a loculicidal or septicidal capsule; indigenous, cultivated, or adventive species.

15. HEDYOTIDEAE

Ovules solitary in each ovary locule.

Fruit multiple (or often simple in Gynochtodes), fleshy; flowers sessile in dense, globose heads (or frequently pedicellate in Gynochtodes); ovules attached at or below middle of dissepiment; indigenous or aboriginally introduced species. .................. MORINDEAE

Fruit simple, fleshy or dry, circumscissile or separating into 1-seeded cocci; flowers usually not united into dense, globose heads.

Ovules basal and erect in each ovary locule; fruit (in our species) drupaceous; flowers not arranged in dense clusters at nodes.

Style simple or at least not divided to base (except in Hedstromia and then not elongate); stamens adnate to corolla tube or corolla polypetalous (Hedstromia).

Inflorescences terminal; indigenous species. ................. PsychotriEAE

Inflorescences axillary; indigenous species. ............. MORINDEAE (Gynochtodes)

Style elongate, divided to base; stamens inserted at base of sympetalous corolla; indigenous

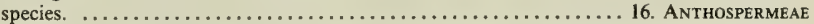

Ovules attached near middle of dissepiment; fruit a circumscissile capsule or separating into 1-seeded cocci; flowers frequently arranged in dense clusters at nodes; adventive species.

17. SPERMACOCEAE

\section{KEYS TO GENERA}

TRIBE 1. GuetTARDEAE

Corolla lobes imbricate in bud; fruit with a several-chambered stone (putamen).

Fruit subglobose; calyx deciduous; flowers $\not \Varangle$ or occasionally unisexual. ............ 1. Guettarda

Fruit more or less oblong; calyx persistent; flowers (in Fijian species) unisexual. .......2. Antirhea Corolla lobes valvate in bud; fruit with few-many separate, single-seeded pyrenes; flowers unisexual. 
Tribe 2. NaucleEaE

Ovaries united; fruit a syncarp; seeds not winged; placenta Y-shaped; stigmas spindle-shaped; stipules flattened, adpressed in terminal bud; cultivated only. .................. Nauclea

Ovaries and fruits separate.

Fruit somewhat fleshy, indehiscent, the distal end thick-walled and cartilaginous; seeds not winged; placenta undivided or Y-shaped; stigmas spindle-shaped; stipules obvolute in terminal bud; culti-

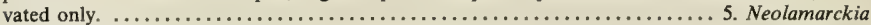

Fruit dry, dehiscent, without cartilaginous thickenings; seeds winged at both ends; placenta obovoid; stigmas subglobose to obovoid; stipules flat, strongly adpressed in terminal bud; indigenous.

TRIBE 3. CinchoneAE

6. Neonauclea

One indigenous genus in Fiji; monoecious trees or shrubs; inflorescences cymose, axillary, the terminal flower $q$, the other flowers $\sigma^{\circ}$.

\section{TRIBE 4. RondeletieaE}

Inflorescences terminal or axillary; corolla lobes imbricate in bud; anthers included or exserted; ovary and fruit subglobose, the seeds usually winged; cultivated only.

8. Rondeletia

Inflorescences terminal; corolla lobes contorted in bud; anthers exserted; ovary and fruit longer than broad, the seeds angular but not winged; indigenous shrubs of riverine habitats (rheophytes).

Tribe 5. CONDAMineEAE

9. Lindenia

Corolla Iobes valvate in bud; anthers hardly exserted; placentas T-shaped in cross section and intrusive into ovary locules, the fruit seemingly 4-locular before dehiscence, septicidally dehiscent. ... 10. Bikkia

Corolla lobes imbricate in bud; anthers long-exserted; placentas Y-shaped, not intrusive, the fruit septici-

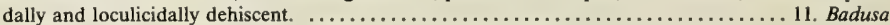

TRIBE 6. ISERTIEAE

One genus only in Fiji; inflorescences terminal or in axils of the most distal pair of leaves, the flowers $\zeta$ or unisexual; anthers included.

12. Mussaenda

TRIBE 7. GardenieAe

Flowers solitary, terminal at inception but soon appearing axillary due to sympodial growth of branchlet; ovary 1-locular, the placentas parietal, alternating with calyx angles or wings; calyx with conspicuous angles or spurlike wings; anthers mostly included; stigmatic lobes connate; young stipular sheaths producing a yellowish exudate; pollen in permanent tetrads; indigenous or cultivated. . . 13. Gardenia

Flowers solitary or arranged in inflorescences; ovary mostly 2-locular, the placentas axile; calyx lacking conspicuous angles or spurlike wings; stipular exudate absent; pollen in monads; indigenous.

Leaf blades large (to $1 \mathrm{~m}$. long); inflorescences axillary; sympodial growth absent; calyx lobes 5 , erect, ovate-deltoid, subulate toward apex; anthers included; style included, the stigmatic lobes divergent; fruit large (more than $3 \mathrm{~cm}$. broad), drying rugose or costate. . . . . . . . . . . Sukunia

Leaf blades not strikingly large; inflorescences terminal at inception but appearing axillary due to sympodial growth of branchlet, distributed at alternate nodes; stigmatic lobes coherent; fruit generally less than $3 \mathrm{~cm}$. broad.

Inflorescences 1-few-flowered, appearing as defoliate spur-branches at alternate, somewhat anisophyllous or defoliate nodes; calyx truncate to denticulate, not enclosing corolla in late bud, persistent; anthers and style included. . ................................ Porterandia

Inflorescences fasciculate to cymose, probably with as many as 30 flowers, occurring at alternate, isophyllous or defoliate nodes; calyx enclosing corolla in late bud, rupturing into 2 or 3 lobes, the limb at length deciduous; anthers and style exserted.

16. Pelagodendron

\section{Tribe 8. Pavetteae}

Flowers (4 or)5(-7)-merous; ovules 1-many in each ovary locule, the seeds angular; style usually conspicuously elongating beyond corolla limb in age, the stigmatic lobes coherent; corollas white; indigenous.

17. Tarenna

Flowers 4(rarely 5)-merous; ovules solitary in each ovary locule, the seeds not angular; style usually not elongating far beyond corolla limb, the stigmatic lobes separate; corollas white to yellow or red; indigenous or cultivated.

Tribe 9. CoFFeEAE

One genus in Fiji, cultivated only; shrubs or small trees with inflorescences axillary in both axils of a leaf

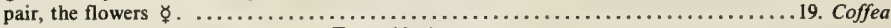

Tribe 10. Alberteae

One indigenous genus in Fiji; our species slender trees or shrubs with $\Varangle$, evidently protandrous flowers. 20. Airosperma 
Tribe 11. VANgurrieaE

Corolla tube broadly cylindric, the tube in our species shorter than lobes; filaments well developed, the anthers in our species long-exserted; style slender, much longer than corolla tube, sometimes narrowing at apex, the stigmatic knob cylindric, longer than broad, hollow to about the middle, bifid or deeply cleft at apex when mature; inflorescences in our species expanded, cymose, 20-40-flowered.

21. Psydrax

Corolla hypocrateriform, the tube longer than lobes; filaments short or essentially none, the anthers exserted; style (at least in our species) only slightly longer than corolla tube, widening below stigmatic knob, this solid, with style attached at base (not recessed); inflorescences 1-few-flowered, fasciculate or occasionally with rudimentary branches. ..................... 22, Cyclophyllum

TRIBE 12, ChIOcOCCEAE

One indigenous genus in Fiji; our species with polypetalous $\Varangle$ flowers, these with the ovary sometimes more than half-superior; fruit with perianth-scar below apex. ............. 23. Mastixiodendron

TRIBE 13. PsychotribaE ${ }^{1}$

Plants with swollen, tuberous stems inhabited by ants, epiphytic (rarely terrestrial).

Flowers unisexual or $\Varangle$ and often heterostylous; corollas glabrous within or pubescent in throat, lacking basal squamellae; stamens with short filaments or these essentially lacking, the anthers subsessile in corolla throat; ovary (in our species) 2-locular, the fruit with 2 pyrenes; stigma 2- or 4-lobed; tubers comparatively broad and lobed at base, the foliate branches usually several from each tuber.

24. Hydnophytum

Flowers $\Varangle$, homostylous; corollas glabrous within but invested with barbate squamellae toward base of tube; filaments of stamens well developed, about as long as anthers; ovary 4-locular, the fruit with 4 pyrenes; stigma discoid-peltate to cupular, the margin fimbriate and reflexed; tubers ellipsoid and not lobed, the foliate branches comparatively few from each tuber. . . . . . . . . 25. Squamellaria

Plants without swollen or tuberous stems; trees, shrubs, vines, or herbs, not epiphytic.

Trailing herbs frequently rooted at nodes; leaf blades palmately nerved from base, reniform to broadly

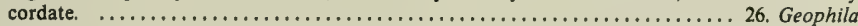

Erect trees or shrubs, occasionally vines; leaf blades variously shaped, but not reniform.

Calyx limb completely enclosing corolla in late bud, fleshy and splitting into 4 slightly unequal lobes, or membranous and opening along one side.

Flowers 4-merous; calyx limb splitting into 4 unequal lobes, these fleshy and resembling corolla lobes in size and texture; disk basally united with style, distally free and urceolate; fruit subcylindric, truncate to depressed at apex. ...................... 27. Readea

Flowers 5-merous; calyx limb spathaceous, membranous, opening along one side or rarely splitting into 2 lobes, these not resembling corolla lobes in size or texture; disk carnose, annular; mature fruits unknown. ........................ 28. Gillespiea

Calyx limb variable but not as described above, sometimes much expanded but not enclosing corolla in late bud.

Inflorescences capitular or capitular-cymose, with conspicuous, often numerous, involucrate, free or united bracts, these pale green to white, at length deciduous; calyx limb relatively large, infundibular, deciduous in fruit. $\ldots \ldots \ldots \ldots \ldots \ldots \ldots \ldots \ldots \ldots \ldots \ldots \ldots \ldots \ldots \ldots$ Calycosia

Inflorescences variable, sometimes capitular, but not with conspicuous, involucrate bracts; calyx limb large or small.

Corolla composed of 5 essentially free petals, the stamens attached at base of corolla; styles 2 , laterally coherent; stipules free nearly to base, rounded to broadly obtuse at apex.

30. Hedstromia

Corolla sympetalous, the stamens attached to corolla tube; style solitary, variously branched; stipules variously united, rarely rounded at apex.

Leaf blades commonly less than $1 \mathrm{~cm}$. long; flowers and fruits appearing solitary and terminal.

31. Amaracarpus

Leaf blades usually more than $1 \mathrm{~cm}$. long; flowers and fruits in terminal inflorescences.

32. Psychotria

1The tribe Psychotrieae ("Psychotriaceae") Cham. \& Schlechtendal (in Linnaea 4: 1, 4. (Jan.) 1829) was nomenclaturally superfluous when published and hence illegitimate (ICBN, Art. 63.1). However, in the sense of the contradictory Art. 63.3 it was not illegitimate (although incorrect when published) because it was based on the stem of a legitimate generic name, and hence it has priority over tribe Psathureae A. Rich. ex Dumortier (Anal. Fam. Pl. 32. (Oct.) 1829). Articles 63.1 and 63.3 of ICBN, presumed to have been clarified in the Sydney (1983) edition, leave much to be desired. 
Tribe 14. MorindeAE

Inflorescences axillary or terminal, the flowers in dense, irregular to globose heads, united by their calyces and forming a several-seeded multiple fruit; ovary 2-or incompletely 4-locular; trees, shrubs, or lianas.

33. Morinda

Inflorescences axillary, paniculate or umbelliform, the flowers pedicellate and free or in pairs or triads united by their calyces and forming a multiple fruit (but frequently with only 1 ovary then developing);

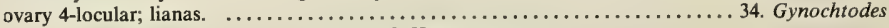

TRIBE 15. HedYotIDEAE

Fruit usually strongly laterally compressed, mitriform to obcordate, mostly broader than long; inflorescences or inflorescence branches often cincinnoid; flowers 5-merous, the corolla white to pink or yellow;

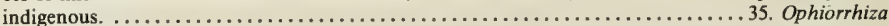

Fruit various but not laterally compressed, mitriform, or obcordate; inflorescences generally not cincinnoid.

Branchlets and inflorescences densely rufo-pubescent; calyx lobes spathulate to oblanceolate; inflorescences axillary; flowers usually 5 -merous, the corolla white to yellowish; fruit separating into 2 closed

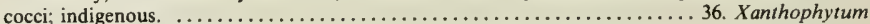

Branchlets and inflorescences not densely rufo-pubescent; calyx various but the lobes usually not spathulate to oblanceolate; inflorescences axillary or terminal; fruit usually a dehiscent capsule, rarely separating into closed cocci.

Inflorescences terminal, congested to umbelliform cymes; flowers 5-merous, the corolla red, pink,

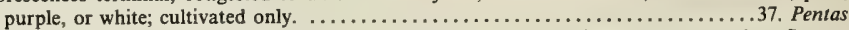

Inflorescences (in our species) terminal and paniculate to cymose, or axillary and glomerulate; flowers usually 4-merous, the corolla usually white; indigenous or adventive. .........38. Hedyotis

TRIBE 16. ANTHOSPERMEAE

One indigenous genus in Fiji; our species a dioecious shrub or small tree.

39. Coprosma

TRIBE 17. SPERMACOCEAE

Ovary usually 3- or 4-locular, the stigmas 3 or 4; fruit separating into 1-seeded mericarps (cocci); seeds longitudinally grooved on inner (ventral) face; inflorescences terminal. .........40. Richardia

Ovary usually 2-locular, the stigmas 2 or 1 and capitate; fruit a capsule, dehiscent longitudinally or circumscissily, or rarely separating into 2 cocci; inflorescences terminal or axillary.

Fruit dehiscent from base or apex (or if separating into 2 cocci then 1 or both of them dehiscent); seeds longitudinally grooved or excavate on inner (ventral) face. . . . . . . . . . Spermacoce

Fruit a circumscissile capsule, the distal portion falling away with calyx limb; seeds with a characteristic $\mathrm{X}$-shaped groove on inner (ventral) face.

42. Mitracarpus

1. Guettarda L. Sp. Pl. 991. 1753; DC. Prodr. 4: 455. 1830; Seem. Fl. Vit. 131, p. p. 1866; Hook. f. in Benth. \& Hook. f. Gen. Pl. 2: 99. 1873; K. Schum. in Engl. \& Prantl, Nat. Pflanzenfam. IV. 4: 95. 1891; S. Darwin in Allertonia 2: 7. 1979.

Trees or shrubs, the stipules interpetiolar, deciduous or persistent; leaf blades often with striate venation; inflorescences axillary, 1-3-branched, cincinnoid, the bracts and bracteoles usually conspicuous, the flowers $\Varangle$ or occasionally unisexual; calyx cupuliform, dentate or truncate, deciduous at maturity; corolla hypocrateriform to slenderly infundibular, 4-9-lobed, the lobes imbricate; stamens inserted at corolla throat, the anthers included; fruit hard, subglobose, with a fibrous mesocarp and a hard, lobed, 4-9-chambered putamen, the seeds solitary in each locule.

TYPE SPECIES: Guettarda speciosa L., the only original species.

Distribution: A largely American genus, probably with more than 100 species, represented in the Old World by the widespread $G$. speciosa and possibly by a few additional species in New Caledonia.

1. Guettarda speciosa L. Sp. Pl. 991. 1753; Seem. in Bonplandia 9: 256. 1861, Viti, 438. 1862, Fl. Vit. 131. 1866; Drake, Ill. Fl. Ins. Mar. Pac. 192. 1890; Reinecke in Bot. Jahrb. 25: 690. 1898; Rechinger in Denkschr. Akad. Wiss. Wien 85: 370. 1910; Guillaumin in J. Arnold Arb. 13: 6. 1932; Christophersen in Bishop Mus. Bull. 128: 201. 1935; Yuncker in op. cit. 178: 112. 1943, in op. cit. 184: 64. 1945; A. C. Sm. in Smithsonian Rep. 1954: opp. 310. pl. 11, fig. 2. 1955; Yuncker in Bishop Mus. Bull. 220: 250. 1959; J. W. Parham, Pl. Fiji Isl. 192. 1964, ed. 2. 271. 1972; 


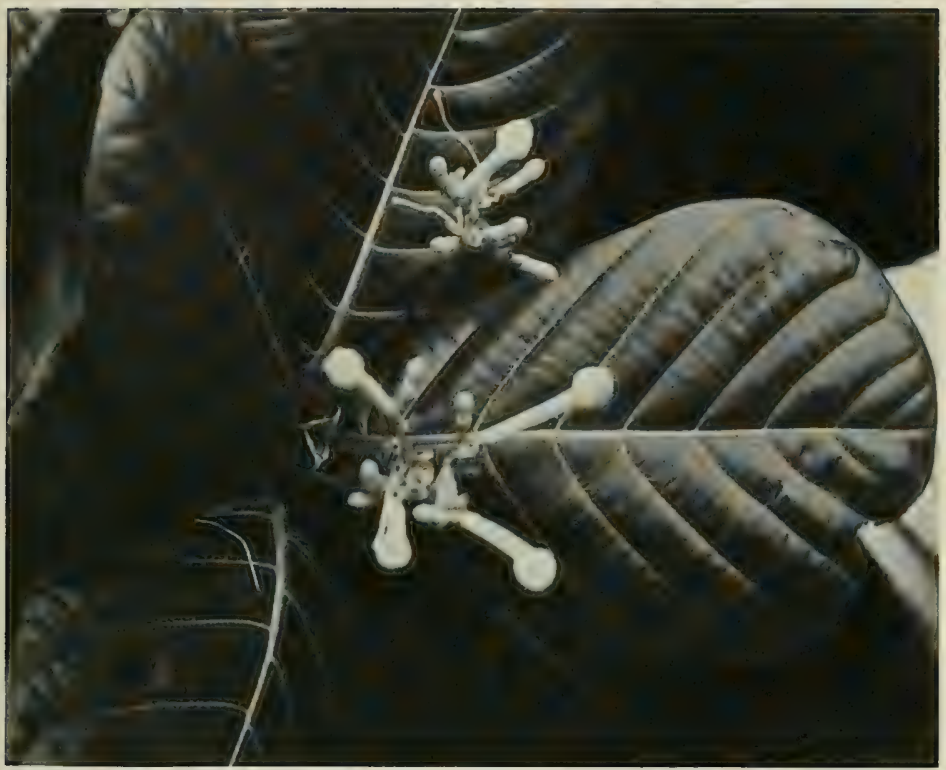
$1 / 2$.

FiguRE 60. Guettarda speciosa on edge of forest along rocky shore on Ngau, from $S m i t h 7915, \times$ about

Sykes in New Zealand Dept. Sci. Indust. Res. Bull. 200: 177. 1970; St. John \& A. C. Sm. in Pacific Sci. 25: 339. 1971; B. E. V. Parham in New Zealand Dept. Sci. Indust. Res. Inform. Ser. 85: 104. 1972; S. Darwin in Allertonia 2: 8. fig. I, A. 1979; Fosberg \& Sachet in D. J. Carr, Sydney Parkinson, 91. pl. 83. 1983; Morat \& Veillon in Bull. Mus. Nat. Hist. Nat. (Paris) IV. 7, Sect. B, Adansonia 3: 315. 1985.

Figures 60, 61.

As seen in Fiji, Guettarda speciosa is an often spreading and freely branched tree 4-20 m. high, often locally abundant near sea level and at scarcely higher elevations in lowland forest and beach thickets, on rocky shores, and on sea cliffs and lagoon cliffs. The fragrant flowers have the corolla white, greenish and pink-tinged in bud, and the fruits are yellow-green. Flowers and fruits may be seen throughout the year.

TyPification: Linnaeus noted the habitat as Java, without citing a collection.

Distribution: Widespread from eastern Africa to Micronesia and eastward to Pacific equatorial islands and the Tuamotus. Some 40 Fijian collections from 13 islands are at hand, but the species may be anticipated on most Fijian islands.

LOCAL NAMES AND USES: Mbuambua is the name in general use, but the seaside habitat is often emphasized by mbuambua ni waitui or mbuambua ni mbaravi. The timber is considered durable and is sometimes used for piling. Vague medicinal uses are sometimes ascribed to the species. 

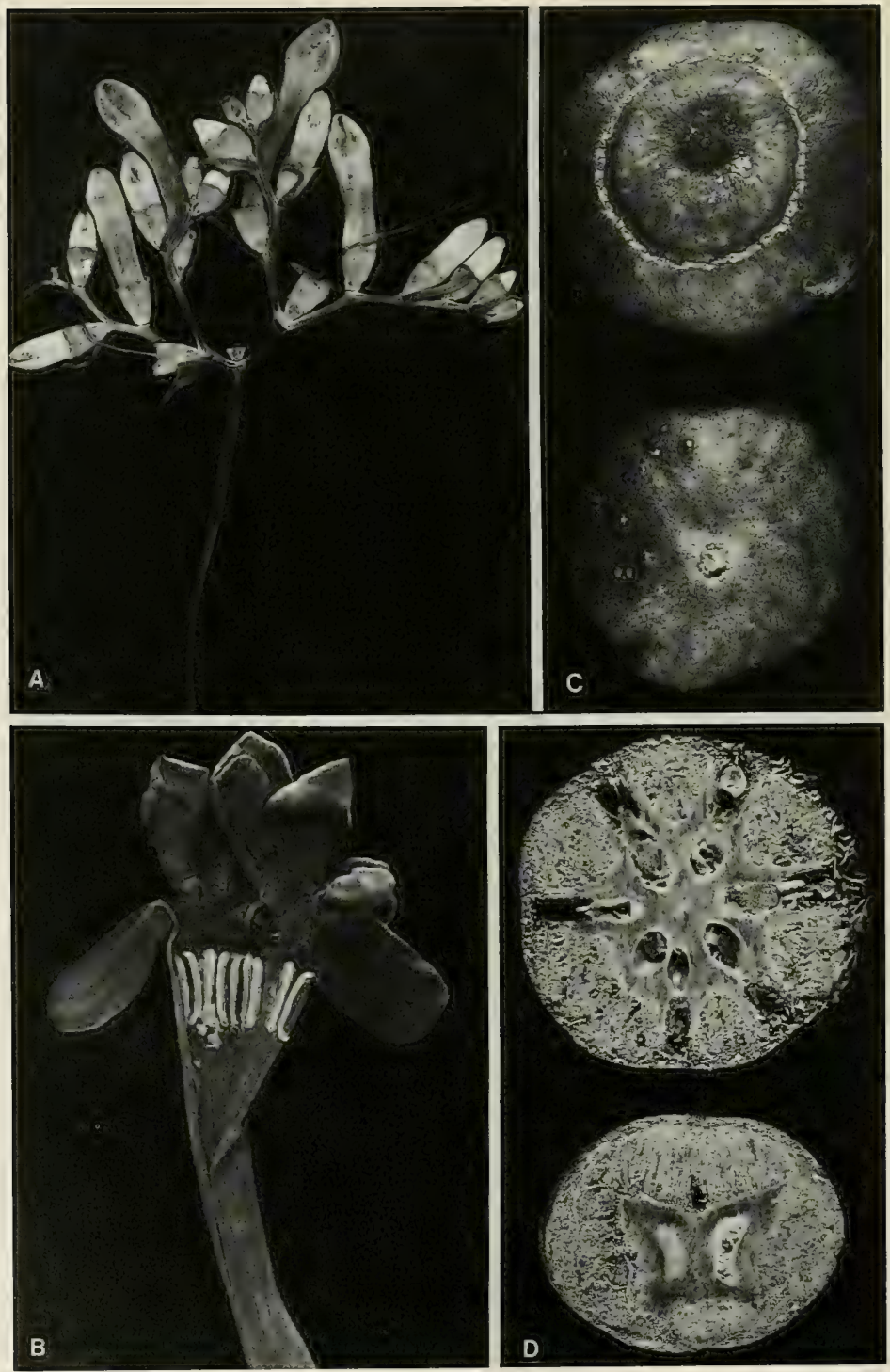
Representative Collections: MAMANUTHAS: Nggalito Island, Malolo Group, $O$. \& $I$. Degener 32208. VITI LEVU: Nandronga \& Navosa: Singatoka, Greenwood 780 (coll. H. Phillips); Korotongo Beach, DA 17321. Serua: Ndeumba Beach, DA 12511. TaIlevu: Matavatathou, DA 15362. Rewa: Near quarry beyond Lami, Gillespie 4598; Nukulau Island, Tothill 558. MBENGGA: Raviravi, DA 13726. KANDAVU: Western end of island, near Cape Washington, Smith 253. KORO: West coast, Smith 1080. NGAU: Shore of Herald Bay, vicinity of Sawaieke, Smith 7915. VANUA LEVU: ThAKAUNDrove: Maravu, near Salt Lake, Degener \& Ordonez 14192. RAMBI: Horne s. n. TAVEUNI: Seemann 237. MOALA: Beach near Maloku, Smith 1328. VANUA MBALAVU: Near Sawana Village, Garnock-Jones 1069. NAVUTU-ILOMA: Bryan 454. FULANGA: On limestone, Smith 1144.

2. Antirhea Commerson ex Juss. Gen. Pl. 204. 1789, in Mém. Mus. Hist. Nat. 6: 377. 1820; Merr. \& Perry in J. Arnold Arb. 26: 233. 1945; S. Darwin in Allertonia 2: 8. 1979; M. E. Jansen in Blumea 29: 565. 1984.

Antirhoea DC. Prodr. 4: 459, orth. var. 1830; Endl. Gen. Pl. 541. 1838; Walp. Ann. Bot. Syst. 2: 764. 1852. Antirrhoea Endl. Ench. Bot. 272, orth. var. 1841; Hook. f. in Benth. \& Hook. f. Gen. P1. 2: 21, 100. 1873;

K. Schum. in Engl. \& Prantl, Nat. Pflanzenfam. IV. 4: 96. 1891.

Guettardella Benth. in Champ. in Hook. J. Bot. Kew Gard. Misc. 4: 197. 1852, Fl. Hongkong. 158. 1861, Fl. Austral. 3: 418. 1867; M. E. Jansen in Blumea 29: 571. 1984.

Guettarda sensu Seem. Fl. Vit. 131, p. p. 1866.

Antirrhaea Benth. Fl. Austral. 3: 418, orth. var. 1867.

Dioecious (in Fiji) trees or shrubs, the stipules interpetiolar, valvate or imbricate; leaf blades with well-developed lateral nerves, the venation not striate; inflorescences axillary, cincinnoid, the bracts and bracteoles obvious or obscure, the flowers often fewer (sometimes solitary) in + plants than in $\sigma^{\top}$ plants; calyx persistent, 3- or 4(rarely 5)-lobed; $\delta^{\prime}$ corolla hypocrateriform, with 3 or 4 imbricate lobes, the stamens attached at corolla throat, included, the style (pistillodium) short, 2-branched; $ᄋ$ corolla infundibular, otherwise similar to $\sigma^{*}$, the staminodia attached at corolla throat, included, the style 2-12(-16)-branched; fruit with a thin, fleshy mesocarp and a hard 2-16-chambered putamen resulting from fusion of pyrenes, the seeds solitary in each locule.

TYPE SPECIES: Antirhea borbonica J. F. Gmelin (Syst. Nat. 2: 244. 1791). The original spelling of the generic name is to be retained in preference to that of several later orthographic variants. The lectotype species of Guettardella is G. chinensis Benth. (vide M. E. Jansen, 1984, p. 565).

Distribution: Madagascar and the Mascarene Islands, and also from southeastern Asia through Malesia and eastward to Samoa, with about 36 species; additionally, more than 100 species from the New World tropics have been referred to Antirhea. Two species are indigenous in Fiji. Jansen (1984) restricts Antirhea to two Mascarene species and assigns the other Old World species to Guettardella. In a more recent study, S.-M. Chaw (in press) provides cogent reasons for referring the Old World species of Antirhea to three subgenera, one limited to the Malagasy region and the other two essentially Asian-Pacific. The relationships of the American species of Antirhea remain to be reviewed.

Useful treatment of Genus: Jansen, M. E. A synopsis of Guettardella Benth. and the Old World species of Antirhea A. L. de Jussieu (Rubiaceae: Guettardeae). Blumea 29: 565-588. 1984.

Figure 61. Guettarda speciosa; A, inflorescence with advanced buds, $\times 1 ;$ B, distal portion of opened corolla, showing stamens, $\times 2 ; \mathrm{C}$, distal and proximal surfaces of fruit, $\times 2 ; \mathrm{D}$, cross section and longitudinal section of fruit, $\times 2$. A from Smith 1328, B from O. \& I. Degener 32208; C \& D from Gillespie 4598. 

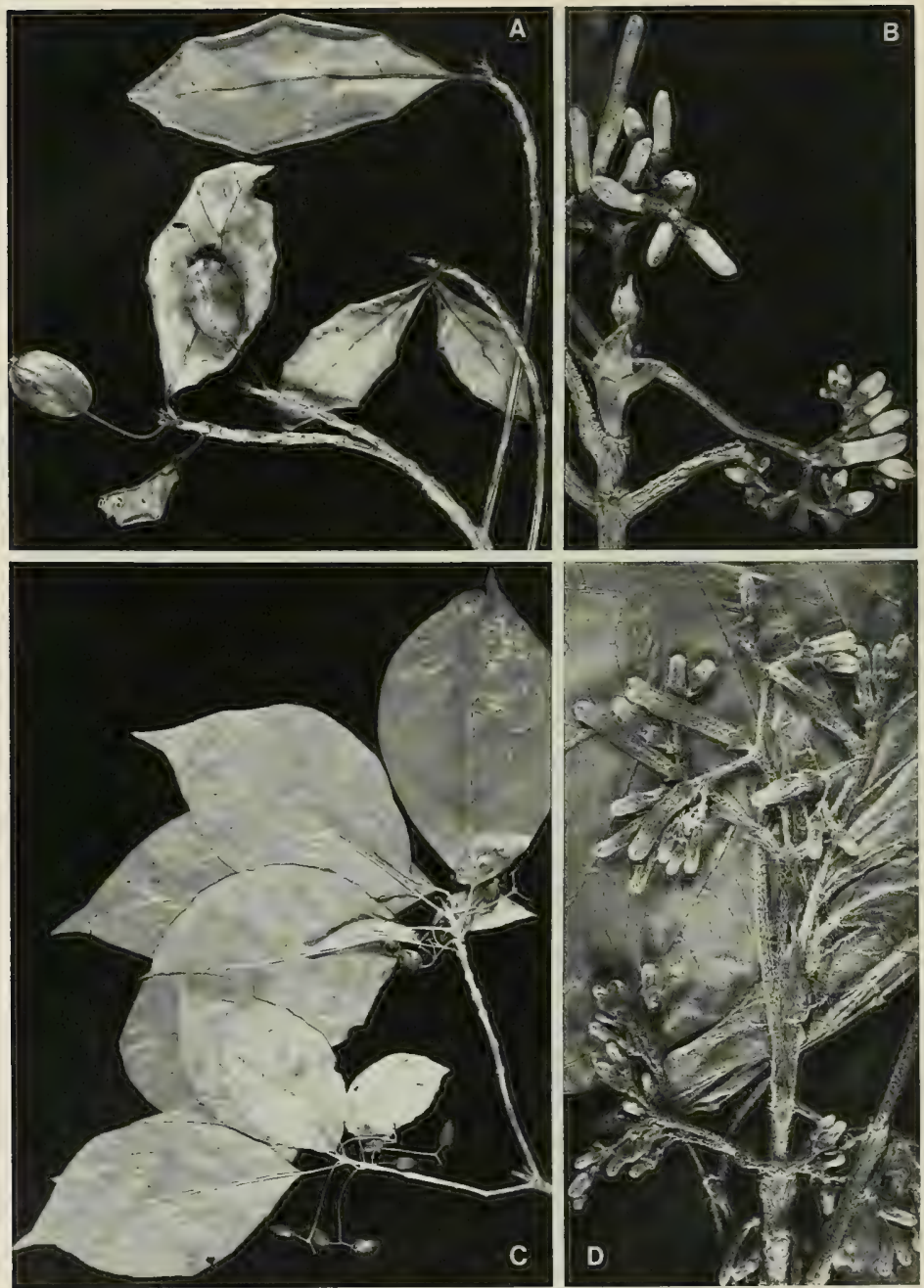

FIgURE 62. A \& B, Antirhea smithii: A, distal portion of branchlet, with foliage and essentially mature fruits, $\times 1 / 2 ; \mathrm{B}$, ơ inflorescences, showing a stipule, $\times 2 . \mathrm{C} \& \mathrm{D}$, Antirhea inconspicua; $\mathrm{C}$, distal portion of branchlet, with foliage and mature infructescences, $\times 1 / 2 ; \mathrm{D}, \sigma$ inflorescences, showing a stipule, $\times 2$. A from DA 15300, B from Gillespie 3522, C from Smith 1269, D from Smith 1131 . 

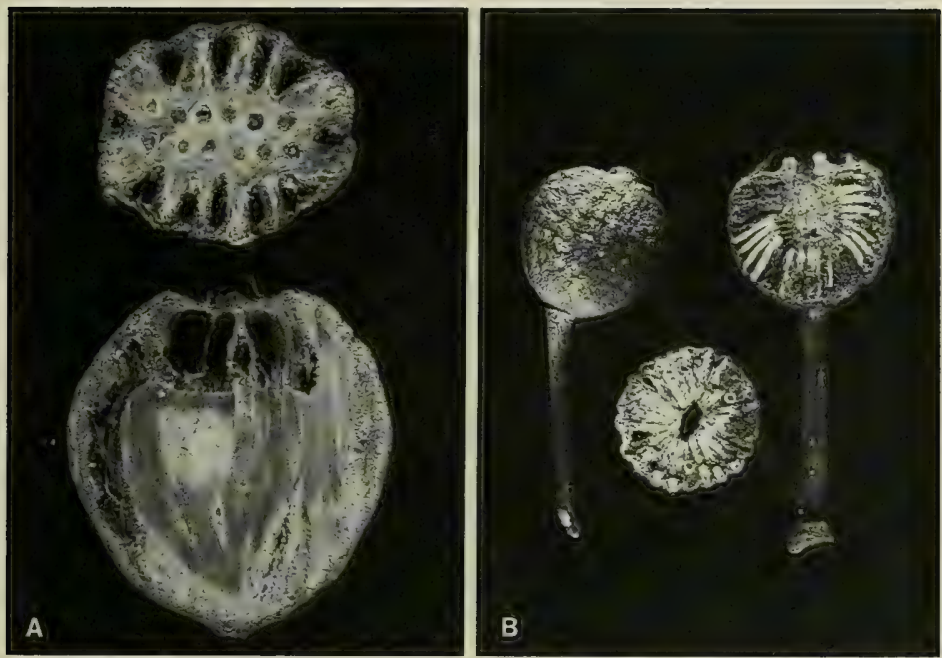

Figure 63. A, Antirhea smithii; cross section and longitudinal section of fruit, $\times 2$. B, Timonius affinis var. affinis; mature fruit, with cross section and longitudinal section, $\times 2$. A from Smith 1930. B from Smith 5507.

KEY TO SPECIES

Stipules deltoid, to $4 \times 3 \mathrm{~mm}$; petioles 5-15 mm. long, about $2 \mathrm{~mm}$. in diameter; leaf blades subcoriaceous to coriaceous, the secondary nerves 5-7 on each side of costa; peduncles of $\sigma^{7}$ inflorescences $1.5-2.5 \mathrm{~mm}$. long, the $\sigma^{\prime}$ corollas with lobes about $2.5 \times 2 \mathrm{~mm}$., the anthers to $6.5 \times 0.5 \mathrm{~mm}$; $q$ flowers solitary; fruits cylindric-ellipsoid, irregularly and shallowly 6-10-ribbed, 15-28 $\times 9-18 \mathrm{~mm}$., with 6-11 seeds.

1. A. smithii

Stipules lanceolate, $5-7 \times$ about $3 \mathrm{~mm}$; petioles $4-8 \mathrm{~mm}$. long, about $1 \mathrm{~mm}$. in diameter; leaf blades chartaceous to membranous, the secondary nerves 7-9 on each side of costa; peduncles of $\sigma^{*}$ inflorescences to $30 \mathrm{~mm}$. long, the $\delta$ corollas with lobes about $1 \times 1 \mathrm{~mm}$., the anthers about $2 \times 0.3 \mathrm{~mm}$.; $q$ inflorescences 6-13-flowered; fruits ellipsoid to obovoid, regularly to irregularly ( 3 or) 4 (or 5)-ribbed,

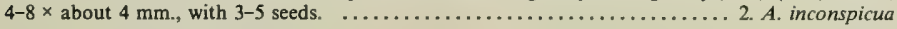

1. Antirhea smithii (Fosberg) Merr. \& Perry in J. Arnold Arb. 26: 233. 1945; J. W. Parham, Pl. Fiji Isl. 187, as Antirrhoea s. 1964, ed. 2. 264, as Antirrhoea s. 1972.

Figures 62A \& B, 63A.

Timonius sp. A. C. Sm. in Bishop Mus. Bull. 141: 140. 1936; J. W. Parham, Pl. Fiji Isl. 210. 1964, ed. 2. 295. 1972.

Timonius smithii Fosberg in Sargentia 1: 121. 1942, in Bull. Torrey Bot. Club 70: 393. 1943.

Guettardella smithii M. E. Jansen in Blumea 29: 585. 1984.

An often slender tree 3-18 m. high, occurring at elevations of $30-550 \mathrm{~m}$. in dense, thin, or secondary forest or in dense crest thickets. The corollas are pale yellow and the mature fruits are deep red to dark maroon. Insofar as specimens are dated, flowers have been collected in October, fruits between March and June. The fruits are said to be eaten by pigeons.

TYPIFICATION: The type is Smith 1347 (US 1676197 HOLOTYPE; many ISOTYPES), collected in fruit March 22, 1934, in forest above Maloku, Moala. 
Distribution: Endemic to Fiji and thus far known from four of the high islands. LOCAL NAMES: Recorded names are ndondolala, mboko ni lekutu, and kaulombo.

Available collections: VITI LEVU: Serua: Inland from Ngaloa, DA 16570; Navua River, between Nakavu and Nukusere, Horne 820. Namosi: Nambukavesi Creek, DA, April 22, 1962 (L.9568), DF 336 (Vaisewa 15). NaITAsiri: Central road, Tothill 275, 420, 421, MacDaniels 327, 1147; Tholo-i-suva, DA, April 4, 1962 (L.9566), 24, p. p., 7574; Suva Pumping Station, Degener \& Ordonez 13760; vicinity of Nasinu, Gillespie 3522. RewA: Veisari, DA 13679; Mt. Korombamba, DA 16535. OVALAU: Hills west of Lovoni Valley, on ridge south of Mt. Korolevu, Smish 7664; summit of Mt. Tana Lailai and adjacent ridge, Smith 7685. VANUA LEVU: MbUa: Lower Wainunu River Valley, Smith 1724. Thakaundrove: Above Naingganggi, DA 15715; Vunimoli, Vaturamulo, DA 15300; hills west of Korotasere, Natewa Bay region, Smith 1930. FIJ without further locality, Howard 67.

2. Antirhea inconspicua (Seem.) Christophersen in Bishop Mus. Bull. 128: 202, as Antirrhoea i. 1935; A. C. Sm. in op. cit. 141: 140, as Antirrhoea i. 1936; J. W. Parham, Pl. Fiji Isl. 187, as Antirrhoea i. 1964, ed. 2. 264, as Antirrhoea i. 1972; S. Darwin in Allertonia 2: 8. fig. 1, B. 1979; Morat \& Veillon in Bull. Mus. Nat. Hist. Nat. (Paris) IV, 7, Sect. B, Adansonia 3: 315. 1985. FIGURE 62C \& D.

Vangueria? (an gen. nov.?) Seem. in Bonplandia 9: 257. 1861.

Vangueria A. Gray in Bonplandia 10: 36. 1862.

Coffeacea Seem. in Bonplandia 10: 296. 1862, Viti, 438. 1862.

Vangueria? sp. Seem. Viti, 438. 1862.

Guettarda vitiensis A. Gray in Proc. Amer. Acad. Arts 5: 319, nom. nud. 1862; Seem. Viti, 438, nom. nud. 1862; A. Gray ex Seem. Fl. Vit. 131, nom. nud. 1866; Drake, Ill. Fl. Ins. Mar. Pac. 192, nom. nud. 1890; J. W. Parham, Pl. Fiji Isl. 192, nom. nud. 1964, ed. 2. 271, nom. nud. 1972.

Guettarda inconspicua Seem. Fl. Vit. 131. 1866; Drake, Ill. Fl. Ins. Mar. Pac. 192. 1890; Rechinger in Denkschr. Akad. Wiss. Wien 85: 370. 1910; Gillespie in Bishop Mus. Bull. 91: 29. fig. 32. 1932.

Guettardella inconspicua M. E. Jansen in Blumea 29: 576. 1984.

Small tree 3-10 m. high found from near sea level to about $200 \mathrm{~m}$. in dry forest, open woods, and thickets, sometimes on the edges of mangrove swamps, and often on limestone. The corolla is yellow, and the fruit turns from red to black at maturity. Flowers seem most frequent between December and March, while fruits persist somewhat longer.

TYPIFICATION AND NOMENCLATURE: In describing Guettarda inconspicua, Seemann cited three collections: (1) Seemann 257, from Ovalau, (2) Storck 893 (BM, GH, K, w), from Port Kinnaird, Ovalau, and (3) McGillivray (BM, w), from Ngau. Gillespie (1932) listed Storck 893 as the type, without discussion; we do not consider this an appropriate lectotypification. As Seemann 257 is the best collection of the three, we suggest: Seemann 257 (K LECTOTYPE here designated; ISOLECTOTYPES at BM, GH, P), collected in 1860 on Ovalau. In 1936 Smith had indicated the Seemann collection as the type, but without discussion. Guettarda vitiensis, never formally described, is based on U. S. Expl. Exped. (GH, us 78367), collected in 1840 in Fiji without further locality.

Distribution: Fiji, Samoa, and the Horne Islands. In Fiji the species is of scattered occurrence, being known from 21 collections from ten islands.

LOCAL NAMES: The species is known in the Lau Group as tambutasia; Storck recorded the name kau lombo from Ovalau.

Available Collections: YASAWAS: Yasawa: Tethi Village, DA 13660. MAMANUTHAS: NgGalito Island, Malolo Group, O. \& I. Degener 32218. VITI LEVU: MBA: North of Lomolomo, Degener \& Ordonez 13633; Vatia, west of Tavua, Degener 14977. Nandronga \& Navosa: Koro Nasingana, H. B. R. Parham 130b. KORO: East coast, Smith 1039. VANUA LEVU: Mbua: Nasau, H. B. $R$. Parham 8. Mathuata: Seanggangga area, DA 13934; Lambasa, Greenwood 557. THAKAundrove: South coast near road to Salt Lake, DA 16829; Maravu, near Salt Lake, Degener \& Ordonez 14240; Mbutha Bay area, Natewa Peninsula, Howard 243. MOALA: Tothill 283; near Maloku, Smith 1330. KAMBARA: On limestone, Smith 1269. FULANGA: On limestone, Smith 1131. Fur without further locality, Horne 350, 401. 
3. Timonius DC. Prodr. 4: 461. 1830; A. Gray in Proc. Amer. Acad. Arts 4: 35. 1858; Seem. Fl. Vit. 130. 1866; Hook. f. in Benth. \& Hook. f. Gen. Pl. 2: 102. 1873; K. Schum. in Engl. \& Prantl, Nat. Pflanzenfam. IV. 4: 98. 1891; Valeton in Bull. Dép. Agric. Ind. Néerl. 26: 1. 1909; Merr. \& Perry in J. Arnold Arb. 26: 235. 1945; S. Darwin in Allertonia 2: 9. 1979. Nom. cons.

Dioecious (or perhaps rarely polygamodioecious) trees, shrubs, or woody epiphytes, the stipules valvate, imbricate, or calyptrate, caducous or persistent, variously pubescent to glabrous; leaf blades with or without strongly striate ("reticulipaxillate"l) venation, the lateral nerves often weakly developed; $\sigma$ " inflorescences few-many-flowered, pedunculate, axillary, often cincinnoid, the bracts and bracteoles present or absent; $\delta$ flowers usually 4- or 5-merous, the calyx lobed, toothed, or truncate, the corolla narrowly infundibular to hypocrateriform, the lobes usually induplicate-valvate, the stamens inserted at corolla throat, included, the gynoecium (pistillodium) short, 2-branched; $q$ inflorescences few-many-flowered or the flowers solitary and axillary, the bracts and bracteoles present or absent; of flowers 4-8- or 10 -merous, the corolla shorter than that of $\delta$ flowers, the staminodia inserted at or below corolla throat, included, usually as many as corolla lobes; fruits soft at maturity, crowned by the persistent calyx and containing few-many separate, bony, 1-seeded pyrenes.

TYPE SPECIES: Timonius rumphii DC., nom. illeg. $=T$. timon (Spreng.) Merr. (Erithalis timon Spreng.), typ. cons.

Distribution: Mascarene and Seychelle Islands to Ceylon and eastward throughout Malesia to tropical Australia, Micronesia, and the Tuamotu Islands, with about 180 species. The two species indigenous in Fiji are only remotely related to one another.

\section{KEY TO SPECIES}

Petioles slender, $15-45 \mathrm{~mm}$. long; stipules imbricate, long-lanceolate to linear, 50-120 $\times 10-20 \mathrm{~mm}$, glabrous on both surfaces; $\sigma^{\circ}$ inflorescences with fewer than 8 flowers, lacking bracts; calyces ( $\sigma^{\circ}$ and @) truncate, glabrous; corollas glabrous; fruits glabrous, usually with 20 or more (rarely as few as 10 ) pyrenes visible in longitudinal section. ........................ affinis

Petioles stout, to $10 \mathrm{~mm}$. long; stipules valvate, ovate-deltoid, to $10 \times 6 \mathrm{~mm}$., scattered-strigillose without, densely strigose within; $\delta$ inflorescences (15-) 25-30-flowered, with bracts present at each node; calyces $\left(\sigma^{\circ}\right.$ and $\left.q\right)$ irregularly 4 - or 5-toothed, pubescent; corollas pubescent; fruits scatteredstrigillose, with fewer than 10 pyrenes visible in longitudinal section. ....... 2, T. polygamus

1. Timonius affinis A. Gray in Proc. Amer. Acad. Arts 4: 36. 1858.

Freely branched tree or shrub 2-13 m. high, found from near sea level to an elevation of $1,160 \mathrm{~m}$. in dense, dry, or thin and rocky forest or in the dense thickets of crests and ridges. The faintly fragrant flowers have corollas with the tube at first greenish yellow but becoming purple without and with pale yellow or white lobes; the fruits, at first green, become purple and at length black at maturity. Flowers and fruits are found throughout the year.

Distribution: Santa Cruz Islands, Fiji, and Samoa. Two varieties are here recognized in Fiji, one of them extending to the Santa Cruz Islands and one endemic. The available Samoan collections of the species are assignable to a third variety, distinguished by its broader petioles and shorter calyces among other characters.

${ }^{1}$ cf. R. Melville in Taxon 25: 553. fig. 29. 1976. 


\section{KEY TO VARIETIES}

Venation obvious on lower leaf surfaces, the finer venation "reticuli-paxillate;" fruits usually with more than

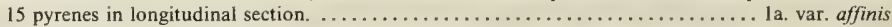
Venation, including lateral nerves, obscure on lower leaf surfaces, these finely rugulose; fruits with fewer than 10 pyrenes in longitudinal section. ...................... var. sapotifolius

1a. Timonius affinis var. affinis; J. W. Parham, Pl. Fiji Isl. 210. 1964, ed. 2. 293. 1972. FigURES 63B, 64A \& B.

Timonius affinis sensu A. Gray in Proc. Amer. Acad. Arts 4: 36. 1858; Seem. Viti, 438. 1862, Fl. Vit. 131. 1866; Drake, Ill. Fl. Ins. Mar. Pac. 193. 1890; Gillespie in Bishop Mus. Bull. 74: 29 (excl. Gillespie 4468). fig. 39. 1930; Fosberg in Bull. Torrey Bot. Club 67: 421. 1940.

The typical variety, with the lower leaf blade surfaces with obvious secondary nerves and fine "reticuli-paxillate" venation, and with comparatively numerous pyrenes in the fruits.

TYPIFICATION: The type is U.S. Expl. Exped. (Us 62264 HOLOTYPE; ISOTYPE at GH), collected in 1840 in Fiji without further locality.

DiSTRIBUTION: The typical variety of this readily recognized species is now represented from Fiji by 50 collections from seven of the high islands.

LOCAL NAMES: That the species is highly suggestive of mangroves is indicated by the widely used names tiri vanua, ndongo, ndongo ni vanua, ndongo ni lekutu, ndongo tangane, ndongo vuto, and ndongondongo. Names recorded only once are mokamoka (Namosi) and naka pinda (Naitasiri).

RePRESENTATIVE COLleCtions: VITI LEVU: MBa: Eastern slope of Mt. Koroyanitu, Mt. Evans Range, Smith 4159; upper slopes of Mt. Koromba, Smith 4640; Mt. Nanggaranambuluta, east of Nandarivatu, Greenwood 873. NANDRONGA \& NAvOSA: Nausori Highlands, Vetawa 8; northern portion of Rairaimatuku Plateau, between Nandrau and Nanga, Smith 5507. SeruA: Namboutini, DA 13712. Namosi: Mt. Naitarandamu, Gillespie 3106; hills east of Wainikoroiluva River, near Namuamua, Smith 9058. NAITASIRI: Taunaisali, Wainimala River Valley, St. John 18339; vicinity of Nasinu, Gillespie 3552. TAILEvU: Hills east of Wainimbuka River, vicinity of Ndakuivuna, Smith 7070. REWA: Quarry near Lami, Gillespie 4613. KANDAVU: Mt. Mbuke Levu, DA 2988. OVALAU: Hills west of Lovoni Valley, on ridge south of Mt. Korolevu, Smith 7526; vicinity of Levuka, Gillespie 4512. KORO: Eastern slope of main ridge, Smith 955. NGAU: Hills east of Herald Bay, inland from Sawaieke, Smith 7777. VANUA LEVU: MATHUATA: Mathuata Range, Smith 6794. Mathuata-Thakaundrove boundary: Crest of Korotini Range, between Navitho Pass and Mt. Ndelaikoro, Smith 547. ThaKaundrove: Mt. Kasi, Yanawai River region, Smith 1764. TAVEUNI: Borders of lake east of Somosomo, Smith 862.

1b. Timonius affinis var. sapotifolius (A. Gray) Fosberg in Sargentia 1: 121, as var. sapotaefolius. 1942; J. W. Parham, Pl. Fiji Isl. 210, as var. sapotaefolius. 1964, ed. 2. 293, as var. sapotaefolius. 1972.

Figure 64C.

Timonius sapotaefolius A. Gray in Proc. Amer. Acad. Arts 4: 35. 1858; Seem. Viti, 438. 1862, Fl. Vit. 130. 1866; Drake, Ill. Fl. Ins. Mar. Pac. 193. 1890.

A variety characterized by having the lower leaf blade surfaces with secondary nerves and fine venation obscure, and with comparatively few pyrenes in the fruits.

Typification: Gray's second Fijian taxon of this alliance is based on $U$. S. Expl. Exped. (US 62268 HOLOTYPE; ISOTYPES at $\mathrm{GH}, \mathrm{K}$ ), obtained in 1840 without further locality. The fact that the only two other collections known to represent this variety are

Figure 64, A \& B, Timonius affinis var. affinis; A, lower surface of leaf blade, showing part of a secondary nerve and "reticuli-paxillate" venation, $\times 10 ; \mathrm{B}$, distal portion of branchlet with foliage and large stipules, showing ㅇ flowers and fruits, $\times 1 / 3$. C, Timonius affinis var. sapotifolius; lower surface of leaf blade, showing rugulose surface, without obvious venation, $\times 10$. D, Timonius polygamus; distal portions of branchlets with foliage and inflorescences, the upper branchlet with of flowers, the lower with $\delta$. flowers, $x$ 1/2. A from Smith 7070, B from Smith 1764, C from Gillespie 4468. D from Smith 1220 (specimens apparently from different individual plants assigned the same number). 

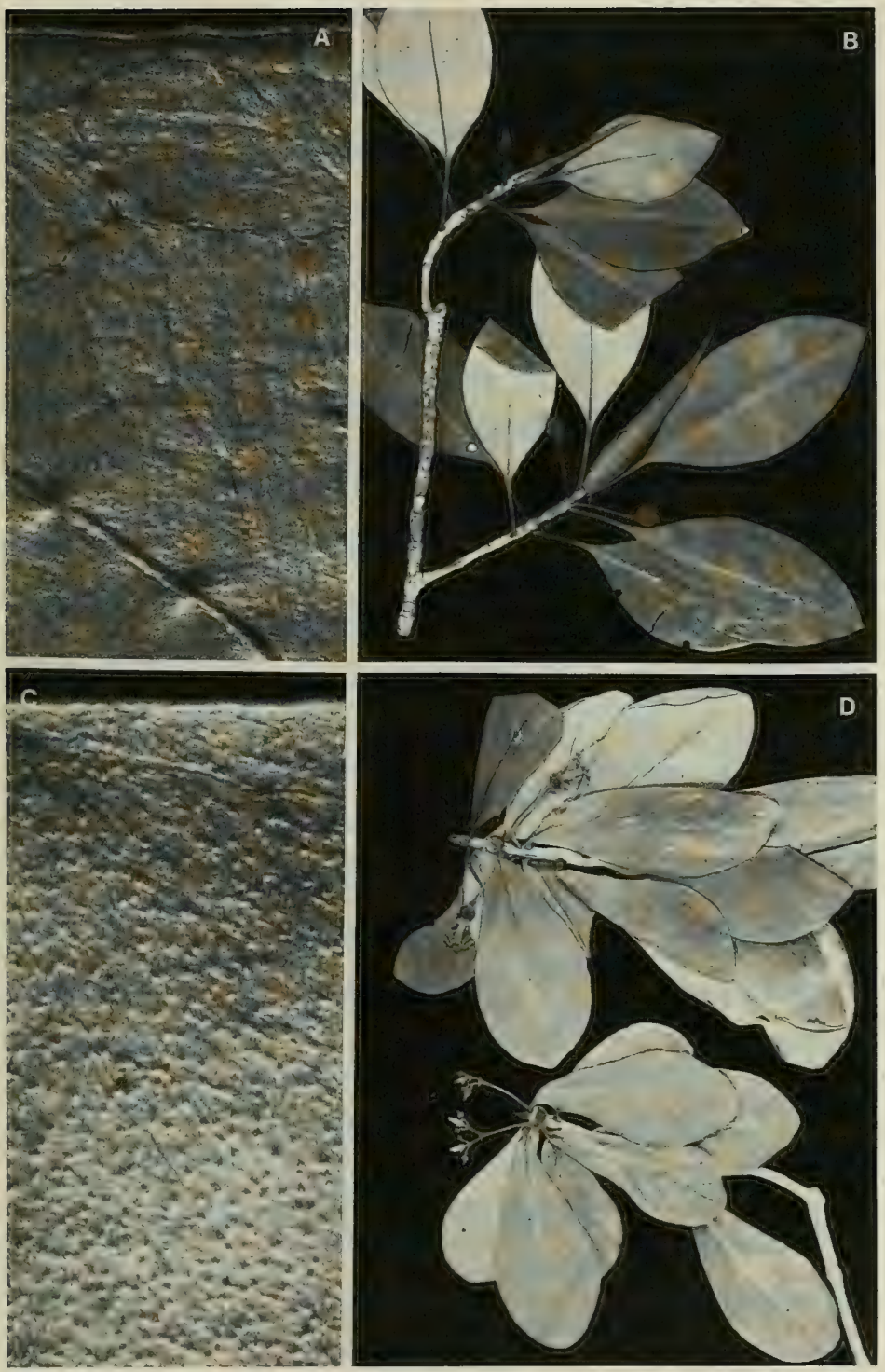
from Ovalau suggests that the Exploring Expedition material may also have come from that island, which was the expedition's principal base in Fiji.

Distribution: Endemic to Fiji and known with certainty only from the island of Ovalau.

\section{LOCAL NAME: Mbaka loa (DA 17018).}

AVAILABLE COLLections: OVALAU: Wooded hills overlooking Levuka, alt. 350 m., Gillespie 4468; Waililevu, alt. $90 \mathrm{~m}$., epiphytic tree on Inocarpus fagifer on open hillside, DA 17018 .

2. Timonius polygamus (Forst. f.) Robinson in Proc. Amer. Acad. Arts 45: 408. 1910; A. C. Sm. in Bishop Mus. Bull. 141: 140. 1936; Yuncker in op. cit. 178: 112. 1943, in op. cit. 220: 251. 1959; J. W. Parham, Pl. Fiji Isl. 210. 1964, ed. 2. 294. 1972; Sykes in New Zealand Dept. Sci. Indust. Res. Bull. 200: 181. 1970; S. Darwin in Allertonia 2: 10. fig. l, D. 1979.

Figure 64D.

Erithalis polygama Forst. f. Fl. Ins. Austr. Prodr. 17. 1786.

Timonius forsteri DC. Prodr. 4: 461, nom. illeg. 1830; A. Gray in Proc. Amer. Acad. Arts 4: 35. 1858;

Seem. Fl. Vit. 130. 1866; Reinecke in Bot, Jahrb. 25: 690. 1898.

As infrequently noted in Fiji, Timonius polygamus is a shrub $0.2-1.5 \mathrm{~m}$. high occurring near sea level on rocky limestone islets and on lagoon cliffs. The corolla is white or pale yellow, and the fruit is green. Flowers have been obtained in February, July, and November, fruits only in July.

Typification: The type was obtained by J. R. \& G. Forster in the Society Islands during Cook's second voyage, but no Forster material of the species seems available at either $\mathrm{BM}$ or $\mathrm{K}$; however, there is no doubt about the application of the name from $\mathrm{G}$. Forster's diagnostic if brief description. Timonius forsteri is illegitimate because Erithalis polygama was cited in synonymy. Gray (1858) and Seemann (1866) list other synonyms, and Seemann mentions an unpublished drawing by Forster.

Distribution: Widely distributed across the southern Pacific from Rennell Island in the Solomons to the Tuamotu Islands (Henderson Island). While the species is abundant in the eastern part of its range, it is known from only three Fijian collections, and the Rennell Island locality is disjunct to the west.

Available COLlections: NANGINGIA (Denham Island, immediately west of Kandavu): DA 14963. FULANGA: On limestone formation, Smith 1220. ONGEA NDRIKI: On rocky islet off shore, Bryan 391.

4. Nauclea L. Sp. Pl. ed. 2. 243. 1762; Merr. in J. Wash. Acad. Sci. 5: 534. 1915; Hallé in Fl. Gabon 12: 38. 1966; Ridsdale \& Bakh. f. in Blumea 22: 547. 1975; Ridsdale in op. cit. 24: 325. 1978.

Moderate-sized to large trees, the stipules ovate, elliptic, or obovate, flattened, often strongly keeled, adpressed in terminal bud; inflorescences terminal or lateral; ovaries united, the styles exserted, the stigmas spindle-shaped, the placentas Y-shaped, attached to the upper third of septum; fruit a syncarp, the seeds bilaterally compressed but not winged.

TYPE SPECIES: Nauclea orientalis (L.) L. (Cephalanthus orientalis L.), the only original species.

Distribution: Tropical Africa; India and Ceylon eastward through southeastern Asia to the Philippines, New Guinea, and tropical Australia, with about ten species. Available specimens and records suggest that two species are cultivated in Fiji. 
1. Nauclea diderrichii (De Wild.) Merr. in J. Wash. Acad. Sci. 5: 535. 1915; E. Petit in Bull. Jard. Bot. Brux. 28: 10. 1958; Hallé in Fl. Gabon 12:44. pl. 4, fig. 1; pl. 5, fig.

1-6. 1966; Ridsdale in Blumea 22: 548. 1975.

Sarcocephalus diderrichii De Wild. in Masui, Etat Indép. Congo Expos. Brux. 439, nom. nud. 1897, in Rev. Cult. Colon. 9: 7. 1901.

Where indigenous, Nauclea diderrichii is a tree to $55 \mathrm{~m}$. high; the flowers are white to greenish or yellowish, and the fruit is fleshy, fragrant, and gray-brown to clear white at maturity. Apparently it has been introduced into Fiji fairly recently as of possible use in reforestation; the only available collection is sterile.

NeOty PIFICATION: Hallé (1966, p. 46) takes as the neotype Briey 189 (BR), from the Belgian Congo, "spécimen authentifié par De Wildeman, les échantillons originaux de Diderrich ayant été perdus."

Distribution: Africa from Sierra Leone to the central forest district of the Congo (Hallé, 1966, p. 47).

Available collection: VITI LEVU: NaItasiRI: Kalambo, Tholo-i-suva, DA 16433 (cult. in Dept. Forestry area).

2. Nauclea orientalis (L.) L. Sp. Pl. ed. 2. 243. 1762; Merr. in J. Wash. Acad. Sci. 5: 536. 1915; Ridsdale in Blumea 24: 327.1978.

Cephalanthus orientalis L. Sp. P1. 95. 1753.

Nauclea cordata Roxb. Hort. Beng. 14, nom. nud. 1814, Fl. Ind. 118. 1824.

Sarcocephalus cordatus Miq. Fl. Ned. Ind. 2: 133. 1856; B. E. V. Parham in Agr. J. Dept. Agr. Fiji 10: 116, as $S$. cordata. 1939.

Where indigenous, Nauclea orientalis is reported as a tree in primary and secondary forests, sometimes occurring on the borders of mangrove swamps and in other brackish localities, and sometimes as a pioneer species in sugarcane fields.

LECTOTYPIFICATION AND NOMENCLATURE: The lectotype of Cephalanthus orientalis is pl. 338 in Hermann's herbarium (BM); cf. Merrill (1915, p. 533; Ridsdale, 1978). This lectotypification has been thoroughly discussed (cf. Committee for Spermatophyta in Taxon 22: 154. 1973; Ridsdale in Blumea 23: 184-186. 1976). Nauclea cordata is based on a Roxburgh specimen cultivated at Calcutta from seeds sent from Ceylon (Ridsdale, 1978, q. v. for an extensive synonymy of $N$. orientalis).

Distribution: Ceylon and Burma throughout Malesia to New Guinea and Australia (Ridsdale, 1978). Parham (1939) records that it was introduced into Fiji in 1918 and was growing well on the property of W. L. Wallace on Tovu Island, Ra Province, Viti Levu. Although no available herbarium material supports this record, the species may persist in Fiji as a potential timber tree.

5. Neolamarckia Bosser in Bull. Mus. Nat. Hist. Nat. (Paris) IV. 6, sect. B. Adansonia 3: 247.1984.

Anthocephalus sensu auct.; non A. Rich.

Moderate-sized to large trees, the stipules narrowly triangular, obvolute, deciduous; inflorescences terminal, solitary, the ovaries and fruits separate; calyx tube infundibular, the lobes linear-spathulate to narrowly elliptic; style exserted, the stigma spindle-shaped; ovary 2-locular (sometimes 4-locular distally due to a false septum), the placentas undivided or Y-shaped; fruit somewhat fleshy, indehiscent, the distal portion usually forming 4 hollow, white, cartilaginous lobes, the seeds somewhat trigonal, without wings.

TYPE SPECIES: Neolamarckia cadamba (Roxb.) Bosser (Nauclea cadamba Roxb.).

Distribution: India eastward to New Guinea, with two species, one of which is sparingly cultivated in Fiji. 
USEFul tREATMEnt of Genus: BosSer, J. Sur le type du Cephalanthus chinensis Lam. Neolamarckia, nouveau nom pour Anthocephalus auct. non A. Rich. (Rubiaceae). Bull. Mus. Nat. Hist. Nat. (Paris) IV. 6, sect. B, Adansonia 3: 243-248. 1984.

Bosser (1984) indicates that Cephalanthus chinensis Lam., the type species of Anthocephalus A. Rich (A. indicus A. Rich., nom. illeg.), is in fact based upon a Commerson specimen ( $\mathrm{P}-\mathrm{LA}$ ) taken from a plant cultivated in Mauritius and belonging to the genus Breonia A. Rich., correctly to be known as Breonia chinensis (Lam.) Capuron (in Adansonia II. 13: 472. 1973; cf. Bosser, 1984, pp. 246-247 for synonymy). Anthocephalus is therefore to be referred to the synonymy of Breonia (for generic synonymy cf. Bosser, 1984, p. 246), and the new generic name Neolamarckia replaces it. The earlier opinion of Bakhuizen (in Taxon 19:469. 1970) and Ridsdale (in Blumea 22: 551. 1975) held that Cephalanthus chinensis was at least partly based upon and lectotypified by an unlocated Sonnerat specimen from eastern Asia; that conclusion, according to Bosser, resulted from Lamarck's confusion as to the origin of his herbarium material.

1. Neolamarckia cadamba (Roxb.) Bosser in Bull. Mus. Nat. Hist. Nat. (Paris) IV. 6, sect. B, Adansonia 3: 247. 1984.

Nauclea cadamba Roxb. Hort. Beng. 14, nom. nud. 1814, Fl, Ind. 2: 121. 1824.

Anthocephalus cadamba Miq. Fl. Ned. Ind. 2: 135. 1856.

Anthocephalus chinensis sensu Bakh. f. in Taxon 19: 469. 1970; Ridsdale in Gard. Bull. Singapore 25: 252. 1970, in Blumea 24: 334. fig. $l, c, 2, a-d$. 1978; non A. Rich. ex Walp.

Nauclea esculenta sensu J. W. Parham, Pl. Fiji Isl. ed. 2. 279. 1972; non Merr.

Where indigenous, Neolamarckia cadamba is a tree to $30 \mathrm{~m}$. high, with spreading branches arranged in tiers, and with elliptic leaf blades up to $50 \times 25 \mathrm{~cm}$.; the flowering heads including styles are $3-5 \mathrm{~cm}$. in diameter and the fruiting heads $2-4.5 \mathrm{~cm}$. in diameter. The Fijian collections were bearing fruits in January, March, and May.

LECTOTYPIFICATION: Although no specimen was mentioned, Roxburgh (1824) gave a lengthy description of Nauclea cadamba, stating that it is "common about Calcutta, where it grows to be a large tree and is not only highly ornamental but very useful from the extensive close shade it yields." He listed a reference to Rheede's "Katou-tajaka," i. e. "Katou-tsjaka" Rheede, Hort. Ind. Malabar. 3: pl. 33. 1682, which Bosser (1984) indicates to be the "type;" presumably lectotype would be more appropriate.

Distribution: India eastward to New Guinea. The species appears to be a fairly recent introduction into Fiji, perhaps as having potential for reforestation or perhaps merely as a shade tree.

AVAilable Collections: VITI LEVU: NaITASIRI: Tholo-i-suva, DA 11788 (L.6494); Nasinu, on school grounds, $D A 3130,7299$.

6. Neonauclea Merr. in J. Wash. Acad. Sci. 5: 538. 1915; Bakh. f. in Taxon 19: 476. 1970; Ridsdale in Gard. Bull. Singapore 25: 253. 1970, in Blumea 24:337. 1978; S. Darwin in Allertonia 2: 12. 1979.

Nauclea sensu Korth. Observ. Naucl. Indic. 17. 1839; Hook. f. in Benth. \& Hook. f. Gen. Pl. 2: 31. 1873; K. Schum. in Engl. \& Prantl, Nat. Pflanzenfam. IV. 4: 57. 1891; Havil. in J. Linn. Soc. Bot. 33: 48. 1897; non $\mathrm{L}$.

Trees or shrubs, the stipules ovate, elliptic, or obovate, usually rounded at apex, strongly adpressed in terminal bud; inflorescences terminal, solitary or 3 (rarely as many as 7) in a terminal dichasium; ovaries separate at anthesis and in fruit; calyx tube short, the lobes clawed, the expanded apical portion deciduous; corolla hypocrateriform, the lobes imbricate in bud; style exserted, the stigma subglobose to 
obovoid, the placentas attached to upper third of ovary septum, the ovules and seeds numerous, pendulous; fruits capsular, loculicidally and septicidally dehiscent, the apical portion and calyx forming a cap, the central axis remaining attached to receptacle, the seeds ellipsoid, winged at both ends.

LectotyPE SPECIES: Neonauclea obtusa (Bl.) Merr. (Nauclea obtusa Bl.) (vide Bakh. f. in Taxon 19: 476. 1970).

Distribution: Southwestern and southeastern Asia to Taiwan and eastward through Malesia to tropical Australia and to the Society Islands, with about 70 species, one of which is indigenous in Fiji.

1. Neonauclea forsteri (Seem. ex Havil.) Merr. in J. Wash. Acad. Sci. 5: 540. 1915;

Christophersen in Bishop Mus. Bull, 128: 198. 1935; Fosberg in Sargentia 1: 119. 1942; Yuncker in Bishop Mus. Bull. 184: 64. 1945, in op. cit. 220: 247. 1959; J. W. Parham, Pl. Fiji Isl. 200. 1964, ed. 2. 279. 1972; Ridsdale in Gard. Bull. Singapore 25: 263. fig. 2, k, 3, 6. 1970; St. John \& A. C. Sm. in Pacific Sci. 25: 340. 1971; B. E. V. Parham in New Zealand Dept. Sci. Indust. Res. Inform. Ser. 85: 12, 92. 1972; S. Darwin in Allertonia 2: 12. fig. 1, E. 1979; Fosberg \& Sachet in D. J. Carr, Sydney Parkinson, 94. pl. 86. 1983; Morat \& Veillon in Bull. Mus. Nat. Hist. Nat. (Paris) IV. 7, Sect. B, Adansonia 3: 316. 1985.

Figure 65.
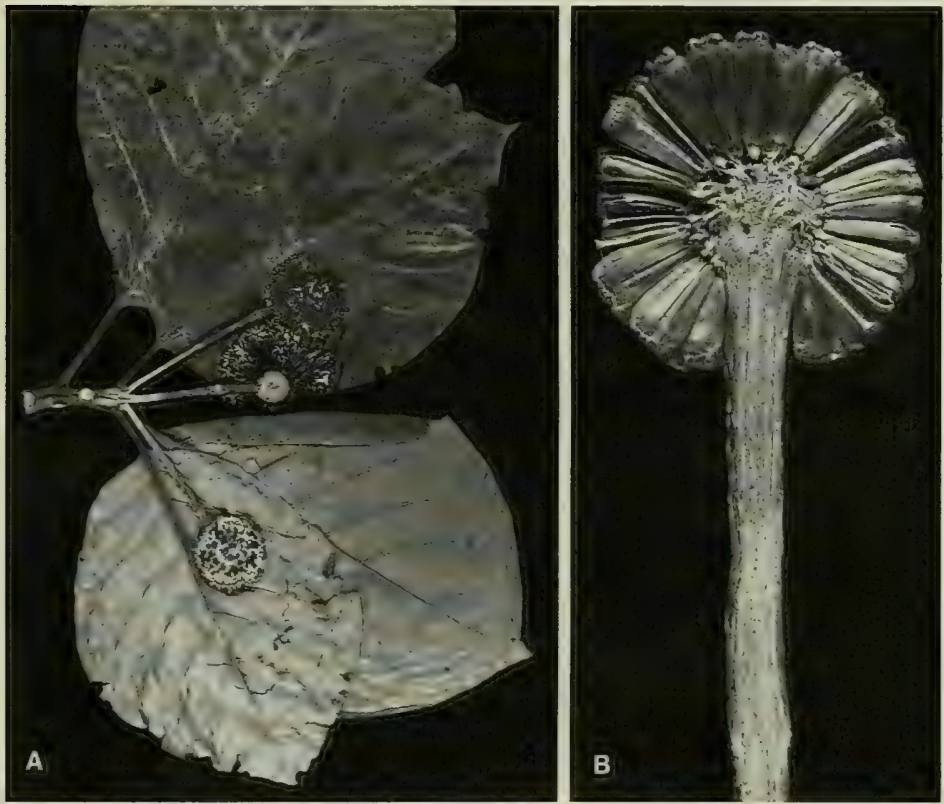

FIGURE 65. Neonauclea forsteri; A, distal portion of branchlet, with foliage and inflorescences, $\times 1,3 ; \mathrm{B}$, longitudinal section of mature fruiting head, $\times 2$. A from Smith 7550, B from DA 14249 . 
Nauclea orientalis sensu Forst. f. Fl. Ins. Austr. Prodr. 15. 1786; non L

Nauclea forsteri Seem. Fl. Vit. 121, nom. nud. 1866; Seem. ex Havil. in J. Linn. Soc. Bot. 33: 56. 1897; Reinecke in Bot. Jahrb. 25: 690. 1898.

Neonauclea vitiensis Gillespie in Bishop Mus. Bull. 74:28. fig. 38. 1930; Fosberg in Bull. Torrey Bot. Club 67: 419.1940.

As seen in Fiji, Neonauclea forsteri is a tree $3-25 \mathrm{~m}$. high with a trunk to $1.5 \mathrm{~m}$. in diameter and a spreading crown, found at elevations from near sea level to about 1,000 $\mathrm{m}$. in usually dry forest. The flowering heads appear yellowish white, the corolla being bright yellow or with a white tube and rich purple lobes; the styles are white; and the mature fruiting heads are brownish. Flowers have been noted between December and June, fruits between April and September.

LECTOTYPIFICATION AND NOMENCLATURE: Seemann (1866) listed the name Nauclea forsteri as based on G. Forster's (1786) interpretation of Nauclea orientalis, but the first valid description was provided by Haviland (1897). The names were based on $J . R$. \& G. Forster (K LECTOTYPE, vide Ridsdale, 1970; ISOLECTOTYPE at BM), collected in the Society Islands during Cook's second voyage. The type of Neonauclea vitiensis is Gillespie 4188 (BISH HOLOTYPE and 2 ISOTYPES), collected Dec. 4, 1927, on steep slopes of "the canyon of the Mata ni Wasi" (Waikumbukumbu Creek tributary?) northeast of the Government Station, Nandarivatu, Mba Province, Viti Levu. Gillespie's material is quite characteristic of the widely distributed species; surprisingly only one Fijian collection (Horne 896) antedates Gillespie's discovery of the genus in Fiji, where it is by no means uncommon.

Distribution: Solomon Islands (Bougainville eastward) through the New Hebrides, Fiji, Tonga, and Samoa to the Society Islands. In Fiji it has been collected on the two largest islands and Ovalau, but presumably is present elsewhere.

LOCAL NAMES AND USES: The names $m b o$, vathea, and vutoro have been recorded. In Naitasiri a decoction of bark is said to be used as a cough medicine, and the species is noted as producing usable timber, although it is presumably not highly regarded as such.

AVailable collections: VITI LEVU: MBa: Mountains near Lautoka, Greenwood 898; Mt. Evans Range, Greenwood 1272; vicinity of Nalotawa, eastern base of Mt. Evans Range, Smith 4470. NANDRONGA \& Navosa: Vicinity of Mbelo, near Vatukarasa, Degener 15232, 15312. NAmosi: Naraiyawa, Wainikoroiluva River, DA L.13307 (Berry 87); Wainambua Creek, DA 14220; Wayauyau Creek, Wainikoroiluva River, DA 14249; hills in vicinity of Namosi Village, Gillespie 2931; Mt. Voma, DA 1806. NAITASIRI: Wainimala Valley, south of Matawailevu, St. John 18375; Waila Creek, near Vunindawa, Howard 350; Waimanu River, DA L.13306 (Berry 52); Central road, Tothill 532. OVALAU: Valley of Mbureta and Lovoni Rivers, Smith 7550. VANUA LEVU: MAThUATA: Naketei, DA 13880 (Bola 93); vicinity of Korovuli, Howard 184. ThaKaundrove: Ndrawa, DA 14328. Fivi without further locality, Horne 896, DA L.12634 (Berry 87), L.13724 (Berry 52), DF 1226 (Naulago 4), Howard 107.

7. Dolicholoвium A. Gray in Proc. Amer. Acad. Arts 4: 308. 1859; Seem. Fl. Vit. 121. 1866; Hook. f. in Benth. \& Hook. f. Gen. Pl. 2: 41. 1873; K. Schum. in Engl. \& Prantl, Nat. Pflanzenfam. IV. 4: 51. 1891; Fosberg in Sargentia 1:118. 1942; A. C. Sm. in J. Arnold Arb. 36: 288. 1955; S. Darwin in Allertonia 2: 21. 1979; M. Jansen \& Ridsdale in Blumea 29: 258. 1983.

Monoecious trees or shrubs, the stipules interpetiolar, laterally free, appressed in bud, entire and parallel-nerved; inflorescences cymose in distal leaf axils, the bracts usually absent, the terminal flower + , the others $\sigma^{7}$; flowers $4-6$-merous, the calyx 
truncate to lobed, persistent in fruit; corolla hypocrateriform, the tube glabrous within, the lobes contorted in bud, the anthers inserted on upper part of corolla tube; ovary (absent in $\sigma^{7}$ flowers) with 2 cylindrical placentas attached for most of their length to septum; fruits long-cylindrical, dehiscent, the mesocarp persistent and fibrous in age, the thin, horny endocarp dehiscing septicidally into 2 valves, the seeds small, lenticular, with a long wing at each end.

LECTOTYPE SPECIES: Dolicholobium oblongifolium A. Gray, one of the two original species (vide Fosberg in Sargentia 1: 119. 1942).

Distribution: Philippine Islands and the Moluccas eastward through New Guinea to the New Hebrides and Fiji, with 30 species or more (28 species, Jansen and Ridsdale, 1983). Three endemic species terminate the generic range in Fiji.

Useful treatment of Genus: J ANSEN, M. E., \& C. E. RidsDale. A revision of the genus Dolicholobium (Rubiaceae). Blumea 29: 251-311, 1983.

Species of Dolicholobium in Fiji are trees 2-20 m. high (rarely noted as shrubs), often slender (with trunks up to $60 \mathrm{~cm}$. in diameter) and sometimes with spreading crowns, occurring from near sea level to about $1,150 \mathrm{~m}$. in dense, dry, or open forest, often along creeks but also on crests and ridges, and occasionally even on the edges of mangrove swamps or on sand dunes. The fragrant flowers have the corolla limb pure white, but the long tube usually has a green or yellowish to reddish tinge. The fruits turn from green to dull red or brownish and, after dehiscing, yield quantities of pale brown seeds. Flowers and fruits of the Fijian species do not appear seasonal.

LOCAL NAMES: Well-established names in Fiji for any species of Dolicholobium are soso ni ura and mbua ni wai. Additional names are noted below under the different species.

Jansen and Ridsdale (1983, p. 252) remark: "Monoecious species with functional male and female flowers, such as are found in Dolicholobium, are unknown in the Cinchoneae and have only been reported for some species in 8 other genera in the Rubiaceae. ... Monoecious taxa are rare in the Rubiaceae and Dolicholobium would seem to occupy a rather isolated position within the Cinchoneae." And also (p. 255): "Enormous stipules are found in D. macgregorii where they may reach $13 \times 7.8 \mathrm{~cm}$., the largest we have ever observed in the Rubiaceae." (In fact, some specimens of $D$. macgregorii have been observed with stipules as large as $15 \times 11 \mathrm{~cm}$.)

In reference to the genus as a whole but to the Fijian collections in particular, Jansen and Ridsdale (1983, p. 253) state: "Although previously taxa were distinguished partly on characters of the indumentum, it was found that no clear delimitation could be made with more abundant material available. The indumentum of the leaves and stipules is notoriously variable, always one or two collections having an exceptional indumentum type. ... Generally we have ignored the indumentum type in delimiting some of the less well collected taxa."

We have examined 176 collections of the genus from Fiji and encounter no problems in distinguishing between the foliar indument of $D$. macgregorii and $D$. oblongifolium (FIGURES 67A \& C) on the one hand and that of D. latifolium (FIGURE 67B) on the other. The foliar indument of $D$. aneityense (FIGURE 67D) is strikingly different from that of any Fijian species, and we firmly reject the inclusion of that New Hebridean taxon in $D$. oblongifolium. 
KEY TO SPECIES

Stipules large, usually $4.5-8 \times 2-4 \mathrm{~cm}$. (sometimes $4-15 \times 1.5-11 \mathrm{~cm}$.), usually persistent at nodes below terminal bud; leaf blades large, usually $18-45 \times 10-22 \mathrm{~cm}$. (sometimes $14-50 \times 7-24 \mathrm{~cm}$.); indument of costa and secondary nerves of lower surface of leaf blades usually appressed, often evanescent; flowers large, the corolla lobes usually $15-20(-23) \mathrm{mm}$. broad. ............... 1. D. macgregorii Stipules smaller, not exceeding $5.5 \times 2.5 \mathrm{~cm}$. and usually smaller, caducous, rarely persisting at node below terminal bud; leaf blades not larger than $25 \times 17 \mathrm{~cm}$. and usually smaller; flowers smaller, the corolla lobes rarely more than $12 \mathrm{~mm}$. broad.

Lower surface of leaf blades uniformly soft-tomentellous, or at least the indument of costa and secondary

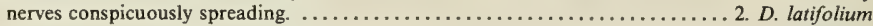

Lower surface of leaf blades, including costa and secondary nerves, sericeous to strigose with appressed

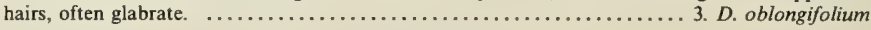

1. Dolicholobium macgregorii Horne ex Baker in J. Linn. Soc. Bot. 20: 360, as $D$. macgregori. 1883; S. Darwin in Allertonia 2: 21. fig. 2, D. 1979; M. Jansen \& Ridsdale in Blumea 29: 308. 1983.

Figures 66A-D, 67A.

Dolicholobium macgregori Horne, A Year in Fiji, 261, nom. nud., as D. McGregori. 1881; Drake, Ill. F1. Ins. Mar. Pac. 185. 1890; Gillespie in Bishop Mus. Bull. 74: 27. fig. 36. 1930; Fosberg in Bull. Torrey Bot. Club 67: 419. 1940, in Sargentia 1: 118. 1942; J. W. Parham, Pl. Fiji Isl. 189. 1964, ed. 2. 267. 1972.

Dolicholobium knollysii Horne, A Year in Fiji, 260, nom. nud., as D. knollysi. 1881; Horne ex Baker in J. Linn. Soc. Bot. 20: 360. 1883; Drake, Ill. Fl. Ins. Mar. Pac. 185. 1890; J. W. Parham, Pl. Fiji Isl. 189. 1964, ed. 2. 267. 1972.

Dolicholobium macgregorii is well characterized by its large, comparatively persistent stipules, its large leaf blades, and its corollas with comparatively broad lobes. Its young foliage and stipules are frequently conspicuously reddish, a characteristic not noted in other Fijian species of the genus. Although a few specimens show dimensional variation toward that of $D$. oblongifolium, the difficulties of distinguishing these two species from one another seem less than implied by Jansen and Ridsdale (1983, pp. 309-310). In the few instances where stipules fall somewhat prematurely (for this species), the broad corolla lobes are highly characteristic.

TYPIFICATION AND NOMENCLATURE: Dolicholobium macgregorii is based on Horne 690 (K HOLOTYPE; ISOTYPE at GH), collected on the banks of the Tamavua River near Suva, in Naitasiri Province, Viti Levu; Dr. MacGregor was the chief medical officer of Fiji at the time of Horne's visit. The type of $D$. knollysii is Horne 729a (K HOLOTYPE; ISOTYPE at GH), obtained in the vicinity of Suva, Rewa or Naitasiri Province, Viti Levu; Captain Knollys, at the time of Horne's visit, was Aide-de-camp to then Governor Sir Arthur H. Gordon. Dolicholobium knollysii is typified by a poor specimen in young fruit, not appreciably different from $D$. macgregorii.

Distribution: Endemic to Fiji and thus far known from only the two largest islands, from which we have seen 34 collections.

LOCAL NAMES: In addition to the usual generic names, these have been listed only once each: songasonga (Serua), molasa (Naitasiri), and kunukulu and uraura (Thakaundrove).

REPRESENTATIVE COLLeCTIONS: VITI LEVU: Mba: Eastern slopes of Mt. Koronayitu, Mt. Evans Range, Smith 4154. Serua: North of Korovou, St. John 18945; inland from Ngaloa, DA 16598. NaITASIRI: Wainamo Creek, near Matawailevu, Wainimala Valley, St. John 18219; Sawani-Serea road, DA 11064; Tholo-i-suva, DA 10655. TAILEvu: Hills east of Wainimbuka River, vicinity of Ndakuivuna, Smith 7130. Rewa: Mt. Korombamba, Parks 20127, Gillespie 2297, Vaughan 3175. VANUA LEVU: Mathuata: Southern base of Mathuata Range, north of Natua, Smith 6840. ThAKAUndRove: Southern slope of Korotini Range, below Navitho Pass, Smith 487; track to Mt. Vatumbutho, DA 17189.

Figure 66. A-D, Dolicholobium macgregorii; A, distal portion of branchlet, with foliage and an inflorescence, showing large stipules, $\times 1 / 3 ; \mathrm{B}$, fruit, $\times 1 / 3$; C, old, dehisced fruit, showing fibrous mesocarp and segments of endocarp, $\times 1 / 4 ; \mathrm{D}$, seeds, $\times 6$. E, Dolicholobium oblongifolium; distal portion of branchlet, with foliage and inflorescences, $\times 1 / 3$. A from St. John 18945, B from Parks 20127, C \& D from Gillespie 2297, E from Gillespie 4284. 


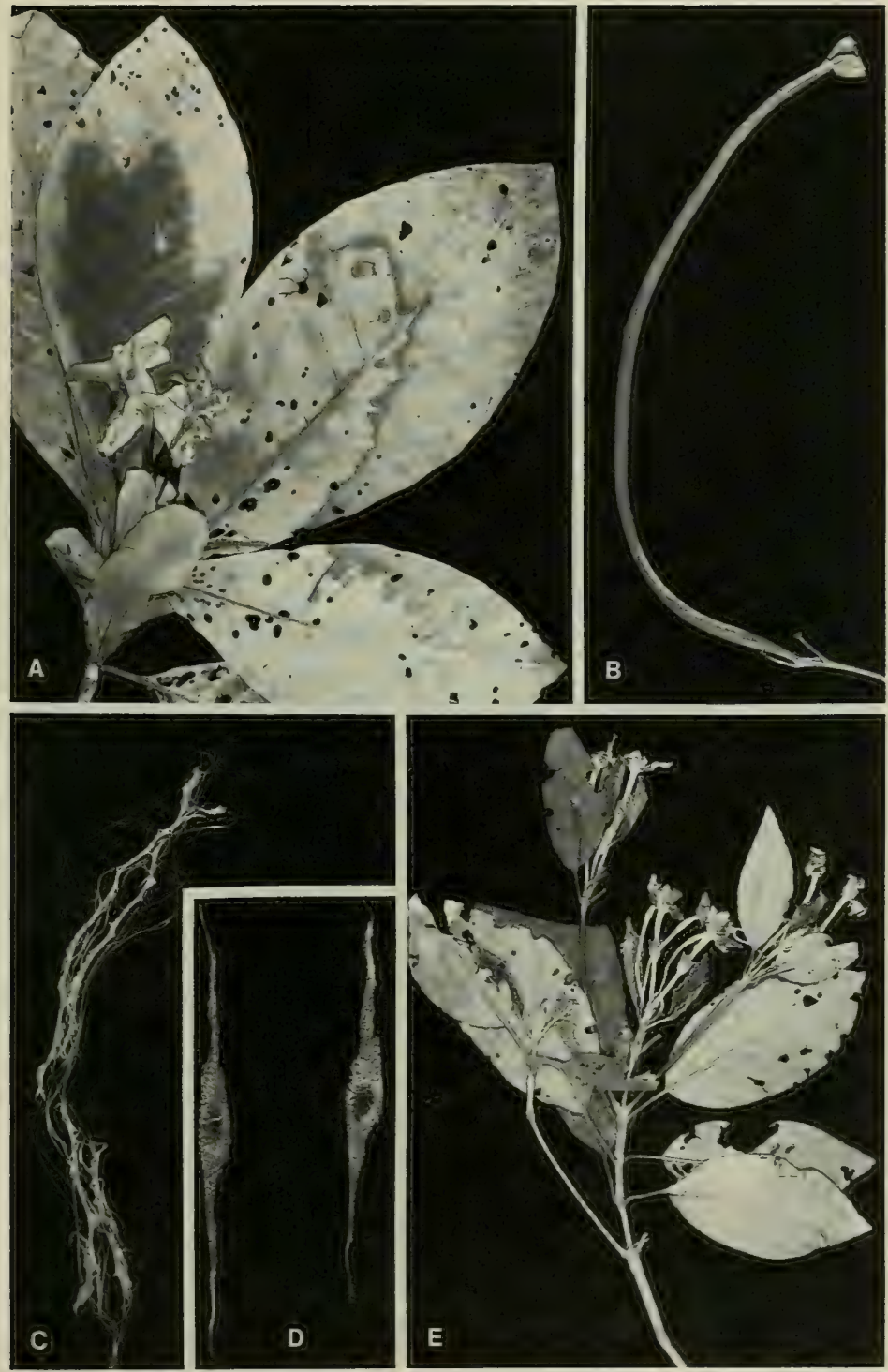


2. Dolicholobium latifolium A. Gray in Proc. Amer. Acad. Arts 4: 309. 1859; Seem. Viti, 438. 1862, Fl. Vit. 121. 1866; Horne, A Year in Fiji, 260. 1881; Drake, Ill. Fl. Ins. Mar. Pac. 185. 1890; Fosberg in Sargentia 1: 118. 1942; J. W. Parham, Pl. Fiji Isl. 189. 1964, ed. 2. 267. 1972.

FIGURE 67B.

Dolicholobium longissimum Seem. in Bonplandia 9: 256, nom. nud. 1861, Viti, 438, nom. nud. 1862; A. Gray in Proc. Amer. Acad. Arts 5: 318, nom. nud. 1862, in Bonplandia 10:36, nom. nud. 1862; Seem. Fl. Vit. 121. t. 25. 1866; Horne, A Year in Fiji, 261. 1881; Drake, Ill. Fl. Ins. Mar. Pac. 185. 1890; J. W. Parham, Pl. Fiji Isl. ed. 2. 267. fig. 79. 1972.

Dolicholobium oblongifolium var. longissimum Fosberg in Sargentia 1: 119. 1942; J. W. Parham, Pl. Fiji Isl. 191. fig. 68. 1964 .

Dolicholobium oblongifolium sensu M. Jansen \& Ridsdale in Blumea 29: 305, p. p. 1983.

In its usual appearance Dolicholobium latifolium (including $D$. longissimum) differs from $D$. oblongifolium in having larger stipules and leaves, but with ample material for consideration these characters prove of little consequence. However, the spreading-hirtellous or soft-tomentellous indument of the lower leaf blade surfaces (persistent and obvious on the costa and secondaries) contrasts with the closely sericeous or strigose, appressed, comparatively evanescent indument of comparable parts of $D$. oblongifolium. In respect to such indument characters, we fail to perceive the "mass of intermediate collections" mentioned by Jansen and Ridsdale (1983, p. 308).

TYPIFICATION AND NOMENClature: The type of Dolicholobium latifolium is $U$.S. Expl. Exped. (US 62252 HOLOTYPE), collected in 1840 on Ovalau; that of D. longissimum (which was mentioned several times prior to its 1866 description) is Seemann 215 ( $\mathrm{K}$ HOLOTYPE; ISOTYPES at BM, GH), collected in July, 1860, on Viti Levu. During that month Seemann collected at several localities between Tailevu Province and the Navua delta region, Serua Province. Although the foliar indument of D. longissimum is more copious than that of $D$. latifolium, it is of the same spreading type on the costa and secondaries of the lower surface, and we believe these taxa not to be separable at any level.

Distribution: Endemic to Fiji and now known from four of the high islands and 32 collections. It appears to be absent from the northern part of Viti Levu, where $D$. oblongifolium is abundant.

LOCAL NAMES: Additional local names noted are mbuambua ni mbaravi and mbuambua ni waitui (Parham, 1964, 1972; the names suggest a seaside habitat) and loaloa (Thakaundrove).

RePRESENTATIVE COLLections: VITI LEVU: SeRUA: Upper Navua River, DA 15517; hills between Waininggere and Waisese Creeks, between Ngaloa and Wainiyambia, Smith 9560. NAMosi: Mt. Naitarandamu, Gillespie 3140; near Nakavu, on Navua River, Horne 834; Wainandoi River, DA 12508. NAITASIRI: Nanggarathangithangi, Mendrausuthu Range, DA 15036; Tamavua-Sawani road, Setchell \& Parks 15100; vicinity of Nasinu, Gillespie 3488. RewA: Queen's Road about 15 miles west of Suva, Vaughan 3457. KANDAVU: Na Kasaleke (Lomanikoro), DA 20. OVALAU: Summit of Mt. Ndelaiovalau and adjacent ridge, Smith 7590. VANUA LEVU: ThaKaundrove: Mt. Mariko, Smith 426; track to Natewa Bay, DA 15073.

3. Dolicholobium oblongifolium A. Gray in Proc. Amer. Acad. Arts 4: 309. 1859; Seem. Viti, 438. 1862, Fl. Vit. 121. 1866; Horne, A Year in Fiji, 261. 1881; Drake, Ill. Fl. Ins. Mar. Pac. 185. 1890; Turrill in J. Linn. Soc. Bot. 43:24. 1915; Fosberg in Sargentia 1: 119. 1942; M. Jansen \& Ridsdale in Blumea 29: 305, p. p. 1983.

Figures 66E, 67C.

Dolicholobium oblongifolium var, oblongifolium; Fosberg in Sargentia 1: 119. 1942; J. W. Parham, Pl. Fiji Isl. 190. 1964, ed. 2. 268. 1972.

Dolicholobium oblongifolium var. degeneri Fosberg in Sargentia 1: 119. 1942; J. W. Parham, Pl. Fiji Isl. 190. 1964 , ed. 2. 268.1972. 
TyPIFICATION AND NOMENCLATURE: Gray based Dolicholobium oblongifolium on three collections: (1) U.S. Expl. Exped. (GH, K, NY, US 62253), collected in 1840 at Mbua (Sandalwood) Bay, Mbua Province, Vanua Levu, a fruiting collection; (2) Milne 38 (к), from the Waimanu River, Naitasiri Province, Viti Levu, with flowers; and (3) Milne 249 (K), from the vicinity of Nandi Bay, Mbua Province, Vanua Levu, with flowers. Fosberg (1942) designated the first of these as the "type," but Gray (1859)
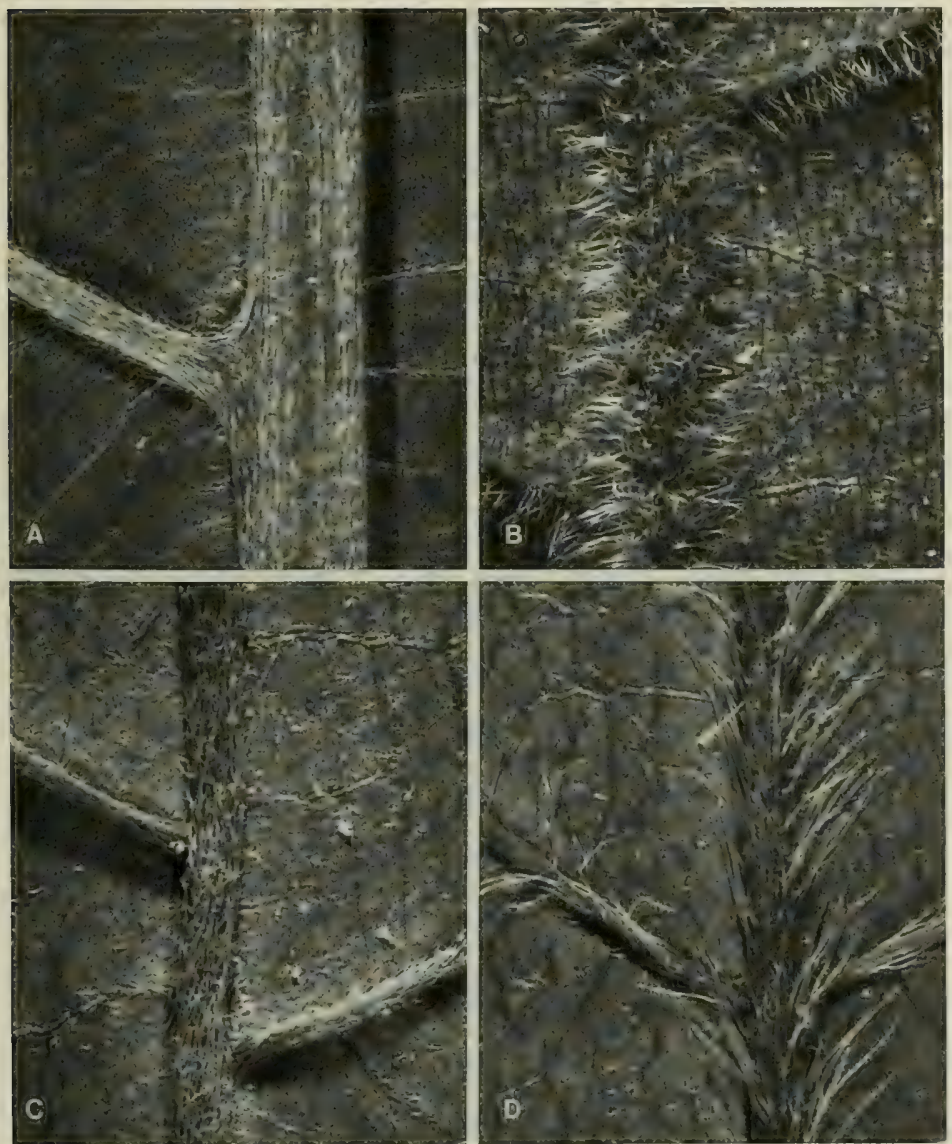

FIGURE 67. Dolicholobium; lower surfaces of leaf blades, with portions of costa and secondary nerves, all $\times 10$. A, D. macgregorii. B, D. latifolium. C, D. oblongifolium. D, D. aneityense. A from Smith $7130, \mathrm{~B}$ from Smith 9560. C from DA 14207, D from Morrison. June 18, 1896, from Aneityum, New Hebrides. 
had stated: “. . . afterwards, in blossom, by Mr. Milne, which afforded the materials required for characterizing the genus." Both of Milne's specimens bear Gray's annotation "Dolicholobium oblongifolium n. g. A. Gray," and therefore we agree with Jansen and Ridsdale that one of the Milne collections would have been a more appropriate choice. A suitable citation is: Milne 38 (K LECTOTYPE), collected along the Waimanu River, Naitasiri Province, Viti Levu (vide Jansen and Ridsdale, 1983, p. 307). Variety degeneri is based on Smith 1643 (US 1672744 HOLOTYPE; many ISOTYPES), collected in flower and fruit April 27, 1934, on Navotuvotu, summit of Mt. Seatura, Mbua Province, Vanua Levu. As noted above in our discussion of the genus, we consider $D$. latifolium (including $D$. longissimum) separable from $D$. oblongifolium, while the New Hebridean D. aneityense Guillaumin (in J. Arnold Arb. 13:2. 1932) is a strikingly distinct taxon.

Distribution: Endemic to Fiji and now known from seven of the high islands, 110 collections being at hand.

LOCAL NAMES: Names recorded only once for this species and hence not very reliable are mbo, vure, and meakavika na tute (Mba), tavotavo (Namosi), mata ni ura (Ovalau), kau ndamu (Mbua), and kasinga (Thakaundrove).

REPRESENTATIVE COLLECTIONS: VITI LEVU: MBA: Vicinity of Nalotawa, eastern base of Mt. Evans Range, Smith 4444; Nandarivatu, im Thurn 299; Mt. Nanggaranambuluta, Gillespie 4284; western and southern slopes of Mt. Tomanivi, Smith 5229. NANDronga \& NavosA: Singatoka dunes, DA 5558. SERUA: Mbuyombuyo, near Namboutini, Tabualewa 15590. NAMOsI: Northern base of Korombasambasanga Range, in drainage of Wainavindrau Creek, Smith 8674; vicinity of Namosi, Gillespie 2646; vicinity of Namuamua, Gillespie 3061. NAITASIRI: Waindina River basin, MacDaniels 1057; Sawani-Serea road, DA 14207; vicinity of Nasinu, Gillespie 3618. TaIlevv: Near Copper Mine, Wainivesi River, DA 13644. REWA: Mt. Korombamba, DA 3854. KANDAVU: Kiombo, Batiratu 2. OVALAU: Hills west of Lovoni Valley, on ridge south of Mt. Korolevu, Smith 7647; near stream above Levuka reservoir, Gillespie 4515. KORO: Main ridge, Smith 1053. VANUA LEVU: MBUA: Southern portion of Seatovo Range, Smith 1573. MaTHUATA: Seanggangga Plateau, in drainage of Korovuli River, vicinity of Natua, Smith 6639. THAKAUNDROVE: Nauluvula Creek, DA 17178; eastern buttress of Mt. Ndikeva, Smith 1871. RAMBI: In mountains, Horne 518. TAVEUN1: Mountains slopes above Somosomo, Gillespie 4819.

8. Rondeletia L. Sp. Pl. 172. 1753; K. Schum. in Engl. \& Prantl, Nat. Pflanzenfam.

IV. 4: 33. 1891; Backer \& Bakh. f. Fl. Java 2: 294. 1965; Steyermark in Mem. New York Bot. Gard. 17: 241, 1967; Kirkbride in Ann. Missouri Bot. Gard. 55: 374. 1969; Standley \& L. O. Williams in Fieldiana, Bot. 24 (11, nos. 1-3): 177. 1975; Dwyer in Ann. Missouri Bot. Gard. 67: 463. 1980.

Trees or shrubs, the stipules interpetiolar, entire or rarely bilobed, obtuse to acuminate at apex, erect or reflexed, persistent; inflorescences terminal or axillary, cymose or paniculate; calyx lobes $4-6$, narrow or broad, often unequal, persistent; corolla infundibular to hypocrateriform, white, yellowish, pink, or red, the tube usually slender, often widening at throat, the lobes 4-6, spreading, imbricate in bud; stamens 4-6, inserted in corolla throat, included or exserted; ovary 2(rarely 3 )-locular, the ovules numerous in each locule; fruit a subglobose capsule, loculicidally or septicidally dehiscent, the seeds numerous, minute, compressed or angular, usually winged.

LeCtoty PE SPECIES: Rondeletia americana L. (vide Hitchcock, Prop. Brit. Bot. 131. 1929), one of Linnaeus's two original species.

Distribution: West Indies and Mexico through Central America into South America, with 125-150 species; two species are recorded in cultivation in Fiji.

It is probable that Rondeletia was introduced into Fiji by $\mathbf{J}$. B. Thurston, as a species of the genus was listed in his 1886 Catalogue; however, we cannot verify the 
identity of Thurston's material.

KEY TO SPECIES

Leaf blade neither bullate nor scabrous, the margin not revolute; stipules foliaceous, reflexed; calyx lobes obtuse; corolla white to pink, densely yellow-pilose in throat. .............. $R$ amoena

Leaf blade bullate, scabrous, the margin revolute; stipules stiff, erect; calyx lobes narrow, acute; corolla

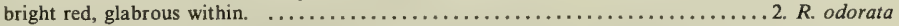

1. Rondeletia amoena (Planch.) Hemsl. Diagn. Pl. Nov. 26. 1879; Kirkbride in Ann. Missouri Bot. Gard. 55: 379. fig. 2. 1969; J. W. Parham, Pl. Fiji Isl. ed. 2. 292. 1972; Standley \& L. O. Williams in Fieldiana, Bot. 24 (11, nos. 1-3): 180. 1975; Dwyer in Ann. Missouri Bot. Gard. 67: 464. 1980.

Rogiera amoena Planch. in Fl. Serres Jard. Eur. 5: $t$. 442.1849.

Sparingly cultivated near sea level in Fiji; where indigenous a shrub or tree to $14 \mathrm{~m}$. high at elevations of 1,000-3,000 m.; stipules triangular to oblong, up to $17 \times 10 \mathrm{~mm}$., reflexed; leaf blades usually densely soft-pilose beneath or eventually glabrate; inflorescences many-flowered, densely pubescent; calyx lobes oblong to obovate-oblong, erect or spreading; corolla white to pink, the tube to $14 \mathrm{~mm}$. long, densely yellow-pilose in throat; capsules to $6 \mathrm{~mm}$. in diameter. The only available Fijian collection was flowering in January.

TYPIFICATION: The species was first described from plants grown in Belgium from seeds obtained in Guatemala (Standley and Williams, 1975).

Distribution: Mexico (Chiapas) to Panama (Chiriqui); often cultivated elsewhere, as in Fiji.

LOCAL NAME AND USE: Known simply as rondeletia in Fiji, this ornamental is "a handsome shrub because of the abundant pink flowers. It was formerly a favorite in northern hothouses, and still is grown occasionally." (Standley and Williams, 1975).

Available Collection: VITI LEVU: Rewa: Suva, in private garden, DA 16210.

2. Rondeletia odorata Jacq. Enum. Syst. Pl. Carib. 16. 1760; Alain, Fl. Cuba 5: 45.

1962; Backer \& Bakh. f. Fl. Java 2: 294. 1965; J. W. Parham, Pl. Fiji Isl. ed. 2. 293.

1972; Fernandez Zequeira \& Herrera Oliver in Acta Bot. Acad. Sci. Hung. 29:37.

fig. 1. 1983.

Sparingly cultivated near sea level in Fiji as a shrub 2-3 m. high; stipules triangular, erect, up to $10 \times 5 \mathrm{~mm}$; leaf blades stiff-coriaceous, bullate, scabrous, the margins revolute; inflorescences terminal, many-flowered, pubescent; calyx lobes narrowly oblong, about $4 \mathrm{~mm}$. long; corolla bright red, orange at center of limb, the tube to 15 $\mathrm{mm}$. long, glabrous within; capsules $3-4 \mathrm{~mm}$. in diameter. The only available Fijian collection was flowering in March.

TyPifiCation: The species is doubtless based on material collected by Jacquin in Cuba. Fernandez Zequeira and Herrera Oliver (1983) cite as the holotype "Linn. Syst. 177: Pl. americ. pict. tab. 61 (ramulus florifer)," indicating the classical locality as Havana, from which they also list a "lectotype" (topotype?).

Distribution: Cuba; cultivated elsewhere, as in Java, Fiji, and Hawaii. The species has sometimes also been attributed to Panama on the basis of var. breviflora Hook., considered by Fernandez and Herrera (1983) a teratological form to be excluded from Rondeletia odorata. Those authors recognize the Cuban endemic species to be composed of three subspecies.

LOCAL NAME AND USE: An attractive ornamental locally known as rondeletia.

Available COLLECTION: VITI LEVU: Rewa: Lami, in private garden, DA 16465. 
9. Lindenia Benth. Pl. Hartw. 84. 1841, in Hook. Icon. Pl. 5: $t$. 476. 1842; Endl. Gen. Pl. Suppl. 2: 53. 1842; Benth. Pl. Hartw. 351. 1857; Hook. in Bot. Mag. 87: t. 5258. 1861; Seem. in Bonplandia 10: 33. 1862, Fl. Vit. 128. 1866; Hook. f. in Benth. \& Hook. f. Gen. Pl. 2: 51. 1873; K. Schum. in Engl. \& Prantl, Nat. Pflanzenfam. IV. 4: 37. 1891; A. C. Sm. in J. Arnold Arb. 36: 288. 1955; van Balgooy, Pacific Plant Areas 3: 330. map 214. 1975; S. Darwin in J. Arnold Arb. 57: 426. 1976, in Allertonia 2: 22. 1979; van Steenis, Rheophytes of the World, 358. fig. 43. 1981.

Siphonia sensu Benth. Pl. Hartw. 84. 1841; non D. Rich. ex Schreber (1791).

Riverine shrubs to $3 \mathrm{~m}$. high, the stipules variable, acuminate or rounded at apex, caducous or persistent; leaf blades long-elliptic, chartaceous; inflorescences terminal, 1-14-flowered; calyx lobes 5, subulate to linear-lanceolate, persistent; corolla white to pinkish, hypocrateriform, the tube slender, to $16 \mathrm{~cm}$. long, the lobes 5 , spreading, sinistrorsely contorted in bud; stamens 5 , attached at corolla throat, the anthers exserted; ovules numerous in each of the 2 ovary locules, the placentas elongate; fruits obovoid, septicidally dehiscent, the seeds small, rhomboidal.

TYPE SPECIES AND NOMENCLATURE: The only original species was Lindenia rivalis Benth. Before distribution of fascicle M (pp. 81-88) of Plantae Hartwegianae, the name Lindenia was written in by hand and Siphonia crossed out; this is accepted as effective publication by indelible autograph as permitted by ICBN, Art. 29.3 (vide Darwin, 1976).

Distribution: A genus of three species, one occurring in southern Mexico and Central America, one endemic to New Caledonia, and one endemic to Fiji. The Old World species represent an unusual New World element in the flora of the southwestern Pacific. The genus seems closely related to Augusta Pohl, of eastern Brazil. A critical review of the tribe Rondeletieae may suggest that Lindenia, because of its contorted corolla lobes, be placed elsewhere.

Recently Tirvengadum (in Bull. Mus. Hist. Nat. (Paris) IV, 6, sect. B, Adansonia 2: 197-205. 1984) has described a new genus Glionnetia, with a single species in the Seychelles, suggesting that it is closely allied to Lindenia. "Notons également la grande importance phytogéographique de ce genre de l'archipel des Seychelles, qui est incontestablement à rattacher à ce group de Rubiacées essentiellement néotropical." (p. 202.)

Useful treatment of Genus: Darwin, S. P. The genus Lindenia (Rubiaceae). J. Arnold Arb. 57: 426-449. 1976.

1. Lindenia vitiensis Seem. in Bonplandia 9: 256, nom. nud. 1861; A. Gray in Proc. Amer. Acad. Arts 5: 318, nom. nud. (Jan.) 1862; Seem. in Bonplandia 10: 33. t. 8. (Feb.) 1862; A. Gray in op. cit. 10: 36. 1862; Seem. Viti, 438. 1862, Fl. Vit. 128. $t$. 24. 1866, op. cit. 430. 1873; Drake, Ill. Fl. Ins. Mar. Pac. 186. 1890; A. C. Sm. in J. Arnold Arb. 36: 288. 1955; J. W. Parham, Pl. Fiji Isl. 195. fig. 71. 1964, ed. 2. 276. fig. 83. 1972; van Balgooy, Pacific Plant Areas 3: 330, p. p. 1975; S. Darwin in J. Arnold Arb. 57: 441. fig. 13-22. 1976; van Steenis, Rheophytes of the World, 359. 1981.

Figure 68.

Shrub 1-2 m. high, occurring infrequently in forest along rivers and streams from near sea level to about $100 \mathrm{~m}$. The fragrant flowers have cream-colored corollas. Insofar as dated collections are available, flowers have been noted in December and fruits in March. However, Seemann's type material, in flower, would have been 

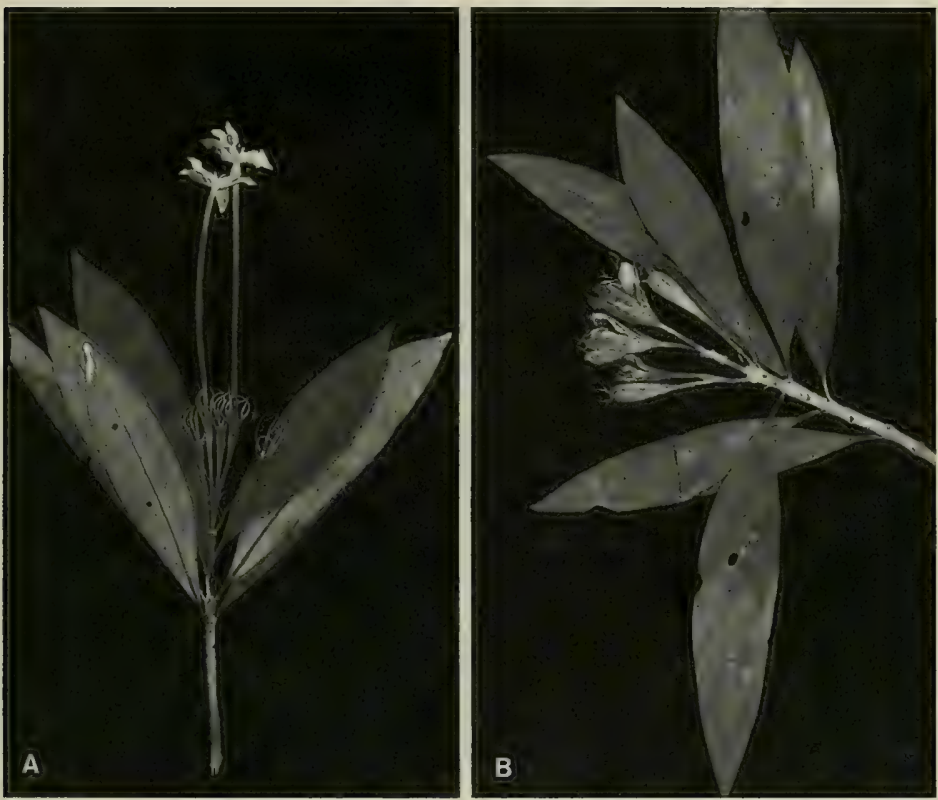

Figure 68. Lindenia vitiensis; A, distal portion of branchlet, with foliage and an inflorescence, $\times 1 / 3 ; \mathrm{B}$, distal portion of branchlet, with foliage and an infructescence, $\times 1 / 3$. A from $D A 2288$, B from $D A 2153$.

collected in August or September (Viti, 1862, pp. 147-155, 206-207). A detailed description and comparison with the related Lindenia austro-caledonica Brongn. are provided by Darwin (1976).

TyPIFICATION: The type is Seemann 217 (K HOLOTYPE; ISOTYPES at BM, GH), collected in 1860 along the Navua River, Serua Province, Viti Levu. Seemann (1862, 1866) indicates the species to occur on Ovalau and Viti Levu, but the holotype bears only the notation "Navua River," while the isotypes give no locality. No collections of the species from Ovalau have been seen, and it may be inferred that Seemann was either depending upon personal observation or was mistaken.

Distribution: Endemic to Fiji and known with certainty only from Viti Levu and Vanua Levu.

LOCAL NAMES: Recorded names are mbore ni wai, mborewai, mborewa, mbuarewai, and mbua siu; all these except the last refer to the riverine habitat.

AVAILABle COLLections: VITI LEVU: NaItasiri: Ndrauniwalai, Waindina River, DA 1811,2153 . VITI LEvU without further locality, Graeffe s. n. (K). VANUA LEVU: MBUA: Nakorotiki, Nalomate River, $D A$ 2288. Fivi without further locality, Horne 186, 964, Graeffe s. n. (BM, "Samoa" but doubtless erroneously so indicated). 
10. BıкKıA Reinw. in Syll. Pl. Nov. 2: 8. 1825; DC. Prodr. 4:405. 1830; Brongn. in Bull. Soc. Bot. France 13: 42. 1866; Hook. f. in Benth. \& Hook. f. Gen. Pl. 2: 46. 1873; K. Schum. in Engl. \& Prantl, Nat. Pflanzenfam. IV. 4: 20. 1891; Stone in Micronesica 6: 539. 1970; S. Darwin in Allertonia 2: 23. 1979; Jérémie \& Hallé in Adansonia II. 15: 342. 1976. Nom. cons.

Portlandia sensu L. f. Suppl. Pl. 143. 1782; Forst. f. Fl. Ins. Austr. Prodr. 15. 1786; non P. Br.

Trees or shrubs, the stipules entire, interpetiolar or frequently united around branchlet; inflorescences (or solitary flowers) axillary; calyx lobes 4 or 5, induplicatemargined, persistent; corolla campanulate to infundibular, the tube plicate in bud, the lobes 4 or 5 , valvate in bud; stamens 4 or 5 , inserted at base of corolla, the anthers basifixed, hardly exserted; ovules numerous in 2-locular ovary, the placentas T-shaped in cross section (ovary thus seemingly 4-chambered); fruit septicidally dehiscent, the seeds numerous, angular.

TYPE SPECIES: Bikkia grandiflora Reinw., nom. illeg. (Portlandia tetrandra L. f.) = Bikkia tetrandra (L. f.) A. Rich.

Distribution: Eastern Malesia to Micronesia, New Caledonia, Fiji, the Horne Islands, Tonga, and Niue, with about 20 species, at least half of them endemic to New Caledonia. The genus is represented by a single species in Fiji.

USEFUl TREATMENT OF GENUS: JÉRÉmie, J., \& N. Hallé. Le genre Bikkia (Rubiaceae-Condamineae) en Nouvelle-Calédonie. Adansonia II. 15: 341-355. 1976.

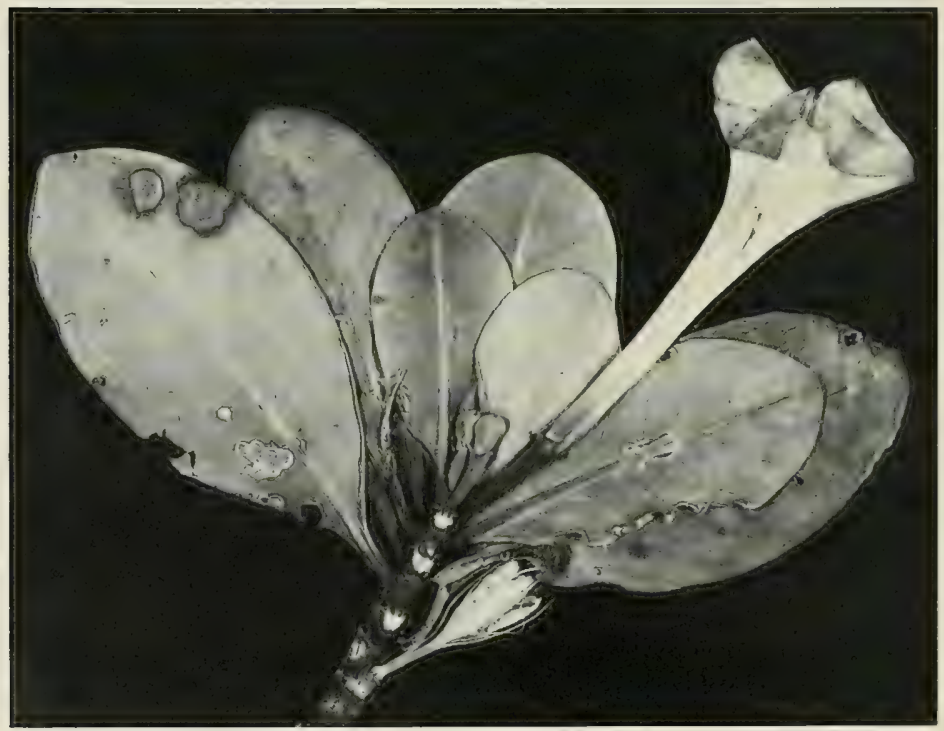

FIGURE 69. Bikkia tetrandra, from DA 14957; distal portion of branchlet, with a mature flower, developing flowers, and a dehisced fruit, $\times$ about $9 / 10$. 
1. Bikkia tetrandra (L. f.) A. Rich. Mém. Fam. Rub. 151. 1830, in Mém. Soc. Hist. Nat. Paris 5: 231. 1834; A. Gray in Proc. Amer. Acad. Arts 4: 307. 1859; Seem. Fl. Vit. 124. 1866; K. Schum. in Engl. \& Prantl, Nat. Pflanzenfam. IV. 4: 20. 1891; Yuncker in Bishop Mus. Bull. 220: 245. 1959; Sykes in New Zealand Dept. Sci. Indust. Res. Bull. 200: 174. 1970; Stone in Micronesica 6: 539. fig. 87; pl. 13f. 1970; St. John \& A. C. Sm. in Pacific Sci. 25: 339. 1971; J. W. Parham, Pl. Fiji Isl. ed. 2. 264. 1972; Jérémie \& Hallé in Adansonia II. 15:344. 1976; S. Darwin in Allertonia 2: 23. 1979; Morat \& Veillon in Bull. Mus. Nat. Hist. Nat. (Paris) IV. 7, Sect. B, Adansonia 3: 315. 1985.

Figure 69.

Portlandia tetrandra L. f. Suppl. Pl. 143. 1782; Forst. f. Fl. Ins. Austr. Prodr. 15. 1786.

Hofmannia (sic) amicorum Spreng. Syst. Veg. 1: 416, nom. illeg. 1824.

Bikkia grandiflora Reinw. in Syll. Pl. Nov. 2:8, nom. illeg. 1825; Hemsl. in J. Linn. Soc. Bot, 30: 180. 1895; Burkill in op. cit. 35: 40. 1901; A. C. Sm. in Bishop Mus. Bull. 141: I35. 1936; Yuncker in op. cit.

178: 110. 1943; J. W. Parham, Pl. Fiji Isl. 187. 1964, ed. 2. 264. 1972.

Bikkia australis DC. Prodr. 4: 405, nom, illeg. 1830.

Bikkia australis var. forsteriana DC. Prodr. 4: 405, nom, illeg. 1830.

Bikkia forsteriana Brongn. in Bull. Soc. Bot. France 13: 42, nom. illeg. 1866.

Bikkia mariannensis Brongn. in Bull. Soc. Bot. France 13:42. 1866; S. Darwin in Allertonia 2: 25. fig. 2, E. 1979.

Bikkia hombroniana Brongn. in Bull. Soc. Bot. France 13: 43.1866.

As seen in the Fijian Region, Bikkia tetrandra is a shrub or small tree $1-3 \mathrm{~m}$. high, found near sea level and usually (or always?) on limestone on rocky coasts, sea cliffs, and lagoon cliffs, with a waxy-white corolla. On the basis of material at hand one would have to assume it infrequent in Fiji, but it has been collected more often in appropriate habitats in Tonga and on Niue. In the area as a whole flowers have been obtained between November and April, fruits being fairly persistent.

TYPIFICATION AND NOMENCLATURE: The type was collected on Niue (Savage Island) during Cook's second voyage by $J$. R. \& G. Forster (LINN 228 HOLOTYPE (vide Jérémie and Hallé, 1976); ISOTYPES at BM, K); although the Forster collection was not actually cited by the younger Linnaeus, material from Niue available to him can have come only from that source (cf. vol. 1 of this Flora, p. 37). Of the synonyms cited above, Hofmannia (sic) amicorum, Bikkia grandiflora, B. australis, B. australis var. forsteri$a n a$, and $B$. forsteriana are illegitimate because Portlandia tetrandra was cited in synonymy or because they were based on the same type material as the younger Linnaeus's species. Bikkia mariannensis is based on collections from Guam made by Gaudichaud and Le Guillou, and $B$. hombroniana on Tongan material collected by Hombron and Le Guillou.

Distribution: Fiji, Tonga, Niue, and the Horne Islands, with a disjunct population in the Marianas Islands. The species is also ascribed to extreme eastern New Caledonia, the Loyalty Islands, and the Isle of Pines by Jérémie and Hallé (1976), and we have seen at least one collection (MacKee 16400, coll. L. Bernier, from Kuébéni, extreme eastern New Caledonia) that we consider correctly assigned to Bikkia tetran$d r a$. However, the broad interpretation of $B$. tetrandra by Jérémie and Hallé includes $B$. pancheri (Brongn.) Guillaumin, which, to judge from available collections, we think distinguishable on the basis of its shorter, more flaring corollas with broader and more rounded lobes and its longer fruits. Specimens we would refer to B. pancheri are from the Isle of Pines (Buchholz 1659), the New Hebrides (Raynal RSNH 16399), Solomon Islands (Brass 2998, Hynes, Templeton Crocker Exped., June 21, 1933), and New Britain (Sayers NGF 24117, Womersley NGF 41210, Croft et al. NGF 41297). Much of 
the Malesian material identified as $B$. grandiflora is quite different from $B$. tetrandra (cf. Yuncker, 1959). The inclusion of New Guinea in the range of B. tetrandra (cf. Jérémie and Hallé, 1976, p. 343) seems incorrect, and we have seen no New Hebridean collections that we would refer to the species.

LOCAL NAME AND USE: A single Fijian local name has been recorded, rongga (Fulanga), and the striking flowers are used in garlands.

Available COLlections: NANGINGIA (Denham Island, west of Kandavu): DA 2656, 14957. FULANGA: On limestone, Smith 1205. FiJI without further locality, DA 17822.

11. Badusa A. Gray in Proc. Amer. Acad. Arts 4: 308. 1859; Hook. f. in Benth. \& Hook. f. Gen. Pl. 2: 42. 1873; K. Schum. in Engl. \& Prantl, Nat. Pflanzenfam. IV. 4: 54. 1891; Gillespie in Bishop Mus. Bull. 74: 28. 1930; S. Darwin in Allertonia 2: 21. 1979; Ridsdale in Blumea 28: 145. 1982.

Small trees or shrubs, the stipules undulate to deltoid, connate and sheathing at base; inflorescences axillary, the flowers ( 4 or)5-merous; calyx undulate to prominently lobed, persistent; corolla infundibular to hypocrateriform, pubescent within, the lobes imbricate; stamens inserted at base of corolla, the filaments briefly united at base, long-exserted, the anthers basifixed; ovules numerous in a 2-locular ovary, the placentas Y-shaped (distally 2-armed); fruit septicidally and loculicidally dehiscent, the seeds small, slightly winged or crested at one end.

TYPE SPECIES: Badusa corymbifera (Forst. f.) A. Gray (Cinchona corymbifera Forst. f.), the only original species.

Distribution: Three or more species, occurring in the Philippines, Palau, and the southwestern Pacific with a disjunct population in Biak (West New Guinea); additional species may be present in the Philippines and the Moluccas (vide Ridsdale, 1982, p. 149).

Useful treatment of genus: Ridsdale, C. E. A revision of Badusa (Rubiaceae, Condamineae, Portlandiinae). Blumea 28: 145-150. 1982.

1. Badusa corymbifera (Forst. f.) A. Gray in Proc. Amer. Acad. Arts 4: 308. 1859; Seem. Fl. Vit. 121. 1866; Horne, A Year in Fiji, 257. 1881; Drake, Ill. Fl. Ins. Mar. Pac. 185. 1890; Gillespie in Bishop Mus. Bull. 74: 28. fig. 37. 1930; Fosberg in Bull. Torrey Bot. Club 67: 418. 1940; Yuncker in Bishop Mus. Bull. 220: 246. 1959; J. W. Parham, Pl. Fiji Isl. 187. fig. 67, A. 1964, ed. 2. 264. fig. 78, A. 1972; Ridsdale in Blumea 28: 147. $1982 . \quad$ FIGURE 70.

Cinchona corymbifera Forst. f. in Nova Acta Regiae Soc. Sci. Uppsal. 3: 176. 1780; L. f. Suppl. Pl. 144. 1782; Forst. f. Fl. Ins. Austr. Prodr. 15. 1786.

Badusa occidentalis Guillaumin in J. Arnold Arb. 13: 3. 1932.

Badusa corymbifera subsp. corymbifera; Ridsdale in Blumea 28: 148.1982.

In Fiji Badusa corymbifera is seen as a shrub or tree $1-6 \mathrm{~m}$. high, often slender or compact, at elevations from near sea level to about $900 \mathrm{~m}$. in rocky forest or thickets, in crest forest, and in rocky open places, often on limestone. The fragrant flowers have the corolla and filaments white, the anthers yellow, and the style faintly purple-tinged; fruits are brown at maturity. Flowers have been obtained between February and July, fruits in most months.

TyPification: Cinchona corymbifera is based on $J . R$. \& G. Forster (K LeCTOTYPE here designated), collected during the second Cook voyage on Tongatapu, Tonga. Although duplicates of the Forster collection may exist elsewhere, none was found at BM and Ridsdale (1982) did not see one. The type of Badusa occidentalis is Kajewski 393 (A HOLOTYPE; ISOTYPES at BISH, P), collected June 8, 1928, at Dillon Bay, Eromanga, New Hebrides; Ridsdale (1982) is certainly correct in this reduction. 

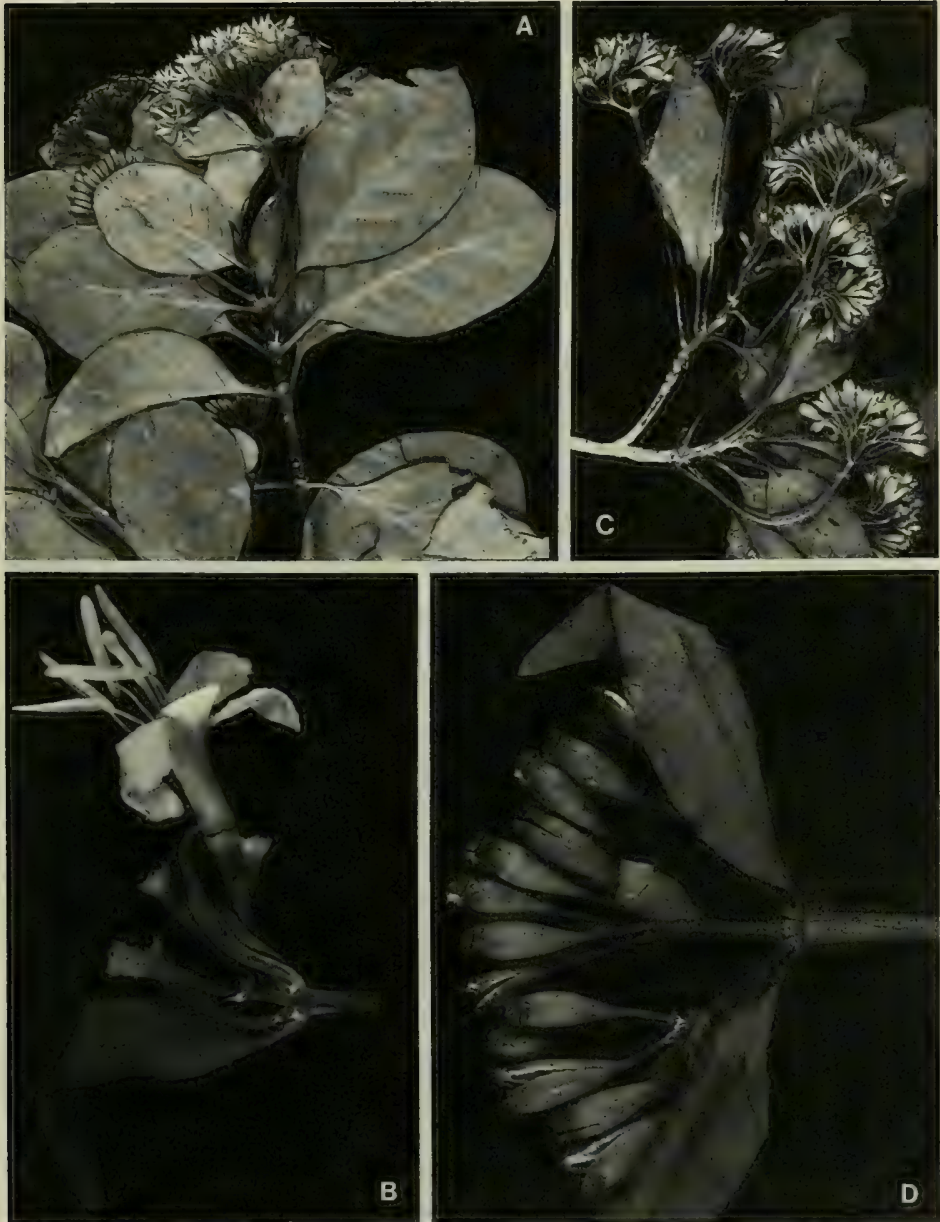

Figure 70. Badusa corymbifera; $\mathrm{A}$, distal portion of branchlet, with foliage and inflorescences, $\times 1 / 2 ; \mathrm{B}$ portion of inflorescence with calyces, a corolla, stamens, and style, $\times 2$; C, distal portion of branchlet, with foliage and infructescences, $\times 1 / 2 ; \mathrm{D}$, infructescence, $\times 2$. A from Smith 1119. B from St. John 18133, C from Bryan, Sept. 20, 1924, D from St. John 18099.

Distribution: Typical Badusa corymbifera occurs in the Solomon Islands (at least from New Georgia eastward), New Hebrides, Fiji, and Tonga. In Fiji it is now known from six islands scattered throughout the group (and hence must be anticipated on 
many others) and 26 collections, all of which are here listed. Ridsdale (1982, p. 148) has described a second subspecies, subsp. biakensis, apparently known only from the type from Biak, Arjombokar, West New Guinea, and differing from the typical subspecies in having longer corolla lobes $(12-13 \mathrm{~mm}$. vs. 5-8 mm.) and deltoid calyx lobes $0.5 \mathrm{~mm}$. long (vs. an undulate to shallowly dentate calyx). In view of the disjunct occurrence of this element, the species should be sought in eastern New Guinea and the western Solomons.

LOCAL NAMES: Recorded names are tarutaru or tarutaru nikora (Waya), mbolovatu (Mba), mbelembele (Mbua), and titeva (Vanua Mbalavu, Fulanga).

Available COllections: YASAWAS: WaYA: Nangua, St. John 18099, 18163; Nakawa Gulch, west side of Mbatinaremba, St. John 18133. VITI LEVU: MBA: Northern slopes of Mt. Namendre, east of Mt. Koromba, Smith 4510; slopes of escarpment north of Nandarivatu, Smith 6296; vicinity of Nandarivatu, Greenwood 841. Gillespie 4261. RewA: Coastal road beyond Lami, Gillespie 4611; Lami, DA 18, 935; Suva Bay, Bryan 185, Parks 20035. VIrI Levu without further locality, Tothill 230 (coll. Mac Daniels). OVALAU: Hills southeast of valley of Mbureta River, Smith 7438. VANUA LEVU: MBUA: Nasau, H. B. R. Parham 34, 87; Mbua without further locality, DA 5027. VANUA MBALAVU: Bryan, Sept. 20, 1924; Nambavatu, Tothill 296; northern limestone section, Smith 1468; southern limestone section, Smith 1445; Namalata islet, south of Vanua Mbalavu, Smith 1440. FULANGA: On limestone, Smith 1119. FiJi without further locality, U. S. Expl. Exped., Horne 510, 581.

12. Mussaenda L. Sp. Pl. 177. 1753; Seem. Fl. Vit. 123. 1866; Hook. f. in Benth. \& Hook. f. Gen. Pl. 2: 64. 1873; K. Schum. in Engl. \& Prantl, Nat. Pflanzenfam. IV. 4: 63. 1891; A. C. Sm. in J. Arnold Arb. 26: 104. 1945; Jayaw. in op. cit. 44: 113. 1963, in op. cit. 45: 101. 1964; Backer \& Bakh. f. Fl. Java 2:304. 1965; Hallé in Fl. Gabon 12: 139. 1966; S. Darwin in Allertonia 2: 24. 1979.

Erect or scandent shrubs or small trees, the stipules interpetiolar, caducous or persistent, variable in shape and texture, broadening at base and extending into leaf axils, entire or frequently bifurcate at apex; inflorescences terminal or in axils of the most distal pair of leaves, few-many-flowered, cymose or corymbiform, the bracts and bracteoles deciduous; flowers $\not{q}$, heterostylous, or unisexual; calyx lobes 5 , deciduous or persistent, one or more lobes in some flowers often expanded into large, petaloid, white to yellow or red appendages; corolla hypocrateriform, white to greenish yellow, the lobes 5, white, yellow, or reddish; stamens 5, attached at top or middle of corolla tube, included; ovules numerous on peltate, fleshy, axile placentas; fruit a berry of variable shape, the seeds numerous, minute, variously reticulate or spiny, the endosperm absent.

TYPE SPECIES: Mussaenda frondosa L., the only original species.

Distribution: Tropical Africa and Madagascar to India and Ceylon, and eastward through Malesia to Australia and the southern Pacific to the Society Islands, with about 190 species. One cultivated species and one abundant indigenous species are found in Fiji.

In an interesting discussion of the morphology of the Asiatic species, Jayaweera (in J. Arnold Arb. 44: 111. 1963) remarks: "The group includes several valuable ornamental shrubs and is of considerable biological interest, both because of the unusual development of one or more of the calyx lobes into large, colorful, petaloid structures and because of the presence of heterostyly (associated with differences in pollen size) in every species of the genus."

KEY TO SPECIES

Cultivated liana or shrub to $4 \mathrm{~m}$. high, often drooping or climbing; branchlets and leaves copiously pilose; inflorescence branches, calyx tube, and corollas reddish-pubescent; enlarged calyx lobe red within,

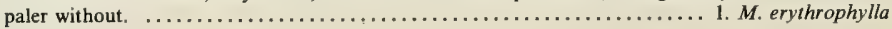


Indigenous and abundant shrub or small tree to $10 \mathrm{~m}$. high; branchlets and leaves hispidulous but often essentially glabrescent; inflorescence branches, calyx tube, and corollas pale- or brownish-hispidulous or -sericeous and often subglabrate; enlarged calyx lobe white or yellowish. ....2. M. raiateensis

1. Mussaenda erythrophylla Schumacher \& Thonn. in Schumacher, Beskr. Guin. Pl. 116. 1827, in Kongel. Danske Vidensk.-Selsk. Skr. 3: 136. 1828; J. W. Parham, Pl. Fiji Isl. 198. 1964, ed. 2. 279. 1972; Backer \& Bakh. f. Fl. Java 2: 304. 1965; Hallé in Fl. Gabon 12: 148. 1966; MacKee, Pl. Intro. Cult. Nouv.-Caléd. 118. 1985.

As cultivated near sea level in Fiji, Mussaenda erythrophylla is a shrub 2-4 m. high, conspicuous in having the enlarged calyx lobe bright red within and somewhat paler without, the other calyx lobes red, and the corolla red-pubescent, with the tube pale yellow within distally. Flowers have been observed in November, January, and March, but fruits have not been noted.

TYPIFICATION: The type is said to be from Ghana but was not seen by Halle (1966).

Distribution: Tropical Africa; now widely cultivated elsewhere in tropical areas, as in Fiji.

LOCAL NAME AND USE: This striking garden ornamental, probably brought into Fiji during the last half century, is locally known merely as red mussaenda.

Available Collections: VITI LEVU: Rewa: Lami, in private garden, DA 16797; Suva, near Department of Agriculture compound, DA 12184; Suva, in private garden, DA 16092.

2. Mussaenda raiateensis J. W. Moore in Bishop Mus. Bull. 102:44. 1933; A. C. Sm. in J. Arnold Arb. 26: 105. 1945; Yuncker in Bishop Mus. Bull. 220: 247. 1959; J. W. Parham, Pl. Fiji Isl. 198. fig. 72. 1964, ed. 2. 279. fig. 84. 1972; St. John \& A. C. Sm. in Pacific Sci. 25: 339. 1971; B. E. V. Parham in New Zealand Dept. Sci. Indust. Res. Inform. Ser. 85: 35, 61. 1972; S. Darwin in Allertonia 2: 24. fig. 2, F. 1979; Morat \& Veillon in Bull. Mus. Nat. Hist. Nat. (Paris) IV, 7, Sect. B, Adansonia 3: 316. 1985.

Figure 131 (upper).

Mussaenda frondosa sensu Forst. f. Fl. Ins. Austr. Prodr. 17. 1786; Seem. in Bonplandia 9:256. 1861, Viti, 438. 1862, in J. Bot. 2: 72. 1864, Fl. Vit. 123. 1866; Drake, Ill. Fl. Ins. Mar. Pac. 189. 1890; Reinecke in Bot. Jahrb. 25: 690. 1898; Gibbs in J. Linn. Soc. Bot. 39: 151. 1909; Guillaumin in J. Arnold Arb. 13:4. 1932; Fosberg in Bull. Torrey Bot. Club 67: 420. I940; Yuncker in Bishop Mus. Bull. 184: 64. 1945; non L.

Mussaenda formosa sensu Seem. Fl. Vit. 123, pro syn. 1866; non L.

Mussaenda frondosa var. pilosissima sensu Reinecke in Bot. Jahrb. 25:690. 1898; Rechinger in Denkschr. Akad. Wiss. Wien 85: 368. 1910; Setchell in Carnegie Inst. Wash. Publ. 341: 43. 1924; non Engl. Mussaenda sp. Christophersen in Bishop Mus. Bull. 128: 199. 1935.

As seen in Fiji, Mussaenda raiateensis is a shrub or small tree $1-10 \mathrm{~m}$. high, often locally abundant from near sea level to $1,050 \mathrm{~m}$. altitude in open or sometimes dense forest, secondary forest, and clearings. It is conspicuous for its white (rarely yellowish) enlarged calyx lobe and its corolla with the tube greenish and the limb bright yellow; the style is pale yellow; and the fruit is brown, usually copiously pale-lenticellate. Flowers and fruits are to be seen throughout the year.

Typification: The type is $J$. $W$. Moore 684 (BISH holotype; isotype at Min), collected March 24, 1927, in a wet gully on the west side of the highest mountain on Raiatea, Society Islands.

Distribution: New Hebrides to Society Islands. From Fiji about 75 collections are available, from 16 islands; the species is reported from a variety of habitats and is one of the commonest plants in second growth thickets, hence it is to be anticipated on most of the islands.

LOCAL NAMES AND USES: The species is well known throughout Fiji as $m b o v u$, mbovo, mbombo, vombo, and vakatharendavui. It is an "all purpose" medicine, parts 
of the plants (leaves, bark, and roots) being used in concoctions to cure fevers, chest complaints, kidney diseases, asthma, and to encourage fertility in women.

RePRESENTATIVE COLleCtions: YASAWAS: WAya: Below Yalombi and Natawa, DA 13674. VITI LEVU: MBa: Slopes of Mt. Nairosa, eastern flank of Mt. Evans Range, Smith 4079; between Nandarivatu and Waikumbukumbu, Gibbs 690. NANDronga \& Navosa: Nausori Highlands, DA 13400. Serua: Hills between Waininggere and Waisese Creeks, between Ngaloa and Wainiyambia, Smith 9344. NAITASIRI: Vicinity of Nasinu, Gillespie 3555. TAILEvU: Hills east of Wainimbuka River, vicinity of Ndakuivuna, Smith 7038. REWA: Queen's Road about 10 miles west of Suva, Vaughan 3146. KANDAVU: Namalata isthmus region, Smith 25. OVALAU: Vicinity of Levuka, Gillespie 447I. MAKONDRONGA: Degener \& Ordonez 13814. KORO: Eastern slope of main ridge, Smith 1030. NAIRAI: Milne 172. NGAU: Milne 158. VANUA LEVU (Mathuata) and LAKEMBA: Seemann 238. VANUA LEVU: MathuaTA: DF 254 (Bola 102). ThaKaUndrove: Mbalanga, Savusavu Bay region, Degener \& Ordonez 13987. TAVEUNI: Vicinity of Wairiki, Gillespie 4754. MATUKU: Moseley. TOTOYA: Milne 87. VANUA MBALAVU: Near Lomaloma, Garnock-Jones 1007. LAKEMBA: Nukunuku Village, Garnock-Jones 819. ONEATA: U. S. Expl. Exped. FULANGA: On limestone, Smith 1173.

13. Gardenia Ellis in Philos. Trans. 51 (2): 935. 1761; Seem. Fl. Vit. 122. 1866; Hook. f. in Benth. \& Hook. f. Gen. Pl. 2: 89. 1873; K. Schum. in Engl. \& Prantl, Nat. Pflanzenfam. IV. 4: 76. 1891; Backer \& Bakh. f. Fl. Java 2: 313. 1965; A. C. Sm. in Amer. J. Bot. 61: 109. 1974. Nom. cons.

Catsjopiri Rumph. Herb. Amb. 7: 26. 1755.

Varneria L. Amoen. Acad. 4: 136. 1759.

Trees or shrubs, glabrous throughout or with indument on young parts and some floral parts, with a conspicuous exudation of yellowish latex from young stipular sheaths; stipules conspicuous, forming a papyraceous sheath, this cylindric to urceolate, bilobed, or with a single unilateral lobe, eventually becoming free by a circumscissile cleft; leaves opposite (sometimes ternate, rarely quaternate), the blades often with domatia; inflorescences 1 -flowered and terminal at inception, soon appearing axillary by development of a vegetative bud, the pedicel enlarged distally into a clavate or prismatic hypanthium, the calyx limb infundibular or narrowly cupuliform and often with conspicuous spurlike wings or angles, these (in our indigenous species) 3-5 in number and often obscurely marsupiiform distally; corolla comparatively large and usually hypocrateriform, the tube slender, the limb with 6-9 sinistrorsely contorted lobes and becoming conspicuously rotate; stamens as many as corolla lobes, inserted in corolla throat, the filaments very short, the anthers dorsifixed, inconspicuously extruded at anthesis; ovary thick-walled, the placentas parietal and alternate with the hypanthial wings or angles or calyx spurs, the ovules numerous in paired, elongate series, soon immersed in pulp apparently of placental origin, the style slender, the stigmas connate into a fusiform mass; fruits often large, smooth to narrowly winged, the endocarp bony, the numerous seeds embedded in firm orange pulp.

TYPE SPECIES: Gardenia jasminoides Ellis ( $=$ G. augusta (L.) Merr.), the only original species. Catsjopiri, a vernacular name rather than a true generic name, and Varneria are based on the species now known as G. augusta (L.) Merr. Although Varneria is not listed by ING (1979), it and the epithet augusta may be considered validly published (vide Smith, 1974).

Distribution: Paleotropical, with about 250 species; nine species (eight of them endemic) are indigenous in Fiji, and a tenth species is infrequently cultivated.

LOCAL NAMES AND USES: The indigenous Fijian species (except for $G$. taitensis, which is locally recognized as quite discrete from the other species) are collectively known as ndrenga, and the latex extruded by the young stipular sheaths is used as a chewing gum or is eaten. Other local names and reputed medicinal uses are noted below under individual species. 
Useful treatment of genus: Smith, A. C. Studies of Pacific Island plants. XXVII. The genus Gardenia (Rubiaceae) in the Fijian Region. Amer. J. Bot. 61: 109-128. 1974. The present treatment is abstracted from the 1974 paper, since publication of which very few additional Fijian collections of the genus have become available.

The eight endemic Fijian species, with stipules connate into an entire sheath and with conspicuously spurred calyx limbs, fall into three well-marked clusters: (1) Gardenia gordonii, G. hutchinsoniana, and G. candida, with broad, distally or laterally ascending calycine spurs that are conspicuously decurrent on the hypanthium, the fruits thus becoming winged or sharply costate, (2) G. vitiensis, G. hillii, and G. grievei, with narrow, ascending calycine spurs not proximally decurrent, the fruits thus essentially smooth, and (3) G. storckii and G. anapetes, with widely spreading calycine spurs exceeded by the calyx limb and with smooth fruits.

\section{KEY TO SPECIES}

Stipules connate proximally, the sheath conspicuously bilobed or with a single unilateral lobe distally; calyx limb narrowly cupuliform or prismatic, not exceeding $15 \mathrm{~mm}$. in length, conspicuously winged or angled to base, terminated and exceeded by ascending, laterally flattened spurs.

Stipules often split nearly to base and with a single unilateral lobe, but sometimes bilobed; calyx limb 5-7-winged, terminated by linear-lanceolate spurs $15-30 \mathrm{~mm}$. long and 1.5-6 $\mathrm{mm}$. broad; corolla double (as seen in our area); petioles 1-8 mm. long; leaf blades elliptic-obovate to oblong-lanceolate, not exceeding $14 \times 5.5 \mathrm{~cm}$, and usually much smaller; cultivated only. ........ 1. G. augusta

Stipules bilobed; calyx limb 3-5-winged, terminated by oblong or oblong-ovate, often conspicuously falcate spurs 10-30 mm. long and (2-) 3-8 mm. broad; corolla single, the tube (25-) 30-40 mm. long, the limb spreading to $45-65(-90) \mathrm{mm}$. in diameter, with 6-8 lobes; petioles usually less than $5 \mathrm{~mm}$. long (but in cultivars to $14 \mathrm{~mm}$. long); leaf blades obovate or broadly elliptic, (3-) 5-18(-25) $\times(1.5-)$ $2.5-9.5(-12) \mathrm{cm}$.; indigenous but sometimes brought into village cultivation. ...2. G. taitensis

Stipules connate into a cylindric or cupuliform or urceolate sheath, this entire and truncate or inconspicuously undulate at apex; indigenous (and endemic) species.

Spurs of the calyx ascending, produced from apex of calyx limb or broadly decurrent on limb and occasionally not exceeding it in length.

Calyx limb 3- or 4-winged or conspicuously angled to base, the wings or angles decurrent on hypanthium, ascending distally and/or laterally from limb into spurs, these semi-obovate to oblong or oblong-lanceolate, $10-40 \mathrm{~mm}$. long, (2-) 4-18 mm. broad; fruits comparatively large, 18-50 $\times$ 18-40 mm., 3- or 4-winged or sharply costate.

Leaf blades glabrous on both sides or evanescently strigillose on costa beneath; pedicels and calyx glabrous or minutely puberulent and soon glabrate; corolla tube $20-45 \mathrm{~mm}$. long, the limb rarely exceeding $80 \mathrm{~mm}$. in diameter, with lobes usually $15-45 \times 7-20 \mathrm{~mm}$.

Stipular sheath 6-13 $(-15) \mathrm{mm}$. long; leaf blades usually 10-22 $\times 4-12.5 \mathrm{~cm}$., with 10-21 secondary nerves per side; calyx spurs conspicuous, $15-40 \mathrm{~mm}$. long and (5-) $8-18 \mathrm{~mm}$. broad; fruits

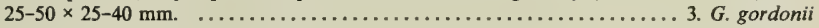

Stipular sheath 3-7 mm. long; leaf blades smaller, usually 6-14 × 3-6.5 cm., with 7-13 secondary nerves per side; calyx spurs smaller, 10-35 mm. long and (2-) 4-9 mm. broad; fruits 18-35 $\times$

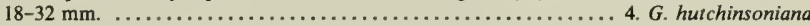

Leaf blades puberulent on costa and secondaries above and there eventually glabrate, copiously pilose beneath, usually $13-20 \times 6-9 \mathrm{~cm}$., with 13-17 secondary nerves per side; stipular sheath 9-12 mm. long; pedicels and calyx copiously spreading-pilose with hairs $0.3-1.5 \mathrm{~mm}$. long; corolla tube $40-55 \mathrm{~mm}$. long, the limb $90-110 \mathrm{~mm}$. in diameter, with lobes $45-55 \times 18-25 \mathrm{~mm}$.

5. $G$. candida

Calyx limb smooth or drying obscurely costate, not laterally winged or angled except sometimes narrowly so toward apex, apically produced into 3 or 4 ascending spurs, these spathulate- or oblong-linear to narrowly obovate, 7-25 mm. long, $1.5-5.5 \mathrm{~mm}$. broad; fruits comparatively small, not exceeding $27 \times 22 \mathrm{~mm}$., smooth, without wings or angles but in drying sometimes becoming inconspicuously multicostate; plants comparatively slender, the stipular sheath less than $6 \mathrm{~mm}$. long, the leaf blades not larger than $14.5 \times 7 \mathrm{~cm}$., with $7-12$ secondary nerves per side.

Apex of calyx limb contracted and with acute sinuses, the limb fusiform-urceolate, 15-40 mm. long, often unilaterally cleft nearly to base and with the corolla consequently laterally emitted.

6. G. vitiensis

Apex of calyx limb not contracted, with flattened or rounded sinuses, the limb not exceeding $13 \mathrm{~mm}$. in length, the corolla apically emitted. 
Calyx limb poculiform or narrowly cupuliform, 7-13 mm. long. ........... G. hillii

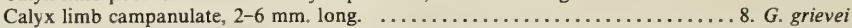
Spurs of the calyx spreading at a wide angle, laterally projecting from calyx limb and not broadly decurrent on it, the limb apically produced slightly or conspicuously beyond distal margins of spurs.

Vegetative and external floral parts essentially glabrous or with an evanescent puberulent or strigose indument; stipular sheath 3-6 (-8) mm. long; hypanthium subterete or shallowly several-sulcate; calyx limb tubular-cupuliform, 3-7 mm. long, proximally bluntly 3-5-angled, distally produced 0.3-1.5 mm. beyond distal margins of spurs, these narrowly spathulate, usually $25-50 \mathrm{~mm}$. long and $2-7.5 \mathrm{~mm}$. broad, narrowed proximally into a subterete or vertically oval claw $1-1.5 \mathrm{~mm}$. in diameter or high; corolla limb $60-75 \mathrm{~mm}$. in diameter, the lobes $30-36 \times 8-15 \mathrm{~mm}$.

9. G. storckii

Vegetative and external floral parts often copiously and subpersistently puberulent, the calyx pilose with hairs to $1.5 \mathrm{~mm}$. long, these persistent in fruit; stipular sheath 10-15 mm. long; hypanthium fusiform-prismatic, obtusely 4-angled; calyx limb turbinate-cylindric, 22-25 mm. long, the distal portion fragile but produced into a tube exceeding distal margins of spurs by $10-14 \mathrm{~mm}$., the spurs linear- or oblong-obovate, $22-42 \mathrm{~mm}$. long and 5-11 mm. broad, slightly narrowed proximally and there 2.5-9 mm. high; corolla limb $80-100 \mathrm{~mm}$. in diameter, the lobes $40-50 \times 15-20 \mathrm{~mm}$.

10. G. anapetes

1. Gardenia augusta (L.) Merr. Interpret. Rumph. Herb. Amb. 485. 1917; Burkill, Dict. Econ. Prodr. Malay Penins. ed. 2. 1075. 1966; A. C. Sm. in Amer. J. Bot. 61: 113. fig. 2. 1974; Tirvengadum in Bull. Mus. Nat. Hist. Nat. (Paris) III. 35: 17. 1978; MacKee, Pl. Intro. Cult. Nouv.-Caléd. 118. 1985.

Catsjopiri Rumph. Herb. Amb. 7: 26. t. 14, fig. 2. 1755.

Varneria augusta L. Amoen. Acad. 4: 136. 1759.

Gardenia jasminoides Ellis in Philos. Trans. 51 (2):935. t. 23. 1761; Christophersen in Bishop Mus. Bull. 128: 200. 1935; Yuncker in op. cit. 220: 249. 1959; Backer \& Bakh. f. FI. Java 2:313. 1965; Sykes in New Zealand Dept. Sci. Indust. Res. Bull. 200: 176. 1970; J. W. Parham, Pl. Fiji Isl, ed. 2. 269. 1972; MacKee, Pl. Intro. Cult. Nouv.-Caléd. 118. 1985.

Gardenia florida L. Sp. Pl. ed. 2. 305, nom. illeg. 1762.

As seen in Fiji and nearby archipelagoes, Gardenia augusta is cultivated near sea level as a tree to $12 \mathrm{~m}$. high; only the double-flowered form has been noted. The fragrant flowers have the corolla pure white, fading yellowish.

TYPIFICATION AND NOMENCLATURE: The description and illustration of Catsjopiri Rumph. may be taken as the type of Varneria augusta; the double-flowered cultivated plant was presumably well established in Malesia at an early date. A similar cultivated form, collected by a Capt. Hutchinson near the Cape of Good Hope, Africa, about 1755, was the basis of Gardenia jasminoides. Gardenia florida is an illegitimate name because Linnaeus cited Ellis's description and plate as well as Rumphius's 1755 publication.

Distribution: China, Japan, the Ryukyu Islands, and Taiwan, in which areas the wild, single-flowered form occurs; now widely cultivated and perhaps occasionally becoming naturalized (although this does not appear to be the case in Fiji). The species may have been introduced into Fiji by J. B. Thurston, being listed (as Gardenia florida) in his 1886 Catalogue; it is conceivable, however, that Thurston was referring to $G$. taitensis.

LOCAL NAMES AND USES: In Fijian gardens this striking ornamental is usually known merely as gardenia, but the names jale and tiale (probably of Polynesian origin) were noted on Taveuni, where a medicinal use of the leaves to cure boils was recorded by Weiner.

Available collections: VITI LEVU: Naitasiri: Cocoa Station, Nanduruloulou, DA 12249. TAVEUNI: Korovou Village, Weiner 71-7-96. 
2. Gardenia taitensis DC. Prodr. 4: 380. 1830; Seem. in J. Bot. 2: 72. 1864, Fl. Vit. 122. 1866; Drake, Ill. Fl. Ins. Mar. Pac. 191. 1890; Setchell in Carnegie Inst. Wash. Publ. 341: 48. 1924; Christophersen in Bishop Mus. Bull. 128:200. 1935; Yuncker in op. cit. 178: 111. 1943, in op. cit. 220: 249. 1959; J. W. Parham, Pl. Fiji Isl. 191. 1964, ed. 2. 269. fig. 80. 1972; Sykes in New Zealand Dept. Sci. Indust. Res. Bull. 200: 176. 1970; St. John \& A. C. Sm. in Pacific Sci. 25:339. 1971; B. E. V. Parham in New Zealand Dept. Sci. Indust. Res. Inform. Ser. 85: 103, 127. 1972; A. C. Sm. in Amer. J. Bot. 61: 114. fig. 3-8. 1974; Morat \& Veillon in Bull. Mus. Nat. Hist. Nat. (Paris) IV. 7, Sect. B, Adansonia 3: 315. 1985.

Gardenia florida sensu Forst. f. Fl. Ins. Austr. Prodr. 20. 1786; Drake, Ill. Fl. Ins. Mar. Pac. 191. 1890; non L.

Garcinia (sic) taitensis sensu Horne, A Year in Fiji, 262, sphalm. 1881.

Gardenia tahitensis DC. ex Drake, Fl. Polynés. Franç. 91. 1893; Rechinger in Denkschr. Akad. Wiss. Wien 85: 368. 1910.

Gardenia tahitensis f. genuina Reinecke in Bot. Jahrb. 25: 683, nom. inadmis. 1898.

Gardenia tahitensis f. minor Reinecke in Bot. Jahrb. 25: 684, nom. nud. 1898.

Gardenia sp. Guillaumin in J. Arnold Arb. 13: 5. 1932.

Gardenia weissichii St. John in Phytologia 39: 108. fig. 1. 1978.

As seen in Fiji, Gardenia taitensis is a shrub or gnarled tree to $6 \mathrm{~m}$. high (frequently dwarfed to about $20 \mathrm{~cm}$. but still floriferous in very exposed situations), occurring near sea level (seldom to elevations of more than $30 \mathrm{~m}$.) on sea cliffs, lagoon cliffs, and on rocky islets, practically always on limestone; it is occasionally brought into village cultivation. The highly fragrant flowers have the corolla tube green-tinged and the limb pure white. The fruits are yellow-green, with cream-colored seeds embedded in orange pulp. Flowers and fruits do not appear seasonal.

TyPifiCation: The type was collected by Dumont d'Urville on Tahiti, Society Islands; the holotype is presumably at G-DC, although Dumont d'Urville's own herbarium is now at $\mathrm{P}$, transferred from $\mathrm{CN}$. The type of Gardenia weissichii is Weissich Fl.2585 (BISH HOLOTYPE), collected July 14, 1976, in the Wahiawa Botanic Garden on Oahu, Hawaii (derived from an apparently wild collection from Malaekahana, Oahu).

Distribution: Gardenia taitensis is indigenous in the New Hebrides, Fiji, the Horne and Wallis Islands, Tonga, and Niue, and quite probably in Samoa as well. In most of these areas it is sometimes brought into village cultivation, and selection seems to have resulted in the development of cultivars with exceptionally large flowers and leaves. Eastward of Samoa to the Tuamotus and equatorial islands the species is widely grown as a village ornamental, infrequently becoming naturalized. It is of interest that G. taitensis had been established as an ornamental in Hawaii prior to Cook's visit (St. John in Pacific Sci. 33: 326. 1979); apparently it had become naturalized on Oahu and was subsequently reintroduced into cultivation (as $G$. weissichii, a cultivar that falls well within a reasonable interpretation of the species as it occurs in the Fijian Region).

LOCAL NAMES AND USES: The commonly used names in Fiji are mbua and mbua toka, but often in cultivation such names as gardenia and tiare (the Tahitian name) are used. The flowers are used for personal adornment, and both flowers and fruits are used to scent coconut oil. Medicinal uses are ascribed to the species in many Pacific archipelagoes, but no such records in Fiji have come to my attention.

Available Collections: NANGINGIA (Denham Island, west of Kandavu): DA 2657, 14960. KANDAVU: Western end of island, near Cape Washington, Smith 315. WAKAYA: Tothill 303. YATHATA: Yathata Village, DA 13941. VANUA MBALAVU: Graeffe 1572, Bryan 399, p. p.; northern limestone section, Smith 
1488; Namalata Islet, southern limestone section, Smith 1444. SUSUI (south of Vanua Mbalavu): Graeffe 1402. LAKEMBA: Tothill 295. AIWA: Bryan 529. FULANGA: Smith 1112, 1204. ONGEA NDRIKI: Isolated rocky islet off northwestern end, Bryan 399, p. p.

3. Gardenia gordonii Baker in J. Linn. Soc. Bot. 20:361, as G. gordoni. 1883; A. C. Sm. in Amer. J. Bot. 61: 117. fig. 11-14. 1974.

Garcinia (sic) arthurgordoni Horne, A Year in Fiji, 262, nom. nud. 1881.

Gardeni (sic) gorriei Horne, A Year in Fiji, 262, nom. nud. 1881.

Gardenia gorriei Horne ex Baker in J. Linn. Soc. Bot. 20: 362. 1883; Drake, Ill. Fl. Ins. Mar. Pac. 191. 1890; J. W. Parham, Pl. Fiji Isl. 191. 1964, ed. 2. 269. 1972.

Gardenia gordoni Baker ex Drake, Ill. Fl. Ins. Mar. Pac. 191. 1890; J. W. Parham, Pl. Fiji Isl. 191. 1964, ed. 2. 269. 1972.

An often slender shrub or tree $2-10 \mathrm{~m}$. high occurring from near sea level to an elevation of $1,075 \mathrm{~m}$. in dense or open forest or on its edges. The flowers, characteristically fragrant like those of the genus, have the corolla white, and the fruit is green until turning blackish at full maturity. Flowers and fruits do not appear seasonal.

TYPIFICATION AND NOMENCLATURE: The type of Gardenia gordonii is Horne 499 (K HOLOTYPE; ISOTYPE at GH), collected in April, 1878, on the island of Rambi; that of $G$. gorriei is Horne 999 (K HOLOTYPE; ISOTYPE at GH), obtained in September, 1878, near Nairukuruku, Wainimala River, Naitasiri Province, Viti Levu. The types of these simultaneously published names are in fruit, but no significant differences permit the retention of both (Smith, 1974, q. v. for the identities of the individuals honored by Horne's epithets).

Distribution: Endemic to Fiji and thus far known from the two largest islands and Rambi.

LOCAL NAMES: In addition to ndrenga, senitheva and mbulumbulu (Mba) and vonu (Thakaundrove) have been noted.

Available COllections: VITI LEVU: MBA: Mt. Evans Range, Greenwood 945; northern portion of Mt. Evans Range, between Mt. Vatuyanitu and Mt. Natondra, Smith 4364; vicinity of Nalotawa, eastern base of Mt. Evans Range, Smith 4452; upper slopes of Mt. Koromba, Smith 4649. Nandronga \& Navosa: Nausori Highlands, $O$. \& I. Degener 32164. Serua: Hills east of Navua River, near Nukusere, Smith 9124 . NamOSI: Nambukavesi Creek, DA 13757 ( DF 189; Bola 51). VANUA LEVU: M ATHUATA: Mountains near Lambasa, Greenwood 614; southern slopes of Mt. Numbuiloa, east of Lambasa, Smith 6333, 6590. THAKAUNDROVE: Namale, southeast of Savusavu, DA 17125; hills west of Korotasere, Natewa Bay region, Smith 1931, DA 15495; Nggararavoravo, DA 16056. FiJi without further locality, Howard 63.

4. Gardenia hutchinsoniana Turrill in J. Linn. Soc. Bot. 43: 24. 1915; J. W. Parham, Pl. Fiji Isl. 191. 1964, ed. 2. 269. 1972; A. C. Sm. in Amer. J. Bot. 61: 118. fig. 15-20. 1974.

Gardeni (sic) sp. n. Horne, A Year in Fiji, 262. 1881.

Gardenia vitiensis sensu Gibbs in J. Linn. Soc. Bot. 39: 151. 1909; non Seem.

A slender tree or shrub 2-10 m. high, with the trunk usually not much exceeding 8 $\mathrm{cm}$. in diameter, found in dense or open forest or in thickets between 400 and $1,200 \mathrm{~m}$. altitude; where noted near sea level it may be an escape from village cultivation. As usual for the genus in Fiji, the flowers are strikingly fragrant, with a white corolla, and the fruits are green. Flowers and fruits are seen throughout the year.

TYPIFICATION: The type is im Thurn 120 (K HOLOTYPE), collected in flower Feb. 26, 1906, in the vicinity of Nandarivatu, Mba Province, Viti Levu.

Distribution: Endemic to Fiji and known only from Viti Levu and Ovalau, now represented by 26 collections. In the upland parts of eastern Mba Province this appears to be the most abundant species of Gardenia.

LOCAL NAMES: In addition to the commonly used ndrenga, names recorded from Mba Province are tokala and langgainggai. 
REPRESENTATIVE Collections: VITI LEVU: MBA: Lewa Valley, west of Nandarivatu, DA 12209 (Watkins 728); vicinity of Nandarivatu, Gibbs 753, Gillespie 3736, Degener \& Ordonez 13532; Mt. Nanggaranambuluta, east of Nandarivatu, Gillespie 3800; hills between Nggaliwana and Tumbeindreketi Creeks, east of the sawmill at Navai, Smith 5997; Mt. Tomanivi, DA 13095. Nandronga \& Navosa: Near Singatoka, DA 16705. Namosi: Mt. Voma, Gillespie 2909. RA: Vicinity of Rakiraki, Degener \& Ordonez 13699. NAITASIRI: Wailoa Creek, below Nasonggo, DA 15333. OVALAU: Slopes of Mt. Korotolutolu, west of Thawathi, Smith 8058; hills southeast of valley of Mbureta River, Smith 7445; mountains west of Levuka, Horne 403.

5. Gardenia candida A. C. Sm. in J. Arnold Arb. 34: 98. 1953; J. W. Parham, Pl. Fiji Isl. 191. 1964, ed. 2. 269. 1972; A. C. Sm. in Amer. J. Bot. 61: 120. fig. 21-23. 1974.

Tree to $7 \mathrm{~m}$. high, found at an elevation of 100-200 m. in patches of forest in open rolling country. The corolla tube is greenish and the lobes are pure white.

TyPIFICATION: The species is based on Smith 6640 (A HOLOTYPE; many ISOTYPES), collected Nov. 25, 1947, on the Seanggangga Plateau, in drainage of Korovuli River, vicinity of Natua, Mathuata Province, Vanua Levu.

Distribution: Endemic to Fiji and thus far represented only by the type collection.

Although Gardenia candida remains known from a single collection, it differs strikingly from its only close ally, G. gordonii, in its conspicuous vegetative and calycine indument and in its substantially larger corollas.

6. Gardenia vitiensis Seem. in Bonplandia 9: 256, nom. nud. 1861; A. Gray in Proc. Amer. Acad. Arts 5: 318, nom. nud. 1862, in Bonplandia 10: 36, nom. nud. 1862; Seem. Viti, 229, 438, nom. nud. 1862, Fl. Vit. 122. t. 26. 1866; Drake, Ill. Fl. Ins. Mar. Pac. 192. 1890; J. W. Parham, Pl. Fiji Isl. 191. fig. 69. 1964, ed. 2. 269. 1972; A. C. Sm. in Amer. J. Bot. 61: 121. fig. 24-27. 1974.

Garcinia (sic) vitiensis sensu Horne, A Year in Fiji, 262, sphalm. 1881.

Tree or shrub 2-8 m. high, found from near sea level to about $350 \mathrm{~m}$. elevation in open forest or on open slopes near the sea. The very fragrant flowers have a pure white corolla and have been noted between October and December; fruits have been obtained in August and October.

TyPIFICATION: Gardenia vitiensis, casually mentioned several times prior to Seemann's 1866 description, is based on Seemann 218 (K HOLOTYPE; ISOTYPES at BM, GH, P), collected Oct. 15, 1860, at "Namuka" (presumably in reference to an area at the mouth of the Nasavu River, Ndongotuki Tikina), Mathuata Province, Vanua Levu. An interesting note on its discovery was published by Seemann (Viti, 229. 1862), as summarized by Smith (1974).

Distribution: Endemic to Fiji and thus far known only from the eastern part of Mathuata Province, Vanua Levu.

LOCAL NAME: A recorded name, other than the usual ndrenga (generic), is ndrenga meilango.

AVailable collections: VANUA LEVU: Mathuata: Vicinity of Lambasa, Greenwood 477 (p. p. Aug. 17, 1922; p. p. Nov. 8, 1922); Wainggili, near Lambasa, DF 238 (Bola 86); southern slopes of Mt. Numbuiloa, east of Lambasa, Smith 6401 .

7. Gardenia hillii Horne ex Baker in J. Linn. Soc. Bot. 20:362. 1883; Drake, Ill. Fl. Ins. Mar. Pac. 191. 1890; J. W. Parham, Pl. Fiji Isl. 191. 1964, ed. 2. 269. 1972; A. C.

Sm. in Amer. J. Bot. 61: 121. fig. 28-32. 1974.

Gardeni hilli (sic) Horne, A Year in Fiji, 262, nom. nud. 1881.

Shrub or slender, freely branching tree $1-9 \mathrm{~m}$. high, sometimes locally frequent and with a trunk to $15 \mathrm{~cm}$. in diameter, noted at elevations of $100-350 \mathrm{~m}$. on open slopes in dry areas (most Mathuata collections) or in forest (Kandavu collections). As in other 
Fijian species the flowers are very fragrant and have white corollas; the fruits as far as seen are green. Flowers and fruits have been observed in October and November, flowers also in April and fruits also in May.

TyPIFICATION: The type is Horne 452 ( $\mathrm{K}$ HOLOTYPE; ISOTYPE at $\mathrm{GH}$ ), collected in April, 1878, in the higher parts of the island of Rambi.

Distribution: Endemic to Fiji and now known from Kandavu, Mathuata Province on Vanua Levu, and Rambi.

Available Collectrons: KANDAVU: Hills above Namalata and Ngaloa Bays, Smith 169; vicinity of Naikorokoro, DF 356 (Damanu 45); Kandavu without further locality, DA 11946 (Watkins 695). VANUA LEVU: MathuATA: Vicinity of Nanduri, Tothill 444; mountains along Mathuata coast, Greenwood 638; northwestern slopes of Mt. Numbuiloa, east of Lambasa, Smith 6489; Nggelemumu, east of Lambasa, $D A$ 8803.

8. Gardenia grievei Horne ex Baker in J. Linn. Soc. Bot. 20:361. 1883; J. W. Parham, Pl. Fiji Isl. 191. 1964, ed. 2. 269. 1972; A. C. Sm. in Amer. J. Bot. 61: 123. fig. 33-41. 1974; S. Darwin in Allertonia 2: 11. fig. $1, L$, as G. grievii. 1979.

Gardenia taitensis sensu A. Gray in Proc. Amer. Acad. Arts 5: 318. 1862; non DC.

Gardenia tahitensis var. parviflora A. Gray in Bonplandia 10: 36, nom. nud. 1862.

Gardeni greivei (sic) Horne, A Year in Fiji, 262, nom. nud. 1881.

Gardenia grivei (sic) Horne ex Drake, Ill. F1. Ins. Mar. Pac. 191. 1890.

A shrub or small tree 2-4 m. high, occurring from near sea level to an elevation of $200 \mathrm{~m}$. in open forest or thickets, often in open rolling country, and sometimes locally abundant. The flowers are typical in their fragrance, greenish white corolla tubes, and white corolla lobes; fruits have been noted as orange-red at maturity. Flowers have been obtained in April, November, and December; fruits between April and September.

TYPIFICATION AND NOMENCLATURE: The type of Gardenia grievei is Horne 1094 (K HOLOTYPE), obtained in September, 1878, in Mbua Province, Vanua Levu. The source of Gray's (perhaps inadvertent) 1862 trinomial was $U$. S. Expl. Exped. (GH, NY, Us 63888), from Vanua Levu without further locality.

Distribution: Endemic to Fiji and thus far known only from western and northern Vanua Levu.

LOCAL NAME: An additionally recorded name from Mathuata is ndelandrenga.

AVAilable COLlections: VANUA LEVU: "On poor soils in some parts of the interior," Horne 6,15. Mbua: Nawailevu, in drainage of Lekutu River, DA 1128. MathuATA: Seanggangga Plateau, in drainage of Korovuli River, vicinity of Natua, Smith 6694, DA 12846; Seanggangga Agricultural Station, DA 12280, 12899.

9. Gardenia storckii Oliver in Hook. Icon. Pl. 15: 38. t. 1448. 1883; J. W. Parham, Pl. Fiji Isl. 191. 1964, ed. 2. 269. 1972; A. C. Sm. in Amer. J. Bot. 61: 124. fig. 42-50. 1974.

Slender tree 2-15 m. high, with a trunk to $14 \mathrm{~cm}$. in diameter, occurring from near sea level to an altitude of $150 \mathrm{~m}$. in dense, dry, or secondary forest. As usual for the genus, the very fragrant flowers have the corolla white, and the observed fruits were green. Flowers were noted in January and March, fruits between April and November.

TyPIFICATION: The type is Storck $I I(\mathrm{~K}, 2$ sheets in flower and fruit; the flowering sheet was designated as the HOLOTYPE, cf. Smith, 1974), collected in Fiji without further locality but probably from southeastern Viti Levu.

Distribution: Endemic to Fiji and probably limited to southeastern Viti Levu; the Nandronga \& Navosa collection cited below was presumably from a forestry trial plot. 
LOCAL NAME AND USE: An additionally recorded name from Serua Province is mbolovatu, and there an extract of roots was said to be used for constipation.

Available collections: VITI leVU: Nandronga \& Navosa: Nausori Highlands, DA 11719 . Serua: Navutulevu Creek, Howard 46; hills west of Waivunu Creek, between Ngaloa and Korovou, Smith 9290; near Mt. Nggamu, vicinity of Ngaloa, Degener 15064; hills between Waininggere and Waisese Creeks, between Ngaloa and Wainiyambia, Smith 9368, 9545; valley of Taunovo River, Vaughan 3157. NAITASIRI: Navolau, DA 634; Tholo-i-suva, DA 229; Central road, Tothill 247; Prince's Road, DA 757; vicinity of Tamavua, Gillespie 2020, 2026; vicinity of Nasinu, Gillespie 3503. RewA; Naikorokoro Creek, Meebold 21933; Mt. Korombamba, Parks 20100, DA 3866, 16980.

10. Gardenia anapetes A. C. Sm. in Amer. J. Bot. 61: 125. fig. 51-55. 1974.

An apparently rare tree 4-8 m. high, found in dense forest at elevations of 300-430 m., with a white corolla. Only two collections are known, one flowering in April and the other fruiting in May.

TYPIFICATION: The type is Smith 1691 (BISH HOLOTYPE; many ISOTYPES), collected April 28, 1934, on the southern slope of Mt. Seatura, Mbua Province, Vanua Levu. Distribution: Endemic to Fiji and known only from southwestern Vanua Levu. LOCAL NAME: Tirikiloki (Mbua).

Available Collection: VANUA LEVU: ThaKaundrove: Mt. Kasi, Yanawai River region, Smith 1794.

14. Sukunia A. C. Sm. in Bishop Mus. Bull. 141: 136. 1936, in J. Arnold Arb. 36: 288. 1955, in Pacific Sci. 23: 391. 1969; S. Darwin in Allertonia 2: 20.1979.

Trees or slender shrubs, the stipules oblong-lanceolate, imbricate in terminal bud, caducous; leaf blades obovate, relatively large (to $1 \mathrm{~m}$. long); inflorescences axillary, congested, fasciculate to cymose, 8-20-flowered, pedunculate to subsessile, the bracts prominent, deciduous, the flowers pedicellate; calyx obconical, the lobes 5 , erect, ovate-deltoid, distally subulate; corolla hypocrateriform to narrowly infundibular, the lobes 5 , as long as or longer than tube, contorted in bud; stamens 5 , inserted in expanded corolla throat, the anthers dorsifixed near base, included; style as long as corolla tube or shorter, cleft at apex; fruit 2-locular, coriaceous, indehiscent, ovoid to ellipsoid, rugose or costate when dry, narrowing to a short conical apex, the calyx persistent or deciduous, the seeds numerous, dorsiventrally compressed, biseriate in each locule, embedded in pulp.

TYPE SPECIES: Sukunia pentagonioides (Seem.) A. C. Sm. (Gardenia pentagonioides Seem.), the only original species.

Distribution: Presumably endemic to Fiji and there represented by two wellmarked species. Sukunia seems most closely allied with Old World taxa previously assigned to Randia, especially with such large-fruited species as Trukia dryadum (S. Moore) Fosberg (in Phytologia 62: 175. 1987), from Papuasia. However, Sukunia differs from Trukia (Kanehira in Bot. Mag. (Tokyo) 49: 278. 1935), which Fosberg (1987, pp. 171-176) now considers to extend from India and Australia to Tahiti, in its prominently lobed (versus truncate or dentate) calyces, elongate corolla tube, and elongate (versus subglobose) fruit, among other characters. A fruiting collection, Kajewski 1706 (BISH), from Bougainville, is very suggestive of Sukunia, but we are reluctant to assign it to that genus without more complete material; however, it will not be unexpected if Sukunia should be found to extend to the New Hebrides and Solomon Islands. 
KEY TO SPECIES

Stipules $3-5 \mathrm{~cm}$. long, hardly $1 \mathrm{~cm}$. broad; leaves not conspicuously apically congested, with petioles 7-20 $\mathrm{cm}$. long and blades $33-70 \mathrm{~cm}$. long; inflorescences subcymose, the peduncle $15-30 \mathrm{~mm}$. long at anthesis and in fruit; flowers comparatively small, the calyx $8-9 \mathrm{~mm}$. long, with lobes about $2 \times 2-2.5 \mathrm{~mm}$., the corolla tube $15-20 \mathrm{~mm}$. long, the lobes $22-25 \mathrm{~mm}$. long; fruits rugose and irregularly 8-10-costate, narrowly ovoid, about 5-8 $\times 3-4 \mathrm{~cm}$., gradually narrowed at base and apex. ..... 1. S. longipes Stipules comparatively large, up to $7 \times 2 \mathrm{~cm}$; leaves densely aggregated near apices of branchlets, sessile or with petioles less than $2 \mathrm{~cm}$. long and with blades $60-100 \mathrm{~cm}$. long; inflorescences subfasciculate, the peduncle obscure, not more than $8 \mathrm{~mm}$. long at anthesis and in fruit; flowers comparatively large, the calyx about $14 \mathrm{~mm}$. long, with lobes $7-8 \times 4-5 \mathrm{~mm}$., the corolla tube $35-43 \mathrm{~mm}$. long, the lobes $35-50$ $\mathrm{mm}$. long; fruits irregularly rugose and indistinctly costate, ovoid, 5-8 $\times 4-5.5 \mathrm{~cm}$., rounded at base,

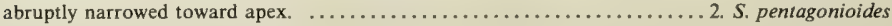

1. Sukunia longipes A. C. Sm. in Pacific Sci. 23: 392. 1969; J. W. Parham, PI. Fiji Isl. ed. 2. 293. 1972.

Figures 71A \& B, 72A.

Slender tree or shrub 3-7 m. high, infrequent in dense or dry forest at elevations of $150-900 \mathrm{~m}$. The fragrant flowers have white corollas, and the fruits become brown in drying. Flowers (known only from the type collection) have been obtained in January, fruits (all the other collections) in June and November.

Typification: The type is DA 11573 (coll. D. Koroiveibau \& S. Pillay) (BISH HOLOTYPE; ISOTYPE at SUVA), collected Jan. 15, 1959, "near the waterfall," Tholo-i-suva, Naitasiri Province, Viti Levu.

Distribution: Endemic to Fiji and known only from southeastern Viti Levu and interior Vanua Levu.

Available Collections: VITI LEVU: NAITASIRI-ReWa boundary: Mt. Kombalevu, Parks 20335, p. p. ReWa: Mt. Korombamba, Parks 20335, p. p. VANUA LEVU: MathuaTA-ThaKaundrove boundary: Crest of Korotini Range, between Navitho Pass and Mt. Ndelaikoro, Smith 560. Thakaundrove: Track to Mt. Nasorolevu, DA 17159 .

2. Sukunia pentagonioides (Seem.) A. C. Sm. in Bishop Mus. Bull. 141: 137. fig. 71 . 1936, in J. Arnold Arb. 36: 288. 1955; J. W. Parham, Pl. Fiji Isl. 210. 1964, ed. 2. 293. fig. 88. 1972; A. C. Sm. in Pacific Sci. 23: 391. 1969, in Amer. J. Bot. 61: 127. 1974; S. Darwin in Allertonia 2: 20. fig. 2, B. 1979.

FiguRES $71 \mathrm{C} \& \mathrm{D}, 72 \mathrm{~B}-\mathrm{E}$.

Gardenia (an gen. nov.?) Seem. in Bonplandia 9: 256. 1861.

Gardenia pentagonioides Seem. Fl. Vit. 122. 1866; Drake, I1l. Fl. Ins. Mar. Pac. 192. 1890.

Garcinia pentagonioides sensu Horne, A Year in Fiji, 262, sphalm. 1881.

Slender tree 2.5-5 m. high, simple and essentially unbranched, with the trunk to 10 $\mathrm{cm}$. in diameter, found at elevations of $600-900 \mathrm{~m}$. in dense forest. The fragrant flowers have the corolla with a greenish tube and pure white lobes; the fruits, borne on the trunk below the leaves, are dull brown. Flowers have been obtained in July and December, fruits in May, July, and August.

TYPIFICATION: The type is Seemann 219 (K HOLOTYPE; ISOTYPE at GH), collected May 30, 1860, "above Somosomo" (doubtless from the vicinity of the crater lake), Taveuni.

Distribution: Endemic to Fiji and, as far as now known, to the island of Taveuni.

Local name: Nai loma ni wase (cf. B. E. V. Parham, Fijian Plant Names, 80. 1942); this name was presumably given for $D A 14384$, cited below.

Figure 71. A \& B, Sukunia longipes; A, distal portion of branchlet, with foliage and inflorescences, $\times$ $1 / 4 ; \mathrm{B}$, distal portion of branchlet, showing petioles, a terminal pair of stipules (s), and inflorescences, $\times 1$. C \& D, Sukunia pentagonioides; $\mathrm{C}$, partial inflorescence and a detached corolla, $\times 1 ; \mathrm{D}$, longitudinal section of corolla throat, showing bases of lobes and 3 stamens, with characteristic indument below them, $\times 4$. A \& B from $D A 11573$, C \& D from Smith 855. 

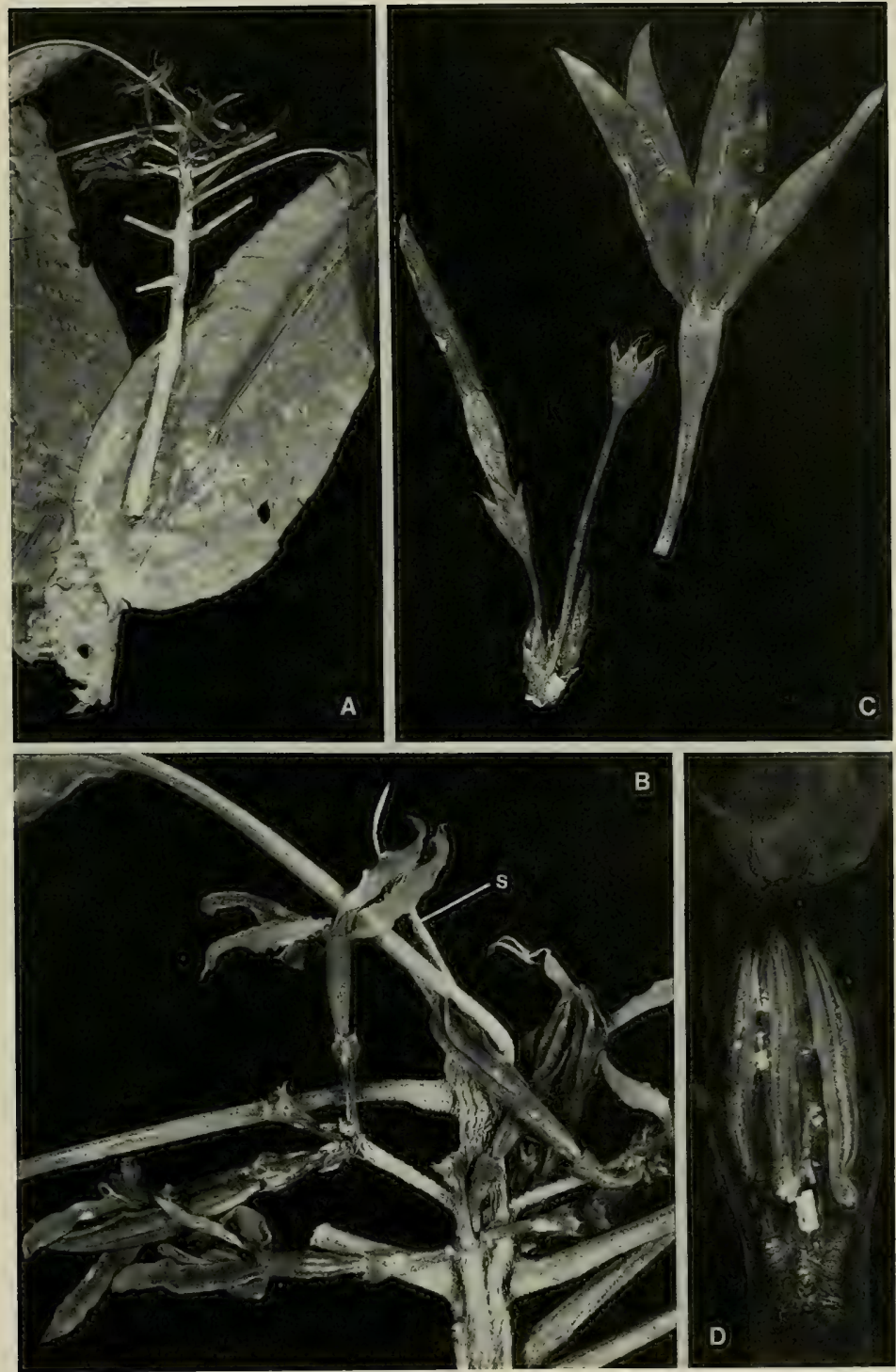

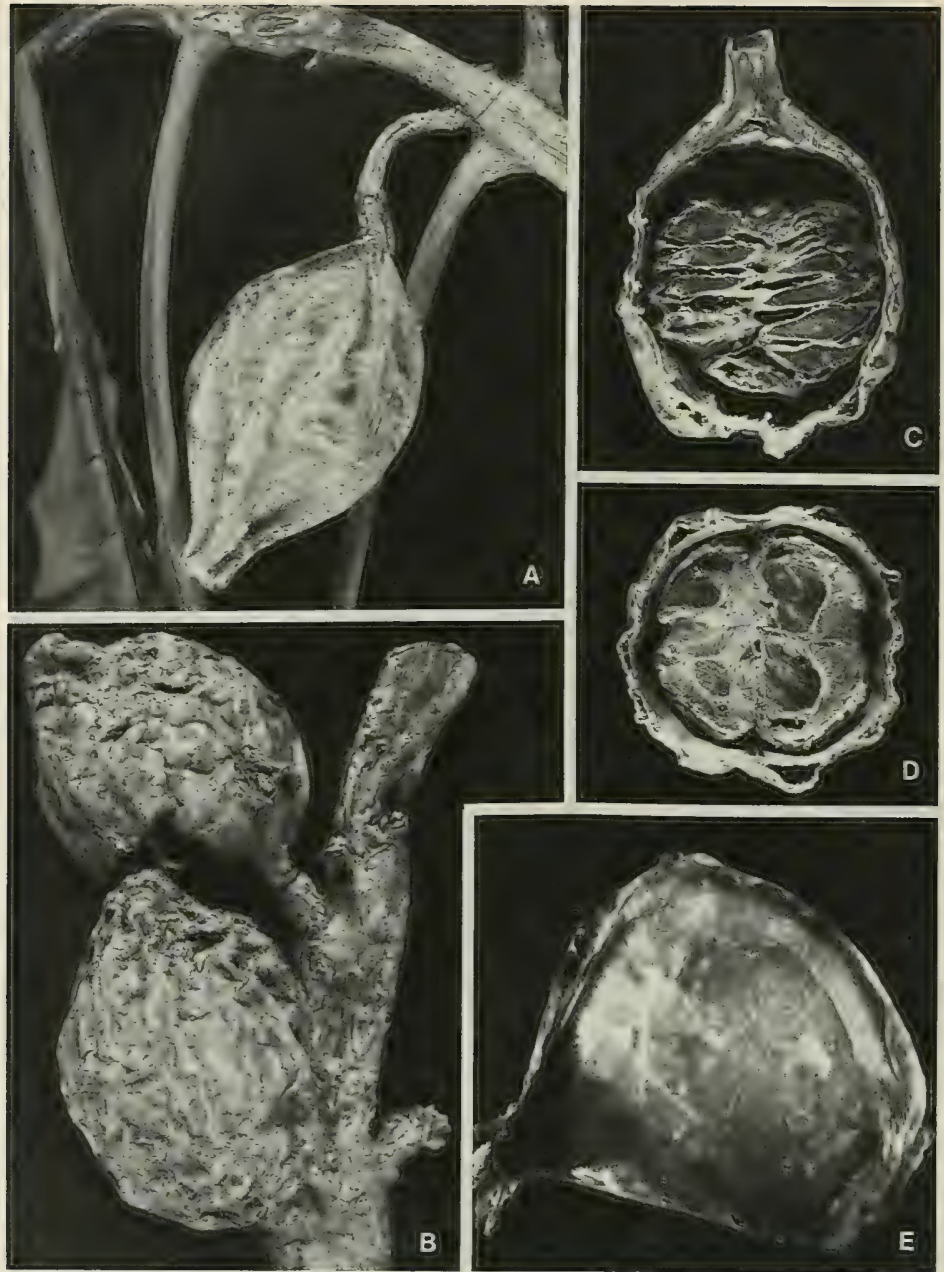

FIGURE 72. A, Sukunia longipes; fruit, $\times 1$. B-E, Sukunia pentagonioides; B, fruits, $\times 1$; C, longitudinal section of fruit, $\times 1$; D, cross section of fruit, showing remnants of the dissepiment (vertical in photo) and biseriate seeds, $\times 1$; E, seed, with adherent pulp, $\times 3$. A from Parks 20335, p. p. (Mt. Kombalevu), B from Smith 8376, C-E from Smith 8301. 
AvaILABLE COLLections: TAVEUNI: Hills east of Somosomo, west of old crater occupied by small swamp and lake, Smith 8376; borders of lake east of Somosomo, Smith 855, DA 14384, 17111; valley between Mt. Manuka and main ridge of island, east of Wairiki, Smith 8301 .

Although most collections of this remarkable species are from the area of "the lake" above Somosomo, a fairly extensive grove of perhaps 100 trees was observed in the valley immediately east of Mt. Manuka (represented by Smith 8301 ); the printed label is in error in mentioning Mt. Koroturanga; see vol. 1 of this Flora, fig. 6 on p. 26, for the locality. Seemann (1866) described the petioles as "7-8 inches long," but his Latin description mentioned "foliis ... in petiolum alatum decurrentibus." His type material (like all other collections of the genus from Taveuni) clearly has very short petioles, his "7-8 inches" presumably referring to the narrowed proximal portions of the leaf blades.

15. Porterandia Ridley in Kew Bull. 1939: 593. 1940; Keay in Bull. Jard. Bot. Brux. 28: 23. 1958; Hallé in Fl. Gabon 17:118. 1970; K. M. Wong in Malayan Nat. J. 38: 44. 1984.

Randia sect. Anisophyllea Hook. f. in Benth. \& Hook. f. Gen. Pl. 2: 89, 1873.

Randia sensu S. Darwin in Allertonia 2: 19, p. p. 1979; non L.

Small to medium-sized trees, the stipules interpetiolar, often sheathing at base; inflorescences 1-several-flowered, terminal at inception and subtended by conspicuously to slightly unequal leaf blades but soon appearing lateral due to sympodial growth of shoot, at length appearing as reduced, defoliate, apparently lateral branchlets borne at alternate nodes; flowers $\Varangle$, protandrous; calyx truncate to 5-dentate, persistent in fruit; corolla hypocrateriform, sometimes expanded at throat, pubescent without, glabrous or pubescent within but not villose in throat, the lobes 5 , contorted in bud; stamens 5, inserted in corolla throat, the anthers subsessile, included, the pollen grains single; style clavate, the lobes remaining coherent, included; ovary 2- or incompletely 4-locular, the ovules many, the placentation axile; fruit a berry, globose to ellipsoid to obovoid, the exocarp woody; seeds numerous, embedded in pulp.

TYPE SPECIES: Porterandia anisophylla (Jack ex Roxb.) Ridley (Gardenia anisophylla Jack ex Roxb.). Although Ridley did not actually indicate a type species, he based his new genus on Randia sect. Anisophyllea, the only species of which (Hooker, 1873) was $R$. anisophylla (Jack ex Roxb.) Hook. f. (Gardenia anisophylla). Keay (1958) also indicated $P$. anisophylla as the type species, and its selection by Wong (1984) as the lectotype species was not necessary.

Distribution: Malay Peninsula eastward to Borneo, and here extended farther eastward to Fiji and Tonga. Ridley originally recognized nine species in the Malay Peninsula and Malesia, and Keay added five African species. Although extension of the generic concept to Africa is indicated above by inclusion of the references to works by Keay (1958) and Hallé (1970), such usage is questioned by E. Robbrecht (in litt., 1987); current investigations will probabiy exclude the several African species from Porterandia.

In proposing Porterandia as a new genus, Ridley (1940) seems to have been the first author to call attention to the heterogeneity of Randia as circumscribed by J. D. Hooker in Genera Plantarum (1873). Fagerlind (in Ark. Bot. 30A (7): 1-57. 1943) noted that a thorough revision of the Old World Gardenieae would necessitate the recognition of additional genera in the Randia alliance, and he went on to reinstate 
Rothmannia Thunb. and to propose Rosenbergiodendron as new (in Svensk Bot. Tidskr. 42: 150. 1948). In reestablishing the genus Aidia Lour., G. Taylor (in Exell, Cat. Vasc. Pl. S. Tomé, 197. 1944) remarked: "It is evident merely from a casual examination of the material included in the genus Randia L. (sensu lat.) that many of the species show such striking disparity that their inclusion in the same genus appears unnatural." The West African species of the Gardenia-Randia assemblage were distributed by Keay (in Bull. Jard. Bot. Brux. 28: 15-72. 1958) among 21 genera, seven of them new. The dismemberment of "Randia" in the Old World was further advanced by other workers. Tirvengadum (in Bull. Mus. Nat. Hist. Nat. (Paris) III. Bot. 35: 3-33. 1978), treating the Gardenieae of Ceylon, has given a concise historical review. The alliance has been discussed for eastern Asia by Yamazaki (in J. Jap. Bot. 45: 337-341. 1970), for tropical Asia by Tirvengadum (in Nordic J. Bot. 3: 455-469. 1983), and for peninsular Malaysia by Wong (in Malayan Nat. J. 38: 1-57. 1984). As presently understood, Randia L. (lectotype species: $R$. mitis L.) is an exclusively American genus, differing from the Old World species in having unisexual flowers, 1-celled ovaries, and pollen grains in permanent tetrads.

A recent survey of the Gardenieae and related tribes by Robbrecht and Puff (in Bot. Jahrb. 108: 63-137. 1986) greatly clarifies the relationships of the more than 100 genera that compose the "Gardenieae-Ixoreae complex." Unfortunately (p. 64) they excluded from their work the genus Porterandia, a genus in need of an in-depth study in order to clarify its delimitation and taxonomic position.

The Papuasian, Australian, and Pacific taxa formerly included in Randia remain to be studied in regard to their generic affinities, although some species have been accommodated in Aidia (cf. Tirvengadum and Sastre in Bull. Mus. Nat. Hist. Nat. (Paris) IV. 8, sect. B, Adansonia 3: 257-296. 1986). The Fijian taxa formerly treated as components of Randia (other than Canthiopsis odorata Seem., which we place in Tarenna, q. v.) are here referred to two genera: Pelagodendron Seem. (with a single endemic Fijian species) and Porterandia Ridley, previously not considered to extend eastward of Borneo. Porterandia is to be anticipated in areas between Borneo and Fiji, but a study of the complexities of "Randia sensu lat." in that area remains to be undertaken.

Ridley apparently distinguished Porterandia on the basis of the usually unequal leaves at each inflorescence-bearing node, a feature also mentioned by Wong (1984), who further noted that the inflorescences are terminal, sometimes on very reduced lateral branchlets. The inflorescence arrangement was also emphasized by Keay (1958, pp. 19-20), who distinguished the African species of Aidia and Porterandia by their 1-many-flowered inflorescences appearing lateral at alternate nodes (terminal at inception but appearing lateral by sympodial growth), solitary pollen grains, corollas pubescent within, stigmas without spreading arms, and subglobose to ellipsoid fruits.

The single Fijian species of Porterandia is closely allied to Porterandia crosbyi (Burkill) A. C. Sm. \& S. Darwin, comb. nov. (Randia crosbyi Burkill in J. Linn. Soc. Bot. 35: 41. 1901; Yuncker in Bishop Mus. Bull. 220: 248. 1959), from Tonga. Other

Figure 73. Porterandia tenuiflora; A, distal portion of branchlet, with petioles and leaf bases, the ultimate node with appressed stipules, the penultimate node with separated stipules and a laterally displaced inflorescence (terminal at inception) with a pedicel, the antepenultimate node lacking stipules, without an inflorescence, and with one leaf fallen, $\times 3$; B, flower, $\times 2$; C, older portion of branchlet with laterally displaced inflorescences, two of them bearing flowers, $\times 1 ; \mathrm{D}$, older portion of branchlet with lateral spur shoots, one of them bearing a fruit, $\times 2$. A-C from Smith 1215, D from Smith 1243. 

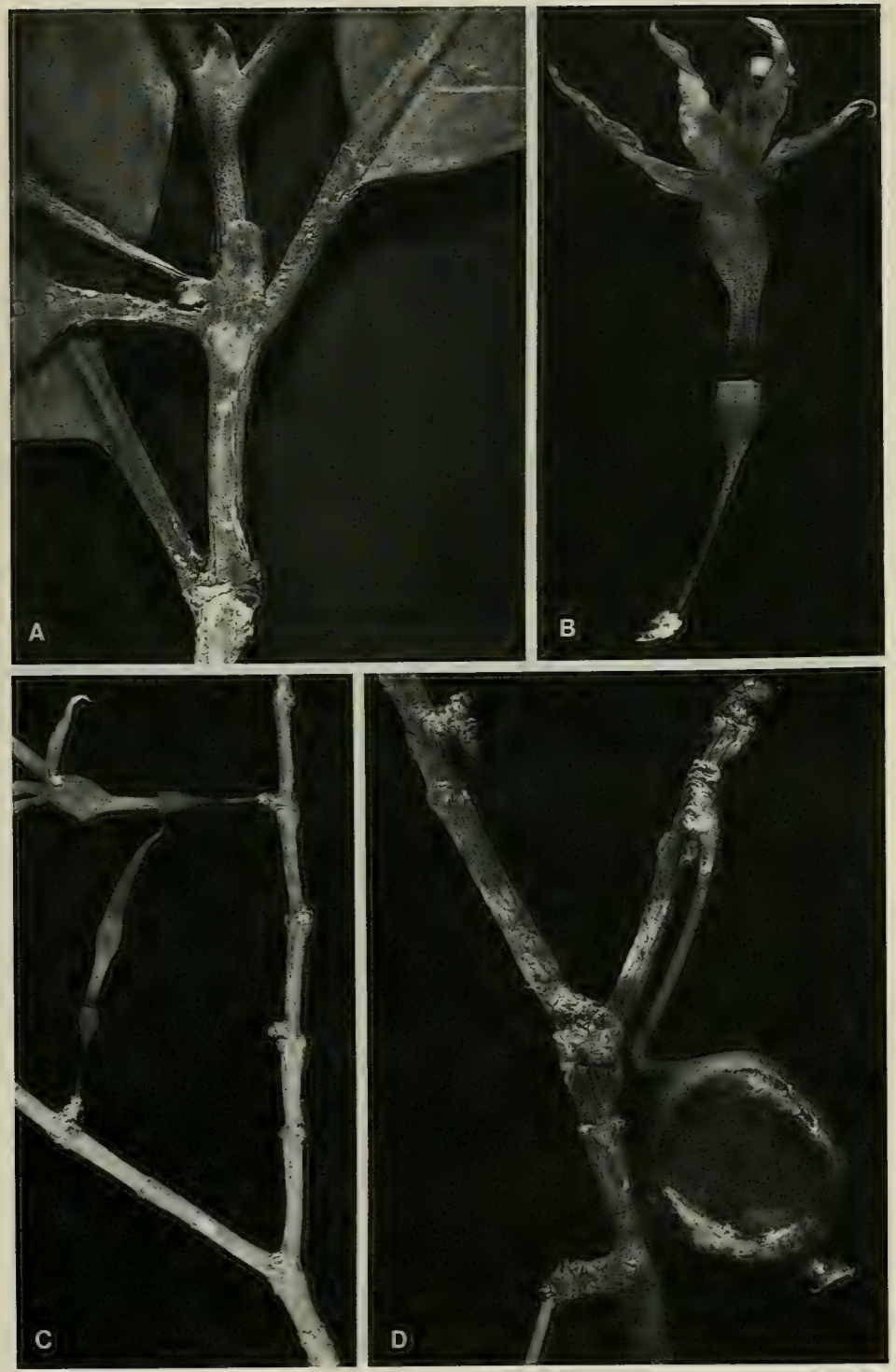

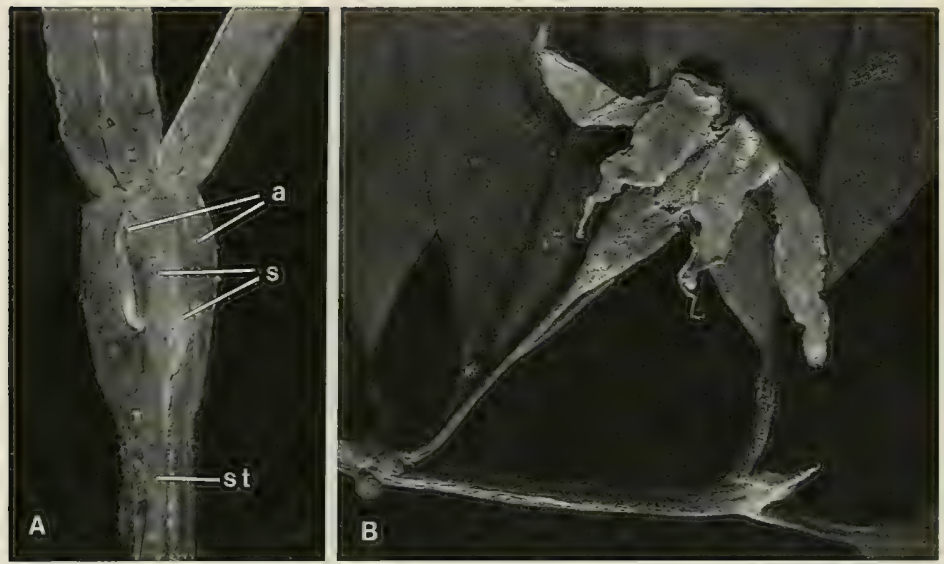

Figure 74. A, Porterandia tenuiflora; longitudinal section of corolla showing three lobes, style (st), and the swollen distal portion of tube including stigmatic lobes (s) and anthers (a), $\times 4$. B, Porterandia crosbyi; distal portion of branchlet, with stipules, leaf bases, and inflorescence bearing a flower, $\times 2$. A from Smith 1215, B from Barclay (Vava'u, Tonga).

Pacific species outside the Fijian Region may also be referable to Porterandia, but a revision of that genus and the appropriate nomenclatural combinations must be left to a specialist.

\section{Porterandia tenuiflora (A. C. Sm.) A. C. Sm. \& S. Darwin, comb. nov.}

Figures 73, 74A.

Randia tenuiflora A. C. Sm. in Bishop Mus. Bull. 141: 135. fig. 70. 1936; J. W. Parham, Pl. Fiji Isl. 209. 1964, ed. 2. 291. 1972.

Usually slender tree 5-10 m. high, apparently infrequent in forest on limestone formation near sea level or to an elevation not exceeding $100 \mathrm{~m}$. The corolla is white; flowers have been obtained in February and March and fruits in March. The Graeffe collection cited below, in fruit, is not dated.

TYPIFICATION: The type is Smith 1215 (BISH HOLOTYPE; many ISOTYPES), collected Feb. 26, 1934, on Fulanga.

Distribution: Endemic to Fiji and thus far known from only three islands of the Lau Group.

\section{LoCAL NAME: Sulu (Kambara).}

Available COLlections: SUSUI (Exploring Islands, south of Vanua Mbalavu): Graeffe 1400 (к). KAMBARA: Smith 1243.

In addition to generic characters, Porterandia tenuiflora and P. crosbyi (FIGURE 74B), apparently its closest relative, have in common a closely strigillose indument on young branchlets, stipules, petioles, and costas and secondaries of the lower surfaces of young leaf blades; both have narrowly elliptic or oblong-elliptic leaf blades slightly inaequilateral at base, obtuse to acute or mucronulate at apex, and with 6-9 pairs of secondary nerves; both have ovate-deltoid stipules 3-5 $\mathrm{mm}$. long that are appressed at the ultimate node, distinct at the penultimate node, and caducous from lower nodes; 
and both have inflorescences strictly terminal at inception and with 1-3 flowers, the minute peduncle being promptly displaced by a vegetative shoot and becoming a lateral, woody, tuberculate or cylindric axis of long duration, eventually as much as 1.5 $\mathrm{cm}$. long and about $2 \mathrm{~mm}$. in diameter with many congested pedicel scars and bearing a succession of terminal flowers and fruits. The two species may be readily separated as follows:

Corolla tube 15-20 mm. long at full anthesis, narrowly cylindric in proximal half (with 6-7 mm. of the cylindric portion obviously projecting beyond apex of calyx limb), swollen and campanulate in distal half, the lobes $15-20 \mathrm{~mm}$. long and 2-3 mm. broad at base; calyx 5-7 mm. long at anthesis (including hypanthium about $2 \mathrm{~mm}$. long), the calyx tube $3-3.5 \mathrm{~mm}$. in diameter at apex, truncate or obscurely denticulate; pedicels at anthesis 7-10 mm. long; petioles 5-12 mm. long; leaf blades (6-) 8-14 $\times(2-)$

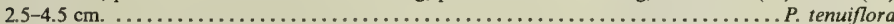

Corolla tube $8-11 \mathrm{~mm}$. long at full anthesis, swollen and campanulate essentially from base (slender basal portion remaining concealed by calyx limb), the lobes $9-14 \mathrm{~mm}$. long and about $3.5 \mathrm{~mm}$. broad at base; calyx 6-10 mm. long at anthesis (including hypanthium about $2 \mathrm{~mm}$. long), the calyx tube 4-5 mm. in diameter at apex, short-dentate, the lobes broadly deltoid, 0.5-1 mm. long and 2-3 mm. broad, subacute or sharply apiculate; pedicels at anthesis $10-15 \mathrm{~mm}$. long; petioles $7-15 \mathrm{~mm}$. long; leaf blades

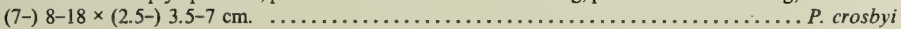

16. Pelagodendron Seem. Fl. Vit. 124. 1866; K. Schum. in Engl. \& Prantl, Nat. Pflanzenfam. IV. 4: 78. 1891.

Randia sensu Fosberg in Sargentia 1: 120, p. p. 1942; S. Darwin in Allertonia 2: 19, p. p. 1979; non L.

Small trees, the stipules interpetiolar, caducous (rarely persisting at the penultimate node); inflorescences terminal at inception and subtended by leaves with subequal blades, soon appearing lateral due to sympodial growth of shoot, and ultimately lateral at alternate (eventually defoliate) nodes and fasciculate to cymose with perhaps as many as 30 flowers, the peduncles short or inflorescences branching from base, the bracts and bracteoles small but apparent; flowers $\zeta$, protandrous, 5-merous; calyx glabrous, completely enclosing corolla in bud, eventually rupturing into 2 or 3 broad, obtuse to rounded lobes, the limb at length deciduous; corolla hypocrateriform, the tube short, puberulent without and within and villose within at throat, the lobes broadly rounded to obtuse, contorted in bud, becoming reflexed; stamens attached in corolla throat, the anthers essentially sessile, exserted; style glabrous, clavate, exserted, the lobes remaining coherent; fruit subglobose to obovoid, indehiscent, 2-locular, the seeds several or many in each locule, horizontal, embedded in pulp.

TYPE SPECIES: Pelagodendron vitiense Seem.

Distribution: On the basis of presently available material, Pelagodendron appears endemic to Fiji, where it is represented by a single species.

Pelagodendron seems most closely related to Aidia Lour., which has more expanded inflorescences associated with strongly anisophyllous (sometimes monophyllous) nodes and a usually 5-dentate calyx which does not enclose the expanding corolla. The closed calyx, well described by Seemann, is striking and provides a major reason for retaining Pelagodendron as a very distinct genus; this character, appreciated by Schumann, has been overlooked by subsequent authors and the genus has sometimes been considered inseparable from Canthiopsis (Fosberg, 1942), which is now seen to be referable to Tarenna (q. v.) in the tribe Pavetteae. On the basis of fruit characters, as described by Seemann, Pelagodendron is appropriately referred to the tribe Gardenieae.

Although Aidia extends eastward to the Horne and Wallis Islands, Samoa, and Tonga, it seems curiously absent from Fiji. Fosberg (in Bull. Torrey Bot. Club 65:614. 1938) has recorded the Pacific species as Randia cochinchinensis (Lour.) Merr. and has indicated its occurrence in both Fiji and the Society Islands, but no unequivocally 
Fijian material has come to our attention. In Samoa (and probably in adjacent parts of western Polynesia) the species concerned is presumably Aidia graeffei (Reinecke) Tirvengadum (in Bull. Mus. Nat. Hist. Nat. (Paris) IV. 8, Sect. B, Adansonia 3: 270. 1986; Randia graeffei Reinecke in Bot. Jahrb. 25: 683. 1898; Christophersen in Bishop Mus. Bull. 128: 200. 1935).

1. Pelagodendron vitiense Seem. Fl. Vit. 124. 1866; Drake, Ill. Fl. Ins. Mar. Pac. 192. 1890; K. Schum. in Engl. \& Prantl, Nat. Pflanzenfam. IV. 4: 78. 1891.

FiguRE 75.

Randia? Seem. in Bonplandia 9: 256. 1861; Seem. ex A. Gray in Proc. Amer. Acad. Arts 5: 319. 1862, in Bonplandia 10: 36. 1862.

Griffithiae? sp. v. gen. nov. Seem. Viti, 438. 1862.

Gardenia? (an gen. nov.?) Seem. Viti, 438. 1862.

Randia vitiensis Fosberg in Sargentia 1: 120, solum quoad basionymum. 1942; J. W. Parham, Pl. Fiji Isl. 209, p. p. 1964 , ed. 2. 292, p. p. 1972.

An apparently infrequent tree $3-5 \mathrm{~m}$. high, occurring from near sea level to an elevation of perhaps a few hundred meters in forest or in forest patches in open, rolling areas. The very fragrant flowers have white or cream-colored corollas. As far as dated, flowers are recorded in October (but perhaps also in June; see comments below on typification); fruits are known only from the type collection.

TyPification: The type is Seemann 240, but some doubt must remain as to the precise locality, which was published by Seemann as "Island of Ovalau." There are two sheets in the type cover at $\mathrm{K}$, and one of these, with flowers and fruits, bears a field label indicating "Ovalau, at Port Kinnaird." The second sheet has a printed label on which (apparently in Seemann's hand) has been written "Korovono" (i. e. Koroivonu, on the east coast of the Natewa Peninsula, Thakaundrove Province, Vanua Levu, a locality visited by Seemann only on June 4, 1860, cf. Viti, 1862, pp. 39-41). The first of these sheets bears sketches showing a longitudinal section of a flower bud with an unruptured calyx, stamens, and a longitudinal section of a fruit. In reference to the last, J. D. Hooker has noted on the sheet that the seeds are shown as too few and too vertical, a correct observation. The second sheet bears a better sketch of a longitudinal section of a fruit, showing the seeds to be numerous, horizontal, and tightly compacted; however, there are no fruits on this specimen and one must assume that a fruit from the "Ovalau" specimen had been utilized.

A reason for hesitation in accepting the localities as noted on the two sheets is the fact that otherwise Pelagodendron vitiense is known only from Vanua Levu. The two Seemann specimens are so similar that they could indeed have been taken from the same tree. Furthermore, Koroivonu is the type locality of Canthiopsis odorata (in the present work referred to Tarenna seemanniana, q. v.). It would indeed have been a coincidence if Seemann had obtained two such remarkable taxa during the few hours of his hurried visit to Koroivonu, although that is indeed a possibility. If that were the case, one would question the Ovalau locality. An alternative explanation is the possibility that "Korovono" was erroneously added to the second sheet of Pelagodendron at a later date.

Figure 75. Pelagodendron vitiense; A, distal portion of branchlet, proximal parts of leaves, and inflorescences at alternate nodes, $\times 1 ; \mathbf{B}$, inflorescence, showing an unruptured calyx and 3 open flowers, 2 lacking corollas and 1 with a corolla and a single persisting stamen, $\times 4$; , flower, showing exserted style and stamens, one stamen fallen and represented by a scar $(\mathrm{s}), \times 4 ; \mathrm{D}$, portion of inflorescence, showing flower bud and rupturing calyx limb, × 4. A \& B from $D A 12934, \mathrm{C}$ from $D A 14111, \mathrm{D}$ from $D A 12883$. 


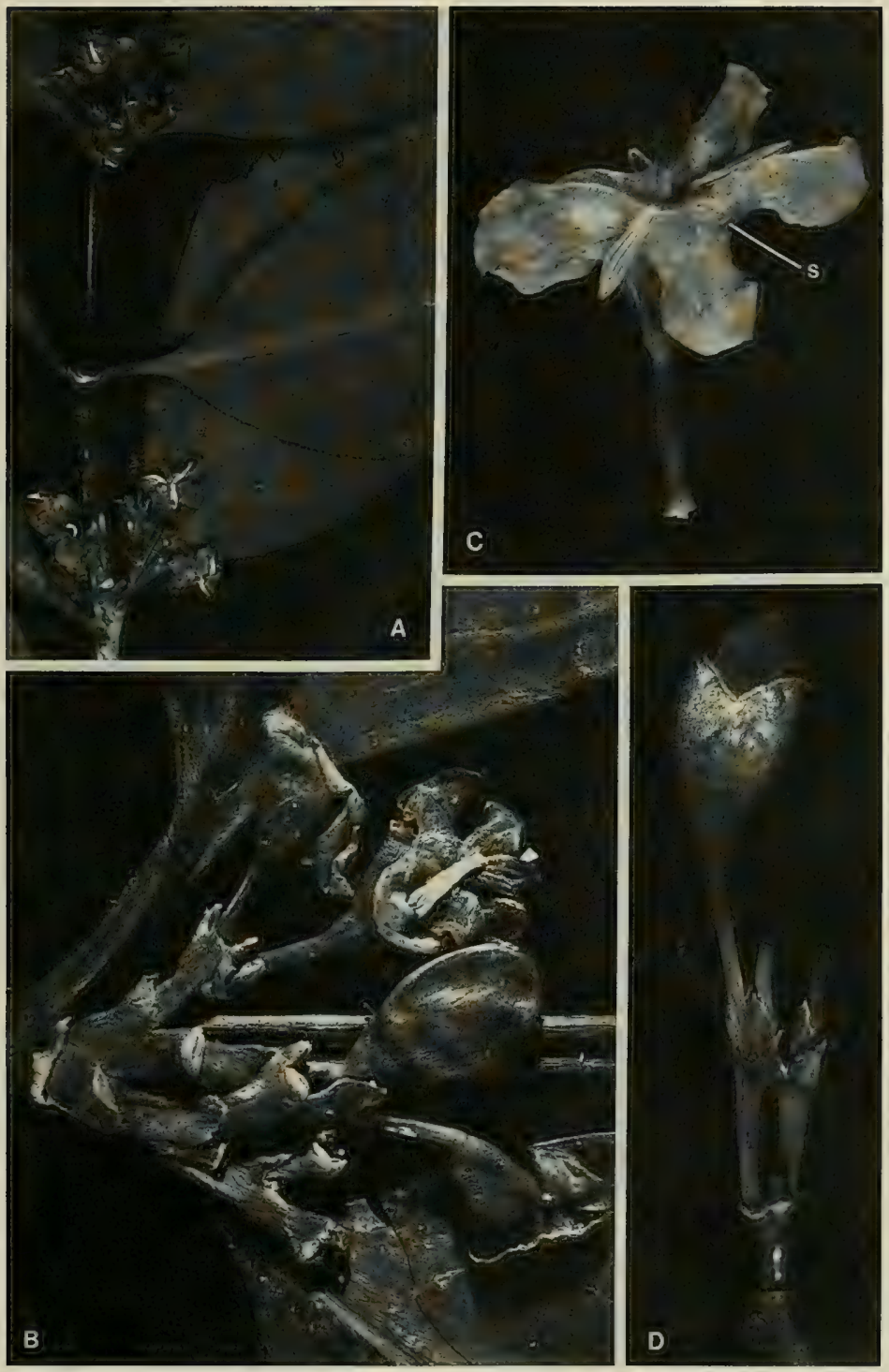


In view of these uncertainties, we believe it best to indicate the type as Seemann 240, p. p. ( $\mathrm{K}$ HOLOTYPE; putative ISOTYPES at BM, NY, P), presumably collected at Port Kinnaird, Ovalau, between June and November, 1860; a second sheet of Seemann 240 (K) purported to be from Koroivonu, Vanua Levu, is not an isotype unless one or the other sheet is mislabelled.

DistRIBUTION: Endemic to Fiji and thus far known with certainty only from Vanua Levu and Ovalau (but see above comments in regard to the type locality). A few other Vanua Levu collections not restudied in connection with the present revision, at one time referred to "Randia vitiensis," may represent either this species or Tarenna seemanniana (the more common of the two species); they cannot be placed without further examination.

Available Collections: VANUA LEVU: MbUa: Mt. Ndrandramea (in drainage of Nambuna River, Wainunu River headwaters, DA 12934. Mathuata: Vicinity of Seanggangga District Farm, DA 12883, 14111. Thakaundrove: Navonu Creek, Natewa Peninsula, DA 14332.

17. Tarenna Gaertn. Fruct. Sem. Pl. 1: 139. 1788; DC. Prodr. 4: 395. 1830; F. Br. in Bishop Mus. Bull. 130: 289. 1935; Hallé in Fl. Gabon 17: 91. 1970; Stone in Micronesica 6: 559. 1970; Bridson in Kew Bull. 34: 377. 1979; S. Darwin in Allertonia 2: 17. 1979.

Chomelia L. Opera Varia, 210. 1758; K. Schum. in Engl. \& Prantl, Nat. Pflanzenfam. IV. 4: 74. 1891. Nom. rejic. vs. Chomelia Jacq. (1760).

Canthiopsis Seem. Fl. Vit, 166. 1866; Bridson \& Robbrecht in Bull. Jard. Bot. Nat. Belg. 55: 87.1985.

Randia sensu Fosberg in Sargentia 1: 120, p. p. 1942; S. Darwin in Allertonia 2: 19, p. p. 1979; non L.

Trees or shrubs, the stipules interpetiolar, usually persistent; inflorescences terminal (sometimes on short, defoliate, lateral branchlets), corymbose; flowers (4 or) $5(-7)$ merous, $\Varangle$, protandrous; calyx variously toothed or lobed; corolla infundibular, glabrous or pubescent without, sparsely to densely pubescent within, the lobes contorted in bud; stamens attached in corolla throat, the anthers usually exserted; style usually conspicuously elongating in age, the stigmas coherent; ovary 2-locular, the ovules 1-many per locule; fruit indehiscent, hard, the seeds angular, with entire or ruminate endosperm.

TYPE SPECIES: Tarenna zeylanica Gaertn. $=T$. asiatica $($ L.) Kuntze ex K. Schum. (Rondeletia asiatica L.). Chomelia L. (nom. rejic.) is also based on Rondeletia asiatica L. Canthiopsis is typified by $C$. odorata Seem., its sole species (in the present treatment referred to Tarenna seemanniana, q. v.).

Distribution: Widespread from tropical Africa, Indian Ocean islands, and southeastern Asia eastward to the Tuamotus, probably with more than 200 species. Three species are indigenous in Fiji, two of them endemic.

USEFUl TREATMENT OF Genus: Bridson, D. M. Studies of Tarenna sensu lato (Rubiaceae subfam. Cinchonoideae) for part 2 of 'Flora of Tropical East Africa: Rubiaceae' Kew Bull 34: 377-402. 1979.

Canthiopsis odorata was correctly placed in the Rubiaceae by J. D. Hooker (in Benth. \& Hook. f. Gen. Pl. 2: 88. 1873) but was assigned to Randia. This generic position was also adopted by Fosberg (1942), who erroneously united the species with Pelagodendron vitiense (as Randia vitiensis, utilizing the older epithet), an opinion followed by later authors (e. g. Darwin, 1979). A careful reevaluation of the two genera was offered by Bridson and Robbrecht (1985): "Pelagodendron has pseudoaxillary inflorescences; the genus is probably a genuine member of the Gardenieae s. s. and closely allied to or perhaps congeneric with Aidia, the generic limits of which have not been fully defined. Canthiopsis has terminal inflorescences and must be considered 
with Tarenna s. 1." The same authors (1985, p. 88) also drew attention to Ixora joskei Horne ex Baker as a distinguishable species probably congeneric with Canthiopsis.

In considering the East African species of Tarenna, Bridson (1979) adopted a provisionally broad interpretation of the genus, arranging the species in six informal groups primarily defined by seed and placental characters. Robbrecht (in Pl. Syst. Evol. 145: 116. 1984) considered Tarenna in this broad sense as occupying a central position in the tribe Pavetteae, comparable to that of Psychotria in the tribe Psychotrieae ("Psathureae"). Robbrecht defined the Pavetteae as comprising members of the large Gardenieae-Coffeeae alliance having terminal inflorescences, 3- or 4-colpate, semitectate pollen, relatively small, 2-locular fruits with a crustose endocarp, solitary to numerous ovules in each ovary locule (the pulpy matrix found in Gardenieae sensu str. being absent), and seed testas having a number of distinctive anatomical features. The assignment of Tarenna and its close relative Ixora to different subfamilies by Hallé (in Fl. Gabon 12: 21. 1966) seems unwarranted, in view of the discussion to the contrary presented by Robbrecht.

The Fijian species here assigned to Tarenna appear to represent two different groups. Tarenna sambucina agrees with $T$. asiatica (L.) Kuntze ex K. Schum., the type species of the genus, in having several ovules per locule and seeds with conspicuously ruminate endosperm (cf. Bridson, 1979, p. 377, fig. 3, X, Y). Tarenna seemanniana and $T$. joskei differ as noted in the following key; while we are confident that these two species can be accommodated in Tarenna sensu lat., we cannot relate them to any of the several groups of African species outlined by Bridson (1979).

KEY TO SPECIES

Domatia present on lower surfaces of leaf blades, represented by pubescent depressions in axils of secondary nerves; inflorescences $9-15 \mathrm{~cm}$. broad at anthesis and with more than 15 (often more than 100) flowers; calyx (including hypanthium) puberulent; corolla puberulent within but not densely villose in throat, the lobes $1 / 3-1 / 2$ as long as tube; fruits about $5 \mathrm{~mm}$. in diameter; endosperm ruminate; a widespread Pacific species. . ............................. sambucina

Domatia absent; inflorescences $3-8 \mathrm{~cm}$. broad at anthesis, 6-15(-18)-flowered; calyx glabrous except ciliate along margins of lobes; corolla glabrous within except densely villose in throat, the lobes longer than tube; endemic species.

Calyx limb 3.5-4.5 mm. broad, the lobes rounded to obtuse or acute, to $1 \mathrm{~mm}$. long; style glabrous; fruits 10-13 mm. in diameter; endosperm entire. ................ 2. Teemanniana

Calyx limb to $3 \mathrm{~mm}$. broad, the lobes deltoid, less than $0.5 \mathrm{~mm}$. long; style pubescent near base; fruits and

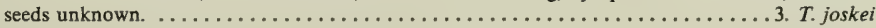

1. Tarenna sambucina (Forst. f.) Durand ex Drake, Ill. Fl. Ins. Mar. Pac. 190. 1890; Christophersen in Bishop Mus. Bull. 128: 199. 1935; Yuncker in op. cit. 178: 111. 1943, in op. cit. 184: 64. 1945, in op. cit. 220: 247. 1959; J. W. Parham, Pl. Fiji Isl. 210. 1964, ed. 2. 293. 1972; Sykes in New Zealand Dept. Sci. Indust. Res. Bull. 200: 181. 1970; St. John \& A. C. Sm. in Pacific Sci. 25: 340. 1971; B. E. V. Parham in New Zealand Dept. Sci. Indust. Res. Inform. Ser. 85: 68. 1972; S. Darwin in Allertonia 2: 18. fig. 1, K. 1979; Morat \& Veillon in Bull. Mus. Nat. Hist. Nat. (Paris) IV. 7, Sect. B. Adansonia 3: 317. 1985. Figures 76A \& B, 77E.

Coffea sambucina Forst. f. Fl. Ins. Austr. Prodr. 16. 1786.

Pavetta sambucina DC. Prodr. 4: 492. 1830; Guillaumin in J. Arnold Arb. 13: 8. 1932.

Stylocoryne pepericarpa Benth, in London J. Bot. 2: 223. 1843; Seem. in Bonplandia 9: 256, as $S$. pipericarpa. 1861.

Stylocoryne sambucina A. Gray in Proc. Amer. Acad. Arts 4: 309. 1859; Seem. Viti, 438. 1862, Fl. Vit. 124. 1866.

Chomelia sambucina Kuntze, Rev. Gen. Pl. 1:278. 1891; Reinecke in Bot. Jahrb. 25:682. 1898; Rechinger in Denkschr. Akad. Wiss. Wien 85: 368. 1910. 
An often abundant shrub or tree $1.5-13 \mathrm{~m}$. high, with a compact crown or freely branched and spreading, found from near sea level to about $450 \mathrm{~m}$. in dense, dry, or littoral forest, coastal thickets or thickets in grassland, in open country, and occasionally on the edges of mangrove swamps. The fragrant flowers have the corolla white to cream-white and turning yellow, the anthers white, and the style greenish to white; the fruit turns from green to black at maturity. Flowers are most often collected between October and April, but fruits persist throughout the year.

TYPIFICATION AND NOMENCLATURE: Coffea sambucina is based on $J . R$. \& $G$. Forster, from Tonga. No Forster material was found at $\mathrm{BM}$, but at $\mathrm{K}$ there is a Forster collection (from LIV) with a garbled label indicating it to be from Tahiti. A suitable lectotype should be sought elsewhere. For Stylocoryne pepericarpa, an obviously identical taxon, Bentham cited: "Feejee Islands, Mr. Hinds (with ripe fruit only.) Friendly Islands, Mr. Barclay, (in young fruit with the remains of a single flower)." The better of the two is: Hinds (K LECTOTYPE here designated), from Fiji without further locality, but doubtless from Nukulau Island, Rewa Province, Viti Levu, and probably from the same plant as Barclay 3432 (вм) from that locality.

Distribution: Mariana Islands, Solomon Islands, and New Caledonia eastward to the Society, Austral, and Tuamotu Islands. In Fiji this widespread species is now represented by about 70 collections from eleven islands.

LOCAL NAMES AND USES: Readily recognized, the species is known as vakatharendavui (vakarumba ni ndavui, ai tharandavui, warumni ndavui) or walangio (welangio, walinanggio, waliangio), or less widely (in Thakaundrove) as ndorondoro kiloto or talatalambia. An extract from the bark is reputed to have medicinal value (for stomach trouble, rheumatism, appendicitis, or to improve the fertility of barren women).

REPRESENTATIVE COLLECTIONS: VITI LEVU: MBA: North of Natalau, south of Lautoka, Degener 14996. NANDRONGa \& Navosa: Southern slopes of Nausori Highlands, in drainage of Namosi Creek above Tumbenasolo, Smith 4726. SERUA: Coastal hills in vicinity of Taunovo River, east of Wainiyambia, Smith 9578. Namosi: Nambukavesi Creek, DA, July 5, 1962 (Damanu 79). RA: Vicinity of Rewasa, near Vaileka, Degener 15350. NaITASIRI: Nanduruloulou, DA 9812. TaIlevu: Navuloa, DA 2720. REWA: Vicinity of Suva, Yeoward 70. MBENGGA: Near Raviravi, Weiner 187. KANDAVU: Namalata isthmus region, Smith 185. OVALAU: Lovoni Valley, DA 17047. WAKAYA: Tothill 292. NGAU: Hills east of Herald Bay, inland from Sawaieke, Smith 7804. VANUA LEVU: Seemann 242, p. p. MbuA: Rukuruku Bay, H. B. R. Parham 4. Mathuata: Lambasa, Greenwood 482. Thakaundrove: Hills south of Nakula Valley, Smith 339. TAVEUNI: Mountain slopes above Somosomo, Gillespie 4814. VANUA MBALAVU: Nambavatu, Tothill 293. LAKEMBA: Seemann 242, p. p. FULANGA: On limestone, Smith 1148. Fivi without further locality, U. S. Expl. Exped.

2. Tarenna seemanniana A. C. Sm. \& S. Darwin, nom. nov. Figures 77A-D, 128.

Rubiacea floribus odoratis Seem. in Bonplandia 9: 257. 1861.

Griffithia A. Gray in Proc. Amer. Acad. Arts 5: 319. 1862, in Bonplandia 10: 36.1862.

Griffithiae sp.? Seem. Viti, 438. 1862.

Canthiopsis odorata Seem. Fl. Vit. 166. pl. 46. 1866; non Tarenna odorata (Roxb.) Robinson (Webera odorata Roxb.).

Randia odorata Hook. f. in Benth. \& Hook. f. Gen. Pl. 2: 88. 1873; Drake, Ill. Fl. Ins. Mar. Pac. 191. 1890; Gillespie in Bishop Mus. Bull. 83: 30. fig. 38. 1931.

Randia vitiensis Fosberg in Sargentia 1: 120, quoad spec. cit., excl. basionymo. 1942; J. W. Parham, Pl. Fiji Isl. 209, p. p. 1964, ed. 2. 292, p. p. 1972.

Tree (or shrub) 2-15 m. high, sometimes freely branched or slender, sometimes locally frequent in dense, dry, or secondary forest, in crest thickets, and sometimes on limestone, at elevations from near sea level to $1,100 \mathrm{~m}$. The fragrant flowers have the

FIgure 76. A \& B, Tarenna sambucina; A, distal portion of branchlet, with foliage and an inflorescence, $\times 1 / 3 ; \mathrm{B}$, cluster of flowers, $\times 3 . \mathrm{C} \& \mathrm{D}$, Tarenna joskei; C, distal portion of branchlet, with foliage and inflorescences, $\times 1 / 3$; D, inflorescence, $\times 3$. A \& B from Smith 339, C \& D from DA 16545. 

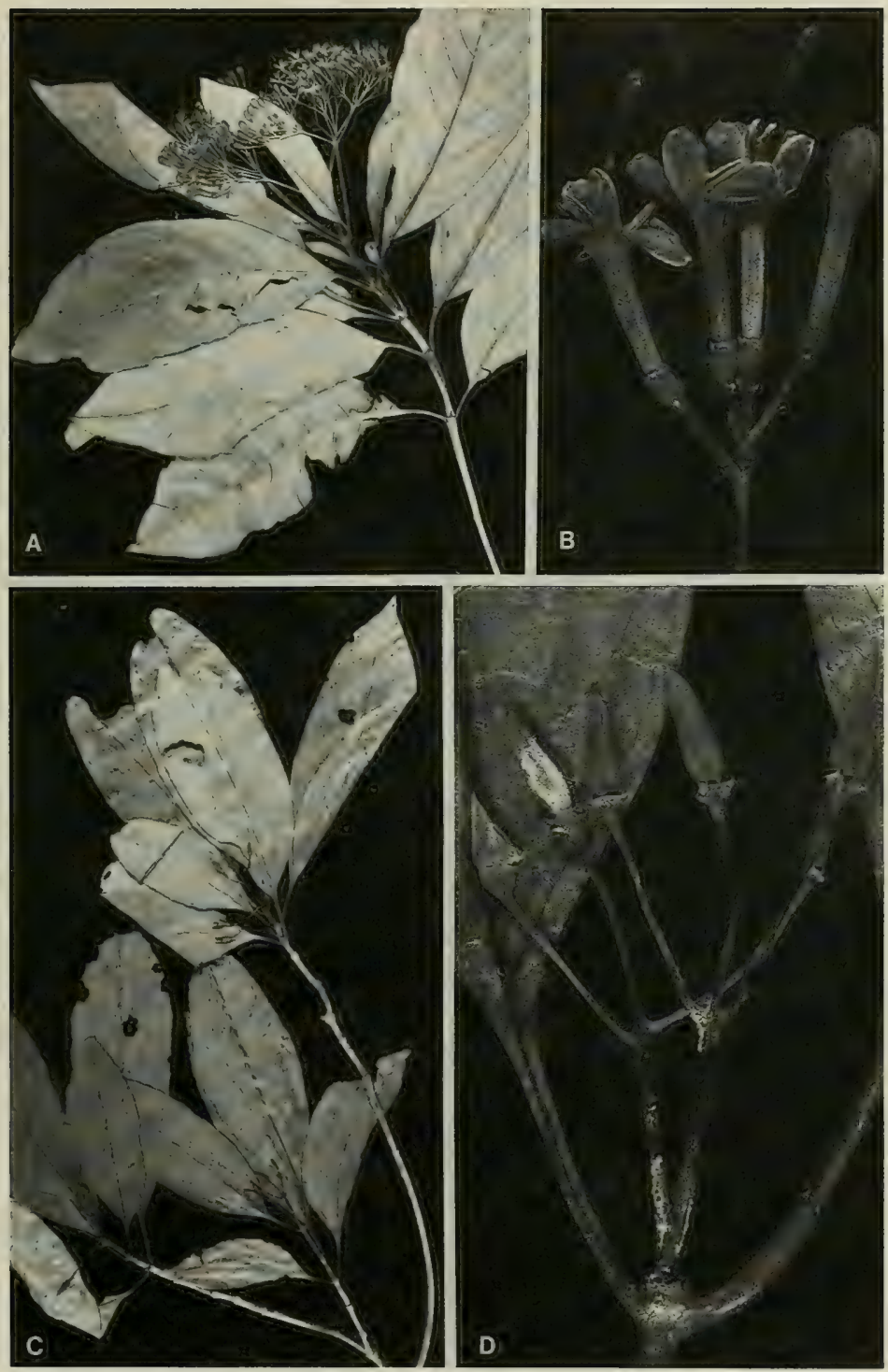
corolla white to cream-colored or yellow and the filaments purplish; the fruit is yellow to dull orange, becoming purple to black at maturity. Flowers have been noted between October and June, fruits throughout the year.

TyPIFICATION: Tarenna seemanniana is a new name for Canthiopsis odorata Seem., of which the type is Seemann 260 (K HOLOTYPE; ISOTYPES at BM, P), collected
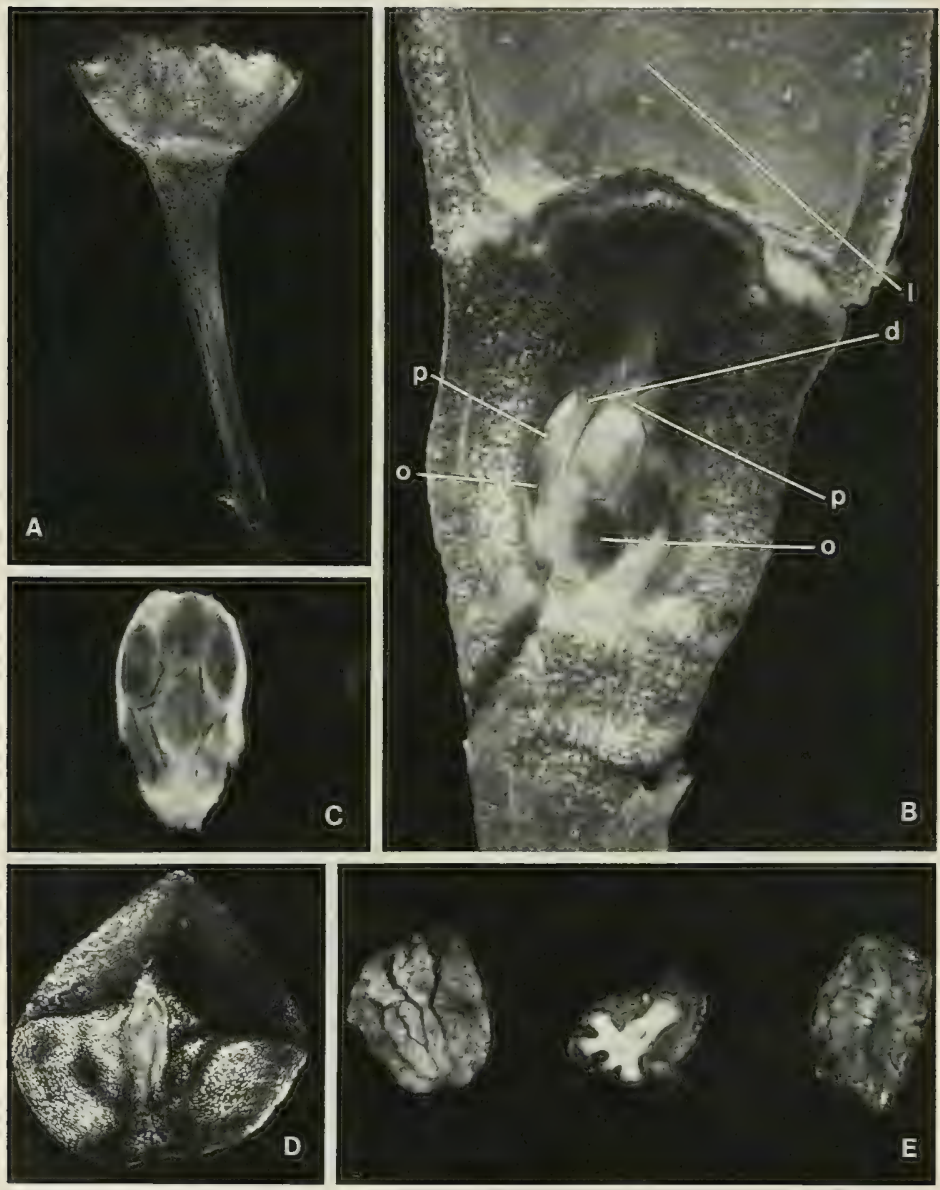

FigurE 77. A-D, Tarenna seemanniana: A, calyx, $\times 6$; B, longitudinal section of ovary, showing inner surface of calyx limb (1), dissepiment (d), placentas (p), and ovules (o), $\times 20$; C, detached placenta, showing abaxial surface and 6 ovules, $\times 20$; D, seed, showing hilar scar, $\times 6$. E, Tarenna sambucina; seeds, showing abaxial surface (left), cross section with cotyledons embedded in ruminate endosperm (center), and adaxial surface with hilar scar, $\times 10$. A-C from DA 16525, D from Degener 15186, E from Smith 7804. 
June 4, 1860, at Koroivonu, east coast of Natewa Peninsula, Thakaundrove Province, Vanua Levu.

DisTribution: Endemic to Fiji and now known from about 45 collections from five islands (the two large islands and three of the Lau Group).

RePresentative Collections: VITI LEVU: Mba: Mt. Evans Range, Greenwood 1062; slopes of Mt. Mbotilamu, Mt. Evans Range, DA 14802; hills east of Nandala Creek, south of Nandarivatu, Smith 6236. Nandronga \& Navosa: Nausori Highlands, DA 12640 (Melville et al. 7013). SERUA: Nathengathenga Creek, upper Navua River, DA L.13368 (Berry 79, coll. Qoro); Vatutavathe, vicinity of Ngaloa, Degener 15186. NaItAsIri: Near Tholo-i-suva, Setchell \& Parks 15126; vicinity of Tamavua, Gillespie 2019. TAILEVU: Waimaro River, near Copper Mine, DA 13634. RewA: Mt. Korombamba, DA 16525. VANUA LEVU: MBuA: Near Nasarowangga, $D A$ 14314. Mathuata: Southern slopes of Mt. Numbuiloa, east of Lambasa, Smith 6560. ThaKaundrove: Eastern drainage of Yanawai River, Degener \& Ordonez 14118. VANUA MBALAVU: Namalata Islet, southern limestone section, Smith 1438. NAVUTU-I-LOMA: Bryan 455. ONGEA NDRIKI: Bryan 412.

In describing Canthiopsis and in referring it to the Loganiaceae, Seemann (or his artist) made two erroneous observations, noted by J. D. Hooker (1873) in his comment: ". . . male quoad ovarii pict. et descr." First, the original description and illustration indicate the ovules to be solitary and pendulous in each ovary locule, the placenta having been mistaken for an ovule; in fact the placenta is subapically attached to the dissepiment and the ovules are 2-7 in number and are flattened on its abaxial surface. Second, the ovary is not as conspicuously semisuperior as illustrated but is essentially immersed in the hypanthium, although a fairly thick disk surmounts the ovarial cavity and there is some variation in the degree to which the ovary is immersed. Drawings attached to the holotype are clearly those from which Seemann's illustration was prepared, but it is of interest that those showing the semisuperior ovary and the placentation have been questioned (presumably by J. D. Hooker); a more recent sketch has been added (perhaps by Hooker) that correctly illustrates the ovarial position and the placentation essentially as depicted in our FIGURE 77B.

In discussing the present species (as Canthiopsis odorata), Bridson and Robbrecht (1985) suggest that the type (Seemann 260) is probably female and another collection (Setchell \& Parks 15126) probably functionally male. In our observations, however, all flowers appear to be hermaphrodite, the degree of protandry doubtless being variable.

3. Tarenna joskei (Horne ex Baker) A. C. Sm. \& S. Darwin, comb. nov.

FIGURE 76C \& D.

Ixora joskei Horne, A Year in Fiji, 263, nom. nud. 1881; Horne ex Baker in J. Linn. Soc. Bot. 20: 363.

1883; Drake, Ill. Fl. Ins. Mar. Pac. 195. 1890; J. W. Parham, Pl. Fiji Isl. 194. 1964, ed. 2. 274.1972.

An apparently rare, slender tree to about $3 \mathrm{~m}$. high, occurring from near sea level to an elevation of about $380 \mathrm{~m}$. in forest. Flowers, with white corollas, have been obtained in April and August.

TyPIFICATION: The type is Horne 731 (K HolotyPE), collected in August, 1878, at Na Vesi ("Navesi"), east of Naikorokoro Creek, Namuka Harbour, Rewa Province, Viti Levu. This is also the type locality of Palaquium hornei (cf. this Flora, vol. 2, p. 774), although that species was obtained in June, 1878. Horne made several visits to that interesting and then heavily forested area (cf. Horne, 1881, p. 30).

Distribution: Endemic to Fiji and, as far as known, to a small area in southeastern Viti Levu.

AVAIlABle COllection: VITI LEVU: Rewa: Upper slopes of Mt. Korombamba, DA 16545.

Although this species and the preceding (Tarenna seemanniana) are sympatric in southeastern Viti Levu, the present species is much less frequent and the two seem readily distinguishable. 
18. IxoRa L. Sp. Pl. 110. 1753; DC. Prodr. 4:485. 1830; Seem. Fl. Vit. 133. 1866; Hook. f. in Benth. \& Hook. f. Gen. Pl. 2: 113. 1873; K. Schum. in Engl. \& Prantl, Nat. Pflanzenfam. IV. 4: 107. 1891; F. Brown in Bishop Mus. Bull. 130: 300. 1935; Bremek. in Bull. Jard. Bot. Buitenzorg III. 14: 198. 1937; Fosberg in Occas. Pap. Bishop Mus. 13: 265. 1937; Backer \& Bakh. f. Fl. Java 2: 324. 1965; S. Darwin in Allertonia 2: 16.1979.

Trees or shrubs, the stipules interpetiolar, cuspidate to aristate, usually briefly united around branchlet; inflorescences corymbose or paniculate, terminal (sometimes on a short, defoliate, lateral branchlet), often subtended by a pair of reduced leaves (here termed bracts), the inflorescence branches articulate or not, opposite to subopposite to alternate; flowers in distinct triads or irregularly arranged, 4(rarely 5)merous, protandrous; ovary 2-locular, the ovules solitary, partly immersed in a fleshy placenta; calyx lobed, toothed, or truncate; corolla hypocrateriform, white to yellow or red, the tube glabrous within or occasionally barbate at throat, the lobes linear to ovate, acute to obtuse or rounded, contorted in bud; stamens affixed in corolla throat, the anthers exserted; style filiform, glabrous or pubescent, bilobed and with divaricate stigmatic lobes at apex; fruit drupaceous, subglobose, red to black.

Lectotype SPECies: Ixora coccinea L. (vide Hitchcock, Prop. Brit. Bot. 124. 1929), one of Linnaeus's two original species.

DistRIBUtion: Pantropical, with perhaps as many as 400 species. The genus is most highly diversified in southeastern Asia and Malesia, especially in Borneo. The distinction between Ixora and Pavetta (which extends as far eastward as New Caledonia and the New Hebrides) has been outlined by Bremekamp; the latter genus, among other separating characters, has conspicuously elongate styles and stigmatic lobes separating only at their tips. Ixora and its allies are characterized by an "ixoroid" pollen presentation mechanism whereby pollen is deposited on the upper portion of the style before the flower bud opens; the pollen is then carried beyond the corolla by the elongating style and is dispersed before the stigmatic lobes separate.

Although the genus has such a vast distribution, individual species throughout its range appear to have very limited areas. In Fiji 27 species are represented, five of them cultivated (very infrequently naturalizing) and 22 indigenous. Of the indigenous species a surprising 21 are endemic; while this might seem an extraordinarily high percentage of specific endemism, a careful examination of species from nearby archipelagoes discloses no reason for skepticism at this time.

USEFul TREATMENT OF GENUS: BREMEKAMP, C. E. B. The Malaysian species of the genus Ixora (Rub.). Bull. Jard. Bot. Buitenzorg III. 14: 197-367. 1937. CORNER, E. J. H. Notes on the systematy and distribution of Malayan phanerogams, IV: Ixora. Gard. Bull. Straits Settlem. III. 11: 177-235. 1941.

Bremekamp's (1937) treatment of the Malesian taxa of Ixora is very useful in a consideration of both indigenous and cultivated species occurring in the southwestern Pacific. Of the three subgenera recognized by Bremekamp, subgen. Ixora (subgen. Eu-Ixora Bremek., 1937, p. 206, nom. inadmis.) includes all the species known to be cultivated in Fiji, subgen. Pavettoides Bremek. (1937, p. 206) includes at least 14 of the indigenous Fijian species, and the third subgenus, subgen. Sathrochlamys Bremek. (1937, p. 207) presumably does not occur eastward of New Guinea. In subgen. Ixora, our cultivated species fall into sect. Ixora (sect. Ixorastrum Bremek., 1937, p. 208, nom. inadmis.) and sect. Chlamydanthus Bremek. (1937, p. 208). Our indigenous species fall into sect. Pavettopsis Bremek. (1937, p. 210), sect. Phylleilema A. Gray (in Proc. Amer. Acad. Arts 4: 40. 1858), and sect. Vitixora Fosberg (in Sargentia 1: 124. 1942). The last two of these sections seem not to have been recorded west of Fiji; in fact, 
sect. Vitixora appears endemic to Fiji, while sect. Phylleilema extends eastward at least to the Society Islands. According to Fosberg (1942), sect. Vitixora is equivalent to groups that were regarded as subgenera by Bremekamp (1937), but Fosberg considered subgenera as unconvincing in Ixora and regarded the major species groups as sections.

\section{KEY TO SECTIONS OCCURRING IN FIII}

Inflorescences with more than 3 flowers, the branching opposite, the nodes conspicuously articulate; bracts and bracteoles well developed in distal portion of inflorescence; cultivated (rarely naturalized) species.

Flowers inodorous, subtended by bracteoles shorter than ovary; calyx lobes as long as or shorter than ovary; corolla red, pink, or yellow, the lobes acute. ...................... Ixora

Flowers fragrant, subtended by bracteoles longer than ovary; calyx lobes elliptic to lanceolate, often green-nerved, longer than ovary; corolla white, the lobes obtuse to rounded. .2. Chlamydanthus

Inflorescences 3-flowered (then subtended by a pair of broad, foliaceous bracts) or with numerous flowers, the branching never opposite (but sometimes subopposite), the nodes never articulate; bracts and bracteoles often not well developed in distal portion of inflorescence; indigenous species.

Inflorescences usually 3-flowered, subtended by a pair of broad, foliaceous bracts. .. 3. Phylleilema Inflorescences with more than 3 flowers; bracts not broad and foliaceous (although inflorescences sometimes subtended by a pair of often highly reduced leaves).

Inflorescences congested, usually subcapitular; bracts and bracteoles linear to filiform; calyx lobes elongate-lanceolate. ................................... 4. Vitixora Inflorescences open (infrequently subcapitular); bracts and bracteoles not conspicuously linear or filiform; calyx lobes not elongate-lanceolate. ................... 5 . Pavetropsis

\section{KEYS TO SPECIES}

SECTION 1. Ixora

Corolla red; leaf blades lanceolate-oblong, (15-) 20-30 $\times 6-11 \mathrm{~cm}$., rounded to acute at base, the petioles obvious, (5-) 10-15 mm. long; inflorescences often with more than 100 flowers; calyx lobes broad,

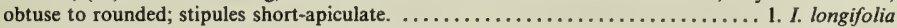

Corolla red, pink, or yellow; leaf blades oblong-elliptic, 5-15 $\times 2-6 \mathrm{~cm}$., rounded to cordate and clasping at base, the petioles short (to $6 \mathrm{~mm}$. long) or essentially none; inflorescences usually with fewer than 100 flowers; calyx lobes as broad as long or longer, acute; stipules usually long-subulate.

Corolla pink, the tube to $3 \mathrm{~cm}$. long, the lobes $5-8 \mathrm{~mm}$. long; leaves usually with petioles 2-6 mm. long.

2. I. siamensis

Corolla red to yellow, the tube to $5 \mathrm{~cm}$. long, the lobes more than $10 \mathrm{~mm}$. long; leaves usually with sessile, clasping blades.

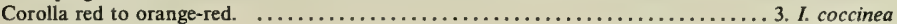

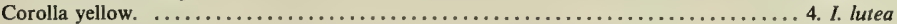

\section{SECTION 2. Chlamydanthus}

A single species in Fiji; petioles 4-8 (-15) mm. long; leaf blades lanceolate-elliptic to -obovate, 6-16 $\times 2-6.5$ $\mathrm{cm}$. or larger, gradually attenuate proximally, obtuse to acute at apex; corolla tube $2-3.5 \mathrm{~cm}$. long, the

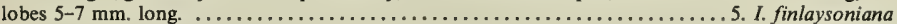

\section{Section 3. Phylleilema}

Stipules apiculate to short-subulate, glabrous; leaf blades ovate to elliptic, $4-13 \times 2.5-7 \mathrm{~cm}$, rounded to obtuse at base, rounded to bluntly acute at apex; inflorescence bracts usually $20-40 \mathrm{~mm}$. long and broad, obtuse to rounded at apex; calyx glabrous without, denticulate to subtruncate; corolla tube 18-25 mm. long, the lobes $8-10(-15) \times 3-7 \mathrm{~mm}$., rounded to obtuse at apex. ....6. I. calcicola

Stipules long-acicular-aristate, glabrous or puberulent; leaf blades acute at apex; inflorescence bracts to 30 $\mathrm{mm}$. long and broad, acute at apex; calyx glabrous or puberulent without, dentate; corolla lobes $7-10 \times$ 2-3 mm., acute at apex.

Leaf blades mostly 2-3 times as long as broad, ovate to elliptic, $3-12 \times 2.7-5 \mathrm{~cm}$., rounded to acute and attenuate at base; distal internodes and stipules glabrous; inflorescence bracts $12-30 \mathrm{~mm}$. long and broad, often strongly cordate at base; calyx glabrous, denticulate, the teeth $0.1-0.4(-0.6) \mathrm{mm}$. long;

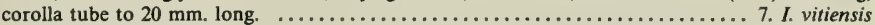

Leaf blades mostly 3-4 times as long as broad, elliptic to lanceolate; distal internodes and stipules glabrous or puberulent; inflorescence bracts rounded to subcordate at base, to $25 \times 20 \mathrm{~mm}$; calyx usually puberulent, the teeth to $1 \mathrm{~mm}$. long.

Distal internodes and stipules glabrous; calyx puberulent, rarely glabrous; corolla tube $15-20 \mathrm{~mm}$. long, the lobes $8-10 \times$ about $2 \mathrm{~mm}$; leaf blades mostly elliptic, $3-9 \times 1.5-3 \mathrm{~cm}$.

8. I. nandarivatensis 
Distal internodes, stipules, and calyces puberulent; corolla tube about $25 \mathrm{~mm}$. long, the lobes about $8 \times$

$3 \mathrm{~mm}$; leaf blades mostly lanceolate, $3-9 \times 1-2.3 \mathrm{~cm}$. ............... I. pedionoma

\section{SECTION 4. Vitixora}

Petioles obvious, 10-20 mm. long; leaf blades broadly elliptic to ovate, $9-27 \times 4-15 \mathrm{~cm}$., tapering at base, pilose beneath; stipules subulate-cuspidate, to $10 \mathrm{~mm}$. long; inflorescences compact; calyx lobes 3-6 $\mathrm{mm}$. long; corolla tube $15-18 \mathrm{~mm}$. long, pilose without. . . . . . . . . . . . 10. I.

Petioles lacking or less than $10 \mathrm{~mm}$. long; leaf blades rounded to cordate at base, often amplexicaul; corolla tube glabrous without.

Leaf blades glabrous beneath, oblong-elliptic to lanceolate, 9-21 $\times 2-7.5 \mathrm{~cm}$.; stipules subulate, $5-10 \mathrm{~mm}$. long; inflorescences compact; calyx lobes $6-8 \mathrm{~mm}$. long; corolla tube $8-18 \mathrm{~mm}$. long.

Leaf blades pubescent beneath.

11. I. amplexicaulis

Inflorescences compact; petioles slender, $5-8 \mathrm{~mm}$. long; leaf blades oblong-elliptic to narrowly ovate or obovate, 14-23 $\times 2-8 \mathrm{~cm}$., obviously pubescent or villose beneath; stipules long-acicular, 10-20 $\mathrm{mm}$. long; calyx lobes 4-6 mm. long; corolla tube $10-15 \mathrm{~mm}$. long. ........ 12. I. pelagica

Inflorescences looser, the internal branching apparent; petioles very stout, to $5 \mathrm{~mm}$. long; leaf blades oblong-elliptic, 30-40 $\times 8-11 \mathrm{~cm}$., minutely pubescent beneath; stipules (as far as known) abruptly acuminate; calyx lobes $5-6 \mathrm{~mm}$. long; corolla tube about $10 \mathrm{~mm}$. long. ..... 13. I. coronata

SECTION 5. Pavettopsis

Inflorescences borne on short, defoliate, lateral branchlets arising well below foliage; corolla tube to $12 \mathrm{~mm}$. long, the lobes spreading.

Leaf blades stiff-chartaceous, long-elliptic, 14-30 $\times 4-10.5 \mathrm{~cm}$, rounded and abruptly attenuate at base, acuminate at apex, the venation submerged beneath, not conspicuously prominulous; petioles relatively slender, $15-25 \mathrm{~mm}$. long and 2-3 $\mathrm{mm}$. in diameter; inflorescences subcapitate.

14. 1 . storckii

Leaf blades thin-chartaceous, narrowly to broadly elliptic, $25-50 \times 10-25 \mathrm{~cm}$., acute to obtuse or attenuate at base, acute at apex, the venation prominulous beneath; petioles stout, 15-30 mm. long and 4-6 $\mathrm{mm}$. in diameter; inflorescences openly branched, to $22 \mathrm{~cm}$. broad. . . . . . . . 15. I. carewii

Inflorescences terminal or, if borne on lateral branchlets these bearing at least one pair of normally developed leaves or, if borne on defoliate lateral branchlets (I. prolixa) then the corolla slender, with a tube to $20 \mathrm{~mm}$. long and reflexed lobes.

Leaf blades neither bullate nor long-ligulate.

Lower surfaces of leaf blades conspicuously pilose or densely to sparsely papillose-puberulent (evident under magnification of $\times 10$ ).

Leaf blades soft-pilose beneath with conspicuous, spreading hairs, broad- to long-elliptic, 16-50 $\times$ 4-14 cm., rounded or obtuse and attenuate at base; stipules usually persistent, to $10 \mathrm{~mm}$. long; inflorescences relatively compact, to $8 \mathrm{~cm}$. broad; calyx spreading-pubescent, the teeth broad, obtuse to rounded; corolla minutely puberulent to glabrous. . . . . . . . . 16. I. maxima

Leaf blades minutely papillose-puberulent beneath, the hairs to $0.1 \mathrm{~mm}$. long; inflorescences usually more than $6(-14) \mathrm{cm}$. broad.

Calycine teeth less than $1 \mathrm{~mm}$. long, usually broader than long, obtuse to rounded; corolla puberulent, the tube $8-10 \mathrm{~mm}$. long; leaf blades ovate to oblong-elliptic to oblanceolate, acute to obtuse or rounded and attenuate at base.

Petioles relatively stout, $5-17 \mathrm{~mm}$. long and 2-3 mm. in diameter; leaf blades $13-32 \times 5-12 \mathrm{~cm}$; lateral nerves $8-14$ on each side of costa; calyx spreading-puberulent. . . . 17. I. pubifolia

Petioles relatively slender, $10-12 \mathrm{~mm}$. long and $1-1.5 \mathrm{~mm}$. in diameter; leaf blades 7-13 $\times 4-7$ $\mathrm{cm}$.; lateral nerves $6-10$ on each side of costa; calyx minutely puberulent.

18. I. greenwoodiana

Calycine teeth to $1.5 \mathrm{~mm}$. long, usually much longer than broad, bluntly acute to rounded; corolla glabrous or obscurely puberulent, the tube to $7 \mathrm{~mm}$. long; leaf blades narrowly long-elliptic, 9-24 × 2.5-11 cm., rounded to subcordate at base; lateral nerves 8-14 on each side of costa.

19. I. arestantha

Lower surfaces of leaf blades entirely glabrous, never papillose.

Leaves conspicuously petiolate, the blades acute to obtuse to rounded and usually attenuate at base, never subcordate.

Petioles frequently more than $16 \mathrm{~mm}$. long; leaf blades obtuse to sharply acuminate at apex; lateral nerves usually fewer than 14 on each side of costa; stipules acuminate to apiculate to long-aristate, usually more than $3 \mathrm{~mm}$. long.

Calyx (including hypanthium) glabrous to sparsely puberulent, the teeth acute to acuminate (rarely obtuse or rounded), (0.3-) $0.5-1 \mathrm{~mm}$. long, as long as broad or longer; corolla lobes reflexed to spreading. 
Inflorescences relatively compact, to $9 \mathrm{~cm}$. broad; calyx minutely granular-puberulent, the teeth to $0.5 \mathrm{~mm}$. long; corolla tube obscurely puberulent, the lobes $8-9 \times 3-4 \mathrm{~mm}$; leaf blades oblong-elliptic to ovate, $7-16 \times 3-8 \mathrm{~cm}$; lateral nerves $10-12$ on each side of costa.

20. I. myrsinoides

Inflorescences compact (about $5 \mathrm{~cm}$. broad) to openly branched (to $24 \mathrm{~cm}$. broad); calyx usually glabrous, the teeth to $1 \mathrm{~mm}$. long; corolla tube glabrous, the lobes less than $7 \mathrm{~mm}$. long; leaf blades elliptic.

Corolla tube $18-22 \mathrm{~mm}$. long, the lobes 5-6.5 $\times 2.5-4 \mathrm{~mm}$.; leaf blades 6-15 $\times 4-8 \mathrm{~cm}$., with 7-11 lateral nerves on each side of costa. ............... tubiflora

Corolla tube to $6 \mathrm{~mm}$. long, the lobes about $5.5 \times 1.5 \mathrm{~mm}$; leaf blades $3-15 \times 2-6 \mathrm{~cm}$., with 8-14 lateral nerves on each side of costa. ................. harveyi

Calyx (including hypanthium) minutely to densely puberulent, the teeth obtuse to rounded, to

$0.5 \mathrm{~mm}$. long, broader than long; corolla lobes strongly reflexed.

Inflorescences to $20(-25) \mathrm{cm}$. broad, borne on foliate branchlets; corolla tube to $7 \mathrm{~mm}$. long.

23. I. elegans

Inflorescences to $30 \mathrm{~cm}$. broad, borne on foliate or short, defoliate branchlets; corolla tube

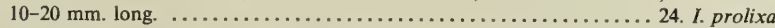

Petioles to $16 \mathrm{~mm}$. long; leaf blades rounded and minutely mucronulate at apex, narrowly elliptic to oblong-lanceolate, 9-13 $\times 2.5-4 \mathrm{~cm}$; lateral nerves 13-18 on each side of costa; stipules apiculate, about $3 \mathrm{~mm}$. long; inflorescences spreading, to $16 \mathrm{~cm}$. broad; calyx minutely puberulent, the teeth obtuse, broader than long. . . . . . . . . . . . . . . . Leaves sessile or with petioles less than $3 \mathrm{~mm}$. long, the blades rounded to subcordate at base, $12-20 \times$ 4-7 cm.; lateral nerves 9-11 on each side of costa; stipules to $6 \mathrm{~mm}$. long; inflorescences to $6 \mathrm{~cm}$. broad; calyx teeth obtuse to rounded, usually broader than long. .......26. I. myrtifolia

Leaf blades conspicuously bullate, long-ligulate, $10-40 \times 1-3 \mathrm{~cm}$., subsessile, cordate-clasping at base, acute at apex; inflorescences subcapitate, to $3 \mathrm{~cm}$. broad; calyx minutely puberulent, the teeth acute to obtuse, longer than broad; corolla minutely puberulent, the tube about $8 \mathrm{~mm}$. long.

27. I. bullata

1. Ixora longifolia Sm. in Rees, Cycl. 19. 1811; Bremek. in Bull. Jard. Bot. Buitenzorg III. 14: 279. 1937; Backer \& Bakh. f. Fl. Java 2: 325. 1965; J. W. Parham, Pl. Fiji Isl. ed. 2. 274. 1972.

Figure 127 (upper).

Ixora macrothyrsa sensu J. W. Parham in Agr. J. Dept. Agr. Fiji 19: 101. 1948; Sykes in New Zealand Dept. Sci. Indust. Res. Bull, 200: 178. 1970; non T. Moore.

This striking ornamental has been noted in Fiji only in cultivation, at elevations from near sea level to about $200 \mathrm{~m}$., as a shrub 1-3 m. high. The inflorescence branches and calyx are dull red, the corolla bright red or orange-red. Flowers may be seen throughout the year.

TYPIFICATION AND NOMENCLATURE: Ixora longifolia is based on Flamma sylvarum Rumph. Herb. Amb. 4: 105. t. 46. 1743. Bremekamp (1937, p. 280) also cites a specimen from Amboina as "Chr. Smith s. n. N. H. (co-typus a Smith descriptus);" although the original description may have been partially based on such a specimen, it was not cited by J. E. Smith. It seems probable that the plants referred by Parham (1948) and Sykes (1970) to I. macrothyrsa (Teijsm. \& Binnend.) T. Moore represent $I$. longifolia; the species are closely related (cf. Bremekamp, 1937, pp. 226, 278-280). Specimens from Micronesia (putatively indigenous but perhaps naturalized) and Hawaii (cultivated) identified as I. casei Hance (cf. Glassman in Bishop Mus. Bull. 209: 94. 1952; Fosberg, Sachet, \& R. Oliver in Micronesica 15: 269. 1979; St. John in Pacific Trop. Bot. Gard. Mem. 1:330. 1973) seem very similar to I. longifolia, if not identical with it.

Distribution: Indigenous in the Moluccas, and now widely cultivated in tropical areas.

LOCAL NAMES AND USE: Locally known as red ixora and giant red ixora, this handsome shrub is a favorite in town and village gardens.

Available collections: VITI LEVU: Namosi: Nanggarawai, Wainikoroiluva River, DA 2166. Rewa: Lami, in private garden, DA 16459, 16464: Suva, in Department of Agriculture compound, DA I2084. 
2. Ixora siamensis Wallich ex G. Don, Gen. Hist. Dichlam. Pl. 3: 573. 1834; Backer \&

Bakh. f. Fl. Java 2: 326. 1965; J. W. Parham, Pl. Fiji Isl. ed. 2. 276.1972.

As seen in Fiji, Ixora siamensis is a shrub 1-3 m. high cultivated near sea level; its corolla is pale pink, or the tube is white to pink and the lobes are salmon-pink. Flowers have been noted in March, April, and November.

TYPIFICATION: The type is Wallich, indicated in his Numerical List (1831-1832) as no. 6162 .

DISTRIBUTION: Indigenous in southeastern Asia, now widely cultivated.

LOCAL NAME AND USE: Pink ixora; a popular ornamental.

Available collections: VITI LEVU: Naitasiri: Cocoa Station, Nanduruloulou, DA 12245. Rewa: Lami, in private garden, $D A$ 16453. VANUA LEVU: THAKAUNDROVE: Namale, southeast of Savusavu, $D A$ 16892.

J. W. Parham (in Agr. J. Dept. Agr. Fiji 19: 101. 1948) listed a plant growing in the Suva Botanical Gardens as Ixora odorata, but that name is not accounted for in his later treatments $(1964,1972)$; the plant was said to be a native of Madagascar, but from the brief notes one may suggest that it represented $I$. siamensis. Ixora odorata Hook. (1845; non Spreng. 1824) is referable to I. hookeri (Oudem.) Bremek., which is not known in cultivation in the Fijian Region. The cultivated plant from Niue listed as $I$. odorata Hook. by Sykes (in New Zealand Dept. Sci. Indust. Res. Bull. 200: 179. 1970) appears to represent a different concept than Parham's and is suggestive of I. finlaysoniana.

3. Ixora coccinea L. Sp. Pl. 110. 1753; Corner in Gard. Bull. Straits Settlem. III. 11: 185. 1941; Yuncker in Bishop Mus. Bull. 178: 112. 1943, in op. cit. 184: 64. 1945; J. W. Parham in Agr. J. Dept. Agr. Fiji 19: 101. 1948, Pl. Fiji Isl. 194. 1964, ed. 2. 273. 1972; Backer \& Bakh. f. Fl. Java 2: 326. 1965; Sykes in New Zealand Dept. Sci. Indust. Res. Bull. 200: 178. 1970; MacKee, Pl. Intro. Cult. Nouv.-Caléd. 118. 1985.

FiguRE 127 (lower).

Shrub 1-2.5 m. high, frequently cultivated from near sea level to about $250 \mathrm{~m}$. The inodorous flowers have the corolla scarlet to orange, light red, or pinkish red. Although flowering much of the year, this species may be most conspicuous between January and April.

TYPIFICATION: In 1753 Linnaeus cited several prior references, but we have not noted a firm lectotypification. Corner (1941) lists Linnaeus's third edition as the place of publication and an Osbeck specimen as the "type," without justifying either statement.

Distribution: Southeastern Asia; now widely cultivated in tropical areas. The species has been grown in Fiji for more than a century, being listed in Thurston's 1886 Catalogue.

LOCAL NAME AND USE: The red ixora is a frequent ornamental in towns and villages and is often shaped into hedges.

Available collections: VITI LEVU: Naitasiri: Tholo-i-suva, DA 13852 (DF 345, Damanu 34). REWA: Suva Botanical Gardens, $D A$ 12328; Suva, in private garden, $D A 16078$.

Ixora coccinea, perhaps the most abundantly cultivated species of the genus throughout the Old World tropics, is often considered highly variable and to include several varieties and forms, some unnamed. As interestingly discussed by Corner (1941, pp. 185-188), I. coccinea would include the following taxon. 
4. Ixora lutea Hutchinson in Bot. Mag. 138: t. 8439. 1912; J. W. Parham in Agr. J. Dept. Agr. Fiji 19: 101. 1948, Pl. Fiji Isl, ed. 2. 274. 1972.

Ixora coccinea var. lutea Corner in Gard. Bull. Straits Settlem. III. 11: 186. 1941.

Shrub 1-2 m. high, often cultivated near sea level; the corolla is yellow, sometimes pale yellow, but never reddening. Flowers have been noted between January and April but probably occur throughout the year.

TYPIFICATION: The type is a cultivated plant presumably originating in the Royal Botanic Gardens, Peradeniya, Ceylon.

DisTRIBUTION: Southeastern Asia; now widely cultivated.

LOCAL NAME AND USE: The yellow ixora is a frequent ornamental in Fijian towns and villages.

Available collections: VITI LEVU: Rewa: Lami, in private garden, DA 16799; Suva Botanical Gardens, DA 12334; Suva, in private gardens, DA 12618, 16079.

Corner's (1941) broad treatment of Ixora coccinea, which includes several named varieties (including var. lutea) and unnamed forms, may prove to be a reasonable treatment of this complex group of taxa. Ixora lutea, at whatever accepted level, is the taxon of this relationship with the corolla tube whitish to pale yellow and the lobes buff-yellow, unchanging or fading pale yellow but never reddening. Other taxa with yellowish corollas that are referred to varietal status under $I$. coccinea have the lobes eventually fading pinkish white or streaked with rose.

5. Ixora finlaysoniana Wallich ex G. Don, Gen. Hist. Dichlam. Pl. 3:572. 1834; Corner in Gard. Bull. Straits Settlem. III. 11: 193. 1941; Yuncker in Bishop Mus. Bull. 220: 253. 1959; Backer \& Bakh. f. Fl. Java 2: 326. 1965; J. W. Parham, Pl. Fiji Isl. ed. 2. 273. 1972; MacKee, Pl. Intro. Cult. Nouv.-Caléd. 118. 1985.

Ixora alba sensu J. W. Parham, Pl. Fiji Isl. 194. 1964; non L.

Shrub or small tree 4-6 m. high, found in cultivation near sea level but also occasionally as an escape along roads and in waste places. The fragrant flowers have the corolla white or cream-white; flowering probably occurs throughout the year.

TYPIFICATION: The type is Wallich, indicated in his Numerical List (1831-1832) as no. 6166.

Distribution: Perhaps indigenous in Siam (Corner, 1941) or in the Andaman Islands (Backer and Bakhuizen, 1965), but established in adjacent areas and cultivated widely beyond them. The species was probably introduced into Fiji by J. B. Thurston and is listed in his 1886 Catalogue as Ixora alba.

LOCAL NAMES AND USE: This fragrant-flowered ornamental is known in Fiji as white ixora, sinu ni mburotu, and matiyavi.

Available collections: VITI leVU: Naitasiri: Nasinu, DA 1572. Rewa: Suva Botanical Gardens, DA 12341. VANUA LEVU: ThaKaundrove: Along Hibiscus Highway leading from Savusavu, Bierhorst FI69. LAKEMBA: Tumbou, DA 1383; Vakano Cemetery, Garnock-Jones 954.

6. Ixora calcicola A. C. Sm. in Bishop Mus. Bull. 220: 251. fig. 13. 1959, in Contr. U. S. Nat. Herb. 37: 91. 1967; St. John \& A. C. Sm. in Pacific Sci. 25: 339. 1971; Morat \& Veillon in Bull. Mus. Nat. Hist. Nat. (Paris) IV. 7, Sect. B, Adansonia 3: 216. 1985.

FiGURE 78A.

Ixora triflora sensu Sykes in New Zealand Dept. Sci. Indust. Res. Bull. 200: 179. 1970; non Seem.

Shrub or small tree 1-4 m. high, occurring near sea level in thickets, on lagoon cliffs, and along rocky coasts, apparently always on limestone. The corollas are white, 
the anthers yellow, and the fruits brown. In Fiji flowers have been obtained in February, fruits in July.

TyPIFICATION: The type is Yuncker 16091 (US 2128541 \& 2157728 HOLOTYPE; ISOTYPES at BISH, BM), collected May 21, 1953, along the upper rim of a limestone cliff on the eastern side of Vava'u, Tonga, below Ha'alaufuli.

Distribution: Fiji, Tonga, Niue, and Horne Islands. Sykes (1970) combined Ixora calcicola with I. bracteata Cheeseman (cf. Smith, 1959, for comparison) and referred both to the synonymy of I. triflora (Forst. f.) Seem. (Fl. Vit. 133. 1866, based on Coffea triflora Forst. f. Fl. Ins. Austr. Prodr. 16. 1786, from Tahiti). These reductions seem unwarranted, although admittedly a careful review of sect. Phylleilema throughout its range is desirable.

Local name: Sinu ni Lau (Fulanga).

Available collections: FULANGA: On limestone, Smith 1145, 1219. ONGEA NDRIKI: On rocky sea coast, Bryan 387.

The four Fijian species of sect. Phylleilema appear to have allopatric distributions, and one may assume that they have different ecological requirements. Ixora calcicola has thus far been found only on the limestone of southern Lau, occurring also in nearby Tonga, Niue, and the Horne Islands; it is the only taxon of the section known from the Lau Group. Ixora vitiensis is quite widely distributed within the archipelago at elevations up to $900 \mathrm{~m}$., but in Viti Levu it seems absent from upland northern and central areas where $I$. nandarivatensis is frequent, and in Vanua Levu it is not known from the Seanggangga region of Mathuata, the type locality of I. pedionoma; the last species being known only from its type collection, distributional data concerning it are of course inconclusive.

7. Ixora vitiensis A. Gray in Proc. Amer. Acad. Arts 4:40. 1858, in op. cit. 5:319. 1862, in Bonplandia 10: 36. 1862; Seem. in op. cit. 10: 155. 1862, Viti, 437. 1862, Fl. Vit. 134. 1866; Drake, Ill. Fl. Ins. Mar. Pac. 195. 1890; Gillespie in Bishop Mus. Bull. 74: 32. fig. 44. 1930; Fosberg in Bull. Torrey Bot. Club 67: 422. 1940; J. W. Parham, Pl. Fiji Isl. 195. fig. 70, B. 1964, ed. 2. 276. fig. 82, B. 1972.

Psychotria? speciosa sensu Seem. in Bonplandia 9: 257. 1861; non Forst. f.

Shrub or small tree 2-8 m. high, often freely branched or spreading, with a trunk to $20 \mathrm{~cm}$. in diameter, occurring at elevations from near sea level to about $900 \mathrm{~m}$. in dense or dry forest and also in beach thickets, often on limestone. The inflorescence bracts are green, reddish at base; the fragrant flowers have the corolla white, pink-tinged distally in bud, and the anthers yellow; and the fruits turn from green through red to purple or black at maturity. Flowers and fruits have been obtained in most months.

TyPIFICATION: The type is $U . S$. Expl. Exped. (US 48665 HolotyPE; ISOTYPE at K), collected in 1840 on Ovalau.

Distribution: Endemic to Fiji and now known from about 35 collections from five islands.

LOCAL NAMES: Names recorded from the Yasawas are rautolu and rauyangili, from Mbua mbulindavo and mbulindavui.

REPRESENTATIVE COLLECTIONS: YASAWAS: WAYA: Nangua, St. John 18118; Nakawa Gulch, west side of Mbatinaremba, St. John 18140. VITI LEVU: RA: Mataimeravula, vicinity of Rewasa, near Vaileka, Degener 15451. Tallevu: Nggelekuro, DA 13595; Namara, Seemann 247, p. p. Rewa: Limestone hills near Lami, Gillespie 4610. OVALAU: Slopes of Mt. Koronimoko, vicinity of Thawathi, Smith 8065; hills behind Levuka, Gillespie 4409; Port Kinnaird, Seemann 247, p. p. KORO: Tothill 287. VANUA LEVU: MBUA: Nasau, Liuka Flat, H. B. R. Parham 33; track to Mt. Seatura, DA 17541 . MAthuata: Mt. Ndelaikoro, DA 12831; vicinity of Lambasa, Greenwood 556. THAKAUNDROVE: Eastern drainage of Yanawai River, Degener \& Ordonez 14112; hills west of Mbutha Bay, Natewa Peninsula, Smith 807. 

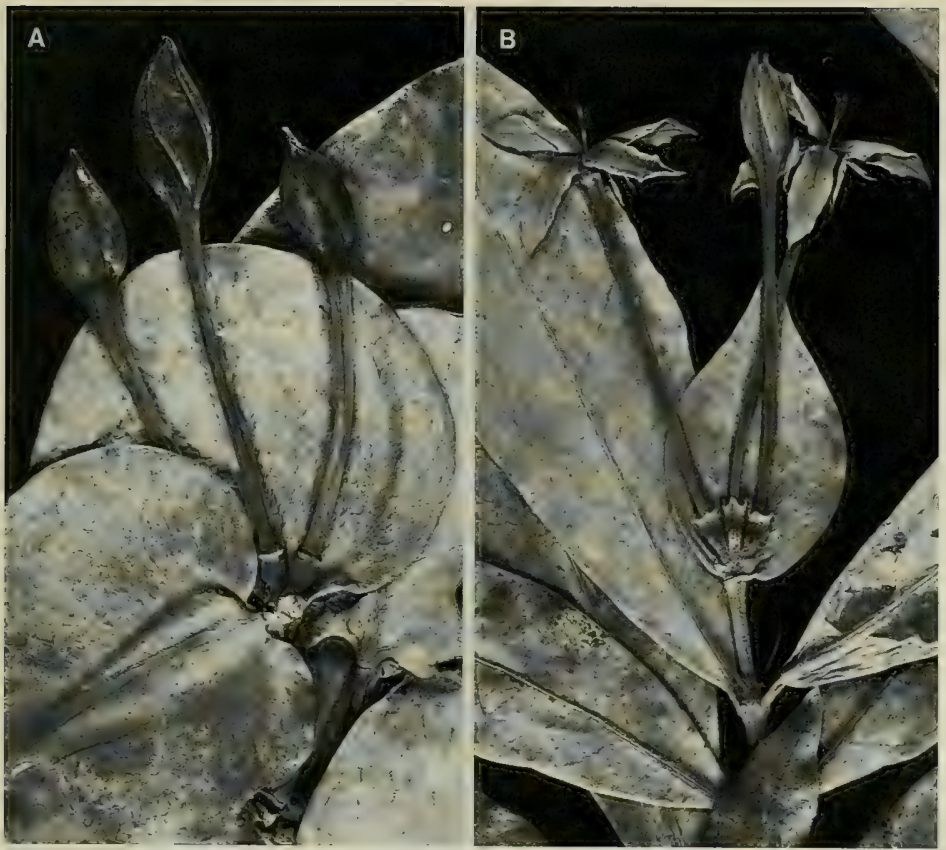

FiguRE 78. A, Ixora calcicola; inflorescence (showing bracts, also bracts of adjacent inflorescences, and part of a foliage leaf in upper right), $\times 2$. B, Ixora pedionoma; foliage and an inflorescence with one bract removed, × 2. A from Smith 1219, B from Smith 6703.

8. Ixora nandarivatensis Gillespie in Bishop Mus. Bull. 74: 31. fig. 42. 1930; J. W. Parham, Pl. Fiji Isl. 195. 1964, ed. 2. 274. 1972.

Shrub or small tree $1.5-5 \mathrm{~m}$. high, sometimes with slender, spreading branches, found in dense or secondary forest at elevations of $150-1,000 \mathrm{~m}$. The bracts are reddish to orange; the fragrant flowers have a white corolla; and fruits have been recorded as red to purple. Flowers have been obtained between November and March, fruits between February and August.

TyPIFICATION: The type is Gillespie 4305 (BISH HOLOTYPE and ISOTYPE), collected Dec. 14, 1927, near Nandarivatu, Mba Province, Viti Levu.

Distribution: Endemic to Fiji and thus far known only from northwestern, northern, and central Viti Levu.

Available Collections: VITI LEVU: MBa: Vunayasi, near Nandi, DA 2354; Nandendeleva, DA 14850 ; Mt. Waikumbukumbu, DA 7054; vicinity of Nandarivatu, Tothill 331, Parks 20582, 20585, Gillespie 4050, Degener \& Ordonez 13577; Wainavothe, DA 7064; track from Navai to Mt. Tomanivi, DA 14967. NANDRONGa \& Navosa: Northern portion of Rairaimatuku Plateau, between Nandrau and Nanga, Smith 5570. Namosi: Mt. Voma, DA 11686.

9. Ixora pedionoma A. C. Sm. in J. Arnold Arb. 34:99. 1953; J. W. Parham, Pl. Fiji Isl. 195. 1964, ed. 2. 274. 1972.

Figure 78B. 
An apparently rare shrub 1-2 m. high, found in patches of forest in open country at an elevation of 100-200 m. The corolla and style are white; flowers and fruits occurred in November.

TYPIFICATION: The type is Smith 6703 (A HOLOTYPE; many ISOTYPES), collected Nov. 28, 1947, on the Seanggangga Plateau, in drainage of Korovuli River, vicinity of Natua, Mathuata Province, Vanua Levu.

Distribution: Endemic to Fiji and thus far known only from the type collection.

10. Ixora somosomaensis Gillespie in Bishop Mus. Bull. 74: 32. fig. 43. 1930; Fosberg in Sargentia 1: 124. 1942; J. W. Parham, Pl. Fiji Isl. 195. 1964, ed. 2. 276. 1972.

Figure 79A.

Shrub or usually slender tree $2-6 \mathrm{~m}$. high, occurring in dense forest or in ridge forest at elevations of $300-925 \mathrm{~m}$., sometimes locally frequent on Taveuni. The inflorescences have red bracts; the corolla has its tube cream-white and its lobes pale pink; and the fruits, up to $15 \mathrm{~mm}$. in diameter, turn from yellow to red and deep purple. Flowers have been noted between October and March, fruits between March and November.

TYPIFICATION: The type is Gillespie 4828 (BISH HOLOTYPE and 2 IsOTYPES), collected March 5, 1928, in flower and fruit, on mountain slopes along the trail east of Somosomo, Taveuni.

Distribution: Endemic to Fiji and thus far known only from Vanua Levu and Taveuni, more commonly from the latter island, where it seems to be the only species of sect. Vitixora.

LOCAL NAME: Ndomondamu (Thakaundrove).

Available Collections: VANUA LeVU: Mathuata: Mt. Ndelaikoro (on Thakaundrove boundary), DA 12834. ThaKaundrove: Southern slope of Korotini Range, below Navitho Pass, Smith 507; track to Mt. Nasorolevu, DA 17135; Mt. Mariko, Smith 434; Nggilokalou, DA 16051. TAVEUNI: Nanggelendamundamu, Nggeleni, DA 15865; mountain slopes along trail east of Somosomo, Gillespie 4828.1; western slope between Somosomo and Wairiki, Smith 768; valley between Mt. Manuka and main ridge of island, east of Wairiki, Smith 8272; above Nggathavulo Estate, DA 16920, 16927.

Like those of sect. Phylleilema, the species of sect. Vitixora are in large part allopatric. Ixora somosomaensis is known only from Taveuni and Vanua Levu; the few known specimens of $I$. coronata are also from the latter island. Ixora amplexicaulis is thus far known only from Viti Levu and predominantly from upland, mostly northern and central parts of the island, while $I$. pelagica occurs in southeastern Viti Levu, Ovalau, and Kandavu.

11. Ixora amplexicaulis Gillespie in Bishop Mus. Bull. 74: 30. fig. 40. 1930; Fosberg in Sargentia 1: 124. 1942; J. W. Parham, Pl. Fiji Isl. 193. 1964, ed. 2. 273. 1972.

FIGURE 79B.

Shrub or slender tree, often few-branched, 2-8 m. high, found at elevations of 120-1,075 m. in often dense forest, frequently along streams and sometimes locally abundant. The bracts and bracteoles are noted as red or pink, the calyx as red, the corolla as white but pinkish distally, and the fruit as red or crimson. Flowers have been obtained between December and March, fruits in months scattered throughout the year.

TyPIFICATION: The species is based on Parks 20574 (BISH HOLOTYPE), collected in fruit in July, 1927, in the vicinity of Nandarivatu, Mba Province, Viti Levu.

Figure 79. A, Ixora somosomaensis; inflorescence and leaf bases, $\times 1$. B, Ixora amplexicaulis; inflorescence and leaf bases, $\times 1$. C, Ixora pelagica; infructescence and leaf bases, $\times 1 . \mathrm{D}$, Ixora coronata; infructescence and leaf bases, $\times 1$. A from Smith 507, B from Degener 14682, C from DA 16807, D from Smith 1718 . 

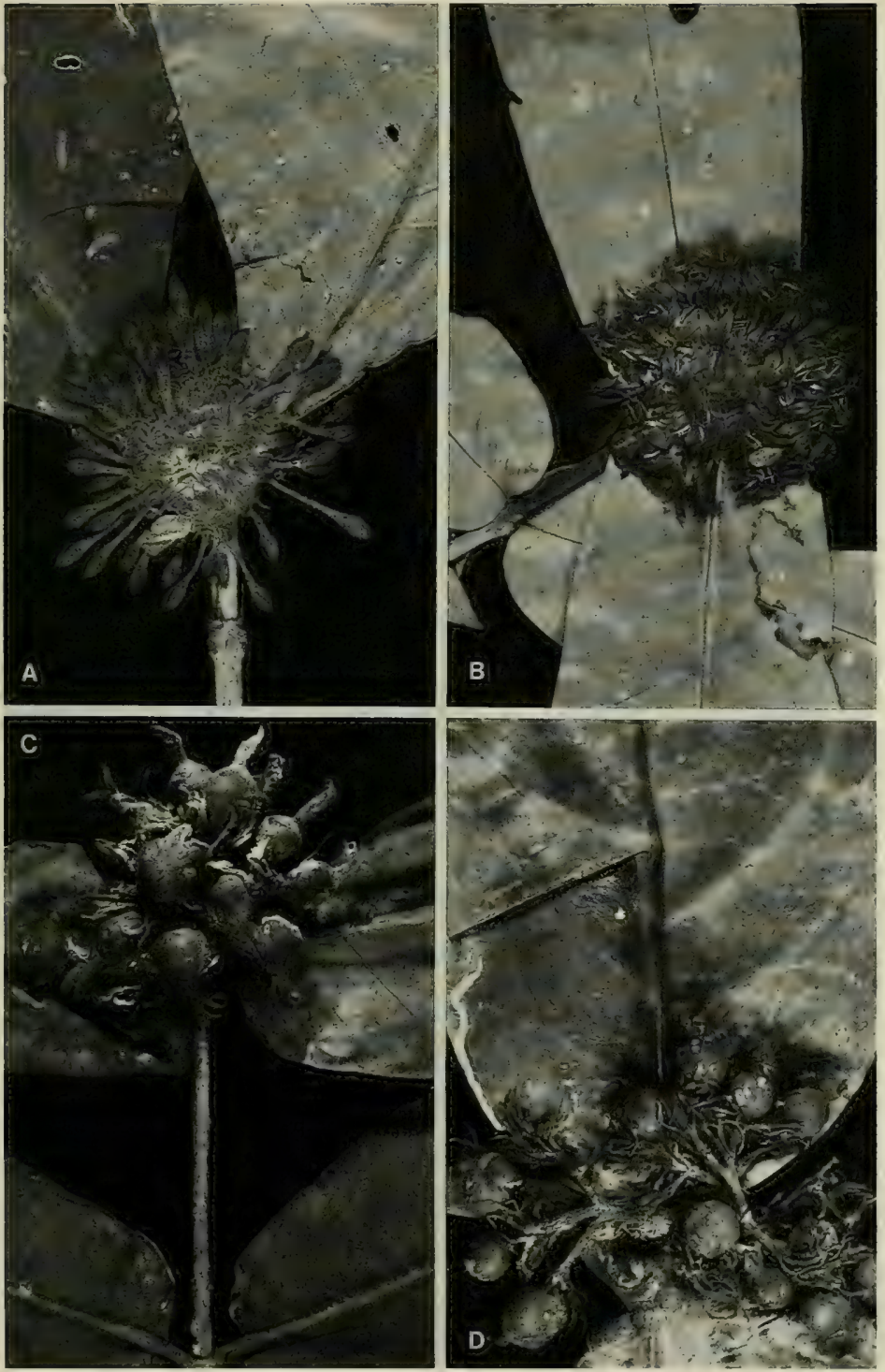
Distribution: Endemic to Fiji and thus far known only from Viti Levu, most frequently collected in the montane northern and western areas. Twenty-eight collections have been examined.

LOCAL NAMES AND USE: Names recorded from the vicinity of Nandarivatu are lera, salera, laumbu, and yasinggele; yasilemba has been noted from the Nausori Highlands. A tea from the bark is reported to be used to relieve elephantiasis.

RePresentative Collections: VITI LEVU: MBa: Upper slopes of Mt. Koromba, Smith 4631; southern slopes of Mt. Ndelainathovu, on escarpment west of Nandarivatu, Smith 4908; vicinity of Nandarivatu, Greenwood 887, Gillespie 3753, Degener 14682; hills between Nggaliwana and Nandala Creeks, south of Nauwangga, Smith 5816; Navai, $O$. \& $I$. Degener 32108. Nandronga \& Navosa: Nausori Highlands, $D F$ 1116 (Damanu 214), DA 11729, 12670 (Melville et al. 7046); Lombau, Singatoka Valley, O. \& I. Degener 32093; Uluvatu, vicinity of Mbelo, near Vatukarasa, Degener 15260. SERUA: Without further locality, $D A$ 12468 (DF 117, Bola 19).

12. Ixora pelagica Seem. Fl. Vit. 134. 1866; Drake, Ill. Fl. Ins. Mar. Pac. 195. 1890; Gillespie in Bishop Mus. Bull. 83: 31. fig. 39. 1931; Fosberg in Sargentia 1: 124. 1942; J. W. Parham, P1. Fiji Isl. 195. fig. 70, A. 1964, ed. 2. 276. fig. 82, A. 1972.

FIGURE 79C.

Psychotriacearum (gen. nov.) Seem. in Bonplandia 9: 257, p. p. 1861.

Ixora A. Gray in Proc. Amer. Acad. Arts 5: 319, p. p. 1862.

Ixora sp. nov. A. Gray in Bonplandia 10: 36, p. p. 1862; Seem. Viti, 437, p. p. 1862.

Shrub or slender tree $1.5-8 \mathrm{~m}$. high, found from near sea level to about $450 \mathrm{~m}$. in dense, dry, or open forest. The inflorescence has red or dull red bracts and bracteoles; the calyx is reddish or pink and sometimes green-tinged; the corolla is white to pale pink; and the fruits are noted as bright red. Flowers have been collected between December and May, fruits between March and November.

TyPifiCation: The type is Seemann 258, p. p. (K HOLOTYPE; ISOTYPE at BM), collected in July, 1860, at Port Kinnaird, Ovalau. Seemann inadvertently used his number 258 for two different species of Ixora, both subsequently described by him (1866) as new and both stated to be from Viti Levu. However, the K sheet of $I$. pelagica is definitely labelled as from Port Kinnaird, Ovalau, whereas the holotype of the second species, I. maxima (q. v.), of sect. Pavettopsis, is not labelled as to locality. Another specimen (Smith 7264) verifies the presence of I. pelagica on Ovalau. During July, 1860 (the date on the K sheets of both parts of Seemann 258), Seemann (1862) collected in southeastern parts of Viti Levu as well as on Ovalau.

Distribution: Abundant in southeastern Viti Levu at fairly low elevations, this Fijian endemic is also known from Kandavu and Ovalau. About 60 collections are at hand.

LOCAL NAMES AND USES: Recorded names are shindiolo (Serua), sulu (Naitasiri), lemba (Naitasiri and Kandavu), and yasilemba (Kandavu). The wood is hard, and sticks of it are used in digging yams, husking coconuts, etc.

RePresentative COlLeCtions: VITI LEVU: SerUA: Nathengathenga Creek, upper Navua River, $D A$ 14273; north of Korovou, St. John 18927; inland from Ngaloa, DA 16807; hills east of Navua River, near Nukusere, Smith 9116. Namosi: Vicinity of Namuamua, Gillespie 3065; hills east of Navua River, Greenwood 977. NAITASIRI: Waindrandra Creek, DA 785; Waimbau Creek, Sawani-Serea road, DA 11209; Tholo-i-suva, DA 13824 (DF 188); vicinity of Nasinu, Gillespie 3470. TAILEvu: Nukurua Creek, DA 1021; King's Road, Forest Reserve, DA 829. RewA: Near quarry beyond Lami, Gillespie 4593; Mt. Korombamba, DA 16510. KANDAVU: Mt. Mbuke Levu, Smith 232; Kiombo, DA 11928 (DF 8, Watkins 677); Naikorokoro, DA 13784 (DF 303). OVALAU: Hills east of Lovoni Valley, Smith 7264.

13. Ixora coronata A. C. Sm. in Bishop Mus. Bull. 141: 141. fig. 73. 1936; Fosberg in Sargentia 1: 124. 1942; J. W. Parham, Pl. Fiji Isl. 194. 1964, ed. 2. 273. 1972. 
A usually sparsely branched shrub 1-3 m. high, apparently infrequent in dense or open forest at elevations between sea level and $200 \mathrm{~m}$. The calyx is red and the corolla pink. Flowers have been obtained in January, February, and May; fruits only in May.

TYPIFICATION: The type is Smith 1718 (BISH HOLOTYPE; ISOTYPES at K, NY, P, US), collected May 7, 1934, in the lower Wainunu River Valley, Mbua Province, Vanua Levu.

Distribution: Endemic to Fiji and thus far known only from Vanua Levu, apparently uncommon in the southern parts of the island.

LoCAL NAME: Tui ni songanga (Mbua).

Available collections: VANUA LEVU: ThaKaundrove: Eastern drainage of Yanawai River, Degener \& Ordonez 14095, p. p. (A, UC, Us); along trail from Mbiangunu to Vemsi over Drayton Peak (Mt. Mariko) (presumably at low elevations), Bierhorst Fl46. The first of these two collections is a mixture of the present species and Tapeinosperma grande (Seem.) Mez (cf, vol. 2 of this Flora, p. 800); at least the BISH specimen represents the myrsinaceous species.

14. Ixora storckii Seem. Fl. Vit. 134. 1866; Drake, Ill. Fl. Ins. Mar. Pac. 195. 1890; J. W. Parham, Pl. Fiji Isl. ed. 2. 276. 1972.

Ixora sp. Seem. in Bonplandia 10: 296. 1862, Viti, 437. 1862.

A small tree 2-3 m. high, found in forest from near sea level to an elevation of about $150 \mathrm{~m}$. The inflorescences are characteristically borne on short, defoliate branchlets arising from the slender trunk or branches well below the foliage; the corolla is pale pink, or the tube may be essentially white. Flowers have been obtained between July and October, fruits between August and December.

TyPification: The type is Storck 894 (K HOLOTYPE), collected in December, 1860 , in fruit, at Port Kinnaird, Ovalau.

Distribution: Endemic to Fiji and known from southeastern Viti Levu and Ovalau; the type is the only available Ovalau collection.

Local NAME: Kau sulu (Storck, Ovalau).

AVAIl able Collections: VITI LEVU: NaITASIRI: Waimanu River, DA 15813; Central road, Tothill 525. 568: vicinity of Tamavua, Gillespie 2115. NAITASIRI or RewA: "Vicinity of Suva," Tothill 480, Meebold 16896. Rewa: 2 miles west of Veisari River, Vaughan 3305.

The remaining 14 species of Ixora in this treatment, all representing sect. Pavettopsis and all endemic, show nearly the degree of allopatric distribution that characterizes those of sects. Phylleilema and Vitixora. For instance, I. greenwoodiana is limited to the Mt. Evans Range of northwestern Viti Levu and I. tubiflora to Taveuni. Species with a coherent range of southeastern Viti Levu and Ovalau are I. storckii and I. arestantha. Ixora prolixa seems limited to the Loma-i-Viti and Lau Groups. Of species endemic to Vanua Levu, I. decora is known only from Mathuata on the north and $I$. myrtifolia only from the southwestern part of the island. Ixora harveyi is known only from Vanua Levu and adjacent Taveuni. The remaining species are either comparatively widespread within Fiji or are known from too few collections to permit conclusions; but in most cases they seem allopatric on a local, presumably ecological level.

15. Ixora carewii Horne ex Baker in J. Linn. Soc. Bot. 20: 364, as I. carewi. 1883.

Figure 80.

Ixora carewi Horne, A Year in Fiji, 263, nom. nud. 1881; Drake, Ill. Fl. Ins. Mar. Pac, 195. 1890; J. W. Parham, Pl. Fiji Isl. 194. 1964, ed. 2. 273. 1972.

Tree 2-9 m. high, usually slender and with a trunk to $6 \mathrm{~cm}$. in diameter, often freely branched, occurring in usually dense forest, sometimes along streams, or in crest thickets at elevations of $250-1,100 \mathrm{~m}$. The inflorescences are borne on defoliate branchlets arising from the trunk, branches, or branchlets well below the foliage, and the inflorescence branches are often reddish. The fragrant flowers have the calyx rich 
pink or reddish, the corolla tube reddish or rich pink and with somewhat paler lobes, the stamens with white filaments and pale yellow anthers, and the style white or pale yellow; fruits at maturity turn from green to red or deep purple. Flowers and fruits have been observed between April and November.

TyPification: The type is Horne 985 (K HOLOTYPE), collected in August, 1878, in the vicinity of Namboumbutho Creek, tributary of Wailoa River, upper Wainimala basin, Naitasiri Province, Viti Levu. This locality (spelled as "Babuca" by Horne) is the source of several of Horne's most interesting discoveries.

Distribution: Endemic to Fiji and known, with the exception of a single Vanua Levu collection, only from upland Viti Levu, mostly from central and northwestern parts of the island.

Available Collections: VITI LEVU: MBa: Mt. Evans Range, Greenwood 322B; eastern slopes of Mt. Koroyanitu, Mt. Evans Range, Smith 4240; slopes of Mt. Nairosa, eastern flank of Mt. Evans Range, Smith 4107; Nandarivatu, DA 10412; slopes and summit of Mt. Nanggaranambuluta, east of Nandarivatu, Greenwood 322 A, Tothill 359, Smith 4772, Parks 20576, Gillespie 3698, DA 10390. Namosi: Hills north of Wainavindrau Creek, between Korombasambasanga Range and Mt. Naitarandamu, Smith 8424 ; northern slopes of Korombasambasanga Range, in drainage of Wainavindrau Creek, Smith 8700 . NAITASIRI: Northern portion of Rairaimatuku Plateau, between Mt. Tomanivi and Nasonggo, Smith 5760; Mt. Nggoronggorotambuatini, near Nasonggo, $D A$ 15326; Wainivakindau Creek, Waimanu River tributary, DA 15405; Wainamu region, "SE. Nasele," DA 15443. VANUA LEVU: THAKAUNDRove: Track to Mt. Nasorolevu, DA 17145. Fiji without further locality, Greenwood 322, Gillespie 4363, DA L.14185.
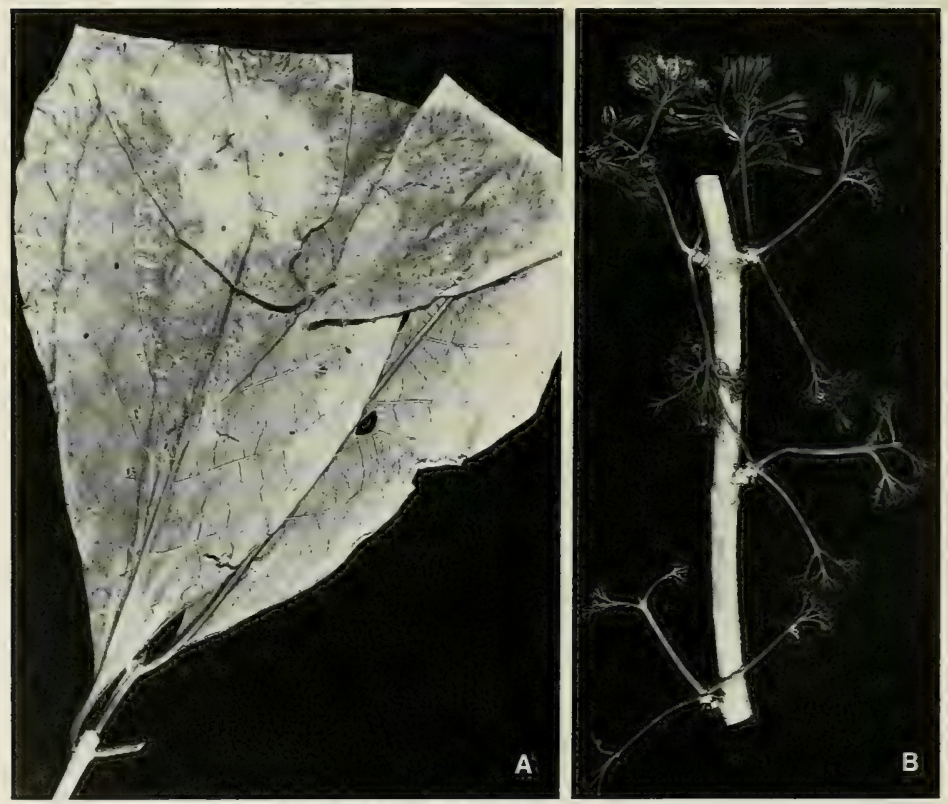

FIGURE 80. Ixora carewii; A, foliage, $\times 1 / 3$; B, inflorescences on lateral branchlets borne well below foliage, $\times 1 / 3$. A from Parks 20576, B from $D A 15443$. 

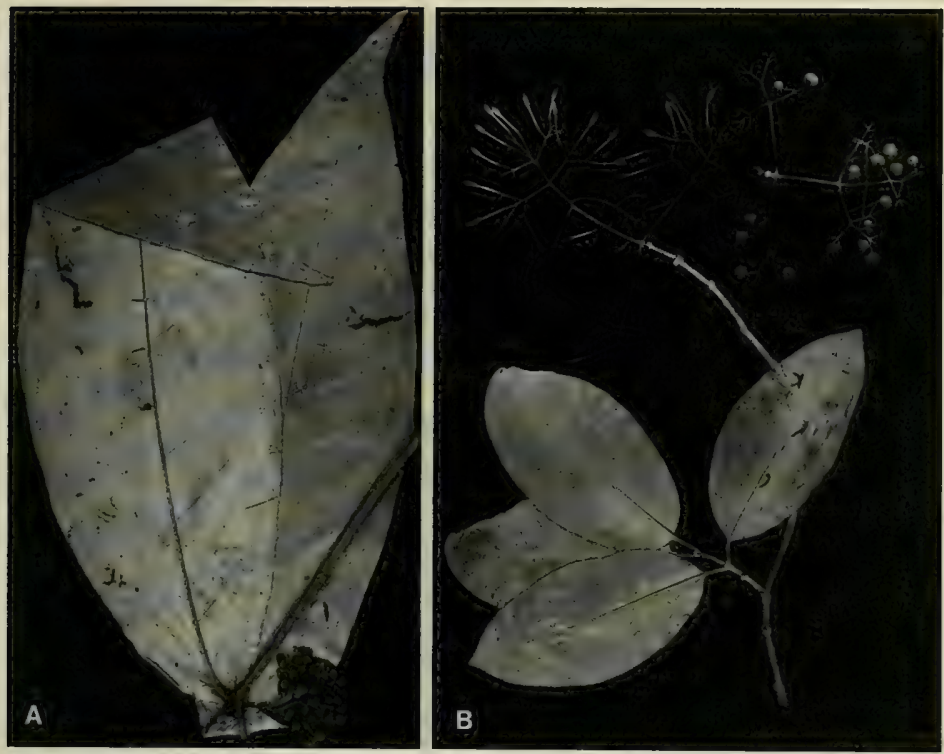

FIGURE 81. A, Ixora maxima; foliage and an infructescence, x 1/4. B, Ixora prolixa; branchlet with foliage and an immature inflorescence, and a detached infructescence, $\times 1 / 4$. A from Smith $945, \mathrm{~B}$ from Smith 1435.

16. Ixora maxima Seem. Fl. Vit. 134. 1866; Drake, Ill. Fl. Ins. Mar. Pac. 195. 1890; J. W. Parham, Pl. Fiji Isl. 194. 1964, ed. 2. 274. 1972. Figures 81 A, 82A, 83A. Psychotriacearum (gen. nov.) Seem. in Bonplandia 9: 257, p. p. 1861.

Ixora A. Gray in Proc. Amer. Acad. Arts 5: 319, p. p. 1862.

Ixora sp. nov. A. Gray in Bonplandia 10: 36, p. p. 1862; Seem. Viti, 437, p. p. 1862.

A slender tree or shrub $2-10 \mathrm{~m}$. high, occurring in forest or on its edges or in forest patches in open country at elevations of $100-400 \mathrm{~m}$. The calyx is dull red, the corolla white and pink-tinged, and the fruits are black at maturity. Flowers have been obtained between October and December, fruits in most months.

TYPIFICATION: The type is Seemann 258, p. p. (K HOLOTYPE), collected in fruit in July, 1860, in Fiji without further locality. The number 258 was used for two different species of Ixora, the other being I. pelagica (q. v.). The type sheet of $I$. pelagica is labelled as from Ovalau. During July, 1860, Seemann could have obtained the type specimen of $I$. maxima from either Ovalau or southeastern Viti Levu; no other collections of the species are at hand from Ovalau, but from its known distribution $I$. maxima may definitely be anticipated to occur there.

Distribution: Endemic to Fiji and now known from southeastern Viti Levu, Koro, and northern Vanua Levu.

Available Collections: VITI LEVU: Naitasiri-Rewa boundary: Mt. Kombalevu, Parks 20333. RewA: Mt. Korombamba, Parks 20114, 20149, 20153, 20351. KORO: Eastern slope of main ridge, Smith 
945, 1006. VANUA LEVU: Mathuata: Vicinity of Nanduri, Tothill 453; Natindoyanga Creek, Korovuli River tributary, DA 17261 ; Seanggangga Plateau, in drainge of Korovuli River, vicinity of Natua, Smith 6687, 6893, 6897; Seanggangga Agricultural Station, DA 12273; Wainikoro River, Greenwood 688. Thakaundrove: Ngasauva, Undu Point, DA 12939, 13481. Fivi without further locality, Horne 108, 431, 462.
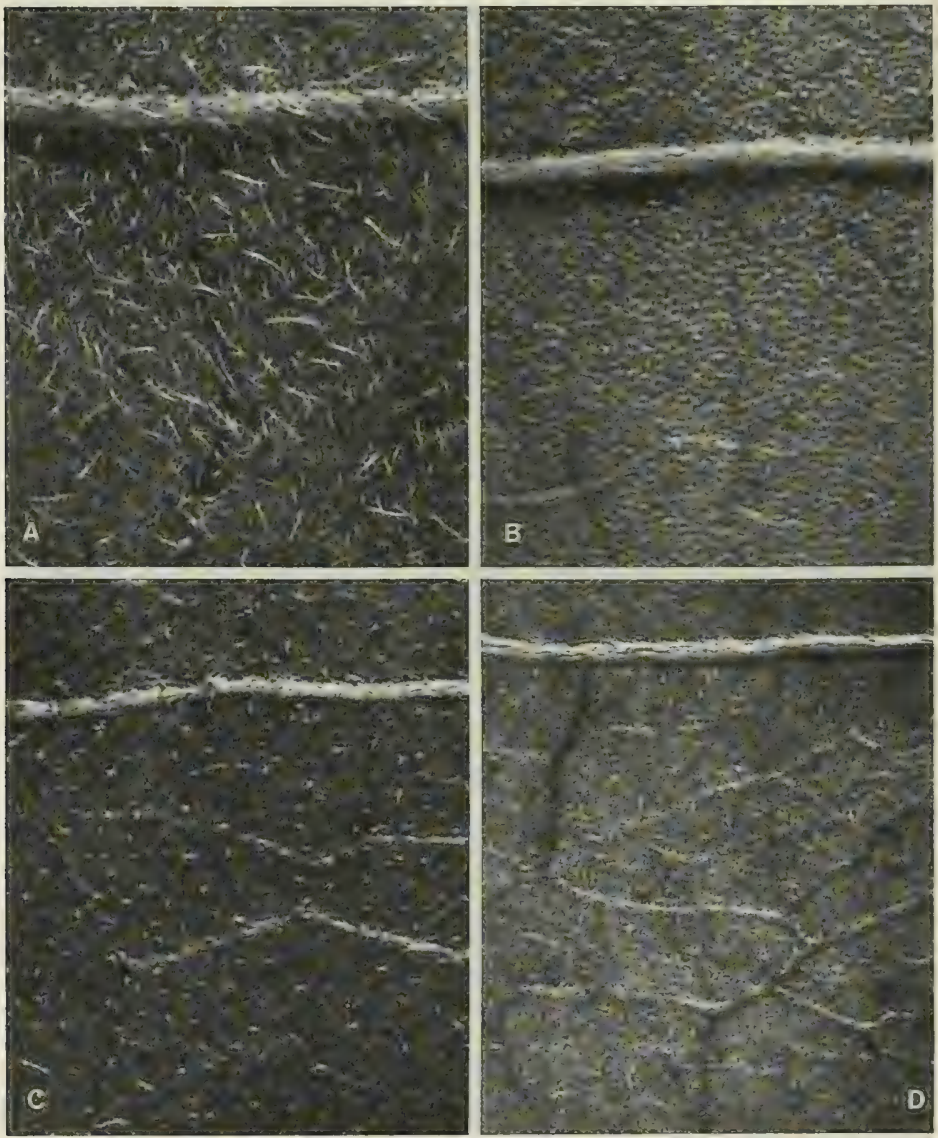

FiguRE 82. Lower surfaces of leaf blades showing a secondary nerve and indument (if present), all $\times 10$. A, Ixora maxima, from Smith 6897. B, Ixora pubifolia, from Smith 835. C, Ixora arestantha, from Smith 9552. D, Ixora harveyi, from Smith 6417. 
17. Ixora pubifolia A. C. Sm. in Bishop Mus. Bull. 141: 145. fig. 76. 1936; J. W. Parham, Pl. Fiji Isl. 195. 1964, ed. 2. 276. 1972.

Figures $82 \mathrm{~B}, 83 \mathrm{~B}$.

Shrub or small tree $1-5 \mathrm{~m}$. high, occurring at elevations of $40-400 \mathrm{~m}$. in dense or open forest. The calyx is reddish, the corolla white, and the fruit turning from greenish to red. Flowers and fruits have been obtained between November and February.

TYPIFICATION: The type is Smith 352 (BISH HOLOTYPE; ISOTYPES at K, NY, P, US), collected Nov. 9, 1933, in low hills south of Nakula Valley, east of Savusavu, Thakaundrove Province, Vanua Levu.

Distribution: Endemic to Fiji but apparently limited, known only from southeastern Vanua Levu and a single collection from southeastern Viti Levu.

Available collections: VITI LEVU: Naitasiri or Rewa: "Vicinity of Suva," Tothill 480. VANUA LEVU: ThaK Aundrove: Savuthuru Mt., near Valethi, Degener \& Ordonez 13844; Vatunivuamonde Mt., Savusavu Bay region, Degener \& Ordonez 13970; peninsula near Savusavu, Bierhorst F33; hills west of Mbutha Bay, Natewa Peninsula, Smith 835.

18. Ixora greenwoodiana A. C. Sm. in J. Arnold Arb. 34: 102. 1953; J. W. Parham, Pl.

Fiji Isl. 194. 1964, ed. 2. 274. 1972.

A slender tree or shrub $3-10 \mathrm{~m}$. high, found in dense forest at elevations of $750-1,150 \mathrm{~m}$. The corolla in advanced bud is deep red, and fruits are pink to red. Flowers have been obtained between October and January, fruits in April, May, and October.

TYPIFICATION: The species is typified by Smith 4249 (A HOLOTYPE; many ISOTYPES), collected May 2, 1947, in fruit, on the eastern slopes of Mt. Koroyanitu, Mt. Evans Range, Mba Province, Viti Levu.

Distribution: Endemic to Fiji and thus far known only from the isolated Mt. Evans Range of northwestern Viti Levu.

Available Collections: VITI LEVU: Mba: Mt. Evans Range, Greenwood 436, 939, DA 14171; Mt. Mbotilamu, Mt. Evans Range, DA 14164; Mt. Lomolomo Levu, Mt. Evans Range, DA 14047.

19. Ixora arestantha A. C. Sm. in Contr. U. S. Nat. Herb. 37:92. 1967; J. W. Parham, Pl. Fiji Isl. ed. 2. 273. 1972.

Figures $82 \mathrm{C}, 83 \mathrm{C}$.

Shrub or slender tree 2-12 m. high, with the trunk to $15 \mathrm{~cm}$. in diameter, found in dense or dry forest at elevations of $50-400 \mathrm{~m}$. The inflorescence branches and calyx are deep pink to bright red; the corolla has a greenish to pale pink tube and white to deep pink lobes; and the fruits are rich pink or deep red. Flowers have been obtained between October and December, fruits in April and May.

TYPIFICATION: The type is Smith 8941 (Us 2191555 HOLOTYPE; many ISOTYPES), obtained Oct. 15, 1953, in hills east of the Wainikoroiluva River, near Namuamua, Namosi Province, Viti Levu.

Distribution: Endemic to Fiji and now known from southeastern Viti Levu and Ovalau.

Available COllections: VITI LEVU: Serua: Vatutavathe, vicinity of Ngaloa, Degener 15199; inland from Ngaloa, DA 16563, 16569; hills between Waininggere and Waisese Creeks, between Ngaloa and Wainiyambia, Smith 9552. NamosI: Vicinity of Namuamua, Gillespie 3253; hills east of Navua River, Greenwood 988. NaITASIRI: Vicinity of Nasinu, Gillespie 3508, 3592. OVALAU: Hills southeast of valley of Mbureta River, Smith 7461.

20. Ixora myrsinoides A. C. Sm. in J. Arnold Arb. 34: 101. 1953; J. W. Parham, Pl. Fiji Isl. 194. 1964, ed. 2. 274. 1972.

Figure 84A.

An apparently rare tree to $8 \mathrm{~m}$. high, found in dense forest at an elevation of $750-900 \mathrm{~m}$. The corolla is white, with the lobes faintly pink-tinged, and the fruits become purple at maturity. Flowers and fruits were noted in May. 
TYPIFICATION: The species is typified by Smith 4529 (A HOLOTYPE; many ISOTYPES), collected May 27, 1947, on the northern slopes of Mt. Namendre, east of Mt. Koromba, Mba Province, Viti Levu.

Distribution: Endemic to Fiji and thus far known only from the type collection, which is the only material of Ixora at hand from the isolated Koromba Range of western Viti Levu.

21. Ixora tubiflora A. C. Sm. in Bishop Mus. Bull. 141: 144. fig. 75. 1936; J. W. Parham, Pl. Fiji Isl. 195. 1964, ed. 2. 276. 1972.

FIGURE 83D.

Ixora elegans sensu Gillespie in Bishop Mus. Bull. 74: 31, quoad spec. Taveun. 1930; non sensu typi.

Shrub or tree 3-7 m. high, occurring in dense forest at an elevation of $700-1,240 \mathrm{~m}$. The corolla is noted as white and the anthers as yellow. Flowers were obtained in December and January, fruits in March.

TYPIFICATION: The type is Smith 856 (BISH HOLOTYPE; many ISOTYPES), collected Dec. 29, 1933, on borders of the lake east of Somosomo, Taveuni.

Distribution: Endemic to Fiji and known only from Taveuni.

Available Collections: TAVEUNI: Summit ridge, trail above Somosomo, Gillespie 4835; borders of lake east of Somosomo, Smith 918; summit of Mt. Uluingalau, Smith 900.

22. Ixora harveyi (A. Gray) A. C. Sm. in Bishop Mus. Bull. 141: 144. 1936; J. W. Parham, Pl. Fiji Isl. 194. 1964, ed. 2. 274. 1972. Figures 82D, 83E, 84C.

Stylocoryne harveyi A. Gray in Proc. Amer. Acad. Arts 4: 309. 1859; Seem. Viti, 438. 1862, FL. Vit. 124. 1866, op. cit. 429. 1873.

Randia harveyi Benth. \& Hook. f. ex Drake, Ill. Fl. Ins. Mar. Pac. 191.1890.

Shrub or small tree 1-6 m. high, usually slender, obtained in dense forest or in dense crest thickets at elevations of $100-1,030 \mathrm{~m}$. The calyx is red or pink, the corolla white or with a pinkish tube, and the fruits turn from green to red. Flowers were observed in October and November, fruits between August and March.

TYPIFICATION: The type is Harvey (K LECTOTYPE here designated; ISOLECTOTYPES at BM, GH), collected in 1855 (between August and November; cf. this Flora, vol. 1, p. 43) in the vicinity of Nandi, Mbua Province, Vanua Levu. Gray did not indicate a depository; the $\mathrm{K}$ and GH sheets are equally good and both are annotated by Gray.

Distribution: Endemic to Fiji and known only from Vanua Levu and Taveuni.

LOCAL NAME: Tomitomi (Thakaundrove).

available collections: VANUA LEVU: Mathuata: Southern base of Mathuata Range, north of Natua, Smith 6772; Korovuli River, DA 12878; Serau, DA 13921; Wainggili sawmill, Lambasa District, DF 246 (Bola 94); summit ridge of Mt. Numbuiloa, east of Lambasa, Smith 6417, 6419; Wainikoro River, Greenwood 693. ThaKaundRove: Eastern drainage of Yanawai River, Degener \& Ordonez 14101; southern slope of Korotini Range, below Navitho Pass, Smith 506; summit of Mt. Mbatini, Smith 700. TAVEUNI: Hills east of Somosomo, west of old crater occupied by small swamp and lake, Smith 8402.

Ixora harveyi normally has the calyx completely glabrous; two Thakaundrove specimens (Smith 506, 700) have scattered-puberulent calyces but are otherwise indistinguishable.

23. Ixora elegans Gillespie in Bishop Mus. Bull. 74: 30. fig. 41. 1930; J. W. Parham, Pl. Fiji Isl. 194. 1964, ed. 2. 273. 1972. Figures 83F, 84D.

Figure 83. A, Ixora maxima; cluster of calyces, $\times 8$. B, Ixora pubifolia; cluster of calyces, $\times 8$. C, Ixora arestantha; cluster of calyces, $\times 8$. D, Ixora tubiflora; flowers, showing calyces and corolla buds, $\times 8$. E, Ixora harveyi; cluster of calyces, $\times 8$. F, Ixora elegans; flowers, showing calyces and proximal portions of young corollas, $\times 8$. A from Smith 6687, B from Degener \& Ordonez 13970, C from Degener 15199, D from Smith 900 , E from $D F 246$, F from Smith 9535. 

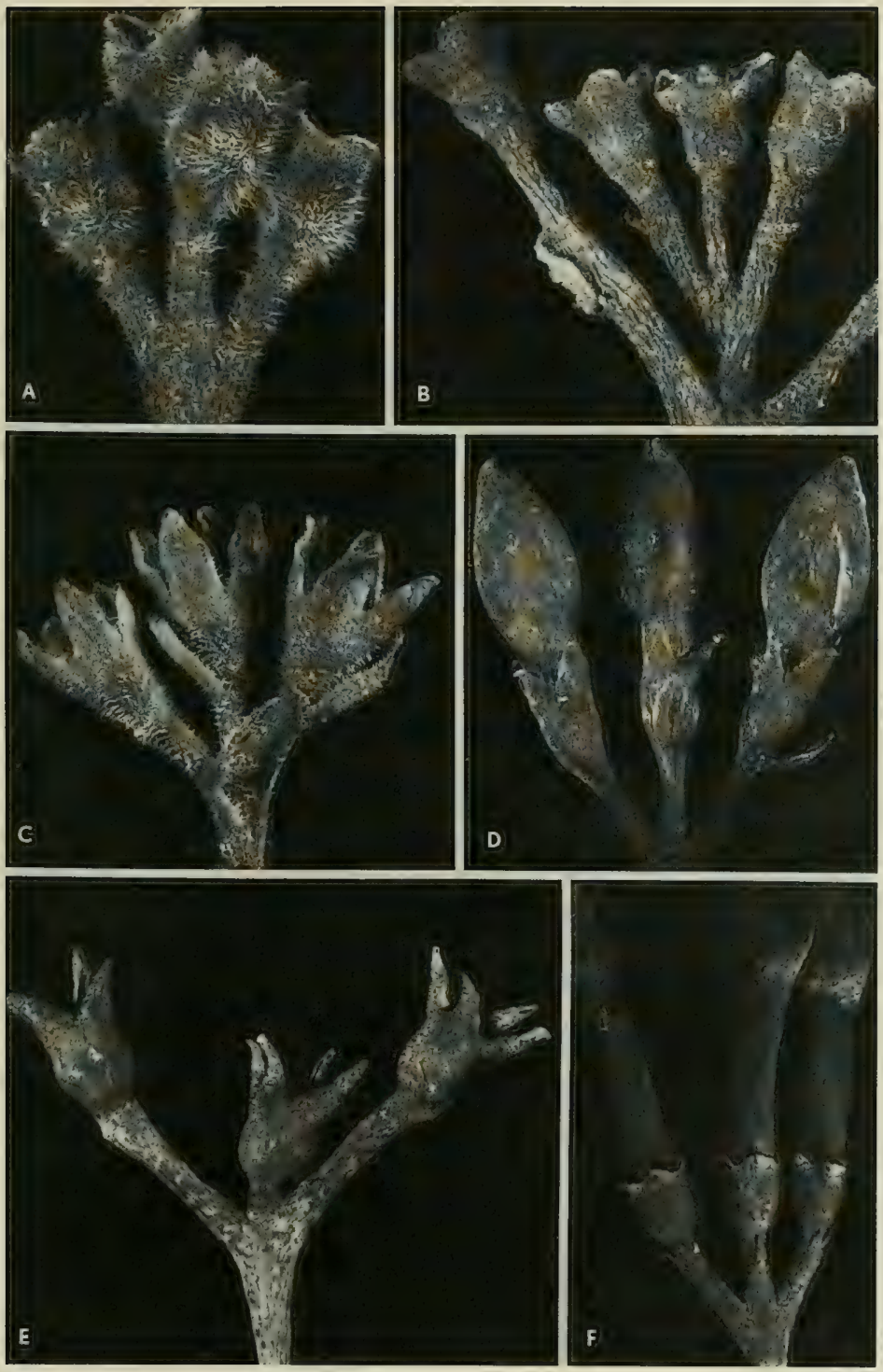
Shrub or small tree, often slender, 3-10 m. high, occurring in dense, dry, or open forest from near sea level to an elevation of $1,000 \mathrm{~m}$. The inflorescence branches and calyx are reddish brown; the fragrant flowers have the corolla yellowish white, tinged with pink; and the young green to yellow fruits become red at maturity. Flowers have been obtained in every month between September and May, fruits in months scattered throughout the year.

TYPIFICATION: The species is based on Gillespie 3526 (BISH HOLOTYPE; ISOTYPES at BISH, K), collected Oct. 24, 1927, in the vicinity of Nasinu, Naitasiri Province, Viti Levu.

Distribution: Endemic to Fiji, with a somewhat broader distribution than characteristic of Ixora in the archipelago, being known from four of the high islands. It is the only species of sect. Pavettopsis thus far recorded from Kandavu.

LoCAL NAMES: Maletawa (Kandavu), motomoto (Thakaundrove).

AVailable Collections: VITI LEVU: MBA: Vicinity of Nandarivatu, Degener 14335; Mt. Nanggaranambuluta, east of Nandarivatu, Greenwood 868; Nauwangga, south of Nandarivatu, Degener 14694; Mt. Tomanivi, DA 12684 (Melville et al. 7062). NANDrongA \& Navosa: Nausori Highlands, DA 13881. SERUA: Hills between Waininggere and Waisese Creeks, between Ngaloa and Wainiyambia, Smith 9369, 9535. Namosi: Wairoro Creek, DA 3423; Nambukavesi Creek, DF 535 (Vaisewa 1). REwA: Track to Mt. Korombamba, DA 16984. KANDAVU: Hills above Namalata and Ngaloa Bays, Smith 168, 170; Naikorokoro (or Kiombo), DA 13843 (Damanu 3); near Ndaku, DA 2958; Kandavu without further locality, $D A$ 11950 (Watkins 699). OVALAU: Hills southeast of valley of Mbureta River, Smith 7451. VANUA LEVU: ThaKaundrove: Natewa Peninsula, hills south of Natewa, Smith 1952; Navonu Creek, Natewa Peninsula, DA 15225 .

24. Ixora prolixa A. C. Sm. in Contr. U. S. Nat. Herb. 37: 93. 1967; J. W. Parham, P1. Fiji Isl. ed. 2. 276. 1972.

Figures $81 \mathrm{~B}, 84 \mathrm{~B}$.

Shrub or tree 5-10 m. high, found in sometimes dense forest, often on limestone, from near sea level to about $500 \mathrm{~m}$. The inflorescence branches and calyx are pink, the corolla white, pinkish at base, the filaments white, and the fruits red or eventually brown. Flowers have been collected in March and September, fruits in scattered months.

TYPIFICATION: The type is Bryan 548 (BISH HOLOTYPE), collected in flower and fruit Sept. 11, 1924, in the central forest of Tuvutha, in the Lau Group.

Distribution: Endemic to Fiji and now known from scattered islands in the Loma-i-Viti and Lau Groups, being the only member of sect. Pavettopsis known to occur in Lau.

AVAILABLE COLLEctions: KORO: Eastern slope of main ridge, Smith 969. NGAU: Slopes of Mt. Ndelaitho, on northern spur toward Navukailangi, Smith 7879. VANUA MBALAVU: Namalata Islet, southern limestone section, Smith 1435. NAYAU: In woods at foot of cliff, Tothill 284.

25. Ixora decora A. C. Sm. in J. Arnold Arb. 34: 100. 1953; J. W. Parham, Pl. Fiji Isl. 194. 1964, ed. 2. 273. 1972.

An apparently rare small tree 2-4 m. high, known from open or secondary forest at elevations of $100-350 \mathrm{~m}$. Although the species is well distinguished by vegetative and calycine characters, flowers are unknown. The fruits, red or crimson, have been obtained in May and October.

TYPIFICATION: The type is Smith 6376 (A HOLOTYPE; many ISOTYPES), collected Oct. 27, 1947, on the northern slope of Mt. Numbuiloa, east of Lambasa, Mathuata Province, Vanua Levu.

Distribution: Endemic to Fiji and to hills near the Mathuata coast; the second known collection has no precise locality but could have been obtained in essentially the type locality.

Available collection: VANUA LEVU: Mathuata: Hills near Mathuata coast, Greenwood 666. 

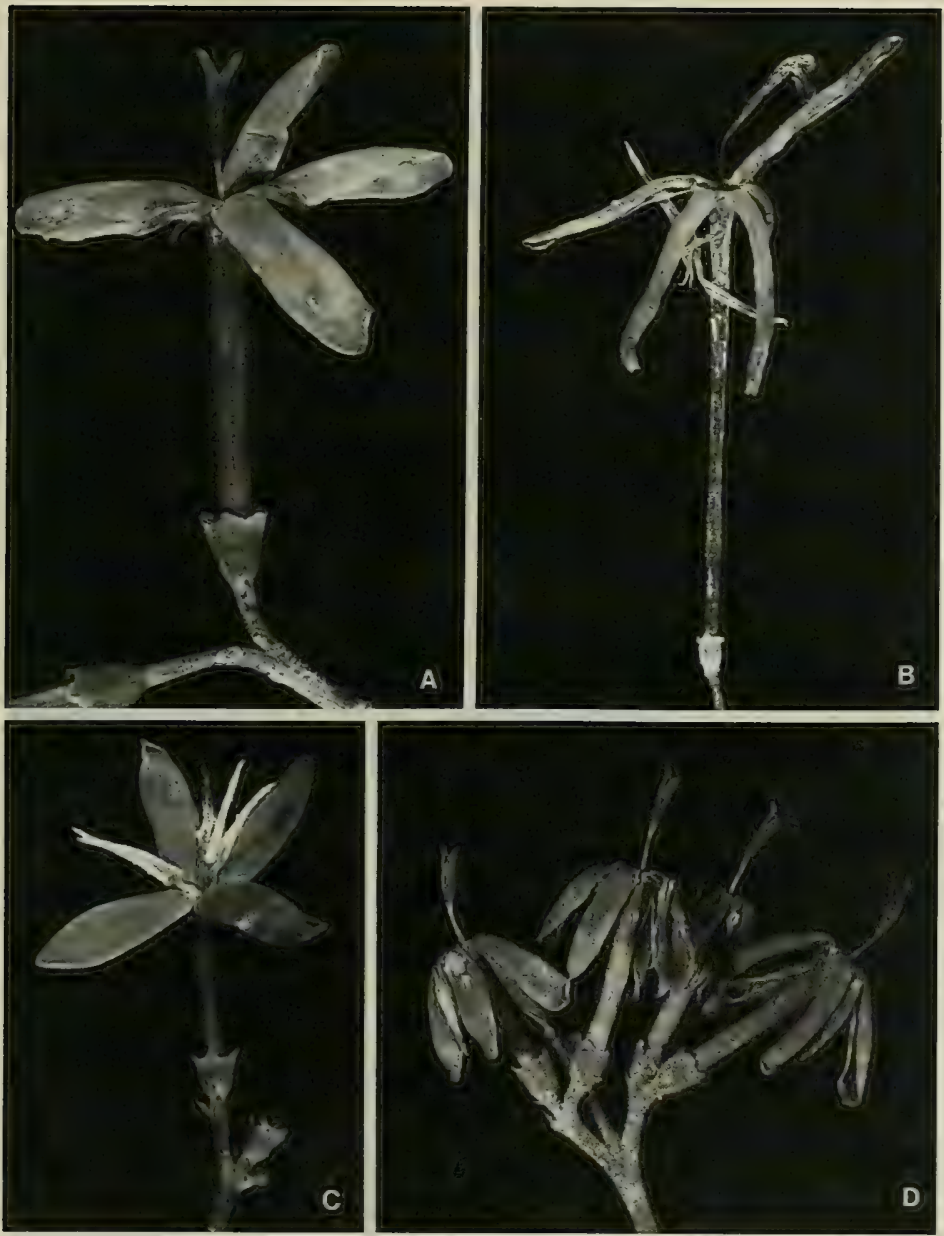

Figure 84. A, Ixora myrsinoides; flower, the deciduous anthers missing, $\times 3$. B, Ixora prolixa; flower, showing elongate style, 2 anthers persisting, $\times 3$. C, Ixora harvey $i$; flower with exserted anthers, the stigmatic surfaces still appressed to one another, $\times 4$. D, Ixora elegans; cluster of flowers, a few withered anthers persisting, the stigmatic surfaces separating, $\times 4$. A from Smith 4529, B from Bryan 548, C from Smith 506, D from Degener 14694. 
26. Ixora myrtifolia A. C. Sm. in Bishop Mus. Bull. 141: 142. fig. 74. 1936; J. W. Parham, Pl. Fiji Isl. 195. 1964, ed. 2. 274. 1972.

An apparently rare shrub about $3 \mathrm{~m}$. high, found in forest or "woods" at an elevation of 100-350 m. The type collection bore old flowers and red fruits in April, the second, undated collection has immature flowers; however, the species is very distinct on the basis of vegetative and calycine characters.

TyPIFICATION: The type is Smith 1550 (BISH HOLOTYPE; many ISOTYPES), collected April 20,1934, in the southern portion of the Seatovo Range, Mbua Province, Vanua Levu.

Distribution: Endemic to Fiji and known only from southwestern Vanua Levu. LOCAL NAME: Tukutuku.

Available Collection: VANUA LEVU: Mbua: Woods above Nandi, Milne 445.

27. Ixora bullata Turrill in J. Linn. Soc. Bot. 43: 25. 1915; A. C. Sm. in J. Arnold Arb. 34: 103. 1953; J. W. Parham, Pl. Fiji Isl. 194. 1964, ed. 2. 273. 1972.

An apparently infrequent shrub or slender tree (1.5-) 2-4 m. high, found in dense forest at elevations of 150-590 m. The bracts of young, compact inflorescences are deep red, the corollas are white, and the fruits are red. Mature flowers have been obtained in April and July, young inflorescences in October, and fruits only in April.

TyPification: The type is im Thurn 359, p. p. (K HOLOTYPE), obtained July 28, 1907, in the vicinity of Tholo-i-suva, Naitasiri Province, Viti Levu. Im Thurn also assigned to his number 359 a specimen of Tapeinosperma ligulifolium (Myrsinaceae; cf. this Flora, vol. 2, p. 798), from the same locality but with a different date. The two species are surprisingly similar in foliage at first glance. It is also an astonishing coincidence that both species, in spite of their rarity, are known from the same locality in Mathuata Province. Im Thurn's number 359 was used still a third time for a collection of Ophiorrhiza leptantha (Rubiaceae).

Distribution: Endemic to Fiji but with a scattered distribution, known from three of the high islands.

Available collections: VANUA LEVU: Mathuata: Summit ridge of Mt. Numbuiloa, east of Lambasa, Smith 6414. THAKAundrove: Vicinity of Korotasere, Natewa Bay, DA 15500 . RAMBI: In mountains, Horne s. $n$.

19. Coffea L. Sp. Pl. 172. 1753; Hiern in Oliver, Fl. Trop. Afr. 3: 179. 1877; K. Schum. in Engl. \& Prantl, Nat. Pflanzenfam. IV. 4: 104. 1891; A. Chev. Caféiers du Globe 1: 69. 1929, op. cit. 3:117. 1947; R. Coste, Caféiers et Cafés dans le Monde 1: 16. 1955; Backer \& Bakh. f. Fl. Java 2: 321. 1965; Purseglove, Trop. Crops, Dicot. 458. 1968.

Shrubs or small trees, the stipules interpetiolar; inflorescences axillary in both axils of a leaf pair, cymose; flowers $\Varangle$, the calyx truncate to dentate; corolla infundibular to hypocrateriform, white to pinkish, glabrous in throat, $(4$ or $) 5-9(-12)$-lobed, the lobes contorted in bud; stamens usually equalling corolla lobes in number, inserted in throat, the anthers dorsifixed, exserted; stigma bilobed, exserted; fruit drupaceous, 2-seeded, red to orange or sometimes black at maturity.

TYPE SPECIES: Coffea arabica L., the only original species.

Distribution: Indigenous throughout most of tropical Africa and Madagascar, but cultivated in virtually all tropical regions as well as in the temperate zone under glass. Coffee had been studied for more than two centuries before Linnaeus described the genus, and by the early part of the present century some 190 species had been 
described. Chevalier (1947) estimated the genus to comprise about 70 species; subsequent investigations reduced the number to about 60 species (Chinnappa and Warner, 1981), but recent studies of the East African flora have revealed a number of previously undescribed taxa (Bridson, 1982). The taxonomy of Coffea is far from settled; Bridson (1982, p. 817) states: "Since most of the characters separating the species of Coffea are generally weak and variable and so many taxa are imperfectly known, definite opinions on the relationships between species can only be made with difficulty." Artificially produced varieties have added to the taxonomic complexity of the cultivated species, no fewer than 40 cultivars of $C$. arabica being known in addition to others in different species (Chinnappa and Warner, 1981, p. 222). The three most widely cultivated species, all assigned to sect. Coffea (sect. Eucoffea, nom. inadmis.) by Chevalier (1947), are represented in Fiji.

Useful treatments of genus: Chevalier, A. Les Caféiers du Globe 1 (in Lechevalier, Encycl. Biologique 5: 1-196). 1929; 2 (in op. cit. 22: 1-36. pl. 1-158). 1942; 3 (in op. cit. 28: 1-356). 1947. CosTE, R. Les Caféiers et les Cafés dans le Monde 1. 1955; 2. 1961. Wellman, F. L. Coffee: Botany, Cultivation and Utilization. 1961. Chinnappa, C. C., \& B. G. WARner. Pollen morphology in the genus Coffea (Rubiaceae) and its taxonomic significance. Bot. J. Linn. Soc. 83: 221-236. 1981. BrIDSON, D. M. Studies in Coffea and Psilanthus (Rubiaceae subfam. Cinchonoideae) for part 2 of 'Flora of Tropical East Africa': Rubiaceae. Kew Bull. 36: 817-859. 1982. Clifford, M. N., \& K. C. Willson (eds.). Coffee: Botany, Biochemistry and Production of Beans and Beverage. 457 pp. AVI Publ., Westport, Conn. 1985.

\section{KEY TO SPECIES}

Leaf blades acuminate or sometimes acute at apex; stipules acute to distinctly aristate; fruits to $20 \mathrm{~mm}$. long, ovoid, ellipsoid, or cylindric, rarely subglobose; corolla lobes 5-7.

Leaf blades mostly 5-20 × 1-8 cm.; inflorescences with bracteoles to $5 \mathrm{~mm}$. long, the calyces well exserted;

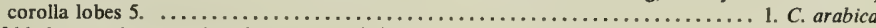

Leaf blades mostly more than $20 \times 10 \mathrm{~cm}$; inflorescences with bracteoles to $22 \mathrm{~mm}$. long, the calyces

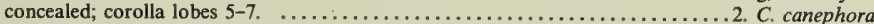

Leaf blades $15-35 \times 6-15 \mathrm{~cm}$, obtuse to rounded or bluntly acuminate at apex; stipules obtuse or occasionally acute, rarely apiculate; fruits to $30 \mathrm{~mm}$. long, subglobose; corolla lobes 6-I1; inflorescences with bracteoles truncate and shorter than calyces. ..................

1. Coffea arabica L. Sp. Pl. 172. 1753; Seem. Fl. Vit. 430. 1873; Hiern in Oliver, Fl. Trop. Afr. 3: 180. 1877; Drake, Ill. Fl. Ins. Mar. Pac. 195. 1890; Rechinger in Denkschr. Akad. Wiss. Wien 85: 370. 1910; A. Chev. Caféiers du Globe 1: 71. fig. 5, 8-10. 1929, op. cit. 2: pl. 17-24. 1942, op. cit. 3: 196. 1947; Guillaumin in J. Arnold Arb. 13: 8. 1932; Yuncker in Bishop Mus. Bull. 178: 112. 1943; J. W. Parham in Agr. J. Dept. Agr. Fiji 19: 101. 1948; R. Coste, Caféiers et Cafés dans le Monde 1: 16. pl. II, V, VII (3), VIII-X. 1955; Yuncker in Bishop Mus. Bull. 220: 251. 1959; J. W. Parham, PI. Fiji Isl. 189. 1964, ed. 2. 267. 1972; Purseglove, Trop. Crops, Dicot. 459. fig. 73. 1968; Sykes in New Zealand Dept. Sci. Indust. Res. Bull. 200: 175. 1970; MacKee, Pl. Intro. Cult. Nouv.-Caléd. 117. 1985.

As seen in Fiji, Coffea arabica is a tree to $4 \mathrm{~m}$. high (to $10 \mathrm{~m}$. where indigenous) cultivated and sparingly naturalized along roads and in forest along creeks from near sea level to an elevation of $900 \mathrm{~m}$. The corolla is white and the fruit red. Our specimens were in flower between September and November and in fruit between February and November.

TYPIFICATION: Linnaeus cited a number of prior references, but we have not noted a lectotypification.

Distribution: Africa, in southeastern Sudan, southwestern Ethiopia, and northern Kenya (Bridson, 1982, p. 817); the most widespread species of Coffea in cultivation, already well established and naturalized in Fiji at the time of Seemann's visit in 1860. 
LOCAL NAMES AND USE: Arabian coffee or kofe. This is by far the most frequently cultivated species of the genus, with numerous varieties and forms that are mostly not given formal taxonomic recognition. Although it is widely grown in Fiji experimentally, or perhaps even for local usage, it is presumably not yet of commercial potential.

AVAIlable Collections: VITI LEVU: MBA: Mountains near Lautoka, Greenwood 1219; Nandi, DA 11707; forest along creek near Nalotawa, eastern base of Mt. Evans Range, Smith 4437; vicinity of Nandarivatu, Gillespie 3835, 3976; Nandala, south of Nandarivatu, Degener 14722. NANDRONGA \& NavOSA: Nausori Highlands, DA 11723; old village site near Tonuve, Singatoka Valley, H. B. R. Parham 195; old village of Mbemana, Singatoka Valley, H. B. R. Parham 205. Namosi: Naloka, track to Namosi, DA 11637; vicinity of Namosi, Gillespie 2514. NAITASIRI: Cocoa Station, Nanduruloulou, DA 12173, 15600. VITI LEVU without further locality, Parks 20166.

2. Coffea canephora Pierre ex Froehner in Notizbl. Bot. Gart. Berlin 1: 237. 1897; A. Chev. Caféiers du Globe 1:82. fig. 14, 15. 1929, op. cit. 2:pl. 28-39. 1942, op. cit. 3: 186. 1947; R. Coste, Caféiers et Cafés dans le Monde 1:23.pl. I (1, 2), III (2, 3), IV, VI (1), VII (1, 2). 1955; J. W. Parham, Pl. Fiji Isl. 189. 1964, ed. 2. 267. 1972; Purseglove, Trop. Crops, Dicot. 482. fig. 74. 1968; MacKee, Pl. Intro. Cult. Nouv.-Caléd. 118, 1985.

In Fiji Coffea canephora is sparingly cultivated near sea level as a tree 4-5 m. high (to $8 \mathrm{~m}$. where indigenous). The very fragrant flowers have white corollas and have been noted only in August.

TYPIfiCation: The type was originally cited as "Gabun (Herb. L. Pierre n. 247)." Chevalier (1947, p. 188), among various localities and collections, cites: "Gabon: . . . pays Eschiras, origine du type! (Klaine 247 et 1775, récolté en avril 1895!)."

Distribution: Widespread and with many local varieties from western and central Africa to Sudan, Uganda, and Tanzania; cultivated elsewhere.

LOCAL NAME AND USE: Robusta coffee was probably introduced comparatively recently and is sparingly grown experimentally in Fiji. Cultivars of the species, although resistant to the rust diseases, produce a beverage inferior to that of Coffea arabica.

Available Collection: VITI LEVU: Naitasiri: Cocoa Station, Nanduruloulou, DA 17385.

3. Coffea liberica Hiern in Trans. Linn. Soc. London, Bot. II. 1: 171. t. 24. 1876, in Oliver, Fl. Trop. Afr. 3: 181. 1877; Rechinger in Denkschr. Akad. Wiss. Wien 85: 370. 1910; A. Chev. Caféiers du Globe 1: 75. fig. 11, 12. 1929, op. cit. 2: pl. 1, 41. 1942, op. cit. 3: 170. 1947; R. Coste, Caféiers et Cafés dans le Monde 1: 24. pl. III (1), VI (2). 1955; J. W. Parham, Pl. Fiji Isl. 189. 1964, ed. 2. 267. 1972; Purseglove, Trop. Crops, Dicot. 488. fig. 75. 1968; Sykes in New Zealand Dept. Sci. Indust. Res. Bull. 200: 175. 1970; St. John \& A. C. Sm. in Pacific Sci. 25: 339. 1971; MacKee, Pl. Intro. Cult. Nouv.-Caléd. 118. 1985; Bridson in Kew Bull. 40: 806. 1985.

Tree or shrub to $8 \mathrm{~m}$. high (to $15 \mathrm{~m}$. where indigenous), infrequently cultivated in Fiji at elevations from near sea level to about $200 \mathrm{~m}$., and also sparingly naturalized in light forest and along trails. The corollas are white and the fruits, as recorded, green. Flowers have been noted in February, fruits between March and May.

TYPIFICATION: Hiern listed five specimens without designating a type, but two of these are now considered to represent Coffea canephora. Bridson (1985) indicated as the most complete material and the collection that served for most of Hiern's illustration Daniell s. n. (вм LестотуPE), from Sierra Leone. 
Distribution: West Africa and eastward to Sudan and Uganda. It may have been introduced into Fiji by $\mathbf{J}$. B. Thurston, being listed in his 1886 Catalogue. It was presumably grown only experimentally in Fiji.

LOCAL NAME AND USE: Liberian coffee is a highly polymorphic species grown for its disease resistance, but yielding a comparatively bitter beverage and now less frequently grown as a commercial crop than Coffea canephora.

Available Collections: VITI LEVU: Namosi: Naloka, track to Namosi, DA 11638. NaITASIRI: Nasinu Experiment Station (and Agricultural Station), DA 1550,5515, 13223. VANUA LEVU: MBUA: Thongea Village, Wainunu River, $D A 15767$.

Coffea liberica is considered to comprise two varieties, var. liberica (Liberian coffees) and var. dewevrei (De Wild. \& T. Durand) Lebrun (Excelsa coffees); vide Bridson, 1985. The available specimens of the species from Fiji seem to fall within the limits of var. dewevrei.

20. Airosperma Lauterb. \& K. Schum. in K. Schum. \& Lauterb. Fl. Deutsch. Schutzgeb. Südsee, 565. 1900; Krause in Engl. \& Prantl, Nat. Pflanzenfam. Nachtr. 3: 328. 1908; A. C. Sm. in J. Arnold Arb. 26: 107. 1945, in op. cit. 36: 288. 1955; S. Darwin in Allertonia 2: 14. 1979, in J. Arnold Arb. 61: 96. 1980; Puff, Robbrecht, \& Randrianasolo in Bull. Jard. Bot. Nat. Belg. 54: 356.1984.

Abramsia Gillespie in Bishop Mus. Bull. 91: 27. 1932.

Dioecious or polygamous trees, shrubs, or ligneous herbs, the stipules interpetiolar, caducous; inflorescences cymose, congested or openly 3-branched, the peduncle short; calyx persistent, the lobes 5, linear to short-deltoid; corolla hypocrateriform, glabrous on both surfaces or densely pubescent in throat, the lobes 5 , sinistrorsely contorted in bud; stamens 5 , inserted in corolla throat, the anthers partially or entirely exserted; ovary 2(or 3)-locular, the ovules solitary and pendulous in each locule; style glabrous, bifid, included or hardly exserted; fruit ovoid, laterally compressed when 2-locular, ovoid-triquetrous when 3-locular, narrowed and somewhat beaked at apex, acute to rounded or cordate at base, the mesocarp thin, fleshy, the endocarp ligneous, enclosing u prominent empty chamber beneath each seed.

LectotyPE SPECIES: Airosperma psychotrioides Lauterb. \& K. Schum. (vide S. Darwin in Allertonia 2: 14. 1979). The type species of Abramsia is A. trichotoma Gillespie (= Airosperma trichotomum (Gillespie) A. C. Sm.), the only original species.

Distribution: As far as now known, Airosperma comprises six species, four endemic to New Guinea and two to Fiji. The genus has not been found in intervening island groups.

Useful tReATMENT OF GENUS: DaRWin, S. P. Notes on Airosperma (Rubiaceae), with a new species from Fiji. J. Arnold Arb. 61: 95-105. 1980.

The two Fijian species of Airosperma are closely related but are readily separable on the basis of floral characters. They differ from the New Guinean species in their smaller stipules, broader corolla limbs, acute to emarginate (rather than apiculate) anthers, larger fruits borne on peduncles that elongate as the fruits mature, and intectate (rather than tectate) pollen. Furthermore, the Fijian species appear to have hermaphrodite and evidently protandrous (or incipiently unisexual?) flowers, while at least two species in New Guinea appear to be dioecious. Specimen label data suggest other differences: in Fiji collections have been taken from low shrubs to medium-sized trees (to $15 \mathrm{~m}$.), and the fruits are noted as becoming white to yellowish when mature; in New Guinea specimens of Airosperma are noted as ligenous herbs or low shrubs, and the fruits are said to become purple or bright blue. While these numerous differ- 
ences indicate a long-standing separation of the Fijian and New Guinean populations, in our opinion they do not at present warrant the reestablishment of Abramsia as a distinct genus.

Most authors concerned with the genus have commented on the doubtful assignment of Airosperma to the tribe Alberteae, in which it was placed by Lauterbach and Schumann. Most recently Puff et al. (1984) have restricted the Alberteae to the African-Madagascan genera Alberta E. Meyer and Nematostylis Hook. f., but they did not suggest an alternative position for Airosperma and other Asiatic genera excluded from that tribe. Neither does a position in the Coffeeae ("Ixoreae"), as tentatively proposed by Gillespie (for Abramsia), seem likely. Pending investigation of the Asiatic genera of the Airosperma alliance (e. g. Boholia Merr., in the Philippines), we retain the genus in Alberteae.

Lauterbach and Schumann, in the original publication of Airosperma, did not specify whether the corolla contortion was dextrorse or sinistrorse. However, their fig. 21 (A. psychotrioides) shows an exterior view (fig. B) of a dextrorsely contorted corolla and an interior view (fig. C) of a clearly sinistrorsely contorted corolla. The latter illustration is correct, from observation of New Guinean material; throughout the genus only sinistrorsely contorted corollas have been noted. Puff et al. (1984) state that the most striking feature of Airosperma is the dextrorse contortion of the corolla lobes, but this observation was perhaps due to their erroneous acceptance of fig. $B$ of Lauterbach and Schumann as correct.

\section{KEY TO SPECIES}

Corolla tube 1-2 mm. long, glabrous in throat; style subequal to corolla tube; anthers about $1 \mathrm{~mm}$. long, the pollen distributed throughout length of locules; presumably limited to Viti Levu.

1. A. trichotomum

Corolla tube 5-9 mm. long, densely pubescent in throat; style (as far as known) much shorter than corolla tube; anthers 1.3-2 mm. long, the locules divided into alternating fertile and sterile segments; presuma-

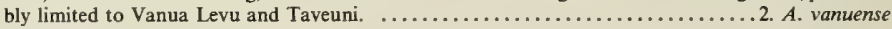

1. Airosperma trichotomum (Gillespie) A. C. Sm. in J. Arnold Arb. 26: 108. 1945, in op. cit. 36: 288. 1955; J. W. Parham, Pl. Fiji Isl. 187. 1964, ed. 2. 264. 1972; S. Darwin in Allertonia 2: 14. fig. 1, H. 1979, in J. Arnold Arb. 61: 101. fig. 5. 1980. FIGURE 85A-D.

Psychotria Seem. in Bonplandia 9: 257. 1861.

Psychotria insularum sensu A. Gray in Proc. Amer. Acad. Arts 5: 319. 1862, in Bonplandia 10: 36. 1862;

Seem. Viti, 437. 1862; non A. Gray (1858).

Abramsia trichotoma Gillespie in Bishop Mus. Bull. 91: 29. fig. 31. 1932; Fosberg in Bull. Torrey Bot. Club 67: 422 . 1940.

Often slender tree or shrub 1-15 m. high, occurring at elevations of 50-1,200 m. in usually dense forest. The corolla is white to pale yellow, and the fruits are green when young, turning through yellow to white, and when mature about $17 \times 13 \mathrm{~mm}$. Flowers have been noted between October and May, fruits throughout the year.

TYPIFICATION: The type is Gillespie 3388 (BISH HOLOTYPE; ISOTYPES at BISH, GH, UC), collected in flower and fruit Nov. 12, 1927, on the slopes of Mt. Nanggaranambuluta, east of Nandarivatu, Mba Province, Viti Levu. As noted by Darwin (1980, p. 102), Gillespie's original citation of the type locality was incorrect.

Distribution: Endemic to Fiji and probably to Viti Levu, from which 38 collections have been examined. 

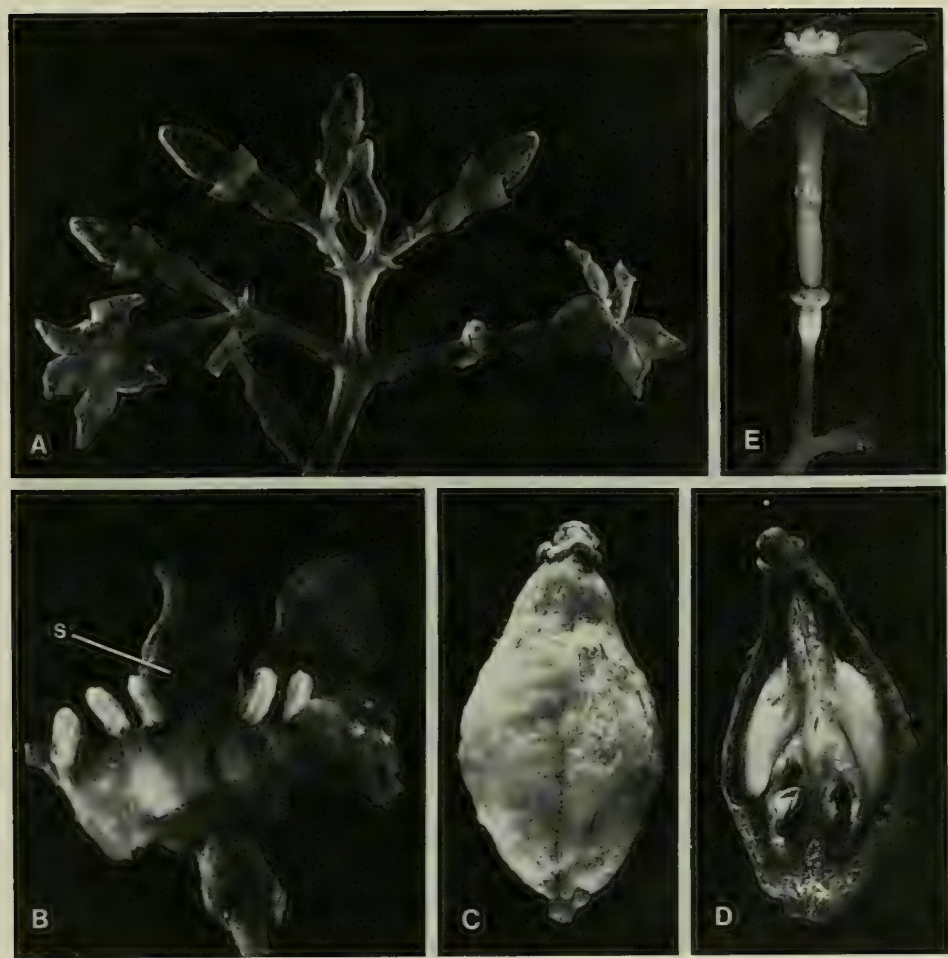

FIGURE 85. A-D, Airosperma trichotomum; A, portion of inflorescence, the open flowers with anthers fallen, $\times 4$; B, flower with opened corolla, showing stamens and stigma (s) borne on style longer than corolla tube, $\times 8 ; \mathrm{C}$, fruit, $\times 4$; D, longitudinal section of fruit, showing empty chambers beneath seeds, $\times 4$. E, Airosperma vanuense; flower, $\times 4$. A from Gillespie 4065, B from DA 11680, C \& D from St. John 18285: E from $D A 16046$.

LOCAL NAMES AND USE: Names each recorded a single time have been maskarawa (Mba), malinimbia (Namosi), and silasila (Naitasiri); the species was once recorded as having a medicinal use as a cathartic in Naitasiri.

RePresentative Collections: VITI LEVU: MBA: Mt. Koroyanitu, Mt. Evans Range, DA 14148; slopes of Mt. Nairosa, eastern flank of Mt. Evans Range, Smith 4426; Nandarivatu, Degener \& Ordonez 15542; Mt. Nanggaranambuluta, Gillespie 4065; Nauwangga, south of Nandarivatu, Degener 14549; Mt. Tomanivi, $O$. \& I. Degener 32086. NANDRONGA \& Navosa: Northern portion of Rairaimatuku Plateau, between Nandrau and Nanga, Smith 5517. Serua: Hills west of Waivunu Creek, between Ngaloa and Korovou, Smith 9473. NAmOSI: Near summit of Mt. Naitarandamu, Gillespie 3315; Namosi (Village?), Seemann 250; Mt. Voma, DA 11680. NAITASIRI: Rarandawai to Nairairaikinasavu, Wainisavulevu Creek, Wainimala Valley, St. John 18285; track to Mendrausuthu Range, DA 15025. TAILEvU: Vicinity of Ndakuivunu, east of Wainimbuka River, DA 11016. 

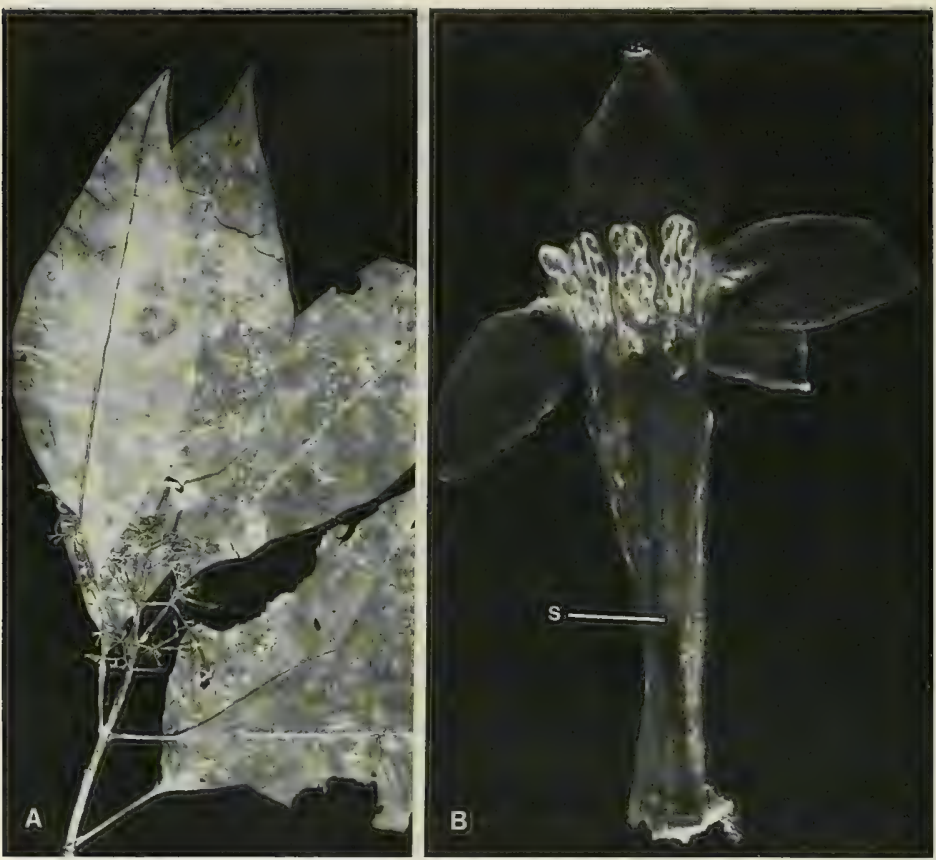

Figure 86. Airosperma vanuense, from DA 16046: A, distal portion of branchlet, with foliage and an inflorescence, $\times 1 / 2 ; \mathrm{B}$, opened corolla, showing anthers with alternating fertile and sterile segments and stigma (s) borne on style much shorter than corolla tube, $\times 8$.

\section{Airosperma vanuense S. Darwin in J. Arnold Arb. 61: 103. fig. 6. 1980.}

Figures $85 \mathrm{E}, 86$.

Abramsia trichotoma sensu Fosberg in Sargentia 1: 125. 1942; non Gillespie.

Slender tree or shrub 2-5 m. high, found in dense forest from about $100 \mathrm{~m}$. (?) to an elevation of $830 \mathrm{~m}$. The white corolla is densely villose-hirsute in throat with white hairs about $1 \mathrm{~mm}$. long. Flowers were obtained in April and May, fruits in August, December, and January.

TYPIFICATION: The type is Smith 1849 (GH HOLOTYPE; many ISOTYPES), collected May 17, 1934, on the Wainunu-Ndreketi divide, Mathuata Province, Vanua Levu. The label data are correct as stated in the protologue, but a more detailed locality is: Between Nanduna (old village site on Nanduna River, headwaters of Wainunu River) and Mt. Ndelanathau.

Distribution: Endemic to Fiji and probably occurring only on Vanua Levu and Taveuni.

AVAilable Collections: VANUA LEVU: ThaKaUndrove: Navavau, DA 16046; along trail from Mbiangunu to Vemsi over Drayton Peak (Mt. Mariko), Bierhorst F154; Vatunivuamonde Mt., Savusavu 
Bay region, Degener \& Ordonez 13964. TAVEUNI: Summit and adjacent slopes of Mt. Manuka, east of Wairiki, Smith 796, 8214.

The available flowering collections (the type and DA 16046) of Airosperma vanuense have flowers with dehiscent anthers having alternating fertile and sterile segments (FIGURE 86B); in the same flowers the styles are much shorter than the corolla tube and the stigmatic lobes are coherent. These flowers may be hermaphrodite and strongly protandrous, in which the styles would eventually elongate, or they may be strictly staminate and the species thus dioecious. In contrast, the stigmas of $A$. trichotomum (FIGURE 85B) are positioned at the level of the anthers and the lobes become divergent. The remaining collections here assigned to $A$. vanuense, from Vanua Levu and Taveuni and all in fruit, come from an area where the species may be anticipated; however, further collections and field studies are required to confirm or negate the assumption that these fruiting specimens are definitely assignable to $A$. vanuense. The cited locality "Navavau" for DA 16046 has not been located, but perhaps the intention was Navava, on the south coast of the isthmus connecting the Natewa Peninsula to the larger part of Vanua Levu; this settlement is not far from the other cited Thakaundrove localities.

21. Psydrax Gaertn. Fruct. Sem. Pl. 1: 125. 1788; DC. Prodr. 4: 476, p. p. 1830; Bridson in Kew Bull. 40: 692. 1985.

Canthium sensu Seem. Fl. Vit. 132, p. p. 1866; Fosberg in Occas. Pap. Bishop Mus. 13: 253, p. p. 1937; Stone in Micronesica 6: 540. 1970; S. Darwin in Allertonia 2: 24, p. p. 1979; non Lam.

Trees or shrubs, sometimes scandent, or lianas; stipules interpetiolar, deltoid to ovate or lanceolate, lacking adaxial indument; inflorescences sessile or pedunculate umbellate or clearly branched cymes; flowers $\not{q}, 4$ - or 5-merous, rarely solitary, the bracts and bracteoles usually inconspicuous; hypanthium broadly ellipsoid to nearly hemispherical, the calyx limb truncate to dentate, usually shorter than hypanthium; corolla tube broadly cylindric, often with deflexed hairs within and pubescent at throat, the lobes reflexed, subequal to tube in length or longer or shorter, often thickened toward apex, usually obtuse to acute; stamens attached in corolla throat, the filaments well developed, the anthers dorsifixed near base, lanceolate to narrowly ovate, usually reflexed; ovary 2-locular, the ovules solitary in each locule, attached to the upper $1 / 3$ of septum, the style slender, longer than corolla tube, glabrous, sometimes narrowing at apex, the stigmatic knob cylindric, longer than broad, hollow to about the middle, bifid or deeply cleft at apex when mature; fruit a 2-seeded drupe, ellipsoid to didymous, the pyrenes cartilaginous to woody, rugulose to deeply furrowed, with a shallow apical cleft, the seeds with entire endosperm.

TYPE SPECIES: Psydrax diococca Gaertn. (Bridson, 1985; “dicoccos," ING, 1979).

Distribution: Palaeotropical; Bridson (1985) recognizes 36 African species and indicates that the genus also occurs at least from Ceylon, India, and China eastward in the Pacific. The type species is restricted to Ceylon and southern India, and Bridson (1985, p. 729 ) has also supplied correct combinations for two other non-African species, one from Malaya and one from Australia, implying that several other taxa currently placed in Canthium or Mesoptera Hook. f. (nom. cons. sed non vs. Psydrax) are also referable to Psydrax. She indicates $(1985$, p. 729$)$ the correct position of $C$. odoratum to be in Psydrax but (in litt.) does not propose to make the formal nomenclatural combination; consequently, at her suggestion, we here transfer the widely distributed $C$. odoratum to Psydrax. This is the only species of the genus occurring in Fiji. With its inclusion the range of Psydrax is extended eastward to the Tuamotus and Hawaii. It may be assumed that, when all the Asian-Malesian-Pacific species of "Canthium" are properly placed, Psydrax will include at least 75 species. 
USEFUl TREATMENT OF GENUS: BRIDSON, D. M. The reinstatement of Psydrax (Rubiaceae, subfam. Cinchonoideae tribe Vanguerieae) and a revision of the African species. Kew Bull. 40: 687-725. 1985.

In reinstating Psydrax for many species previously referred to Canthium Lam., Bridson (1985) utilizes as distinguishing generic characters the elongate style (exceeding corolla tube by two or three times), the longer than broad stigmatic knob, the fully exserted and usually reflexed anthers, the stipules without fine hairs inside, and the cotyledons lying parallel to ventral face of seed. In contrast, Canthium has the style usually equalling the corolla tube (seldom twice as long), the stigmatic knob about as long as broad, the anthers with only the tips (or sometimes fully) exserted but never reflexed, the stipules often with fine hairs inside, and the cotyledons lying perpendicular to ventral face of seed. A closer relative of Psydrax than Canthium is Keetia E. Phillips (limited to tropical and southern Africa), cf. Bridson, 1985, and in Kew Bull. 41: 965-994. 1986.

The floral biology of "Canthium," particularly of C. odoratum, has been described by Skottsberg (in Ark. Bot. 32 (5): 1-12. 1945). The swollen stigmatic knob acts as a pollen receptacle much as in the "ixoroid" pollen presentation mechanism described by Bremekamp (in Acta Bot. Neerl. 15: 18. 1966) and suggesting a relationship among the Vanguerieae, "Ixoreae" (Coffeeae and Pavetteae), Gardenieae, Chiococceae, and a few other tribes assigned to his subfamily Ixoroideae.

1. Psydrax odorata (Forst. f.) A. C. Sm. \& S. Darwin, comb. nov.

Figures $87 \mathrm{~A} \& \mathrm{~B}, 88 \mathrm{~A}$.

Coffea odorata Forst. f. Fl. Ins. Austr. Prodr. 16. 1786.

Canthium lucidum Hook. \& Arn. Bot. Beechey Voy. 65, nom. illeg. 1832; Seem. in Bonplandia 9: 256. 1861, Viti, 437, p. p. 1862; A. Gray in Proc. Amer. Acad. Arts 5:318, p. p. 1862, in Bonplandia 10:36, p. p. 1862 ; non $\mathrm{R}$. Br.

Stylocoryne coffaeoides A. Gray in Proc. Amer. Acad. Arts 4: 309, nom. illeg. 1859; Seem. Fl. Vit. 123, solum quoad nomen. 1866.

Canthium odoratum Seem. Fl. Vit. 132. 1866; Fosberg in Occas. Pap. Bishop Mus. 13: 253. 1937, in Bull. Torrey Bot. Club 67: 421. 1940; Yuncker in Bishop Mus. Bull. 220:250. 1959; J. W. Parham, Pl. Fiji Isl. 189. 1964 , ed. 2. 266. 1972.

Randia coffeoides A. Gray ex Hook. f. in Benth. \& Hook. f. Gen. Pl. 2: 88, nom. illeg. 1873; Drake, Ill. Fl. Ins. Mar. Pac. 191, excl. spec. 1890.

Plectronia odorata Benth. \& Hook. f. ex Hillebr. Fl. Haw. Isl. 175. 1888; Guillaumin in J. Arnold Arb. 13: 7. 1932.

In Fiji this abundant species is a tree or shrub 1-12 m. high, compact or slender or spreading, occurring from near sea level to about $1,200 \mathrm{~m}$. in thin or dry forest, often in beach thickets, frequently on limestone and sometimes on lagoon cliffs, in patches of forest in open areas, and in the thickets of crests and ridges. The stipules are acute to subulate from a broad base and 2-5 (-6) $\mathrm{mm}$. long; petioles 3-10 $\mathrm{mm}$. long; leaf blades obovate to elliptic to rhombic-elliptic, $3-8 \times 1.5-5 \mathrm{~cm}$., rounded to bluntly acuminate at apex, attenuate at base and decurrent on petiole, glossy above, with domatia porate in axils of secondary nerves beneath or absent, the secondary nerves 3-6 on each side of costa; inflorescences expanded, usually 20-40-flowered, the peduncle 8-15 mm. long to a pair of bracts (or scars) and frequently extending beyond them to the first inflorescence dichotomy; flowers fragrant, with white corollas, filaments, and styles; corolla tube $1-1.5 \mathrm{~mm}$. long, short-villose in throat, the lobes spreading, about $3 \mathrm{~mm}$. long; stamens long-exserted, the filaments to $3 \mathrm{~mm}$. long, the anthers yellow, about 1.5 $\mathrm{mm}$. long; style elongating to $5(-8) \mathrm{mm}$., the stigmatic knob greenish, subcylindric, 2-lobed at apex; fruit black at maturity, 5-10 $\mathrm{mm}$. broad. Flowers and fruits have been obtained in essentially every month. 

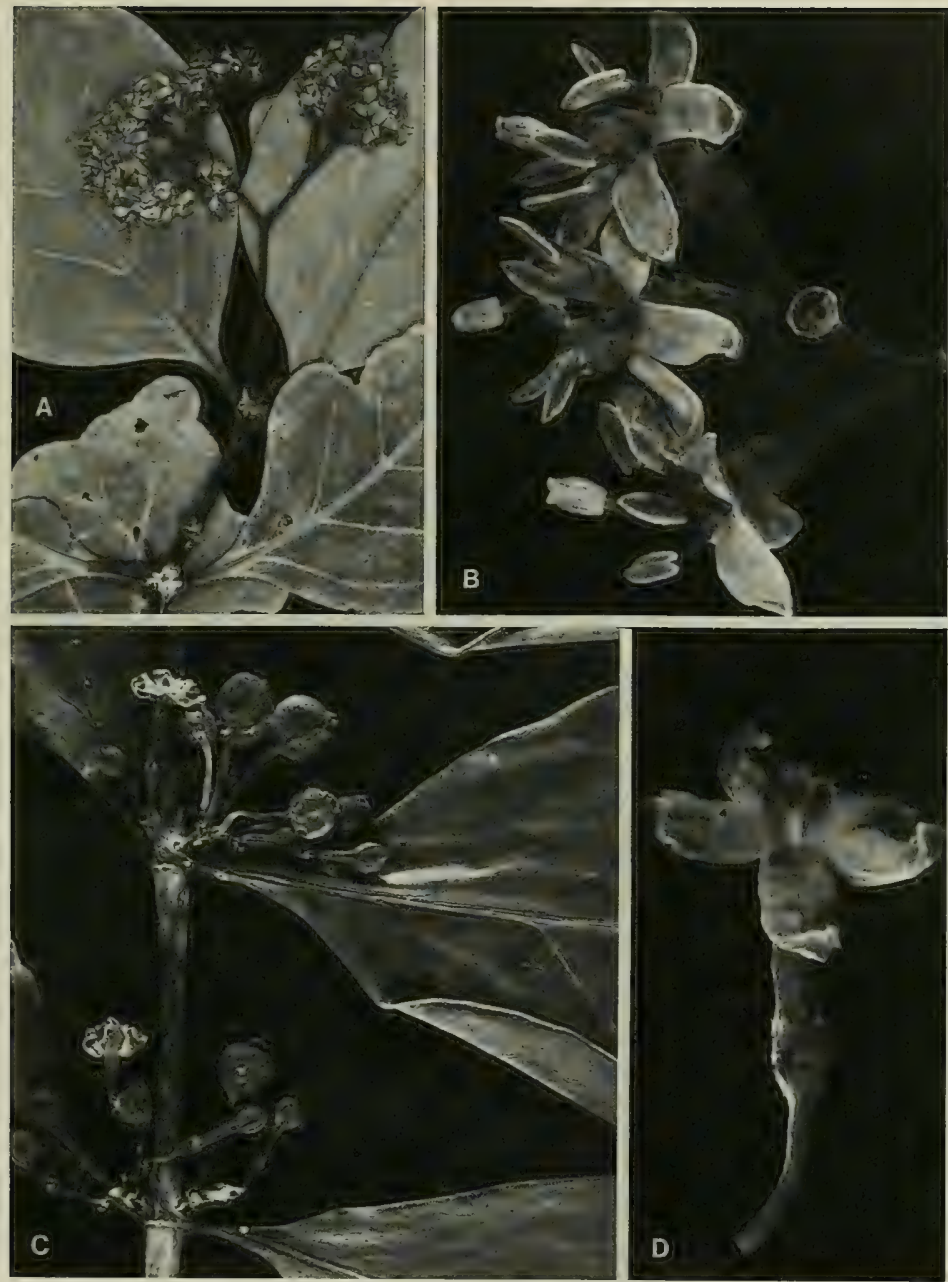

Figure 87. A \& B, Psydrax odorata; A, distal portion of branchlet, with foliage and an inflorescence, $\times 1$; B, portion of inflorescence and flowers, $\times 6 . \mathrm{C} \& \mathrm{D}$, Cyclophyllum barbatum; $\mathrm{C}$, inflorescences and proximal portions of leaves, $\times 2$; D, flower, with two anthers fallen, $\times 6$. A \& B from Smith 1216, C \& D from Gillespie 4586. 
TyPIFICATION AND NOMENCLATURE: Forster's original citation for Coffea odorata was "Tanna et Amicorum insulae;" an appropriate citation is $J$. R. \& G. Forster (BM LECTOTYPE here designated), collected during Cook's second voyage on Tanna, New Hebrides. A Forster specimen at $\mathrm{K}$, from Nomuka Island, Tonga, may then be considered a paratype. Although Fosberg (1937, p. 255) states that the type locality is Tahiti, that island was not mentioned in Forster's protologue. In view of this, the Sparrman (s) specimen from Tahiti discussed by Skottsberg (in Ark. Bot. 32 (5): 1. 1945) cannot be considered a paratype.

Canthium lucidum Hook. \& Arn., nom. illeg. (C. beecheyi Steudel) is based on Beechey (or collectors) (K HOLOTYPE), from the Gambier Islands.

In introducing the binomial Stylocoryne coffaeoides, Gray provided no description or specimen citation, merely indicating ". . . which I take for Forster's Coffea odorata." Regardless of other names mentioned by Gray, we believe that his binomial must be taken as an illegitimate name for the present species, although Fosberg (in Bull. Torrey Bot. Club 65: 614. 1939) referred it to the synonymy of Randia cochinchinensis; the identity of specimens annotated by Gray does not seem pertinent.

Distribution: Mariana Islands to New Caledonia (perhaps westward to New Guinea, cf. Merrill and Perry in J. Arnold Arb. 26: 230. 1945) and eastward to the Tuamotus and Hawaii. In Fiji the species may be anticipated on practically all islands; we have now examined more than 50 collections from 17 islands.

LOCAL NAMES: In view of its abundance it is surprising that this species has no general Fijian name, each of the following having been reported only once or twice: tuva ngga and mbolambatu (Yasawas), weitina (Mba), nanokonisavu (Mbua), mbulavatu and vunambuli (Vanua Mbalavu), matandra vula (Kambara), and sausauthangi (Fulanga).

RePresentative Collections: YASAWAS: Yasawa: Tethi Village, DA 13658. Nathula: Malakati, DA 13666. WAYA: Nangua, St. John 18101. VITI LEVU: MBA: Natua Levu, Mt. Evans Range, DA 14049; Nandarivatu, Tothill 265. SERUA: Coastal hills in vicinity of Taunovo River, east of Wainiyambia, Smith 9568. Namosi: Mt. Voma, DA 11671. Ra: Ndombuilevu, DA 11893. NaITaSIRI: Central road, Tothill 543. TAILEVU: Nggelekuro, DA 13597. Rewa; Near quarry beyond Lami, Gillespie 4587. OVALAU: Vicinity of Levuka, Gillespie 4469. NAIRAI: Milne 168. NGAU: Shore of Herald Bay, vicinity of Sawaieke, Smith 7909. VANUA LEVU: Seemann 221, p. p. Mbua: Rukuruku Bay, H. B. R. Parham 41. Mathuata: Mt. Ndelanathau, DA 16063; Wainikoro River, Greenwood 702. THAKaundrove: Maravu, near Salt Lake, Degener \& Ordonez 14160. THIKOMBIA: Tothill 280. TAVEUNI: DA L.9593. MOALA: Tothill 379. KANATHEA: Graeffe. VANUA MBALAVU: Northern limestone section, Smith 1469. MUNIA: Graeffe 1406. LAKEMBA: Seemann 221, p. p. KAMBARA: On limestone, Smith 1258. FULANGA: On limestone, Smith 1216.

If infraspecific taxa are recognized in Psydrax odorata, material from the Fijian Region is referable to the type-inciuding element. Although a minor degree of local variation is evident in Micronesia (Stone, 1970), eastern Polynesia (Fosberg, 1937), and Hawaii (Skottsberg, 1945), no complete taxonomic review seems available.

22. Cyclophyllum Hook. f. in Benth. \& Hook. f. Gen. Pl. 2: pars prima Addend. 535. (April) 1873, in Hook. Icon. Pl. 12: pl. 1158. (Dec.) 1873, in Benth. \& Hook. f. Gen. Pl. 2: 1229. 1876; K. Schum. in Engl. \& Prantl, Nat. Pflanzenfam. IV. 4: 94. 1891; Guillaumin, Fl. Nouv.-Caléd. 332. 1948.

Canthium sensu Seem. Fl. Vit. 132, p. p. 1866; Fosberg in Occas. Pap. Bishop Mus. 13: 253, p. p. 1937; S. Darwin in Allertonia 2: 24, p. p. 1979.

Trees or shrubs; stipules interpetiolar, lanceolate to oblong, acute or sometimes long-acuminate to subulate; leaves petiolate or essentially sessile, the blades with 
obscure tertiary nerves; inflorescences axillary, 1-few-flowered, fasciculate or occasionally with rudimentary branches, lacking paired bracts that surround inflorescence in bud; flowers ఫో, 4-6-merous; hypanthium ellipsoid to hemispherical, the calyx limb short to cupular, sometimes dentate; corolla hypocrateriform, somewhat fleshy, drying dark with the lobes pale above, the tube longer than lobes and lacking a welldefined ring of deflexed hairs within, the throat with usually crisped hairs projecting and surrounding anthers, the lobes valvate in bud; disk small, annular, glabrous; stamens attached in corolla throat (or sometimes near base of corolla tube in early bud?), the filaments essentially none or short, the anthers dorsifixed near base, exserted, with the dorsal face (except for margin) covered with dark connective; ovary 2-locular, the ovules solitary and pendulous in each locule, the style widening below stigmatic knob, this pyriform to subcylindric-capitate, solid, with style attached at base (not recessed); fruit fleshy, subspherical to bilobed or didymous, drupaceous, the pyrenes obovoid-ellipsoid, crested around apex.

TYPE SPECIES: Cyclophyllum deplanchei Hook. f., first published in the original descriptio generico-specifica and amplified, with an excellent illustration, in Icones Plantarum. As Genera Plantarum is bound in many libraries, the "Addenda et Corrigenda" of Part 1 (pp. 535-537) and the Index to that Part (pp. 539-554) are lacking, but they were validly published and both include Cyclophyllum. Part 2 pagination repeats p. 533 (of Part 1) and continues to p. 1279, including "Addenda et Corrigenda" (pp. 1227-1245) and the Index to the whole volume (pp. 1247-1279); in this Index, however, only p. 1229 is given for Cyclophyllum. According to Stafleu and Cowan (Tax. Lit. ed. 2. 1: 179. 1976): "The first sets of all duplicate pages were 'cancels,' intended to be destroyed and consequently not counted in numbering the pages of the following parts; they included, however, descriptions of several new genera."

Distribution: Cyclophyllum was originally proposed as an endemic New Caledonian genus; it is now taken to extend from the Moluccas, New Guinea, and Australia eastward to the Tuamotus (Bridson, 1987, map 1). In her treatment of Pyrostria Commerson ex Juss., Bridson (1987) discusses Cyclophyllum as one of several related groups probably to be separated from Pyrostria sensu str., noting (p. 616) that "the question of whether recognition of Cyclophyllum should be generic or at an infrageneric rank of Pyrostria (or even Canthium) remains to be settled." Since her discussion (1987, pp. 613-614 ("SYNOPSIS of GROUPs"), p. 612(TABLE 1)) suggests that Cyclophyllum possesses a combination of characters that clearly distinguishes it from both Canthium and Pyrostria sensu str., we consider that its use at the generic level is well justified. Bridson (1987, p. 616) lists eight species of "Canthium" (from outside New Caledonia) that should be considered for transfer to Cyclophyllum, but she refrains from proposing the implied nomenclatural combinations and (in litt.) kindly suggests that we make them for the species occurring in Fiji, with a reservation as to the true position of Canthium rectinervium, as noted below. We are greatly indebted to Mrs. Bridson for advice on this step toward the clarification of "Canthium" in the Pacific area. Some 17 binomials in Cyclophyllum have already been proposed, all from New Caledonia except one from the New Hebrides. Guillaumin (1948) has keyed 14 species from New Caledonia. When Cyclophyllum has been fully considered throughout its range, it may be expected to comprise at least 30 taxa at the specific level.

USEFul TREATMENT OF GenUS: Bridson, D. M. Studies in African Rubiaceae-Vanguerieae: a new circumscription of Pyrostria and a new subgenus, Canthium subgen. Bullockia. Kew Bull. 42: 611-639. 1987. 
KEY TO SPECIES

Stipules subulate from a deltoid base, $2-5 \mathrm{~mm}$. long; leaf blades rarely exceeding $12 \times 7 \mathrm{~cm}$., with 3-6 secondary nerves on each side of costa; inflorescences fasciculate-cymose, sometimes with 2 short arms, 1-3(-8)-flowered, the peduncles to $2 \mathrm{~mm}$. long; stamens attached in corolla throat, the anthers exserted, subsessile; fruit up to $15 \mathrm{~mm}$. broad.

Petioles 3-10 (-13) mm. long; leaf blades comparatively well spaced, elliptic to ovate- or obovate-elliptic, (4-) 5-12 (-14) $\times(1.5-) 3-7(-10) \mathrm{cm}$., acute to attenuate at base and decurrent on petiole, acute to bluntly cuspidate or short-acuminate at apex; domatia pocketlike excavations in axils of secondary nerves, sometimes absent; pedicels $2-6 \mathrm{~mm}$. long at anthesis, to $13 \mathrm{~mm}$. long in fruit; flowers 5-merous, the corolla tube 2.5-5 mm. long; anthers about $1 \mathrm{~mm}$. long; stigmatic knob subcylindriccapitate; fruit $8-15 \mathrm{~mm}$. broad. ................................ barbatum

Petioles 1-2 mm. long; leaf blades congested, suborbicular to elliptic, (1.5-) 2-8 $\times(1-) 1.5-5.5 \mathrm{~cm}$., subcordate or rounded to broadly obtuse at base, rounded or broadly obtuse at apex; domatia absent; pedicels 3-10 mm. long at anthesis; flowers 5- or 6-merous, the corolla tube 8-12 mm. long; anthers about $1.5 \mathrm{~mm}$. long; stigmatic knob cylindric-obconical; fruit (immature?) to $7 \mathrm{~mm}$. broad.

2. C. sessilifolium

Stipules lanceolate to oblong, acute, 7-10 mm. long; leaf blades oblong-elliptic, 13-19 $5-7 \mathrm{~cm}$, , sharply acuminate at apex, obtuse to acute at base and decurrent on petiole, the secondary nerves 7-9 on each side of costa; domatia porate to slitlike in axils of secondary nerves; petioles 4-7 mm. long; inflorescences fasciculate, 2-5-flowered, the peduncles 1-2 mm. long, the pedicels stout and to $8 \mathrm{~mm}$. long in fruit; flowers 5-merous, the stamens (seen only in very young bud) attached near base of corolla tube; fruit solitary, laterally compressed, heart-shaped, broadly emarginate at apex, 35-40 × 30-35 × 14-16 mm.

3. C. rectinervium

1. Cyclophyllum barbatum (Forst. f.) A. C. Sm. \& S. Darwin, comb. nov.

FiguRES $87 \mathrm{C} \& \mathrm{D}, 88 \mathrm{~B}$.

Chiococca barbata Forst. f. Fl. Ins. Austr. Prodr. 16. 1786.

Canthium harveyi sensu Seem. in Bonplandia 9: 256. 1861; non A. Gray.

Canthium lucidum sensu A. Gray in Proc. Amer. Acad. Arts 5: 318, p. p. 1862, in Bonplandia 10:36, p. p. 1862; Seem. Viti, 437, p. p. 1862; non Hook. \& Arn.

Canthium barbatum Seem. Fl. Vit. 132. 1866; Christophersen in Bishop Mus. Bull. 128: 200. 1935;

Fosberg in Occas. Pap. Bishop Mus. 13: 255. fig. 2, 3. 1937; Yuncker in Bishop Mus. Bull. $220: 249$.

1959; J. W. Parham, Pl. Fiji Isl. 189. 1964, ed. 2. 266. 1972; Fosberg \& Sachet in D. J. Carr, Sydney Parkinson, 92. pl. 84. 1983; Bridson in Kew Bull. 42: 616. fig. 1, K; 2, G. 1987.

Plectronia barbata Benth. \& Hook. f. ex Drake, Ill. Fl. Ins. Mar. Pac. 194. 1890; K. Schum. in Engl. \& Prantl, Nat. Pflanzenfam. IV. 4: 92. 1891; Rechinger in Denkschr. Akad. Wiss. Wien 85: 369. 1910.

This widespread species is seen in Fiji as an often slender tree or shrub $2-15 \mathrm{~m}$. high at elevations from near sea level to $1,030 \mathrm{~m}$., occurring in coastal forests and thickets, in thin or dry forest of interior areas, in forest patches in open country, and in the thickets of crests and ridges. The fragrant flowers have the corollas white or creamwhite, turning yellowish or orange; the fruits turn from green through red to black at maturity. Flowers have most often been collected between August and February, while fruits are found throughout the year.

TyPIFICATION: Chiococca barbata was recorded by Forster as from "Marchionis, Societatis et Amicorum insulae." In considering lectotypification, four specimens at BM may be discussed: (1) "G. Forster's Herbarium, 90 (96?), Chiococca barbata;" this specimen, without locality but probably from the Society Islands, bears good foliage but only a couple of old flowers; (2) "Otaheite, Wiles \& Smith;" (3) "Tonga IslandsCapt. Cook."” and (4) "Otaheite, J. B." (i. e. Banks). The last three of these are not appropriate lectotypes, but the Banks collection is probably from the plant illustrated in Sydney Parkinson (1983). In the type cover at $\mathrm{K}$ are two pertinent specimens: (1) "Forster Herbarium, Chiococca barbata . . . Habitat in Marchionis, Societies Isls;" Fosberg has annotated this sheet as "not from Marquesas" and as "var. barbatum;" (2)

Figure 88. A, Psydrax odorata; fruits, × 4. B, Cyclophyllum barbatum; fruit, × 4. C \& D, Cyciophyllum sessilifolium; C, foliage and an inflorescence, $\times 2 ; \mathrm{D}$, flower, $\times 4 . \mathrm{E}$, Cyclophyllum rectinervium; fruit and proximal portions of leaves, $\times 1$. A from Gillespie 4587, B from Gillespie 4602, C \& D from Smith I463, E from Smith 558 . 

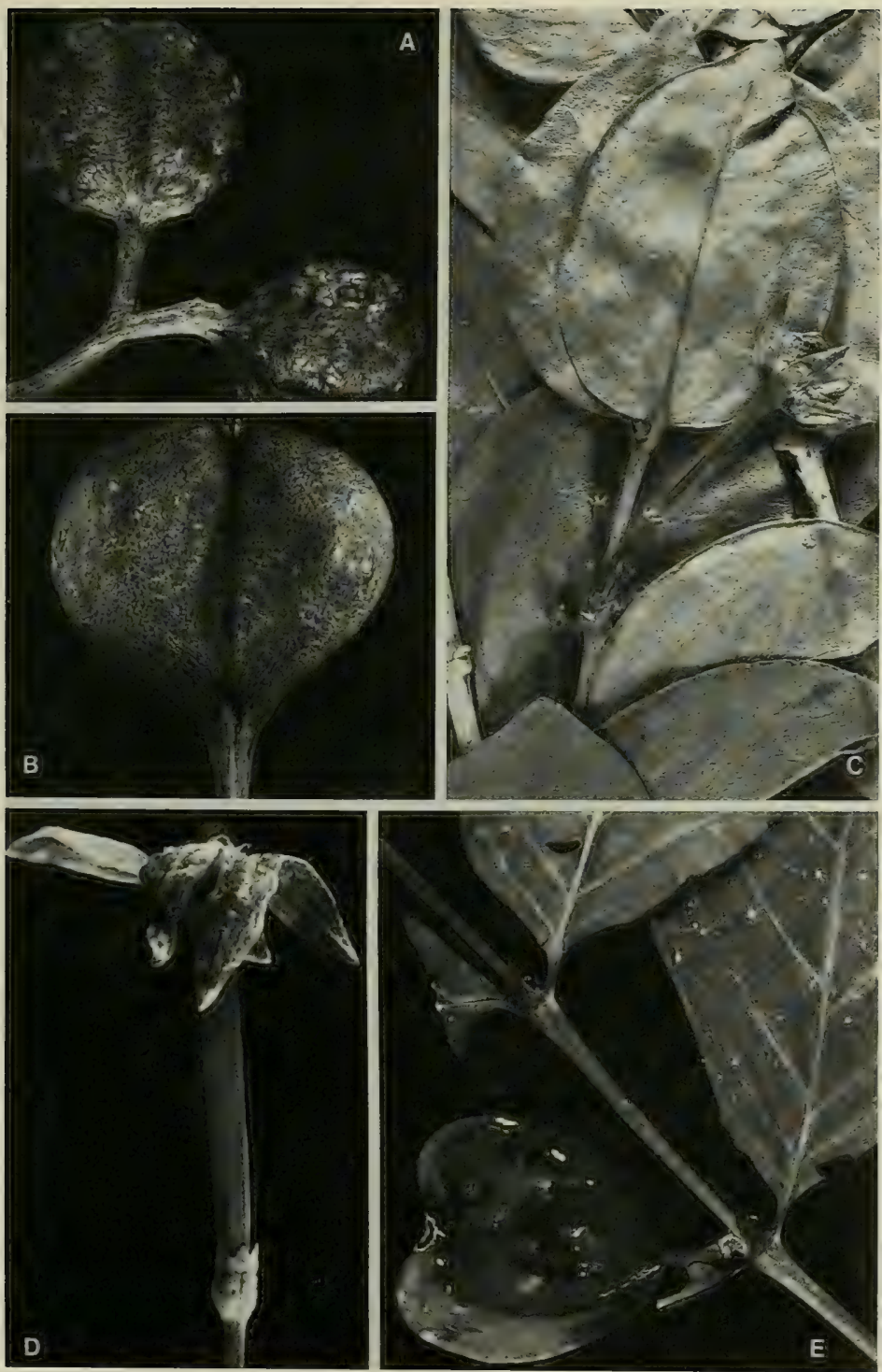
a specimen noted as "var. forsteri," subsequently annotated by Fosberg as "var. societense Fosb." A suitable citation is: J. R. \& G. Forster (BM LECTOTYPE here designated; ISOLECTOTYPE at $\mathrm{K}$ ), collected during Cook's second voyage and presumably in the Society Islands.

Distribution: Caroline and Solomon Islands (and perhaps westward into parts of Malesia) through the southern Pacific to the Tuamotus. Fosberg (1937) recognizes 13 infraspecific taxa from eastern Polynesia, although it is not clear how his var. societense is separable from the type-including element. A different variety is recognized in the Caroline Islands (Fosberg, Sachet, and R. Oliver in Micronesica 15: 262. 1979). Fosberg (1937) considers the Tongan population (probably known to Forster from the "Capt. Cook" collection mentioned above) to represent a different (unnamed) variety, and his annotation at $\mathrm{K}$ indicates that var. barbatum (the specimen here considered an isolectotype of the species) does not occur in the Marquesas. No study of the variation within "Canthium" barbatum throughout its range has been offered, and on the basis of material now at hand we are content to consider collections from the Fijian Region as representing the type-including element. In Fiji Cyclophyllum barbatum is known to us from seven islands and 27 collections, being less abundant than Psydrax odorata but essentially as widely distributed.

LOCAL NAME: Of the available Fijian collections only one, from Kambara, bears a local name, ola.

REPRESENTATIVE COLLECTIONS: VITI LEVU: MBA: Northern portion of Mt. Evans Range, between Mt. Vatuyanitu and Mt. Natondra, Smith 4376. Serua: Flat coastal strip in vicinity of Ngaloa, Smith 9684. Rewa: Near quarry beyond Lami, Gillespie 4602; near Lami Village, Gillespie 4586. VITI LEVU without further locality, Seemann 220. OVALAU: Hills southeast of valley of Mbureta River, Smith 7426. NGAU: Hills east of Herald Bay, inland from Sawaieke, Smith 7851. VANUA LEVU: MbUA: Near Ndama, DA 17532. Mathuata: Seanggangga Plateau, in drainage of Korovuli River, vicinity of Natua, Smith 6673; Mt. Numbuiloa, east of Lambasa, DA 14641. Thak aundrove: Mt. Mbatini, Smith 665. MUNIA: Graeffe 1405: TUVUTHA: Limestone ridge, interior forest, Bryan 551. KAMBARA: Central wooded basin, Bryan 508.

2. Cyclophyllum sessilifolium (A. Gray) A. C. Sm. \& S. Darwin, comb. nov.

Figure $88 \mathrm{C} \& \mathrm{D}$.

Canthium sessilifolium A. Gray in Proc. Amer. Acad. Arts 4: 39. 1858; Seem. Viti, 437. 1862, Fl. Vit. 132. 1866; Yuncker in Bishop Mus. Bull. 220: 250. 1959; J. W. Parham, Pl. Fiji Isl. 189. 1964, ed. 2. 267. 1972; Bridson in Kew Bull. 42: 616. 1987.

Plectronia sessilifolia Benth. \& Hook. f. ex Drake, Ill. Fl. Ins. Mar. Pac. 194. 1890.

Shrub 1-3 m. high, usually compact, found from near sea level to an elevation of perhaps $500 \mathrm{~m}$. in sometimes open forest or in wind-swept thickets, often in exposed places on limestone. The calyx is yellow-tinged, the corolla white, and the fruit pink-or reddish-tinged. Flowers have been obtained between October and April, fruits in October and November (but the holotype, in fruit, must have been collected between May and August).

TyPIFICATION: The type is $U$. S. Expl. Exped. (us 62261 HolotyPE), collected in 1840 on Vanua Levu, without further locality.

Distribution: Fiji and Tonga (three collections from 'Eua are available to us). In Fiji the species is thus far known only from Vanua Levu, Totoya, and two islands of the Lau Group.

AVAilable Collections: VANUA LEVU: Mathuata: Vicinity of Lambasa, Greenwood 540; northwestern slopes of Mt. Numbuiloa, east of Lambasa, Smith 653l; southern slopes of Mt. Numbuiloa, $\operatorname{Smith} 6342$. TOTOYA: Tothill 299. VANUA MBALAVU: Northern limestone section, Smith 1463; vicinity of Lomaloma, DA 13618. FULANGA: On limestone, Smith 1139. 
3. Cyclophyllum rectinervium (A. C. Sm.) A. C. Sm. \& S. Darwin, comb. nov.

FIGURE 88E.

Canthium rectinervium A. C. Sm. in Bishop Mus. Bull. 141: 139. fig. 72. 1936; J. W. Parham, PI. Fiji IsI. 189. 1964, ed. 2. 267. 1972; Bridson in Kew Bull. 42:616. 1987.

An apparently rare tree about $7 \mathrm{~m}$. high, known from a single collection from dense forest at an elevation of 650-900 m.

TYPIFICATION: The type is Smith 558 (BISH HOLOTYPE; many ISOTYPES), collected Nov. 21, 1933, with mature fruits and very young inflorescences, on the crest of the Korotini Range between Navitho Pass and Mt. Ndelaikoro, Mathuata-Thakaundrove boundary, Vanua Levu.

Distribution: Endemic to Fiji and thus far known only from the type collection.

LOCAL NAME: The name ngaungau, offered at the time of collection, has no obvious application to a plant and may have been jocularly applied (as no doubt is the case with many recorded Fijian plant names).

Of the three species of Cyclophyllum here recorded from Fiji, C. rectinervium is the most obviously distinct, although in fact all three differ so sharply from one another that one must hypothesize three separate colonization events from more westerly archipelagoes to account for them. In the absence of good flowering material, the reference of Canthium rectinervium to Cyclophyllum is suggested with trepidation, but we feel that it cannot be left in Canthium, and no other genus of Vanguerieae than the easily recognized Psydrax falls within the geographical range of Cyclophyllum (Bridson, 1987, p. 616). In fact, the heart-shaped fruit of the present species is somewhat suggested by some specimens of Cyclophyllum barbatum, and the remarkable size of the fruit is approached by at least one New Guinean species of "Canthium" that will probably also be referred to Cyclophyllum. The possibility of an undescribed genus of this relationship, of course, is not to be summarily dismissed.

23. Mastixiodendron Melchior in Bot. Jahrb. 60: 167. 1925; Danser in Blumea 1:69. 1934; Merr. \& Perry in J. Arnold Arb. 23:416. 1942; A. C. Sm. in op. cit. 26: 108. 1945; Merr. \& Perry in op. cit. 26: 254. 1945; A. C. Sm. in op. cit. 36: 288. 1955, in Pacific Sci. 23: 390. 1969; S. Darwin in J. Arnold Arb. 58:356. 1977, in Allertonia 2: 26.1979.

Dorisia Gillespie in Hook. Icon. Pl. 32: pl. 3190. 1933.

Trees or rarely shrubs, the stipules strongly imbricate and often dextrorsely contorted, caducous; inflorescences axillary, thyrsoid with opposite branching; flowers 4(or 5)-merous, ఫ̧; calyx lobes short, broadly deltoid; corolla lobes free to base (the tube absent), valvate in bud, fleshy, adaxially pubescent; stamens alternate with corolla lobes; ovary 2-locular, inferior to more than half-superior, the ovules solitary and pendulous in each locule; style glabrous, briefly bifid at apex, often caducous; fruits drupaceous, woody to fibrous, crowned or variously ringed by perianth scar.

TYPE SPECIES: Mastixiodendron pachycladon (K. Schum.) Melchior (Fagraea pachyclados K. Schum.), the only original species; the correct spelling of the epithet of the type species was discussed at some length by Darwin (1977, p. 359), and an alternative conclusion is expressed by Nicolson (in Taxon 35: 327. 1986). The type species of Dorisia is Gillespie's only original species, D. rarissima Gillespie (= Mastixiodendron flavidum (Seem.) A. C. Sm.). 

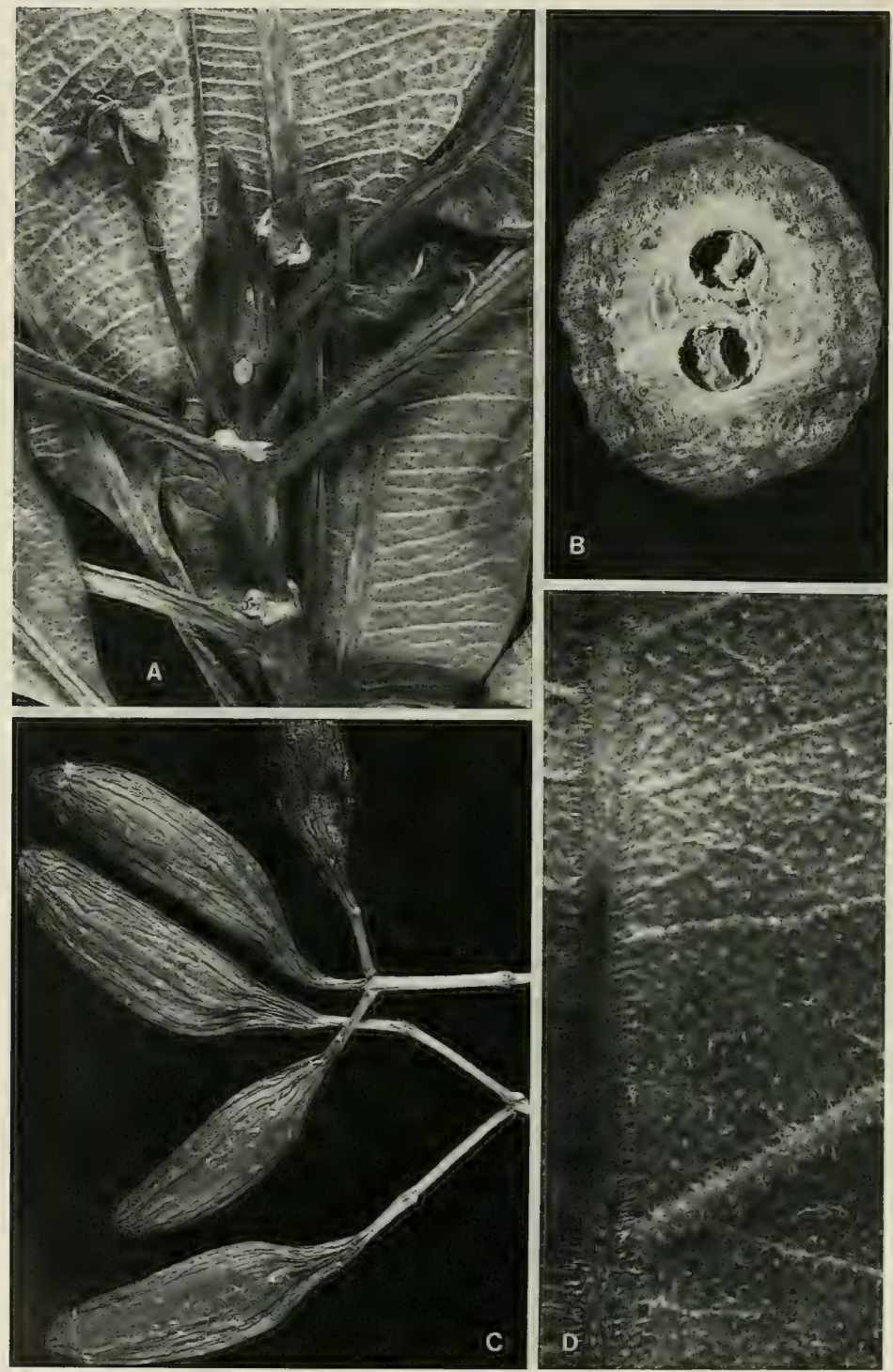
Distribution: Moluccas through New Guinea to the Solomon Islands and Fiji, with seven species, three of them endemic to Fiji.

Useful treatment of Genus: Darwin, Steven P. The genus Mastixiodendron (Rubiaceae). J. Arnold Arb. 58: 349-381. 1977.

Mastixiodendron is unusual among Rubiaceae in its sometimes semisuperior ovaries and polypetalous corollas, characteristics that occur in a number of rubiaceous tribes and are considered evolutionarily derived within the family. Species of the genus had been placed in Loganiaceae (Fagraea) by Schumann, and then in Cornaceae by Melchior, before Danser (and later Merrill and Perry) assigned the genus to Rubiaceae. Smith effected the union of Mastixiodendron with Dorisia, originally considered an endemic Fijian genus by Gillespie and placed in Cornaceae. A summary of familial and tribal relationships is given by Darwin (1977).

\section{KEY TO SPECIES}

Peduncles relatively stout, usually more than $3 \mathrm{~mm}$. in diameter; calyx lobes usually more than $1.5 \mathrm{~mm}$. broad at base; corolla lobes usually more than $2 \mathrm{~mm}$. broad; fruits more than $15 \mathrm{~mm}$. broad, the

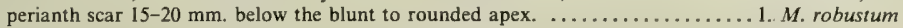

Peduncles less than $3 \mathrm{~mm}$. in diameter; calyx lobes less than $1.5 \mathrm{~mm}$. broad at base; corolla lobes to $2 \mathrm{~mm}$. broad; fruits less than $15 \mathrm{~mm}$. broad, the perianth scar less than $10 \mathrm{~mm}$. from the acute apex.

Leaf blades glabrous beneath, rarely puberulent; flower buds nearly as broad as long; corolla lobes less than $3 \mathrm{~mm}$. long; disk broadly rounded, less than $0.5 \mathrm{~mm}$. high; style less than $1 \mathrm{~mm}$. long.

2. M. flavidum

Leaf blades pilose to tomentulose beneath; flower buds more than twice as long as broad; corolla lobes 4-4.5 mm. long; disk subconical, about $1.5 \mathrm{~mm}$. high; style $1.5-2 \mathrm{~mm}$. long. ... 3. M. pilosum

1. Mastixiodendron robustum A. C. Sm. in Pacific Sci. 23: 390. 1969; J. W. Parham, Pl. Fiji Isl. ed. 2. 278. 1972; S. Darwin in J. Arnold Arb. 58: 373. fig. 3, 13. 1977.

Figure 89A \& B.

Spreading tree 6-25 m. high, with a trunk to $80 \mathrm{~cm}$. in diameter, spreading buttresses, and a dense, rounded crown, occurring from near sea level to an elevation of perhaps $200 \mathrm{~m}$. in dense, dry, or rocky forest, often along coasts. The corolla lobes are white to yellow, the filaments pale yellow, and the fruit green when young, turning through yellow to pale or dark brown. Flowers have been obtained between September and December, fruits in scattered months between October and June.

TyPifiCation: The type is DA L. 13374 (Berry 31, coll. I. Qoro) (BISH HolotyPE; ISOTYPES at K, sUVA), collected in flower Sept. 1, 1967, along the Waimanu River above Vatuvula Village, Naitasiri Province, Viti Levu.

Distribution: Endemic to Fiji and thus far known only from the two largest islands.

LOCAL NAMES AND USE: A frequently used name is ndovula or nduvula; others are kauloa (Naitasiri, Tailevu), ndukinduki (Naitasiri), sarosaro (Mathuata), and yanduva (Mathuata). Foresters report the species to be a useful timber tree.

Available Collections: VITI LEVU: Serua: Flat coastal strip in vicinity of Ngaloa, Smith 9690. Namosi: Nambukavesi Creek, DF 767. NAITASIRI: Navuakethe (old Tikina), Waindrandra Creek, DA 169. TAILEvU: Ridge west of Waisei Village, Berry 166; Raralevu, DA 2546, 2667. Rewa: Base of Mt. Korombamba, DA 1189 . VANUA LEVU: MATHUATA: Ridge above Nasingasinga, Berry 52; Mt. Ratinitini forests, on slopes at Seanggangga, DF 486 (Loweth 2256); vicinity of Natua, Berry 14; inland from Lambasa, DF 238 (Bola 86). Thakaundrove: Navonu Creek, Natewa Peninsula, Howard 94. Fiji without further locality, Damanu NI-32.

FigurE 89. A \& B, Mastixiodendron robustum: A, inflorescences, stipules, and proximal portions of leaves, $\times 2$; B, cross section of fruit, $\times 2$. C, Mastixiodendron flavidum; portion of infructescence, $\times 2 . \mathrm{D}$, Mastixiodendron pilosum; lower surface of leaf blade, with junction of costa and a secondary nerve, $\times 10 . \mathrm{A}$ from DA L.13374, B from Howard 94, C from Smith 1932, D from DA 17094. 
2. Mastixiodendron flavidum (Seem.) A. C. Sm. in J. Arnold Arb. 26: 109. 1945; J. W. Parham, Pl. Fiji Isl. 197. 1964, ed. 2. 277. 1972; S. Darwin in J. Arnold Arb. 58: 375. fig. 2, 14, a-e. 1977.

FIGURE 89C.

Rubiacearum gen. (nov.?) Seem. in Bonplandia 9: 257. 1861.

Canthium aff. lucidum sensu A. Gray in Proc. Amer. Acad. Arts 5: 319. 1862, in Bonplandia 10: 36. 1862; non Hook. \& Arn.

Canthium flavidum Seem. Fl. Vit. 132. 1866.

Plectronia flavida Benth. \& Hook. f. ex Drake, Ill. Fl. Ins. Mar. Pac. 194. 1890.

Dorisia rarissima Gillespie in Hook. Icon. P1. 32: pl. 3190. 1933.

Dorisia flavida A. C. Sm. in Bishop Mus. Bull. 141: 140. 1936; Fosberg in Sargentia 1: 120. 1942.

Tree 3-20 m. high, often slender or spreading, found at elevations between approximately 100 and $1,200 \mathrm{~m}$. in dense, thin, open, or secondary forest or in thickets. The corolla lobes are white to pale yellow or orange; the filaments and style are greenish white to pale yellow; and the fruits turn from green through yellow and orange, drying red-brown to nearly black. Flowers have been obtained between September and February, and fruits seem available in most months.

TyPification: The type of Canthium flavidum is Seemann 256 (K HOLOTYPE; ISOTYPES at BM, GH), collected in Mathuata Province without further locality, Vanua Levu, presumably in October, 1860; that of Dorisia rarissima is Greenwood 517 (K Holoty PE), obtained Sept. 17, 1922, near Lambasa, Mathuata Province, Vanua Levu.

Distribution: Endemic to Fiji and now known from 22 collections from the two largest islands and Rambi.

LOCAL NAMES: Three names have been recorded but only once each: tembatemba (Nandronga \& Navosa), tuva ni Viti (Namosi), and reiova (Thakaundrove).

RePresentative Collections: VITI LEVU: MBA: Northern portion of Mt. Evans Range, between Mt. Vatuyanitu and Mt. Natondra, Smith 4368; vicinity of Nandarivatu, Degener \& Ordonez 13579; Navai, DA 14978: Mt. Tomanivi, Lam 6845. Nandronga \& Navosa: Northern portion of Rairaimatuku Plateau, between Nandrau and Nanga, Smith 5561. NAmosi: Mt. Vakarongasiu, DA I6I28. VANUA LEVU: Mathuata: Nasealevu, Rumbeyanganirumbu Creek, DA 15242; southern slopes of Mt. Numbuiloa, east of Lambasa, Smith 6365. ThaKAundrove: Mt. Kasi, Yanawai River region, Smith I790; mountains between Waiwai and Lomaloma, Horne 608; hills west of Korotasere, Natewa Bay region, Smith 1932. RAMBI: In mountains, Horne 441

3. Mastixiodendron pilosum A. C. Sm. in J. Arnold Arb. 26: 109. 1945, in op. cit. 34: 99. 1953; J. W. Parham, Pl. Fiji Isl. 198. 1964, ed. 2. 278. 1972; S. Darwin in J. Arnold Arb. 58: 379. fig. 5, 14, f-j. 1977.

Figure 89D.

A comparatively infrequent tree $6-10 \mathrm{~m}$. high, with a trunk to $75 \mathrm{~cm}$. in diameter, occurring in dense or dry forest at probable elevations between 100 and $250 \mathrm{~m}$. The corolla lobes are yellow, and the fruits are dull yellow or orange, drying dark orange to nearly black. Flowers and fruits have been obtained between September and January.

TYPIFICATION: The type is Horne 1132 (GH HOLOTYPE; ISOTYPE at $\mathrm{K}$ ), collected in September, 1878, in Mbua Province without further locality, Vanua Levu.

Distribution: Less common than the other two Fijian species of Mastixiodendron, M. pilosum is known from the two largest islands.

Available COLLections: VITI LEVU: NAmosi: Wainandoi River Valley, DA 17094. VANUA LEVU: Mbua: Between Mbua and Ndevoka, H. B. R. Parham III (A). Mathuata: Southern base of Mathuata Range, north of Natua, Smith 6781 .

24. Hydnophytum Jack in Trans. Linn. Soc. 14: 124. 1823; Seem. Fl. Vit. 138. 1866; Hook. f. in Benth. \& Hook. f. Gen. Pl. 2: 132. 1873; Becc. Malesia 2: 120. 1884; K. Schum. in Engl. \& Prantl, Nat. Pflanzenfam. IV. 4: 123. 1891; A. C. Sm. in J. Arnold Arb. 36: 289. 1955; S. Darwin in Allertonia 2: 35.1979. 
Suffrutescent, glabrous or rarely pilose epiphytic (rarely terrestrial) plants with swollen, tuberous bases, the tubers typically broad and lobed at base, with copious ant-inhabited cavities, the foliate branches usually several from each tuber, articulatenodose, woody to subherbaceous; stipules small, interpetiolar, deciduous or persistent; inflorescences solitary at nodes, interpetiolar or supra-axillary, usually on alternating sides along length of branchlet, few-flowered, fasciculate, contracted, or vermiform and sometimes branched in age; flowers 4(or 5)-merous, sessile, $\Varangle$ (and then usually heterostylous) or unisexual (and plants then probably polygamodioecious); calyx limb short-cupular, truncate to shallowly dentate, persistent; corolla hypocrateriform to narrowly infundibular, glabrous within or variously pubescent in throat, the lobes valvate in bud, spreading or reflexed; stamens (and staminodia) inserted in corolla throat, the anthers (in our species) essentially sessile; ovary 2-locular (as in our species) or rarely 4-locular, the ovules solitary and erect in each locule; style short or long, the stigma 2-4-lobed; fruit drupaceous, ovoid, obovoid, or turbinate, sometimes distally gibbous-tuberculate.

TYPE SPECIES: Hydnophytum formicarum Jack, the only original species.

Distribution: Southeastern Asia throughout Malesia into Micronesia and eastward to Fiji, with approximately 80 species. The generic range presumably terminates in Fiji, from which three endemic species are here recognized. Van Balgooy's mention (in Blumea Suppl. 6: 193. 1971) of the genus in Samoa seems questionable; possibly it was based on an erroneously labelled specimen of Graeffe, several of whose Fijian plants have been attributed to Samoa.

USEFUl TREATMENT OF GENUS: BECCARI, O. Rubiacee formicarie. Malesia 2: 80-227. 1884-1886.

The genera of myrmecophytic Rubiaceae ("ant-plants") have interested students of plant-animal interaction since the time of Rumphius. A history of those investigations and a study of the biology of Myrmecodia and Hydnophytum are provided by C. R. Huxley (in New Phytol. 80: 231-268. 1978), who also gives a summary of ant-epiphyte symbiosis in general (in Biol. Rev. Cambridge Philos. Soc. 55: 321-340. 1980). However, Beccari's exhaustive study remains the most recent taxonomic treatment of Hydnophytum.

Beccari recognized five Fijian species of Hydnophytum and relegated them to a separate group differing from the Malesian species in their heterostylous flowers with comparatively long corollas. Among the Fijian specimens presently available for study we are readily able to distinguish two species, $H$. grandiflorum and $H$. longiflorum, differing primarily in corolla length and throat pubescence and secondarily in leaf blade shape and petiole length, as noted in the following key. We maintain $H$. wilkinsonii on the basis of Beccari's description and illustration of its distinctive fruit. The characters of calyx limb shape and ciliolation employed by Beccari to distinguish $H$. horneanum seem inconsequential to us.

The flowers of Hydnophytum grandiflorum and $H$. longiflorum are commonly dimorphic. The pistillate flowers have manifestly sterile anthers (inserted in corolla throat), styles exserted a few millimeters beyond the corolla, and expanded, 4-lobed stigmas. Most flowers having fertile anthers (also inserted in corolla throat) are equipped with well-included styles, although in some apparently hermaphrodite flowers both fertile anthers and elongate styles occur. Some collections seem to bear staminate or pistillate flowers exclusively, while in others both staminate and apparently hermaphrodite flowers occur. It seems likely that polygamodioecism in these outlying species of Hydnophytum may have evolved through heterostyly, a condition commonly encountered in genera of tribe Psychotrieae. 
KEY TO SPECIES

Corolla barbate to pilose in throat, the tube (8-) 20-40 $\mathrm{mm}$. long, the lobes pilose to papillose or rarely glabrous within, 4-12 (-15) $\times 1-5(-7) \mathrm{mm}$; leaf blades ovate to elliptic to oblong-obovate, 1.5-8 $(-11) \times$ $1-4.5 \mathrm{~cm}$., rounded to truncate to subcordate (rarely acute) at base; petioles $0-2(-8) \mathrm{mm}$. long.

1. H. grandiflorum

Corolla glabrous in throat.

Fruits rounded at apex; leaf blades narrowly elliptic to oblanceolate to obovate, rarely oblong-obovate, narrowly attenuate at base (rarely obtuse to subcordate), $3-9.5 \times 1.2-3.5 \mathrm{~cm}$. (rarely to $12 \times 5 \mathrm{~cm}$.); petioles 2-12 mm. long; corolla tube (3-) 7-12(-15) mm. long at anthesis, the lobes $2-3.5 \times 1.5-2.2$

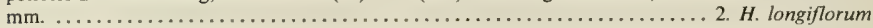

Fruits expanded and lobed at apex; leaf blades obovate-oblong, 1-3 $\times 0.5-1.2 \mathrm{~cm}$; petioles about $2 \mathrm{~mm}$. long; corolla tube about $6 \mathrm{~mm}$. long at anthesis, the lobes about $2 \times 1 \mathrm{~mm}$. . . 3. H. wilkinsonii

1. Hydnophytum grandiflorum Becc. Malesia 2: 171. t. 44, fig. 13-25. 1885; Gibbs in J. Linn. Soc. Bot. 39: 153. 1909; J. W. Parham, Pl. Fiji Isl. 193. 1964, ed. 2. 271. 1972; S. Darwin in Allertonia 2: 37. fig. 3, C. $1979 . \quad$ Figures 90A \& B, 129.

Myrmecodia vitiensis Seem. in Bonplandia 9: 256, nom. nud. 1861; A. Gray in op. cit. 10: 36, pro syn. 1862; Seem. Viti, 438, pro syn. 1862.

Hydnophytum longiflorum sensu A. Gray in Proc. Amer. Acad. Arts 5: 318. 1862, in Bonplandia $10: 36$. 1862; Seem Viti, 438. 1862, Fl. Vit. 138, p. p. 1866; Drake, Ill. Fl. Ins. Mar. Pac. 199, p. p. 1890; Becc. Malesia 2: 172. t. 45, fig. 1-7. 1885; J. W. Parham, Pl. Fiji Isl. 193, p. p. 1964, ed. 2. 272, p. p. 1972; non A. Gray (1858).

Epiphytic shrub (or sometimes on cliffs or in rocky places in forest), with antinhabited tubers to $30 \mathrm{~cm}$. in diameter and with suberect to trailing branches $0.3-2 \mathrm{~m}$. long, occurring at elevations from near sea level to $1,127 \mathrm{~m}$. in dense or thin forest or in the forests of crests and ridges. The calyx at anthesis is pale green, and the corolla, anthers, style, and stigma are white, the corolla fading to yellow with age. Flowers have been obtained between September and February (and also in May and June); fruits seem infrequent but may occur together with flowers.

TYPIFICATION AND NOMENCLATURE: In describing Hydnophytum grandiflorum, Beccari cited two specimens. An appropriate citation is: Graeffe (K LECTOTYPE here designated), collected in December, 1864, on Mt. Tana Lailai, Ovalau. Horne (к), also from Ovalau, is then a paratype. The Graeffe specimen provided the description of the flower and the Horne material that of the fruit. The name Myrmecodia vitiensis was based on Seemann 216 (BM, K), collected on Mt. Mbuke Levu, Kandavu, on Sept. 6, 1860. Subsequently this name was erroneously referred to $H$. longiflorum by Gray and others, but Seemann's collection clearly represents $H$. grandiflorum. In fact, Beccari's entire treatment of $H$. longiflorum, including his drawings, is based on Seemann's collection; he did not see type material of $H$. longiflorum and consequently did not appreciate its similarity to his own $H$. horneanum and $H$. tenuiflorum.

Distribution: Endemic to Fiji and now known from five of the high islands; a few additional specimens probably of this species but not seen during the present review are not cited.

Local NAME: Only one collection, from Mba Province, indicates a local name, sekeseke.

Available collections: VITI LEVU: MBA: Vicinity of Nandarivatu, Gibbs 729; summit of Mt. Nanggaranambuluta, east of Nandarivatu, Gillespie 4351; ridge between Mt. Nanggaranambuluta and Mt. Namama, Smith 4974. Namosi: Mt. Voma, DA 11688; summit of Mt. Vakarongasiu, Gillespie 3297.

FIGURE 90. A \& B, Hydnophytum grandiflorum; A, foliage and inflorescences, $\times 1$; B, distal part of corolla, showing indument in throat and on lobes, and fertile anthers, $\times 4 . \mathrm{C}-\mathrm{F}$, Hydnophytum longiflorum; $\mathrm{C}$, foliage and inflorescences, $\times 1$; D, corolla, showing sterile ant hers and receptive stigma, $\times 4$; E, distal part of opened corolla, glabrous in throat, and fertile anthers, $\times 4 ; \mathrm{F}$, mature inflorescences lateral to petiole scars, and a detached corolla, $\times 2$. A from Gillespie 4467, B from Smith 7603, C from Gillespie 3633, D from Gillespie 2164, E from Smith 7425, F from Smith 8496. 


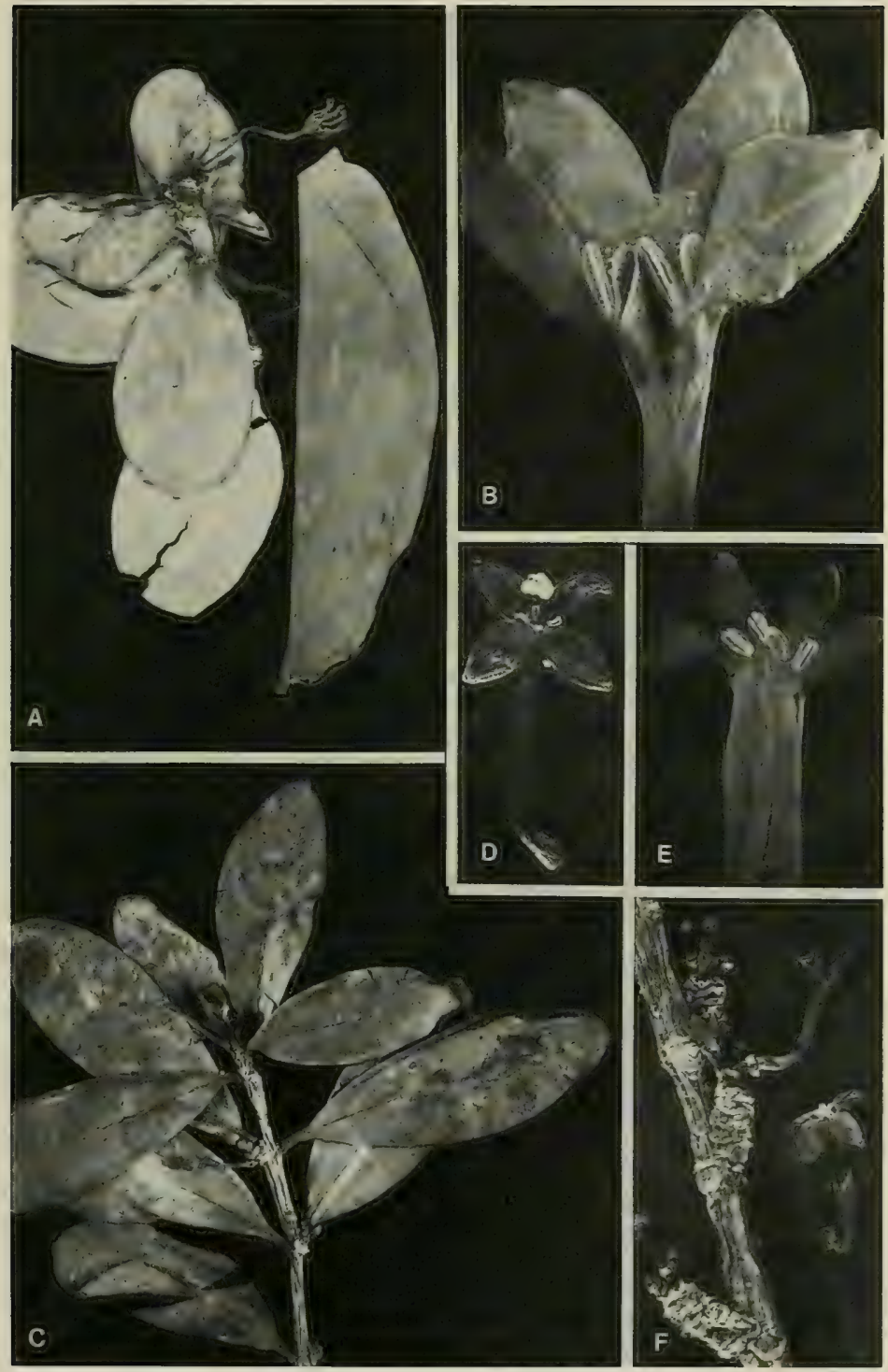


NaItASIRI: Northern portion of Rairaimatuku Plateau, between Mt. Tomanivi and Nasonggo, Smith 6136. KANDAVU: Mt. Mbuke Levu, Smith 240. OVALAU: Summit of Mt. Ndelaiovalau and adjacent ridge, Smith 7603; vicinity of Levuka, Gillespie 4467. VANUA LEVU: MATHUATA: Southern slopes of Mt. Numbuiloa, east of Lambasa, Smith 6435. ThaKAundrove: Mt. Mariko, Smith 455. TAVEUNI: Borders of lake east of Somosomo, Smith 851 .

Hydnophytum grandiflorum is here taken to include all Fijian specimens of the genus with pubescent corolla throats, at least at the point of stamen insertion but with the pubescence variously extending to the base of the corolla lobes or even to the entire inner surface of the lobes. Virtually all the collections here assigned have leaf blades with rounded to subcordate bases and very short petioles (to $2 \mathrm{~mm}$.); in only one collection, Smith 455, are the leaf blades narrowly tapering at base to longer petioles (to $8 \mathrm{~mm}$.), like those usually found in $H$. longiflorum.

2. Hydnophytum longiflorum A. Gray in Proc. Amer. Acad. Arts 4: 42. 1858; Seem. Fl. Vit. 138, p. p. 1866; Drake, Ill. Fl. Ins. Mar. Pac. 199, p. p. 1890; Hook. f. in Bot. Mag. 120: $t$. 7343. 1894; J. W. Parham, Pl. Fiji Isl. 193, p. p. 1964, ed. 2. 272, p. p. 1972.

Figure 90C-F.

Hydnophytum horneanum Becc. Malesia 2: 168. $t$. 43, fig. 15-25. 1885; J. W. Parham, Pl. Fiji Isl. 193. 1964 , ed. 2. 272.1972.

Hydnophytum tenuiflorum Becc. Malesia 2: 169. Ł. 43, fig. 1-14. 1885; J. W. Parham, Pl. Fiji Isl. 193. 1964, ed. 2. 272. 1972.

Epiphytic shrub, with ant-inhabited tubers to $25 \mathrm{~cm}$. in diameter and with suberect branches $0.3-1 \mathrm{~m}$. long, occurring from near sea level to an elevation of about $1,000 \mathrm{~m}$. in dense or thin forest or rarely on the edges of mangrove swamps. The calyx is pale green, the corolla white, and the fruit is red at apparent maturity. Flowers seem to occur throughout the year but fruits are infrequent.

TYPIFICATION AND NOMENCLATURE: The type of Hydnophytum longiflorum is $U$. S. Expl. Exped. (US 62267 ноLотYPE), collected on Ovalau in 1840. Hydnophytum horneanum is based on a single specimen, Horne 282 (K HOLOTYPE), collected in Fiji but without indicated locality or date. Beccari cited two Graeffe collections in describing $H$. tenuiflorum; the floral parts were drawn from Graeffe 1573 (K LECTOTYPE here designated), from Viti Levu. Graeffe $1555(\mathrm{~K})$, from Ovalau, is then a paratype. Although Beccari describes and illustrates some differences between his two species in characters pertaining to the calyx limb and corolla length, we find these inconsequential in view of reasonable variation among the many available collections of $H$. longiflorum, a species misunderstood by Beccari.

Distribution: Endemic to Fiji and known only from Viti Levu and Ovalau, apparently very frequent in the southeastern parts of Viti Levu from which Hydnophytum grandiflorum seems absent. About 35 collections are here referable. A report of the occurrence of $H$. horneanum in the Caroline Islands seem very questionable and should be further investigated.

LOCAL NAMES: Names recorded once each have been mokamoka (Namosi) and ndatokaikai (Tailevu).

RePresentative collections: VITI LEVU: Nandronga \& Navosa: Nausori Highlands, $O$. \& $I$. Degener 32155. Namosi: Mt. Naitarandamu, Gillespie 3091; hills north of Wainavindrau Creek, between Korombasambasanga Range and Mt. Naitarandamu, Smith 8496. NaItasiri: Tholo-i-suva, DA 11813 ; Toninaiwau, Tholo-i-suva, DA 16036; vicinity of Tamavua, Gillespie 2164; vicinity of Nasinu, Gillespie 3633. TAllevU: Hills east of Wainimbuka River, vicinity of Ndakuivuna, Smith 7144. REWA: Southeastern slopes of Mt. Korombamba, Gillespie 2226; east of Suva Harbor, Parks 20028. OVALAU: Hills southeast of valley of Mbureta River, Smith 7425; near stream above Levuka reservoir, Gillespie 4528. CULTIVATED: $\mathrm{K}$ material illustrated by J. D. Hooker (1894) and originating from Yeoward (K) material sent in August, 1891 , and probably originating in southeastern Viti Levu. 
3. Hydnophytum wilkinsonii Horne ex Baker in J. Linn. Soc. Bot. 20: 365, as $H$. wilkinsoni. 1883; Becc. Malesia 2: 170. t. 44, fig. 1-12. 1885.

Hydnophytum wilkinsoni Horne, A Year in Fiji, 263, nom. nud. 1881; Drake, Ill. Fl. Ins. Mar. Pac. 200. 1890; J. W. Parham, Pl. Fiji Isl. 193. 1964, ed. 2. 272.1972.

A presumably epiphytic shrub with a large, ant-inhabited tuber, characterized by its small leaves, short corolla tube, and fruit with conspicuous distal lobes, known only from the type specimen.

TyPIfICATION: The type is Horne 1077 (к HоLOTYPE), collected in September, 1878, in Mbua Province without further locality, Vanua Levu.

Distribution: Endemic to Fiji, inadequately known.

Beccari described the fruit of Hydnophytum wilkinsonii as "superne tuberculatogibbosus;" his illustration shows eight erect, rounded lobes surrounding the elevated disk and calyx at the distal end of an obovoid, 2-locular drupe. Since the pyrenes are described as having rounded apices, the lobes must be composed only of outer, fleshy layers of the fruit wall. For the present, $H$. wilkinsonii may be accepted as a distinct species; the type and only known specimen is the only collection of Hydnophytum with glabrous corollas thus far known from Vanua Levu.

25. Squamellaria Becc. Malesia 2: 228. 1886; K. Schum. in Engl. \& Prantl, Nat. Pflanzenfam. IV. 4: 123. 1891; A. C. Sm. in J. Arnold Arb. 36: 289. 1955; S. Darwin in Allertonia 2: 35. 1979.

Myrmecodia sensu Seem. FI. Vit. 137. 1866; non Jack.

Epiphytic shrubs with swollen, tuberous bases, the tubers typically ellipsoid and not lobed, with copious ant-inhabited cavities, the foliate branches woody to subherbaceous; stipules interpetiolar, deciduous; inflorescences solitary at nodes, interpetiolar on alternating sides along length of branchlet, few-flowered, fasciculate or becoming vermiform in age; flowers 4 -merous, subsessile, $\Varangle$ and apparently homostylous; calyx limb cupular, contracted at base, membranous, truncate to shallowly undulate, persistent; corolla tubular-infundibular, glabrous to puberulent without, glabrous within but squamate toward base (squamellae 4, membranaceous, barbate), the lobes valvate in bud; stamens inserted in corolla throat, the anthers exserted on short filaments; ovary 4-locular, the ovules solitary in each locule; style as long as corolla tube, the stigma peltate or discoid, depressed at apex, fimbriate and reflexed at margin; fruit drupaceous, ellipsoid or angular-obovoid, the pyrenes thick-walled.

LECTOTYPE SPECIES: Squamellaria imberbis (A. Gray) Becc. (Myrmecodia imberbis A. Gray); vide S. Darwin in Allertonia 2: 36.1979.

Distribution: Squamellaria is endemic to Fiji, with three species apparently confined to Vanua Levu and Taveuni. It is more closely related to Hydnophytum than to Myrmecodia, to which genus Gray had assigned the type species. Myrmecodia, which extends as far east as the Solomon Islands, is distinct in having but one or a few leaf-bearing branches arising from the tuber, the branches usually fleshy, unbranched, covered with fleshy, shield-shaped outgrowths, and armed with spines. 1886

USEFul tReatment of Genus: BeCCARI, O. Squamellaria nuovo genere di Rubiacee. Malesia 2: 228-230.

\section{KEY TO SPECIES}

Leaf blades elliptic to elliptic-lanceolate, sharply acute at apex, the nervation prominulous on both sides; petioles 5-40 mm. long, I-2 $\mathrm{mm}$. broad; calyx limb 2-3 mm. long; corolla glabrous or puberulent without, the tube $12-20 \mathrm{~mm}$. long; fruit obovoid-turbinate, prominently 4-angled.

Petioles 5-10 mm. long; leaf blades $3.5-6 \times 1.5-2 \mathrm{~cm}$., obtuse and abruptly decurrent at base; calyx limb about $2 \mathrm{~mm}$. broad. 

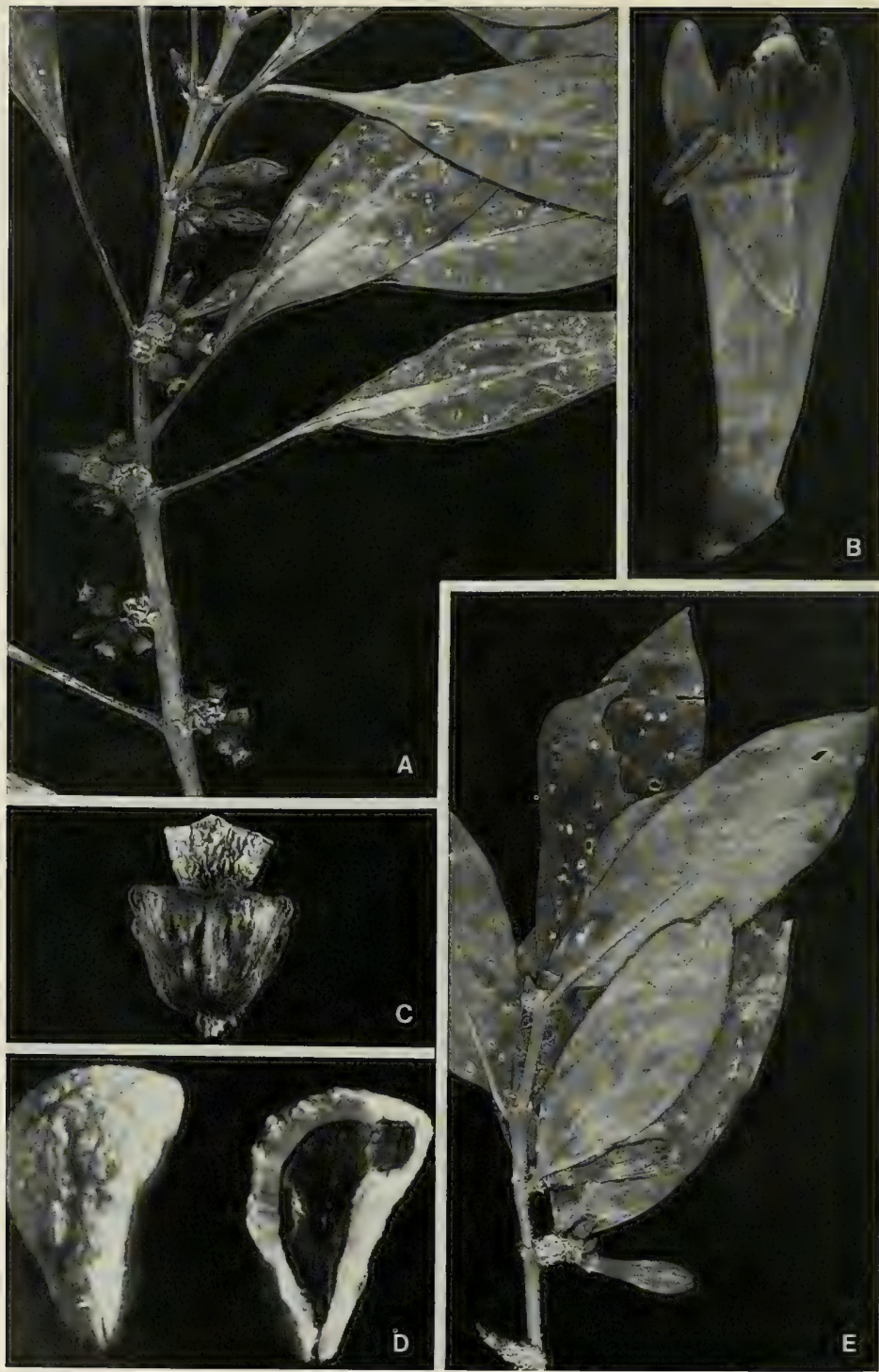
Petioles (10-) 15-40 mm. long; leaf blades 6-12 2 2-3.5 cm., narrowly attenuate-decurrent at base; calyx

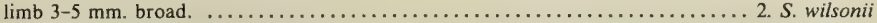
Leaf blades oblong-lanceolate, (8-) 12-17 × (3-) 4-6.5 cm., broadly rounded to erose-cuspidate at apex, obtuse and decurrent on petiole at base, the nervation prominently elevated on both sides; petioles to 5 $\mathrm{mm}$. long and $4 \mathrm{~mm}$. broad; calyx limb 3-4 mm. long, 3-5 mm. broad; corolla puberulent without, the tube $25-45 \mathrm{~mm}$. long; fruit ellipsoid, not prominently angled. .............. S. major

1. Squamellaria imberbis (A. Gray) Becc. Malesia 2: 228. t. 46, fig. 1-12. 1886; A. C. Sm. in J. Arnold Arb. 36: 289. 1955; J. W. Parham, Pl. Fiji Isl. 209. 1964, ed. 2. 293. 1972.

Figure 91E.

Myrmecodia imberbis A. Gray in Proc. Amer. Acad. Arts 4: 42. 1858; Seem. Fl. Vit. 138. 1866.

Myrmecodia inermis A. Gray ex Hook. f, in Benth. \& Hook. f. Gen. Pl. 2: 132, sphalm. 1873.

Hydnophytum imberbe Benth. \& Hook. f. ex Drake, Ill. Fl. Ins. Mar. Pac. 200. 1890.

Epiphytic shrub with short branches arising from ant-inhabited tubers, sparingly known at elevations up to $430 \mathrm{~m}$. in dense forest, with white corollas. The only dated specimen bore flowers and fruits in May.

TyPifiCation: The type is U.S. Expl. Exped. (us 62266 HOLOTYPE; ISOTYPE at K), collected in 1840 in Mathuata Province without further locality, Vanua Levu.

Distribution: Endemic to Fiji and apparently rare, known from only two collections from Vanua Levu.

Local NAME: Theketuawa (from Smith 1787).

AVAilable COLlection: VANUA LEVU: ThakaUndrove: Mt. Kasi, Yanawai River region, Smith 1787.

2. Squamellaria wilsonii (Horne ex Baker) Becc. Malesia 2: 229. t. 46, fig. 13-21. 1886;

A. C. Sm. in J. Arnold Arb. 36: 289. 1955; S. Darwin in Allertonia 2: 35. fig. 3, D. 1979.

Figures $91 \mathrm{~A}-\mathrm{D}, 130$.

Hydnophytum wilsoni Horne, A Year in Fiji, 263, nom. nud. 1881; Horne ex Baker in J. Linn. Soc. Bot. 20: 365. 1883; Drake, Ill. Fl. Ins. Mar. Pac. 200. 1890.

Squamellaria wilsoni Becc. ex J. W. Parham, Pl. Fiji lsl. 209. 1964, ed. 2. 293. 1972.

Epiphytic shrub with branches arising from ellipsoid tubers up to $40 \times 25 \mathrm{~cm}$. and ant-inhabited, occurring in dense forest at elevations of $200-900 \mathrm{~m}$. The calyx is pale green and the corolla white. Flowers and fruits have been obtained between May and December.

TYPIFICATION: The type is Horne 1139 (K HOLOTYPE), collected in September, 1878, on wooded mountains near the coffee estate of Forest Creek, Taveuni. This locality is not found on modern maps but is discussed by Horne (A Year in Fiji, 54. 1881) and is shown on his map as being on the western slope of Taveuni a few kilometers northeast of Vuna Point.

Distribution: Endemic to Fiji and known only from Vanua Levu and Taveuni.

AVAilable COllections: VANUA LEVU: Mathuata-Thakaundrove boundary: Crest of Korotini Range, between Navitho Pass and Mt. Ndelaikoro, Smith 564. TAVEUNI: Western slope between Somosomo and Wairiki, Smith 750; slopes of Mt. Manuka, east of Wairiki, Smith 8191,8326; above Nggathavula Estate, DA 16935; Nggarawalu Freehold, DA 11901.

3. Squamellaria major A. C. Sm. in Contr. U. S. Nat. Herb. 37: 90. 1967; J. W. Parham, Pl. Fiji Isl. ed. 2. 293. 1972.

Figure 92.

An apparently rare epiphytic shrub, with ellipsoid tubers to $40 \mathrm{~cm}$. long and ant-inhabited, found in dense forest at an elevation of $300-600 \mathrm{~m}$. The calyx tube is white and pink-tinged, with the limb green at margin; the corolla is white, faintly

Figure 91. A-D, Squamellaria wilsonii; A, portion of branchlet with foliage and inflorescences, some with both flowers and fruits, $\times 1$; B, flower, showing dehisced anthers, style, and receptive stigma, $\times 3$; C, fruit, $\times 4 ; \mathrm{D}$, pyrene and longitudinal section of pyrene showing embryo, $\times 10$. E, Squamellaria imberbis; foliage and inflorescences, × 1. A \& B from Smith 750, C \& D from Smith 564, E from Smith 1787. 
pink-tinged distally within; the stamens have white filaments and pinkish anthers, and the style is pale pink. Flowers and fruits are known from a single collection obtained in August.

TYPIFICATION: The type is Smith 8323 (US 2191043 HOLOTYPE; many ISOTYPES), collected Aug. 14, 1953, on the slopes of Mt. Manuka, east of Wairiki, Taveuni.

Distribution: Endemic to Fiji and thus far known only from the type collection.

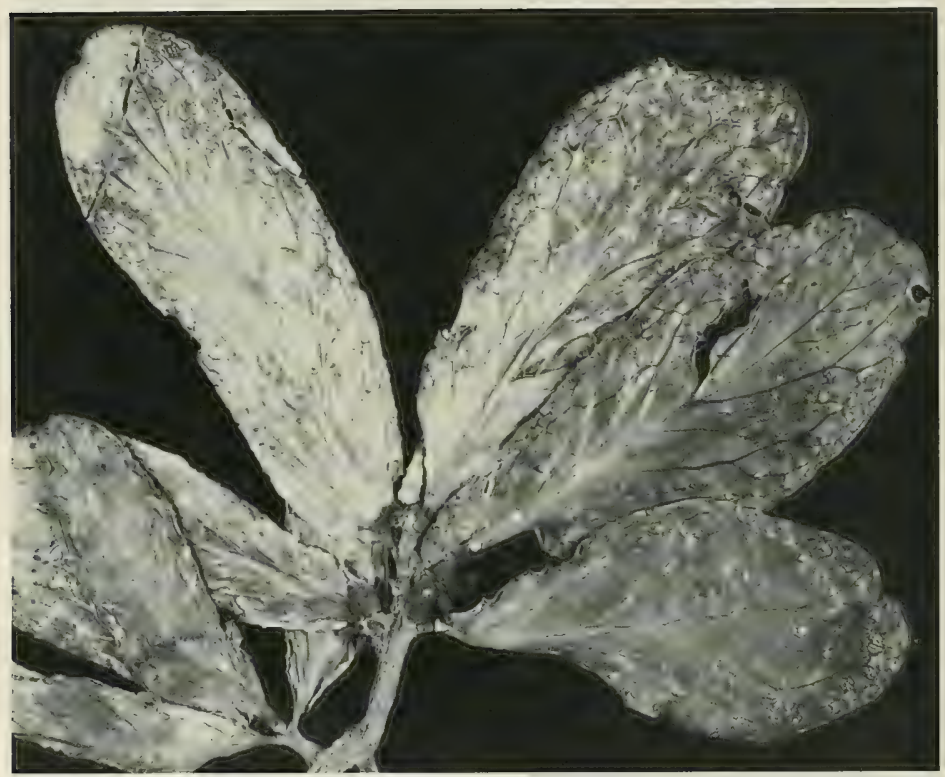

FrgURE 92. Squamellaria major; distal portion of branchlet with foliage and inflorescences, $\times 5 / 8$; from Smith 8323.

26. Geophila D. Don, Prodr. Fl. Nepal. 136. 1825; Seem. Fl. Vit. 138. 1866; K. Schum. in Engl. \& Prantl, Nat. Pflanzenfam. IV. 4: 118. 1891; Fosberg in Taxon 11: 180. 1962; Backer \& Bakh. f. Fl. Java 2: 334. 1965; Verdcourt in Fl. Trop. E. Afr. Rub. 109. 1976; S. Darwin in Allertonia 2: 36. 1979. Nom. cons.

Carinta W. F. Wight in Safford in Contr. U. S. Nat. Herb. 9: 216. 1905.

Creeping, perennial herbs rooting at nodes, the stipules interpetiolar, broad, entire or bilobed, persistent; leaf blades usually orbicular to reniform and cordate; flowers solitary or in terminal, pedunculate heads or umbels, bracteate, subsessile, $\Varangle$ (sometimes heterostylous), 4-7-merous; calyx persistent, the lobes usually slender; corolla tubular-infundibular, pubescent or glabrous in throat, the lobes valvate in bud; stamens inserted in or below corolla throat, the filaments filiform, the anthers included or exserted; ovary 2-locular, the ovules solitary and erect in each locule, the style slender, the stigma 2-lobed; fruit fleshy, drupaceous, containing 2 pyrenes. 
TYPE SPECIES: Geophila reniformis D. Don, nom. illeg. (Psychotria herbacea L.) = G. repens (L.) I. M. Johnston. Carinta W. F. Wight, a substitute name proposed for Geophila D. Don, is based on the same type.

Distribution: Pantropical, with about $10-15$ species. One widespread species is indigenous in Fiji.

1. Geophila repens (L.) I. M. Johnston in Sargentia 8: 281. 1949; Backer \& Bakh. f. Fl. Java 2: 334. 1965; Sykes in New Zealand Dept. Sci. Indust. Res. Bull. 200: 176. 1970; St. John \& A. C. Sm. in Pacific Sci. 25:339. 1971; J. W. Parham, Pl. Fiji Isl. ed. 2. 270. 1972; Verdcourt in Fl. Trop. E. Afr. Rub. 110. fig. 7(1, 2). 1976; Morat \& Veillon in Bull. Mus. Nat. Hist. Nat. (Paris) IV. 7, Sect. B, Adansonia 3: 315. 1985.

Rondeletia repens L. Syst. Nat. ed. 10. 928. (Oct.) 1759.

Psychotria repens L. ex Sandmark, Fl. Jam. 14. (Dec.) 1759, Amoen. Acad. 5: 377. 1760.

Psychotria herbacea Jacq. Enum. Syst. Pl. Carib. 16. 1760.

Psychotria herbacea L. Sp. Pl. ed. 2. 245, nom. illeg. 1762; Forst. f. Fl. Ins. Austr. Prodr. 16. 1786; non Jacq.

Geophila reniformis D. Don, Prodr. Fl. Nepal. 136, nom. illeg. 1825; Cham. \& Schlechtendal in Linnaea 4: 137. 1829; Seem. in Bonplandia 9: 256. 1861, Viti, 437. 1862, Fl. Vit. 138. 1866; Drake, Ill. Fl. Ins. Mar. Pac. 199. 1890; Reinecke in Bot. Jahrb. 25:689. 1898; Rechinger in Denkschr. Akad. Wiss. Wien 85: 377.1910.

Geophila herbacea K. Schum. in Engl. \& Prantl, Nat. Pflanzenfam. IV. 4: 119, nom. illeg. 1891; Kuntze, Rev. Gen. Pl. 300. 1891; Christophersen in Bishop Mus. Bull. 128: 205. 1935; Yuncker in op. cit, 178: 113. 1943, in op. cit. 184: 65. 1945; B. E. V. Parham in New Zealand Dept. Sci. Indust. Res. Inform. Ser. 85: 52, 88, 95. 1972; S. Darwin in Allertonia 2: 36. fig. 3, E: 1979.

Carinta herbacea W. F. Wight in Safford in Contr. U. S. Nat. Herb. 9:216. 1905; Yuncker in Bishop Mus. Bull. 220: 258. 1959.

Carinta repens L. B. Sm. \& Downs in Sellowia 7: 88. 1956.

A sprawling, repent herb found from near sea level to an elevation of about $600 \mathrm{~m}$. in dense or open forest, usually on rich humus in wet, shady places. The corolla is white and the attractive fruit is red or orange. Flowers are most often collected between October and January but are seen sporadically throughout the year, and fruits are found in all months.

Typification: For Rondeletia repens Linnaeus cited two sources: Rheede, Hort. Ind. Malabar. 10: pl. 21. 1690, and Sloane, Voy. Jam. Nat. Hist. 1: 243. 1707. A firm lectotypification has not been located, but by common consent, when doubt of the conspecificity of the Old and New World elements has been expressed, the latter has been used as nomenclaturally typical. The type of Psychotria herbacea Jacq. is a Jacquin West Indian specimen probably deposited at w (Verdcourt, 1976), although Jacquin also cited the Rheede (1690) publication. Psychotria herbacea L., although illegitimate because of Jacquin's binomial, is based on a Browne collection from Jamaica, probably a specimen at LINN but not so labelled (Verdcourt, 1976). Geophila reniformis was based on Wallich (BM) from Bangladesh, although Don's name was illegitimate because Psychotria herbacea L. was cited as a synonym. Geophila herbacea K. Schum. was based on Psychotria herbacea L., while Carinta herbacea W. F. Wight was based on $P$. herbacea Jacq.

Distribution: Geophila repens is frequently treated as a pantropical species, although Johnston (1949) and L. O. Williams (in Phytologia 26:264. 1973) suggest that the binomial should be applied only to the New World element. According to Verdcourt (1976), the species is fairly uniform in the Old World, while New World specimens often have 5-flowered (rarely 1 -flowered) inflorescences and hence a rather different appearance. While inflorescences of Fijian plants are usually 1-or 3-flowered, 
the advisability of dividing the species seems to us very questionable; furthermore, if this should be suggested, Geophila reniformis, being illegitimate, could not serve as a basionym. Possibly an Old World taxon, if deemed desirable, could be based on Geophila reniformis var, asiatica Cham. \& Schlechtendal (cf. Fosberg, Sachet, and R. Oliver in Micronesica 15: 265. 1979).

In Fiji the species is fairly frequent and is to be anticipated on many islands, although at hand are only about 35 collections from five islands.

LOCAL NAMES AND USE: Widespread names are totondro and salokota, with variants like totondro ni veikau (Tailevu) and totondro ni vei ivi(Ovalau). Other recorded names (Namosi Province) are namola and molia. The leaves are sometimes chewed as a cough remedy.

RePresentative Collections: VITI LEVU: MBa: Mountains near Lautoka, Greenwood 79. NandRoNGA \& NAvOSA: Southern slopes of Nausori Highlands, in drainage of Namosi Creek above Tumbenasolo, Smith 4566; Lombau, Singatoka Valley, O. \& I. Degener 32092. SeRUA: Hills between Navua River and Wainiyavu Creek, near Namuamua, Smith 8998. Namosi: Namosi Village, Weiner 16; near Namuamua, Gillespie 3026. NaITASIRr: Near Tholo-i-suva, Vaughan 3344. TaILevu: Matavatathou, DA 7752. REwA: Lami, Meebold 16478. OVALAU: Hills southeast of valley of Mbureta River, Smith 7399. VANUA LEVU: Mbua: Ndriti, DA 2283. Mathuata: Mountains near Lambasa, Greenwood 79 A. Thakaundrove: Cocoa Station, Wainingata, DA 11902 . TAVEUNI: Seemann 239; western slope between Somosomo and Wairiki, Smith 726. VANUA MBALAVU: Nambavatu, northern limestone section, Tothill 276.

27. Readea Gillespie in Bishop Mus. Bull. 74: 35. 1930; Fosberg in Sargentia 1: 136. 1942; A. C. Sm. in J. Arnold Arb. 36: 289. 1955, in Pacific Sci. 23: 367. 1969; S. Darwin in Allertonia 2: 36. 1979.

Trees or shrubs, the stipules interpetiolar, connate into a short, subtruncate sheath and often persistent at 1 or 2 distal nodes; inflorescences terminal, cymose, the bracts small; flowers $\Varangle, 4$-merous; hypanthium pyriform, contracted at apex, the calyx limb enclosing corolla in bud, fleshy, eventually splitting from apex into 4 lobes, these alternately slightly unequal in width, similar to corolla lobes in size and texture and alternate with them; corolla infundibular, glabrous, the lobes spreading, slightly longer than tube; stamens attached at apex of corolla tube, the anthers dorsifixed; style shorter than corolla, distally bifid, surrounded at base by an urceolate disk; ovary 2-locular, the ovules solitary and basal in each locule; fruit fleshy, obovoid-cylindric, smooth when fresh, often 8-costate when dry, truncate or shallowly depressed at apex, the pyrenes dorsally tricarinate, the carinas rounded.

TYPE SPECIES: Readea membranacea Gillespie.

Distribution: A monotypic genus endemic to Fiji and thus far known only from Viti Levu, Vanua Levu, and Taveuni. Two taxa subsequently described in Readea are now referred to Psychotria ( $P$. roseata and $P$. prismoclavata, q. v.).

Readea is readily separable from Psychotria in characters pertaining to the calyx, disk, and fruit.

1. Readea membranacea Gillespie in Bishop Mus. Bull. 74: 35. fig. 49. 1930; Fosberg in Sargentia 1: 136. 1942; J. W. Parham, PI. Fiji Isl. 209. 1964, ed. 2. 292. fig. 87. 1972; A. C. Sm. in Pacific Sci. 23: 368. 1969; S. Darwin in Allertonia 2: 36. fig. 3, F. 1979.

Figures 93, 94.

Figure 93. Readea membranacea; A, leaf, inflorescence, and distal portion of branchlet with stipular sheath persisting at penultimate node, $\times 1 / 3 ; \mathrm{B}$, closed flower, with calyx limb just beginning to split from apex, $\times 4$; C, longitudinal section of flower in advanced bud, showing 3 anthers (a), style, stigmatic lobes (s), disk (d), adherent lower part of calyx limb (c), and upper part of hypanthium (h), $\times 8$; D, calyx limb divided to middle, disclosing corolla and tips of anthers, $\times 4$. A from Gillespie 3446. B \& C from Degener 14520, D from Gillespie 4622. 

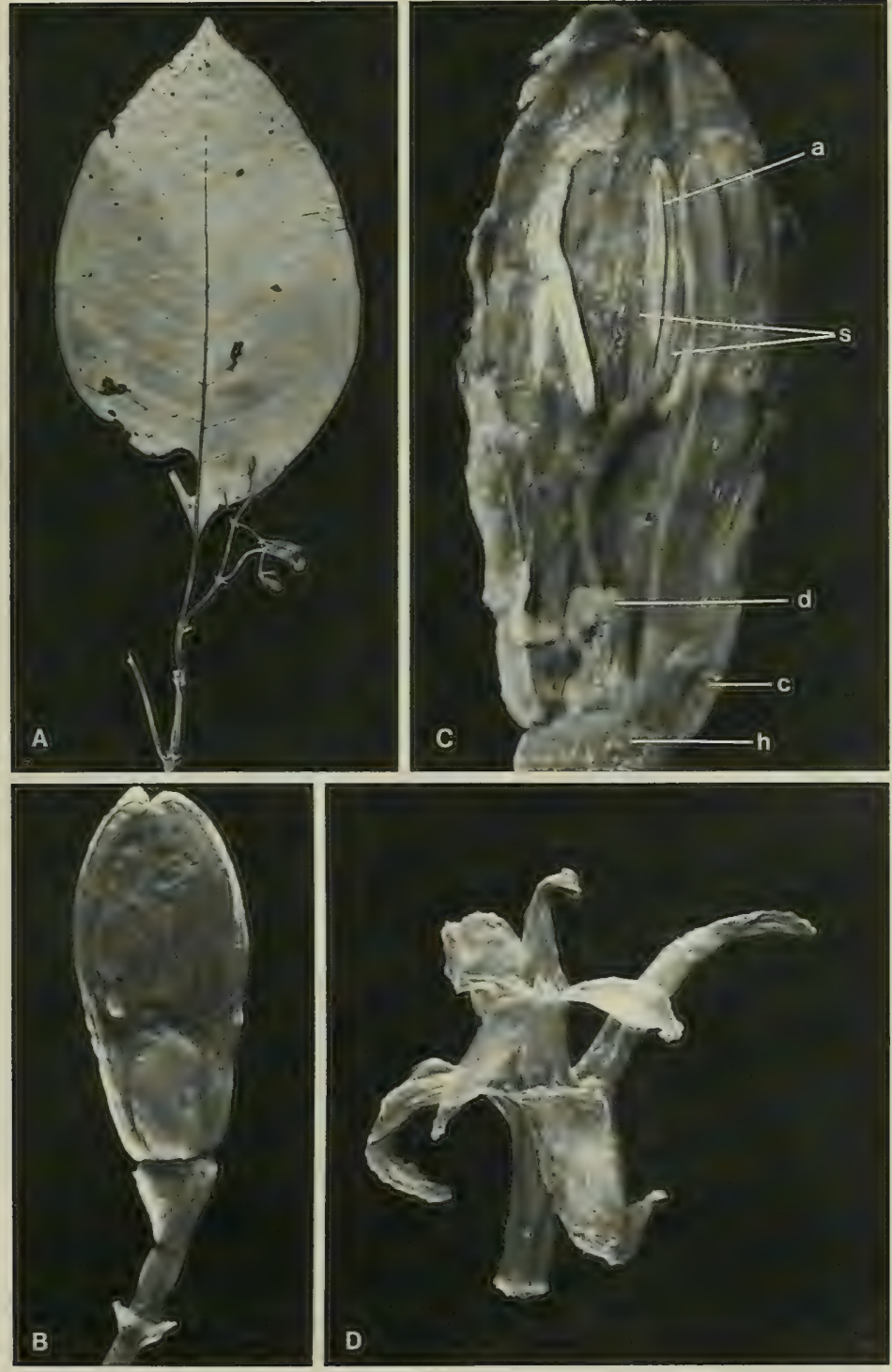


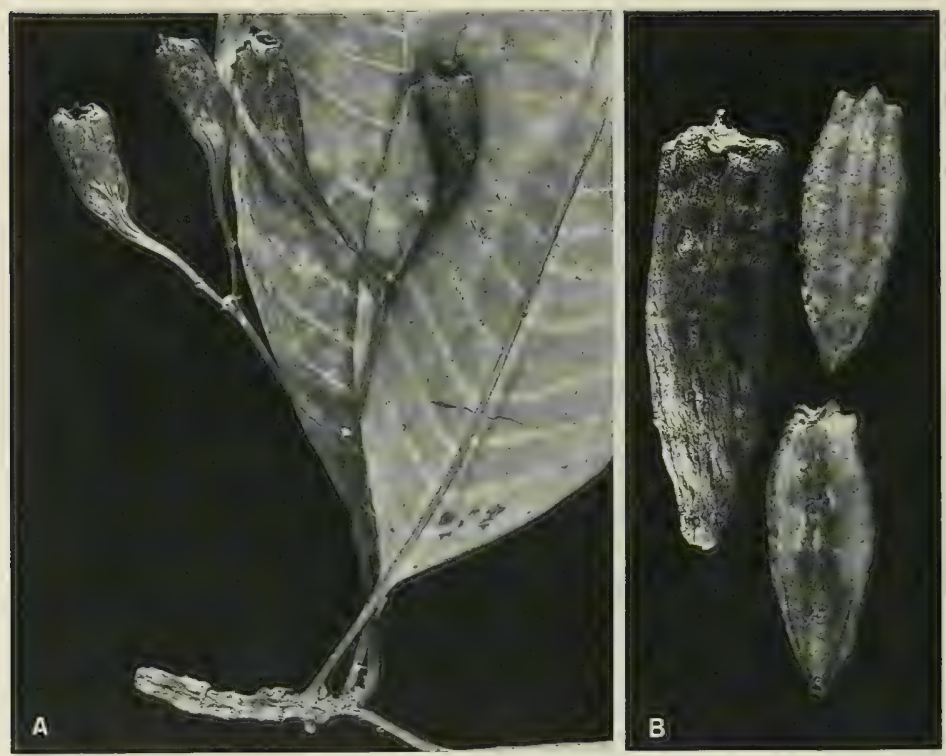

FIGURE 94. Readea membranacea; A, infructescence and foliage, $\times 1$; B, fruit, with abaxial and adaxial surfaces of pyrenes, $\times 2$. A from Smith 1530 , B from Smith 727.

An often slender tree 2-7 m. high, rarely noted as a shrub, often locally frequent in dense, open, or secondary forest at elevations from near sea level to $1,100 \mathrm{~m}$. The faintly fragrant flowers are sometimes pink-tinged at base; the calyx and corolla are pale green and the anthers bright yellow; and the green fruit becomes dark red or purple at maturity and attains a size up to $4 \times 2 \mathrm{~cm}$. Flowers and fruits do not appear seasonal, the former having been collected in scattered months throughout the year and the latter in every month.

TyPIFICATION: The type is Gillespie 4622 (BISH HOLOTYPE; ISOTYPES at BISH, K, US), collected in flower Feb. 20, 1928, in the vicinity of Waiyevo, Taveuni.

Distribution: Endemic to Fiji and now known from the three largest islands; 44 collections have been examined.

LOCAL NAMES: Only two specimens record local names: okeoke (Mbua) and turuturu (Taveuni).

REPRESENTATIVE COLlections: VITI LEVU: MBA: Mountains inland from Lautoka, Greenwood 22 (April, 1920, apparently the first collection of the species); Mt. Nanggaranambuluta, east of Nandarivatu, Webster \& Hildreth 14219; Nauwangga, south of Nandarivatu, Degener 14520; Mt. Tomanivi, O.\& I. Degener 32068. NANDRONGA \& NAvOSA: Northern portion of Rairaimatuku Plateau, between Nandrau and Nanga, Smith 5541. NAmosI: Northern slopes of Korombasambasanga Range, in drainage of Wainavindrau Creek, Smith 8738; Wainandoi River, DF 204 (Bola 63); vicinity of Nasinu, Gillespie 3446 . VANUA LEVU: Mbua: Mt. Seatura, DA 15171; southern portion of Seatovo Range, Smith 1530. Mathuata: Southern base of Mathuata Range, north of Natua, Smith 6767. THAKaUndrove: Southern slope of Korotini Range, below Navitho Pass, Smith 504; Mt. Vatunivuamonde, Savusavu Bay region, Degener \& Ordonez 14005 ; Navonu Creek, Natewa Peninsula, DA 13815. TAVEUNI: Western slope between Somosomo and Wairiki, Smith 727; slopes of Mt. Manuka, east of Wairiki, Smith 8128. 

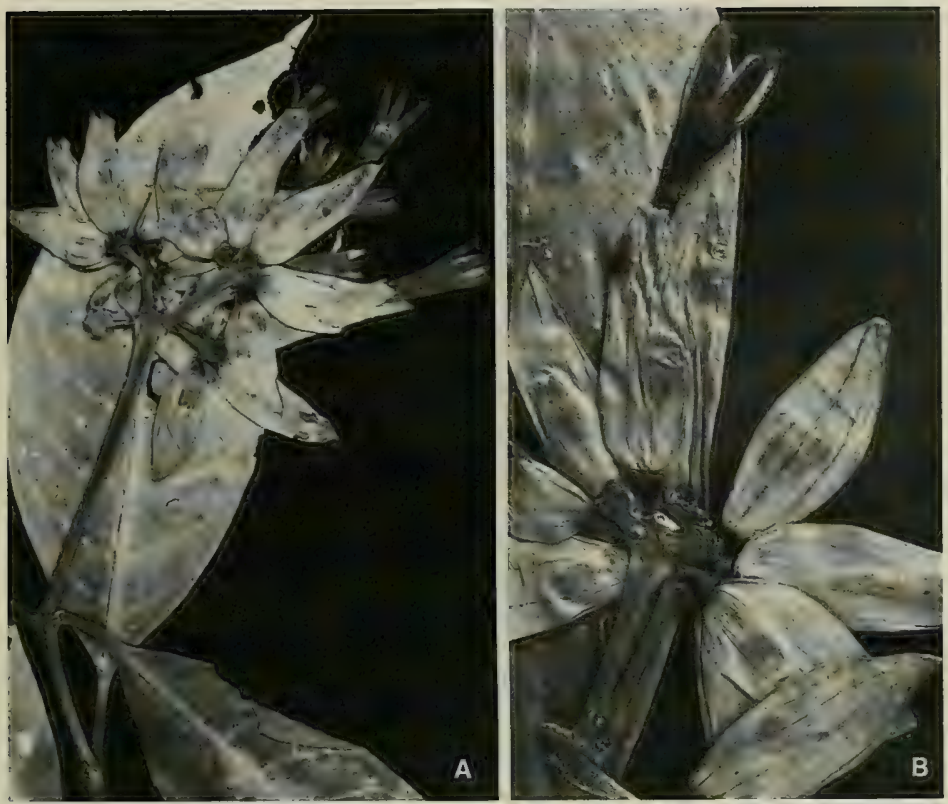

Figure 95. Gillespiea speciosa, from Smith 518; A, distal portion of branchlet, with foliage and an inflorescence, $\times 1 ; \mathrm{B}$, portion of inflorescence with calyces completely closed in bud, one opening to show distal part of corolla, $\times 2$.

28. Gillespiea A. C. Sm. in Bishop Mus. Bull. 141: 158. 1936, in J. Arnold Arb. 36: 289. 1955; S. Darwin in Allertonia 2: 38. 1979.

Shrubs or small trees, the stipules small, interpetiolar, soon deciduous; inflorescences terminal, pedunculate or parted from base, cymose, few-flowered, apparently ebracteate; flowers $\Varangle, 5$-merous; hypanthium subglobose or obovoid, slightly contracted at apex, the calyx limb membranous, spathaceous, completely developed before anthesis, acute at closed apex, and enclosing corolla, splitting along one side as corolla matures or rarely splitting into 2 lobes, at length deciduous; corolla tubular, pubescent within, the lobes valvate; stamens borne in corolla throat, the filaments ligulate, short, the anthers dorsifixed; ovary 2-locular, the ovules solitary and basal in each locule, the style filiform, bifid at apex, surrounded at base by a conspicuous, carnose, annular disk; mature fruits unknown.

TYPE SPECIES: Gillespiea speciosa A. C. Sm.

Distribution: Endemic to Fiji and monotypic, known only from Vanua Levu.

It seems surprising that this extraordinary genus remains known only from the four Vanua Levu collections originally cited, from two localities about 16 kilometers apart, both in the southern drainage of the island. The genus was originally contrasted with Calycosia, but its alliance to Readea (similarly monotypic and endemic) is also evidenced by the fact that both genera have the calyx limb completely closed in bud, 
although quite differently opening and very different in texture. Fruits of Gillespiea remain unknown, but from the shape and texture of advanced hypanthia it seems more likely that they will prove to resemble the fruits of Psychotria and its closer relatives rather than those of Readea.

1. Gillespiea speciosa A. C. Sm. in Bishop Mus. Bull. 141: 160. fig. 82. 1936, in J. Arnold Arb. 36: 289. 1955; J. W. Parham, Pl. Fiji Isl. 191. 1964, ed. 2. 270. 1972; S. Darwin in Allertonia 2: 38. fig. 3, G. 1979.

Figure 95.

Shrub or tree 1-6 m. high, apparently rare in dense forest at elevations of 300-881 $\mathrm{m}$. The calyx and corolla are white; flowers have been collected only in November.

TYPIFICATION: The type is Smith 518 (BISH HOLOTYPE; many ISOTYPES), collected Nov. 21, 1933, on the southern slopes of the Korotini Range, below Navitho Pass, Thakaundrove Province, Vanua Levu.

Distribution: Endemic to Fiji and thus far known only from Vanua Levu.

LOCAL NAMES: Recorded names are nakau and sola ni mbongi.

Available Collections: VANUA LEVU: ThaKaundrove: Southern slopes of Korotini Range, below Navitho Pass, Smith 493; Mt. Mariko, Smith 419, 477.

29. Calycosia A. Gray in Proc. Amer. Acad. Arts 4: 47. 1858; Seem. Fl. Vit. 132, p. p. 1866; A. C. Sm. in Bishop Mus. Bull. 141: 152. 1936; Fosberg in Sargentia 1: 137. 1942; A. C. Sm. in Pacific Sci. 23: 388. 1969; S. Darwin in Allertonia 2: 38.1979. Uragoga sensu Gillespie in Bishop Mus. Bull. 74: 36. 1930; non Baill.

Uragoga sect. Sertoides Hochr. in Candollea 5: 273. 1934.

Trees or shrubs, the stipules interpetiolar, united and conspicuously sheathing at base, bifid at apex, usually soon caducous; inflorescences capitular to capitularcymose, terminal at inception but often soon appearing lateral due to sympodial growth of shoot, the bracts conspicuous, often numerous, involucrate, free or united, fimbriate-ciliate at margin (at least apically), pale green to white, at length deciduous; flowers sessile or short-pedicellate, subtended by comparatively large bracteoles; calyx limb infundibular, deciduous in fruit, the lobes $5-7$, often unequal, fimbriate-ciliate; corolla narrowly infundibular, white, densely to sparsely pubescent within, the lobes 5 , valvate in bud, becoming spreading; stamens 5 , inserted in or below corolla throat, the anthers subsessile; ovary 2(or 3)-locular, the ovules solitary and basal in each locule, the style filiform, the stigmas 2 (or 3), linear to filiform; fruit drupaceous, truncate at apex, narrowed at base, the pyrenes plane to ridged but not strongly carinate.

LeCtotype SPECIES: Calycosia petiolata A. Gray, one of the two original species; vide A. C. Smith in Bishop Mus. Bull. 141: 153. 1936. Uragoga sect. Sertoides was based on $U$. cyrtandroides Hochr. (= Calycosia sessilis A. Gray, endemic to Samoa).

Distribution: As presently circumscribed, Calycosia comprises six species, four endemic to Fiji, one to Samoa, and one to the Solomon Islands. We have seen no material of the genus from the New Hebrides. Other Pacific species that have been assigned to Calycosia are for the most part now referred to Psychotria.

As remarked by Fosberg (1942), Calycosia has been a genus difficult to define, in part because the large, capitular (or capitular-cymose) inflorescences are often collected in a rain-soaked condition and are not readily interpreted from herbarium material. The large, infundibular calyx limb and the corolla (FIGURE 96D) do not provide characters that separate the genus from all groups of Psychotria. However, the morphology of the inflorescence is reasonably distinctive; it is subtended by large, enveloping bracts, the outermost of which are either united into an urceolate or cyathiform cupule (cf. Gillespie in Bishop Mus. Bull. 74: fig. 50. 1930) or essentially free. Many involucrate bracts conceal the ramifications of the congested-cymose 
inflorescences; these bracts are often very large but decrease in size at successive nodes to flower-subtending bracteoles (FIGURE 97).

\section{KEY TO SPECIES}

Inflorescences pedunculate (or sessile), not basally subtended by numerous, essentially free, imbricate bracts; stipules and inflorescence parts essentially glabrous except fimbriate at margins; leaf blades with copious reddish glandular patches on both surfaces especially when young, the lower surfaces glabrous; corolla tube (15-) 25-40 mm. long, the lobes 4-8 $\times 1.5-3 \mathrm{~mm}$.

Heads solitary (rarely in threes), the outer bracts united except at apex into an urceolate cupule $1-2 \mathrm{~cm}$. broad at anthesis; stipules $1-2 \mathrm{~cm}$. long; leaf blades $10-26 \times 3-12 \mathrm{~cm} . \ldots \ldots 1$. . lageniformis

Heads usually in threes, the outer bracts of each head united (at least partially) into a broad cyathiform cupule at least $2 \mathrm{~cm}$. broad at anthesis; stipules $2.5-4 \mathrm{~cm}$. long; leaf blades $18-35 \times 8-15 \mathrm{~cm}$.

2. C. macrocyatha

Inflorescences sessile, complex, branching from base, subtended by numerous, essentially free, imbricate bracts, the bracts of the ultimate heads also essentially free; stipules (2-) 3-6 cm. long, sometimes pilose basally, fimbriate at margins; leaf blades lacking reddish glandular patches, the lower surfaces usually scattered-puberulent with spreading hairs; corolla tube 13-17 mm. long, the lobes 2-3.5 $\times 1-2 \mathrm{~mm}$.

Bracts dorsally glabrous, often ciliolate, rarely sparsely pilose distally, the calyx limb dorsally glabrous or rarely sparsely pilose, glabrous within, often ciliolate apically; petioles $2-8 \mathrm{~cm}$. long; leaf blades oblanceolate to narrowly elliptic, $12-40 \times 4-15 \mathrm{~cm} . \ldots \ldots \ldots \ldots \ldots \ldots \ldots \ldots . \ldots \ldots$. petiolata

Bracts and calyx limb dorsally copiously pilose with reddish, multicellular, spreading hairs, rarely very tardily glabrate, the calyx limb similarly pilose (hairs $0.5-1 \mathrm{~mm}$. long) within except toward base; petioles 3-12 cm. long; leaf blades broadly elliptic, $25-42 \times 10-19 \mathrm{~cm} . \ldots . \ldots .4$. . callithrix

1. Calycosia lageniformis (Gillespie) A. C. Sm. in Bishop Mus. Bull. 141: 154. 1936; Fosberg in Sargentia 1: 139. 1942; J. W. Parham, Pl. Fiji Isl. 187. 1964, ed. 2. 266. 1972.

Figure 96A.

Uragoga lageniformis Gillespie in Bishop Mus. Bull. 74: 36. fig. 50. 1930.

Small tree or shrub 3-15 m. high, often freely branched, locally frequent in dense forest at elevations of $725-1,150 \mathrm{~m}$. The bracts, bracteoles, and corollas are white, and the mature fruit is orange to red or scarlet. Flowers have been collected between October and January and also in May, fruits between February and November.

TYPIFICATION: The type is Gillespie 3688 (BISH HOLOTYPE and ISOTYPE), collected Nov. 14, 1927, on the slopes of Mt. Nanggaranambuluta, east of Nandarivatu, Mba Province, Viti Levu.

Distribution: Endemic to Fiji and thus far known only from high elevations in northwestern and north-central Viti Levu; in the latter area it is sympatric with Calycosia petiolata but not with the other two Fijian species of the genus.

LOCAL NAMES: In Mba Province the names kau yalewa and lewalekaleka have been recorded.

Available Collections: VITI LEVU: MBa: Mt. Evans Range, Greenwood 942, 1245; slopes of Mt. Nairosa, eastern flank of Mt. Evans Range, Smith 4037; southern slopes of Mt. Ndelainathovu, on escarpment west of Nandarivatu, Smith 4925; vicinity of Nandarivatu, Tothill 339A, Degener \& Ordonez 13607, DA 2374; slopes and summit of Mt. Nanggaranambuluta, Tothill 339, Gillespie 4286, DA 14030 , 14673; Nauwangga, south of Nandarivatu, Degener 14540; slopes of Mt. Tomanivi, Smith 5110, DA 12762 (Melville et al. 7154), 14660. NANDRONGA \& NAvOSA: Northern portion of Rairaimatuku Plateau, between Nandrau and Rewasau, Smith 5440, 5635.

2. Calycosia macrocyatha Fosberg in Sargentia 1: 139. 1942. FIGURE 96C \& D.

Calycosia macrocyatha Fosberg var. macrocyatha; Fosberg in Sargentia 1: 139. 1942; J. W. Parham, P1. Fiji Isi. 187. 1964, ed. 2. 266. 1972.

Calycosia macrocyatha var. kandavuensis Fosberg in Sargentia 1: 140. 1942; J. W. Parham, Pl. Fiji Isl. 188. 1964 , ed. 2. 266. 1972.

An often slender tree or shrub 3-13 m. high, scattered in dense forest at elevations from near sea level to $1,160 \mathrm{~m}$. As throughout the genus, the involucral bracts are white and the fruits red. Flowers have been noted between August and February, fruits in January and August. 

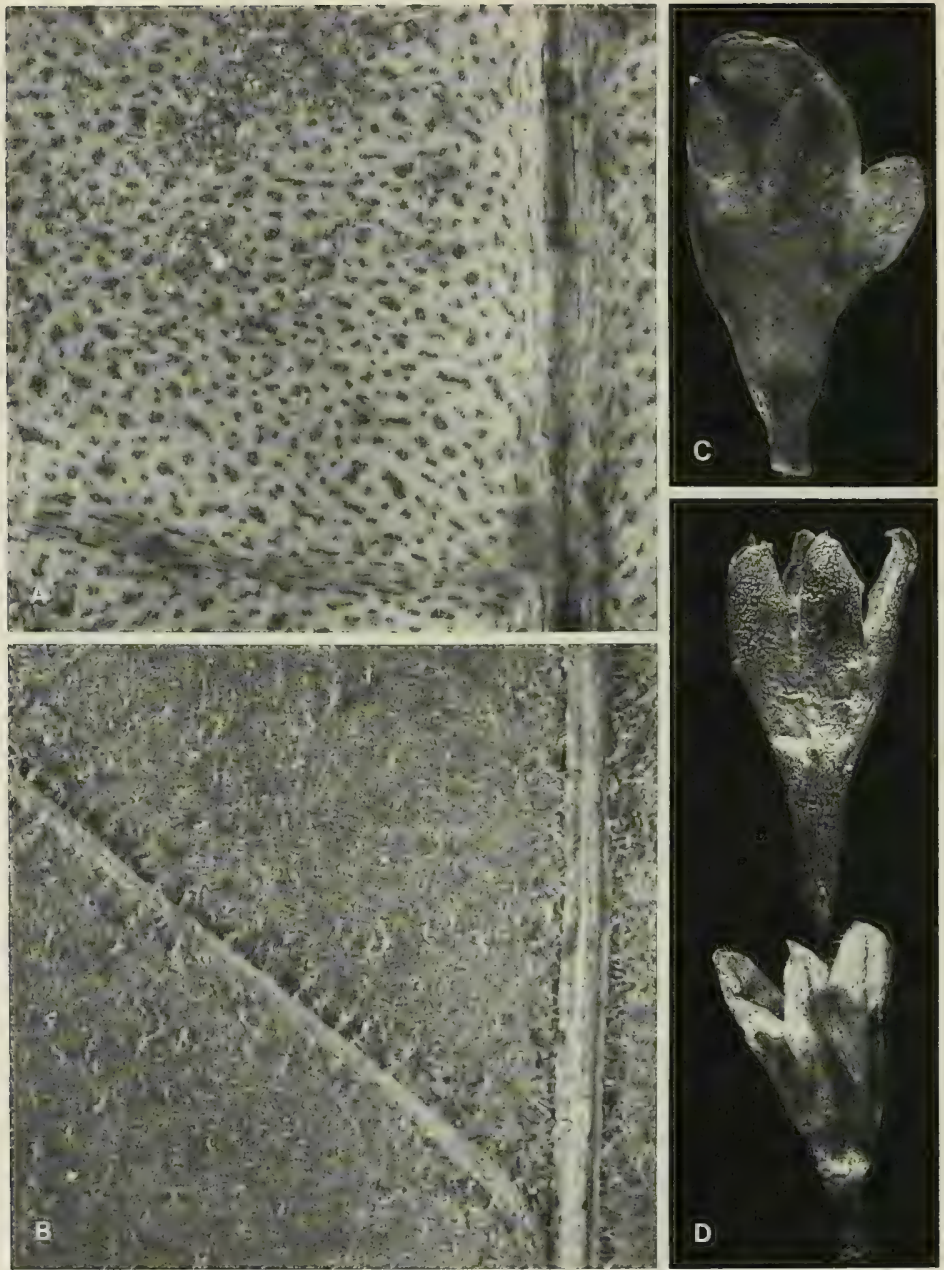

FIGURE 96. A, Calycosia lageniformis; lower surface of leaf blade (at junction of costa and secondary nerve) showing characteristic glandular patches, $\times 10 . \mathrm{B}$, Calycosia petiolata; lower surface of leaf blade (at junction of costa and secondary nerve) showing scattered indument and lack of glandular patches, $\times 10 . C \&$ D, Calycosia macrocyatha; C, calyx and corolla bud, $\times 4$; D, flower at anthesis, $\times 3$. A from Smith 5440, B from Smilh 7066, C \& D from Smith 970 

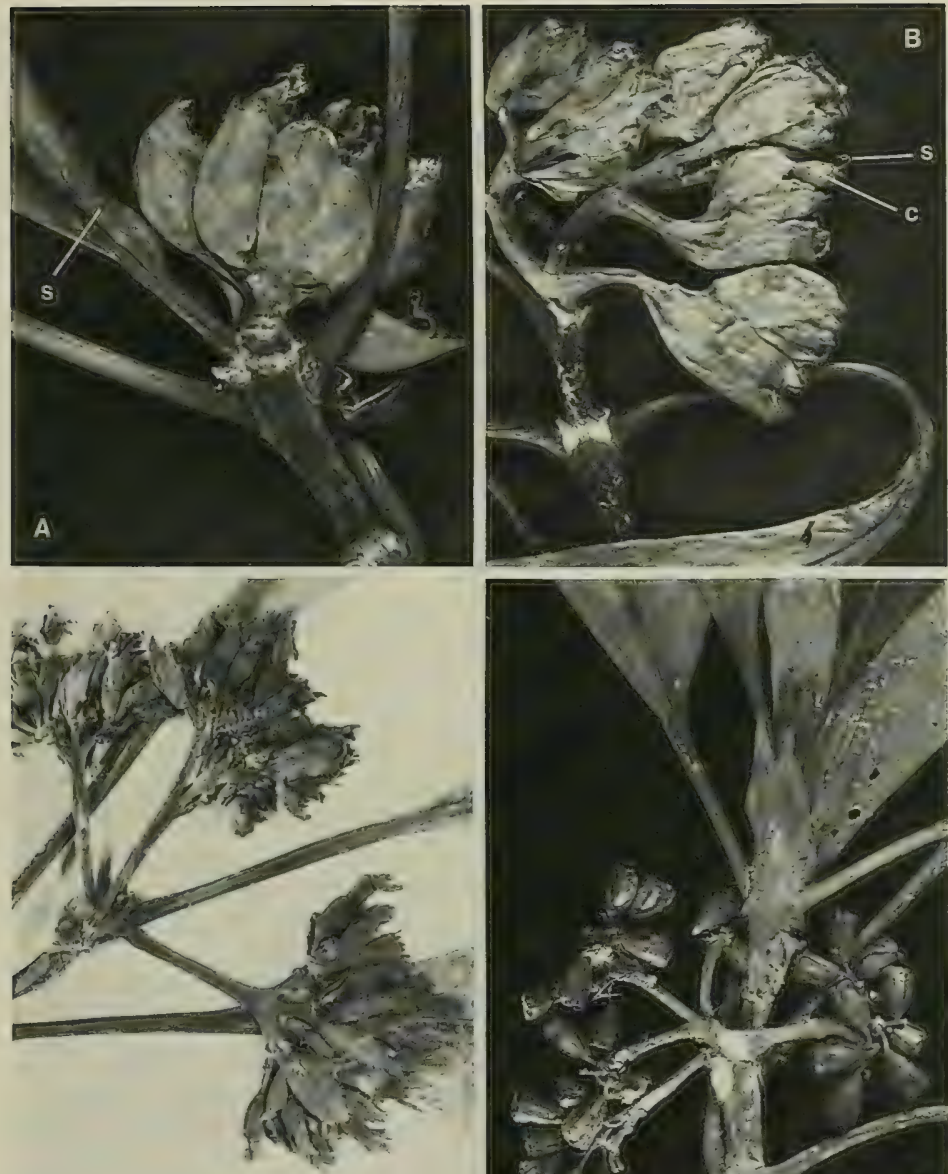

C

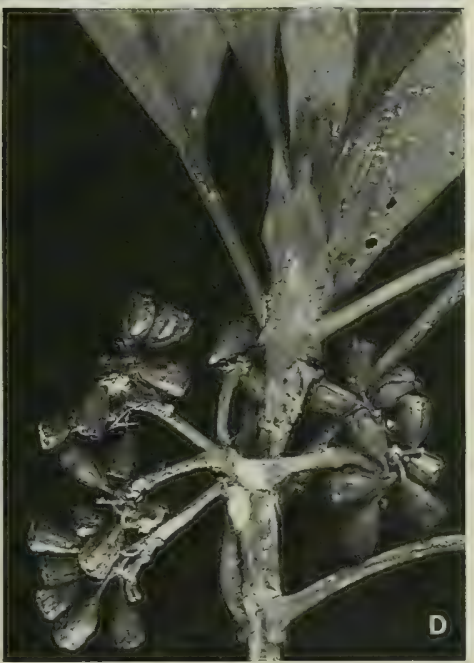

Figure 97. Calycosia petiolata, stages of inflorescence development, all $\times 1$; $\mathbf{A}$, outer bracts fallen and secondary heads beginning to separate, showing a lateral branchlet arising from terminal node, with interpetiolar stipules (s) and developing leaves; B, secondary heads further separating, disclosing some calyces (c) and styles (s); C, larger bracts fallen, disclosing smaller bracts, bracteoles, young fruits, and calyx limbs; D, infructescence, with all bracts and calyx limbs fallen and with essentially mature fruits, overtopped by a lateral branch with stipules and developing leaves. A from Smith 5924, B from Gillespie 4098, C from Smith 8030, D from DA 13642. 
TYPIFICATION AND NOMENClATURE: The type of Calycosia macrocyatha var. macrocyatha is Smith 472 (US 1672896 HOLOTYPE; ISOTYPES at BISH, K, NY, P), collected Nov. 14, 1933, on Mt. Mariko, Thakaundrove Province, Vanua Levu; that of var. kandavuensis is Smith 273 (NY HOLOTYPE; many ISOTYPES), obtained Oct. 25, 1933, on the summit of Mt. Mbuke Levu, Kandavu. Whether the inflorescence is sessile or pedunculate and the degree to which the outermost bracts are united, characters upon which Fosberg relied in recognizing two varieties of $C$. macrocyatha, are seen to be variable (cf. Smith in Pacific Sci. 23: 388. 1969). Even in C. lageniformis, where the urceolate cupules are typically solitary and pedunculate, they are rarely in threes or sessile.

Distribution: Endemic to Fiji and now known (from few specimens) from four of the high islands; it does not appear to be sympatric with the preceding species.

Local NAME: Lera ni veikau (recorded from upper Naitasiri Province).

Available collections: VITI LEVU: Serua: Ngaloa (probably inland from), DA 14100, 14678. NAItASIRI: Taunaisali, Wainisavulevu-Numbulolo divide, near watershed between Wainimala and Singatoka Rivers, St. John 18326. KORO: Eastern slope of main ridge, Smith 970 . VANUA LEVU: THAKAUNDROVE: Along trail from Mbiangunu to Vemsi over Drayton Peak (Mt. Mariko), Bierhorst F151.

3. Calycosia petiolata A. Gray in Proc. Amer. Acad. Arts 4: 48. 1858; Seem. Viti, 437. 1862, Fl. Vit. 133. 1866; Drake, Ill. Fl. Ins. Mar. Pac. 196. 1890; A. C. Sm. in Bishop Mus. Bull. 141: 153, p. p. 1936; Fosberg in Bull. Torrey Bot. Club. 67:425, p. p. 1940, in Sargentia 1: 138. 1942; J. W. Parham, Pl. Fiji Isl. 189. fig. 67, B. 1964, ed. 2. 266. fig. 78, B. 1972; S. Darwin in Allertonia 2: 38. fig. 3, H. 1979.

Figures 96B, 97.

Uragoga petiolata Gillespie in Bishop Mus. Bull. 74: 37. fig. 51. 1930.

Shrub or tree $1.5-8 \mathrm{~m}$. high, sometimes locally frequent at elevations from near sea level to $1,100 \mathrm{~m}$. in dense forest or on its edges, sometimes near creeks. The bracts, bracteoles, and calyx are pale green or white, the corolla and style are white, and the mature fruits are red or scarlet. Flowers and fruits have been obtained in months scattered throughout the year.

TyPification: The type is U. S. Expl. Exped. (US 62354 HolotyPE), collected in 1840 in Fiji without further locality (nor is a locality indicated in Gray's publication); however, a putative isotype (NY) is indicated as from Ovalau.

Distribution: Endemic to Fiji and thus far known only from Viti Levu and Ovalau; it is well distributed on both these islands and is the most frequently collected species of the genus, 40 collections being at hand.

LOCAL NAMES AND USE: Recorded local names are soisoi (Tailevu), and nasithi and makamakandora (upper Naitasiri); the last of these names and the use of the bark as a toothache remedy are from St. John 18217, part of which number represents the following species.

RePresentative COLlections: VITI LEVU: Mba: Vicinity of Nandarivatu, Degener \& Ordonez 13611; near summit of Mt. Nanggaranambuluta, Gillespie 4288; hills east of Nandala Creek, south of Nandarivatu, Smith 5924; slopes of Mt. Tomanivi, Gillespie 4098. NANDRONGA \& NAVOSA: Northern portion of Rairaimatuku Plateau, between Nandrau and Nanga, Smith 5473. Serua: Vunimbua Creek, Nambukelevu, upper Navua River, $D A$ 14864. NAmosi: Valley of Wainambua Creek, south of Mt. Naitarandamu, Smith 8779. RA: Tuvavatu, vicinity of Rewasa, near Vaileka, Degener 15379. NaITASIRI: Wailoa Creek, below Nasonggo, DA 15334; Wainamo Creek, near Matawailevu, Wainimala Valley, St. John 18217, p. p.; Viria, Meebold 17053. TAllevu: Hills east of Wainimbuka River, vicinity of Ndakuivuna, Smith 7066; near Copper Mine, Waimaro River, DA 13642. OVALAU: Horne 71; Lovoni Valley, DA 17075; summit and adjacent slopes of Mt. Korotolutolu, west of Thawathi, Smith 8030; vicinity of Levuka, Gillespie 4507. 
4. Caly cosia callithrix A. C. Sm. in Pacific Sci. 23: 388. 1969; J. W. Parham, Pl. Fiji Isl. ed. 2. 266. 1972.

Slender tree or shrub 2-7 m. high, found in dense forest at elevations of $150-600 \mathrm{~m}$. The bracts and bracteoles are noted as pale green or white, the calyx limb as pale green, the corolla as white, and the fruit as red. Flowers and fruits have been obtained between April and October.

TyPIFICATION: The type is Smith 8422 (Us 2191117 \& 2191118 HOLOTYPE; many ISOTYPES), collected Sept. 11, 1953, in hills north of Wainavindrau Creek, between Korombasambasanga Range and Mt. Naitarandamu, Namosi Province, Viti Levu.

Distribution: Endemic to Fiji and thus far known only from southeastern Viti Levu.

AVAllable Collections: VITI LEVU: NAMOSI: Northern base of Korombasambasanga Range, in drainage of Wainavindrau Creek, Smith 8631; Wainivisova Creek, Navunikambi, Wainikoroiluva River, DA 14995; vicinity of Namosi, Parks 20272, Gillespie 2920.1; lower slopes of Mt. Voma, Gillespie 2518. NaItASIRI: Wainamo Creek, near Matawailevu, Wainimala Valley, St. John 18217, p. p.; near Naitauvoli, Waingga Creek, Wainimala River basin, DA 14017; between Nanduna and Serea, DA 12591; vicinity of Nasinu, Gillespie 3464. Rewa: Waimbue Creek, Waimanu River tributary, DA 15566, p. p. FiJi without further locality, DA L.13310.

30. Hedstromia A. C. Sm. in Bishop Mus. Bull. 141: 146. 1936, in J. Arnold Arb. 36: 289. 1955, in Pacific Sci. 23: 389. 1969; S. Darwin in Allertonia 2: 39.1979.

Small trees, the stipules interpetiolar, free nearly to base, rounded to broadly obtuse, caducous; inflorescences terminal, cymose, many-flowered; hypanthium broadly obconical to turbinate and thick-carnose at anthesis, the calyx limb very short, minutely 5-dentate, incurved, persistent; corolla polypetalous, the petals 5 , carnose, valvate in bud; stamens 5 , attached at base of corolla, the anthers subsessile; ovary 2-locular, the ovules solitary and basal in each locule, the styles 2, laterally coherent; fruits turbinate, rugulose and 8-costate when dried, the pyrenes dorsally 3-carinate.

TYPE SPECIES: Hedstromia latifolia A. C. Sm.

Distribution: Endemic to Fiji and known from a single species.

1. Hedstromia latifolia A. C. Sm. in Bishop Mus. Bull. 141: 148. fig. 77. 1936, in J. Arnold Arb. 36: 289. 1955; J. W. Parham, Pl. Fiji Isl. 193. 1964, ed. 2. 271. fig. 81. 1972; A. C. Sm. in Pacific Sci. 23: 389. 1969.

Figures 98, 99A \& B.

Tree 4-9 m. high, apparently infrequent in dense or secondary forest or on its edges at elevations from near sea level to $300 \mathrm{~m}$. The flower buds are pale green (but probably the petals turn white at anthesis), and the fruits turn from yellow to red at maturity, with the persistent calyx limb remaining green. Flowers have been obtained between April and June, fruits in July and November.

TYPIFICATION: The type is Smith 1944 (BISH HOLOTYPE; many ISOTYPES), collected June 8, 1934, in hills west of Korotasere, Natewa Bay region, Thakaundrove Province, Vanua Levu.

Distribution: Endemic to Fiji and thus far known from Vanua Levu, Taveuni, and Yathata (an island of northern Lau about $60 \mathrm{~km}$. southeast of Taveuni).

LOCAL NAME: Mbulei (recorded only from type collection).

Available collections: VANUA LEVU: Thakaundrove: Vicinity of Wailevu, Savusavu Bay, $D A$ 14278; track to Mt. Nasorolevu, DA 17152; Navonu Creek, Natewa Peninsula, DA 15052. TAVEUNI: Wainisavu, Nggeleni, DA 14405. YATHATA: Navakathuru, DA 16305.

Since the original description and a note based on a fruiting specimen (Smith, 1936, 1969), several additional collections of Hedstromia latifolia have become available, including one (DA 15052) with flowers at full anthesis. The inflorescences of the type 
collection were not fully mature, and hence the following amplification seems desirable.

Leaf blades to $23 \mathrm{~cm}$. long; inflorescences at full anthesis ample, to $15 \mathrm{~cm}$. long and $24 \mathrm{~cm}$. broad, with stout peduncle and spreading branchlets (as described for infructescences, cf. Smith, 1969); flowers comparatively few, i. e. many buds of young inflorescences (cf. Smith, 1936, fig. 77, e) caducous and leaving scars on ultimate inflorescence branchlets; pedicels at anthesis to $13 \mathrm{~mm}$. long, broadened into a thick-carnose, turbinate hypanthium to $7 \times 9 \mathrm{~mm}$., the calyx limb $1-1.5 \mathrm{~mm}$. long, incurved, carnose at base, decreasing in thickness to a sharp, obscurely 5-dentate margin; petals free at anthesis, deltoid- or ovate-oblong, thick-carnose, 4-4.5 × 2-2.5 mm., subacute, thickened and slightly inflexed at apex; anthers thick-carnose, deltoid-oblong, 1.5-1.8 mm. long, obtuse; styles remaining minute.

31. Amaracarpus Bl. Bijdr. Fl. Ned. Ind. 954. 1826; K. Schum. in Engl. \& Prantl, Nat. Pflanzenfam. IV. 4: 122. 1891; Merr. \& Perry in J. Arnold Arb. 27: 221. 1946; A. C. Sm. in op.cit. 36: 289. 1955; Backer \& Bakh. f. Fl. Java 2:345. 1965; S. Darwin in Allertonia 2: 39. 1979; van Royen, Alpine Fl. New Guinea 4: 2680. 1983.

Trees, shrubs, or subshrubs, the stipules interpetiolar, membranous, sometimes united and sheathing at base, at apex with 2 or more long bristles or entire; flowers solitary or fascicled, usually sessile, terminal on normal branchlets or terminal on reduced brachyblasts, sometimes subtended by reduced leaves or stipule-like bracts, $\Varangle, 4$ - or 5(-7)-merous; calyx obconical, persistent, the lobes equal or unequal, sometimes absent; corolla infundibular to campanulate, pilose in throat, the lobes valvate in bud; stamens inserted in corolla throat, the filaments well developed or the anthers subsessile and hardly exserted; ovary 2-locular, the ovules solitary and basal in each locule, the style filiform, the stigmas 2 , linear; fruit drupaceous, the pyrenes dorsally convex or unicarinate.

TYPE SPECIES: Amaracarpus pubescens $\mathrm{Bl}$, the only original species.

Distribution: Malay Peninsula eastward through Malesia to Micronesia and Fiji, with perhaps 60 species, about 40 of them occurring in New Guinea including ten in alpine regions. One endemic species terminates the generic range in Fiji.

As presently construed, Amaracarpus is a poorly understood and heteromorphic genus closely related to $P$ sychotria. It was first distinguished by the apparently axillary inflorescences or solitary flowers, as opposed to the terminal inflorescences in Psychotria. However, a close study reveals that the flowers are borne terminally on short, axillary brachyblasts (cf. Backer and Bakhuizen, 1965) or, as in our species, at the tips of normal branchlets. If these observations are accurate, the distinction between Amaracarpus and Psychotria appears uncertain. Merrill and Perry (1946), in discussing Amaracarpus in Malesia, recognized three species groups based upon degree of pubescence, size and form of inflorescence, disposition of leaves and branchlets, and shape of stipules. However, none of the groups was considered to be exclusive in its characters. Amaracarpus muscifer, the Fijian species, seems most similar to Merrill and Perry's second group: "plants generally pubescent with rather thick hairs on young shoots and with a distinctive habit marked by horizontally placed small leaves and branches, flowers solitary and sessile or very short pedicellate, usually subtended by reduced leaves and stipules or stipule-like bracts." The Fijian species, while having small leaves and copiously pubescent distal branchlets, is reported simply as a small or

Figure 98. Hedstromia latifolia; A, distal portion of branchlet, with foliage and an infructescence, $\times 1 / 4$; $\mathrm{B}$, stipules, $\times 4$; C, flower, the essentially mature corolla projecting above the margin of the calyx limb, $\times 6$; $\mathrm{D}$, mature flower, showing separate petals, $\times 4$; E, distal part of flower with part of calyx and 2 petals removed, showing anthers, $\times 6$. A from $D A 14405$, B from Smith 1944, C-E from DA 15052. 

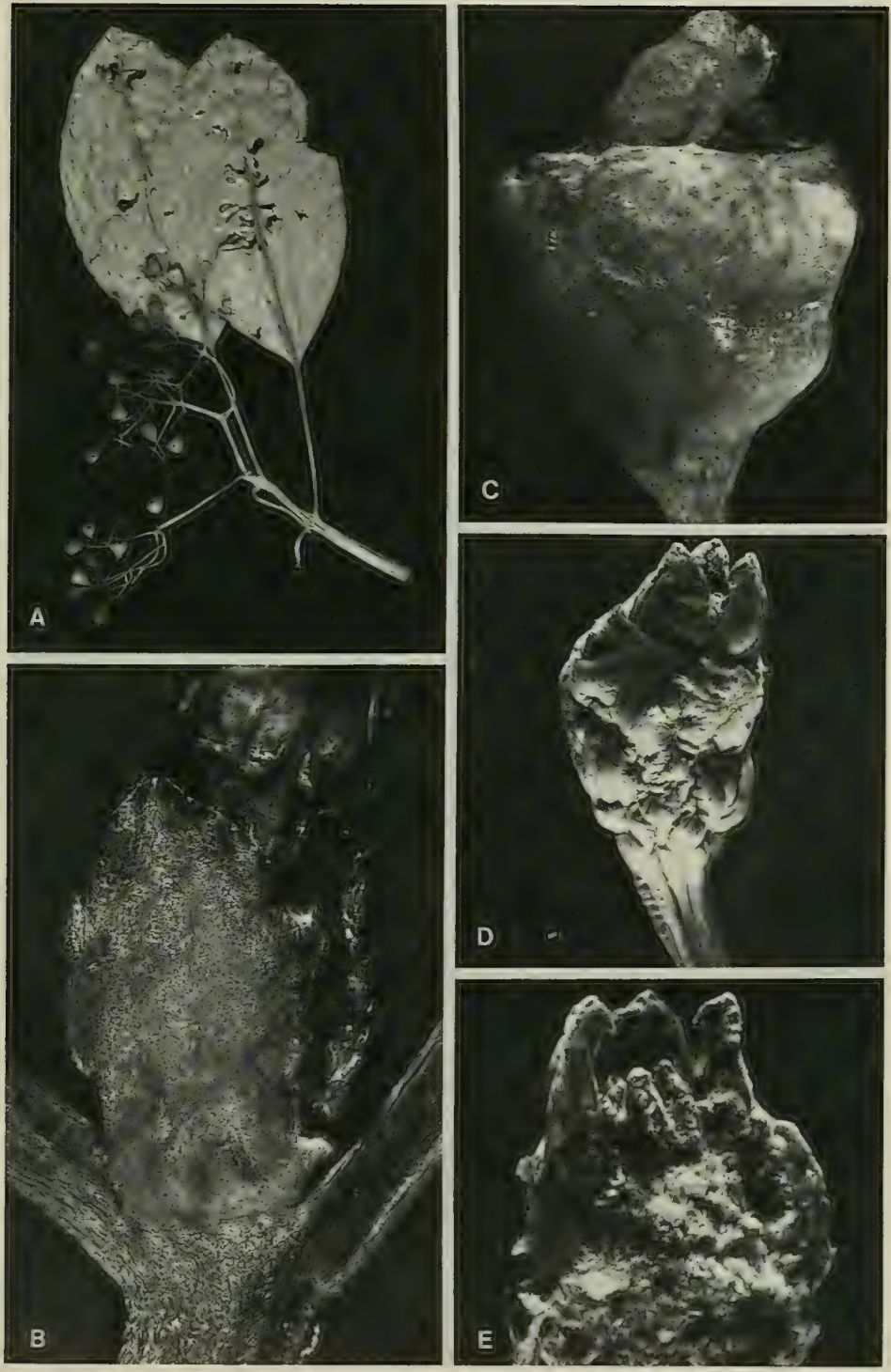

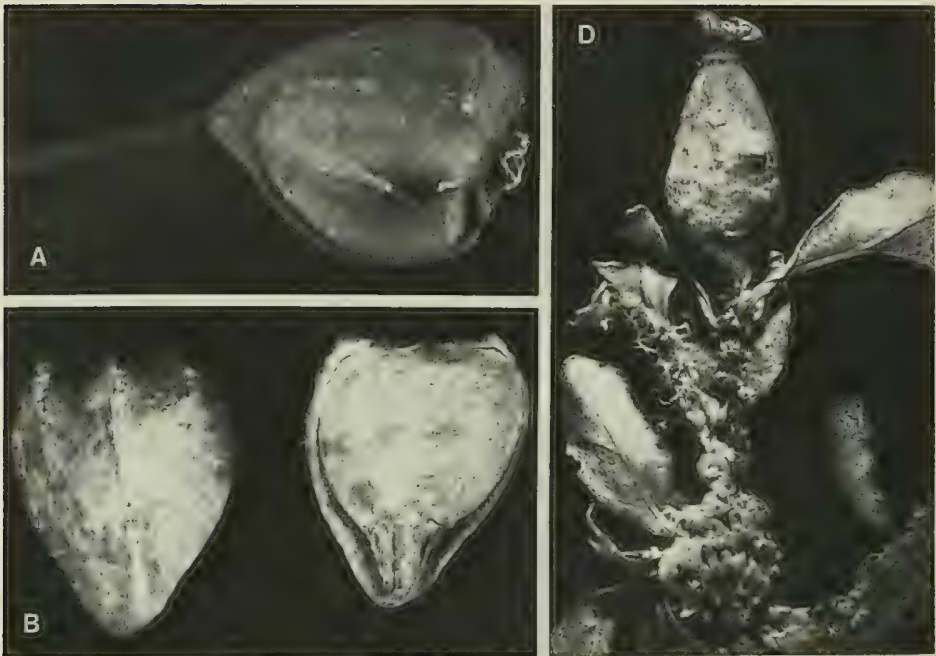

B
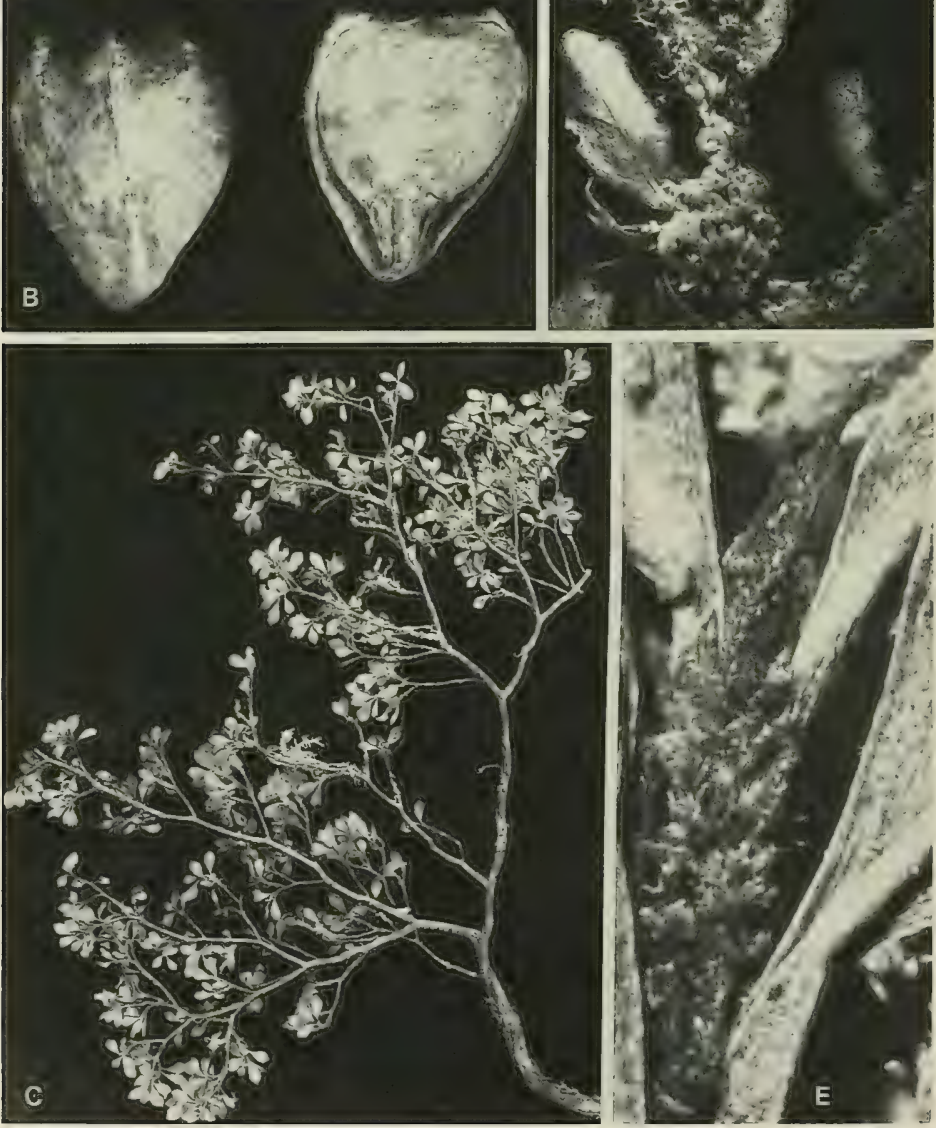
gnarled shrub, and the flowers and fruits are solitary or paired. Should the three groups discussed by Merrill and Perry eventually be referred to different genera, their second group (including $A$. muscifer) would presumably remain in Amaracarpus, the type species of which is from Java (cf. Backer and Bakhuizen, 1965, for description).

1. Amaracarpus muscifer A. C. Sm. in J. Arnold Arb. 27: 321, as A. musciferus. 1946, in op. cit. 36: 289 ("musciferus"). 1955; J. W. Parham, Pl. Fiji Isl. 187 ("musciferus"). 1964, ed. 2. 264 ("musciferus"). 1972.

FIGURE 99C-E.

Small, often gnarled shrub $0.6-2 \mathrm{~m}$. high, apparently infrequent in dense forest at elevations of $365-842 \mathrm{~m}$. The only color notes indicate that the fruits are red. Flowers have been obtained in April, fruits in April and November.

TYPIFICATION: The type is Smith 1646 (GH HOLOTYPE; many ISOTYPES), collected April 27, 1934 (with fruits and very few flowers), on Navotuvotu, summit of Mt. Seatura, Mbua Province, Vanua Levu.

Distribution: Endemic to Fiji and, as far as now known, to Vanua Levu.

Available collections: VANUA LEVU: Mathuata: Naura Creek (tributary of Wailevu Creek, Yanawai River headwaters), DA s. n. (coll. J. W. Parham, Nov. 20, 1970) (A, MASs, NY, suva, UC, Us). ThaKaundrove: Inland from Waiwai (on Savusavu Bay), Horne 571 (K), April, 1878.

Since the species was first described two additional collections have come to light; both localities are in the southern drainage of Vanua Levu approximately 24 and 52 $\mathrm{km}$. east of the type locality, at reported elevations of 1,200 and $1,500 \mathrm{ft}$. respectively. Both collections agree excellently with the originally described material, although the leaf blades of the Parham specimens may be only $1.5-2.5 \mathrm{~mm}$. broad (rather than 3-3.7 $\mathrm{mm}$. as originally mentioned); that collection is very sparsely fruiting, while the Horne specimen seems sterile.

32. Psychotria L. Syst. Nat. ed. 10. 929. 1759; Seem. Fl. Vit. 134. 1866; K. Schum. in Engl. \& Prantl, Nat. Pflanzenfam. IV. 4: 112. 1891; Fosberg in Sargentia 1: 125. 1942; Petit in Bull. Jard. Bot. Brux. 34: 18. 1964; Backer \& Bakh. f. Fl. Java 2: 328. 1965; Steyermark in Mem. New York Bot. Gard. 23: 406. 1972; Verdcourt in Fl. Trop. E. Afr. Rub. 26. 1976; S. Darwin in Allertonia 2: 40. 1979; Whistler in J. Arnold Arb. 67: 343. 1986. Nom. cons.

Eumachia DC. Prodr. 4: 478. 1830.

Psychotria subgen. Piptilema A. Gray in Proc. Amer. Acad. Arts 4: 46. 1858.

Psychotria sect. Eumachia A. C. Sm. in Bishop Mus. Bull. 141: 151. 1936.

Calycodendron A. C. Sm. in Bishop Mus. Bull, 141: 154. 1936.

Eumorphanthus A. C. Sm. in Bishop Mus. Bull. 141: 157. 1936.

Trees, shrubs, or sometimes lianas, rarely herbs (but none of our species); stipules diverse, interpetiolar, persistent or caducous, often sheathing at least toward base, variously divided, lobed, or truncate, glabrous or pubescent, sometimes with fimbrillate hairs within the base, these then briefly persisting distal to stipular scars; leaves petiolate, rarely sessile (in none of our species), the blades sometimes drying reddish brown (or dark green or yellowish green), sometimes bearing domatia on lower surfaces in axils of secondary nerves or with bacterial nodules (in none of our species); inflorescences terminal (said to be axillary in some American species), paniculate, umbelliform, thyrsoid, cymose, or capitular, pedunculate to sessile, the bracts and bracteoles large and conspicuous (but not in our species) to minute or absent; flowers

FiguRE 99. A \& B, Hedstromia latifolia; A, mature fruit, $\times 4$; B, abaxial and adaxial surfaces of pyrenes, $\times 4$. C-E, Amaracarpus muscifer; $\mathrm{C}$, distal portion of branchlet, with foliage and a few fruits, $\times 1 / 2 ; \mathrm{D}$, branchlet and terminal fruit, $\times 6$; E, tip of branchlet and lower portions of leaves, showing indument, stipules, and glandular patches on leaf blade surfaces, $\times 25$. A \& B from DA 14405 , C-E from Smith 1646. 
६, 4- or 5(-8)-merous, often heterostylous; calyx limb variable, minute or short to greatly expanded, truncate, toothed, or prominently lobed, persistent or caducous; corolla short to long, tubular to infundibular, usually pubescent in throat, the lobes spreading to reflexed, valvate in bud; stamens inserted near middle or in throat of corolla tube, the filaments long (in short-styled flowers) to short (in long-styled flowers), the anthers included or exserted; ovary 2(rarely 3-or 4)-locular, the ovules solitary and basal in each locule; style filiform, exserted or included, the stigmas 2 (rarely 3 or 4), linear; disk small or sometimes conspicuous, surrounding base of style; fruit drupaceous, variable in color and shape; pyrenes adaxially smooth, sulcate, or carinate, abaxially convex and often prominently costate or carinate, the endosperm horny, entire or ruminate, sometimes ventrally fissured.

TYPE SPECIES AND NOMENCLATURE: Psychotria was based on $P$. asiatica L., the only original species. Linnaeus's concept of that species was based on two specimens representing different species, a $P$. Browne collection (s) from Jamaica and a specimen (LINN) probably of Asiatic origin. Swartz (Obs. Bot., 1791) effectively lectotypified $P$. asiatica by the Old World element; the West Indian specimen is the type of $P$. brownei Spreng. (cf. Petit, 1964, p. 8). Eumachia and Psychotria sect. Eumachia are typified by E. carnea (Forst. f.) DC. (Petesia carnea Forst. f. = Psychotria carnea (Forst. f.) A. C. Sm.). Psychotria subgen. Piptilema was based by Gray on three Fijian species, $P$. cordata, $P$. pickeringii, and $P$. platycocca. Actually, the last of these does not entirely fit the description of Gray's subgenus ("Flores sessiles, capitellati, . .."); we herewith lectotypify Gray's subgeneric concept by P. pickeringii A. Gray. The type species of Calycodendron is C. pubiflorum (A. Gray) A. C. Sm. (= Psychotria pubiflora (A. Gray) Fosberg); that of Eumorphanthus is E. fragrans A. C. Sm. (= Psychotria eumorphanthus Fosberg).

Most of these names as synonyms of Psychotria were discussed by Fosberg( 1942); on a broader scale, many other generic names have been discussed and combined with Psychotria by Petit (1964), Steyermark (1972), and Verdcourt (1976). Psychotria is now generally construed in a broad sense, with which in general we are able to agree. The maintenance in the present review of the endemic Fijian (27) Readea, (28) Gillespiea, and (30) Hedstromia as distinct genera seems to us well justified; as to such genera as (29) Calycosia and (31) Amaracarpus, retained above as distinct, we are aware that questions remain and will be resolved only by future research on Indomalesian taxa of this relationship.

Distribution: Pantropical. Airy Shaw (in Willis, Dict. Fl. Pl. Ferns, ed. 8. 1973) estimated the size of the genus as approximately 700 species, while Verdcourt (1976) thought 500 closer to the actual number. However, these figures seem substantially too low. Steyermark (1972), for example, recognized more than 240 species from Venezuela, the Guianas, and Amazonian Brazil, and recent estimates for Malesia are in the nature of 600 species (S. H. Sohmer, pers. comm.). If Psychotria is broadly interpreted, as seems to be the preference of modern authors, then a figure of at least 2,000 species would seem a reasonable estimate of its size.

In Fiji we here recognize 76 species, considering all but four of them to be endemic. Psychotria is fairly ubiquitous in any forested and reasonably undisturbed area of Fiji. The present study is based on examination of more than 1,500 Fijian collections.

Useful treatments of genus: Petit, E. Les espèces Africaines du genre Psychotria L. (Rubiaceae)-I. Bull. Jard. Bot. Brux. 34: 1-229. 1964. Steyermark, J. A. Psychotria. In: Maguire, B., et al. The botany of the Guyana Highland-Part IX. Mem. New York Bot. Gard. 23:406-717. 1972. Verdcourt, B. Psychotria. In: Polhill, R. M. (ed.). Fl. Trop. E. Afr. Rubiaceae, 26-109. 1976. WhistLeR, W. A. A revision of Psychotria (Rubiaceae) in Samoa. J. Amold Arb. 67: 341-370. 1986. 

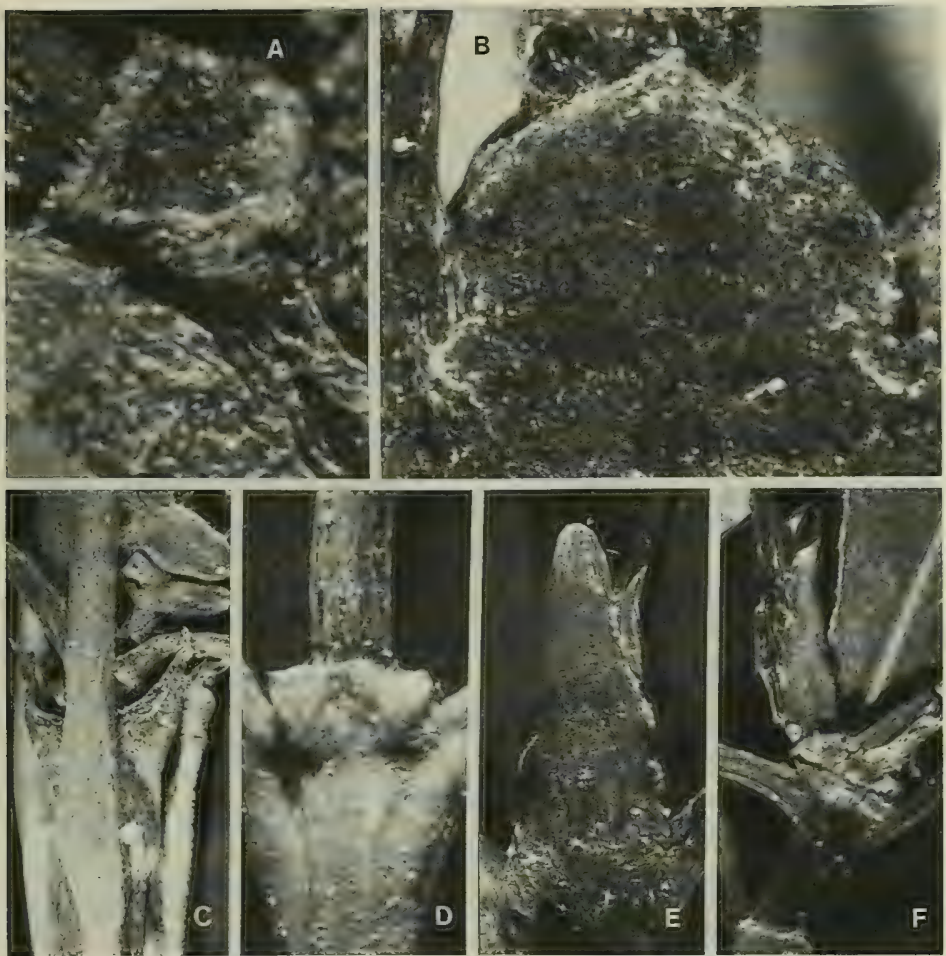

Figure 100. Psychotria: Stipules. A, P. exilis, $\times 50$. B, P. macroserpens, $\times 30 . \mathrm{C}, P$. levuensis, $\times 4 . \mathrm{D}, P$. carnea $\times 10 . \mathrm{E}, P$. confertiloba, $\times 4 . \mathrm{F}, P$. gracilior, $\times 4$. A from Smith 620, B from Smith $1246, \mathrm{C}$ from Meebold 17042, D from O. \& I. Degener 32161, E from Degener \& Ordonez 14014, F from Smith 6186.

Significant morphological characters of Psychotria in Fiji. Characters that are useful in grouping the Fijian species of Psychotria into meaningful clusters refer to habit, stipules, inflorescences, calyces, corollas, indument, fruits, and pyrenes. In the following discussion, alternative character states or combinations are parenthetically numbered; their distribution among the species groups recognized in Fiji is summarized in TABLE 1.

Habit. Fijian species of Psychotria are either (1) trees or shrubs or (2) slender, sprawling or often high-climbing lianas.

Stipules. It is probable that all Fijian species have stipular scars with ferrugineous (or pale) fimbrillate hairs, therefore falling into subgen. Psychotria sensu str. rather than subgen. Heteropsychotria Steyermark (cf. Steyermark, 1972, pp. 444, 484; Verdcourt, 1976, p. 27), although such hairs are often so promptly caducous that their presence or absence as a primary character to divide Psychotria into subgenera seems questionable. 


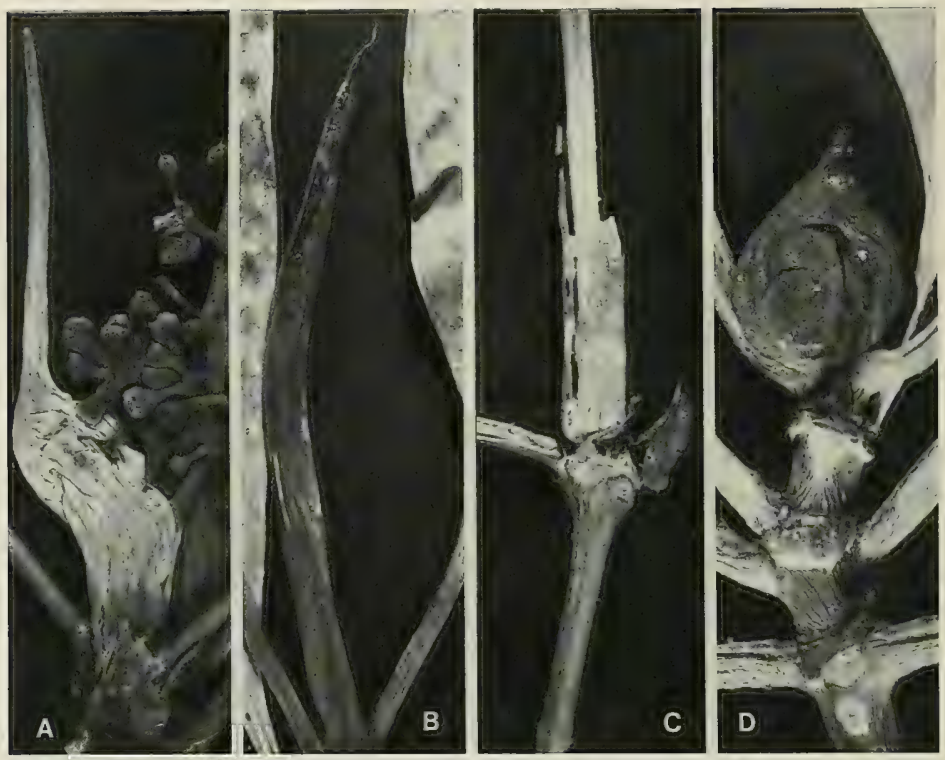

Figure 101. Psychotria: Stipules. A, P. forsteriana, $\times 3$. B, P. oncocarpa, $\times 3$. C, P. archboldiana, $\times 4$. D, $P$. valleculata, $\times 4$. A from Smith 1721, B from Degener 14362, C from Smith 4713, D from DA 13889.

Stipules provide very useful criteria in the grouping of species, although it must be emphasized that substantial variability in size may exist in the stipules of a single species, and the difference in size may be especially obvious between the stipules that enclose vegetative buds and those that enclose developing inflorescences, the latter usually forming a broader bud-enclosing sheath than the former. Stipules of all our species are interpetiolar, valvate in aestivation, and united (i. e. also intrapetiolar) at least to some degree at the terminal node. The stipule types differ principally in the manner of opening (only at apex, along both sides, along one side only) and in apices (free or united at terminal node, entire or notched to deeply bifid). The stipules are usually caducous after the terminal bud develops, but occasionally they persist at the penultimate or even lower nodes, sometimes there partially disintegrating. Among Fijian species the following types of stipules are noted. (1) Stipules connate at least at very base, the apices entire or very rarely briefly (to $1 \mathrm{~mm}$.) divided, acute, apicular, or long-acicular from a broadly ovate to lanceolate base (FIGURES 100A-D, 111A). (2) Stipules basally connate, the apices entire, obtuse to rounded (FIGURE 100E). (3) Stipules connate and sheathing when young, separating along one side usually to base (Figures 100F, 101A). (4) Stipules connate and sheathing, separating toward apex, subpersistent but eventually disintegrating except for a short basal collar (FIGURE $101 \mathrm{~B} \& \mathrm{C}$ ). (5) Stipules in the terminal bud united to the very apex, separating along both sides to base, orbicular to long-lanceolate in outline, obtuse to subulate at apex (FIGURES 101D, 102A \& B, 113). (6) Stipules usually long-lanceolate in outline, in the 

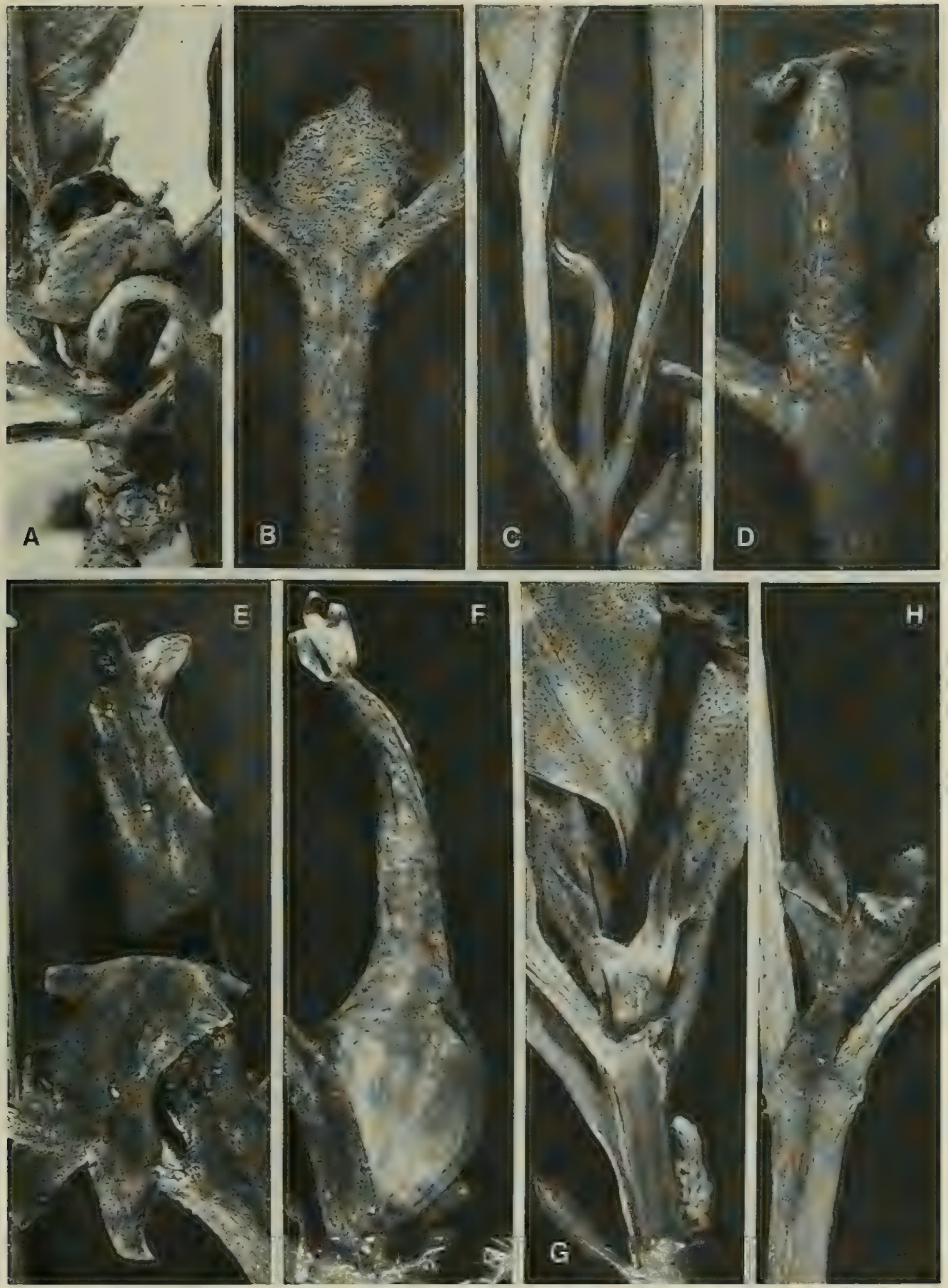

Figure 102. Psychotria: Stipules, all $\times$ 4. A, P. pickeringii. B, P. bullata. C, P. platycocca. D, P. broweri. E, P. glabra. F, P. ampullacea. G, P. calycosa. H, P. furcans. A from U. S. Expl. Exped. (GH ISOTYPE), B from Seemann 248 (GH ISOTYPE), C from Gillespie 3346, D from Seemann 254 (GH ISOTYPE), E from DA 15446, F from Smith 5659, G from Smith 7378, H from Degener 14450. 

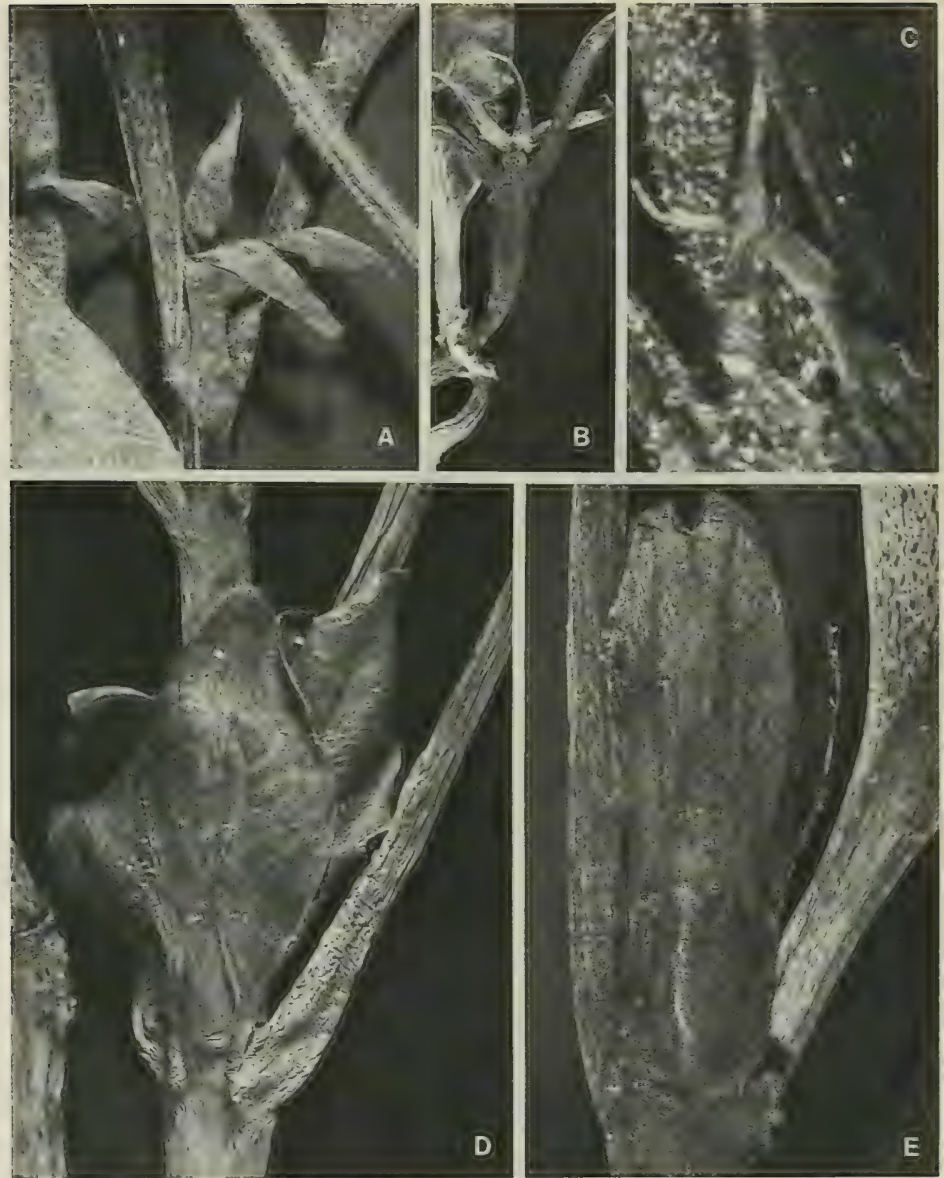

Figure 103. Psychotria: Stipules. A, P. pubiflora, $\times 4$. B, P. gibbsiae, $\times 4$. C, $P$. gracilis, $\times 30 . \mathrm{D}, P$. pritchardii, $\times 4$. E, P. pachyantha, $\times 4$. A from $D A$ 12549, B from Gillespie 3907, C from U. S. Expl. Exped. (HOLOTYPE), D from DA 15709 , E from Smith 1648.

terminal bud with separate and often diverging, acute or apiculate to long-filiform apices, the apices themselves entire or very briefly (to $1 \mathrm{~mm}$.) divided, the stipules eventually separating along both sides to base (FIGURE 102C \& D). (7) Stipules basally united, free distally and conspicuously notched to deeply bifid into two broadly ovate to long-linear or filiform lobes (FIgures 102E-H, 103). 

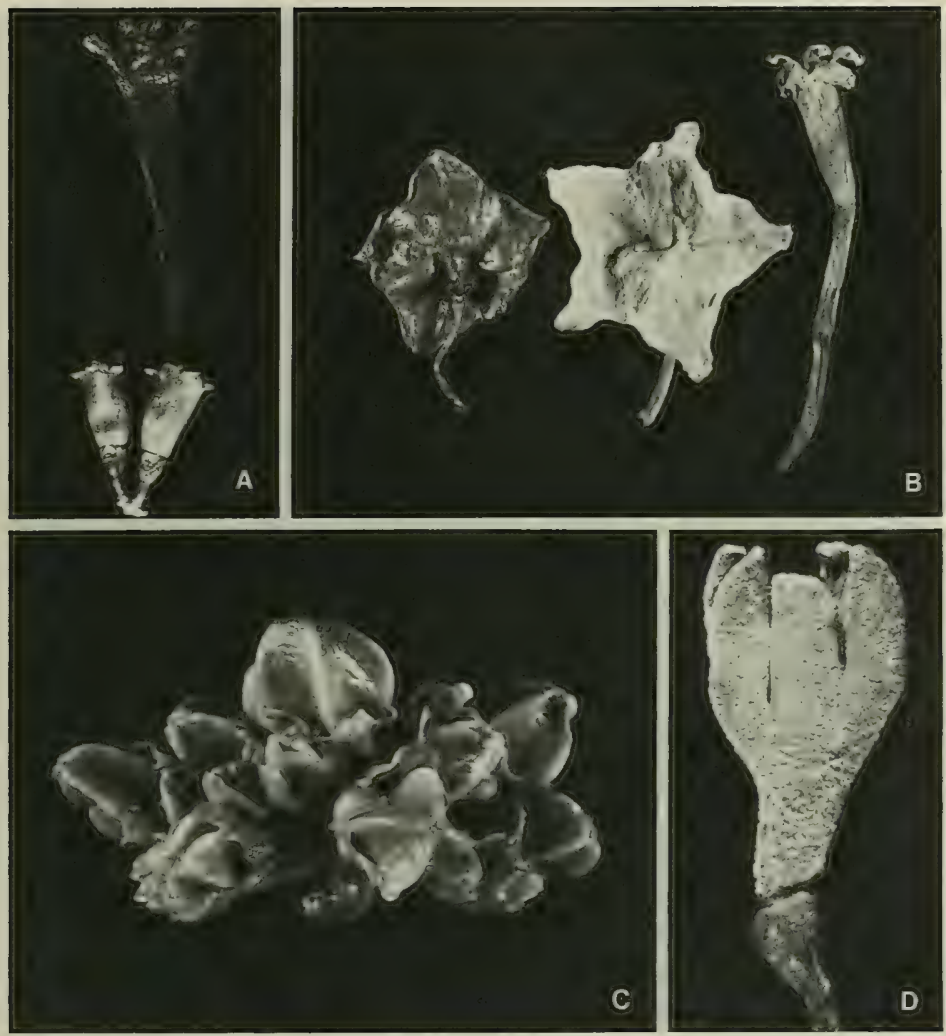

Figure 104. Psychotria: Calyces and corollas. A, $P$. vitiensis, calyces and a corolla, $\times 2$. B, $P$. magnifica, proximal surface of calyx, distal surface of calyx limb and young corolla, and mature corolla, $\times 2$. C, $P$. archboldiana, cluster of flowers prior to anthesis, $\times 4 . \mathrm{D}$, P. exilis, flower, $\times 10$. A from Gillespie $2722, \mathrm{~B}$ from Gillespie 3307.1, C from DA 14973, D from Krauss 1015.

Inflorescences. Inflorescences in Psychotria are terminal, although often laterally displaced due to elongation of a bud and development of a new leader-shoot from a node immediately below or close to the inflorescence. Peduncles are frequently well developed and erect (1), or rarely they are abruptly reflexed from base (2). Peduncles are absent in many species, the inflorescence branchlets arising directly from the stem apex (3). However, it is not uncommon to find erect-pedunculate (1) and sessile (3) inflorescences on the same specimen. It seems likely that in some instances the sessile type results when the peduncle fails to elongate, but it is apparent that in many Fijian species with sessile inflorescences a secondarily pedunculate form is produced by the suppression of all but one of the inflorescence branchlets. Strikingly pedunculate 

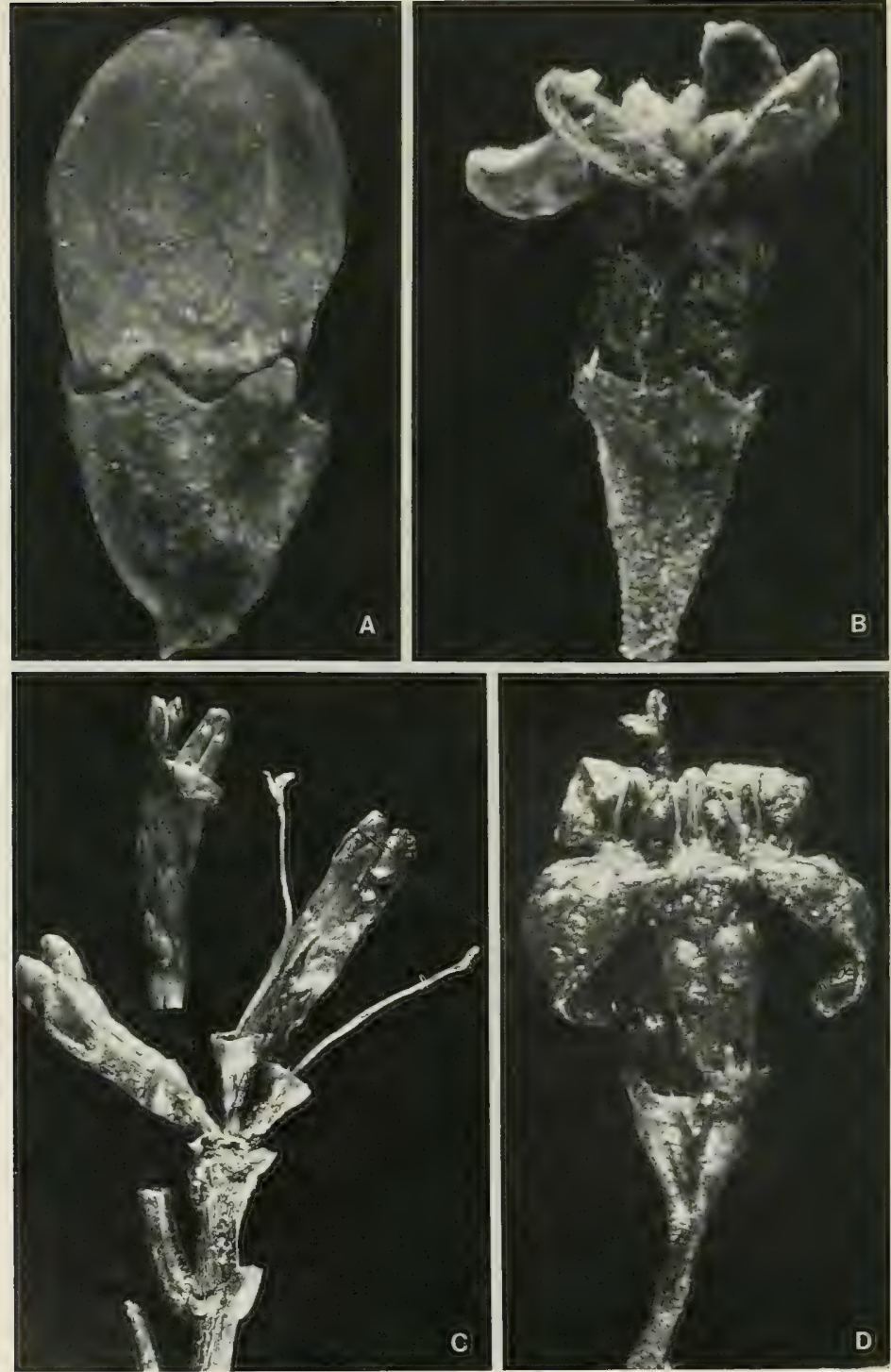

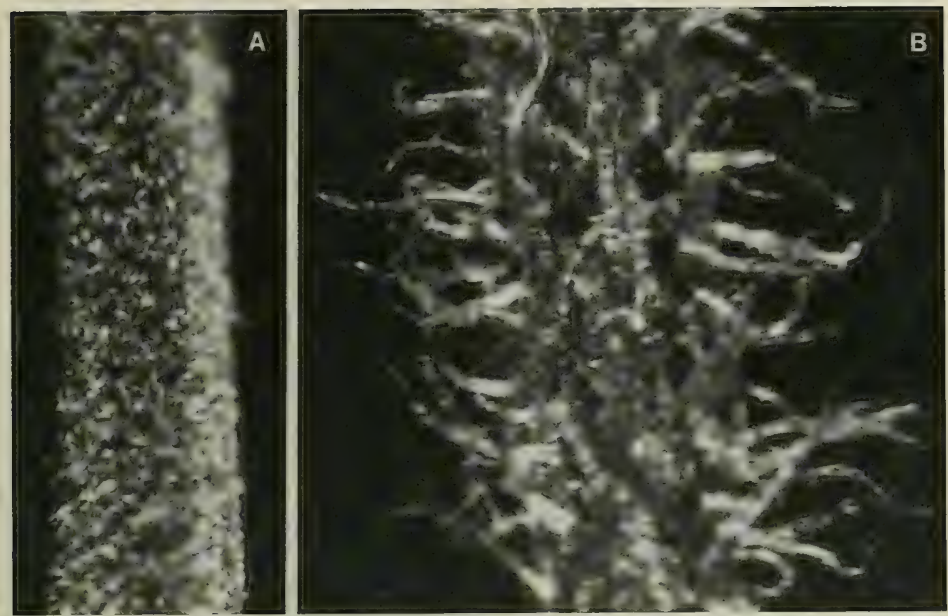

FIGURE 106. Psychotria: Indument of inflorescence branchlets, $\times 60$. A, P. tephrosantha. B, P. storckii. A from Smith 4810, B from Degener 15374.

inflorescences seem to occur only when the peduncle is distinctly reflexed (2), a situation found among Fijian species only in $P$. furcans and $P$. pritchardii. In a few species (4) the inflorescence branchlets as well as the peduncles are totally lacking, the flowers and fruits then usually being sessile in a capitular or subcapitular head at the stem apex (FIGURES 105C, 113B).

Calyces. The most diverse characters of the flowers of Psychotria in Fiji seem to occur in the calyx, and consequently calycine morphology has frequently been used as a taxonomic criterion to group taxa into clusters. In the present treatment the outer adherent covering of the ovary is considered to be calycine tissue and is designated as hypanthium, the free portion of the calyx being referred to as the calyx limb. Among Fijian species the calyx limb attains strikingly diverse shapes and sizes. (1) Calyx limb erect, subcylindric or infundibular, much longer than hypanthium at anthesis, 4-23 $\mathrm{mm}$. long, often white, not conspicuously broadened at apex, long-persistent in fruit, when at length falling leaving a conspicuous scar (FIGURES 107A, 111C). (2) Calyx limb ellipsoid-cylindric, urceolate, fusiform, narrowly campanulate, or infundibular, longer than hypanthium at anthesis, $2-10 \mathrm{~mm}$. long, often constricted toward apex and then briefly flaring, the expanded portion rarely more than $5 \mathrm{~mm}$. in apical diameter, the entire limb caducous in fruit and leaving an obvious scar (FIGURES 104A, 108B). (3) Calyx limb longer than hypanthium at anthesis, 2-25 $\mathrm{mm}$. long, usually white, subrotate from base or campanulate and gradually broadened from base or, if fusiform proximally and then constricted, ultimately broadened into a conspicuously flaring apex (6-) 7-25 mm. in diameter, subpersistent or soon caducous in fruit and leaving an obvious scar (FIgures 104B, 108A, 131 (lower)). (4) Calyx limb suberect or erectopatent, 2-5 mm. long (longer than hypanthium at anthesis), green, often thin in texture and obviously nerved, spreading to $7 \mathrm{~mm}$. in diameter, long-persistent in fruit (FIGURE 104C). (5) Calyx limb comparatively inconspicuous, erect or erecto-patent at anthesis

Figure 105. Psychotria: Calyces and corollas. A, $P$. leiophylla, flower just prior to anthesis, $\times 20 . \mathrm{B}, P$. evansensis, flower, $\times 20$. C, $P$. pickeringii, inflorescence, showing calyces, corollas, and styles, $\times 4 . \mathrm{D}, P$. st.-johnii, flower, $\times 10$. A from DA 13617, B from DA 11609, C from Smith 7686, D from St. John 18279. 
and shorter than or subequal to hypanthium in length, negligible to $2(-4) \mathrm{mm}$. long, not perceptibly veined or thin or greenish in drying, usually persistent in fruit, if eventually falling leaving an inconspicuous scar (FIGURES 105, 109B, 110C). (6) Calyx limb as in (5) but perceptibly veined, thin, and greenish in drying.

Corollas. The corolla in Fijian species of Psychotria is slender, tubular or infundibular, with 4-8 lobes that eventually become spreading or somewhat reflexed; although diversity is limited, length is a usable criterion at the species level, and sometimes the shape of the bud formed by the lobes is characteristic. Several corolla types may be noted. (1) Corolla elongate, $25-78 \mathrm{~mm}$. long, the tube $18-50 \mathrm{~mm}$. long, the lobes 5 or 6 , 5-28 mm. long, before anthesis forming a smooth (or inconspicuously angled or costate) bud (FIgURE 111D). (2) Corolla of medium length, (7-) 9-30 mm. long, the tube (6-) 8-25 mm. long, the lobes (4 or) 5 or $6(-8), 1.5-6 \mathrm{~mm}$. long, before anthesis as in (1) (Figures 104A \& B, 113B, 114B). (3) Corolla short, 2-8 mm. long, the tube $1-4.5$ $\mathrm{mm}$. long, the lobes 5, 1-4 mm. long, before anthesis as in (1) and (2) or rounded into a 5-costate bud (FIGURES 104D, 105). (4) Corolla of medium length, 6-30 mm. long, the tube 2-18 $\mathrm{mm}$. long, the lobes 4 (or 5), 4-12 mm. long, obviously veined, before anthesis sharply enlarged into a conspicuously 4(or 5)-angled or -winged bud (FIGURE 104C). Many (perhaps most) Fijian species of Psychotria have a degree of indument on the inner corolla surface: the tube may be puberulent, the lobes more or less arachnoidpilose, and the throat tufted-pilose. Externally the corolla may appear totally glabrous (FIgUREs 104A, 105A, 111C \& D), short-tufted-pilose at tips of lobes (FIGUREs 104C, 105C), sporadically puberulent or short-hispidulous on the tube as well (FIGURES 104B, 105B, 113B, 114B), or copiously and uniformly puberulent (FIGURE 104D). We do not find corolla indument a very useful or dependable diagnostic character in Psychotria. Stamens are attached to the corolla tube or in the corolla throat, the filaments and anthers usually being short and not offering characters of striking value in delimiting clusters of species, although of course there are differences in dimensions.

Indument. Indument may occur on vegetative parts (branchlets, stipules, leaves) and inflorescence parts (peduncles and branchlets, bracts, bracteoles, pedicels, calyces, and corollas). In herbarium specimens indument (or its absence) seems most readily observable for purposes of categorization on inflorescence branchlets and calyces. Such indument may be either (1) lacking (although otherwise glabrous species presumably have fimbrillate hairs at the inner bases of caducous stipules, and such species may also be variably pilose on the outer surface of the corolla and also pilose in the corolla throat and sometimes on inner surfaces of the corolla tube and lobes); (2) present, the hairs being pale, minute, $0.05-0.1 \mathrm{~mm}$. long, and 1-3-cellular (indument of this type gives an inconspicuously puberulent appearance to those parts on which it may occur and may be so sparse as to be overlooked) (FIGURE 106A); or (3) more obviously present, the hairs being reddish (often brownish or pale but then usually with a reddish tinge at intercellular septa), 0.1-1.2 mm. long, and several-many-septate (indument of this type gives a conspicuously hirsute or tomentose appearance to those parts on which it occurs) (FIgURES 106B, 108C).

Fruit shape. The fruits of Psychotria in Fiji show variation in size and shape, falling into several generalized categories. (1) Fruit large, when fresh (11-) 20-40 × (7-) 15-28 mm., ellipsoid or obtusely 4-angled, and with a carnose pericarp, drying sharply 4-angled, with a conspicuous calycine scar (FIG URES 107A \& D, 112). (2) Fruit medium in size, when fresh 4.5-20 (-23) × 5-15 mm., ellipsoid to subglobose, obovoid, or turbinate, and with a carnose pericarp, drying with 4-10 longitudinal angles or sulci (sometimes irregularly rugulose), essentially symmetrical but sometimes slightly flattened in one plane proximally, with a conspicuous or inconspicuous calycine scar or with a persistent calyx limb (Figures 107B, 108, 109A). (3) Fruit as in (2) when fresh, drying asymmetrically, 4-angled but flattened proximally in one plane and swollen distally in the other plane, the calycine scar inconspicuous or the short calyx limb persistent (FIGUREs 109B, C, E). (4) Fruit comparatively small, when fresh 4-10 mm. long and broad, subglobose, and with a comparatively thin pericarp, drying with a smooth surface or with 6-10 shallow sulci, the short calyx limb persistent (FIGURE 110). 

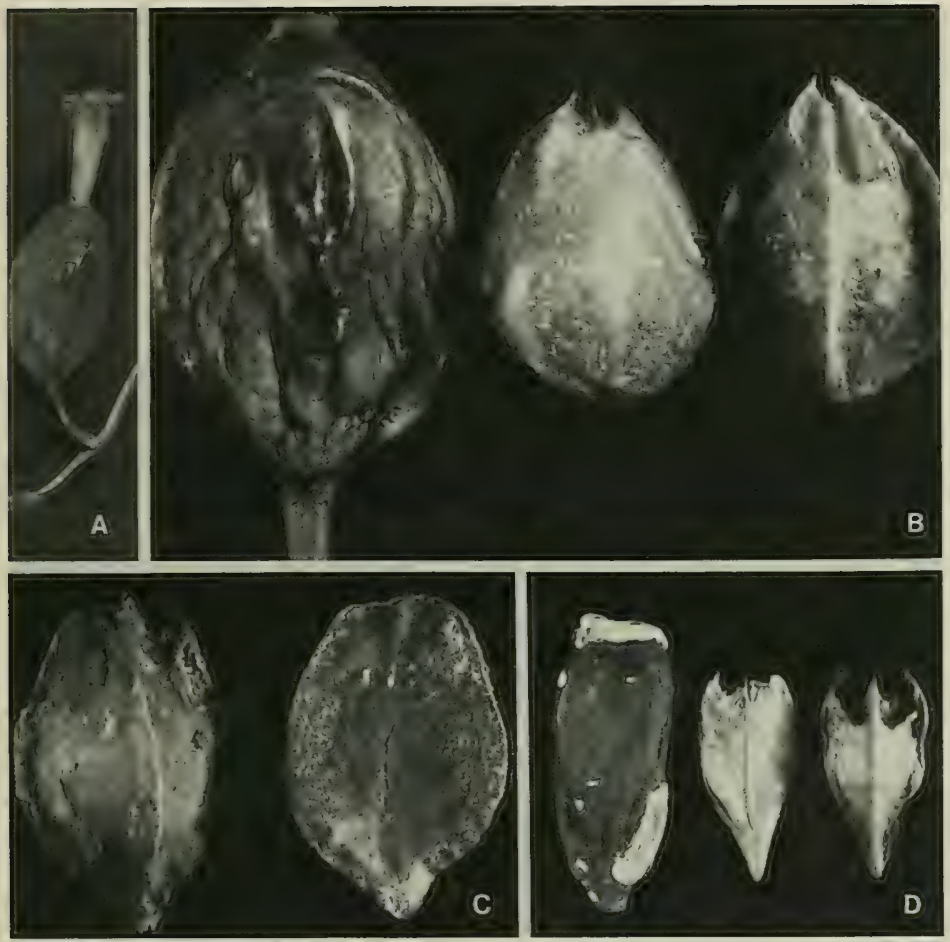

Figure 107. Psychotria: Fruits and pyrenes. A, P. eumorphanthus, fruit, with persistent calyx limb, $\times 1$. B, P. hypargyraea, fruit and adaxial and abaxial surfaces of pyrene, $\times 4$. C, P. gracilior, abaxial and adaxial surfaces of pyrene, $\times 3 . \mathrm{D}, P$. prismoclavata, fruit, the calyx limb fallen, and adaxial and abaxial surfaces of pyrene, $\times 2$. A from $D A 14378$, B from Smith 7348, C from Smith 6186, D from Gillespie 3272.

Fruit color. In color and markings the mature fruit may be (1) pink or orange to deep red, without obvious raphid bundles in the pericarp; (2) white to yellow, without obvious raphid bundles in the pericarp; (3) white to yellow, but with obvious raphid bundles in the pericarp; or (4) pink to orange or red, and with obvious raphid bundles in the pericarp.

Pyrenes. Pyrenes are closely correlated in shape with that of dried fruits in Psychotria and show useful characters for grouping species into clusters; several types of pyrene are apparent among the Fijian species. (1) Pyrenes elliptic in outline, comparatively large, $11-28 \times 6.5-18 \mathrm{~mm}$., adaxially smooth, abaxially sharply and conspicuously 1-carinate for entire length, essentially entire at apex (FIGURE 107C). (2) Pyrenes obovate in outline, comparatively large, (7-) 8-14 $\times 5-7 \mathrm{~mm}$., the adaxial and abaxial surfaces as in (1) but the apex deeply tridentate (FIgURE 107D). (3) Pyrenes suborbicular or elliptic in outline, thin in texture, medium-sized, 8-11 $\times 6-9 \mathrm{~mm}$., adaxially smooth, abaxially sharply and conspicuously 1-carinate for entire length, sometimes with one or two smaller carinae toward apex or in distal half, shallowly 

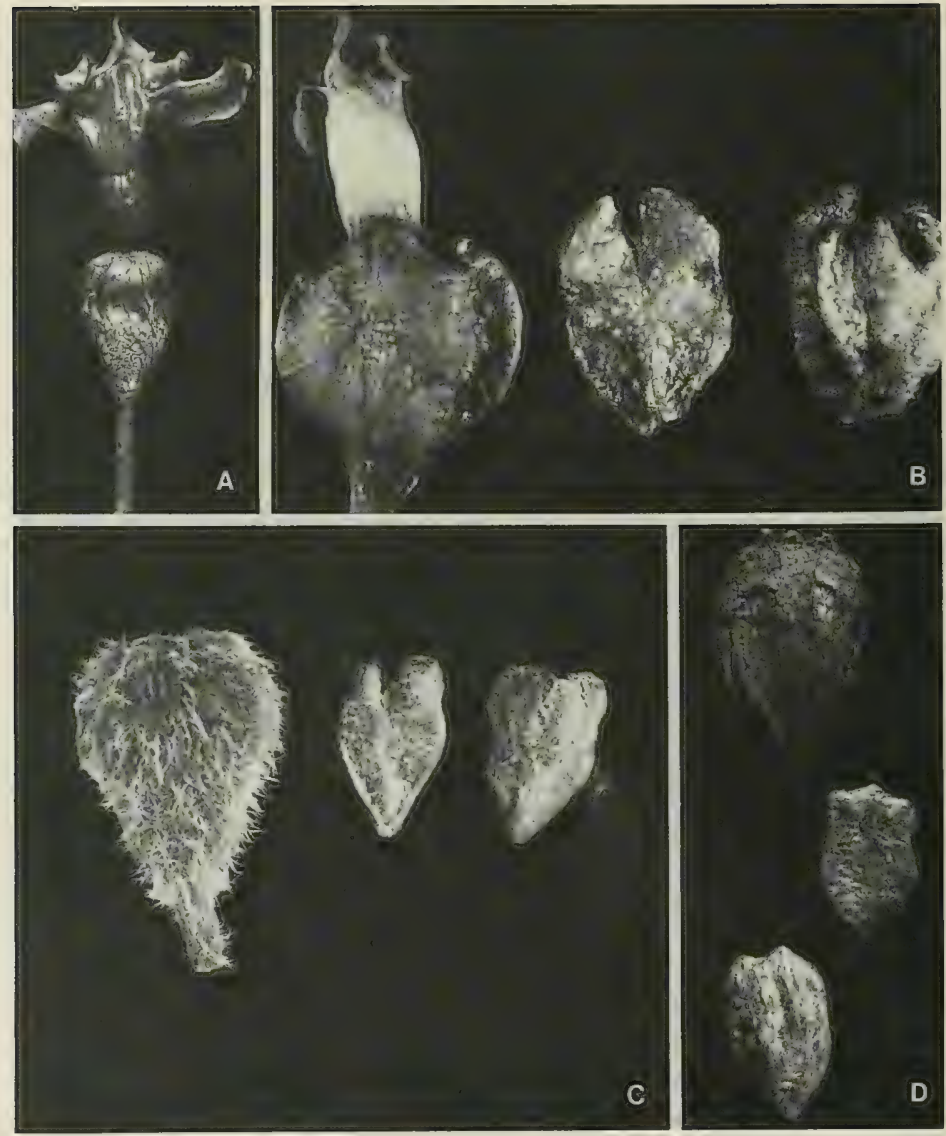

Figure 108. Psychotria: Fruits and pyrenes. A, $P$. glabra, young fruit with persistent calyx limb, $\times 2$. B, $P$. tomaniviensis, fruit, with persistent calyx limb, and adaxial and abaxial surfaces of pyrene, $\times 4 . \mathrm{C}, P$. brevicalyx, fruit, the calyx limb fallen, and adaxial and abaxial surfaces of pyrene, $\times 4 . \mathrm{D}, P$. storckii, fruit and adaxial and abaxial surfaces of pyrene, $\times 4$. A from Smith 7456, B from Gillespie 3995, C from Degener 15292, D from $D A 14869$.

indented at apex, the central carina slightly mucronate into the apical sinus (FIGURE 107B). (4) Pyrenes semiellipsoid or semiobovoid, medium-sized, 4-11 (-15) $\times 2.5-7$ $(-12) \mathrm{mm}$., adaxially smooth or with an inconspicuous longitudinal ridge, obtuse to subacute at base, abaxially bluntly 1-3-carinate essentially for entire length (sometimes irregularly tuberculate-rugulose especially distally), the carinae slightly projecting at the irregular apex (Figure 108B). (5) Pyrenes similar to those of (4) but with 

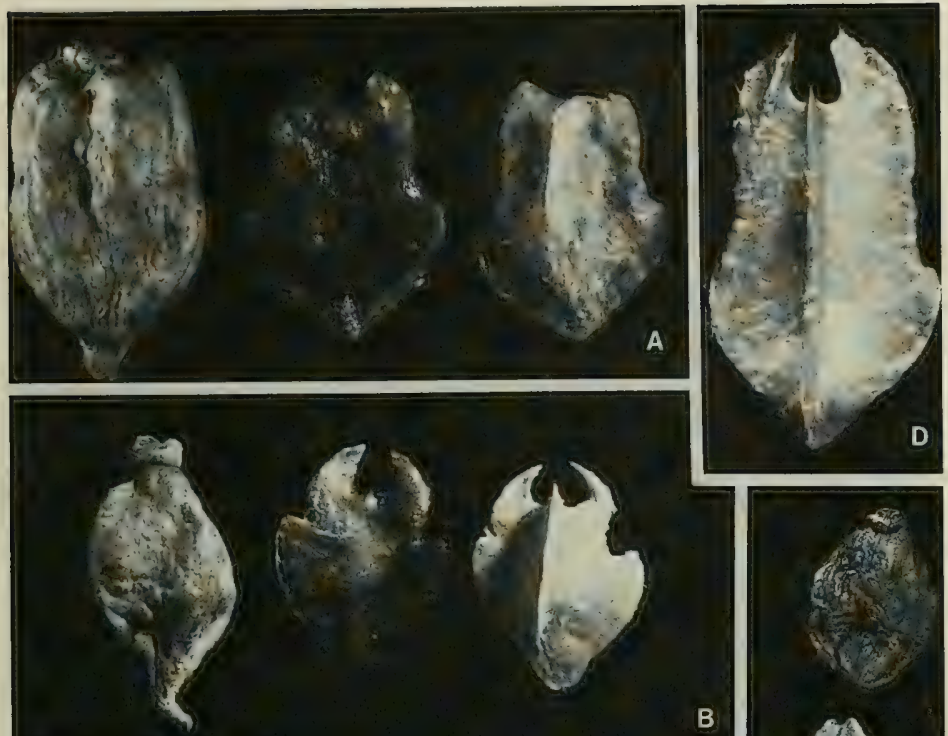

B
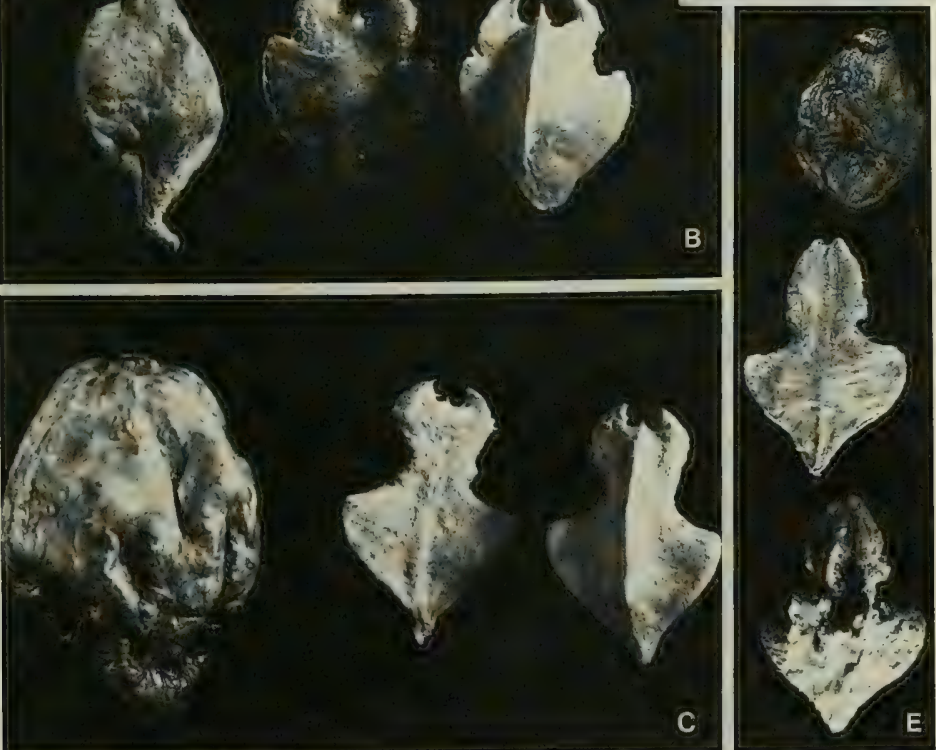

Figure 109. Psychotria: Fruits and pyrenes, all $\times 4$. A, P. impercepta, fruit and adaxial and abaxial surfaces of pyrene. B, P. platycocca, fruit and adaxial and abaxial surfaces of pyrene. C, $P$. pickeringii, fruit and adaxial and abaxial surfaces of pyrene. D, P. aurantiocarpa, abaxial surface of pyrene. E, P. taviunensis, fruit and adaxial and abaxial surfaces of pyrene. A from Smith $9005, \mathrm{~B}$ from DA 11494. C from DA 16574, D from Smith 449, E from Smith 752.

slight lateral indentations above middle, the basal portion subhastate and abaxially rounded to 3- or 5-carinate to subtuberculate, the carinae sometimes apparent only toward apex distal to lateral indentations (Figures 108C \& D, 109A). (6) Pyrenes 

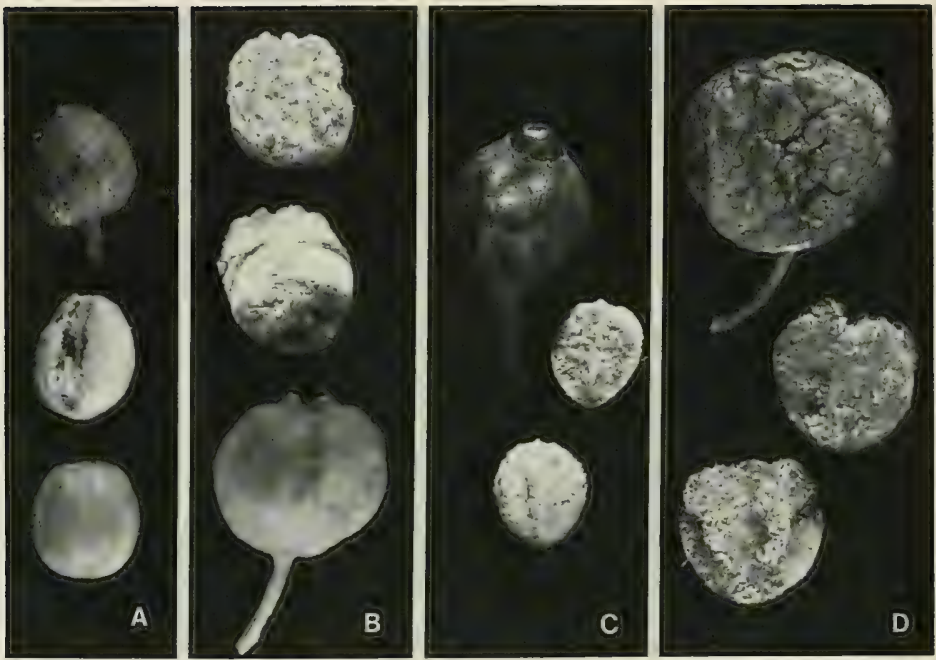

Figure 110. Psychotria: Fruits and pyrenes, all $\because 4 . \mathrm{A}, P$. leiophylla, fruit and adaxial and abaxial surfaces of pyrene. B, $P$. forsteriana, abaxial and adaxial surfaces of pyrene and fruit. C, $P$. tephrosantha, fruit and adaxial and abaxial surfaces of pyrene. D, $P$. parvula, fruit and adaxial and abaxial surfaces of pyrene. A from Smith 1239, B from Smith 7071, C from Degener 14392, D from O. \& I. Degener 32099.

rhomboid in outline and often conspicuously indented on lateral margins near or above middle, deeply or shallowly emarginate apically, medium-sized, 4-14 $\times 3-10$ $\mathrm{mm}$., adaxially smooth or with an inconspicuous longitudinal ridge, subacute to obtuse at base, abaxially acutely or bluntly 1-carinate essentially for entire length or only in distal half, the carina often slightly projecting distally into the apical notch (FIgure 109B-E). (7) Pyrenes semiglobose to semiellipsoid, small, 3-6 × 3-5 mm., adaxially smooth, abaxially 2-4-carinate, the carinae extending from base to apex (FIGURE 110B-D). (8) Pyrenes semiglobose to semiellipsoid, small, 4-5 × 3.5-4 mm., adaxially with a conspicuous median sulcus (this partially or completely bridged by a longitudinal, slender, fragile rib), abaxially smooth (FIGURE 110A).

Conclusions. An examination of TABLE 1, in which the types of significant morphological characters are assigned to the nine species groups into which we have divided the Fijian species of Psychotria, indicates that correlations are unsatisfactory. Except for the very obvious division of the taxa into trees or shrubs vs. vines, we have found the most satisfactory characters to repose in stipular type, calyces, and pyrenes, but the relationships among taxa are so highly reticulate that one must assume the genus to be in an active evolutionary state, its members sharing characters in such a way that no classification seems satisfactory. It is possible that the lianoid species, which are reasonably constant in other characters as well, may merit designation as a subgenus or section on a worldwide basis. Certainly there are no other alliances in Fiji that could be contemplated at the level of subgenus or section, although such categories have been utilized by Petit (1964), Steyermark (1972), and Verdcourt (1976) in their respective 
TAble 1. Fijian Psychotria: CORRElation of Significant morphological Characters With SPECiES GROUPS

\begin{tabular}{|c|c|c|c|c|c|c|c|c|c|}
\hline Species group & $\begin{array}{l}\text { 范 } \\
\text { 竞 }\end{array}$ & $\frac{\mathscr{E}}{3}$ & 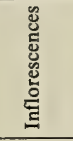 & $\frac{\mathscr{d}}{0}$ & $\begin{array}{l}\stackrel{2}{0} \\
\overline{0} \\
\dot{0} \\
0\end{array}$ & 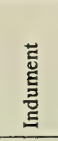 & 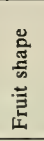 & $\begin{array}{l}\frac{5}{8} \\
\stackrel{8}{3} \\
\end{array}$ & 总 \\
\hline 1. Confertilobae & 1 & $1,2,3$ & 1,3 & 1,2 & 1 & 1,3 & 1 & 1,2 & 1 \\
\hline 2. Macrocalyces & 1 & 1 & 1,3 & 2,3 & 2 & $1,2,3$ & 2 & 1 & 4 \\
\hline 3. Turbinatae & 1 & 7 & $1,3,4$ & 2,3 & 1,2 & $1,2,3$ & 2 & 1,2 & $2,4,5$ \\
\hline 4. Carneae & 1 & 1,4 & $1,3,4$ & 4 & 4 & 1,2 & 2 & 1 & 4 \\
\hline 5. Forsterianae & 1 & 1,3 & 1,3 & 6 & 3 & 1,2 & 2,4 & 4 & $4,7,8$ \\
\hline 6. Pickeringiae & 1 & 5 & 4 & 5 & 2 & $1,2,3$ & 3 & 1,2 & 6 \\
\hline 7. Filipedes & 1 & 6 & 1,3 & 5 & 2,3 & 1,3 & 3 & 1 & 6 \\
\hline 8. Brackenridgeae & 1 & 7 & $1,2,3,4$ & 5 & 2,3 & $1,2,3$ & 2,3 & 1 & $3,4,5,6$ \\
\hline 9. Tephrosanthae & 2 & 1 & 1,3 & 5 & 3 & 1,2 & 4 & 3 & 7 \\
\hline
\end{tabular}

geographical areas. We suspect that at present the use of subgenera in Psychotria is not realistic and that sectional categories are not yet satisfactorily apparent if a worldwide classification of the genus is contemplated. The use of species groups (the names of which are devoid of nomenclatural status) in each geographical area seems to provide the best means of bringing a modicum of order to this intractable genus even at a very local level.

We have refrained from using trinomial nomenclature in treating the Fijian species of Psychotria, feeling that such usage gives a false sense of security in the interpretation of taxa. There are certainly occasional specimens that are intermediate in one or more characters among taxa that we recognize as species, but whether such fringing populations represent occasional introgression or merely small populations that still persist in actively speciating complexes is not perceptible without experimental studies. To apply trinomials to such populations may merely obscure their true nature.

Trees or shrubs; flowers and fruits various.

KEY TO SPECIES GROUPS

Calyx limb conspicuous, variously modified, at anthesis exceeding the hypanthium in length and at least 2 $\mathrm{mm}$. long; fruit at maturity pink to orange or deep red (rarely white), without obvious raphid bundles in the pericarp.

Corolla limb essentially smooth just prior to anthesis, not sharply angled, the lobes 5 or more, not conspicuously veined; calyx limb various, erect to rotate, usually with immersed nerves, often caducous in fruit.

Fruit large, $20-40 \times 12-28 \mathrm{~mm}$. at maturity, ellipsoid or obtusely 4-angled, sharply 4-angled when dried, the calyx limb long-persistent, when eventually caducous leaving a conspicuous scar; pyrenes elliptic in outline, comparatively large, 11-28 $\times 6.5-18 \mathrm{~mm}$., abaxially sharply and conspicuously 1-carinate for entire length, essentially entire at apex; calyx limb erect, subcylindric to infundibular, (3-) 4-23 mm. long, 3-10 mm. in diameter at apex; corolla elongate, the tube $18-50 \mathrm{~mm}$. long, the lobes $8-28 \mathrm{~mm}$. long. ............. Group 1. Confertilobae

Fruit comparatively small, $4.5-20(-25) \times 5-15 \mathrm{~mm}$. at maturity, ellipsoid to subglobose, obovoid, or turbinate, drying with 4-10 longitudinal angles or sulci, the calyx limb often long-persistent, when eventually caducous usually leaving a conspicuous scar; pyrenes semiellipsoid or semiobovoid, of medium size, 4-11 $(-15) \times 2.5-7(-12) \mathrm{mm}$., abaxially bluntly 1-3-carinate essentially for entire length, the carinae slightly projecting at the irregular apex (pyrenes of $P$. prismoclavata, species no. 13, exceptional in being abaxially sharply 1 -carinate and apically deeply 3-dentate); calyx limb variable in shape, $2-25 \mathrm{~mm}$. long, up to $25 \mathrm{~mm}$. in diameter at apex (but often much narrower); corolla of medium length, the tube (6-) 8-25(-35) $\mathrm{mm}$. long, the lobes $1.5-6(-8) \mathrm{mm}$. long. 
Stipules not bifid, lanceolate or elongate-deltoid, 3-8 $\mathrm{mm}$. long, free above middle or nearly from base, subacute to subulate at apex (rarely the apex minutely and narrowly divided to $1 \mathrm{~mm}$. but not obviously bifid); calyx limb not exceeding $9 \mathrm{~mm}$. in length or $10 \mathrm{~mm}$. in apical

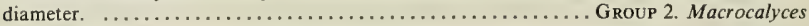
Stipules basally united, free distally and obviously bifid; calyx limb variable.

Group 3. Turbinatae

Corolla limb sharply enlarged and 4(or 5)-angled or -winged just prior to anthesis, the lobes broad, 4-12 $\mathrm{mm}$. long, obviously veined, their margins appressed to form the angles or wings, the corolla tube 3-20 mm. long; calyx limb suberect or erecto-patent, 2-5 mm. long, often thin in texture and obviously nerved, spreading to $7 \mathrm{~mm}$. in diameter; fruit prevailingly obovoid, $5-23 \mathrm{~mm}$. long, sometimes drying irregularly tuberculate; pyrenes semiobovoid, as in species groups 2 and 3 but sometimes abaxially irregularly tuberculate-rugulose. ..................... Carneae

Calyx limb comparatively inconspicuous, erect or erecto-patent at anthesis, usually shorter than or subequal to hypanthium in length or, if somewhat longer, rarely more than $2(-4) \mathrm{mm}$. long, usually persistent in fruit or, if eventually caducous, leaving an inconspicuous scar.

Stipules either connate and sheathing (separating along one side usually to base) or broadly ovatedeltoid and apiculate; corolla 3-5.5 mm. long, copiously barbellate in throat, the lobes approximately as long as the tube; vegetative and inflorescence parts (young branchlets, stipules, petioles, leaf blades, calyces, and pericarp of fruit) often copiously lineolate with raphid bundles (these becoming less obvious in fully mature parts but usually discernible in some organs); fruit at maturity pink to orange or deep red. ......................... Foup 5. Forsterianae

Stipules orbicular to ovate, obovate, or lanceolate, eventually separating along both sides, at apex obtuse to a piculate, acute, long-filiform, or bifid; corolla very rarely as short as $2 \mathrm{~mm}$., often much longer (to $18 \mathrm{~mm}$. long), with lobes obviously shorter than the tube, infrequently conspicuously barbellate in throat; raphid bundles present in various vegetative and inflorescence parts but usually inconspicuous and often obscure; fruit at maturity pink to orange to deep red (rarely yellowish).

Inflorescences strictly capitate, unbranched, the flowers sessile and subtended by obvious, usually scariose bracts (pedicels occasionally obscurely developing in fruit but never exceeding $1.5 \mathrm{~mm}$. in length); stipules obtuse to apiculate or linear-lanceolate at apex, not bifid; corolla 8-15 mm. long; fruit drying asymmetrically 4-angled but flattened proximally in one plane and swollen distally in the other plane, the pyrenes rhomboid, indented on lateral margins near middle, emarginate at apex, abaxially 1-carinate at least in distal half. ...... Group 6. Pickeringiae

Inflorescences branched, sometimes inconspicuously so but not strictly capitate (or if very rarely subcapitate then with obvious, elongate pedicels); fruit and pyrenes as in species group Pickeringiae or fruit drying symmetrically and pyrenes abaxially 1-4-carinate and not or only slightly indented on lateral margins.

Stipules usually long-lanceolate, in the terminal bud with separate and often diverging, acute or apiculate to long-filiform apices, the apices themselves entire or very briefly (to $1 \mathrm{~mm}$.) divided, the stipules eventually separating along both sides to base, not persisting at penultimate node; inflorescences (2-)4-6(-9)-branched from base or from apex of a short, ęrect peduncle not exceeding $2 \mathrm{~cm}$. in length; calyx limb inconspicuous, usually $0.3-1 \mathrm{~mm}$. long and subentire or obscurely dentate (rarely to $3 \mathrm{~mm}$. long and appreciably lobed); corolla 2-9 mm. long; leaf blades sometimes cordate at base, but often acute to attenuate and decurrent on

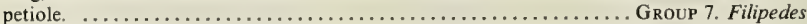

Stipules basally united, free distally and conspicuously notched to deeply bifid into broadly ovate to long-linear or filiform lobes, occasionally persisting at 3 or 4 distal nodes; inflorescences $2-7(-10)$-branched from base or from apex of a peduncle, this sometimes obvious, occasionally sharply reflexed; calyx limb usually inconspicuous, $0.2-2 \mathrm{~mm}$. long (sometimes to 3.5 $\mathrm{mm}$. long), subentire to obtusely short-dentate or with broadly deltoid lobes; corolla 4-18 $\mathrm{mm}$. long; leaf blades acute to attenuate at base and decurrent on petiole, never cordate.

Group 8. Brackenridgeae

Lianas or scrambling or scandent shrubs; inflorescences pedunculate or less frequently 3-branched from base, paniculate-cymose; flowers comparatively small, the calyx limb (less than $1 \mathrm{~mm}$. long) shorter than hypanthium, the corolla (including lobes) $4-9 \mathrm{~mm}$. long at anthesis, conspicuously farinosepuberulent without, the lobes 4 or 5 (or 6), before anthesis forming a smooth or costate bud; fruit subglobose, 4-10 mm. in diameter, smooth or shallowly sulcate, white to yellow, with obvious raphid bundles in the pericarp, the pyrenes abaxially 2-4-carinate from base to apex; stipules short, deltoid to

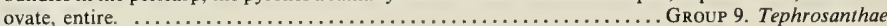




\section{KEYS TO SPECIES \\ Group 1. Confertilobae}

Stipules connate and sheathing when young, separating along one side usually to base, $6-28 \mathrm{~mm}$. long. Calyx limb 15-23 mm. long; corolla tube 30-50 mm. long, the lobes $13-28 \mathrm{~mm}$. long; anthers $3.5-4 \mathrm{~mm}$. long.

Stipules up to $28 \mathrm{~mm}$. long; petioles $1-4 \mathrm{~cm}$. long; leaf blades elliptic to obovate-elliptic, usually (9-) 13-25 $\times(4-) 6-9 \mathrm{~cm}$, , attenuate at base, abruptly acuminate at apex, with 8-15 arcuate-ascending secondary nerves per side; inflorescence branches and flowers (except corolla at throat) glabrous; calyx limb 15-23 mm. long and 5-10 mm. in diameter at apex; corolla tube $40-50 \mathrm{~mm}$. long, the lobes 24-28 mm. long; mature fruit 25-40 × 15-28 mm., the pyrenes 20-28 $\times 13-18 \mathrm{~mm}$.

1. P. eumorphanthus

Stipules 6-8 mm. long; petioles $1-3 \mathrm{~cm}$. long; leaf blades elliptic to oblanceolate, usually 7-12 $\times 3-5 \mathrm{~cm}$., acute to attenuate at base, cus pidate at apex, with 6-9 arcuate-spreading secondary nerves per side; inflorescence branches, pedicels, and often calyx pilose with pale, several-celled hairs $0.1-0.3 \mathrm{~mm}$. long; calyx limb 15-20 mm. long and 5-7 mm. in diameter at apex; corolla tube $30-40 \mathrm{~mm}$. long, puberulent without, the lobes $13-15 \mathrm{~mm}$. long; mature fruit up to $23 \times 15 \mathrm{~mm}$, the pyrenes about 15

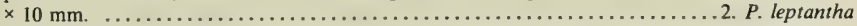

Calyx limb 4-5 mm. long; fruit up to $20 \times 15 \mathrm{~mm}$., the pyrenes $11-12 \times 6.5-8 \mathrm{~mm}$.; indument lacking; stipules 10-15 mm. long; petioles slender, 1-2 cm. long; leaf blades oblanceolate, $(6-)$ 8-11 $\times(2-)$ 2.5-4 cm., attenuate at base, acuminate at apex, with 7-9 ascending secondary nerves per side.

3. $P$. gracilior

Stipules connate only proximally, $1.5-12 \mathrm{~mm}$. long, the apices entire, acute to rounded; calyx limb not exceeding $8 \mathrm{~mm}$. in length; corolla tube less than $30 \mathrm{~mm}$. long, the lobes not more than $15 \mathrm{~mm}$. long; anthers about $2 \mathrm{~mm}$. long.

Petioles less than $2 \mathrm{~cm}$. long, very slender; leaf blades lanceolate, 6-10 $\times 1.5-2.8 \mathrm{~cm}$., narrowly acute at apex, the secondary nerves 8-10 per side; pedicels 5-7 mm. long; calyx limb 5-8 $\mathrm{mm}$. long, about 3 $\mathrm{mm}$. in diameter at a pex; corolla tube very slender ( $1-1.5 \mathrm{~mm}$. in diameter), $18-22 \mathrm{~mm}$. long, the lobes 8-9 $\times 2-3 \mathrm{~mm}$; stipules $1.5-3 \mathrm{~mm}$. long, acute at apex. ............. araiosantha

Petioles 1.5-6 cm. long, comparatively robust; leaf blades oblong-elliptic to obovate, usually (7-) 10-20× (3-) 5-9 cm., obtuse or obtusely cuspidate at apex, the secondary nerves spreading, curved, 8-15 per side; pedicels 1-6 mm. long; calyx limb (3-) 4-8 mm. long, 4-8 mm. in diameter at apex; corolla tube comparatively robust (about $2 \mathrm{~mm}$. in diameter), $20-30 \mathrm{~mm}$. long, the lobes $8-15 \times 3-4 \mathrm{~mm}$; fruit $20-27 \times 12-20 \mathrm{~mm}$., the pyrenes 11-15 $\times 9-13 \mathrm{~mm}$.; stipules 5-12 mm. long, rounded or obtuse at

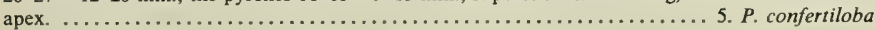

\section{Group 2. Macrocalyces}

Inflorescences (except calyx limb of $P$. roseata) and leaf blades glabrous, the calyx limb narrowly campanulate to fusiform-cylindric, 3-8 mm. long, 2-5 mm. in apical diameter; leaf blades prevailingly oblongelliptic, about 3 times as long as broad.

Flowers and fruits sessile or on pedicels to $4 \mathrm{~mm}$. long, the calyx limb glabrous; fruit pyriform to ellipsoid, 5-7 $\times 3.5-6 \mathrm{~mm}$., the pyrenes 4-6.5 $\times 3-5 \mathrm{~mm}$; leaf blades not exceeding $8 \times 3.2 \mathrm{~cm}$.

Mature corolla 13-15 mm. long; petioles 2-7 mm. long; leaf blades lanceolate to oblong-elliptic, (2-) $3-8 \times(0.5-) \quad 1-3.2 \mathrm{~cm}$; inflorescences branched from base or with inconspicuous peduncles to 2 $\mathrm{mm}$. long. . . . . . . macrocaly $x$ Mature corolla 23-32 mm. long; petioles $8-12 \mathrm{~mm}$. long; leaf blades obovate- to oblong-elliptic, 5-8 $\times$ 1.5-3 cm.; inflorescences pedunculate, the peduncle $1-5 \mathrm{~cm}$. long. ........ $7 . P$. vitiensis

Flowers and fruits borne on pedicels $5-15 \mathrm{~mm}$. long, the calyx limb crispate-pilose without (hairs multicellular, about $0.2 \mathrm{~mm}$. long), eventually glabrate; mature corolla $22-28 \mathrm{~mm}$. long; fruit narrowly ellipsoid-cylindric, 8-13 × 3.5-6 mm., the pyrenes 6-10 × 2.5-3.5 mm.; inflorescences few-branched from base; leaf blades (5-) $8-13 \times(1.5-) 3-4.5 \mathrm{~cm} . \ldots \ldots \ldots \ldots . . .8$ roseata

Inflorescences 3-5-branched from base, with branchlets, calyces, and corollas copiously and densely puberulent with pale hairs less than $0.1 \mathrm{~mm}$. long; branchlets distally and lower surfaces of leaf blades similarly minutely but copiously puberulent (but becoming glabrate).

Calyx limb fusiform to obovoid, 3-5 mm. long, abruptly flaring to a briefly spreading apex 3-5 $\mathrm{mm}$. in diameter; mature corolla $10-15 \mathrm{~mm}$. long; leaf blades narrowly oblanceolate, 5-6 times as long as broad, $7-18 \times 1.2-3.8 \mathrm{~cm}$., strongly revolute at margin. . . . . . . . . . . . . 9. P. levuensis

Calyx limb 5-9 mm. long, composed of a fusiform-cylindric basal part (1.5-2.5 mm. long and in diameter) and a campanulate-subrotate distal part $(6-10 \mathrm{~mm}$. in diameter at apex); mature corolla $13-17 \mathrm{~mm}$. long, leaf blades lanceolate to elliptic-lanceolate, 3-4 times as long as broad, (6-)10-25 × (2.5-) 3-6.5

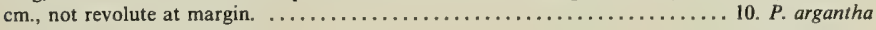




\section{Group 3. Turbinatae}

Inflorescences subcapitate, usually 9-12-flowered, the pedicels 1-3 mm. long; calyx limb 6-8.5 mm. long, narrowly campanulate, $3-5 \mathrm{~mm}$. in diameter at a pex, the lobes suberect; corolla 20-22 $\mathrm{mm}$. long; leaf blades lanceolate to oblanceolate, (7-) $10-17 \times(2-) 3.5-5 \mathrm{~cm}$.

Inflorescence-subtending stipules $20-25 \mathrm{~mm}$. long, connate into a flask-shaped sheath, free and bifid only in the distal $3 \mathrm{~mm}$; pedicels $2-3 \mathrm{~mm}$. long, copiously pilose with many-celled hairs; corolla pilose like pedicels; lower surfaces of leaf blades similarly reddish-pilose. . . . . . . . 11. P. ampullacea

Inflorescence-subtending stipules to $15 \mathrm{~mm}$. long, less highly connate, free in distal half or 2/3; pedicels about $1 \mathrm{~mm}$. long, glabrous; corolla essentially glabrous or distally weakly pale-pilose; leaf blades

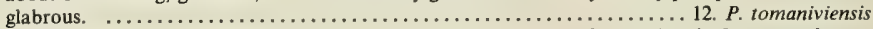

Inflorescences branched, not subcapitate (if compact and apparently 1-3-flowered, as in $P$. prismoclavata, not truly subcapitate but then usually short-pedunculate and with obviously pedicellate flowers, the stipules connate only in the basal $1-2 \mathrm{~mm}$.).

Indument lacking from inflorescences (except corollas sometimes puberulent) and vegetative parts.

Inflorescences compact, apparently 1- or 3-flowered, the peduncle if present to $1.5 \mathrm{~cm}$. long, the pedicels in fruit becoming 10-30 mm. long; calyx limb (7-) $10 \mathrm{~mm}$. long, proximally narrowly campanulate and distally enlarged to $9-10 \mathrm{~mm}$. in apical diameter; fruit drying clavate-prismatic or quadrangular-pyriform, (8-) 11-20 $\times(5-)$ 7-10 mm., the pyrenes (7-) 8-14 $\times 5-7 \mathrm{~mm}$., conspicuously and sharply I-carinate abaxially and tridentate at apex; leaf blades elliptic-obovate, $5-9 \times$

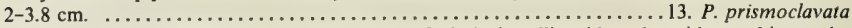
Inflorescences freely branching and many-flowered; fruit drying ellipsoid to obovoid or turbinate, the pyrenes bluntly carinate.

Calyx limb broadly flaring or subrotate, 7-25 mm. in apical diameter.

Calyx limb $10-25 \mathrm{~mm}$. long, the ascending basal portion cylindric or narrowly campanulate, 3-8 $\mathrm{mm}$. long, the distal portion campanulate or cupuliform, gradually broadened and flaring, 10-25 mm. in apical diameter, often conspicuously glandular; mature corolla $25-35 \mathrm{~mm}$. long; inflorescences ample, 6-15 cm. long, 2- or 3-times branched, the peduncle to $9 \mathrm{~cm}$. long (but sometimes essentially lacking); fruit turbinate, 7-15 × 6-7.5 mm.; leaf blades elliptic to elliptic-obovate, (7-) $10-25 \times(2.5-) 4.5-9 \mathrm{~cm} . \ldots \ldots \ldots \ldots \ldots \ldots \ldots \ldots$ 14. P. glabra

Calyx limb subrotate, broadly flaring and flattened nearly from base (i. e. from apex of hypanthium), the ascending basal portion of limb no more than $2.5 \mathrm{~mm}$. long, the distal portion $7-20$ $\mathrm{mm}$. in apical diameter.

Inflorescences pedunculate or 2- or 3-parted from base, $5-11 \mathrm{~cm}$. broad, the primary or secondary peduncles 1-6 cm. long, ascending (i. e. continuing direction of inflorescencebearing branchlet); petioles $0.7-2.5 \mathrm{~cm}$. long; leaf blades oblong-elliptic to obovate, not larger than $18 \times 7.5 \mathrm{~cm}$.

Calyx limb chartaceous, without conspicuous nerves, copiously reddish-glandular-punctate or -lineolate; mature corolla $18-25 \mathrm{~mm}$. long; leaf blades usually 6-13 $\times 2-5 \mathrm{~cm}$., with copious glandular markings on both surfaces. ........... fragrans

Calyx limb membranaceous, conspicuously reticulate-nerved, without glandular markings or these very obscure; mature corolla $23-30 \mathrm{~mm}$. long; leaf blades usually $10-18 \times 4-7.5 \mathrm{~cm}$., without glandular markings (or these very inconspicuous). .......

Inflorescences 3-parted and spreading from base, forming lax clusters $7-20 \mathrm{~cm}$. in diameter; calyx limb obviously nerved, eglandular; mature corolla $15-25 \mathrm{~mm}$. long; petioles 2-9 cm. long; 'leaf blades broadly oblong-elliptic, $15-32 \times 6-12 \mathrm{~cm}$., without glandular markings.

17. $P$, koroiveibaui

Calyx limb campanulate or fusiform to cylindric, gradually or abruptly flaring to an apical diameter of 2-7 mm.; leaf blades oblong-elliptic to -oblanceolate, with 6-12 secondary nerves per side.

Calyx limb campanulate, $2-5 \mathrm{~mm}$. long, gradually broadening distally; inflorescences pedunculate or divided from base.

Inflorescences pedunculate, $2-6 \mathrm{~cm}$. broad at maturity, the peduncle $1.5-3.5 \mathrm{~cm}$. long, the pedicels 2-4 mm. long; mature corolla $12-18 \mathrm{~mm}$. long; petioles $5-10 \mathrm{~mm}$. long; leaf blades

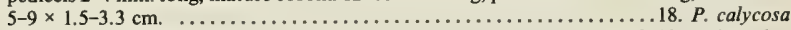

Inflorescences divided from base or spreading from a peduncle to $1 \mathrm{~cm}$. long, $5-13 \mathrm{~cm}$. broad at maturity, the secondary peduncles $1-5 \mathrm{~cm}$. long, the pedicels $5-17 \mathrm{~mm}$. long; mature corolla 17-27 mm. long; petioles 10-35 mm. long; leaf blades (5-) 7-11.5 $\times(1.5-) 2-4.5 \mathrm{~cm}$.

19. P. gillespieana

Calyx limb fusiform to cylindric, 2-6 mm. long, abruptly flaring distally; corolla to $15 \mathrm{~mm}$. long; inflorescences 3- or 4-divided from base, spreading to $9 \mathrm{~cm}$. in diameter, the secondary peduncles to $3.5 \mathrm{~cm}$. long, the pedicels $5-10 \mathrm{~mm}$. long; petioles 7-15 mm. long; leaf blades 7-10 $\times 2.5-5 \mathrm{~cm}$. 
Indument associated with inflorescences (branchlets, bracts, pedicels, bracteoles, and/or calyces) apparent, often composed of many-celled, reddish or golden hairs, sometimes of minute, 1-3-celled hairs, a similar indument also present on some vegetative parts.

Calyx limb 6-18 mm. long, the ascending basal portion cylindric or fusiform or narrowly campanulate, 3-10 mm. long, gradually or abruptly expanding into a broadly obconical distal portion 6-17 mm. in apical diameter; indument (on those inflorescence parts where it occurs) composed of predominantly reddish, several-many-celled hairs $0.1-1.2 \mathrm{~mm}$. long.

Lower surfaces of leaf blades pilose with usually reddish many-celled hairs $0.2-1 \mathrm{~mm}$. long (these sometimes becoming sparse and occasionally essentially lacking).

Leaf blades (8-) 12-28 $\times(2.5-)$ 4-12 cm., copiously hirtellous beneath with hairs uniformly distributed and persistent; indument of inflorescence branches, pedicels, and calyces similarly copious and persistent (even on fruits). $\ldots \ldots \ldots \ldots \ldots \ldots \ldots \ldots \ldots \ldots \ldots \ldots \ldots \ldots$. brevicalyx

Leaf blades usually smaller, (4-) 7-16 × (1.5-) 3-6 cm., sporadically hirtellous beneath, the hairs more obvious on costa and secondaries than on surface (and rarely essentially lacking); indument of inflorescence branches, pedicels, and calyces similar, often sporadic (and rarely essentially lacking), not persistent on fruit. .......... nandarivatensis

Lower surfaces of leaf blades glabrous or minutely puberulent (hairs less than $0.05 \mathrm{~mm}$. long, pale, obscurely 1-3-celled).

Leaf blades elliptic-lanceolate, 7-15 × 3-5 cm., with 8-11 secondary nerves per side, the upper surfaces copiously reddish-glandular-blotched; petioles $(0.7-) 1-3 \mathrm{~cm}$. long; inflorescences pedunculate (or 2- or 3-branched from base but then the secondary peduncles straight, erect), the peduncle (or secondary peduncles) $2-4 \mathrm{~cm}$. long. ........... pubiflora

Leaf blades broadly elliptic to obovate, $(11-) 15-25 \times 4.5-10.5 \mathrm{~cm}$., with $11-15$ secondary nerves per side, the upper surfaces not (or inconspicuously) glandular; petioles $1.8-4 \mathrm{~cm}$. long; inflorescences 2-4-branched from base. ..................... crassiflora

Calyx limb (2.5-) 3-8 (-10) $\mathrm{mm}$. long, campanulate or rotate or infundibular, the ascending basal portion less than $3 \mathrm{~mm}$. long and gradually or abruptly expanding distally to an apical diameter of 3-17 $\mathrm{mm}$. (or if ascending basal portion of calyx limb to $5 \mathrm{~mm}$. long then abruptly flaring to an apical diameter of only $2.5-5 \mathrm{~mm}$.).

Indument (on those inflorescence parts where it occurs) composed of predominantly reddish, several-many-celled hairs $0.1-1 \mathrm{~mm}$. long; calyx limb rotate, abruptly expanded to a spreading, flattened apical portion 5-17 $\mathrm{mm}$. in diameter.

Calyx limb 5-6 mm. in apical diameter; inflorescences 3-5-branched from base, at anthesis widespreading to a diameter of $8-14 \mathrm{~cm}$. (to $20 \mathrm{~cm}$. in fruit), freely branching, the flowers essentially sessile in ultimate triads or on short (apically jointed) branchlets; indument of inflorescence branchlets and calyx copious, uniformly distributed; stipules, petioles, and lower leaf blade surfaces similarly densely ferrugineous-tomentose; petioles $1-2.5 \mathrm{~cm}$. long; leaf blades oblanceolate to narrowly obovate, $7-16 \times 2-5.5 \mathrm{~cm}$., somewhat revolute at margin.

25. $P$. timonioides

Calyx limb 6-17 mm. in apical diameter; pedicels 3-20 mm. long; leaves glabrous, the blades not revolute at margin.

Inflorescence branches, pedicels, and hypanthium uniformly pilose with reddish hairs $0.1-0.2$ $\mathrm{mm}$. long, the principal bracts slenderly subulate with a single awn $1.5-3 \mathrm{~mm}$. long arising from a minutely deltoid base; inflorescences pedunculate (peduncle $1-3 \mathrm{~cm}$. long), suberect (continuing direction of branchlet growth, not widespreading), 4-7 cm. in diameter; calyx limb 8-17 mm. in apical diameter, copiously glandular; mature corolla 15-27 mm. long; petioles (2-) 5-20 mm. long; leaf blades oblong- to obovate-elliptic, (4-) 10-19 $\times(1.5-)$ 3-5.5

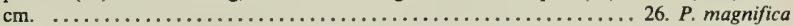

Inflorescence branches and pedicels glabrous, the principal bracts not slenderly subulate with a single awn; mature corolla $10-13 \mathrm{~mm}$. long; petioles $15-45 \mathrm{~mm}$. long; leaf blades elliptic, (8-) $10-15 \times(3.5-) 4-8 \mathrm{~cm}$.

Hypanthium glabrous, the calyx limb glabrous, $10-12 \mathrm{~mm}$. in apical diameter; bracts and bracteoles of inflorescences copiously reddish-pilose, the principal bracts lanceolate, 7-10 mm. long, deeply 3-5-lobed, the ultimate bracteoles 1-3 mm. long; inflorescences pedunculate (peduncle $2.5-3 \mathrm{~cm}$. long), suberect (continuing direction of branchlet growth, not widespreading), to $7 \mathrm{~cm}$. in diameter. ............ 27. P. jugalis

Hypanthium copiously pilose with stiff reddish hairs about $0.5 \mathrm{~mm}$. long, the calyx limb glabrous, 6-10 mm. in apical diameter; bracts and bracteoles of inflorescences minute but copiously reddish-tufted-pilose; inflorescences several-branched, spreading essentially from base to a diameter of $4-9 \mathrm{~cm} \ldots \ldots \ldots \ldots \ldots \ldots \ldots \ldots \ldots \ldots \ldots$. rufocalyx 
Indument (on those inflorescence parts where it occurs) composed of pale, minute, obscurely 1-3-celled hairs $0.05-0.1(-0.2) \mathrm{mm}$. long; calyx limb campanulate or infundibular to fusiform, the apex not exceeding $9(-14) \mathrm{mm}$. in diameter.

Calyx limb campanulate, gradually expanding nearly from apex of hypanthium (basal erect portion less than $2 \mathrm{~mm}$. long) to an apical diameter of 3-9 (-14) mm.; mature corolla 14-18 $\mathrm{mm}$. long; pedicels 1-4 (-8) mm. long; inflorescences 2-or 3-branched from base or with a peduncle to $3 \mathrm{~cm}$. long, at anthesis and in fruit up to $5(-9) \mathrm{cm}$. long and broad; petioles 3-15 $(-22) \mathrm{mm}$. long; leaf blades oblanceolate to oblong-elliptic, (3-) 4-9 (-15) $\times 1-3.5(-5.5) \mathrm{cm}$., with 6-10 secondary nerves per side, glabrous beneath and usually copiously reticulate-

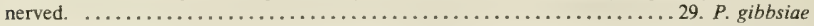

Calyx limb infundibular to fusiform to narrowly campanulate, erect in the ascending basal portion (this 2-5 mm. long) and then abruptly flaring to an apical diameter of $2.5-7 \mathrm{~mm}$; mature corolla (11-) 20-30 mm. long; pedicels (1-) 3-8 mm. long; inflorescences 3-several-branched from base or with a peduncle to $4 \mathrm{~cm}$. long, at anthesis and in fruit up to $9 \times 12 \mathrm{~cm}$; petioles 7-35 mm. long; leaf blades elliptic-obovate to narrowly elliptic, (8-) 9-23 $\times 3-9.5 \mathrm{~cm}$., with 10-14 secondary nerves per side, minutely but uniformly (and sometimes obscurely) palepuberulent beneath. ................................. turbinata

\section{Group 4. Carneae}

Stipules at ultimate node deltoid to broadly ovate-deltoid, 1-2.5 mm. long, apiculate at apex, often persistent at 1-3 distal nodes and there forming an erect, symmetrical, submembranaceous or subcoriaceous collar 1-3 mm. long, this eventually irregularly caducous from lower nodes; inflorescences longor short-pedunculate, 4-11 cm. in diameter at full anthesis and in fruit, 2- or 3-times branched, the peduncle (2-) 5-50 mm. long, erect or slightly reflexed, the flowers mostly borne in triads at apices of ultimate inflorescence branchlets, the pedicels $1.5-10 \mathrm{~mm}$. long; inflorescence branchlets, pedicels, bracts, and calyx often puberulent (hairs pale, minute, $0.05-0.1 \mathrm{~mm}$. long) but sometimes entirely glabrous; corolla at anthesis $15-20 \mathrm{~mm}$. long, 4-lobed, the lobes 5-7 mm. long; mature fruit 10-18 mm. long, often drying irregularly tuberculate; petioles (5-) 8-35 mm. long; leaf blades elliptic-oblong to

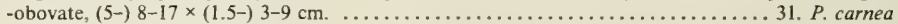

Stipules at ultimate node ovate to lanceolate or acicular, connate and sheathing along most of their length, (2-) 3-25 (-35) $\mathrm{mm}$. long, disintegrating at penultimate and lower nodes and often leaving a frayed basal portion.

Inflorescences epedunculate or with peduncles to $45 \mathrm{~mm}$. long, 4-13 cm. in diameter at full anthesis and in fruit, 2-4-times branched, glabrous throughout, the flowers mostly borne in triads at apices of ultimate inflorescence branchlets, the pedicels $1-10(-15) \mathrm{mm}$. long.

Stipules at ultimate node lanceolate to acicular, 5-25(-35) mm. long; pedicels at anthesis (2-) 3-10 (-15) $\mathrm{mm}$. long; corolla at anthesis $15-20 \mathrm{~mm}$. long, 4-lobed, the lobes 5-7 mm. long; mature fruit 10-18 $\mathrm{mm}$. long, often drying irregularly tuberculate; petioles (5-) 10-40 mm. long; leaf blades ellipticoblong to -obovate, sometimes lanceolate, $(6-) 8-18 \times(2-) 3.5-9.5 \mathrm{~cm}$. .... 32. P. oncocarpa

Stipules at ultimate node ovate to lanceolate, (3-) 4-10 (-15) mm. long; pedicels at anthesis 1-7 $\mathrm{mm}$. long; corolla at anthesis $23-30 \mathrm{~mm}$. long, 4- or 5-lobed, the lobes 8-12 mm. long; mature fruit (10-) 15-23 mm. long, usually drying smoothly 4-angled, sometimes slightly tuberculate; petioles (5-) 10-25 mm. long; leaf blades lanceolate to elliptic, (6-) 9-14 $\times(2-) 2.5-6.5 \mathrm{~cm}$.

33. P. hunteri

Inflorescences simple or l(rarely 2)-times branched, $1.5-4 \mathrm{~cm}$. in diameter at full anthesis and in fruit, the flowers borne in clusters of 4 or more; petioles $5-20 \mathrm{~mm}$. long; leaf blades lanceolate to narrowly elliptic.

Stipules at ultimate node ovate to lanceolate or acicular, (2-) 3-10 mm. long; inflorescences pedunculate (peduncle (3-) 5-12 (-23) mm. long), capitate to subcapitate, the flowers sessile or subsessile (pedicels in flower and fruit lacking or less than $3 \mathrm{~mm}$. long), 6-20 in clusters at apex of peduncle or short secondary branchlets to $3(-5) \mathrm{mm}$. long, the peduncle and calyx limb minutely but perceptibly puberulent; corolla at anthesis $6-7 \mathrm{~mm}$. long, the lobes 4 , about $4 \mathrm{~mm}$. long; mature fruit 5-12 mm. long, drying irregularly tuberculate; leaf blades 5-12.5 × 1.5-4 cm.

34. $P$. archboldiana

Stipules at ultimate node lanceolate to acicular, 10-20 mm. long; infructescences composed of an essentially sessile receptacle (rarely with obscure secondary peduncles), the fruits in clusters of 4-9, the pedicels 6-15 mm. long, glabrous, the calyx limb in fruit glabrous or obscurely puberulent; mature fruit 9-15 mm. long, drying smooth or slightly tuberculate; leaf blades (5-) 6-8.5 × (1.3-) $2-3.5 \mathrm{~cm}$. 


\section{Group 5. ForsterianaE}

Stipules at ultimate node scariose, lanceolate-oblong, sheathing, 5-30 mm. long, the sheath splitting along one side, often irregularly eroding from lower nodes; inflorescences 3-branched from base or shortpedunculate; calyx limb essentially entire or minutely 5-denticulate; fruit obovoid, drying inconspicuously 6-10-costate, without obvious longitudinal nerves or these subimmersed, sometimes irregularly rugulose, (3-) 4-8 × (3-) 3.5-7 mm.; pyrenes semiobovoid, usually 4-6.5 × 3.5-4.5 mm., abaxially smooth (or somewhat concave but not sulcate), adaxially bluntly 3-or 4-carinate (sometimes incons picuously so), often drying slightly and irregularly tuberculate, the carinae slightly swollen distally or bluntly projecting at apex.

Petioles (5-) 8-35 mm. long; leaf blades elliptic to oblong-lanceolate or -obovate, (4-) 6-22 × (1.5-) 3-8 $\mathrm{cm}$., usually 3-4 times longer than broad, with 5-12 secondary nerves per side, acute to sharply acuminate at apex; inflorescences many-flowered, of ten to $7 \mathrm{~cm}$. in diameter at anthesis and to $10 \mathrm{~cm}$. in fruit, the peduncle (when present) to $2 \mathrm{~cm}$. long, the pedicels $1-3 \mathrm{~mm}$. long, corolla 4-5 mm. long.

36. $P$. forsteriana

Petioles (2-) 5-20 mm. long; leaf blades ovate-elliptic to lanceolate, (1.5-) 3-6×(0.5-) $1.5-2.8 \mathrm{~cm}$., usually 2-3 times longer than broad, with 4-8 inconspicuous secondary nerves per side, acute to cuspidate and callose-apiculate at apex; inflorescences comparatively few-flowered, $2-4 \mathrm{~cm}$. in diameter at anthesis and in fruit, the peduncle (when present) rarely to $1 \mathrm{~cm}$. long, the pedicels $1.5-5 \mathrm{~mm}$. long (sometimes to $9 \mathrm{~mm}$. long in fruit); corolla $3-4 \mathrm{~mm}$. long. .................. amoena

Stipules at ultimate node broadly ovate or ovate-deltoid, apiculate, $0.7-5 \mathrm{~mm}$. long, forming a minute interpetiolar collar or free nearly to base; pedicels 1-2(-3) mm. long; calyx limb with obvious teeth or lobes; corollas $3-5.5 \mathrm{~mm}$. long.

Fruit broadly ovoid-ellipsoid to subglobose or slightly oblate, deeply or shallowly longitudinally bilobed, 4-6 $\times$ 4-7.5 mm., the pericarp thin-carnose, drying with 8-10 slender longitudinal nerves from base to apex; pyrenes semiellipsoid or semiglobose, usually 4-5 × 3.5-4 mm., adaxially deeply longitudinally sulcate, usually bisulcate by a median ridge but this often disrupted (usually persisting at base and apex), abaxially smooth; stipules broadly ovate, sometimes with 1 or 2 minute subsidiary denticles, forming an interpetiolar collar copiously lineolate with horizontal raphid bundles, 0.7-2 mm. long; petioles 10-50 mm. long; leaf blades narrowly elliptic to lanceolate, 8-19 × 3-7 cm., usually 2-3 $(-3.5)$ times longer than broad, with (5-) 7-10 secondary nerves per side; inflorescences $3-7 \mathrm{~cm}$. in diameter at anthesis and in fruit, 2- or 3-branched from base or with a peduncle 1-3 cm. long; calyx limb short-dentate. . . . . . . leiophylla

Fruit obovoid, 11-12 $\times 9-12 \mathrm{~mm}$., drying 6-10-costate and often rugulose, the pericarp carnose, without obvious nerves; pyrenes semiobovoid, about $10 \times 7.5 \mathrm{~mm}$., adaxially flattened, sometimes slightly rugulose and costate toward base, abaxially conspicuously 3-carinate with blunt, rugulose carinae; stipules broadly ovate-deltoid, 3-5 mm. long, subpersistent at 1-4 distal nodes; petioles 20-55 mm. long; leaf blades oblong to lanceolate-oblong, 16-28 $\times 5-9 \mathrm{~cm}$., usually 3-4 times longer than broad, with 12-18 secondary nerves per side; inflorescences $4-9 \mathrm{~cm}$. in diameter at anthesis and in fruit, with a peduncle $1.5-2.5 \mathrm{~cm}$. long bearing 4 or 5 branches at its apex; calyx limb 5-lobed nearly to base.

39. $P$. evansensis

Group 6. Pickeringiae

Indument lacking on branchlets, stipules, petioles, and leaf blades (or reddish hairs, if present on these parts, very sporadic).

Leaf blades deeply cordate at base, slenderly long-acuminate at apex (acumen 10-25 mm. long), oblongto lanceolate-ovate or slightly obovate, (4-) $5-8.5 \times(1.3-) 2-4 \mathrm{~cm}$., the petiole $15-35 \mathrm{~mm}$. long; stipules ovate or suborbicular, $2.5-12 \mathrm{~mm}$. long and broad; flowers about 6 per head, the calyx limb 0.5-0.7 mm. long, minutely apiculate-dentate, the corolla 9-10 mm. long; mature fruit to $9 \times 7 \mathrm{~mm}$.

40. P. cordata

Leaf blades attenuate to narrowly and inconspicuously subcordate at base, rounded to obtuse to gradually acuminate at apex (acumen rarely more than $18 \mathrm{~mm}$. long), the petiole to $18 \mathrm{~mm}$. long.

Apex of leat blades rounded to obtuse or obtusely short-cuspidate, the base gradually narrowed, cuneate to long-attenuate; calyx limb minute, $0.2-0.5 \mathrm{~mm}$. long, minutely denticulate.

Stipules deltoid-lanceolate or ovate, $6-11 \mathrm{~mm}$. long, the inflorescence-subtending ones to $6 \mathrm{~mm}$. broad, those subtending vegetative buds $2-3 \mathrm{~mm}$. broad; petioles $6-18 \mathrm{~mm}$. long; leaf blades oblong-obovate, (5-) 8-13 x (2-) 3.5-5.5 cm., rounded or broadly obtuse at apex, with 8-12 secondary nerves per side; mature fruit $8-15$ per head, $8-11 \times 5-8 \mathrm{~mm}$. . .41. $P$. valleculata Stipules ovate, 3-5 mm. long; leaf blades obovate to oblanceolate, not exceeding $6 \times 3.2 \mathrm{~cm}$., obtuse or obtusely short-cuspidate at apex, with 5-8 secondary nerves per side; mature fruit not more than 4 per head, $5-9 \times 3-8 \mathrm{~mm}$. 
Petioles slender, 6-12 mm. long; leaf blades obovate, (2.5-) 4-6 $\times(1.5-) 2-3.2 \mathrm{~cm}$.

42. P. monocarpa

Petioles essentially none to $4 \mathrm{~mm}$. long; leaf blades obovate or oblanceolate, (2-) $2.5-3.7 \times(0.7-)$

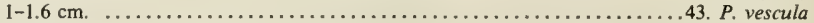

Apex of leaf blades acute to gradually acuminate, the base obtuse to cuneate to narrowly and inconspicuously subcordate; leaf blades obovate to oblong-elliptic or lanceolate, (4-) 5-15 × (I-) 1.5-6 cm., with 6-12 secondary nerves per side, the petioles (3-) 5-18 mm. long; flower-subtending bracts suborbicular to elliptic, 7-12 mm. long (rarely projected into a subulate tip to $7 \mathrm{~mm}$. long); corolla 8-15 mm. long, the lobes 5-7; mature fruit 8-18 × 6-18 mm.

Calyx limb minute, $0.3-1(-1.2) \mathrm{mm}$. long, without obvious nerves; flowers (2-) 5-10 per head; indument of calyx and inflorescence bracts usually sporadic or lacking. ...44. P. pickeringii

Calyx limb apparent, (1.2-) 2-4 mm. long, usually obviously nerved; flowers 3-20 per head; indument usually present on calyx and inflorescence bracts, only rarely lacking.

45. P. solanoides

Indument (usually on young branchlets, stipules, petioles, and/or lower surfaces of leaf blades, at least on costa and secondaries) obvious, composed of several- or many-celled reddish hairs $0.1-1 \mathrm{~mm}$. long.

Calyx limb (1.2-) 1.5-4 mm. long; corolla glabrous.

Inflorescence-enclosing stipules suborbicular to broadly ovate, 5-15 $\times 3-10 \mathrm{~mm}$, obtuse to apiculate at apex or with lanceolate tips to $3 \mathrm{~mm}$. long; petioles (3-) 4-18 $\mathrm{mm}$. long; leaf blades ovate-lanceolate to obovate-elliptic or -lanceolate, usually exceeding $7 \times 3 \mathrm{~cm}$., gradually acuminate at apex; indument usually present on inflorescence bracts and calyx, that of inflorescence and vegetative parts composed of comparatively elongate hairs $0.5-1 \mathrm{~mm}$. long.

Leaf blades 6-15 $\times 1.5-6 \mathrm{~cm}$., narrowly subcordate to cuneate at base, the secondary nerves 9-12 per side; corolla $10-15 \mathrm{~mm}$. long; fruits $10-18$ per head, usually soon glabrate, $10-18 \times 7-18 \mathrm{~mm}$., the persistent calyx limb usually $2-4 \mathrm{~mm}$. long. ................ $45 . P$. solanoides

Leaf blades (6-) 10-20 x (1.5-) 2-6.5 cm., sometimes noticeably bullate, obtuse to acute or narrowly rounded at base, the secondary nerves (9-) $15-20$ per side; fruits $6-10$ per head, remaining copiously hirsute, 7-10 × 4-8 mm., the persistent calyx limb $1.5-2.5 \mathrm{~mm}$. long.

46. $P$. bullata

Inflorescence-enclosing stipules forming an ampulliform sheath $10-20 \mathrm{~mm}$. long, 3-4 mm. broad, acuminate at apex; petioles 3-7 mm. long; leaf blades elliptic to obovate-elliptic, (3-) 4-7 $\times(1.3-)$ 1.7-2.8 cm., acute at base, acute to short-cuspidate at apex, with 8-10 secondary nerves; inflorescences glabrous, the flowers and fruits $2-4$ per head, the corolla $11-12 \mathrm{~mm}$. long; fruit $10-12 \times 8-10$ $\mathrm{mm}$; indument of vegetative parts composed of several-celled hairs $0.1-0.3 \mathrm{~mm}$. long.

47. P. kuruvolit

Calyx limb scarcely apparent, $0.3-0.5 \mathrm{~mm}$. long, truncate or minutely denticulate; flowers 8-12 per head; corolla $12-15 \mathrm{~mm}$. long at anthesis, sparsely pubescent without; fruit about $8 \times 5-6 \mathrm{~mm}$; stipules forming an ampulliform sheath $17-20 \mathrm{~mm}$. long, 7-9 $\mathrm{mm}$, broad, narrowed and subobtuse at apex; petioles 15-30 mm. long; leaf blades elliptic, 10-17 × 5-7 mm., cuneate to attenuate at base, obtusely cuspidate at apex, with $11-13$ secondary nerves per side. . . . . . . .

GROUP 7. Fil IPEDES

Indument essentially lacking on young branchlets, petioles, lower surfaces of leaf blades, inflorescence branches, pedicels, and calyces (occasionally present on stipules, youngest vegetative parts, costas of lower leaf blade surfaces, and inflorescence branches, but then sporadic and not long-persistent).

Leaf blades oblong-ovate to -obovate or -oblanceolate, $7-12 \times 2.3-6 \mathrm{~cm}$., with 8-13 secondary nerves per side, lacking indument on costa beneath, cordate to truncate (rarely broadly cuneate) at base, not obviously decurrent on petiole, abruptly to gradually acuminate at apex (acumen 8-15 mm. long); petioles slender (1-1.5 mm. in diameter), (10-) 15-40 mm. long; inflorescences widespreading, 8-15 $\mathrm{cm}$. in diameter at anthesis and in fruit, each primary branch very slender and often filiform, (2-) 3-6 $\mathrm{cm}$. long to first division, then 2-4-times divided, the flowers ( 1 or) 2 or 3 in the ultimate clusters, the pedicels 1-6 (-8) mm. long; corolla 4-6 mm. long; fruit $6-8 \times 4-7 \mathrm{~mm}$. ....... 49 . filipes

Leaf blades acute to attenuate (very rarely rounded or subcordate) at base, usually gradually decurrent on petiole; petioles seldom longer than $20 \mathrm{~mm}$; inflorescences not exceeding $12 \mathrm{~cm}$. in diameter at anthesis and in fruit.

Inflorescences $10-12 \mathrm{~cm}$, in diameter at anthesis, each primary branch $3-5 \mathrm{~cm}$. long to first division, then 3-or 4-times divided, the flowers ( 2 or) 3-6 in the ultimate clusters, the pedicels 4-9 mm. long; corolla 6-8 mm. long; petioles 10-20 (-25) mm. long, slender (0.5-1.5 mm. in diameter); leaf blades elliptic to elliptic-oblanceolate, (6-) 7-15 $\times(2.5-)$ 3-6 cm., sometimes with reddish indument on costa beneath, with 10-15 secondary nerves per side, sometimes tending toward rounded or subcordate at base, cuspidate to acuminate at apex (acumen 5-20 mm. long). 
Inflorescences 2-9 cm, in diameter at anthesis and in fruit, each primary branch 1-4 cm. long to first division, then 1-3-times divided, the flowers ( 1 or) 2 or 3 in the ultimate clusters, sessile or on pedicels to $3 \mathrm{~mm}$. long (to $7 \mathrm{~mm}$. in fruit); corolla $2.5-5 \mathrm{~mm}$. long; leaf blades obviously acute to attenuate at base and decurrent on petiole, lacking indument even on costa beneath, cuspidate to acuminate at apex (acumen not more than $15 \mathrm{~mm}$. long).

Petioles (3-) 5-17 mm. long, slender, (0.5-1.5 mm. in diameter); leaf blades oblong-elliptic to -obovate or -lanceolate, (3-) 4.5-11 x (1-) 1.5-5 cm., with 6-12 secondary nerves per side; inflorescences strictly glabrous, $2-6(-9) \mathrm{cm}$. in diameter at anthesis and in fruit, each primary branch 1-2 $(-3.5) \mathrm{cm}$. long to first division; corolla $2.5-5 \mathrm{~mm}$. long; fruit 8-12 x 5-8 mm.

51. $P$. platycocca

Petioles 10-35 mm. long, comparatively robust $(1.5-2.5 \mathrm{~mm}$. in diameter); leaf blades elliptic or ovate- to obovate-oblong, (9-) 12-23 x (3-) 4-10 cm., with 10-20 secondary nerves per side; inflorescences sometimes reddish-pilose on branchlets but sometimes strictly glabrous, $4-9 \mathrm{~cm}$. in diameter at anthesis and in fruit, each primary branch (1.5-) 2-4 cm. long to first division.

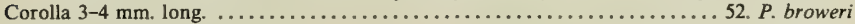

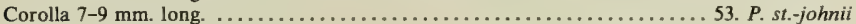

Indument (usually on young branchlets, petioles, and/ or lower surfaces of leaf blades, at least on costa and secondaries, often also on stipules, sometimes also on inflorescence branches, pedicels, and calyces) obvious, composed of several- or many-celled reddish hairs $0.1-1 \mathrm{~mm}$. long.

Leaf blades acute to attenuate at base, gradually decurrent on petiole; inflorescences 5-12 cm. in diameter at anthesis and in fruit.

Calyx limb inconspicuous, less than $1 \mathrm{~mm}$. long; inflorescences 3-6(-9)-branched from base, each branch 2-4-times divided; petioles 10-35 mm. long, comparatively robust (1.5-3 mm. in diameter); leaf blades comparatively large, elliptic to oblong- or elliptic-obovate, (7-) $10-25 \times(3-) 4-11 \mathrm{~cm}$., with (8-) 12-20 secondary nerves per side.

Corolla 7-9 mm. long at anthesis, glabrous without; calyx (hypanthium and limb) and fruit glabrous; pedicels very variable in length, $1-10 \mathrm{~mm}$. long; leaf blades usually slenderly acuminate (acumen

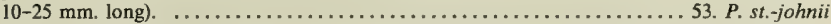

Corolla 2-4 mm. long at anthesis, the lobes spreading, giving a subrotate appearance to mature corolla, this pilose without at least distally; calyx (hypanthium and limb) pilose, the fruit often pilose but tardily glabrate; flowers essentially sessile or with pilose pedicels to $1.5 \mathrm{~mm}$. long; leaf blades obtuse to cuspidate or gradually acuminate (acumen then usually $3-20 \mathrm{~mm}$. long).

54. $P$. unicarinata

Calyx limb 2-3 mm. long; inflorescences 3-5-branched from base, each branch once or twice divided; petioles (6-) 10-30 mm. long, comparatively slender $(0.8-2 \mathrm{~mm}$. in diameter); leaf blades comparatively small, elliptic- to obovate-lanceolate, 6-19 $\times 2-6.5 \mathrm{~cm}$., with 11-16 secondary nerves per side.

Inflorescence branches once or twice divided, the fruit glabrous, with obvious and glabrate pedicels 5-8.5 mm. long; foliage indument close (hairs of petioles and costa and secondaries of lower leaf blade surfaces several-celled but only $0.1-0.2 \mathrm{~mm}$. long); leaf blades $6-12 \times 2-4.5 \mathrm{~cm}$., the

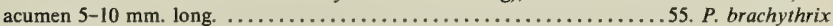

Inflorescence branches once divided, each division bearing 2 or 3 sessile or subsessile flowers at apex, the calyx (hypanthium and limb) copiously hirtellous; corolla 4-5 $\mathrm{mm}$. Iong; foliage indument comparatively lax (hairs of petioles and costa and secondaries of lower leaf blade surfaces many-celled, 0.5-1 mm. long); leaf blades (7-) 9-19 $\times(2-) 3-6.5 \mathrm{~cm}$., the acumen 10-20 $\mathrm{mm}$.

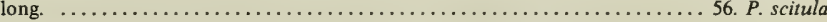

Leaf blades cordate at base, not decurrent on petiole; calyx and corolla glabrous.

Calyx limb minute, $0.3-0.5 \mathrm{~mm}$. long, essentially truncate; corolla campanulate to subrotate, 3-5 mm. long; mature fruit 7-10 $\times 4-10 \mathrm{~mm}$; inflorescences $4-14 \mathrm{~cm}$. in diameter at anthesis and in fruit, each primary branch 1-6 cm. long to first division, then 2-4-times divided, the flowers often sessile but the fruit sometimes with short pedicels (to $3 \mathrm{~mm}$. long); leaves large, the petioles 10-55 (-100) $\mathrm{mm}$. long, robust $(1.5-3.5 \mathrm{~mm}$. in diameter), the blades $7-26 \times(3-)$ 4-15.5 cm., with 10-17 secondary nerves per side.

Petioles 10-40 mm. long; leaf blades elliptic to elliptic-obovate, 7-15 x (3-) 4-7.5 cm., obtuse or obtusely short-cuspidate at apex. ....................... 57. P. griseifolia

Petioles 20-55 (-100) mm. long; leaf blades broadly ovate to broadly elliptic or obovate, (11-) 12-26 $\times(6-) 7-15.5 \mathrm{~cm}$, acuminate (usually abruptly so) at apex (acumen $10-20 \mathrm{~mm}$. long).

58. P. taviunensis 
Calyx limb 2.5-3 mm. long, with 4-6 oblong lobes $0.7-1.3 \mathrm{~mm}$. long; corolla broadly infundibular, 7-8 $\mathrm{mm}$. long; mature fruit 10-15 × 7-10 mm.; inflorescences 2-6 cm. in diameter at anthesis and in fruit, each primary branch $0.7-2.5 \mathrm{~cm}$. long to first division, then once or twice divided, the pedicels 1-2 mm. long at anthesis (to $5 \mathrm{~mm}$. long in fruit); leaves comparatively small, the petioles $5-15 \mathrm{~mm}$. long, slender (0.5-1 mm. in diameter), the blades ovate-oblong, (2-) 4-5.5 $\times(1-) 2-3.5 \mathrm{~cm}$., with 6-9 secondary nerves per side, cuspidate or short-acuminate at apex (acumen 3-5 mm. long).

59. P. podantha

\section{GROUP 8. BRACKENRIDGEAE}

Indument lacking from vegetative parts and inflorescences (or, if inconspicuously present on inflorescence branches, pedicels, calyces, and corollas, then composed of minute, cinereous (rarely brownish) 1-3-celled hairs less than $0.1 \mathrm{~mm}$. long).

Inflorescences pedunculate, the peduncle sharply reflexed or obviously geniculate (very rarely suberect), (1.5-) 2-35 cm. long; petioles 10-55 mm. long, often stout (1-3 mm. in diameter); leaf blades oblong or elliptic or lanceolate, acute to short-acuminate (acumen broad, 5-10 mm. long), with 10-20 secondary nerves per side; calyx limb 1-2 (-3) mm. long, subentire to obtusely lobed; corolla 9-13 $\mathrm{mm}$. long; fruit ellipsoid to obovoid, 7-12 $\times$ 5-12 mm., drying 6-8-angled or tuberculate, the pyrenes subhastate or with unindented lateral margins, 5-10 $\times 4-8 \mathrm{~mm}$, abaxially obtusely and inconspicuously 3- or 4-carinate (the median carina sometimes the most prominent), irregularly truncate at apex.

Stipules 4-12 mm. long, not persisting at penultimate or lower nodes, the free portions sharply bifid, the lobes lanceolate, $2-7 \times 0.5-2.5 \mathrm{~mm}$, attenuate to acute or subacute at apex; petioles $10-50 \mathrm{~mm}$. long; leaf blades (6-) 8-20 $\times(2-)$ 2.5-7.5 cm; inflorescence peduncle $(1.5-) 2-7 \mathrm{~cm}$. long, 3-6-branched at apex, each branch 1-4 $(-4.5) \mathrm{cm}$. long and 2-4-times divided, the pedicels 1-7 mm.

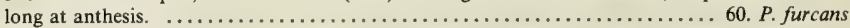

Stipules (7-) 10-20 mm. long, often venulose, sometimes subauriculate at base and interconnected by a narrow flange outside petiole, often persistent at 2-4 distal nodes, the free portions broadly obovate, often spreading or reflexed, shallowly bilobed, the lobes broadly deltoid, $1-5 \times 2-10 \mathrm{~mm}$. (broader than long), obtuse to rounded at apex; petioles $25-55 \mathrm{~mm}$. long; leaf blades (8-) 12-25 $\times$ (2.5-) 3-11 cm.; inflorescence peduncle (3-) 6-35 cm. long, 3-5-branched at apex, each branch (1.5-) 2.5-12 cm. long and 3- or 4-times divided, the pedicels 4-10 mm. long at anthesis.

61. P. pritchardii

Inflorescences branched from base or pedunculate, the peduncle then erect (continuing direction of branchlet) and rarely exceeding $1 \mathrm{~cm}$. in length.

Habit very slender, stipules $1.5-2.5 \mathrm{~mm}$. long, cleft nearly to base, each lobe lanceolate, $1.3-1.8 \mathrm{~mm}$. long and 0.2-0.4 mm. broad; petioles slender (about $0.5 \mathrm{~mm}$. in diameter), 3-8 mm. long; leaf blades lanceolate, $5-7 \times 0.8-1.2 \mathrm{~cm}$., gradually and slenderly acuminate (acumen 10-15 mm. long), with 10-14 secondary nerves per side; inflorescences $1.5-2.5 \mathrm{~cm}$. long, with peduncles 7-11 mm. long, 2-4-times branched, the flowers $10-15$, sessile or minutely pedicellate; calyx limb minute, to $0.5 \mathrm{~mm}$. long, with 4 inconspicuous, deltoid, subacute teeth; corolla about $6 \mathrm{~mm}$. long at anthesis; indument of inflorescence branches and external floral parts composed of minute, cinerȩous,

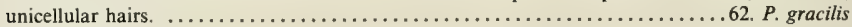

Habit comparatively robust; stipules 4-35 mm. long; petioles (0.8-) 1-3 (-3.5) mm. in diameter, (5-) $10-30(-50) \mathrm{mm}$. long; leaf blades seldom less than $2 \mathrm{~cm}$. broad, acute to cuspidate or shortacuminate at apex (acumen if apparent broad and $5-10 \mathrm{~mm}$. long).

Inflorescences compact and congested, 2-5(-8)-branched from base, 1.5-5 × 2-7 cm. at anthesis and in fruit (including corollas and fruits), each primary branch $0.1-3 \mathrm{~cm}$. long to first division, then 1-3-times divided or 3-flowered at its apex, the flowers subsessile or with pedicels rarely to $3 \mathrm{~mm}$. long (to $6 \mathrm{~mm}$. long in fruit); stipules 5-14 mm. long (if inflorescence-enclosing to $20 \mathrm{~mm}$. long), the free portions bifid into lanceolate or deltoid-oblong, acute to attenuate lobes $1-6 \times 0.5-2$ $\mathrm{mm}$; leaf blades (4-) 5-18 x (1-) 2-6.5 cm.

Calyx limb $0.5-2 \mathrm{~mm}$. long, inconspicuously dentate or undulate with acute to rounded lobes $0.2-0.5 \mathrm{~mm}$. long; corolla $4-10 \mathrm{~mm}$. long, barbellate in throat; fruit ellipsoid to obovoid or subglobose, 7-16 × 6-11 mm., drying 4-8-angled, the pyrenes suborbicular or elliptic in outline, dorsiventrally somewhat flattened but abaxially sharply 3-carinate or 1-carinate with subsidiary carinae only inconspicuous and distal, with lateral margins rounded (not indented), the apex shallowly indented; inflorescences with each primary branch $0.5-3 \mathrm{~cm}$. long to first division, then 2- or 3-times divided; petioles $5-20 \mathrm{~mm}$. long.

63. $P$. hypargyraea

Calyx limb scarcely $0.5 \mathrm{~mm}$. long, minutely 5 -denticulate, exceeded by the prominent, pulvinate disk; corolla 12-18 mm. long, inconspicuously pilose in throat; fruit oblong-to subrhomboidellipsoid or subglobose, $8-14 \times 6-11(-14) \mathrm{mm}$., drying obtusely 6-8-angled, the pyrenes subhastate-semiellipsoid, abaxially bluntly 2- or 3-carinate or proximally rounded, with 
lateral margins inconspicuously or obviously indented near or below middle, the apex inconspicuously indented; inflorescences with each primary branch $0.1-0.7(-1.5) \mathrm{cm}$. long to first division and either 3-flowered at apex or once again divided; petioles (10-) 15-35 mm.

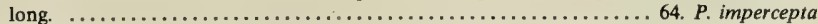

Inflorescences comparatively open, (3-) 4-15 $\times(4-) 7-15 \mathrm{~cm}$. at anthesis and in fruit (including corollas and fruits), each primary branch $1-10 \mathrm{~cm}$. long to first division, then 2-4-times divided, the pedicels 1-10 (-15) mm. long; leaf blades (8-) $10-30 \times(2.5-) 3-12 \mathrm{~cm}$.

Stipules oblong- to elliptic-obovate, 10-35 $\mathrm{mm}$. long; petioles $10-50 \mathrm{~mm}$. long; inflorescences with each branch $1-5(-10) \mathrm{cm}$. long to first division and then 2- or 3-times divided; calyx limb (1-) 2-3.5 mm. long, inconspicuously denticulate or with broadly deltoid lobes to $0.5 \mathrm{~mm}$. long; corolla with 4-6 lobes.

Corolla 10-12 mm. long, 4-6-lobed, usually slightly or copiously pilose without; inflorescences 3-7(-10)-branched from base, the pedicels $1-4 \mathrm{~mm}$. long at anthesis, $4-12 \mathrm{~mm}$. long in fruit; stipules with free portions $6-30 \mathrm{~mm}$. long and obviously bifid, the lobes oblong-deltoid to lanceolate, 3-12 $\mathrm{mm}$. long and 1-8 $\mathrm{mm}$. broad, subacute to obtuse at apex; leaf blades oblong-elliptic or -obovate to elliptic-lanceolate or oblanceolate, (9-) 15-30 $\times(2.5-)$ 5-12 cm., with 11-20 secondary nerves per side. ..............6. 68 . brackenridgei

Corolla 16-18 mm. long, 5- or 6-lobed, glabrous without or cinereous-puberulent distally; inflorescences $3(-5)$-branched from base or from apex of an erect peduncle 3-7 mm. long, the pedicels 3-10 $\mathrm{mm}$. long at anthesis; stipules with free portions $8-15 \mathrm{~mm}$. long and 5-7 $\mathrm{mm}$. broad, merely notched apically by an acute indentation 1-2 $\mathrm{mm}$. deep (lobes rounded to obtuse); leaf blades elliptic to slightly obovate, (8-) $10-26 \times 3-11 \mathrm{~cm}$, with $8-11$ secondary nerves per side. ......................... pachyantha

Stipules oblong, 4-7 mm. long, the free portions with lanceolate, acute lobes 3-5 mm. long and 0.5-1 mm. broad; petioles $10-25 \mathrm{~mm}$. long; leaf blades narrowly elliptic to elliptic-obovate, (9-) 12-20 × 3.5-6.5 cm., with 7-11 secondary nerves per side; inflorescences 2-4-branched from base or from a pex of an erect peduncle to $1 \mathrm{~cm}$. long, each branch $2.5-4 \mathrm{~cm}$. long to first division and then twice divided, the pedicels $7-15 \mathrm{~mm}$. long; calyx limb broadly cupuliform, 1.5-2.5 mm. long, truncate or slightly undulate at apex, not lobed or denticulate; corolla 8-13 $\mathrm{mm}$. long, 6-8-lobed, the lobes reddish-puberulent or glabrous without. . . .66. P. edentata Indument obvious at least on inflorescence branches (often also on pedicels, calyces, and corollas, sometimes on vegetative parts), composed of 2-many-celled reddish (rarely pale) hairs $0.1-1 \mathrm{~mm}$. long.

Inflorescences (known only in fruit) comparatively simple, 2-or 3-branched from base, each branch 2-2.5 $\mathrm{cm}$. long and bearing at its apex 1 or 2 (or 3?) sessile fruits, these subhastate-ovoid, $12-18 \times 8-10 \mathrm{~mm}$, drying sharply 4-angled, the pyrenes rhomboid-oblong, about $14 \times 8 \mathrm{~mm}$, abaxially sharply 1-carinate, the lateral margins slightly indented below middle, the apex deeply notched; stipules with free portions deeply bifid into filiform lobes 6-7 $\times 0.2-0.3 \mathrm{~mm}$; petioles $10-15 \mathrm{~mm}$. long; leaf blades narrowly elliptic-oblong to oblanceolate, (7-) 10-13 x (2.3-) 3-4 cm., with a slender acumen 10-15 $\mathrm{mm}$. long and with 8-10 secondary nerves per side; indument restricted to inflorescence branches.

67. $P$. aurantiocarpa

Inflorescences more complex, 2-7(-10)-branched from base or pedunculate, each branch 1-3-times divided (or rarely 3-flowered at its apex); fruits oblong-obovoid to turbinate, 6-16 $\times 5-14 \mathrm{~mm}$., drying 6-8-angled, the pyrenes oblong, 6-10 $\times 4-9 \mathrm{~mm}$., abaxially bluntly 2-or 3-carinate, the apex irregularly truncate; stipules with free portions bifid into oblong-deltoid or lanceolate lobes $2-12 \times$ 0.5-8 $\mathrm{mm}$.

Distal internodes of branchlets, stipules, petioles, and lower surfaces of leaf blades (except infrequently on costa and secondaries) glabrous; leaf blades obtuse to bluntly acuminate at apex (acumen not more than $10 \mathrm{~mm}$. long).

Petioles 5-50 mm. long; leaf blades (5-) 7-30 x (1.5-) 3-12 cm.; inflorescences comparatively ample, usually 5-15 cm. long and broad (including corollas and fruits); calyx limb (1-) 1.5-3.5 mm. long; fruits $7-16 \times 5-14 \mathrm{~mm}$.

Inflorescences epedunculate, 3-7(-10)-branched from base, each branch 1-10 $\mathrm{cm}$. long to first division, then 2- or 3-times divided, the pedicels $1-4 \mathrm{~mm}$. long in flower, to $12 \mathrm{~mm}$. long in fruit; corolla 10-12 mm. long; fruit 7-16 $\times 5-14 \mathrm{~mm}$.; stipules $10-17 \mathrm{~mm}$. long (to $35 \mathrm{~mm}$. long when inflorescence-subtending), the free portions broadly obovate, with lobes 3-12 $\times 1-8$ mm.; petioles 15-50 mm. long; leaf blades (9-) 15-30 × (2.5-) 5-12 cm., with 11-20 secondary nerves per side. ................................. brackenridgei

Inflorescences prevailingly pedunculate, the peduncle erect, 1-7 cm. long, with 3-6 branches spreading from its apex (but occasionally inflorescences 2-6-branched from base), each primary branch (or peduncle) 1-7 cm. long to first division, then 2- or 3-times divided, the pedicels $0.5-2 \mathrm{~mm}$. long in flower and fruit; corolla $10-15 \mathrm{~mm}$. long; fruit 7-10 $5-7 \mathrm{~mm}$; stipules 5-10 $\mathrm{mm}$. long (to $25 \mathrm{~mm}$. long when inflorescence-subtending), the free portions oblong-obovate, with lobes 3-4 × 1-2.5 mm.; petioles 5-30 (-40) mm. long; leaf blades (5-) $7-18.5 \times(1.5-)$ 3-7.5 cm., with 10-15 secondary nerves per side. . . . . 69. P. imthurnii 
Petioles 5-20 mm. long; leaf blades 5-14 $\times(1.2-)$ 2-5 cm.; inflorescences usually less ample, 1.5-7× $1.5-8 \mathrm{~cm}$. (including corollas and fruits); fruit 6-7 $\times 5-7 \mathrm{~mm}$; stipules with free portions 3-8 $\mathrm{mm}$. long, the lobes lanceolate or oblong-deltoid, 2-6 $\times 1-2 \mathrm{~mm}$.

Leaf blades obovate to oblanceolate, (5-) 7-14 $\times(1.2-) 2-5 \mathrm{~cm}$., often revolute at margin and drying greenish yellow; inflorescences usually with an erect peduncle $1-4 \mathrm{~cm}$. long and 3-6-branched from its apex (or 2- or 3-branched from base), the branches $1-2.5 \mathrm{~cm}$. long to first division, then 2- or 3-times divided, the flowers many, sessile (but pedicels to $2 \mathrm{~mm}$. long in fruit); calyx limb less than $1 \mathrm{~mm}$. long, shallowly 5-dentate; corolla 7-10 $\mathrm{mm}$. long, copiously pilose in bud but glabrescent. ................ 70 . pittosporifolia

Leaf blades elliptic to obovate, 5-10 $\times 2.5-5 \mathrm{~cm}$; ; inflorescences 3-5-branched from base, each branch (rarely once-divided) $0.5-4 \mathrm{~cm}$. long and 3-flowered at its apex, the flowers 9-15 (but some not developing), sessile; calyx limb about $2 \mathrm{~mm}$. long, with deltoid, apiculate lobes about $0.5 \mathrm{~mm}$. long; corolla $10-12 \mathrm{~mm}$. long, glabrous. ............. vomensis

Distal internodes of branchlets, stipules (frequently), petioles, and lower surfaces of leaf blades (at least costas and secondaries) reddish-pilose, often copiously so; stipules 10-25 mm. long (inflorescenceenclosing ones greatly distended proximally), the free portions $5-15 \mathrm{~mm}$. long, with oblonglanceolate lobes 2-10 $(-12) \times 0.5-4(-5) \mathrm{mm}$; p petioles $15-60 \mathrm{~mm}$. long; leaf blades elliptic-oblong to -lanceolate or obovate, (8-) 13-30 × (3-)4-14 cm., gradually acuminate (acumen 10-20 mm. long), with 12-20 secondary nerves per side; inflorescences 3-5(-10)-branched from base, 3-9 $(-12) \times$ $4-10(-15) \mathrm{cm}$. (including corollas and fruits), each branch $0.5-3 \mathrm{~cm}$. long to first division and then 2- or 3-times divided, the pedicels 1-5 mm. long (to $8 \mathrm{~mm}$. long in fruit); calyx limb 1-3 mm. long, subtruncate or shallowly denticulate; corolla $8-15 \mathrm{~mm}$. long. ........... 72. P. storckii

\section{Group 9. TEPHROSANTHAE}

Leaf blades oblong-elliptic or ovate to lanceolate, (2-) 2.5-7-times longer than broad, long-attenuate at base, (cuspidate to) acute to acuminate at apex (acumen 5-15 mm. long); mature fruit 4-7 × 3.5-6 mm.

Stipules deltoid, $1-2(-3) \times 1-1.5 \mathrm{~mm}$., acute at apex or with a short acumen $0.5-1 \mathrm{~mm}$. long; petioles (5-) 8-40 mm. long, comparatively stout (1-1.5 mm. in diameter); leaf blades (3.5-) 7-15 $\times(1-) 2-6 \mathrm{~cm}$., usually 2.5-4-times longer than broad, with 7-15 secondary nerves per side; inflorescences (3-) 5-25 $(-30) \times 5-20 \mathrm{~cm}$., many-flowered, the peduncle (rarely lacking) $1-8 \mathrm{~cm}$, long at anthesis and in fruit, the branchlets 2-5 pairs, each $1.5-5 \mathrm{~cm}$. long to first division and then 2-4-times divided, the pedicels 2-5 $\mathrm{mm}$. long (to $8 \mathrm{~mm}$. long in fruit); inflorescence branches, pedicels, and calyces copiously but minutely puberulent at anthesis; corolla $5-9 \mathrm{~mm}$. long. ........... 73. $P$. tephrosantha

Stipules broadly deltoid, $0.5-0.8 \times 0.8-1.2 \mathrm{~mm}$., rounded or broadly obtuse at apex; petioles $2-5 \mathrm{~mm}$. long, slender (less than $0.5 \mathrm{~mm}$. in diameter); leaf blades (3-) 4-6.5 × (0.6-) 0.8-1.2 cm., 4-7-times longer than broad, with 5-8 secondary nerves per side; inflorescences (1.5-) $2.5-5 \times(1.5-) 2-4 \mathrm{~cm}$, with 25-30 flowers, the peduncle $0.3-0.7 \mathrm{~cm}$. long at anthesis and to $2 \mathrm{~cm}$. long in fruit, the branchlets 2 or 3 pairs, each $0.5-0.7 \mathrm{~cm}$. long to first division and then twice divided, the pedicels $2-3 \mathrm{~mm}$. long; inflorescence branches, pedicels, and calyces glabrous even in young inflorescences; corolla 4-6.5

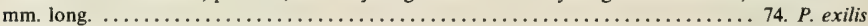

Leaf blades obovate to ovate to broadly elliptic or broadly ovate, less than 3-times as long as broad, rounded or obtuse or obtusely cuspidate at apex.

Stipules deltoid to ovate, $0.5-0.9 \mathrm{~mm}$. long and broad, rounded to obtuse or inconspicuously mucronulate at apex; petioles 2-7 mm. long, slender $(0.5-0.8 \mathrm{~mm}$. in diameter $)$; leaf blades (1-) $1.5-4(-4.5) \times(0.5-)$ 1-2 cm., 2-3-times longer than broad, acute to attenuate or cuneate at base, with 3-6 secondary nerves per side; inflorescences $1.5-7 \mathrm{~cm}$. long and broad, with few-several (rarely many) flowers and fruits, the peduncle (rarely lacking) (0.1-) 0.5-2.3 cm. long at anthesis and in fruit, the branchlets (1 or) 2 or 3 pairs, each $0.5-1.5 \mathrm{~cm}$. long to first division and then 1-3-times divided, the pedicels $1-2$ $\mathrm{mm}$. long (to $4 \mathrm{~mm}$. long in fruit); inflorescence branches, pedicels, and calyces glabrous or sparsely and minutely puberulent; corolla 6-6.5 mm. long; mature fruit 4-7 mm. in diameter.

75. P. parvula

Stipules semiorbicular-ovate, 1.5-2 $\times$ about $2 \mathrm{~mm}$., minutely apiculate at apex; petioles $8-17 \mathrm{~mm}$. long, comparatively stout (1-1.5 mm. in diameter); leaf blades (3-) 4-6.5 $\times(2.5-) 3-5 \mathrm{~cm}$., only slightly longer than broad, broadly obtuse at base but long-decurrent on petiole, with 5-7 secondary nerves per side; infructescences $4-8 \mathrm{~cm}$. long and broad, with many fruits, the peduncle stout, $2-3 \mathrm{~cm}$. long, the branchlets 2 or 3 pairs, each $2-3 \mathrm{~cm}$. long to first division and then usually 3-times divided, the fruiting pedicels $2-3 \mathrm{~mm}$. long; infructescence branches and pedicels copiously but minutely and persistently puberulent; mature fruit $8-10 \mathrm{~mm}$. in diameter. ......... 76 . macroserpens 
1. Psychotria eumorphanthus Fosberg in Sargentia 1: 127. 1942; A. C. Sm. in J. Arnold Arb. 34: 122. 1953; J. W. Parham, Pl. Fiji Isl. 203. 1964, ed. 2. 284. 1972.

Figure 107A.

Eumorphanthus fragrans A. C. Sm. in Bishop Mus. Bull. 141: 158. fig. 81. 1936; non Psychotria fragrans Fosberg (1942).

Shrub or tree 2-6 m. high, infrequent and local in dense forest at elevations of $500-1,150 \mathrm{~m}$. The fragrant flowers have the calyx limb at first green and then white and the corolla white; fruits are green turning to deep red and at length becoming white. Flowers have been obtained in January and July, fruits between May and September and also in January.

TYPIFICATION: The type of Eumorphanthus fragrans, for which Psychotria eumorphanthus was a new name, is Smith 916 (BISH HOLOTYPE; many ISOTYPES), collected in flower and fruit Jan. 8, 1934, on the border of the lake east of Somosomo, Taveuni.

Distribution: Endemic to Fiji and thus far known only from north-central Viti Levu (on Mt. Tomanivi and vicinity) and Taveuni.

AVAILABLE COLlections: VITI LEVU: MBA: Western and southern slopes of Mt. Tomanivi, Smith 5091 , DA 12732 (Melville et al. 7122), 14665. NAITASIRI: Nggoronggorotambuatini, near Nasonggo, DA 15308. TAVEUNI: Track to lake above Somosomo, DA 14374; edges of lake east of Somosomo, DA 14378, 14395; summit and adjacent slopes of Mt. Manuka, east of Wairiki, Smith 8238.

This striking species, with the largest flowers and fruits of any known Fijian Psychotria, is not infrequent in the two quite limited areas from which it is known.

2. Psychotria leptantha A. C. Sm. in J. Arnold Arb. 34: 122. 1953; J. W. Parham, Pl. Fiji Isl. 206. 1964, ed. 2. 287. 1972.

Tree 8-12 m. high, apparently rare and local in dense forest at an elevation of $700-1,050 \mathrm{~m}$. The calyx and corolla are pure white; flowers were collected in April and fruits in May.

TYPIFICATION: The type is Smith 4048 (A HOLOTYPE; many ISOTYPES), collected April 26, 1947, on the slopes of Mt. Nairosa, eastern flank of Mt. Evans Range, Mba Province, Viti Levu.

Distribution: Endemic to Fiji and thus far known only from the isolated Mt. Evans Range in northwestern Viti Levu.

AvaIlable Collection: VITI LEVU: MBa: Slopes of Mt. Nairosa, eastern flank of Mt. Evans Range, Smith 4423.

Psychotria leptantha, still known only from the two originally cited collections, is closely related only to $P$. eumorphanthus, from which it differs in the obvious features noted in the key: much shorter stipules, smaller leaves, the presence of indument on inflorescence parts, and the smaller flowers and fruits. Although both species occur on Viti Levu, they are not sympatric.

3. Psychotria gracilior A. C. Sm. in J. Arnold Arb. 34: 123. 1953; J. W. Parham, Pl. Fiji Isl. 204. 1964, ed. 2. 285. 1972.

Figures 100F, 107C.

Tree $5-10 \mathrm{~m}$. high, apparently rare and local in dense forest at an elevation of $750-850 \mathrm{~m}$. The fruit, deep red in color, is known from a single collection obtained in September.

TYPIFICATION: The species is based on Smith 6186 (A HOLOTYPE; many ISOTYPES), collected Sept. 22, 1947, in hills between Nandala and Nukunuku Creeks, along trail from Nandarivatu toward Lewa, Mba Province, Viti Levu.

Distribution: Endemic to Fiji and still known only from the type collection. 
As originally noted, Psychotria gracilior suggests the preceding species, P. leptantha, from which it is sharply distinct in its comparatively short calyx limb. Other separating characters may be noted as the longer stipules, lack of indument, somewhat narrower leaf blades, and slightly smaller fruits. Flowers of $P$. gracilior remain unknown, but in species group Confertilobae the characteristic calyx limb persists on quite mature fruits and provides a distinctive feature.

4. Psychotria araiosantha A. C. Sm. \& S. Darwin, sp. nov. ${ }^{1}$

Figure 111.

Small tree about $3 \mathrm{~m}$. high, apparently infrequent in forest at an elevation of about $100 \mathrm{~m}$. The flowers (presumably both calyces and corollas) are white and were obtained in March.

TYPIFICATION: The type is DA 14335 (coll. I. Qoro) (BISH HOLOTYPE; ISOTYPES at K, SUVA), collected in March, 1965, in the valley of Navonu Creek, Natewa Peninsula, Thakaundrove Province, Vanua Levu.

Distribution: Endemic to Fiji and thus far known only from the type collection.

At first glance the new species may readily be taken for the preceding species, Psychotria gracilior, but a closer examination reveals that the stipules are much shorter and of an entirely different type. Additionally, the leaf blades of $P$. araiosantha are even narrower and the calyx limb is longer. The new species is remarkable for its very slender flowers, but unfortunately flowers are still unknown for $P$. gracilior, as are fruits for $P$. araiosantha. On the basis of stipular characters, which appear quite reliable in Psychotria, the new species is more closely allied to $P$. confertiloba than to $P$. gracilior; foliage and floral characters, noted in the key, readily distinguish it from P. confertiloba.

5. Psychotria confertiloba A. C. Sm. in Bishop Mus. Bull. 141: 152. 1936; J. W. Parham, Pl. Fiji Isl. 201. fig. 73, B. 1964, ed. 2. 282. fig. 85, B. 1972.

Figures 100E, 112.

Psychotria umbraticola Gillespie in Bishop Mus. Bull. 91: 36. fig. 42. 1932; non Vatke (1875).

A tree (occasionally noted as a shrub) 2-10 m. high, often slender or spreading, sometimes locally abundant in dense, open, or secondary forest from near sea level to an elevation of $1,250 \mathrm{~m}$. The fragrant flowers have pure white, readily caducous

IPsychotria araiosantha A. C. Sm. \& S. Darwin, sp. nov.

Arbor parva ad $3 \mathrm{~m}$. alta ubique glabra, ramulis gracilibus subteretibus apices versus $1.5-2 \mathrm{~mm}$. diametro, internodis distalibus $2-4 \mathrm{~mm}$. longis; stipulis parvis $1.5-3 \mathrm{~mm}$. longis, basim versus connatis, superne liberis deltoideis acutis, mox caducis; petiolis semiteretibus gracilibus (0.5-1 mm. diametro) 12-18 $\mathrm{mm}$. longis, foliorum laminis papyraceis in sicco fusco-viridibus lanceolatis, $6-10 \mathrm{~cm}$. longis, $1.5-2.8 \mathrm{~cm}$. latis, basi gradatim attenuatis et in petiolum decurrentibus, apice anguste acutis, margine integris, costa gracili utrinque subprominente vel supra anguste canaliculata, nervis secundariis utrinsecus $8-10$ leviter curvatis patentibus utrinque in sicco paulo elevatis, rete venularum immerso; inflorescentia terminali gracili e basi 3-partita 9-15-flora sub anthesi corolla inclusa 5-7 cm. longa et lata, basi bracteis pluribus deltoideis obtusis ad $3 \mathrm{~mm}$. longis caducis subtenta, ramulis pedicellisque gracilibus; pedicellis sub anthesi 5-7 mm. longis in calycem gradatim crassatis; calyce graciliter infundibulari sub anthesi $5-8 \mathrm{~mm}$. longo, hypanthio parvo, limbo erecto submembranaceo obscure nervoso apice circiter $3 \mathrm{~mm}$. diametro inconspicue 5 -lobato, lobis obtuse deltoideis suberectis; corolla pergraciliter hypocrateriformi submembranacea, tubo sub anthesi 18-22 mm. longo et 1-1.5 mm. diametro, lobis 5 effusis anguste oblongis obtusis $8-9 \mathrm{~mm}$. longis et 2-3 mm. latis; staminibus 5 tubi corollae apicem versus insertis et paulo exsertis, filamentis brevibus gracilibus, antheris anguste oblongis circiter $2 \mathrm{~mm}$. longis; stylo gracili corollae tubum subaequanti in stigmata ad 2 $\mathrm{mm}$. longa fisso; fructibus ignotis. Holotype: FIJI: VANUA LEVU: ThaKaUndrove: DA 14335 (BISH).

Figure 111. Psychotria araiosantha, from DA 14335; A, stipules at ultimate node of branchlet, $\times 9$; B, distal portion of branchlet, with foliage and inflorescences, $\times 1 / 2 ; \mathrm{C}$, cluster of 3 flowers, the corollas not fully elongated, $\times 4 ; \mathrm{D}$, calyx, style (broken), stigma, and corolla with anthers in throat, $\times 2$. 


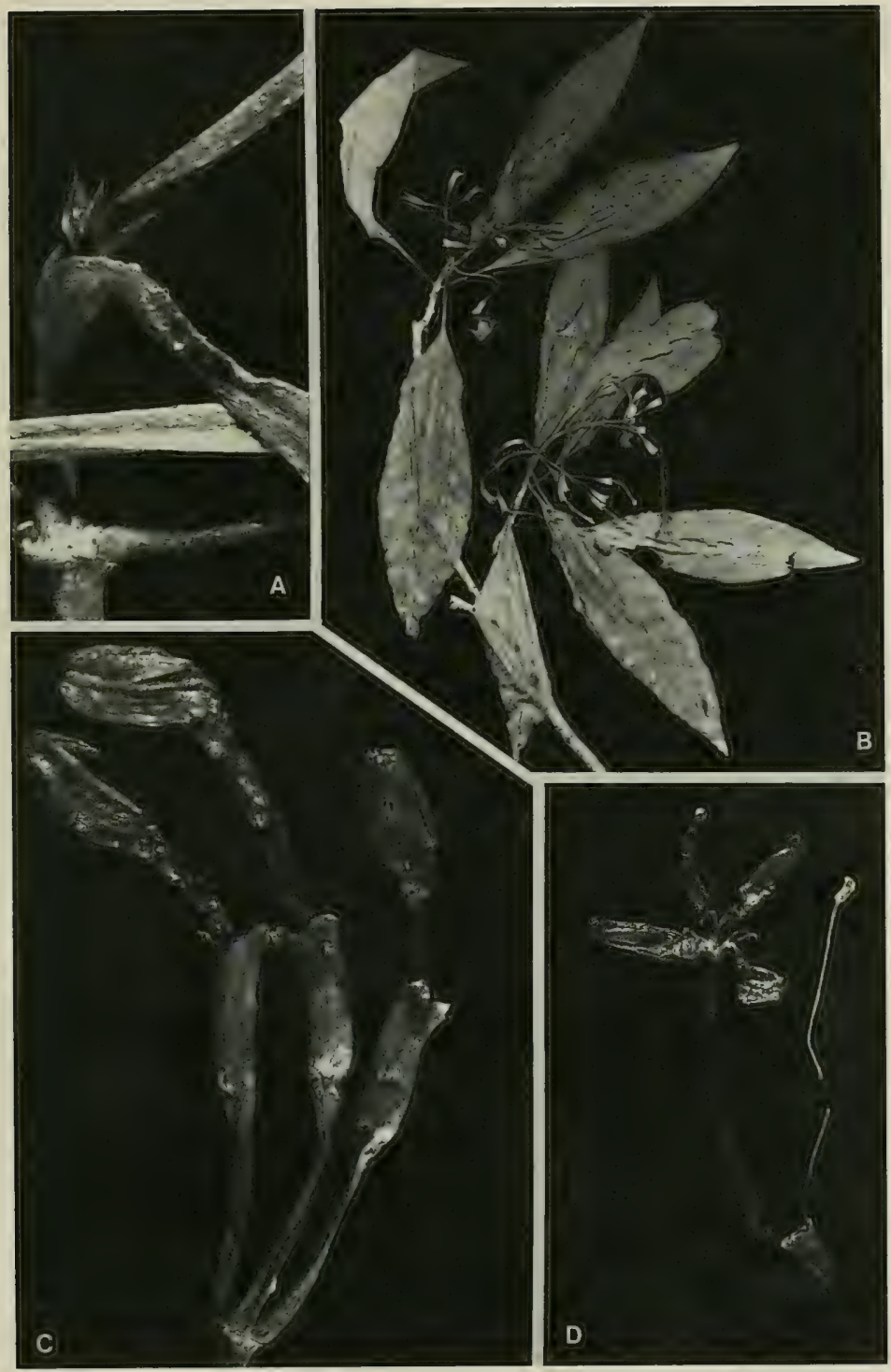




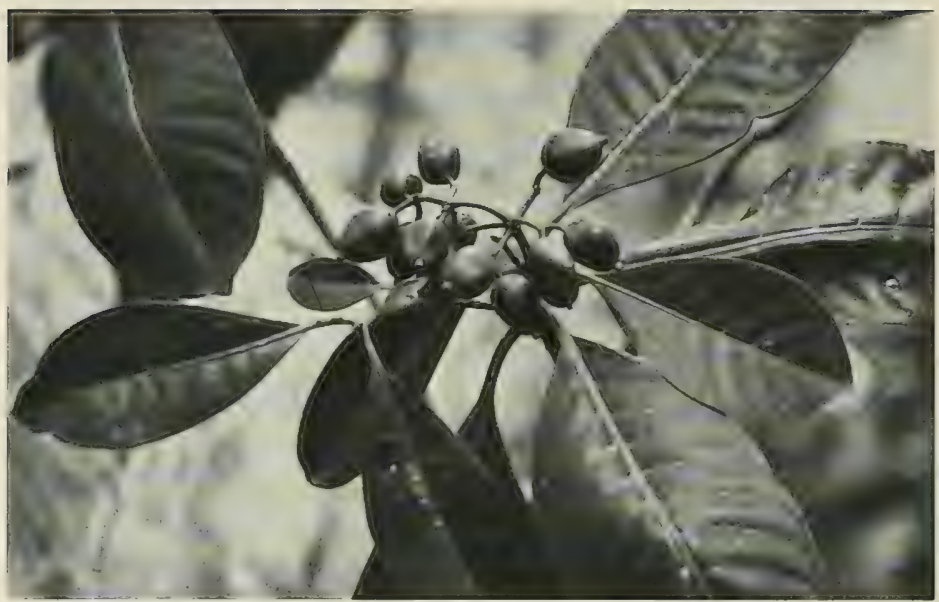

FIgure 112. Psychotria confertiloba; fruiting branchlet, from Smith 8921, $\times$ about 1/2.

corollas; the fruits range in color from red or orange to purple. Flowers have been noted between December and September, fruits in every month.

TYPIFICATION: The type of Psychotria umbraticola Gillespie, for which $P$. confertiloba was a new name, is Gillespie 3525 (BISH HOLOTYPE; ISOTYPE at K), collected in fruit Oct. 24, 1927, in the vicinity of Nasinu, Naitasiri Province, Viti Levu.

Distribution: Endemic to Fiji and now known from the two large islands and Taveuni; about 80 collections are at hand.

LoCAL NAMES: In spite of its abundance, Psychotria confertiloba seems to have no established Fijian name; locally the following have been utilized for it: kaimila, matik, and nduralevu (Mba), thindrai (Nandronga \& Navosa), ndava (Serua), takala (Rewa), and tambulima (Vanua Levu).

Representative Collections: VITI LEVU: Mba: Slopes of Mt. Mbotilamu, Mt. Evans Range, $D A$ 14804; northern slopes of Mt. Namendre, east of Mt. Koromba, Smith 4542; vicinity of Nandarivatu, Degener 14280; Mt. Nanggaranambuluta, Gillespie 3392; western and southern slopes of Mt. Tomanivi, Smith 5129. NANDRONGA \& Navosa: Nausori Highlands, DF 398 (Vetawa 14); northern portion of Rairaimatuku Plateau, between Nandrau and Nanga, Smith 5560. SERuA: Inland from Namboutini, DA 14260; inland from Ngaloa, DA 16559. NAMosI: Hills east of Wainikoroiluva River, near Namuamua, Smith 8921. NaItAsiri: Near Lutu, Wainimala River, DA 14016; Viria, Meebold 16455. ReWA: Vicinity of Lami, Gillespie 4607. VANUA LEVU: MbUa: Upper Ndama River Valley, Smith 1589; above Nandi, Milne. Mathuata: Seanggangga area, DA 12281; summit ridge of Mt. Numbuiloa, east of Lambasa, Smith 6470. ThAKAUndRove: Southern slope of Korotini Range, below Navitho Pass, Smith 520; Mt. Vatunivuamonde, Savusavu Bay region, Degener \& Ordonez 14010. TAVEUNI: Track to lake above Somosomo, DA 14066.

Psychotria confertiloba is a striking and conspicuous plant, with large, glossy leaves, conspicuous white flowers, and brightly colored large fruits that become sharply quadrangular in drying. In these respects it epitomizes our first species group, of which it is the only abundant species, although in stipular characters it is unlike the other four species here included. 
6. Psychotria macrocalyx A. Gray in Proc. Amer. Acad. Arts 4: 46. 1858, in op. cit. 5: 319. 1862, in Bonplandia 10: 36. 1862; Seem. Viti, 437. 1862, Fl. Vit. 136. 1866; Drake, Ill. Fl. Ins. Mar. Pac. 198. 1890; Gillespie in Bishop Mus. Bull. 91: 33, p. p. excl. fig. 37. 1932; Yuncker in op. cit. 220: 258. 1959; J. W. Parham, Pl. Fiji Isl. 206. 1964, ed. 2. 288. 1972; A. C. Sm. in Pacific Sci. 23: 376. 1969.

Psychotria calycosa sensu Seem. in Bonplandia 9: 256. 1861; non A. Gray.

Psychotria mundula A. C. Sm. in J. Arnold Arb. 34: 119. 1953; J. W. Parham, PI. Fiji Isl. 207. 1964, ed. 2. 288. 1972.

Shrub or tree $0.5-3 \mathrm{~m}$. high, infrequent in dry forest and crest thickets and on dry, open hillsides at elevations from near sea level to $590 \mathrm{~m}$. Flowers, with a white corolla, have been noted between October and December, fruits between April and June, insofar as collections are dated.

TYPIFICATION: Although for Psychotria macrocalyx Gray originally cited "Feejee Islands and Tongatabu," it seems clear that the latter locality was erroneous, even though it was added to the label of the holotype. The species is now known from several Fijian collections but has not appeared in material from Tonga (cf. Gillespie, 1932; Smith, 1969). A suitable citation is: U. S. Expl. Exped. (US 62345 HOLOTYPE; ISOTYPE at $\mathrm{GH}$ ), collected in 1840 in Fiji without further locality but stated by Gillespie (from manuscript data at GH?) to be from Mbua Bay, Mbua Province, Vanua Levu. Psychotria mundula is typified by Smith 6533 (A HOLOTYPE; many ISOTYPES), collected Nov. 6, 1947, on the northwestern slopes of Mt. Numbuiloa, east of Lambasa, Mathuata Province, Vanua Levu.

Distribution: Endemic to Fiji but known from only three islands.

LOCAL NAME AND USE: Langaingai (Ra); from the same Province an extract of the leaves is said to be used for eye trouble.

AVAILABLE COLLECTIONS: VITI LEVU: MBA: Mountains near Lautoka, Greenwood I226 and 127 I (from same plant), 1227 and 1270 (from same plant). RA: Vicinity of Rewasa, near Vaileka, Degener 15393. VANUA LEVU: Mbua: Nasau, Rukuruku Bay, H. B. R. Parham 3. Mathuata: Vicinity of Lambasa, Greenwood 563; Mathuata coast, Horne 644. VANUA LevU without further locality, Seemann 243, H. B. R. Parham 337. VANUA MBALAVU: Graeffe 1416.

Species group Macrocalyces is not very appropriately named, since the calyces of included species, although they have conspicuous limbs, have them dimensionally toward the lower limits of those of the following species group (Turbinatae). Nevertheless we take the name from the nomenclaturally oldest species, $P$. macrocalyx. In characters pertaining to calyces, corollas, fruits, and pyrenes, the five species of group Macrocalyces could readily be accommodated in group Turbinatae, but their stipules with essentially undivided apices provide a degree of cohesion.

When first described, Psychotria mundula was erroneously contrasted with $P$. gillespieana, a species with entirely different stipules; its alliance to $P$. macrocaly $x$ was subsequently realized (Smith in Pacific Sci. 23: 377. 1969), although the usefulness of stipular characters was not even then appreciated. The present reconsideration indicates that only small, congested leaves separate $P$. mundula from $P$. macrocalyx, and it may be assumed that collections referred to the former merely represent a minor variant from exposed, windswept habitats. 
7. Psychotria vitiensis Fosberg in Sargentia 1: 127. 1942; J. W. Parham, Pl. Fiji Isl. 209. 1964, ed. 2. 291. 1972; A. C. Sm. in Pacific Sci. 23: 375. $1969 . \quad$ Figure 104A.

Psychotria vitiensis Seem. in Bonplandia 9: 257, nom. nud. 1861, Fl. Vit. 136, pro syn. 1866.

Psychotria calycosa sensu Seem. Viti, 437. 1862, Fl. Vit. 136, p. p. 1866; Drake, Ill. Fl. Ins. Mar. Pac. 198. 1890; non A. Gray.

Psychotria gracilis sensu Drake, Ill. Fl. Ins. Mar. Pac. 198. 1890; non A. Gray.

Calycosia monticola Gillespie in Bishop Mus. Bull. 74: 39. fig. 55. 1930; non Psychotria monticola Hiern (1877).

Shrub or tree 1-3 m. high, localized but frequent in forest, on forested cliffs, and in ridge and crest forest at elevations of $450-923 \mathrm{~m}$. The corolla is white and the fruits are green, becoming red at maturity. Flowers have been noted between June and September, fruits in September, February, and March.

TyPIFICATION: In proposing Psychotria vitiensis as a new name, Fosberg (1942) included in his concept Seemann's nomen nudum (based on Seemann 246) as well as Calycosia monticola Gillespie. Since only the latter has prior nomenclatural status, no lectotypification (Smith, 1969) is necessary and the type automatically is: Gillespie 2896 (BISH HOLOTYPE; ISOTYPES at BISH, UC), collected Sept. 11, 1927, on the slopes of Mt. Voma, along trail from Namosi Village, Namosi Province, Viti Levu.

Distribution: Endemic to Fiji and apparently known only from a very limited area in south-central Viti Levu.

AVAil able COllections: VITI LEVU: Namosi: Hills about Namosi, Horne 775, 789; slopes and summit of Mt. Voma, Seemann 246, Gillespie 2677, 2722, 2784, 2795, DA 546, 553, 613, 614, 1706, 1912, $5549,11657$. NaITASIR: Mendrausuthu Range, DA 15479.

8. Psychotria roseata (Fosberg) A. C. Sm. in Pacific Sci. 23: 375. 1969; J. W. Parham, Pl. Fiji Isl. ed. 2. 290. 1972.

Psychotria macrocalyx sensu Gillespie in Bishop Mus. Bull, 91: 33, p. p. excl. typum sed quoad fig. 37. 1932; non A. Gray.

Readea roseata Fosberg in Sargentia 1: 136. 1942; J. W. Parham, Pl. Fiji Isl. 209. 1964.

Tree about $3 \mathrm{~m}$. high, apparently rare and local in forest at an elevation of $750-1,050 \mathrm{~m}$. The fruit is recorded as deep pink and was collected in March and November. The corolla illustrated by Gillespie (1932, fig. 37) was obtained in November.

TYPIFICATION: The type is Degener 14818 (us 2334019 and 2334020 HOLOTYPE; ISOTYPES at A, BISH, K, US 1759601), collected March 13, 1941, at Nauwangga, south of Nandarivatu, Mba Province, Viti Levu.

Distribution: Endemic to Fiji and thus far known from only two collections from upland north-central Viti Levu.

AVAilable COllection: VITI LEVU: MBa: Slopes near base of Mt. Nanggaranambuluta, east of Nandarivatu, Gillespie 3922.

9. Psychotria levuensis Gillespie in Bishop Mus. Bull. 91: 32. fig. 36. 1932; J. W.

Parham, Pl. Fiji Isl. 206. 1964, ed. 2. 288. 1972.

Figure 100C.

Shrub or tree $1.5-4 \mathrm{~m}$. high, local in shady forest on slopes and ridges from near sea level to an elevation of $429 \mathrm{~m}$. The corolla is white, flowers having been obtained between May and August and in November; fruits remain unknown.

TYPIFICATION: The type is Gillespie 2332 (BISH HOLOTYPE; ISOTYPES at BISH, K), collected Aug. 23, 1927, near the summit of Mt. Korombamba, Rewa Province, Viti Levu.

Distribution: Endemic to Fiji and known only from southeastern Viti Levu.

AVAilable COllections: VITI LEVU: ReWA: Veisari, DA 10991; slopes and summit of Mt. Korombamba, Gillespie 2397, DA 1254, 1257, 17376, Webster \& Hildreth 14087. VITI Levu without further locality, Parks 20911, DA 1426 (DF 123). 
Psychotria levuensis is well distinguished by its minute but copious indument, compact inflorescences, and narrow, strongly revolute leaf blades. In its indument and calyx it is very suggestive of $P$. turbinata (species group Turbinatae), but of course it is very different in its stipules, and even lacking them it is readily separable by its narrow, revolute leaf blades.

10. Psychotria argantha A. C. Sm. in Pacific Sci. 23: 373. 1969; J. W. Parham, Pl. Fiji Isl. ed. 2. 281. 1972.

Slender tree or shrub $1.5-4 \mathrm{~m}$. high, occasional in forested areas and in dense crest thickets at elevations of $100-1,032 \mathrm{~m}$. The calyx and corolla are white, the fruit orange to crimson. Both flowers and fruits have been obtained between March and May and in November.

TYPIFICATION: The species is typified by Smith 1749 (BISH HOLOTYPE; many ISOTYPES), collected May 7, 1934, in the lower Wainunu River Valley between Thongea and Navakasali, Mbua Province, Vanua Levu.

Distribution: Endemic to Fiji but known only from Vanua Levu.

Available Collections: VANUA LEVU: MbUa: Near Nasarowangga, DA 14310,14311 . Mathuata: Mountains of Mathuata coast, Greenwood 724. ThaKaundrove: Summit ridge of Mt. Mbatini, Smith 666 , 688; Nggararavoravo, $D A$ 16057; track to Natewa, $D A 15084$.

Although here grouped with Psychotria levuensis because of its stipule and indument characters, $P$. argantha has the campanulate-rotate type of calyx limb more characteristic of such species of group Turbinatae as $P$. magnifica and $P$. gibbsiae, species immediately separated from $P$. argantha by their obviously bifid stipules.

11. Psychotria ampullacea A. C. Sm. in J. Arnold Arb. 34: 109. 1953; J. W. Parham,

Pl. Fiji Isl. 200. 1964, ed. 2. 281. 1972.

FIGURE 102F.

Slender tree about $5 \mathrm{~m}$. high, apparently rare in dense forest at an elevation of $725-825 \mathrm{~m}$. The calyx is pale green, the corolla white, and the indument of the pedicels, corollas, and lower leaf blade surfaces is composed of pale reddish many-celled hairs. The only known collection was flowering in August.

TYPIFICATION: The type is Smith 5659 (A HOLOTYPE; many ISOTYPES), collected Aug. 11,1947 , on the northern portion of the Rairaimatuku Plateau, between Nandrau and Rewasau, Nandronga \& Navosa Province, Viti Levu.

Distribution: Endemic to Fiji and thus far known only from the type collection.

This species and the next, of species group Turbinatae, appear to be the only Fijian species of Psychotria with the combination of large, obviously bifid stipules, essentially capitate inflorescences, and large calyx limbs, the flowers having very short pedicels. Other species with capitate inflorescences have very different stipule and calycine characters and are placed in species group Pickeringiae.

12. Psychotria tomaniviensis A. C. Sm. in J. Arnold Arb. 34: 110. 1953; J. W. Parham, Pl. Fiji Isl. 208. 1964, ed. 2. 291. 1972.

FiguRE 108B.

Shrub or small tree 3-4 m. high, found in dense forest at elevations of $800-1,150 \mathrm{~m}$. The calyx is green, the corolla pure white, and the fruit red. Flowers have been noted in July and December, fruits in July and November.

TYPIFICATION: The species is typified by Smith 5294 (A HOLOTYPE; many ISOTYPES), collected July 17, 1947, in flower and fruit, on the western and southern slopes of Mt. Tomanivi, Mba Province, Viti Levu.

Distribution: Endemic to Fiji and known sparingly from north-central Viti Levu.

Available collections: VITI LEVU: MBA: Vicinity of Nandarivatu, Gillespie 3995; Navai, south of Nandarivatu, O. \& I. Degener 32111 . 
13. Psychotria prismoclavata (Fosberg) A. C. Sm. in Pacific Sci. 23: 370. 1969; J. W. Parham, Pl. Fiji Isl. ed. 2. 289. 1972.

FIGURE 107D.

Readea prismoclavata Fosberg in Sargentia 1: 137. 1942; J. W. Parham, PI. Fiji Isl. 209. 1964.

Shrub or small tree $2-3 \mathrm{~m}$. high, found at elevations of $750-1,120 \mathrm{~m}$. in dense forest and in the dense thickets of exposed crests and ridges. Fruits have been variously noted as pale green and becoming red, pink, or white; the calyx limb appears to be green, but no corollas have been available. Young flowers (lacking corollas) have been seen in January and March, fruits in the same months and between July and October.

TYPIFICATION: Readea prismoclavata is based on a fruiting collection, Gillespie 3272 (GH HOLOTYPE; ISOTYPES at A and BISH; photo of holotype at Us), collected Oct. 2, 1927, on Mt. Vakarongasiu, Namosi Province, Viti Levu.

Distribution: Endemic to Fiji and known only from upland central Viti Levu. The Vanua Levu specimen cited as this species by Smith $(1969$, p. 371) must be removed from it, although it is inadequate to be elsewhere referred at this time.

AVAILABLE COLLECTIONS: VITI LEVU: Mba: Ridge between Mt. Nanggaranambuluta and Mt. Namama, east of Nandarivatu, Smith 4984, 5684. NAmosI: Korombasambasanga Range, DA 2202; track to Mt. Vakarongasiu, DA 17602. NAITASIRI: Mendrausuthu Range, DA 15462.

This puzzling, inadequately known species is difficult to place in a logical sequence, but its deeply bifid stipules, large calyx limb, and glabrous facies seem best to ally it to the species cluster centering on Psychotria glabra. Its fruits are more suggestive of those of species group Confertilobae than those of species group Turbinatae, and its pyrenes seem unique among Fijian species of the genus.

14. Psychotria glabra (Turrill) Fosberg in Sargentia 1: 126. 1942; J. W. Parham, Pl. Fiji Isl. 204. 1964, ed. 2. 285. 1972; A. C. Sm. in Pacific Sci. 23: 369. 1969.

Figures 102E, 108A.

Calycosia milnei sensu Seem. in Bonplandia 9:256. 1861, Viti, 437, p. p. 1862; A. Gray in Proc. Amer. Acad. Arts 5: 318. 1862, in Bonplandia 10: 36. 1862; Seem. Fl. Vit. 133, p. p. 1866; Drake, Ill. Fl. Ins. Mar. Pac. 196, p. p. 1890; non A. Gray (1860).

Calycosia glabra Turrill in J. Linn. Soc. Bot. 43: 26. 1915.

Calycodendron glabrum A. C. Sm. in Bishop Mus. Bull. 141: 155. 1936.

Psychotria milnei sensu J. W. Parham, Pl. Fiji Isl. 206, excl. syn. 1964; non K. Schum.

A sometimes slender tree $2-5 \mathrm{~m}$. high, found in dense forest at elevations of $100-850 \mathrm{~m}$. The fragrant flowers have the large calyx limb pure white and often conspicuously reddish-glandular and the corolla white. Young fruits are green, becoming pink or red when mature. Flowers have been observed between September and April, fruits between November and May.

TYPIFICATION: Calycosia glabra is based on im Thurn F.10 (K HOLOTYPE), collected March 5, 1905, on the slopes of Mt. Mbuke Levu, Kandavu. The erroneous reference of this species to the New Hebridean Psychotria milnei (A. Gray) K. Schum. was discussed by Smith (1969).

Distribution: Endemic to Fiji and now known from southern Viti Levu, Kandavu, and Ovalau; about 20 collections are known to represent the species.

LOCAL NAME: The name kau wai was noted by Seemann on Ovalau.

Representative Collections: VITI LEVU: SeruA: Track to Mt. Tikituru, DA 14473; Namoli Creek, Nambukelevu, upper Navua River, $D A$ 14486; inland from Ngaloa, DA 14095. Namosi: Headwaters of Wainikoroiluva River, DA 2477. NAMosi or REWA: Hills between Wainandoi River and Wainamboro Creek, Vaughan 3340. NaITASIRI: Track from Waimanu River to Tongalevu, DA 15446; Sawani-Serea road, DA 11192. RewA: Mt. Korombamba, DA 3843. KANDAVU: Mt. Mbuke Levu, Smith 272, DA 14940. OVALAU: Hills southeast of valley of Mbureta River, Smith 7456; Port Kinnaird, Seemann 213. 
15. Psychotria fragrans (Gillespie) Fosberg in Sargentia 1: 125. 1942; J. W. Parham, Pl. Fiji Isl. 203. 1964, ed. 2. 284. 1972.

Calycosia fragrans Gillespie in Bishop Mus. Bull. 74: 38. fig. 52. 1930.

Calycodendron fragrans A. C. Sm. in Bishop Mus. Bull. 141: 155. 1936.

A sometimes freely branched tree $4-8 \mathrm{~m}$. high, occurring in dense forest at an elevation of $250-1,000 \mathrm{~m}$. The fragrant flowers have the calyx limb and corolla pure white, the former usually conspicuously reddish-glandular. Flowers and fruits have been collected in August and September.

TyPIFICATION: Calycosia fragrans is typified by Gillespie 3085 (BISH HOLOTYPE; ISOTYPES at BISH, K), collected Sept. 27, 1927, in flower and fruit, on Mt. Naitarandamu, Namosi Province, Viti Levu.

Distribution: Endemic to Fiji and now known from south-central Viti Levu; a single collection from Taveuni also seems to belong here.

AVAILABLE COLLECTIONS: VITI LEVU: NAMOSI: Hills north of Wainavindrau Creek, between Korombasambasanga Range and Mt. Naitarandamu, Smith 8444; northern base of Korombasambasanga Range, in drainage of Wainavindrau Creek, Smith 8661. REWA: Mt. Korombamba, Gillespie 2218. TAVEUNI: Hills east of Somosomo, west of old crater occupied by small swamp and lake, Smith 8358.

Psychotria fragrans and the two species here following it are not very satisfactorily delineated by key characters, and future collections of ample material of this alliance may warrant their combination. However, we here retain them, as the separating characters, even if of questionable value, are usable in material at hand. The most distinct of the three is $P$. koroiveibaui, limited to Vanua Levu and a nearby island except for the type collection from southern Viti Levu. Of the other two species, $P$. fragrans is known from south-central Viti Levu with a disjunct collection from Taveuni, and P. leucocalyx from north-central Viti Levu.

16. Psychotria leucocalyx A. C. Sm. in J. Arnold Arb. 34: 115. 1953; J. W. Parham, Pl. Fiji Isl. 206. 1964, ed. 2. 288. 1972.

Calycodendron magnificum sensu Fosberg in Bull. Torrey Bot. Club 67: 425. 1940; non A. C. Sm.

Tree or shrub 1-6 m. high, occurring in dense forest at elevations of $660-1,250 \mathrm{~m}$. The slightly fragrant flowers have the calyx limb and corolla white, and the fruit is pale yellow, becoming peach-colored. Flowers have been noted between July and December, fruits in May and July.

TyPIfICATION: The type is Smith 6103 (a HOLOTYPE; many isoTyPES), collected Sept. 18, 1947, on the northern portion of the Rairaimatuku Plateau, between Mt. Tomanivi and Nasonggo, Naitasiri Province, Viti Levu.

Distribution: Endemic to Fiji and known only from north-central Viti Levu.

LOCAL NAME AND USE: The name na tialeni Viti and use of the flowers in necklaces have been recorded from upper Naitasiri (St. John 18329).

AVAILAble Collections: VITI LEVU: MBa: Vicinity of Nandarivatu, Gillespie 4045, DA 2377; Mt. Nanggaranambuluta, east of Nandarivatu, DA 15260, p. p.; upper western slopes of Mt. Tomanivi, Smith 5203. DA 12716 (Melville et al. 7105), I3045, O. \& I. Degener 32065. NAITASIRI: Taunaisali, Wainisavulevu Creek, near divide with Numbulolo Creek, St. John 18329. Fis without further locality, Gillespies. n. (part of no. 4045?)

17. Psychotria koroiveibaui A. C. Sm. in Pacific Sci. 23: 371. 1969; J. W. Parham, Pl.

Fiji Isl. ed. 2. 287, as P. koroiveibauii. 1972.

Tree 3-6 m. high, found in forest or crest thickets from near sea level to an elevation of about $700 \mathrm{~m}$. The calyx limb and corolla are white and the fruit, probably not fully mature, is green. Flowers have been obtained between April and June, fruits in May and June. 
TyPifiCATION: The type is DA 14880 (coll. D. Koroiveibau \& I. Qoro) (BISH HOLOTYPE; ISOTYPES at K, SUVA), collected April 21, 1966, in Vunimaravu forest in upper Navua River region, Serua Province, Viti Levu.

Distribution: Endemic to Fiji and with a scattered distribution of southern Viti Levu (type collection only), Vanua Levu, and Yathata, a small island southeast of Taveuni.

Available collections: VANUA LEVU: MbUa: Singasinga Creek, Ndriti, upper Ndama River Valley, DA 15192; Mt. Seatura, DA 15185. ThaKaUndrove: Eastern buttress of Mt. Ndikeva, Smith 1891. YATHATA: Navakathuru, $D A 16303$.

18. Psychotria calycosa A. Gray in Proc. Amer. Acad. Arts 4:45. 1858; Seem. Fl. Vit. 136, p. p. 1866; Drake, Ill. Fl. Ins. Mar. Pac. 197, p. p. 1890; Fosberg in Sargentia 1: 127. 1942; J. W. Parham, Pl. Fiji Isl. 201. 1964, ed. 2. 282. 1972.

Figure 102G.

A freely branched or gnarled tree 2-6 m. high, occurring in dense forest or in dense crest thickets at elevations up to $626 \mathrm{~m}$. (probably not lower than $400 \mathrm{~m}$.). The calyx limb is pale green, the corolla pure white, and the fruit dull pink. Flowers and fruits have been obtained between May and July, insofar as collections are dated.

TyPIFICATION: The type is $U$. S. Expl. Exped. (us 62342 HOLOTYPE; ISOTYPES at GH, NY), collected in 1840 on Ovalau, without further data. Although Psychotria calycosa has been confused with $P$. hypargyraea A. Gray (type also collected on Ovalau) in herbarium identifications, the two taxa have very different calyces and fruits and were well recognized as distinct by Gray. In the present treatment $P$. hypargyraea is referred to species group Brackenridgeae.

Distribution: Endemic to Fiji and, on the basis of currently available material, known only from Ovalau.

Available Collections: OVALAU: Hills west of Lovoni Valley, on ridge south of Mt. Korolevu, Smith 7658; summit and adjacent slopes of Mt. Korotolutolu, west of Thawathi, Smith 8029; summit of Mt. Ndelaiovalau and adjacent ridge, Smith 7378, 7586; summit of Mt. Tana Lailai and adjacent ridge, Smith 7712. Ovalau without further locality, Milne 248, p. p., Horne 31 (alt, 2,000 ft.), 33 (alt. 1,500 ft.).

Psychotria calycosa and the two species here grouped with it, essentially glabrous throughout, differ from the $P$. glabra alliance in having much smaller calyx limbs. Differences among them, although not striking, are apparent, and their ranges are discrete.

19. Psychotria gillespieana A. C. Sm. in Bishop Mus. Bull. 141: 151. 1936; J. W. Parham, Pl. Fiji Isl. 204. fig. 74, A. 1964, ed. 2. 285. fig. 86, A. 1972.

Calycosia laxiflora Gillespie in Bishop Mus. Bull. 74: 38. fig. 53. 1930; non Psychotria laxiflora Bl.

An often gnarled small tree 2-8 m. high, very local but sometimes abundant at elevations of $1,050-1,323 \mathrm{~m}$. in dense, mossy upland forest or in crest thickets. The corolla is white and the fruit green, becoming orange to red at maturity. Flowers and fruits have been collected in months scattered throughout the year.

Typification: The type of Calycosia laxiflora Gillespie, for which Psychotria gillespieana was a new name, is Gillespie 4116 (BISH HOLOTYPE and ISOTYPES), collected Nov. 29, 1927, in flower and fruit, on the slopes of Mt. Tomanivi, Mba Province, Viti Levu.

DistRIBUTION: Endemic to Fiji and thus far known only from high areas in central and western Viti Levu; it is a characteristic species of the wet crest vegetation of Mt. Tomanivi, for which reason all collections seen by us are cited below. 
Available Collections: VITI LEVU: MBa: Summit of Mt. Koromba, DA 14739, 14744; upper slopes and summit of Mt. Tomanivi, Gillespie 4111, Parks 20809, 20824, 20836, Smith 5180, 5184, DA 13072, 13076, p. p., 14655, Webster \& Hildreth 14196, O. \& I. Degener 32078, 32081, 32082. Namosi: Korombasambasanga Range, $D A 2170$.

20. Psychotria stenantha A. C. Sm. in Contr. U. S. Nat. Herb. 37: 96. 1967, in Pacific Sci. 23: 376. 1969; J. W. Parham, Pl. Fiji Isl. ed. 2. 290.1972.

Shrub or tree $3-5 \mathrm{~m}$. high, apparently rare and local in dense forest or on its edges at an elevation of about $1,050 \mathrm{~m}$. The corollas are white and the fruit bright yellow. Flowers have been obtained in September and October, fruits in April.

TYPIFICATION: The type is Greenwood 1062A (A HOLOTYPE; ISOTYPES at BISH, K), collected in young flower on Sept. 24, 1944, in the Mt. Evans Range inland from Lautoka, Mba Province, Viti Levu.

Distribution: Endemic to Fiji and apparently to the isolated Mt. Evans Range in northwestern Viti Levu. Greenwood's earlier collections, cited below, bear more mature inflorescences than the type collection; they may have been obtained from the same locality.

Available Collections: VITI LEVU: MBa: Mt. Evans Range inland from Lautoka, Greenwood 375 (K), in flower Oct. 10, 1921, in fruit April 23, 1922.

21. Psychotria brevicalyx Fosberg in Sargentia 1: 132. 1942; J. W. Parham, Pl. Fiji Isl. 201. 1964, ed. 2. 282. 1972; A. C. Sm. in Contr. U. S. Nat. Herb. 37: 95.1967.

Figures 108C, 131 (lower).

Psychotria gibbsiae var. velutina Fosberg in Sargentia 1: 127. 1942; J. W. Parham, Pl. Fiji Isl. 204. 1964, ed. 2. 285.1972.

Slender or freely branching tree or shrub 1-5 m. high, occurring in usually dense forest from near sea level to an elevation of $650(-1,153$ ? $) \mathrm{m}$. The calyx becomes pure white at anthesis, and the corolla turns from pale green to white; the fruit is pink to red. Flowers and fruits have been obtained in months scattered throughout the year.

TyPifiCation: Psychotria brevicalyx is typified by Degener 15292 (us 2333974 HOLOTYPE; ISOTYPES at A, BISH, K), collected in fruit May 15, 1941, near Yawe, vicinity of Mbelo, near Vatukarasa, Nandronga \& Navosa Province, Viti Levu; P. gibbsiae var. velutina by Tabualewa 15605 (US 2333984 HOLOTYPE; ISOTYPE at A), obtained in young inflorescence June 18, 1941, at Mbuyombuyo, near Namboutini, Serua Province, Viti Levu.

Distribution: Endemic to Fiji and, with the exception of a single Vanua Levu collection here referred, to south-central Viti Levu. Gillespie 3131, said to be from the summit of Mt. Naitarandamu, is the only collection from a higher elevation than 650 $\mathrm{m}$. The collection from Vanua Levu here cited is unexpected, but no reason for its exclusion is apparent. We have examined 23 collections.

RePRESENTATIVE COLLECTIONS: VITI LEVU: NANDRONGA \& NAVOSA: Uluvatu, vicinity of Mbelo, near Vatukarasa, Degener 15256. Serua: Ngaloa Nature Reserve, DA 16590; hills between Waininggere and Waisese Creeks, between Ngaloa and Wainiyambia, Smith 9656; hills between Navua River and Wainiyavu Creek, near Namuamua, Smith 8997. Namosi: Mt. Naitarandamu, Gillespie 3131; northern slope of Korombasambasanga Range, in drainage of Wainavindrau Creek, Smith 8726; Matai Suva, near Wainikoro Creek, $D A$ 16175; track to Mt. Vakarongasiu, DA 17609. NaITASIRI: Track from Waimanu River to Tongalevu, DA 15448. VANUA LEVU: ThaKAUNDROVE: Eastern buttress of Mt. Ndikeva, Smith 1856.

Although the epithet is inappropriate (Smith, 1967), Psychotria brevicalyx is clearly a member of species group Turbinatae as here defined because of its bifid stipules and large, spreading calyx limb (this caducous in fruit and leaving a conspicuous, often ragged scar). 
22. Psychotria nandarivatensis A. C. Sm. in J. Arnold Arb. 34: 117. 1953; J. W.

Parham, Pl. Fiji Isl. 207. 1964, ed. 2. 288. 1972.

Pisonia umbellifera sensu Gibbs in J. Linn. Soc. Bot. 39: 161. 1909; non Seem.

Tree or shrub 3-10 m. high, compact or slender or freely branched, sometimes locally frequent at elevations of 750-1,195 m. (very rarely from near sea level) in dense forest or in ridge and crest thickets. The calyx limb is white or sometimes greenish proximally, the corolla is white, and the fruit becomes orange or red at maturity. Flowers have been noted between May and January, fruits in practically every month.

TYPIFICATION: The type is Smith 5031 (A HOLOTYPE; many ISOTYPES), collected in flower July 2, 1947, in the immediate vicinity of Nandarivatu, Mba Province, Viti Levu.

Distribution: Endemic to Fiji and (with the exception of a collection from Yathata Island mentioned below) known only from central and north-western Viti Levu, being especially abundant in the area from Nandarivatu to Mt. Tomanivi in Mba Province. Forty collections have been studied.

LOCAL NAME: The name lewalekaleka was recorded from Mt. Tomanivi.

REPRESENTATIVE COLLECTIONS: VITI LEVU: MBA: Koro-O road, west of Nandarivatu, DA 13514; vicinity of Nandarivatu, Gillespie 3390, Degener \& Ordonez 13598, Vaughan 3433; Mt. Nanggaranambuluta, east of Nandarivatu, DA 12529; slopes of Mt. Tomanivi, Parks 20845, Smith 5283, DA 13077. MBA or NaITASIRI: Between Navai and Nasonggo, Gibbs 546. SeruA: Near summit of Mt. Tikituru, DA 14479. YATHATA: Navakathuru, DA 16307.

The population of this relationship occurring in the isolated Mt. Evans and Mt. Koromba Ranges of northwestern Viti Levu is puzzling. Some specimens of this population clearly have the many-celled reddish hairs and the cylindrically ascending basal portion of the calyx limb that characterize Psychorria nandarivatensis, but it must be acknowledged that the indument is occasionally practically or entirely lacking. Individuals of this complex in these areas often have substantially smaller leaves than those of typical $P$. nandarivatensis from north-central Viti Levu, and their separation from $P$. gibbsiae on the one hand and from $P$. gillespieana (which does occur on the summit of Mt. Koromba) on the other must appear arbitrary (at least in the absence of fully mature calyces). On the whole these western populations, when mature calyces and/or even a faint trace of indument are available, resemble $P$. nandarivatensis more than they do the other two mentioned species, but we readily admit that their placement is problematic. To apply a trinomial to these populations, in our opinion, would offer no solution. The observed specimens representing them are:

VITI LEVU: MвA: Mt. Evans Range, Greenwood 454, 963A, 968, 1057; summit and upper slopes of Mt. Koroyanitu, high point of Mt. Evans Range, Smith 4158, 4160, 4177, 4184, DA 14153; northern slopes of Mt. Namendre, east of Mt. Koromba, Smith 4523, 4549; upper slopes (alt. 900 m.) of Mt. Koromba, $D A$ 14734.

The single collection from Yathata Island (in poor fruit) cited above is surprisingly far out of the expected range of the species and is from near sea level, but we find no obvious reason for its exclusion.

23. Psychotria pubiflora (A. Gray) Fosberg in Sargentia 1: 126. 1942; J. W. Parham, Pl. Fiji Isl. 207, p. p. 1964, ed. 2. 289, p. p. 1972; A. C. Sm. in Pacific Sci. 23: 372. 1969.

FiguRE 103A.

Calycosia pubiflora A. Gray in Proc. Amer. Acad. Arts 4: 306. 1859; Seem. Fl. Vit. 133, p. p. 1866; Drake, Ill. Fl. Ins. Mar. Pac. 196, p. p. 1890.

Calycodendron pubiflorum A. C. Sm. in Bishop Mus. Bull. 141: 155, p. p. minore sed quoad basionymum. 1936.

Calycodendron sp. A. C. Sm. in Bishop Mus. Bull. 141: 157. 1936. 
An often slender tree or shrub 2-7 m. high, occurring in dense or secondary forest at elevations of about $100-300 \mathrm{~m}$. The calyx limb and corolla are white, and the fruit, as far as recorded, is green. Flowers are best developed between August and December, fruits between February and April.

TyPIFICATION: In describing Calycosia pubiflora, Gray cited Milne material from Viti Levu. Of two such available collections, Smith (1936) indicated Milne 73 as the "type." A suitable citation is: Milne 73 (K LECTOTY PE; fragment at GH), collected in 1856 from the vicinity of Namosi, Namosi Province, Viti Levu. A paratype from the same locality is Milne $290(\mathrm{~K})$.

Distribution: Endemic to Fiji and known from southeastern Viti Levu and Kandavu.

Available Collections: VITI LEVU: NaItasiri: Central road, Tothill 258, 324, 325, 467, MacDaniels 1133; Tholo-i-suva, DA 11972, 14517, 15359; Savura Creek, DA 12429 (DF 74, Watkins 738), 12549; Tamavua, Gillespie 2086, Tothill 320. Rewa: Vicinity of Suva, Tothill 272, Meebold 8119. KANDAVU: Hills above Namalata and Ngaloa Bays, Smith 202.

With some diffidence we here retain Psychotria pubiflora and P. crassiflora as distinct taxa, as suggested by Smith (1969). Their separation is not entirely satisfactory, but two populations of this alliance are to a degree discernible. As a rule specimens from southeastern Viti Levu (including the type of $P$. pubiflora) and Kandavu have the smaller leaf blades with upper surfaces usually copiously reddishglandular-blotched, whereas specimens from south-central coastal Viti Levu (Serua Province, including the type of $P$. crassiflora, with deformed flowers) have the larger leaves, with essentially eglandular blades. However, leaf size, shape, and surface markings are not totally correlated with distribution. Whether the inflorescence is pedunculate or 2-4-branched from base (Smith, 1969) is of questionable value as a differentiating character.

24. Psychotria crassiflora Fosberg in Sargentia 1: 132. 1942; J. W. Parham, Pl. Fiji Isl. 202. 1964, ed. 2. 283. 1972; A. C. Sm. in Pacific Sci. 23: 373. 1969.

Tree or shrub $2-5 \mathrm{~m}$. high, often slender, found in dense or dry forest from near sea level to an elevation of about $400(-800) \mathrm{m}$. The calyx and corolla are white. Flowers have been obtained between October and May, but apparently fruits have not been collected.

TYPIFICATION: The type is Degener 15178 (us 1759497 HOLOTYPE; ISOTYPES at A, BISH, K), collected May 5, 1941, near Vatutavathe, vicinity of Ngaloa, Serua Province, Viti Levu.

Distribution: Endemic to Fiji and for the most part to coastal south-central Viti Levu, with a single collection from higher elevation in Mba Province.

Available Collections: VITI LEVU: MBa: Track from Navai to Mt. Tomanivi, DA 14972. Serua: Inland from Namboutini, DF 943 (Lora 2); hills north of Ngaloa, in drainage of Waininggere Creek, Smith 9204; hills between Waininggere and Waisese Creeks, between Ngaloa and Wainiyambia, Smith 9519 ; vicinity of Wainiyambia, $D A 13836$ ( $D F 448$, Damanu 103); coastal hills in vicinity of Taunovo River, east of Wainiyambia, Smith 9571. NAITASIRI: Near Tholo-i-suva, Vaughan 3345. VITI LEvU without further locality, W. L. Parham 118.

25. Psychotria timonioides Fosberg in Sargentia 1: 136. 1942; J. W. Parham, Pl. Fiji Isl. 208. 1964, ed. 2. 291. 1972.

Tree or shrub 2-9 m. high, found in forest at elevations of about $100-300 \mathrm{~m}$. The calyx limb is white or yellowish, the corolla white, and the fruit noted as brown. Flowers were collected between April and July, fruits in July and December. 
TyPIFICATION: The type is Degener 15180a (A HOLOTYPE; ISOTYPE at US), collected May 5, 1941, near Vatutavathe, vicinity of Ngaloa, Serua Province, Viti Levu.

Distribution: Endemic to Fiji and thus far narrowly known only from Serua Province, Viti Levu.

Available Collections: VITI LEVU: Serua: Upper Navua River, $D A 14875,15523,15536$; Nathengathenga Creek, upper Navua River, DF 946 (Lora 5); inland from Namboutini, DA 13985. SERUA without further locality, DA 12473 (DF 122, Bola 24).

This apparently very local species is one of the more obviously distinct members of the genus in Fiji, of the general alliance of Psychotria magnifica but sharply characterized by the abundance and uniformity of the striking pubescence of inflorescence and vegetative parts and by its sharply rotate and comparatively small calyx limb.

26. Psychotria magnifica (Gillespie) Fosberg in Sargentia 1: 126. 1942; J. W. Parham, Pl. Fiji Isl. 206. 1964, ed. 2. 288. 1972.

FIGURE 104B.

Calycosia magnifica Gillespie in Bishop Mus. Bull. 74: 39. fig. 54. 1930.

Calycodendron magnificum A. C. Sm. in Bishop Mus. Bull. 141: 156, quoad basionymum. 1936.

An often freely branched tree 5-9 m. high, infrequent in dense forest at elevations of $250-1,100 \mathrm{~m}$. The calyx limb is white and the hypanthium may be pink-tinged, and the corolla is white. Flowers have been obtained in August and September, but apparently fruits are uncollected.

TYPIFICATION: The type is Gillespie 3307.1 (BISH HOLOTYPE; ISOTYPES at BISH, K, US), collected Sept. 28, 1927, on Mt. Naitarandamu, Namosi Province, Viti Levu.

DisTribution: Endemic to Fiji and apparently rare in central Viti Levu.

Available collections: Viti LEVU: Nandronga \& Navosa: Near Naloka, DA 1424 (DF 125). NAMOSI: Hills north of Wainavindrau Creek, between Korombasambasanga Range and Mt. Naitarandamu, Smith 8441 .

27. Psychotria jugalis A. C. Sm. in J. Arnold Arb. 34: 116. 1953; J. W. Parham, Pl. Fiji Isl. 206. 1964, ed. 2. 287. 1972.

An apparently rare, compact tree about $4 \mathrm{~m}$. high, found in dense forest at an elevation of 1,050-1,120 m. The calyx limb and corolla are white, observed in August.

TYPIFICATION: The type is Smith 5681 (A HOLOTYPE; many ISOTYPES), collected Aug. 18, 1947, in flower, on the ridge between Mt. Nanggaranambuluta and Mt. Namama, east of Nandarivatu, Mba Province, Viti Levu.

Distribution: Endemic to Fiji and thus far known only from the type collection.

This species and the next, although each is known from only a single collection, are strikingly distinct by virtue of different distributions of inflorescence indument and by their unusual bracts and bracteoles, although they are evidently of the alliance of Psychotria magnifica.

28. Psychotria rufocalyx Fosberg in Sargentia 1: 127. 1942; J: W. Parham, Pl. Fiji Isl. 207. 1964 , ed. 2. 290.1972.

Calycodendron rufescens A. C. Sm. in Bishop Mus. Bull. 141: 156. fig. 80. 1936; non Psychotria rufescens H. B. K.

Shrub about $3 \mathrm{~m}$. high, rare in crest thickets at an elevation of $700-842 \mathrm{~m}$. The corolla is white, pink-tinged distally, and the fruit is orange, both observed in April.

TYPIFICATION: The type is Smith 1655 (BISH HOLOTYPE; many ISOTYPES), collected April 27, 1934, on Navotuvotu, summit of Mt. Seatura, Mbua Province, Vanua Levu.

Distribution: Endemic to Fiji and thus far known only from the type collection. 
29. Psychotria gibbsiae S. Moore in J. Linn. Soc. Bot. 39: 152. 1909; Turrill in op. cit. 43: 27. 1915; A. C. Sm. in J. Arnold Arb. 34: 117. 1953.

Figure 103B.

Calycosia pubiflora sensu Seem. in Bonplandia 9:256. 1861, Viti, 437. 1862, Fl. Vit. 133, p. p. 1866; non A. Gray.

Psychotria neurocalyx Gillespie in Bishop Mus. Bull. 91: 34. fig. 38. 1932; J. W. Parham, Pl. Fiji Isl. 207. 1964, ed. 2. 289.1972.

Calycodendron gibbsiae A. C. Sm. in Bishop Mus. Bull. 141: 156. 1936.

Psychotria gibbsiae var. gibbsiae; J. W. Parham, Pl. Fiji Isl. 203. 1964, ed. 2. 285. 1972.

Tree or shrub 1-8 m. high, freely branching, slender, compact, or gnarled, sometimes locally abundant, found at elevations of $600-1,127 \mathrm{~m}$. in dense forest or in the thickets of crests and ridges. The calyx limb and corolla are white, and the mature fruit is pale pink to orange or red. Flowers and fruits have been obtained in practically every month.

Typification: Moore originally cited two Gibbs collections for Psychotria gibbsiae, one of which was indicated by Smith (1936) as the "type;" an appropriate citation is: Gibbs 734 (BM LECTOTYPE; ISOLECTOTYPE at K), collected in September, 1907, at the edge of the escarpment at Nandarivatu, Mba Province, Viti Levu. Gibbs 664 (BM) is then a paratype, with the same locality data. The type of $P$. neurocalyx is Parks 20613 (BISH HOLOTYPE; ISOTYPES at BISH, SUVA, US), collected in July, 1927, on wet hillsides near Nandarivatu, Mba Province, Viti Levu.

Distribution: Endemic to Fiji and a frequent component of the upland forest of north-central Viti Levu; it also occurs infrequently in upland Vanua Levu and abundantly on Taveuni. About 50 collections have been examined.

LOCAL NAMES: Vakande and malumu have been recorded from Vanua Levu.

REPRESENTATIVE COLleCtIONS: VITI LEVU: MBA: South Ridge, 5 miles west of Nandarivatu, Webster \& Hildreth 14262; Koro-O, west of Nandarivatu, Watkins 757; Nandarivatu, im Thurn 267, Gillespie 3907; slopes and summit of Mt. Nanggaranambuluta, east of Nandarivatu, Gillespie 4337, Stauffer \& Koroiveibau 5837; ridge between Mt. Nanggaranambuluta and Mt. Namama, Smith 4967. Nandronga \& Navosa: Northern portion of Rairaimatuku Plateau, between Nandrau and Rewasau, Smith 5410. VANUA LEVU: Mathuata-Thakaundrove boundary: Crest of Korotini Range, between Navitho Pass and Mt. Ndelaikoro, Smith 541. Thakaundrove: Mt. Mariko, Smith 418; eastern buttress of Mt. Ndikeva, Smith 1878. TAVEUNI: "Somosomo" (doubtless hills above), Seemann 214 (err. 314); summit ridge east of Somosomo, Gillespie 4845; near lake east of Somosomo, DA 1589I; summit and adjacent slopes of Mt. Manuka, east of Wairiki, Smith 8218; above Nggathavulo Estate, DA 16928.

Psychotria neurocaly $x$ appears to be merely an inconsequential variant of $P$. gibbsiae with slightly smaller leaves and flowers, chàracteristic of the higher and more exposed situations in the vicinity of Nandarivatu and not meriting nomenclatural recognition at any level. Specimens from Vanua Levu and Taveuni here referred sometimes appear more robust (as indicated by parenthetical dimensions in the key) than those from upland Viti Levu, but some material from the two smaller islands is quite typical, and no sound basis can be suggested for the nomenclatural removal of such Vanua Levu and Taveuni populations from a reasonable interpretation of $P$. gibbsiae.

30. Psychotria turbinata A. Gray in Proc. Amer. Acad. Arts 4: 45. 1858, in op. cit. 4: 306. 1859; Seem. Viti, 437. 1862, Fl. Vit. 135. 1866; Drake, Ill. Fl. Ins. Mar. Pac. 199. 1890; Gillespie in Bishop Mus. Bull. 91: 36. fig. 41. 1932; Fosberg in Bull. Torrey Bot. Club 67: 425. 1940; J. W. Parham, Pl. Fiji Isl. 208. 1964, ed. 2. 291. 1972. 
Calycosia pubiflora sensu Turrill in J. Linn. Soc. Bot. 43: 26. 1915; non A. Gray.

Psychotria vaughanii A. C. Sm. in J. Arnold Arb. 34: 118. 1953; J. W. Parham, Pl. Fiji Isl. 209. 1964, ed. 2. 291. 1972.

Psychotria leptocalyx A. C. Sm. in J. Arnold Arb. 34: 121. 1953; J. W. Parham, Pl. Fiji Isl. 206. 1964, ed. 2. 288.1972.

Shrub or small tree 1-7 m. high, often locally frequent from near sea level to an elevation of $1,153 \mathrm{~m}$. in dense or secondary forest and in the thickets of crests and ridges. The calyx is white (sometimes with the hypanthium pink), the corolla is white, and the mature fruit turns from yellow to orange or pink to red. Flowers have been obtained between August and March, fruits between January and September.

TYPIFICATION AND NOMENClatuRE: Psychotria turbinata is based on U. S. Expl. Exped. (US 62346 HOLOTYPE; ISOTYPES at GH, K; photo of GH isotype at BISH), collected in 1840 on Ovalau; $P$. vaughanii on Vaughan 3323 (BM HOLOTYPE; ISOTYPE at $\mathrm{K}$; photos of holotype at A, BISH, US), collected Nov. 10, 1946, along Prince's Road near Tholo-iSuva, Naitasiri Province, Viti Levu; and P. leptocalyx on Smith 6215 (A HOLOTYPE; many ISOTYPES), collected Sept. 25, 1947, in hills east of Nandala Creek, south of Nandarivatu, Mba Province, Viti Levu. When they were described, $P$. vaughanii and $P$. leptocaly $x$ were erroneously referred to other alliances, $P$. turbinata having been typified by a fruiting specimen (the fruit with an early caducous calyx limb) and often misconstrued, although in fact Gillespie (1932) had correctly interpreted it. Whether the inflorescence has a single peduncle or is branched directly from the base is now seen to be inconsequential, both states often occurring on the same individual. The same inflorescence situation in this respect prevails in $P$. gibbsiae (and in many other species of Psychotria).

Distribution: Endemic to Fiji and known with certainty only from Viti Levu and Ovalau. It appears to be one of the most frequent species of Psychotria on Viti Levu, where it occurs in forested areas over a wide altitudinal range. About 90 collections have been studied.

LOCAL NAMES: Recorded names are chimbi (Naitasiri) and soso ni ura and makamakandora (Namosi).

RePRESENTATIVE COLleCtions: VITI LEVU: MBA: Vicinity of Nandarivatu, im Thurn 298, Parks 20733, Degener 14632; Nandala, south of Nandarivatu, $O$. \& I. Degener 32054; slopes of Mt. Tomanivi, $O$. \& I. Degener 32073. NANDRONGA \& NAVOSA: Northern portion of Rairaimatuku Plateau, between Nandrau and Nanga, Smith 5559. Serua: Inland from Namboutini, $D A 13744$ (DF 224, Bola 73); vicinity of Ngaloa, $D A$ 12570. Namosi: Summit of Mt. Naitarandamu, Gillespie 3125; hills north of Wainavindrau Creek, between Korombasambasanga Range and Mt. Naitarandamu, Smith 8417; Mt. Voma, DA 11653. NaITASIRI: Rarandawai, Wainamo-Wainisavulevu divide, Wainimala Valley, St. John 18267; Viria-Naisonggo trail, Parks 20466; Tholo-i-suva, DA 14613. VITI LEvU without further locality, MacGillivray (or Milne?) 95. OVALAU: Hills east of Lovoni Valley, Smith 7350; summit of Mt. Ndelaiovalau and adjacent ridge, Smith 7605 .

31. Psychotria carnea (Forst. f.) A. C. Sm. in Bishop Mus. Bull. 141: 151, quoad basionymum et p. p. majore. 1936; Yuncker in op. cit. 220: 255. 1959; J. W. Parham, Pl. Fiji Isl. 201. fig. 73, A. 1964, ed. 2. 282. 1972. FIgURE 100D.

Petesia carnea Forst. f. Fl. Ins. Austr. Prodr. 10. 1786.

Eumachia carnea DC. Prodr. 4: 479. 1830; Seem. Fl. Vit. 133. 1866.

Chasalia amicorum A. Gray in Proc. Amer. Acad. Arts 4: 43. 1858.

Ixora carnea Benth. \& Hook. f. ex Drake, Ill. Fl. Ins. Mar. Pac. 195. 1890.

Psychotria amicorum Benth. \& Hook. f. ex Drake, Ill. Fl. Ins. Mar. Pac. 197. 1890.

Psychotria hemisphaerica Gillespie in Bishop Mus. Bull. 91: 32. fig. 35. 1932; A. C. Sm. in Contr. U. S.

Nat. Herb. 37: 97. 1967; J. W. Parham, Pl. Fiji Isl. ed. 2. 287. fig. 85, A. 1972.

Psychotria carnea subsp. carnea; Whistler in J. Arnold Arb. 67: 353. 1986.

Tree or shrub 3-10 m. high, often freely branching or sometimes with a compact crown, locally frequent at elevations from near sea level to about $800 \mathrm{~m}$. in dense or dry 
forest or on its edges. The persistent calyx limb is green; the corolla is greenish yellow when young but soon becomes white; and the fruits are green when young, turning through yellow and orange to deep red at maturity. Flowers have been collected between November and June, fruits in practically every month.

TyPIFICATION: In proposing Petesia carnea, G. Forster cited as a locality "Namoka." The вм sheet bears this locality, while the $\mathrm{K}$ sheet is inscribed: "Habitat in Tonga-Tabboo." A suggested citation is: $J$. $R$. \& G. Forster (BM LeCTOTYPE, cf. Whistler, 1986; ISOLECTOTYPE at K), collected during Cook's second voyage on Nomuka or Tongatapu (or both), Tonga. Chasalia amicorum is based on U.S. Expl. Exped. (US 62358 HOLOTYPE; ISOTYPE at GH), collected in 1840 on Tongatapu, Tonga. Gillespie did not indicate a type for Psychotria hemisphaerica, but a suitable specimen is Gillespie 2208 (BISH LECTOTYPE, cf. Smith, 1967), collected in fruit Aug. 11, 1927, on the southeastern slopes of Mt. Korombamba, Rewa Province, Viti Levu.

Distribution: Fiji and Tonga; in Fiji it is known from approximately 80 collections from at least seven islands. In our opinion Psychotria carnea does not occur in Samoa, all Samoan collections of this immediate relationship examined by us now being referred to $P$. oncocarpa.

LOCAL NAME: The only name recorded in Fiji has been kau mbua (Tailevu).

Representative collections: VITI LEVU: Nandronga \& Navosa: Nausori Highlands, $O$. \& $I$. Degener 32161. Serua: Mbuyombuyo, near Namboutini, Tabualewa 15581; hills between Waininggere and Waisese Creeks, between Ngaloa and Wainiyambia, Smith 9363. Namosi: Hills near Navua River, Greenwood 1041. NaItASIRI: Waimbau, Sawani-Serea road, DA 11196; Tholo-i-suva, DA 11096; vicinity of Nasinu, Gillespie 3519. NaItasiri-Rewa boundary: Mt. Kombalevu, Parks 20315. Tailevu: Near Copper Mine, Waimaro River, DA 13645. Rewa: Mt. Korombamba, Parks 20121. OVALAU: Lovoni Valley, DA 17056; slopes of Mt. Korotolutolu, west of Thawathi, Smith 8010. KORO: Eastern slope of main ridge, Smith 1018. NGAU: Hills east of Herald Bay, inland from Sawaieke, Smith 7837. VANUA LEVU: M BUA: Koromba Forest, DA 15104. Mathuata: Summit ridge of Mt. Numbuiloa, east of Lambasa, Smith 6420. Thakaundrove: Hills west of Mbutha Bay, Natewa Peninsula, Smith 832. KAMBARA: Bryan, Aug. 25, 1924. ONGEA LEVU: Bryan 422.

In first proposing the combination Psychotria carnea, Smith (1936) included in its synonymy both $P$. oncocarpa and $P$. hemisphaerica. It is now apparent that $P$. carnea has stipules (see key to species) of a type not otherwise seen in species group Carneae and that $P$. oncocarpa must be separated from it; these two species are so similar in other respects that stipular differences, which seem very dependable, provide the only reliable means of distinguishing them. Subsequently Smith (1967) reinstated $P$. hemisphaerica as distinct from $P$. carnea on the basis of its minutely puberulent inflorescence parts. In fact, these two taxa are identical in stipule type, and the inflorescence indument is too variable to be useful. In many Fijian and Tongan specimens all gradients of inflorescence indument (from obvious to quite lacking) may be noted, and therefore we again return $P$. hemisphaerica to the synonymy of $P$. carnea.

32. Psychotria oncocarpa K. Schum. in Bot. Jahrb. 25: 688. 1898; Rechinger in Denkschr. Akad. Wiss. Wien 85: 377. 1910.

FIGURE 101B.

Psychotria carnea sensu Christophersen in Bishop Mus. Bull. 154:49, quoad spec. sam. 1938; Fosberg in Bull. Torrey Bot. Club 67:422. 1940; B. E. V. Parham in New Zealand Dept. Sci. Indust. Res. Inform. Ser. 85: 58. 1972; non A. C. Sm.

Psychotria carnea subsp. oncocarpa Whistler in J. Arnold Arb. 67: 354. 1986.

Slender or freely branched tree or shrub 2-10 m. high, found at elevations of $100-1,300 \mathrm{~m}$. in dense forest. The flowers (only one Fijian flowering specimen noted) are said to be yellowish, but doubtless at anthesis the calyx is green and the corolla white; the fruits are green, becoming bright red at maturity. Flowers were noted in April and fruits throughout the year. 
TyPIFICATION: In describing Psychotria oncocarpa, Schumann cited the locality Vailele, Upolu, Samoa, the collector being Reinecke by implication. Christophersen (1938) indicated that he examined the type at $\mathrm{B}$, but he did not state a collector or number. Whistler (1986) noted two Reinecke specimens without locality (nos. 202 and 349 ) at G and designated Reinecke 202 (G) as the LECTOTYPE.

Distribution: Fiji and Samoa; in Fiji the species is known from approximately 20 collections, all from Viti Levu except one from Vanua Levu. On Viti Levu, as contrasted with Psychotria carnea, $P$. oncocarpa seems more frequently to occur at the higher elevations and in the north-central part of the island, although the two species are not entirely allopatric.

LOCAL NAMES AND USE: The name kai motu has been noted in $\mathrm{Mba}$; in upper Naitasiri the plant has been recorded as rapunapungipungi, karua ni sukau, and langaingai, and there a bark decoction is said to be used medicinally for any relapse.

RePRESENTATIVE COLLections: VITI LEVU: MBa: Vicinity of Nandarivatu, Degener 14362; summit of Mt. Nanggaranambuluta, east of Nandarivatu, Smith 4868; near summit of Mt. Tomanivi, Parks 20821. NANDRONGa \& Navosa: Northern portion of Rairaimatuku Plateau, between Nandrau and Nanga, Smith 5539. SeRUA: Hills between Navua River and Wainiyavu Creek, near Namuamua, Smith 8993 . NAMOSI: Near summit of Mt. Naitarandamu, Gillespie 3300; hills north of Wainavindrau Creek, between Korombasambasanga Range and Mt. Naitarandamu, Smith 8414; vicinity of Namosi, Parks 20265. NAITASIRI: Northern portion of Rairaimatuku Plateau, between Mt. Tomanivi and Nasonggo, Smith 5791; Taunaisali, Wainisavulevu-Numbulolo divide, St. John 18318. REWA: Trail from Waimbue Creek to Waimanu River, $D A 15570$. VANUA LEVU: ThaKAUNDROVE: Navavau, $D A 16045$.

Whistler (1986, p. 353) referred Chasalia pyriformis A. Gray (in Proc. Amer. Acad. Arts 4: 44. 1858) to the synonymy of Psychotria carnea (subsp. carnea), but he could not locate type material of Gray's species at either US or GH. There are presumably six Samoan species of this general relationship (Whistler, 1986, pp. 343, 349-354). It is possible that Chasalia pyriformis will provide an earlier epithet for $P$. oncocarpa, but Gray's description is inconclusive; his phrase "cyma pauciflora sessili" casts doubt on this disposition, being more suggestive of $P$. sclerocarpa Whistler (1986, p. 351). Until type material is located, the identity of Chasalia pyriformis probably must remain questionable.

33. Psychotria hunteri(Horne ex Baker) A. C. Sm. in Bishop Mus. Bull. 141: 152. 1936; J. W. Parham, Pl. Fiji Isl. 204. 1964, ed. 2. 287. 1972.

Calycosia hunteri Horne, A Year in Fiji, 258, nom. nud. 1881; Horne ex Baker in J. Linn. Soc. Bot. 20: 364. 1883; Drake, Ill. Fl. Ins. Mar. Pac. 196. 1890.

Slender tree or shrub 2-5 m. high, occurring in dense forest or in crest thickets at elevations of $75-1,032 \mathrm{~m}$. The fragrant flowers have the calyx limb green and the corolla pale yellow to white; fruits turn from green to dark red at maturity. Flowers and fruits have been noted in scattered months between May and December.

TYPIFICATION: The type of Calycosia hunteri is Horne 1137 (K HOLOTYPE; ISOTYPE at $\mathrm{GH})$, collected in flower in the vicinity of Salialevu, southeastern Taveuni, probably in September, 1878.

Distribution: Endemic to Fiji and now known from the islands of Vanua Levu and Taveuni, usually toward the higher elevations.

LOCAL NAME: A name recorded in Thakaundrove Province is kariva.

Available collections: VANUA LEVU: Mathuata: Summit ridge of Mt. Numbuiloa, east of Lambasa, Smith 6466. ThaKaundrove: Summit of Mt. Mbatini, Smith 699; track to Mt. Nasorolevu, DA 17147; eastern slope of Mt. Ndikeva, Smith 1907. TAVEUNI: Wailailai, Nggeleni, DA 14408; track to lake east of Somosomo, DA 14372; borders of lake east of Somosomo, Smith 870; western slope between 
Somosomo and Wairiki, Smith 770; summit and adjacent slopes of Mt. Manuka, east of Wairiki, Smith 8212; above Nggathavulo Estate, DA 16929.

When flowers are available, Psychotria hunteri is readily distinguishable from the related $P$. oncocarpa by its larger, occasionally 5-lobed corolla; its fruits in general are larger and dry more smoothly. The two species are probably allopatric.

34. Psychotria archboldiana Fosberg in Sargentia 1: 131. 1942; J. W. Parham, Pl. Fiji Isl. 200. 1964, ed. 2. 281. 1972.

Figures 101C, 104C.

Tree or shrub $1.5-7 \mathrm{~m}$. high, usually slender, found from near sea level to an elevation of $925 \mathrm{~m}$. in dense or secondary forest and occasionally on crests and ridges. The calyx limb is green; the corolla white to cream-colored or yellowish and sometimes pink-tinged; the fruit green turning to red at maturity. Flowers have been collected between January and July, fruits between April and August.

TyPifiCATION: The type is Degener 15316 (us 2333966 \& 2333967 HolotyPE; ISOTYPES at A, BISH, K), collected in flower May 18, 1941, near Naruku, vicinity of Mbelo, near Vatukarasa, Nandronga \& Navosa Province, Viti Levu.

Distribution: Endemic to Fiji and known with certainty only from Viti Levu and a single Kandavu collection. Some 34 collections are now referred to the species, which seems amply distinct from its probably closest relative, Psychotria oncocarpa, especially in the southern parts of Viti Levu where it is most abundant.

RePresentative COLlections: VITI LEVU: MBA: Mangondro Tikina, DA 14904; track from Navai toward Mt. Tomanivi, DA 14973. NANDRONGA \& NavoSA: Southern slopes of Nausori Highlands, in drainage of Namosi Creek above Tumbenasolo, Smith 4713; Uluvatu, vicinity of Mbelo, near Vatukarasa, Degener 15258; inland from Mbelo, near Vatukarasa, $O$. \& I. Degener 32189; Viro, near Saru, Tamanua Creek, Tabualewa 15614. Serua: Inland from Ngaloa, DA 16555. Namosi: Hills east of Wainikoroiluva River, near Namuamua, Smith 8915; hills east of Navua River, Greenwood 994; Nambukavesi Creek, DA 13743 (DF 195, Bola 57). KANDAVU: Kiombo, DA 11926 (Watkins 675).

35. Psychotria incompta A. C. Sm. in J. Arnold Arb. 34: 114. 1953; J. W. Parham, Pl. Fiji Isl. 204. 1964, ed. 2. 287. 1972.

Compact tree about $4 \mathrm{~m}$. high, infrequent and local in dense crest forest at an elevation of $1,100-1,200 \mathrm{~m}$. Flowers remain unknown, fruits having been obtained in July, August, and November.

TYPIFICATION: The type is Smith 5208 (A HOLOTYPE; many ISOTYPES), collected July 10, 1947, on the upper western slopes of Mt. Tomanivi, Mba Province, Viti Levu.

Distribution: Endemic to Fiji and thus far known only from upland north-central Viti Levu.

Available Collectrons: VITI LEVU: Mba: Summit of Mt. Nanggaranambuluta, east of Nandarivatu, Gillespie 3793, Smith 5672.

36. Psychotria forsteriana A. Gray in Proc. Amer. Acad. Arts 4: 44. 1858, in Bonplandia 10: 36. 1862; Seem. Fl. Vit. 135. 1866; K. Schum. in Bot. Jahrb. 25: 688. 1898; Rechinger in Denkschr. Akad. Wiss. Wien 85: 376. 1910; Gillespie in Bishop Mus. Bull. 91: 31. fig. 34. 1932; Christophersen in op. cit. 154: 51. 1938; J. W. Parham, Pl. Fiji Isl. 203. 1964, ed. 2. 284. 1972; B. E. V. Parham in New Zealand Dept. Sci. Indust. Res. Inform. Ser. 85: 69, 77, 111. 1972; Whistler in J. Arnold Arb. 67: 348. 1986.

Figures 101A, $110 \mathrm{~B}$.

Psychotria forsteriana var. vitiensis A. Gray in Proc. Amer. Acad. Arts 4: 44. 1858, in op. cit. 5: 318. 1862; Seem. Viti, 437. 1862, Fl. Vit. 135. 1866; Drake, Ill. Fl. Ins. Mar. Pac. 198. 1890.

Stylocoryne corymbosa sensu Seem. in Bonplandia 9: 256. 1861; non Labill.

Uragoga forsteriana Drake, Fl. Polynés. Franç. 98, quoad basionymum. 1893; Reinecke in Bot. Jahrb. 25: 689 , quoad basionymum. 1898. 
Tree or shrub 1-7 m. high, often slender or compact, found in local abundance in dense, thin, or secondary forest and on forested ridges and crest thickets from near sea level to an elevation of about $600 \mathrm{~m}$. (rarely as high as $900 \mathrm{~m}$.). The inflorescence branches and calyx are often faintly pink-tinged; the corolla is yellowish to white; and the fruit turns through pink or orange to red at maturity. Flowers and fruits have been obtained in every month.

TyPIfICATION: The type of Psychotria forsteriana is U.S. Expl. Exped. (us 62339 HOLOTYPE; ISOTYPE at GH), collected in Samoa without further locality. The fact that Gray attributed his species to Tahiti on the basis of $P$. asiatica sensu Forst. f. (Fl. Ins. Austr. Prodr. 16. 1786) is of no consequence in either its typification or distribution; the identity of Forster's material remains questionable (Whistler, 1986). Gray's var. vitiensis was based on U. S. Expl. Exped. (us 62340 \& 62341 (fl. \& fr.) HOLOTYPE; ISOTYPE at NY), collected in 1840 on Ovalau. On the basis of the now available material, there seem no differences of consequence between Gray's two taxa. In discussing the species as contrasted to $P$. evansensis, Smith (in J. Arnold Arb. 34: 112. 1953) mentioned pyrene differences between the typical variety and var. vitiensis in the degree to which dorsal carinae are obvious, but in view of the collections now at hand such differences seem unreliable.

Distribution: Samoa and Fiji; in the latter archipelago now known from about 100 collections from at least seven islands, apparently being very frequent in southeastern Viti Levu. Whistler (1986) mentions occurrence of the species on 'Eua, Tonga, but such material has not been seen by us.

LOCAL NAMES: No Fijian name seems established for this common species, but vesou (Kandavu) and ndranga meilango (Mbua) have been recorded.

REPRESENTATIVE COLLECTIONS: VITI LEVU: MBA: Near base of Mt. Nanggaranambuluta, Nandarivatu, Gillespie 4054. NANDRONGA \& NAvOSA: Nausori Highlands, DA 13894; Yawe, vicinity of Mbelo, near Vatukarasa, Degener 15277. SeruA: Mbuyombuyo, near Namboutini, Tabualewa 15601; hills west of Waivunu Creek, between Ngaloa and Korovou, Smith 9494. RA: Mountains near Penang, Greenwood 759. NaITASIRI: Waimbau Creek, Sawani-Serea road, DA 11210; vicinity of Navuso, DA 12599; Central road, MacDaniels 1142; vicinity of Tamavua, Gillespie 2431; vicinity of Nasinu, Gillespie 3434. TAILEvu: Hills east of Wainimbuka River, vicinity of Ndakuivuna, Smith 7071. RewA: Mt. Korombamba, Gillespie 2245. KANDAVU: Hills above Namalata and Ngaloa Bays, Smith 146. OVALAU: Seemann 236, p. p.; summit of Mt. Tana Lailai and adjacent ridge, Smith 7695. MOTURIKI: Seemann 236, p. p. KORO: Eastern slope of main ridge, Smith 1025. VANUA LEVU: MBUA: Lower Wainunu River Valley, Smith 1721 . MathUATA: Mt. Ndrandramea, $D A$ 13500; Seanggangga Agricultural Station, DA 12282; southern slopes óf Mt. Numbuiloa, east of Lambasa, Smith 6561. ThaKaundrove: Mt. Kasi, Yanawai River region, Smith 1781. MOALA: High ridge in forest, Bryan 320.

The four species here assembled in species group Forsterianae are admittedly diverse in stipule and fruit characters; their stipules are of two general types (see key to species groups) neither of which is to be found among the other species groups composed of trees and shrubs with short, usually persistent calyx limbs. A relationship among the four species is suggested by their very short corollas with copiously barbellate throats, as well as in the sometimes striking obviousness of raphid bundles in vegetative and inflorescence parts.

We have seen no material from west of Fiji that we consider to represent Psychotria forsteriana, although the species group Forsterianae, as here circumscribed, doubtless does occur in western Melanesia and Papuasia, represented at least by $P$. leiophylla Merr. \& Perry, P. trichostoma Merr. \& Perry (Solomon Islands and New Hebrides), and $P$. aneityensis Guillaumin (New Hebrides); the last in stipule characters is suggestive of $P$. leiophylla (species no. 38 in this treatment), but its fruits remove it from that species. 
37. Psychotria amoena A. C. Sm. in J. Arnold Arb. 34: 113. 1953; J. W. Parham, Pl.

Fiji Isl. 200. 1964, ed. 2. 281. 1972.

Compact or slender tree or shrub $1.5-8 \mathrm{~m}$. high, occasional in dense forest or on forested ridges at elevations of $125-1,180 \mathrm{~m}$. The flowers have the hypanthium and disk pink-tinged and the corolla, anthers, and style white; the fruit turns from dull orange to deep red at maturity. Flowers and fruits have been noted in months scattered throughout the year.

TYPIFICATION: The type is Smith 5949 (A HOLOTYPE; many ISOTYPES), collected Sept. 9, 1947, in hills east of Nandala Creek, about 3 miles south of Nandarivatu, Mba Province, Viti Levu.

Distribution: Endemic to Fiji and apparently to the two largest islands, from which about 20 collections have been examined.

LOCAL NAME: The only recorded name is ndengendenge (Nandronga \& Navosa).

RePresentative Collections: VITI LEVU: MBA: Mi. Evans Range, Greenwood 960, DA 14159; slopes of Mt. Nairosa, eastern flank of Mt. Evans Range, Smith 4090; hills above Nandarivatu, Gillespie 3906. NANDRONGA \& NAvOSA: Northern portion of Rairaimatuku Plateau, between Nandrau and Rewasau, Smith 5402. VANUA LEVU: MBUA: Koromba Forest, DA 15106; without further locality, Horne 1115 . Mathuata: District Farm Northern, Seanggangga area, DA 15385.

Psychotria amoena differs from $P$. forsteriana in its smaller and usually proportionately broader leaf blades, more compact and fewer-flowered inflorescences (but usually with longer pedicels), and even smaller flowers, but the two species are not sharply differentiated. As a rule $P$. amoena occurs at the higher elevations, at least on Viti Levu, where it is frequent in the northwestern and north-central parts of the island where $P$. forsteriana is lacking or very infrequent. Another closely related species, the Samoan endemic $P$. samoana $\mathrm{K}$. Schum., has narrowly lanceolate leaf blades 4-7 times longer than broad, with 8-11 secondary nerves per side and with the apex slenderly long-acuminate.

\section{Psychotria leiophylla Merr. \& Perry in J. Arnold Arb. 27: 215. 1946.}

Figures 105A, 110A.

As seen in Fiji, Psychotria leiophylla is a shrub 1-3 m. high, apparently infrequent near sea level in forest on limestone and in beach thickets. The corolla is white and the fruit pink. Flowers have been obtained only in December, fruits in February, March, and August.

TyPIFICATION: The type is Brass 3133 (A HOLOTYPE), collected in October, 1932, in coastal rain forest at Star Harbour, San Cristobal, Solomon Islands.

Distribution: Solomon Islands (San Cristobal and offshore islands), Fiji (Lau Group), and Samoa (Savai'i and Upolu). No specimens from the New Hebrides have been noted which we would refer to this taxon. It is interesting to note that Psychotria leiophylla, as far as it is known in the Solomon Islands and Fiji, occurs near sea level, while in Samoa it has been recorded from inland forests at elevations of 400-850 m.

LOCAL NAME: The name roroya was applied to the species on Kambara.

AVAILABlE COLlections: VANUA MBALAVU: Lomaloma (Raviravi), DA 13617 . NAMUKA-I-LAU: Bryan 470. KAMBARA: On limestone, Smith 1239. FULANGA: On limestone, Smith 1179.

Examination of the numerous Fijian and Samoan collections that have been referred to Psychotria forsteriana discloses a number that prove very different from that species in characters of stipules and fruits, although the overall similarity is striking. We are unable to distinguish such collections from $P$. leiophylla and here suggest that the range of that species be extended eastward into Fiji and Samoa. From Samoa, $P$. leiophylla is represented by at least the following among the many collec- 
tions cited by Whistler (1986) as P. forsteriana: Savai'i: Bryan 180, Cox 242, 260, Vaupel 11, p. p., Whistler 899, 1762; Upolu: Whistler 754, 1665, 2038.

While Psychotria leiophylla is readily distinguishable from $P$. forsteriana in characters of the stipules and fruit (see key to species), in the absence of one or the other the two taxa are separable with difficulty. However, it may be noted that the stipular scar of $P$. leiophylla is extremely narrow $(0.1-0.2 \mathrm{~mm}$. broad) and the multicellular fimbrillate hairs within it are brown; in contrast the stipular scar of $P$. forsteriana (after complete disappearance of stipule remnants) is more obvious $(0.2-0.5 \mathrm{~mm}$. broad) and the fimbrillate hairs are white or stramineous.

39. Psychotria evansensis A. C. Sm. in J. Arnold Arb. 34: 112. 1953; J. W. Parham, Pl. Fiji Isl. 203. 1964, ed. 2. 284. 1972.

Figure 105B.

Slender tree or shrub 1-5 m. high, apparently infrequent in dense or light forest at elevations of $100-1,050 \mathrm{~m}$. The corolla is said to be pinkish white, the mature fruit deep red. Flowers have been obtained in February and November, fruits in April, September, and October.

TyPIFICATION: The type is Smith 4072 (A HOLOTYPE; ISOTYPES at K, Us), collected April 28, 1947, on the slopes of Mt. Nairosa, eastern flank of Mt. Evans Range, Mba Province, Viti Levu.

Distribution: Endemic to Fiji and thus far known only from central and northwestern Viti Levu.

Available Collections: VITI LEVU: Mra: Slopes of Mt. Nairosa, eastern flank of Mt. Evans Range, Smith 4024. NAmosI: Mborotu, DA 11609; Matai Suva, above Wainikoro Creek, DA 16178; vicinity of Namuamua, near trail toward Namosi, Gillespie 3006; hills east of Wainikoroiluva River, near Namuamua, Smith 8952.

Previously known only from the Mt. Evans Range and from fruiting material, Psychotria evansensis is now better known through reference to it of a few collections from Namosi Province, two of which are in flower and verify its general relationship to other species of species group Forsterianae. However, it is not closely allied to other Fijian species, being characterized by stipule, fruit, and foliage characters not precisely matched in our area.

40. Psychotria cordata A. Gray in Proc. Amer. Acad. Arts 4:46. 1858; Seem. Viti, 437. 1862, Fl. Vit. 137. 1866; Drake, Ill. Fl. Ins. Mar. Pac. 197. 1890; Fosberg in Sargentia 1: 130. 1942; A. C. Sm. in Pacific Sci. 23: 378. 1969; J. W. Parham, Pl. Fiji Isl. ed. 2. 282. 1972.

Psychotria cordata var. cordata; J. W. Parham, Pl. Fiji Isl. 201. 1964.

Tree or shrub 2-4 m. high, found in usually dense forest at elevations of 750-1,090 $\mathrm{m}$. (and presumably lower as represented by the type). The inflorescence-enclosing stipules are pale brown, the corolla is white, and the fruit turns from green to red at maturity. Flowers have been obtained in March (and inflorescence buds in October), fruits between August and January.

TyPification: The type is U. S. Expl. Exped. (us 62338 HOLOTYPE; ISOTYPE at GH), collected in 1840 in Mathuata Province, Vanua Levu.

Distribution: Endemic to Fiji. Although Gray did not cite a locality, the holotype bears the indication of Mathuata. Curiously, all the other available collections of the species come from the isolated Mt. Evans Range of northwestern Viti Levu, the species not having been recollected on Vanua Levu. While this is not entirely surprising, considering the inadequacy of material from Mathuata Province and especially from 
the Mathuata Range (doubtless visited by the Exploring Expedition), it may raise a question of the accuracy of the provenance of the type.

Available Collections: VITI LEVU: Mba: Mt. Evans Range, Greenwood 943 ( 2 sheets, Oct. 25 and Dec. 20, 1942), 1247; Nandendelevu, Mt. Evans Range, DA 14836; Mt. Mbotilamu, Mt. Evans Range, $D A$ 14165,14801 .

Of the species (numbered 40-48) comprising a well-marked species group Pickeringiae, several are inadequately known, represented by one or two collections, some lacking flowers. Nevertheless all are reasonably distinct from one another (see key to species) on the basis of vegetative characters. Psychotria cordata is one of the most readily recognized Fijian species of the genus, marked by long-petiolate leaves with deeply cordate and slenderly acuminate blades.

41. Psychotria valleculata A. C. Sm. in J. Arnold Arb. 34: 111. 1953; J. W. Parham, Pl. Fiji Isl. 208. 1964, ed. 2. 291. 1972.

FiguRE 101D.

Tree or shrub $2.5-4 \mathrm{~m}$. high, rare and local in dense forest at an elevation of 300-600 m. Flowers remain unknown; the fruits are red and have been obtained in June and July.

TYPIFICATION: The species is based on Smith 4721 (A HOLOTYPE; ISOTYPES at BISH, K, P, Us), collected June 4, 1947, on the southern slope of the Nausori Highlands, in drainage of Namosi Creek above Tumbenasolo, Nandronga \& Navosa Province, Viti Levu.

Distribution: Endemic to Fiji and thus far known only from essentially the type locality, in northwestern Viti Levu.

available Collection: Viti LeVU: Nandronga \& Navosa: Nausori Highlands, DA 13889.

42. Psychotria monocarpa Fosberg in Sargentia 1: 130. 1942; J. W. Parham, Pl. Fiji Isl. 206. 1964, ed. 2. 288. 1972.

Shrub 3-4 m. high, apparently rare in dense forest at an elevation of $400-600 \mathrm{~m}$. Flowers are still unknown; the bright orange fruits were obtained in June.

TYPIFICATION: The type is Smith 1951 (NY HOLOTYPE; many ISOTYPES), collected June 12, 1934, in hills south of Natewa, Natewa Peninsula, Thakaundrove Province, Vanua Levu.

Distribution: Endemic to Fiji and thus far known only from the type collection.

43. Psychotria vescula A. C. Sm. in Pacific Sci. 25: 499.1971.

An apparently rare shrub $1.8-2.5 \mathrm{~m}$. high, collected in forest at an unstated altitude (probably 500-800 m.). Flowers are not yet known; the red fruits were obtained in May.

TyPIfICATION: The type is DA 14728 (coll. D. Koroiveibau \& I. Qoro) (BISH HOLOTYPE; ISOTYPES at BRI, CHR, K, MASS, SUVA), collected in forest below Mt. Koromba, Mba Province, Viti Levu.

Distribution: Endemic to Fiji and known only from the type from western Viti Levu.

LOCAL NAME: The name langgainggai was noted by the collectors.

44. Psychotria pickeringii A. Gray in Proc. Amer. Acad. Arts 4:47. 1858, in op. cit. 5: 319. 1862, in Bonplandia 10: 36. 1862; Seem. Viti, 437. 1862, Fl. Vit. 137. 1866; Drake, Ill. Fl. Ins. Mar. Pac. 198. 1890; Gillespie in Bishop Mus. Bull. 74: 34. fig. 47. 1930.

Figures 102A, 105C, 109C. 
Psychotria Seem. in Bonplandia 9: 257. 1861.

Psychotria platycocca sensu A. Gray in Proc. Amer. Acad. Arts 5: 319. 1862, in Bonplandia 10: 36. 1862;

Seem. Viti, 437. 1862, Fl. Vit. 137. 1866; Drake, Ill. Fl. Ins. Mar. Pac. 198. 1890; non A. Gray (1858).

Psychotria tetragona Seem. Fl. Vit. 137. 1866; Drake, Ill. Fl. Ins. Mar. Pac. 199. 1890; J. W. Parham, Pl.

Fiji Isl. 208, p. p. 1964, ed. 2. 291, p. p. 1972.

Psychotria pickeringii var. pickeringii; J. W. Parham, Pl. Fiji Isl. 207. fig. 74, B. 1964, ed. 2. 289. fig. 86, B. 1972 .

Shrub or small tree $1.5-7 \mathrm{~m}$. high, often freely branched or spreading or with a compact crown, sometimes locally frequent in dense or dry forest, often along streams, and in crest thickets at elevations from near sea level to $1,153 \mathrm{~m}$. (more frequent at the lower or middle elevations). The inflorescences, sometimes recorded as faintly fragrant, have the stipules and calyx pink-tinged, the corolla, stamens, disk, and style white; the fruits are bright orange to red at maturity. Flowers and fruits have been obtained throughout the year.

Typification: Psychotria pickeringii is based on U. S. Expl. Exped. (us 62344 HOLOTYPE; ISOTYPE at GH), collected in 1840 in Fiji without further locality. The type of $P$. tetragona is Seemann 252 (K HOLOTYPE; ISOTYPES at BM, GH), obtained on Ovalau in 1860. The latter species has frequently been misinterpreted in herbaria, specimens so identified often being referable to P. platycocca (of our species group Filipedes) and to $P$. hypargyraea and a new species $P$. impercepta (of our species group Brackenridgeae). The type material of $P$. tetragona, however, has strictly sessile and capitate fruits and ovate, readily caducous stipules, precisely resembling such features of $P$. pickeringii. The latter species is frequent on Ovalau; although there is a substantial degree of variation in its foliage, the lanceolate leaf blades of the type of $P$. tetragona are essentially similar to those of several other Ovalau collections (e. g. Smith 7686, 7688) that indubitably represent $P$. pickeringii.

Distribution: Endemic to Fiji; we refer about 70 collections to this species, although it is known with certainty from only four of the islands, appearing particularly abundant in southeastern Viti Levu and Ovalau.

REPRESENTATIVE COLLECTIONS: VITI LEVU: MBA: Mt. Evans Range, DA 14192; northern slopes of Mt. Namendre, east of Mt. Koromba, Smith 4538. SeruA: Vunimbua Creek, near Nambukelevu, upper Navua River, DA 14868; vicinity of Namboutini, DA 14005; hills west of Waivunu Creek, between Ngaloa and Korovou, Smith 9295; inland from Ngaloa, DA 16574; hills east of Navua River, near Nukusere, $S m i t h$ 9101. NAmosI: Summit of Mt. Naitarandamu, Gillespie 3250; northern slopes of Korombasambasanga Range, in drainage of Wainavindrau Creek, Smith 8702; above waterfall near Namuamua, Gillespie 2984. NAITASIRI: Tholo-i-suva, DA 11973; Savura Water Supply, DA 12523; vicinity of Tamavua, Gillespie 2137; vicinity of Nasinu, Gillespie 3595. ReWA: Mt. Korombamba, Parks 20117, Gillespie 2318. Vitr LeVu without further locality, Seemann 249. OVALAU: Summit of Mt. Tana Lailai and adjacent ridge, Smith 7686; Port Kinnaird, Seemann 251. VANUA LEVU: MaThUATA: Vicinity of Lambasa, Greenwood 505; hills along Mathuata coast, Greenwood 505A. KAMBARA: Interior wooded basin, Bryan 498; on limestone, Smith 1238.

We are aware that recognition of Psychotria solanoides (the following species in this treatment) from $P$. pickeringii at the specific level is not entirely convincing. Our separation of them is primarily based on the fact that $P$. pickeringii (sensu str.) has a very short calyx limb in contrast to that of $P$. solanoides, in which the calyx limb is comparatively long and obvious in both flowers and fruits. Secondarily is the fact that $P$. pickeringii is typically glabrous throughout, whereas $P$. solanoides is usually pilose with obvious reddish hairs on vegetative and inflorescence parts. Psychotria pickeringii (sensu str.) is to be expected throughout Fiji, whereas $P$. solanoides seems most frequent at the higher elevations of northern Viti Levu; but the taxa are not strictly allopatric. One lowland specimen (Smith 9101 , from Serua) has the short calyx limb of 
$P$. pickeringii (sensu str.) and a considerable degree of indument suggesting $P$. solanoides. On the other hand, collections from Taveuni have the other combination of these characters: the obvious calyx limb of $P$. solanoides and the essentially glabrous habit of $P$. pickeringii. It would be entirely reasonable in this complex to recognize a single species with two (or three) infraspecific taxa, but with the exceptions noted we find it readily separable into two populations that may be retained as species.

45. Psychotria solanoides Turrill in J. Linn. Soc. Bot. 43: 28. 1915.

Psychotria pickeringii var. solanoides Fosberg in Sargentia 1: 128. 1942; J. W. Parham, PI. Fiji Isl. 207. 1964, ed. 2. 289. 1972.

Shrub or tree 1-5 m. high, compact or freely branched, occurring in dense or open forest or on forested ridges at elevations of $50-1,100 \mathrm{~m}$. (more frequent at the higher elevations). The inflorescence bracts are dull red, the corolla and stamens white, and the mature fruits bright orange or red. Flowers have been collected between May and November, fruits in practically every month.

TyPifiCATION: The type is im Thurn 257 (K HOLOTYPE), collected Nov. 19, 1906, in flower and fruit, near Nandarivatu, Mba Province, Viti Levu.

Distribution: Endemic to Fiji and recorded from the two large islands and Taveuni; we have examined 21 specimens, most of them from northern Viti Levu.

LOCAL NAME: The name malawai was recorded from Mba Province.

REPRESENTATIVE COLLECTIONS: VITI LEVU: MBA: Northern slopes of Mt. Namendre, east of Mt. Koromba, Smith 4522; Savundamatau Creek, west of Nandarivatu, Webster \& Hildreth 14245; vicinity of Nandarivatu, Parks 20743, Gillespie 4376, Degener 14522; western slopes of Mt. Nanggaranambuluta, east of Nandarivatu, Smith 6324. NANDRONGA \& NAVOSA: Southern slopes of Nausori Highlands, in drainage of Namosi Creek above Tumbenasolo, Smith 4592. RA: Tuvavatu, vicinity of Rewasa, near Vaileka, Degener 15368. VANUA LEVU: MATHUATA: Valembasonga, east of Lambasa, DA I6678. TAVEUNI: Summit and adjacent slopes of Mt. Manuka, east of Wairiki, Smith 795, 8236; above Nggathavula Estate, DA 16931 .

46. Psychotria bullata Seem. Fl. Vit. 137. 1866; Drake, Ill. Fl. Ins. Mar. Pac. 197. 1890;

J. W. Parham, Pl. Fiji Isl. 201. 1964, ed. 2. 282. $1972 . \quad$ FIGURE 102B.

Psychotria foliis bullatis Seem. in Bonplandia 9: 257. 1861.

Psychotria sp. foliis bullatis Seem. Viti, 437. 1862.

Psychotria A. Gray in Proc. Amer. Acad. Arts 5: 319. 1862, in Bonplandia 10: 36.1862.

Shrub 1-3 m. high, apparently rare in forest from near sea level to a probable elevation of $400 \mathrm{~m}$. The fruits become pink at maturity. Young inflorescence buds have been obtained in June and July, fruits in April and May.

TYPIFICATION: The species is based on Seemann 248 (K HOLOTYPE; ISOTYPE at GH), collected June 4, 1860, near Koroivono, Natewa Peninsula, Thakaundrove Province, Vanua Levu.

Distribution: Endemic to Fiji and known sparingly from the two largest islands.

AVAILABLE Collections: VITI LEVU: Serua: Inland from Ngaloa, DA 16562. Namosi: Near Vienungga Creek, Horne 878. VANUA LEVU: ThaKaundrove: Navonu Creek, Natewa Peninsula, DA 15053.

Although Psychotria bullata remains inadequately known (two of the four collections having unopened inflorescence buds and two being in fruit), its relationship to the $P$. pickeringii complex, and particularly to $P$. solanoides, is apparent. From $P$. solanoides it appears amply distinct on the basis of its proportionately longer leaf blades with more numerous secondary nerves, which are sometimes impressed above, like the tertiary nerves, to give the blade a distinctly bullate appearance; the indument of vegetative parts and fruits is usually even more pronounced and persistent than that of $P$. solanoides. 
47. Psychotria kuruvolii A. C. Sm. in Pacific Sci. 23: 378. 1969; J. W. Parham, Pl. Fiji Isl. ed. 2. 287. 1972.

FIGURE 113A.

An apparently rare shrub or small tree $1-1.5 \mathrm{~m}$. high, found in forest at an elevation of $400-500 \mathrm{~m}$. The corollas are white and the fruits turn through yellowish to red at maturity. Flowers and fruits were obtained in April and May.

TyPIFICATION: The type is DA 14896 (coll. I. T. Kuruvoli) (BISH HOLOTYPE; ISOTYPES at K, SUVA), collected in flower and fruit April 26, 1966, on Mt. Seatura, Mbua Province, Vanua Levu.

Distribution: Endemic to Fiji and known only from the type locality.

Available Collection: VANUA LEVU: MBUA: Mt. Seatura, DA 15163.

48. Psychotria tetragonoides Fosberg in Sargentia 1: 135. 1942; J. W. Parham, Pl. Fiji

Isl. 208. 1964, ed. 2. 291. 1972.

Figure 113B.

A small tree infrequent in forest at elevations of approximately $100-750 \mathrm{~m}$. The corolla is white, known from the type collection, and the fruit is red.

TyPIFICATION: Psychotria tetragonoides is typified by Degener 15213 (us 2333990 HOLOTYPE; ISOTYPES at A, BISH, K), collected May 5, 1941, at Vatutavathe, vicinity of Ngaloa, Serua Province, Viti Levu.

Distribution: Endemic to Fiji and known from only two collections from Viti Levu. We have not seen the second collection, cited below, in connection with the present review; apparently it provided the fruit characters described by Fosberg. us).

Available collection: VITI LEVU: Nandronga \& Navosa: Vicinity of Nandrau, Degener 14919 (A,

49. Psychotria filipes A. Gray in Proc. Amer. Acad. Arts 4: 46. 1858; Seem. Viti, 437.

1862, Fl. Vit. 136. 1866; Drake, Ill. Fl. Ins. Mar. Pac. 197. 1890; Gillespie in Bishop Mus. Bull. 74: 33. fig. 46. 1930; Fosberg in Sargentia 1: 129. 1942; J. W.

Parham, Pl. Fiji Isl. 203. 1964, ed. 2. 284. 1972.

Psychotria Seem. in Bonplandia 9: 257, 1861; A. Gray in op. cit. 10: 36. 1862, in Proc. Amer. Acad. Arts 5: 319. 1862.

Psychotria sp. nov. aff. filipedis Seem. Viti, 437. 1862.

Psychotria pelagica Seem. Fl. Vit. 136. 1866; Drake, Ill. Fl. Ins. Mar. Pac. 198. 1890; J. W. Parham, Pl.

Fiji Isl. 207. 1964, ed. 2. 289. 1972.

Shrub or tree 2-4 m. high, often freely branched, occurring in usually dense forest at elevations of $300-923 \mathrm{~m}$. The corolla is noted as greenish white, the stamens and style as white, and the mature fruit as red. Flowers have been obtained between May and September, fruits in January and May.

TYPIFICATION: Psychotria filipes is typified by U. S. Expl. Exped. (us 62336 HOLOTYPE; ISOTYPE at GH), collected in 1840 in Fiji without further locality. The type of $P$. pelagica is Seemann 253 (K HOLOTYPE; ISOTYPES at BM, GH), collected in 1860 at the "town of Navua," Serua Province, Viti Levu. This locality must be questioned, Navua being the settlement near the mouth of the Navua River, an area probably cleared of most native forest even in 1860 . Seemann (Viti, 1862, pp. 97-117, 146-147, 207-209) made stays at Navua on three occasions, during the first of which (July 4-9) he travelled westward along the coast for perhaps $15 \mathrm{~km}$; the later stays at Navua (Aug. 19-21, Sept. 3-5) were made enroute to and from his interior trip to Namosi and probably did not permit time for collecting. Since the species is not known from coastal Serua (or even from that Province), it may be suggested that Seemann 253 was obtained enroute to or near Namosi Village rather than near the town of Navua. 

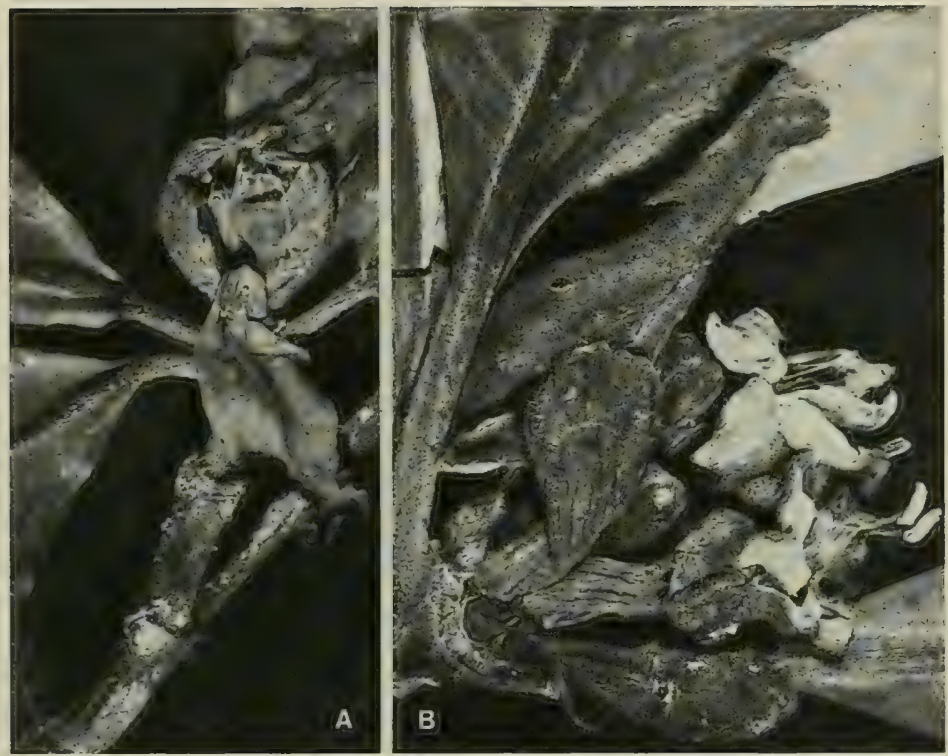

FigURE 113. A, Psychotria kuruvolii; inflorescence-subtending stipules separating laterally, apically connate, $\times$ 4. B, Psychotria tetragonoides; inflorescence (and stipular scar), a second stipule-enclosed inflorescence from a different node shown above, $\times 4$. A from $D A 14896$, B from Degener 15213 .

Distribution: Endemic to Fiji and thus far known only from south-central Viti Levu and Ovalau.

Local NAME: A name recorded from Namosi Province is kau thoko ni vola.

AVAILABLE COLlections: VITI LEVU: NandRonga \& Navosa: Ridge above Naloka, DA 2478. NAmosI: Near Namosi Village, Gillespie 2876; mountain ridge southeast of Namosi Village, Gillespie 2861; Mt. Voma, $D A$ 554, 568, 1727; track to Mt. Vakarongasiu, DA 16143, 17616. OVALAU: Hills west of Lovoni Valley, on ridge south of Mt. Korolevu, Smith 7633.

50. Psychotria diffusiflora A. C. Sm. in J. Arnold Arb. 34: 107. 1953; J. W. Parham, Pl.

Fiji Isl. 203. 1964, ed. 2. 284. 1972.

Shrub or tree $2-5 \mathrm{~m}$. high, often slender, found in dense forest at elevations of $250-1,150 \mathrm{~m}$. The pedicel and all flower parts are noted as white. Flowering material has been obtained between July and October, but fruits remain uncollected.

TyPIFICATION: The type is Smith 6087 (A HOLOTYPE; ISOTYPES at BISH, K, Us), collected Sept. 18, 1947, on the southern slopes of Mt. Tomanivi, Mba Province, Viti Levu.

Distribution: Endemic to Fiji and apparently uncommon, known only from central and north-central Viti Levu.

AVAilable Collections: VITI LEVU: Mba: Southern slopes of Mt. Tomanivi, Smith 5247. Namosi: Mt. Naitarandamu, Gillespie 3108; valley of Wainambua Creek, south of Mt. Naitarandamu, Smith 8806. 
As indicated in the protologue, Psychotria diffusiflora is not very convincingly separated from $P$. filipes, having leaves with shorter petioles and blades that are usually attenuate (although sometimes essentially rounded or faintly subcordate) at base and sometimes obviously pilose on the costa beneath; its inflorescences are slightly more compact and with more robust branches; and its corollas appear longer. It is here retained as specifically distinct with some diffidence. As the two taxa occur on Viti Levu, $P$. diffusiflora as here accepted has a more northerly distribution than $P$. filipes.

51. Psychotria platycocca A. Gray in Proc. Amer. Acad. Arts 4:47. 1858; Fosberg in Sargentia 1: 128. 1942; J. W. Parham, Pl. Fiji Isl. 207. 1964, ed. 2. 289. 1972. Figures 102C, 109B.

Psychotria caldwelli Gillespie in Bishop Mus. Bull. 91 : 30. fig. 33 (excl. $a-c$ ). 1932; J. W. Parham, Pl. Fiji Isl. 201. 1964, ed. 2. 282. 1972.

A sometimes locally abundant tree or shrub 1-7 m. high, often freely branched or compact, found at elevations of $100-1,155 \mathrm{~m}$. in dense or secondary forest or in the forest of crests and ridges. The flowers have white or cream-colored corollas with sometimes greenish lobes, and the stamens and style are white; fruits are noted as orange to scarlet or red. Flowers have been obtained between May and November, fruits in every month.

Typification AND NOMENClature: The type of Psychotria platycocca is $U . S$. Expl. Exped. (US 62337 holotyPE; ISOTYPE at GH), collected in 1840 in Fiji; Gray did not specify a locality, but the holotype is indicated as from Ovalau. Gillespie typified $P$. caldwellii ("caldwelli") by Gillespie 3346 (BISH нOLOTYPE and ISOTYPE), collected Sept. 29,1927 , in flower and fruit, near the summit of Mt. Naitarandamu, Namosi Province, Viti Levu. His drawings of the fruit and seed (fig. 33, $a-c$ ) were made from Gillespie 3993, from Nandarivatu, which is referable to $P$. hypargyraea. Gillespie did not suggest the relationship of $P$. caldwellii, but in herbaria he correctly referred several of his own collections from Mba Province to P. platycocca, and we discern no means of separating that species from his concept of $P$. caldwellii as that is based on material from Mt. Naitarandamu.

Distribution: Endemic to Fiji and known from Viti Levu and Vanua Levu, and also from Ovalau if the holotype is correctly labelled, which seems entirely probable. However, only the type material is thus far known to represent the species on Ovalau, where the name Psychotria platycocca has been erroneously used in herbaria for the very different $P$. hypargyraea (of species group Brackenridgeae), which is common on Ovalau. We have examined about 50 collections of $P$. platycocca as here circumscribed; it seems locally abundant only at the middle and higher elevations of Viti Levu.

Local NAME: In Mba Province the name malawai has been recorded.

RePRESENTATIVE COLLECTIONS: VITI LEVU: MBA: Mt. Koromba, DA 14737; Koro-O road, west of Nandarivatu, DA 13515; vicinity of Nandarivatu, Gillespie 3184; Mt. Nanggaranambuluta, east of Nandarivatu, Gillespie 3792; slopes of Mt. Tomanivi, Gillespie 4093, DA 12743 (Melville et al. 7135). NANDRONGA \& Navosa: Nausori Highlands, $O . \&$ I. Degener 32163; northern portion of Rairaimatuku Plateau, between Nandrau and Nanga, Smith 5558. SeRUA; Hills east of Navua River, near Nukusere, Smith 9140 . NAMOSI: Near summit of Mt. Naitarandamu, Gillespie 4895; Mt. Vakarongasiu, Gillespie 3261. RA: Ridge from Mt. Namama (east of Nandarivatu) toward Mt. Tomanivi, Smith 5708. NAITASIRI: Nggoronggorotambuatini, near Nasonggo, DA 15307. VANUA LEVU: Mathuata: Mt. Ndelaikoro, DA 11494; summit ridge of Mt. 
Numbuiloa, east of Lambasa, Smith 6445. Mathuata-Thakaundrove boundary: Crest of Korotini Range, between Navitho Pass and Mt. Ndelaikoro, Smith 556. ThaK aundrove: Navonu Creek, Natewa Peninsula, DA 15060.

The Vanua Levu material here assigned is probably correctly placed in Psychotria platycocca, but three other collections from the Savusavu Bay area of Thakaundrove Province (Degener \& Ordonez 14241 and DA 13123 and 13282) have the leaf shape more suggestive of $P$. filipes. However, they have the compact inflorescences of $P$. platycocca, DA 13282 has minute, pale indument on its inflorescence branches.

A Samoan species of this general relationship is Psychotria insularum A. Gray, which has the type of stipule and inflorescence of our species group Filipedes; however, its fruits and pyrenes are not of the "Piptilema" type, and its corolla is comparatively large and more obviously pilose in the throat. As discussed by Whistler (1986, pp. 366-369), $P$. insularum is a highly variable species.

52. Psychotria broweri Seem. Fl. Vit. 135, as P. browerii. 1866; Drake, Ill. Fl. Ins. Mar. Pac. 197. 1890; A. C. Sm. in J. Arnold Arb. 34: 104, solum quoad lectotypum. 1953; J. W. Parham, Pl. Fiji Isl. 201. 1964, ed. 2. 282, p. p. 1972; A. C. Sm. in Contr. U. S. Nat. Herb. 37: 102. 1967.

Figure 102D.

Psychotria Seem. in Bonplandia 9: 257. 1861.

Psychotria collina sensu A. Gray in Proc. Amer. Acad. Arts 5:319, p. p. 1862, in Bonplandia 10: 36, p. p. 1862; Seem. Viti, 437, p. p. 1862; non Labill.

Tree or shrub 2-3 m. high, occurring in forest from near sea level to an elevation of about $250 \mathrm{~m}$. Flowers, with white corollas, have been noted in July, September, and November; fruits in March and June.

TyPIfICATION: In describing Psychotria broweri, Seemann (influenced by Gray's references to $P$. collina) cited his numbers 244 and 254, both collected on the island of Moturiki in 1860. The lectotype is Seemann 254 (K LECTOTYPE; ISOLECTOTYPES at BM, GH) (cf. Smith, 1953, 1967); in the present treatment no. 244 is referred to P. tephrosantha (q. v.). In spite of the lectotypification, the importance of stipule characters was not appreciated, the various specimens (other than the lectotype) cited by Smith (1953) actually representing species of group Brackenridgeae as here construed.

Distribution: Endemic to Fiji, and as here circumscribed limited to southeastern Viti Levu with the exception of the type collection from Moturiki, immediately south of Ovalau.

AVAIlable COllections: VITI LEVU: NaITASIRI: Wainivakindau Creek (Waimanu River tributary), DA 15416; Viria, Parks 20454; hills between Savu and Nathokaika, DA 910, 925, 929; Sawani-Serea road, DA 11057; Lomaivuna, DA 2512; Tholo-i-suva, DA 13683 (L.8233). TAILEvu: Wailotua, DA 760, p. p.

As represented by its type collection (and apparently the only collection from elsewhere than Viti Levu), Psychotria broweri is obviously closely related to $P$. platycocca (although it also has been widely misinterpreted in herbaria). However, its foliage appears substantially more robust than that of $P$. platycocca, and we are reluctant to combine two taxa that appear superficially to be quite distinct. This decision is supported by material from southeastern Viti Levu, where the larger-leaved collections of this immediate alliance emphasize the comparatively robust facies of $P$. broweri in contrast to P. platycocca, which occurs abundantly in higher areas of Viti Levu. Some of the Viti Levu collections of $P$. broweri are obviously pilose on inflorescence branches, in this respect suggesting $P$. st.-johnii, the following species in the present treatment. 
53. Psychotria st.-johnii Fosberg in Bull. Torrey Bot. Club 67: 423. 1940; A. C. Sm. in J. Arnold Arb. 34: 106. 1953; J. W. Parham, Pl. Fiji Isl. 208. 1964, ed. 2. 290. 1972.

Figure 105D.

Tree or shrub $2-8 \mathrm{~m}$. high, often spreading or slender, found in usually dense forest at elevations of 100-1,050 m. (more often toward the higher elevations). The flowers are noted as having white calyces, corollas, stamens, and styles; the fruits are bright orange to red. Flowers and fruits have been obtained between April and November.

TYPIFICATION: The type is St. John 18284 (BISH HOLOTYPE and ISOTYPES), collected Aug. 12, 1937, in the upper Wainimala River Valley, along Wainisavulevu Creek (Rarandawai to Nairairaikinasavu), Naitasiri Province, Viti Levu.

Distribution: Endemic to Fiji and thus far known only from Viti Levu. Although 16 collections have been recorded as seen in various herbaria, we here cite only those studied in connection with the present review.

LOCAL NAMES: St. John recorded the following names from Naitasiri Province: lewalekaleka, kali, aroasawa.

RePresentative Collections: VITI LEVU: MBA: Slopes of Mt. Nairosa, eastern flank of Mt. Evans Range, Smith 4025, 4049; hills between Nggaliwana and Tumbeindreketi Creeks, east of the sawmill at Navai, Smith 5991. NANDRONGA \& NAvosa: Northern portion of Rairaimatuku Plateau, between Nandrau and Rewasau, Smith 5648. Serua: Hills east of Navua River, near Nukusere, Smith 9087 . Namosi: Northern base and slopes of Korombasambasanga Range, in drainage of Wainavindrau Creek, Smith 8626, 8733; vicinity of Namuamua, Gillespie 2988. NAITASIRI: Wainimala River Valley, Rarandawai, divide between Wainisavulevu and Wainamo Creeks, St. John 18275, 18279. TAILEvU: Wailotua, DA 9408.

Psychotria st.-johnii is part of a confusing complex that includes $P$. broweri and $P$. diffusiflora. In general, $P$. broweri, as here interpreted, lacks the obvious foliar indument of $P$. st.-johnii, but some specimens from lowland Naitasiri Province have traces of such indument on inflorescence branches. These specimens have the shorter corollas (3-4 mm. long) of $P$. broweri and in the present treatment are there assigned. The corollas of $P$. st.-johnii appear always to be $7-9 \mathrm{~mm}$. long (including those of the type and paratype specimens, despite the measurements stated in the protologue). Other collections from Namosi and inland Serua Provinces have corollas typical of $P$. st.-johnii but are nearly devoid of the foliar and inflorescence indument of that species, to which they are here assigned. However, such specimens are also suggestive of $P$. diffusiflora and can be separated from it only by their larger leaves and more robust facies.

In short, the three taxa here discussed, despite the obviously distinct nature of their type collections, lack really satisfactory separating characters when all available collections of the relationship are considered. As in many other complexes in Psychotria, the assignment of individual collections to one or the other taxon can be somewhat arbitrary, reflecting general impressions and geographic occurrence.

54. Psychotria unicarinata (Fosberg) A. C. Sm. \& S. Darwin, comb. et stat. nov.

Psychotria griseifolia var. unicarinata Fosberg in Sargentia 1: 129. 1942; J. W. Parham, Pl. Fiji Isl. 204. 1964, ed. 2. 285.1972.

Shrub or small tree 1-4 m. high, found in dense forest at elevations of about $150-1,150 \mathrm{~m}$. The stipular sheath is often dull red and the young calyx is white; corollas are white or cream-white, or pale green when young, and anthers are cream-white; fruits are bright orange or red. Flowers have been noted between August and Decemher, fruits between July and January. 
TyPIfICATION: Psychotria griseifolia var. unicarinata is typified by Degener 14640 (A HOLOTYPE), collected Feb. 28, 1941, on Mt. Matomba, south of Nandarivatu, Mba Province, Viti Levu.

Distribution: Endemic to Fiji and known only from Viti Levu, where it is represented by 30 or 40 collections. In herbaria Psychotria unicarinata has been confused with $P$. storckii (of our species group Brackenridgeae), from which its stipules immediately distinguish it.

RePRESENTATIVE COLleCtIONS: VITI LEVU: MBA: Vicinity of Nandarivatu, Parks 20666, Gillespie 3991; Mt. Matomba, Nandala, south of Nandarivatu, Degener 14510; Nauwangga, south of Nandarivatu, Degener 14624; hills between Nggaliwana and Nandala Creeks, south of Nauwangga, Smith 5843. NAMOSI: Mt. Naitarandamu, Gillespie 3093; hills bordering Wainavindrau Creek, vicinity of Wainimakutu, Smith 8530; hills east of Wainikoroiluva River, near Namuamua, Smith 8926. NaITAsıri: Tholo-i-suva, DA 9860 ; near Tamavua, Gillespie 2089. Rewa: Mt. Korombamba, Gillespie 2299, 2404.

The present taxon seems to be less closely related to Psychotria griseifolia than to $P$. st.-johnii, from which it is readily separable if corollas are available, those of $P$. unicarinata being substantially shorter and appearing subrotate. In the absence of corollas, $P$. unicarinata is distinguishable from its ally by its more copious indument (extending to calyces and fruits), short pedicels, and leaf blades with obtuse to comparatively inconspicuous apices.

55. Psychotria brachythrix A. C. Sm. in Pacific Sci. 25: 500. 1971.

Small tree 2-3 m. high, apparently rare in forest along creek at an elevation of about $150 \mathrm{~m}$. Flowers remain unknown, and the fruits, not fully mature, were obtained in May.

TyPification: The type is DA 15188 (coll. D. Koroiveibau) (BISH HOLOTYPE; ISOTYPES at CHR, K, MASS, SUVA), collected May 29, 1967, along Singasingau Creek, above Ndriti, in drainage of Ndama River, Mbua Province, Vanua Levu.

Distribution: Endemic to Fiji and still known only from the type collection. It provides still another example of a sharply marked species known from inadequate material from Vanua Levu, which remains deplorably undercollected by botanists.

A probably undescribed species of this general alliance in Vanua Levu is represented by Smith 495 (with many available duplicates), collected Nov. 21, 1933, on the southern slopes of the Korotini Range below Navitho Pass, Thakaundrove Province. The fruits, of the "Piptilema" type, appear to be two or three in number and arise directly from a small, subcapitate inflorescence, with slender pedicels $12-18 \mathrm{~mm}$. long. The stipules are of the type occurring in our species groups Pickeringiae and Filipedes. While the foliage resembles that of Psychotria brachythrix, the indument is composed of the longer hairs characteristic of $P$. unicarinata, which is also suggested by the short calyx limb.

56. Psychotria scitula A. C. Sm. in Contr. U. S. Nat. Herb. 37:98. 1967; J. W. Parham, Pl. Fiji Isl. ed. 2. 290. 1972.

A small tree occurring very locally in forest, sometimes on crests and ridges, at elevations of 350-923 m. Flowers were obtained in August and September, but fruits remain unknown.

TyPIfICATION: The type is Gillespie 2789 (BISH HOLOTYPE), collected Sept. 6, 1927, on Mt. Voma, Namosi Province, Viti Levu.

Distribution: Endemic to Fiji and thus far known only from the type locality.

Available collections: VITI LEVU: Namosi: Mt. Voma, Gillespie 2672, DA 562, 563, 587. 
57. Psychotria griseifolia S. Moore in J. Linn. Soc. Bot. 39: 153. 1909; Fosberg in Sargentia 1: 129. 1942.

Psychotria griseifolia var. griseifolia; J. W. Parham, Pl. Fiji Isl. 204. 1964, ed. 2. 285. 1972.

Tree or shrub 3-6 m. high, of limited occurrence in dense forest at elevations of $750-940 \mathrm{~m}$. The corolla is white and the fruit bright yellow to orange. Flowers have been collected in September, fruits from February to May and also in September.

TYPIFICATION: The type is Gibbs 706 (BM HOLOTYPE), collected in September, 1907, in the vicinity of Nandarivatu ("ridge of Matani Siga"), Mba Province, Viti Levu.

Distribution: Endemic to Fiji and apparently limited to north-central Viti Levu.

Local NAME: Malawai (Mba).

AVAilable Collections: VITI LEVU: MBA: Hills between Nandala and Nukunuku Creeks, along trail from Nandarivatu toward Lewa, Smith 6188; vicinity of Nandarivatu, Degener 14336; Sovutawambu, vicinity of Nandarivatu, Degener 1466I; Nauwangga, south of Nandarivatu, Degener 14524 (A, BISH, US p. p. minore); Mt. Natomba, Nandala, Degener 15362.

58. Psychotria taviunensis Gillespie in Bishop Mus. Bull. 74: 34. fig. 48. 1930; Fosberg in Sargentia 1: 128. 1942; J. W. Parham, Pl. Fiji Isl. 208. 1964, ed. 2. 290. 1972.

Figure 109E.

Tree or shrub 2-6 m. high, often freely branched, found in dense forest or crest thickets at elevations of $150-900 \mathrm{~m}$. The corolla and stamens are white, the fruits orange to red at maturity. Flowers and fruits have been obtained in months scattered throughout the year.

TYPIFICATION: The type is Gillespie 4722 (BISH HOLOTYPE; ISOTYPES at BISH, NY), collected in flower and fruit Feb. 27, 1928, on slopes above coconut plantations in the vicinity of Waiyevo, Taveuni.

Distribution: Endemic to Fiji and thus far known only from Vanua Levu and Taveuni.

Available collections: VANUA LEVU: Mbua: Singasingau Creek, above Ndriti, in drainage of Ndama River, DA 15191. ThaKAUNDRove: Southern slope of Valanga Range, Smith 386; Mt. Vatunivuamonde, Savusavu Bay region, Degener \& Ordonez 13999; eastern buttress of Mt. Ndikeva, Smith 1892. TAVEUNI: Track to lake east of Somosomo, $D A$ 14068; western slope between Somosomo and Wairiki, Smith 752; slopes of Mt. Manuka, east of Wairiki, Smith 8144.

Although Psychotria taviunensis is scarcely separable from $P$. griseifolia in inflorescence and fruit characters, its leaves are strikingly larger, with obviously acuminate rather than essentially obtuse blades. The taxa are entirely allopatric.

59. Psychotria podantha (Fosberg) A. C. Sm. in Pacific Sci. 23: 379. 1969; J. W. Parham, Pl. Fiji Isl. ed. 2. 289. 1972.

Psychotria platycocca sensu Gibbs in J. Linn. Soc. Bot. 39: 152. 1909; non A. Gray.

Psychotria cordata var. podantha Fosberg in Sargentia 1: 130. 1942; J. W. Parham, Pl. Fiji Isl. 202. 1964.

Shrub or tree $2-5 \mathrm{~m}$. high, apparently local in dense or open forest at an elevation of $750-1,100 \mathrm{~m}$. The corolla is white and the fruit orange. Flowers have been obtained between June and August, fruits between January and March.

TyPification: The type is Degener 14831 (US 2333978 HolotyPE; iSOTYPE at A), collected March 13, 1941, near Nauwangga, south of Nandarivatu, Mba Province, Viti Levu.

Distribution: Endemic to Fiji and apparently limited to a small area of northcentral Viti Levu.

AVAILABLE COLLections: VITI LEVU: MBA: Vicinity of Nandarivatu, Gibbs 596 (BM, K); western slopes of Mt. Nanggaranambuluta, east of Nandarivatu, Smith 4821; Nauwangga, south of Nandarivatu, Degener $14827,14829$. 
60. Psychotria furcans Fosberg in Sargentia 1: 133. 1942; A. C. Sm. in J. Arnold Arb. 34: 105. 1953; J. W. Parham, Pl. Fiji Isl. 203. 1964, ed. 2. 285. 1972.

Figure 102H.

Chasalia amicorum sensu Seem. in Bonplandia 9: 256. 1861, Viti, 437. 1862; non A. Gray.

Psychotria consobrina A. C. Sm. in Contr. U. S. Nat. Herb. 37: 100. 1967; J. W. Parham, Pl. Fiji Isl. ed. 2. 282. 1972.

Shrub or slender tree 1-12 m. high, often locally frequent from near sea level to an elevation of $1,075 \mathrm{~m}$. in dense or dry forest, patches of forest in open areas, or in crest forest. The calyx limb is green or sometimes has a reddish tinge; the corolla is white, or the tube may be greenish; and the mature fruits are orange to red. Flowers and fruits have been obtained in every month.

TyPIFICATION AND NOMENClATURE: Psychotria furcans is typified by Degener 14450 (US 2333983 HOLOTYPE; ISOTYPES at A, BISH, K, US 1759599), collected Feb. 18, 1941, in flower and fruit, on Mt. Natomba, Nandala, south of Nandarivatu, Mba Province, Viti Levu. The type of P. consobrina is Gillespie 4596 (BISH HOLOTYPE; ISOTYPES at BISH, GH, K, UC), obtained Feb. 6, 1928, in flower, near the quarry beyond Lami, Rewa Province, Viti Levu. Mature consideration indicates that the indument characters utilized to propose $P$. consobrina as distinct from $P$. furcans are inconsequential.

Distribution: Endemic to Fiji and known only from the two largest islands, being much more abundant on Viti Levu than on Vanua Levu; we have examined about 70 collections.

LOCAL NAMES: Recorded names are songasonga (Serua) and ngoru $(\mathrm{Ra})$.

RePresentative Collections: VITI LEVU: MBA: Mt. Evans Range, Greenwood I250; upper slopes of Mt. Koromba, Smith 4661; vicinity of Nandarivatu, Degener 14625; hills between Nggaliwana and Tumbeindreketi Creeks, east of the sawmill at Navai, Smith 5980. NANDRONGA \& NavosA: Nausori Highlands, DA 12633 (Melville et al. 7004); northern portion of Rairaimatuku Plateau, between Nandrau and Rewasau, Smith 5411; Uluvatu, vicinity of Mbelo, near Vatukarasa, Tabualewa 15623. SerUA: Upper Navua River, DA 14878; Namboutini, DA 14264; north of Korovou, St. John 18933. Namosi: Vicinity of Namosi, Seemann 241; vicinity of Namuamua, Gillespie 2996. RA: Vicinity of Rewasa, near Vaileka, Degener 15335. Rewa: Vicinity of Lami, Meebold 17020. VANUA LEVU: MathUaTA: Southern base of Mathuata Range, north of Natua, Smith 6824. ThaKAUNDRove: Eastern drainage of Yanawai River, Degener \& Ordonez 14092.

61. Psychotria pritchardii Seem. Fl. Vit. 135. 1866; Drake, Ill. Fl. Ins. Mar. Pac. 198. 1890; A. C. Sm. in J. Arnold Arb. 34: 105. 1953; J. W. Parham, Pl. Fiji Isl. 207. 1964, ed. 2. 289. 1972.

Figure 103 D.

Rubiacea (an gen. nov.?) Seem. in Bonplandia 9: 257. 1861.

Psychotria sp. aff. brackenridgei Seem. Viti, 437. 1862.

Psychotria A. Gray in Proc. Amer. Acad. Arts 5: 319. 1862, in Bonplandia 10: 36.1862.

Tree (rarely noted as a shrub) 1-8 m. high, often slender or freely branched, occurring from near sea level to about $900 \mathrm{~m}$. in dense or secondary forest or in forest patches in open country. The corolla is white or sometimes distally pink-tinged, and the mature fruit is orange to red. Flowers have been obtained between March and November, fruits in most months.

TyPIFICATION: The type is Seemann 259 (K HOLOTYPE; ISOTYPES at BM, GH), collected in June, 1860, on Taveuni, without further locality.

Distribution: Endemic to Fiji and apparently to Vanua Levu and Taveuni; we have examined 21 collections.

RePRESENTATIVE COLlections: VANUA LEVU: MbUA: Upper Ndama River Valley, Smith 1606; Mt. Seatura, DA 14891. M AThUATA: Naliuninga, Seanggangga, DA 10487; Seanggangga Plateau, in drainage of Korovuli River, vicinity of Natua, Smith 6744. THAKAUNDROVE: Eastern drainage of Yanawai River, 
Degener \& Ordonez 14097; above Naingganggi, DA 15709; Savusavu Bay region, Degener \& Ordonez 13820. TAVEUNI: Vicinity of Somosomo, Gillespie 4826; vicinity of lake east of Somosomo, DA 17115; western slope between Somosomo and Wairiki, Smith 743; slopes of Mt. Manuka, east of Wairiki, Smith 8345 .

This remarkable species is sharply delimited by its rounded, often auriculate stipules and its reflexed, long-pedunculate inflorescence; it is clearly related to Psychotria furcans (the two species forming a sharply marked subgroup of species group Brackenridgeae), but is readily separable by its stipules and striking inflorescences. In indument it shows the same variability noted in P. furcans (including $P$. consobrina), and these two species must be taken to encompass that degree of variation (however, the hairs, when present on inflorescence parts, are never of the many-celled reddish type so common in Psychotria, but are rather 1-3-cellular, usually cinereous, rarely brownish, and not exceeding $0.1 \mathrm{~mm}$. in length).

62. Psychotria gracilis A. Gray in Proc. Amer. Acad. Arts 4: 45. 1858; Seem. Viti, 437. 1862, Fl. Vit. 136. 1866; J. W. Parham, Pl. Fiji Isl. 204. 1964, ed. 2. 285. 1972; A. C. Sm. in Pacific Sci. 23: 382.1969.

FIGURE 103C.

An inadequately known species, presumably a shrub, with a very slender habit and foliage, very small stipules bifid nearly to base, few-flowered, pedunculate inflorescences, and slender 4-merous flowers.

TYPIFICATION: The type is $U . S$. Expl. Exped. (US 58426 HOLOTYPE; ISOTYPE at GH), collected in 1840 in Mathuata Province, Vanua Levu.

Distribution: Endemic to Fiji and known only from the type collection.

In redescribing Psychotria gracilis, then and still known only from the type material, Smith (1969) erroneously referred it to the alliance of $P$. tephrosantha. Nothing suggests a scandent habit for $P$. gracilis; its stipules and calyx indicate its correct position in our species group Brackenridgeae, in which its slender facies, narrowly lanceolate leaf blades, and small flowers set it apart as a morphologically isolated taxon.

63. Psychotria hypargyraea A. Gray in Proc. Amer. Acad. Arts 4: 46. 1858; Seem. Viti, 437. 1862, Fl. Vit. 136. 1866; Drake, Ill. Fl. Ins. Mar. Pac. 198, as P. hypargyrea. 1890; J. W. Parham, Pl. Fiji Isl. 204. 1964, ed. 2. 287. 1972. Figure 107B.

Tree or shrub $2-8 \mathrm{~m}$. high, sometimes slender or gnarled, occurring in dense or secondary forest or in dense crest thickets at elevations of 100-850 m. The stipules are sometimes noted as pink-tinged; the calyx is pale green to dull pink or pink-tinged; the corolla, stamens, and style are white; and the fruit is bright orange, sometimes pink-tinged. Flowers have been observed between February and June, fruits between October and January and also between April and June.

TyPification: The type is $U$. S. Expl. Exped. (US 62347 HOLOTYPE; ISOTYPE at GH), collected in 1840 on Ovalau. Gray described both flowers and fruits of Psychotria hypargyraea, but the type material now lacks flowers, although there is a drawing of a longitudinal section of an unopened flower on the GH isotype. Other available Ovalau collections now make possible an adequate understanding of this well-marked but frequently misinterpreted taxon.

Distribution: Endemic to Fiji and now known from the two largest islands and Ovalau. Although it is frequent on Ovalau, the species is otherwise known from only two collections from north-central Viti Levu and several scattered collections from Vanua Levu. All the material of it examined in connection with the present review is here cited. 


\section{LOCAL NAME: Vavakoa has been recorded from Thakaundrove.}

Available COlLections: VITI LEVU: MBa: Vicinity of Nandarivatu, Gillespie 3993; Navai Tea Block, DA 14976. OVALAU: Hills west of Lovoni Valley, on ridge south of Mt. Korolevu, Smith 7636; Lovoni Valley, DA 17078; hills east of Lovoni Valley, Smith 7294, 7303, 7335, 7348, 7351, 7352; summit of Mt. Ndelaiovalau and adjacent ridge, Smith 7376; vicinity of Levuka, Gillespie 4505. VANUA LEVU: MBUA: Southern slope of Mt. Seatura, Smith 1616. MATHuATA: Nasealevu, Sasa Tikina, DA 15243. THAKAUndRove: Hills west of Korotasere, Natewa Bay region, Smith 1937; vicinity of Korotasere, $D A$ 15491; hills south of Natewa, Natewa Peninsula, Smith 1948.

Psychotria hypargyraea is readily distinguished from its allies in species group Brackenridgeae in fruit, its pyrenes being dorsiventrally thin in texture and elliptic in outline, with unindented lateral margins and with 1-3 sharp carinae; other species of this alliance have dorsiventrally thicker pyrenes, with often indented lateral margins and with usually blunt carinae. In general $P$. hypargyraea seems related to the more glabrous phase of $P$. brackenridgei, than which it has more congested inflorescences, shorter corollas, smaller leaf blades, and smaller stipules.

64. Psychotria impercepta A. C. Sm. \& S. Darwin, sp. nov. ${ }^{1}$ Figures 109A, 114.

Psychotria tetragona sensu A. C. Sm. in J. Arnold Arb. 34: 108. 1953; J. W. Parham, Pl. Fiji Isl. 208, p. p. 1964 , ed. 2. 291 , p. p. 1972; non Seem.

Tree or shrub $2-8 \mathrm{~m}$. high, sometimes spreading, occurring in usually dense forest at elevations of $30-1,100 \mathrm{~m}$. The flowers, sometimes noted as fragrant, have the calyx pure white or pink-tinged and the corolla white; the mature fruits are bright orange or bright red. Flowers have been obtained between March and August and also in November, fruits throughout the year.

TYPIFICATION: As type we designate one of several excellent flowering collections: Degener 15276 (A HOLOTYPE; ISOTYPE at us 2156378), collected May 15, 1941, at Yawe, vicinity of Mbelo, near Vatukarasa, Nandronga \& Navosa Province, Viti Levu.

Distribution: Endemic to Fiji and, with the exception of a single collection from Kandavu, known only from Viti Levu. The species is abundant in south-central Viti Levu but extends into the higher northern parts of the island with some frequency. Thirty-nine collections have been seen, but only those studied in connection with the present review are cited below.

\footnotetext{
'Psychotria impercepta A. C. Sm. \& S. Darwin, sp. nov.

Frutex vel arbor parva ad $8 \mathrm{~m}$. alta ubique glabra (vel stipulis petiolis et costis subtus raro rubiginosopilosis), ramulis gracilibus subteretibus vel superne obtuse angulatis; stipulis (5-) 8-12 mm. longis bifidis (eis inflorescentias juveniles obtegentibus ad $20 \mathrm{~mm}$. longis et basi ampliatis), partibus liberis in lobis deltoideooblongis vel lanceolatis 1-6 $\times 1-2 \mathrm{~mm}$. acutis vel attenuatis divisis; petiolis (10-) 15-35 mm. longis gracilibus (1-2 mm. diametro) vadose canaliculatis, foliorum laminis subcoriaceis in sicco viridi-brunneis anguste ellipticis vel lanceolato-vel obovato-ellipticis, (6-) $10-18 \mathrm{~cm}$. longis, (1.5-) $3-6.5 \mathrm{~cm}$. latis, utrinque glandulis rubidis inconspicuis vel immersis ornatis, basi acutis vel attenuatis et in petiolum decurrentibus, apice cuspidatis vel in acuminem ad $7 \mathrm{~mm}$. longum obtusum brevi-acuminatis, margine integris, costa supra paulo elevata subtus prominente, nervis secundariis utrinsecus (10-) 12-18 curvatis patentibus supra subimpressis vel planis subtus elevatis, rete venularum utrinque prominulo vel inconspicuo; inflorescentia terminali sub anthesi primum visa subcapitata sed vero congesta e basi 3-5-partita 10-25-flora corollis vel fructibus inclusis $2-2.5 \times 3-4 \mathrm{~cm}$., bracteis bracteolisque minutis caducis, ramo omni $1-7(-15) \mathrm{mm}$. longo ibi 3-floro vel iterum diviso, floribus plerumque ternatis, pedicellis ad $1.5 \mathrm{~mm}$. (sub fructu ad $6 \mathrm{~mm}$.) longis; hypanthio breviter turbinato, calycis limbo haud $0.5 \mathrm{~mm}$. longo minute 5 -denticulato quam disco prominenti pulvinato breviore; corolla graciliter infundibulari sub anthesi $12-18 \mathrm{~mm}$. longa fauce inconspicue pilosa, tubo $10-14 \mathrm{~mm}$. longo, lobis 5 oblongis obtusis $2-5 \mathrm{~mm}$. longis et 2-3 mm. latis; staminibus 5 tubi corollae apicem versus insertis et paulo exsertis, filamentis sub anthesi $3-5 \mathrm{~mm}$. longis, antheris gracilibus dorsifixis $1.5-2 \mathrm{~mm}$. longis; stylo corollae tubum subaequanti apice bifido; fructibus oblongo- vel subrhomboideo-ellipsoideis vel subglobosis in vivo levibus in sicco obtuse 6-8-angulatis $8-14 \times 6-11(-14)$ $\mathrm{mm}$. calycis limbo inconspicuo et disco persistenti coronatis; pyrenis subhastato-semiellipsoideis 7-9 $\times 5-7$ $\mathrm{mm}$., basi obtusis, apice inconspicue indentatis, dorso plerumque basim versus rotundatis et superne obtuse 2- vel 3-carinatis, marginibus lateralibus medium versus inconspicue vel manifeste indentatis. HOLOTYPE: FIJI: VITI LEVU; NANDRONGA \& Navosa: Degener 15276 (A).
} 

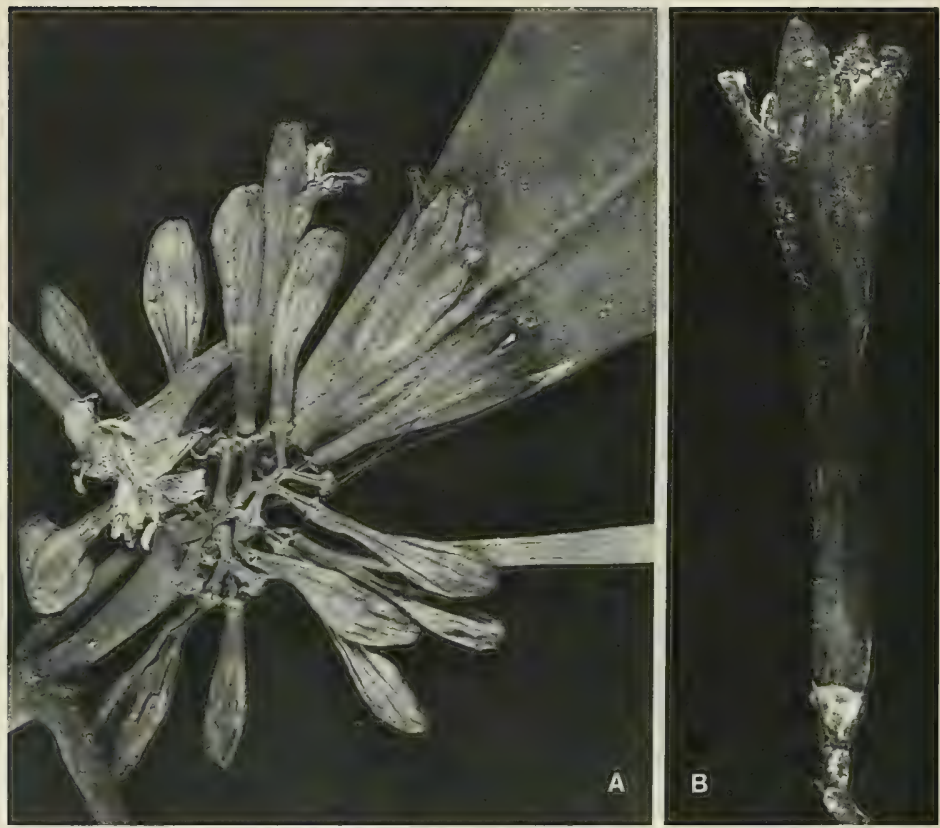

Figure 114. Psychotria impercepta; $\mathrm{A}$, inflorescence at ultimate node, $\times 3 ; \mathrm{B}$, flower, $\times 8$. A from $D A$ 14872, B from $D A 12573$, p. p.

Available collections: VITI LEVU: Mba: Northern portion of Mt. Evans Range, between Mt. Vatuyanitu and Mt. Natondra, Smith 4352; northern slopes of Mt. Namendre, east of Mt. Koromba, Smith 4551; slopes and summit of Mt. Ndelaiyoö, on the escarpment west of Nandarivatu, Smith 5057, 5058; vicinity of Nandarivatu, Gillespie 3849, Degener 14611, DA 10414; ridges of Mt. Nanggaranambuluta, Gillespie 4064; Mt. Matomba, Nandala, south of Nandarivatu, Degener 14448, 14731. SERUA: Vunambua Creek, west of Nambukelevu, upper Navua River drainage, DA 14872; upper Navua River, DA 14874; Mbuyombuyo, near Namboutini, Tabualewa 15586; hills north of Ngaloa, in drainage of Waininggere Creek, Smith 9187, 9188, 9430; vicinity of Ngaloa, DA 12571, 12573, p. p., 14693, 14695; Ngaloa Nature Reserve, DA 16582, 16588; Vatuvilakia, vicinity of Ngaloa, Degener 15167; near Mt. Nggamu, east of Ngaloa, Degener 15057; hills between Navua River and Wainiyavu Creek, near Namuamua, Smith 9005 ; "in hills," Greenwood 1021. Namosi: Vicinity of Namuamua, Gillespie 3070; Nakavu, on Navua River, Parks 20395. NaItasiri: Sawani-Serea road, DA 11292. Viti Levu without further locality, Parks 20115. KANDAVU: Without further locality, DA 11936 (Watkins 685).

Psychotria impercepta is the taxon that in herbaria has usually been referred to $P$. tetragona Seem., but the type of that species is now seen to represent $P$. pickeringii A. Gray (q. v.), of our species group Pickeringiae. Although the new species is superficially suggestive of the preceding species in our sequence, $P$. hypargyraea A. Gray, its inflorescence is even more congested, its calyx limb is even shorter and more obviously exceeded by the prominent disk, its corolla is longer, and its fruits have very different 
pyrenes. A closer relationship of $P$. impercepta is probably with $P$. brackenridgei A. Gray (which is here construed as sometimes having quite glabrous inflorescence parts, although typically these are reddish-pilose). From $P$. brackenridgei the new species differs in its much more congested inflorescences, short pedicels, very small calyx limb, longer corolla, and smaller stipules and leaves.

In considering this taxon (erroneously as Psychotria tetragona) in 1953, Smith discussed two collections from western Viti Levu (the first two cited above) as being extreme. They are listed as representing $P$. impercepta with some diffidence, although in inflorescence characters they are quite characteristic. Number 4551 in particular must be considered atypical of the new species because of indument on the costa of its lower leaf blade surfaces; this suggests a degree of introgression between $P$. impercepta and $P$. storckii Seem., the extremes of which are so distinct that to combine the two taxa seems out of the question.

65. Psychotria pachyantha A. C. Sm. in Bishop Mus. Bull. 141: 148. fig. 78. 1936; J. W. Parham, Pl. Fiji Isl. 207. 1964, ed. 2. 289. 1972. Figure 103E.

Tree or shrub 2-4 m. high, usually slender, infrequent in dense forest or on its edges at elevations from near sea level to $842 \mathrm{~m}$. The calyx and corolla are noted as white and the fruits as orange or red at maturity. Both flowers and fruits have been obtained in April and May.

TYPIFICATION: The type is Smith 1648 (BISH HOLOTYPE; ISOTYPES at K, NY), collected April 27, 1934, on Navotuvotu, summit of Mt. Seatura, Mbua Province, Vanua Levu.

Distribution: Endemic to Fiji and thus far known only from Vanua Levu and the island of Yathata, in northern Lau.

available collections: VANUA LEVU: Mathuata: Coastal mountains, Greenwood 659. ThakauNDROVE: Mt. Kasi, Yanawai River region, Smith 1759. YATHATA: Near Navakathuru, DA 15554, 16190.

Psychotria pachyantha and the next species in this sequence, $P$. edentata, appear closely related to $P$. brackenridgei, but we believe that both may be retained as distinct taxa. Both have inflorescences with comparatively few branches, which sometimes arise from a short, erect peduncle; in $P$. brackenridgei the inflorescence is always epedunculate and 3-7(-10)-branched from base. Of the three taxa, P. pachyantha has the longest mature corollas; its large stipules are shallowly notched at the broad apices rather than deeply bifid. Both $P$. pachyantha and $P$. edentata, in comparison with $P$. brackenridgei, have leaf blades usually with fewer secondary nerves and flowers with longer pedicels; $P$. edentata is further characterized by its essentially truncate calyx limb and its more numerous (6-8 rather than 4-6) corolla lobes and stamens, as well as by its small stipules.

66. Psychotria edentata A. C. Sm. in Bishop Mus. Bull. 141: 148. fig. 78, b, 79. 1936; J. W. Parham, Pl. Fiji Isl. 203. 1964, ed. 2. 284. 1972.

A slender shrub $2-3 \mathrm{~m}$. high, infrequent in forest on limestone from near sea level to an elevation of $100 \mathrm{~m}$. The white corollas were observed in February and March, but fruits are not yet known.

TYPIFICATION: The type is Smith 1437 (BISH HOLOTYPE; many ISOTYPES), collected March 29, 1934, on Namalata islet, southern limestone section of Vanua Mbalavu.

Distribution: Endemic to Fiji and known to us only from the two Lauan collections originally cited.

LOCAL NAME: The name ndoko ni mbu was noted on Fulanga.

Available collection: FUlangA: On limestone, Smith 1132. 
67. Psychotria aurantiocarpa Fosberg in Sargentia 1: 130. 1942; J. W. Parham, Pl. Fiji Isl. 200. 1964, ed. 2. 281. 1972.

Figure 109D.

Shrub $4 \mathrm{~m}$. high, apparently rare in dense forest at an elevation of $600-881 \mathrm{~m}$. The mature fruit is bright orange and was obtained in November.

TYPIFICATION: The species is based on Smith 449 (NY HOLOTYPE; many ISOTYPES), collected Nov. 14, 1933, on Mt. Mariko, Thakaundrove Province, Vanua Levu.

Distribution: Endemic to Fiji and thus far known from a single collection.

Psychotria aurantiocarpa, still known only from its fruiting type collection, appears to be a well-marked taxon of the general relationship of $P$. brackenridgei. It is characterized by a comparatively simple infructescence, of which the undivided branches are reddish-pilose, bearing sessile fruits that are large for species group Brackenridgeae and unusual in having slightly hastate, sharply unicarinate, apically deeply indented pyrenes. Its stipules have essentially filiform lobes much narrower than those of any allied species. The species provides still another reminder of the inadequacy of collections from Vanua Levu.

68. Psychotria brackenridgei A. Gray in Proc. Amer. Acad. Arts 4: 44, as P. brackenridgii. 1858; Seem. Viti, 437. 1862, Fl. Vit. 135, as P. brackenridgii. 1866; Drake, Ill. Fl. Ins. Mar. Pac. 197. 1890; Gillespie in Bishop Mus. Bull. 74:33. fig. 45, as $P$. brackenridgii. 1930; A. C. Sm. in J. Arnold Arb. 34: 104. 1953; J. W. Parham, Pl. Fiji Isl. 201. 1964, ed. 2. 281. 1972.

Psychotria salticola A. C. Sm. in Contr. U. S. Nat. Herb. 37: 102. 1967; J. W. Parham, PI. Fiji Isl. ed. 2. 290. 1972.

Tree or shrub 1-8 m. high, often slender, sometimes locally abundant in dense, thin, or secondary forest or in the forest of crests and ridges from near sea level to an elevation of about $1,150 \mathrm{~m}$. The stipules, inflorescence branches, pedicels, and calyces are sometimes dull pink or pink-tinged, the corollas are white, and the mature fruits are orange or red. Flowers and fruits have been noted throughout the year.

TyPifiCATION AND NOMENClature: Psychotria brackenridgei is typified by $U . S$. Expl. Exped. (US 2593834 HOLOTYPE; ISOTYPE at GH), collected in 1840 on Ovalau. In 1953 Smith noted that no Exploring Expedition specimen of $P$. brackenridgei had been found at Us; since then, however, a good fruiting specimen with Gray's annotation has been located, and this is the appropriate holotype, especially as it is a more ample specimen than the GH duplicate. The type of $P$. salticola is Smith 8550 (us $2191239 \&$ 2191240 HOLOTYPE; many ISOTYPES), collected Sept. 17, 1953, in hills bordering Wainavindrau Creek, vicinity of Wainimakutu, Namosi Province, Viti Levu. As P. brackenridgei is here interpreted, $P$. salticola cannot be excluded from it.

Distribution: Endemic to Fiji and widespread within the archipelago; about 110 collections have been examined from nine islands, including several of the Lau Group.

LOCAL NAME: The only recorded local name is mbuluwai (Mbua Province).

Representative Collections: VITI LEVU: MBa: Northern slopes of Mt. Namendre, east of Mt. Koromba, Smith 4548; vicinity of Nandarivatu, DA 13004; western and southern slopes of Mt. Tomanivi, Smith 5137, DA 12752 (Melville et al. 7144 , p. p.). NANDRONGA \& Navosa: Nausori Highlands, $O$. \& $I$. Degener 32177; northern portion of Rairaimatuku Plateau, between Nandrau and Nanga, Smith 5483. SERUA: Inland from Ngaloa, DA 16556; hills east of Navua River, near Nukusere, Smith 9096 . Namosi: Hills east of Navua River, Greenwood 1004; hills north of Wainavindrau Creek, between Korombasambasanga Range and Mt. Naitarandamu, Smith 849I. NAITASIRI: Tholo-i-suva, DA 9264 (McKee 2830); vicinity of Tamavua, Gillespie 2128; vicinity of Nasinu, Gillespie 3476. TAILEVU: Hills east of Wainimbuka River, 
vicinity of Ndakuivuna, Smith 7115. RewA: Mt. Korombamba, Parks 20111. KANDAVU: Hills above Namalata and Ngaloa Bays, Smith 172. OVALAU: Slopes of Mt. Korotolutolu, Smith 8057; vicinity of Levuka, Gillespie 4506. KORO: Eastern slope of main ridge, Smith 1023. VANUA LEVU: MBUA: Southern portion of Seatovo Range, Smith 1559; track to Mt. Seatura, DA 18196. Mathuata-ThaXaundrove boundary: Crest of Korotini Range, between Navitho Pass and Mt. Ndelaikoro, Smith 531. THAKAUNDROvE: Wailevu, DA 14285; track to Mt. Nasorolevu, DA 17139. TAVEUNI: Trail above Somosomo, Gillespie 4821; valley between Mt. Manuka and main ridge of island, east of Wairiki, Smith 8293; above Nggathavula Estate, DA 16910. TUVUTHA: Central basin forest, Bryan 544. ONEATA: Graeffe s. $n$. KARONI (near Mothe): Rocky slope above mangrove swamp, Bryan 480.

In agreement with Gillespie (1930) we have concluded that Psychotria brackenridgei is best interpreted as a species with considerable variation as to the presence or absence of reddish indument on inflorescence branches, pedicels, and calyces. The type material and most other collections here referred possess such indument, but it is sometimes evanescent and occasionally quite lacking. In other respects (robust habit, comparatively large leaves with numerous secondaries, ample but epedunculate inflorescences, obvious calyx limbs, large and predominantly oblong-obovoid fruits with the pyrenes bluntly carinate) $P$. brackenridgei is a reasonably well-demarcated species. Glabrous or promptly glabrescent individuals seem most frequent in the population of southeastern Viti Levu.

Among the various taxa that are certainly closely allied to Psychotria brackenridgei (P. pachyantha, $P$. edentata, $P$. imthurnii, and even $P$. storckii), the one most likely to be confused with it is $P$. imthurnii, which follows in the present sequence.

69. Psychotria imthurnii Turrill in J. Linn. Soc. Bot. 43: 27. 1915; J. W. Parham, Pl. Fiji Isl. 204. 1964, ed. 2. 287. 1972.

Psychotria storckii sensu Gibbs in J. Linn. Soc. Bot. 39: 15I. 1909; non Seem.

Psychotria chrysophylla Fosberg in Bull. Torrey Bot. Club 67: 423. 1940; A. C. Sm. in J. Arnold Arb. 34: 106. 1953; J. W. Parham, Pl. Fiji Isl. 201. 1964, ed. 2. 282. 1972.

Tree or shrub $1.5-7 \mathrm{~m}$. high, often slender or freely branching, found in usually dense forest at elevations of (200-) 600-1,160 m. The inflorescence branches are sometimes noted as white and the calyces as pale green; the corolla is white; and the fruits, although recorded as green, doubtless turn red at maturity. Flowers have been collected between February and November, fruits between June and November.

TYPIFICATION AND NOMENCLATURE: The type of Psychotria imthurnit is im Thurn 106 ( $\mathrm{K}$ HOLOTYPE; ISOTYPE at BM), collected with flower buds Feb. 13, 1906, in the vicinity of Nandarivatu, Mba Province, Viti Levu. Psychotria chrysophylla is based on St. John 18344 (BISH HOLOTYPE and ISOTYPES), obtained Aug. 18, 1937, in flower, at Taunaisali, near the divide between Wainisavulevu and Numbulolo Creeks, on the plateau between the drainages of the Wainimala and Singatoka Rivers, Naitasiri Province, Viti Levu. We discern no consequential differences between these two collections.

Distribution: Endemic to Fiji and found on Viti Levu and Vanua Levu; we have examined about 30 collections. On Viti Levu, Psychotria imthurnii as here delimited seems restricted to the north-central parts of the island. The cited Vanua Levu collections are referred here with less confidence, but they seem better placed in $P$. imthurnii than in $P$. brackenridgei.

LOCAL NAMES AND USE: Names recorded by collectors are thauthau ni Viti (Naitasiri), kau simbala (Nandronga \& Navosa), and sevula (Thakaundrove). In upper Naitasiri a decoction of leaves was used as a cough medicine. 
REPRESENTATIVE COLLECTIONS: VITI LEVU: MBA: Koro-O, west of Nandarivatu, Watkins 759; southern slopes of Mt. Ndelainathovu, on the escarpment west of Nandarivatu, Smith 4931; vicinity of Nandarivatu, Gibbs 702, 742; Mt. Nanggaranambuluta, east of Nandarivatu, Webster \& Hildreth 14208; western and southern slopes of Mt. Tomanivi, Smith 5296. NANDRONGA \& NAVOSA: Northern portion of Rairaimatuku Plateau, between Nandrau and Nanga, Smith 5545. NAmosi: Mt. Naitarandamu, Gillespie 3102; Namosi without further locality, $D A$ 14223. RA: Ridge from Mt. Namama (east of Nandarivatu) toward Mt. Tomanivi, Smith 5702. NAITASIRI: Northern portion of Rairaimatuku Plateau, between Mt. Tomanivi and Nasonggo, Smith 6130. VANUA LEVU: ThaKaUndrove: Southern slope of Korotini Range, below Navitho Pass, Smith 508; near Waiwai, Horne 586; Mt. Mariko, Smith 415; Navonu Creek, Natewa Peninsula, $D A 15088$.

Although Psychotria imthurnii is perhaps merely a more or less stabilized and somewhat localized variant of the widespread and variable $P$. brackenridgei, it probably merits retention on the basis of its usually pedunculate inflorescences. As a rule the erect peduncles are solitary and obvious, whereas the inflorescences of $P$. brackenrid$g e i$ are always divided from the base. However, this character of $P$. imthurnii is not entirely dependable, as sometimes the inflorescences lack a peduncle and are branched directly from the base; even in the type material of $P$. chrysophylla such variability may be noted. Supporting characters for the retention of $P$. imthurnii are the tendency toward shorter pedicels, more slender calyces and fruits, longer corollas, and smaller stipules and leaves. A yellow-green tinge is often apparent in material from northcentral Viti Levu (as mentioned by Fosberg for P. chrysophylla), whereas the leaves of $P$. brackenridgei tend to dry a more brownish color, although this is scarcely a basic or dependable character.

70. Psychotria pittosporifolia Fosberg in Sargentia 1: 134. 1942; J. W. Parham, Pl. Fiji

Is1. 207. 1964, ed. 2. 289. 1972.

Shrub or small tree $2-4 \mathrm{~m}$. high, apparently local in forest at elevations from near sea level to $450(-850$ ?) $\mathrm{m}$. The only collectors' notes indicate that the corolla is white. Flowers have been obtained between April and October, fruits in August and January.

TYPIFICATION: The type is Degener 15180 (US 2333992 HOLOTYPE; ISOTYPES at A, BISH, K), collected May 5, 1941, in flower, near Vatutavathe, vicinity of Ngaloa, Serua Province, Viti Levu.

Distribution: Endemic to Fiji and limited to south-central and southeastern Viti Levu not far from the coast, with the exception of a single collection from Taveuni (and presumably from higher elevation); the latter seems entirely typical of this well-marked species.

LOCAL NAME: The name kalimali was recorded for the type collection.

AVAilable COllections: VITI LEVU: SeruA: Inland from Ngaloa, DA 16573; near Mt. Nggamu, east of Ngaloa, Degener 15059. Namosi: Hills east of Navua River, Greenwood 1009. NaItasiri: Central road, Tothill 569; Prince's Road, DA 3807; Tholo-i-suva, DA 7586; vicinity of Tamavua, Gillespie 2163.5, 2418. REWA: Namboro, DA 5931; Mt. Korombamba, Gillespie 2353, DA 1255, 1257, 3861, 3868; vicinity of Suva, Tothill 53I. TAVEUNI: Mt. Koroturanga (Des Voeux Peak), DA 17734. FIJI without further locality, $D A$ 3934.

Psychotria pittosporifolia, perhaps most closely related to $P$. imthurnii, is well characterized by its comparatively narrow, prevailingly oblanceolate, often revolutemargined leaf blades, sessile flowers, very short calyx limb, and comparatively short corollas.

71. Psychotria vomensis Gillespie in Bishop Mus. Bull. 91: 37. fig. 43. 1932; J. W. Parham, Pl. Fiji Isl. 209. 1964, ed. 2. 291. 1972.

A small tree 3-4 m. high, apparently rare in ridge forest at an elevation of $600-1,100$ $\mathrm{m}$. The corollas are said to be reddish, and the fruits are mentioned as being green. 
Flowers have been obtained in September, fruits in that month and also in November.

TYPIFICATION: The type is Gillespie 2901 (BISH HOLOTYPE and ISOTYPE), collected Sept. 11, 1927, on the slope of Mt. Voma, Namosi Province, Viti Levu.

Distribution: Endemic to Fiji and still known only from the three collections originally cited, from mountainous areas in Namosi Province, Viti Levu.

AVAILABLE Collections: VITI LEVU: Namosi: Mt. Naitarandamu, Gillespie 3088, 3304.

In species group Brackenridgeae, Psychotria vomensis is well characterized by its small, elliptic to obovate leaf blades, its compact, closely pubescent inflorescences branched from the base, each branch being usually undivided and bearing sessile flowers, and its flowers with obvious calyx limbs about $2 \mathrm{~mm}$. long. An interesting relationship, outside the limits of our (admittedly artificial) species groups, may be noted between $P$. vomensis and the more abundant $P$. turbinata A. Gray (species no. 30 in the present treatment, of species group Turbinatae). Although as a rule $P$. turbinat $a$ has substantially larger leaves than $P$. vomensis, more ample inflorescences, and comparatively conspicuous and apically flaring calyx limbs, it may be noted that $P$. turbinata occurs sympatrically with $P$. vomensis and may indeed have contributed to its gene pool.

72. Psychotria storckii Seem. Fl. Vit. 135. 1866; Drake, Ill. Fl. Ins. Mar. Pac. 199. 1890; J. W. Parham, Pl. Fiji Isl. 208. 1964, ed. 2. 290. 1972.

Figures 106B, 108D.

Psychotria (aff. P. turbinata A. Gray) Seem. in Bonplandia 9: 257. 1861.

Psychotria A. Gray in Proc. Amer. Acad. Arts 5: 319. 1862, in Bonplandia 10: 36. 1862.

Psychotria sp. nov. aff. brackenridgei Seem. Viti, 437. 1862.

Psychotria degeneri Fosberg in Sargentia 1: 134, 1942; A. C. Sm. in J. Arnold Arb. 34: 107. 1953; J. W. Parham, Pl. Fiji Isl. 203. 1964, ed. 2. 284. 1972.

Tree or shrub $1-10 \mathrm{~m}$. high, often slender or freely branched, sometimes locally abundant in dense or dry forest from near sea level to an elevation of $1,160 \mathrm{~m}$. The inflorescence branches, pedicels, and calyces are white to cream-white or pinkish; the corolla is white, with pinkish indument; and the mature fruit becomes orange or bright red. Flowers and fruits are to be seen throughout the year.

TYPIFICATION AND NOMENClatURE: In his protologue for Psychotria storckii, Seemann cited Milne and Seemann 255. However, there are three sheets in the type cover at K: (1) Milne, from Viti Levu, with very young flowers; (2) Seemann 255, labelled "Taviuni, Ovalau, Navua" (most of this specimen, with fruits, represents $P$. brackenridgei, but a small portion with a young inflorescence and stipules seems to belong with the following sheet; the fruiting portion probably came from Taveuni or Ovalau); (3) a second sheet of Seemann 255 with a good inflorescence and mature flowers, indicated as "Viti Levu, July 1860." To retain current usage and to conform to the intent of Seemann's description, we here lectotypify the species by the third of these sheets, Seemann 255, p. p. (K LECTOTYPE; ISOLECTOTYPES at BM, GH), collected in July, 1860, probably in the Navua River area, Serua Province, Viti Levu.

The type of Psychotria degeneri is Degener 15374 (us 2333981 HOLOTYPE; ISOTYPES at A, BISH, K, US 1759610), collected May 30, 1941, in flower, at Tuvavatu, vicinity of Rewasa, near Vaileka, Ra Province, Viti Levu. The two type collections are essentially identical.

Distribution: Endemic to Fiji and known from four of the high islands, although all but a few collections come from Viti Levu. We have examined about 95 collections referable to the species. 
RePresentative Collections: VITI LEVU: MBA: Nandarivatu, Greenwood 848, Parks 20772; western slopes of Mt. Nanggaranambuluta, Smith 4773; Mt. Matomba, Nandala, south of Nandarivatu, Degener 14447; slopes of Mt. Tomanivi, Smith 5301. DA 12725 (Melville et al. 7114, p. p.). NANDRONGA \& NavoSA: Northern portion of Rairaimatuku Plateau, between Nandrau and Nanga, Smith 5540. SERUA: Vunambua Creek, west of Nambukelevu, upper Navua River, DA 14869; Namboutini, DA 14268; Ngaloa Nature Reserve, DA 16581; hills between Navua River and Wainiyavu Creek, near Namuamua, Smith 8994. Namosi: Summit of Mt. Naitarandamu, Gillespie 3138; northern slopes of Korombasambasanga Range, in drainge of Wainavindrau Creek, Smith 8715; hills east of Navua River, Greenwood 995. NAITASIRI: Between Matawailevu and Waiyamo, Wainimala River, $D A$ 18142; Nanggarathangithangi, Mendrausuthu Range, DA 15040; vicinity of Tamavua, Gillespie 2458. RewA: Mt. Korombamba, Parks 20124. OVALAU: Mt. Tana Lailai, Graeffes. $n$. VANUA LEVU: ThAKAUndRove: Eastern drainage of Yanawai River, Degener \& Ordonez 14108; eastern slope of Mt. Ndikeva, Smith 1909. TAVEUNI: Borders of lake east of Somosomo, Smith 857.

Psychotria storckii, with the most profuse indument of any species of our group Brackenridgeae, is readily separable from its perhaps closest relative, $P$. brackenridgei, on that basis. In vegetative aspect, $P$. storckii is strikingly similar to $P$. unicarinata (sp. no. 54 in our sequence) and $P$. st.-johnii (no. 53), but those species have the undivided stipules of species group Filipedes; both also have shorter calyx limbs and shorter corollas than P. storckii, and both have fruits with pyrenes of the "Piptilema" type (conspicuously indented laterally and unicarinate); the pyrenes of $P$. storckii are scarcely indented laterally and are bluntly 2 - or 3-carinate.

73. Psychotria tephrosantha A. Gray in Proc. Amer. Acad. Arts 4: 45. 1858; Seem. Viti, 437. 1862, Fl. Vit. 136. 1866; Drake, Ill. Fl. Ins. Mar. Pac. 199. 1890; Gillespie in Bishop Mus. Bull. 91: 35. fig. 40. 1932; A. C. Sm. in op. cit. 141: 150. 1936; Fosberg in Bull. Torrey Bot. Club 67: 424. 1940; J. W. Parham, Pl. Fiji Isl. 208. 1964, ed. 2. 290. 1972; A. C. Sm. in Pacific Sci. 23: 381.1969.

FIGURES 106A, 110C.

Psychotria collina sensu Seem. in Bonplandia 9: 257. 1861, Viti, 437, p. p. 1862; A. Gray in Proc. Amer. Acad. Arts 5: 319, p. p. 1862, in Bonplandia 10: 36, p. p. 1862; non Labill.

Psychotria sp. Seem. in Bonplandia 10: 296. 1862, Viti, 437. 1862.

Psychotria sulphurea Seem. Fl. Vit. 134. 1866; Drake, Ill. Fl. Ins. Mar. Pac. 199. 1890; Gibbs in J. Linn. Soc. Bot. 39: 152. 1909.

Psychotria effusa Turrill in J. Linn. Soc. Bot. 43: 26. 1915.

Psychotria setchelli Gillespie in Bishop Mus. Bull. 91: 35. fig. 39. 1932; J. W. Parham, Pl. Fiji Isl. 208. 1964.

Liana or scrambling shrub, often locally frequent from near sea level to an elevation of $1,195 \mathrm{~m}$. in dense, dry, or open forest or in the forest and thickets of ridges. The fragrant flowers have the corollas and stamens white, and the fruits at maturity are yellow to white. Flowers and fruits occur throughout the year.

TyPification AND NOMEnClature: Psychotria tephrosantha is based on $U . S$. Expl. Exped. (us 62343 HоLOTYPE), collected in 1840 in Fiji without further data. The type of $P$. sulphurea is Storck 895 (K HOLOTYPE; ISOTYPE at BM), obtained in December, 1860, at Port Kinnaird, Ovalau. In describing $P$. effusa, Turrill cited two collections: (1) Gibbs 542 (K, obtained in 1907 between Navai and Nasonggo, in either Mba or Naitasiri Province, Viti Levu; actually included on this $\mathrm{K}$ sheet are scraps of Gibbs 660 and 813 , from Nandarivatu, Mba Province, no. 660 being also represented at BM by a good specimen) and (2) im Thurn 281; an appropriate citation is: im Thurn 281 ( $\mathrm{K}$ LECTOTYPE here designated, 2 sheets; ISOLECTOTYPE at BM), collected Nov. 24, 1906, at Nandarivatu, Mba Province, Viti Levu. The type of P. setchelli (sic) is Setchell \& Parks 15118 (UC 289533 HOLOTYPE; ISOTYPE at BM; cf. Smith, 1969), obtained May 25, 1926, along the Tamavua-Sawani road (i. e. Prince's Road), Naitasiri Province, Viti Levu. Differences among these type specimens are scarcely to be justified (Smith, 1936, 1969). 
Distribution: Of this abundant and unmistakable Fijian endemic we have examined 112 collections (including 95 from Viti Levu) from six of the high islands; it is surely to be anticipated from many other islands.

LOCAL NAMES AND USE: Other than the generalized name wa kau, this species has been locally recorded in Mba Province as wa lo, wa masi, and mbutimboni, in Naitasiri as nai vaka reva nimbatha, wa salai, and vonoyauyau, in Mbua as solui, and in Thakaundrove as waramende. In upper Naitasiri a leaf decoction was recorded as having a medicinal use for stomach and bowel disorders.

REPRESENTATIVE COLlectIons: VITI LEVU: MBA: Summit of Mt. Koroyanitu, high point of Mt. Evans Range, Smith 4172; upper slopes of Mt. Koromba, Smith 4702; vicinity of Nandarivatu, Degener 14392; slopes of Mt. Nanggaranambuluta, Smith 4810: slopes of Mt. Tomanivi, DA 12720 (Melville et al. 7109). NANDRONGA \& NavOSA: Northern portion of Rairaimatuku Plateau, between Nandrau and Nanga, Smith 5476; vicinity of Mbelo, near Vatukarasa, Degener 15240. SeruA: Ngaloa Nature Reserve, DA 1659 l. NAmosI: Mt. Naitarandamu, Gillespie 3101; hills east of Wainikoroiluva River, near Namuamua, Smith 9059. RA: Vicinity of Rewasa, near Vaileka, Degener 15386. NAITASIRI: Rarandawai to Nairairaikinasavu, Wainisavulevu Creek, St. John 18306; Mendrausuthu Range, DA 15474; Prince's Road, DA 1619. TAILEvU: Hills east of Wainimbuka River, vicinity of Ndakuivuna, Smith 7065. Rewa: Mt. Korombamba, Gillespie 2322. OVALAU: Hills west of Lovoni Valley, on ridge south of Mt. Korolevu, Smith 7514. MOTURIKI: Seemann 244. NGAU: Hills east of Herald Bay, inland from Sawaieke, Smith 7749. VANUA LEVU: MBUA: Upper Ndama River Valley, Smith 1602. MathUATA: Summit ridge of Mt. Numbuiloa, east of Lambasa, Smith 6411. ThaKAUNDRove: Mt. Mariko, Smith 424. TAVEUNI: Slopes of Mt. Manuka, east of Wairiki, Smith 8155 .

We have seen no representatives of species group Tephrosanthae from Samoa, but members of the group are doubtless numerous to the west of Fiji. A New Hebridean relative of Psychotria tephrosantha is P. nacdado Guillaumin (in J. Arnold Arb. 13:9. 1932) (cf. Smith, 1969), which probably also occurs in the Santa Cruz and Solomon Islands as P. purpurea Merr. \& Perry (in J. Arnold Arb. 27: 195. 1946).

74. Psychotria exilis A. C. Sm. in Pacific Sci. 23: 381. 1969; J. W. Parham, Pl. Fiji Isl. ed. 2. 284. 1972.

Figures 100A, 104D.

A scandent shrub 1-2 m. high, apparently rare and local in dense forest at an elevation of 300-700 m. Flowers have been obtained in March and fruits in November.

TyPIFICATION: The type is Smith 620 (BISH HOLOTYPE; many ISOTYPEs), collected Nov. 28, 1933, on the southwestern slope of Mt. Mbatini, Thakaundrove Province, Vanua Levu.

DistRIBUtion: Known only from Fiji and thus far from a limited area of Vanua Levu. (BISH)

Avallable collection: VANUA LEVU: ThaKaUndrove: Waivula, east of Savusavu, Krauss 1015

75. Psychotria parvula A. Gray in Proc. Amer. Acad. Arts 4:45. 1858; Seem. Viti, 437. 1862.

Figure $110 \mathrm{D}$.

Psychotria serpens sensu A. Gray in Proc. Amer. Acad. Arts 4: 306. 1859; Seem. Fl. Vit. 136. 1866; Drake,

Ill. Fl. Ins. Mar. Pac. 199. 1890; Fosberg in Bull. Torrey Bot. Club 67: 424. 1940; non L.

Psychotria sarmentosa sensu Seem. in Bonplandia 9: 257. 1861, Viti, 437. 1862; non Bl.

Psychotria minor Turrill in J. Linn. Soc. Bot. 43: 27. 1915.

Psychotria serpens var. parvula Fosberg in Sargentia 1: 131. 1942; J. W. Parham, Pl. Fiji Isl. 208. 1964, ed. 2. 290.1972.

Liana or scrambling shrub (occasionally indicated as a compact tree to $4 \mathrm{~m}$. high or a dwarf shrub as small as $50 \mathrm{~cm}$. high, but then doubtless with scandent branches), occurring at elevations of $400-1,323 \mathrm{~m}$. in dense forest or in crest thickets. The corollas are white and the fruits at maturity are dull or pale yellow. Flowers have been collected in months scattered between November and July, fruits more or less throughout the year. 
TyPifiCation And NOMEnClature: Psychotria parvula was based on $U$. S. Expl. Exped. (us 73914 HOLOTYPE; ISOTYPES at K, NY), collected in 1840 in Fiji without further locality, although "Mathuata" (Vanua Levu) is noted on the holotype label; no other material of the species from Mathuata Province is at hand, but that locality is probably correct. The type of P. minor is im Thurn F.2I (K HOLOTY PE), collected May 1, 1905, on the summit of Mt. Tomanivi, Mba Province, Viti Levu. The two types are surely referable to the same concept.

Distribution: Endemic to Fiji and now known from three of the high islands. All specimens examined by us are here cited.

LOCAL NAME: The name tomoli ni veikau was noted in upper Naitasiri.

Avallable Collections: VITI LEVU: MBa: Vicinity of Nandarivatu, Tothill 259, 261, Degener 14378. DA 12383; Mt. Nanggaranambuluta, east of Nandarivatu, $O$. \& I. Degener 32099, DA 13950; upper slopes and summit of Mt. Tomanivi, Vaughan 3418. Smith 5150, DA 7097, 7099, 12689 (Melville et al. 7067). NandRonga \& Navosa: Nausori Highlands, DA 13794 (DF 430, Vetawa 23), O. \& I. Degener 32162; northern portion of Rairaimatuku Plateau, between Nandrau and Nanga, Smith 5463, 5589. NAMosi: Mt. Voma, Seemann 245. NaITASIRI: Wainimala Valley, divide between Wainisavulevu and Numbulolo Creeks, St. John 18343. Vrti LeVu without further locality, Parks 20697. OVALAU: Mt. Tana Lailai and adjacent ridge, Graeffe, Dec., 1864, Smith 7702; summit of Mt. Ndelaiovalau and adjacent ridge, Smith 7379. VANUA LEVU: ThaKaUndrove: Mt. Kasi, Yanawai River region, Smith 1760; summit of Mt. Mbatini, Smith 692, 693. FiJI without further locality, Horne 778, 824.

Although Gray almost immediately reduced his Psychotria parvula to P. serpens L., and although Fosberg indicated the Fijian taxon to merit only varietal status, surely such treatments completely ignore the striking stipular differences between $P$. parvula and the eastern Asiatic populations of $P$. serpens (cf. Ohwi, Fl. Japan (in English), 826. 1965; E. Walker, Fl. Okinawa \& S. Ryukyu Isl.982. 1976). In the Asiatic taxon the stipules, although similarly evanescent at the ultimate node, are comparatively conspicuous, oblong, $2-4 \times 2-3 \mathrm{~mm}$., and obviously rounded at apex; in $P$. parvula they are deltoid to ovate, less than $1 \mathrm{~mm}$. long and broad, and often obtuse to mucronulate at apex. In other respects the taxa are similar, although in general the Fijian material has somewhat more congested and usually smaller leaves than $P$. serpens. In view of the dependability of stipular characters (even though they are not easily observed) in Psychotria, one cannot discount them, especially when taxa are widely allopatric.

76. Psychotria macroserpens Fosberg in Sargentia 1: 131. 1942; J. W. Parham, Pl. Fiji Isl. 206. 1964, ed. 2. 288. 1972.

FIGURE 100B.

Liana in limestone forest, apparently rare at elevations from sea level to perhaps $100 \mathrm{~m}$. Although the corolla is noted as white, no flowers have been observed on the type duplicates examined. The fruit is white.

TYPIFICATION: The type is Smith 1246 (NY HOLOTYPE; many ISOTYPES), collected March 2, 1934, on Kambara.

Distribution: Endemic to Fiji and known only from the type collection, which is apparently the only material of species group Tephrosanthae yet obtained in the Lau Group.

LOCAL NAME: Wa ni lekutu.

33. Morinda L. Sp. Pl. 176. 1753; Seem. Fl. Vit. 128. 1866; Hook. f. in Benth. \& Hook. f. Gen. Pl. 2: 117. 1873; K. Schum. in Engl. \& Prantl, Nat. Pflanzenfam. IV. 4: 138. 1891; Fosberg in Sargentia 1: 122. 1942; Backer \& Bakh. f. Fl. Java 2: 349. 
1965; Verdcourt in Fl. Trop. E. Afr. Rub. 145. 1976; S. Darwin in Allertonia 2: 33. 1979; K. M. Wong in Malayan Nat. J. 38: 89. 1984.

Trees, shrubs, or lianas, the stipules interpetiolar, free or united with bases of petioles, undivided, sometimes foliaceous; inflorescences capitate, the capitula pedunculate or rarely sessile, terminal or axillary with 1-several at each node, sometimes appearing leaf-opposed, frequently in umbel-like clusters, the bracts small, the calyx tubes of flowers fused at least basally; flowers $\zeta$ (often heterostylous) or unisexual, (3-)5(-7)-merous; calyx limb short, truncate to dentate, persistent; corolla often fleshy, infundibular to hypocrateriform, glabrous or infrequently pilose without, often barbate-pilose in throat, the lobes valvate in bud; stamens inserted in corolla throat, the filaments short, the anthers included or usually exserted; ovary 2-or incompletely 4-locular, the ovules solitary, erect, subbasal in each locule; style 2-branched, included or exserted; fruit a fleshy syncarp containing several 1-seeded pyrenes, or these rarely united into a 2- or 4-locular putamen.

LeCtotype SPecies: Morinda royoc L. (vide Hitchcock, Prop. Brit. Bot. 132. 1929), one of Linnaeus's three original species.

Distribution: Pantropical, with about 80 species. Five species occur in Fiji, one probably an aboriginal introduction and three of the others apparently endemic.

Identifications of Fijian material of Morinda have been confused by the reference of much of it to M. umbellata L. (Sp. Pl. 176. 1753), typified by Hermann (BM) from Ceylon (cf. Seemann, 1866, p. 129). Ceylonese and continental specimens of $M$. umbellata have long stipules and pilose domatia, a combination of dependable characters that does not occur in the Fijian Region and eastward, although true $M$. umbellata may possibly occur in parts of Malesia (Backer and Bakhuizen, 1965, p. 350), Micronesia (Fosberg, Sachet, and R. Oliver in Micronesica 15: 272. 1979), and Australia (Ross in Stanley and Ross, Fl. S.-E. Queensland 2: 335. 1986); we suggest that such reports require verification.

It is interesting to note that Gray in 1858 described precisely the four indigenous species of Morinda in Fiji that are now recognizable and well differentiated.

\section{KEY TO SPECIES}

Trees or shrubs; stipules chartaceous, broadly deltoid, 7-20 $\mathrm{mm}$. long, obtuse to rounded at apex, often auriculate-cordate and recurved; branchlets obtusely quadrangular; leaf blades large, often exceeding $30 \times 15 \mathrm{~cm}$., the domatia when present pilose; capitula solitary and often leaf-opposed; corollas 8-12 $\mathrm{mm}$. long; syncarps large, 3-10 cm. in diameter at maturity; presumably aboriginally introduced, now

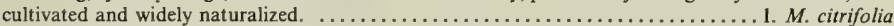

Lianas, often high-climbing and copiously branched; stipules membranous and with obvious raphid bundles, acute to acuminate at apex, appressed to subterete branchlets and not recurved; leaf blades not exceeding $15 \times 7.5 \mathrm{~cm}$; capitula clustered at ultimate node or their peduncles aggregated on a primary peduncle, rarely appearing axillary at penultimate and antepenultimate nodes; indigenous species.

Stipules short, 0.8-2 mm. long, laterally connate, acute at apex; vegetative parts glabrous, the domatia when present pilose and lacking membranous or cartilaginous margins; capitula borne in clusters of 2-6; corollas at anthesis $5-8 \mathrm{~mm}$. long.

Syncarps at maturity $20-30 \mathrm{~mm}$. in diameter, the calycine rims $4-5 \mathrm{~mm}$. in diameter, each surrounded by a pale circular ridge $7-10 \mathrm{~mm}$. in diameter; capitula at anthesis $5-8 \mathrm{~mm}$. in diameter (excluding corollas), with 15-22 flowers; corollas copiously tomentose at throat and on lobes within; anthers about $2 \mathrm{~mm}$. long; peduncles of capitula $2-4$ at ultimate node, to $2 \mathrm{~cm}$. long, minutely puberulent; petioles $1.5-3 \mathrm{~cm}$. long; leaf blades 7-15 $\times(2-)$ 4-7 cm., often acuminate at apex, the venation copiously reticulate but only faintly prominulous. $\ldots \ldots \ldots \ldots \ldots \ldots \ldots \ldots \ldots ., \ldots \ldots$ grayi

Syncarps at maturity 7-12 $\mathrm{mm}$. in diameter, the calycine rims $1-2 \mathrm{~mm}$. in diameter; capitula at anthesis 4-5 mm. in diameter (excluding corollas), with 8-15 flowers; corollas sparsely pilose at throat; anthers 2.5-3 mm. long; peduncles of capitula $0.5-1 \mathrm{~cm}$. long, glabrous, 3-6 at ultimate node or aggregated on a primary peduncle to $2.5 \mathrm{~cm}$. long; petioles $0.8-1.5 \mathrm{~cm}$. long; leaf blades $5-9(-10) \times$ $1.5-5 \mathrm{~cm}$., obtuse to obtusely acuminate at apex, the venation immersed and not obvious. 
Stipules comparatively elongate, 4-12 mm. long; domatia when present glabrous and with incurved, membranous or cartilaginous margins; peduncles of capitula borne in clusters of 3-18 or aggregated on a primary peduncle to $1.5 \mathrm{~cm}$. long, the capitula at anthesis $3-5 \mathrm{~mm}$. in diameter (excluding corollas), with 7-30 flowers; corollas at anthesis $3-5 \mathrm{~mm}$. long, copiously villose-barbate in throat; anthers $0.7-1.5 \mathrm{~mm}$. long; syncarps at maturity $6-12 \mathrm{~mm}$. in diameter, the calycine rims $1-1.5 \mathrm{~mm}$. in diameter.

Branchlets, leaves, peduncles, and syncarps velutinous-pubescent with several-celled hairs; stipules firmly connate into a copiously hispidulous tube, free and acute only in apical $0.5-1 \mathrm{~mm}$., the tube sometimes splitting down one side, usually cleanly caducous; petioles $(0.8-) 1-2.5 \mathrm{~cm}$. long; leaf blades (4-) 6-12 $\times(2-)$ 4-7.5 cm., membranaceous or thin-chartaceous, subcordate to obtuse at base, caudate-acuminate to obtuse at apex, the secondary nerves $6-10$ pairs, the venation slightly prominulous beneath; corollas copiously short-pilose without. $\ldots \ldots \ldots \ldots \ldots \ldots . .$. mollis

Branchlets, leaves, and syncarps essentially glabrous, the peduncles glabrous or obscurely puberulent; stipules glabrous or sparsely pubescent, laterally highly connate and often separating along one side, gradually acuminate or acute at apex, often irregularly eroding and leaving a short, ragged remnant; petioles $0.8-1.5 \mathrm{~cm}$. long; leaf blades (3-) 5-12 $\times(1.5-) 2-6 \mathrm{~cm}$, coriaceous or thickchartaceous, acute to attenuate at base, rounded or retuse to short-acuminate at apex, the secondary nerves 4-8 pairs, the venation prominulous, copious, and obvious beneath; corollas

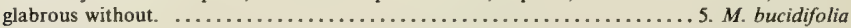

1. Morinda citrifolia L. Sp. Pl. 176. 1753; Seem. in Bonplandia 9: 256. 1861, Viti, 438. 1862, Fl. Vit. 129. 1866; Drake, Ill. Fl. Ins. Mar. Pac. 195. 1890; Reinecke in Bot. Jahrb. 25: 689. 1898; Rechinger in Denkschr. Akad. Wiss. Wien 85: 377. 1910; Guillaumin in J. Arnold Arb. 13: 8. 1932; Christophersen in Bishop Mus. Bull. 128: 206. 1935; Yuncker in op. cit. 178: 113. 1943, in op. cit. 184: 65. 1945, in op. cit. 220: 258. 1959; J. W. Parham, Pl. Fiji Isl. 198. 1964; Sykes in New Zealand Dept. Sci. Indust. Res. Bull. 200: 180. 1970; St. John \& A. C. Sm. in Pacific Sci. 25: 339. 1971; B. E. V. Parham in New Zealand Dept. Sci. Indust. Res. Inform. Ser. 85: 43, 91. 1972; Morat \& Veillon in Bull. Mus. Nat. Hist. Nat. (Paris) IV. 7, Sect. B, Adansonia 3: 316. 1985.

Morinda citrifolia var. citrifolia; J. W. Parham, Pl. Fiji Isl. ed. 2. 278. 1972.

As noted in Fiji, Morinda citrifolia is a tree or shrub $1.5-11 \mathrm{~m}$. high, sometimes gnarled or compact, cultivated or abundantly naturalized along roads and rocky coasts, in thickets, often along creeks or on the edges of mangrove swamps, or in open or even dense forest at elevations from near sea level to $450 \mathrm{~m}$. The corollas are white and the syncarps are green or yellowish, becoming black at maturity. Flowers and fruits are seen throughout the year.

TyPIFICATION: Linnaeus mentioned earlier references, including Flora Zeylanica; presumably a Hermann specimen would be a suitable lectotype.

Distribution: Probably indigenous in Indo-Malesia, but with an extended distribution throughout the Pacific, including Hawaii, and other tropical areas. It is considered an aboriginal introduction into Pacific areas (St. John in Occas. Pap. Bishop Mus. 18: 85. 1945, in Pacific Sci. 33:369. 1980), being extensively utilized as a dye plant, for medicine, and as an emergency food plant. In places it is thoroughly established as a common understorey plant in coastal forest. Although Guppy (Obs. Nat. Pac. 2: 135. 1906) mentions Morinda citrifolia as a widespread littoral species distributed by currents, he also states (pp. 107, 112) that the floating power of the syncarp is derived from empty seed cavities. Since $M$. citrifolia is morphologically a very isolated taxon that is related to no other Pacific species, an argument for its dispersal by natural means seems dubious. Although the species is very frequent in Fijian villages and along coasts, only 30 collections from seven islands are at hand. 
LOCAL NAMES AND USES: The usual name is kura, but also noted are kura kana and $k u r u$. Although the ripe syncarps are bitter and unpleasant to the taste, they are edible. A yellow dye is prepared from the root and a red dye from the bark. The leaves and young fruits are used medicinally for usually unspecified ailments, sometimes to alleviate throat irritation.

RePRESENTATIVE COLLECTIONS: VITI LEVU: MBA: Tavakumbu, Lautoka, DA 10727. NandRongA \& Navosa: Southern slopes of Nausori Highlands, in drainage of Namosi Creek above Tumbenasolo, Smith 4579. Serua: Vicinity of Navua, Parks 20401. Namosi: Vicinity of Namosi, Gillespie 2812. Ra: Rakiraki, $D A$ 7934. NaITASIRI: Vunindawa, DA 10014. TaIlevu: Matavatathou, DA 9243 (McKee 2808). Rewa: Suva Point, Weiner 71-7-63. OVALAU: Valley of Mbureta and Lovoni Rivers, Smith 7500. VANUA LEVU: Mbua: Woods above Nandi, Milne. Mathuata: Semaniura, Lambasa, DA 10478. Thakaundrove: Near Wainingata turnoff, DA 16848. MOALA: North coast, Smith 1387. VANUA MBALAVU: Near Lomaloma, Garnock-Jones 1084. LAKEMBA: Nukunuku Village, Garnock-Jones 813. FULANGA: On limestone, Smith 1109. Fiji without further locality, Seemann 225.

The following taxon is believed worth noting as a probable cultivar.

\section{la. Morinda citrifolia L. cv. 'Potteri.'}

Morinda citrifolia var. potteri Degener, Nat. So. Pac. Exped. Fiji, 296. I949; J. W. Parham, Pl. Fiji Isl. ed. 2. 278.1972.

Shrub or small tree 2-4 m. high, cultivated in gardens and perhaps sparingly naturalized in waste places near sea level, the leaves with pale green or white blotches. Flowers and fruits are similar to those of the usual form and have been noted between November and March.

TYPIFICATION: The type of Morinda citrifolia var. potteri is Degener 19222 (NY HOLOTYPE; ISOTYPE at BISH), taken in March, 1949, from a plant grown at Mokuleia Beach, Oahu, Hawaii. The plants in Degener's garden at Mokuleia and those at the Foster Gardens in Honolulu were grown from seeds sent from Fiji by Degener to Colin Potter, then custodian of Foster Gardens. Doubtless the seeds were originally obtained from the same plant as Degener \& Ordonez 13663 (BISH, K), collected in November or December, 1940, a cultivated plant from Suva, Rewa Province, Viti Levu.

DiSTRIBUTION: Whether the plant with variegated leaves occurs naturally outside of Fiji is not known to us, but in Suva it is occasionally seen in garden cultivation. It may have arisen at various times and places as a sport from its widespread parent, but we believe it to be of the nature of a cultivar rather than meriting varietal status.

LOCAL NAME AND USE: This form of kura is locally considered an ornamental.

AVAILABLE COLLECTIONS: VITI LEVU: REWA: Lami, in private garden, DA 16476; Suva, in private garden, $D A 16221$.

2. Morinda grayi Seem. Fl. Vit. 130. 1866; Drake, Ill. Fl. Ins. Mar. Pac. 196. 1890; Fosberg in Sargentia 1: 122. 1942; J. W. Parham, Pl. Fiji Isl. 198. 1964, ed. 2. 278. 1972.

FiguRE 115A-C.

Morinda lucida A. Gray in Proc. Amer. Acad. Arts 4:41. 1858; Seem. Viti, 438. 1862; non Benth. (1849). Morinda sp. foliis glabris Seem. in Bonplandia 9: 256, p. p. 1861.

Morinda myrtifolia sensu A. Gray in Bonplandia 10:36, p. p. 1862, in Proc. Amer. Acad. Arts 5: 318 , p. p. 1862; Seem. Viti, 437, p. p. 1862, Fl. Vit. 129, p. p. 1866; non A. Gray (1858).

A liana occurring from near sea level to $400 \mathrm{~m}$. in dense, dry, or secondary forest, sometimes in beach forest or in forest patches in open country. The corolla has been noted as yellowish white to pale orange or purple-tinged without and is whitepubescent within; the mature syncarps, to $3 \mathrm{~cm}$. in diameter, are brown or blackish. Flowers have been collected between August and January, fruits between February and August. 

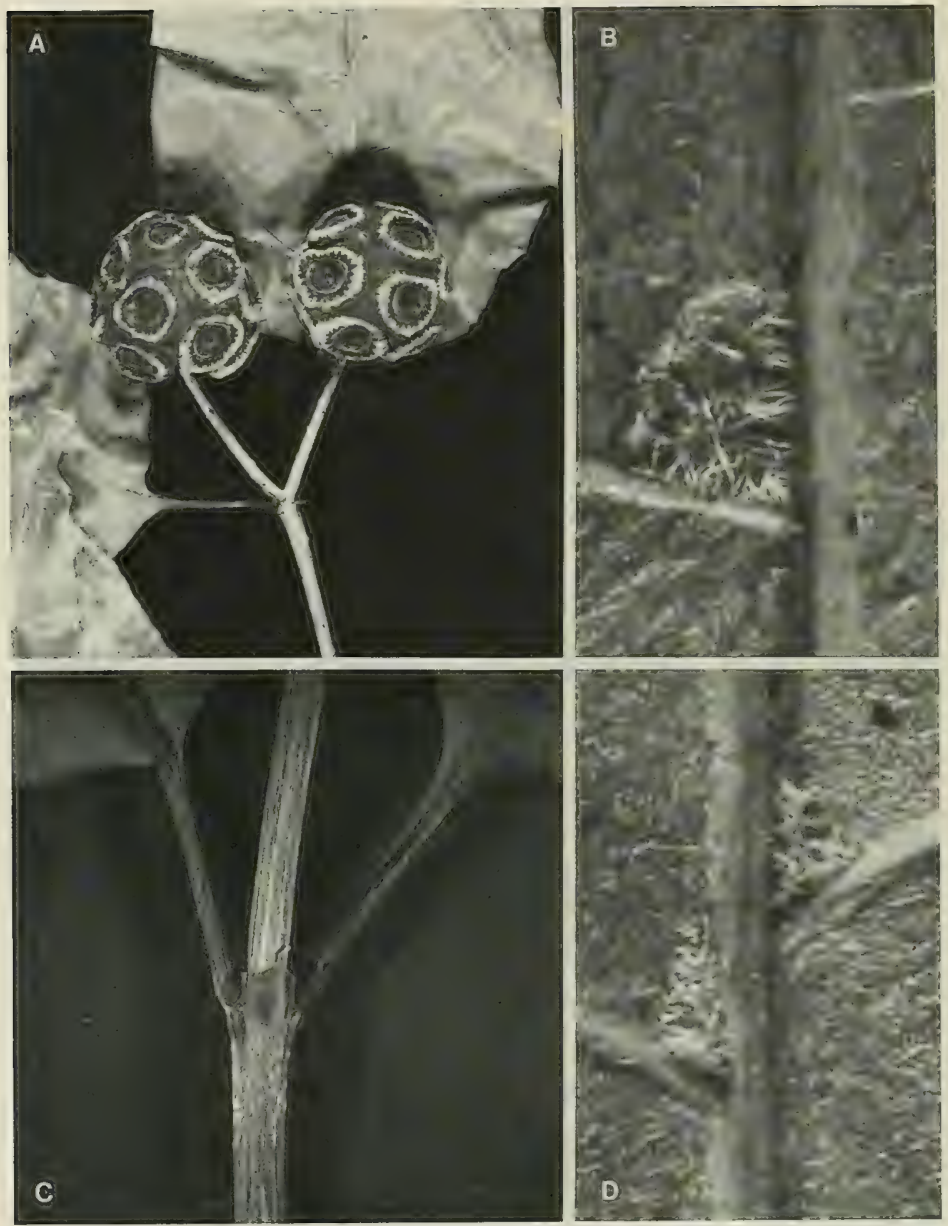

FIGURE 115. A-C, Morinda grayi; A, syncarps and proximal portions of leaves, $\times 1$; B, lower surface of leaf blade along costa, showing secondaries, veinlets, and a domatium, $\times 20$; C, branchlet with stipules and proximal portions of leaves, $\times 4$. D, Morinda myrifolia; lower surface of leaf blade along costa, showing secondaries and domatia, $\times 20$. A from Smith 1521, B from Smith 6869, C from Smith 9317, D from Smith $4 I 75$. 
Typification: Morinda lucida A. Gray, for which $M$. grayi was a new name, is typified by $U$. S. Expl. Exped. (US 62353 HOLOTYPE; ISOTYPES at GH, K), collected in Fiji without further locality in 1840.

Distribution: Endemic to Fiji and thus far known from three of the high islands; 28 collections have been examined.

LOCAL NAME: Wa vatu (Mbua).

REPRESENTATIVE COLLeCtIONS: VITI LEVU: NandRONGA \& Navosa: Uluvatu, vicinity of Mbelo, near Vatukarasa, Degener 15261. Serua: Hills west of Waivunu Creek, between Ngaloa and Korovou, Smith 9317. Namosi: Navunikambi, Wainikoroiluva River, DA L.13308 (Berry 14). NAITASIRI: Viria-Naisonggo trail, Parks 20467; Tamavua, Yeoward 53. OVALAU: 3 miles northwest of Levuka, Gillespie 4550. VANUA LEVU: Mbua: Southern portion of Seatovo Range, Smith 1521. Mathuata: Seanggangga Plateau, in drainage of Korovuli River, vicinity of Natua, Smith 6869; Lambasa, behind mangrove formation, Greenwood 475; Mathuata coast, Seemann 223, p. p. (BM, GH, K). Thakaundrove: Waiwai, Savusavu Bay, Horne; hills south of Nakula Valley, Smith 348.

Morinda grayi is suggestive of the Papuasian M. glomerata(B1.) Miq., like which it has short stipules, pilose domatia, and large syncarps. In $M$. glomerata the syncarps have the component fruits cylindrically projecting some 3-5 mm., whereas in $M$. grayi the mature syncarps are essentially smooth, the component fruits being scarcely elevated above the level of capitular tissue.

3. Morinda myrtifolia A. Gray in Proc. Amer. Acad. Arts 4: 41. 1858; Seem. Fl. Vit. 129, p. p. 1866; Fosberg in Bull. Torrey Bot. Club 67: 422.1940.

Figures 115D, 116A \& B.

Morinda umbellata sensu Forst. f. Fl. Ins. Austr. Prodr. 17. 1786; non L.

Morinda phyllireoides sensu Seem. in Bonplandia 9: 256. 1861; non Labill.

Morinda phillyreoides sensu Seem. ex A. Gray in Bonplandia 10:36. 1862, in Proc. Amer. Acad. Arts 5: 318. 1862; Seem. Viti, 437. 1862; non Labill.

Morinda forsteri Seem. Fl. Vit. 129. 1866; Drake, Ill. Fl. Ins. Mar. Pac. 196. 1890; Reinecke in Bot. Jahrb. 25: 689. 1898; Gibbs in J. Linn. Soc. Bot. 39: 151. 1909; Guillaumin in J. Arnold Arb. 13: 8. 1932; Fosberg in Bull. Torrey Bot. Club 67: 422. 1940; Yuncker in Bishop Mus. Bull, 178: 113. 1943.

Morinda umbellata var. forsteri Fosberg in Sargentia 1: 123. 1942; Yuncker in Bishop Mus. Bull. $220: 259$. 1959; J. W. Parham, Pl. Fiji Isl. 198. 1964, ed. 2. 279. 1972; Sykes in New Zealand Dept. Sci. Indust. Res. Bull. 200: 180. 1970; Morat \& Veillon in Bull. Mus. Nat. Hist. Nat. (Paris) IV. 7, Sect. B, Adansonia 3: 316. 1985.

A liana found from near sea level to an elevation of $1,195 \mathrm{~m}$. in thin or open forest, in thickets especially on ridges, and in the forest-grassland transition. The fragrant flowers have the corolla white or cream-yellow, sometimes pink-tinged, and greenish white within; the anthers are white and the style pale green; and the mature syncarps are dull purple to purple-black. Flowers have been noted between February and October, fruits in practically every month.

TYPIFICATION AND NOMENCLATURE: The type of Morinda myrtifolia is $U$. S. Expl. Exped. (US 62351 HOLOTYPE; ISOTYPE at K), collected in 1840 in Fiji without further locality. In describing $M$. forsteri Seemann listed four collections: Forster and Nelson from the Society Islands, Home from Tonga, and Seemann 222 (actually M. bucidifolia), as well as Parkinson's unpublished drawing (for which there is a Banks \& Solander voucher at BM); doubtless his concept was primarily based on Forster's 1786 record of "99. M. umbellata." An appropriate citation is: $J$. R. \& G. Forster (K LECTOTYPE here designated; fragmentary ISOLECTOTYPE at BM), collected in the Society Islands during Cook's second voyage. The Exploring Expedition material has slightly the narrower leaves that lack domatia, but otherwise (stipules, leaf texture and venation, etc.) the 
concepts are scarcely separable, and numerous intermediate collections (with characteristic domatia) are available; absence of domatia from many leaves is to be expected in Morinda.

Distribution: Morinda myrtifolia is the most widespread Pacific species of the genus, found from New Caledonia to the Marquesas, Tuamotu, and Austral Islands. In Fiji it is now known from seven islands and about 45 collections.

LOCAL NAMES: Wa kurukuru (Mba) and wa lukamba (Nandronga \& Navosa), each recorded only once.

RePresentative COllections: VITI LEVU: Mba: Summit of Mt. Koroyanitu, high point of Mt. Evans Range, Smith 4175; Naloto Range, DA 14762; slopes of escarpment north of Nandarivatu, Smith 6257; Nandarivatu, Gibbs 561, Greenwood 884. NANDRONGA \& NavosA: Northern portion of Rairaimatuku Plateau, between Nandrau and Nanga, Smith 5450. NAmosi: Vicinity of Namuamua, Gillespie 2980. RA: Yanggara, Greenwood 796. NAITASIRI: Vatavula, Wainimala River, Gibbs 538. TAILevu: Nggelekuro, $D A$ 13600. REWA: Mt. Korombamba, Webster \& Hildreth 14086. KANDAVU: Hills above Namalata and Ngaloa Bays, Smith 198. VANUA LEVU: MATHUATA: Southern base of Mathuata Range, north of Natua, Smith 6804; Lambasa, Greenwood 476. ThaKAUndrove: Uluinambathi Mt., Savusavu Bay region, Degener \& Ordonez 13956a. VANUA MBALAVU: Northern limestone section, Smith 1467. LAKEMBA: Seemann 226. KAMBARA: Central basin, Bryan 503. FULANGA: On limestone, Smith 1186.

4. Morinda mollis A. Gray in Proc. Amer. Acad. Arts 4:41. 1858, in Bonplandia 10: 36. 1862, in Proc. Amer. Acad. Arts 5: 318. 1862; Seem. Viti, 437. 1862, Fl. Vit. 130. 1866; Drake, Ill. Fl. Ins. Mar. Pac. 196. 1890; Fosberg in Sargentia 1: 124. 1942; J. W. Parham, Pl. Fiji Isl. 198. 1964, ed. 2. 278. $1972 . \quad$ Figure 116C \& D.

Morinda sp. foliis pubescentibus Seem. in Bonplandia 9: 256. 1861.

A liana, scattered and comparatively infrequent, found in open forest or dry woods from near sea level to $600 \mathrm{~m}$. The fruits are noted as being green and turning orange at maturity. Flowers and fruits have been obtained only between February and June, as far as dates are recorded.

TyPIFICATION: Morinda mollis was based on U. S. Expl. Exped. (US 62377 HOLOTYPE; ISOTYPE at K), collected in 1840 in Fiji without further locality.

Distribution: Endemic to Fiji and now known from only 13 collections from four islands.

LOCAL NAME: Mbumbuthorua (Mba), recorded only once.

Available collections: MAMANUTHAS: Nggalito Island, Malolo Group, O. \& I. Degener 32217. 32221, 32236. VITI LEVU: MBA: Lautoka, Greenwood 578; vicinity of Nalotawa, eastern base of Mt. Evans Range, Smith 4448. Nandronga \& Navosa: Nausori Highlands, DA 13393; Mbulu, near Sovi Bay, Degener 15030; Uluvatu, vicinity of Mbelo, near Vatukarasa, Degener 15262. TAlLevu: Uthunivanua, DA 9248 (McKee 2814). OVAlAU: Port Kinnaird, Seemann 224. VANUA LEVU: Mathuata: Lambasa, Greenwood 578A. FIJI without further locality, Horne 1123.

5. Morinda bucidifolia A. Gray in Proc. Amer. Acad. Arts 4: 41, as M. bucidaefolia. 1858; Gillespie in Bishop Mus. Bull. 74: 40. fig. 56. 1930. Figure 117.

Morinda umbellata sensu Seem. in Bonplandia 9: 256. 1861, Viti, 437. 1862; Fosberg in Sargentia 1: 122 , p. p. 1942; S. Darwin in Allertonia 2: 33. fig. 3, A. 1979; non L.

Morinda sp. folits glabris Seem. in Bonplandia 9: 256, p. p. 1861.

Morinda bucidaefolia A. Gray ex Seem. Viti, 438. 1862, Fl. Vit. 130. 1866; Drake, Ill. Fl. Ins. Mar. Pac. 195. 1890; Fosberg in Bull. Torrey Bot. Club 67: 422. 1940.

Morinda myrtifolia sensu A. Gray in Bonplandia 10: 36, p. p. 1862, in Proc. Amer. Acad. Arts 5: 318, p. p. 1862, Seem. Viti, 437, p. p. 1862, Fl. Vit. 129, p. p. 1866; Drake, Ill. Fl. Ins. Mar. Pac. 196, p. p. 1890; non A. Gray (1858).

Figure 116. A \& B, Morinda myrifolia; A, apical portion of branchlet with foliage and inflorescences aggregated on a primary peduncle, $\times 2$; B, branchlet with stipules and proximal portions of leaves, $\times 4$. C \& D, Morinda mollis; C, branchlet with stipules and proximal portions of leaves, $\times 4 ; \mathrm{D}$, lower surface of leaf blade along costa, showing secondaries, veinlets, indument, and domatia, $\times 20$. A from Smith $6257, \mathrm{~B}$ from Smith 1186, C from O. \& I. Degener 32236, D from Smith 4448. 

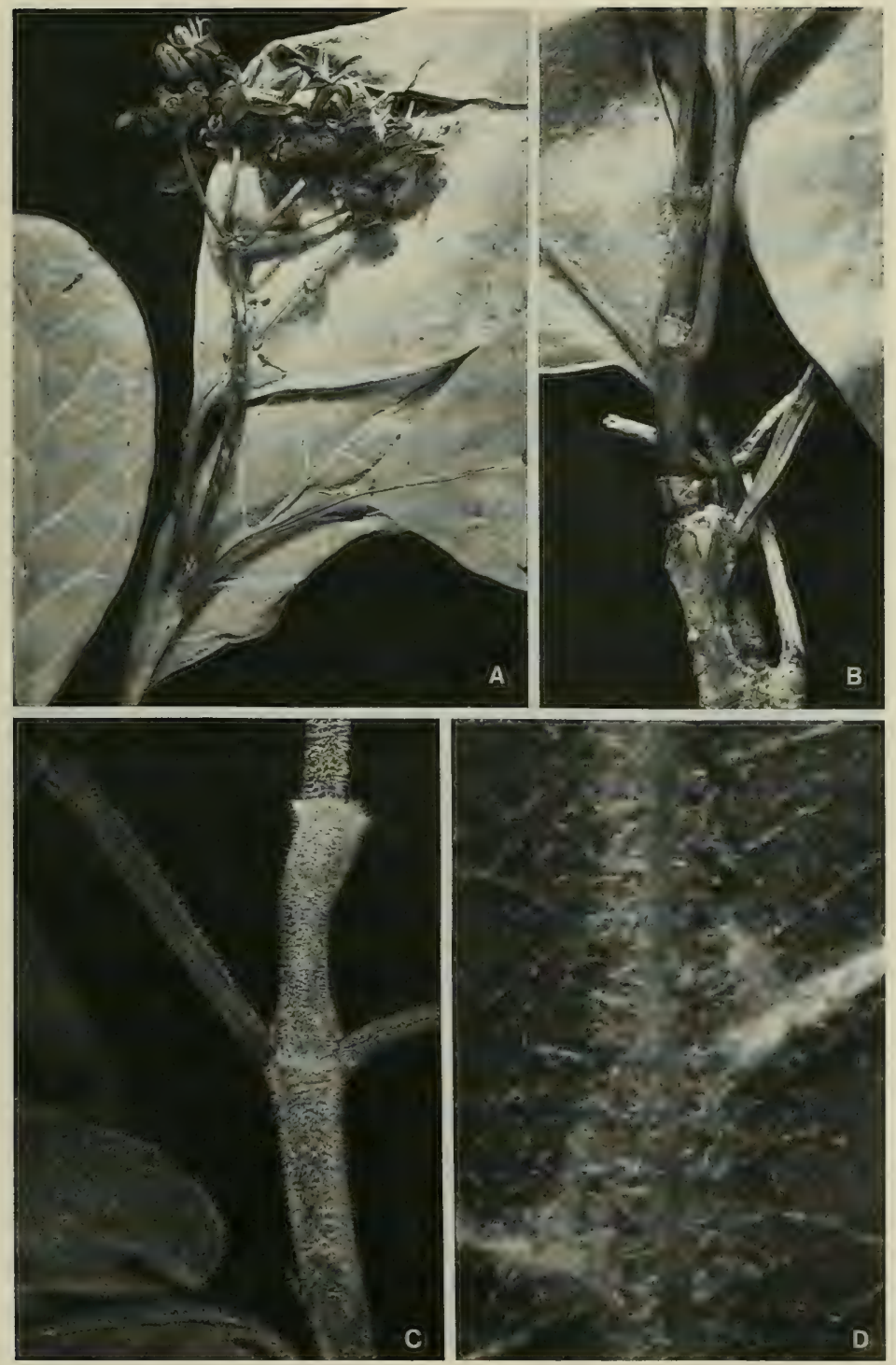

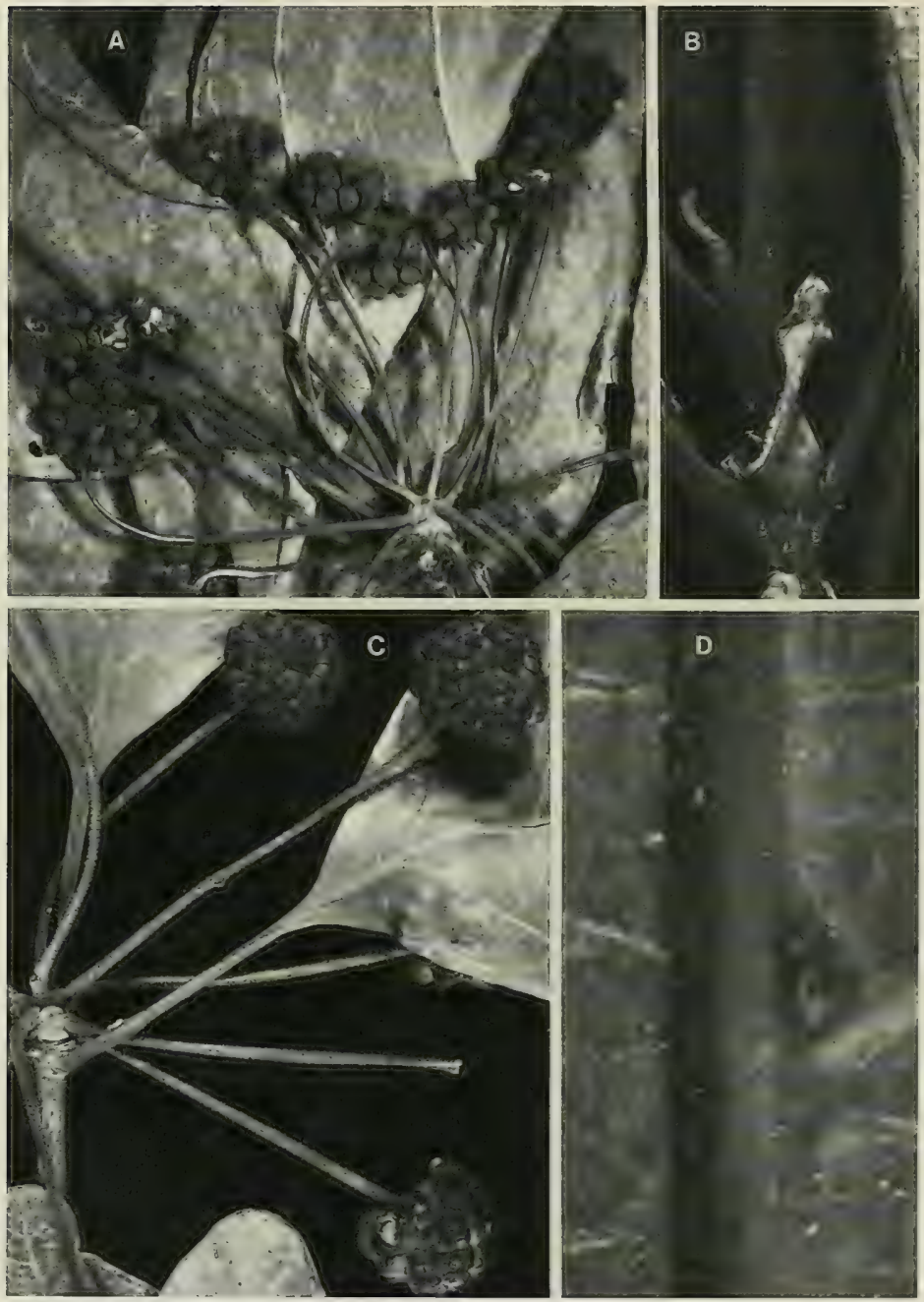

Figure 117. Morinda bucidifolia; A, inflorescences and foliage, $\times 2$; $\mathrm{B}$, branchlet with stipules and petioles, $\times 4 ; \mathrm{C}$, syncarps and proximal portions of leaves, $\times 2 ; \mathrm{D}$, lower surface of leaf blade along costa, showing a secondary nerve with an axillary domatium, $\times 20$. A from Degener 15115 , B from DA 15472, C from Smith 7135, D from $D A 13676$. 
Morinda nandarivatensis Gillespie in Bishop Mus. Bull. 74: 40. fig. 57. 1930; J. W. Parham, PI. Fiji Is1. 198. 1964, ed. 2. 278.1972.

Morinda umbellata var. bucidifolia Fosberg in Sargentia 1: 123, as var. bucidaefolia. 1942; J. W. Parham, Pl. Fïi Isl. 198. 1964, ed. 2. 278. 1972.

Morinda umbellata var. archboldiana Fosberg in Sargentia 1: 123. 1942; J. W. Parham, Pl. Fiji Isl. 198. 1964, ed. 2. 278. 1972.

An often copiously branching and high-climbing liana, locally abundant at all elevations (from near sea level to $1,323 \mathrm{~m}$.) in littoral forest, dense or open forest, or in the thickets of crests and ridges. At anthesis the calyx is frequently purplish, and the corolla usually has the tube purple and the lobes yellow to white; the anthers are yellow; and the mature syncarps are purple to black. Flowers and fruits have been obtained in every month.

TYPIFICATION AND NOMENCLATURE: Three types are involved in the above citations. That of Morinda bucidifolia is $U$. S. Expl. Exped. (US 62352 HOLOTYPE; ISOTY PES at GH, K), collected in 1840 at Mbua (Sandalwood) Bay, Mbua Province, Vanua Levu. Morinda nandarivatensis is typified by Gillespie 3786 (BISH HOLOTYPE), collected Nov. 16, 1927, on Mt. Nanggaranambuluta, east of Nandarivatu, Mba Province, Viti Levu. The type of $M$. umbellata var. archboldiana is Degener 15115 (us 2333933 HOLOTYPE; ISOTYPES at A, BISH, K, US 1759496), obtained April 29, 1941, at Thulanuku, vicinity of Ngaloa, Serua Province, Viti Levu. While minor differences among these collections are observable, the distinctions are inconsequential in view of normal variation.

Distribution: Endemic to Fiji but known from only three of the islands; although 74 collections are at hand, all but six or seven of them come from Viti Levu.

LOCAL NAMES: Frequently noted merely as wa kau (woody vine), this abundant species has been recorded in Namosi Province as wa voni, wa vani, and wa pani.

REPRESENTATIVE COLLeCtIons: VITI LEVU: MBA: Summit of Mt. Koroyanitu, high point of Mt. Evans Range, Smith 4176; upper slopes of Mt. Koromba, Smith 4645; Nandarivatu, Tothill 232; Mt. Nanggaranambuluta, Gillespie 3673; summit and slopes of Mt. Tomanivi, Smith 5147, DA 12729 (Melville et al. 7119 ). NANDRONGA \& NAvOSA: Southern slopes of Nausori Highlands, in drainage of Namosi Creek above Tumbenasolo, Smith 4587. Serua: Hills between Navua River and Wainiyavu Creek, near Namuamua, Smith 8985. NAmosi: Summit of Mt. Naitarandamu, Gillespie 3370; Korombasambasanga Range, DA 2196; summit of Mt. Voma, Gillespie 2743; Wainandoi River, DA 10805. NaITAsIri: Northern portion of Rairaimatuku Plateau, between Mt. Tomanivi and Nasonggo, Smith 5749; Tholo-i-suva, DA 13676. TAILEVU: Hills east of Wainimbuka River, vicinity of Ndakuivuna, Smith 7135; Namara, Seemann 223, p. p. (k). Rewa: Limestone quarry near Suva, Livingston, July, 1945. OVALAU: U. S. Expl. Exped. (GH); summit of Mt. Ndelaiovalau and adjacent ridge, Smith 7561. VANUA LEVU: ThakAundrove: Mt. Uluingala, Natewa Peninsula, Smith 1999. Fiji without further locality, Seemann 222.

A close relative of Morinda bucidifolia is the rare Samoan M. tripetala Christophersen (in Bishop Mus. Bull. 154: 73. fig. 21. 1938), which is very similar to the Fijian endemic in essential characters, differing in having the capitula borne in clusters of 20-35 (rather than 6-18) and usually with only 6-14 (rather than 7-25) flowers, these with only 3 (rarely 4 ) corolla lobes and stamens. The Fijian species has flowers with 4 corolla lobes and stamens, but an occasional 3-merous flower may be noted.

34. Gynochtodes Bl. Bijdr. Fl. Ned. Ind. 993. 1826-1827; Endl. Gen. P1. 543. 1838; Baill. Hist. Pl. 7: 416. 1880.

Gynochthodes Bl. ex Hook. f. in Benth. \& Hook. f. Gen. Pl. 2: 119. 1873; K. Schum. in Engl. \& Prantl, Nat. Pflanzenfam. IV. 4: 137. 1891; Backer \& Bakh. f. Fl. Java 2: 349. 1965; S. Darwin in Allertonia 2: 33. 1979.

Glabrous lianas or scrambling shrubs, the stipules interpetiolar; inflorescences axillary, umbelliform to paniculiform cymes, the flowers of terminal triads sessile or pedicellate, free or united by their hypanthia; flowers 4-6-merous; calyx limb short, 

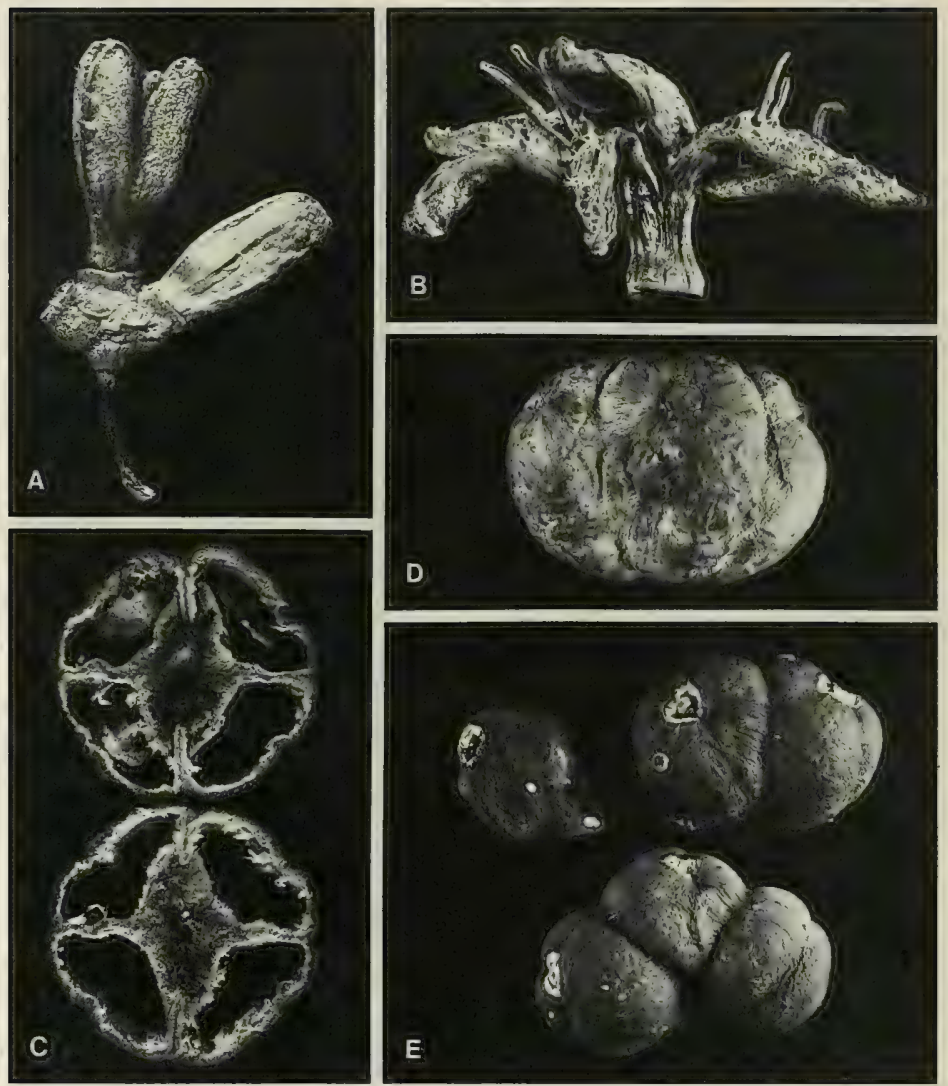

FIGURE 118. Gynochtodes epiphytica; A, three fused hypanthia, the young corollas of two flowers persisting, $\times 4$; B, corolla and stamens, $\times 4$; C, cross section of a simple, mature fruit, $\times 2 ; D$, mature multiple fruit, $\times 2$; E, immature simple and multiple fruits from a single plant, $\times 2$. A \& B from Smith $9377, \mathrm{C}$ from Christophersen 3016 (Savai'i, Samoa), D from Parks 20113, E from Smith 5088.

annular, dentate, persistent; corolla hypocrateriform, pilose within especially in throat, the lobes with incurved apices, valvate in bud; stamens inserted in corolla throat or near base of tube, the anthers included or exserted; ovary 4-locular, the ovules solitary and subbasal in each locule, the style simple or 2-branched; fruit drupaceous, sometimes multiple, with thin-walled 1-seeded pyrenes.

TYPE SPECIES: Gynachtodes coriacea Bl., the only original species.

Distribution: Southeastern Asia through Malesia to Micronesia and eastward to Tonga, Niue, and Samoa, with about 14 species. A single species is indigenous in the Fijian Region. 

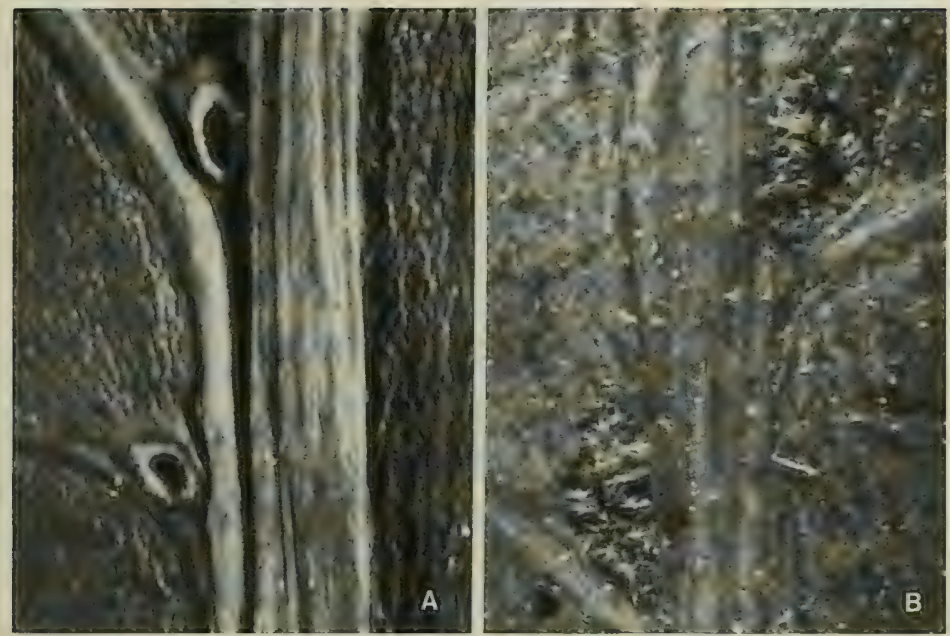

FIGURE 119. A, Gynochtodes epiphytica; lower surface of leaf blade along costa, showing secondaries and domatia, $\times 20$. B, Gynochtodes ovalifolia; lower surface of leaf blade along costa, showing secondaries and domatia, $\times 20$. A from Smith 9415, B from Takamatsu 1741 (Garikiai, Palau Islands).

As noted by Backer and Bakhuizen van den Brink (1965), Blume's original spelling was Gynochtodes; this spelling has also been used by Miquel (Fl. Ned. Ind. 2: 313. 1857, Fl. Ned. Ind. Suppl. 548. 1861), Endlicher (1838), Baillon (1880), and more recently by Christophersen (in Bishop Mus. Bull. 154: 64. 1938). Perhaps Hooker (1873) was the first author to change the spelling to Gynochthodes, th being the usual transliteration of the Greek $\theta$ (as in ochthodes). Most subsequent authors have used the spelling Gynochthodes, as does ING (1979), but there appears to be no justification for such a change in ICBN (Art. 73.1). Below we use the original spelling of the generic name, without indicating the usage of cited authors.

1. Gynochtodes epiphytica (Rechinger) A. C. Sm. \& S. Darwin, comb. nov.

Figures 118, 119A.

Plectronia epiphytica Rechinger in Denkschr. Akad. Wiss. Wien 85: 369. 1910.

Gynochtodes ovalifolia sensu A. C. Sm. in Bishop Mus. Bull. 141: 162. 1936; Christophersen in op. cit. 154: 64. fig. 18. 1938; Yuncker in op. cit. 178: 113. 1943; Sykes in New Zealand Dept. Sci. Indust. Res. Bull. 200: 177. 1970; forsan non Kaneh.

Gynochtodes ovalifolia var, smithii Fosberg in Bull. Torrey Bot. Club. 67: 421. 1940; Yuncker in Bishop Mus. Bull. 220: 258. 1959; J. W. Parham, PI. Fiji Isl. 193. 1964, ed. 2. 271. 1972.

A liana or scrambling woody vine, sometimes high-climbing, occurring from near sea level to an elevation of about $900 \mathrm{~m}$. in dense, thin, or dry forest or in thickets, frequently on limestone. The leaf blades, which characteristically darken in drying, are thin-coriaceous to chartaceous, ovate to elliptic, $5-15 \times 3-10.5 \mathrm{~cm}$., acute to rounded at base, acute to acuminate at apex, with 4-6 pairs of curved, ascending secondaries, and are borne on slender petioles $1-3.5 \mathrm{~cm}$. long. The fragrant flowers have the corolla white or cream-colored (drying black); the stamens have white filaments and yellow 
anthers that soon turn brownish purple; and the fruits become black at maturity. Flowers have been noted in Fiji only in November and December (on dated collections), while fruits have been collected between January and September.

TyPIFICATION: Rechinger cited three syntypes from Upolu, Samoa, for Plectronia epiphytica: Rechinger 1851, 1923, and 48. A suggested citation is: Rechinger 1851 (W 2349 LECTOTYPE; photo and fragment at BISH), collected Aug. 4, 1905, on "Berg Lanutoo," Upolu, Samoa. Gynochtodes ovalifolia var. smithii is typified by St. John 18298 (BISH HOLOTYPE; ISOTYPES at BISH, K, US), collected Aug. 13, 1937, at Matawailevu, Wainimala River, Naitasiri Province, Viti Levu.

Distribution: Fiji, Tonga, Niue, and Samoa. From Fiji we have studied 23 collections from four islands.

LOCAL NAMES AND USE: Recorded names from Naitasiri are wa thoro and sererakavona, and in that Province the stems are used to bind timbers in house-building.

REPRESENTATIVE COLLECTIONS: VITI LEVU: MBA: Vicinity of Nandarivatu, Smith 5088. NANDRONGA \& Navosa: Naruku, vicinity of Mbelo, near Vatukarasa, Degener 15321. Serua: Hills north of Ngaloa, in drainage of Waininggere Creek, Smith 9415; hills between Waininggere and Waisese Creeks, between Ngaloa and Wainiyambia, Smith 9377. Namosi: Hills east of Navua River, Greenwood 1005. NAITASIRI: Viria, Meebold 16906; Central road, Tothill 535; Nasinu, DA 7280. REWA: Mt. Korombamba, Parks 20113. VANUA LEVU: Mbua: Lower Wainunu River Valley, Smith 1716. Mathuata: Ndreketi, DA 12953; Mathuata coast, Greenwood 660. Thak Aundrove: Korotasere, Natewa Bay, DA 15489. YATHATA: DA 13624 , p. p. FULANGA: On limestone formation, Smith 1127.

The material of Gynochtodes from Samoa, Tonga, Niue, and Fiji has previously been referred to $G$. ovalifolia (Valeton) Kaneh. (in Bot. Mag. (Tokyo) 45: 351. 1931, based on Plectronia ovalifolia Valeton in Bot. Jahrb. 63: 310. 1930, with Ledermann 14143 and 14200 from Korror, Palau Islands, as syntypes), but such reference has clearly been due to oversight of the binomial Plectronia epiphytica, which provides the earliest epithet for Gynochtodes in the Fijian Region. We find no means of distinguishing more than one taxon of this alliance in our area, although many Fijian specimens have flowers in terminal pairs or triads united by their hypanthia (FIGURE 118A) and consequently have multiple fruits (FIGURE 118D \& E). On the same individuals, however, free flowers and simple fruits, similar to those of Samoan specimens, also occur. Fosberg (1940) noted the tendency of Fijian material to have fused ovaries in proposing the trinomial $G$. ovalifolia var. smithii, but he also noted the infrequent occurrence of fused ovaries in Samoa (this is also the case in Tonga). We consider ovary fusion somewhat random and scarcely a basis for nomenclatural status, although no reason is apparent for its prevalence in Fiji.

The stipules of specimens of this alliance from western Polynesia, Fiji, and Micronesia are essentially identical; they are short (0.5-1 mm. long), broadly ovate and joined into an inconspicuous tube, obtuse to acute, and ephemerally ciliolate. No characters of inflorescence or foliage seem to differentiate collections from the Caroline and Palau Islands from those of Fiji and Polynesia, except that many of the Micronesian specimens that have been referred to Gynochtodes ovalifolia have broad, pilose domatia (FIGURE 119B), whereas the domatia in the Fijian Region are characteristically small, glabrous, and cartilaginous-margined (FIGURE 119A). It must be noted, however, that domatia in Gynochtodes are not geographically constant; those of Hosokawa 8328 (TYPE of $G$. trukensis Hosokawa in Trans. Nat. Hist. Soc. Formosa 32: 18. 1942) are suggestive of those of Fijian specimens, whereas those of some Samoan specimens (e. g. Whistler 977, 1719) are sometimes broad and without cartilaginous margins (although glabrous). For present purposes we restrict our concept of $G$. 
epiphytica to western Polynesia and Fiji, but students of Micronesian plants may well decide that it must also include $G$. ovalifolia and $G$. trukensis.

35. Ophiorrhiza L. Sp. Pl. 150. 1753; Seem. Fl. Vit. 126. 1866; Hook. f. in Benth. \& Hook. f. Gen. PI. 2: 63. 1873; K. Schum. in Engl. \& Prantl, Nat. Pflanzenfam. IV. 4: 29. 1891; Backer \& Bakh. f. Fl. Java 2: 289. 1965; S. Darwin in Lyonia 1: 47. 1976, in Allertonia 2: 29. 1979.

Creeping to erect herbs, subshrubs, or shrubs, the stipules interpetiolar, entire to lobed, fimbriate, or setaceous; inflorescences axillary or terminal cymes, usually dichotomously branched or unbranched, often spiciform to cincinniform, the bracts well developed or absent; flowers $\Varangle, 5$-merous; calyx limb persistent, truncate to lobed, the lobes often keeled; corolla urceolate to infundibular or hypocrateriform, glabrous or pubescent, often pilose in throat, the lobes valvate in bud; stamens inserted at various levels in corolla tube, included or exserted, the filaments short or long; ovary 2-locular, the ovules numerous in each locule, attached to elongate-clavate placentas; style included or exserted, filiform, 2-branched, the stigmas coherent or separate, sometimes disciform; fruits capsular, usually laterally compressed perpendicular to dissepiment, triangular to obcordate or obreniform in outline, sometimes subglobose (but not in our species), loculicidally dehiscent; seeds small, angular-rhomboid, the surface smooth.

LECTOTYPE SPECIES: Ophiorrhiza mungos L. (vide Hitchcock, Prop. Brit. Bot. 129. 1929), one of Linnaeus's two original species. The spelling Ophiorhiza was used by Linnaeus in Gen. Pl. ed. 5. 74. 1754, and also by a few later authors (e. g. A. Gray in Proc. Amer. Acad. Arts 4: 311,312. 1859); that orthographic variant is not indicated below.

Distribution: India and Ceylon eastward to Micronesia and the Society Islands, with about 150 species. Three species (two of them endemic) are indigenous in Fiji, and nine are endemic in the Society Islands. Absence of the genus from Tonga, Samoa, and the Cook and Austral Islands is unexpected (Darwin, 1976, p. 49). The present review is abstracted from Darwin's 1976 treatment.

Useful treatment of Genus: Darwin, S. P. The Pacific species of Ophiorrhiza L. (Rubiaceae). Lyonia 1: 47-102. 1976.

The Fijian species are all widespread within the archipelago and have wide altitudinal ranges; in general Ophirrhiza peploides may be expected in darker, more humid areas than the other two species, but all three occur in dense forests as well as in more open areas.

KEY TO SPECIES

Stipules deltoid, to $0.4 \mathrm{~mm}$. long, ephemeral, not readily discernible; calyx lobes $0.3-0.5 \times$ about $0.3 \mathrm{~mm}$.; corolla broadly infundibular, the tube $3.6-6.5 \mathrm{~mm}$. long, the lobes sometimes longer than tube, 2.8-9 $\mathrm{mm}$. long; stamens with filaments $2.6-7 \mathrm{~mm}$. long, the anthers $0.8-1.3(-1.6) \mathrm{mm}$. long; branchlets slender, up to $0.5 \mathrm{~mm}$. in diameter toward apex; leaf blades usually less than $3 \times 1 \mathrm{~cm}$. (infrequently to $4.3 \times 1.2 \mathrm{~cm}$.), ovate to oblanceolate and spathulate, usually without a discernible petiole.

1. O. peploides

Stipules narrowly deltoid, 3-10 mm. long, narrowly subulate to setaceous, often 1-4-times divided; calyx lobes $0.4-1.5 \times 0.3-0.8 \mathrm{~mm}$; corolla narrowly infundibular to hypocrateriform, the lobes much shorter than tube; branchlets relatively stout, $0.8-2 \mathrm{~mm}$. or more in diameter toward apex; leaf blades $2.5-2 \mathrm{I} \times$ $0.8-5(-7) \mathrm{cm}$., lanceolate to ovate or elliptic, rarely oblanceolate, petiolate (petioles $2-45 \mathrm{~mm}$. long or longer).

Branchlets comparatively slender, up to $1 \mathrm{~mm}$. in diameter toward apex; inflorescences rarely more than 4-branched, with 3-35 flowers, the peduncles up to $2 \mathrm{~cm}$. long, the pedicels $0.8-4.5 \mathrm{~mm}$. long at anthesis; corolla tube $(4.6-)$ 8-12 $(-14.2) \mathrm{mm}$. long, the lobes 2-3.6 mm. long; hypanthium and calyx tube usually glabrous or finely puberulent with minute, rarely yellow hairs; anthers subsessile (filaments up to $0.3 \mathrm{~mm}$. long), 1.3-1.5 mm. long, attached at corolla throat amid long white hairs;

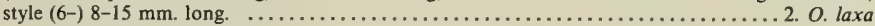


Branchlets relatively stout, 0.8-1.8 (-2.6) mm. in diameter toward apex; inflorescences 5-15-branched, with 9-80 flowers, the peduncles (1.8-) 2.5-4.6 cm. long, the pedicels 4-7.8 mm. long at anthesis; corolla tube (14-) 17.5-30.8 mm. long, the lobes 2.6-9.5 mm. long; hypanthium and calyx tube puberulent with minute, yellow to orange hairs; stamens attached well below corolla throat or at throat with filaments $0.6-8 \mathrm{~mm}$. long, the anthers $1.3-1.8 \mathrm{~mm}$. long; style (15-) $18-20.4 \mathrm{~mm}$. long.

3. O. leptantha

1. Ophiorrhiza peploides A. Gray in Proc. Amer. Acad. Arts 4: 311. 1859; Seem. in Bonplandia 9: 256. 1861, Viti, 438. 1862, Fl. Vit. 127. 1866; Drake, Ill. Fl. Ins. Mar. Pac. 189. 1890; Gibbs in J. Linn. Soc. Bot. 39: 151. 1909; Turrill in op. cit. 43: 24. 1915; Gillespie in Bishop Mus. Bull. 74: 26. fig. 35, $a-c$. 1930; J. W. Parham, Pl. Fiji Isl. 200. 1964, ed. 2. 281. 1972; S. Darwin in Lyonia 1: 66. fig. 1, E; 2, A;3, A; 4, B-E. 1976.

Herb, subligneous toward base, or dwarf shrub $0.1-0.6(-1) \mathrm{m}$. high, occurring from near sea level to $1,100 \mathrm{~m}$. elevation in dense or open forest but most often in rocky places in deep shade or along streams, sometimes in tidal marshes or on the inner edges of mangrove swamps. The fragrant flowers have the corolla white or sometimes pink-tinged, the filaments and style white, and the anthers pale yellow; the mature fruits are purplish. Flowers and fruits occur throughout the year.

Typification: The lectotype (Darwin, 1976) is U. S. Expl. Exped. (us 47493 LECTOTYPE; ISOLECTOTYPES at GH, K, NY), collected on Ovalau in 1840. Gray also cited material obtained by Milne and Harvey, cited below.

Distribution: Endemic to Fiji and now known from more than 70 collections obtained on eight of the islands; it may be anticipated on all islands that provide a habitat of dark, humid forests.

LOCAL NAMES AND USES: Often used names are lera, lera ndamu, and thandrai; also recorded are ndindindi (Mba), ndrendrewai and uthu ni raurau (Nandronga \& Navosa), asiasi ni vatu (Serua), and tondaolo (Rewa). Parts of the plant are said to be used as a hairwash on Viti Levu, and the plant is occasionally considered edible.

RePresentative Collections: VITI LEVU: MBA: Mountains inland from Lautoka, Greenwood 73; Nandarivatu, Gibbs 607; Navai, im Thurn 202. NANDRONGA \& NAvosA: Inland from Mbelo, near Vatukarasa, O. \& I. Degener 32119. Serua: Track to Mt. Tuvutau, DA 14494. Namosi: Ridges near Namosi, Gillespie 2706. RA: Mountains near Penang, Greenwood73A. NAITASIRI: Near Korovou, Wainimala River, DA 14018. TAIlevU: Nukurua Creek, DA 1025. RewA: Near Lami, Gillespie 4577. KANDAVU: Namalata isthmus region, Smith 43. OVALAU: Milne 50; vicinity of Levuka, Gillespie 4462. KORO: Western slope, Smith 1069. NGAU: Hills east of Herald Bay, on slopes of Mt. Vonda and toward Waikama, Smith 7980. VANUA LEVU: Mbua: Nandi, Milne 263. Mathuata: Southern slopes of Mt. Numbuiloa, east of Lambasa, Smith 6355. ThaKaundrove: Maravu, near Salt Lake, Degener \& Ordonez 14132; hills west of Mbutha Bay, Natewa Peninsula, Smith 823. TAVEUNI: Somosomo, Seemann 228; slopes of Mt. Manuka, east of Wairiki, Smith 8333. MATUKU: Milne 106. Fivi without further locality, Harvey, Nov., 1855.

2. Ophiorrhiza laxa A. Gray in Proc. Amer. Acad. Arts 4: 312. 1859; Seem. Fl. Vit. 127, p. p. 1866; Drake, Ill. Fl. Ins. Mar. Pac. 188. 1890; Gibbs in J. Linn. Soc. Bot. 39: 151. 1909; Turrill in op. cit. 43: 24, p. p. 1915; J. W. Parham, Pl. Fiji Isl. ed. 2. 279. 1972; S. Darwin in Lyonia 1: 70. fig. $1, F ; 2, B ; 4, F-H ; 5, A .1976$.

Ophiorrhiza leptantha var. yasawana Fosberg in Bull. Torrey Bot. Club 67: 420. 1940; J. W. Parham, Pl. Fiji Isl. 200. 1964, ed. 2. 281. 1972.

A copiously branched shrub or subligneous herb $0.2-3 \mathrm{~m}$. high, often compact, found at elevations from near sea level to $1,280 \mathrm{~m}$. in dense or open forest, in thickets on ridges and crests, and sometimes on cliffs. The corolla is white, sometimes with the tube yellow to pink or purple- or crimson-tinged; the mature fruits are crimson to purplish. Flowers and fruits may be found throughout the year. 
Typification: The lectotype (Darwin, 1976) is U. S. Expl. Exped. (us 47491 LECTOTYPE), collected on Ovalau in 1840. Other collections mentioned by Gray (Milne and Exploring Expedition), cited below, are to be considered paratypes. The type of Ophiorrhiza leptantha var. yasawana is St. John 18126 (BISH HOLOTYPE), collected July 19,1937 , in woods along Olo Creek, north of Yalombi, Waya Island, Yasawas.

Distribution: Endemic to Fiji and now represented by more than 80 collections from six islands, but of course to be expected on others.

LOCAL NAMES AND USE: Recorded names are karaua (Yasawas), kethe and mothemothe (Mba), ndraunikau ni mbata (Namosi), na sendua (Naitasiri), and ndrau rau ni $u l u$ (area?). A medicinal use was noted in Naitasiri, the leaves being chewed to stop blood in urine.

RePRESENTATIVE Collections: VITI LEVU: MBa: Summit of Mt. Koroyanitu, high point of Mt. Evans Range, Smith 4202; upper slopes of Mt. Koromba, Smith 4706; Nandarivatu, Gibbs 606, im Thurn 259, p. p. (BM, K); Mt. Tomanivi, DA 12714 (Melville et al. 7103). NANDRONGA \& NAVOSA: Nausori Highlands, O. \& I. Degener 32186. Serua: Vicinity of Ngaloa, Degener 15133. Namosi: Mt. Naitarandamu, Gillespie 3122. NAITASIRI: Wainisavulevu-Numbulolo divide, Wainimala Valley, St. John 18328; vicinity of Tamavua, Gillespie 2440. ReWA: Mt. Korombamba, Meebold 16684. VITI LeVu without further locality, Milne I2, Milne or MacGillivray. OVALAU: U. S. Expl. Exped. (nY), Milne 52; slopes of Mt. Korotolutolu, west of Thawathi, Smith 8017. NGAU: Milne 215. VANUA LEVU: Mathuata: Near Lambasa, Greenwood 530. ThakAUndrove: Nakorothau, Krauss 1018. TAVEUNI: Mt. Manuka, east of Wairiki, Smith 785.

3. Ophiorrhiza leptantha A. Gray in Proc. Amer. Acad. Arts 4: 312. 1859; Seem. in Bonplandia 9: 256. 1861, Viti, 438. 1862, Fl. Vit. 127, p. p. 1866; Drake, Ill. Fl. Ins. Mar. Pac. 188. 1890; Turrill in J. Linn. Soc. Bot. 43: 24, p. p. 1915; Gillespie in Bishop Mus. Bull. 74: 26. fig. 35, $d-f$. 1930; Fosberg in Bull. Torrey Bot. Club 67: 420. 1940; St. John \& A. C. Sm. in Pacific Sci. 25: 340. 1971; S. Darwin in Lyonia 1: 74. fig. 5, $B-H ; 6, A-D$. 1976; Morat \& Veillon in Bull. Mus. Nat. Hist. Nat. (Paris) IV. 7, Sect. B, Adansonia 3: 316. 1985.

Ophiorrhiza laxa sensu Seem. in Bonplandia 9:256. 1861, Viti, 438. 1862, Fl. Vit. 127, p. p. 1866; non A. Gray.

Ophiorrhiza leptantha var. leptantha; J. W. Parham, PI. Fiji Isl. 200. 1964, ed. 2. 280.1972.

Shrub or subligneous herb $0.5-3 \mathrm{~m}$. high, occurring from near sea level to an elevation of $1,150 \mathrm{~m}$. in dense or wet forest or on its edges, sometimes along streams. The inflorescence branches and calyx are sometimes purple-tinged, and the corolla is white to orange or pale pink. Flowers and fruits occur throughout the year.

Typification: The lectotype (Darwin, 1976) is U. S. Expl. Exped. (us 47492 LECTOTYPE), collected on Ovalau in 1840. Gray also cited a collection by Harvey, and other Exploring Expedition specimens cited below are not necessarily from the same collection as the lectotype.

Distribution: Fiji and the Horne Islands. From Fiji more than 60 collections are at hand from eight islands. Although Ophiorrhiza leptantha and $O$. laxa are sometimes essentially sympatric within Fiji, the former is usually found in moister, less exposed areas. It is less frequent than $O$. laxa at high elevations, less common in general on Viti Levu, more common on Vanua Levu, and more widely distributed within the archipelago.

Local Names AND uSE: Probably the two related species of Ophiorrhiza are not clearly separated in local concept. Recorded names for $O$. leptantha are ndomale (Serua), ndraunikau ni ula (Namosi), kurukuru inggele (Naitasiri), and mbulu (Thakaundrove). A medicinal use was noted in Serua, a decoction of mashed leaves being used for stomachache. 
RePRESENTATIVE COLlections: VITI LEVU: MBA: Nandarivatu, im Thurn 259, p. p.; slopes of Mt. Nanggaranambuluta, Gillespie 4361; western and southern slopes of Mt. Tomanivi, Smith 5104. SERUA: North of Korovou, St. John 18928. Namosi: Summit of Mt. Naitarandamu, Gillespie 3295. NAMOSI or REWA: Between Wainandoi River and Wainamboro Creek, Vaughan 3365. NAITASIRI: Tamavua-Sawani road, Setchell \& Parks 15046; Tholo-i-suva, im Thurn 359, p. p. TAILEVU; Nukurua Creek, DA 1020. REWA: Slopes of Mt. Korombamba, Gillespie 2247. VITI Levu without further locality, Seemann 229, p. p. KANDAVU: Mt. Mbuke Levu, Smith 265. OVALAU: Mt. Tana Lailai, Graeffe; Port Kinnaird, Seemann 229, p. p. NGAU: Milne 234. VANUA LEVU: MATHUATA: Southern base of Mathuata Range, north of Natua, Smith 6762. ThaKaundrove: Mt. Kasi, Yanawai River region, Smith 1804; Savusavu Bay region, Degener \& Ordonez 14008. TAVEUNI: Natambua, Nggeleni, DA 15887. VANUA MBALAVU: Nambavatu, northern limestone area, Tothill 291. TUVUTHA: Central forest, Bryan 550. FiJt without further locality, U. S. Expl. Exped. (K, P, us 47490), Seemann 227, Harvey (BM, GH, K).

Although Ophiorrhiza leptantha and $O$. laxa have been combined by some authors, they are (with very few exceptions) readily distinguished by number and size of flowers, amount and color of calycine indument, and staminal characters (Darwin, 1976).

36. Xanthophytum Reinw. ex Bl. Bijdr. Fl. Ned. Ind. 989. 1826-1827; Hook. f. in Benth. \& Hook. f. Gen. Pl. 2: 53. 1873; K. Schum. in Engl. \& Prantl, Nat. Pflanzenfam. IV. 4: 24. 1891; A. C. Sm. in J. Arnold Arb. 36: 288. 1955; Backer \& Bakh. f. Fl. Java 2: 283. 1965; S. Darwin in Allertonia 2: 31. 1979.

Lerchea sensu A. Gray in Proc. Amer. Acad. Arts 4: 311. 1859; Seem. Fl. Vit. 127. 1866; non L.

Shrubs or small trees, usually with rufo-sericeous indument, the stipules interpetiolar; inflorescences short to slender-pedunculate, axillary, few-branched thyrses, the bracts and bracteoles small; flowers ( 4 or) 5-merous, $\not$; calyx limb persistent, the lobes short or (as in our species) spathulate or oblanceolate, slightly accrescent after anthesis; corolla tubular-infundibular, the tube glabrous or pubescent in throat and on lobes, the lobes valvate in bud; stamens inserted near base of corolla, the filaments glabrous, the anthers included or exserted; ovary 2-locular, the ovules numerous in each locule, the placentas globose, affixed to middle of dissepiment; style cylindric, the stigma globose to slightly 2-lobed; fruit dry, separating into 2 cocci, the seeds angular, reticulate.

TYPE SPECIES: Xanthophytum fruticulosum Reinw, ex Bl.

Distribution: Southeastern Asia and Malesia and eastward in the Pacific to Fiji, with approximately 15 species. One species represents the genus in Fiji and the New Hebrides.

1. Xanthophytum calycinum (A. Gray) Benth. \& Hook. f. ex Drake, Ill. Fl. Ins. Mar. Pac. 186. 1890; Gibbs in J. Linn. Soc. Bot. 39: 150. 1909; A. C. Sm. in J. Arnold Arb. 36: 288. 1955; J. W. Parham, Pl. Fiji Isl. 210. 1964, ed. 2. 295. 1972; S. Darwin in Allertonia 2: 31. fig. 2, J. 1979.

Figure 120.

Lerchea calycina A. Gray in Proc. Amer. Acad. Arts 4:311. 1859; Seem. Viti, 438. 1862, Fl. Vit. 128. 1866.

Shrub or usually slender tree $1.5-10 \mathrm{~m}$. high, with a trunk to $25 \mathrm{~cm}$. in diameter, found at elevations of $150-1,030 \mathrm{~m}$. in dense forest or in the thickets of crests and ridges. Young parts of the plant bear a conspicuous, silky, ferrugineous indument; the calyx is pale green; and the corolla is pale green to white, soon turning yellowish and quickly caducous. Flowers have been noted between March and November, fruits throughout the year.

FIGURE 120. Xanthophytum calycinum; A, distal portion of branchlet, with foliage and infructescences, $\times 1 / 2 ; B$, apical part of branchlet, showing stipules, indument, and part of a developing inflorescence, $\times 4 ; C$, cluster of flowers, showing calyx lobes and a corolla bud, $\times 15 ; \mathrm{D}$, flower with mature corolla, $\times 15 ; \mathrm{E}$, dehisced fruit, showing seeds (s), $\times 15$. A from DA 15033, B from Gillespie 2410. C from Smith 9106, D \& E from Parks 20142 . 

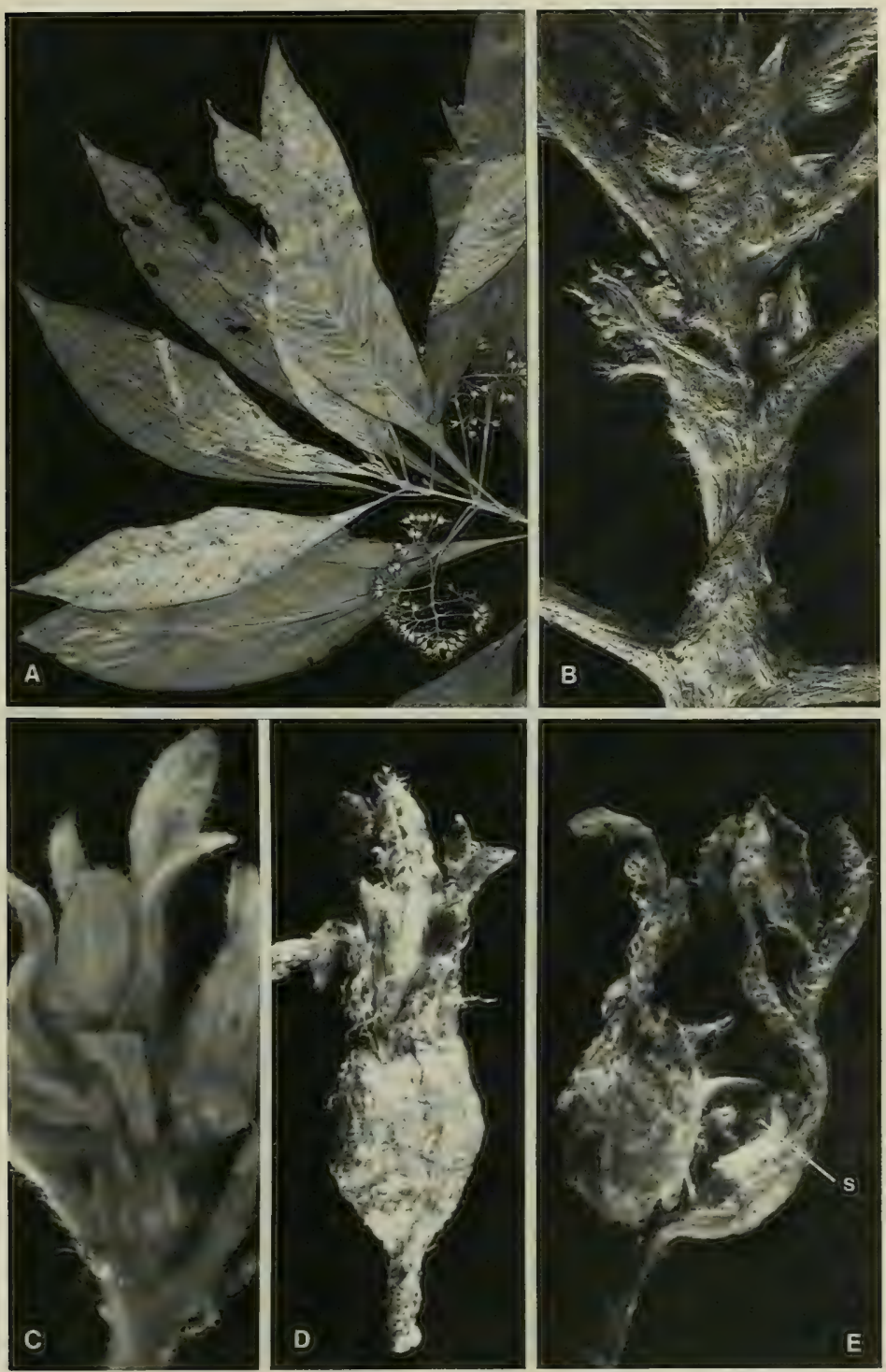
TYPIFICATION: Gray listed two collections, but since his paper dealt primarily with Exploring Expedition collections an appropriate citation is: U. S. Expl. Exped. (US 48660 LECTOTYPE), a fruiting specimen collected on Ovalau in 1840. A paratype is Milne $85(\mathrm{~K})$, from Viti Levu without further locality, a specimen with flower buds and fruits.

Distribution: Fiji and the New Hebrides (but there known to us only from a single specimen, Cheesman (K) without further locality). From Fiji 28 specimens are available, but all of these are from Viti Levu except the lectotype from Ovalau and one collection from Vanua Levu.

REPRESENTATIVE COLLECTIONS: VITI LEVU: MBA: Northern slopes of Mt. Namendre, east of Mt. Koromba, Smith 4545; vicinity of Nandarivatu, Gibbs 704. Serua: Ngaloa Nature Reserve, DA 16587 ; hills east of Navua River, near Nukusere, Smith 9106. NAmosI: Mt. Nambui track, Korombasambasanga Range, DA 14554; track to Mt. Vakarongasiu, DA 16108. NAITASIRI: Nanggarathangithangi, Mendrausuthu Range, DA 15033; Central road, Tothill 310; vicinity of Tamavua, Gillespie 2410. RewA: Mt. Korombamba, Parks 20142. VANUA LEVU: ThaKaundrove: Mt. Mbatini, Smith 658.

37. Pentas Benth. in Bot. Mag. 70: $t$. 4086. 1844; K. Schum. in Engl. \& Prantl, Nat. Pflanzenfam. IV. 4: 29. 1891; Verdcourt in Bull. Jard. Bot. Brux. 23: 238. 1953; Backer \& Bakh. f. Fl. Java 2: 292. 1965; Verdcourt in Fl. Trop. E. Afr. Rub. 183. 1976.

Perennial (rarely biennial) herbs or shrubs, the stipules interpetiolar, divided into 2-many filiform, colleter-tipped segments; inflorescences mostly complex terminal cymes, with branches often becoming spicate in fruit; flowers small to large, $\not$ (or sometimes unisexual?), mono-, di-, or trimorphic, 5-merous; calyx limb annular, equally to unequally lobed, 1-3 lobes often larger than the others or sometimes foliaceous; corolla short- to long-tubular, pubescent in throat, the lobes ovate to oblong, valvate in bud; stamens included in the conspicuously dilated corolla throat or exserted, with well-developed filaments or subsessile anthers; ovary 2-locular, the ovules numerous in each locule, the placentas attached to dissepiment; style filiform, 2-lobed, included or exserted; fruits capsular, obpyramidal to ovoid, ribbed and frequently beaked, splitting from apex into 2 or 4 valves or sometimes separating into 2 cocci; seeds minute, irregularly globose to tetrahedral, the surface reticulate.

TyPe SPECIES: Pentas carnea Benth. Verdcourt (1953) notes that other species than $P$. carnea included by Bentham in Pentas are assignable to other genera. Pentas carnea was based on a cultivated plant which Verdcourt suggests was derived from material collected in the Comoro Islands, referring the taxon to $P$. lanceolata subsp. cymosa var, carnea (Benth.) Verdcourt.

Distribution: Tropical Africa, tropical Arabia, Madagascar, and the Comoro Islands, with about 40 species (Verdcourt, 1976). A widely cultivated species is grown in Fiji.

USEFUl TREATMENT of Genus: Verdcourt, B. A revision of certain African genera of herbaceous Rubiaceae V. A revision of the genus Pentas Bentham together with a key to related genera. Bull. Jard. Bot. Brux. 23: 237-371. 1953. 
1. Pentas lanceolata (Forssk.) Deflers, Voy. Yemen, 142. 1889; Verdcourt in Kew Bull. 6: 377. 1951, in Bull. Jard. Bot. Brux. 23: 339. 1953; J. W. Parham, Pl. Fiji Isl. 200. 1964, ed. 2. 281. 1972; Sykes in New Zealand Dept. Sci. Indust. Res. Bull. 200: 180. 1970; Verdcourt in Fl. Trop. E. Afr. Rub. 208. 1976; Morat \& Veillon in Bull. Mus. Nat. Hist. Nat. (Paris) IV. 7, Sect. B, Adansonia 3: 316. 1985; MacKee, Pl. Intro. Cult. Nouv.-Caléd. 118. 1985.

Ophiorrhiza lanceolata Forssk. Fl. Aegypt.-Arab. 42. 1775.

Shrub $0.5-3 \mathrm{~m}$. high, often abundantly cultivated in towns and villages and European gardens at elevations from near sea level to about $250 \mathrm{~m}$. The corolla is very variable in color in Fijian specimens, ranging from white to light or deep pink, bright red, or rich purple; the filaments are white and the stigmas white to rich purple. Flowers and fruits have been noted between February and July.

Distribution: The species as a whole occurs in Yemen, tropical East Africa, and the Comoro Islands, and is now widely cultivated in other tropical areas.

LOCAL NAMES AND USE: Probably introduced into Fiji during the present century, Pentas lanceolata is commonly known as Lady Fletcher or merely as pentas; Fijian names are $\sin u$ and $\sin u$ vula. It is a favorite garden ornamental.

Avallable Collections: VITI LEVU: Naitasiri: Toninaiwau, Tholo-i-suva, DA 16722, 16755; Principal Agricultural Station, Koronivia, DA 12118, 12120. REWA: Lami, in private garden, DA 16461; Suva, in private garden, DA 12617. OVALAU: Lovoni Village, Smith 7488, 7492.

In discussing Pentas lanceolata, Verdcourt (1953) noted it as "one of the most variable complexes to be found in African Rubiaceae," recognizing four subspecies and a number of varieties. Later (1976) he stated: "It is not possible to produce a key to these variants which will work efficiently and they are best named from geographical considerations; nevertheless it is not feasible to ignore the variants completely since extremes are very distinct. . There are many doubtless who would prefer not to recognise more than two variants and this they may do by calling the long-flowered specimens subsp. lanceolata and the short-flowered ones subsp. quartiniana." Utilizing this expedient, which seems the only feasible one when the geographic source is unknown, we refer the above-cited specimens $D A 12617$ and Smith 7488 and 7492 to subsp. lanceolata, DA 16461 to subsp. quartiniana. In connection with the present review we have not reexamined the other cited specimens, but the following key (slightly modified from Verdcourt, 1976) would appear usable:

KEY TO SUBSPECIES

Corolla predominantly white but occasionally tinged with lilac or pink, sometimes rich purple, the tube 2-4

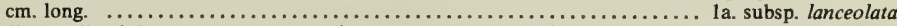
Corolla usually pink, mauve, magenta, bright red, etc., rarely white, the tube $1-2.2 \mathrm{~cm}$. long.

1b. subsp. quartiniana

1a. Pentas lanceolata subsp. lanceolata; Verdcourt in Bull. Jard. Bot. Brux. 23: 339. fig. 35, D, G. 1953, in Fl. Trop. E. Afr. Rub. 210. 1976.

TYPIFICATION: The type of Ophiorrhiza lanceolata is Forsskal (c HOLOTYPE; ISOTYPE at BM), from Hadie Mts., Yemen (Verdcourt, 1976). 
1b. Pentas lanceolata subsp. quartiniana (A. Rich.) Verdcourt in Bull. Jard. Bot. Brux. 23: 364. 1953, in Fl. Trop. E. Afr. Rub. 210. 1976.

Vignaldia quartiniana A. Rich. Tent. Fl. Abyss. 4: 357. 1847-1848.

TYPIFICATION: The type of Vignaldia quartiniana is Quartin \& Dillon 6 (P HOLOTYPE; ISOTYPES at S, W), from Maiguiga, Ethiopia (Verdcourt, 1976).

38. Hedyotis L. Sp. Pl. 101. 1753; Seem. Fl. Vit. 125. 1866; Hook. f. in Benth. \& Hook. f. Gen. Pl. 2: 56. 1873; Fosberg in Bishop Mus. Bull. 174: 18. 1943; Backer \& Bakh.

f. Fl. Java 2: 284. 1965; S. Darwin in Allertonia 2: 28.1979.

Oldenlandia L. Sp. Pl. 119. 1753; Seem. Fl. Vit. 125. 1866; Hook. f. in Benth. \& Hook. f. Gen. Pl, 2: 58. 1873; K. Schum. in Engl. \& Prantl, Nat. Pflanzenfam. IV. 4: 24. 1891; Verdcourt in Fl. Trop. E. Afr. Rub. 268. 1976.

Shrubs, subshrubs, or herbs, rarely climbing shrubs, the stipules interpetiolar, often adnate to petiole bases and sheathing, entire to dentate to fimbriate or divided; inflorescences axillary or terminal, glomerate, capitate, cymose, or thyrsoid, sometimes with flowers solitary; flowers 4(or 5)-merous, $\Varangle$, often heterostylous; calyx limb persistent, the lobes equal, sometimes alternating with secondary teeth; corolla hypocrateriform, infundibular, campanulate, or nearly rotate, thin to fleshy in texture, often pilose in throat, the lobes valvate in bud; stamens variously inserted in corolla tube, the anthers sessile or on short filaments, included or exserted; ovary inferior to partially superior, 2(-4)-locular, the ovules few-numerous in each locule, attached to a fleshy, peltate placenta; style cylindric to filiform, bifid at apex, the lobes linear to subglobose, included or exserted; fruit dry (rarely fleshy), capsular, with endocarp weakly to strongly sclerified, dehiscing loculicidally apically or nearly to base, if dehiscing only toward apex then frequently also septicidally dehiscent, or dehiscing septicidally only and the fruit separating into 2 closed cocci, or the fruit sometimes indehiscent; seeds subspherical to peltate to angular or angular-alate, the surfaces smooth to alveolate.

TYPE SPECIES AND NOMENCLATURE: Of the three species originally included in Hedyotis by Linnaeus, $H$. auricularia L. was first indicated as the lectotype ("type") species by Chamisso and Schlechtendal (in Linnaea 4: 153. 1829; cf. Fosberg, 1943). Bremekamp (in Rec. Trav. Bot. Néerl. 36: 438. 1939, in Verh. Kon. Ned. Akad. Wetensch., Afd. Natuurk., Tweede Sect. II. 48(2): 29. 1952) rejected that lectotypification in favor of $H$. fruticosa L., in which he was supported by Bullock (in Kew Bull. 12: 99. 1958), and $H$. fruticosa is listed as the lectotype species by ING (1979). In spite of the arguments presented by Bremekamp and Bullock, there seems no compelling reason to set aside the first lectotypification, even though $H$. auricularia has indehiscent fruits; we believe that Fosberg (1943) correctly accepted that choice.

Linnaeus originally included four species in Oldenlandia, O. corymbosa L. (vide Hitchcock, Prop. Brit. Bot. 125. 1929) being the generally accepted lectotype species (ING, 1979).

Ever since the simultaneous publication of Hedyotis and Oldenlandia by Linnaeus (1753), botanists have been uncertain whether or not the two taxa should be maintained as separate genera, and no consensus of opinion has yet been reached. Lamarck 
(Tabl. Encycl. Méth. Bot. 1:269. 1792) seems to have been the first author to unite the two, selecting Hedyotis as the name for the enlarged genus. A similarly broad generic concept was adopted by Wight and Arnott (Prodr. Fl. Ind. Orient. 405. 1834), Bentham (Fl. Austral. 3: 403. 1867), and Schumann(1891), among others. In contrast, both genera were accepted by many authors, among them de Candolle (Prodr. 4: 419, 424. 1830), A. Gray (in Proc. Amer. Acad. Arts 4:312. 1859), and J. D. Hooker (1873). An account of these and other opinions is provided by Fosberg (1943, pp. 5-7); more recent and equally vacillating opinions are summarized by Verdcourt (1976, p. 269).

In separating Hedyotis and Oldenlandia, authors have relied primarily on characters of fruit texture and dehiscence, secondarily on features of habit, leaf size, and calyx limb shape. J. D. Hooker (Fl. Brit. Ind. 3: 18. 1880), for example, considered septicidal and loculicidal fruit dehiscence typical of Hedyotis, while he characterized Oldenlandia as having loculicidal and exclusively apical dehiscence. Schumann(1891) described Oldenlandia sect. Euoldenlandia as having loculicidal and also often septicidal fruits, and sect. Hedyotis as having often indehiscent or only partially dehiscent fruits. Gray (1859) drew attention to the hard, nutlike fruits of Hedyotis as opposed to the thinner-walled capsules of Oldenlandia. Many authors have mentioned species having intermediate fruit characters.

In his treatment of Polynesian species, Fosberg (1943) adopted the inclusive interpretation of Hedyotis, finding no structural differences warranting recognition of segregate genera, although characters of habit, inflorescence size and position, shape of corolla, stigmas, and seeds were utilized to recognize subgenera. At least until the complex is treated on a worldwide basis, perhaps with special reference to the Asian species, it seems best to extend the broad generic concept applied in Polynesia to the Fijian species.

DisTRIBUTION: In the broadest sense the genus perhaps includes about 500 species in tropical and subtropical regions, with comparatively few species in temperate areas. Five species are here taken to represent the genus in Fiji, four of them presumably indigenous.

Useful treatment of genus: Fosberg, F. R. The Polynesian species of Hedyotis (Rubiaceae). Bishop Mus. Bull. 174: 1-102. 1943.

\section{KEY TO SPECIES}

Fruits indehiscent, subglobose, $1.5-2 \mathrm{~mm}$. in diameter; leaf blades elliptic to elliptic-lanceolate, $3-11 \times 0.8-3$ $\mathrm{cm}$., chartaceous, the secondary nerves prominent and sharply ascending toward an acute apex; inflorescences axillary, congested, subsessile, glomerate, the corolla $4-5 \mathrm{~mm}$. long at anthesis; stems and inflorescences minutely appressed-hirtellous; stipules broadly ovate to deltoid, conspicuously fimbriate-pectinate; presumably indigenous but often appearing weedy (subgen. Hedyotis).

1. H. lapeyrousii

Fruits dehiscent at least at apex; leaf blades without prominent secondary nerves; flowers solitary or in pedunculate inflorescences, not in dense axillary glomerules.

Shrubs or sometimes herbs with woody bases; inflorescences terminal, many-flowered, openly branched, corymbiform to paniculate cymes, the corolla 4-5 mm. long at anthesis; leaf blades somewhat fleshy, elliptic, $2.5-9 \times 0.8-3 \mathrm{~cm}$., acute at apex, the secondary nerves immersed; stems and inflorescences glabrous; stipules broadly ovate-deltoid, cuspidate to mucronate at apex; fruits depressed-globose, thick-walled, 3-4 mm. broad; indigenous (subgen. Diplophragma).

2. H. foetida 

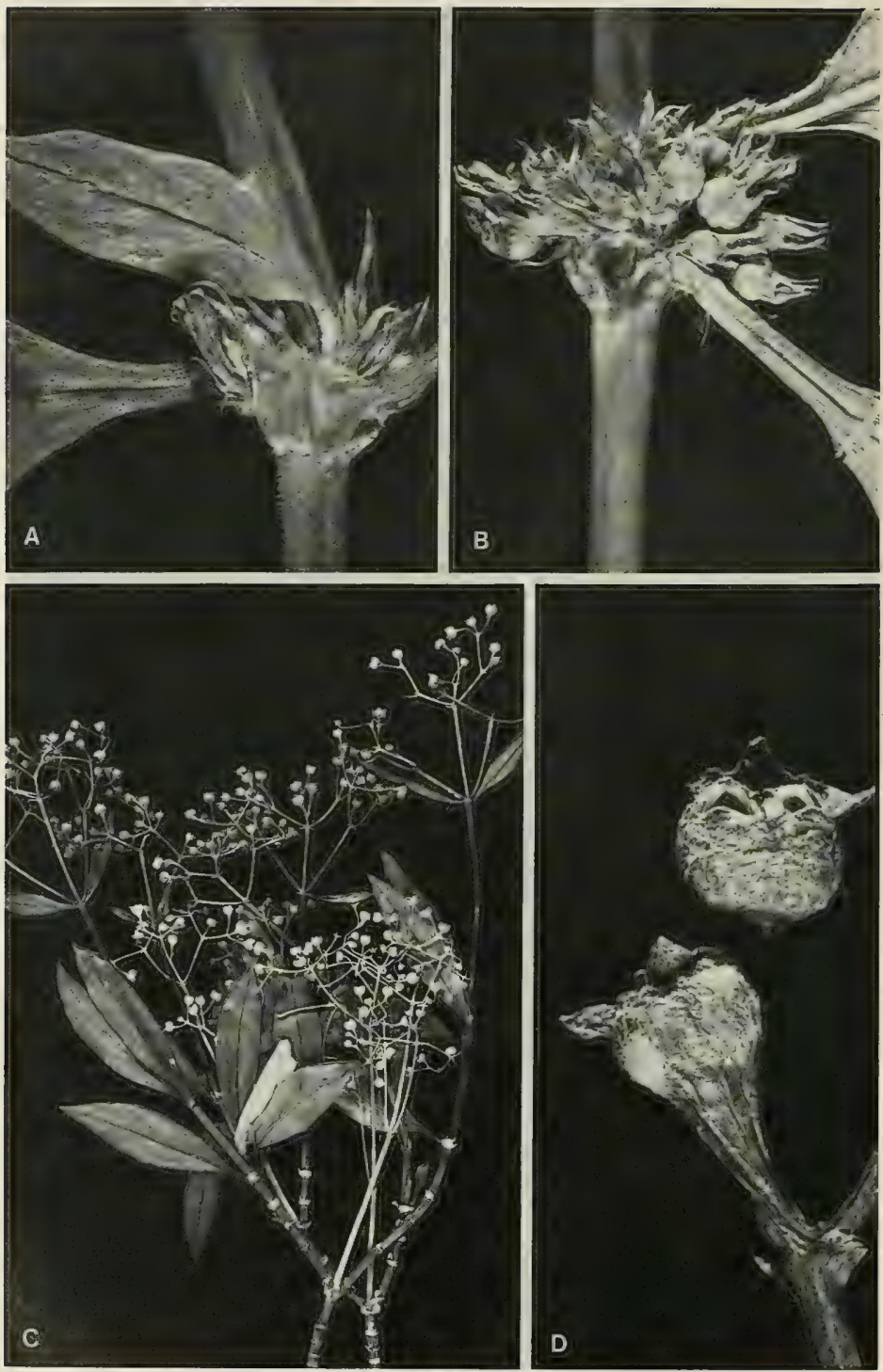
Erect or sprawling (often suffrutescent) herbs; inflorescences axillary or terminal, usually few-flowered or with solitary flowers, the corolla $3 \mathrm{~mm}$. long or shorter at anthesis; fruits with relatively thin walls (subgen. Oldenlandia).

Leaf blades chartaceous, linear to narrowly elliptic, 1-5 × $0.1-0.3 \mathrm{~cm}$; flowers axillary, solitary; stems glabrous; stipules cuspidate to short-fimbriate; fruits subglobose to depressed-globose, $2.5-4 \mathrm{~mm}$.

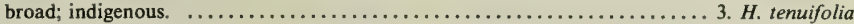

Leaf blades ovate to elliptic to obovate; inflorescences usually with 2 or more flowers (or flowers occasionally solitary).

Stems and inflorescences scabridulous; leaf blades somewhat fleshy, ovate to elliptic or obovate, $0.5-3(-8) \times 0.2-1.5(-2.5) \mathrm{cm}$., rounded to obtuse or acute at apex; stipules broadly ovate, cuspidate to long-mucronate; fruits $2.5-4 \mathrm{~mm}$. broad and long; indigenous. ... 4. H. biflora

Stems and inflorescences glabrous; leaf blades thin-chartaceous, elliptic, (0.3-) $0.6-1.5(-1.7) \times$ $0.2-0.6 \mathrm{~cm}$., obtuse to acuminate at apex; stipules fimbriate-pectinate or sometimes with only 1 or 2 setae; fruits about $3 \times 2$ mm.; adventive. .................... pumila

1. Hedyotis lapeyrousii DC. Prodr. 4: 420. 1830; A. Rich. in Dumont d'Urville, Sert. Astrolab. Atlas, pl. 23. 1833, 64. 1834; Merr. \& Perry in J. Arnold Arb. 26: 4. 1945.

Figure $121 \mathrm{~A} \& \mathrm{~B}$.

Hedyotis bracteogonum sensu Seem. in Bonplandia 9: 256, as H. bractegonum. 1861; A. Gray in op. cit. 10: 36. 1862; Seem. Viti, 438. 1862; non Spreng. (sphalm.?; binomial not located).

Hedyotis crataeogonum sensu Seem. Fl. Vit. 125. 1866; Drake, Ill. Fl. Ins. Mar. Pac. 186. 1890; Gibbs in J. Linn. Soc. Bot. 39: 151. 1909; J. W. Parham, P1. Fiji Isl. 193. 1964, ed. 2. 271. 1972; non Spreng.

Oldenlandia crataeogonum sensu Guillaumin in Notul. Syst. (Paris) 3: 160. 1915, in J. Arnold Arb. 13:4. 1932; non Hedyotis crataeogonum Spreng.

Hedyotis auricularia var. melanesica Fosberg in Bull. Torrey Bot. Club 67: 419. 1940; J. W. Parham, Pl. Fiji Isl. 193. 1964, ed. 2. 271. 1972.

Hedyotis auricularia sensu Greenwood in Proc. Linn. Soc. 154: 99. 1943; non L.

A coarse herb $0.3-1.5 \mathrm{~m}$. high, sprawling and subligneous toward base, found from near sea level to an elevation of about $970 \mathrm{~m}$. in dry or open forest or on open hillsides, sometimes locally abundant along trails and roads and appearing weedy in fields and plantations. The corolla and anthers are white. Although corollas are evanescent, flowers and fruits occur throughout the year.

TYPIFICATION AND NOMENCLATURE: Hedyotis lapeyrousii is based on Lesson (HOLOTYPE presumably at G-DC), from Vanikoro, Santa Cruz Islands. The type of $H$. auricularia var. melanesica is Smith 157 (NY HOLOTYPE; many ISOTYPES), collected Oct. 16, 1933, in hills above Namalata and Ngaloa Bays, Kandavu. It seems unwise to submerge this well-marked Papuasian-Melanesian taxon in $H$. auricularia L., best typified by material from Ceylon, in view of the uncertain delimitation of the latter, of which most Asian specimens seem to have smaller leaves, more obvious indument, and shorter corollas.

Distribution: New Guinea to New Caledonia, the New Hebrides, and Fiji. From Fiji we have examined 45 collections from nine islands.

LOCAL NAMES AND USES: No Fijian name seems established for this species, which has been locally recorded as tinggetingge (Mba), poroporo $i$ langi and kavokavoro (Naitasiri), and kauvoro na langi (Tailevu). Decoctions of leaves are used medicinally for headache, eye trouble, and to check bleeding and promote healing.

Figure 121. A \& B, Hedyotis lapeyrousii; A, node showing stipule and inflorescences, $\times$ 4; B, node showing infructescences, $\times 4$. C \& D, Hedyotis foetida; C, distal portions of branchlets, with foliage and infructescences, $\times 1 / 2 ; \mathrm{D}$, dehisced fruits, $\times 8$. A from Meebold 26522 , B from Smith 7054, C \& D from Smith 1231 . 
RePRESENTATIVE COLLeCtions: VITI LEVU: MBA: Mountains near Lautoka, Greenwood 155; between Nandarivatu and Waikumbukumbu, Gibbs 874. NANDRONGA \& NAvosA: Nausori Highlands, $O$. \& $I$. Degener 32180. SERUA: Hills east of Navua River, near Nukusere, Smith 9079. Namosi: Hills bordering Wainavindrau Creek, vicinity of Wainimakutu, Smith 8596. NaITASIRI: Matawailevu, Wainimala Valley, St. John 18281; Sawani-Serea road, DA 11500. TAILEvU: Hills east of Wainimbuka River, vicinity of Ndakuivuna, Smith 7054; Namara, Seemann 235, p. p. Rewa: Suva, Meebold 26522. OVALAU: Milne 237. NAIRAI: Milne 158. NGAU: Milne 212. VANUA LEVU: MATHUATA: Mountains near Lambasa, Greenwood 155 A. ThaKaUndrove: Namoliwawa, DA 13154. TAVEUNI: Seemann 235, p. p. MOALA: Bryan 316d. TOTOYA: Milne 79. VANUA MBALAVU: Between Lomaloma and Ndakuilomaloma, GarnockJones 1143. Fivi without further locality, U. S. Expl. Exped., Harvey.

2. Hedyotis foetida (Forst. f.) Sm. in Rees, Cycl. 17. 1811; Spreng. Pl. Min. Cogn. Pugill. 2: 28. 1815; A. C. Sm. in Bishop Mus. Bull. 141: 135. 1936; Fosberg in Bull. Torrey Bot. Club 67:420. 1940, in Bishop Mus. Bull. 174: 21. fig. 2. 1943; Yuncker in op. cit. 178: 111. 1943, in op. cit. 184: 63. 1945, in op. cit. 220:246. 1959; J. W. Parham, Pl. Fiji Isl. 193. 1964, ed. 2. 271. 1972; Sykes in New Zealand Dept. Sci. Indust. Res. Bull. 200: 178, 1970.

Figure $121 \mathrm{C} \& \mathrm{D}$.

Oldenlandia foetida Forst. f. Fl. Ins. Austr. Prodr. 10. 1786; Seem. Fl. Vit. 126. 1866; Christophersen in Bishop Mus. Bull. 154: 48. 1938.

An infrequent dwarf shrub less than $1 \mathrm{~m}$. high, found near sea level on rocky islets or on bare limestone. Flowers have been noted in July, fruits in July and February.

TyPification: The type was collected by $J . R$. \& $G$. Forster (BM LECTOTYPE) on Tongatapu, Tonga, during Cook's second voyage.

Distribution: New Caledonia to Austral Islands. Although it appears rare in Fiji, this may be due to the paucity of collections from small limestone islands; the wide distribution of the species (Fosberg, 1943) suggests that it should be more frequent. Seemann (1866) did not encounter the species in Fiji.

Available COLleCtions: FULANGA: On limestone, Smith 1231. ONGEA NDRIKI: Rocky isolated islet off northwest side, Bryan 400 .

3. Hedyotis tenuifolia Sm. in Rees, Cycl. 17. 1811; Seem. in Bonplandia 9: 256. 1861, Viti, 438. 1862; A. C. Sm. in J. Arnold Arb. 34: 97. 1953; J. W. Parham, Pl. Fiji Isl. 193. 1964, ed. 2. 271.1972.

Figure 122A-C.

Oldenlandia tenuifolia sensu Forst. f. Fl. Ins. Austr. Prodr. 11. 1786; DC. Prodr. 4: 425. 1830; Seem. Fl. Vit. 126. 1866; Drake, Ill. Fl. Ins. Mar. Pac. 186. 1890; Guillaumin in Bull. Soc. Bot. France 74: 698. 1927; non Burm. (1768).

Hedyotis galioides F. v. Muell. Fragm. Phyt. Austral. 4: 38. 1863; Benth. Fl. Austral. 3: 404. 1866; F. M. Bailey, Queensland Fl. 3: 748. 1900; Ross in Stanley \& Ross, Fl, S.-E. Queensland 2: 323. fig. 46, D. 1986.

Oldenlandia galioides Hook. f. in Benth. \& Hook. f. Gen. Pl. 2: 58. 1873; Greenwood in Proc. Linn. Soc. 154: 99. 1943; J. W. Parham, PI. Fiji Isl. 200. 1964, ed. 2. 279. 1972.

As seen in Fiji, Hedyotis tenuifolia is a sprawling herb with erect branches 15-60 $\mathrm{cm}$. high, infrequent at elevations from near sea level to about $200 \mathrm{~m}$. in swamps, moist depressions, and pond edges in open country, with a very small, white corolla. The few available specimens that are dated bear flowers and fruits between November and January and in July.

Figure 122. A-C, Hedyotis tenuifolia; A, portions of plant in flower and fruit, $\times 1$; B, stipule and flower, with portions of leaves, $\times 4$; C, dehiscing fruit and stipules, with portions of leaves, $\times 8$. D, Hedyotis biflora; distal portions of branchlets, with foliage, flowers, and fruits, × 1. A from Smith 6886, B \& C from DA 17339 . D from Smith 1285 . 

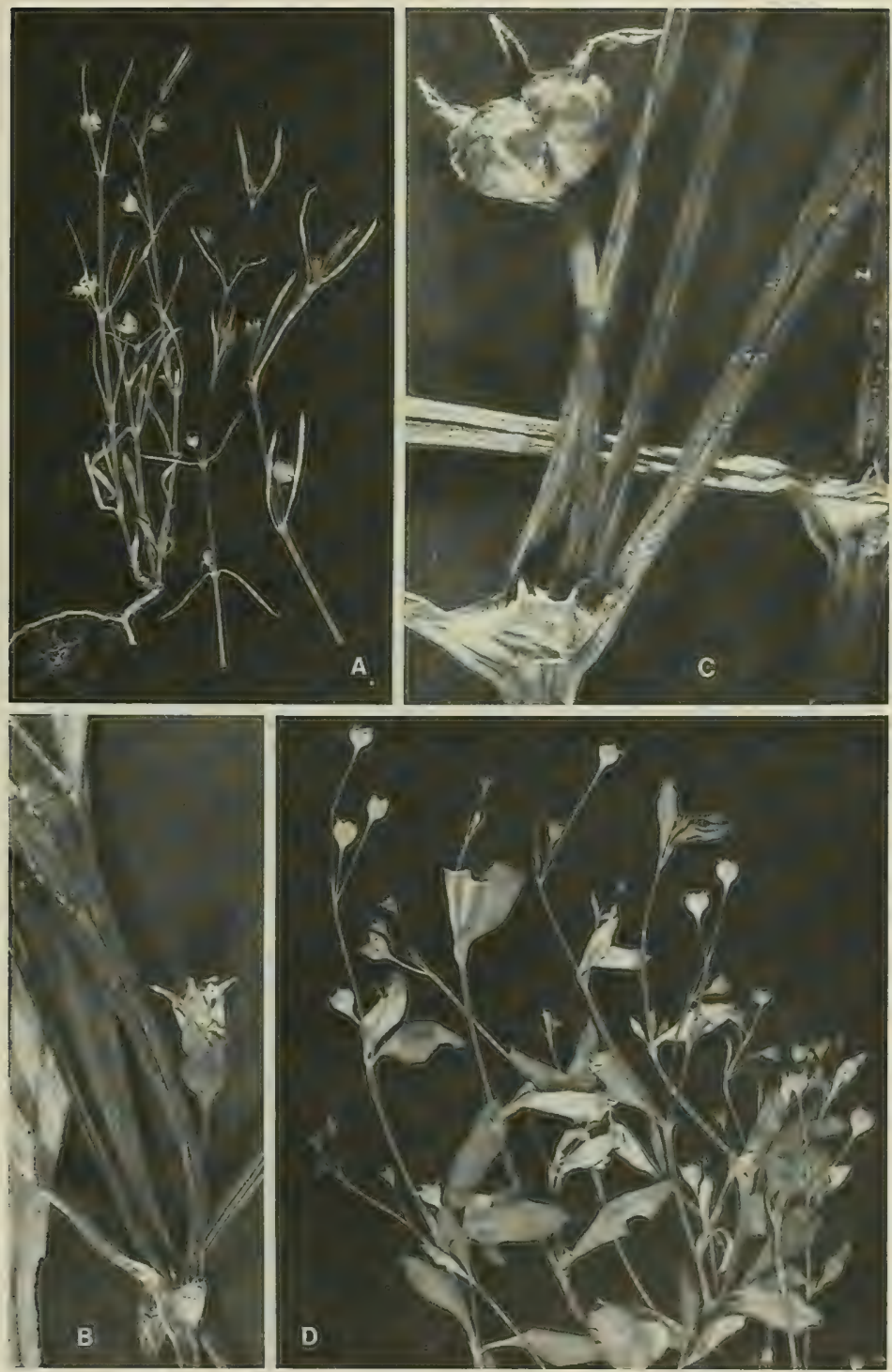
TYPIFICATION AND NOMENCLATURE: Hedyotis tenuifolia was based upon Forster's 1786 interpretation of Oldenlandia tenuifolia Burm. (1768); although Forster is not to be taken as the parenthetical author, $H$. tenuifolia may be considered a new species dating from Smith's 1811 treatment (Smith, 1953) and based on J. R. \& G. Forster (BM LECTOTYPE), collected on Tanna, New Hebrides, during Cook's second voyage. It seems probable that the same species was described from Australia as $H$. galioides; that taxon is well described and illustrated by Ross (1986), but students of the Australian flora should examine this situation. Mueller based his species on two collections, Mueller from the Victoria River and Bowman from Broad Sound, Queensland.

Distribution: New Hebrides and Fiji and (if Hedyotis galioides is correctly placed here) Australia. In Fiji the species is known definitely only from the two largest islands, but there seems no reason to assume that it is an adventive, as implied by Greenwood (1943, as Oldenlandia galioides).

AVAilable COLLECTIONS: VITI LEVU: MBA: Lengalenga flats near Wangandra, between Natova and Nandi, Greenwood 754. TAIlevu: Namara, Seemann 231. ReWA: Ndraundrutukuva, DA 17339. VITI LEVU without further locality, Graeffe 1517. VANUA LEVU: MathuATA: Seanggangga Plateau, in drainage of Korovuli River, vicinity of Natua, Smith 6886 . Fus without further locality, U. S. Expl. Exped., Harvey, Nov. 1855, Horne 887 , s. $n$.

4. Hedyotis biflora (L.) Lam. Tabl. Encycl. Méth. Bot. 1:272. 1792; Fosberg in Bishop Mus. Bull. 174: 19. 1943; Greenwood in J. Arnold Arb. 25: 400. 1944; Yuncker in Bishop Mus. Bull. 184: 63. 1945, in op. cit. 220: 246. 1959; J. W. Parham, Pl. Fiji Isl. 193. 1964, ed. 2. 271. 1972; Backer \& Bakh. f. Fl. Java 2: 285. 1965; Sykes in New Zealand Dept. Sci. Indust. Res. Bull. 200: 177. 1970; St. John \& A. C. Sm. in Pacific Sci. 25: 339. 1971; Morat \& Veillon in Bull. Mus. Nat. Hist. Nat. (Paris) IV. 7, Sect. B, Adansonia 3: 315. 1985.

FIGURE 122D.

Oldenlandia biflora L. Sp. Pl. 119. 1753; Hook. f. Fl. Brit. Ind. 3: 70. 1880; Trimen, Handb. Fl. Ceylon 2: 317. 1894; Christophersen in Bishop Mus. Bull. 128: 198. 1935.

Oldenlandia paniculata L. Sp. Pl. ed. 2. 1667. 1763; Seem. Fl. Vit. 126. 1866; Drake, Ill. Fl. Ins. Mar. Pac. 186. 1890; Reinecke in Bot. Jahrb. 25: 690. 1898; Rechinger in Denkschr. Akad. Wiss. Wein 85: 366. 1910; J. W. Parham, Pl. Fiji Isl. 200. 1964, ed. 2. 279. 1972.

Oldenlandia debilis Forst. f. Fl. Ins. Austr. Prodr. 10. 1786.

Hedyotis paniculata Lam. Encycl. Méth. Bot. 3: 79. 1789; Seem. in Bonplandia 9: 256. 1861, Viti, 438. 1862.

Hedyotis paniculata var. crassifolia A. Gray ex Seem. in Bonplandia 9: 256, nom. nud. 1861, Viti, 438, nom. nud. 1862.

As seen in Fiji, Hedyotis biflora is a prostrate herb, subligneous at base and with branches ascending to $30 \mathrm{~cm}$. high, occurring near sea level on limestone, on cliffs, and in crevices of arid rocks along coasts. The corolla is white. Flowers and fruits have been obtained, insofar as material is dated, between March and July.

TyPIFICATION AND NOMENCLATURE: The only reference given for Oldenlandia biflora is Flora Zeylanica, and a Hermann (Bм) specimen provides the type. For $O$. paniculata the citation is "Habitat in India orientali." Oldenlandia debilis is typified by $J$. R. \& G. Forster (вм LECTOTYPE), collected on Tongatapu, Tonga, during Cook's second voyage. These and other names are combined by Fosberg (1943). 
Distribution: Tropical Asia to Mauritius, throughout Malesia, and eastward in the Pacific to Tonga, Niue, and Samoa. Its known distribution in Fiji is scattered, but it may be assumed to be indigenous.

LOCAL NAME: The only name noted is tho ni vatu (Kambara).

AVAilable COllections: VITI LEVU: Nandronga \& Navosa: Thuvu, west of Singatoka, Greenwood 918; Natumbakula, near Singatoka, Degener 15111. VITr LEvu without further locality, Seemann 234. VANUA LEVU: Without further locality, Seemann 233, p. p. TAVEUNI: Seemann 233, p. p. MATUKU: Moseley. KAMBARA: On limestone, Smith 1285. FiJI without further locality, U. S. Expl. Exped., Barclay, Horne 102.

5. Hedyotis pumila L. f. Suppl. Pl. 119. 1782; Backer \& Bakh. f. Fl. Java 2:285. 1965; J. W. Parham, Pl, Fiji Isl. ed. 2. 271. 1972.

Oldenlandia pumila DC. Prodr. 4: 425. 1830; Verdcourt in Fl. Trop. E. Afr. Rub. 307. fig. 41 (32). 1976.

A sprawling herb seen in Fiji near sea level as a weed in lawns, cultivated areas, and waste places, with a white corolla. Flowers and fruits have been noted between February and November.

TyPIFICATION: The species is based on a collection of König from Tranquebar, India (not found, Verdcourt, 1976).

Distribution: Indigenous in India, southeastern Asia, and perhaps in western Malesia, spread as a weed in other parts of the tropics. In Fiji it has become well established in Suva but thus far it has not seemed to spread.

Available Collections: VITI LEVU: Rewa: Suva, wharf area, DA 3123 (L.2899); Suva, Department of Agriculture compound, $D A 7417,10192,14533,17212$ : Suva golf course, $D A 11424$; Suva, along streets, $D A$ $2600,9644(L .4460), 16037$.

39. Coprosma J. R. \& G. Forst. Char. Gen. P1. 69. 1775, ed. 2. 137. 1776; Seem. Fl. Vit. 139. 1866; Hook. f. in Benth. \& Hook. f. Gen. Pl. 2: 139. 1873; K. Schum. in Engl. \& Prantl, Nat. Pflanzenfam. IV. 4: 132. 1891; W. Oliver in Bishop Mus. Bull. 132: 27. 1935; Backer \& Bakh. f. F1. Java 2: 348. 1965; S. Darwin in Allertonia 2: 42. 1979.

Dioecious or polygamous or rarely monoecious shrubs or small trees, sometimes creeping and rooting at nodes, often foetid when bruised, the stipules interpetiolar, entire to dentate, sometimes united and sheathing the stem; inflorescences axillary cymes or with axillary and solitary flowers, these small, often greenish, usually unisexual, rarely $\Varangle, 4$ - or 5(-10)-merous; calyx limb persistent, lobed, or usually absent in $\sigma^{\prime}$ flowers; corolla infundibular to campanulate, the lobes valvate in bud; stamens inserted at base of corolla, the filaments long, the anthers exserted and pendulous at anthesis; ovary 2(3- or 4)-locular, the ovules solitary and basal in each locule; styles divided nearly to base, filiform, papillose-hirsute, long-exserted; fruit fleshy, drupaceous, ovoid to globose, with 2 (3 or 4) plano-convex, 1-seeded pyrenes.

LeCtotype sPecies: Coprosma foetidissima J. R. \& G. Forst. (vide W. Oliver in Bishop Mus. Bull. 132: 27. 1935; Rehder, Bibl. Cult. Trees Shrubs, 597. 1949), one of the two species originally included in the genus. 

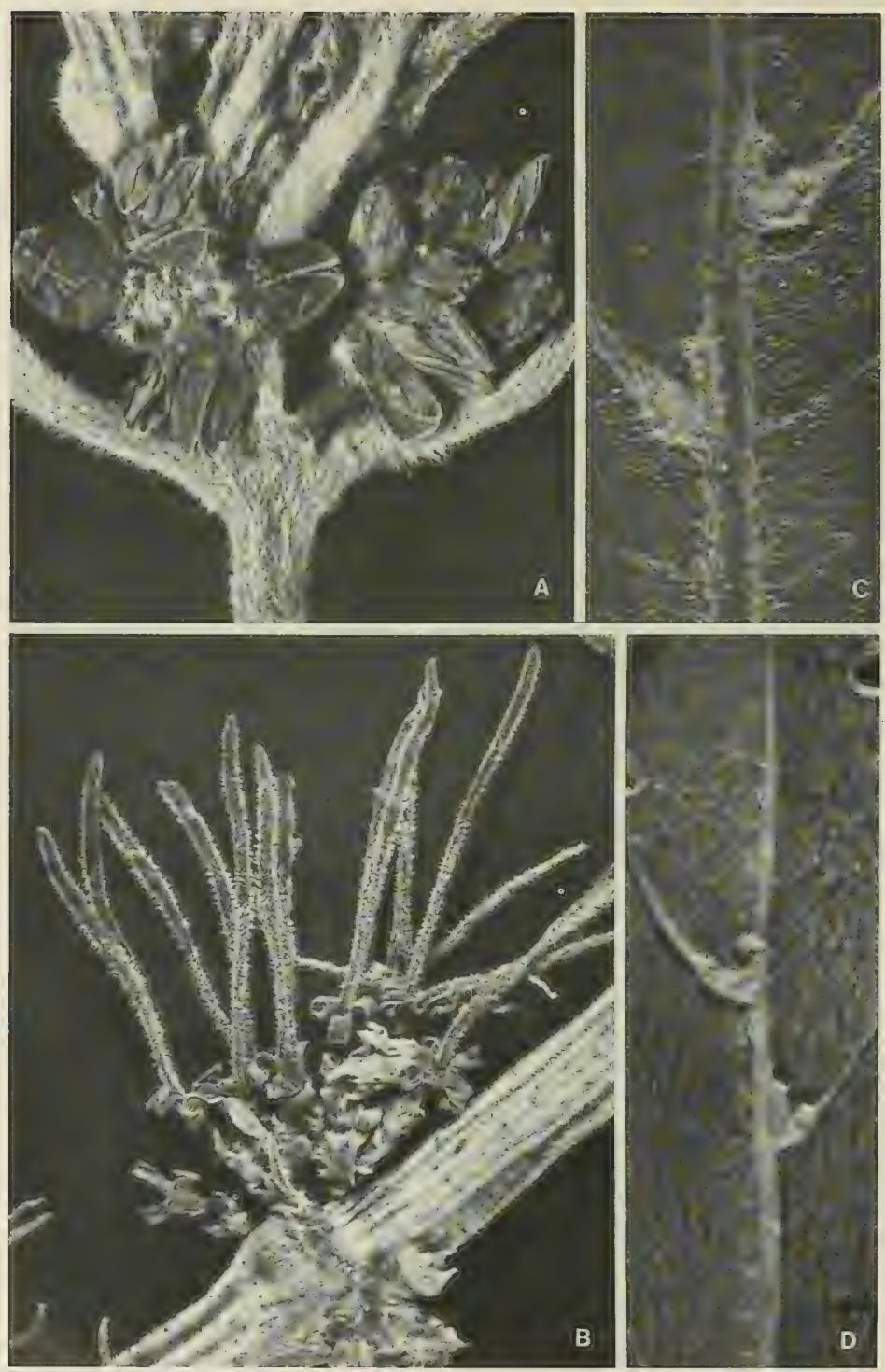

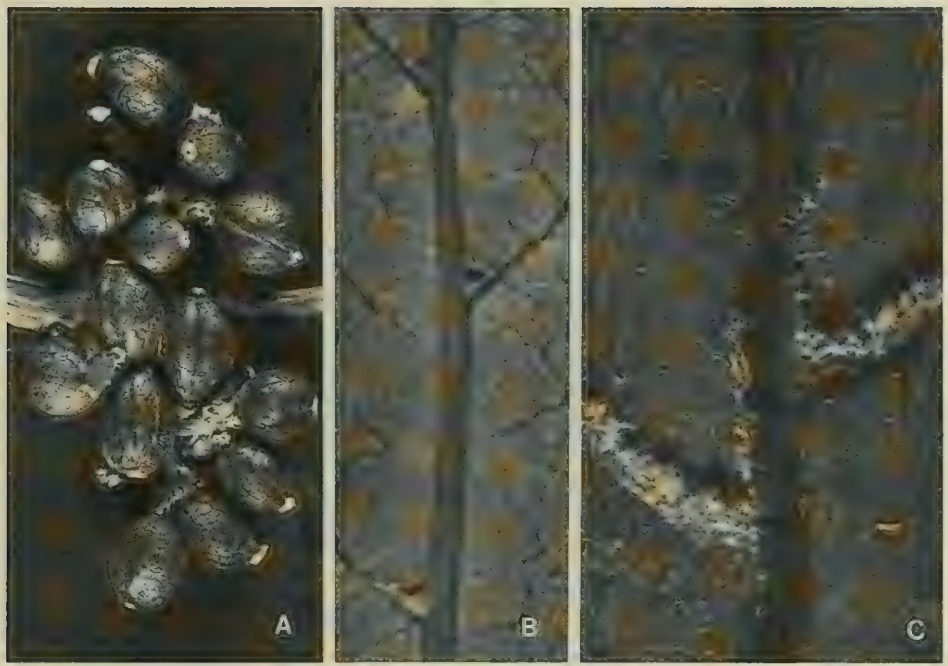

FIGURE 124. Coprosma persicifolia; A, infructescences, $\times 4$; B \& C, lower surfaces of leaf blades including costa and domatia, × 10. A from O. \& I. Degener 32101, B from Smith 8036, C from Gillespie 3206.

Distribution: Borneo and Java to Tasmania and New Zealand, and eastward in the Pacific to Hawaii and Juan Fernandez, with about 90 species. One species is indigenous (and presumably endemic) in Fiji.

Useful treatment of genus: Oliver, W. R. B. The genus Coprosma. Bishop Mus. Bull. 132: 1-207. 1935.

1. Coprosma persicifolia A. Gray in Proc. Amer. Acad. Arts 4: 50, as C. persicaefolia. 1858; J. W. Parham, Pl. Fiji Isl. ed. 2. 267. 1972.

Figures 123, 124.

Coprosma persicaefolia A. Gray ex Seem. Viti, 437. 1862, Fl. Vit. 139. 1866; Drake, Ill. Fl. Ins. Mar. Pac. 201. 1890; Gillespie in Bishop Mus. Bull. 83: 32. fig. 40. 1931; W. Oliver in op. cit. 132: 138. fig. 47; pl. 36. 1935; Fosberg in Sargentia 1: 140. 1942; J. W. Parham, Pl. Fiji Isl. 189. 1964.

Coprosma imthurniana Gibbs in J. Linn. Soc. Bot. 39: 154. 1909; Turrill in op. cit. 43: 29. 1915.

Shrub or small tree 1-6 m. high, usually slender or compact, with yellowish wood, found at elevations of $50-1,240 \mathrm{~m}$. in open forest, hillside thickets, and in the dense thickets of crests and ridges. The flower buds are cream-colored and purple-tinged, the mature corolla greenish white to yellowish green, the filaments pale greenish, the anthers and styles white, and the fruits blue turning to black. Flowers and fruits have been obtained in practically every month.

FIgure 123. Coprosma persicifolia; A, $\sigma$ inflorescences, the anthers mature but not yet exserted, $\times 8 ; \mathrm{B}$, o inflorescence, $\times 6 ;$ C \& D, lower surfaces of leaf blades including costa and domatia, $\times 10$. A from Greenwood 48A, B \& C from Smith 6179, D from Smith 6532. 
TyPifiCation: The type of Coprosma persicifolia is U. S. Expl. Exped. (us 62263 HOLOTYPE; ISOTYPE at GH; photo of isotype at BISH), collected in 1840 in Fiji without further locality. Coprosma imthurniana was based on two collections made in August, 1907, at Nandarivatu, Mba Province, Viti Levu, from $\sigma^{*}$ and $\$$ plants; at both BM and $\mathrm{K}$ the two are mounted on single sheets. The better specimen in each case is from the $\sigma^{\prime}$ plant: Gibbs 554 (вM LECTOTYPE here designated; ISOLECTOTYPE at K); Gibbs 543 (BM, K) is a paratype. A photograph of the BM sheet is at BISH.

Distribution: Endemic to Fiji and known to us from 33 collections from five islands.

LOCAL NAMES AND USE: Reported names are kandrakandravili and turulevu(Mba) and timo ( $\mathrm{Ra}$ ); in the latter Province an external medicinal use for aches has been noted.

RePresentative collections: VITI LEVU: Mba: Mt. Evans Range, Greenwood 48A; hills between Nandala and Nukunuku Creeks, along trail from Nandarivatu to Lewa, Smith 6179; Nandarivatu, im Thurn 280; Mt. Nanggaranambuluta, east of Nandarivatu, $O . \& 1$. Degener 32101 . Nandronga \& Navosa: Nausori, H. B. R. Parham 112. NAMOSI: Valley of Wainambua Creek, south of Mt. Naitarandamu, Smith 8774; between Nanggarawai and Saliandrau, Wainikoroiluva River, Gillespie 3206. RA: Vicinity of Rewasa, near Vaileka, Degener 15353. OVALAU: Summit and adjacent slopes of Mt. Korotolutolu, west of Thawathi, Smith 8036; Lovoni Valley, Horne 129. VANUA LEVU: MathuATA: Mt. Ndelaikoro, DA 12810; northwestern slopes of Mt. Numbuiloa, east of Lambasa, Smith 6532. RAMBI: In mountains, Horne s. n. TAVEUNI: Summit of Mt. Uluingalau, Smith 893.

In his 1935 revision Oliver considers three species to comprise his "group of Coprosma persicaefolia," each endemic to its own archipelago: C. persicifolia to Fiji, C. strigulosa Lauterb. to Samoa, and C. novaehebridae W. Oliver to the New Hebrides. One cannot have much confidence in the value of the foliage characters used to separate these species (cf. Fosberg, 1942), but until a new generic treatment is undertaken the taxa may be maintained. As pointed out by Oliver, the type material of $C$. imthurniana, like most of the collections from upland northern and western Viti Levu, has the branchlets, leaves, and domatia copiously pilose (FIGURE 123A, C). Material from Ovalau resembles Gray's type (possibly also from Ovalau, like many of the Exploring Expedition collections) in being essentially glabrous and with small domatia (FIGURE 124B). Specimens intermediate in indument and prominence of domatia have been noted from Vanua Levu (FIGURE 123D) and Taveuni, while several collections from central Viti Levu have the domatial areas extended and more conspicuously pilose (FIGURE 124C). In view of this variation, which is geographically not entirely dependable, we accept Oliver's opinion that a single species represents Coprosma in Fiji. 


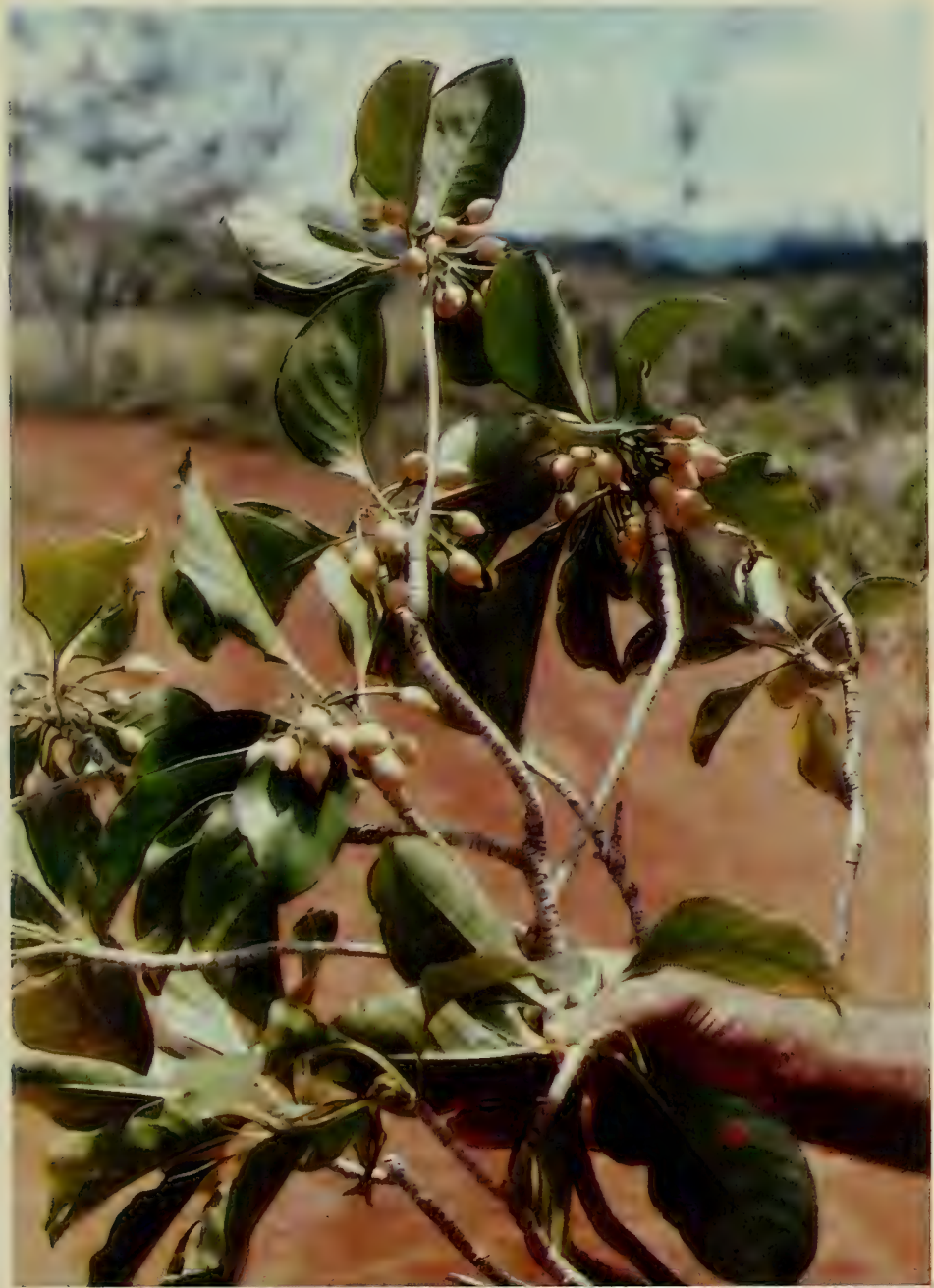

FIGURE 125. Foliage and infructescences of Fagraea gracilipes (Loganiaceae), from Mathuata Province, Vanua Levu (Smith 6665), $\times$ about $1 / 4$ 

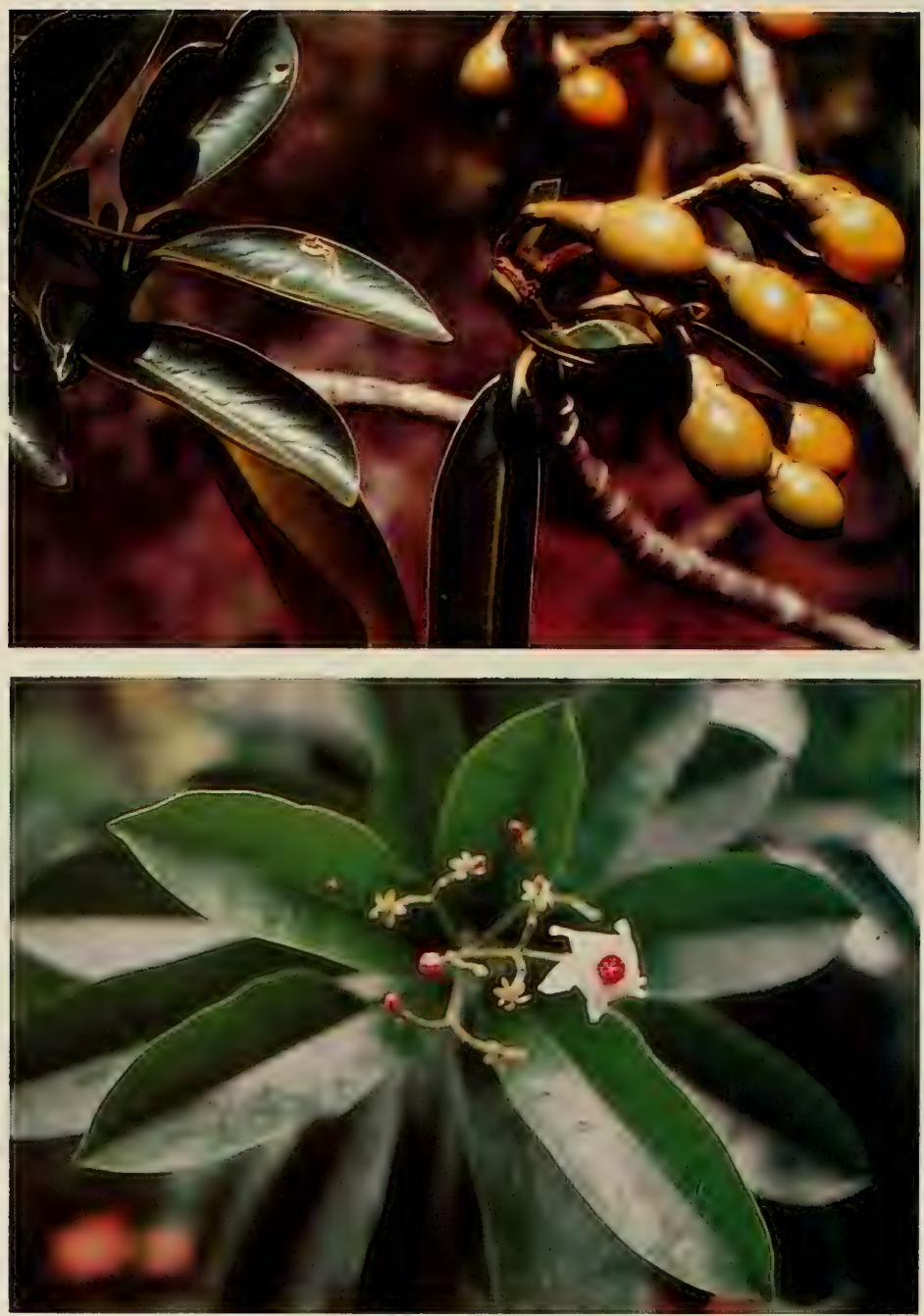

FIGURE 126. (Upper) Foliage and infructescences of Fagraea berteroana (Loganiaceae), from the vicinity of Nandarivatu, Mba Province, Viti Levu (no voucher), $\times$ about $2 / 5$.

(Lower) Foliage and an inflorescence, with one open flower, of Cerbera manghas (Apocynaceae), from Mt. Korombamba, Rewa Province, Viti Levu (photograph by William G. Ziarnik), x about 1/2. 

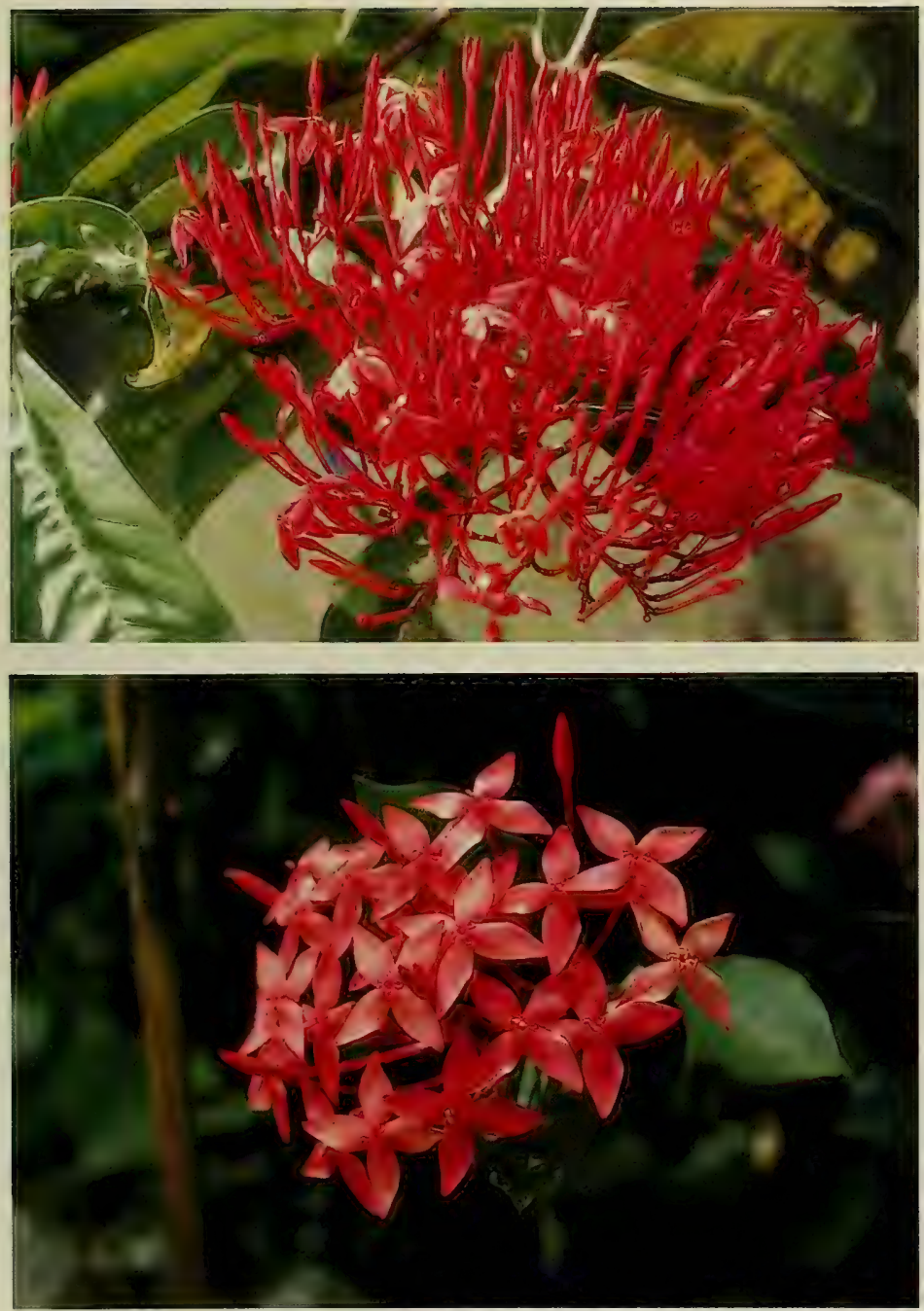

FIGURE 127. (Upper) Inflorescence and foliage of Ixora longifolia (Rubiaceae), cultivated in Suva, Rewa Province, Viti Levu (no voucher, but photo from same plant as DA 12084), $\times$ about $2 / 3$.

(Lower) Inflorescence and foliage of another commonly cultivated species of $I x o r a, I$. coccinea, in a garden at Lami, Rewa Province, Viti Levu (no voucher), $\times$ about $2 / 3$. 


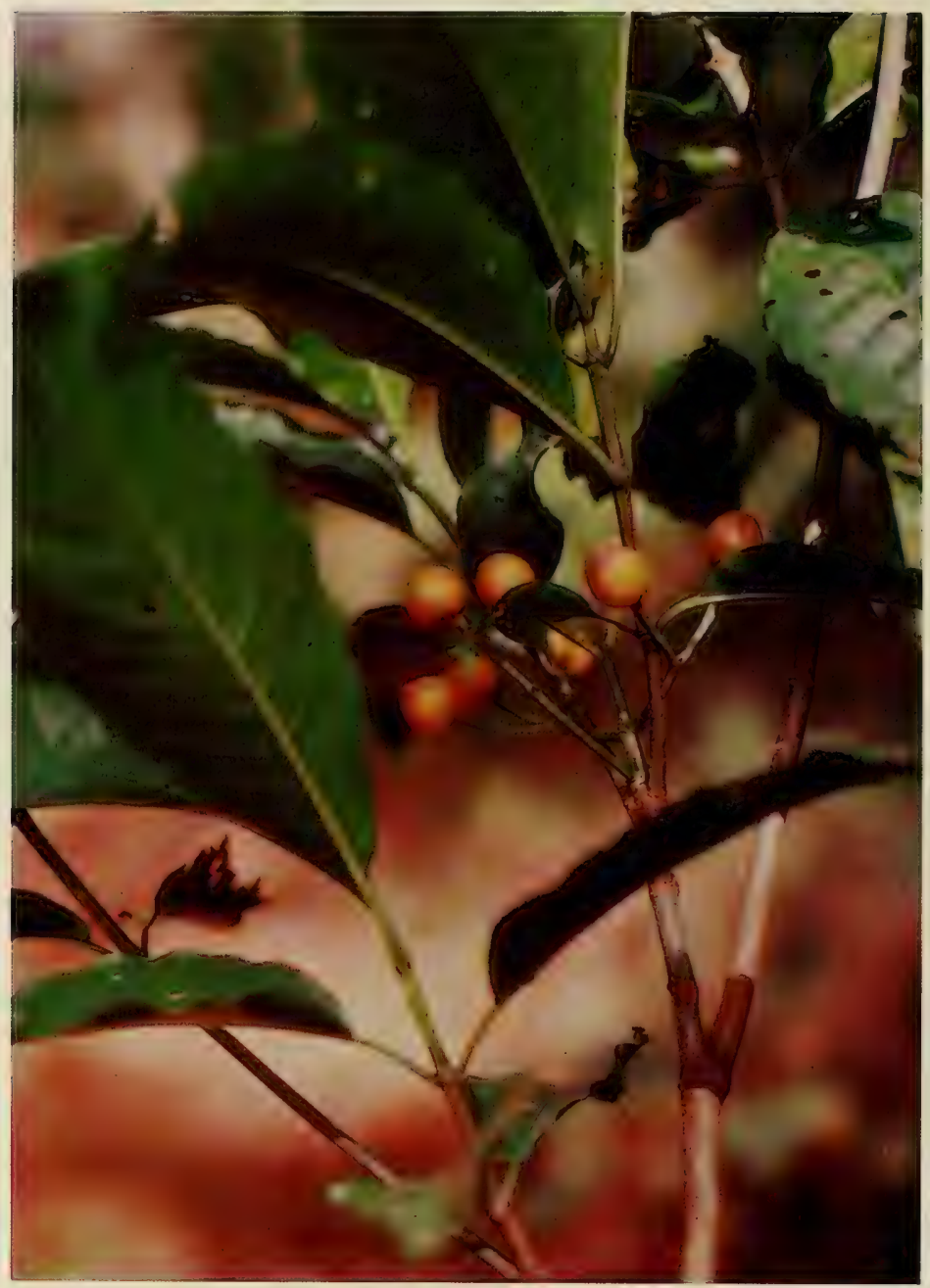

FIGURE 128. Foliage and fruits of Tarenna seemanniana (Rubiaceae), from Mt. Korombamba, Rewa Province, Viti Levu (photograph by William G. Ziarnik), $\times$ about $3 / 5$. 


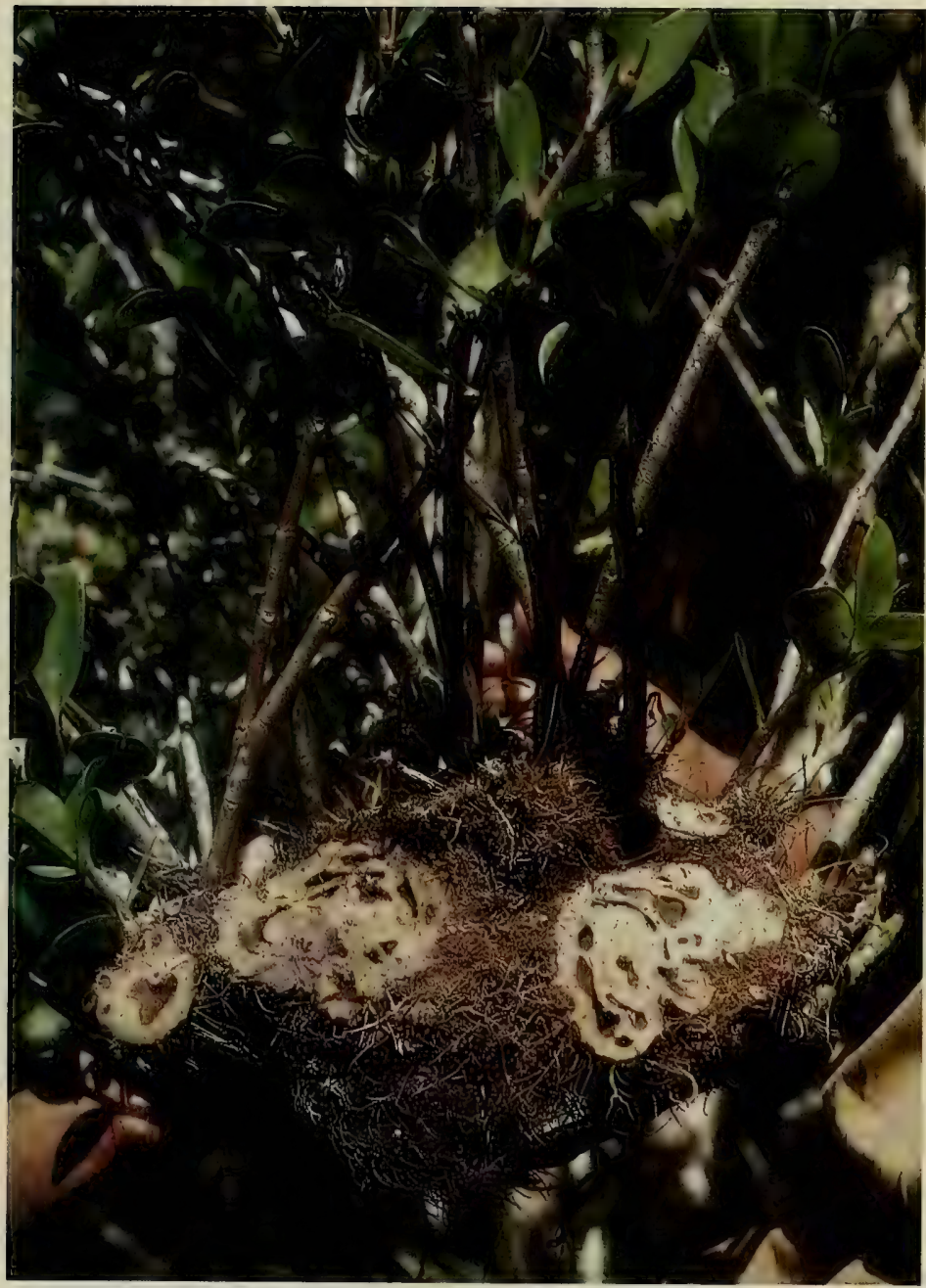

FIGURE 129. Tubers and flowering branches of Hydnophytum grandiflorum (Rubiaceae), from Mathuata Province, Vanua Levu (Smith 6435), $\times$ about $2 / 5$. 


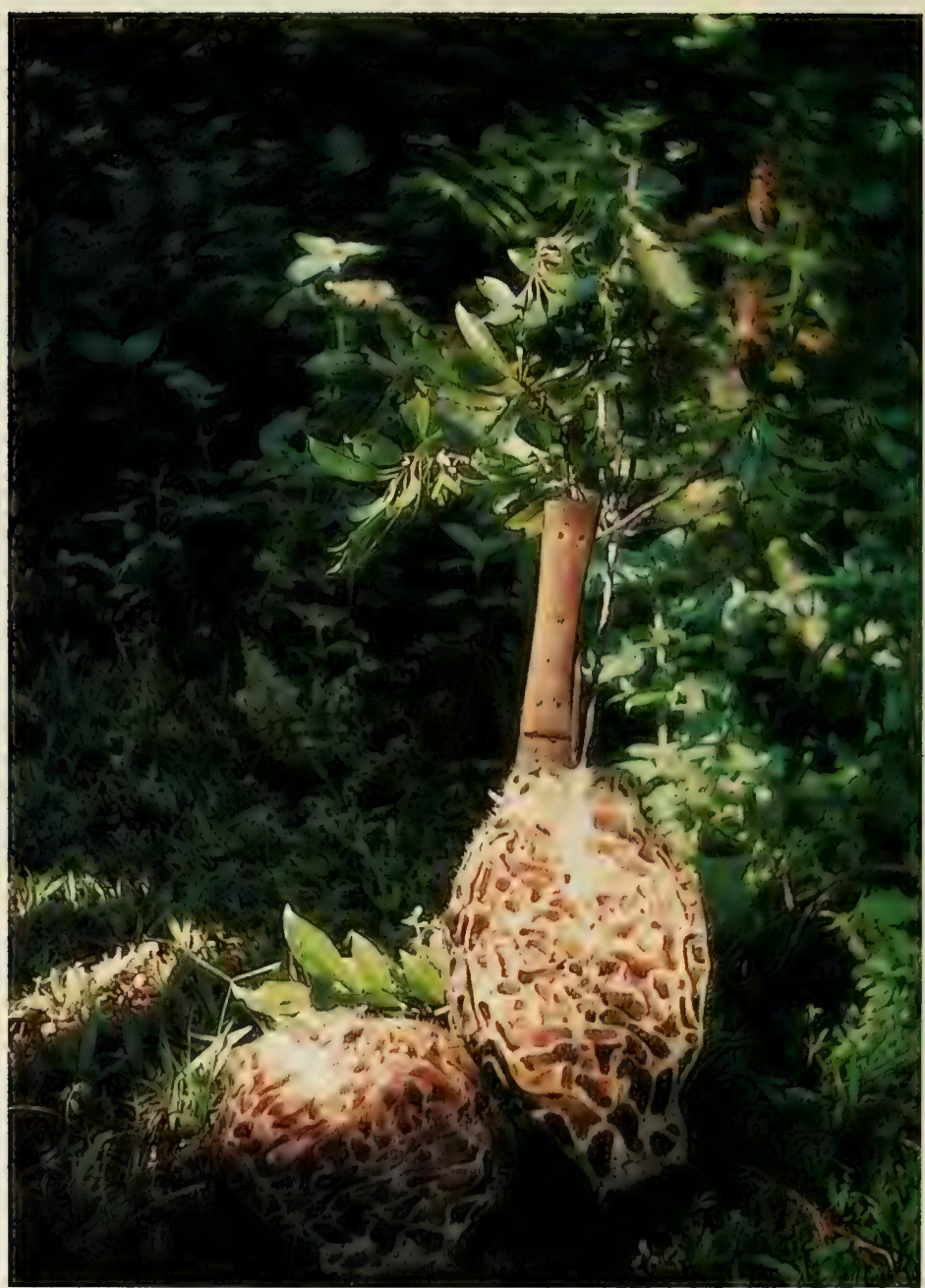

Figure 130. Tuber and flowering branches of Squamellaria wilsonii (Rubiaceae), from Taveuni (DA $16935), \times$ about $1 / 5$. 

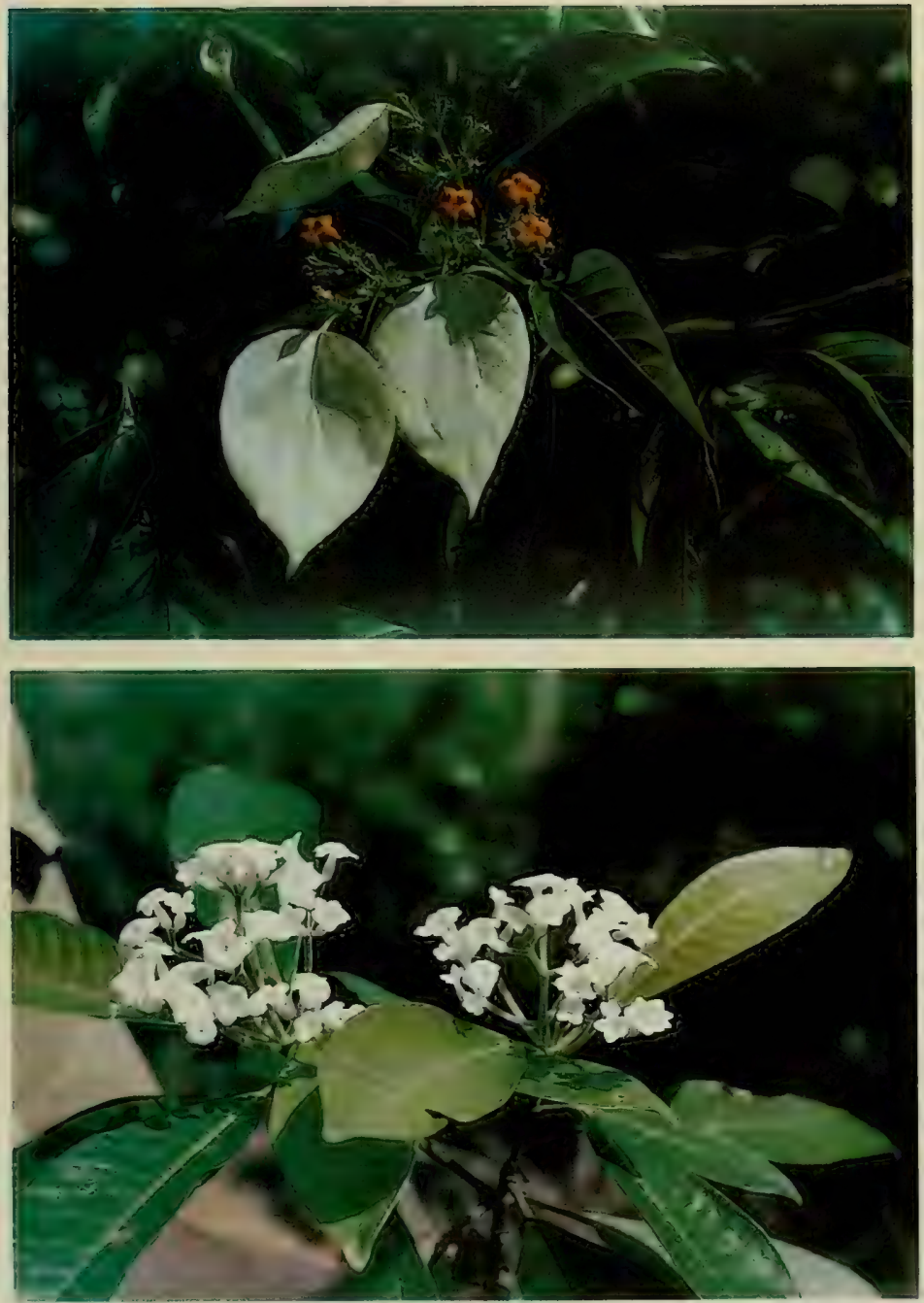

Figure 131. (Upper) Foliage and inflorescences of Mussaenda raiateensis (Rubiaceae), from Serua Province, Viti Levu (Smith 9344), $\times$ about $2 / 5$.

(Lower) Foliage and inflorescences of Psychotria brevicalyx (Rubiaceae), from Serua Province, Viti Levu (Smith 9656), showing calyx limbs which briefly persist after corollas have fallen and before fruits develop, $\times$ about $1 / 2$. 

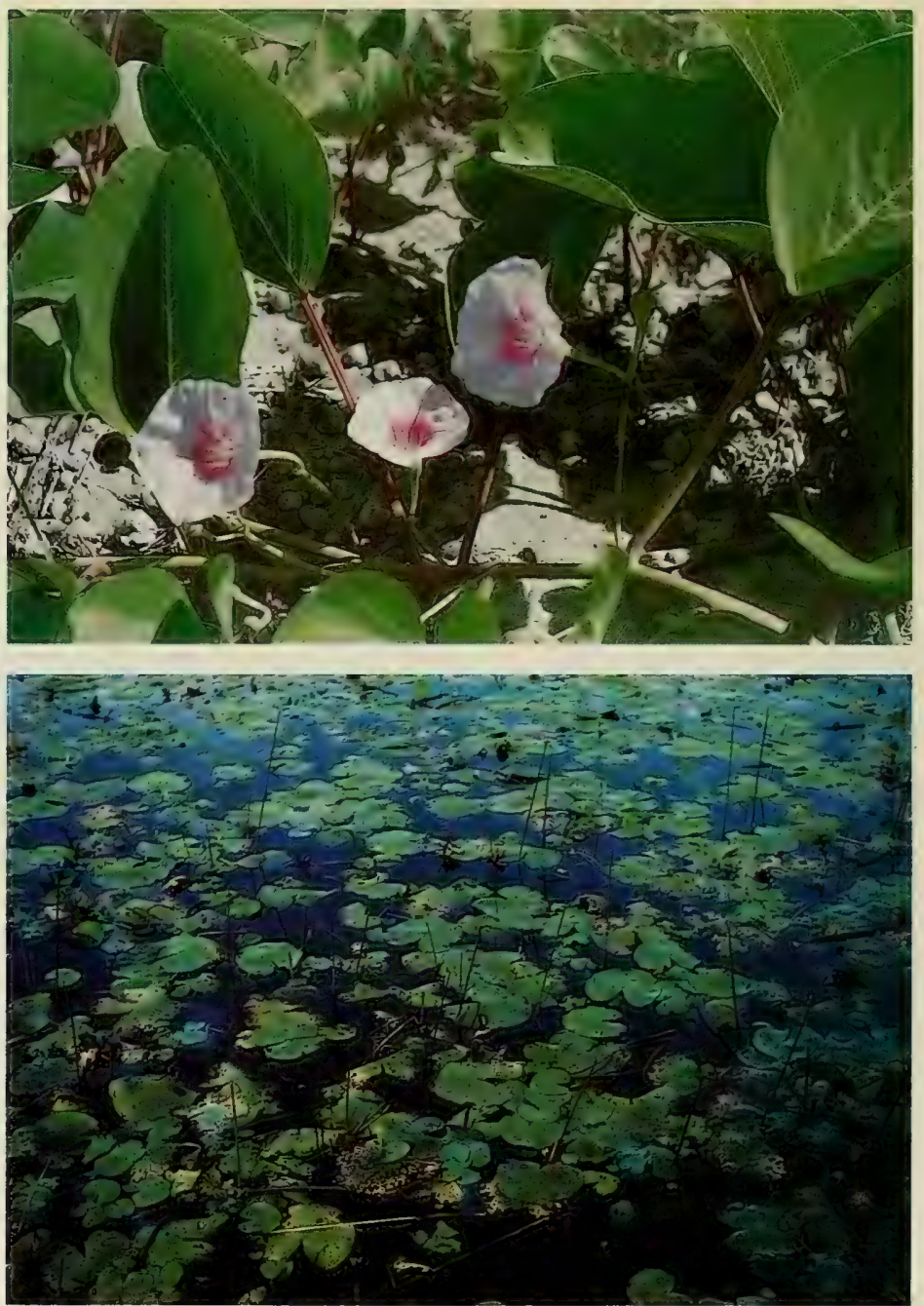

Figure 132. (Upper) Foliage and flowers of Ipomoea pes-caprae var. brasiliensis (Convolvulaceae), from Serua Province, Viti Levu (Smith 9624), $\times$ about 1/3.

(Lower) Nymphoides indica (Menyanthaceae) growing in a small lake on the northern part of the Rairaimatuku Plateau, Nandronga \& Navosa Province, Viti Levu (Smith 5387), × about 1/8; cf. this Flora, vol. 1 , fig. 8 (lower) 
40. RichaRdia L. Sp. Pl. 330. 1753; Backer \& Bakh. f. Fl. Java 2: 351. 1965; W. Lewis \& R. Oliver in Brittonia 26: 273. 1974; Verdcourt in Fl. Trop. E. Afr. Rub. 377. 1976; Ross in Stanley \& Ross, Fl. S.-E. Queensland 2: 325.1986.

Richardsonia Kunth in Mém. Mus. Hist. Nat. 4:430, nom. superfl. 1818; H. B. K. Nova Gen. et Sp. 3: 350. 1819; Hook, f. in Benth. \& Hook. f. Gen. Pl. 2: 147. 1873; K. Schum. in Engl. \& Prantl, Nat. Pflanzenfam. IV. 4: 139. 1891.

Annual or perennial, erect to prostrate herbs, the stipules united with bases of petioles, fimbriate; inflorescences dense, pedunculate, terminal heads of few (rarely 1)-many flowers enclosed by an involucre of (2-) 4 leaves; flowers $\zeta$ (sometimes reported as unisexual), not heterostylous, 3-6(-8)-merous; calyx limb deeply lobed, persistent; corolla short-infundibular to hypocrateriform, the tube pubescent toward base within, glabrous in throat, the lobes valvate in bud; stamens inserted in corolla throat, the anthers exserted; ovary ( 2 or)3- or 4(-6)-locular, the ovules solitary in each locule, attached near middle of dissepiment, the style filiform, the stigma (2 or)3- or $4(-6)$-lobed; fruit a capsule separating into 1-seeded cocci, these mostly obovoid, smooth or often muricate to papillose, the seeds oblong-ellipsoid or obovoid, ventrally grooved.

TYPE SPECIES: Richardia scabra L., the only original species. Richardsonia was published as an unintentional correction for Richardia.

Distribution: Southern United States and parts of the West Indies southward to Argentina, with about 15 species, a few of which are now widespread as weeds in other tropical areas. A single species has been noted in Fiji.

Useful treatment of Genus: Lewis, W. H. \& R, L. Oliver. Revision of Richardia (Rubiaceae). Brittonia 26: 271-301. 1974.

1. Richardia scabra L. Sp. Pl. 330. 1753; Backer \& Bakh. f. Fl. Java 2: 351. 1965; W. Lewis \& R. Oliver in Brittonia 26: 282. fig. 4. 1974; Verdcourt in Fl. Trop. E. Afr. Rub. 380. fig. 56 (1-8). 1976; Ross in Stanley \& Ross, Fl. S.-E. Queensland 2: 326. fig. 461.1986.

Richardsonia scabra A. St.-Hil. PI. Usuel. Bras. pl. 8, solum quoad basionymum. 1824.

A sprawling annual herb with erect or ascending, soft-hirsute stems, said to be locally common as a weed in ricefields. The corollas are white or pale pink and have been noted in February.

TYPIFICATION: The type is Houstoun (LINN 451.1 HOLOTYPE; ISOTYPE at BM), from Veracruz, Mexico.

Distribution: Southern United States, Central America, Cuba, Jamaica, and western South America to Bolivia. Its adventive occurrence now includes at least Africa, Java, and Australia. The first Fijian record is dated 1957, the only presently available collections being from western Viti Levu.

AVAILABLE COLLECTIONS: VITI LEVU: MBA: Wanggandra, near Nandi airport, DA 10676; Mbuambua Island, near Nandi, $D A 11708$.

41. Spermacoce L. Sp. Pl. 102. 1753; Hook. f. in Benth. \& Hook. f. Gen. Pl. 2: 145. 1873; K. Schum. in Engl. \& Prantl, Nat. Pflanzenfam. IV. 4: 145. 1891; Backer \& Bakh. f. Fl. Java 2: 355. 1965; Verdcourt in Kew Bull. 30: 301. 1975, in Fl. Trop. E. Afr. Rub. 339. 1976; Ross in Stanley \& Ross, Fl. S.-E. Queensland 2: 327. 1986.

Borreria G. F. W. Meyer, Prim. Fl. Esseq. 79. 1818; K. Schum. in Engl. \& Prantl, Nat. Pflanzenfam. IV. 4: 143. 1891; Backer \& Bakh. f. Fl. Java 2: 352. 1965; Steyermark in Mem. New York Bot. Gard. 23: 805. 1972. Nom. cons, sed non vs. Spermacoce.

Spermacoce sect. Borreria Verdcourt in Kew Bull. 30: 366. 1975. 
Annual or perennial herbs or small subshrubs, with opposite or sometimes falsely whorled leaves, the stipules interpetiolar, often united with petiole bases, usually divided into 1-many filiform fimbriae; inflorescences axillary, mostly globose, often very many-flowered clusters or less often terminal capitula, subtended by 1 or 2 (or more) pairs of bractlike leaves, sometimes the axillary inflorescences running together to form extended, spikelike inflorescences with bracts distributed throughout; flowers usually small, $\not$, usually not heterostylous; calyx limb mostly persistent, $2-4(-8)-$ lobed, sometimes with intermediate denticles; corolla campanulate to infundibular or hypocrateriform, the tube sometimes very slender, the throat glabrous or pubescent, the lobes ( 3 or) 4 , valvate in bud; stamens 4 , the filaments inserted in corolla tube or in throat, the anthers included or exserted; ovary 2-locular, the ovules solitary in each locule, attached to middle of dissepiment, the style filiform, usually exserted, the stigma capitate or briefly 2-lobed; fruits separating into 2 cocci (one coccus usually being open, the other remaining closed) or a capsule dehiscing from apex or from base and the valves remaining united by the calyx limb, the seeds oblong, ellipsoid, or ovoid, ventrally grooved, the surface often clearly reticulate.

TYPE SPECIES: Of the three species originally included in Spermacoce, the lectotype species is $S$. tenuior L. (vide Britton \& Brown, Ill. Fl. N. U. S. ed. 2. 3: 256. 1913). Borreria is typified by B. suaveolens G. F. W. Meyer (typ. cons., ICBN).

Distribution: Tropical and subtropical, with 150-250 species, these mainly American but some also in Africa and other areas (Verdcourt, 1976). Many species have become weeds of cultivation; three of these are established adventives in Fiji.

Concerning Spermacoce vs. Borreria and other segregated genera, Verdcourt (1975, p. 302) remarks: "The technical differences between the various genera depend on the fruit-if it divides into dehiscent or indehiscent cocci or whether it is a capsule splitting either from base to apex or in the reverse direction. These are it is true not difficult to see if the fruit is available but they do not always divide the assemblage into truly related groups. Only after a complete world revision would this be realizable and since this is not feasible for the purpose in hand I have compromised." (I. e. he has united Spermacoce, Borreria, and some smaller genera but has kept Diodia L. separate.) Again (1976, p. 341) Verdcourt notes: "It has been accepted practice for a hundred years or so to split up this genus, but although the technical characters of the fruit dehiscence sound admirable on paper there is no associated habit facies and it is not possible without additional knowledge to assign flowering material to the genera concerned."

KEY TO SPECIES

Calyx lobes 2 or rarely 4 , inserted on narrow sides of laterally compressed ovary; corolla campanulateurceolate, less than $1 \mathrm{~mm}$. long, deeply divided, white, glabrous within; stamens inserted near base of corolla, usually included; stigmas capitate to subcapitate, usually included; stems sharply 2-4-angled or -winged, the angles spreading- to retrorse-pubescent; leaf blades elliptic to elliptic-oblong, rounded to obtuse or acute, to $3.5 \times 1.5 \mathrm{~cm}$., scabrid near margin and of ten on costa but otherwise mostly glabrous; fruits about $1 \mathrm{~mm}$. long, the seeds reticulate. .................... mauritiana

Calyx lobes 4 ; corolla infundibular, more than $1 \mathrm{~mm}$. long, white or tinged with purple or pink; stamens inserted in corolla throat, exserted; stigmas exserted.

Corolla 1.5-3.5 mm. long, glabrous within, white or the lobes pink-tinged; stigmas capitate or slightly lobed; leaf blades oblong-lanceolate, $2.5-5.5 \times 0.5-2.5 \mathrm{~cm}$., more than 2.5 times as long as broad, scabrid near margin but otherwise mostly glabrous; stems not sharply angled or winged; fruits 1-4

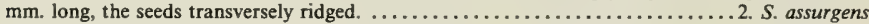

Corolla 3-10 mm. long, pubescent within, white or occasionally purplish; stigmas 2, linear; leaf blades broadly elliptic to ovate-oblong, acute to obtuse, 2-6 $\times 0.5-4 \mathrm{~cm} ., 1-2$ times as long as broad, pubescent-scabrid above and beneath, often strikingly yellow-green and red-margined; stems sharply 4-angled or -winged; fruits 3-4 mm. long, the seeds reticulate-rugulose with a deep ventral excava-

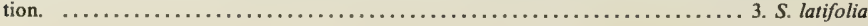


1. Spermacoce mauritiana Gideon in Verdcourt in Kew Bull. 37: 547. 1983.

Borreria repens DC. Prodr. 4: 544. 1830; Backer \& Bakh. f. Fl. Java 2: 353. 1965; non Spermacoce repens Willd. ex Cham. \& Schlechtendal (1828).

Borreria ocymoides sensu Christophersen in Bishop Mus. Bull. 154: 74, as B. ocimoides. 1938; J. W. Parham, Pl. Fiji Isl. ed. 2. 266. 1972; Steyermark in Mem. New York Bot. Gard. 23: 815, as B. ocimoides. 1972; et auct. mult.; non DC.

Spermacoce ocymoides sensu Verdcourt in Fl. Trop. E. Afr. Rub. 361, p. p. 1976; et auct. mult.; non Burm. f.

As noted in Fiji, Spermacoce mauritiana is an occasional weed in villages and gardens between sea level and $200 \mathrm{~m}$., with a minute white corolla. Flowers and fruits have been noted only in April.

TYPIFICATION: The type of Borreria repens is Sieber 144 (G HOLOTYPE; ISOTYPE at P), from Mauritius. As the epithet is not available in Spermacoce, Gideon has proposed the new name $S$. mauritiana for the taxon. In Fiji and Samoa, as in many other areas, this species has been included in a concept of Spermacoce (or Borreria) ocymoides, but that supposedly cosmopolitan species is actually a complex of species separable on seed characters (Verdcourt, 1983).

Distribution: Spermacoce mauritiana (i. e. Borreria repens DC.) is now a pantropical weedy plant, but probably it was of American origin and was early introduced into the Old World tropics, where it now gives the appearance of being indigenous in parts of Africa, Indian Ocean islands, southeastern Asia, and Malesia. True $S$. ocymoides Burm. f. seems to be endemic in Malesia and Ceylon, not known from tropical America (F. R. Fosberg, pers. comm.). Spermacoce mauritiana is more obviously a weed in the Solomon Islands, the Caroline Islands, the Fijian Region, and Hawaii; in Fiji it is presently known only from eastern Viti Levu, the earlier of the two available collections being dated 1940 .

AVAilable Collections: VITI LEVU: NaItasiRI: Nanduruloulou, in Department of Agriculture compound, DA 2272. TAILEvU: Ndakuivuna, in hills east of Wainimbuka River (weed in village), Smith 7078.

2. Spermacoce assurgens Ruiz \& Pavón, Fl. Per. Chil. 1: 60. t. 92, b. 1798; Verdcourt in Kew Bull. 37: 547. 1983; Morat \& Veillon in Bull. Mus. Nat. Hist. Nat. (Paris) IV. 7, Sect. B, Adansonia 3: 317. 1985.

Borreria laevis sensu Christophersen in Bishop Mus. Bull. 154: 74. 1938; Yuncker in op. cit. 178: 114. 1943; Greenwood in J. Arnold Arb. 25: 397. 1944, in op. cit. 30: 77. 1949; Yuncker in Bishop Mus. Bull. 220: 259. 1959; J. W. Parham in Dept. Agr. Fiji Bull. 35: 103. fig. 51. 1959, Pl. Fiji Isl. 187. 1964, ed. 2. 266. 1972; Backer \& Bakh. f. Fl. Java 2: 354. 1965; Sykes in New Zealand Dept. Sci. Indust. Res. Bull. 200: 175. 1970; Steyermark in Mem. New York Bot. Gard. 23: 818. 1972; MacKee, Pl. Intro. Cult. Nouv.Caléd. 117. 1985; et auct. mult.; non Griseb. quoad basionymum.

Borreria verticillata sensu Greenwood in Proc. Linn. Soc. 154:99. 1943; J. W. Parham in Dept. Agr. Fiji Bull. 35: 103. 1959, PI. Fiji Isl. 187. 1964; Sykes in New Zealand Dept. Sci. Indust. Res. Bull. 200: 175. 1970; non G. F. W. Meyer (Spermacoce verticillata L.).

Spermacoce laevis sensu Verdcourt in Fl. Trop. E. Afr. Rub. 357. 1976; et auct. mult.; non Lam.

As seen in Fiji, Spermacoce assurgens is a sprawling or subprostrate herb 20-50 $\mathrm{cm}$. high, occurring between sea level and $850 \mathrm{~m}$. elevation as an abundantly naturalized weed on grassy slopes, along roadsides, and in villages, canefields, and gardens. The white corolla has the lobes faintly pink-tinged; the stamens have white filaments and pale blue or bluish-tinged anthers; the style is white and pink-tinged; and the fruits are brown. Flowers and fruits occur throughout the year.

TyPification: Ruiz and Pavón cited "Habitat in ruderatis Limae Chancay et Huanuci," Peru, and also "?Plukenet Alm. 33, tab. 136/4." An authentic Ruiz and Pavón specimen has not been located, and so the original plate may best be taken as the type. This taxon is the weedy species that has long been passing as Borreria laevis 
(Lam.) Griseb., based on Spermacoce laevis Lam. (1792), which is typified by Joseph Martin (Herb. Lamarck 102, HOLOTYPE at P), from Santo Domingo, but that bears little resemblance to the widespread plant for which the Ruiz and Pavon name seems to be the earliest available one (F. R. Fosberg, pers. comm.).

Distribution: Southeastern United States through Central America and the West Indies to Peru and Bolivia, now widely dispersed as a weed in many tropical areas. In Fiji it is known to us from about 45 collections from seven islands, but it may be anticipated on most of the populated islands. Greenwood 151 may be the earliest Fijian collection; the species probably became established in the archipelago during the first quarter of the present century.

RePRESENTATIVE COLlections: VITI LEVU: MBA: Lautoka, Greenwood 151; Nandi airport, DA 9738; Nalotawa, eastern base of Mt. Evans Range, Smith 4319; Nandarivatu, DA 10416. NANDRoNGA \& NavosA: Keiyasi, Singatoka River, DA 10180. SERUA: Ngaloa, Smith 9444. RA: Pasture Seed and Production Farm, Ndombuilevu, DA 9521. NaItasiri: Vunindawa, DA 10006; Nasinu, Gillespie 3424. TaIlevu: Mbau road, near Kuku, DA 10622. Rewa: Suva, Meebold 16690. OVALAU: Lovoni Village, Smith 7473. VANUA LEVU: Mathuata: Lambasa, DA 10470. Thakaundrove: Thavanandi, DA 10767. TAVEUNI: Waiyevo, Gillespie 4400.3. KANATHEA: Bryan 57I. VANUA MBALAVU: Near Lomaloma, Garnock-Jones 983. LAKEMBA: Near Tumbou, Garnock-Jones 908.

3. Spermacoce latifolia Aubl. Hist. Pl. Guiane Fr. 1:55. t. 19, fig. 1. 1775; Amaratunga in Ceylon J. Sci., Biol. Sci. 10: 155. pl. 1. 1973; Verdcourt in Fl. Trop. E. Afr. Rub. 364. fig. 50 (22). 1976.

Borreria latifolia K. Schum. in Mart. Fl. Bras. 6(6): 61, t. 80. 1888; Bremek. in Pulle, Fl. Suriname 4: 291. 1932; Steyermark in Mem. New York Bot. Gard. 23: 807. 1972.

Borreria alata sensu Backer \& Bakh. f. Fl. Java 2: 354. 1965; J. W. Parham, Pl. Fiji Isl. ed. 2. 266, p. p. 1972; non DC.

Straggling or prostrate annual herb, sparingly adventive near sea level, with branches to $60 \mathrm{~cm}$. high, these quadrangular, narrowly winged, and sparingly hirsute; the corolla is white to purplish. The only available collection was in flower and fruit in October.

TYPIFICATION: Spermacoce latifolia is based on Aublet (HOLOTYPE presumably at P), from Cayenne, French Guiana.

Distribution: Trinidad and South America to Peru, Bolivia, and Brazil, and now a common weed in many parts of the tropics including Africa, India, Ceylon, Malesia, and Australia. From Fiji we have seen only a single collection, dated 1954.

Available collection: VITI LEVU: Naitasiri: Nanduruloulou, DA 9624 (L.3998).

Spermacoce latifolia has often been confused with $S$. alata Aubl., but the two species (under Borreria) are separated by Steyermark (1972, pp. 806, 811) as follows:

Heads terminal on main stems or lateral branches, unilateral, subtended by 4 leaves in 2 unequal pairs;

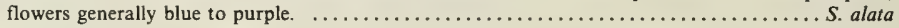
Heads chiefly axillary, in verticils on both sides of stem, subtended by 2 equal leaves; flowers generally white, rarely bluish.

42. Mitracarpus Zucc. in J. A. \& J. H. Schultes, Mant. Syst. Veg. 3:210. 1827; Hook. f. in Benth. \& Hook. f. Gen. Pl. 2: 146, as Mitracarpum. 1873; K. Schum. in Engl. \& Prantl, Nat. Pflanzenfam. IV. 4: 146. 1891; W. R. Anderson in Taxon 20: 643. 1971; Verdcourt in Fl. Trop. E. Afr. Rub. 375. 1976; Ross in Stanley \& Ross, Fl. S.-E. Queensland 2: 326. 1986. 
Annual or perennial, erect to prostrate herbs with 4-angled stems, the stipules united with bases of petioles, fimbriate; inflorescences dense, usually many-flowered terminal or axillary heads; flowers not or only slightly heterostylous, 4- or 5-merous; calyx limb lobed, often unequally so, sometimes with alternating supplementary teeth, persistent; corolla hypocrateriform to infundibular, the tube often pubescent toward base within, the throat glabrous or pubescent, the lobes valvate in bud; stamens inserted in corolla throat, the anthers included or exserted; ovary 2(or 3)-locular, the ovules solitary in each locule, attached near middle of dissepiment, the style short or long, divided into 2 short-linear lobes; fruit a thin-walled circumscissile capsule, the distal portion falling away with calyx limb, the dissepiment usually persistent; seeds oblong to globose, the ventral face divided into 4 distinct areas by an X-shaped groove.

TYPE SPECIES: Mitracarpus scaber Zucc. in J. A. \& J. H. Schultes, the only original species. Comments on the correct gender of the generic name are provided by Anderson (1971) and Verdcourt (1976).

Distribution: Tropical America, with 30-40 species; one species is now adventive in many tropical areas.

1. Mitracarpus hirtus (L.) DC. Prodr. 4: 572. 1830; K. Schum. in Mart. Fl. Bras. 6(6):

84. 1888, in Engl. \& Prantl, Nat. Pflanzenfam. IV. 4: 142. fig. 46, U. 1891;

Nicolson in Taxon 26: 574. 1977; Ross in Stanley \& Ross, Fl. S.-E. Queensland 2: 326. fig. 46, K. 1986.

Spermacoce hirta L. Sp. Pl. ed. 2. 148. 1762; non sensu L. 1767 nec Sw. 1791.

Spermacoce villosa Sw. Nov. Gen. \& Sp. Prodr. 29. 1788.

Mitracarpus villosus DC. Prodr. 4: 572. 1830; Steyermark in Mem. New York Bot. Gard. 23: 782. 1972;

Verdcourt in Kew Bull. 30: 322. 1975, in Fl. Trop. E. Afr. Rub. 375. fig. 55. 1976.

Erect or spreading annual herb $20-50 \mathrm{~cm}$. high, found as an occasional weed near sea level along roadsides, in pasture plots, and along beaches; the corolla is white and the fruit straw-colored. Our specimens bore flowers and fruits between November and March.

TyPification: Spermacoce hirta is typified by $P$. Browne (LINN 125.8 HOLOTYPE), from Jamaica (Verdcourt, 1975, p. 318), and $S$. villosa by Swartz (s HOLOTYPE; ISOTYPE at BM), also from Jamaica (Verdcourt, 1975, p. 319). There seems to be complete agreement that these two concepts, as regards their types, are conspecific.

Distribution: Widespread in tropical America and presumably an early introduction to Africa, now a pantropical weed, occurring in Australia, Micronesia, and Hawaii as well as in Fiji, where thus far it seems infrequent on Viti Levu, from which the earliest collection is dated 1956.

Available Collections: VITI LEVU: Serua: Waimate, on roadsides and near beach, Ndeumba, $D A$ 10111, 11596. NAITASIRI: Koronivia Research Station, in pasture plots, DA 15360.

There has been considerable disagreement as to the correct name of this widespread weedy plant-whether Mitracarpus hirtus (L.) DC., M. hirtus (Sw.) DC., or $M$. villosus (Sw.) DC. Verdcourt's thorough discussion (1975, pp. 317-322) implies his opinion that $M$. hirtus (L.) DC. is the correct name, but against his better judgment he accepted other advice and adopted the name $M$. villosus (Sw.) DC. $(1975,1976)$. Nicolson (1977, pp. 569-574) utilized this example in proposing a clarification of ICBN Art. 48.1 which has now been put into effect (cf. the "Sydney edition," 1983, in contrast to the "Leningrad edition," 1978). 
Subsequent to his 1762 publication of the name Spermacoce hirta, Linnaeus (Syst. Nat. ed. 12. 2: 115. 1767) circumscribed another taxon as $S$. hirta; this is represented by LINN 125.4, which apparently belongs to a different genus than Mitracarpus (Nicolson, 1977 , p. 572); however, Linnaeus's 1767 use of S. hirta is simply a misapplication of his 1762 binomial and is not to be considered a later homonym.

After his description of Spermacoce villosa in 1788, Swartz (Obs. Bot. 45. 1791) applied the name $S$. hirta to a taxon of which the identity is still unclear (Verdcourt, 1975 , p. 320; Nicolson, 1977 , p. 573); however, Swartz did not explicitly exclude the type of $S$. hirta L. from his 1791 concept, which therefore is not to be construed as a later homonym but merely as a misapplication of Linnaeus's 1762 binomial.

In proposing the combination Mitracarpus hirtus in 1830 de Candolle based it on Spermacoce hirta Sw. Like Swartz (1791), de Candolle did not explicitly exclude the type of $S$. hirta L., and it should be recognized that he actually made a new combination based on S. hirta L. (Verdcourt, 1975, p. 321; Nicolson, 1977, p. 573). In accord with today's nomenclatural practices, of course, de Candolle should not have considered Swartz the author of the name $S$. hirta; if in his opinion Swartz's 1791 name $S$. hirta was a later homonym, he should have considered it illegitimate and proposed for it a new, or at least a different, epithet (ICBN, Art. 45.3, 64.1).

The preceding is a very condensed review of a complex and confusing nomenclatural situation; for full expositions the reader, if interested, should consult the illuminating accounts by Verdcourt (1975) and Nicolson (1977).

\section{ORDER DIPSACALES \\ FAMILY 169. CAPRIFOLIACEAE}

CAPrifoliaceae Juss. Gen. Pl. 210, as Caprifolia. 1789.

Shrubs or woody vines, sometimes small trees, seldom herbs; stipules lacking or vestigial or sometimes present, then small and adnate to petiole at least basally, lacking colleters; leaves opposite (sometimes connate-perfoliate), usually simple, infrequently deeply divided (but not in our representative), the blades entire to crenate or serrate, occasionally lobed; inflorescences basically cymose, usually bracteolate; flowers $\zeta$, actinomorphic or somewhat zygomorphic, epigynous (or usually so), with a constriction below calyx limb, usually (4 or) 5 -merous; calyx limb usually small, the lobes or teeth imbricate or open in bud; corolla sympetalous, regular or somewhat irregular, sometimes bilabiate, the lower part of tube often nectariferous, sometimes gibbous or spurred at base, the lobes imbricate (rarely valvate) in bud; stamens attached to corolla tube and alternate with lobes (sometimes only 4 or 2 in 5 -merous corolla), the anthers 2-locular, dorsifixed, versatile, dehiscing by longitudinal slits; ovary inferior (seldom semi-inferior), ( 1 or)2-5(-8)-locular, the placentation axile (or partitions not meeting distally), the ovules 1-many per locule, pendulous, anatropous, the style terminal, slender or obsolete, with capitate or lobed stigma; fruit a berry or drupe, rarely a capsule, the seeds with copious endosperm and a small, straight embryo.

Distribution: North temperate and boreal regions, with extensions into Australasia and South America, with about 15 genera and 400 species. One genus has an introduced species in Fiji.

Useful treatment of family: KeRn, J. H., \& C. G. G. J. van Steenis. Caprifoliaceae. Fl. Males. I. 4: 175-194. 1951. 
1. Lonicera L. Sp. Pl. 173. 1753; van Steenis in Fl. Males I. 4: 176. 1951; Backer \& Bakh. f. Fl. Java 2: 360. 1965; Hutchinson, Gen. Fl. Pl. 2: 87.1967 ; Ross in Stanley

\& Ross, Fl. S.-E. Queensland 2: 472. 1986.

Twining, sprawling, or rarely suberect shrubs, estipulate, the adult branchlets usually fistular; leaves simple, entire (or rarely lobed), the petioles of a pair often with a connecting transverse line; flowers in axillary, pedunculate pairs (each pair with 2 bracts and 4 bracteoles), sometimes combined into leafy, paniculiform inflorescences, sometimes in sessile whorls, 5-merous; calyx tube dentate or essentially truncate; corolla tubular-infundibular, bilabiate, with 1-5 nectaries within tube, the upper lip composed of 4 mostly connate lobes, the lower lip of the fifth lobe; stamens 5 , exserted, the anthers with introrsely dehiscent locules; ovary inferior, 2- or 3(-5)-locular, the ovules 2-8 per locule, the style slender, elongate, the stigma small, indistinctly lobed; fruit a fleshy berry, the seeds (1-) few, ovoid or oblong, the testa crustaceous.

LECTOTYPE SPECIES: Lonicera caprifolium L. (vide Britton \& Brown, Ill. Fl. N. U. S. ed. 2. 3: 277 . 1913), one of the 15 original species.

Distribution: Northern Hemisphere, extending into Malesia, with 150-200 species. One species is widely cultivated and often naturalized in Pacific areas.

1. Lonicera japonica Thunb. Fl. Jap. 89. 1784; Christophersen in Bishop Mus. Bull. 128: 206. 1935; Yuncker in op. cit. 178: 114. 1943; van Steenis in Fl. Males. I. 4: 177. 1951; Backer \& Bakh. f. Fl. Java 2: 360. 1965; Sykes in New Zealand Dept. Sci. Indust. Res. Bull. 200: 57. 1970; J. W. Parham, Pl. Fiji Isl. ed. 2. 130. 1972; Ross in Stanley \& Ross, Fl. S.-E. Queensland 2: 472.1985.

As seen in Fiji, Lonicera japonica is cultivated and sparingly naturalized from near sea level to an elevation of about $850 \mathrm{~m}$. It is a sprawling or scrambling shrub, becoming scandent, with the fragrant flowers in axillary pedunculate pairs subtended by foliaceous bracts; the corolla is $4-5 \mathrm{~cm}$. long, white, turning cream-colored and yellow during anthesis; the filaments are pale yellow; and the fruits (not yet noted in Fiji) are black, shiny, subglobose, $5-7 \mathrm{~mm}$. in diameter. Flowers have been collected in March and July.

TYPIFICATION: The species was based on Kampfer (HOLOTYPE presumably at BM), collected near Nagasaki, Japan.

Distribution: Eastern Asia and Japan, now widely cultivated and often naturalized, in Pacific areas occurring from Australia to Pitcairn Island and Hawaii. The date of introduction into Fiji is uncertain, but possibly this is the species indicated in J. B. Thurston's Catalogue (1886) as Lonicera alba.

LOCAL NAMES AND USE: The honeysuckle or Japanese honeysuckle is a garden ornamental, presumably not fruiting in Fiji.

AVAILABLE COLLECTIONS: VITI LEVU: MBA: Immediate vicinity of Nandarivatu (naturalized), Smith 5025. NaItasiri: Plant Introduction and Quarantine Station, Nanduruloulou, DA 12152. REWA: Suva, in private garden, $D A 16781$. 




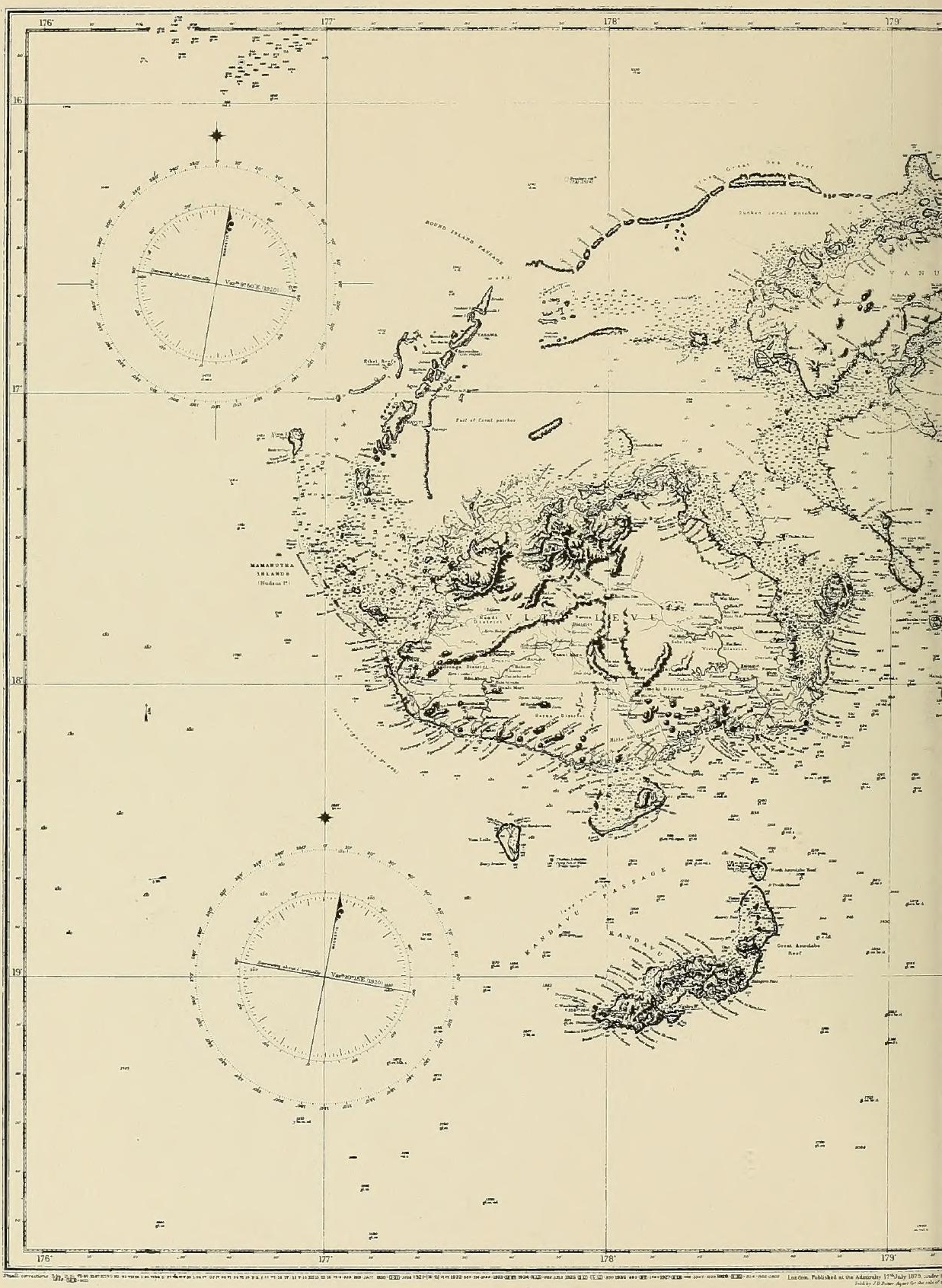


SMITHSONIAN INSTITUTION LIBRARIES 